LUIS NAVARRO GARCIA

\title{
DON JOSE DE GALVEZ Y LA COMANDANCIA GENERAL DE LAS PROVINCIAS INTERNAS DEL NORTE DE NUEVA ESPAÑA
}

\author{
PREMIO «RAIMUNDO LULIO» 1961, \\ del C. S. I. C.
}

PROLOGO DE JOSE ANTONIO CALDERON QUIJANO

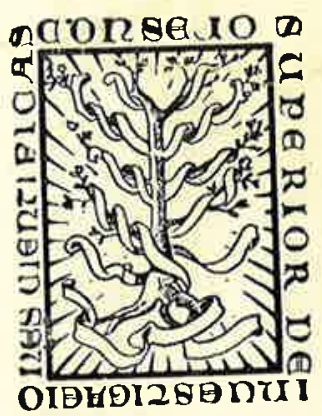

SEVILLA， 1964 
th

$\therefore \cdots$ 


DON JOSE DE GALVEZ Y LA COMANDANCIA GENERAL DE LAS PROVINCIAS INTERNAS DEL NORTE DE NUEVA ESPAÑA 


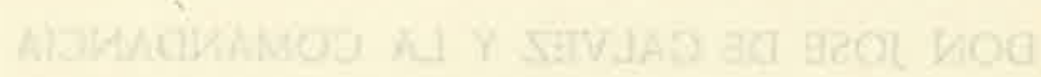

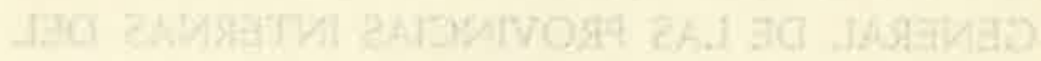

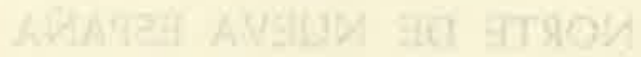


PUBLICACIONES DE LA

\title{
ESCUELA DE ESTUDIOS HISPANO-AMERICANOS DE SEVILLA
}

\author{
CXLVIII \\ (N. ${ }^{\circ}$ general)
}

2. ${ }^{a}$ Serie

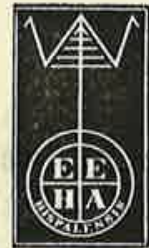

Las noticias, asertos y opiniones contenidas en este trabajo son de la exclusiva reuponsabilidad de su autor. La Escuela de Estudios Hispano-Americanos sólo responde del interés científico de sus publicaciones. 
Primera edición de mil ejemplares.

Depósito legal SE - 138 - 1965

Núm. de Registro SE - 38 - 1965

G. E. H. A.-Alfonso XII, 12,-SEviLu.

R. 53289 
LUIS NAVARRO GARCIA

\title{
DON JOSE DE GALVEZ Y LA COMANDANCIA GENERAL DE LAS PROVINCIAS INTERNAS DEL NORTE DE NUEVA ESPAÑA
}

\author{
PREMIO «RAIMUNDO LULIO» 1961, \\ del C. S. I. C.
}

PROLOGO DE JOSE ANTONIO CALDERON QUIJANO

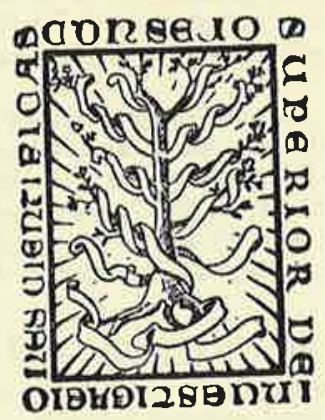

SEVILLA, 1964

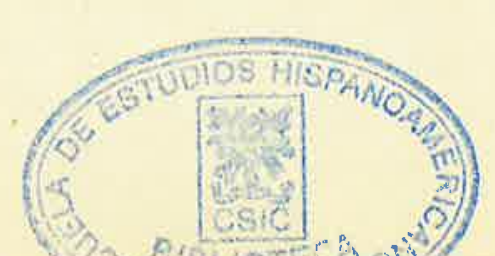




$$
\text { AIDЯAD OS }
$$

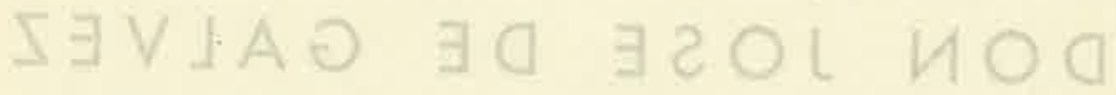 IAGजИヨО AIDИACMAMOO A」 Y

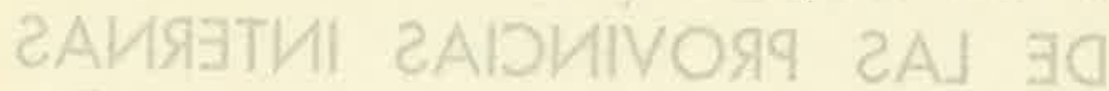

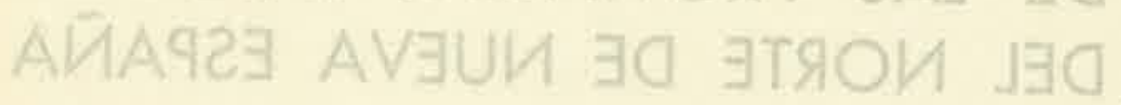

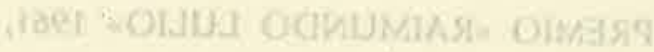 \\ $.9 .25 \mathrm{bb}$
}

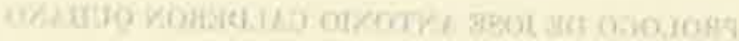

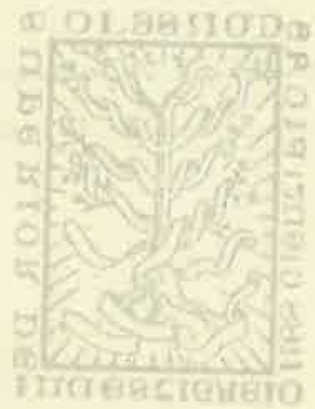

lael AHIVFe 


\section{$\begin{array}{llllllllllllllll} & \mathrm{N} & \mathrm{D} & \mathrm{I} & \mathrm{C} & \mathrm{E} & \mathrm{G} & \mathrm{E} & \mathrm{N} & \mathrm{E} & \mathrm{R} & \mathrm{A} & \mathrm{L}\end{array}$}

Páginas

$\mathrm{XI}$

XIII

XVII

$\mathbf{I}-46$

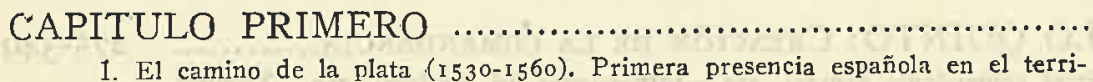
torio, I.-El camino de la plata, 3.-El Bajío, 6.

I1. El nacimiento de las provincias internas (I560-I640). La fundación de Nueva Vizcaya, 7.-Conquista de Nuevo México, 10.-La actividad misional, 1 2.- Los presidios, 15. - Las fronteras orientales, 17.- La expansión territorial, I 8.

III. $\mathrm{La}$ era de las invasiones $\mathrm{y}$ de las sublevaciones (I640-I680). Un nuevo frente, I8.-La triple sublevación tarahumara, 19.-El Bolsón de Mapimí, 20.--Los presidios del camino real, 22,-Los apaches y Nuevo México hasta I $680,23$.

IV. La expansión en el cambio de siglo (1680-1720). El alzamiento de Nuevo México. El Paso, 25.- $\mathrm{La}$ amplia zona de las naciones oscuras, 28.-El ataque de los tobosos, 30.- La erección de los presidios, 32.-Coahuila, Nuevo León, Texas, 33- - Sonora y la Tarahumara: una nueva frontera, 34.--Los tobosos, 36.-La visita de Marin, 38.-La presencia francesa y texas, 40.-De Sonora al Gila y al Moqui, 43.-De Sonora a California, 44.

CAPITULO SEGUNDO : LOS PRINCIPIOS DE LA GRAN ÉPOCA......

El poder real en las provincias internas, 47.-Las visitas, 58 . - El régimen de los presidios, 60.- La guerra, 65. - $\mathrm{La}$ frontera hacia $1725,69 .-\mathrm{La}$ visita de Rivera, 71.-El Reglamento de Rivera, 74.-Consecueneias de la visita de Rivera, 77 . - La búsqueda del Río Gande, 78.- Sonora y California, 81, - Los intentos de expansión al noroeste, 88.-Los proyectos del virreinato, 90- - La costa tamaulipeca y texana, 94.-Texas frente a la pradera, 98.-Apaches, franceses y comanches en Nuevo México, r03.-Los apaches sobre Nueva Vizcaya, 108. Las provincias internas a los dos siglos de su historia, 114.- La campaña propuesta por Tamarón, 122.-El precio de la defensa, 124.- Las vías y el comercio, 127. 
CAPITULO TERCERO : LA ÉPOCA DE GÁLVEZ ......................

La frontera en $1765,131,-\mathrm{La}$ expulsión de los jesuitas, $133 .-\mathrm{La}$ visita del marqués de Rubi, 134.-Reorganización interna de los prosidios, 141 .- La idea de la campaña en Gálvez, I 43.-Primeras realizaciones: el astillero y el ejército expedicionario, 148.-Preparativos de la marcha del visitador, 153. $\rightarrow$ Primera ampliación de los objetivos, $156 .-\mathrm{La}$ visión de Gálvez, 157.-El plan de la Comandancia, r58.- Los poderes de Gálvez y las primeras medidas para el fomento del noroeste, 160.-El puerto de San Blas y la guerra de Sonora, 16x. Gálvez en California, t68.-Campaña inicial y primer $y$ segundo ataques al Cerro Prieto, 170.-Gálvez en Sonora, 174.- Tercer ataque al Cerro Prieto y fin de la expedición, 178.-El gobierno ante la campaña, 185.- La expedición de Nueva Vizcaya, I87.-Don Bernardo de Gálvez, comandante de la frontera, 191 - Nuevo México y las provincias de oriente, 197.-Ultima actuación de Gálvez y Croix en M'éxico, 200.-Sonora pacificada, 205.

\section{CAPITULO CUARTO: LA LÍNEA DE PRESIDIOS}

Bucareli y O'Conor, 209.-O'Conor en la frontera, 212,-El Reglamento de 1772,215 . - Primera expedición de $O^{\prime}$ Conor, 221. - La lucha por la paz en todo el frente, 224.- - Segunda expedición de O'Conor, 229.-Tercera expedición de O'Conor, 233.- Cuarta expedición de O'Conor, 234.- La campaña general, 238.- La segunda campaña general, $24 \mathrm{x}$. - Principio de la última guerra en Nuevo México, 244.-Cinco años de transición en Sonora, 250.-La ruta de San Francisco y el Moqui, 264.-La defensa de Coahuila y Texas, 268.

\section{CAPITULO QUINTO : CREACIóN dE LA COMANDANCIA............}

E1 primet comandante general, 275.-Intrucciones del ministro, 277.-Teodoro Croix en México, 28r.-Causas de los nuevos trastornos, 284.-E1 plan de acción de Croix, 287.-La crisis de Querétaro, 290.-Croix en Coahuila y Texas, 293.-Creación de la tropa ligera y del presidio ópata, 297.-El caballero de Croix en Chihuahua, 30r.-La comandancia en 1778, 303.-Las juntas de Chihuahua, 307.-Plan de Croix sobre las provincias de Oriente, 309.-Organización de la comandancia, 313.-Las noticias de Nueva Vizcaya, 316.-Establecimiento de correos en la comandancia, 3r8.-Ultima etapa de la estancia de Croix en Chihuahua, 32r.-Cesión de la superintendencia, 323.-Anza, Corbalán y Tueros, en Sonora, 324.-Tres años de indecisión en Nuevo Méxic6, 333.- Nueva Vizcaya cambia de fisonomia, 336. - La paz inestable en Coahuila y Texas, 345 .

\section{CAPITULO SEXTO: LA Comandancia ESTABLECIDA ............}

El primer informe general, 351.-Aprobación del plan de Croix, 357.-Organización de la comandancia, 359.-Impulso hacendístico y económico, 362.-Las nuevas poblaciones, 367 . - Los fondos de milicias, 369 . - La paz en oriente, 372. Don Juan de Ugalde, gobernador de Coahuila, 376.- La dificil subsistencia de Anza, 384.- Sonora, la inestabilidad permanente, $387 .-\mathrm{La}$ rebelión de los yumas, 393. - Las Californias bajo Teodoro de Croix, 396.- La vida de los presidios, 398.-El abastecimiento de la tropa, 402.- La vida en las provincias 405.- Las misiones franciscanas, 421 .

\section{CAPITULO SEPTIMO : EL FIN DEL SIGLO XVIII}

Un nuevo momento histórico, 427.- - Los interregnos, 428.-.Don Felipe de Neve, 429.-El mando militar de las provincias, 433.-E1 último levantamiento de los seris, 435.- La campaña del Gila, 437.-El bandolerismo, 441.-Don José 
Antonio Rengel, 443.-Actividad de Rengel, 446.--Don Jacobo de Ugarte y Loyola, 450.- La instrucción del conde de Gálvez, 452.- Anuncios de paz, 456. ¿La paz lograda?, 457.--La doble comandancia bajo el virrey Flores, 460.-E1 conde de Revillagigedo, 472.-Revillagigedo, Nava y Castro, 478.-E1 gobierno de Mazatlán, 485.- La reunificación bajo D. Pedro de Nava, 486-Replanteamiento de la comandancia, 488.- La defensa de las provincias internas, 490. La presión de los Estados Unidos. 494.-La crisis hacendística, 495.-EI desarrollo económico, 498.-E1 gobierno de Nava, 50I.-Valor geopolítico de Nuevo México, 504.-Las intendencias, 508 .

Catálogo comentado de los mapas y planos de las provincias

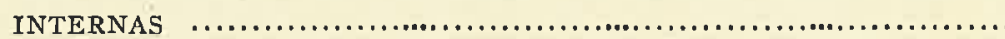

INDICR ANALIÍTICO 


\section{aniti 4}

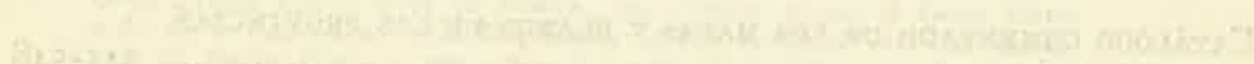
$12+2=2$

far a

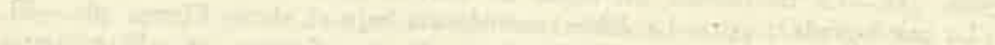

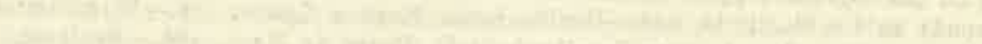

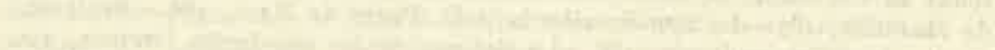
and ant 
A María del Pópulo 



\section{$\begin{array}{llllllll}P & R & O & L & O & G & O\end{array}$}

Luis Navarro García nos presenta en este libro la segunda monografía que debemos a su pluma. Es un nuevo trabajo sobre materia que conoce bien, y $a^{\cdot}$ la que ha dedicado una gran parte de sus investigaciones. Se trata del problema de la expansión, la organización politico-administrativa, militar y económica, la proyección demográfica y las tensiones que se originaron al norte de Nueva España.

Los protagonistas del portentoso hecho de la penetración hacia el norte fueron conquistadores, mineros y misioneros jesuitas o franciscanos.

Dicha penetración determina, después de la creación de Nueva Galicia, los sucesivos establecimientos de las gobernaciones de Nueva Vizcaya, Nuevo México, Coahuila, Texas, Sonora, Nuevo León y Nuevo Santander. Llamadas las cinco primeras "Provincias Internas", van a constituir uno de los objetivos de las reformas en que se empeñaron los hombres de Carlos III, 'deseosos de dar al Imperio nuevas y más eficaces estructuras.

Los nombres de Tamarón, Rubi, O'Conor, Teodoro de Croix, Bucareli, Bernardo de Gálvez, y sobre todo del gran creador de la idea general de la mueva entidad política, José de Galvez, serán los que den a aquellos territorios nueva savia, y mueva forma de vida. Junto a ellos, piolíticos, militares y administradores, aparecen también, y quizás como adelantados en vanguardia, los apostoles o evangelizadores como Fr. Junipero Serra o Fr. Financiscio Garcés.

Constituye el serio y primario problema de la frontera septentrional de Nueva España la defensa de los pobladores contra el merodeador nómada, ya de antiguo en fricción constante con el indígena sedentario.

Texas aparece como una provincia "sui generis", lejana, inmensa, con un medio indígena hostil, poco poblada por españoles, con comercio clandestino abundante, que va degenerar en contrabando, y proximidad peligrosa con Luisiana a través del Missisipi y Misuri, donde los comerciantes franceses actuaban con gran actividad. Igualmente ocurría en la vertiente pacífica con 

los rusos, que desde Kamchatka amenazaban con la expansión hacia California.
A ella llegaban de sur a norte los ingleses y holandeses en busca del estrecho de Anian o Paso del Noroeste, movidos del equívoco que hasta muy tarde planteb este error geográfico. Las posesiones inglesas, extendidas de la Bahía de Hudson al Cabo Sable, desde $\mathrm{I}_{3} \mathrm{C}_{3}$, constituyen también un motivo poderoso
de preocupación ante la creciente debilidad del Imperio Español. Estas eran
las tensiones que confluian sobre la linea fronterion que las tensiones que confluian sobre la linea fronteriza que iba del Golfo de México al de California, a través de Texas, y de los movedizos territorios constitutizios
de aquel inacabable "limes".

Desde 1748 el tráfico francés de armas de fuego con los comanches, que atacan ferozmente a los españoles, constituye un estado de guerra en derarse territorios. A ello se une la acción de los apaches, ansiosos de aposidad permanente de de las provincias, contribuyendo asi a crear una necepasa a manos españolas, los ingleses de las Trontera. Cuando Luisiana en $I_{7} 6_{3}$ ceses en el tráfico de armas de fuego. Rus Trece Colonias suceden a los franel comercio de pieles desde Bering go. Rusia ha hecho acto de presencia en

El Marqués de Rubi va a fijar Chiricof en I74I.

zada por un enemigo comín, el apach linea de frontera continua, hostililinea, las guarniciones se establecen ache. Los presidios irán racionalizando la no da cabida en su concepción estra iguales intervalos. El Marqués de Rubí Se limita considerar la estratégica a un planteamiento internacional. terizas.

José de Gálver entiende que la frontera para el es Sonora, caya y California. Su idea es bue la frontera para él es Sonora, Nueva Vizla vieja ambición del Padre Kiscar expansión por aquellos rumbos. Hereda fornia. Progresión que es simultáneanectar Sonora y la peninsula de Calipor un lado de sujetar a los indios rebelde terrestre y maritima. Necesidad establecer un cordón de poblaciones seldes pimas y seris. Intento por otro de

Gálve ve demasiado largo de la frontera. parece admitir que los ingleses, la vanguardia del avance ruso en América, llegar al Pacífico por el río Coloradoros de Francia en el Missisipi puedan bierno. Concibe con centro en Sonora Por ello hace la planificación del gomandancia General cuyos objetivos expana entidad casi virreinal, una Cosus informes a la Corte. Impulsa su proyección hacis bien conocidos por y San Francisco. objetivos. San Blas es liciones terrestres y maritimas se van alcanzando'los aquel puerto, la plata de California mejicana en el Pacífico. Con las naves de Vizcay'a y la colonización de la frontera Sonora, la paz de Sonora y Nueva nato, mediante fundación de villas y condad pobladores del interior del Virreirealización política tan suya.

Los logros inmediatos fueron San Blas y la Alta California. 
Gálvez, al revés de Rubí sólo veía la politica expansionista, y la urgencia de la situación internacional, frente al problema elemental y cotidiano de la agresión de los indios. Rubí propone una linea continuada de puestos fronterizos, con una idea de unidad y continuidad. Gálvez introduce una idea de autoridad superior y comin a todos los presidios: el Comandante Inspector. Dependerá éste del Comandante General. El hombre que implanta el nuevo Reglamento de Presidios, y ejerce por primera vez el cargo de Comandante Inspector es Don Hugo O'Conor. El plan es establecer nuevas lineas defensivas según las normas de Rubi y Lafora, y emprender una serie de campañas generales que eliminen el peligro apache y abran una muera era de expansióm.

O'Conor, seis años Comandante de la frontera. Etapa de transición. Su autoridad no alcanza a California, y en la frontera es sólo militar. El fin de su misión es una acción defensiva, pero dentro de su etapa tiene lugar la expedición de Juan Bautista de Anza, que logra enlazar Sonora con la Alta California.

I776. Se crea la Comandancia General proyectada por Gálvez ocho años anies. Es el año en que Gálvez asciende al Ministerio. La Comandancia comprende California, Sonora, Nueva Viscaya y Nuevo México. Luego se incorporan Coahuila y Texas, tipicamente fronterizas. La Comandancia es el fortalecimiento y unificación de las cuatro gobernaciones occidentales. La capital es Ariape, punto idealmente céntrico. La agregación de Coahuila y. Texas es para defender a estas dos provincias pobres, sujetas a ataques de apaches y comanches. Coahuila y Texas colaborarán con Nuevo México y Nueva Vizcaya para defender la puerta trasera del flanco constituído desde Taos a la Laguna.

Luego se plantearán dos problemas: la unidad o fragmentación de la Comandancia, y su autonomía o sujeción al Virreinato.

La unidad de la Comandancia está condicionada por la distinta indole de las provincias orientales y occidentales, por las enormes distancias, y por la aparición de un peligro exterior en el oriente al pasar Luisiana a manos de los Estados Unidos. A lo largo de cerca de medio siglo la Comandancia se fragmentará varias veces, volviendo a reunificarse.

La dependencia económica de las provincias internas del Virrey recibió soluciones contradictorias en diversas ocasiones. El Comandante Generai dependia de las remesas de Mé.tico. No había Casa de Moneda que respaldase la autonomía de su gobierno y de'la producción minera del país. Las Provincias Internas hacen el comercio europeo a través de Veracruz. Cuando se habilitan puertos en Nuevo Santander o Texas es tarde.

Hubo discontinuidad en el desarrollo de la idea de Gálvez. La Comandancia ha de renunciar a la expansión al Noroeste. Despojada de California, la capitalidad no tardará en pasar a Chihuahua y aun a Durango. Mientras, las guerras y las alianzas con las tribus bárbaras buscan una paz basada en el equilibrio de éstas. 
La vida de la frontera se reduce a una serie de escaramuzas. Todas las tentativas de asentar y asimilar a los apaches desembocan en fracaso, perdurando aquel problema, aunque mitigado, al fin del Imperio Español.

La presión de los Estados Unidos sobre Texas y Nuevo México, se hará patente en la guerra de $I 847$.

Cuarenta y cinco años de régimen de Comandancia General de Provincias Internas representaron un avance en todos los órdenes, del demográfico al cultural, manteniéndose incólumes las posesiones españolas y los derechos de España sobre territorios vecinos no dominados. Ello se debió al acierto de coordinar la unidad politica y administrativa superior de las gobernaciones de las Provincias Internas. Dos Obispados y tres Intendencias hicieron llegár a todas partes la acción misional, los centros de enseñanza, el fomento de la
mineria y el comercio.

Este es en breves rasgos el esquema de las ideas básicas del libro de Luis Navarro. Es el planteamiento más amplio y ambicioso de esta problemática histórica, aunque los trabajos de Bolton, Priestley, Chapman, Thomas y Hernández Sánchez-Barba constituyeron en su momento hitos importantes en la historiografía de la frontera del norte de Nueva España. La idea de conjunto,
que hoy se manifiesta en la obra que prologamos, es demostrativa de una investigación profunda sobre el tema.

Novedad indudable en la misma es la variedad de las fuentes utilizadas. Sobre los inagotables acervos documentales de los Archivos de Indias y Simancas y de otros archivos y bibliotecas españolas, Luis Navarro ha consultado fondos hasta ahora desconocidos del Museo Británico, Public Record Office, Biblioteca Nacional de París, etc. Ha aprovechado una novisima cartografia sobre Provincias Internas, hoy en el Museo Británico, pero que algún día debió figurar en los anaqueles del Archivo de' Indias.

La obra en si, tanto en lo que se refiere a la metodología histórica seguida, como al criterio de selección y utilización de fuentes, sistemas de exposición, y conclusiones obtenidas, constituye sin duda una valiosa aportación
a la historia del Virreinato de Nueva España. 


\section{$I N T R O D U C C I O N$}

Entre las muchas zonas y los incontables episodios olvidados en la historia de la presencia de España en América, las provincias internas mexicanas y la lucha alli tenida para mantener las extremas posiciones del Imperio no eran las menos importantes. Historia eminentemente "externa", y "politica", si se quiere, pero necesaria para poner de manifiesto que el impulso conquistador, poblador, colonizador de los españoles no acabó con Hernán Cortés, antes bien, una inmensa tarea de siglos llevaría la frontera de mineros, evangelizadores y soldados en progresión constante hasta alcanzar la máxima dilatación posible de las fuerzas espirituales y materiales de un pueblo, atesoradas y comprimidas a lo largo de ocho siglos y liberadas en la jubilosa mañana del Descubrimiento.

Narrar ese proceso, conocerlo previamente a través de sus prolijas huellas documentales, estructurarlo de la forma que nos pareció más coherente, ha sido una labor de la que este libro es sólo resultado parcial. Casi simultáneamente aparecerá nuestra historia de las Provincias Internas en el siglo XIX, y algunos estudios de aspectos concretos de la vida de las provincias han visto ya o verán próximamente la luz. Tal vez al final de nuestras investigaciones, que ain prosiguen, se haya logrado un cuadro preciso del pasado de estos países a los que el brillo de la metrópoli mexicana ha mantenido en la penumbra de la historia del Imperio.

El apoyo que durante años nos ha prestado la Comisaría General de Protección Escolar y Asistencia Social, en concepto de Profesor Ayudante Becario, hizo en gran parte posible nuestra dedicación a la consulta de los fondos manuscritos de Sevilla y Simancas y nuestros viajes a Paris y Londres. El Archivo General de Indias nos autorizó para la publicación de diferentes mapas y planos recientemente hallados en sus legajos y cuya clasificación, encomendada al profesor Don Julio González y González, se lleva a cabo en la actualidad. El Consejo Superior de Investigaciones Científicas, que premió y edita esta obra, y su Escuela de Estudios Hispanoamericanos, que constantemente alentó nuestros esfuerzos, son justos acreedores a muestra gratitud, especialmente en la persona del Director de este Centro, Don José Antonio Calderón Quijano, que lo ha sido de nuestros trabajos desde I957. 


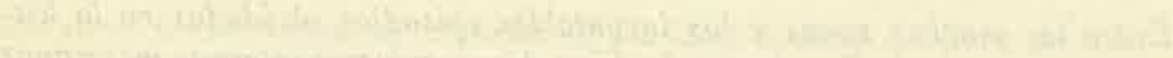

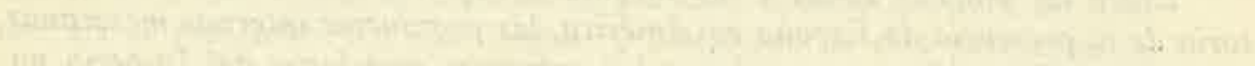

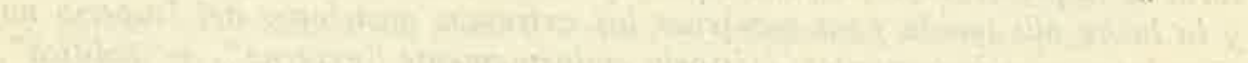

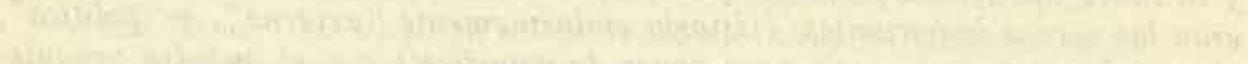

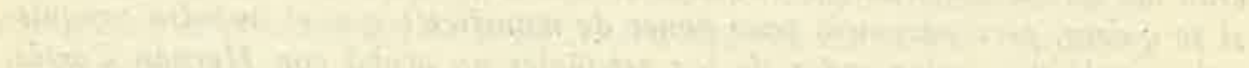

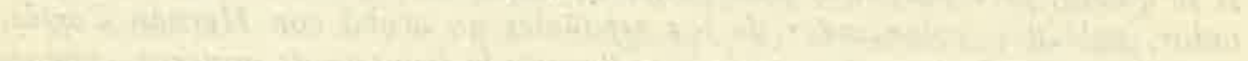

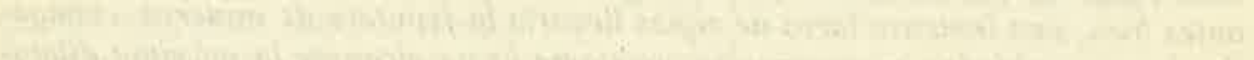

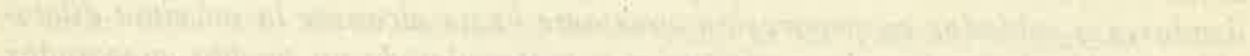

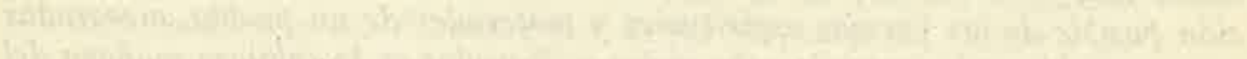

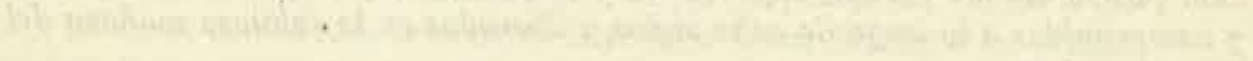

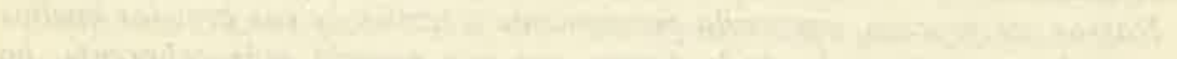

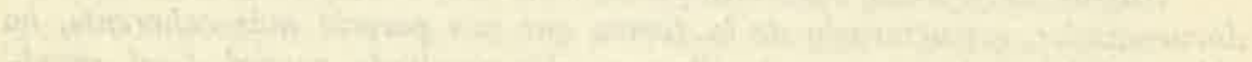

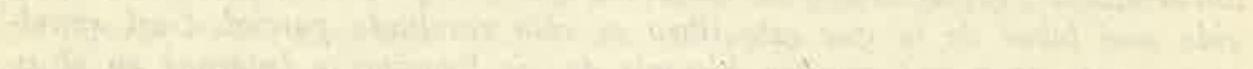
The

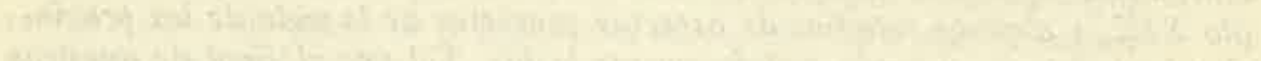

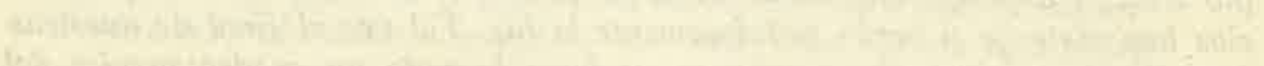

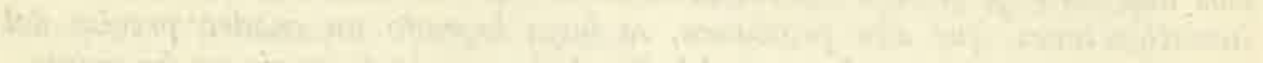

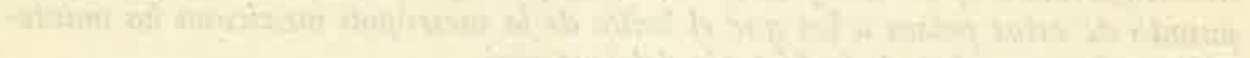

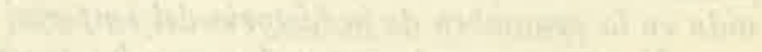

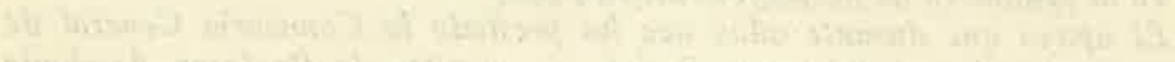

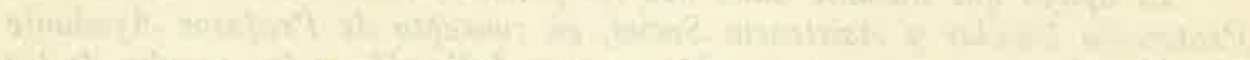

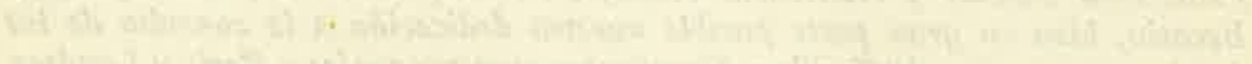
Wate

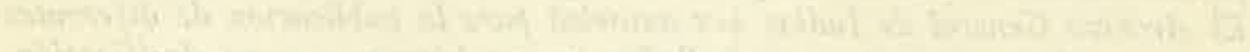

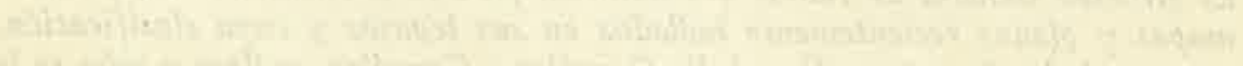

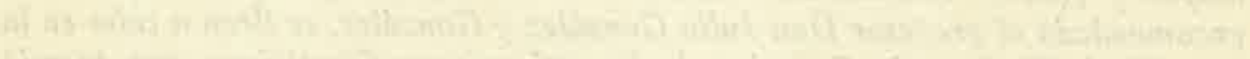

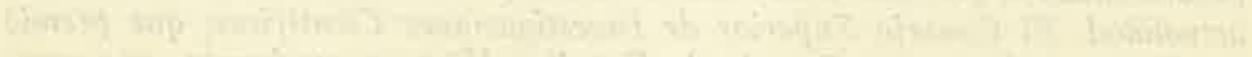

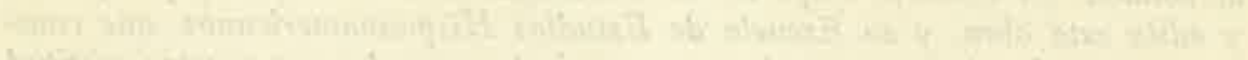

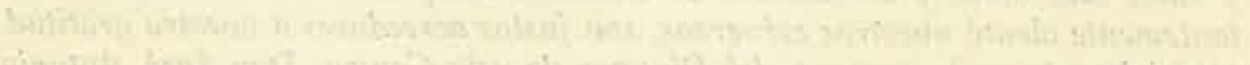

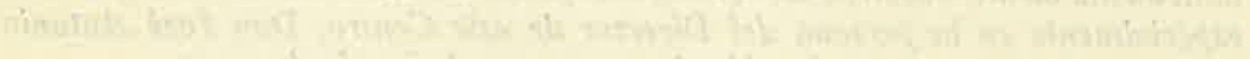

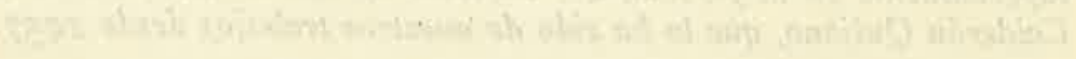




\section{CAPITUI.O PRIMERO}

Cuando ya entrado el siglo XVIII empieza a esbozarse y a cuajar la idea de la unidad global de las provincias fronterizas del Norte de Nueva España, llevan éstas ya casi dos siglos de existencia histórica, período que ha ido modelando su fisonomía imprimiéndole rasgos auténticamente diferenciadores respecto de las demás porciones del virreinato.

No podíamos, pues, dejar de hacer siquiera un sumario de los principales acontecimientos de esa etapa previa a la estudiada propiamente en el presente estudio. Dicho sumario puede estructurarse en cuatro apartados, que responden a la realidad de cuatro momentos históricos distintos sucesivos. El primero recoge la penetración española en el umbral de las provincias internas que constituyen la región de Zacatecas y el Bajío. El segundo presenta el nacimiento de los tres núcleos iniciales de la actividad españoia en el norte del virreinato: Nueva Vizcaya, Nuevo León y Nuevo México. En el tercer momento, la consolidación de la frontera ante el doble peligro interno da a las provincias su inconfundible carácter de país en estado de alarma permanente. El cuarto momento significa la aparición del conflicto interliacional en el costado oriental al mismo tiempo que una efectiva expansión en el extremo opuesto, con lo que viene a hacerse continua la línea defensiva de mar a mar.

\section{EL CAMINO DE LA PLATA (I530-I560)}

Primera presencia española

EN EL TERRITORIO

La historia de las Provincias Internas empieza realmente una vez pasado el primer momento de las grandes y rápidas conquistas de los españoles en el Nuevo Mundo y de la floración de grandes empresas prontamente abo- 
cadas a la gloria y al fracaso. De éstas, tuvieron como escenario las provincias internas la de Nuño de Guzmán, las navegaciones californianas de Cortés y las expediciones a Cibola.

Todas ellas no fueron más que profundas exploraciones de las costas y del interior del continente en pos de una leyenda, tras el señuelo de una segunáa México, de una Nueva México que nunca fue hallada tal como imaginada. Como tampoco se alcanzaría nunca aquel fabuloso Estrecho de Anián. cuya existencia torturaba las mentes de navegantes y mercaderes.

De todo ello quecló el oscuro conocimiento de una tierra -C ¿isla o peninsula? - llamada por Cortés Santa Cruz, y la convicción de que era inútil buscar otros Moctezumas en aquellas inmensas provincias ocupadas por tribus de indios nómadas a seminómadas que pronto se mostraban hostiles. Tan sólo los indios pueblo, agricultores, fueron objeto por este motivo de una significativamente porfiada conquista. Nuño de Guzmán había realizado la última conquista eficaz al fundar Guadalajara y sus cinco poblados circundantes y crear Nueva Galicia, con aquel alejado enclave de Culiacán, estabiecido en $\mathrm{I}_{53} \mathrm{I}$. Fuera de este logro, los conquistadores habíanse visto reducidos al no menos honroso pero sí menos halagiieño papel de exploradores, empeñados en los amplios cuanto estériles sondeos del continente.

Así, al mediar el siglo XVI, los establecimientos españoles veianse prácticamente contenidos en la línea de los ríos Santiago y Pánuco, presentando una frontera en forma de arco cóncavo a la Gran Chichimeca.

En adelante, y aun desde la época inmediatamente posterior a Nuño de Guzmán, los españoles, tanto como a colonizar, han de atender a su propia defensa. En primer lugar, con ocasión del alzamiento de la Cazcana, la "guerra de Jalisco", que estuvo a punto de terminar con Nueva Galicia. Luego, culando el núcleo de Guadalajara empieza a expansionarse, los españoles tienen que sostener una lucha constante para no ver cortadas sus precarias líneas de comunicación.

De I 550 a 1720 , en que aproximadamente da comienzo riuestro estudio, ha tenido lugar un enorme avance de los límites del territorio español, avance que se ha desarrollado bajo unas circunstancias especiales que no hemos podido menos de inquirir con vistas a una más exacta interpretación de la realidad que, en $I 720$, se nos hace patente a través de nuestras fuentes documentales.

Hay, desde luego, un momento inicial en este período de casi dos siglos consistente en la expansión natural de Nueva Galicia. Nuño de Guzmán, el rival de Cortés, había soñado una gobernación titulada Nueva Conquista de la Mayor España, que cerrase las posibilidades expansivas de México al Norte, como se lo propuso al realizar la audaz marcha, desde Guadalajara 
a Pánuco. La audiencia sucesora de Guzmán heredó esta orientación, y junto a algún intento aislado de entrar hacia Chiametla - región que ya en tiempos de Guzmán había "quedado de guerra" - mostró especial interés por las tierras del interior. Apenas la ciudad se había visto libre del asedio de los cazcanes y de la guerra de Nochistlán, parten las expediciones, como las de Ginés Vázquez de Mercado y de Juan de Tolosa. Esta última, en I546, daba como fruto el descubrimiento de minas de plata en la región de Zacatecas. ${ }^{\mathrm{I}}$

\section{El CAMino DE LA PLATA}

A la primera ojeada se advierte el proceso del avance español en esta verdadera antesala de las provincias internas. Una doble corriente inmigratoria penetra, desde Guadalajara y México, en tierras al norte de los ríos Santiago y Pánuco. La procedente de Nueva Galicia alcanzará Zacatecas, que será punto de apoyo para la ocupación de las provincias septentrionales. La del virreinato irradia de Guanajuato y Querétaro hasta San Luis de Potosí.

Con el descubrimiento en 1546 de las abundantes minas de plata de Zacatecas por los hombres de Nueva Galicia vencedores del Mixtón daba comienzo una epopeya de la que esta guerra no había sido más que el preludio.

Pasado el gran peligro que corriera Guadalajara, se inicia la ocupación por los españoles del amplio semicírculo que delimitaban los ríos Grandes de Santiago y Pánuco. Ocupación que se hace desde Guadalajara en primer lugar. El incentivo de las minas llevó a los españoles a un género de vida extraño y arriesgado. A salvar la distancia que media entre Zacatecas y México en continuo sobresalto. A empeñar largas y crueles luchas con los indios que señoreaban el territorio y no se avenían a ser desalojados de él ni a amoldarse a las faenas para que los invasores blancos los requerían.

I Sobre Nuño Beltrán de Guzmán pueden consultarse las siguientes obras: López-Portillo y Weber, José : La conquista de Nueva Galicia, M'éxico, i 935. Carrera Stampa, Manuel : Nuño de Gusmán. México, 1955. Este mismo autor ha publicado la Memoria de los servicios que habia hecho Nuño de Gusmán, desde que fue nombrado gobernador de Pámuco en 1525. México, 1955. La Relación del Capitán Don Diego de Gusmán, publicada con comentarios de José G. Heredia, en "Estudios históricos de Sinaloa". Congreso Mexicano de Historia, México, 1960. Págs. 123-143. Sobre las navegaciones californianas de Cortés, Portillo, Alvaro del: Descubrimientos y exploraciones en las costas de California. Madrid, I947. La guerra de Jalisco ha sido historiada por López-Portillo y Weber, José: La rebelión de Nueva Galicia. México, 1939. Pérez Bustamante, Ciriaco: Don Antonio de Mendosa. Santiago, r928. Aiton, Arthur S.: Antonio de Mendoza, first Viceroy of New Spain. Durham, 1927. La empresa de Coronado, con todas sus circunstancias y precedentes, halló su más perfecto estudio en Bolton, Herbert E.: Coronado, Knight of pueblos and plains. Alburquerque, 1949 . 
Por los años treinta del siglo XVI había introducido el español Sebastián de Aparicio en el virreinato la gran carreta llevada por bueyes o mulas que ya durante siglos se verá conduciendo las mercancías de México a Veracruz por casi intransitables caminos. Pero no tardó Aparicio en ambicionar extender su tráfico a las tierras del exterior; y así, con no pocas penalidades, consiguió abrir la ruta de México a Zacatecas: con ello, este hombre que andando el tiempo subiría a los altares en hábito de franciscano había sido uno de los más eficaces forjadores de la expansión española por tierras mexicanas y había asentado uno de los pilares de la prosperidad del virreinato.

En adelante, continuas caravanas de carretas y mulas recorrerán la nueva vía en ambos sentidos. Desde México se introduce las mercancías europeas. De Zacatecas bajan las barras de plata para ser acuñadas en la Casa de la Moneda o para ser remitidas a España.

El florecimiento del país sólo tropezaba con un obstáculo: los indios hostiles que asaltaban los convoyes y cometían cantidad considerable de muertes en los viandantes. Estos chichimecas, como habían llamado los habitantes del Anáhuac a sus bárbaros vecinos del norte, empiezan a entorpecer las comunicaciones desde 1550 , y un año después, tras haber sufrido un duro asalto, se hace preciso a los españoles evacuar el poblado de San Miguel establecido más allá de los ríos Santiago y Pánuco. Las hostilidades se hacían sentir igualmente en la ruta de Zacatecas a Guadalajara, pese a las guarniciones o presidios ya establecidos por Oñate a poco de acabar la guerra del Mixtón. A los nómadas chichimecas uníanse aquí los restos de las tribus vencidas, refugiadas en las asperezas del Nayarit. Desde i 544 la situación se había hecho difícil. El oidor Herrera, enviado por la audiencia de Nueva Galicia, no había podido batir a los enemigos. Por fin, el asalto dado en el paso de los Ojtuelos por el caudillo Maxorro a un convoy que marchaba a Zacatecas vino a hacer patente la necesidad de una solución.

Las carretas y viajeros se reunían en gran número para emprender la travesía de las tierras de las tribus insumisas. Entre ellas siempre iba alguna totalmente cerrada con fuertes maderos con sólo algunas troneras o aspilleras desde las que los arcabuceros podían hacer fuego a salvo para contener a los obstinados asaltantes. Con esto y pequeñas escoltas se pretendía salvaguardar la conducción de personas y mercancías y mantener abierta la comunicación con Zacatecas.

Pero se hacía preciso ocupar efectivamente aquel territorio. El descubrimiento de nuevas minas en la zona de Guanajuato, donde se establecieron cuatro fortines en I 554, proporcionó otro punto de apoyo. En I 555 el virrey Velasco ordena la repoblación de San Miguel el Grande con gentes 
de Huango, Acámbaro, Cuitzeo y Querétaro. San Miguel protegería a las tribus amigas de los otomíes. Poco después se proyectaba otra fundación en. Celaya.

$\mathrm{El}$ año I $56 \mathrm{r}$ presencia un levantamiento general de los chichimecas. Para proteger las minas de Zacatecas, San Martín y Avino, la audiencia de Guadalajara envió a Pedro de Ahumada de Sámano con cuarenta jinetes y cuatrocientos indios auxiliares. Ahumada atacó a los enemigos en las sierras entre Zacatecas y San Miguel, por donde deshizo muchas rancherías de chichimecas. Por su parte, el virrey providenciaba la fundación de San Felipe de los Reyes, que había de servir de antemural a los indios pacíficos reducidos en Xichú. En r 563, por orden suya; Nueva Galicia erige las poblaciones de Santa María y San Juan de los Lagos. Con esto el virrey Velasco había dado un notable impulso a la colonización del territorio. La zona de Zacatecas experimenta una época de florecimiento con el incremento de la extracción argentífera de Mazapil, que es en esta época la población más oriental y septentrional de las avanzadas al norte en esta zona. Con ella había alcanzado su tope la expansión del núcleo Guadalajara-Zacatecas que ha constituido una cuña de pujante vida económica entre la escabrosa región del Nayarit y el Bajío, teatro de las correrías de los huachichiles.

Bajo el mandato del virrey subsiguiente Enríquez, se colocan guarniciones en Sombrerete y Fresnillo (I 568) y San Felipe, Ojuelos, Portezuelos, Bocas, 'Ciénaga 'Grande y Palmillas; se fundan: Nuestra Señora de la Concepción de la Frontera por el virrey, y Jerez de la Frontera por Nueva Galicia ( 570 ), en tanto que el alcalde mayor de Guanajuato, Don Juan de Torres de Laguna, daba una batida con cuatro compañías y trescientos indios auxiliares a las rancherías de huachichiles y borrados, llegando hasta las proximidades de Mazapil.

En la década de los setenta se lleva a cabo la ocupación efectiva de todo el territorio con la erección de presidios en Palmar de la Vega, Jofre, Jasó y Río Santa Catarina. La fundación de la población guarnecida de Aguas Calientes y de la villa de León ( I 575) aseguraba definitivamente las comulnicaciones de la capital con la región minera por excelencia del virreinato, mientras que la colocación de otros efectivos militares en Tazazalco y Maxcala (I576), Pénjamo y Xamay (I577) garantizaba el contacto con Guadalajara.

A partir de entonces el triángulo México-Guadalajara-Zacatecas está bien afirmado bajo el gobierno español. A su costado occidental, sin embargo, subsiste el inexpugnable Nayarit, rochela y refugio de las tribus insumisas. 
Al oriental, un nuevo campo de actividad se abre para los españoles con el descubrimiento de las minas de San Luis de Potosí. ${ }^{2}$

EL Bajío

El hallazgo de las minas de Potosí fue, como lo fuera el de las de Guanajuato, uno de tantos episodios como con abundancia se entremezclan en. esta azarosa sucesión de campañas contra los indios y asaltos de éstos a los establecimientos españoles y tuvo lugar hacia I573, sin que las continuadas hostilidades hiciesen posible el asentamiento de los mineros. Igualmente fracasaron los intentos de poblar Charcas y Tepezala. Pero en I589, tras la última guerra, el general Don Rodrigo del Río de la Losa puso fin a las campañas haciendo la paz con los huachichiles que, o bien se sometieron, o bien se retiraron a las vecinas tierras tamaulipecas.

Por aquel entonces, guarniciones de Nueva Galicia y Nueva España delimitaron el territorio de guerra: de acuélla eran, en la frontera occidental, las de Ojuelos, Encinillas, Ciénaga de Mata, la Pendencia, Aguas del Espíritu Santo, y Maticolla. De Nueva España, por el sur, San Felipe, Valle de San Francisco, Atotonilco y Santa María del Río; por la parte oriental, jalonando el valle del Pánuco, se habían establecido los de Jalpa, Valles, Maguaos y Tamos, que protegían la Huaxteca. Las villas de Pánuco y Tampico quedarán como fronterizas hasta el siglo XVIII, constituyendo la avanzada septentrional de Nueva España en el golfo de México.

En el interior, San Luis de Potosí vive unos días de esplendor en el tránsito de los siglos XVI al XVII, y conserva luego su rango gracias a la puesta en explotación posteriormente ( 1620 ) de los minerales de Guadalcázar, Pinos, Peñol Blanco, Charcas y Xilliú.

La prosperidad de la región no es, sin embargo, comparable con la pujante actividad de Zacatecas, y los reales de minas asentados en la Sierra Madre Occidental cuya opulencia no tiene parangón posible en toda Nueva España, siendo a un tiempo causa y consecuencia de la enorme masa de población que su explotación moviliza o atrae.

3 Philip Wayne Powell, en una scrie de trabajos publicados desde 1944 , ha sirlo el principal investigador del proceso de penetración en la cuenca minera de Zacatecas. Su obra principal es Soldiers, indians and silver. The Northrvard advance of New Spain. I550-I6oo. Berkeley and Los Angeles, 1952, Noticias sobre Fr. Sebastián de Aparicio, en Ocaranza, Fernando: La beatificación del venerable Sebastián de Aparicio. México, I934. Marmolejo, Lncio: Efemérides guanajuatenses o datos para formur la historia de la ciudad de Guanajuato, 2 vols. Guanajuato, I93'S. I, Ifo-I4I. Cuevas, Mariano: Historia de la Iglesia cn Mérico. 5 vols. México, I946-I947. II, 478-480. Datos sobre !a dificultad y características de las comunicaciones, en Pérez de Ribas, Andrés: Historia de los triunfos de muestra Santa fe entre gentes las más bárbaras y fieras del Nuevo Orbe... Año I645. Reimpreso en México, 1944. 3 vols. Libro XII, cap. 2. 
En la región del Bajío, los establecimientos mineros dan ya cabida igualmente a una serie de haciendas agrícolas y ganaderas, representando por esto un punto de transición al tipo de organización económica de las provincias septentrionales.

Potosí conserva, por otra parte, igualmente hasta entrado el siglo XVII t1n cierto carácter de avanzada fronteriza ante los indios huachichiles que amenazan por retaguardia a Mazapil y las poblaciones de Nueva Vizcaya oriental y Nuevo León, y tienen un reducto en: la Sierra Gorda"de Tamaulipas. Entre ella y la del Nayarit, y entre la entrada meridional del Bolsón de Mapiní y la cuenca del río Lerma, todo un primer tramo de la extensión septentrional del Anahuac - en otro tiempo residencia de los indios cazcanes, zacatecos, huachichiles, panes, copuces, guamares y otomíes- era de esta manera incorporado a los dominios del rey de España bajo la triple corriente expansiva de los mineros, los soldados y los franciscanos, cuya predicación irradia desde Zacatecas. 3

\section{EL NACIMIENTO DE LAS PROVINCIAS INTERNAS (I 560-I640)}

\section{La fundación de Nueva Vizcaya}

Es extraño que ninguno de los historiadores del Norte de México haya reparado en la presencia del nombre de Nueva Vizcaya en la obra cumbre de la literatura española. Efectivamente, Cervantes, en el capítulo XVIII de la Primera Parte de El Quijote, al narrar el imaginario combate de los dos ejércitos, pone en boca de su héroe la alusión a un reino de Nueva Vizcaya cuyo príncipe era Timonel de Carcajona. Imposible saber qué idea suscitaba en el escritor aquel nombre, pero por tratarse de Cervantes bien merece esta curiosidad hasta ahora ignorada su inserción aquí. $Y$ ahora pasemos a narrar los orígenes reales de la provincia.

Si bien el nacimiento de Nueva Vizcaya está fundamentalmente enraizado en Zacatecas, y aún más, en Nueva Galicia, con su aparición entramos

3 La zona nordeste de Nueva España carece, en general, de un buen estudio histórics, y especialmente por lo tocante al siglo XVI. Vid. para las noticias recogidas arriba, Feliciano Velázquez, Primo: Historia de San Luis de Potosi, 4 vols. México, I946-ig'48. Muro, Manuel: Historia de San Luis de Potosí. San Luis de Potosi, I849. Chevalier, François: La formation des grandes domaines au Mexique. Terre et societé aux XVIe-XVIIe ciècles. París. 1952. Pág. 43. Toussaint, Manuel: La conquista de Panuco. M'éxico, I948. Rodríguez, Blas E.: Tampico. Datos para la historia de la Huasteca. México, 1932. Meade, Joaquín: Documentos intéditos para la historia de Tampico. Siglos XVI y XVII. México, I939. La colonización llevada a cabo con indios de Xilotepec y Tlaxcaia es estudiada por Gibson, Charles E.: Tlaxcala in the sixteenth century. New Haven-London, I952. 
en un momento histórico distinto por el hecho de haberse constituido Nueva Vizcaya desde el principio como una entidad políticamente independiente de la Audiencia Gobernadora de Guadalajara y subordinada inmediatamente al virrey.

Su fundador y conquistador, Francisco de Ibarra, hizo uso de esa autonomía para ampliar, con su dinamismo y una iniciativa realmente admirable, los límites de su gobernación tanto como pudo.

En ágiles campañas e incursiones pasó de la cuenca del río Aguanaval a las del Nasas y Mezquital, donde surgirán Durango (Guadiana) y Nombre de Dios. De aquí, a la sierra, a la conquista de Topía, la pretendida Copala, y más tarde a la costa, donde establece las villas de San Juan Bautista de Carapoa o de Sinaloa, reconstruida y rebautizada luego como San Felipe y Santiago de Sinaloa, algunas leguas más al sur en el río de Petatlán, al norte de Culiacán; y San Sebastián de Chiametla, al sur de este enclave. En este último caso, Ibarra invadía territorios que correspondían propiamente a la gobernación de Nueva Galicia, que había intentado, aunque sin éxito, su colonización. Por el momento, el país no parecía rico, habiendo sufrido sus primitivos pobladores las depredaciones de Nuño de Guzmán, tras lo que había quedado de guerra. Siendo San Sebastián la primera población que conseguía mantenerse allí, toda la provincia fue reconocida, en el pleito que siguió, como de Nueva Vizcaya, considerándose como límite con Nueva Galicia el río de las Cañas. Con la ocupación de Chiametla y el dominio ejercido por los españoles sobre la sierra en la región de Topía venía a cerrarse un cerco en torno al reducto insumiso de Nayarit.

Todavía llevó Ibarra a cabo una expedición más, esta vez inevitablemente fracasada, con dirección al norte, en busca del fabuloso Paquimé. Pero esta orientación ya no se cumpliría sino al cabo de un siglo, como resultado de una lenta progresión misional.

En el interior, Santa Bárbara es, en el valle del río Florido, el punto más septentrional alcanzado por la colonización de Nueva Vizcaya. Y estos fueron, durante mucho tiempo, los límites que contuvieron a la gobernación.

Los franciscanos, que entran en el territorio con los conquistadores e incluso los preceden en algunos sitios, y los jesuitas que llegan a fin de siglo, inician inmediatamente su acción evangelizadora. Los indios, salvo en Topía, no han puesto resistencia a la penetración española en el interior. Y sólo en la costa se prevé una continua hostilidad en Chiametla, frente a los indios de la sierra, y en la región de la villa de Sinaloa: a esta última fueron enviados los dos primeros jesuitas llegados a Durango, y con este hecho se abre un campo misional de horizontes insospechados a la Compañía.

Tepehuanes, acajees, jijimes e innumerables tribus de la costa del Pací- 
fico acababan de entrar en contacto con España, y su intervención a partir de entonces va a llenar bastantes páginas y cubrir de luto muchos días de la historia de Nueva Vizcaya.

Ya en la actuación de Francisco de Ibarra se hace ostensible la decidida tendencia a encaminarse siempre al Norte y al Oeste, y al Oeste como camino hacia el Norte. Su expedición al Paquimé es continuación o repetición de las de Guzmán, Niza y Coronado, y puede considerarse como la que definitivamente cierra este ciclo. La gran cordillera y el camino que entre ella y el mar conducía al norte parecían haber obsesionado a muchos hombres.

En lo sucesivo, ya no será así. Las provincias marítimas pierden importancia a ojos vistas. Perdura Sinaloa tras incontables vicisitudes y aquel reducido núcleo pronto tiene un marcado carácter casi exclusivo de foco misional. Protegidos por los capitanes Díaz y Hurdaide, los jesuitas van avanzando en sus tareas evangelizadoras hasta los ríos Fuerte, Majo y Yaqui. Hacia el interior se alcanza la región de Chínipas.

Entre tanto, al otro lado de la Sierra, una débil penetración hacia el Oriente, contorneando y poniendo límites por el norte a los territorios de Nueva Galicia, halla su límite extremo en la fundación de la villa de Saltillo, que por muchos años será la población española más septentrional en aquella región. Aislada al mismo tiempo del resto de la provincia por la pantanosa región de la Laguna, que inundaban las crecidas del Nazas y del Aguanaval, por donde merodeaban los bárbaros zacatecos e irritilas, su historia se encontrará siempre más vinculada a Mazapil en Nueva Galicia, y a Monterrey, en Nuevo León, que a la matriz neovizcaína, y será, como Sinaloa respecto de Sonora, el punto de apoyo necesario para emprender la penetración colonizadora y misional en Coahuila.

Pero la hermosa y rica Nueva Vizcaya tenía sus propios problemas. No era sólo la Laguna la que coartaba su posible expansión oriental. Más al norte de aquella región hacía acto de presencia el desierto, sólo recorrido por las familias nómadas de los tobosos, que a su vez rechazaba de nuevo a los españoles al Oeste y al Norte.

$\mathrm{Y}$ así constituyóse Nueva Vizcaya a caballo de la Sierra Madre Occidental, de la que ya no se separaría. En torno a Durango, franciscanos y jesuitas rivalizaban en las tareas de cristianizar los pueblos de tepehuanes, acajees y jijimes, mientras los grupos de mineros obtenían crecidas sumas de plata y oro en las minas de San Andrés y Topía, Santa Bárbara, Indé, Pánuco, Avino y Cuencamé.

Sin embargo, pronto veríase el reino entero envuelto en una larga serie de penosas luchas por su subsistencia, luchas a través de las cuales se con- 
solidaría el claro tinte militar que nunca perdiera desde los días de su erección. 4

\section{Conguista de Nuevo México}

La entrada de Oñate en Cibola fue la única que produjo resultadios duraderos (aparte la de Ibarra) de todas las emprendidas a fines del XVI por los rumbos septentrionales.

Apoyándose en la ya dominada Nueva Vizcaya, le fue posible a Oñate llevar ${ }^{\circ}$ a cabo la empresa en cuyo intento ya le habían precedido, legal o ilegalmente, una serie de conquistadores menos afortunados. Tampoco lo fue él en cuanto a las ganancias materiales obtenidas, y por eso se esfuerza en explorar ampliamente toda la comarca circundante, tratando intítilmente de localizar aquel fabuloso "Nuevo México" que nunca se halló tal como se soñara. Así recorre desde las proximidades del Misisipí hasta el golfo de California, y ve desplomarse sus pretensiones de convertirse en virrey, pese a los esfuerzos y a las enormes cantidades de dinero impendidos.

Oñate es el íltimo de los conquistadores que sufrieron la alucinación del Norte. Y allí estaba la mísera realidad del anhelado imperio: unos poblados de barro, curiosos por sus edificaciones de varios pisos, y sus extrañas cámaras subterráneas, pero sin ningún incentivo que asegurase la afluencia de nuevos colonos y sin la menor perspectiva de alguna futura prosperidad.

Era absurdo, en estas circunstancias, pretendẹr erigir Nuevo México en virreinato, puesto que las organizaciones políticas con carácter de tal tenían como nota específica el ser económicamente autosuficientes, e incluso el ser el respaldo financiero de las provincias menos favorecidas. Oñate clamó en vano para que se le permitiera establecer puertos y enviar barcos y soldados. E1 nuevo reino conquistado no podía ofrecer a la Corona ni a los futuros posibles pobladores otra cosa que tierras, pero esto era algo excesivamente abundante en la monarquía española; había, eso sí, un núcleo de población indígena y en un grado aceptable de civilización, pero su expiotación como mano de obra en las haciendas y ranchos de los españoles, ¿qué beneficios pecuniarios reportaría a éstos, que no tendrían ningún mercado en que expender sus productos?

La desalentadora realidad condujo a muchos de los acompañantes de

4 Son de primordial interés para los temas abordados en este epigrafe las obras de Mecham, J. Lloyd: Francisco de Ibarra and Nueva Viscaya. Durham, 1927. Alessio Robles, Vito: Francisco de Urdiñola y el norte de la Nueva España. México, 1931. Saravia, Atanasio G.: Apuntes para la historia de la Nueva Viscava, 3 volúmenes publicados. México. 1938ribs6. Vol. I: La Conquista. Dunne, Peter Masten: Pioneer jesuits in northern Mésico. Berkeley and Los Angeles, 1944. Gallegos, José Ignacio: Durango Colonial, r563-182r. Durango, 1960. 
Oñate a abandonar el territorio, y éste estuvo a punto de perderse definitivamente para los españoles, de no haber surgido un problema que sólo se comprende en las circunstancias de la España de los Siglos de Oro. La cuestión que se plantean la junta de teólogos y juristas convocada en México por el virrey Velasco, y el Consejo de Indias en Madrid, es la de si es lícito en conciencia abandonar de nuevo, para ser reabsorbidos por la gentilidad, los indios ya bautizados por los franciscanos en Nuevo México. La junta, en I602, estuvo por la conveniencia de enviar algunos soldados que protegiesen a los frailes, caso de que todos los colonos regresasen. El Consejo, en I608, viendo lo gravoso que resultaría a la Corona mantener su dominación sobre el territorio, decide desalojarlo, dejando a opción de los religiosos el quedar o no allí voluntariamente, bien entendido que en el último caso se traería a los indios cristianos, de grado o por fuerza, a las poblaciones españolas más meridionales. Finalmente, ante la noticia que dio el $P$. Jiménez de que los bautismos llegaban ya a siete mil, la Corona resolvió tomar la provincia bajo su protección, haciendo quedar en ella cincuenta colonos españoles, y enviando misioneros y soldados. Con dieciséis de éstos hizo su entrada el nuevo gobernador Don Pedro Peralta en I609, verificándose a poco la erección de la capital en Santa Fe, en sustitución de la antigua de San Gabriel.

De esta manera se consolidó el dominio de España sobre Nuevo México, en el curso superior del río Grande. Santa Fe venía a estar en la mediación de la distancia entre Taos, la localidad más septentrional, e Isleta, la más meridional. Hacia el este los asentamientos más alejados de los pueblos se situaban en el primer tramo del río Pecos. Hacia el oeste, los franciscanos alcanzaron la región de los moquinos, junto al río Colorado. Cientos de leguas separaban la provincia de los más septentrionales poblados de la frontera de Nueva Vizcaya: abandonando Santa Bárbara, el cordón de los carros que subían a Nuevo México se internaba siguiendo el curso del río Conchos, remontando luego el Grande. Estas caravanas llegarían a hacerse anules hasta el día de la Emancipación. 5

5 La mejor obra sobre la conquista de Nuevo M'éxico es, sin duda, la de Hammond, George, P.: Don Juan de Onate, and the foundirg of New Mexico. Santa Fe, I927. Del mismo, Oñate's effort to gain political antonomy of New Mexico. H.A.H.E., XXVII, 19:52, 32I-330. Del mismo y Rey, Agapito: The Crozen's purticipation in the founding of New Mexico. N.M.H.R., XXXII, 4, oct. 1957, 293-309. Hammond y Rey han publicado dos volímenes de documentos relativos a la conquista de esta provincia, con el título de Don Juan de Oñate, colonizer of New Mexico, 1595-1628. Cuarto Colorado Centennial Publications. The University of New Mexico Press, Iy53. Imposible olvidar la Historia de la Nueva Mértico, de Gaspar de Villagrá, reimpresa por e! Museo Nacional de México, con apéndices documentales, en 2 vols. México, 1900. 


\section{LA ACTIVIDAD MISIONAL}

Franciscanos y jesuitas son los dos puntales sobre los que apoya toda la acción evangelizadora desplegada en las provincias internas. Sobre la Orden y la Compañía recayó todo el peso de esta ardua labor, y hay que decir que ambas estuvieron perfectamente a la altura requerida, entregándose de lleno y con enorme entusiasmo a su labor. El éxito que alcanzaron, sin embargo, les fue cobrado al precio de la sangre de ciento treinta y dos misioneros inmolados sobre aquellas tierras por los indígenas, a lo largo de doscientos cincuenta años de actividad.

Los primeros en penetrar en el territorio fueron los franciscanos, que descle Zacatecas pasaban, el mismo año de I555, a establecerse en Nombre de Dios. En esta población radicó desde i 566 la Custodia de los indios zacatecas, que reunió los conventos de Durango ( ${ }_{5} 6_{3}$ ), Topía, el Valle de San Bartolomé (I564) y San: Juan del Río (I 568). En I 584 y i 588 se fundaban las misiones de San Juan y San Francisco de Mezquital.

Desde el mismo centro difusor de Zacatecas se dirigieron los frailes a Saltillo (I 595) y, por el río Aguanaval, a Cuencamé (I 593). En todos estos sitios fue anterior la penetración misional al asentamiento de poblaciones o reales de minas españoles si bien no en todos perduraron los establecimientos franciscanos, pues a fin de siglo esíaban abandonados los de Topía, Saltillo y Cuencamé. En cambio no tardan en aparecer nuevos centros misionales en San Francisco de Conchos (1604), más al norte de San Bartolomé, y Guazamota ( 1606 ), en la región de Nayarit, a las que poco a poco fueron introduciéndose.

Estas fundaciones son contemporáneas a las verificadas en la región de Zacatecas y San Luis de Potosí, a que hemos hecho referencia en el capítulo anterior. En Nueva Vizcaya, la actividad franciscana se intensifica en las proximidades de Durango y en la cuenca alta del Conchos, donde tiene lugar la erección del convento de Parral, en I642.

Ya en estas fechas, la expansión de los franciscanos halla amplio y nuevo campo hacia el oriente, por tierras de Nuevo León, y no es ya hasta r669 cuando se da un nuevo avance por los religiosos de la Orden en Nueva Vizcaya, que van ahora de nuevo de un sólo impulso, a establecerse en la más avanzada posición, en Casas Grandes, en el extremo septentrional de 1a Tarahumara, región que se evangeliza desde las misiones de Torreón. Carretas, Natividad, Namiquipa, Babonoyaba, Santa Isabel y San Andrés, fundadas en esta época a fines del XVII: desde estos puntos se intenta la evangelización de conchos, sumas, janos y apaches.

Entre tanto. un importante núcleo misional se ha formado más al norté, 
en Nuevo México, lugar a cuya evangelización tenían sobrado derecho los franciscanos después de las expediciones de Fray Marcos de Niza y de los frailes que desde San Bartolomé habían salido con Espejo, hallando el martirio junto al río Bravo.

Nueve individuos de la orden acompañaron a Oñate en la conquista, dando comienzo a la conversión de los indios pueblo. Cuando en I608 Nuevo México queda convertida en provincia de misión, los franciscanos empiezan a crecer en número, de tal manera que en 1622 se cuentan dieciocho frailes y seis legos, y los indios bautizados se acercan a los veinte mil. La evangelización se extiende por ambos lados del río Grande, sobre todo hacia el oeste, por la región llamada del Moqui. Los intentos de ampliar la labor de apostolado hacia el sur cristalizan, ya mediando el siglo, en la fundación de la misión de Nuestra Señora de Guadalupe del Paso, a orillas del río Grande, realizada el 8 de diciembre de 1659 . Este establecimiento sería embrión del segundo núcleo colonizador de Nuevo México.

En un avance paralelo al de las misiones franciscanas, los jesuitas, aunque llegados años más tarde que aquéllos, no tardan en extenderse por ambas vertientes de la Sierra Madre Occidental.

En I590 hacían su entrada en Durango por primera vez, pero sólo años después, con la fundación de un Colegio, arraigarían en la capital. En cambio, los primeros padres llegados pasaron inmediatamente a la villa de Sinaloa, donde establecieron su primer foco misional, de actividad ininterrumpida hasta la fecha de su expulsión. Con los de Sinaloa, las misiones de la Tepehuana, iniciadas en I596, y las de Topía, a que da comienzo el P. Santarén en I600, son los principales campos de actividad de los jesuitas. Un cuarto núcleo de evangelización fue establecido, desde Zacatecas, en la región de la Laguna, a partir de $\mathbf{5} 54$.

En Sinaloa, desde su llegada, los dos primeros misioneros ejercen su apostolado en la región. En I 593 pasan al río Fuerte, y posteriormente al Mayo hasta que es asesinado el P. Tapia (I 594). Con estë acontecimiento la evangelización se limitó al Fuerte por unos años. Luego, en I6I4 vuelve a alcanzarse el Mayo, y en I6I6 el P. Ribas solicitó permiso para avanzar hasta el Yaqui, lo que se verificó al año siguiente. Remontando su curso, los jestitas llegaron a las tierras de los indios ópatas y pimas. Por aquella fecha los padres de la Compañía que trabajaban en la región eran veintisiete, con algunos hermanos. En la tercera década del XVII, el número de bautizados pasaba de ciento cincuenta mil. A mitad de siglo llegaba a los cuatrocientos mil.

Desde Durango, en cambio, situada en el centro del país de los tepehuanes, se había iniciado ya en 1596 , de manera accidental, la evangelización 
de estos indios. En I 597 el P. Ramírez, bajando por el río Santiago, fundaba la misión de Santiago Papasquiaro, y remontando el de Tepehuanes establecía la de Santa Catalina. La tercera misión erigida aquel mismo año por el Padre Ramírez, fue la de Guanacevi. El paso principal se había dado con esto con incréble rapidez y éxito. Después, entre 1606 y I607 quedan establecidas las misiones de San Gregorio, en el límite con los jijimes; Otatitlán con los sobaibos; Tamazula con el distrito de Topía y San Andrés; Baimoa, con las minas de Carantapa; y Atotonilco. En estas cinco misiones se afanaban ocho jesuitas.

La naciente prosperidad de los establecimientos se vio turbada con las inquietudes de jijimes y tepehuanes, en años posteriores. Pero ya a partir de ${ }^{6} 630$ fue posible extender las predicaciones a los territorios más meridionales, por tierras de los hinas y humis, en la cuenca alta de los ríos Piaxtla, Guarisamey, Humas, San Bartolomé y San Pedro, por el corazón de la Sierra. El pueblo de San Pablo, en las fuentes del río del Presidio marca la máxima expansión alcanzada por la Compañía hacia el sur: Santa María Otaes, Guarisamey y Yamoriba eran las misiones intermedias.

El padre Ramírez, que actuó diligentemente en los primeros días de las misiones de los tepehuanes y de Topía, había sido el primero en predicar el Evangelio, en I 594, en los ríos de las Nieves y Nazas, en la zona de Cuencamé, donde un anterior convento franciscano habíase extinguido tiempo atrás. Cuatro años después verificábase la erección de la misión de Santa María de Parras, doncle se formó pueblo con un grupo de tlaxcaltecas venidos de Salitllo. Descle Parras se lleva ahora a cabo la evangelización de la Laguna: a principios de siglo se fundan misiones de indios zacatecas en San Pedro, Santa Ana, y San Ignacio. En 1604 ya hay cinco mil quinientos bautizadios. Sucédense luego algunas calamidades: viruelas, que alcanzaron a Mapimí, donde ya se había fundado misión jesuita, e inundaciones. Más adelante la predicación se hace extensiva a más de doscientas familias de indios conchos y de otras naciones que vienen a establecerse en el país. Todos estos indios "laguneros" estuvieron un momento complicados en el levantamiento de los tepehuanes en I6I6, y parece que intervinieron en el asalto a Mapimí; pero los misioneros lograron pacificarlos, y al año siguiente son ya los más fieles aliados contra los insurrectos. Magníficos arqueros, el gobernador Alvear utilizó un centenar de laguneros en sus campañas.

Durante treinta años las misiones de la Laguna se mantienen en paz y bonanza, hasta que en 1646 el obispo de Durango hace que los jesuitas las entreguen al clero diocesano. A' poco, todas ellas estuvieron despobladas. 6

6 Aden1ás de las obras de Cuevas y Dunne, ya citadas, aluden al movimiento misional las de Alegre, Francisco Javier: Historia de la Compañía de Jêsús en Nueva España. 3 vols. M'éxi- 


\section{LOS PRESIDIOS}

Hasta época muy reciente, el vocablo castellano "presidio" conservó iodo su sabor clásico de "fortaleza" o "cuartel", y con este sentido se aplicó a las guarniciones militares establecidas en diferentes tiempos y lugares en todas las provincias internas, como en el resto del Imperio Español.

Los presidios fueron, en Nueva Vizcaya, fruto de la necesidad y expresión máxima del carácter de frontera que tọda la región presenta.

Todos los habitantes de las provincias internas tenían en común con el hombre de la Reconquista española el ser a un tiempo trabajadores y soldados, y esto tiene validez general, sobre todo en los dos primeros siglos de la dominación española. Claro ejemplo lo da Saltillo. Ganaderos erar, en su mayoría, los vecinos de la villa; agricultores los indios del vecino pueblo de San Esteban de Nueva Tlaxcala. Y unos y otros levantaban compañías de hasta cien hombres cada vez que era preciso defenderse o acudir en al1xilio de las localidades vecinas de Coahuila y Nuevo León.

La necesidad de la propia defensa planteóse por primera vez en la villa de San Felipe y Santiago de Sinaloa, que después del asesinato del P. Tapia, fortaleció el Capitán Alonso Díaz en I 595 y guarneció con veinticuatro soldados. Antes de este hecho, ya la primera ocupación de los españoles al fundarse la población había sido la de edificar un pequeño reducto. Más adelante, gobernando el virrey condé de Monterrey, erigiéronse presidios en Chiametla y Sinaloa, bajo la advocación de San Sebastián y San Juan Bautista. Este último, a orillas del río Fuerte, al que dio nombre, fue llamado Fuerte de Montesclaros. Aquél, como el de Ácaponeta, aseguran el país frente a los vecinos indios del insumiso Nayarit.

Por aquellos mismo años, primeros del siglo XVII, la preocupación defensiva fue tomando preponderancia en toda Nueva Vizcaya. En efecto, ya en I60 i tuvo lugar el primero de los continuados levantamientos que conmovieron el reino durante todo el siglo. Los acajees sublevados llegaron incluso a sitiar una guarnición española de cuarenta hombres en San Andrés, en la sierra. Todavía tres años más tarde hubo de acudir el famoso Urdiñola

\footnotetext{
co, I842. Decorme, Gerard: La obra de los jesuitas mexicanos durante la época colonial. 1572176\%. (Compendio histórico). 2 vols. México, i941. La sucesión de lars fundaciones franciscanaz se desprende de la relación publicada por Peña, Francisco: Estudio histórico sobre San Lwis de Potosí. Potosí, I894, págs. 24-27. La labor realizada en Nuevo México se evidencia en el Memorial de 1630 de Fr. Alonso Benavides, reimpreso en México, I 89,9 , en el segundo volumen de la Historia de Villagrá y traducido al inglés últimamente por Peter P. Forrestal, con comentarios de Cyprian J. Lynch, publicado por la Academy of American Franciscan History, Washington, 1954. E1 Memorial revisado de 1634 fue traducido y publicado por Hammond y Rey en Alburquerque, 1945. Es sumamente ilustrativa la obra de Saravia, Atanasio G.: Los misioneros muertos en el norte de Nueva España. 2." edición, México, I943.
} 
a sofocar los íltimos fuegos de la rebelión, después de lo cual le fue posible retirar parte de los soldados que había en aquel presidio, asegurando que pronto sería factible hacer lo mismo con los demás.

San Andrés y San Hipólito parecen hacer sido los únicos presidios existentes tal vez antes de entrar en el siglo XVIII, con objeto de asegurar la sumisión de los acajees y jijimes. Sin embargo, en ningún caso se logró. En I6r I, el capitán de San Hipólito, Bartolomé Juárez, hubo de actuar enérgicamente para reprimir una insurgencia entre los jijimes.

Pero las verdaderas turbaciones empezaron con la inquietud de los tepehuanes, la nación más numerosa de Nueva Vizcaya, que durante dos años llevaron a calo tuna sangrienta rebelión. Con este motivo volvió a intervenir el capitán Juárez en I6.16, y el Gobernador Alvear tuvo que dejar constituido otro presidio de veinticinco hombres en el real de Guanacevi, y socorrer el de Acaponeta, dentro de la jurisdicción de Nueva Galicia, que los tepehuanes habían incendiado. El mismo Juárez se encargó de reducir a los alzados de las sierras de Mezquital y Guazamota, y quizás entonces se fundara un presidio en este lugar, del que fue nombrado capitán Don Jeróniimo de San Román. A fines de гбт7 llegaron de México tres compañías de soldados dispuestos a intervenir, y numerosos capitanes actúan por diversos rumbos con objeto de dominar la rebelión de los tepehuanes y sus aliados conchos, salineros, tobosos, etc.

"De hoy más pretende el Gobernador presidiar la tierra y asegurar los caminos con escoltas, y que anden dos compañías para lo que fuere menester". Fruto de este deseo, que Alvear es el primer gobernador en manifestar, pero que se convertirá en verdadera obsesión en todos sus sucesores, debió ser el presidio de Santa Catalina de Tepehuanes que ya existía en la tercera década del siglo XVII.

Sin embargo, concluída la revuelta de los tepehuanes, aguardaban a Nueva Vizcaya unos listros de paz. Y en 1635 , necesitando el rey hacer una poda en sus diferentes presupuestos con objeto de allegar fondos para la organización de la armada de Barlovento, encargó al virrey marqués de Cadereita suprimiese aquéllos de los presidios internos que pudieran excusarse sin riesgo. La reforma, en efecto, se hizo, ahorrándose cada año dos mi! pesos en beneficio de la armada, subsistiendo en lo sucesivo sólo cuatro presidios en toda la gobernación: San Sebastián, en Chiametla; San Felipe, en Sinaloa; San Hipólito, en la sierra, entre los jijimes; y Santa Catalina, entre los tepehuanes. 7

7 Se hallatá información soble los primeros presidios en Bandelier, Adolph F. A. and Bandelier Fanny R.: Historical documents relating to Nere Mexico, Nueva Vizcaya and approaches thereto, to 1773. Edición, introducción y notas por Hackett, Charles Wilson. 2 vols, Washington, I926. 


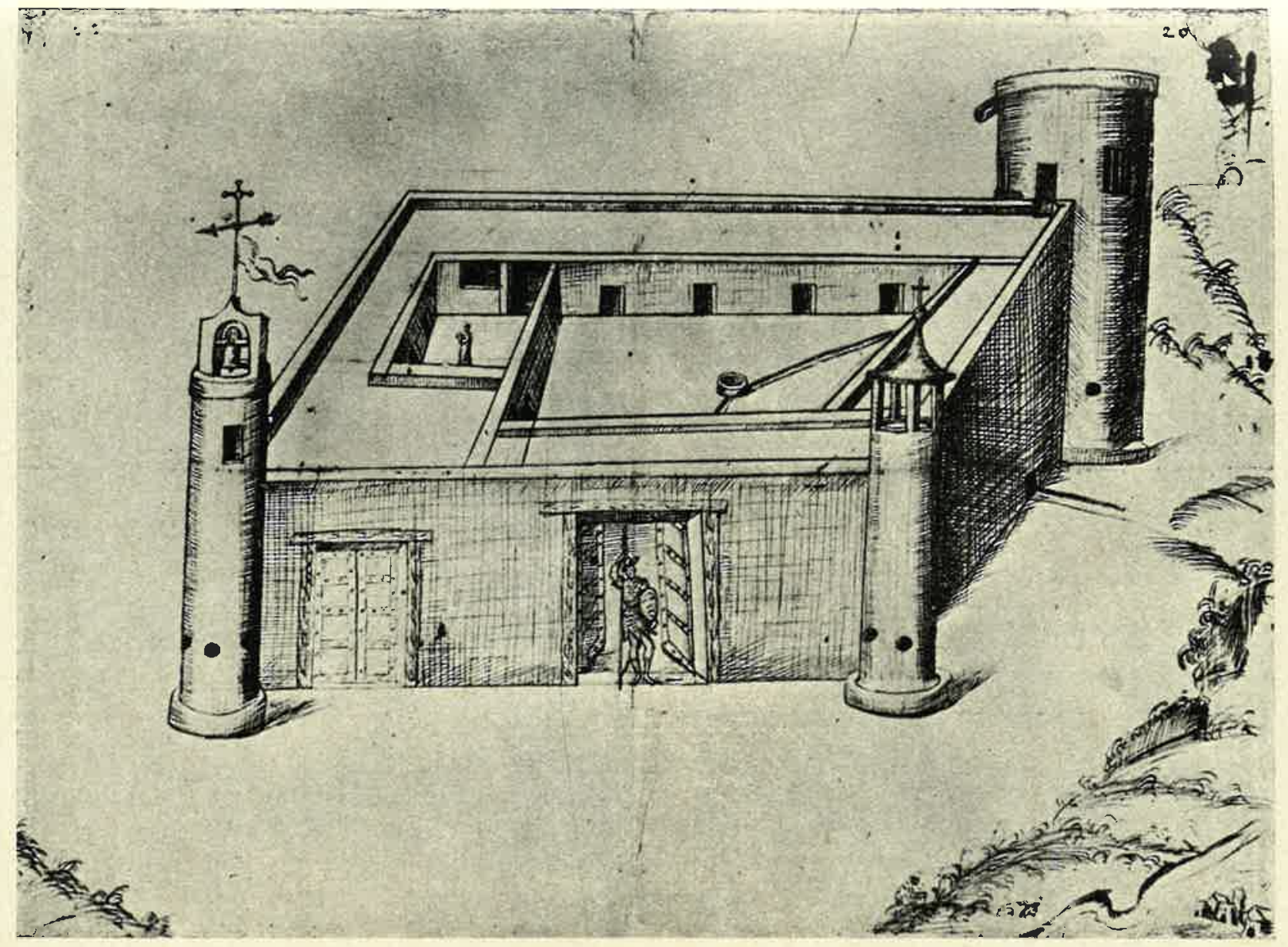

1. El presidio de Jalpa en 1576. 

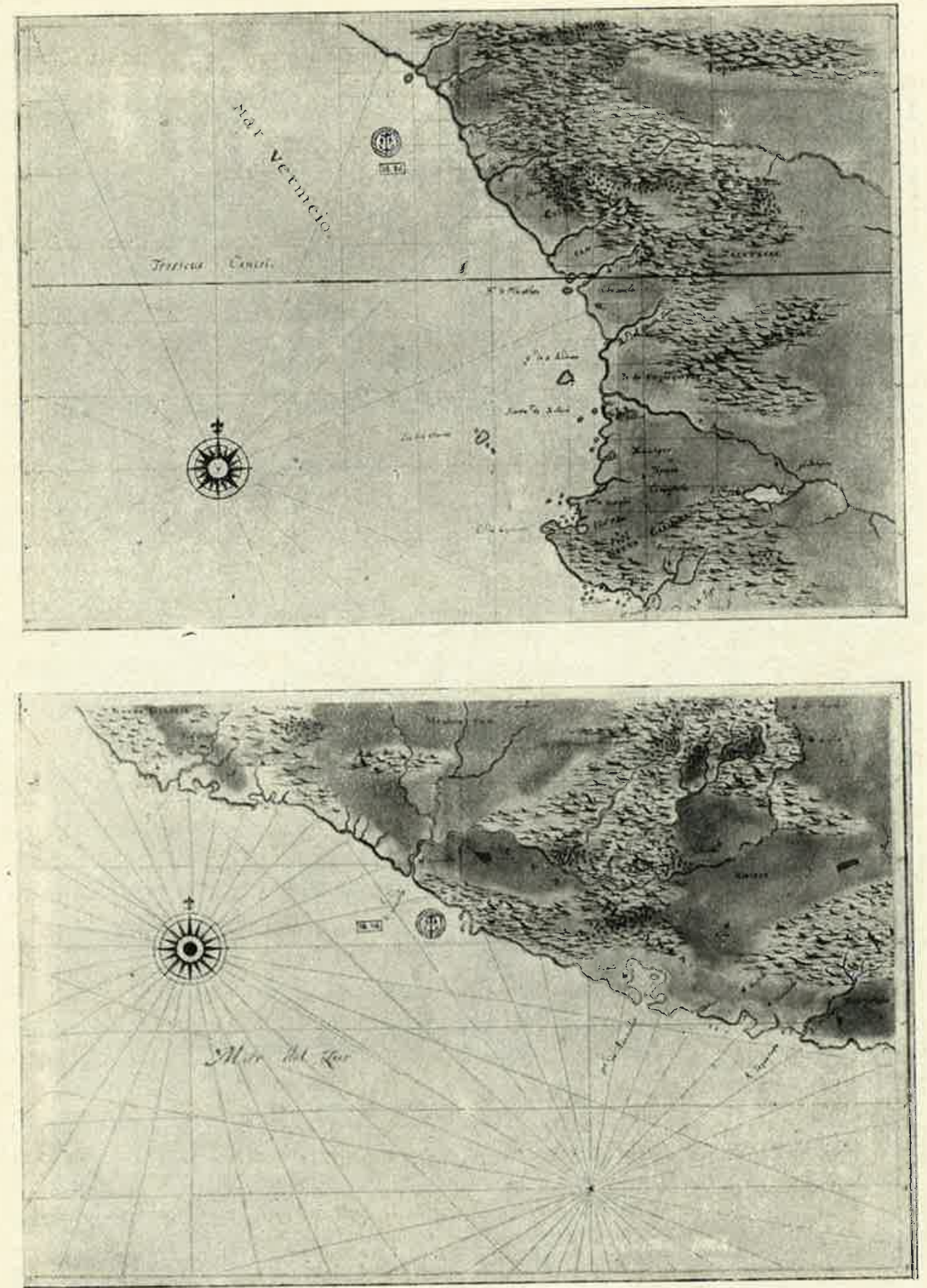

2. Mapal en ruarterones de Nueva España. is. XVII? La costa del Pacifico. 


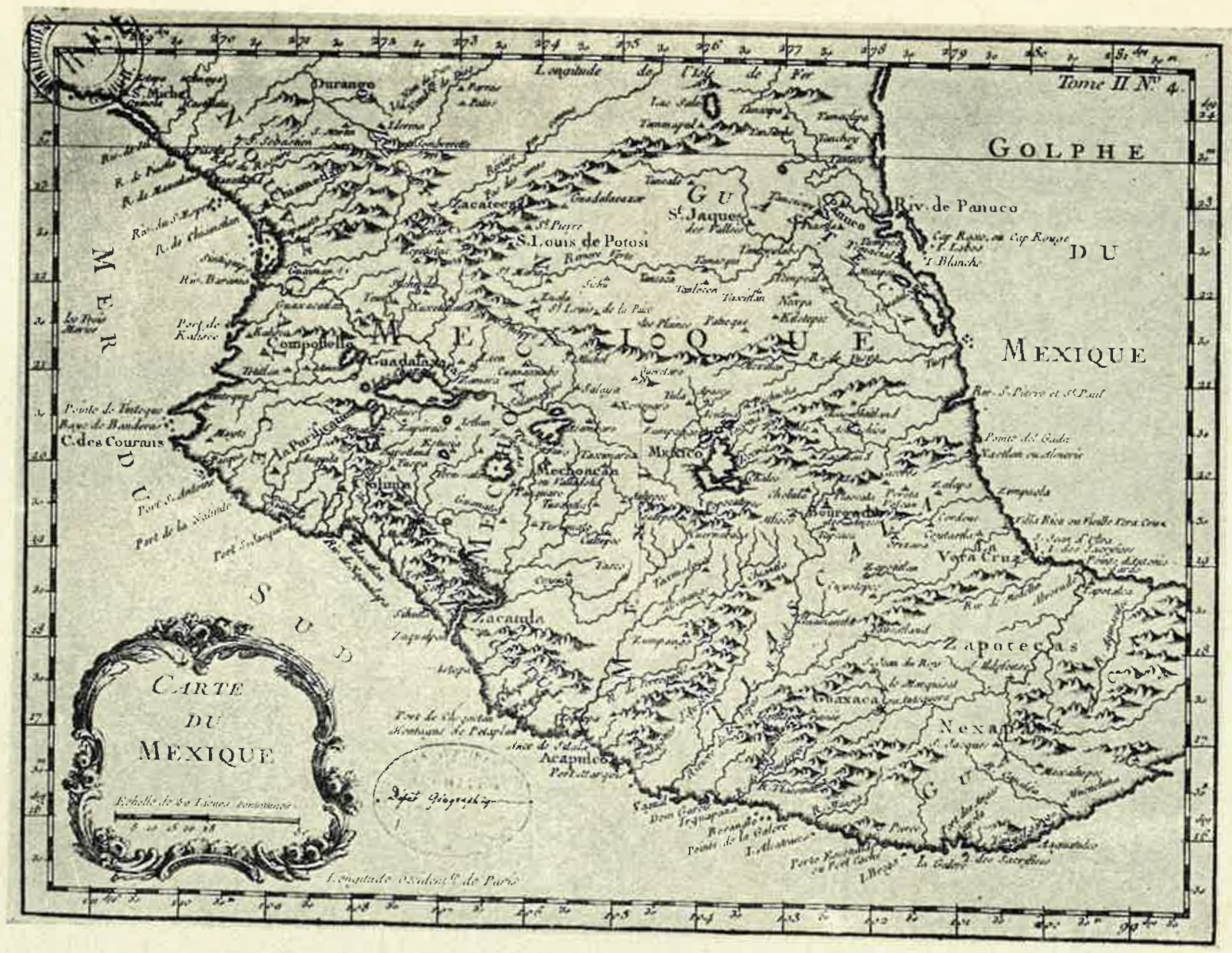

3. Mapa francés de Nueva España. S. XVIl. 


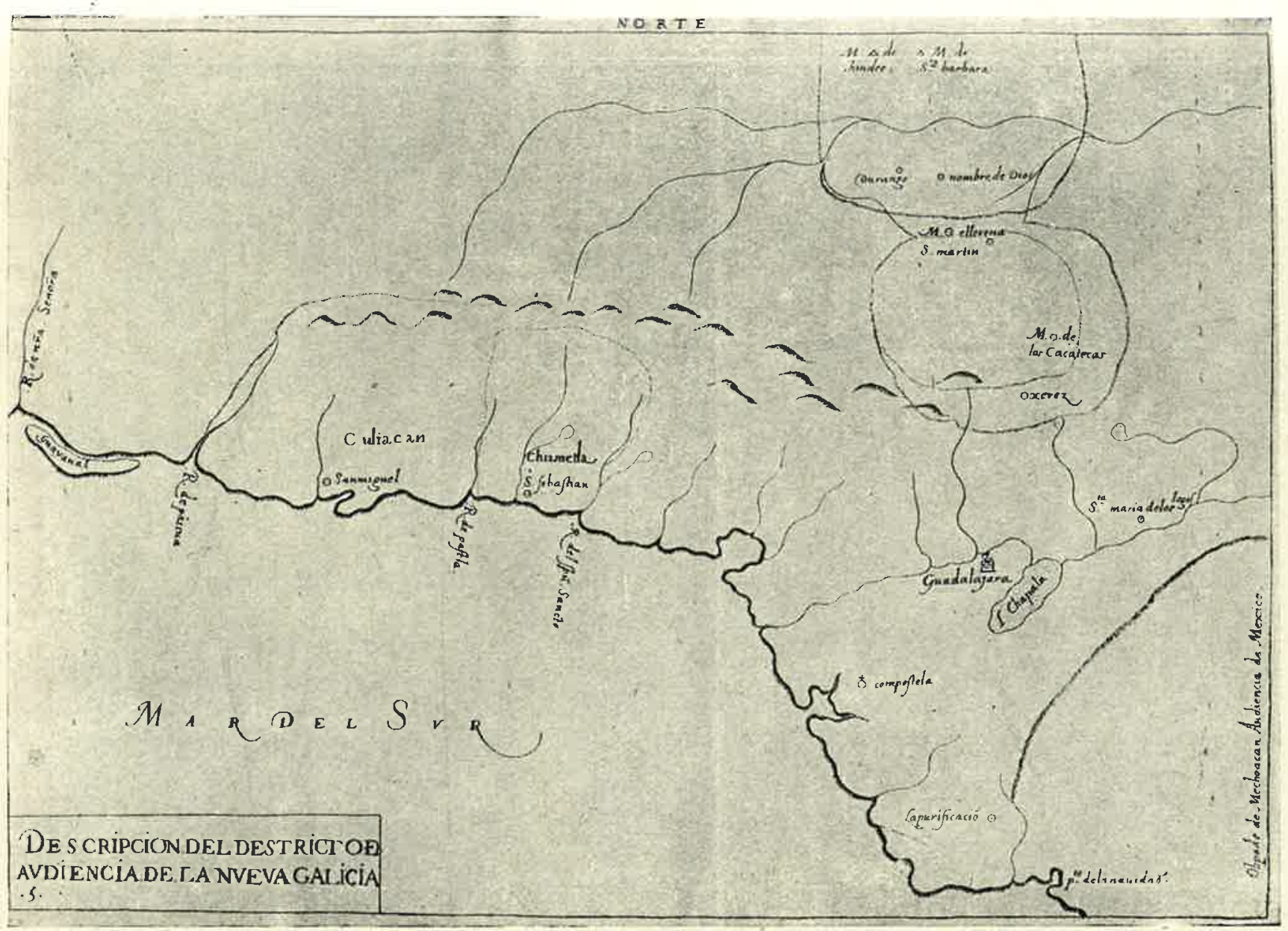

1. Nueva Galicia, en la obra de Herrera. 


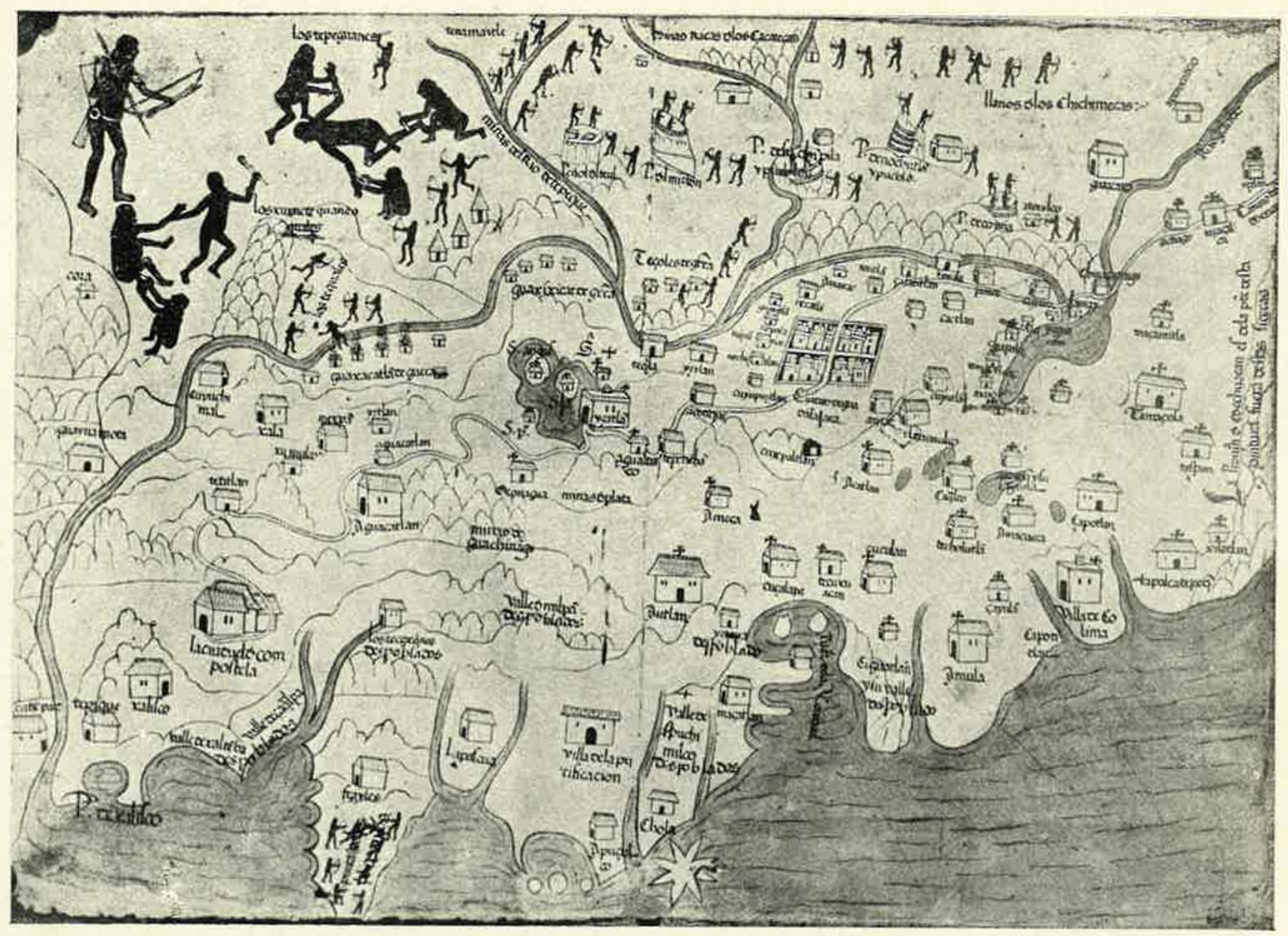

5. Mapa de los contornos de Guadalajara. S. XVI. 


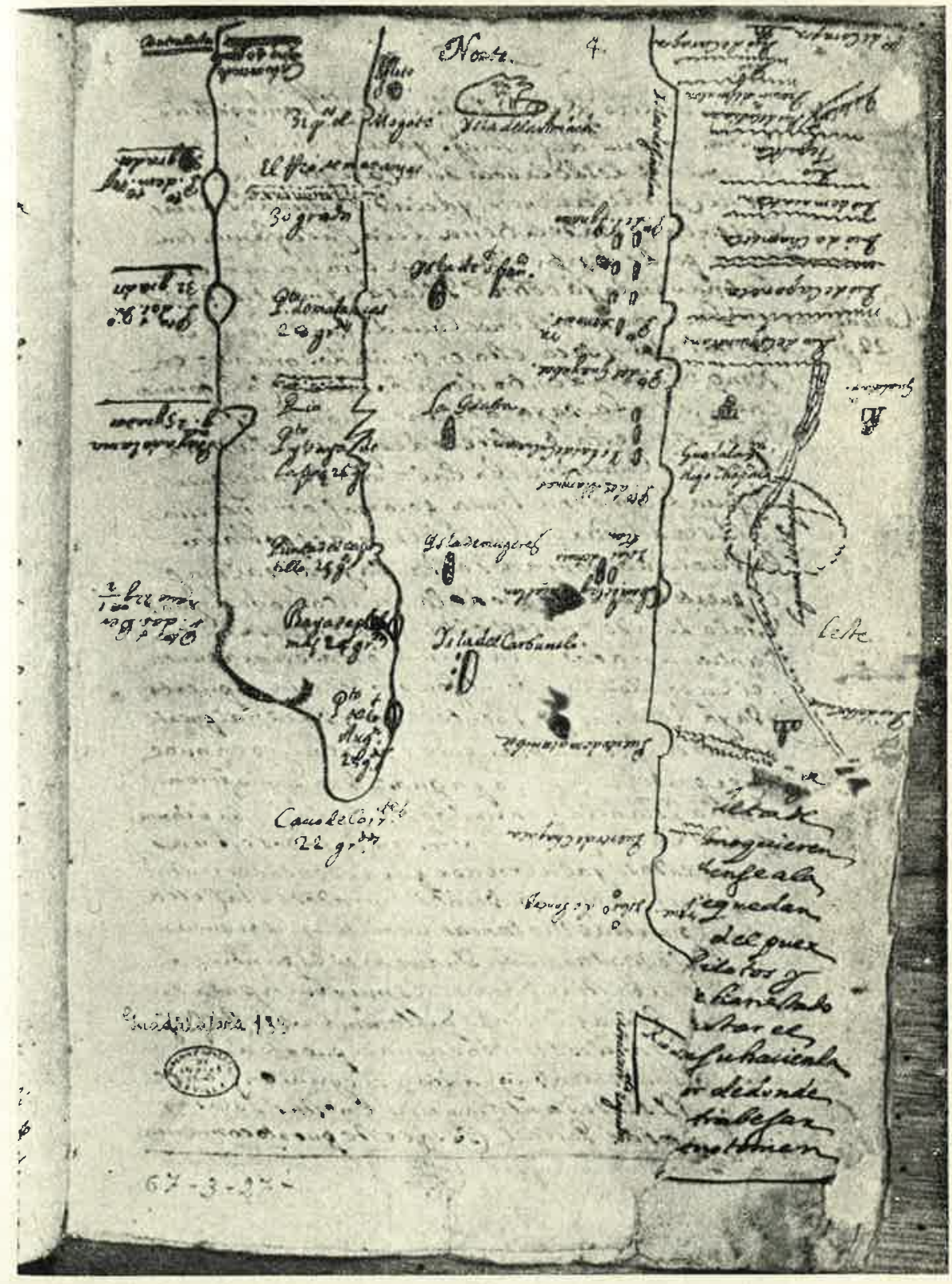

6. Croquis del golfo y peninsula de Californias. S. XVII. 


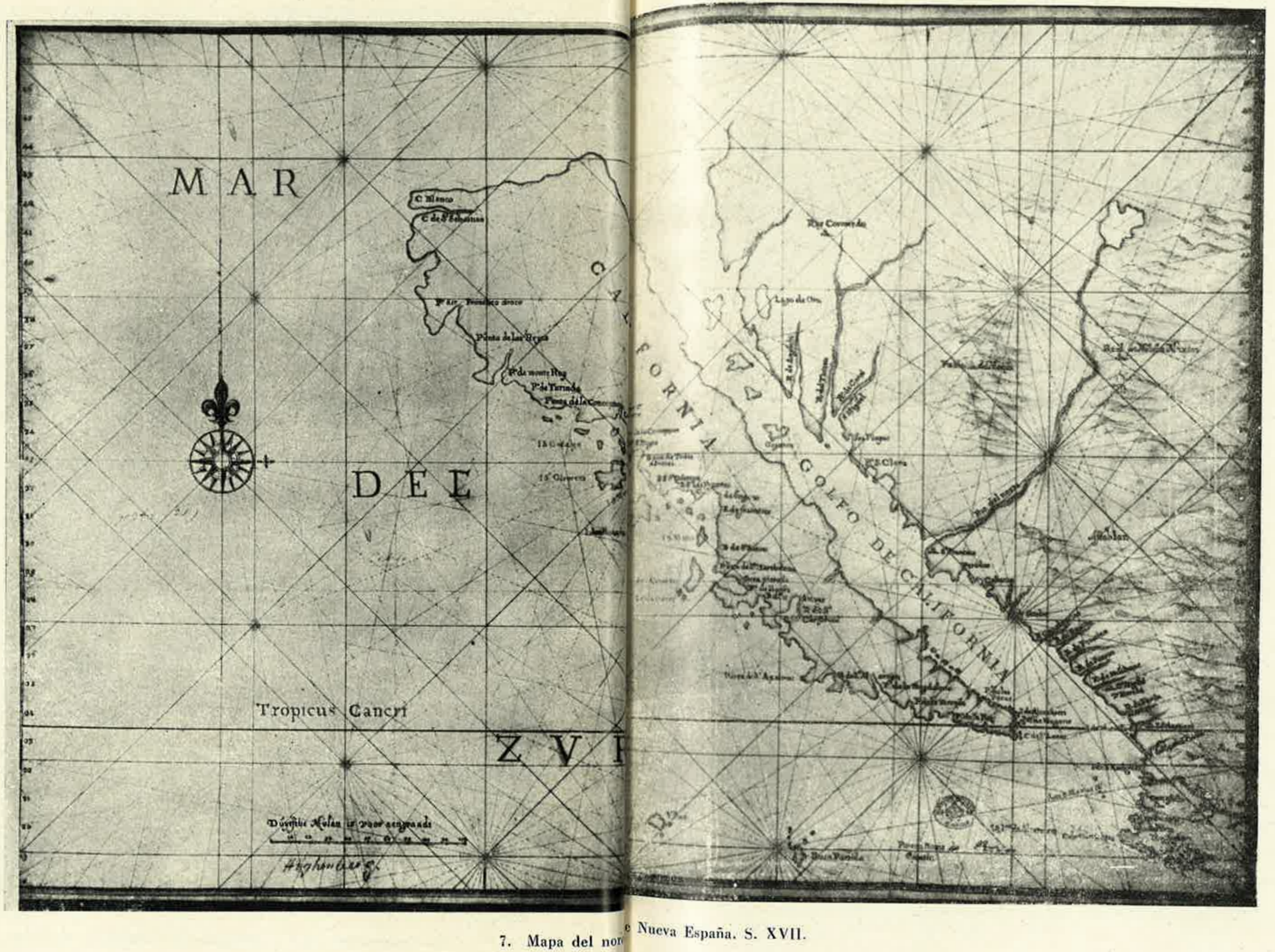




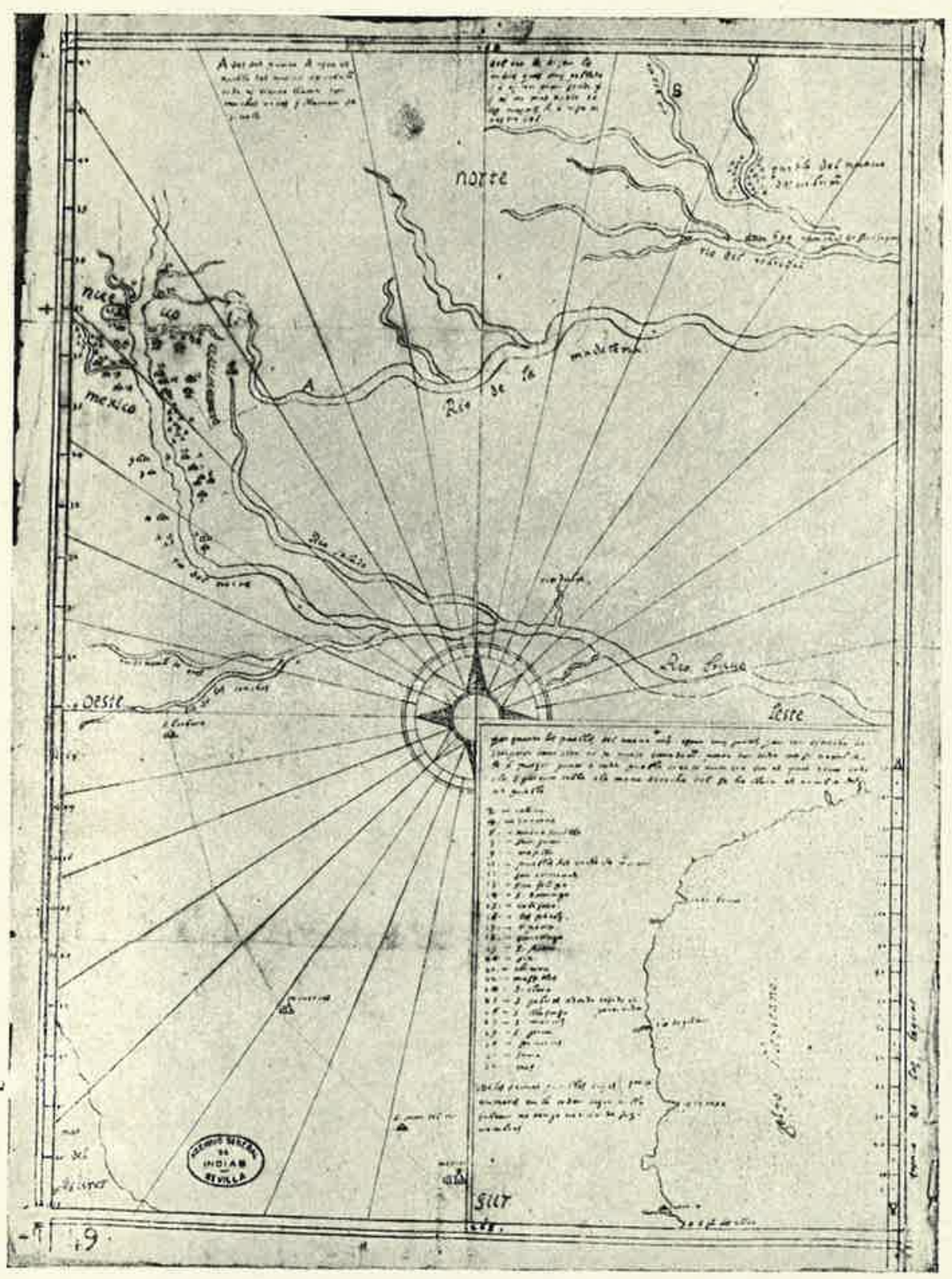

8. Mapa del eamino a Nuevo México y Quivira. 1601. 


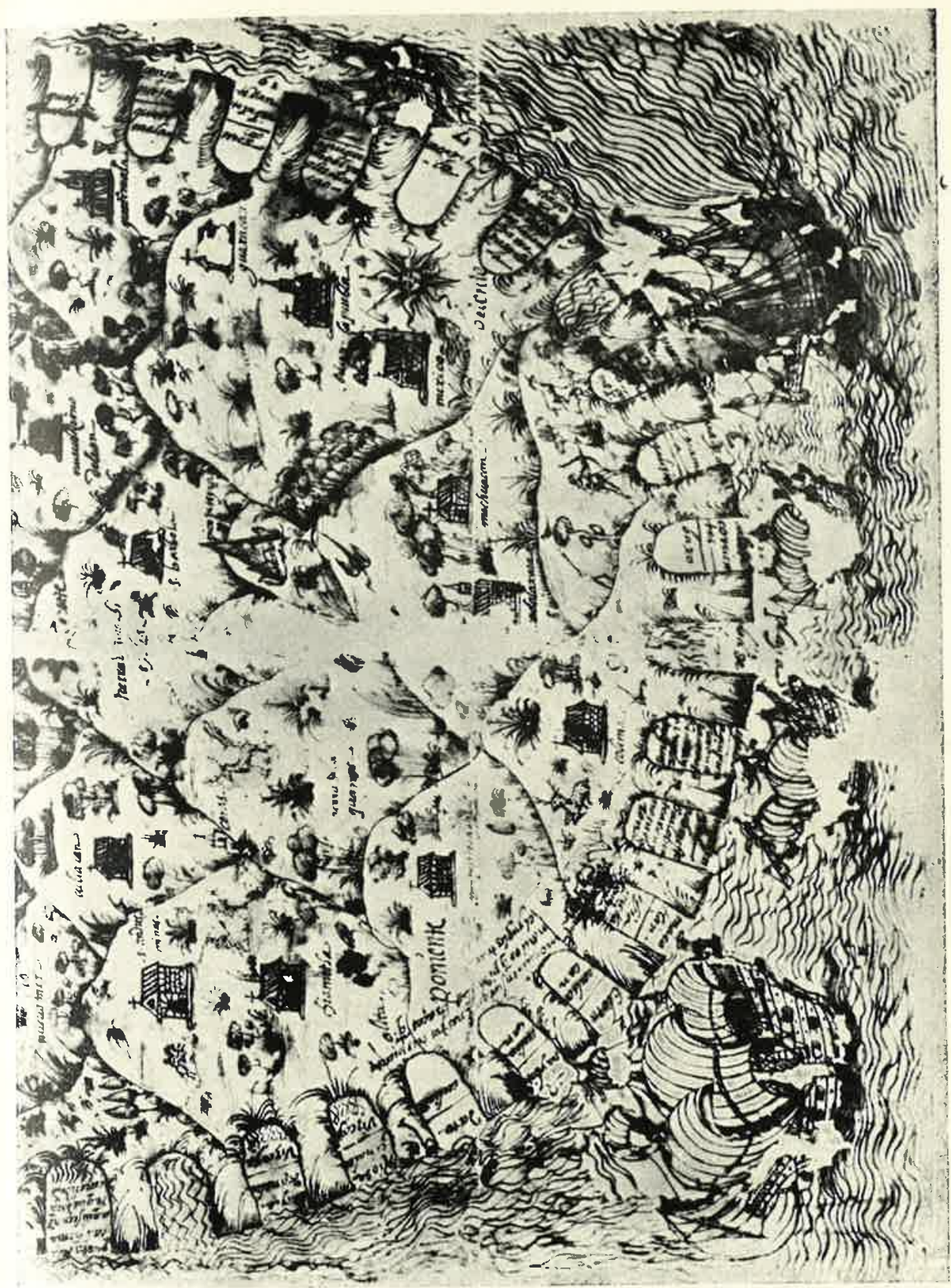

9. Diseño de las costas de Nueva España al Pacífico. S. XVII. 


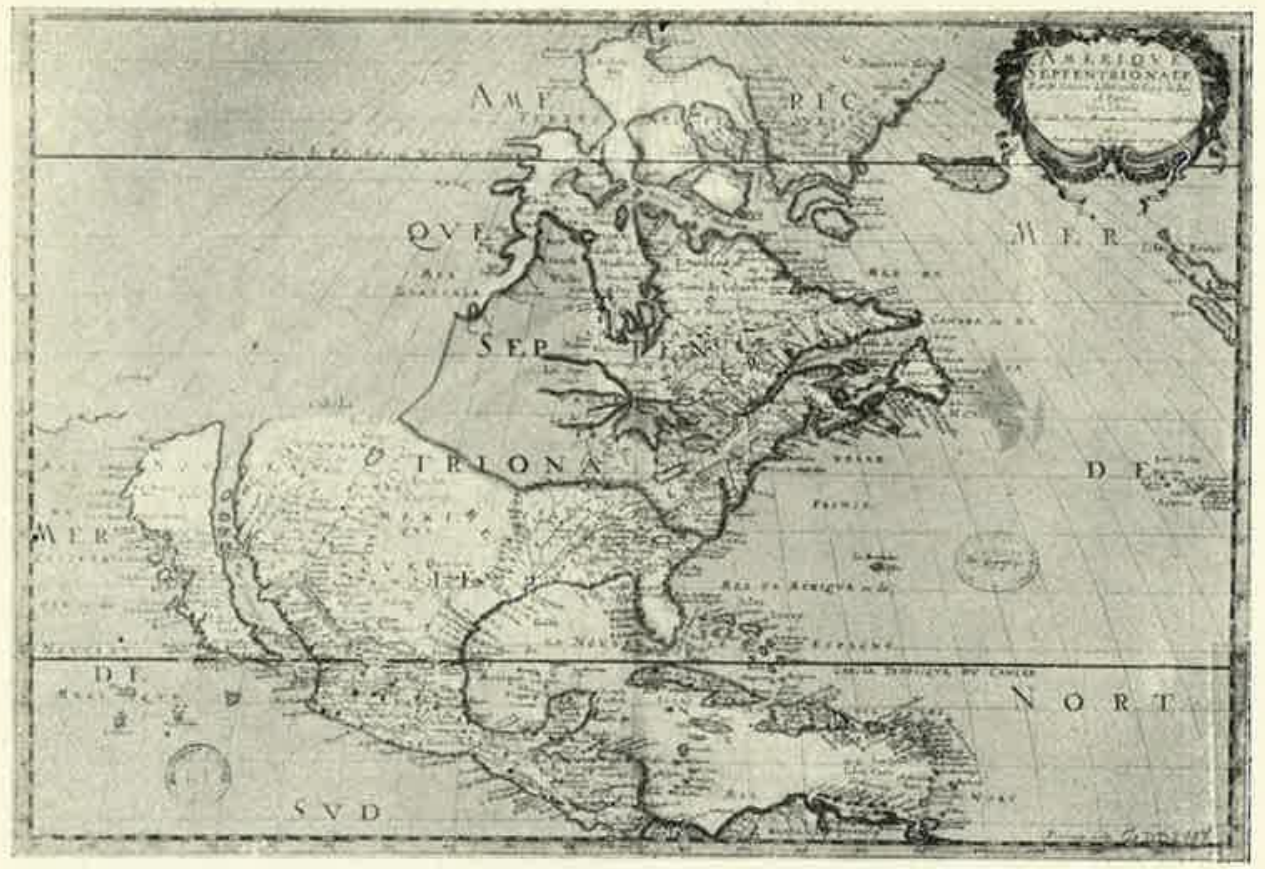

10. América del Norte, por Sansun, tusti.

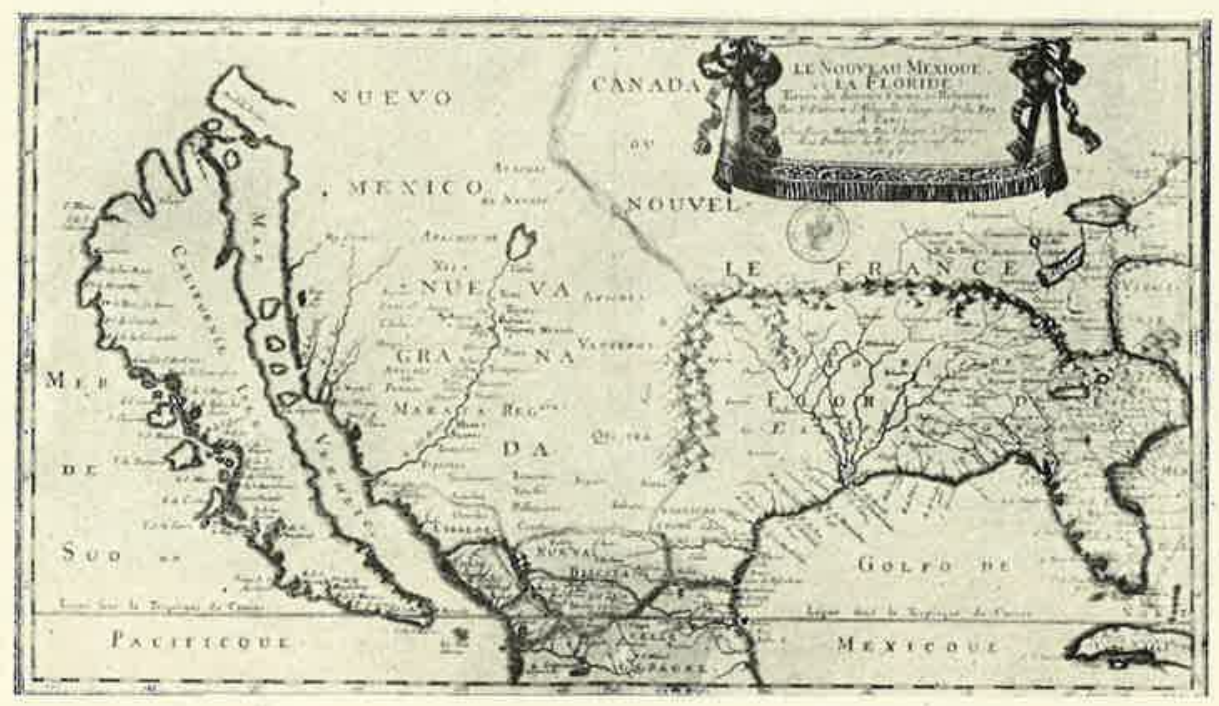

11. Nuevo México v Florida, por Sansón. 1656. 


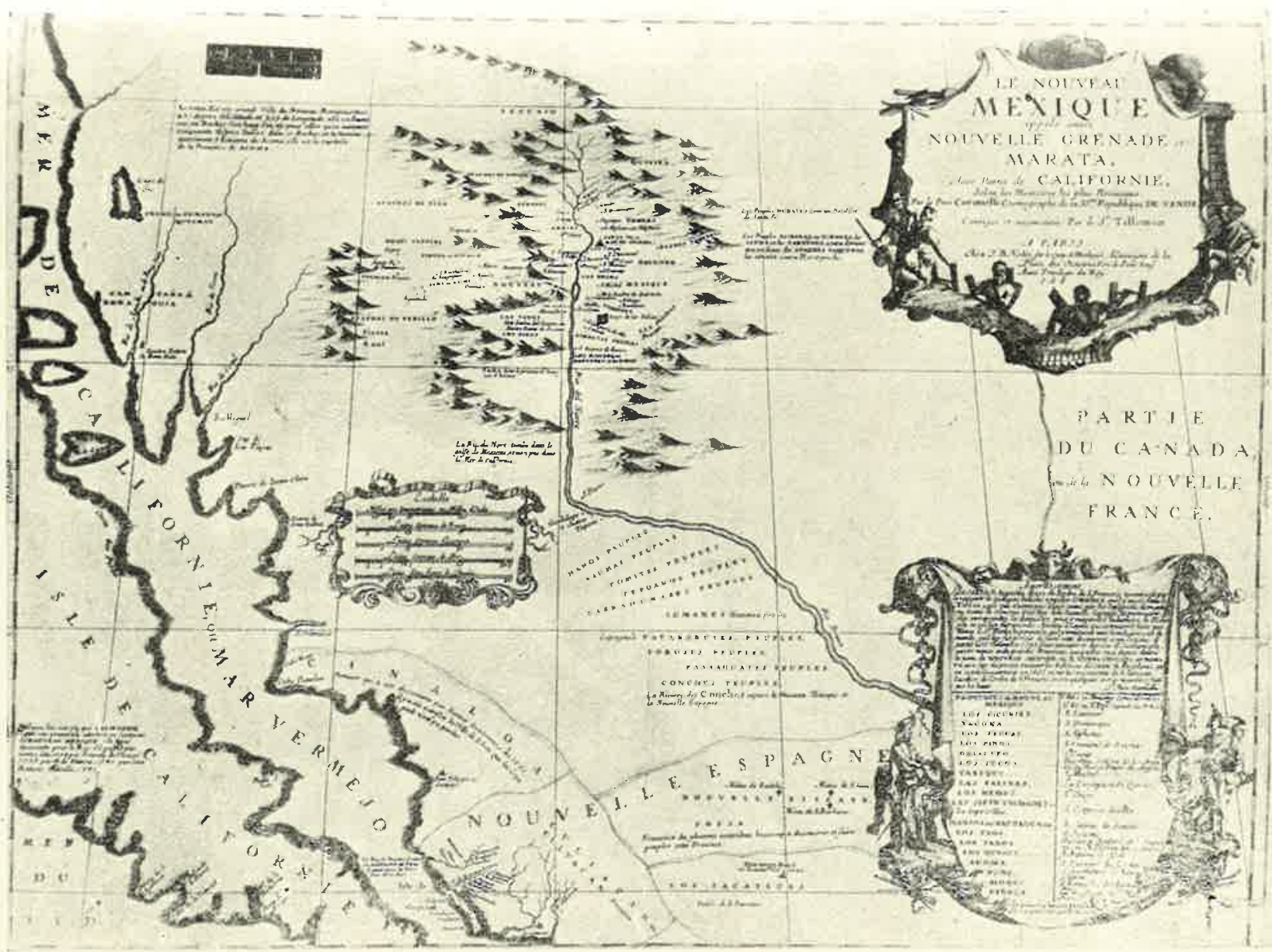

12. Nueve Méxieu, por Nolin. 1680. 


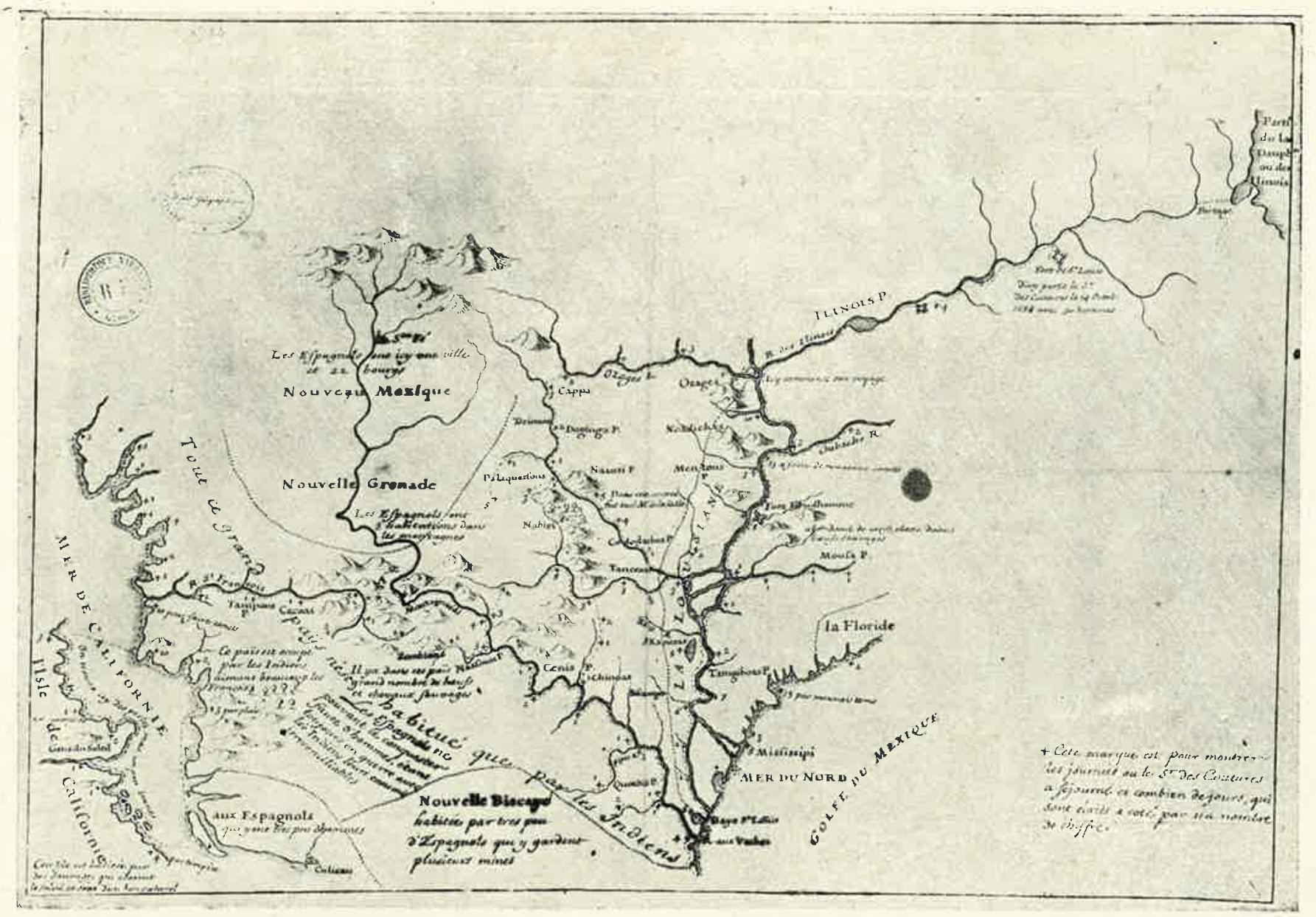

13. Luisiana y Nuevo México. ¿1700? 


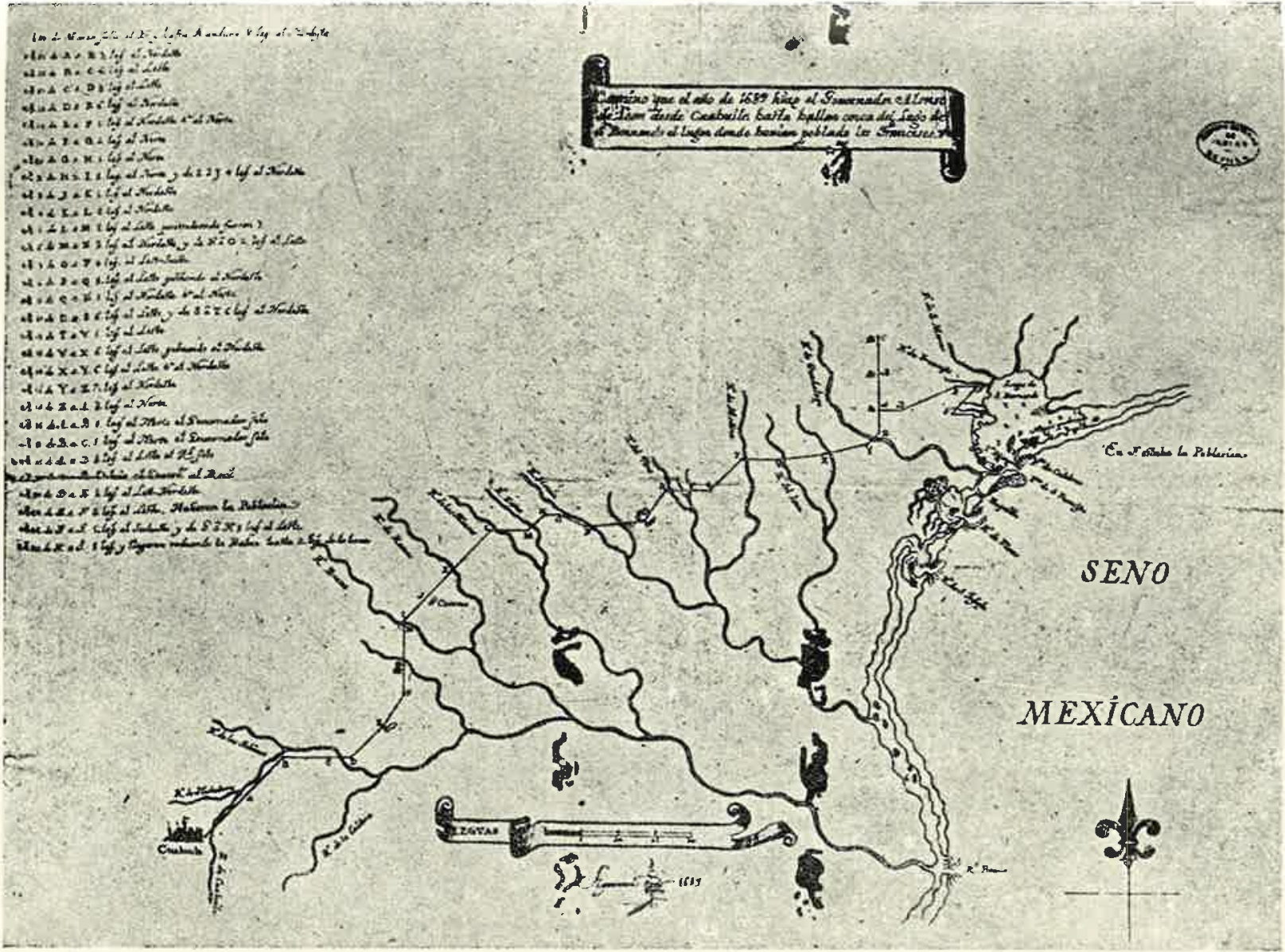

14. Ruta de Alonso de León, de Monclova a la Bahía del Espíritu Santo. 1689. 


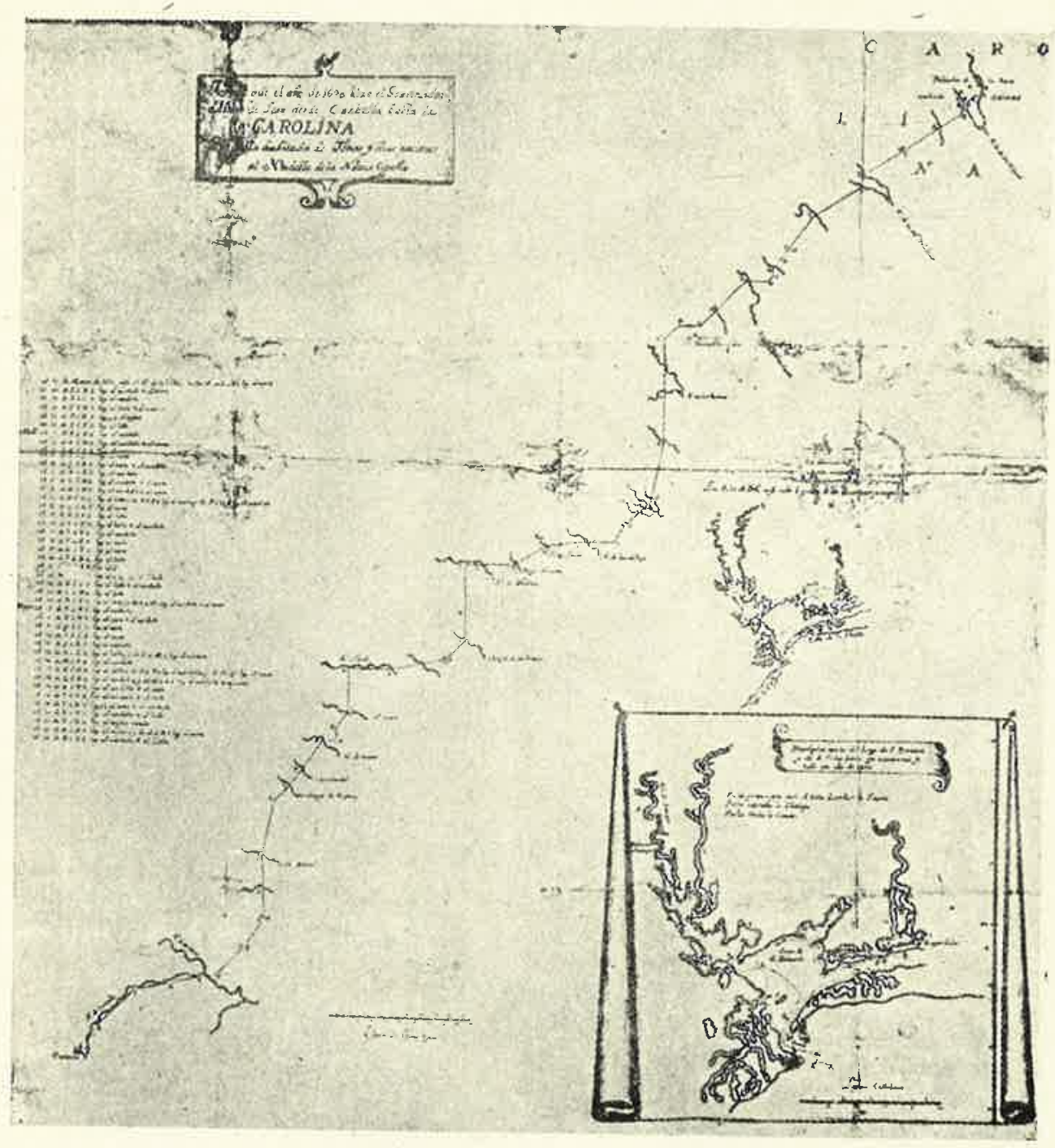

15. Ruta de Alonso de León, de Monclova a los Asinais. 1690. 


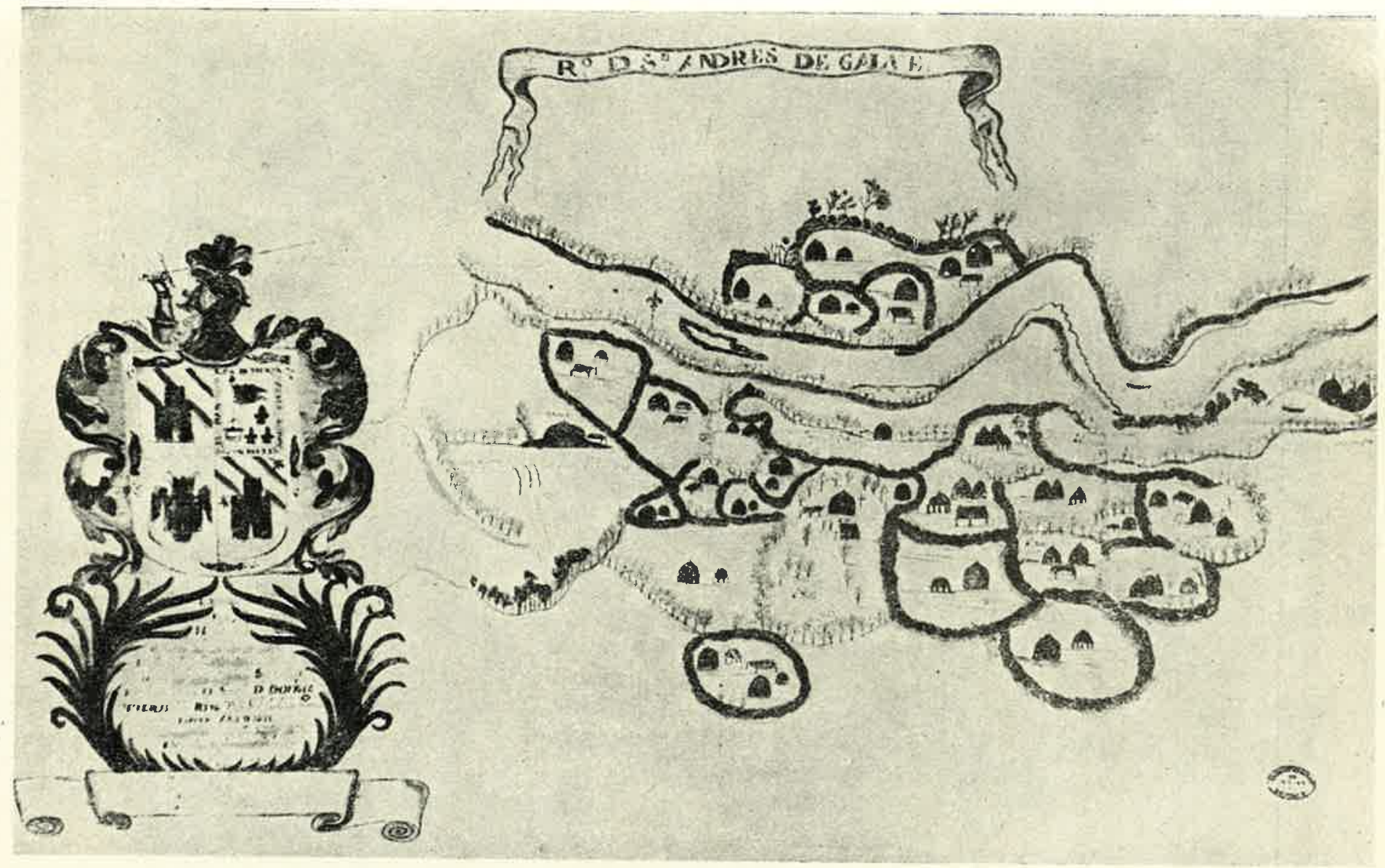

16. El país de los cadodachos, visitado por Terán de los Ríos. 1691. 


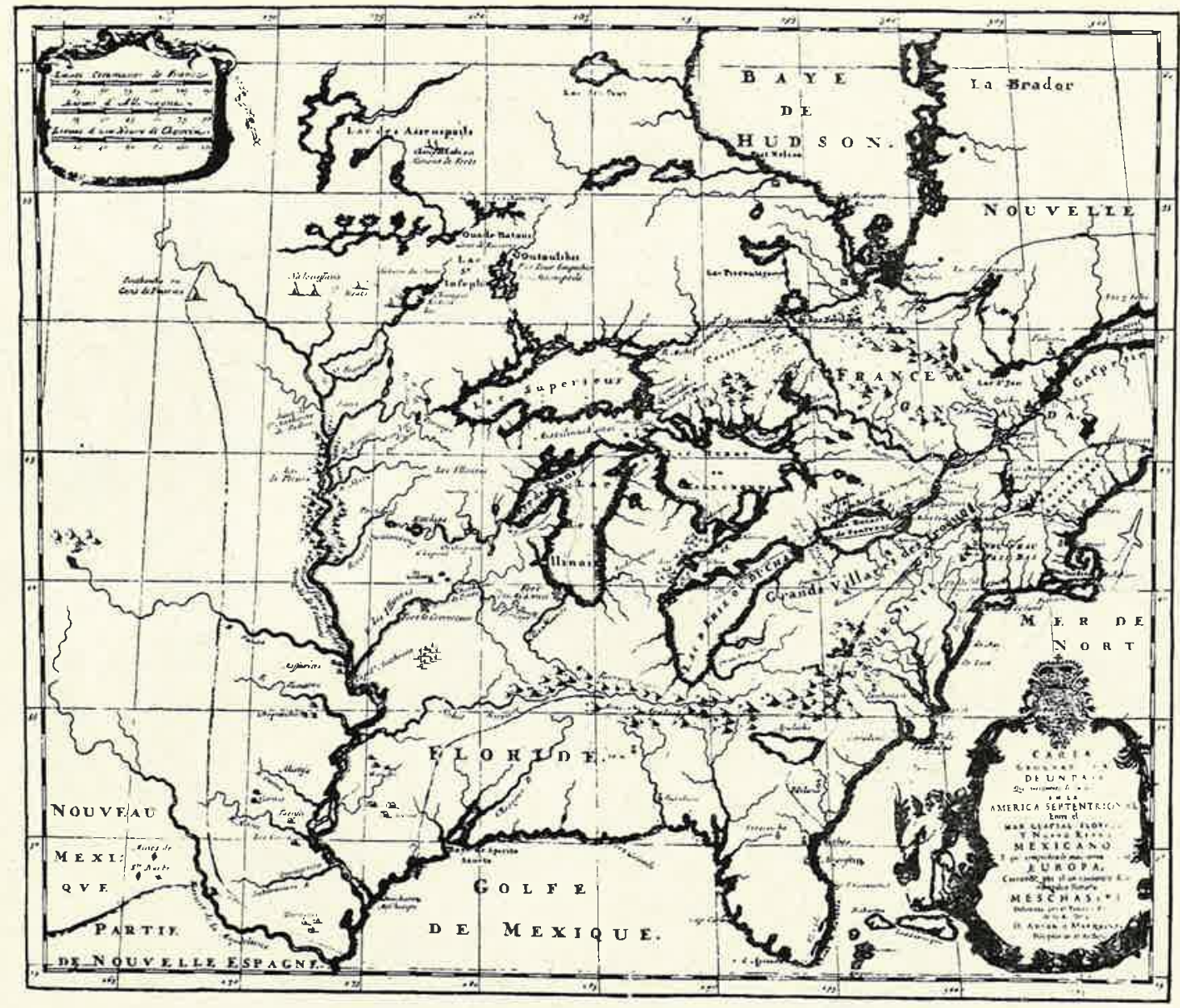

17. El descubrimiento del Misisipi, en un mapa español. 1699. 


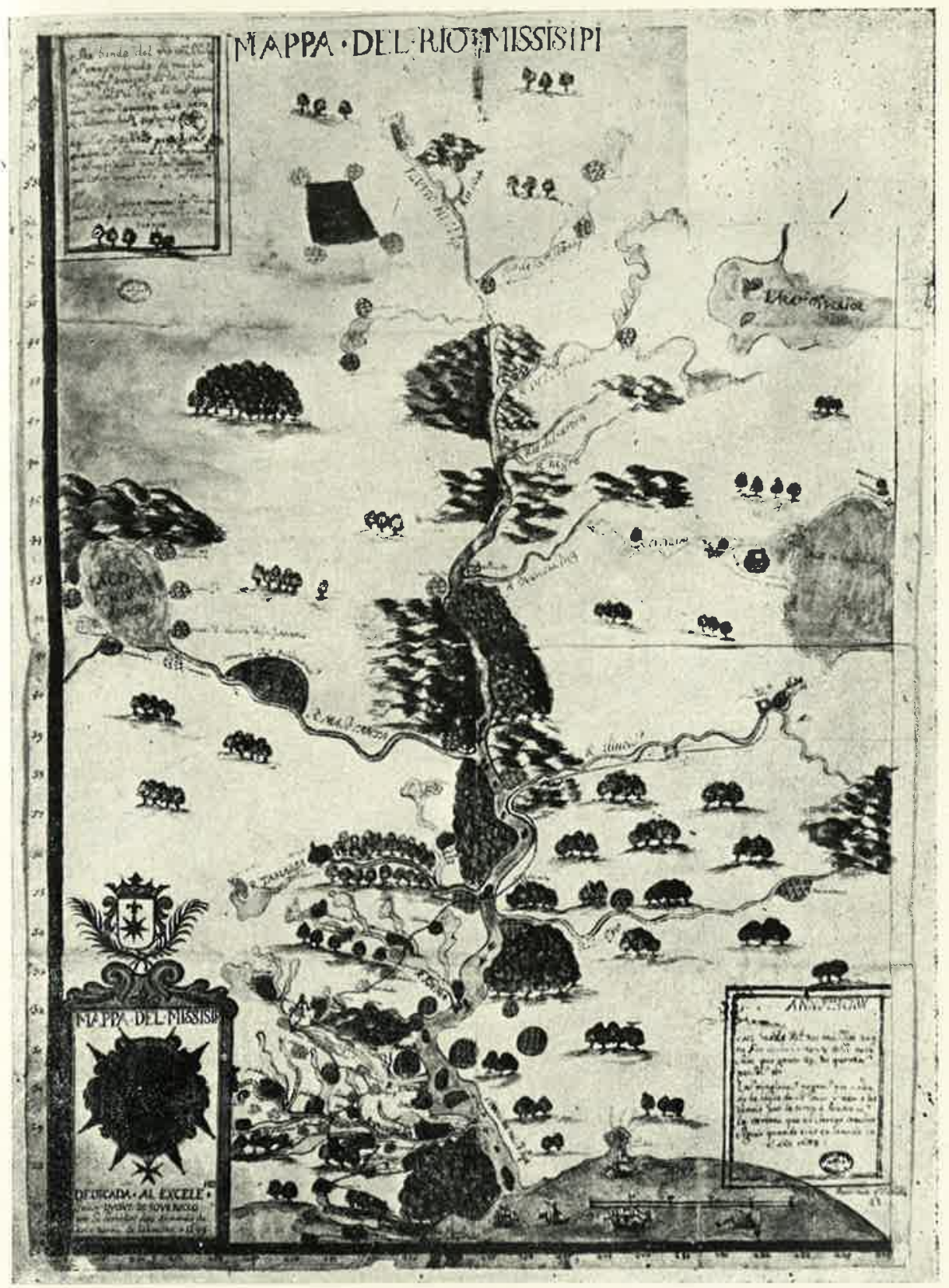

18. Mapa del rio Misisipi, según La Hontan. 1699. 


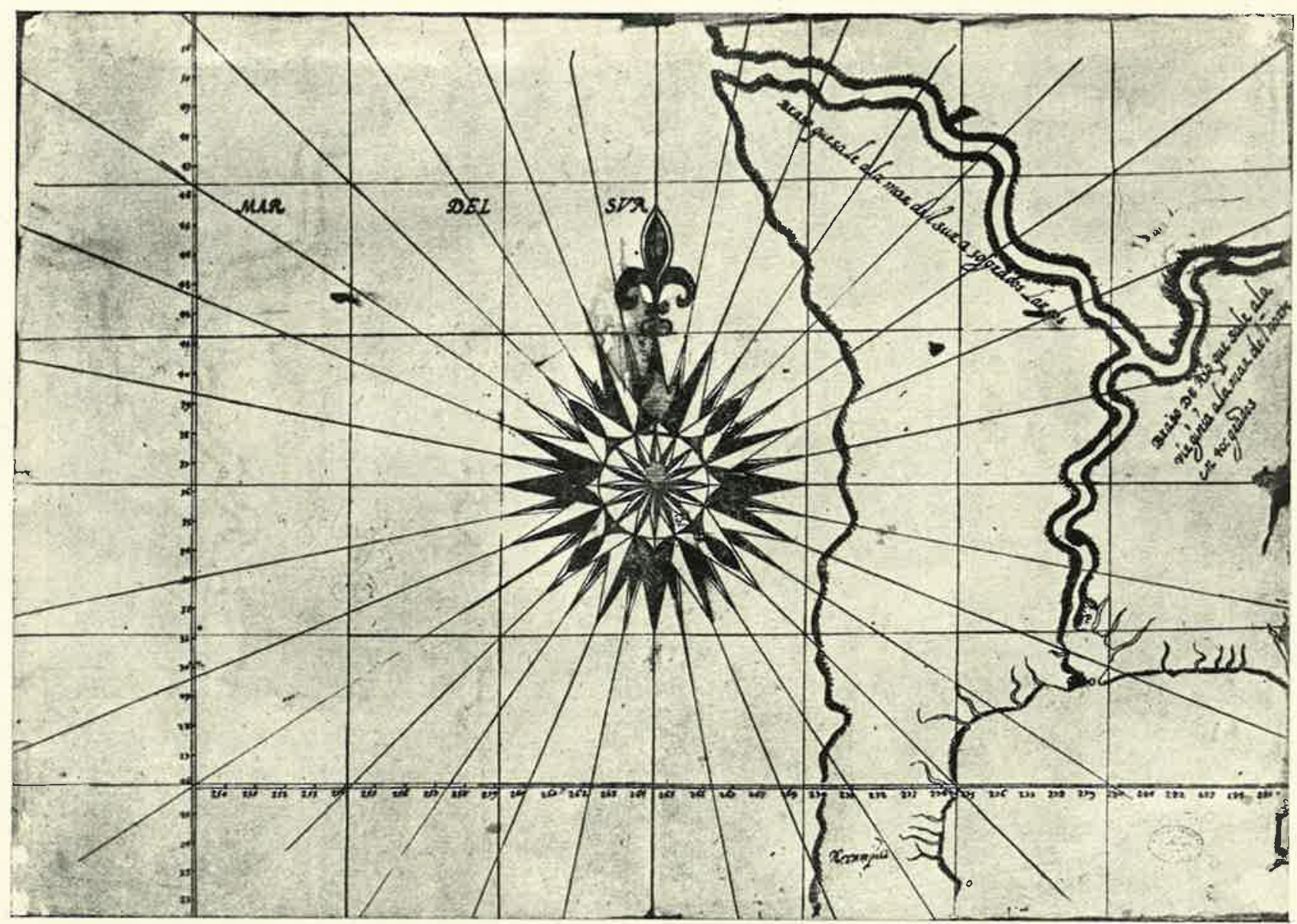

19. Croquis del hipotético Estrectho de Anián. ¿1700? 


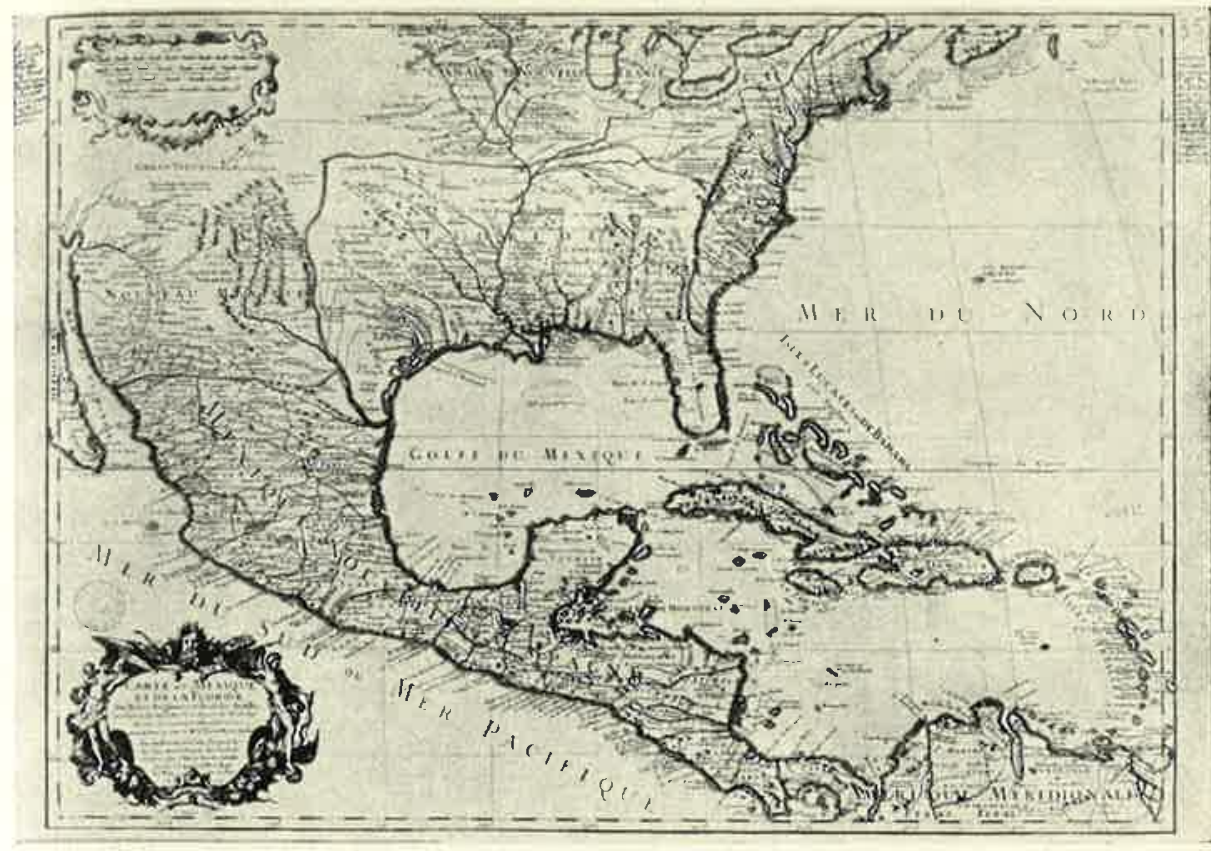

20. México y Florida, por de L'Isle. 1703.

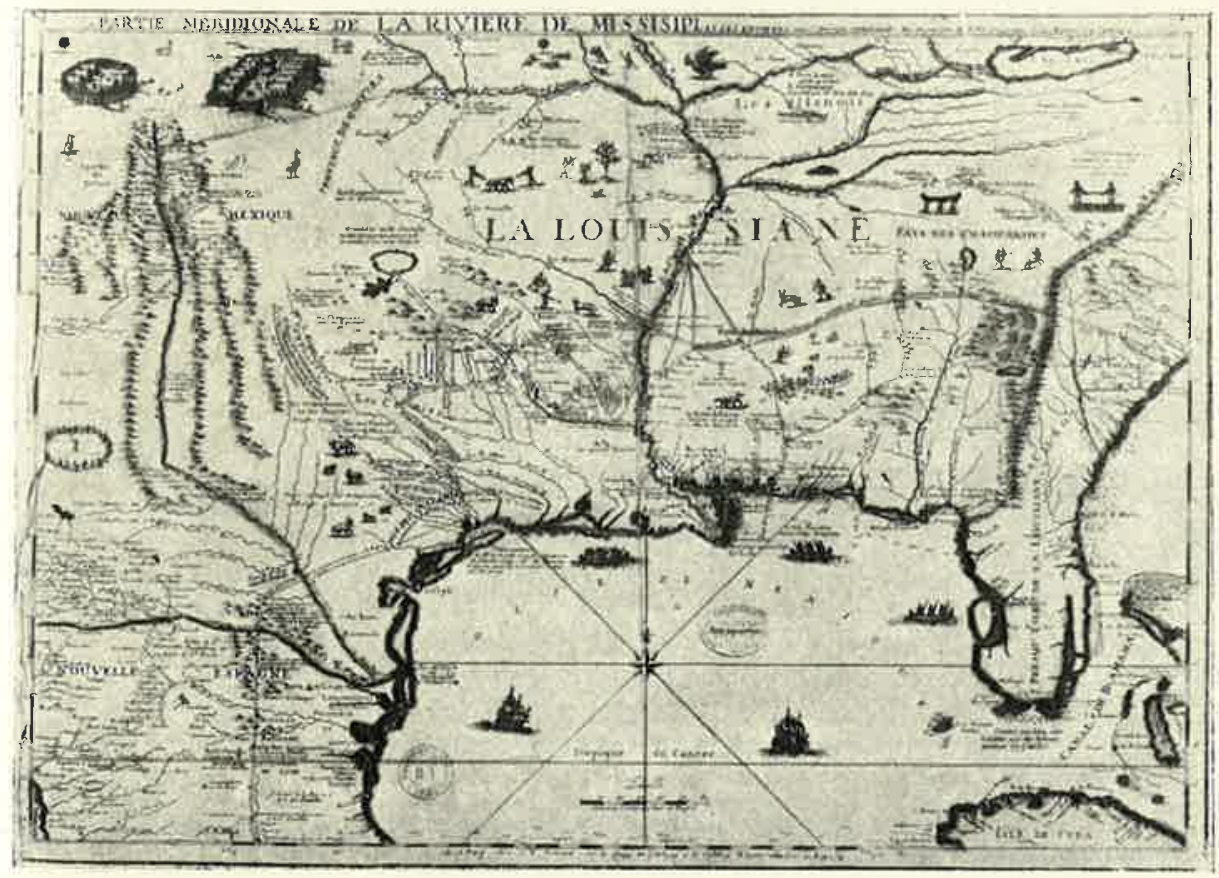

21. Luisiana, por de Fer. 1718. 


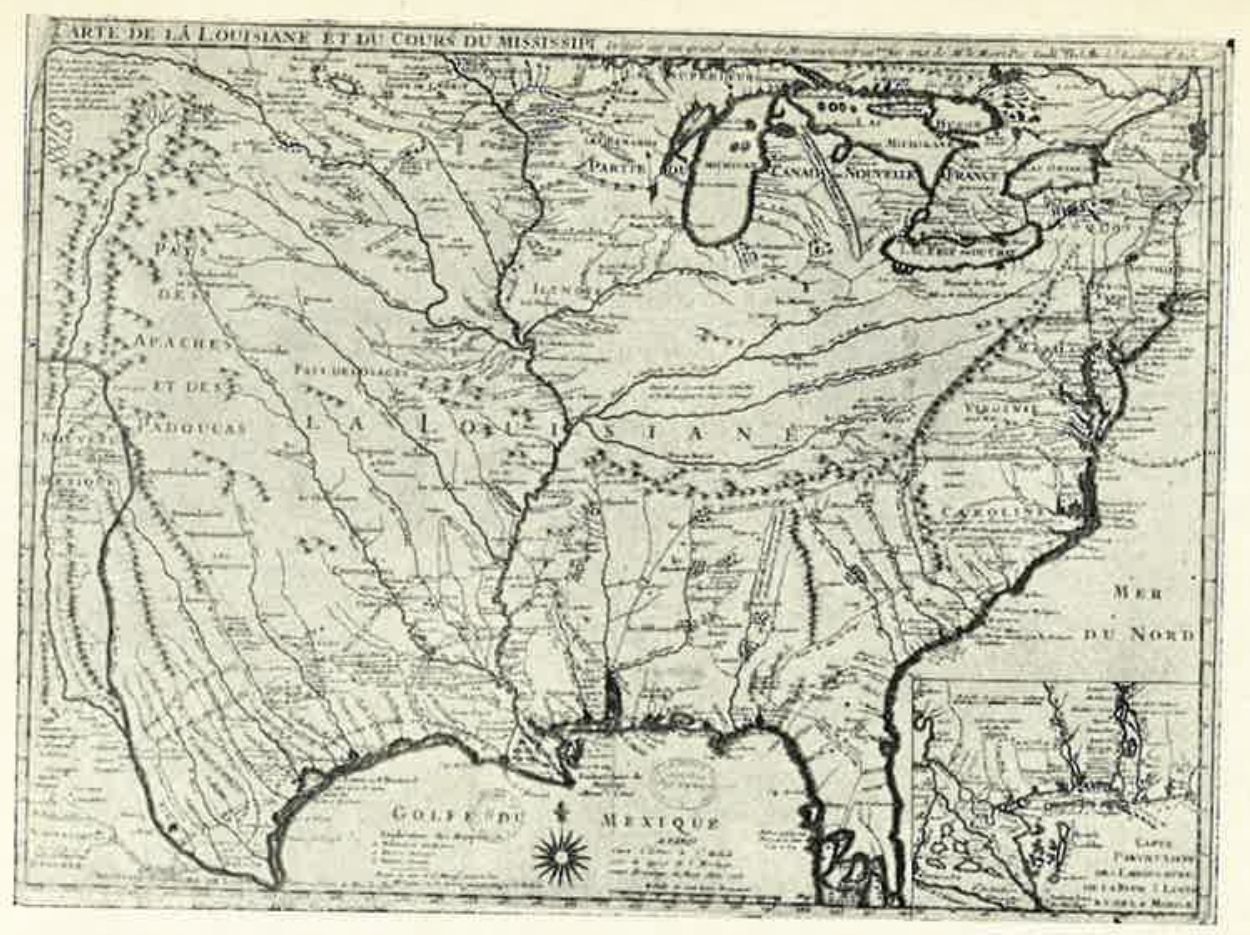

22. Luisiana, por de L'[sle. 1718.

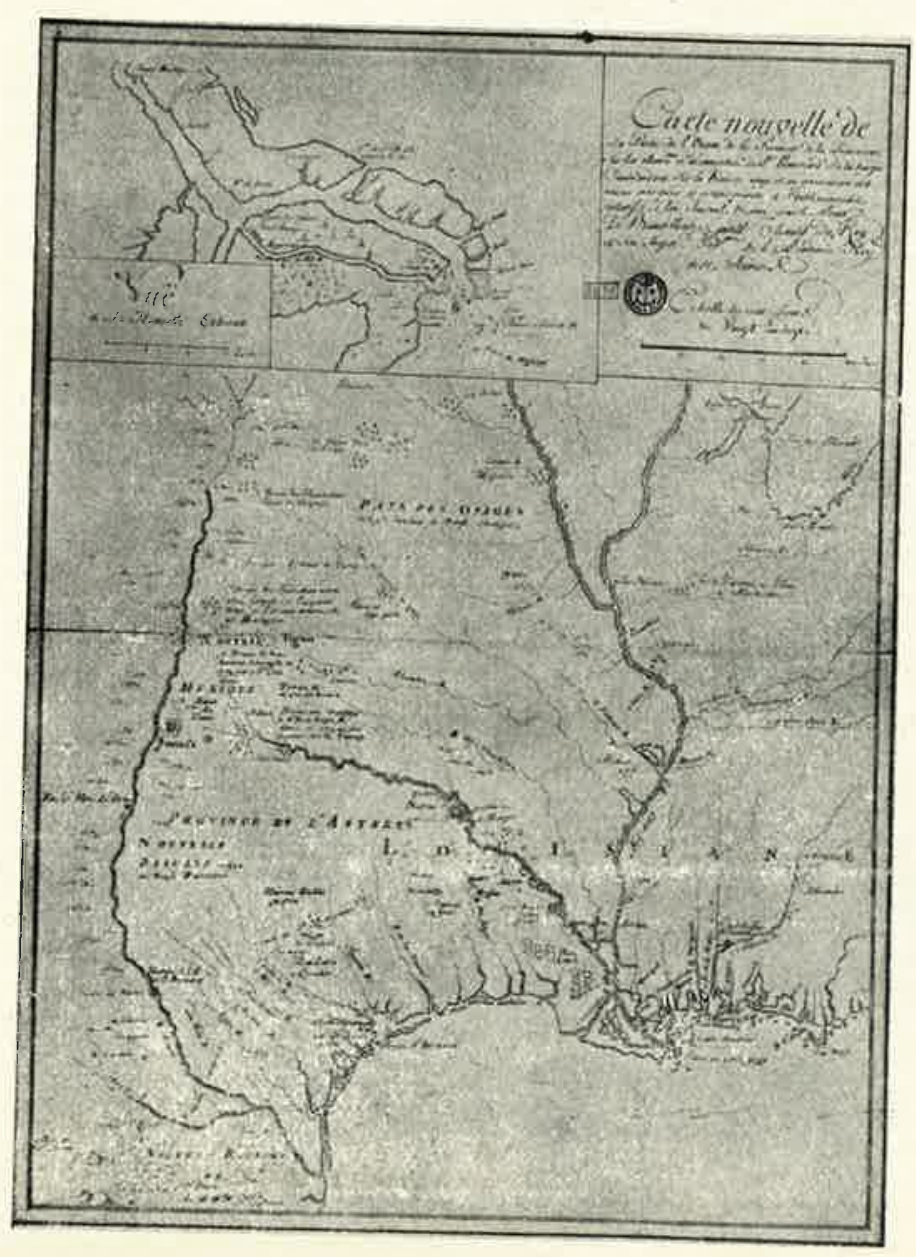

23. Luisiana, por Bealu. villiers. S. XVIII. 


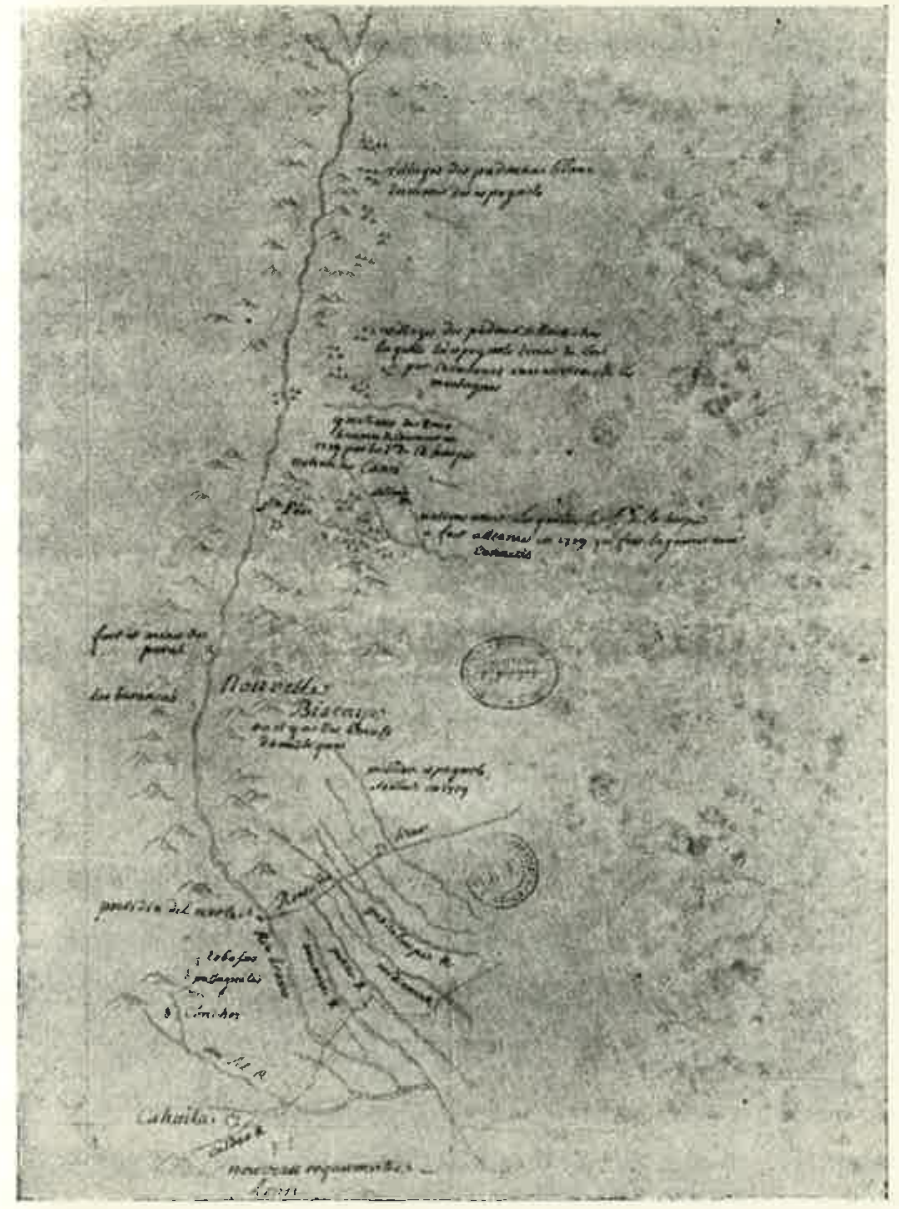

24. Mapa francés del río Grande. S. XVIII.

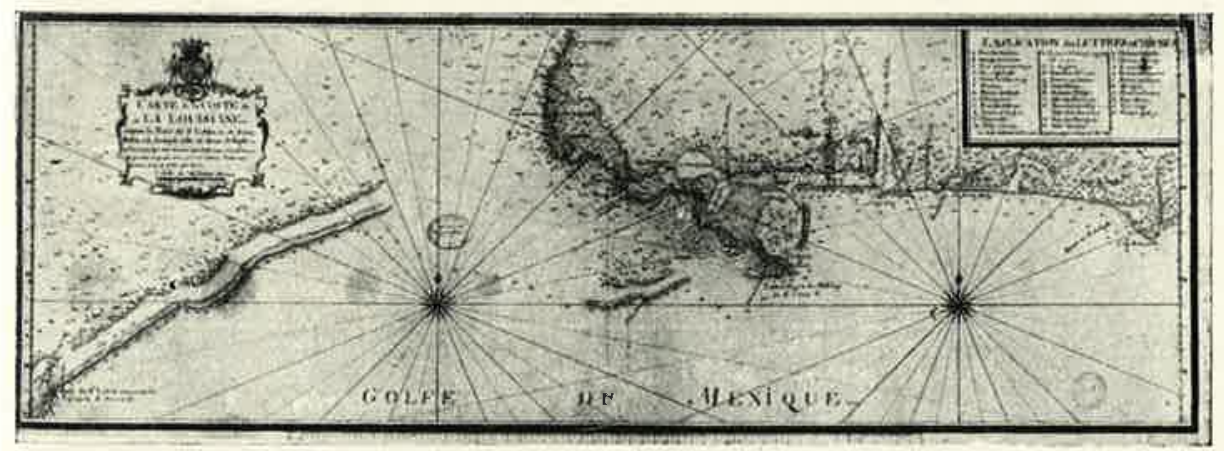

25. La costa de Luisiana, por Devis. 1719-1720. 


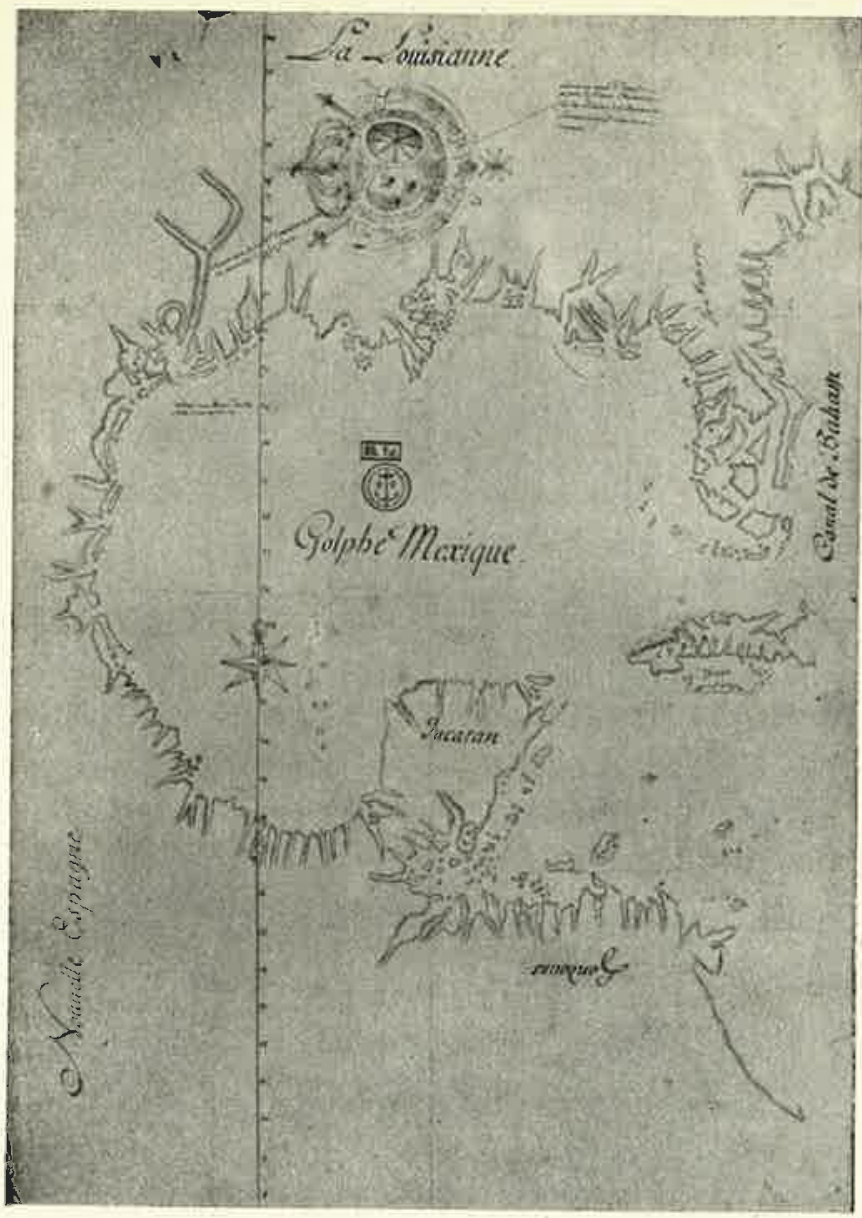

26. Ciala francesa

del Golfo. ;.1700?

27. EI Golfo y el Caribe, por Les Caiz. 1708.

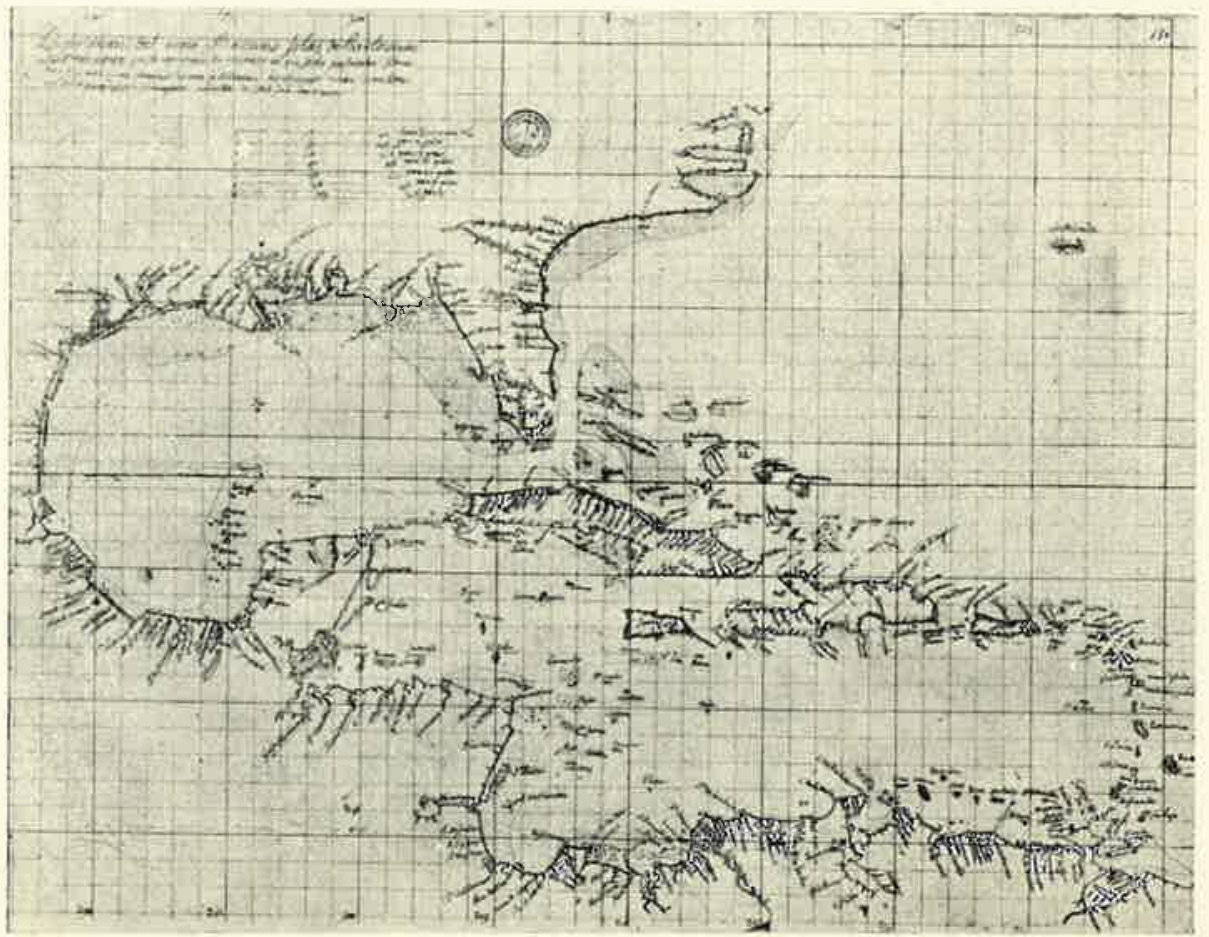


Hasta aquí hemos expuesto, en resumen, la situación en que se enconuraba Nueva Vizcaya entrando el siglo XVII. En la fecha - r635- en que acabamos de interrumpir nuestro discurso una vasta extensión territorial jodía considerarse definitivamente anexionada a la corona española. Desde el Pacífico a Saltillo, desde Chiametla y Nombre de Dios al Yaqui y el río Florido, es decir, prácticamente la conquista hecha por Francisco de Ibarra habíase consolidado $y$, sobre todo, había prosperado de manera indudable.

Más al Oriente de Saltillo, en cambio, la penetración española encontraba obstáculos difíciles de superar. Aún más azarosa que la de Saltillo, la historia de su vecina Monterrey sufre colapsos y rigores incontables. El Nuevo Reino de León se asienta sobre la inexistente base de unas tribus nómadas. Sus primeros tiempos van ligados a las figuras de Carvajal y Castaño de Sosa y su trágico destino. De sus viajes y fundaciones nada queda, y ellos entran de lleno en ese conjunto de conquistadores de imposibles, con Guzmán, Coronado e Ibarra, que soñaron en la atracción del norte.

Durante casi un siglo, lo único que existe más allá del Saltillo, hacia el Atlántico, es este Nuevo Reino de León, reducido a la mísera subsistencia de Monterrey, fundada definitivamente en I 596, y que no empieza a expansionarse hasta 1626 con la fundación de Cerralvo, seguida de la erección de Cadereita once años después.

Más al sur del Nuevo Reino de León se extienden las tierras de Nueva España, cuyas poblaciones más septentrionales siguen siendo Pánuco y Tampico en el golfo, y Santiago de los Valles, San Juis de Potosí y Guadalcázar en el interior, a muchas leguas al sur de Monterrey. La escasa población del reino ocupábase en la cría de ganados, que se vendían en la región minera de Mazapil y Zacatecas, y aun en el mismo México, y en una débil explotación minera. La producción harinera trató de hallar salida por Tampico.

Más al norte de Saltillo, fracasados tres intentos de población, las tierras de Coahıila se convierten en una provincia desértica en litigio entre Nueva Vizcaya y Nuevo León.

Y mucho más al norte aún, en la cuenca alta del Río Bravo, Nuevo México desenvuelve una monótona existencia campesina en medio de un heroico aislamiento. ${ }^{8}$

8 Morales Gómez, Antonio: Cronologia de Nuevo León. I527-I955. México, 1955. Alessio Robles, Vito: Coahuila y Texas en la época colonial. México, I938. León, Alonso de: Historia. de Nuevo Lén con noticias sobre Coahuila, Texas y Nuevo Mérico. "Documentos inéditos o muy raros para la historia de México". Publicados por Genaro García, tomo XXV. México, I.909.

(2) 


\section{LA EXPANSIÓN TERRITORIAL}

Ahora que hemos redondeado el cuadro de las Provincias Internas se hace evidente el papel preponderante que en él desempeña y ha de desempeñar en el futuro Nueva Vizcaya.

Toda la región está pacificada, salvo el nudo montañoso donde se refugian los indios coras y algunos restos de los tepehuanes después de su fracasada revuelta. Este reducto del Nayarit quedará insumiso hasta bien entrado ti siglo XVIII.

En el resto del territorio la obra evangelizadora prospera. Los jesuitas se adelantan a internarse más al Norte por la misma Sierra Madre, en tierras de los tarahuniaras, tanto como en la costa. En efecto, en 1636 el Capitán Pedro Perea sucesor de Díaz y Hurdaide en el mando del presidio de Sinaloa capitulaba con el virrey Cadereita la conquista de la provincia al norte del Yaqui, que recibió el nombre de Sonora. La progresión fue tan rápida, que habiéndose fundado las primeras misiones en la nueva provincia en 1638 , quince años después había en ella treinta y cinco mil indios cristianos. Las cuencas de los ríos Yaqui, Matape y Sonora habían entrado a formar parte del Imperio y de la Cristiandad por obra de los jesuitas. Otros miembros de la Compañía, en la otra vertiente de la sierra, habían alcanzado ya el Conchos: la Tarahumara empezaba a ser conocida de los españoles. Pero ¿ququí había de verterse mucha sangre para hacer factible la penetración.

\section{LA ERA DE LAS INVASIONES Y DE LAS SUBLEVACIONES (1640-I680)}

\section{UN NUEVO FRENTE}

Por aquel entonces la crudeza de los hechos vino a poner de manifiesto un problema que, si bien venía latiendo desde los primeros días de Nueva Vizcaya, ahora se presentó como realidad insoslayable.

En el Valle de San Bartolomé, en la llamada Provincia de Santa Bárbara, conchos y tobosos, juntamente con otras diversas familias y tribus, del oriente de Nueva Vizcaya, habían tomado parte en algunas de las revueltas de los tepehuanes y dieron en otras ocasiones señales de inquietud. Pero, jor lo general, se mantenían, como los tarahumaras, en buenas relaciones con los españoles, cuyos campos prestábanse a trabajar. Así, en mayo de i62 I se presentaban cinco indios al Gobernador en Durango para ofrecer la paz en nombre de los tobosos, nonoties, achaclanes y xipocales que bajarian al valle de San Bartolomé a las íaenas de la recolección. Don Mateo de Vesga 
ordenó que se les protegiera y retribuyera en su trabajo. En noviembre, en cambio, hacíase preciso salir en busca de los conchos, que se mostraban reacios a presentarse como jornaleros en las labores y haciendas del mismc valle. E1 mismo gobernador había establecido meses antes varios capitanes y soldados en él, con instrucciones precisas para su comportamiento. .

Sin embargo, años después, la constante progresión de la frontera hacia el Norte va igualmente ampliando el flanco oriental indefenso, y por esta misma época empiezan a hacerse crónicas las correrías de los bárbaros contra las haciendas e incluso las poblaciones de los españoles. Podemos suponer que uno de los factores que contribuyeron igualmente a hacer más sensible este hecho fue el restablecimiento del real de minas de Mapimí en un lugar avanzado hacia el desierto al que dio su nombre: el Bolsón de Mapimí.

Cuencamé, Mapimí, Indé, Santa Bárbara y Parral son por tanto las poblaciones destinadas a soportar el peso de las hostilidades que ahora comienzan. Con el cambio de frente que esto supone se produce también un canbio en las condiciones estratégicas del reino. Antes se trataba de mantener sumisos a los pueblos de la Sierra por medio de pequeñas guarniciones repartidas aquí y allá. En lo sucesivo estas guarniciones irán desplazándose hacia la periferia con el fin de precaver las incursiones del enemigro exterior.

En 1646, por primera vez, el Gobernador Valdés pide autorización para erigir un presidio en el paraje de Cerro Gordo, en la frontera, sacando soldados de los otros cuatro.

\section{La TRIPLE SUBLEVACIÓN TARAHUMARA}

Mediado ya el siglo XVII sufre Nueva Vizcaya la última convulsión con motivo del alzamiento de los tarahumaras, precedido de la inquietud de lus tobosos y la conjuración de las siete tribus: tobosos, conchos, cabezas, mamites, salineros, julimes y colorados asolaron la frontera y destruyeron la misión de San Francisco de los Conchos, en I645, sin que hubiese servido el escarmiento que dos años antes les aplicara el capitán de Santa Catalina cle Tepehuanes, Juan de Barrasa, que con tres compañías alcanzó en la persecución el río Grande del Norte. Desde esta fecha puede considerarse declarada la guerra en el flanco oriental del reino. Pero cuando el gobernador Valdés piensa aplicar el remedio que le parecía más oportuno, una nueva preocupación viene a distraer su atención, agravándose el problema.

De 1648 a 1652 tiene lugar un triple levantamiento de la Tarahumara que puso en conmoción a toda la porción septentrional del reino. Poco después de este episodio el dominio español quedó incontestable y definitivamente afirmado. 
El gobernador Guajardo Fajardo actuó decididamente. Pacificado el primer movimiento, resolvió erigir una población en medio mismo del país insumiso, y a la villa de Aguilar así establecida fue destinado el Capitán Juan de Barrasa con treinta hombres que debieran haber constituido el presidio de Cerro Gordo solicitado por Valdés.

Desde entonces la villa de Aguilar fue el punto que atrajo todas las hostilidades de los tarahumaras, que si fracasaron en el segundo levantamiento, lograron por fin su objetivo en el de 1652 , que revistió proporciones ingentes; toda la región entre Sonora y Nueva Vizcaya luchaba por recobrar su independencia. Con la villa desaparecieron ocho misiones jesuiticas y una franciscana. Pero al acabarse esta llama cesó la resistencia, y Guajardo Fajardo pudo dividir toda la Tarahumara en cinco circunscripciones que facilitasen el control del país y su rápida incorporación al mundo español.

La fundación en 1669 de la misión franciscana de Casas Grandes marca, muy pocos años después de la insurrección últimamente aludida, el tope septentrional de la expansión de Nueva Vizcaya por el rumbo de la Sierra. La restauración de la misión de San Francisco de los Conchos ocho años después indicaba a los franciscanos la orientación hacia el Río Grande. Mientras, los jesuitas se apresuran a volver a entrar por Satevó, San Pablo, San Miguel y San Jerónimo y se internan en la Tarahumara Alta. Después de 1673 se fundan San Bernabé de Cosiguriachic y las misiones del río Papigochic: la Purísima y San José de Temaichic, Jesús de Tutuaca, la Natividad, San Mateo, San Ignacio y Corachic.

E1 avance de misioneros y colonos dio por resultado que hacia 1680 toda la región entre el río Sacramento, Casas Grandes y el Paso - donde había franciscanos de Nuevo México desde I659- estuviese ocupada por misiones, estancias y haciendas. 9

\section{El bolsón de Mapimí}

A partir de la pacificación de la Tarahumara, Nueva Vizcaya vive durante más de un siglo pendiente del Bolsón de Mapimí, receptáculo de tribus hostiles o simplemente reacias a someterse al dominio español, pero que no vacilaban en invadir los territorios del Reino para asaltar a los pasajeros que transitaban por el Camino Real de Durango a Parral, colindante con el Bolsón en gran parte de su recorrido.

AJ Bolsón de Mapimí habíanse acogido, empujadas por el avance de

9 Saravia, Atanasio G.: Apuntes para la historia de la Nueva Vigcaya. Vol, III : Las sublevaciones. 
los españoles, multitud de tribus que en otro tiempo señorearon con sus correrías toda la región al este de la Sierra Madre Occidental. Nómadas que no se avenían a avecindarse junto a algunas de las misiones franciscanas de la región y que, cuando más, presentábanse en las haciendas fronterizas de Nueva Vizcaya en las épocas de la recolección para emplearse como braceros.

Sin embargo, en estos contactos tuvieron ocasión de conocer la vida de los tepehuanes o tarahumaras reducidos, e incluso de recibir, muchos de ellos, el batutismo. Particularmente fue habitual que los padres trajeran a sus hijos pequeños a recibir el Sacramento, por lo que años despuis los indios hostiles recibían el calificativo de apóstatas.

Conforme los españoles fueron realizando la ocupación efectiva de las mejores tierras del país para establecer sus haciendas agrícolas o ganaderas, viéronse los indios desplazados hacia el desierto. Era evidente que aquí carecían de posibilidades de subsistencia, y por lo tanto viéronse obligados a recurrir al robo en las ganaderías españolas, dando lugar a la consiguiente guerra defensiva por parte de los pobladores del Reino.

En el ataque a la misión del Conchos en 1645 podemos ver el primer movimiento que abre paso a la franca rebeldía por parte de los indios conchos, julimes, tobosos, salineros, etc. Con aquel acto declaraban rotundamente su repugnancia a someterse a la vida sedentaria. Otro tanto ocurrió en la zona de Saltillo, donde los tlaxcaltecas establecidos allí para facilitar la civilización de los cuahuchichiles fueron ineficaces y empujaron a éstos a abandonar la región.

Al este de Parral y Mapimí, al norte de Saltillo, vagaban estas familias dispersas. Su fuente de alimentación era la caza. Cazaban, pues, cibolos, es decir, bisontes, a los que los españoles dieron aquel nombre, describiéndolos como un animal "entre toro y camello". Las manadas de cibolos eran, sin embargo, escasas en la cuenca inferior de río Grande, y los indios por otra parte, acababan de descubrir algo más fácil de conseguir: las reses o las bestias de los españoles. Y había algo de particular valor para ellos: el caballo.

Todas estas naciones, cuyos nombres forman una larga relación, vivieron desde entonces en el bolsón, pero en las inmediaciones de los establecimientos españoles, subsistiendo junto a los pequeñísimos charcos o aguajes, en los valles del montuoso desierto. Todos ellos recibieron el nombre genérico de tobosos, por ser éstos los más bravos y, al decir de Barreiro, los únicos que por el tamaño reducido de sus arcos podían combatir a caballo.

Fue, pues, la actividad de estos indios la que hizo que la preocupaciŕn defensiva de Nueva Vizcaya se desplazase hacia el bolsón. 


\section{LOS PRESIDIOS DEL CAMINO REAL}

Había ya pedido el Gobernador Valdés la erección de un presidio en el paraje de Cerro Gordo, cuando el alzamiento de los tarahumaras obligó a situar los efectivos que a él iban destinados, al mando del capitán Juan de Barrasa, en la villa de Aguilar, de tan corta existencia. Esta coyuntura dio oportunidad a los tobosos para recrudecer sus hostilidades, por lo que, pacificada la Sierra, hubo de atender el gobernador a escarmentar a los indios de la frontera, quedando ya fijado el presidio de Cerro Gordo en su lugar clebido; sin embargo, el retraso de su colocación había sido lo suficientemente largo como para que el real de minas de Mapimí, la población de españoles más avanzada sobre el desierto, tuviera que ser abandonada por haberse hect:o la situación insostenible. A la salida de los mineros los tobosos acamparon en el real. La misma ayuda proporcionada por Cerro Gordo era tan escasa que el gobernador Dávila se apresuró a elevar sus representaciones al virrey para que se le permitiera establecer una compañía de cien hombres en Parral; poco después añadía a ésta la solicitud de un presidio en Mapimí, que protegiera a Parras y Cuencamé y enlazara con Cerro Gordo. Sólo diez días después, sus instancias habian variado en el sentido de que se guarneciera con veinticinco hombres Mapimi, poniendo otros tantos en Atotonilco y cincuenta, con cien indios fieles auxiliares, en Parral. Para que esto no resultara sravoso se suprimiría el presidio de San Sebastián y se traerían veinte soldados de Sinaloa, aplicándose adenás los sueldos de los protectores de Saltillo y Mazapil y el gasto de carne y maíz que éstos consumían. El virrey Alburquerque mantúvose en una postura tan rígida que sus palabras eran que 110 claría "ni un alfiler".

Entonces Dávila formó expediente con todas sus cartas y las respuestas de Alburquerque, y con una serie de consultas dadas por personas entendidas del reino (cntre ellos Barrasa y Nevares, capitanes cle Cerro Gordo y Santa Catalina), y lo envió al Consejo de Indias. Su petición fue reforzada por la noticia de ser cierto el despoblamiento de Mapimí que dio la audiencia de Guadalajara, y halló buena acogida, puesto que, al tiempo que se aprobaba su actitud, al viriey se le indicaba sería conveniente atendiese a la necesidad en que se encontra Dávila. Que estableciese los presidios que fuesen prerisos más una escuadra cerca del gobernador, para acudir donde hiciese falta.

Pero aun así, lo único que se consiguió fue la creación en Parral de una compañia llamada "de campaña" de treinta hombres. En I660, al dejar el gobierno de Nueva Vizcaya, Guajardo Fajardo recomendaba reunir en Parral las guarniciones de todos los presidios del reino, que se habían hecho innecesarios. Su sucesor, Gorráez y Beaumon1, insistió en la misma idea, 
sugiriendo se estableciesen presidios de diez o quince hombres a lo largo del Camino Real, de más de doscientos sesenta leguas, por despoblados, que llegaba a México. Quejábase también Gorráez de que siendo los capitanes de Sinaloa, Santa Catalina y Cerro Gordo de nombramiento del virrey, no mostraban al gobernador la obediencia debida. El virrey conde de Baños antorizó a Gorráez a mudar los presidios a los lugares que le parecieran más provechosos, en vista de los destrozos que causaban los que Baños sigue llamando chichimecas. Sin embargo, tampoco esta vez se llevó a efecto el cambio que se esperaba.

Algún tiempo después Oca y Sarmiento anuncia haber pacificado a los conchos, pero que los cabezas, tobosos y acoclames continuaban realizando hostilidades. Propone reunir en diez atalayas situadas en el camino real el centenar de soldados que hay en el reino, con cuarenta indios amigos que sirvieran de exploradores.

Por los mismos años, de 1660 en adelante, comienzan igualmente a experimentarse invasiones de bárbaros en las proximidades del Saltillo, pero aquí los vecinos, tanto españoles como tlaxcaltecas, unidos a los de Monterrey y mandados por Don Juan de la Garza llevaron a cabo una expedición que duró cinco meses, haciendo a los indios más de cien muertos y ciento veinticinco prisioneros. Los de Monterrey llegaron en otra ocasión, en I665, a veinticuatro leguas más al norte del río Bravo, con iguales resultados.

En 1677 , el oidor de México Don Lope de Sierra Osorio, a quien: el arzobispo-virrey nombró gobernador de la Vizcaya, había logrado pacificar a los tobosos, la más temible de las once naciones que hostilizaban los alrededores de Parral, y restablecía la misión de Conchos, apoyada por veinte soldados que hizo venir de Sinaloa. Sierra decía además que los tobosos habían quedado enemistados con las otras naciones del Bolsón, "con lo que ahora se convertirán en las mejores guarniciones de la frontera". Sin embargo, el trayecto de cien leguas por despoblados que había de Parral a Durango estaba siempre expuesto a cualquier insulto. ${ }^{\text {to }}$

\section{Los Apaches y Nuevo MÉxico hasta i68o}

De todas las tribus de la pradera que sucesivamente fueron tomando contacto con los españoles, las de la familia de los apaches fueron las primeramente conocidas y las que más importante papel juegan en la historia de los establecimientos españoles del norte.

Al superponerse los colonizadores blancos a la población preexisiente

Io Bandelier: Historical documents, II. 
indígena de Nuevo México, heredaron la situación de núcleo sedentario hos. tilizado continuamente por los nómadas que los indios pueblo mantenían hacía ya más de dos siglos; situación que no siempre es superada con éxito por los cultivadores, puesto que hacia el I $400 \mathrm{~d}$. de C. una maravillosa cultura de base agrícola había sido totalmente arruinada en la cuenca del Gila por los advenedizos "apaches". De todos modos, el curso de la Historia es siempre, a la larga, favorable a los cultivadores, y los nómadas han de verse finalmente abocados al casi insoluble dilema, porque no hay tiempo para elegir, de sedentarizarse o perecer.

Mostráronse los apaches, en sus primeros encuentros con los españoles, en actitud amigable, nada extraña si se piensa en el efecto que les causaría hallarse en presencia de un mundo maravilloso que les infundía a un tiempo temor y admiración. Sin embargo, estas manifestaciones no tardaron en trocarse en un recrudecimiento de los asaltos a las localidades de los sedentarios: con la llegada de los blancos, el anterior anhelado botín de maíz se 1. abía hecho más apetecible, variado y rico al introducir los hombres de Onate otras semillas, ganado ovino $\mathrm{y}$ vacuno $\mathrm{y}$, muy especialmente, los caballos.

Al tiempo que se incrementaba de esta manera el incentivo del robo, no tardó en hacerse visible la tendencia de los pueblos a solidarizarse con los nómadias frente al conquistador blanco. Actitud que no dejará de repetirse en otras ocasiones, en Sonora y Nueva Vizcaya, si bien, lógicamente, si a los indios sometidos los mueve el afán cle recuperar su jndependencia, a los nómadas sigue guiándolos la misma propensión a la rapiña. Pero frente al español hallaron uno y otros diversos vínculos de raza y de mentalicad, hasta entonces insospechados.

En torno a Nuevo México, las distintas parcialidades de la familia apache, desgajada del tronco atapasco, constituían un cerco de que repetidas expediciones hicieron conscientes a los españoles. La numerosa indiada del Gila hallábase estrechamente ligada por parentesco y alianza con las tribus de los navajos, situadas en la margen derecha del río Grande. Por el norte, los apaches se extendían más allá del río Arkansas, y por el este, hasta el curso medio de los aftuentes del Misisipi-Misuri. Las relaciones nos han conservado nombres -quinia, escanjaques, siete ríos, jumanos, etc.- no siempre fáciles de localizar.

El nivel cultural de las tribus no era homogéneo. Pero exa común la base alimenticia constituída por el búfalo. Había, sin embargo, zonas a las que empezaba a irradiar la cultura agrícola de los pueblo, sin olvidar que esta misma designación abarca núcleos entre los que no existe cohesión racial : hopis o moquis, tanos, zıñis, queres. 
El único acercamiento posible en aquellas tribus, a las que difícilmente se hubiera extendido la dominación española, verificábase en las ferias o mercados, de los que el más importante era Taos. Allí concurrían los apaches trayendo pieles de búfalos, gamuzas de ciervo y antílope, carne, sebo y sal; buscaban mantas de algodón, cerámica, maiz, objetos de adorno para su indumentaria $\mathrm{y}$ tocado. Pero estas ferias no dejaban de ser ocasión de engaños, disputas y pendencias que los forasteros consideraban casus belli dando así comienzo a una nueva serie de hostilidades.

Los colonos veíanse obligados a proporcionar escolta a las caravanas que subíai o bajaban a Nueva Vizcaya, a lo largo del río. Otras veces, hacíase preciso realizar una campaña punitiva contra los enemigos. Pero las incursiones de éstos van haciéndose cada vez más y más terribles, y poco a poco sus efectos se patentizan en la reducción del territorio español. Hacia I 670 los ataques se recrudecen, con ocasión de la pertinaz sequía que devasta el territorio. Asaltos, saqueos, incendios, robos de ganados, cautivos: ésta es la triste realidad cotidiana en una provincia que es prácticamente frontera toda ella, dada la forma y extensión de su territorio, estrecho y alargado. Como consecuencia, la resistencia va cediendo en algunos puntos: se despueblan Cuarac, en la región de las Salinas, Senecú, en los Piros. En I676, la situación es ya insostenible cuando el P. Ayeta pide cincuenta soldados y mil caballos para que se pueda hacer una defensa eficaz. Por entonces, las comunicaciones entre los pueblos y los apaches - nombre que hasta estas fechas alude principalmente a los navajos - se patentizan a los ojos de todos: un grupo de indios taos abandona su residencia y se introduce en la pradera, siendo hallado después establecido entre unas familias apaches del Cuartelejo, que practicaban una agricultura rudimentaria. En estas circunstancias se desenvolvía la existencia de Nuevo México al ocurrir la sublevación general de la provincia en I680. II

\section{LA EXPANSION EN EL CAMBIO DE SIGLO (I680-I 720)}

El Alzamiento de Nuevo México. El Paso.

El hambre, los continuos ataques de los apaches y las instigaciones de

II Schroeder, Albert H. : Documentary evidence pertaining to the early historic periad of southern Arizona. N.M.H.R., XXVII, 2, abril de 1952, $137-168$. Worcester, Donald E.: The navoho during the Spanish regime in New Merico. N.M.H.R, XXV, 2, abril rols5, Tot-1t8. $1958,36-52$. 
estos a la población sometida provocaron el levantamiento general de todo el reino de Nuevo México contra los españoles, el ro de agosto de 1680 . La muterte de veintiún franciscanos, el sitio de Santa $\mathrm{Fe}$ por los rebeldes, la clesastrosa retirada de los colonos hacia el sur, siguiendo el curso del río Grande, hasta concentrarse en la zona del Paso, son los episodios sucesivos de este acontecimiento doloroso.

E! alcance de sus efectos es difícil de precisar. Los más inmediatos iueron la colonización de la región del Paso del Río del Norte, donde surgen numerosas poblaciones y misiones en los once años que median entre la sublevación y la reconquista de la provincia, así como la erección de presidio en E! Paso. Luego, la propagación del alzamiento por todas las fronteras de Sonora y Nueva Vizcaya, lo que produce un momento de extremado peligro para estas provincias a fines del XVII. Finalmente, la definitiva pérdida de la región del Moqui, única porción de Nuevo México que no volvió a la. dominación española, la convertirá en móvil misional de numerosas empresas durante un siglo. Pero quizá su más importante consectrencia fue la saculida que produjo en la consciencia de los gobernantes, haciéndoles volver súbitamente los ojos hacia aquellas lejanas y casi olvidadas posesiones del norte de Nueva España.

Desde El Paso, los franciscanos fundaron las misiones de San Francisco de los Sumas y la Soledad de Janos, el Sacramento y San Pedro de Alcántara, Santa Gertrudis, San Lorenzo, Nuestra Señora del Pilar y San José, que enlazaban con la de Casas Grandes, correspondiente a Nueva Vizcaya. En ellas se evangelizaba a sumas, jumanos, piros, tanos y apaches. Muchos indios se congregan en los pueblos de la Salineta, San Lorenzo, Senecú y El Socorro, fundados en T682. La actividad de los misiones se propagó igualmente descendiendo por el río Grande, hasta la confluencia con el Conchos, donde en 1683 tuvieron principio las dos misiones de la Junta. Los padres se internaron hasta la región de los jumanos, hallando siempre campo propicio a su predicación.

En aquel mismo año, el gobernador de Nuevo México, don Doningo de Gironza y Petriz de Cruzat, pudo realizar el establecimiento del presidio de cincuenta soldados que ya en I68 I había sido concedido a su antecesor Otermin. Gironza lo situó entre El Paso y las misiones de San Lorenzo, Nuestra Señora del Pilar y San José, y fue designado bajo esta última advocación; pero un año despttés lo trasladó a Guadalupe del Paso, donde subsistió casi 11n. siglo.

Lo que más se demoró fue la reconquista del reino sublevado, pues aunquie a! año siguiente del hecho la intetara Otermin, a quien fueron enviados varios escuadrones de refuerzo desde México, la empresa fracasó. Diversas 
tentativas se llevaron a cabo en los años sucesivos, hasta que alcanzara éxito la de Vargas en 1693.

Entre tanto, a diversas inquietudes tendentes a la insurrección que se advertían entre las poblaciones indígenas de la periferia de Sonora y Nueva Vizcaya, vino a proporcionarles impulso aquel lastimoso ejemplo de la expulsión de los españoles de Nuevo México, y esto dio lugar al alzamiento general producido entre los años 1683 y I684, y que abarcó desde el norte de Sonora hasta la Junta de los ríos Grande y Conchos y hasta la región de La Laguna, al fondo del Bolsón de Mapimí. E.l alzamiento dio principio en I684. con una conjuración general de mansos, piros, tiguas, sumas y janos, que atacarían El Paso, Janos y Casas Grandes simultáneamente. La rebelión habida en el norte cuatro años antes estuvo a punto de reproducirse ahora en este reducto de Nuevo México. Afortunadamente, abortó en E1 Paso; en la zona de Janos queda destruida la misión de la Soledad, e igualmente la de Carretas, más al este, y el pueblo de Casas Grandes. Pero aquí el alcaide mayor, Francisco Ramírez de Salazar, rechaza a los enemigos y los localiza en la sierra del Diablo. Se le une el capitán Juan Fernández de la Fuente con treinta arcabuceros, y la situación es dominada por los españoles, aunque la inquietud no se calma: es destruida Santa Gertrudis de los Sumas y los mansos abandonan los pueblos. Por otra parte, el movimiento subversivo se ha propagado a Julimes, Conchos, San Martín y Parral, por lo que no se recibe ayuda de Nueva Vizcaya, y sólo llegan dieciocho soldados y treinta indios de Sinaloa, más algunos refuerzos procedentes de El Paso, traídos por Ramírez. Algo después se incorpora el sargento mayor Diego de Quirós con doscientos indios sonorenses. Un par de victorias dejan ya definitivamente a los españoles dueños del campo, pero la inseguridad obliga a los franciscanos a abandonar la Junta, más cuando se advierte hostilidad por parte de conchos y julimeños.

El alboroto había durado un año cuando en . ${ }^{6} 685$ empieza a serenarse, salvo en la parte de la sierra colindante con Sonora. Sus consecuencias han sido devastadoras. Toda la región del norte de Parral, hasta El Paso, queda en manos de los indios hostiles conchos y julimeños, abandonándose los pueblos de Carretas, Casas Grandes, que ardió; San Antonio de Julimes, San Francisco de Conchos, Nombre de Dios y San Jerónimo, con las misiones de San Javier y Torreón, administrados todos estos establecimientos por los franciscanos de Zacatecas. Las pérdidas en ganado mayor y menor, robado o muerto, fueron muy crecidas, y quedaron destruidas las haciendas de plata del Ojo de Ramos, San Lorenzo, Tabalaopa, Encinillas y la del Capitán Falcón. Los valles de Encinillas y Sacramento fueron desalojados. Esta fue la revuelta de los pueblos marginales de la órbita de las pose- 
siones españolas. Sus efectos seguirán sintiéndose cuando los tarahumaras y pimas cuieran rebelarse, pocos años después, en: Nueva Vizcaya y Sonora. Entre El Paso y La Laguna, a partir de I682, la defensa se había hecho difícil, $y$ esto ftue el punto inicial para la fortificación de la frontera y el desplazaniento de los contingentes militares, así como de la atención de los gobernantes, del interior a la periferia. A ello condujeron el escarmiento de la sublevación de los pueblos y las turbaciones experimentadas en $\mathrm{Q}$ Faso, de que informó el capitán Ramírez de Salazar. ${ }^{12}$

\section{LA. AMPLTA ZONA DE LAS NACTONES OSCURAS}

Seguramente podrían contarse por centenares los nombres de lribus que cita la documentación referente a toda la extensión de fronteras que corre desde Sonora a Nuevo León y entre Nueva Vizcaya y Nuevo México. Esta es la zona en que se dan los más frecuentes contactos éłnicos y culturales entre toda clase de grupos indios y entre estos indios y los españoles; en su centro aproximado acabamos de ver cómo viene a fijarse el núcleo importantísimo de El Paso. De hecho podemos considerar el espacio que media del Valle del Río Florido al pueblo de Sandía cono un extenso correder al que confluyen las naciones indias del este $y$ del oeste; las que se retiran al norte empujadas por los españoles, y las que se dirigen al sur atraídas precisamente por los establecimientos de éstos. Del contacto nacerán docenas de perutueños grupos que sólo un siglo más tarde quedarán definitivamente Fundidos bajo el apelativo común de apaches.

Ahora, to que se presenta a los españoles gute han sufrido la violenta acometida de los años ochenta del siglo XVII es un mosaico de pequieñas tribus, nuty diversificadas en lenguas y culturas. Dominar este amplio esprcio

r2. Hughes, Anne E.: The Beginnings of Spanish settlenent in tho El Paso disirict. Berkeley, rg r 4. Sigüenza y Góngora, Carlos de: Mercurio Volante. Con la noticia de la recuperación de las provincias del Nuevo México, conseguida por Don Diego de Vargas Zapata y Lujän Ponce de León, gobernador y casitón general de aquel reino. Wéxico, íg.. Haclsett. Charles Wilson: The Revolt of the Pueblo Indians of New Merico and Oterminis altempted reconquest. I680-r682. 2 vols. Alburquerque, 1942. Rubio Mañé, J. Ignacio: Introdicción al estudio de los virreyes de Nucva España. 2 vols. publicados. Vol. IT: Expansion y defonsa. México, raso. Bailey, Jessie Brnmilow: Diego de Vargas and the reconquest of New Mexico. Alburquerque, 1940. Espinosa, Juan Manuel: The recapture of Santa Fe, Now Mexico, by the Spaniards. Degember 29-30, 1603. H.A.H.R., XIX, 4 oct. 1939, 443-463. Espincsa, Juan Martiel: First expedition of Vargas into New Mexico, I692. "Cuarto Colorado Centennial Publications, I5401940", vol. X. Alburquerque, 1940. Documentos que sobre el levantamionto de los indios del ario de r68o formb Don Antonio de Otermin, gobernador y capitán general del reino de Nuevo México. Biblioteca Histórica, México, 1947. Para la historia de Nuevo México de la fundación a la rebelión, vid. Hallenbeck, Cleve: Land of Conquistadores, Caldwell (Idaho), 1950. Scholes, France V.: Civil government and socioty in Now Mevico in the scventeentl century. N.M.H.R., X, 2 abril I935, 7I-1II; más los trabajos ya citado de Reeve y del último autor aludido. Forbes, Jack D, : Apache, Navaho and Spaniard. Norman, University of Oklahoma Press, igfo. 
no es cosa fácil. La primera entrada, hecha a mitad de la centuria, ha sido anulada en esta sublevación. Aparentemente, los indios han ganado el dominio del terreno. Pero El Paso se ha sostenido. El qtro punto clave del territorio es precisamente la Junta de los Ríos, hacia donde se orienta la expansión del núcleo de El Paso; sin embargo, de las dos rutas convergentes en la Junta, será la del Conchos la que predomine, y esto varias décadas más tarde. El Paso era un centro de importancia secundaria para poder dominar la Junta: Nueva Vizcaya, a fines del XVII, quedaba todavía bastante lejos para octuparse de ello. No obstante, cuando la Junta y El Paso queden definitivamente en manos de los españoles, se habrá ganado toda la extensión geográfica de lo que hoy es Chiluuahua. Y en ese momento las naciones unidas de indios hostiles habrán prácticamente desaparecido.

Los conchos eran la más extendida de esas naciones; en el XVIII aparecen tan sólo constituyendo un par de poblados al borde de Bolsón, pero en el XVII cubrían el área entre el río Florido y Sonora, alcanzando la porción noroeste de la provincia. Prácticamente, ellos eran el arco que envolvía el cuadrante ocupado por los tahumaras. Al sur de la porción septentrional de Nuevo México, a uno y otro lado de río Grande, encontramos a los apaches. Entre apaches y conchos están, en el curso del río, entre El Paso y La Junta, los sumas, y más al occidente, los janos, jocomes, chinarras, mansos, piros, etc.; hasta tocar con la más importante nación del noroeste, los yumas; y al oriente y al norte de los sumas, los jumanos. E1 Paso y La Junta son los únicos lugares donde aún puede desarrollarse, en muy precarias condiciones, una cultura india de base agrícola. Ni que decir tiene que muchas de estas naciones pertenecen a un tronco común: conchos, jumanos y sumas podrían formar parte de una misma familia, o bien sumas, mansos y apaches podían estar estrechamente emparentados; los janos y los jocomes probablemente tenían la misnia lengua y tal vez fueran rama de los sumas, y eran, como éstos, cultivadores incipientes en las márgenes de los afluentes meridionales del Gila, sobre las fronteras de la Sierra Madre. Cuando no fueran todas estas naciones de una misma procedencia, diversificadas tan sólo como resultado de los diferentes espacios geográficos que habitaban, siempre sería evidente que mantenían entre sí un estrecho contacto y que con frecuencia se las ve adoptar una actitud única ante los españoles, para hacer la paz o para abrir la guerra.

La fundación de Chihuahua marcará el fin de estos pueblos como protagonistas en la historias del norte. Los núcleos apaches que han adoptado el caballo mediado el siglo XVII pasan al primer plano de la frontera a principios de la siguiente centuria, y ante su empuje se esfuman -al menos en la retina de los españoles- los otros grupos que antes asolaron ranchos, 
haciendas, minas, misiones y pueblos. Al sur, en el Bolsón, los tobosos -Cuna avanzada de los apaches?- actuaban sobre la retaguardia de Nueva Vizcaya, ${ }^{13}$

\section{EL ATAQUE DE LOS TOBOSOS}

Contrariamente a la idea de que tras la conquista de Nueva Ispaña por Cortés sucedieron tres siglos de pacífica ocupación y ampliación de los territorios por los españoles, la historia de las provincias internas nos muestra unia sucesión de insurrecciones y campañas defensivas y ofensivas que, si bien en general resultaron favorabies a los españoles, hicieron el movimiento expansivo sumamente lento y condujeron al final a una casi definitiva paralización de sir impulso.

$Y$ es que los pobladores españoles, buscadores de riqueza o misioneros, encontraron en su progresión liacia el norte un medio indígena cada vez más reacio por su mentalidad y régimen de vida más primitivo a dejarse influir o dominar por las costumbres europeas.

Por el contrario, la presencia del hombre blanco en sus tierras, con sus armas, cabalgaduras, ganados y ropas, stiscitó nuevos e insospechados incentivos para la vida de pillaje que siempre ha ejercido el nómada sobre los pueblos sedentarios.

De esta manera hallamos que, por estos motivos, las provincias internas siempre fueron frontera; en el tiltimo cuarto de siglo Nueva Vizcaya se conviejte en un país cuyo problema defensivo priva sobre todos los demás. En 1683 se sublevaron ochenta y cinco naciones del río Nazas y La Laguna, uniéndose a las siemjre hostiles tribus del Bolsón. Las consecuencias fueron tan inmediatas que rápidamente se produjo el despueble del real de Mapimí, por segunda vez, y de Gimulco y Casco. Los incesantes asaltos se hicieron sentir a lo largo de toda la frontera, poniendo ignalmente en peligro los

I 3 Schroeder, Albert H.: Documentary caidence pertaining to the early historic period of Sonther, Arisona, N.M.T.R., XXVIT, 2, april 1952, г37-16\%. Schroeder, Albert H.: Frr. Marco de Nisa, Coronado and the Yavapai. N.M.H.R., XXX, 4 oct, 1955, 256-296; XXX, I, jan, r956, 24-37. Satuer, Carl: The distribution of aboriginal tribes and languages in northern Mexico. Iberoamericana, 5. Berkeley, 1934. Sauer, Carl: Abcriginal population of northwestern Mexico. Iberoamericana, 1o. Berkeley, 1935. Forbes, Jack Douglas: The janos, jocomes, mansos and sumas indians. N.M.H.R, XXXII, 4, oct. 1057, 319-334. La fecha en que los apaches adoptan el caballo, que Ewers, siguiendo a Francis Hainer, sitúa con posterioridad a 1655 , es anticipada por Worcester a los años entre I620 y 1530 . En cambio. Schroeder está con Haines, Vid. Dwers, John C.: The horse in blackfoot indian culture. Smithsonian Institution. Bureau of American Ethnology, Bulletin I 59. Washington, I955. Worcester, Donald $\mathrm{E}$. The spread of Spanish horses in the southwest. N.M.H.R., XIX, 3, july I944, 225-232; XX, T, jan. I045, I-I.3. Sclioles France V, and Mera, I. P.: Some aspects of the Jumano Problem. Carnegie Institution, I 940. 
cstablecimientos mineros de San Juan Bautista, Indé, Guanacevi, Santa Bárbara y Parral.

En aquel momento, los efectivos militares de Nueva Vizcaya se reducían a treinta soldados de la compañía de campaña de Parral, que el gobernador Neira y Quiroga distribuyó entre esta localidad y Cuencamé, más veintitrés hombres $y$ un capitán en Cerro Gordo que se ocupaban en dar escolta a los viajeros y correos por el Camino Real; y finalmente, la escuadra de nucve hombres y un cabo situada en el presidio de Santa Catalina de Tepehuanes. Luego, ya en el interior, los presidios de San Hipólito, Sinaloa y San Sebastián, que sumaban otros sesenta soldados. Así, pues, Neira y Quiroga expuso al virrey y al Consejo de Indias la apurada situación en que se hallaba.

En Madrid, sobre una proptiesta redactada for el ex gobernador don Lope de Sierra en que pedía erección de presidios en el Gallo, Cuencamé y San Francisco de Conchos, para que éstos, operando en conljinación con ias fuerzas de Parral y Cerro Gordo, pudiesen llevar a cabo una defensa eficaz, resolvióse ordenar al virrey conde de Paredes estudiase en junta si convendría el establecimiento de los dos de Cuencamé y el Gallo, con veinticinco hombres cada uno.

Entre tanto el mismo Paredes, manteniéndose en la tradicional postura de los virreyes de resistirse a cualquier gasto, se había limitado a insinuar a Neira y Quiroga se valiese de los soldados y mineros para la protección de la frontera, y que para allegar fondos le autorizaba a percibir el $2 \%$ sobre el diezmo y el I \% sobre el I \% de la plata de Nueva Vizcaya, Zacatecas y Sombrerete. Así lo había aconscjado la junta de hacienda y guerra de México.

Cuando se tuvo noticia de esto en Madrid, la respuesta fue la que menos se podía esperar el virrey. La dura reprobación contenida en la real cédula de 22 de diciembre de 1685 se expresa en estos términos: "Se ha extrañado que en materia de tanta importancia como ésta tomase la Junta una resolución tan tibia como la de los medios que se propusieron en ella, pues se han considerado impracticables para ocurrir prontanente a tan grave urgencia, y que Vos os hubiéseis conformado con su parecer, cuando la obligación de vuestro puesto os debía empeñar a que valiéndoos de todos los medios posibles acudiéseis al reparo de tan fatal suceso, yendo en persona a la reducción de estos indios. pues de des reciarse un caso como éste y no haberse aplicado en tiempo el remedio conveniente sucedió la pérdida de la Nueva México". Debió enviar, sigue diciendo la cédula, uno o varios cabos y cuarenta o cincuenta mil pesos, y abundantes armas y municiones. En definitiva, a la vista de la situación, el rey disponía añadir aún otro presidio, en San Francisco de Conchos, y que tanto éste como los de Cuencamé y Gallo tuvie- 
sen por lo menos cincuenta soldados, siendo sus cabos o capitanes y los de Cerro Gordo, Sinaloa y San Sebastián, vitalicios, y propuestos por el gobernador: El virrey debería estudiar en Junta el modo más conveniente de hacer la guerra, encargándosele atienda a este problema de manera preferente, "sobrescyendo (por ahora) en las nuevas conquistas de las Califorriias".

Apenas mes y medio después, "deseando afianzar más aquel reino", ordenaba el establecimiento de otro presidio en Casas Grandes, para asegurar' los caminos de Sonora al Parral.

\section{LA ERECCIÓN DE LOS PRESIDIOS}

La catástrote de Nuevo México, a la que se alude directamente en la Real Cédula transciita parcialmente líneas arriba, había sacudido de tal manera el tranquilo despacho de los asuntos en el Consejo de Indias como para que se diera el caso de que en sólo el lapso de junio de 1685 a febrero de 1686 , y en repetidas disposiciones, se recriminase violentamente la inacción del virrey, se ordenase la erección simultánea de cuatro presiclios, el aumento de sus dotaciones y la elaboración de un plan de campaña.

Los cuatro presidios fueron, efectivamente, establecidos, suprimiéndose en cambio, para evitar dispendios, los de San Sebastián y San Hipólito. Anualmente, en la época de aguas, se visitaría la región de San Hipólito, para precaver cualquier movimiento de los jijimes. No sería posible hacer lo misno en la parte de San Sebastián porque quedaba demasiado lejos. A mediados de 168 y ya estaban nombrados los capitanes de los nuevos presidios, que comenzaban en seguida a actuar contra los tobosos, y eran: de Cuencamé, el sargento nnayor Juan Batutista de Escorza; del Gallo, Luis de Quintana; de Cerro Gordo, Martín de Hugalde, que lo había sido de Santa Catalina: de Conchos, Juan de Retana; de Sinaloa, Diego de Quirós, a quien el virrey había hecho, además, alcalde mayor cle Sinaloa y del nuevo descubrimiento de Frailes. Omite Neira mencionar açıí el de Casas Grandes, que lo fue Tuan Fernández de la Fuente, tal vez el más famoso guerrero del norte en su época y a quien pronto veremos actuar en Sonora, y al del aún subsistente presidio de Santa Catalina, que 10 fue Benito Perea Morales.

En esta fecha, por tanto, se ha dado el primer paso decisivo para la tormación del cinturón defensivo que poco a poco va ajustándose en torno a Nueva Vizcaya, modalidad bélica que no tardará en ir apareciendo en las demás provincias internas hasta dar lugar, ya pasada la mitad del siglo XVIII, a la idea de unificar y coordinar el sistema.

Poi el momento, Nueva Vizcaya había creado en su frontera oriental 


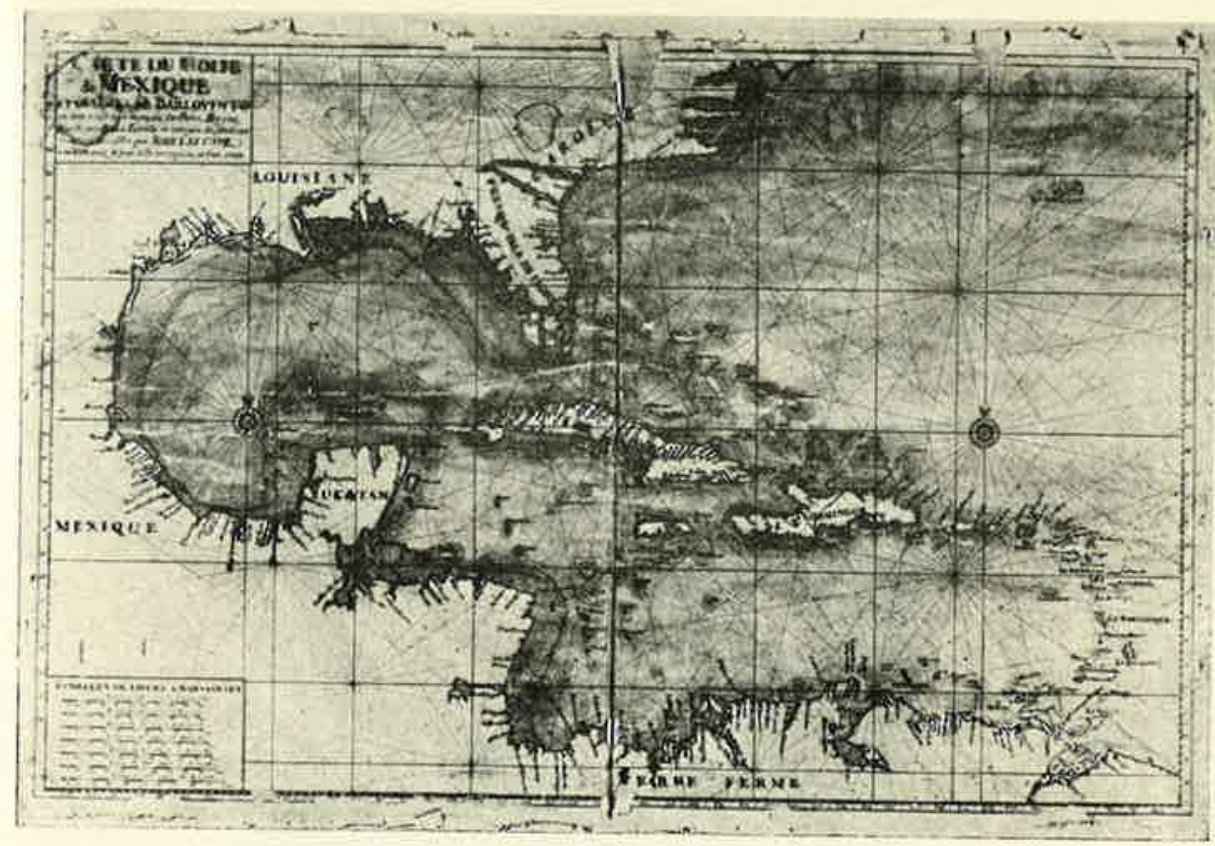

28. Réplica francesa al mapa de Les Carz.

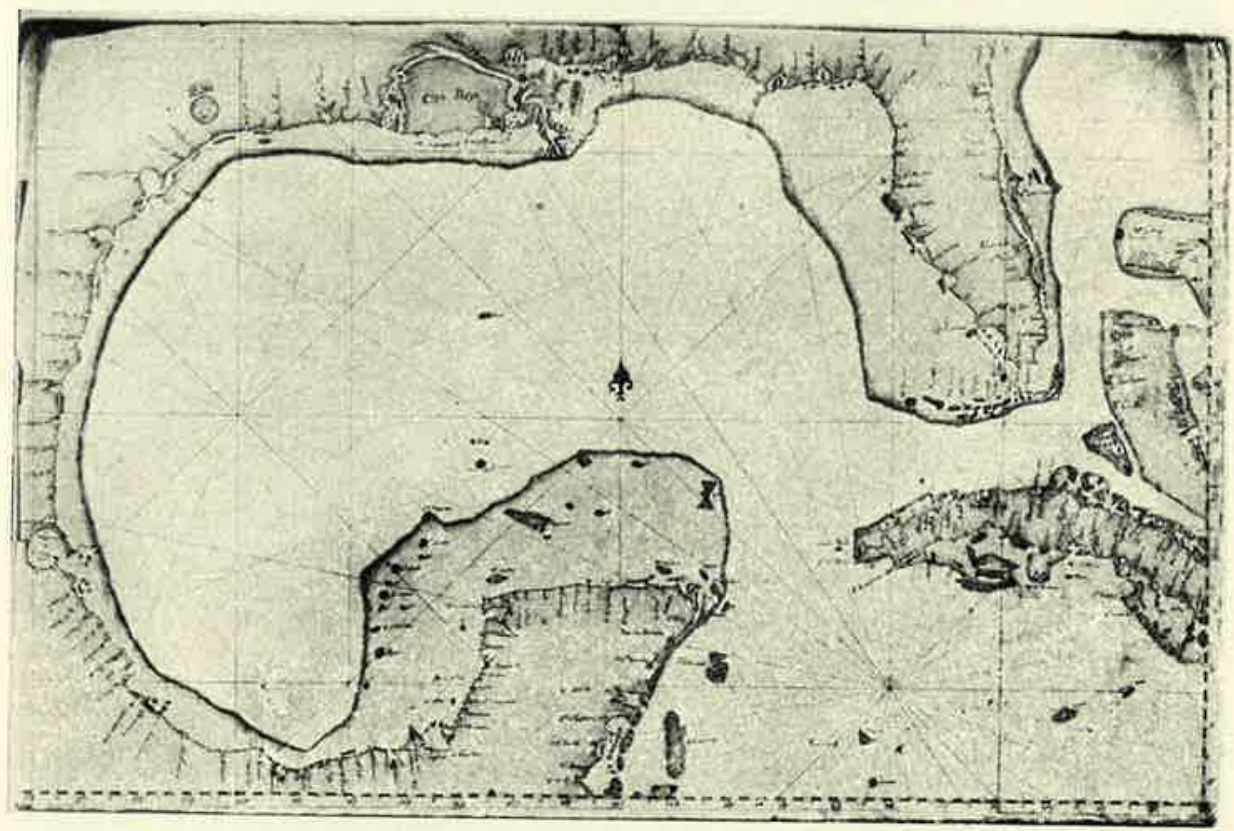

29. Mapa español del Golfo. ¿1750? 


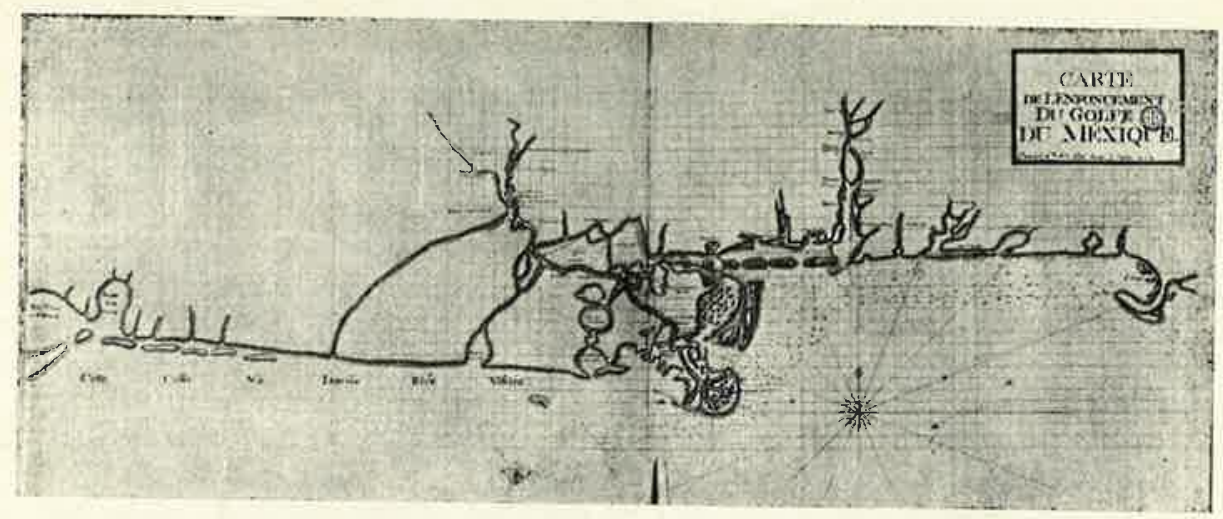

30. Carta francesa del ufondon del Golfo. 1769.

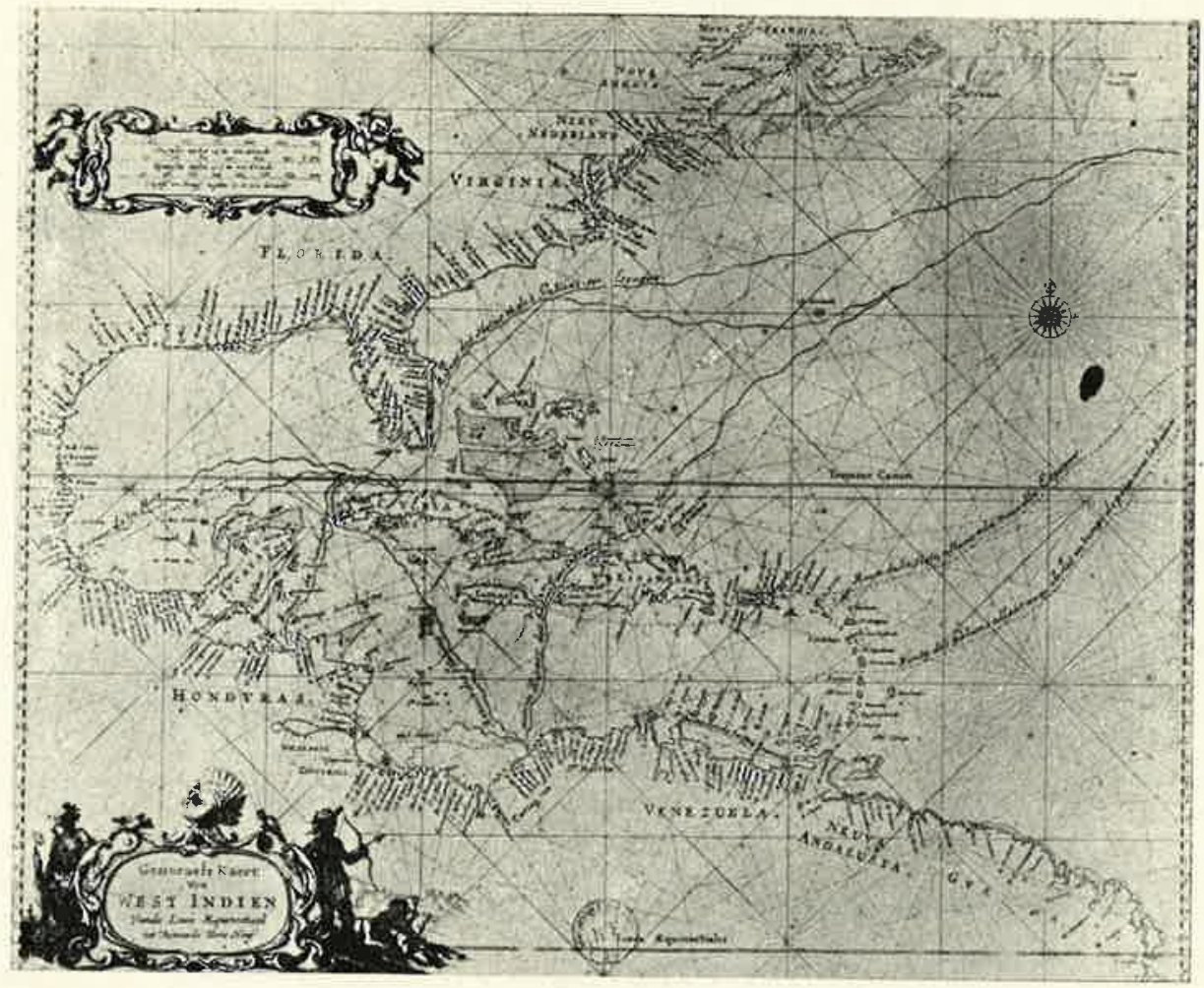

31. Carla holanslesa de las Indias Occidentales. is. XVII? 


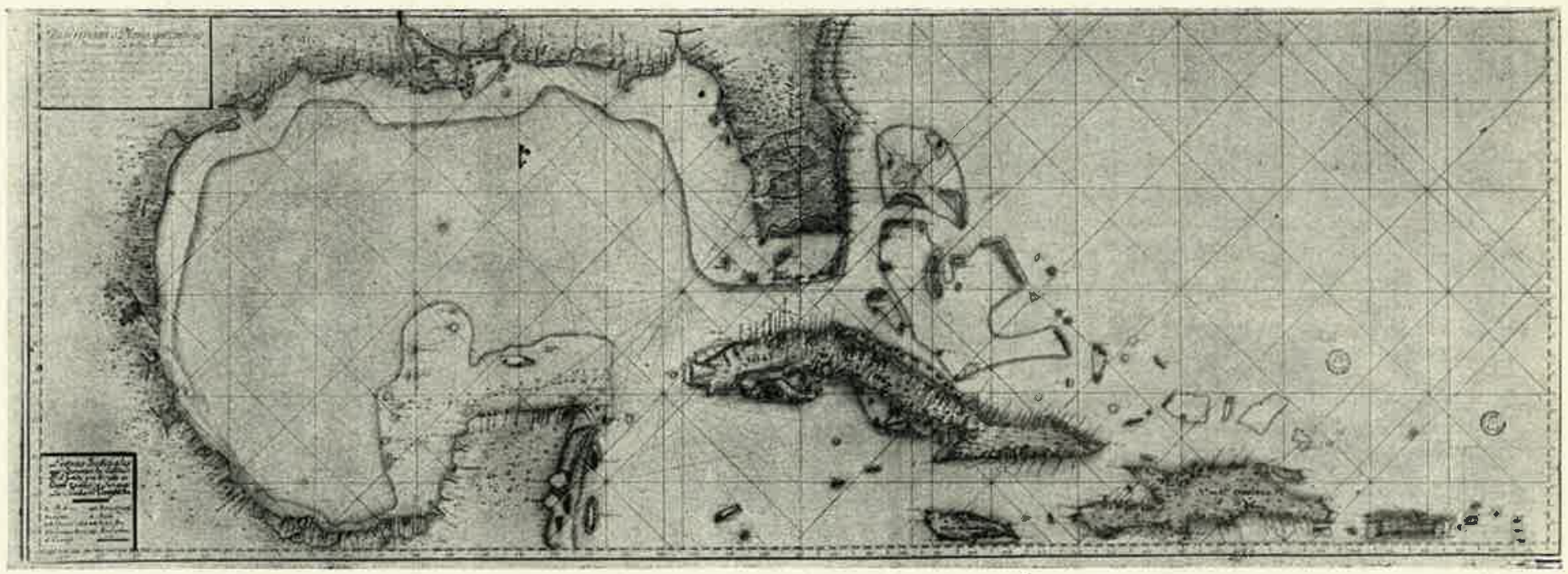

32. Carta española del Golfo. ¿1750? 


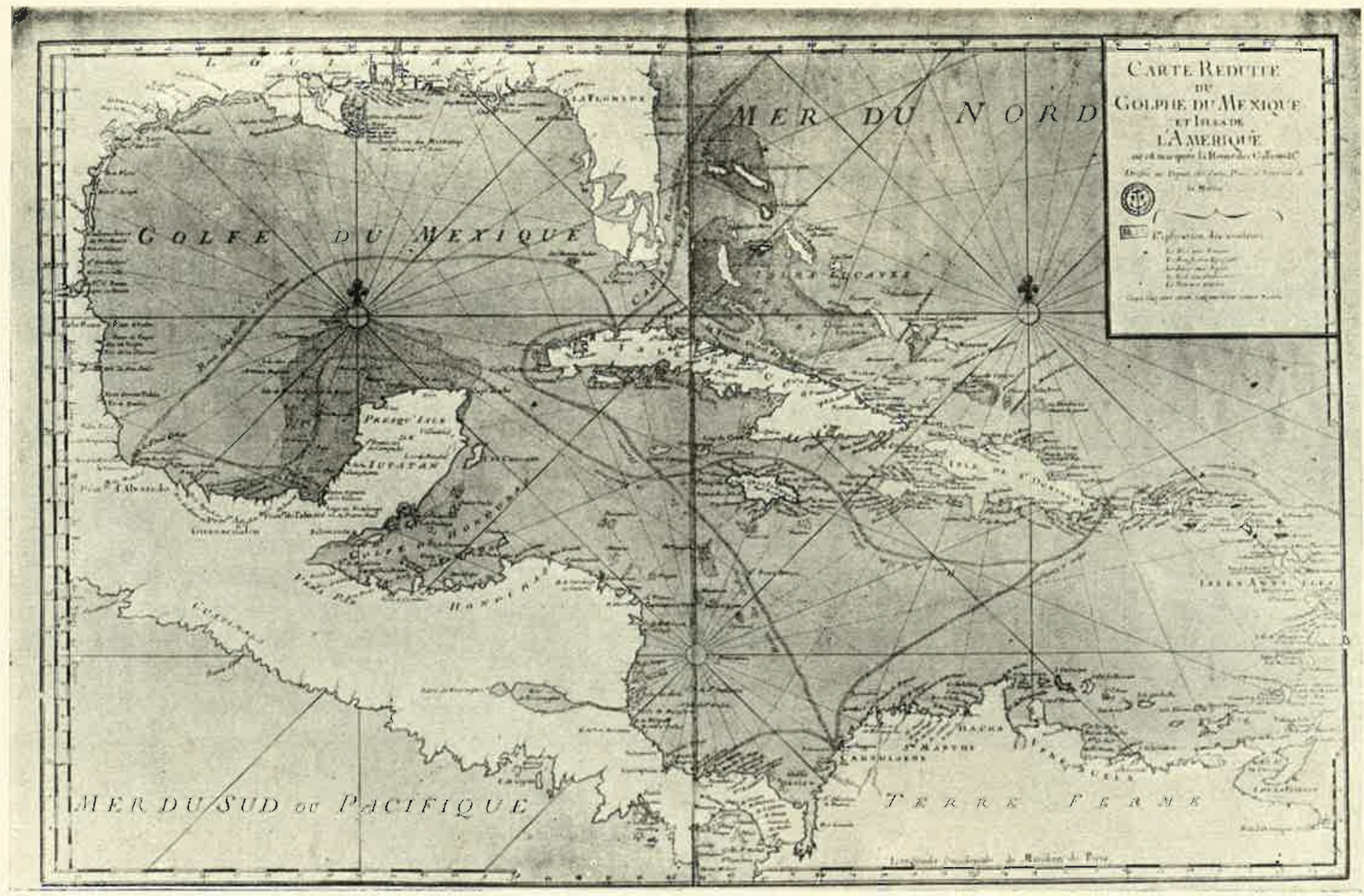

33. Carta francesa del Golfo y el Caribe zil750? 


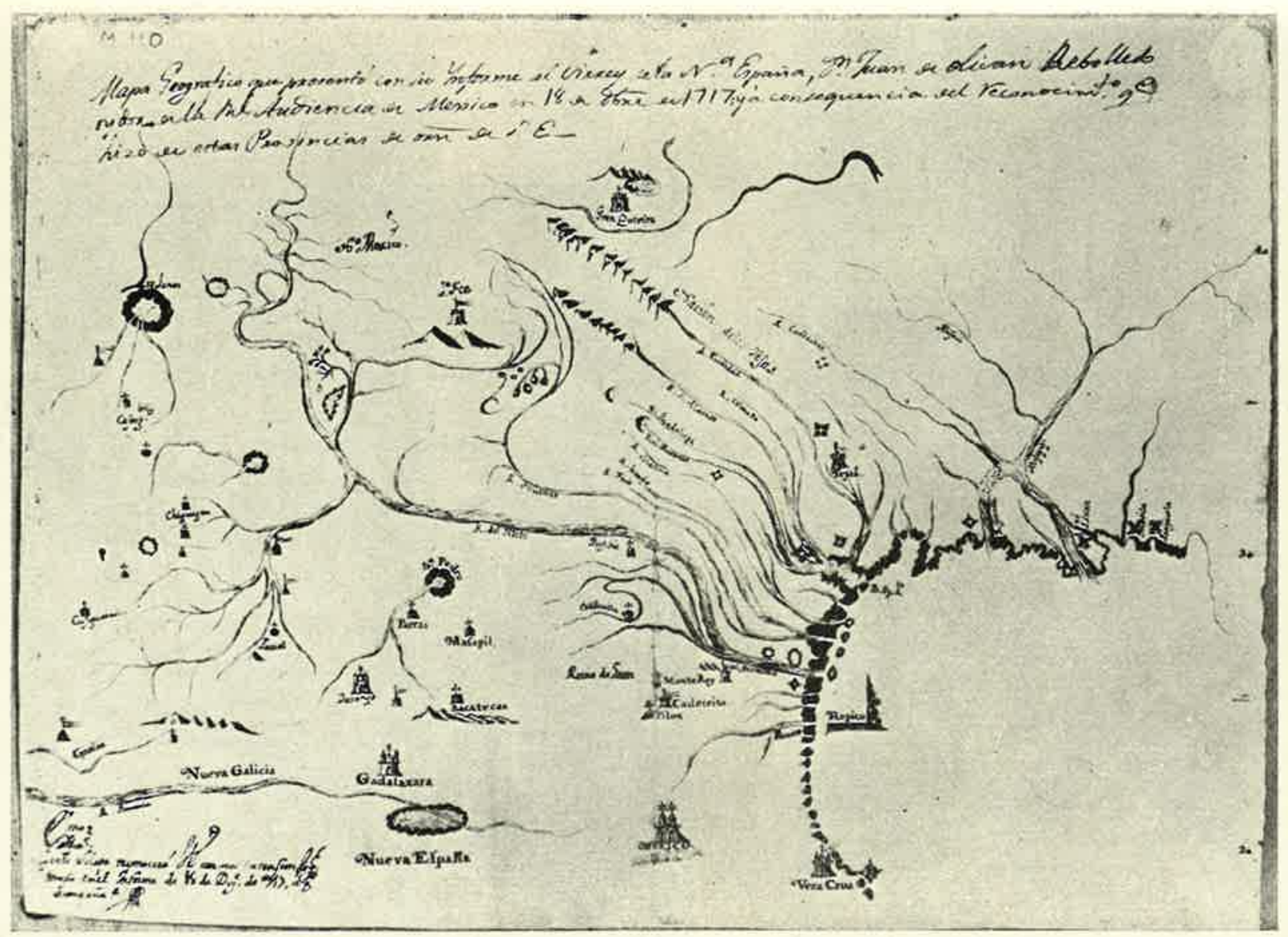

34. El norte de Nueva España. por el oidor Oliván. 1717. 


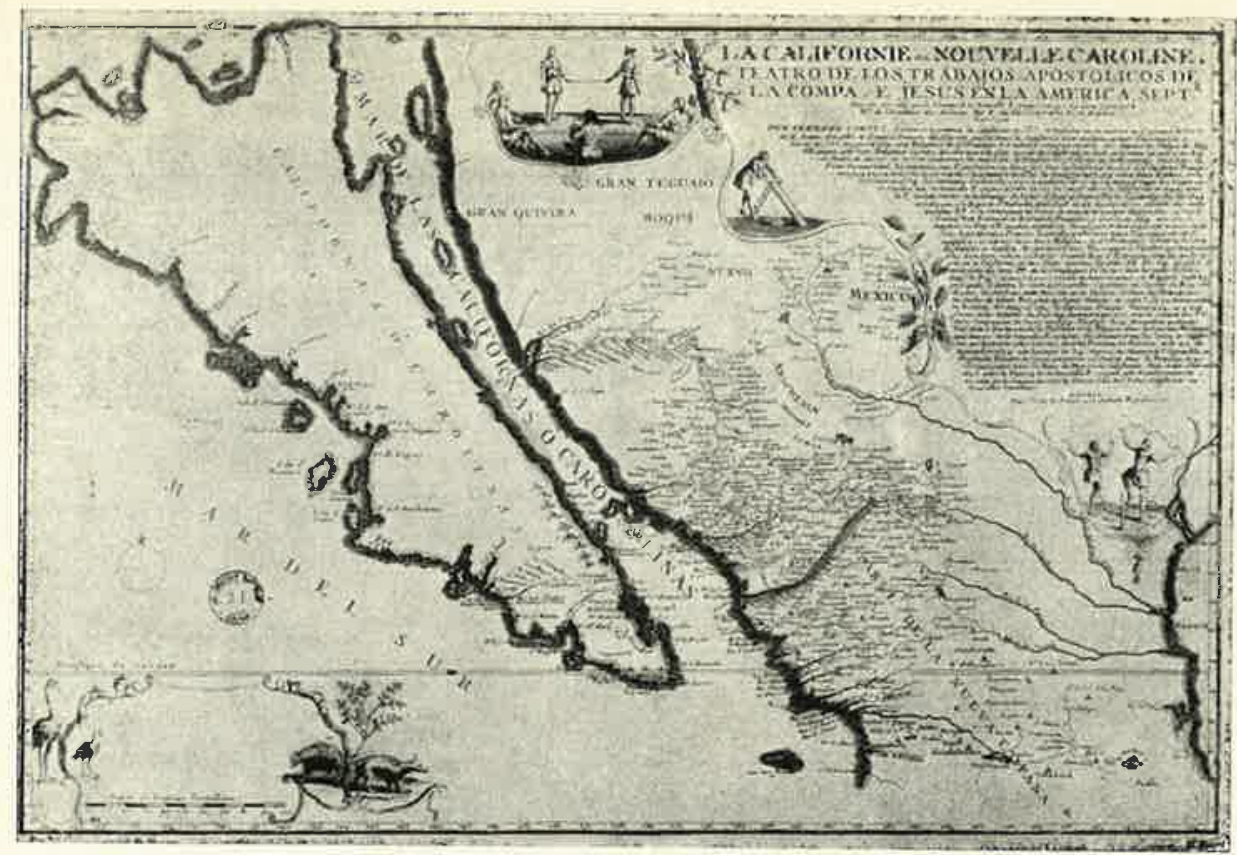

35. El noroeste del virreinato, por Kino. 1699.

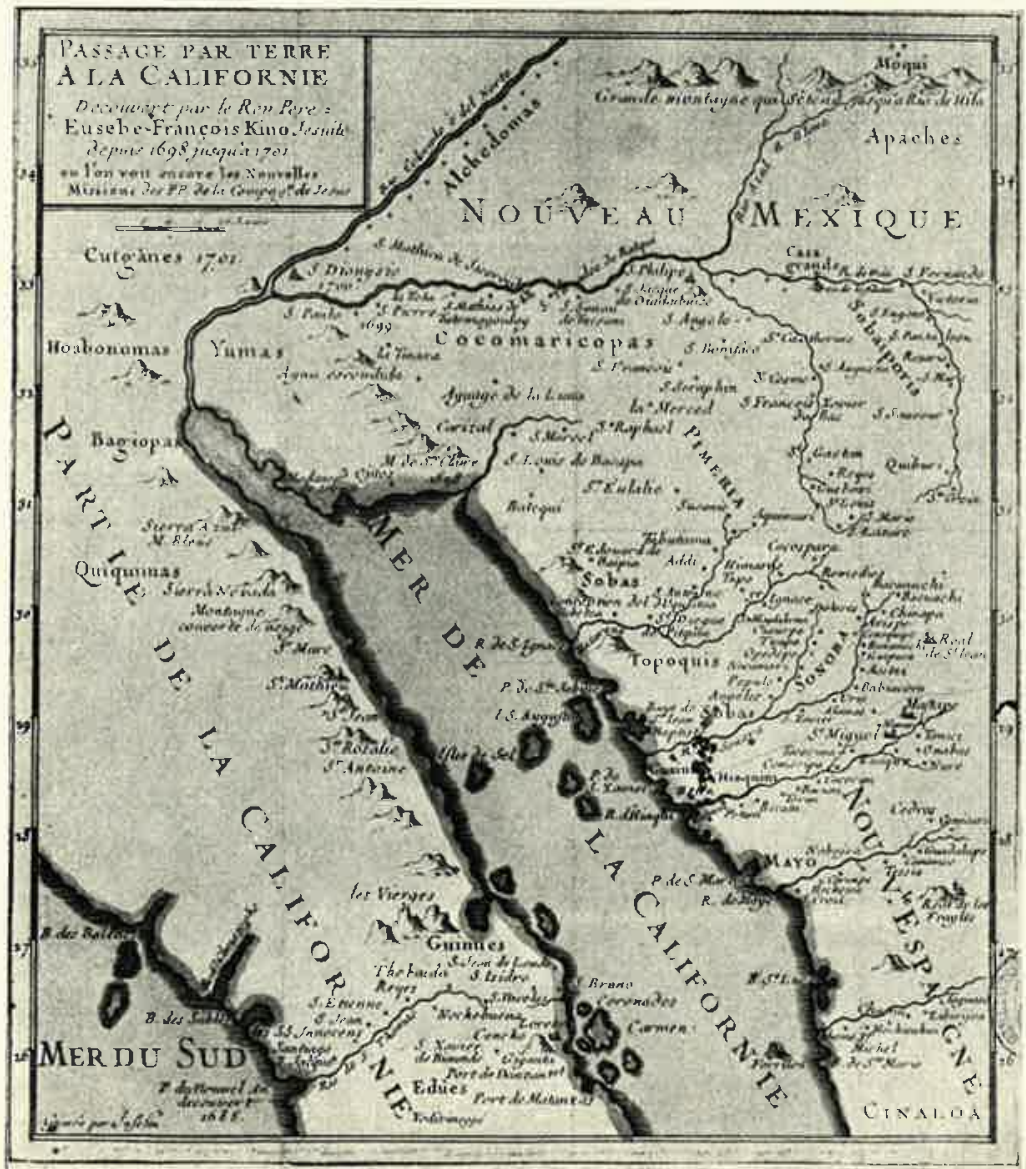

36. Paso por tierrat a Cialilornia, semún Kino, 1705. 


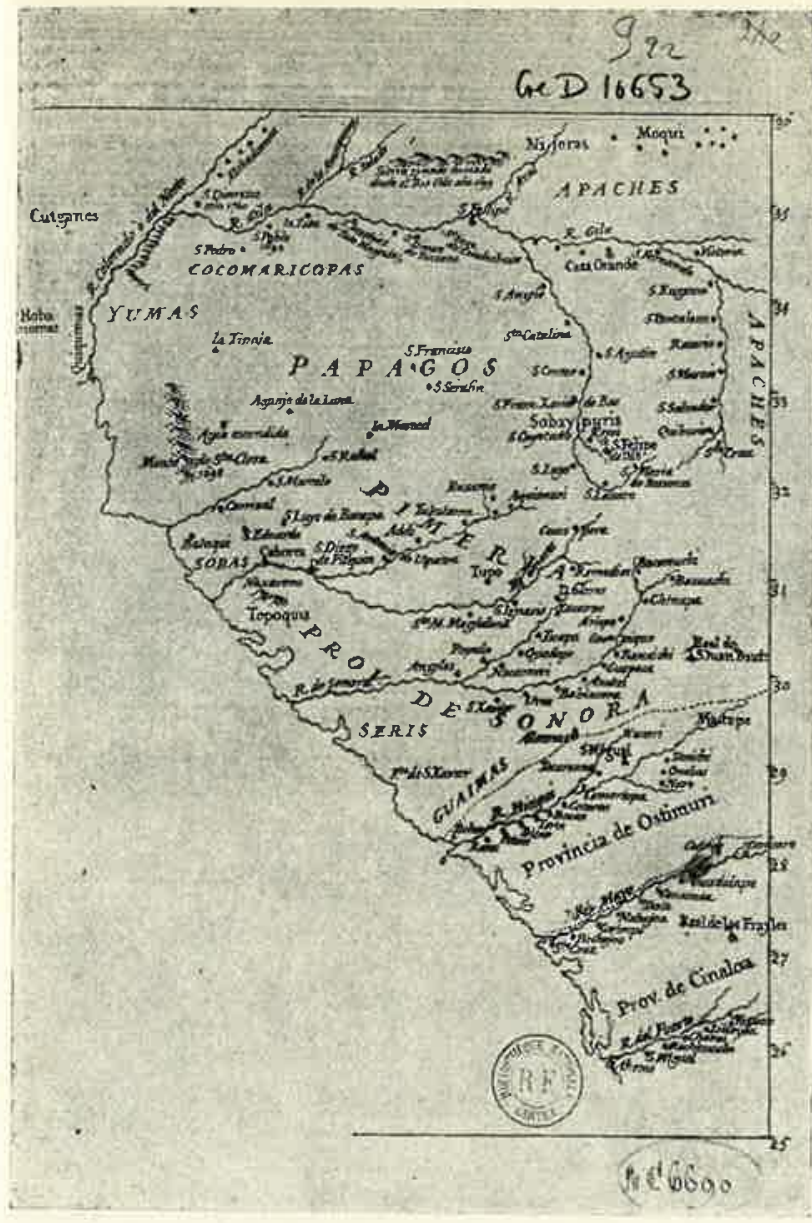

37. Mapa de Sonora y el Gilia. S. XVIII.

38. Sonora y California, copia de d'Anville. 1724.

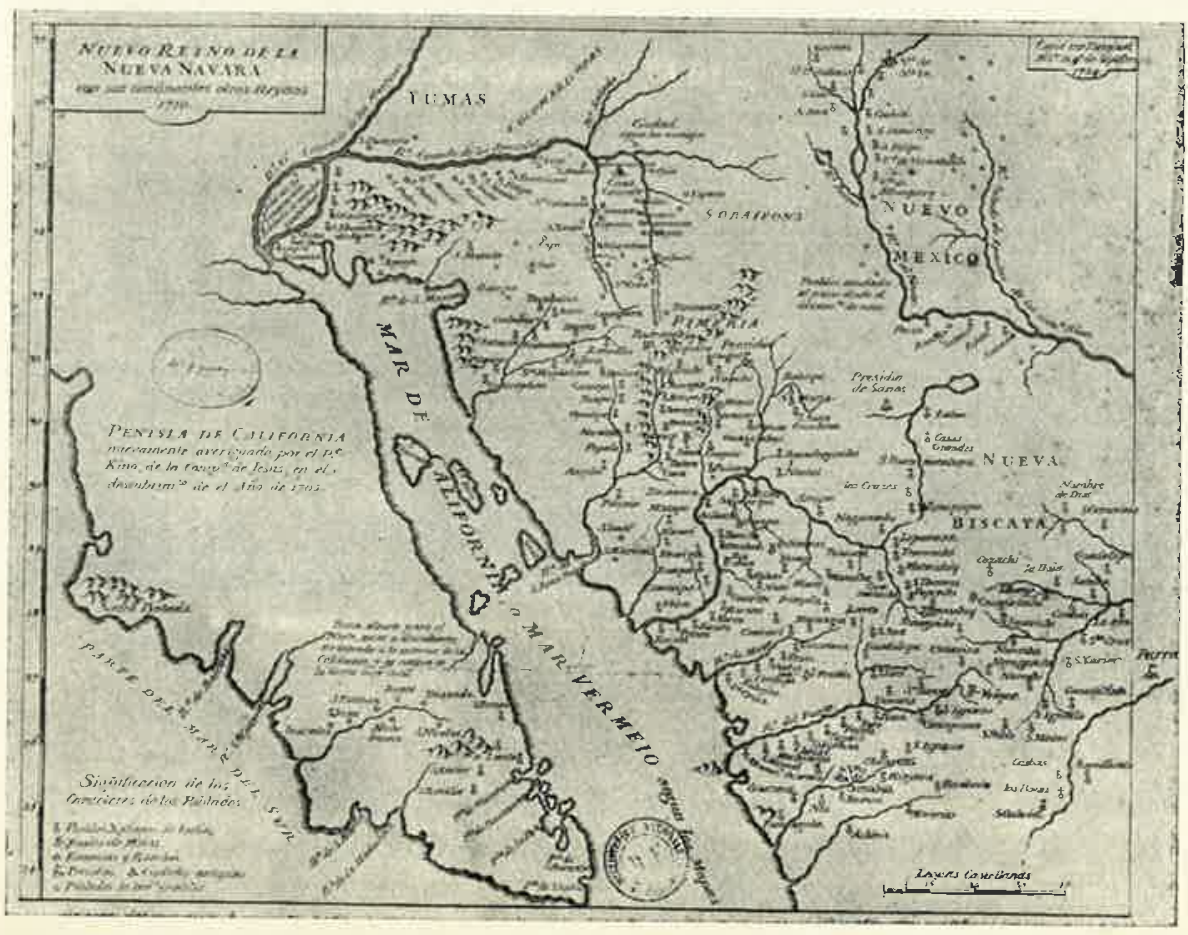




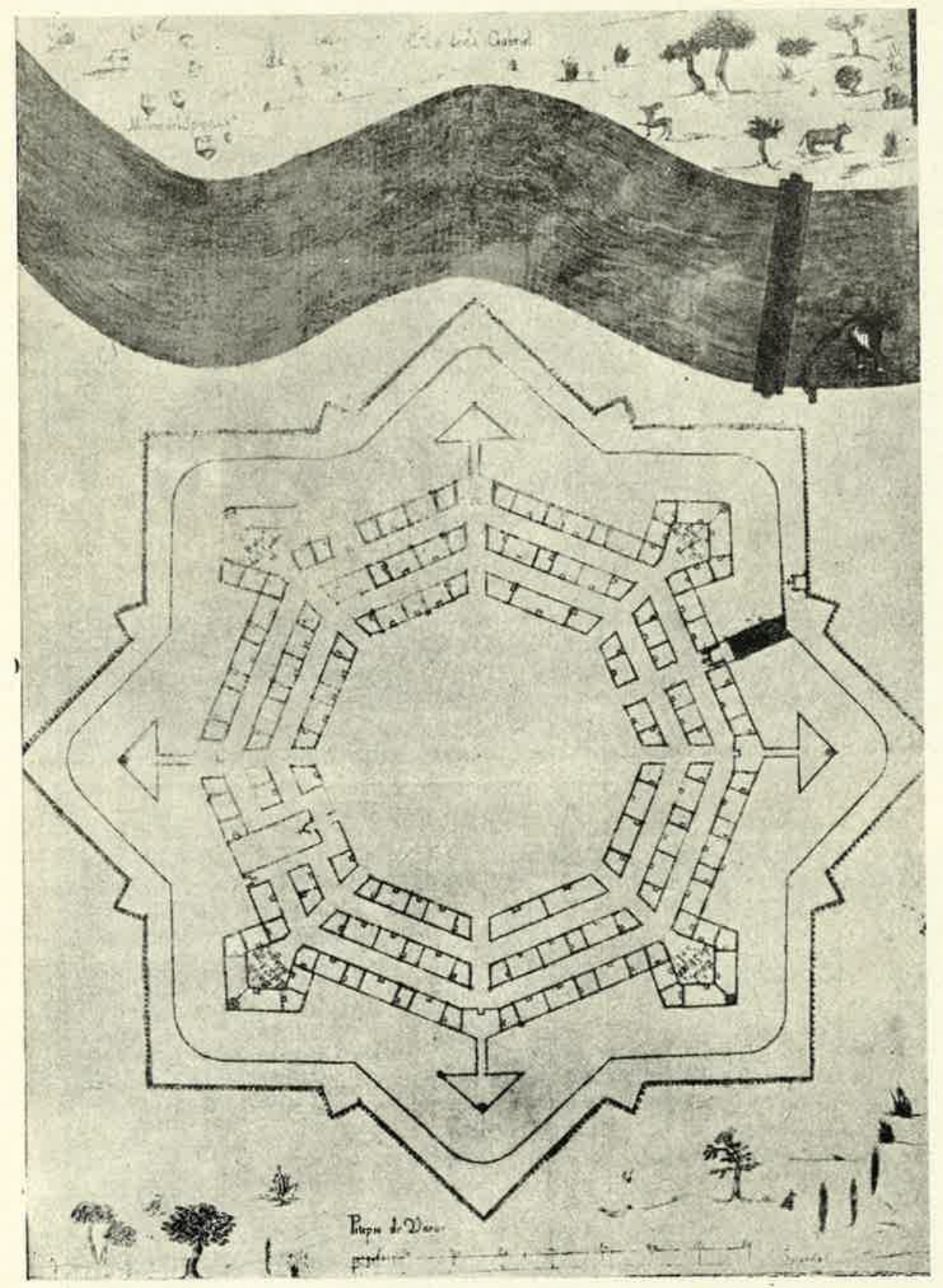

39. Presidio de Loreto, en la Bahia del Espiritu Santo, Texas, por Peña. 1722. 


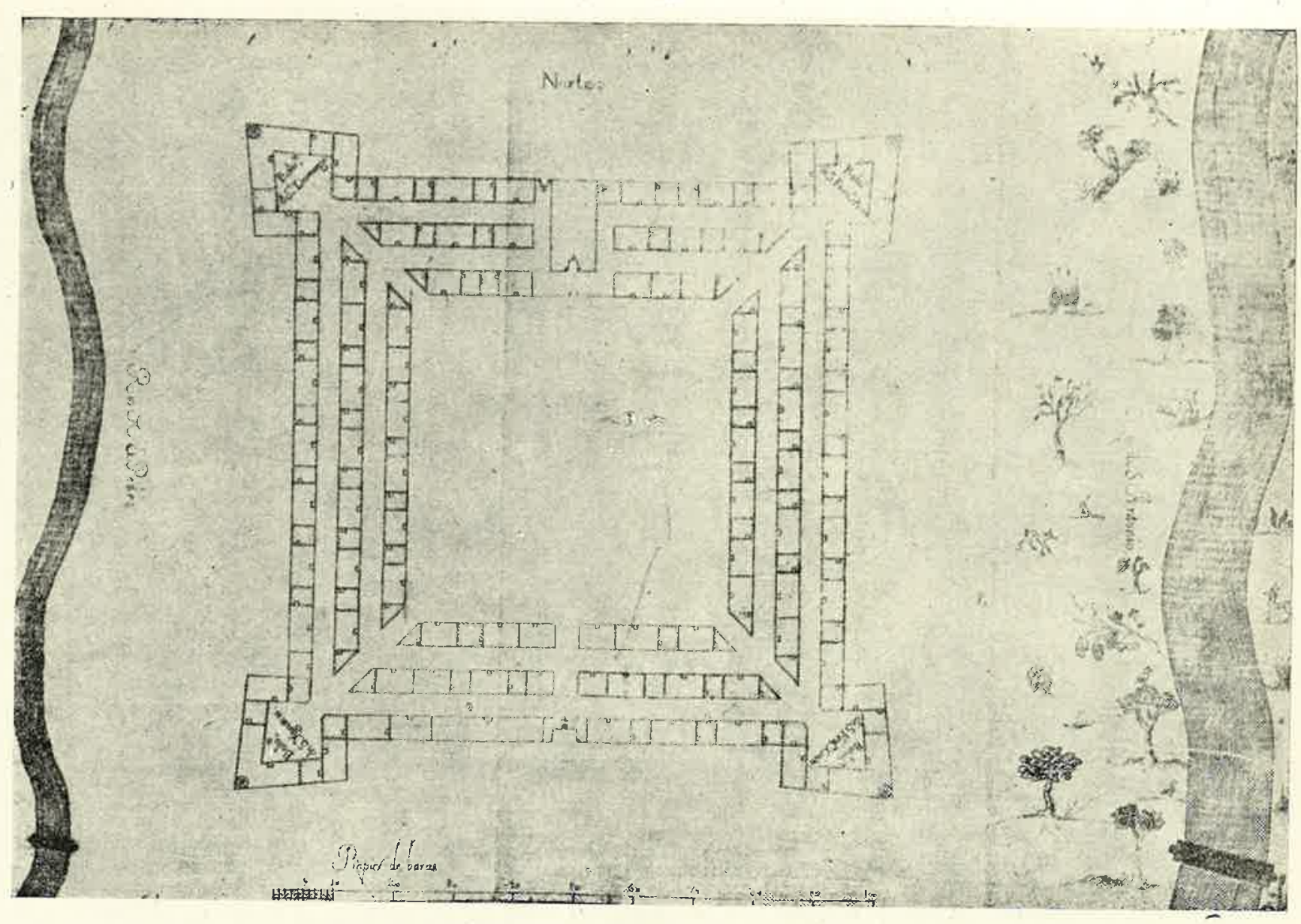

40. Presidio de San Antonio, en Texas, por Peña. 1722. 


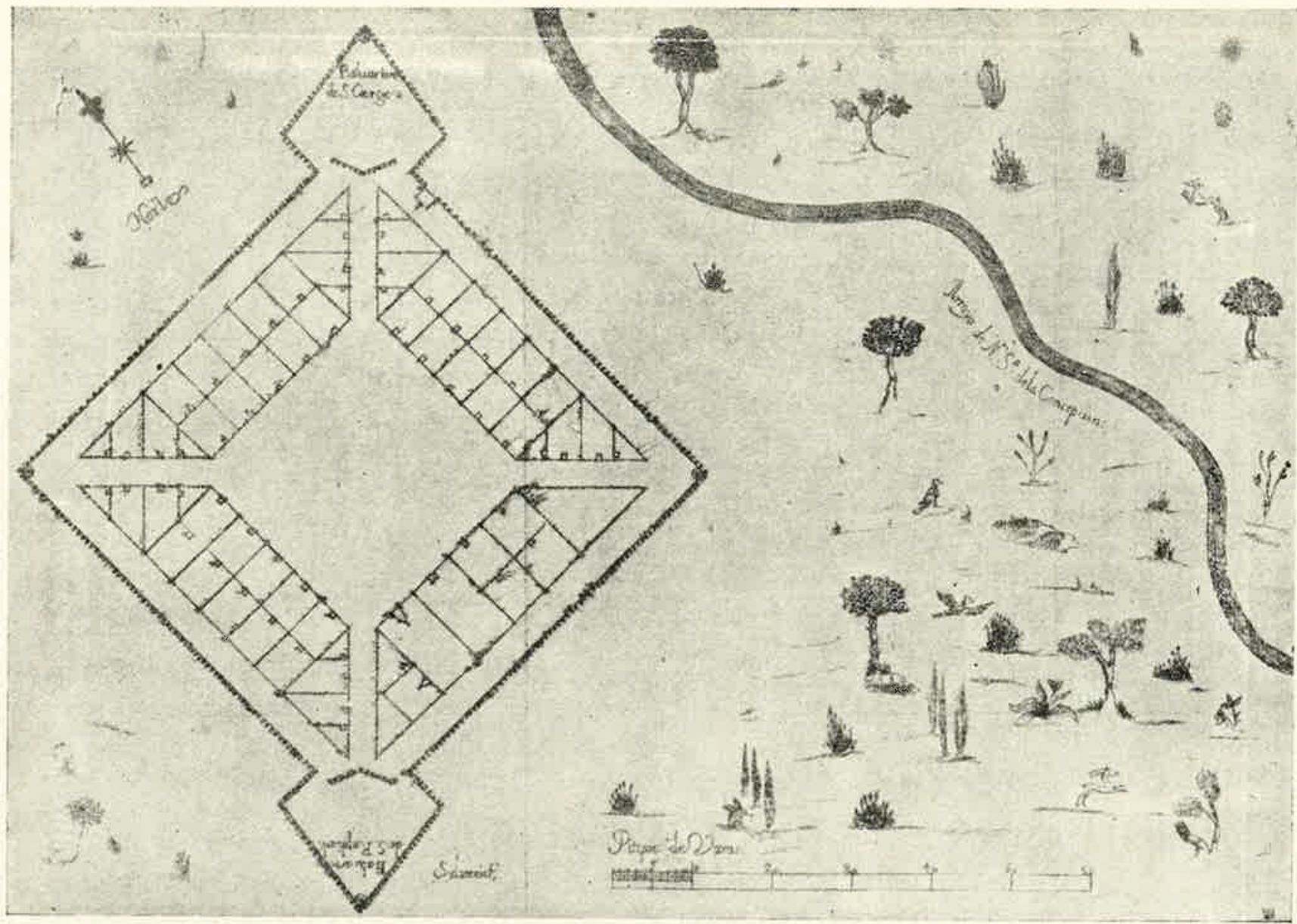

41. Presidio de los Dolores de los Texase por Peña. 1793. 


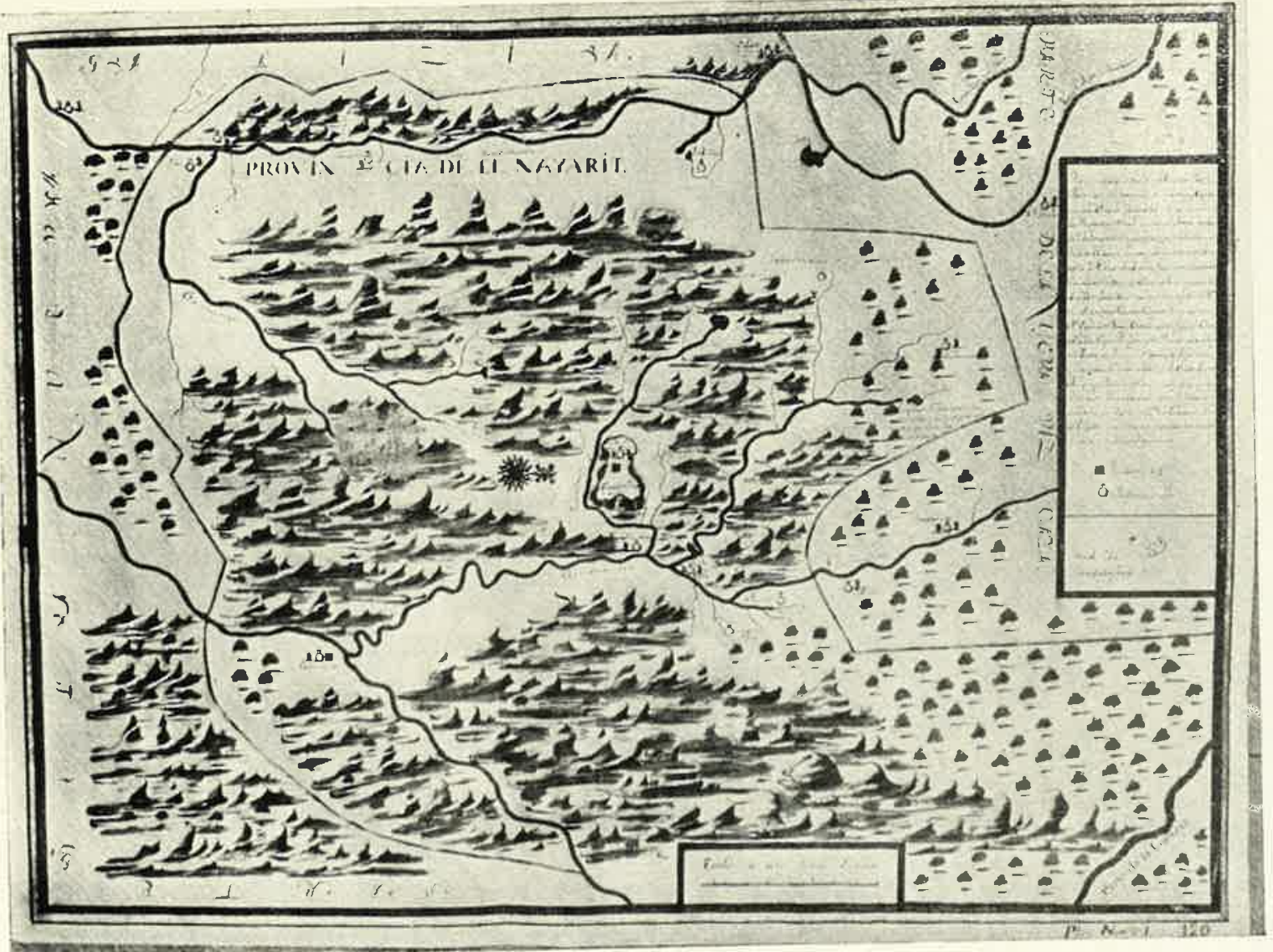

42. Mapa del Nayarit, por Barreiro. 1725. 


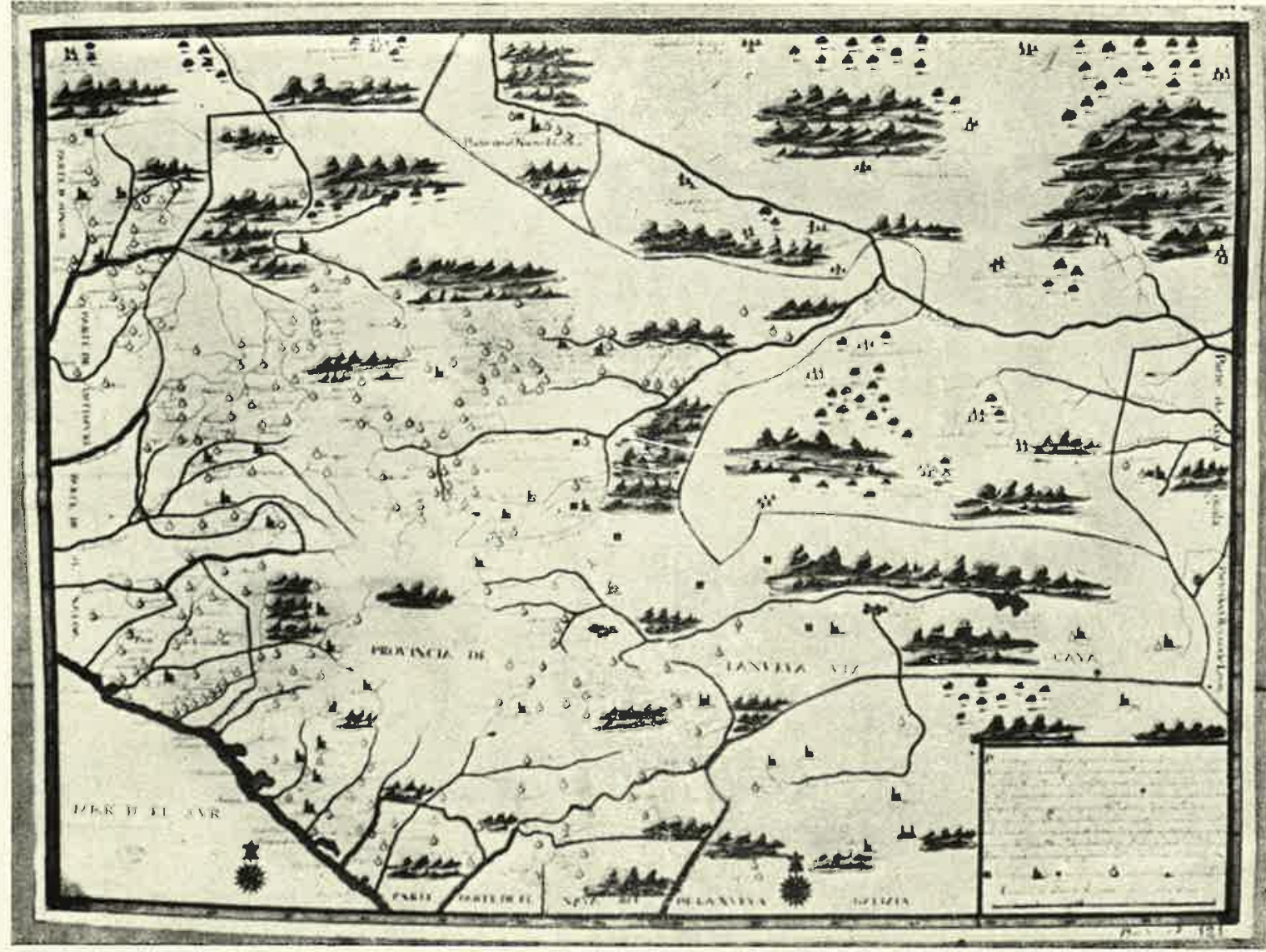

43. Nueva Vizcaya y Guliacán, por Barreiro. 1726. 


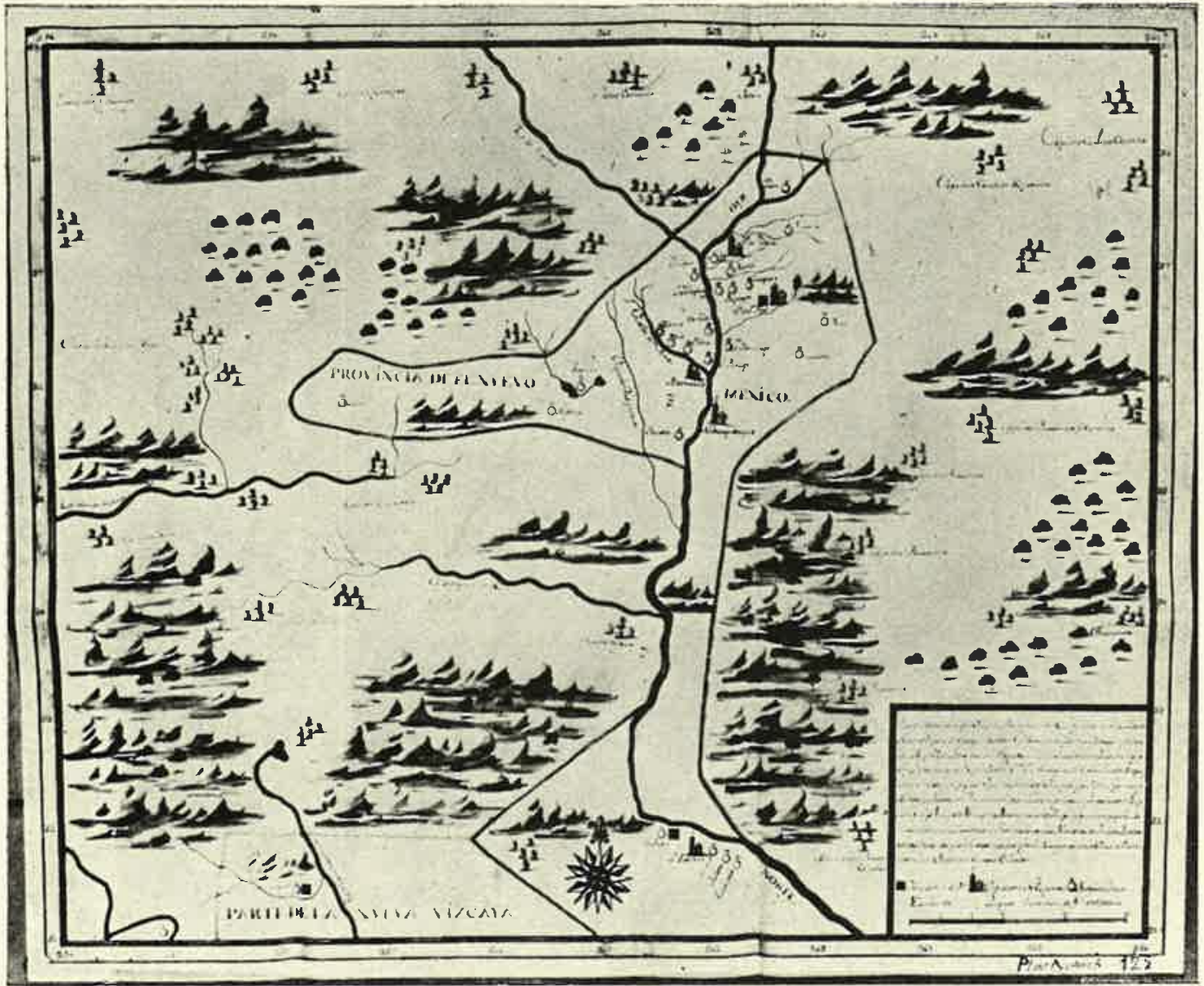

44. Nuevo México, por Barreiro. 1727. 


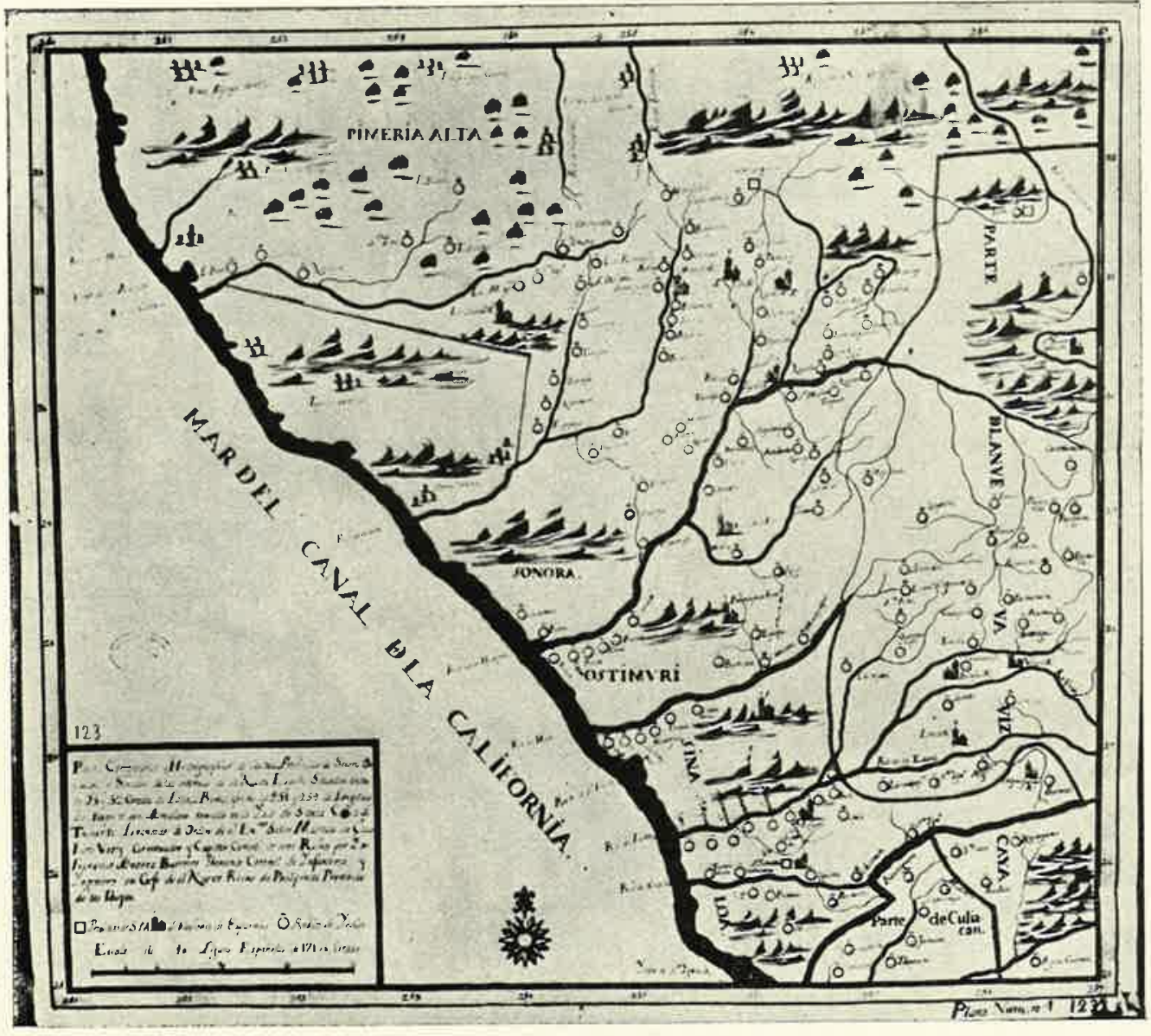

45. Sonora, por Barreiro. $172 \pi$. 


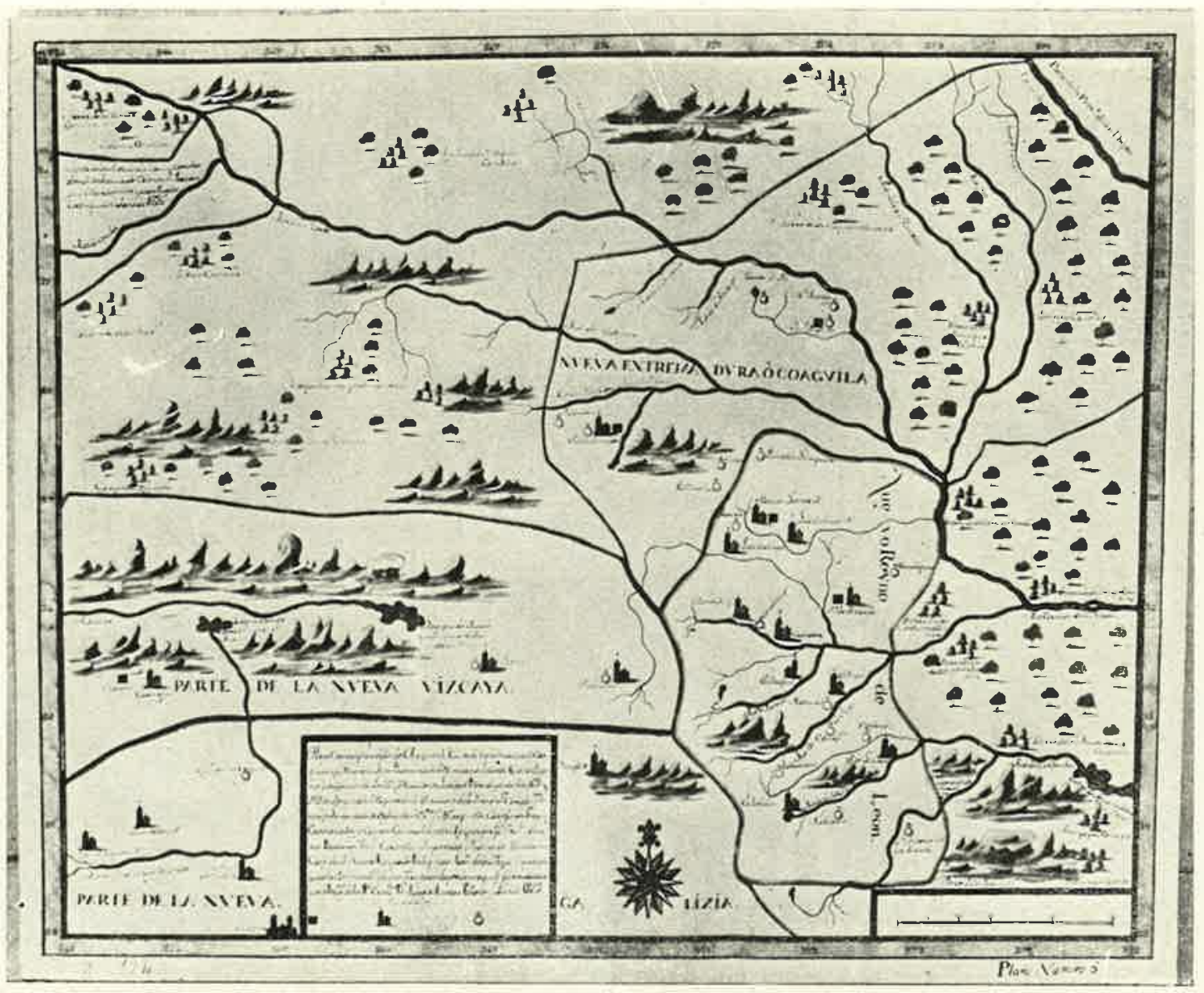

46. Coahuila y Nuevo Lein, por Barreiro. 1727. 


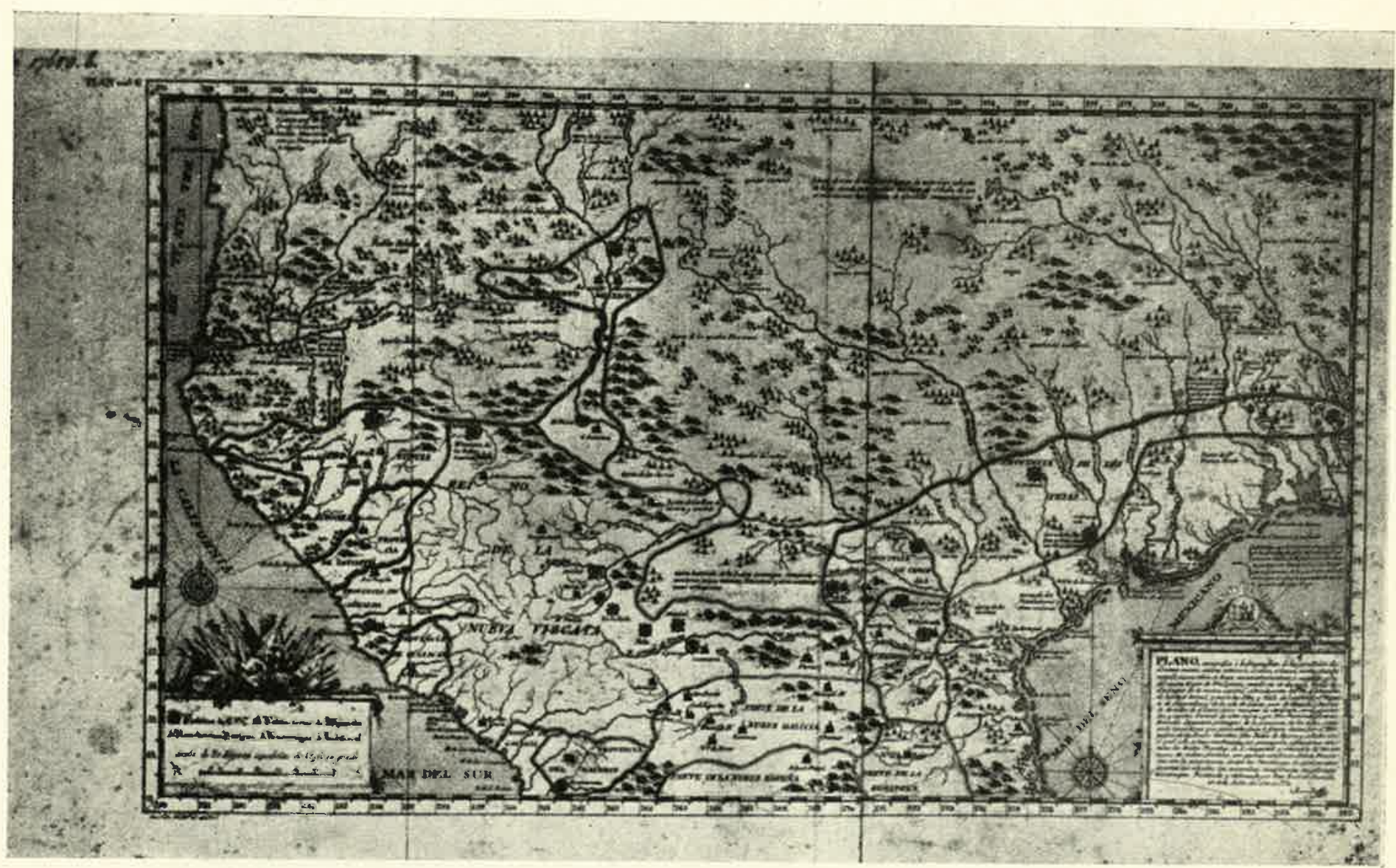

4.7. Tals provincias internas, por Barreiro. 1727. 
un limes al que servía de camino de ronda el mismo camino real de cien leguas que enlazaba Durango con Parral. A treinta leguas de aquella ciudad se encontraba el presidio de Nuestra Señora del Pasaje de Cuencamé; veinticuatro leguas más allá, el del Gallo, y otras veinticuatro más al norte, el de Cerro Gordo. De Cerro Gordo a Parral, donde estaba la compañía de campaña, había también veinticuatro leguas, y a veinte de este último lugar se hallaba el presidio de Conchos. Un poco retrasado hacia el oeste y el interior quedaba el de Santa Catalina de Tepehuanes, y a setenta leguas de Durango. Mientras que el real de Mapimí, renacido nuevamente, se adelantaba con gran riesgo hacia el Bolsón, y durante algún tiempo vacilaron los gobernadores en trasladar a aquel sitio el presidio del Gallo.

Por rumbo distinto, enormemente aislado, a cien leguas de Parral y a catorce de las misiones de Casas Grandes, alcanzábase el presidio de Janos, en la extremidad septentrional del Reino, de espaldas a la Tarahumara y haciendo frente a un enemigo cuyo nombre iba a llenar en breve tiempo los informes de todo género acerca de las provincias internas: la nación apache, que en Janos entraba en contacto por primera vez con Nueva Vizcaya.

\section{Coahuila, Nuevo León, Texas}

El enorme ámbito territorial en que se mueven los protagonistas de nuestra historia nos obliga a trasladar frecuentemente nuestra atención de unas a otras provincias, según la van solicitando los diversos acontecimientos ocurridos. Al hacerlo así, procuramos ir salvando o apuntando la relación cronológica tanto como la causal, cuando la hay, entre unos y otros hechos.

Por eso ahora nos fijamos en las tierras situadas al otro lado de la frontera de guerra de Nueva Vizcaya, más allá de las tribus hostiles y del desierto y al norte de Saltillo donde, en I689, tiene lugar la fundación de la villa de Santiago de Monclova, casi sobre los cimientos de tres fundaciones anteriores fracasadas, por el capitán Alonso de León, que logra al fin dejar establecida la provincia de Coahuila. Una guarnición de veinticinco soldados sería el instrumento inmediato utilizado por el gobernador para rechazar los ataques o sofocar las rebeliones de los indios, en las tierras que iban siendo ocupadas por las misiones franciscanas y por las haciendas de los recién
llegados colonos.

Las consecuencias de esta obstrucción de la salida oriental del Bolsón no habían de tardar en dejarse sentir. $Y$ al propio tiempo, Coahuila quedaba asentada como otro Nuevo México, rodeada de indios hostiles por tres de los rumbos, y extraordinariamente alejada del débil respaldo que podían proporcionarle los núcleos de Saltillo y Monterrey, siendo así que éste último 
se debatía entre las constantes sublevaciones ocasionadas por el desarreglado sistema de encomiendas o congregas allí imperante.

Sin embargo, Saltillo, Monterrey y Monclova ya constituían una apreciable base de partida para actuar al otro lado del río Grande, y con este signo nace Coahuila, vinculada a las expediciones de su fundador al territorio de Texas: con la presencia en las costas setentrionales del Golfo del Caballero de la Salle ha surgido una poderosa razón para que España haga manifiesto su señorío en aquellos países. Y por esto; cuando el acicate de las minas o de las tierras es inexistente, o bien la situación poco firme de las provincias limítrofes impide responder adecuadamente a aquel incentivo, un reto de carácter estratégico-político impone la necesidad de una empresa dirigida por la Corona, y éste es el último móvil por el que España intentará contornear el Golfo por tierra, alcanzar las aguas del Misisipí, y enlazar con la Florida, lo que no logrará hasta un siglo más tarde y en circunstancias muy peculiares.

Por de pronto, desde 1686 Alonso de León realiza una expedición cada año, intentando descubrir la población fundada por la Salle, como lo logró en r689. Al año siguiente, alarmado ya el gobierno por el riesgo que suponía dejar aquel territorio desocupado, inicia una débil penetración con el establecimiento de tres misiones franciscanas por el mismo de León, misiones que dos años después fueron abandonadas por su ineficacia. Hasta la segunda década del siglo XVIII no se volverá a intentar la ocupación del suelo texano. ${ }^{14}$

\section{SONORA Y LA TARAHUMARA:}

UNA NUEVA FRONTERA

Apenas había logrado Neira y Quiroga el establecimiento del sistema defensivo de Nueva Vizcaya, cuando surge de nuevo el fantasma de la sublevación en la Tarahumara. Treinta años después de la pacificación de esta provincia creíase en stı absoluta cristianización. Evidentemente, los misioneros franciscanos y jesuitas habian desplegado una actividad evangelizadora incomparable, preparando el terreno para la penetración del elemento civil; cuando éste llegó, se sucedieron los descubrimientos de ricas minas : el sucesor de Neira, Juan Isidro de Pardiñas, habla de Santa Rosa de Tarahumaras y otros minerales que se iban poblando en el camino de Sonora, y dice que rá-

I4 Gil Munilla, Roberto: Política española en el golfo mexicano. Expediciones motivadas por la entrada del caballero de la Salle ( I685-I707). "Antuario de Estudios Americanos", XII, I955; 467-7I1. Folmer, Henry: Franco-Spanish rivalry in North America. I524-1763. Glendale, I953. 
pidamente se procedía a la construcción de ingenios para el beneficio de la plata por fuego y azogue.

Sonora acababa de pasar una crisis semejante a la que en Nueva Vizcaya había determinado la adopción de enérgicas medidas militares cuando, a partir de I68I, empiezan a percibirse inquietudes entre los pimas colindantes con la Tarahumara. Alzáronse finalmente dispuestos a rechazar a los españoles, y se produjo un movimiento general de desbandada en los reales de minas que comenzaban a nacer en la provincia. Acudió Pardiñas a sofocar el movimiento subversivo, enviando gran cantidad de tropas: actuaron setenta hombres de Sonora juntamente con cuarenta de Santa Rosa Tarahumaras, treinta de Parral y treinta de Casas Grandes, interviniendo aquí el capitán de Janos, Fernández de la Fuente. Los pimas atacaron entonces resueltamente el campo de los españoles, pero allí mismo sufrieron una decisiva derrota que les obligó a pedir la paz y someterse plenamente.

La inquietud perduraba, no obstante, en la sierra, y poco después la Tarahumara Alta, donde la naciente explotación minera la iba incubando entre los indios, alzóse en arnas en I690. Aquí fueron precisos dos años de campañas en las que tomaron parte dos centenares de soldados de todos los presidios al mando de Juan Fernández de Retana, con más de quinientos indios auxiliares chizos, conchos, tapacolmes, norteños, cibolos y tepehuanes. La región no quedó sosegada hasta I69I, quedando obligado el presidio de Conchos a partir de esa fecha a verificar una visita anual a la Tarahumara con objeto de volver a los pueblos a los indios que todavía se escapaban a los montes rehuyendo la vida y el trabajo reglamentados por los misioneros. Dos jesuitas habían hallado la muerte en la sublevación, y habían ardido las misiones de Yepómera, Tutuaca, Matachic, Tomochic, Cocomorichic y Cahurichic.

Casi simultáneamente, Sonora abríase, como Nueva Vizcaya un siglo antes, al peligro exterior unido a la inquietud interior.

El progreso de los misioneros había sido tan rápido como libre de obstáculos hasta el momento del alzamiento pima. Pero siguiendo la trayectoria de la evangelización se advierte cómo crtizado el Yaqui se hace una marcha frontal hacia el río de Sonora, abarcando del mar a la sierra; mientras que, llegados al río de Sonora, los jesuitas reducen su campo de acción a la región comprendida entre su valle y la cordillera, que es prácticamente la cuenca de aquel río. En la parte costera, en efecto, no hay más que una seca y abrasada marisma que se prolonga hacia el norte para enlanzar con el desierto de Colorado. $Y$ aquí quedaron confinados los indios seris y tepocas, habitantes de la costa y de la vecina isla del Tiburón, que pronto iban a crear un estado de cosas en todo semejante al del Bolsón de Mapimí. La década de 
I670 había visto la apertura de las hostilidades de los seris sobre las misiones vecinas a su territorio. El embolsamiento de estas tribus fue completo al alcanzar los misioneros el río de 'Caborca y descender hasta el mar siguiendo su curso.

Por otra parte, la periferia de la provincia, por donde las misiones estaban a punto de alcanzar las fuentes de los ríos de Santa Cruz y Guebavi, había cobrado repentinamente vida al llegar a las zonas habitadas por los nómadas. Los apaches habían comenzado sus incursiones a los pueblos, recorriendo a sangre y fuego los bordes de la Opatería, y el capitán de Janos, aun auxiliado por una escuadra del presidio de Sinaloa, se veía impotente para contener la avalancha.

Así, pues, apenas habían quedado de paz los pimas, sublevados en i688, y mientras se experimentaban las conmociones de la Tarahumara, un nuevo enemigo hacía su entrada en escena para oscurecer más el horizonte. Decidió entonces el virrey formar una compañía volante, con veinte soldados de Sinaloa, diez del Gallo y otros tantos de Cuencamé, que puso al mando del capitán Francisco Ramírez de Salazar. Llevó éste a cabo una corta campaña contra los apaches, después de la cual se convenció de la esterilidad de sus esfuerzos y marchó a México para exponer la necesidad de aumentar los efectivos, dejando los cuarenta hombres que tenía repartidos en cuatro posiciones a lo largo de la frontera.

Parece que el virrey accedió a la formación de una nueva compañía voiante de cincuenta soldados, pero Ramírez de Salazar murió cuando regresaba a Sonora, y el conde de Galve nombró en su lugar a Don Domingo de Gironza y Petriz de Cruzat, exgobernador de Nuevo México y fundador del presidio de El Paso, a quien posteriormente se permitió reclutar veinte hombres más.

Pero mientras Gironza llegaba a su nuevo destino, los apaches, unidos con grupos de sobas y pimas, asaltaban Nacosari, Bacanuchi, Natividad y Chinapas y empezaban a robar caballadas y muladas. ${ }^{15}$

\section{Los товоsos}

Hemos hecho un largo paréntesis con el fin de examinar siquiera sea rápidamente la situación de las provincias vecinas a Nueva Vizcaya en los últimos años del siglo XVII. Finalmente, volvemos a considerar la frontera occidental del Bolsón, en la que los presidios de Cordillera, se veían obligados

I 5 Forbes, Jack Douglas: The janos, jocomes, and sumas indians. N.M.H.R., XXXII, octubre 1957, 319-334. Christelow, Allan: Father Joseph Newmann jesuit missionary to the Tarahumares H.A.H.R., XIX, nov. I939, 423-442. 
a desplegar toda su actividad para evitar o castigar las incursiones de los bárbaros, a los que las armas de Monclova rechazaban en el otro extremo del oriente.

Concluída la pacificación de la Tarahumara, iniciáronse las campañas de las tropas presidiales por el Bolsón. Tiodos los años, por los meses de septiembre y octubre, se formaban destacamentos de cincuenta a ochenta soldados que salían a patrullar por distintos rumbos. En una ocasión, tres de estos destacamentos sitiaron en la sierra Mojada a los cocoyomes y acoclames, pero éstos lograron finalmente escapar. Los presidios atendían tanto a las expediciones como a convoyar los grupos de viajeros que transitaban en ambos sentidos el camino real. Sin embargo, su misma protección se mostraba insuficiente, ptesto que en varias ocasiones atacaron los enemigos a los pasajeros, incluso yendo escoltados, en parajes como el Arroyo de Baus, Los Patos y Agua Nueva. Hízose entonces inevitable que el gobernador dispusiera que todos los cordones saliesen a principio de cada mes del Pasaje, para entrar en Nueva Vizcaya, y del Valle de San Bartolomé, para salir, llevando cada convoy veinticinco soldados y otros tantos auxiliares para su protección.

Entonces los bárbaros, viendo imposible el atacar a los viandantes, empezaron a asaltar haciendas, vaquerías y casas. Las cartas del gobernador Castillo nos informan de que las regiones hostilizadas eran precisamente las del fondo del Bolsón adentrándose los bárbaros al corazón del Reino por la despoblada cuenca inferior de los ríos Nazas y Aguanaval, hastal atacar las proximidades de San Juan del Río, llegando a seis leguas de Sombrerete. Los alrededores de Cuencamé vivían en continuo sobresalto. La misma ciudad de Durango estaba en peligro. Los atacantes eran, no ya solo tobosos, sino miembros de una multitud de tribus, la mayoría de Coahuila, de las tierras entre Santa Rosa y el río Turbio o del Norte. Dos capitanes de estas bandas, Tecolote y Luquillas, organizaban la guerra y atraían a los grupos a tomar parte en sus asaltos.

Castillo se resolvió, desde que se hizo cargo del gobierno, a pasar a la ofensiva, y así, apenas llegado a Durango, ordena al capitán del Pasaje, Escorza, una exploración de toda la extremidad meridional del Bolsón. Luego organiza campañas conjuntas o simultáneas de los diferentes presidios. $Y_{i}$ de la misma manera empieza a solicitar incremento de los efectivos militares. Quisiera aumentar los quince soldados que hay en Parral - pues los quince restantes de la compañía de campaña estaban desde I69i en Durango- al número de cuarenta. Además proyecta alistar cien indios amigos, a los que hay que dar raciones de carne y harina y dos reales diarios. Necesitará más fondos. 
$Y$ entretanto los ataques de los indios se recrudecen y se propagan hacia el norte a lo largo de la frontera. Empiezan a ser frecuentes en torno a $\mathrm{Pa}$ rral. Castillo quiere que la compañía de este lugar, aumentada como pide, proteja también a Urique y Cusihuiriáchic.

Otras muchas naciones empiezan a aparecer en el escenario constantemente ampliado de la guerra. El capitán Retana, de Conchos, con la alianza de las llamadas naciones del Norte, persigue a los suninoliglas, chichitames, chisos, guasapoliglas y sisimbres, osotayoliglas, cocoyomes, cabezas... que tan pronto atacan en Parral como en Coahuila, como guerrean entre sí.

A fines de 1693 salían a un tiempo de los presidios Retana, Hugalde y Escorza, por diferentes rumbos, y Castillo ponía precio a las cabezas de Don Francisco el Tecolote, Contrerillas, Lorencillo, Luquillas, Cola de Coyote y Maimara, capitancillos de los bárbaros. La consigna del gobernador, siempre repetida, era la de pasar a cuchillo a los enemigos si no aceptaban la rendición incondicional. En este último caso, su proyecto era enviarlos a México.

Las más efectivas de estas campañas fueron las del capitán Retana, que consiguió someter a los chizos y otras once naciones hasta el río del Norte, siguiendo el curso del Conchos. El y Castillo solicitaron el envío de misioneros que los evangelizaran. ${ }^{16}$

\section{LA VISITA DE MARÍN}

E1 entonces virrey conde de Galve concibió, sin embargo, la idea de si sería posible que, suprimidos los presidios, se formase una sola compañía volante que estuviese en continuo movimiento atendiendo a la vigilancia de la frontera: de este modo se ahorrarían algunos sueldos de capitanes y cabos. Y encomendó Galve al maestre de campo Don José Francisco Marín, que pasaba a Nueva Vizcaya para formar juicio de residencia al ex-gobernador Pardiñas, estudiase sobre el terreno la posibilidad de poner en práctica su proyecto.

Por tal motivo, Marin es autor de una serie de informes que abarcan la situación de Nueva Vizcaya y Sonora y en los que, entre otras cosas, da una largúsima relación de los nombres de todas las naciones conocidas de indios salvajes más allá de nuestras fronteras. Para formarlos se valió tanto de lo

I6 Kelley, Charles J.: The historic indian pueblos of La Junta de los Rios. N.M.H.R., XXVII, 4, octulure I952, 257-295; XXVIII, I, jan, I953, 26-52. Rocha, José G.: Campaña de los gobernadores de Nueva. Vizcaya contra los indios rebeldes: una cruel matanza de tobosos. Boletír de la sociedad chihualiuense, t. II, uúm, 5, octubre 1939, 166-193. 
que por sí mismo presenció como de los informes que pidió a diferentes personas.

En cuanto a la situación defensiva, Marín la considera delicada. Cree necesaria la subsistencia de los presidios, y aun de que se radique en algún lugar determinado - Coaguiona, Bavispe o Teuricachi- la hasta ahora compañía volante de Sonora, que mandaba Gironza. El único presidio sobre el que los dictámenes de las personas consultadas son controvertidos es el de Sinaloa: se propone tanto extinguirlo, como trasladarlo a la frontera sonorense. Marín se inclinó por fin por suprimirlo, contando en Sonora con la compañía de milicia recientemente formada en el real de los Frailes y que mandaba Don Juan Antonio de Anguis, y con las que, como ésta, podrían reclutarse. Sin embargo, el presidio de Sinaloa subsistió en su primitivo emplazamiento hasta entrado el siglo XVIII.

Pero Marín se planteó de manera más profunda el problema del riesgo que corría Nueva Vizcaya. "Hay - escribía - falta de gente y de caudales y sobra de hostilidades de indios". Pero este segundo inconveniente se remediaría solucionando el primero. Fomentando la población holgarían los presidios, y por eso propone colonizar todo el contorno del Bolsón, desde el río Conchos al Nazas. Haciéndolo igualmente en la región de Janos y en Sonora, costaría todo un millón una sola vez. La gente podría traerse de Galicia y de Canarias, internándolas en barcazas por el río Bravo.

$Y$ de esta manera encontróse el conde de Galve con un proyecto tan ambicioso que bien podía considerarse disparatado. Sin embargo, fue enviado para su deliberación al Consejo de Indias, donde a fines de I698 estaba listo el expediente para su resolución que, sin embargo, no llegó hasta I 702 : se decidía hacer guerra ofensiva a los indios, mantener los presidios y el aumento de la compañía de campaña; y procurar el poblamiento en las proximidades de aquéllos. El grandioso sistema de población ideado por Marín quedaba reducido a un punto: procuraría el virrey la fundación de una villa que recibiría el nombre de San Felipe, a la que enviaría familias entre las que debían distribuirse tierras. Así nació oficialmente San Felipe el Real de Chihuahua, cuyo primer corregidor, Don Felipe de Orozco, estuvo directamente a las órdenes del virrey.

Entre tanto, continuaban las campañas en el Bolsón. Los bárbaros no cejaban en sus hostilidades y constantemente se hacía preciso reforzar la frontera. En I7I I, por orden del virrey duque de Linares, se formó el presidio de Mapimí con hombres destacados de los otros del Pasaje, Gallo, Cerro Gordo y Conchos, de la compañía de campaña y del de Santa Catalina, que desaparece en esta ocasión. Con ello se logró revitalizar el real de minas, 
cuyos metales plomosos y ligas servían para el beneficio de muchos otros minerales.

La guerra proseguía con suerte varia, aunque su final era previsible. Los gobernadores consumían la dotación de paz y guerra en las respectivas expediciones, y no siendo esto bastante el vecindario de Nueva Vizcaya contribuyó con treinta mil pesos más, aparte que ofrecían sus personas equipadas para la lucha y para escoltar los cordones. Cada año hacíanse las campañas que mandaban por turno los capitanes de los diversos presidios, y en cada una se capturaban unas docenas de prisioneros. Sin embargo, los salvajes no dejaban de observar el momento en que las tropas se internaban en el Bolsón, para atacar entonces los puntos que habían quedado desguarnecidos. Así entraron a sangre y fuego en la hacienda de Ramos, que desde entonces quedó despoblada; al año siguiente asaltaron el mismo presidio de Conchos, y luego los de Cerro Gordo, Gallo y Mapimí. Precisamente los presidios, por contar con manadas de ganado caballar para montura de los soldados, constituían para ellos un objetivo predilecto.

\section{LA PRESENCIA FRANCESA Y TEXAS}

La llegada del caballero de la Salle a las bocas del Misisipi, bajando por este río, en 1682 había sido tuno de los sucesos que revolucionarían la situación internacional y la política española en el golfo de México. Situación que se hizo delicada y tensa cuando se recibieron en España las noticias de la ulterior expedición del mismo la Salle con la fundación de San Luis en un lugar que durante mucho tiempo resultó indeterminado.

La búsqueda del asentamiento francés, llevada a cabo por mar y por tierra, logró finalmente el éxito deseado cuando en $r 689$ el fundador y gobernador de Coahuila Don Alonso de León encontró el fuerte de San Luis en la bahía del Espíritu Santo o lago de San Bernardo. La subsiguiente acción colonizadora por parte de los españoles, emprendida por el mismo León con franciscanos del colegio de Santa Cruz de Querétaro, en ı69o, fracasó al ser abandonados los establecimientos misionales en I693, después de la feliz intervención del sucesor de León, Don Pedro Terán de los Ríos.

Pero si la desgracia se había cebado repentinamente en la última expedición de la Salle, los franceses lograrían por fin afincarse a orillas del Misisipí en 1699 , gracias a le Moyne d'Yberville, y este hecho que habría de provocar cierta actividad española por parte de la Florida, y el recelo inglés por el futuro de sus colonias que iban a verse envueltas y privadas de mayores posibilidades de expansión territorial, no dejaría igualmente de tener importantes consecuencias para el futuro de las provincias internas. 
En efecto, teniendo por base la extensa línea del Misisipí, con el siglo entrante empiezan las incursiones de los mercaderes franceses hacia el país occidental, buscando un poco el comercio con los indígenas y otro tanto la máxima aproximación posible a la rica región minera ocupada por los españoles. Ya en I70o la Harpe y du Tisné se internan por los ríos Red y Arkansas hasta las tierras de los osage, pawnee y jumanos, con los que entablan relaciones comerciales : la principal de sus transacciones es la de las armas de fuego por los caballos que los indios tenían en su poder. En adelante, será invariable la necesidad de caballos que se experinente en Luisiana, y coincidiendo con el interés de los indios por conseguir armas europeas, se establecerá un circuito que no redunda más que en perjuicio de los españoles: a costa de la real hacienda, Nueva Vizcaya proporciona a Nuevo México los caballos que roban los indios de la pradera para canjearlos por fusiles, pólvora y balas en los establecimientos franceses. El caballo se ha convertido así, definitivamente, en la principal unidad monetaria de la pradera, y ha adquirido a los ojos del indio el máximo y más definido valor.

En el mismo año de I700 daban comienzo las expediciones de Louis Jucherau de Saint Denis, llamado por los indios "Capitán Piernas Gordas", que en I7I4 había de alcanzar, por una ruta más al sur, paralela a la costa, los establecimientos españoles del río Grande.

Constituían éstos la avanzada septentrional de Coahuila y eran fundación de los religiosos franciscanos de Querétaro, cuyo colegio de Propaganda Fide, erigido en I $68_{3}$ bajo la advocación de la Santa Cruz, denotaba con ella su propósito de mantener aquella línea de penetración misional que le había sido encomendada desde las expediciones de Alonso de León. Fracasada la primera tentativa llevaba a cabo por el padre Masanet y sus compañeros, que abandonaron la provincia en 1693 , se buscó el establecimiento de un núcleo misional y poblador en la zona del río Grande que sirviese de punto de partida para una nueva entrada y garantizase la seguridad de los suministros que precisaban los frailes. Así, en I 698 se había fundado la misión de Nuestra Señora de los Dolores en la Punta de Lampazos, en el extremo norte del Nuevo Reino de León; y en I699 la de San Juan Bautista del Río Grande, que sufrió dos traslados hasta quedar situada en el actual paraje de Eagle Pass. Allí se erigió el presidio de Río Grande, en I 700 , el más occidental en aquel momento. En el mismo distrito surgieron las de San Bernabé y San Francisco Solano. Pocos años después — I 708- había congregadas en torno a las cuatro misiones un millar de familias indígenas, buena parte ya bautizadas.

Fue precisamente un motivo misional, la ingenua carta de Fray Francisco Hidalgo, que proponía al gobernador de Luisiana Cadillac la colabora- 
ción de los franceses para la evangelización de Texas, el último pretexto necesario para que Cadillac encargara a Saint Denis la expedición que, en suma, sólo pretendía acercarce a las minas de los españoles, si no para ocuparlas, sí por lo menos para comerciar con los núcleos de población en ellas radicados. Comercio que, por la concepción monopolista de la Corona española, sólo podía tener un nombre: contrabando.

Por eso la réplica no se hizo esperar. El virrey Linares encargó al capitán Domingo Ramón del presidio de Río Grande la reocupación de Texas, donde en I 7 I 6 y г 7 I 7 fueron situadas seis misiones, tres de las cuales tenían los religiosos de Propaganda Fide de Querétaro, y otras tres los del colegio filial de Nuestra Señora de Guadalupe de Zacatecas. Se estableció entonces contacto con el puesto francés de Natchitoches, pero desde ese mismo: momento quedó claro el magnífico negocio de contrabando que los franceses, con la cooperación de españoles interesados iban a realizar a través de Texas, recibiendo, a cambio de sus mercancias - principalmente telas y encajesplata y caballos. En I 7 I7 y I 718, en dos entradas consecutivas, Don Martín de Garay que había sido nombrado gobernador de Coahuila y Texas, fundó la villa de Béjar sobre el río San Antonio, y un presidio de veinticinco soldados entre las seis misiones franciscanas, que estaban todas entre el río Trinidad $y$ el Sabinas, en el extremo oriental de Texas, colindante con Luisiana.

Esta situación no duró más que unos meses. A mediados de I7 I9, habị́ndose declarado la guerra entre España y Francia, un contigente de franceses invadió las misiones de Texas, que fueron abandonadas por segunda vez, y en este estado quedaron hasta que en I72 I fueron restablecidas por el marqués de Aguayo, que voluntariamente se ofreció para llerar a cabo la reconquista.

El marqués de San Miguel de Aguayo, nombrado gobernador de Coahuila y Texas, hizo prácticamente a sus expensas la costosísima expedición, en la que movilizó quinientos hombres, en gran parte equipados y abastecidos por él mismo, al precio incluso de fletar un barco que los avituallase en la Bahía del Espíritu Santo. Los resultados prácticos consistieron en la restauración de las anteriores misiones y fundación de cuatro más, quedando organizada la defensa a base de los cuatro presidios de San Antonio de Béjar, Nuestra Señora de los Dolores, Nuestra Señora del Pilar y Bahía del Espíritu Santo. Los establecimientos españoles constituyeron entonces tres núcleos: el más primitivo en la frontera con Luisiana; el central, sobre el río San Antonio, en torno a la villa de Béjar : el tercero y más reducido, en la costa. Veremos que esta situación tampoco duró mucho, pues se alteró de resultas de la visita girada por Don Pedro de Rivera. 
Desde que Aguayo se retira de Texas, queda su gobierno separado del de Coahuila y establecida la capitalidad en Adaes. ${ }^{17}$

\section{De Sonora al Gila y al MoQui}

El período que hemos iniciado para las provincias internas con la sublevación de los indios pueblo tiene su más adecuado umbral en el extremo oriental texano con la aparición de los franceses, y en el occidental con la presencia del $\mathrm{P}$. Kino en la frontera de Sonora y la penetración misional de la baja California.

Por aquel entonces, Opodepe, en en el río San Miguel, era la más avanzada misión al norte de Sonora. Apenas llegado a la provincia, el P. Kino estableció la suya de Dolores en el curso alto del mismo río, y desde allí empezó a extender su ministerio al valle de Magdalena. Con esto, en 1687 se empezaba la evangelización de la Pimería Alta. En I689, cuando se le nombra rector de aquellas misiones, las de Remedios, Imuris, Cocospera, San Ignacio, Tubutana y Oquitoa abrazaban toda la cuenca alta del Altar con el Magdalena. Visitando las nuevas fundaciones en r691 con el Padre Salvatierra, pasaron ambos al río Santa Cruz cuyo curso de sur a norte apuntaba al Gila. Desde entonces, la conquista espiritual de los sobas y sobaipuris es el primer objetivo de Kino.

En efecto, en 1692 visita a los sobaipuris de los ríos Santa Cruz y San Pedro. En r694, a los sobas del curso inferior del Altar, y alcanza el Gila. A poco se establecía la misión de Caborca. Este impulso inicial se vio frenado con el alzamiento de los pimas de I695, que costó la vida al Padre Saeta, en Caborca. En la dura represión tomaron parte las tropas de Nueva Vizcaya, de los presidios del Gallo, Parral y Sinaloa. Aún al año siguiente continuaban las revueltas, acaudilladas por Quihué. Después, Kino remprende sus viajes hasta el Gila y el Colorado, por donde se puso en contacto con los yumas y cocomaricopas. Su fruto, dificultado por las incursiones de los apaches, y por el recelo que en general se tenía de la fidelidad de los pimas, empezó a notarse con la fundación en I699 de la Magdalena de los Tepocas y, en I700, de San Javier del Bac. Aquélla estaba a las puertas de los seris, de cuya hostilidad empieza ahora a tenerse repetidas pruebas, haciéndose nuevas expediciones contra ellos. San Javier del Bac, en el río Sta. 'Cruz, se con-

I7 Bonilla, Antonio: Breve compendio de los sucesos ocurridos en la provincia de Texas.. 1772. Introducción y notas por Edmundo O. Gorman. Bol. Arch. Gen. Nac., IX, 4, 68I-729. México, I938. Morfi, Fray Juan Agustín: History of Texas, 1673-1779. Introducción y notas por Carlos Eduardo Castañeda. 2 vols. Alburquerque, 1935. "Relación" sobre Texas en A.H.N. Estado, 3028-64. "Extracto de lo acaecido en las entradas y poblaciones de franceses en el Seno Mexicano", A.G.I., Guadalajara, 19.34. 
virtió en el establecimiento más setentrional, entre los sobaipuris. Desde el río de San Pedro al oeste, todos los pueblos eran agricultores y se mostraban propicios al bautismo. La muerte del Padre Kino sin embargo, en I7II, señala una época de depresión en la actividad de Sonora. Las misiones fronterizas se abandonan, y los apaches arrecian en sus incursiones, penetrando por la sierra Madre, mientras que el presidio de Fronteras, donde a Gironza habían sucedido Fuensaldaña y Alvarez de Tuñón, entra en un período de completa inactividad e ineficacia. La viruela, por otra parte, diezmó a los pimas que acababan de entrar en contacto plenamente con los blancos. De esta manera, a los veinte años de la desaparición de Kino, Cuquiarachi entre los ópatas, Cucurpe entre los eudeves, y San Ignacio entre los pimas constituían el límite de la expansión nacional.

Pue el Padre Campos, misionero de San Ignacio y antiguo amigo de Kino, quien propugnó la idea de hacer por el Gila una entrada hasta el Moqui, que se mostraba reacio a los franciscanos desde la rebelión de 1680 . Defendió el proyecto Becerra, capitán del vecino presidio de Janos, en I 723. Pero la paralización general que se observa en toda la frontera, la falta de misioneros o la menor calidad humana de estos, la carencia de las pensiones que debía proporcionar la Corona, y el deseo de evitar una enojosa competencia con los franciscanos de Nuevo México, cortó en flor esta idea que es una primera, vaga tentativa de vincular Nuevo México a Sonora, y que se volverá a repetir, aunque con poco éxito, en años posteriores. Entretanto, o simultáneamente, se ha buscado el mismo enlace con California. ${ }^{18}$

\section{De Sonora a California}

En 1697 tiene lugar el primer asentamiento duradero de los españoles en tierra californiana, después de innúmeras tentativas frustradas, desde la época cortesiana. Los fracasos anteriores mostraban que la provincia no ofrecía ninguna ventaja ni incentivo para la colonización. Tierra pobre. su único interés estaba en su valor estratégico, como lugar que era preciso ocupar antes que otra potencia lo efectuase poniendo en riesgo la seguridad de toda Nueva España; por otra parte, ya los piratas ingleses y holandeses habían merodeado sus costas a la espera del galeón de Manila. Pero ni aun esto había sido suficiente para empeñarse seriamente en la conquista de California, que en 1685 abandona por última vez el almirante Atondo y Antillón, convencido de la esterilidad de la tierra, que hacía imposible su colonización.

IS Bolton Herbert, Eugene: Rim of Christendom. A biography of Eusebio Francisco Kino, Pacific Coast pioneer. New York, т936. Del micmo autor, Kino's historical memoir of Pimería Alta. Berkeley and Los Angeles, 1946. 
Atondo había intentado, no obstante, otro medio de asegurar la subsistencia de cualquier establecimiento en la península: abastecerlo desde Sonora. Pero esto también le había parecido sobradamente difícil. Sin embargo, el Padre Kino, que había figurado en las expediciones de Atondo, propísose una vez dedicado a las misiones de Pimería convertir sus pueblos en el granero de California. El, que fue quien puso la idea y el primer entusiasmo; Salvatierra, que defendió el proyecto ante el virrey y la Compañía; Ugarte, que se negó a abandonar la empresa una vez acometida, son los tres héroes de la evangelización de California.

Para llevarla a cabo fue preciso acudir a las limosnas de particulares, con las que se fundó el llamado Fondo Piadoso, cuyas rentas aseguraban la continuidad de la misión. Así se allegaron provisiones y barcos y se hizo posible la fundación de la primera, bajo la advocación de Nuestra Señora de Loreto, el i9 de octubre de 1697 , en la costa del Golfo, por Salvatierra. Y desde el año siguiente empiezan los viajes del Padre Kino, hacia el Colorado, que llega a atravesar, buscando por tierra la comunicación con Loreto. Kino busca el establecimiento de misión en Sonoita, que sería una buena escala en el camino. El mismo Salvatierra le acompaña y participa en su entusiasmo y le anima movido del mismo fervor. Sin embargo, todo ello había de quedar en un intento frustrado: Loreto estaba demasiado lejos, demasiado al sur de la península. El Colorado era demasiado difícil de pasar, y ante él solo se extendía un desierto, con el único oasis de Sonoita.

Salvatierra halló una nueva solución en la fundación de misión dependiente de las de Californias en Guaymas, en la fronteriza costa sonorense, en I7or : la llamó de San José de la Laguna. En ella se congregaron unos cuatro mil pimas, y su producción agrícola y ganadera abastecería la península.

Entre tanto, al otro lado del Golfo, el pequeño punto de apoyo de Loreto se amplía a ojos vistas. En I699 aparecía la nueva misión de San Javier Vigé y San Juan de Londo. En I705 la de Santiago de Liguig y Santa Rosalía de Mulegé. En I7o8, la de San José Comondú. En I720, la del Pilar de la Paz y la de Guadalupe Guasinapi; en r 72 I se sustituyó la de Liguig por Nuestra Señora de los Dolores del Sur o la Pasión, y se fundó la de Santiago de los Coras. En i 722 , Ugarte funda la de la Purísima. La erección de la de San Ignacio en I728 completa un primer ciclo de esta expansión.

Los jesuitas — con la única protección del corto presidio de Loretohabían logrado arraigar en la península, aunque moviéndose siempre agobiados por la escasez, por la esterilidad de la tierra y por la dificultad para las comunicaciones marítimas. Sin embargo, los mismos padres fueron introdu- 
ciendo los cultivos de gramíneas y frutales que poco a poco proporcionaron algún desahogo.

De esta manera, en I 730 estaba prácticamente evangelizada la porción meridional de la península. Ya hemos apuntado anteriormente las características principales de este establecimiento misional: aparte los padres, no había más españoles que los que componían la pequeña guarnición de Loreto, y éstos estaban en todo sujetos al mismo superior de la misión. ${ }^{\text {Ig }}$

I9 Dunne, Peter M'asten: Black robes in lower California. Berkeley and Los Angeles, I 948. Engelhardt, Zephyrin. The mission and missionaries of California. 2 vols. Vol. I: Lozerer California. San Francisco, 1908. 


\section{CAPITULO SEGUNDO}

\section{LOS PRINCIPIOS DE LA GRAN EPOCA}

EL PODER REAL EN LAS PROVINCIAS INTERNAS

Como todos los dominios españoles en América, las provincias internas nacieron como tales provincias en virtud de una capitulación hecha por el conquistador con la Corona - bien directamente, bien a través de su representante inmediato el virrey--, mediante la cual aquél adquiría para ésta todo un reino a cambio de que se le reconociesen determinados privilegios.

Indudablemente, ésta era una empresa reservada únicamente a hombres que pudieran invertir en ella las crecidas sumas de dinero que requería el movilizar un pequeño ejército, abastecerlo y equiparlo, y emplear nuevas cantidades, una vez conquistado el territorio, en organizarlo, erigir ciudades, villas y pueblos y suministrar a los pobladores utensilios, ganados, semillas con el fin de crear o poner en explotación las posibles fuentes de riqueza del país.

La experiencia de los contemporáneos, y la que nosotros podemos obtener del conocimiento de los hechos históricos, muestran que las empresas de este tipo en pocos, contadísimos casos, aun habiendo tenido éxito en sus objetivos, resultaron económicamente beneficiosas para hombres que habían arriesgado en ellas todo su caudal y sus vidas, amén de innumerables esfuerzos y penalidades. Pero no es menos cierto que los conquistadores españoles, más propiamente los capitanes de la conquista española, buscaron, sobre la ventaja pecuniaria, las del honor y el poder.

Ibarra, Oñate, Carvajal, Zabala, el marqués de Aguayo y Escandón, cuando se comprometen a realizar, y efectivamente llevan a cabo la conquista de diferentes territorios de tierra adentro, corrían, más que tras la riqueza -que ya poseían en grado no común-, tras la ambición del poder y el lustre 
que éste da; tras la consecución, si posible fuese, de una ejecutoria de nobleza; tras el brillo de un blasón que los elevase sobre la consideración social de mineros afortunados. El hábito de una orden militar, el título de Castilla, son recompensa sobrada a todos sus trabajos; las tierras que se esfuerzan en acaparar sirven para la erección de mayorazgos, es decir para la perpetuación de una casa que ellos han hecho ilustre con sus obras.

A la Corona, al hacer recaer todo el peso de la conquista sobre algunos. particulares enriquecidos, la guía una norma de reducción de gastos. A los particulares, un criterio netamente antieconómico les lleva a posponerlo todo con tal de alcanzar un encumbramiento en la rígida organización estamental. De esta manera, no el apetito del poder, sino el de.la dignidad y honor que este poder representa, lleva a los hombres que acaban de adquirir riquezas prodigiosas en las minas de Zacatecas, a dilapidarlas en la conquista de nuevos reinos.

De todos ellos, el más ambicioso fue Oñate, que pretendía alcanzar la misma condición de virrey que lograron Cortés y Pizarro. Fue el gran fracasado, pero su sola pretensión propugnada a ultranza muestra el verdadero objetivo de su empresa.

He aquí, pues, que en virtud de las circunstancias unos cuantos nuevos ricos van a gobernar extensas provincias del Imperio durante algún tiempo. Su mando es, en general, beneficioso: Ibarra dota de utillaje las primeras minas halladas en su distrito; Zabala distribuye grandes concesiones de tierras a los ganaderos del altiplano para atraer sus rebaños a Nuevo León. Por la misma concepción paternalista del poder que tienen estos hombres que han creado con sus manos el gobierno que ahora regentan, no tienen a mal otorgarse a sí mismos amplios lotes de tierras, y constituídos en eje de sus familias mantienen a su alrededor una serie de deudos y protegidos en los que ejercitan sus liberalidades de gran señor.

Con todo esto, sin embargo, el poder real se veía no muty bien parado, y no podía tardar en volver por sus fueros, y la situación entra por cauces más normales cuando empiezan a nombrarse gobernadores extraños al territorio y sin intereses de ninguna clase en él. Por otra parte, la Corona fue mostrando una preocupación lentamente creciente por las provincias septentrionales del virreinato, debido primero a las sublevaciones que se producían, después al peligro de una invasión por los bárbaros y finalmente al que representó la aparición de poderes extranjeros en sus proximidades.

En las provincias internas se manifiesta, no obstante, en esta precisa época que aquí abordamos, como reflejo de la crisis de la hacienda real, el sistema de provisión de los cargos en el mejor postor, si no con generalidad, sí con frecuencia suficiente para ser un rasgo destacable en este período. 


\section{Gobernaciones, Corregimienios y Alcaldías Mayores beneficiados en las provincias internas}

Nueva Vizcaya

\section{GOBE R A C I O N E S}

D. Martín de Rebollar

D. Bartolomé de Estrada

D. Gaspar de la Plaza

D. Juan Isidro de Pardiñas

D. Gabriel del Castilio

D. Juan Bautista de Larrea

D. Antonio de Deza y Ulloa

D. Antonio de Deza y Ulloa

D. Juan Bautista de Belaunzarán

D. Juan de Palma Tobón

D. Enrique de Cossío y Campa

D. Ignacio de Echéverz y Subiza

D. Juan Francisco de la Puerta

Nuevo México

D. Diego de Vargas Zapata y Luján

D. Pedro Rodríguez Cubero

D. José Chacón Medina y Salazar

D. Juan Ignacio Flores Mogollón

D. Manuel de Soldevilla

D. Plácido Porra

D. Plácido Porras

D. Agustín Moreno de Castro

D. Antonio de Herrero
30000 pesos en plata blanca

4500 doblones de 2 escs. oro

14000 pesas +6000 ps.

10000 pesos +25000 ps.

I0000 pesos + I0000 ps.

8000 escudos de plata +8000

I 0500 escudos

I 2000 escudos de plata

14000 pesos de ro reales de plata

2400 pesos

I6000 pesos de 1o reales de plata

20000 pesos

20000 pesos fuertes

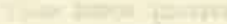

2500 escs. de ro rs. de plata en oro

2000 escudos de plata

4000 pesos

3500 pesos

750 doblones de 2 escs. de oro

I 000 pesos

5000 pesos

I 2000 pesos fuertes

I 3800 pesos fuertes
29 mayo $\quad$ 688

$\begin{array}{rlr}24 & \text { junio } & I 675 \\ 31 & \text { dicbre. } & \text { I } 677 \\ & & \\ I 3 & \text { abril } & 1682 \\ 4 & \text { enero } & I 684 \\ 30 & \text { mayo } & I 684 \\ 23 & \text { octubre } & I 689 \\ & & \\ 22 & \text { agosto } & \text { I } 695 \\ 4 & \text { novbre. } & \text { I } 704 \\ 28 & \text { novbre. } & \text { I733 } \\ & & \text { I733 } \\ \text { I } 8 & \text { setbre. } & \text { I735 } \\ & & \\ 30 & \text { julio } & \text { I742 } \\ \text { I5 } & \text { setbre. } & \text { I743 }\end{array}$

6 junio $\mathbf{I} 69 \cdot 2$

3 I marzo 1705

27 setbre. 1707

24. octubre 1709

2 dicbre. I 7 I 3

3 agosto I 7 I 90

I 3 dicbre. I749
AGS, DGT, I70-4II Sch. AGI, Guad. 3

AGS, DGT, I 70-439 ¿ Sch.?

AGI, Guad. 3

" " "

" " "

"Sch.

" " " Sch.

AGS, DGT, I 7 I-I 80

" $" 72-10$ ¿ Sch,?

$\therefore$ I $\quad$ I74-4

" $"$ I $79-389$

AGI, Guad. 300

AGS, DGT, I79-I44

AGI, Guad. 30I

AGS, DGT, I8I-213

AGI, Guad. 30I

AGI, Guad. 3

AGS, DGT, I 73-63

AGI, Guad. 3

AGS, DGT, I7 2-335

AGS, DGT, I74-242

" " I74-276

" $\quad$ I75-68

" $\quad$ I $77-406$

AGI, Guad. 300

AGS, DGT, $180-206$

1 8:2-32 
Coaluita

D. Francisco Cuervo y Valdés

D. Pedro Fermín de Echéverz y Subiza

D. Antonio Fernández Vallejo

D. Francisco García

D. Luis Garcia de Pruneda

D. Vicente Bueno de la Borbolla

D. Juan Antonio Bustillo y Cebalios

D. José Ventura de Respaldiza

Texas

D. Tomás Cantelmi

Nuevo León

D. Juan de Vergara

D. Pedro del Barrio Junco y Espriella

D. Antonio de los Cobos

D. Pedro Gil de Tejada

D. Vicente Bueno de la Borbolla

D. Juan Manuel Muñoz y Villavicencio
2000 pesos escudos de plata

1000 pesos escudos de plata

I 500 pesos escudos de plata.

I 000 pesos

2000 pesos de 20 reales de vellón

3500 pesos fuertes

3700 pesos fuertes

7000 pesos fuertes

60.000 reales

3200 escudos de plata

3300 pesos

4000 pesos

4200 pesos fuertes

4000 pesos fuertes

5 coo pesos fuertes
30 agosto 1695

2I setbre. I 695

8 marzo 1698

2 marzo I7I0

22 mayo 1738

4 julio I 740

3 I dicbre. 1744

I novbre. 1748

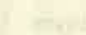

I7 75

I5 mayo I 692

27 marzo I 737

6 junio I740

23 enero I745

I9 abril I745

6 dicbre. 1746
AGS, DGT, I72-I 10

AGI, Guad. 3

AGS, DGT, I72-3I8

AGI, Guad, 3

AGS, DGT, I73-18

AGI, Guad. 3

AGS, DGT, I75-I04

" $"$ inv. $20^{\circ} 8-34$

" $\quad$ 180-396

AGI, Guad. 302

AGS, DGT, I80-565

" I $8 \mathrm{I}-250$

AGI, Guad. 302

AGS, DGT, I82-344

AGI, Guad. 302

AGI, Guad. 300

AGI, Guad. 3

AGI, Guad. 300

$"$ " $"$

" $" \quad$ "

$" \quad, \quad$, 


\section{ALCALDIAS MAYORES Y CORREGIMIENTOS}

\section{Alcaldia del Rosario}

D. Francisco Cortés

D. Juan Bautista de Larrea

Alcaldía de Culiacán

D. Cristóbal de Agramont y Arce

Alcaldía de Sinaloo

D. Jacinto de Fuensaldaña

Alcaldía de Sonora

D. Melchor Ruiz

D. Diego de Arroyabe

D. Francisco de Gorrástegui

D. Miguel Rodríguez

D. Antonio de Cobos

Alcaldía de Nombre de Dios

D. Juan de la Cuesta Mercadillo

D. José de Herrera

Corrcginiento de Chihuahua

D. Juan Felipe de Orozco

D. Juan Clemente Sánchez Durán

D. Juan de Palma Tobón

D. Tomás de Guzmán Emanuel

D. Tadeo de la Puerta Sánchez de

Tagle

U. Juan de Palma Tobón
I 000 escudos de plata

700 escudos de plata

1000 escudos de Io reales de plata

$$
\text { en oro }
$$

rooo doblones de 2 escudos de oro

2 agosto 1695

Io dicbre. 1690

28 dicbre. I73 I

20 agosto 1732

3 junio $\quad$ I 736

23 julio $=1742$

2000 pesos de ro reales de 2500 pesos fuertes

200 doblones de 2 escudos de oro 200 doblones

29 febrero I708

I 4 julio I7I 3

800 pesos

800 pesos de io reales

1000 pesos de 8 reales

200 pesos fuertes

4 marzo It I9

I I julio I $73 \mathrm{I}$

I5 octubre 1733

29 abril 1742

1300 yesos fuertes

I000 ps. +5019 rs. 20 mrs. vellón
AGI., Guad. 3

AGS, DGT, I 7I-35

AGI, Guad. 3

AGS, DGT, I72-244

AGI, Guad. I 54

AGI, Guad. 3

AGS, DGT, I 79-II 2

$" \quad " I 79-180$

$" \quad=\quad 180-414$

I $80-55$

AGS, DGT, I 74-287

I 76 -II 5

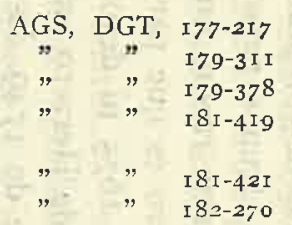


Muchos comentarios podrían sin duda hacerse a la vista de tan extensas jistas de compradores de cargos públicos, ${ }^{\mathrm{I}} \mathrm{y}$ aún se nos quedan los nombres de algunos personajes cuyo acceso a ellos es muy posible se debiera a la misma razón, aunque en el día no podamos asegurarlo con certeza. El primero es que parece claro que ninguno de estos oficios se "benefició" antes de 1675 ni después de I750: el último título que de este tipo hallamos es el de Herrero para el gobierno de Nuevo México, expedido el I 3 de dicienbre de I749. Esto nos cierra con plena claridad el ciclo de tres tercios de siglo en que se da la venta de los gobiernos y alcaldías de las provincias internas y que este hecho, lejos de decrecer, se amplía considerablemente bajo los Borbones. Se hace preciso luego recordar cómo tales tratos del rey con los particulares no pueden designarse exactamente con el nombre de ventas con que habitualmente son recordados. No se entrega un cargo a cambio de una cierta cantidad de dinero, pues en la mentalidad política del momento, como en la actual, no era, no podía aquél ser objeto de un pacto mercantil. Basta aludir a dos detalles de la cuestión. Del lado del rey, la concesión de un nombramiento es siempre una gracia, una merced que libremente otorga cuándo, cómo y a quién quiera. El desembolso por parte del beneficiado de una determinada suma no obliga al rey sino en la manera en que le "obligan" los servicios de cada vasallo, de qualquier indole que aquéllos sean. $Y$ aquí está el segundo punto de la cuestión : el pago de unos miles de pesos es y se consiclera hecho por un particular de la Corona; servicio equiparable al del vasallo que acudía a luchar en las filas de los ejércitos reales, al del comerciante cuyo barco era utilizado para algunas empresas bélicas, al del letrado que ponía su ciencia y su persona a contribución en el desempeño de esta o aquella tarea de interés público. No estaría de más parar mientes en el hecho repetido de hacerse cargo conforme a las leyes a algún gobernador o alcalde mayor de haber

I Esta relación está elaborada con datos procedentes de un "Indice de reales órdenes sobre Sinaloa, Nueva Vizcaya, Nuevo México, Nuevo Reino de León, Coahuila y Texas", en A. G. I., Guadalajara, 302, y de una serie de títulos existentes en A. G. I., Guadalajara, 30z. No hemos - podido identificar a Cosío y Campa ni a Herrero, que probablemente no llegaron a gobernar por sí mismos. Echeverz y Subiza perdió la gracia por no abonar la cantidad ofrecida. Con esto, aún se reduce más el número de ventas de oficios de gobernador para el norte de Nueva España. Moreno de Castro era marqués de Valle Ameno, Al parecer, se obtenía la prórroga eṇ el gobierno abonando dos tercios de la cantidad ofrecida la primera vez. La abreviacura Sch señala los únicos siete cargos de las provincias internas cuya venta conoció Schäfer, y son, por ello, los únicos casos también que cita Parry, según se pueden identificar con alguna seguridad. Schäfer, Ernesto: El Conscjo Real y Supremo de las Indias, z vols., Sevilla, i935 y 1947. Parry, J. H.: The sal? of public office in the Spanish Indies under the Hapsburgs. Ibero-Americana, 37. Berkeley and Los Angeles, I 953 . 
vendido los oficios que está en su mano proveer, siendo esto en cambio cosa lícita por admitida en el rey. Adviértase en ello con toda luz que la compra a la Corona de un empleo es un auténtico servicio a la causa pública, al Estado, mientras que el caso perseguido sería verdadera inmoralidad por redundar en exclusivo provecho de un particular

Más y mejor sirve aquél que más tiene y, forzoso es decirlo, el "servicio económico" o "pecuniario" había de ser especialmente agradecido por el rey en ocasión en que el erario pasaba por las estrecheces conocidas de fines de siglo XVII; era, por consiguiente, una manera apropiada para arrancar gracias de quien podía concederlas; era, sobre todo, la puerta ancha por la que en esta época podían entrar al enaltecedor ejercicio de un puesto de gobierno los burgueses - comerciante y mineros-que en otros tiempos habían logrado, y que todavía lograrían más adelante, capitular con el rey el descubrimiento y conquista de una provincia; por este camino tenían acceso no solo a las escribanias o notarías de todo tipo, a los regimientos, alcaldías, alferecías, o alguacilazgos de los ayuntamientos, a las oficialías reales y demás cargos de real hacienda, sino a los oficios de más plena representación real, como son los que figuran en las listas insertas, y que llevan implícitas las más nítidas funciones de gobierno, justicia y guerra. Por supuesto que aquellos otros cargos que no hemos incluido en nuestra relación también se "vendieron" en las provincias internas, pero siendo en su mayor parte de carácter marcadamente honorífico, tienen menos interés para nosotros, aparte que muestran bien cómo brillar y ascender en la consideración social es el objetivo de sus compradores. Podríamos además citar algunos casos en que los oficios beneficiados son de puro carácter militar: así la obtención de la capitanía de la compañía volante de Río Grande llevó a don Diego Ramón a entregar en I 709 mil pesos

Nos saldríamos demasiado de nuestro propósito si continuáramos esta divagación de tipo general aludiendo a las críticas y censuras que en su época no dejaron de hacerse sobre estos puntos, particularmente por el Consejo de Indias y sobre el beneficio de oficios de justicia. Para el caso de las provincias internas, obsérvese ahora cómo los solicitantes de estos empleos suelen alegar en muchas ocasiones servicios militares, a veces largos y valiosos, además del económico que explícitamente ofrecen. Los memoriales recogen todos los hechos de armas de las guerras de Portugal, Cataluña, Italia y Flandes; las campañas y sitios de plaza menudean tanto como los encuentros navales de la Armada Real y de la Armada de la Guardia de la Carrera de las Indias. En los ejércitos, por ejemplo, Rebollar y Pedro Fermín de Echéverz; en la marina o en ambos sitios, Plaza, Pardiñas, Castillo, Larrea, Rodríguez Cubero, Chacón y Cortés. De algunos se afirman servicios políticos 
y militares sin especificación, y de otros sabemos que proceden de cargos administrativos. Y no se olvide a los que aluden a méritos contraídos en Indias, $y$ en especial en las mismas fronteras internas, en constante guerra viva.

Será seguramente ilustrativo el conocimiento de los trámites por los que se llegaba a la obtención de un cargo mediante la prestación de servicios pecuniarios. El solicitante comenzaba dirigiendo un memorial al rey en el que, naturalmente, hacía relación más o menos profusa de sus anteriores servicios, cuando los tenía, indicaba el empleo que deseaba obtener y ofrecía servir con una cantidad concreta. No son infrecuentes los casos en que esta cantidad se divide en dos partes, como se recoge en nuestra lista, de las que la primera sería dinero entregado en concepto de donativo, mientras la segunda sólo lo sería como préstamo sin interés, a reintegrar por lo común por las cajas de México. Otras veces el donativo será hecho efectivo en dos pagos: el primero al ser otorgada la merced, y el segundo días o meses más tarde, en Madrid o en otra ciudad de la península o de Nueva España. En ocasiones, residiendo el memorialista en Indias, se compromete a pagar por medio de letra girada sobre un comerciante; así lo propuso y se aceptó a Vargas, el reconquistador de Nuevo México.

De todos modos, la promesa de donativo era afianzada por dos firmas: la primera solía ser de un consejero de Indias, a veces del propio presidente del Consejo; la segunda, cuando no del propio solicitante, de un mercader u hombre de negocios, y en algunos casos antecede una cláusula garantizado. ra de la oferta. Tal ocurre en el documento últimamente citado, la solicitud de Vargas, a cuyo final se inserta: "Yo Juan González Calderón, me obligó a que el dinero será efectivo en la conformidad que se ofrece en este memorial", y a continuación aparecen las firmas de Manuel Francisco de Lara y del propio Calderón. En el memorial en que Cuervo solicita el Gobierno de Coahuila se añade que: "Sin embargo de que este presidio está entre indios bárbaros de guerra y es sólo de 25 soldados y de que es menester estar siempre con las armas en la mano, en fuerza de lo cual se ha proveído hasta ahora for servicios", sumará el interesado a los suyos el de dos mil pesos, a pagar mil en la Corte y mii en Cádiz, tras de lo cual firman D. Juan de Larrea y Francisco Cuervo. El memorial de Pedro Fermín de Echéverz aparece firmado por el mismo Larrea y Justiniano Justiniani; el de Francisco Cortés, por Don Juan de Angulo y Don Juan de Goyeneche. Y así tantos más; ni que decir tiene que Lira y Larrea eran miembros del Consejo de la Cámara de Indias; Angulo era secrelario de Estado. La doble firma era tan de ritual, que cuando el rey remite el memorial a la Cámara para su consulta, o bien sim- 
plemente comunicándole ha decidido convenir en la gracia pedida, recoge en el decreto los nombres que autorizan y respaldan la solicitud.

Este decreto de nombramiento, y el título que en su virtud se expide, suelen hacer alusión a las urgencias del real erario, que hace apetecible el servicio pecuniario del aspirante. Las urgencias eran tan fuertes que arrastraban al rey a conceder futuras, esto es, nombramientos anticipados que no tendrán efectividad sino en el caso de vacar el cargo por muerte de su actual propietario, o cuando éste cumpla el trienio o quinquenio por que fue provisto. La proximidad de fechas de dos o más títulos para una misma plaza en nuestra lista muestra bien a las claras que nos hallamos ante alguno de estos casos. Movido por la misma necesidad, recurrió el rey a invadir el campo jurisdiccional de los virreyes, de las audiencias y de los mismos gobernadores, recabando sin previo aviso el nombramiento de justicia para cargos cuya provisión correspondía a aquellas autoridades Así ocurrió en el cargo de gobernador de Nuevo México y Nuevo León, y la alcaldía de Nombre de Dios, que habían sido de la provisión del virrey, y en las alcaldías de la costa del Pacífico, cuyo nombramiento tocaba, según los casos, al virrey, al presidente de la audiencia de Nueva Galicia o al gobernador de Nueva Vizcaya. A veces se halla en los títulos frases como éstas: "por justas consideraciones del real servicio se separó del gobierno de Nueva Vizcaya la provisión de alcalde mayor y capitán de Sonora, real de minas de San Juan Bautista..."; se nombra alcalde de Culiacán "aunque este cargo ha sido hasta ahora de la provisión de la audiencia". Tal intromisión real en campos en que previamente no había ejercitado su attoridad acarrea una serie notable de imprecisiones o errores en los títulos en orden a determinar el salario, las facultades o las instrucciones que deba llevar el provisto, ante quién habrá de jurar su empleo o prestar juicio de residencia, etcétera, que no es del caso analizar aquí. Justo es añadir que en otras ocasiones el rey procedió a nombrar por primera vez un gobernador sin que mediase ese interés de la prestación económica, como en el caso de Salinas Varona en Coahuila, del mismo modo que entre los que aportaban una cantidad para lograr un puesto, se hallan otros titulares que fueron designados sin que acudieran a este tipo de servicio; y ya se habrá advertido que no todos los que figuran en las listas llegaron a ejercer su empleo, bien por fallecimiento o renuncia, bien por otras causas.

La penuria de las arcas reales de que venimos hablando, y que, en contra del sentir común, es más acentuada bajo los Borbones que con los A'ustrias, obligaba al rey, de manera cada vez más frecuente, a otras concesiones que iban despojando al "servicio" de su primitivo sentido; una de ellas era el compromiso que adquiría la Corona de reintegrar al particular 
o a sus herederos la cantidad desembolsada si aquél muriera antes de tomar posesión o por cualquier circunstancia no llegase a ocupar el cargo obtenido. Otra concesión que sólo se observa en el XVIII es la de que el electo pueda designar sustituto "con aprobación del virrey", citándose muchas veces por sus nombres los posibles sustitutos, mientras que en algún caso se llega a tolerar que a un gobernador de Nuevo México le puteda suplir en todo o en parte del ciuinquenio "la persona que casare o hubiera casado con alguna de las hijas legítimas de Don Jacinto Martínez y Aguirre o Don Juan Martínez de Astiz, siendo de la aprobación de mi virrey". El rey volvió sobre sus mercedes en más de nna ocasión por escrúpulos o por conceder el empleo a otro individuo más meritorio; estas "reformas" son las que dieron lugar a que Deza y Ulloa y Porras tuvieran que servir pecuniariamente por segunda vez para hacer efectivo el nombramiento ya una vez logrado y anulado más tarde. Y mot:varon también el que en otros títulos se hiciera contar que entrarian en vigor no obstante cualcuier reforma general o particular que se pudiera introducir.

Si continuamos ahondando en este hecho de los oficios vendibles, tan típico de la Edad Moderna en toda Europa, veremos que para el caso de las provincias internas, como tal sistema, fue seguido por una serie de personas con la misma regularidad con que cualquier funcionario o militar aspira a sucesivos cargos y ascensos. Bastarán unos ejemplos. Encontramos casos como el de los hermanos Estrada - Bartolomé y Andrés-, que obtienen a la vez, respectivamente, el gobierno de Nueva Vizcaya y el corregimiento de Zacatecas, y otros que inducen a sospechas, como la obtención simultánea de Nueva Vizcaya y el corregimiento de Guanajuato por Respaldiza, o de Sinaloa y la capitanía de Sonora por Fuensaldaña. El prototipo es el hombre que "hace carrera" pasando de unos a otros puestos mediante repetidas donaciones de dinero. Así Cobos, que sucesivamente "beneficia" Nuevo León y Sonora; Cuervo, que tras haber logrado una oficialía Real en Guadalajara solicita indistintamente los gobiernos de Nuevo México y Coahtrila, desempeñando mediante servicio éste, y logrando al cabo aquél, aunque no nos conste cómo lo alcanzó. Mientras que Bartolomé de Estrada había sido Oficial Real en México antes de acceder a Durango como gobernador. Todo esto no podía dejar de prestarse a una serie de abusos y corruptelas, vicios de siempre previstos por el Consejo, que representó al rey contra este sisterna cuando se hallaba en sus principios la provisión de empleos de justicia por servicios pecuniarios. Los más comunes eran el proceder el nombrado por el rey a vender a su vez - disimuladamente, por stipuesto- los cargos subalternos de su distrito y el dedicarse a comerciar "por interpósitas personas".

Pero siendo las provincias en buena parte más una carga que una renta 
¡ara el Estado español, y siendo también exigua o nula e imaginaria la remuneración que por su empleo percibía el gobernador o alcalde mayor, aquél obtenía con la venta del empleo algún ingreso y el mercader solicitante buscaba en su actividad como tal mercader un complemento a sus ingresos como gobernante.

Esto se daba ya por descontado cuando, por ejemplo, Don Francisco de la Rocha Ferrer, antiguo gobernador de Maracaibo y Santo Domingo. escribía desde México al marqués de la Ensenada agradeciéndole le hubiese obtenido del rey el gobierno poco apetecible de Nuevo México. "Esta gracia - dice Rocha ${ }^{2}$ - no me trae consigo el más mínimo alivio por las circunstancias del empleo (que sólo puede ser bueno para un mercader rico, y no para un pobre cargado de familia como yo), que dista de esta capital más de seiscientas leguas por unos caminos desiertos y llenos de imponderables riesgos".

Concebidos los gobiernos como sólo deseables por comerciantes, llegados éstos a dichos puestos comenzaban a vender las alcaldías a otros tales y mejoraban sus emolumentos dedicándose al tráfico con los indios o valiéndose de su autoridad para reservarse la exclusiva de determinado comercio, como los alcaldes lo hacían también en su jurisdicción.

En I756, el virrey Amarillas nos describe uno de los lugartenientes o testaferros de Respaldizar en Coahuila, Don Francisco Antonio del Campo, en quien aquél había delegado el gobierno, "siendo este sujeto de ejercicio cacahuatero, entendido en esos reinos con el nombre de pulperos, cuyo empleo en las esquinas es la venta de carbón, manteca y otros semejantes utensilios". 3

$\mathrm{El}$ conocimiento de algunos de estos hechos había llevado a la Corona a reaccionar a tiempo, y ya desde $\mathrm{I} 75 \mathrm{I}$ estaaba dada una real cédula que ordenaba a los virreyes no dar el pase para ningún gobierno a individuos de este tipo. Por lo mismo, cuando Amarillas notificó aquella situación, por reales órdenes de 3 I de agosto de 1756 se antuló la gracia concedida a Respaldizar, a quien serían devuteltos los siete mil pesos que había entregado para obtenerla. 4

A mitad de siglo había cesado la venta de las gobernaciones de las provincias internas. Algunas, por cierto, jamás se vieron afectadas por aquel sistema. Tal es el caso de Texas, por disposición del rey, pues habiendo entregado Don Tomás Cantelmi por este gobierno sesenta mil reales en $\mathrm{I} 745$, le fueron devueltos "porque S. M. no quiso beneficiar este empleo". 5 a Rocha a Ensenada. México 2 I de agosto de I748. A. G. I., Guadalajara, 300. Es evidente
que Rocha no compraba el empleo.

3 Amarillas a Arriaga. México 3 de marzo de r756. A. G. I., Guadalajara, 302.

4. A. G. I., Guadalajara, 302.

5 "Indice de reales órdenes". A. G. I., Guadalajara, 300. 
Esta expresión indica la conciencia cada vez más clara en el gobierno de la importancia de poner ante todo en manos competentes y fieles la dirección de aquellos dominios remotos de creciente interés estratégico.

Por las mismas causas, poco a poco se va procurando desde el virreinato una mayor centralización y una más inmediata sujeción y subordinación de aquellos gobernadores casi autónomos, dadas las distancias a que se encontraban. Testimonio de esto son las cada vez más frecuentes visitas, o las pesquisas secretas que encargan los virreyes. También la costosa organización militar establecida hace que se preste atención a su utilidad y necesidad.

De esta manera, a mediados del siglo XVIII, las provincias internas se hallan en el punto final de un proceso que encuentra su justa conclusión en ia visita del mismo Don José de Gálvez.

\section{LAS VISITAS}

El mismo gravamen que para la real hacienda supuso a partir de 1685 la erección de los cinco nuevos presidios de Nueva Vizcaya, hizo a los virreyes cuidadosos acerca de su utilidad, y a esto obedece la repetición de las visitas que, poco clespués de aquella fecha, empiezan a decretarse.

La primera, a la que ya hemos hecho alusión, es la del maestre de campo Don José Francisco Marín, a quien la encomendó el virrey conde de Galve en 20 de febrero de 1693 por dos motivos. Uno de ellos era hallarse con noticias de que los soldados y capitanes de los presidios no se ocupaban en el ministerio y fin para que éstos fueron erigidos. El otro, la posibilidad de reducirlos a una sola compañía volante. Ambos móviles tienen a su vez riistintas causas.

La idea del ahorro no puede extrañar, pero menos conociendo que ya al virrey conde de Paredes debió parecerle algo insólito la audacia con que la Corona se lanzó a unos gastos y fundaciones a que él se había resistido tanto. Paredes no dejaría de influir en el ánimo de su sucesor en el virreinato, conde de la Monclova, y éste, autor de la instrucción dada al gobernador de Nueva Vizcaya, Pardiñas, para la guerra contra los bárbaros, se muestra por demás escéptico: "los insultos — dice en carta al rey ${ }^{6}$ - que he oído decir se han hecho por los indios en Nueva Vizcaya de treinta años a esta parte no sé que hayan sido mayores que los que han sucedido en estos dos años, y éstos y aquéllos consisten en matar cuatro o seis españoles cuando van descuidados y hacer diferentes presas de caballadas y muladas, con que hallo que por tan corta hostilidad se sacan de las reales cajas de $\mathrm{S}_{\mathfrak{1}}$ Majestad para con-

6 Monclova a S. M., to de enero de r689. A. G. I., Guaclalajara, I47. 
servación de los cuatro presidios añadidos (sin contar los sueldos de los capitanes) noventa mil pesos, que estos montan los doscientos soldados que se han puerto en ellos, a cuatrocientos cincuenta pesos de sueldo al año a cada soldado, y me parece que si Su Majestad abre la puerta a que por proposición de los gobernadores y capitanes generales de la Nueva Vizcaya y con alaridos y casos que pintan para que lleguen al Real Consejo y Junta de Guerra de Indias mandar dar providencia a esta proporción para el resguardo de aquel reino, será muy contra su real servicio, y juzgo muy conveniente que para reformar estos presidios de manera que en cada uno queden veinticinco soldados atienda Su Majestad a lo que el conde de Galve mi sucesor le representará".

Galve, en efecto, se adhirió a la anterior representación de Monclova, y el 20 de febrero de 1689 comisionaba a Marín para la visita de los presidios, movido por las razones que hemos expuesto arriba. 7 Sin embargo, el mismo Galve había de verse obligado por las circunstancias a decretar la formación de una nueva compañía en Sonora y a autorizar el aumento de los efectivos de la de campaña del Parral.

En I697 dispone el virrey Moctezuma la segunda visita de los presidios, que debía llevar a cabo el ex gobernador de Nueva Vizcaya Don Isidro de Pardiñas. Pero, tras un largo debate promovido por el gobernador electo Don Juan de Larrea, la voluntad del virrey no se llevó a efecto. Larrea alegaba que Pardiñas se había creado ciertas animosidades por parte de los soldados en su período de mạdato y, fuera esto o no cierto, consiguió su pretensión de evitar su pesquisa. ${ }^{8}$

El virrey duque de Linares fue el tercero en preocuparse por el estado de los presidios en este sentido. En la memoria de gobierno que dejó a su sucesor, Valero, dice haberse aplicado a estudiar su ejercicio. Considera sus tropas sumamente necesarias, pero distintas y aun opuestas al método de las reglas en vestidos y pagamentos. Linares envió al coronel Don Juan José Mazoni a visitar los presidios, al parecer todos los existentes en las provincias internas. Así lo hizo Mazoni, pero desgraciadamente se ahogó en la flota de Ubilla, y con él se perdieron los informes que llevaba al rey. 9

7 En 3 de febrero escribía Gálvez estar de acuerdo con lo expuesto por isu antecesor, pero que esperaría a tener más información sobre el particular. A. G. I., Guadalajara, r 47. Galve i S. M., núm. 8. El decreto para la visita e información secreta del estado de los presidios, 20 de febrero de I 693, en A. G. I., Guadalajara, i 5 I.

8 La documentación sobre esta fallida visita, en A. G. I., Guadalajara, I 55.

9 Instrucción de Linares a Valero, en Instrucciones que los virrejes de Nueva España dejaron a sus sucesores. México, I687. Págs. 3I3-3I4. Real Cédula aprobando el nombramiento de Mazoni, i5 de octubre de i7 15. A. G. I., México, 486 B. Mazoni había sido nombrado ingeniero con destino en la plaza de Veracruz por real cédula dada en Zaragoza, 29 de abril de I711. cuando ya ostentaba el grado de coronel; fue propuesto para este empleo por la Junta de Guerra 
Después de Linares, cuyo interés habíase hundido en el fracaso, el virrey marqués de Casafuerte ha de ser el que ejerza una acción eficaz y duradera sobre la organización defensiva de las provincias septentrionales. Su representante $\mathrm{y}$ hombre de confianza en ellas es el brigadier Don Pedro de Rivera, que las recorrerá todas e introducirá una serie de reformas e innovaciones, y dará lugar a un informe, un reglamento y una colección de mapas de la frontera, que merecen más detallado comentario, que haremos páginas adelante. El mismo Rivera, sin embargo, nos cla a conocer la actividad de un predecesor suyo en la visita de Nueva Vizcaya, Don Antonio Cobián Busto, cuyos autos, según dice en su informe, puso en estado de sentencia. ${ }^{10}$

\section{EL RÉGIMFN DE LOS PRESIDIOS}

A1 entrar el siglo XVIII, contaban las provincias internas con doce presidios, de los que seis Nueva Vizcaya, dos Nueva México y otros tantos Nuevo León y uno cada una de las provincias de Sonora y Coahuila. De entre ellos tenía consideración de compañía volante la de Sonora, mientras que la de campaña de Nueva Vizcaya se dividía en dos escuadras: una de treinta hombres situada en Parral, y otra de quince en Durango. La fuerza total de estas guarniciones no pasaba de quinientos tres hombres. La exigüidad de los medios de defensa no puede ser más patente si se tiene en cuenta la magnitud de los territorios que con ellos se pretendía asgurar. ¿ $Y$ quién podrá valuar los miles de "gandules", de indios de arco y flecha, de guerreros enemigos que presionaban sobre esas mismas posiciones? Sin embargo, como ha de verse, en breve plazo se procederá todavía a una drástica reducción de esta fuerza de contención.

La paga de los soldados era de $45^{\circ}$ pesos anuales. En el siglo anterior habíanse dado los pasos necesarios para unificar todos estos sueldos que en los primitivos presidios, nacidos esporádicamente en diversas épocas y circunstancias y constituidos en las más dispares maneras y con desiguales fuerzas, habían sido sumamente variables.

En I zor, al erigirse el nuevo presidio de San Juan Bautista del Río Grande, prorrateóse su costo de nueve mil pesos entre los restantes para no sobrecargar el real erario, y se redujo la paga de cada soldado a 432 pesos,

dc Indias al regresar a Europa el francés Don Luis Bouchard de Becour que lo servía. A. G. I., México 2424, y A.G.S., D.G. Tesoro, inv. $2 .^{\circ}, 10-14$. Se le concedió título de ingeniero a Mazoni por real cédula de 12 de julio de 1709 para que atendiese a las obras de defensa del virreinato del Perú. A. G. I., Lima, 588, Libro 33 (Dato que nos facilita el investigador peruano Don Migitel
Maticorena Estrada).

I a Rivera cita a Cobián al referirse a los presidios del Pasaje, Gallo y Cerro Gordo. Diario, ed. Vito Alessio Robles, págs. 102-103, 104 y 1 i 8. 
Io granos. Los treinta hombres de Río Grande cobrarían a 300 pesos. El cesto total de los presidios era de 226.350 pesos al año, cantidad que se hacía efectiva en distintas Cajas Reales del virreinato, según el siguiente esquema, que indica igualmente el número de hombres de cada guarnición.

$$
\text { CAJA }
$$

Zacatecas
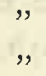

,

,

"

,

,

"

Guadiana

(Durango)

Guadalajara
PRESIDIO

Casas Grandes

San Francisco de Conchos

San Pedro del Gallo

N. ${ }^{a}$ S. ${ }^{a}$ del Pasaje de Cuencamé

El Paso

Compañía Volante

Cerralvo

Cadereita

San Francisco

Compañía de Campaña

Cerro Gordo

Santa Fe
PROVINCIA FUERZA COSTO

\begin{tabular}{|c|c|c|}
\hline Nueva Vizcaya & 50 & 22.500 \\
\hline 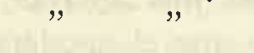 & 50 & 22.500 \\
\hline$"$ & 45 & 20,250 \\
\hline & 45 & 20.250 \\
\hline Nuevo México & 50 & 22.500 \\
\hline Sonora & 50 & 22.500 \\
\hline Nuevo León & IO & 4.500 \\
\hline , & IO & 4.500 \\
\hline Coahuila & 25 & I I. 25 \\
\hline
\end{tabular}

Nueva Vizcaya

Nuevo México

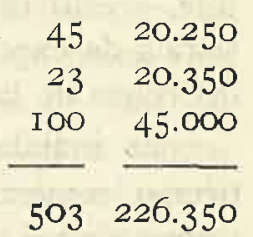

$\mathrm{La}$ incongruente correlación entre los presidios y las cajas en que perciben sus situados es uno de los defectos que se subsanará en el período siguiente, haciendo que todos ellos se cobren en la de México. II

I Los conceptos y la relación de presidios, fuerza y costos expresados en los párrafos anteriores, están sacados de la carta de los contadores Andrés de Herrera y José de Vergara Alegri, México, ir de marzo de 1705, en A. G. I., Guadalajara, 142. Se advierte a primera vista, y de manera inexplicable, la omisión de los presidios de Sinaloa, Tanos y Santa Catalina de Tepehuanes, ciertamente existentes en esta época, y cuya composición y costo debía ser como sigue:

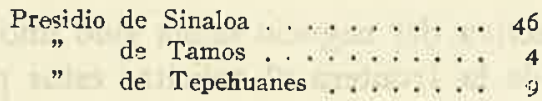

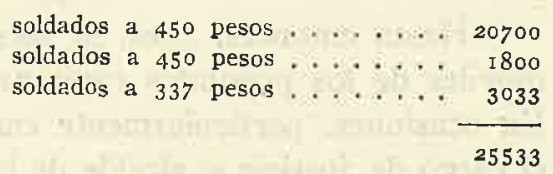

Con lo que la fuerza total de la frontera asciende a 562 soldados, y su subsistencia grava al erario en 251883 pesos. El presidio de Río Grande, que no constituye nueva carga, aumenta treinta hombres más a la defensa, que corre por fin a cargo de 592 soldados. Según una real cédula de 4 de marzo de 1705 , hasta 1700 los soldados de Sinaloa sólo cobraban 3r 5 pesos anuales. En I7or la representaron así al entonces arzobispo-virrey Don Juan de Ortega Montañés, que les concedió el aumento a 450 pesos, como los de los demás presidios. La cédula aludida aprueba esta elevación de sueldos, que cobraban por afios adelantados en la Caja de Guadalajara. Al parecer tenia entonces el presidio suarenta y tres plazas. A. G. I., México, 2418. 
Pero el principal problema que se plantea en cuanto al régimen de los presidios es el de la condición en que quedan constituídos los soldados en virtud de determinadas características de aquellos establecimientos. Teniendo en cuenta que los presidios estaban, en general, situados en lugares de escaso tráfico mercantil, hízose costumbre que los capitanes encargasen a un comerciante - el aviador- que hacía las veces de apoderado, la percepción de las pagas en la caja correspondiente, y seguidamente las invirtiese en las distintas mercaderías que podían necesitarse en el presidio: estos géneros era lo que el apoderado remitía al capitán, quien los vendía a sus soldados, según ellos lo iban pidiendo, contra sus respectivos haberes, no sin otorgarse a sí mismo un considerable coeficiente de interés.

La situación así creada era por demás injusta: El capitán habíase convertido en un comerciante - cuando no lo era ya al solicitar el empleo-que negociaba con caudales pertenecientes a los hombres a quienes mandaba. Las usuras eran casi lo ordinario. Los precios excesivos a que se expendían los géneros - ropas, armas, etc- - convertía a los soldados en deudores de su jefe, y esto redundaba en menoscabo del servicio, puesto que el capitán se retraía de exponer su compañía a un combate por temor de quedar privado del cobro de las cantidades adeudadas por los hombres que muriesen en él.

Es indudable que muchos de los capitanes presidiales eran al mismo tiempo comerciantes, cuando no mineros o dueños de haciendas. Principalmente para aquéllos, la obtención del mando de una compañía significaba una segura y lucrativa ampliación de su negocio. La duplicidad de empleos, militar y civil, no debe extrañar habida cuenta de que, como mucho se ha insistido, desde el principio de la conquista, todos los españoles eran soldados al tiempo que ejercían alguna otra actividad. Sólo muy entrado el XVIII, contemporáneamente a la creación en Nueva España del ejército regular, empezarán a imponerse en el norte los oficiales militares de profesión, pero con esto vino a advertirse también la necesidad de subir los sueldos de los cuadros de mando de los presidios.

Hasta entonces, pues, la perspectiva del negocio había sido uno de los móviles de los presuntos capitanes de la frontera al solicitar estos puestos. En ocasiones, particularmente cuando la capitanía del presidio comportaba el cargo de justicia o alcalde de la población adyacente - tal el caso de Mapimí- los capitanes pretendian, y procuraban por todos los medios, hacerse con la exclusiva del comercio en el distrito. Todo esto, por fuerza, no podía ir en ventaja del servicio. En Nuevo México, soldados y vecinos se quejaron de que el capitán del presidio de Santa Fe, que era el mismo gobernador de la provincia, vendía a aquellos los géneros a crecidísimo 
precio, con notorio abuso, y dificultaba a éstos el comercio de pieles con los infieles, que pretendía acaparar.

De manera semejante, y precisamente por las relaciones de dependencia personal que el sistema establecía entre capitán y subordinados, le era posible a aquél encargar a uno o varios de estos la atención de sus propios rebaños o caballadas, o el cultivo de sus tierras, o bien despacharlos a distintos puntos lejanos del presidio encomendándoles algún asunto o comisión de su interés particular. De tal manera que los capitanes no hallaban empacho en emplear a sus soldados como pastores, vaqueros, o labradores en su beneficio propio. Esto, por otra parte, nos sirve de índice para calcular que los individuos que componían las guarniciones eran en gran parte mestizos, cuando no indios, ya que se avenían a estos menesteres en tales condiciones. "De color quebrado", efectivamente, decía el ex-gobernador Don Manuel San Juan de Santa Cruz que eran los soldados de Nueva Vizcaya. ${ }^{2}$

Los capitanes, una vez obtenido el mando de un presidio, no estaban distantes de considerarlo como algo de su propiedad particular y como algo, además, que les confería autoridad y poder. Gobernando aquellas docenas de soldados, cuyas familias vivían también en el presidio, como quien rige casa propia, venían a atribuirse el carácter de grandes señores de vasallos, tanto como cualquier latifundista dueño de haciendas, estancias o minas, si es que ellos mismos no lo eran, y por supuesto tal actitud venía reforzada por el hecho de ser los capitanes vitalicios, después de la real cédula de 22 de diciembre de 1680 .

Para que se venga en conocimiento del coste que las provincias internas tenían, damos a continuación un estado más preciso que el anterior y que recoge algunos presidios, guarniciones y gastos que aquel dejó en el olvido.

I Este sistema to atestigua ya el duque Linares, quien dice que se pagaba a los soldados con especies de todas clases, que los aviadores mandaban a los capitanes; pero que aquéllos las recibian España dejaron pedida por San Juan de Santa Cruz, R A H 1867 , pág. 314. Demanda de información de testigos pedida por San Juan de Santa Cruz, R. A. H., Boturini, 20, fols. 9-16 v. 


\section{FUERZA Y COSTO DE LOS PRESIDIOS EN I7 I7}

\section{Provincta}

Nuevo México

Sinaloa

\section{Fuerza y Sueldo}

I00 hombres a 450 pesos

43 hombres a 450 pesos I gobernador 200 pesos

I cabo caudillo, 800 pesos

Coahuila 50 hombres a 450 pesos
Saltillo

Paso del Río del Norte

Cerralbo, Cadereita, y León

Cuencamé

S. Antonio Casas Grandes

Sonora

Conchos

Corring

25 hombres a 450 pesos I gobernador, 750 pesos
I capitán protector, 500 pesos 49 hombres a 450 pesos I capitán, 600 pesos 20 hombres a 450 pesas 2 capitanes a 725 pesos 40 hombres a 450 pesos I capitán, 600 pesos 50 hombres a 450 pesos I capitán 600 pesos I capitán, 600 pesos

50 hombres a 450 pesos I capitán, 600 pesos

Gallo

Pasaje

43 hombres a 450 pesos I capitán, 600 pesos 45 hombres a 450 pesos I capitán, 600 pesos

Paz y guerra

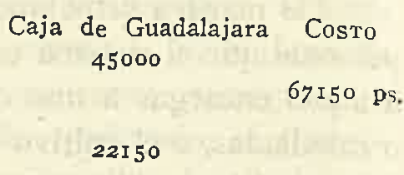

Caja de Zacatecas

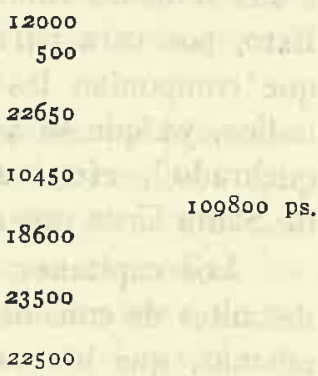

\section{Caja de Guanajuato}

23 I 00

23100

Caja de Sombrerete

I 9950

$20850 \quad 40800$

Caja de Guadiana

I I $35^{\circ}$

I capitán, r 000 pesos

9 h. a 337 ps. 4 toms I capitán, 337 ps. 4 toms

I 5 hombres a 450 pesos

30 hombres a 450 pesos

I capitán a 450 pesas

I teniente a 450 pesos

I sargento a 450 pesos
3375

6750

38325

I 4850

2000 
Este es el estado de los presidios presentado por el oidor Don Juan de Oliván y Rebolledo al virrey Valero el 24 de diciembre de 17 I7, cuando se debate la cuestión de cómo costear la fundación de varias nuevas guarniciones que se pretenden establecer en la provincia de Texas con objeto de ocuparla defintivamente. ${ }^{13}$ De dicha relación ya hemos suprimido-por no referirse concretamente a gastos de guerra o a nuestro territorio- las cantidades consignadas como salarios del gobernador de Nuevo León (32250 pesos) y del capitán protector de las fronteras de Tepic y Colotlán y escribano de guerra de Nueva Galicia (70o ps. en total). La inclusión del primero requeriría con más motivo la de los gobernadores de Coahuila, Nueva Vizcaya y Nuevo México, que no figuran en el estado. El total de soldados y oficiales es de 623 hombres, en la práctica 653 , sumados los treinta del presidio de San Juan Bautista de Río Grande en Coahuila, que no figuraban en ias listas, sino que se pagaban haciendo una merma en sus salarios a todas las tropas de la frontera. Tampoco aparece en la relación el presidio de Mapimí, que ya se dijo que fue establecido en I 7 I I con destacamentos del $\mathrm{Pa}$ saje, Gallo, Cerro Gordo y Conchos, más los quince hombres de la compañía de campaña que se suponen en Durango y los diez hombres de Santa Catalina, mostrándose en cambio todas estas guarniciones con el completo de sus plazas; pero Mapimí no altera el total de la fuerza ni su coste.

\section{LA GUERRA}

Las tropas de los presidios ocupábanse, cuando no se realizaban campañas, en escoltar los pasajeros y convoyes que entraban o salían de las provincias internas. Ordinariamente su guerra era puramente defensiva, y aun cuando se verificaban incursiones en persecución de los bárbaros, el móvil de estas operaciones era tan sólo la protección de las provincias ocupadas por los españoles, y no el de extender las conquistas.

E1 enemigo - las innumerables tribus del Bolsón, los apaches que ahora sólo actúan en Sonora y el Norte de Nueva Vizcaya y en Nuevo México, los seris; los chichimecas que hostilizan Nuevo León, las tribus texanasataca con arco y flecha. Los españoles manejan las armas de fuego, lanzas y espadas, cubriéndose para su protección con la pesada coraza o cuera y con la adarga. Acerca del contraste entre estas armas y de la manera en que se desarrolla un combate, oigamos a un anónimo autor, que asegura ser temibles los bárbaros, basándose en la experiencia, "manteniéndose muchos que no la tienen en el error de ser débil arma el arco y la flecha, que es lo que

I 3 A. G. I., M'éxico, 633 . 
usan con suma destreza, como si no fuese lo mismo morir de una bala que de una flecha, pues hace el mismo efecto que una escopeta de cinco cuartas, como se ha visto muchas veces tirando al blanco desde igual distancia los soldados y los indios amigos, que penetran igualmente una pared o árbol éstos con sus flechas que aquéllos con sus fusiles, a que se añade que mientras el soldado carga un arma, dispara veinticinco flechas el indio, y así, casi siempre logramos buen éxito en nuestras armas por los indios amigos que acompañan a los soldados, y éstos se libertan más que por armas, por la agilidad que tienen en el manejo de los caballos, pues hacen lo mismo con un potro que con el más dócil, con la izquierda la rienda y adarga en que recibe con gran habilidad todas las flechas que le vienen a él y al caballo, con la derecha amagando con la escopeta, que regularmente no disparan, porque viéndoles privado de esta defensa cargarían tantos sobre él que no habría resistencia, hacen una defensa digna de loarse; que si llegan a mezclarse, es la espada con la que consiguen la victoria".

Este texto arroja tanta luz sobre las condiciones de la lucha, que bien merece un somero análisis, pues explica de modo muy distinto al que habitualmente se supone la victoria de los españoles sobre los indios en todos los campos de batalla de América.

En primer lugar, no hay la pretendida superioridad del arma de fuego, sino que, por el contrario, el arco es tan eficaz como aquélla y la aventaja de manera abrumadora en velocidad de tiro. En estas circustancias, la escopeta casi se ve reducida a pura arma defensiva, que el español no llega a disparar, pues de hacerlo se hallaría sin protección; se limita a amenazar con su fuego al enemigo, para mantenerlo a distancia. Mientras, los auxiliares indígenas son los que replican a los disparos del adversario con sus mismas armas; las condiciones de inferioridad del blanco son, hasta aquí, evidentes. Jinete en su caballo, con la adarga atiende a detener las flechas dirigidas contra él y su cabalgadura. El caballo, que en otro tiempo proporcionó también considerable superioridad sobre el indio, no desempeña ya aqui ese papel. El indio no solo ha perdido el miedo al caballo, sino que lo ha domesticado y lo monta y lo atiende con verdadera habilidad, y guerrea también sobre sus lomos.

El español se impone precisamente en un terreno tan elemental como el combate cuerpo a cuerpo, con arma tan primaria como la espada. En cambio, los indios nunca parecieron interesarse por la espada; su atención se fija sólo en los arcabuces y escopetas, y únicamente de las tribus que se hallaban en contacto con los franceses tenemos noticias que adquirían de éstos unos a modo de sables cortos o cuchillos largos. Por su parte, el español no siempre se dedicó a sacar partido del arma entonces más propia de la caballería:

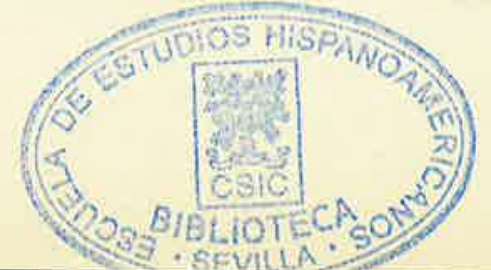


la lanza, que figura en el equipo de los presidiales, pero de cuya utilización no tenemos una sóla referencia en la primera mitad del siglo, al tiempo que la carabina, arma de fuego típica y más adecuada del jinete, no se introducirá en la frontera hasta los últimos tiempos del dominio español.

Para su defensa tenían los bárbaros el chimal o escudo de cuero, semejante a las adargas de los españoles. Pero si ambos eran eficaz protección de las flechas, no así contra las balas de un arcabuz, y por eso daba resultado aquel "amagar con la escopeta" que practicaban los españoles en la batalla. ${ }^{14}$ Cubríanse éstos, además, con una especie de coselete de tiras de cuero y lana trenzada: la cuera, según se la llamaba, así como a los presidiales "soldados de cuera". Fabricábanse las cueras principalmente en Nuevo México, con piel de gamuza, pero su origen puede remontarse a los tiempos de la conquista en que los españoles abandonaron la coraza metálica, demasiado pesada, quedando sólo con la prenda de lana que antes les había protegido de su roce $y$ ahora se mostraba bastante defensa ante las armas de los indígenas: precisamente los aztecas utilizaban una prenda semejante de algodón. ${ }^{15}$

I4 "Breve relación en que se describe el puerto de Veracruz y su castillo; salida de flotas y azogues, Armada de Barlovento; Campeche, Habana y Cuba; Astillero de Alvarado; Puebla de los Angeles; Los juzgados de Bienes de Difuntos; Fiscales de México y Lima; Universidad y Hospitales; Casas de Moneda; Comercio dẹ Nueva España; variedad de gentes; prohibición de Comercio a los alcaldes mayores; natural genio de los indios; situación de México; Acapulco, su comercio con el Perú y Filipinas; Guadalajara; Colima, Valle de Banderas; Puerto de Matanchel; Bahía del Espíritu Santo; Provincias de los Caribes; Conquista de Nayarit; Operaciones de Oficiales Reales; Juez privativo de Tierras y Ramos de Real Hacienda; Práctica de los presidios y grandes perjuicios en ellos; régimen de los virreyes en la provisión de empleos; vicio del juego; y vulneración de la jurisdicción ordinaria y sus consecuencias: Año de 1735". Biblioteca del Palacio Real, Madrid. Miscelánea de Ayala, tomo LV, sig. 2873, folios 295 y sigs. Fols. 321-323. Pasar las escopetas por la cara, apuntar sin disparar, son expresiones frecuentes en el poema de Villagrá, que muestra ya la misma actitud de los españoles en la lucha con el indio a fin del XVI, en la conquista de Nuevo México y, con toda seguridad, en todas las guerras desde la del Mixtón.

I5 Baltasar de Obregón nos ha dejado la noticia del uso del "escuaguipil", arma defensiva de ropa, por el capitán Alearaz, gobernador del pueblo de Corazones, fundado por Coronado en Sonora (Obregón, ${ }^{1} 52-153$ ). Es Cordero quien ya a fin del XVIII declara saber que las cueras se fabricaban principalmente en Nuevo México, de teis a siete tiras de gamuza y rellenas de algodón, pero sin que él conociese cómo. Pfefferkorn se expresa así: "En Sonora todo soldado usa este jubón cuando va a campaña o monta guardia. La cuera consiste en seis u ocho capas de bien curtidas pieles de venado unidas por sus bordes por una fuerte costura. Esta cuera, larga hasta las rodillas, tiene corte semejante al de una chaqueta. Carce de mangas, de modo que no entorpece al soldado en el uso de sus armas. A pesar de ser abotonada, va cerrada por delante con correas que rodean toda la prenda. Las costuras y los bolsillos están decorados con cuero afiligranado forrado con paño rojo. Esta decoración es casi hermosa, porque la piel es blanca. Estas cueras sirven a los soldados de armaduras contra las flechas de los bárbaros. Uno pensaria - añade Pfefferkorn, completando lo ya expuesto acerca del poder de las armas de los indiosque tal indumento proporcionaria completa protección, pero a veces ocurre que una flecha no sólo penetra la piel de venado, sino también el cuerpo del soldado. La muerte de muchos españoles muestra que incluso ocho pieles son insuficiente defensa contra las flechas indias". Pfefferkorn, S. J.: Sonora. A description of the Province. Transl. by Th. E. Treutlein. Colorado Cuarto 
Huelga pensar en uniformidad de vestuario en este ejército, en América, hasta muy entrado el siglo XVIII. Los presidiales pudieron, pues, equiparse a este respecto a su gusto, que era el de todos los jinetes mexicanos, complaciéndose en el uso de los más anchos sombreros y de las enorme espuelas estrelladas de plata.

Todo su orgullo se cifra en la habilidad y arrojo montando a caballo. Encontramos repetidas quejas de los jefes profesionales, más adelante, sobre este particular, pues en su afán de lucimiento, los presidiales sometían a sus corceles a las más duras pruebas, sin el menor miramiento, y así los destrozaban en poco tiempo. Hasta I 730 contaba cada soldado de cuera con diez caballos. En esto, ningún ejército europeo se hallará semejante. Pero el presidial de las provincias internas se pasa los días prácticamente montado, en un cabalgar constante, y cuando se ha de emprender una persecución, es preciso tener siempre gran cantidad de caballos de remuda para no aminorar nunca la velocidad.

Esto tiene sus inconvenientes. Por una parte, en días de paz, el servicio de guardia a las caballadas exige varios hombres que quedan imposibilitados para cualquier otra actividad. Y esta caballada hay que cuidarla como pastores de ganado y hay que defenderla de cualquier golpe de mano del enemigo que encuentra en los presidios aquellos caballos que tanto codicia. Los presidios jamás tuvieron establos, en que los animales pudieran alimentarse de heno y grano, de manera que era preciso tenerlos en el campo, en pastos a veces muy distantes del acuartelamiento, bajo la vigilancia de una escolta suficiente. Cuando la compañía entra en campaña, toda la caballada va en pos de ella $y$, penetrando en territorio enemigo, se hace preciso reforzar su protección: estos hombres, aunque no sean hostilizados, han de atender como simples vaqueros al ganado que, en una compañía de cincuenta hombres, es de cuatrocientas cincuenta cabezas, y quedan imposibilitados de engrosar el número de los combatientes que se encuentra así mermado al ocurrir un choque con el adversario.

Por lo demás, la crecida caballada es una considerable servidumbre en campaña, pues la enorme polvareda que levanta a su paso, visible desde muy lejos, descubre enseguida al ejército que opera y elimina casi por completo la posibilidad de un ataque por sorpresa. Esto sin contar con que todas las precauciones para conservar el ganado son generalmente inútiles en el caso

Centennial Publications, I540-I940, vol. XII. Univ, of New Mexico Press. Alburquerque, I949. Nota en págs. I55-156. "Salen - dice Pérez de Rivas refiriéndose a los indios de Sinaloa- tan diestros en tirar la flecha y usan de ella con tanta velocidad y presteza, que mientras se dispone y dispara un soldado español su arcabuz hacen ellos ocho o diez tiros". Triunfos, I3r. Vid. también Sallta Maria, Fray Vicente, Relación histórica de la Colonia de Nuevo Santander y Costa del Seno Mexicano. Publicaciones del A. G. N. XV, 35I-483, págs. 423-424, nota 26. 
de que los enemigos se propongar robarlo, pues nada más fácil para ellos que provocar una estampida de los caballos con sus horrísonos alaridos y sus flechas. Otra servidumbre de no menor entidad impuesta por la enorme caballada era la dificultad que acarreaba para operar por regiones semi clesérticas como lo son gran parte de las de la frontera del norte de Nueva España.

Finalmente, el factor decisivo del éxito de los españoles, vista la general inferioridad de su número y la ninguna ventaja que sus armas le concedían, ha de encontrarse en la disciplina que normalmente se advirtió en los presidios y en su superioridad táctica al concebir las campañas y dar batallas, frente a grupos indígenas sólo habituados a las guerras tribales. Cuando los apaches adquirieron pericia en la lucha contra los blancos y advirtieron la inferioridad de éstos en el combate a pie se planteó un problema muy difícil para las armas españolas.

\section{LA FRONTERA HACIA I725}

Páginas atrás hemos presentado la distribución de las fuerzas presidiales en las provincias internas en I 70I y I7I7. Pero aquella situación no fue duradera, pues en los años subsiguientes los efectivos militares se incrementaron de manera considerable y el costo de los diferentes presidios volvió a hacerse muy desigual.

En 1725 , los presidios eran veintidós, ${ }^{16}$ con un total de novecientos cinco hombres, lo cual supone un considerable incremento de las fuerzas. Sólo en parte el aumento viene dado por las conquistas del Nayarit y de Texas. Así, en Nayarit se ha creado un presidio; en Nueva Vizcaya, otro, el de Mapimí, y en Sonora la compañía volante se ha establecido definitivamente en Fronteras, además de la antigua compañía de Sinaloa. En Texas, cuatro quedó constituidos el marqués de Aguayo. Y aún queda una escuadra de catorce hombres en Saltillo, y otra de ocho en la Villa de Valles.

Para esta época, la compañía de campaña del Parral se había fijado también como presidio en el valle de San Bartolomé. El gobernador de la provincia había concedido título de capitán del presidio por primera vez hacia I7I5. En el valle había treinta soldados. El presidio de Mapimí sabemos que fue fundado en I7I 4 ; el virrey Linares dice que fue posible repoblar el real de minas, que llevaba ya entonces muchos años en poder de los bárbaros, y había varias misiones en su distrito. ${ }^{77}$ Al presidio de Mapimí se

I6 Sin Loreto, que no enlaza con el sistema general defensivo.

I7 Instrucción de Linares a Valero, en Instrucciones que los virreyes de Nueva España dejaron a sus sucesores, México 1867, pág. 315. 
habían agregado los quince hombres que en tiempo del conde de Galve se aumentaron a la compañía de campaña y a los que en un principio estuvo encomendada la salvaguardia de Durango. El cabildo de esta ciudad ios reclamaba de nuevo al gobernador de la provincia, aunque en vano. ${ }^{8} 8$

Después del ataque realizado por los bárbaros en 1725 contra Monclova, el virrey Valero aumentó diez plazas al presidio de San Francisco de Coahuila establecido en aquella villa, y creó una escuadra de doce hombres que, con base en Saltillo, escoltarían desde este punto al presidio de San Juan Rautista de Río Grande, distante ciento treinta leguas, los bastimentos necesarios en Texas $y$ las limosnas destinadas a aquellas misiones. ${ }^{19}$

A orillas del Río Grande, el presidio de San Juan Bautista había nacido en 1698 como compañía volante para el resguardo de las misiones de los franciscanos de Propaganda Fide de Querétaro, pero ya desde i 70 I era presidio fijo, si bien carecía de tierras propias y se le consideraba dependiente de los misioneros, lo cual no era cierto. En este presidio concluía la cadena de los que contorneaban la gran bolsa de Mapimí y las tierras setentrionales 170 dominadas por los españoles. Desde aquí la frontera volvía a torcer al este, mantenida por los cuatro presidios de Texas.

De estos, los más fuertes eran el de Nuestra Señora del Pilar de Zaragoza de los Adays, frente al puesto francés de Natchitoches, y el de Nuestra Señora de Loreto de la bahía del Espíritu Santo, en la costa, con cien y noventa hombres, respectivamente. Eran guarniciones destinadas a precaver cualquier tentativa de penetración por parte de alguna potencia europea. En cambio, los de Nuestra Señora de los Dolores de Texas, con veinticinco hombres descle I715, y de San Antonio de Béjar, con cincutenta y cuatro soldados, custodiaban los núcleos de misiones del río de San Antonio y del de la Trinidad. ${ }^{20}$

Durante un cuarto de siglo más mantendría España toda una frontera terrestre al oriente, lo cual hace patente la debilidad de las posesiones cas11anas en Texas. Desde la bahía del Espíritu Santo al sur, siguiendo la costa, la primera población es Tampico, a más de cien leguas. Los establecimientos del interior distan unas cincuenta leguas del mar. Todo ese territorio virtualmente español pero prácticamente insumiso está en manos de las tribus

I8 Diario de Rivera, ed. V. Alessio Robles, págs. ror, 103-104, 117, 121. El presidio tuvo en principio sólo treinta y tres hombres, de los que nueve procedian del extinguido de Santa Catalina Tepehuanes. Así fue posible proteger aquel lugar, muy hostilizado, y ocupar el aguaje inmediato a la sierra del mismo nombre; donde se refugiaban los indios enemigos. Según Hernández, el repoblamiento tuvo lugar en 1711 , y en Jueves Santo de 1715 ocurrió la matanza del cura, cien españoles y trescientos criollos por los bárbaros, que motivó el tercer abandono del paraje. Hernández, Durango Gráfico, 34. Gallegos, Durango Colonial, 343.

I9 Diario de Rivera, ed. V. Alessio Robles, págs, $18 \mathrm{r}-185$.

20 Ibid., págs. Iro-11t. 
tamaulipecas que hostilizan las poblaciones de Nuevo León y la Huaxteca y las obligan a permanecer en estado de continua alarma. Para su protección existen los pequeños presidios de Cerralbo - doce hombres- y San Juan Bautista de Cadereita y Villa de los Valles - ocho hombres cada uno-. ${ }^{2 x}$

Finalmente, en el extremo noroccidental del virreinato, la salvaguardia de las misiones jesuíticas de la península de California está encomendada a la pequeña guarnición situada en Loreto desde $I 703 ;{ }^{22}$ presidio, este sí, que está subordinado al superior jesuita de la región.

Con todas estas nuevas erecciones, el sostenimiento de la frontera se hizo, sólo en lo militar, mucho más gravoso al real erario. Cierta desigualdad, sin embargo, en haberes y costos de los diferentes presidios es en esta época manifiesta.

Un soldado del Nayarit y Diolores cobraba 400 pesos. Uno de Fronteras, 450. ${ }^{23}$ Los del antiguo presidio de Santa Catalina agregado al de Mapimí seguían percibiendo sólo 337 pesos. El haber era en Río Grande de 300 pesos. Los capitanes, cuando no tenían haber como simples soldados, cobraban 500 ó 600 pesos, menos los dos de Nuevo León, que percibían 725 y el cabo caudillo de Sinaloa que devengaba 800 . En total, los presidios costaban a la corona 444.883 pesos al año. La frontera es, desde luego, en esta época, un hecho de verdadera magnitud. De California a Texas se extiende un cordón defensivo que, aunque no creado con esta intención, parece donotar la renuncia española a profundizar más aún en el continente americano. En el siglo que queda de la historia virreinal de estos territorios se harán perceptibles los intentos, y los fracasos obtenidos en general al ponerlos en práctica, para llevar más al setentrión el limes ahora naciente.

\section{LA VISITA DE RiverA}

En 26 de mayo de 1723 proponía Casafuerte a Su Majestad se dispusiese la visita de los presidios internos, con vistas a remediar los abusos y usurpaciones que en ellos se cometían en detrimento de los soldados de sus guarniciones. El rey aprobó en I9 de febrero de I724 la elección hecha por

2 I Ibid, págs. II 2 -I I 4 .

22 La fecha es insegura. Las reales órdenes de I7 de julio de I 701,28 de septiembre de 1703 y 29 de enero de I7 6 concedieron diversas cantidades para el sostenimiento y nvance de las misiones de California y para la erección de presidios y colonias que asegurasen la ruta del galeón de Manila. Chapman, The founding..., 20-22.

23 La misma paga de Fronteras percibian los soldados de Sinaloá, Janos, Conchos, San Bartolomé, Mapimi, Cerro Gordo, Gallo, Pasaje, Saltillo, Monclova, Cerralbo, Cadereita, Valles, Adaes, Bahía, Béjar, Paso y Santa Fe. 
el virrey en el brigadier Don Pedro de Rivera para esta comisión, y nueve meses clespués - 2 I de noviembre--, en compañía de un escribano y dos amanuenses, partía Rivera de México emprendiendo un largo viaje de más de tres años y medio de duración en que recorrería todas las provincias internas salvo la Baja California. De México se dirigió Rivera a Nayarit. Lttego, atravesando Nueva Vizcaya, a Nuevo México, de aquí a Sonora y Sinaloa, para cruzar seguidamente hasta Coahuila y Texas, y regresar por Nuevo León y San Luis de Potosí a la capital del virreinato. Entre los miembros de la expedición figuraba Don Francisco Alvarez Barreiro, autor de una serie de mapas de las provincias transitadas.

Tanto como de mejorar el régimen interior de los presidios se trataba en esta empresa de conocer la utilidad de dichos puestos militares y de, suprimiendo los que pareciesen menos necesarios, procurar algín desahogo al erario. De todo esto trata el informe rendido por Rivera al término de su comisión y que comprende tanto el diario de su viaje, como el estudio de cada presidio y su posible mejora o supresión, y un proyecto de reglamento que sirviera de norma de gobierno para todos, con un arancel de precios aplicables a los géneros en que los capitanes pagaban a los soldados sus haberes. ${ }^{24}$ De esta manera, Rivera, al tiempo que una fuente de noticias, marca un tipo en la historia de las provincias internas; habiendo recorrido toda la línea defensiva de extremo a extremo, es el primero en considerarla como una unidad y; desde este punto de vista, examina sus fallos y proyecta s11 robustecimiento.

El es, consiguientemente, el primero en señalar como punto débil la ancha hendidura que el Bolsón de Mapiní supone en la continutidad del limes. Por eso propondrá y propugnará desde México la exploración y ocupación del territorio que mediaba entre Nueva Vizcaya y Coahuila, y la fijación del cordón de presidios en una barrera natural: el Río Grande. Esta idea de Rivera ha de poner en movimiento las armas de aquellas dos provincias y, recogida por el marqués de Rubí, constituirá, por otra parte, uno de los ideales jamás totalmente logrado del período posterior.

En orden a una ninoración de los gastos que erogaban los presidios,

24 Diario y derrotero de lo caminado, visto y observado en la visita que hiso a los presidios de la Nueza España Septentrional el Brigadiar Don Pedro de Rivera. Introducción y notas por
Vito Alessio-Robles. Archivo. Históricosidios Vito Alessio-Robles. Archivo Histórico Militar Mexicane, núm 2, México, 1946. Diario y derro-
tero de lo camtinado, visto y observado en el discurso rincias Internas de Nueva España, que de orden de S. M. executó Don Peral de presidios en las Prode los Reales Ejorcitos. I724-1726. Introducción por el Lic, Guillermo Porras. Tera, Brigadier por Guillermo Porras Muñoz. México, 1945. Hemos por el Lic. Guillermo Porras. Textos y notas de Alessio Robles, que incluye el "Informe y Proyecto", págs. las citas del texto sobre la edición nas 199-234, ausentes en la de Porras Muñoz, que, en cambio, ofrece muy buenemento", páginotas $y$ apéndices. Ta documentación correspondiente a esta visita, ofrece muy buena introducción, 
Rivera aconseja y obtiene la supresión de las escuadras de Durango y Saltillo y los presidios de la Villa de Valles y Nuestra Señora de Texas, y reduce las guarniciones de Nayarit, Santa Fe de Nuevo México y Sinaloa, proponiendo además en muchos casos otras reducciones tanto de efectivos como de sueldos. En cambio, frente a la tónica general de igualdad de haberes de todos los hombres de un presidio, él hace ver la conveniencia de otorgar paga más crecida al capitán y de señalar a los tenientes, alféreces y sargentos alguna ventaja, al tiempo que limita a dos mil pesos anuales la consignación de "paz y guerra" de seis mil que hasta entonces habían gozado los gobernadores de Nueva Vizcaya. Sus disposiciones dieron por resultado que los presidios no costasen más que 352.540 pesos, y según sus proyectos aún podía reducirse este gasto a 283.930 , lo que daría un ahorro sobre el costo anterior a la visita de 160.953 pesos. ${ }^{25}$

Veamos otras reformas introducidas o propuestas por él en la frontera. De la mayor importancia es la que llevó a efecto en Texas donde, considerando nula la defensa que ante un eventual ataque francés podían realizar los establecimientos y presidios orientales, y que en cambio favorecían extraordinariamente en todo momento el contrabando con Luisiana, resolvió el repliegue de todos ellos al distrito de Béjar, quedando sólo el presidio de Adais, con su guarnición mermada de 100 a 60 hombres, habiéndose propuesto la supresión del de Nuestra Señora de los Dolores de Texas. ${ }^{26}$ Las misiones, visto su escaso éxito, viniẹron a situarse en el río San Antonio.

En Sinaloa, ${ }^{27}$ por el contrario, tras haber consultado ser conveniente la extinción de aquel presidio y su traslado a Sonora, a Pitic, se retractó al verificar su informe por considerarlo útil para precaver una posible incursión de corsarios, y además, para aquella fecha, ya la sublevación de los pimas bajos y seris de I 725 había sido dominada por el alcalde mayor de Sonora y el mismo gobernador de Sinaloa, que penetró en el Cerro Prieto. Donde Rivera impuso su criterio fue en la constitución de una gobernación independiente de Nueva Vizcaya con todas las tierras entre la Sierra Madre

25 Mapa que hace patentes los presidios de las provincias internas, lo que cada una dista de México, la latibud y longitud en que se hallan situados, cl numero de oficiales y soldados que los guarnecen, los sueldos que unos y otros gozaban antes de que se visitasen, cstado en que quedaron después de la visita, y el que por última disposición de Su Excelencia convendrá sa. pongan, incluyéndose los efectos de Paz y Guerra que se consumian en la Vizcaya y el estado a que se redujeron aquellos gastos. México, I i de diciembre de 1728. A. G. I., Guadalajara, I 44. Puede consultarse reproducido en León, Nicolás: Biblioteca mexicana del XVIII, 7 vols. M'éxico I 903, vol. 7, págs. I I2-I I3. Utiliza los datos del Mapa, sin citarlo, Mota Padilla, D. Matías: Historia de la Conquista de la Provincia de la Nueva Galicia, escrita por el Lic. en I742. Pub. por la Soc. Mex, de Geog. y Estadística. México, I870. Caps. XXXV y XCVI. Edición de José Ireneo González, Guadalajara I.9zo.

26 Diario, I09-III y I62-г7o,

27 Ibídem, I $57-$ - 62 . 
y el Pacífico, comprensiva de las cinco provincias de Sonora, Ostimuri, Sinaioa, Culiacán y Chiametla.

En el Bolsón de Mapimí halla Rivera que ya sólo se sienten algunas hostiliclades en su boca septentrional, en las proximidades de Chihuahua. Precisamente a su llegada a esta villa se tuvo noticia de un movimiento entre los indios de la Junta de los Ríos. En cambio, el mismo visitador, intervendrá en el asentamiento de la niayor parte de los indios sumas en los pueblos del distrito del Paso. Movido por aquella impresión, Rivera acorta los efectivos de los presidios de cordillera y aun propone desplazar hacia el norte el del Valle de San Bartolomé, a Atotonilco, entre los ríos Florido y del Parral. Por otra parte, Rivera sacó soldados de las distintas guarniciones con el objeto de formar una nueva compañía que constituiría el presidio del Sacramento, que proyecta situar en la Junta de los Ríos. Sin embargo, distintas causas motivaron que se desistiera de la empresa. ${ }^{28}$

\section{El reglanento de Rivera}

E1 reglamento para todos los presidios de las provincias internas promulgado por el marqués de Casafuerte en 22 de mayo de i 729 fue elaborado

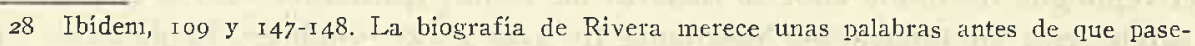
mos a exponer su Reglamento. Don Pedro de Rivera hacía nacido en Antequera (Málaga) y habiéndose alistado como soldado raso en el ejército, sirvió en Europa y América, en Flandes, Extre11 adura $y$ las flotas, y ascendió hasta el empleo de maestre de campo, que desempeñaba en Tlaxcala en I7I0. Obtuvo entonces el gobierno de esta provincia y el grado de coronel de infantería, y en I7I el mando del castillo de Ulúa, cuando llevaba ya treinta y cuatro años dedicado al ejercicio de las armas. En iziz, habiendo muerto en Veracruz el genẹral de la Armada de Barlovento Don Andrés de Arriola, expidió el virrey ductue de Linares título de tal a Rivera en 22 de noviembre, y así regresó a España en I713. El rey le concedió sueldo de 200 ducado,s mensuales por este cervicio, y lo nombró almirante de la próxima flota para que se restituyese a Veracruz; pero los navíos que debían componer la flota de r 73 fueron destinados a la expedición de Barcelona, en la que Rivera actuó como isegundo cabo de ellos (Reales Cédulas de ro de octubre de I7r3 y 8 de agosto de I7r5. A. G. I., México, 24 8). De nuevo en América, debió reasumir el mando de Tlaxcala en r7ı6, hasta que el virrey marqués de Valero lo nombró, en $\mathbf{r}_{4}$ de enero de I7I9, gobernador de las armas de Yucatán, y como tal debió dominar una revuelta en Tabasco y proceder a la expulsión de unos corsarios ingleses en la isla del Carmen, y luego continuó en el gobierno de Tlaxcala hasta ser designado visitador de los presidios internos, con grado de brigadier, a que lo ascendió el propio virrey Casafuerte para estimularlo en el desempeño de su comisión. El éxito de la visita valió a Rivera el grado de mariscal en I73 I, siendo ya gobernador de Veracruz y castellano de Ulúa. Al año siguiente era promovido al cargo de gobernador y capitán general de Guatemala y presidente de aquella audiencia. En Guatemala publicó, en i736, su Diario de la visita a las provincias fronterizas, $y$ alli permaneció hasta $x 743$, en que, al retirarse, le fue concedida una pensión de 3.000 escudos anuales en cajas de Ḿéxico, en atención a sus largos méritos (Real Cédula de 15 de septiembre de 1743 . Tbíd.). Murió en México el $24^{\circ}$ de noviembre de ${ }^{1744}$. (Vid las introducciones, notas y apéndices de Porras y Alessio Robles al "Diario" de Rivera, y Rodríguez del Valle, Mariana, El Castillo de San Felipe del Golfo Dulce. Historia de las fortificaciones de Guatomala en la Edad Moderna. Sevilla, 1960, págs. 54-65).

Don Francisco Alvarez Barreiro, "ingeniero militar en jefe del Nuevo Reino de Filipinas, provincia de Texas", habia tomado parte en la entrada de Martín de Alarcón a este país en 1718. En ${ }^{1727}$ se le ascendio al grado de teniente coronel de infanteria con 125 pesos mensuales (Real Cédula de 23 de noviembre de 1727. A. G. I., México, 2424). 
sobre la base de la experiencia directa que de los presidios había obtenido el brigadier Rivera en su visita y, como expresa el proemio, con el asesoramiento del auditor general de guerra Don Juan de Oliván y Rebolledo. Su primera providencia, que se halla inserta en el mismo prefacio, consiste en disponer que los tenientes gocen siempre treinta pesos, los alféreces veinte y los sargentos quince más que los simples soldados.

Los ciento noventa y seis artículos que el reglamento comprende tratan de la organización de los presidios, de los que se extinguen aquellos que Rivera mostró innecesarios, y de su gobierno, de la vigilancia de los indios sometidos, de las campañas contra los enemigos, y de los precios a que se deben vender los géneros a los soldados en los presidios.

Resérvase el virrey el nombramiento de todos los capitanes, incluso de milicias provinciales, de sargentos mayores y de tenientes de capitán general. Para los capitanes de presidio pueden los gobernadores proponer una terna y el designado por el virrey deberá obtener confirmación de Su Majestad. ${ }^{29}$

Considerando la importancia de que los gobernadores de las provincias estén siempre a punto para poder atender a las urgencias de la guerra, les fija como capitales donde siempre se deberían hallar, al de Nueva Vizcaya, Parral; al de Nuevo México, Santa Fe; al de Nuevo León, Monterrey; y al de Texas, el presidio de Adays. 30

En cambio, a los soldados encarga usen la lanza tanto como la espada ancha y la escopeta, y que se vistan todos uniformemente, así en el color como en el traje, sin variar del que habían acostumbrado. Los diez caballos aue antes tenía cada hombre ahora quedan reducidos a seis y una mula, para cargar el equipaje; en Nayarit sólo se necesitan tres caballos. ${ }^{3 \mathrm{I}}$

El presidio del Pasaje quedaba obligado a la visita mensual de la Tepehuana, por Durango, Sauceda, San Juan del Río, y Papasquiaro, y la escolta de convoyes de Durango a Sombrerete. A principios de cada mes quince hombres del Pasaje escoltarían a los pasajeros y recuas hasta el Gallo; otros quince de éste, hasta Cerro Gordo; el mismo número de soldados de este presidio, hasta el río Florido o Valle de San Bartolomé, verificándose otro tanto al regreso. Sistema semejante se practicaría entre El Paso y Santa $\mathrm{Fe}$ con los cordones entrantes o salientes de Nuevo México, y lo mismo en Janos para las recuas que pasaban a Sonora, hasta el Río de Santa María Basaraca. ${ }^{32}$

Por el rumbo de Texas, diez soldados de Monclova darían guardia al

29 "Reglamento", arts. 26-32.

30 Art. 49.

31 Arts. 63-65.

32 Arts. I $4 I-I 45$. 
convoy que trimestralmente pasaba de Saltillo a aquella provincia, hasta Río Grande; aquí se proporcionaría otra escolta hasta Béjar, y nuevamente aquí hasta Adais. 33

El capitán del Paso protegería la población del Carrizal, que estaba a sus principios; el de Janos, el valle de Buenaventura, y el de Fronteras, el de Opodepe, procurando al mismo tiempo mantener en alianza a los indios amigos de la Pimería Alta. P.or su parte, el capitán de Sinaloa enviaría anualmente una escuadra hasta Cerro Prieto y Pitquín, y otra a la región de Chínipas. 34

El presidio del Gallo y el del Pasaje reconocerían anualmente la Tepehuana, y el de Conchos, la Tarahumara. 35 De esta manera se procuraría la más perfecta vigilancia de los pueblos de la sierra Madre Occidental.

El presidio de Cerralbo vigilaría la frontera oriental mientras los grandes rebaños de ganado menor pastaban en Nuevo León, y las guarniciones de Adais y San Antonio evitarían cualquier internación de extranjeros por la
costa texana. 36

A los presidios de Janos, Paso y Corodeguachi se confía la represión de los apaches, gilas, mezcaleros, salineros y natajes; a los de Sonora y Sinaloa, la pacificación de seris y tepocas; a los de la cordillera, la extinción de cocoyomes, acoclames, tripas blancas, terocodames, cicimbres, chizos y gavilanes, apresándolos "con astucia, halago o fuerza - sin matarlos-" y remitiéndolos a México para que se aplicasen a lo dispuesto por Su Ma-
jestad. 37

Jamás, bajo ningún pretexto, podrían los oficiales de los presidios repartir los prisioneros, y en todo momento se concedería la paz a cualquier indio que la solicitase. Los cautivos serían siempre enviados a México "para darles el destino conveniente a su quietud y la de las provincias, respecto a que el buen trato que hasta aquí se les ha dado sólo ha servido para que, abusando de él, continúen sus atrevimientos". ${ }^{38}$.

Este reglamento general expedido por Casafuerte sustituyó al particular que en cada presidio había dejado establecido Rivera tomando como base para formarlo el de La Habana, según se le había encargado.

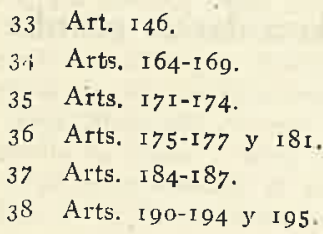




\section{Consecuencias de la visita de Rivera}

Dieciocho años después de la puesta en vigor del reglamento del virrey Casafuerte trataba de hacer ver en un informe el capitán de Conchos, Berroterán, los fallos que aquél contenía y su fracaso en la política de restricción de gastos. ${ }^{39}$ Es evidente, por ejemplo, que nada supuso el ahorro obtenido en reducción de guarniciones y minoración de gastos a la par que se erigían riuevos presidios en Sonora y Texas y se hacían campañas contra los rebeldes de Sinaloa. Sin contar los presidios que por todas partes se pedían en el Gila, en el Moqui, etc.

Por otra parte, la reducción del número de caballos que se inpuso a las tropas no podía redundar en bien del servicio, en opinión del mismo capitán. Y la limitación a sólo dos mil pesos del fondo de "paz y guerra" que estaba a disposición del gobernador era una traba para cualquier proyecto de campaña. Pero, sobre todo, la debilitación numérica de las guarniciones trajo como consecuencia la imposibilidad de cumplir con las extensas obligaciones anotadas en el reglamento: escoltas de pasajeros, guarniciones del cuartel y la caballada, visitas de pueblos de indios, etc.

Como consecuencia del desuso en que cayeron las visitas de la Tarahumara, nuchos indios andaban fugitivos de sus pueblos, viviendo como gentiles, por los peñoles, sierras y barrancos. Pero con dos mil pesos el gobernador no podía atender a los gastos que para su sujeción a las misiones era preciso efectuar en equipar y abastecer destacamentos que fuesen a sacarlos de las asperezas a que se habían retirado.

En los presidios de la cordillera no había más que ciento veintinueve soldados, con lo que, atendidas las necesidades de guardias y escoltas, no quedaba número suficiente para hacer campaña alguna. Aparte que para esta fecha no quedaba en el Bolsón enemigo contra quién hacerla. Sin embargo, a juicio de Berroterán, los presidiós tenían una misión que cumplir en la vigilancia de los indios y en precaver una posible hostilidad por parte de los cuatrocientos y más apaches que se habían últimamente internado en el Bolsón, entre Nueva Vizcaya y Coahuila.

Precisamente aquel año de 1748 acababan de ocurrir dieciséis o dieciocho muertes en la región del río Nasas, sin que hasta la fecha se hubiera averiguado si los ejecutores habían sido estos apaches o los siete individuos únicos

39 "Copia del informe que en el año i 748 hizo al virrey de Nueva España conde de Revillagigedo el capitán Don José de Berroterán sobre los principales sucesos ocurridos en la Nueva Vizcaya, $y$ dando noticias de las ca'mpañas que ejecutó contra los indios enemigos". México, I7 de abril de 1748. En ochenta y cuatro artículos. A. G. I., Guadalajara, 513. Este informe se reproduce íntegro en "Documentos para la historia de México". 2." serie, tomo I, págs. i6I-224. 
que se habían escapado de los antiguos pobladores de aquel desierto, o bien algunos de los indios fugitivos de los pueblos de misión.

Berroterán, pues, nos pinta un cuadro en que tras las desgracias y problemas que se esfuerza en presentar como irremediables se nos hacen patentes los dieciocho benignos años de paz que había vivido Nueva Vizcaya desde la visita de Rivera. En realidad, aquella paz no se había visto turbada desde el fin de la última sublevación de la Tarahumara Alta y tenía ya tan larga existencia como el siglo. Los leves incidentes de la Junta de los Ríos, tal vez por la escasa importancia que se les otorgó, no inquietaron la provincia. Los acontecimientos de Sonora - a los que nos referiremos más adelante- tampoco habían alterado su situación, mucho menos desde que Sonora era gobierno independiente. Por cierto que las campañas del Bolsón, en el primer cuarto del siglo XVIII, habían tenido mayor entidad : pero — excepción hecha de la desgracia de Mapimí- fueron netamente victoriosas y condujeron a la feliz conciencia de haber sido eliminado el peligro oriental.

El mismo Berroterán había tomado parte muy principal en estas expediciones, y a él correspondió presenciar la presentación en Conchos en I 740 de los últimos indios que quedaban por enemigos, y pasaron inmediatamente a Sinaloa, como auxiliares para la campaña que allí se verificaba. Tres indias $y$ dos indios cicimbres fueron los últimos en mostrarse de paz en aquel presidio, y el propio Berroterán dio testimonio de ello.

Dos son los peligros que están latentes en las palabras del capitán de Conchos, aunque él mismo no podía suponer la trascendencia que en pocos años habían de adquirir: son los tarahumaras huídos de la Sierra y los apaches. Estos procuraba Berroterán tenerlos de paz pactando con ellos de modo que, de los dos caudillos que los del Bolsón en aquel momento tenían, Pascual y el Ligero, el capitán se había hecho compadre de aquél. Pero ya antes de desaparecer del cuadro histórico se verá obligado Berroterán a figurar en la primera campaña, dirigida contra ellos en I749 por orden del gobernador Puerta y Barrera.

El año anterior de 174.8 , en el que Berroterán había redactado su inLorme, no tardaría en ser considerado como la fecha inicial de una era de infelicidad para Nueva Vizcaya y, en general, para todas las provincias internas.

\section{La BúSQUeda DEL Río Grande}

"Siendo la mejor tierra la que se halla despoblada de la Vizcaya por el temor de los enemigos, si las armas continuasen en sus correrías pudieran encontrarse algunos parajes apropósito para poblarlos, y suponiendo que no 
sucediera así, siempre será conveniente se transite aquella tierra para tenerla limpia de enemigos que puedan insultarla".

$\mathrm{He}$ aquí el pensamiento de Rivera $4^{\circ}$ sobre el espacio desierto que mediaba entre Nueva Vizcaya y Coahuila. Idea que pretendía contradecir todas las anteriores descripciones del Bolsón, de las que la de Don Lope de Sierra Osorio, sesenta años atrás, no es la menos expresiva. Pero, suponiendo que no fuera cual él la imaginaba — no sabemos en qué fundaría el visitador su juicio-, Rivera apuntaba la idea de transitarlo al menos para evitar el asen:amiento en él de algunos posibles enemigos.

E1 brigadier había llegado a la capital del virreinato el 2 I de junio de ${ }^{2} 728$ y sus planes sobre aquel punto concreto de la frontera debían de ser claros y convincentes cuando, a poco, partían las órdenes del marqués de Casafuerte al gobernador de Nueva Vizcaya y no más tarde del 27 de octubre de aquel año se internaba una expedición en el desierto. El comandante de aquel destacamento de cincuenta y seis presidiales y cuarenta y seis indios auxiliares no era otro que el capitán de San Francisco de Conchos Don José de Berroterán, que tardó un mes justo en volver a su base. ${ }^{1}$ I En este tiempo se había reconocido el territorio de Mapimí a Coahuila, pero Rivera insistió ante el virrey la necesidad de reconocer el Río Grande, y Casafuerte decretó prosiguiese la exploración. ${ }^{42}$

Para entonçes, Berroterán estaba a mitad de camino de su segunda - campaña de más de cuatro meses - I3 de enero a 20 de mayo de I729- que je condujo desde Conchos a Mapimí, Monclova y San Juan Bautista. De aquí remontó el Río Grande, sin conseguir alcanzar la Junta porque por falta de bastimentos y por la aspereza del terreno hubo de desistir, de manera que desde el punto más septentrional de la gran curva del río se dirigió al suroeste en demanda de su presidio. Tratábase de descubrir el lugar apropiado para establecer un presidio, aquel del Sacramento que Rivera no había llegado a erigir, entre la Junta y San Juan Bautista. Pero Berroterán no logró descubrir un lugar apropiado en las inextricables serranías que atraviesa el río y le obligan a describir enorme rodeo. Los esfuerzos y penalidades del capitán de Conchos, sin embargo, no disculparon a los ojos de Rivera y del auditor Oliván y Rebolledo su falta de éxito. 43

40 Informe de Rivera, México 30 de marzo de I729. A. G. I., Guadalajara, 5r3. La idea le había sido sugerida por el auditor Oliván y Rebolledo antes de la visita. Castañeda, II, 328-329.

4 I El diario de esta expedición de Berroterán, en A. G. I., Guadalajara, 5I3.

42 El informe de Rivera es el citado en nota 35 . El decreto del virrey, ibídem.

43 Diario de la segunda campaña de Berroterán, firmado en Conchos el 22 de mayo de i 729. Dictamen del brigadier D. Pedro de Rivera, M'éxico 9 de septiembre de I729. Dictamen del auditor D. Juan de Oliván y Rebolledo, México i 2 de mayo de i730. A. G. I., Guadalajara, 513. Vito Alessio Robles estudia el itinerario de esta expedición en Coahuila y Texas en la época colonial, México D. F., 1938, págs. 479-487. 
Berroterán, en su principal informe de I748 expone 44 que el Bolsón "no puede ser habitable ni poblado de racional cristiano, porque el que hubiese y se determinase a ello ha de ser separándose del pasto espiritual, pues no es dable comunicarles este bien, respecto de ser lo poblable sus aguajes, y éstos hallarse en distancias los unos de los otros de veinte a veinticinco y treinta leguas, y tan cortos que apenas se puede mantener un vecino en cada uno de ellos, con el corto chinchorro de ciento cincuenta cabezas de ganado mayor y caballada, y los más internados en las serranías, variándose sus situaciones por distintos rumbos". Sólo en Acatita la Grande y las Charquerías de lluvia podría mantenerse una compañía de cincuenta soldados en la época de éstas. Lo poblable del seno era la zona desde la Sierra de San Marcos de las Cuatro Ciénagas, hasta el río Grande, al oriente, en sus intervalos a las de Nadadores y Santa Rosa. Y de aquí para el poniente todo era desierio y ninguna sierra tenía nominación.

Rivera había hecho presente la utilidad de que las armas de Nueva Vizcaya explorasen toda la región, 'de modo que los bárbaros se sintiesen perseguidos allí donde antes se creían seguros. Por otra parte, le parecía vergonzoso "que habiendo armas en Nueva Vizcaya se hubiese ignorado en donde estaba Coahuila y el presidio de Río Grancle”. Ahora podrán tener comunicación las dos provincias, aunque, dice, a sus armas no los ha parecido apropósito, "porque extendiéndose los dominios se les aumentan los trabajos". 45 Es bastante atrevida la aseveración del ex visitador y mucho más * fácil de creer que, realmente, las dificultades para ocupar el Bolsón y la línea de Río Grande eran casi insuperables. Por otra parte, la experiencia del largo período de tanteo de estas posibilidades, que Rivera no había hecho más que abrir, vendría a demostrar esto mismo. $Y$, de momento, el fracaso de Berroterán condujo el intento a un punto muerto. El presidio del Sacramento seguía sin establecerse cuando en I736 el arzobispo-virrey Vizarrón ordenó remprender las exploraciones desde Coahuila. Don Blas de la Garza Falcón y Don José de Ecay Muzquiz, gobernador de la provincia y capitán de San Juan Bautista respectivamente, tras un corto sondeo del terreno recomendaron como apropiado asentamiento del presidio el río de San Diego, afluente por la derecha del río Grande, y así lo dispuso Vizarrón en I 3 de febrero de $\mathbf{7 3 7}$, nombrando capitán al hijo de Don Blas, Don Miguel de la Garza

44 Vid. nota 39.

45 Informe de 9 de septiembre de r729. El del auditor al virrey dice que la expedición se dirigia "a conocer el río del Norte, unir Vizcaya con Coahuila y tener noticias del lugar donde se funde el presidio de Sacramento, en Coahuila y no en Vizcaya, según propuso Rivera, y a otros fines reservados de V. E." México I2 de mayo de 1730. Como consecuencia de ambos dictámenes se expidió en I7 de junio siguiente una orden al gobernador de Nueva Vizcaya en términos poco favorables a Berroterán. A. G. I., Guadalajara, 513. 


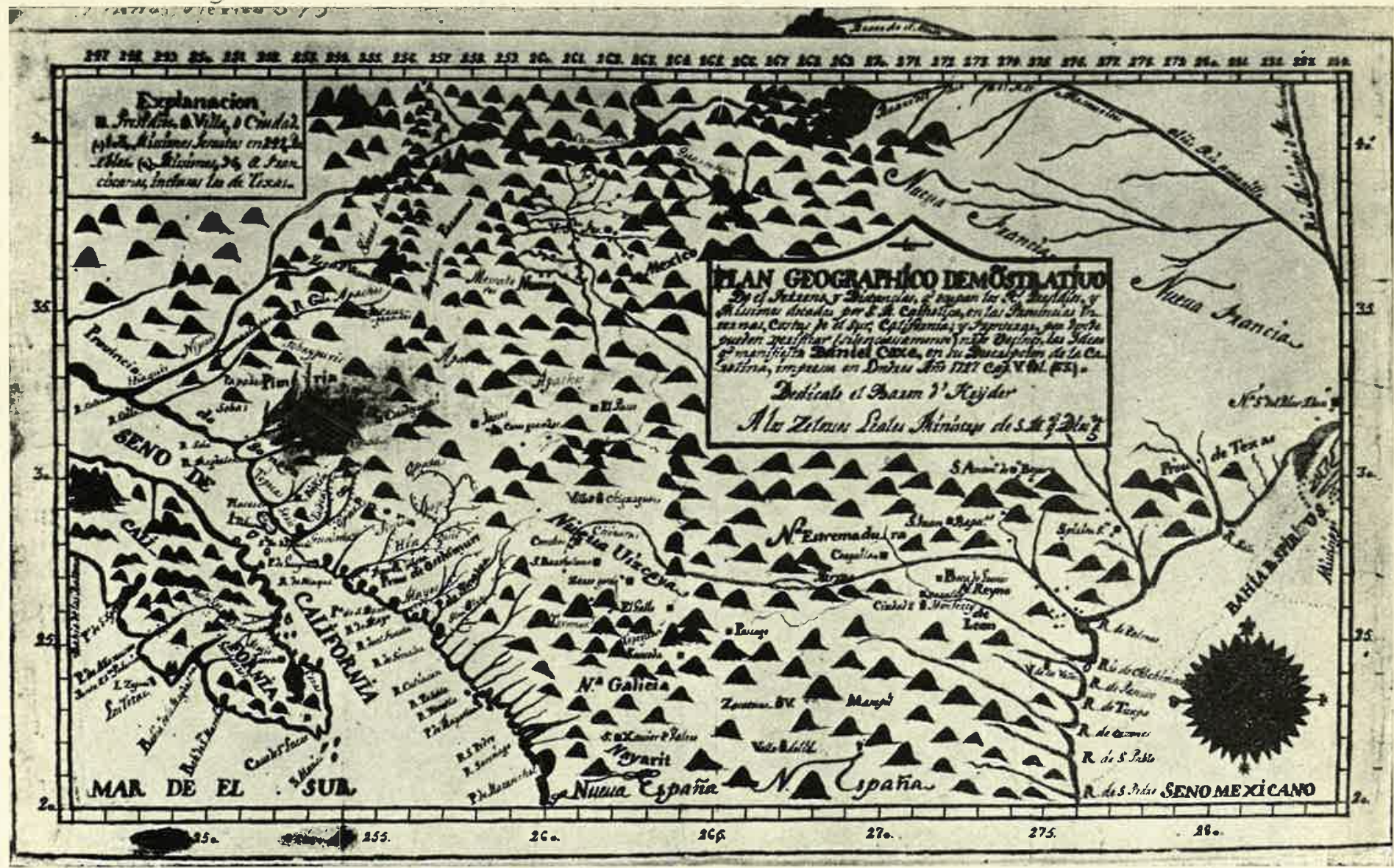

48. El norle de Nueva España, por el barón de Heyder. i.1730? 


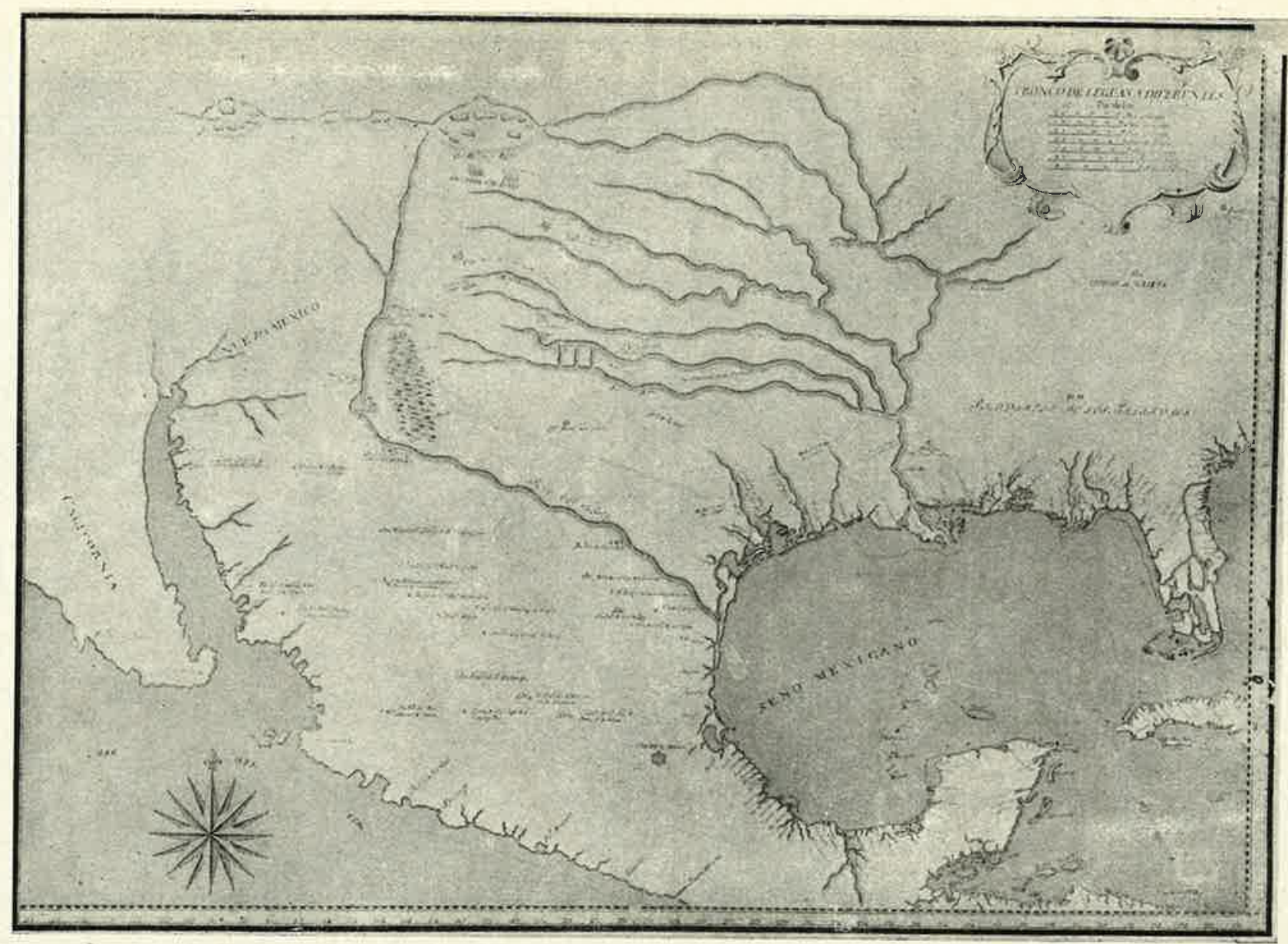

49. Nueva Españat y el Misistui ; 1730 ? 


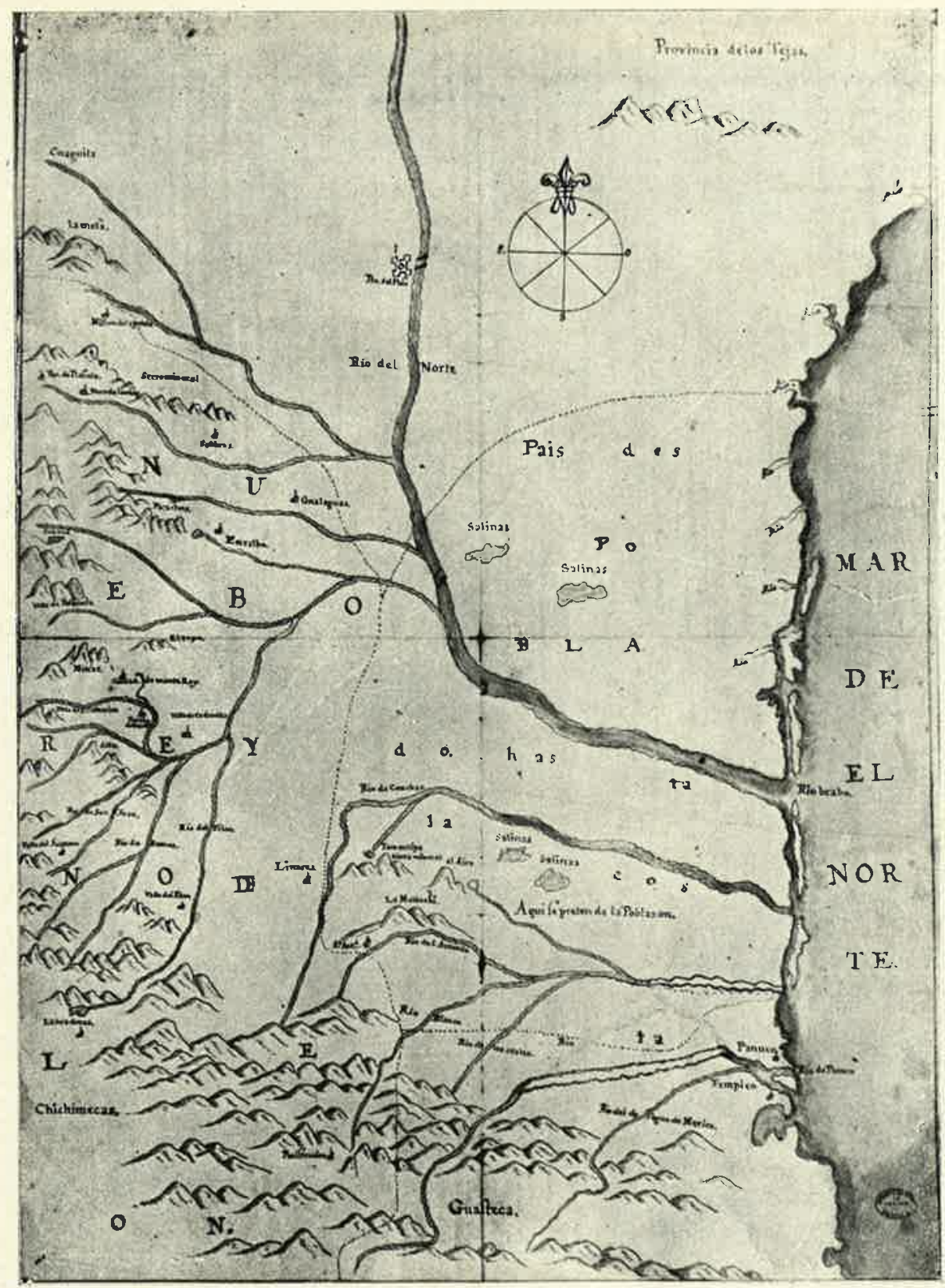

50. Nuevo León y la Costa del Seno Mexicano, por Jáuregui. 1736. 


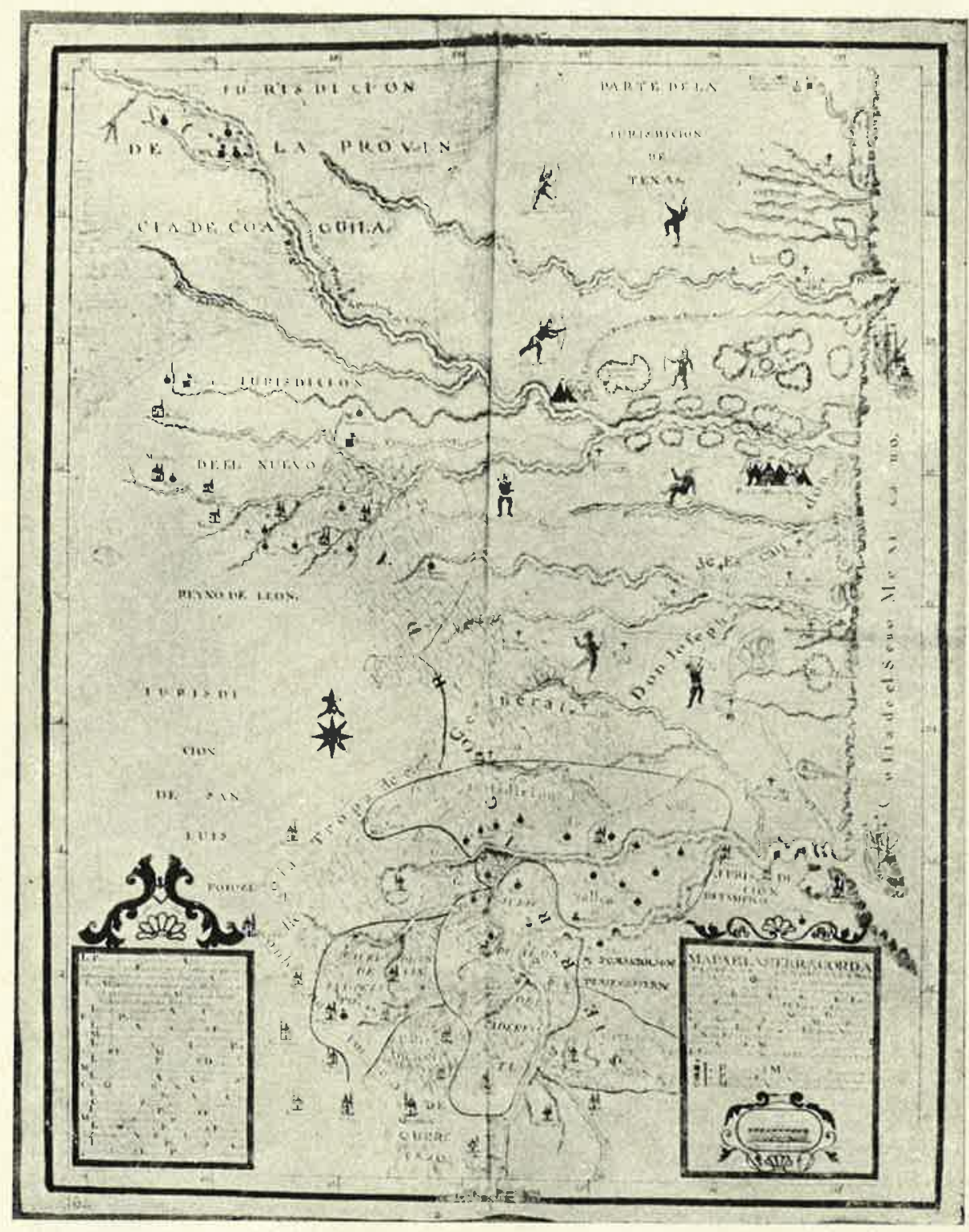

51. Sierra Gorda y la Costa del Seno Mexicano, por Escandón. 1744. 


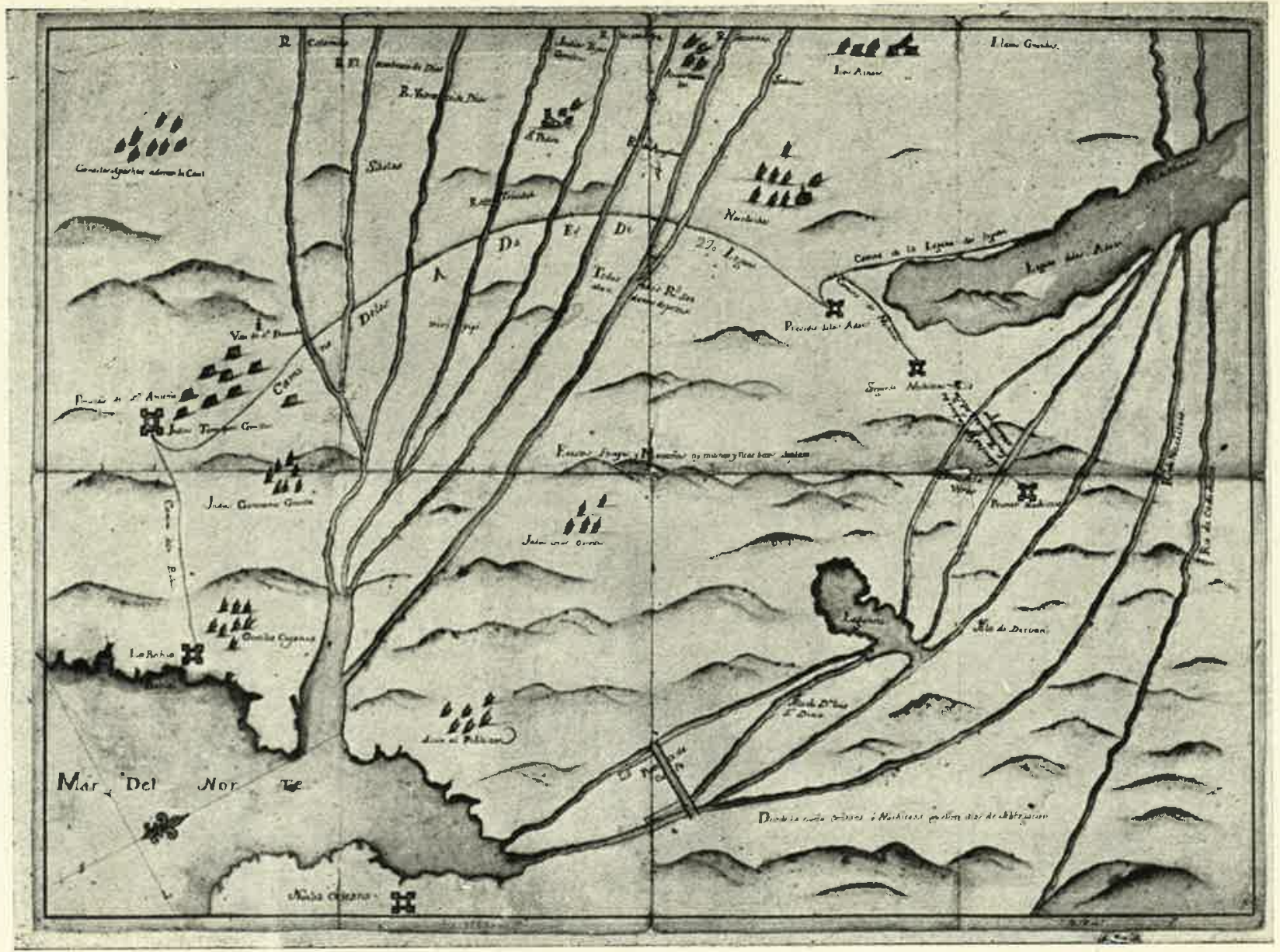

52. Texas hacia 1750 . 


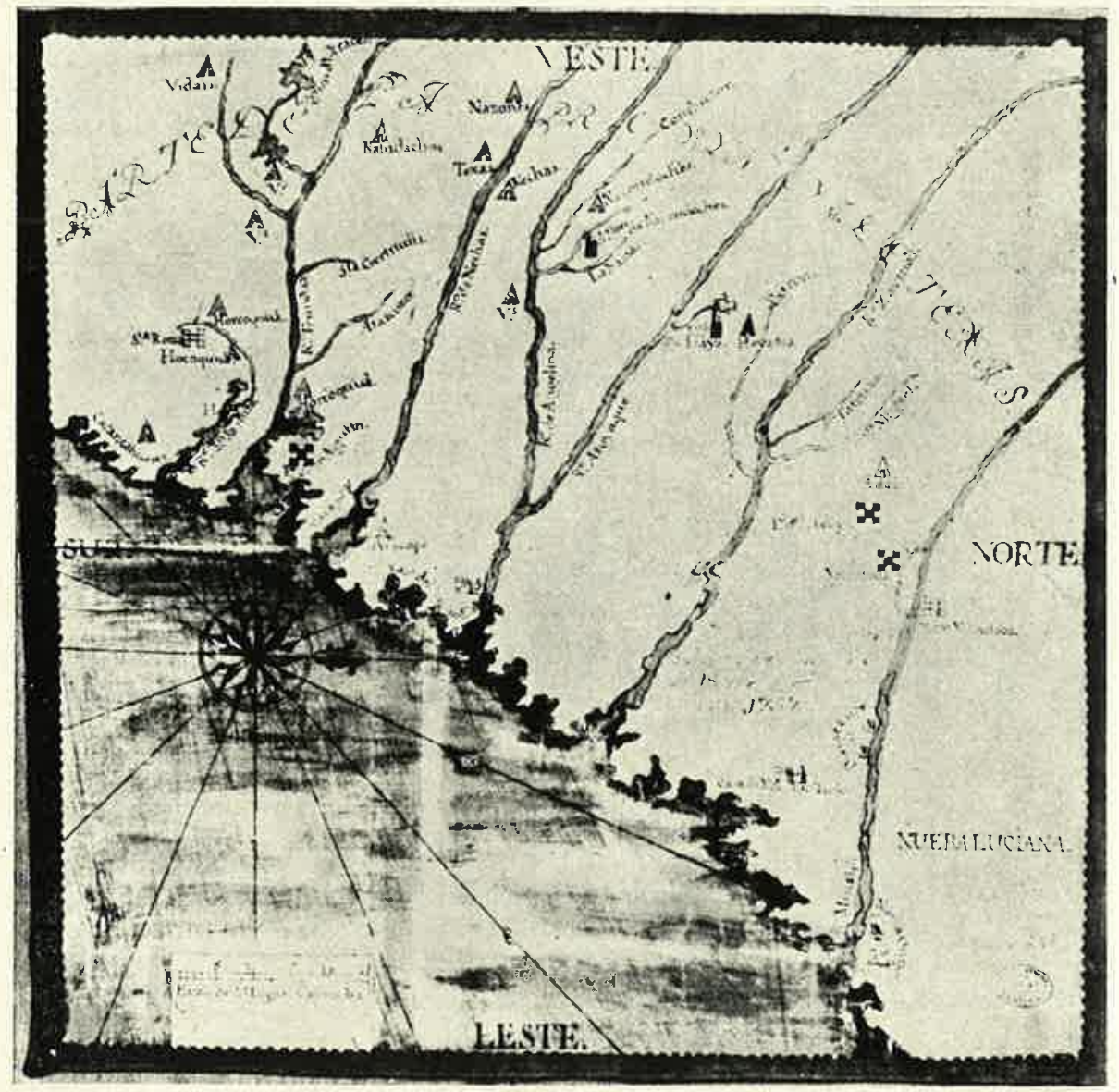

53. Texas oriental. 1757. 


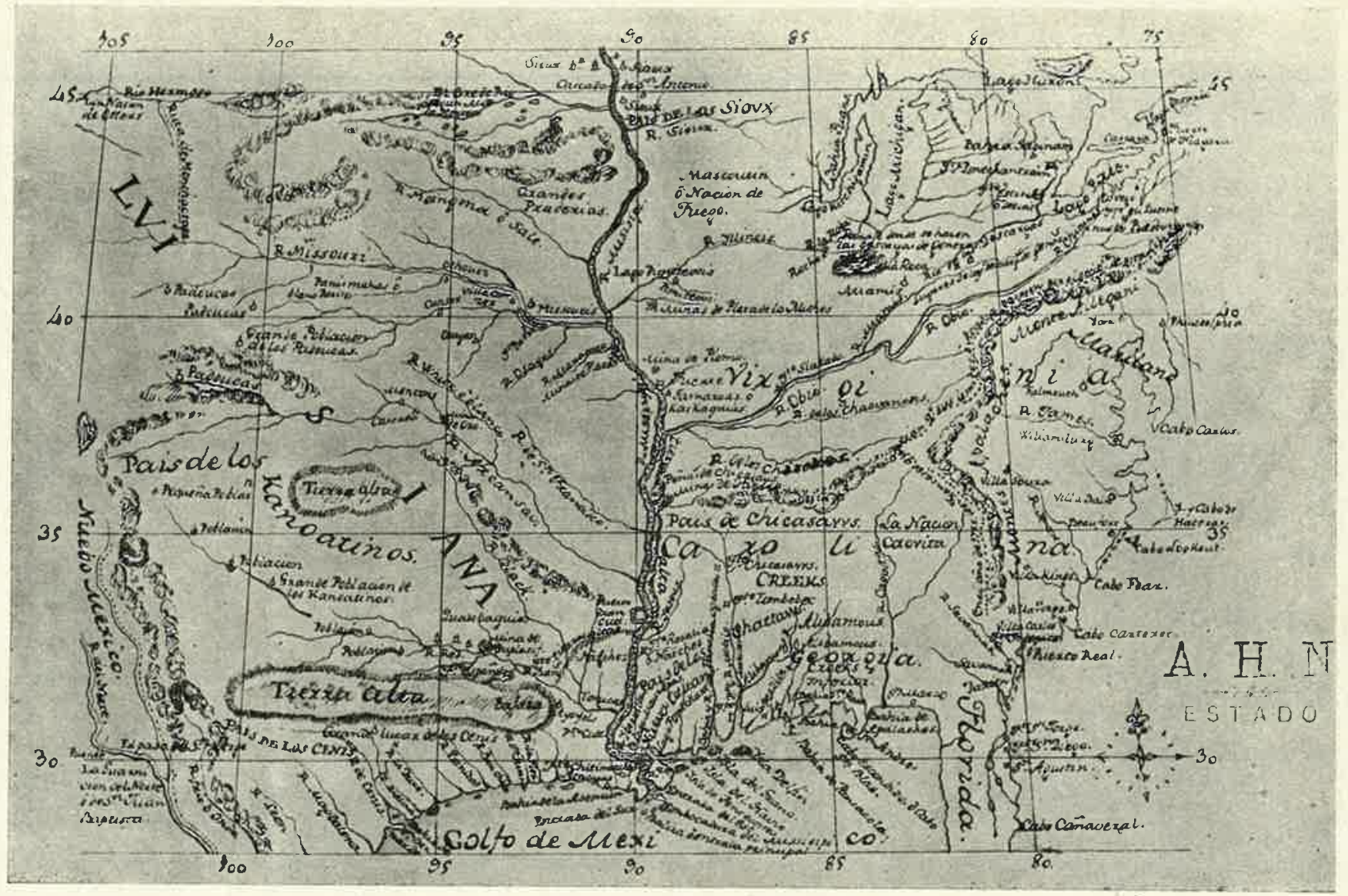

54. Luisiana y las colonias inglesas. ¿1763? 


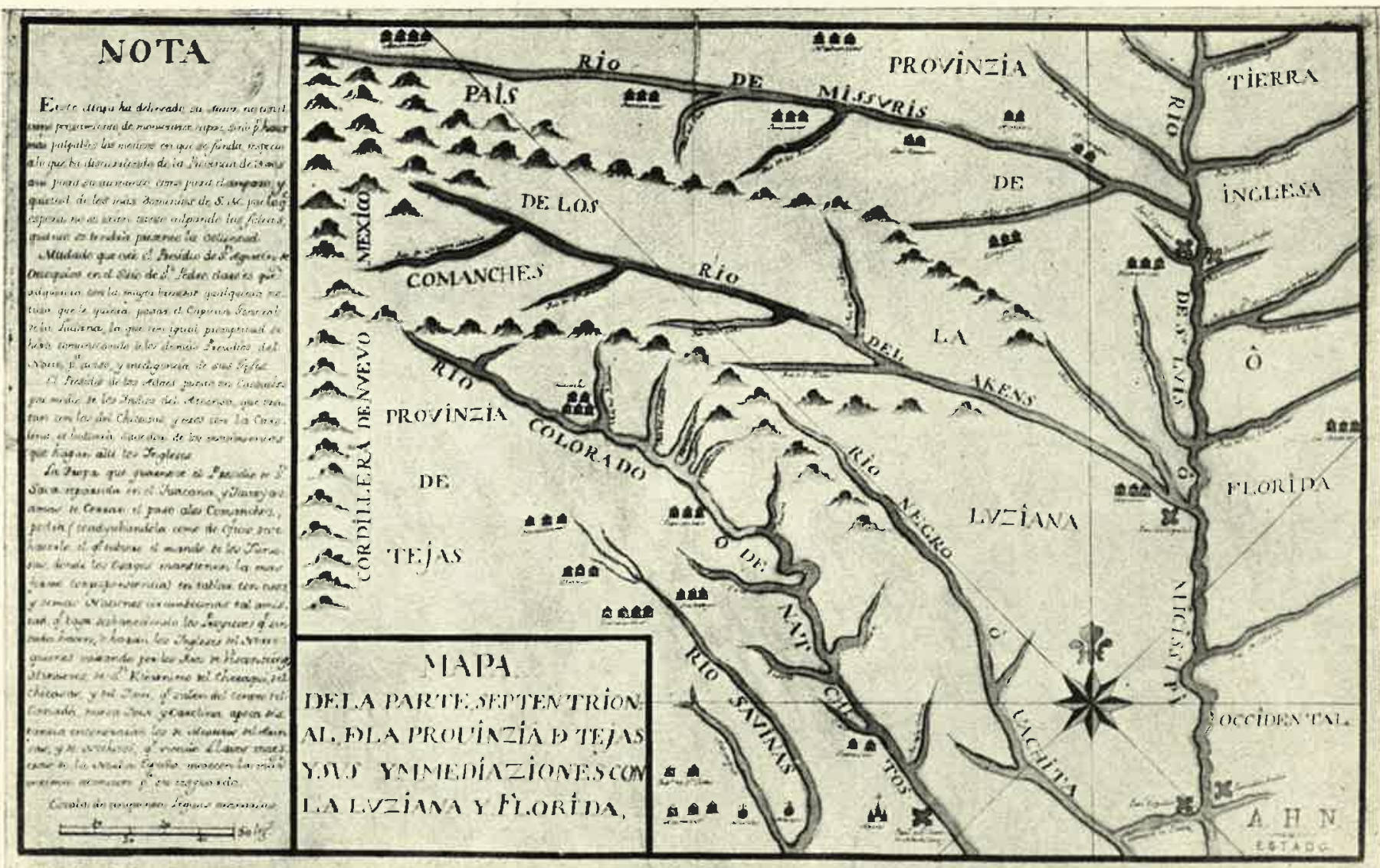

55. Matpa de la parte eptentrional de Traxis. ;1763? 
Falcón. Sólo dos años después se traslaba el presidio al valle de Santa Rosa, cincuenta leguas al este, por haberse hallado incómora y. poco eficaz la primitiva posición. 46

No será hasta fines de 1747 cuando se logre establecer contacto. directo entre Coahuila y las misiones de la Junta de los Ríos, pero esto será marchando directamente desde Monclova a aquel lugar sin seguir en principio el curso del río Grande que Rábago y Terán, gobernador entonces de Coahuila y jefe de la expedición, encontrará sólo a medio camino, de manera que para entonces aún quedaba inexplorada la gran curva que el río describe en el extremo norte del Bolsón. 47 Por consiguiente, Rábago había cumplicio el objetivo del auditor marqués de Altamira, promotor de la empresa, en cuanto que había atravesado la boca del desierto, pero no había hallado lugares apropiados para establecimientos militares que impidiesen a los bárbaros la penetración en aquel espacio, ni menos aún había definido el curso del Río Grande, la pretendida frontera natural cuyo recorrido accidentaban sierras intransitables que impedían su reconocimiento.

El I 3 de enero de I 748, tres meses antes de la redacción del informe de Berroterán, expedía el gobernador de Coahuila el suyo, correspondiente a este itinerario por él seguido, cuya importancia geográfica aún sigue en pie, puesto que los territorios atravesados todavía hay no han sido explorados a fondo.

En la misma tendencia de procurar el cerramiento de la boca del Bolsón hay que consignar la fundación de la villa de San Fernando de Austria el 1. ${ }^{\circ}$ de febrero de 1753 por el mismo Rábago y Terán, obedeciendo un decreto re Revillagigedo. Nutrieron la pequeña nueva población a orillas del río Escondido antiguos vecinos de San Juan Bautista de Río Grande. 48

\section{SONORA y CALifornia}

L.a sangrienta hostilidad de los seris en 1725 , de que nos habla Rivera, no fue más que el principio de una larga serie de ataques $y$ sublevaciones que van a durar más de cuarenta años. Aquella primera, siendo de los seris y pimas bajos, nos los mostró refugiados en el Cerro Prieto, de donde los desalojó el gobernador de Sinaloa, después que habían asesinado a veintidós personas en el rea! de Opodepe y saqueado la iglesia de Tecoripa. 49 Desde

46 Alessio Robles, Coahuila y Te.ros, 543-55I.

47 La expedición de Rábago y Terán, ibid. pázs. 559-568. El diario de ro de noviembre de

I 747 a 21 de enero de 1748 , en A. G. I., Guadalajara, 513.

48 Alessio Robles, op, cit., 57 I-573.

49 Diario de Rivera, ed. V. Alessio Robles, 157-162. 
entonces quedó formada una compañía voluntaria de infantería española miliciana de la que fue sombrado capitán Don Agustín de Vildósola. ${ }^{0}$

A Rivera se debió la propuesta de segregar las provincias costeras de Nueva Vizcaya, y desde I733 es Sonora gobierno independiente del de Ditrango, al ponerse en vigor la real cédula de I4 de marzo del año anterior, siendo su primer gobernador, con carácter vitalicio, Manuel Bernal de Huicobro, capitán del presidio de Sinaloa, donde tuvo su capital. ${ }^{5}$ Huidobro hubo de acudir a California a pacificar una sublevación de los pericúes en I734, y a poco, en I737, se declaraba un nuevo alzamiento de los pimas bajos de Tecoripa y Suaqui, que por segunda vez se acogieron al Cerro Prieto. La situación de Sonora en el intervalo de estas fechas se nos hace presente en las palabras de Don Gabriel Prudhon, barón de Heyder, alcalde mayor de San Juan de Sonora. "Dios — dice-y el genio especialísimo de los jesuitas para sobrellevar la brutalidad de los indios sostiene la provincia". Apaches y seris cometen incesantes depredaciones. "Por más diligencias que haga la celosísima diligencia del capitán vitalicio de Corodeguachi Don Juan Bautista de Anza, por más que yo compela a los vecinos pocos y pobres que hay a salir como salen a mi costa y la de su sargento mayor Don Agustín de Vildósola y la de los padres jesuitas (prontísimos a sufragar en estos casos con cuanto pueden), apenas se recobra el tercio de lo que llevan". Los cincuenta hombres de Corodeguachi - de los que doce en la frontera seri y doce en Pinería Alta, más los ocupados en las escoltas, caballada y presidio- no podían cubrir las doscientas leguas de la provincia. Janos estaba a sesenta leguas; Sinaloa, a doscientas... Prudhon pide erección de presidio en Terrenate, pero antes de que esto ocurriera sucede la nueva sublevación de pimas. Dominados por Juan Bautista de Anza, capitán de Fronteras, que entrando al Cerro dio muerte al jefe indio Arizusivi y azotó a otros cabecillas, reduciendo a todos los pimas a sus pueblos, ${ }^{52}$ sólo tres años después de reaparece

5o Título de capitán sin sueldo dado por el virrey Casafuerte en México, 22 de diciembre de 1729 , ratificando el nombramiento hecho con anterioridad por el gobernador de Nueva Vizcaya, Barrutia. A. G. I., Guadalajara, 188. Muerto el sargento mayor D. Mantuel Hugues de San Martín, Barrutia nombró a Vildósola para este cargo, que le fue ratificado por Casafuerte en 21 de marzo de 1733 . Ibid.

51 Rivera a Casafuerte, 30 de junio de 1729 . "Testimonio de los autos en virtud de real cédula sobre que las cinco provincias de Sinaloa, Sonora, Ostimuri, el Rosatio y Culiacán se erijan en un gobierno y que sea la capital la villa de Sinaloa". A. G. I., Guadalajara, 18r. Real cédula de 14 de marzo de 1732, en AGI, Guadalajara 234. Vid. Porras Muñoz, Guillermo: "El Gobierno y Capitania General de la Nueva Vizcaya". Tesis doctoral en derecho, inédita, Sevilla, 1951. La real cédula va también inserta en el título de gobernador interino de Vildó sola, México 29 de abril de 1740. A. G. I., Guadalajara I88.

52 Según Prudhom, ni él ni Anza habían podido pasar ocho dias seguidos en su casa. El no percibia sueldo ni emolumento alguno, y cargado de empeños, cumplido su quinquenio - fue rombrado en 1726 - no se le hallaba sucesor. El barón de Heyder a Patiño, San Juan de 
la inquietud, esta vez entre los yaquis y mayos, que asolaron Ostimuri. El foco de la rebelión estuvo en Torin, en la "colina sagrada del Yaqui"; los españoles se hicieron fuertes en el vecino cerro del Tambor. Los indios asaltantes sufrieron en el primer ataque más de dos mil bajas; en el segundo, yaquis y mayos tuvieron tres mil muertos. Desde la plaza de Torim se ve este cerro, que desde entoncęs se llamó de Otancahui, nombre que en lengua cahita significa "Cerro de los huesos", porque durante mucho tiempo blanqueaba con las osamentas de los que allí cayeron. 53 Manifiesta la pusilanimidad de Huidobro, Agustín de Vildósola logró la pacificación de los alzados y en él recayó interinamente el gobierno - que pronto se le confirió en propiedad-, cuando Huidobro fue destituido y llamado a México por el virrey marqués de la Conquista. 54 Vildósola dominó la situación eliminando a los jefes rebeldes Calixto Muni y Bernabelillo. Después de esto los yaquis y mayos se mantendrán ell paz hasta I825.

Este último alzamiento había motivado el envío de tropas desde Nueva Vizcaya. Los capitanes Idoyaga y Uranga habían llevado cien presidiales y doscientos ochenta y cinco auxiliares; Díaz del Campo, otros treinta soldados de Janos, mientras que Gómez de Silva había aproximado veintidós más desde Corodeguachi, a los que añadió otros quince reclutados durante la campaña. Otros ciento cincuenta hombres habían alistado en tres compañías los capitanes Miranda, Baso y Ezquerra. Sumados los treinta y un soldados de Sinaloa, Vildósola contaba al ocurrir la paz casi con quinientos hombres. Vueltas a sus presidios las tropas de Nueva Vizcaya y Corocleguachi, y licenciados gran parte de los milicianos, quedose Vildósola con ciento treinta. Descontada la guarnición de Sinaloa, puso cincuenta soldados en Buenavista y diez en Tecoripa para evitar el contacto de pimas bajos y yaquis; reinte en Cahamoa y veinte más en la villa del Fuerte. Y finalmente propuso la erección de presidio con cien hombres en Pitic y la segregación de Sonora y Ostimuri como provincia aparte, mostrando conveniente, de no hacerse así, que el gobernador de todas ellas residiese en Pitic poniendo un teniente en las provincias del sur. 55

Sonora, 24 de marzo de 1734 . A. G. I. Guadalajara 400. Prudhom remitió con su informe u1 interesante mapa de la provincia que llama Nueva Andalucía de San Juan Bautista de Snnora. "Resumen de Noticias". R. A. H., Boturini, 17, fols, r86 v.-192.

53 Vito Alessio Robles, Bosquejos Históricos, "La colina sagrada del Yaqui", 373-383.

54 Título de gobernador interino y propietario expedidos por el marqués de la Conquista en México, 29 abril y I5 de noviembre de 1740, en A. G. I., Guadalajara, r88. Vildósola recibió aún nuevo nombramiento expedido por el rey en Madrid en 27 de julio de 1744 , cuando Huidobro había logrado ser absuelto de los cargos que le hiciera el marqués de la Conquista, pero se halló excesivo el tiempo que habia sido gobernador de Sonora, pese a que en principio su título era vitalicio. A. G. I., Guadalajara 301 y 118 .

55 Vildósola a Conquista, Sinaloa i7 de 'marzo de I741. Ibíd. Según Vildósola ya hacía años se había proyectado poner un presidio en Pitic 
El marqués de la Conquista aprobó la erección de presidios en Pitic y Terrenate en $\mathrm{I741}$, y a aquel lugar trasladó Vildósola la guarnición de Sinaloa, que dejó de tenerla. El nuevo presidio se llamó de San Pedro de la Conquista del Pitic. El otro presidio era el de San Felipe de Jesús Gracia Real de Guebavi o Terrenate, cuyo primer capitán fue Don Bernardo de Tagle y Bustamante, nombrado por el virrey conde de Fuenclara a la muerte de Gómez de Silva, que había sido anteriormente designado. ${ }^{56} \mathrm{Al}$ mismo tiempo subsistió el destacamento situado por Vildósola en Buenavista. En 1744, el virrey conde de Fuenclara inquirió de Vildósola la posibilidad de suprimir los dos nuevos presidios con objeto de reducir gastos, pero el mismo vecindario de Sonora clamó por su subsistencia. Las hostilidades apaches eran constantes y el gobernador había dispuesto que tres destacamentos de quince hombres de Pitic, Guebavi y Corodeguachi estuviesen siempre, con otras tropas milicianas, en la frontera de más peligro. $57 \mathrm{La}$ paz mantenida por Vildósola se alteró al ser éste destinado y llamado a México en 1748 por el virrey primer marqués de Revillagigedo, de resultas de las contraversias que aquél tenía con los capitanes de los presidios y otros particulares, que en 16 de enero de 1747 informaron al virrey que la provincia estaba a punto de perderse.

En su lugar, interinamente y con carácter de juez comisario, visitador y pesquisidor de los presidios fue enviado el licenciado Don José Rodríguez Gallardo, $5^{8}$ cuyo comportamiento en las relaciones con los apaches no hizo más que empeorarlas, y que, habiendo trasladado el presidio del Pitic que encontró sin levantar a San Miguel de Horcasitas, causó con esto la inquietud de los seris. 59 Hallábanse gran parte de estos indios congregados desde

56 Conquista a Vildósola, Veracruz iz de junio de I74I. Ibíd. En otra de Orizaba, I7 de julio de $\mathrm{I} 74 \mathrm{I}$, le indica procure formar pueblos junto a los prcsidios. Ibíd. Cfr. Mota Padilla, Corquista de Nueva Galicia, cap. XCVI. Mota cree hubiera sido de más utilidad establecer dos pueblos y fundar obispado con Sonora y California. Había librado Conquista cincuenta y un mil pesos para los presidios.

57 Fuenclara a Vildósola, México i 5 de junio de I744. El vecindario de Sonora a Fuenclara, 20 de Agosto de I744. A. G. I., Guadalajara I744.

58 El decreto en que Revillagigedo nombra al licenciado Rodríguez Gallardo, abogado de la audiencia de México, visitador de los cuatro presidios de Sonora -México, 26 de enero de 1748- deja entender que se considera permanente el de Buenavista, que se supone ser el antes existente en Sinaloa. A. G. I., Guadalajara, 188. Lo primero ya se advierte en el informe del auditor Altamira en México 28 de enero de 1747. A. G. I., Guadalajara, I97. En lo segundo insiste Revillagigedo en carta al rey, sin número, de $z 7$ de julio de 1749 , A, G. I., Guadalajara 301. El virrey ordenó a Vildósola entregar el bastón de mando a Gallardo, a su llegada, y en el plazo de seis días ponerse en camino para México. Revillagigedo a Vildósola, México ro de febrero de 1748. A. G. I., Guadalajara, I 88. Relación de los méritos y servicios del Ldo. Don José Rafael Rodríguce Gallardo. Madrid, i2 de julio de I7oo. A. G. I., México, 319o. Después de esta actuación, Rodriguez Gallardo figurará en todas las juntas habidas en México sobre problemas de las provinciar internas.

59 Sobre procedimientos judiciales del licenciado Gallardo, prisioneros de apaches que hizo, y mal estado de Sonora: Tomás Pardo de Navas y Ambrosio Montes a Vildósola. Pitic, 25 
antes de I 730 en las misiones de los Angeles y del Pópulo, a dieciocho leguas de Pitic. Cuando más concurridas, había habido en ellas hasta ciento setenta y cinco seris, no siendo estos en total más de trecientos, lo cual es comprensible dado su género de vida en las "ochenta o noventa leguas de los ardentísimos areniscos, secos, inhabitables playazos de aquella costa hasta la misión que hay en ella, nombrada de Caborca". A aquellas misiones trasladó Gallardo el presidio de Pitic con nombre de San Miguel, y abrió sus cimientos y empezó la fábrica con el producto de algunas multas, más cien reses y cien fanegas de maíz que dio un hacendado de las cercanías. Revillagigedo libró en seguida $\mathbf{5} .000$ pesos, que dio al teniente coronel Don Diego Ortiz. Parrilla a quien nombró gobernador interino. ${ }^{60}$ Pero el traslado produjo de inmediato más desgracia que beneficios pues los seris, disgustados con la proximidad del presidio, se pusieron seguidamente en rebeldía. Ya no se apaciguarían nunca.

El licenciado Rodríguez Gallardo, que había dado por concluida la visita de Sinaloa y Sonora en 26 de enero de I749, había merecido, por dictamen del auditor marqués de Altamira, la aprobación de su actuación y el nombramiento de gobernador y capitán general de aquellas provincias hasta la llegada de Ortiz Parrilla, y así se le expidió título en 22 de marzo de I749. En estas circunstancias dispuso una campaña a la Sierra de Chiricahuí contra los apaches; remitió collera de cautivos, entre los que estaban los jefes apaches Bautista y Pedro, y el seri Canito; visitó los presidios de Fronteras, Terrenate y Pitic, restituyendo a la hacienda más de 5.000 pesos, valor de cierto número de plazas vacantes en ellos. Atendió a la erección de pueble en el paraje de Horcasitas - a donde hizo pasar el último presidio citado- congregando familias y repartiendo tierras, "siendo éste el primer formal vecindario de la Sonora que se verificó en casi dos siglos" y esta fundación tuvo como consecuencia el despueble del antiguo real de San Juan Bautista de Sonora, hasta entonces capital de la provincia, cuya parroquia permitió el obispo Sánchez de Tagle de Durango pasase a Horcasitas. Practicó diversas agregaciones de pueblos y misiones casi exhaustas, visitó el paraje de Guaymas, haciendo reconocer y sondear su puerto, donde propuso

de junio y San José de Gracia, 24 de junio de 1740. A. G. I., Guadalajara, 188. Las primeras noticias del alzaminto general de los seris las dan Juan Tomás de Beldarráin a Gallardo. Pitic, 20 de diciembre de 1748 , y Pedro Felipe de Anza a Vildósola, Pitic, 30 de enero de 1749 . Ibíd.

60 Decorme, Jesuitas mexicanos, II, 448-450. Revillagigedo a S. M. Sin número, México 27 de julio de 1749 . A. G. I., Guadalajara, 301. Villaseñor, cuyo Theatro mexicano se publicó en $1746-1748$, hace constar el presidio de Buenavista inmediato a la Junta del Yaqui, con veintinueve soldados, capitán, teniente y sargento; y en la Junta del río de Pitic, el presidio de este nombre, con cuarenta y siete soldados. II, 392. Según Revillagigedo, el presidio del Pitic tenía cincuenta plazas. La relación entre el traslado de la fuerza y la sublevación seri la establece un "Testimonio de cartas", México 28 de enero de 1750. A. G. I., Guadalajara 188. 
establecer nueva misión, y organizó otra campaña a Chiricahuí. Dejó por fin a su sucesor dos cuadernos de instrucciones y tres copiosos informes sobre las misiones, los presidios y la manera de fomentar la provincia mediante el impulso del poblamiento, la circulación de la moneda, el tráfico por el mar del Sur y la división de aquel vasto gobierno.

En 1749 recibió Sonora nuevo gobernador en la persona de Don Diego Ortíz Parrilla, quien apenas llegado, después de tener junta de guerra con Rodríguez Gallardo, intentando dominar a los seris, cautivó a todos los que vivían en el Pópulo y los envió en collera a México; una parte de los varones logró fugarse, pero las mujeres fueron repartidas por todo el virreinato. La guerra que con este motivo se inicia con los seris no tendrá ya prácticamente fin. El gobernador los persiguió cruel e inútilmente en sus territorios continentales y en la isla del Tiburón. Ellos lograron escapar al Carrizal. 6r Seguidamente, en I75I, se alzaron los pimas altos y pápagos sublevación que costó la vida a dos jesuitas y más de cien españoles, y que se prolongará hasta más de quince años después, sin que Arce y Arroyo, Mendoza, Tienda de Cuervo ni Pineda, sucesivos gobernadores de Sonora, lograsen implantar una paz duradera ni reducir a los seris, acogidos el Cerro Prieto, en donde una serie de campañas dirigida por el capitán Don Gabriel Vildósola tuvo poco éxito. Arce y Arroyo, que apresó a los dos Luises cabecillas de los pimas, había fracasado en sus intentos de atraer a los seris a la paz, logrando sólo una tregua poco duradera, de modo que Don Juan Antonio de Mendoza hubo de combatirlos nuevamente en el Cerro Prieto, donde les hizo un ataque general sorprendiéndolos con toques de tambor, que los pusieron en fuga, y poco después, invadida su tierra, hallaba Mendoza "varias enigmáticas cruces", clara solicitud de paz. ${ }^{62}$ Pero en 1760 el propio gobernador hallaba la muerte cuando combatía a una nueva partida seri acogida al Cerro ${ }^{63}$ y aunque Don José Tienda de Cuervo, poniendo a Don Gabriel de Vildósola al frente de cuatrocientos veinte hombres los derrotó allí en 7 de noviembre de ij6r haciéndoles cuarenta y nueve muertos y sesenta y tres prisioneros, no logró dominarlos, habiendo huido los seris

61 Baltazar, Apostólicos afanes, 361-362, marca, sobria y encomiásticamente, la actuación de Ortiz Parrilla y de los aliados pimas contra los seris. Es Alegre, III, 290-300, quien relaciona los sucesos del Pópulo y considera falsa la victoria en la isla, añadiendo que el exceso de halagos y confianza dados por el gobernador a los pimas y a su jefe Luis fue origen de la subsiguiente sublevación de éstos, de que se culpó a los jesuitas. Sin embargo, en relación de méritos posterior asentará Ortiz Parrilla el de haber hecho la expedición a la isla del Tiburón, "con particular ahorro de Real hacienda y logro de los importantes fines que se tuvieron por objeto en ella". A. G. I., Guadalajara, 515. Villa, págs, $137-138$, sigue a Alegre.

62 Mendoza a Pedro Anselmo Sánchez de Tagle. Horcasitas, 15 de febrero, de 1757 , ibid.

63 Villa 139 . 
con su jefe Marcos a la isla de San Juan Bautista o San Esteban. ${ }^{64} \mathrm{La}$ primera medida decisiva para dominar esta situación no se tomó hasta I764, cuando se decidió la fundación del presidio de Buenavista, en el Yaqui. ¿Cómo atender a un tiempo a esta cruda guerra y a la que desde el norte hacían los apaches? Desde I75 I venían haciéndose campañas contra éstos. El presidio de San Ignacio de Tubac, y la guarnición puesta en Altar —que pronto fue considerada igualmente presidio- triplicaban en $175^{2}$ la defensa del límite setentrional de la provincia. ${ }_{5}$ En I757, fuerzas de Fronteras daban una batida en las fuentes del Gila dando muerte a treinta apaches y haciendo treinta y nueve cautivos. Pero esto distaba mucho de ser un remedio eficaz, y lo único visible era un incesante incremento de los efectivos militares, aunque se buscaba también favorecer la expansión de las misiones. ${ }^{6}$ Pero de éstas, restablecidas en I73 I las de Guebavi, San Javier del Bac y Santa María Suamca o de los Pimas, ninguna más se fundó, pues la de Guaymas, creada en la costa en I750, hubo de ser abandonada a los seis meses, por los ataques de los indios.

Sin embargo, la Compañía se esforzaba en impulsar la penetración hacia el norte, y habiendo hecho entrega de las misiones de Topia y Tepehuanes, cuyos ministros vinieron a engrosar las filas de las de Sonora, confiaba en alcanzar en breve la región del río Colorado, por donde se anhelaba tomar contacto con las misiones de la península vecina. Aquí, la fundación de misión en San José del Cabo en I730, seguida de la de Santa Rosa tres años después, denotaron la ampliación de la acción evangelizadora de los jesuitas a la extremidad meridional de California, pero este establecimiento sufrió la dura prueba del levantamiento en I734 de pericúes y guaicurúes que destruyeron todas las misiones al sur de Dolores y aun causaron muertes entre los pasajeros de la nao de Filipinas. Este hecho determinó la torpe expedición de Huidobro a la península, donde al fin fue erigido el nuevo presidio de San José del Cabo, en 1735 . La rápida extinción de los pericúes después de restablecidas las misiones del Cabo condujo a la supresión de las de San José y Santa Rosa, y el traslado de la de la Paz a Todos los Santos. A mitad del siglo, Don Manuel de Ocio único europeo de cuyas andanzas

64 Mendoza, herido primeramente en un talón, murió flechado por el indio Becerro el 27 de noviembre de I760. Tamarón a Arriaga, Real del Oro de Agua Caliente, 8 de enero der76r. A. G. I., Guadalajara, 40I. Tamarón a S. M. Sombrerete, 29 de marzo de iz6r. Ibid. Alegre, A. B. Z.., IV, 441 .

65 Revillagigedo a S. M., s. n.", México i6 de enero de i752. A. G. I., Guadalajara, 301. La "Descripción" de Sonora de I764 (R. A. H., Boturini, I6, fols. I-ro v.) asienta que la tropa de Altar era la antigua guarnición de Sinaloa, trasladada en I74I a Buenavista y en I75I a Pimería Alta, radicándose en r753 ó I754 en Altar, donde Don Bernardo de Urrea fue su primer capitán. Sus efectivos ascendían en este momento a cincuenta hombres.

66 Mendoza a Sánchez de Tagle. Horcasitas, i 5 de febrero de r757. A.G.I., Guadalajara, 30 I. 
en esta tierra en la época tenemos noticias, inició sus trabajos de pesquerías de perlas en la costa y la explotación minera en Santa Rosa y San Antonio, por esta zona.

La ftundación de misiones continuó desputés más al norte: Santa Gertrudis, en I752; San Borja, en I762; Santa María de los Angeles, en el 1.766. ${ }^{67}$ Esta fue la última obra de los jesuitas en el virreinato, pues al año siguiente eran expulsados de todos los dominios españoles.

Para esta fecha sin embargo, ya desde Kino se había apuntado y se labía insistido sobradamente en la órientación de la expansión española hacia el norceste. El Gila y el Colorado eran metas ambicionadas de la evangelización $\mathrm{y}$ colonización españolas. El entronque de Sonora y California concebido por. Kino había hallado sus continuadores en Sedelmayer y Keller. Los criaderos de plata hallados en Arizona fueron un incentivo económico que se unió al deseo de progresión al norte que el padre Campos enfocaba hacia el Moqui. El capitán Anza, de Fronteras, propuso llevar a cabo una expedición exploradora que su muerte por los apaches en r739 cortó en embrión.

Sin embargo, la posibilidad de ganar terreno al norte es cosa que se proyecta, discute e intenta con increíble tesón y entusiasmo durante más de medio șiglo.

\section{LOS INTENTOS DE EXXPANSIÓN AL NOROESTE}

Hemos de incluir aquí tanto las disposiciones gubernamentales tendentes a la ocupación del Colorado, como los proyectos de misioneros y particulares para ensanchar por estos rumbos las fronteras del Imperio Español.

Llegados los jesuitas a California, la Corona se interesó por estas fundaciones, en principio, por cuanto podían facilitar el comercio con Oriente a través de Filipinas. A este respecto se expidieron las reales cédulas de 17 de julio de I7O y 28 de septiembre de 1703 , que conceden subvenciones a los misioneros y hacen patente el deseo de guarnecer los puertos del Pacífico. En el mismo sentido, la de 29 de enero de I7I6 que, movida por las representaciones de Kino, trata de impulsar el avance de las misiones en Sonora y California, hasta su conjunción, y las advertencias hechas al virrey sobre la conveniencia de fundar colonias y fuertes en la costa occidental de la península, cosa que los jesuitas mostraron difícil. Aún se dieron disposiciones en este sentido en I72I, I723, e incluso en fechas posteriores. 68

67 Decorme, II, 533, 535, 538. Dunne, Black Robes, 377, 378, 404.

68 Chapman, The Founding.... 20-23. Los subsidios concedidos por estas órdenes llegan a treinta mil pesos, pero no tuvieron realidad. 
Pero mientras, un nuevo objetivo - el Moqui- había surgido, y yà vimos los intentos del padre Campos en I 7 I5. Cuatro años después el Rey ofrecía el Moqui a los jesuitas como campo misional, y en I 725 se ordenaba realizar expediciones que alcanzasen la Pimería Alta y Nuevo México, y así lo intentó el obispo de Durango Don Benito Crespo, proponiendo la fundación de misiones que fuesen acortando la distancia al Moqui. Cuando estuvieron fundadas las de Suamca, Guebavi y San Javier del Bac, en I732, la inquietud se incrementó al aparecer las famosas bolas de plata de Arizona en I736. De éste y el siguiente años, son las expediciones al Gila del padre Keller y las fallidas proposiciones del capitán Anza que, 'sin embargo, tuvieron honda repercusión en el virreinato y la Corte. ${ }^{69}$

En 1742 , un nuevo motivo se suma para promover esta expansión: la aparición en las costas californianas del pirata inglés Anson. En I743, el presidente de la audiencia de Guadalajara marqués del Castillo de Aisa muestra la conveniencia de fomentar la minoría y pesquería de perlas en las islas y costa de Sonora, y un año después el virrey Fuenclara pide más misioneros para Sonora y Californias. Por otra parte, la stublevación sufrida en la península diez años atrás había hecho pensar seriamente en el interés de conservar estos establecimientos, y en su consecuencia, una real orden de 13 de noviembre de $1744^{70}$ promueve la fundación de pueblos españoles $y$ presidios en el sur y centro de la Baja California, y la intensificación de la evangelización del resto de la península, que se lograría si los misioneros pudiesen entrar por su parte norte, para lo cual convendría duplicar el número de los que había en la frontera de Sonora, poniéndoles la escolta correspondiente para que entrasen por los cocomaricopas y yumas a establecer un pueblo en el río Colorado, y otro entre los hobaomas o bajiopas en la margen opuesta: para las escoltas podría echarse mano de las tropas de Terrenate o Pitic, o bien pasar la de este presidio a Terrenate y distribuir la de Terrenate entre las misiones como escolta que quedaría subordinada a los jesuitas.

En I 742 había fracasado una pequeña expedición al Moqui en la que figuraha el padre Keller, al ser asaltada la caravana una noche con muerte de un soldado, pero desde el año siguiente se inician los viajes del padre Sedelmayer desde su misión de Tubutama al Gila y al Colorado. 汪 En estas circunstancias, a la llegada de la real orden de I744 siguieron diversos informes, dos de los cuales, los del provincial jesuita padre Escobar y del gobernador de Sonora Vildósola coinciden en un punto fundamental: se debe centrar toda la atención en un primer objetivo que es el río Gila, fundándose

69 Ibid., 23-29. Baltazar, Apostólicos afanes, 243-360.

7o Baltazar, Apostólicos afanes, 363-364.

7 I Tbid., 343-360. 
allí un presidio de cien hombres. Vildósola especifica 72 que pueden sacarse ochenta soldados de Guebavi, Corodeguechi, Janos y El Paso y colocar la nueva guarnición en el Paso de Todos los Santos o de la Casita, en el Gila. Propone igualmente el gobernador de Sonora la erección de otro presidio en el puesto de San Felipe de Jesús en California, y la de una misión en la isla del Tiburón, e insiste en la necesidad de dividir su gobierno en dos, poniendo la división en el real de Alamos, subordinando el gobierno del strr al del norte.

Hasta la erección de nuevos presidios en Tubac y Altar a raíz del alzamiento pina de $\mathrm{I} 75 \mathrm{I}$, que pueden considerarse primer paso para alcanzar el Gila, la expedición por mar del padre Consag desde 'California al fondo del Golfo en I746, es uno de los acontecimientos principales. Al año siguiente, una real orden de 7 de diciembre insiste en la de 1 744. Los trámites y consultas se suceden, dificultados en su ejecución por los sucesivos alzamientos de Sonora, que pusieron un freno a la ambición expansiva. Finalmente. en $175^{2}$, una expedición de más de setecientos hombres enviada por el virrey contra los apaches, que hubiese abierto el camino del Moqui, no halló enemigos pero sí, al regresar, las poblaciones españolas asoladas por ellos durante la ausencia de las guarniciones. 73

Después de esto, el impulso bélico y nisional decayó. En cambio, entre tanto habían surgido nuevas razones que aconsejaban la ocupación de las tierras del norte. En efecto, en el cuarto de siglo siguiente, no se acomete una penetración seria y organizada del noroeste, pero se acumulan los proyectos para una acción semejante, proyectos a los que Gálvez dará, al cabo de aquel tiempo, una concreción admirable.

\section{LOS PROYEC'TOS DEL VIRREINATO}

Justamente a mitad de siglo, al fin de la segunda expedición de Bering en 1749 , había quedado descubierto el estrecho de Bering, había sido cartografiada la costa ártica de Asia del mar Blanco al río Kolima, y la costa pacífica de América del cabo Addington a la isla de Bering había sido dada a conocer. 74 Pero no fue esto, sino la presencia de dos barcos holandeses en el Pacífico lo que movió al ministerjo español en I75o a considerar si no

72 Vildósola a Fuenclara, Pitic, 26 de marzo de 1746. A. G. I., Guadalajara, 188.

73 Decorme II, 436. Baltazar, Apostblicos afanes, 431-439.

74 Colder, F. A.: Bering's Voyages. An acconnt of the efforts of the Russians to determine the relation of Asia and America, 2 vols., New York, 1922 y 1925, I, 4-5. Del mismo autor, Russian expansion on the Pacific $164 I-1850$. An account of the earliest and later expeditions made by the Russians along the Pacific coast of Asia and North America; inchuding some related expeditions to the Artic Regions. Cleveland, 1914. 
convendría segregar toda Nueva Galicia del mando del virrey convirtiéndolá en gobierno independiente. Inmediatamente después, cuatro memoriales de 2 de marzo y 15 de mayo de 175 I remitidos por Don Fernando Sánchez Salvador, capitán de coraceros en Sinaloa y Sonora, traza los posibles caminos conducentes a la pacificación del territorio de estas provincias, su fomento, su constitución en virreinato juntamente con la de Nueva Vizcaya y la región del Colorado, con capital en San Juan de Sonora o alguna población de Chihuahua, y su expansión más al norte de California. Sánchez Salvador preconiza igualmente la comunicación con Nuevo México por el Moqui, y señala el peligro de la proximidad de los franceses a aquella provincia, argumento que recogerá Gálvez en su día. 75

Entre 1760 y I76r, otros cuatro memoriales de Don Pedro Labaquera, que había actuado como teniente de capitán general en Nueva Galicia, ${ }^{76}$ insisten en las descripciones del Cabo San Lucas, del Colorado y del Gila y de la Apachería, en la presencia de franceses e ingleses en el primero, y en la proximidad de aquéllos al segundo. Tal vez, dice, el Colorado tenga una desembocadura al Pacífico. Propone explorar la región de Arizona a sus expensas, dándosele el mando de un presidio. La amenaza apache sería rechazada con sólo doscientos fusileros españoles, con armas de largo alcance, dirigidos por un jefe desinteresado. La similitud de pensamiento entre Labaquera y Sánchez Salvador, es evidente.

75 Chapman, The founding, 36-39. La empresa expansiva la había sugerido ya la relación anónima existente en la Biblioteca del Palacio Real, en Madrid. "Para la conquista del río Colorado se propone lo que la práctica y noticias impelen", fechada en México, I4 de octubre de I750. Miscelánea de Ayala, tomo 5, sig. 2816, fols. $189-19 \mathrm{r}$ v. De fecha semejante debe ser otro papel titulado "Trata de las islas Marías, que median desde Matanchén a la California y también sobre una aguada que hay en ésta y tiene oportunidad de erigirle defensa, teniéndola guardada en la forma que dice", s, a, n. d., ibid., fols. 192-194 v. De 1753 es el "Testimonio de los autos formados en el Superior Gobierno de este reino de la Nueva Galicia para informar a S. M. sobre si será conveniente el que las provincias de Motines, Colima y las de Abalos que son del gobierno de Nueva Espania, y también las cuatro jurisdicciones de la villa de la Purificación, Acaponeta y Sentipaque que pertenecen al reino de la Nueva Galicia se ponga bajo de un gobierno". A. G. I., Guadalajara, 329. Es resultado de la real cédula de $3 I$ de octubre de i750 expedida al aparecer los navios holandeses. A algunos de estos proyectos y expedientes deben aludir O'Gorman y Orozco Berra cuando dicen que desde 1752 se trataba en la corte española de formar un gobierno independiente con la porción setentrional del virreinato mexicano. Orozco y Berra. Historia de la dominación española en Mérico. México, 1938. O'Gorman, Edmundo, Cuadro histórico de las divisiones territoriales de Mérico, México, 1948.

76 Chapman, The Fonnding..., 64-66. En relación de méritos impresa en M'adrid, 3 de septiembre de 1759 , Labaquera dice llevar trece años de teniente de capitán general de las costas del mar del sur, en Nueva Galicia, y solicita sueldo o el corregimiento de Bolaños. Había pasado a América cơmo gentil hombre del virrey Conquista, en I 7 qo. Seis años después edificó una batería. en Matanchel para protección del galeón de Manila. En I747 rechazó un navío holandés de comercio. Habia recorrido y mapeado la costa. Su solicitud aparece recomendada por el presidente Basarte en Guadalajara, io de abril de I758. A. G. I., Guadalajara, 401. Su demanda fue, al menos en parte, atendida, pues en 25 de enero de 1762 toma poseción de la alcaldia mayor de Fresenillo, A. G. I, Guadalajara. 329. 
Pero el proyecto más amplio y al mismo tiempo concreto aparece en I760, anónimo, con el doble interés, además, de haber servido de contraste para la formulación del posterior y definitivo de Gálvez y Croix. 77 Los títulos anuncian bastantemente la idea del redactor. $\mathrm{La}$ inmensidad del territorio le lleva a proponer se reduzca la jurisdicción del virreinato de Nueva España a las provincias de Oaxaca, Tabasco, Veracruz, Puebla, Michoacán y costas de Oriente y Sur hasta el puerto de Navidad, y lo comprendido al sur de una línea desde este punto a Nuevo Santander. Un virreinato setentrional, de nueva creación con sede en Durango, comprendería las çiudades de Guadalajara, Zacatecas y Durango; las villas de Chihuahua, Parras, Saltillo, Monterrey, Charcas, Lagos, Aguas Calientes, Jerez, Fresnillo y Sombrerete; tos reales de Comanja, Sierra de Pinos, Charcas, Matehuala, Mazapil, Los Angeles, Boca de Leones, Asientos de Ibarra, Zacatecas, Fresnillo, Sombrerete, Mieres, Chalchihuites, Bolaños, Santa Rosa, Santa Bárbara, Mezquital, Santa Cruz de las Flores, Guachinango, Mojarras, Rosario, Plomosas, Pánuco, Copala, Paloblanco, Alamos, La Santísima Trinidad, Morotal, Topago, Batopilas, Chihuahua o Santa Eulalia, Cusiguriachic, Santa Bárbara del Valle, San José del Parral, Nuestra Señora del Oro, Indé, Cuencamé, Mapimí, Conereto, y otros. La larga relación da idea de la entidad y riqueza del territorio.

Durante tendría en seguida Casa de Moneda, con lo que cesaría la escasez de ella que se experimentaba en todo el norte, y sería sede de la Audiencia de Guadalajara, a la que se aumentarían culatro alcaldes de corte que entendiesen en las causas criminales. Si estos cuatros se tomaban de

77 El proyecto aparece por duplicado en la Biblioteca del Palacio Real, en Madrid, con algunas variantes en titulo y fecha, que son como sigue: "Proyecto sobre el establecimiento de un virreinato en la Nueva Vizcaya, cuya capital es Durango, y separación de provincias que al efecto debería ejecutarse del de México con el fin de proporcionar por medio de esta agregación una buena administración de justicia y conocimiento práctico de los virreyes para dictar sus providencias con el que se requiere en unos dominios tan vastos a que no puede atender el de Nueva Espafia. Propónense los medios de su plantificación, por qué parajes se han de tirar las líneas divisorias, providencias que deberán darse, breve noticia de las producciones de sus provincias, clima, minerales, y démás circunstancias que concurren a efectuar el pensamiento; manifestando las dificultades que se pueden ofrecer a varias personas; a que da solución, declarando el autor de este papel el motivo que le estimuló a hacer presente sus pensamientos. Año de 1760". Madrid, 12 de mayo de 1760. Miscelánea de Ayala, tomo LIV, sig. 2872, fols. 203-227. "Idea que manifiesta las ventajas que resultarian a la seguridad de los reinos de Nueva España, fomento de sus minas y frutos con la erección de un nuevo virreinato en la ciudad de Durango, capital de la Nueva Vizcaya, separando del de México para su jurisdicción las provincias que sefila y trasladando a dicha ciudad la audiencia de Guadalajara, con el aumento de cuatro alcaldes de corte que entendiesen en lo criminal. Y propone para relevar a la real hacienda de la satisfacción de estos sueldos propone el medio de que pasen los supernumerarios de México". Madrid, 18 de diciembre de 1760 . Mis. Ayala, tomo X, sig. 2824 , fols. $30-41$ v. Uno y otro documentos son por lo demás iguales, salvo que el primero está dividido en cuarenta y nueve puntos numerados,
y no asi el segundo. 
los supernumerarios que había en México, solo se cargaría a la hacienda el sueldo del virrey y de algunos ministros togados. En Guadalajara quedaría establecida una gobernación.

$\mathrm{El}$ anónimo autor concibe incluso que un virrey que lo hubiese sido de toda Nueva España, pasase a establecer el virreinato de Durango. Ve indudable el progreso en la minería, los descubrimientos y la evangelización. El virrey recorrería todo el territorio y pondría fin al avance de los franceses desde Luisiana y de los ingleses desde sus colonias, fortificaría el cabo San Lucas y dispondría entradas por el río Colorado. Se establecería en el puerto de Banderas o en Chacala la estación terminal del galeón de Manila, y se fomentaría el comercio de Nueva Galicia con Guatemala.

A la vista de lo ocurrido antes y después de I760 sobre este asunto, y de casos que guardan cierto parentesco con el que nos ocupa, no podemos dejar de apuntar algunos comentarios sobre el proyecto que acabamos de presentar. El rasgo más destacado es sin duda la inclusión de Nueva Galicia en el marco del virreinato imaginario, que con esto habría logrado un potencial económico - la magnífica región minera de Zacatecas- de que siempre careció la posterior Comandancia General de Gálvez. Este mismo hecho justifica la ubicación de la capitalidad en Durango, mientras que Gálvez la empujará hacia el norte, hasta la misma frontera. La viabilidad y conveniencia de aquella medida se hacen patentes si se considera que del mismo modo se procedió en el momento de crear el virreinato del Plata, al que se adscribió sin otro motivo todo el Alto Perú. Escapóse, en cambio, de la mente del memorialista algo tan importante - según se vería despuéscomo la necesidad de dotar al virreinato concebido de un puerto en el Golfo para el tráfico mercantil con España y Europa, lo cual lo dotaría de autonomía y verdadera independencia respecto de la Nueva España, en cuyo litoral se hallaría el tradicional puerto monopolizador de Veracruz y en cuya capital residía el más poderoso núcleo mercantil del virreinato.

De otro modo, se puede incluso suponer que sería perjudicial para los mineros zacatecanos tener que ir a la casa de la moneda de Durango y volver al sur de nuevo por Zacatecas para acudir con las platas ya amonedadas a realizar sus compras en México.

El autor del proyecto, que se muestra en general bien versado en los ásuntos de Nueva Galicia, no olvida por otra parte la vieja y siempre renovada apetencia de Guadalajara de fijar en uno de sus puertos —el de Banderas, el de Chacala - el punto de arribada del galeón de Manila, arrebatando este derecho al puerto novohispano de Acapulco.

No merecería este proyecto tanta detención de no haber sido explícitamente citado en el Plan de la Comandancia General elaborado por Gálvez, que 
parece haberse formulado como una reducción de este de 1760 para hacerlo más fácilmente realizable.

Adviértase en la sucesión de propuestas, por último, cómo en la idea de un virreinato septentrional van siempre enlazadas las provincias de Sonora y Nueva Vizcaya, y cómo al mismo tiempo el centro en principio imaginado en Griadalajara se desplaza seguidamente a Durango.

\section{La costa Tamaulipeca y Texana.}

Es un hecho singular la débil penetración que desde la región de Zacatecas se hace, durante más de siglo y medio, hacia el nordeste, describiendo un arco que duplica el de las aguas del Golfo, y que no se desvía de su ruta hacia las praderas ni hacia la costa. Penetración que tiene sus pilares primeros en Saltillo y Monterrey y que ya desde Monclova se orienta segín un amplio punteado del mapa que halla sus asientos en Río Grande, Béjar y Adaes. No puede decirse que la ocupación de Texas en esta época fuese mucho más que la subsistencia de éstas como escalas de un camino que llevase a Lusiana. Así lo reconoció Rivera.

Pero en las tres décadas siguientes, cambios trascendentales van a operarse no sólo en Texas, sino en la finosomía general de todo el sector nordoriental del virreinato, en virtud sobre todo del esfuerzo de un grupo de hombres y de una concatenación de circunstancias ciertamente admirables.

A poco más de treinta leguas al norte y nordeste de México comenzaba la faja de más de ciento cincuenta leguas de largo y cincuenta de ancho, comprensiva de la sierra Madre Oriental tamaulipeca, señoreada por los bárbaros, que desde allí continuaban hostigando las regiones pobladas circundantes. 78 Por ello, Pánuco, Tampico, Tamos y Villa de Valles seguían siendo lugares fronterizos, y lo mismo Tula que Santa Catalina Mártir de Río Verde y el real de Guadalcázar, en la jurisdicción de Potosí, así como los establecimientos de Nuevo León, se veían amenazados por su flanco oriental. Sólo el presisio de la Bahía fundado por Aguayo, en la boca del río Guadalupe, constituía un puesto de vigilancia español en la costa. Las misiones de Río Verde, de la cuenca del Pánuco, desde principios del XVII, venían cerrando el paso de los bárbaros al Sur. Al este y al oeste del río del Desagüe, ocho centros de evangelización sostenían los religiosos apostólicos de San Fernando y San Diego. Tula, donde se mantenía una compañía de cincuenta hombres, era

78 Instrucción sobre lo ocurrido en el Nuevo Santander y su pacificación por el conde de Sierra Gorda. Acompaña a la Instrucción del Sr. conde de Revillagigedo al Señor marqués de las Amarillas, en Instrucciónes que los virreyes dé Nueva España dejaron a sus sucesores, pág. 36-39. 
centro de otras siete misiones. 79 Aquella compañía, que costaba 8.500 pesos al año, había sido resto de la expedición dirigida en I7I 5 por Guerrero de Ardila para lograr la pacificación de la Sierra Gorda, sin que ésta ni otras anteriores empresas semejantes hubiesen tenido éxito. 80

En 1739 y 1743 , dos reales cédulas impusieron se tomasen las medidas pertinentes a la pacificación y ocupación del territorio ${ }^{81}$ sin que hasta 1748 se decidiese acometer firmemente esta tarea, encomendándola a Don José de Escandón, que desde I74I era teniente general de la Sierra Gorda, sus fronteras y presidios, y había realizado ya una exploración previa del territorio y sometido a consideración del virrey y de la Junta de Hacienda y Guerra un plan concreto y detallado para la colonización. ${ }^{82}$ En virtud de este plan, aquel mismo año de 1748 se organizaba una entrada simultánea de contingentes de tropas que sumaban setecientos sesenta y cinco hombres procedentes de Tampico, la Huaxteca, Querétaro, Linares, Cerralbo, Río Grande y la Bahía del Espíritu Santo; todos fueron convergiendo hacia el que mandaba el propio Escandón, que desde Querétaro, por San Luis de Potosí, marchó al río Guayalejo, y de aquí al del Pilón y al de las Conchas hasta poner su campamento o real en la proximidad de la desembocadura del Grande. De esta manera quedaba prácticamente batido todo el país de la así naciente provincia, que recibía el nombre de Colonia del Nuevo Santander, y el genérico de Costa del Seno Mexicano. Doce misiones franciscanas del Colegio de Zacatecas acometían inmediatamente la empresa evangelizadora entre los olives, janambres, pames, pisones y demás numerosas naciones de indios gentiles. Las poblaciones de blancos, mestizos y mulatos civilizados quedaron escalonadas en los valles de los cuatro ríos. Lera, Escandón, Horcasitas y Altamira, en el Guayalejo o Tamesí. Los Reales de las Infantes y de Borbón, con Aguayo, Güemes, Hoyos, Padilla, Santander (destinada a capital de la Colonia), Santillana y Soto la Marina, en la amplia cuenca del río que de esta última población toma su nombre. Burgos y San Fernando se asentaron a orillas del río de las Conchas. Revilla, Mier, Camargo y Reinosa quedaron a la banda sur del Grande, mientras que Laredo y Dolores se situaron al norte, junto con varios ranchos. El límite de la Colonia con Texas quedó fijado en el río de San Antonio, inmediatamente al sur del presidio de la Bahía.

Así, en I755 Escandón podía considerar concluída su labor. A más de

79 Villaseñor, Theatro Americano, I, 28, 5 I, 55.

8o Cuevas, Historia de la Iglesia en México, III, 438-441.

8I Instrucción sobre lo ocurrido en Nuevo Santander... cit., 36-37.

8. Hill, Laurence Francis, José de Escandón and the founding of Nuevo Santander. A study in Spanish colonization. Columbus I926. 59-68. 
cinco mil ascendía el número de los colonizadores llegados a Nuevo Santander en sólo siete años, y se acercaban a dos mil los indios congregados en las misiones. ${ }^{8}$ Sin embargo, las noticias sobre el particular eran un tanto confusas $y$ contradictorias en el ministerio en Madrid, y por eso el bailío Arriaga encargaba al virrey Amarillas en la instrucción de gobierno que le dio que hiciese visitar el país, levantar un mapa y reconocer el puerto de Santander por un práctico. ${ }^{84} \mathrm{La}$ visita se ellevó a cabo de marzo a octubre de 1757 por el capitán Don José Tienda de Cuervo y el teniente coronel ingeniero Don Agustín López de la Cámara Alta. De ella se desprendió la propuesta de traslado de algunas poblaciones y la fundación de otras, 85 tarea a la que se entregó Escandón hasta su separación del gobierno de la Colonia en 1766. La organización defensiva consistía en doce escuadras con un total de ciento cuarenta y cinco hombres que gravaban al erario en más de treinta y seis mil pesos. ${ }^{86} \mathrm{La}$ empresa había tenido pacífico y brillante éxito. Con esto, de Tampico a la Bahía del Espíritu Santo, la costa Mexicana del Golfo entraba de hecho a formar parte de los dominios españoles en el Nuevo Mundo.

No ocurría del mismo modo en el intervalo de la Bahía a la frontera de Luisiana. Desde I726 el presidio de Nuestra Señora de Loreto había radicado a orillas del Guadalupe, ${ }^{87}$ y diez años después, iniciándose con fortuna los cultivos de secano, podía considerarse un pilar aislado, pero firmemente establecido, para la conversión de las tribus coahuiltecas que mediaban hasta el río Grande, los karankawas de las islas vecinas y los pequeños grupos nómadas que se extendían hasta el Colorado.

Más allá de este río, los indios eran incluso desconocidos para los españoles y hasta ellos llegaba, en cambio, la influencia francesa a través de los mercaderes que entraban por tierra desde Pachina, en el Misisipí, o bien remontaban en barco los cursos del Neches, del Trinidad y del Brazos. Esta es la situación que pinta, ya en I74I, el gobernador de Texas, Don Prudencio Orobio y Basterra. El capitán de la Bahía, Don Joaquín Orobio, pariente del

83 Instrucción sobre lo ocurrido en Nuevo Santander... cit,, 37-38. Hill, José de Escandón, 69-105. Medel Pecino, Matilde, "La colonización de Nuevo Santander en el siglo XVIII". Tesis de licenciatura, inédita. Sevilla, 1957. Un buen resumen de la obra de Escandón en Cervantes, Enrique A., Visita a la Colonia de Nuevo Santander hecha por el licenciado D. Lino Nepomuceno espiritual del Nuevo Santander. Madrid,

84 Instrucciones que

85 Estado general de las fundaciones hechas por dejaron a sus sucesores, 100-101. Nuevo Santander, Costa del Seno Mexicano Dochas por Don José de Escandón en la Colonia del de la provincia efectuada por el capilán de Dragonentos originales que contienen la inspección mismo al virrey y un apéndice con la Relación Histórica Josó Tienda de Cuervo, el informe del Santa Maria. 2 vols. Publicaciones del Relación Histórica del Nuevo Santander, por Fray Vicente

86 Op. cit., en nota anterior, II, 40. I., XIX y XX. México, 1929.

87 Castañeda, Our catholic heritage, III, $85-87$. 
gobernador, encargado por éste de hacer un reconocimiento, visitó en 1746 las tierras de los vidais y orcoquizas, en el bajo Trinidad, donde nunca se había visto un español. En I747 los orcoquizas pidieron misión. Un año después, Orobio exploró la región aún más al este, hacia el Sabinas. ${ }^{88}$

Desde I75I, orcoquizas y vidais entraron más de lleno en la órbita española cuando el gobernador Barrios Jáuregui estableció relaciones comerciales con estos grupos, a los que vendía mercancías francesas de Natchitoches a cambio de caballos, trigo, pieles y cueros, que a su vez expendía en Adaes o Natchitoches, o por medio de un comisionado en Saltillo. 89 Sin embargo, los franceses seguían actuando en la misma zona y Barrios decidió proceder a su detención.

La presencia francesa era constante no sólo entre los indios, sino entre los mismos españoles. El gobernador de Luisiana Kerlerec procuraba por todos los medios impulsar este comercio. El gobierno español había expedido en cambio en I75 I una orden en virtud de la cual debía instarse a los franceses a desalojar Natchitoches y la Isla de Labores. Pero Revillagigedo, después de reunir Junta tres días seguidos, decidió no obrar así y limitarse a impedir la actividad de los traficantes del Misisipí. 90 Fue entonces cuando las diligencias practicadas por Barrios llevaron a la detención del viejo Blancpain, con otros dos franceses y dos negros. Blancpain decía estar esperando en la boca del Trinidad la llegada de una colonia de cincuenta familias de Nueva Orleans. El comandante de Natchitoches declaraba que aquel paraje pertenecía a Francia. ${ }^{91}$

De resultas de aquellas novedades, el virrey Amarillas decretaba, a propuesta del auditor Valcárcel, la erección de presidio de treinta soldados, misión y población de cincuenta familias en el Trinidad. ${ }^{92}$ En mayo de ${ }^{2} 756$ quedaba establecido el presidio de San Agustín de Ahumada (o de las Amarillas); las cincuenta familias - Barrios pretendía que veinticinco fueran de tlaxcaltecas- no llegaron a reclutarse. ${ }^{93} \mathrm{La}$ misión y los indios en ella congregados tuvieron una vida difícil, por ser el lugar poco saludable, pero el traslado proyectado en $I 760$ no se llevó a efecto, por oposición del capitán

88 Ibid, IV, 46-52.

89 Este comercio figura en la "Nota de cargos" contra Barrios en Cruillas a Arriaga, 11, 5 r, M'éxico, I 3 de octubre de I764, A. G. I., Guadalajara, 302.

90 Instrución de Arriaga a Amarillas en Instrucciones que los virreyes de Nueva España dejaron a sus sucesores. Punto 8 pág. 96-97. Un ejemplar de dicha Instrucción en A. G. I., México, 1507.

9 I Castañeda, op. cit., IV, 53-56. El expediente sobre Blancpain, en A. G. I., Guadalajara, 4 о I.

92 Amarillas a Arriaga, México, 14 de marzo de 1756. A. G. I., Guadalajara, 401.

93 Castañeda, op. cit., IV, 65-69. Barrios había cumplido ya su periodo de gobierno, pero solicitó prórroga al virrey para concluir este establecimiento. Entre tanto, su sucesor Martos se hizo cargo del gobierno interino de Coahuila. 
Don Rafael Martínez Pacheco, a las órdenes del gobernador Martos y Navarrete. A poco, el presidio sufría un asalto y consiguiente incendio por los indios, hecho de que resultó inculpado el propio gobernador. 94

\section{Texas frente a la pradera}

Contemporáneamente a esta ocupación progresiva de la costa del Golfo, afrontaba la provincia de Texas el problema de su más intensa colonización y de su subsistencia. Después de la visita de Rivera, tres acontecimientos principales destacan en la historia de la provincia en los treinta años siguientes, en los que se realizan los principales esfuerzos y se intentan los más adecuados proyectos tendentes a vigorizar, fomentar e hispanizar la región.

La aplicación de reglamento de Rivera significó la supresión del presidio de Nuestra Señora de los Dolores de Texas y la reducción de efectivos en la de Nuestra Señora del Pilar de los Adaes. La presencia española en la parte oriental de la provincia se debilita así considerablemente, en beneficio de la influencia francesa, aunque aquello no ocurriera sin protestas por parte de los misioneros queretaranos, del gobernador Mediavilla Azcona y del capitán Becerra. 95

Claramente desaparece ahora el foco misional del Neches. Los franciscanos, después de una breve estancia en el río de San Marcos, vinieron a fijarse en el San Antonio, acompañados de un gran grupo de indios ais, nasones y neches. El presidio de San Antonio y el de Adaes centran ahora la vida de Texas. 96

En I73I, en cambio, llegan al primer núcleo cincuenta y seis personas, constituyendo quince familias, que se asientan en la población de San Fernando. Hasta cuatrocientas familias había proyectado el gobierno español sacar de Canarias para contrarrestar la penetración francesa en Texas, pero el virrey Casafuerte informó no ser necesario mayor número, pues siempre habría gente en Nueva España para colonizar las Nuevas Filipinas. 97

Inútil especular sobre el giro que hubiera tomado el desarrollo histórico de Texas de haberse llevado a efecto la idea tal como concebida, pero tal especulación no puede menos de ser sugerente para quien conozca que ésta, como las demás provincias de Nueva España que hoy forman parte de los

94 Castañeda, op. cit., IV, $83,87-94$.

95 Ibid, op. cit., II, $237-238$.

96 Ibid, op. cit., II, 239-242.

97 Ibid., op. cit., II, 283. Morales Padrón, Francisco: Colonos canarios en Indias "Anuario de Estudios Americanos", VIII, 399-44I. Sevilla, 195I) da en pág. 428 la cifra de sesenta familias que la mayoría de estas familias quedaron en Cuba. 
Estados Unidos, se perdieron para el mundo hispánico por la superficialidad de la ocupación mantenida por españoles y mexicanos. Y Texas habría de ser la vanguardia latina frente a la expansión sajona.

Las quince familias canarias, raquítica expresión de la colonización proyectada por el marqués de Aguayo, erigieron cabildo en San Fernando y no tardaron en suscitar problemas al gobierno con sus disputas con los misioneros que, naturalmente, llegados antes, habían acaparado para sus neófitos las mejores tierras. ${ }^{8}$

En este momento, los apaches, que ya hostilizaban la región a la llegada de Aguayo, multiplican sus ataques sobre el camino de Río Grande y las misiones de San Antonio, de tal manera que el mismo Rivera ha de aconsejar se organice una campaña represiva, ${ }^{99}$ y con esta cuestión, que ya nos va a conducir al intrincado problema de las relaciones con los "indios del norte", se completa la visión de la vida de Texas en estas décadas. Don Fernando Pérez de Almazán, primer gobernador después de Aguado, obtenía el i 8 de septiembre de I73I una victoria, cuando ya parecía perdido el encuentro, sobre casi seiscientos bárbaros que habían atacado Béjar. Después del breve interinato de Mediavilla Azcona, Don Juan Bustillo y Ceballos emprendió una expedición con más de doscientos españoles e indios de misión y consiguió derrotar a más de setecientos apaches en el río San Sabá, capturando setecientos caballos, cien cargas de peletería y treinta prisioneros, en octubre de 1732.100

Al año siguinte, el virrey nombró capitán de Béjar a Don José de Urrutia, el oficial más experimentado en la guerra con los indios, y refuerza este presidio con treinta soldados procedentes por mitad de la Bahía y de Adaes. Así comenzaba la beligerancia de apaches y españoles en la zona de San Antonio. Los intentos de paz no fueron observados por los indios. Al fin de la década, Urrutia pedía establecimiento de presidio en el Guadalupe. Sus atenciones se dividían entre la defensa de las misiones y la tranquilidad de los indios evangelizados, que después de una terrible epidemia padecida en 1739 desertan en gran número, siendo difícil volverlos a congregar. ${ }^{\text {ror }}$

Pero el problema apache adquirirá más adelante nuevos aspectos. En I746, Fray Mariano de los Dolores establece una misión de indios yojuanes, deadoses, mayeyes, verbipianes y cocos en la confluencia de los ríos San Ja-

98 Fue el autor del Theatro Americano (II, 320) el encargado de hacer el diseño de la población por el virrey Casafuerte, que en cambio no quiso darle su nombre. Cfr., la fundación de Béjar, en Alessio Robles, V., Coahuila y Texas, 515-5i6.

99 Castañeda, op. cit., II, 247.

I 00 Ibid, III, $37-38,40-4$ I.

Io I Ibid, III, 44-48, 67-74. En I739, José de Urrutia, y en r 745 su hijo, Toribio de Urrutia, realizaron campañas victoriosas contra los apaches por el rumbo de San Sabá.

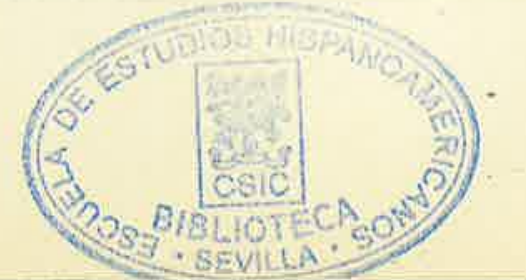


vier y Animas. Se discute en Texas y México sobre la conveniencia de poner allí presidio con diez soldados de Adaes y doce de Béjar; pero cuando esta decisión se toma en I747, la amenaza apache ha dispersado a los indios que allí se congregaran. Las órdenes repetidas por dos veces aquel año llevan por fin a la creación del presidio de San Javier con treinta hombres - trece de la Bahía y diecisiete de Adaes-, que luego aumentarán a cuarenta y ocho mandados por Juan Galván, fundándose a su amparo tres misiones. ${ }^{\text {x } 22 ~} \mathrm{El}$ riesgo, sin embargo, es muy grande, y acentuado por las discordias intestinas, que culminan con la muerte de dos misioneros en ì $75^{2}{ }^{\text {103 }}$

Y a pesar de ello, desde r743 Fray Benito Fernández de Santa Ana ha propuesto la erección de una misión para los apaches, insistiendo en su idea años después. En I749, después de la campaña de Toribio de Urrutia habida en I745, los apaches establecen la paz, y más de novecientos natajes, cibolos I cutubantes se hallan asentados en ambas márgenes del río Grande, en Coahuila, en I754. A fin de año -2 I de diciembre- se fundaba la misión de San Lorenzo para ellos, que la incendiaron a los diez meses. ${ }^{104}$

Entre tanto, en Texas, Galván había explorado el terreno, decidiéndose por el valle de San Sabá para asentamiento de una misión, con agrado por parte de los apaches. No obstante, esto sólo sería el origen de una incómoda peregrinación. En San Javier se ha declarado epidemia y todos se hallan deseosos de trasladarse, pero Rábago y Terán decide en I755 llevar el presidio y misiones de San Javier a San Marcos, y a fines de 1766 al río Guadalupe, vista la imposibilidad de practicar regadíos en San Marcos. ${ }^{\text {I05. Para }}$ entonces las órdenes han sido dadas en México para llevar a cabo, bajo el patrocinio de Don Pedro Romero de Terreros, la fundación de San Sabá: alli se trasladaría, aumentando la fuerza a cien hombres, la guarnición de San Javier. Fray Alonso Giraldo de Terreros, que dirigiría la misión, recoge nueve familias tlaxcaltecas a su paso por Saltillo, y en abril-mayo de I757 se establecen, en efecto, la misión y presidio de San Luis de Amarillas. Y contra todo lo esperado, la misión queda desierta; los apaches sólo están en ella de paso y se niegan a ser evangelizados. En ella permanecen los tres queretaranos presididos por Fray Alonso Giraldo - luego llegará un fernandino-, cinco soldados de custodia, ocho o diez tlaxcaltecas y algunos indios sirvientes. En el presidio hay de trescientas a cuatrocientas personas, de las que doscientas treinta y siete son mujeres y niños. Se rumorea la guerra existente

I02 Ibid, III, 242-273. La fundación de San Javier como presidio nuevo, no con los soldados de otra procedencia, no se decidió hasta I75I, en Junta de Guerra y Hacienda de II de marzo, y nunca se llegó a construir. A. G. I., Guadalajara, 197.

Io3 Castañeda, op. cit., III, 3I0-33I. Alessio Robles. Coahuila y Texas, 518-519.

I04 Castañeda, op. cit., III, 340-345; $356-358$.

105 Ibid, III, $363-368,376-379,384-385$. 
entre los apaches y los indios del norte. Los apaches desaparecen de la región, y el 16 de marzo de 1758 llegan los enemigos: unos dos mil texas, vidais, tonkawas, yojuanes y, principalmente, comanches. Dos frailes encontraron la muerte en las violencias desencadenadas sobre la misión. ${ }^{106}$

El terror invade Texas al divulgarse los sucesos ocurridos, hasta que el nuevo gobernador, Don Diego Ortiz Parrilla, propone dirigir una campaña contra los invasores. Estos se han retirado a espaldas de San Sabá, al San Marcos, Guadalupe, San Antonio y Medina, y han decidido no tener residencia fija hasta haber vencido a los norteños, por temor a una sorpresa, con lo cual San Sabá venía a ser inútil. Por lo demás, los apaches eran invariablemente derrotados por sus enemigos. ${ }^{\text {roy }}$

La junta de 3 de enero de 1759 congregó en San Antonio a Barrios, gobernador de Texas; Martos, que lo era de Coahuila; Ortiz Parrilla, capitán de San Sabá; Rodríguez, de Río Grande, y Ramírez, de Bahía; Eca, teniente de San Sabá, y Castillo, de Monclova. Estos siete oficiales decidieron las características de la campaña a realizar.

Expedición ésta de envergadura, pues tomaron parte en ella más de quinientos hombres procedentes de todas las provincias más o menos próximas.

La composición de la fuerza era ésta:

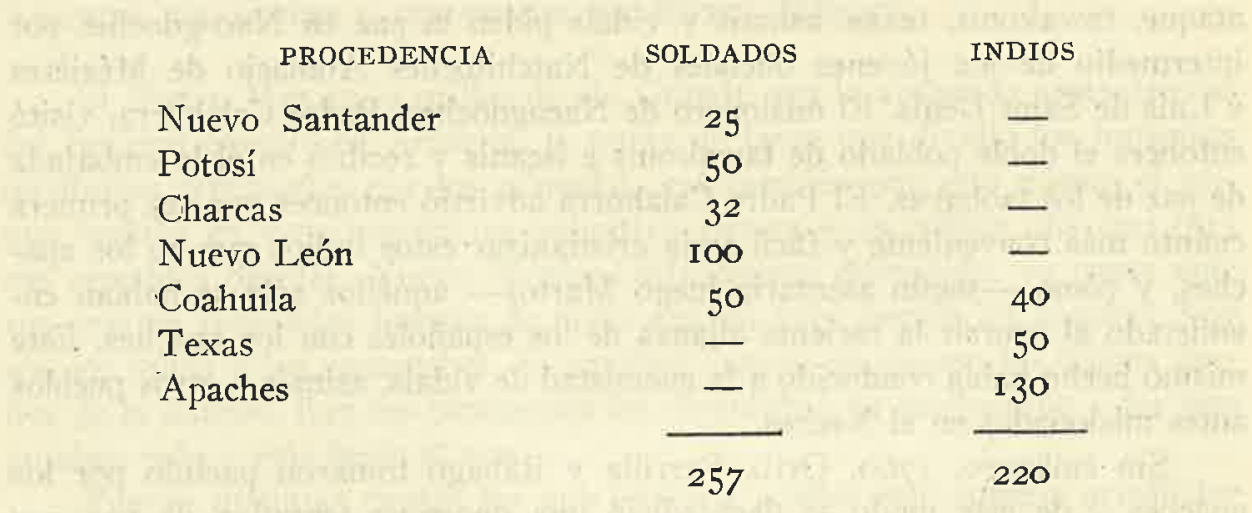

I 06 Ibíd., 391-402. Las vicisitudes del presidio de San Javier hasta su definitivo mantenimiento en San Sabá, en Amarillas a S. M', México i de noviembre de I756, A. G. I., Guadalajara, 197. En la "Nota de los cargos" contra el gobernador de Texas, y luego de Coahuila, Barrios y Jáuregui consta "que en la provincia de Texas tuvo comercio de pólvora y municiones con los indios bárbaros inmediatos y presunciones bastantes de que estas municiones sirvieron para el ataque ejecutado contra el presidio fronterizo de San Sabá en que fueron muertos los religiosos misioneros de San Francisco por los indios". Cruillas a Arriaga, núm. 5 I, México, iz de octubre de 1764. A. G. I., Guadalajara, 302.

ro7 Castañeda, op. cit., IV, I о I, I08-109. Puede verse también: "Relación de los sacrílegos arrojos y sangrientos homicidios acaecidos en los confines del reino de los Texas en el río de San Sabá este año de 58 a i 6 de marzo". B. N., I8758-i5. 
Los soldados de los presidios de Texas y los milicianos de Nueva Vizcaya y de las estancias de Coahuila hacían elevar el número de presidiales y voluntarios a trescientos sesenta hombres. ${ }^{08}$ A la cabeza de estas tropas, Ortiz Parrilla obtuvo la sorpresa de un poblado tonkawa sobre el Brazos, con muerte de cincuenta y cinco enemigos, de los que hizo además ciento cuarenta y nueve prisioneros. Gran cantidad de ganado de San Sabá fue recogido aquí.

Cuatro días después - 6 de octubre de I759- se hallaba ante el poblado de los taobayas, donde encontraba una verdadera fortaleza con su estacada protegida con un foso lleno de agua y cientos de indios - taobayas, comanches, tawakonis, wichitas - armados de rifles. La bandera francesa tremolaba sobre las obras de defensa, y catorce individuos de esta nacionalidad fueron avistados entre los enemigos. La batalla se dio, los españoles tuvieron cincuenta y dos bajas y perdieron dos cañones y muchos caballos; el adversario sufrió unas cien bajas y Ortiz Parrilla se retiró, entrando el 25 en San Sabá. ${ }^{109}$

Una ulterior campaña fue diferida y Ortiz Parrilla se dirigió a México a tratar del asunto. Mientras, Don Felipe Rábago y Terán, antes comandante de San Javier, recibía el mando de San Sabá. ${ }^{109} \mathrm{La}$ expedición de Ortiz, aunque concluída en retirada, daba sus frutos: en 1760 , cuando se esperaba un ataque. tawakonis, texas, asinais y vidais piden la paz en Nacogdoches por intermedio de los jóvenes oficiales de Natchitoches Atanasio de Mézières y Lutis de Saint Denis. El misionero de Nacogdoches, Padre Calahorra, visitó entonces el doble poblado de tawakonis e iscanis y recibió en él la embajada de paz de los taobayas. E1 Padre Calahorra advirtió entonces por vez primera cuánto más conveniente y fácil sería cristianizar estos indios que no los apaches, y cómo - según asentaría luego Martos- aquéllos sólo se habían enemistado al ocurrir la reciente alianza de los españoles con los apaches. Este mismo hecho había conducido a la enemistad de vidais, asinais y otros pueblos antes misionados en el Neches.

Sin embargo, I760, Ortiz Parrilla y Rábago tomaron partido por los apàches $\mathrm{y}$ de este modo se desperdició una oportuna tentativa de paz por parte de los "indios del norte". iro

Rábago, aunque de historial poco limpio, capitán sucesivamente de San Javier, Sacramento y Amarillas, era hombre de indudable temple y competencia. Bajo sus auspicios se llevará a cabo la tercera y última tentativa de conversión de los apaches. Para tomar posesión del presidio de Amarillas

\footnotetext{
I 08 Ibid, IV, 1 I 4-I I 8 , I 25.

I og Ibid, IV, I 26-I 30 .

I I Ibid, IV, I 40-I 47.
} 
en San Sabá marchó directamente abriendo camino desde San Fernando de Austria en Coahuila. Por entonces, muchos indios norteños acudían durante el invierno a los presidios de Texas. Hacia marzo se esperaba siempre ataque comanche. Rábago reconstruyó y fortificó el presidio y envió una partida de exploración -que sólo llegó hasta el Pecos- en busca del camino de Nuevo México. Los apaches se mostraban ahora más dóciles, pero deseaban congregarse siempre a espaldas de San Sabá. Así se establecieron a principios de i762 las misiones de San Lorenzo y la Candelaria en el Nueces Alto. Pronto hubo en ellas ochocientos apaches, y se pidió nuevo presidió allí, a cuarenta leguas de Amarillas. La situación, sin embargo, no era fácil, porque habiendo fracasado las siembras, los indios se dispersaban para acudir a las cacerías y los frailes dependían de los suministros de Río Grande y San Antonio. Lo más grave es que los mismos apaches volvían a cometer depredaciones en los ganados de colonos y misiones, replanteándose la misma situación que treinta años atrás. ${ }^{\mathbf{1 1 1}}$

En I763, Don Lorenzo Cancio, entonces capitán de Monclova, fue enviado a visitar San Sabá, ${ }^{112}$ pero el resultado de este asunto se demoró hasta conocer el informe que debía emitir el también visitador marqués de Rubí, que había de dictaminar la supresión del presidio.

\section{Apaches, franceses y comanches en Nuevo México}

Si Nuevo México, a orillas de río Grande, era la avanzada septentrional del Imperio español en América, la punta de lanza que dividía los inmensos territorios señoreados por los nómadas, era también por esto mismo el primer bastión en experimentar su primitiva fiereza y en recibir una tras otra sus repetidas oleadas. Nuevo México, difícilmente defendido, ve pasar ante sus puertas renovadas huestes de invasores. Si ayer fueron los apaches, hoy son los yutas y los comanches. Si aquéllos fueron un tiempo los únicos dueños de la llanura, hoy los comanches les disputaban su predominio y los empujaban más y más hacia el sur.

Fueron distintas causas las que hicieron posible este empuje arrollador de la nueva raza que entra en la pradera. Una de ellas, su mayor combatividad de prieblo en estado cultural más atrasado, frente a los apaches que se inician en la sedentarización por la agricultura, después de un contacto de más de tres siglos con los pueblos y los españoles. De la misma manera su número. $Y$, finalmente, su contacto con los franceses, que les proporcionaron las armas de fuego que los españoles rehusaban a los apaches. 
En I726, estando Rivera en Santa Fe, t11vo noticia de la presencia de los franceses algo más al norte, entre los comanches, y nos dejó la siguiente interesante pintura de éstos: "Todos los años, por cierto tiempo, se introduce en aquella provinncia (de Nuevo México) una nación de indios tan bárbaros como belicosos; su nombre comanches, nunca baja de mil y quinientos su número, y su origen se ignora, porque siempre andan peregrinando $y$ en forma de batalla, por tener guerra con todas las naciones, y así se acampan en cualquier paraje, armando sus tiendas de campaña que son pieles de cibolas, y las cargan unos perros grandes que crían para este efecto. $\mathrm{Su}$ vestuario de los hombres no pasa del ombligo, y el de làs mujeres les pasa de la rodilla; y luego que concluye el comercio que alli los conduce, que se reduce a gamuzas, pieles de Cibola y los indios de poca edad que cautivan (porque los grandes los matan) se retiran, continuando su peregrinación hasta ctro tiempo, y habiéndome parecido ser singular esta nación, la puse en esta
descripción para su noticia". ${ }^{13}$

Tan bárbaros como belicosos, los llama Rivera, y ciertamente era así. Pero su potencia guerrera se vio multiplicada cuando empezaron a adquirir las armas europeas de los franceses. Estos, desde sus bases del Misisipí, intensifican su penetración en la pradera y abren nueva vía hacia los establecimientos españoles del oeste. En I739, por primera vez, la expedición francesa de los Mallet, llegaba a Nuevo México, a Pecuries, por el Platte, y regresaba a Nueva Orleans por el Canadian. ${ }^{114}$ Desde entonces, en doce años alcanzan Nuevo México no menos de siete grupos de comerciantes franceses, que por otra parte establecen en Fort Cavagnolle en el Misisipí una importante factoría cuya actividad se extiende a los osages, misuris y kansas. Desde 1746 empiezan a pactar alianzas con los comanches y jumanos y dos años después treinta y dos comerciantes franceses se hallan vendiendo escopetas a los comanches en la Jicarilla. En 1749, Febre, Satin y Riballo se presentan en Taos, y en I750 y I757 les siguen otros once. En I752, desde los Grandes Lagos, desde Michilimakinac, por Fort Cavagnolle, alcanzan Nuevo México,
Chapuis y Feuilli. ${ }^{115}$

El contacto de franceses y españoles, sin embargo, no pasó de aquí; los franceses no lograron asentamientos duraderos más al oeste del Misisipí, y de aquí a las provincias españolas había demasiada distancia, salvo en Texas.

I13 Diario, V. Alessio Robles.

I14 Extracto del Diario de los Mallet en Margry, Mémoires, VI, $445-462$. Ibíd., páginas 462-465, certificación expedida por Don Juan Páez Hurtado, teniente de gobernador y alcalde
mayor de Santa Fe, en 30 de Orleans pidiendo mercancias. Vid. Castafied y carta del vicario Roibal al P. Beaubois de Nueva Thomas, Plains Indians, $\mathbf{1 5 - 2 0 .}$

I 5 Bolton, op. cit., 391-405. 
El segundo cuarto del siglo XVIII no es, por otra parte, época afortunada para Luisiana. Las rebeliones natches y las hostilidades de los chickasaws no dieron momento de respiro durante años a la afligida colonia francesa. "I73 I marca su vuelta al gobierno por la monarquía, por renuncia de la Compañía de las Indias. Sólo a mitad del siglo empieza a advertirse algún desarrollo, debido sobre todo al lento crecimiento demográfico. Fracasado el primer objetivo - la ocupación de las supuestas ricas minas españolas de Nuevo México-, el comercio con los establecimientos españoles pronto se mostró como un negocio dudoso. Practicable sólo en Texas con cierta continuidad, las operaciones fueron siempre, sin duda, de muy pequeña envergadura, y en realidad no rebasaron el plano de mero intercambio de economías locales complementarias. Por ello mismo, la supresión del comercio impuesta por Rivera se hizo muy pronto insostenible, y otro tanto ocurre cuando es Saint Denis quien quiere cortar el tráfico. Luisiana siempre dependió de Texas para su aprovisionamiento de caballos y reses de las misiones; Adaes y Béjar se surtían de harinas y verduras de Natchitoches. En cuanto a mercancías francesas, las que adquirían los españoles no subian en valor a más de doscientos pesos al año; "la razón -dice un testimonio francés-- es que nuestras mercancías son infinitamente más caras que las que los ingleses les proporcionan, y que no son de tan buena calidad". ${ }^{116}$ Los incidentes fronterizos, sobre todo el traslado de Natchitoches a la orilla derecha del Rojo y la presencia de Blancpain en el Trinidad, nunca adquirieron caracteres de verdadera gravedad. ${ }^{117}$ Del mismo modo la capacidad adquisitiva de los

I 6 Mémoria sobre Natchitoches, en Margry, Mémoires, VI, 228-236. Los españoles, según este documento, "pagan a sus tropas con estas mercancías inglesas a razón de cuatrocientos cincuenta pesos a cada soldado por año, sobre las que el gobernador que se las proporciona obtiene un beneficio de por lo menos el seiscientos por ciento". Los franceses codician el ganado español, sobre todo las vacas. La instrucción de la Compañía de las Indias al gobernador Périer (ibid, VI, 226-227) le ordena procurar adquirir ganado español. Sobre la interrupción de relaciones comerciales, Castañada, op. cit., II, 265; III, 76; IV, 59, 67-68. Esto que Giraud 1lama "mala fe de los españoles" fue una de las causas de falta de vitalidad de Luisiana. Giraud, Marcel, France et Lonisiane, 198. Lo que era indudablemente activo era el tráfico de los franceses entre los indios. Otros testimonios, en cambio nos hablan de los viajes de soldados y paisanos de Texas, en balsas, a Nueva Orleans, llevando efectos y hasta sillas de montar y trayendo ropas. Hasta cuarenta individuos de Texas se hallaban en la capital de Luisiana en un momento de 1749. Revillagigedo a Ensenada, México, 29 de junio de I753. A. G. I., Guadalajara, 400.

I 7 En noviembre de I735, Saint Denis hizo pasar el presidio de Natchitcches que estaba en una isla, en el río, a la orilla derecha del Rojo, habiendo concluído el traslado en agosto siguiente. Castañeda, op. cit., III, 82. Sabemos que Revillagigedo se abstuvo de tomar cartas en el asunto por no constar que el Colorado (Rojo) haya sido la frontera. Sin embargo, hasta I 736 la orilla derecha del río había sido llamada por los franceses Terré d'Espagne, según consta del viaje de la Harpe y de la Memoria anónima. Margry, Mémoires, VI, ibíd. Pero la convivencia de españoles y franceses se refleja, mejor que en el ridiculo episodio de Blondel, o en este de la ubicación del fuerte de St. Denis, en la ayuda que los españoles prestaron al ser éste sitiado por los indios en I730. Castañeda, op. cit., III, 77. Hacia I 750 parece se hizo por la parte francesa el más serio intento de ampiliar su puesto de Natchitoches, cuando llevaron tropas y familias en 
pobres establecimientos españoles de Nuevo México no debió abrirles demasiadas perspectivas para su comercio de contrabando y, comenzada poco después la guerra de los Siete Años, terminando con la cesión de Canadá y Luisiana a Inglaterra y España, las anteriores tentativas quedaron en algo casi anecdótico. Sin embargo, dejaron una huella profunda en la pradera y, de rechazo, en la frontera española.

En efecto, las armas europeas estaban ganando una batalla entre los indios. Los comanches, dotados de la movilidad de los nómadas, que no hizo sino altmentar cuando conocieron el caballo, se pusieron en contacto con los franceses antes que los apaches, a pesar de haber sido los últimos en llegar a la pradera. Desde este momento - hacia I725- interfirieron los comanches a sus ya tradicionales enemigos el paso a las factorías francesas, impidiendo así que adquirieran las armas europeas que los españoles no les vendían. La misma presencia de los franceses canalizó la migración comanche hacia las proximidades del Misisipí, forzando a los apaches a replegarse hacia el este, al Pecos, o hacia el sur, al río Grande. ${ }^{118}$ De esta manera, mientras los comanches presionan al norte de Nuevo México, los apaches empiezan a agolparse a todo lo largo de la frontera oriental de las provincias internas. I.as consectencias son pronto visibles.

La apachería fugitiva de los comanches y de sus aliados pawnees, tobayas, vidais y demás tribus vecinas al Misisipí se precipita contra las poblaciones españolas. Sus asaltos se convierten en acontecimientos casi cotidianos. Desplazados de los cazaderos de bisontes, se vuelven los apaches con mayor insistencia hacia los rebaños de Nuevo México y Texas. En esta última provincia, donde en tiempos de la visita de Rivera su presencia era una pincelada fugaz y secundaria, años después son el azote de los ranchos y misiones. Cuando ocurre el desastre de San Sabá en I758, ya los apaches han retrocedido al sur de esta posición y tratan de situarse a la defensiva, a retaguardia de los españoles. Después de r76o sus correrías les llevan a hostilizar hasta el presidio y misiones de la Bahía: ' 19 . En Nuevo México, mediado el siglo, todas las antiguas parcialidades apaches que en otro tiempo ocupaban regiones muy distantes se hallan ahora concentradas sobre El Paso. En el norte, los jicarillas han cedido a los yutas y comanches la puerta de entrada de Nuevo México desde I730; piden misioneros en Taos y pretenden pasar a establecerse entre los navajos; por parte de los españoles es inútil que el go-

\footnotetext{
cuatro barcos de guerra y treinta y seis mercantes, con ánimo de poblar Cadodachos, Pointe Coupé, Cirimó y el mismo Natchitoches. Pero se vieron obstaculizados estos propósitos por iz escasez cle bastimentos $y$ la falta de agua, que hacía innavegable el rio Colorado. Revillagigedo

a. Enı,enada, México, 29 de junio de I753. A. G. I., Guadalajara, 400.
I I.8 Thomas, Plains Indians, 58-59.

I 9 Castañeda, op. cit., IV, 32 .
} 
bernador pida la erección de un presidio en esta localidad o en la Jicarilla. Hacia 1740 , los comanches han alcanzado el Canadian y los faraones han bajado a Alburquerque, mientras los cuartelejos y palomas se sitúan junto al Pecos, y antes de mediar el siglo ya los comanches han causado ciento cincuenta muertos en Pecos y atacan durante Galisteo. El predominio de los comanches es tan grande que sus antiguos aliados yutas se unen ahora a los apaches. Toda la frontera oriental sufre los embates de los bárbaros. I2I Los vecindarios de los pequeños núcleos afluyen en busca de refugio a las localidades más considerables. Así aumenta la población en Santa Fe, Pecos y Galisteo, sin que esto, por otra parte, contuviese la ruina del país. ${ }^{122}$

Finalmente, hacia la mitad del siglo, los apaches han llegado a cruzar el río Grande, y ya en I 748 Berroterán nos los ha mostrado arranchados en el Bolsón, en número de más de cuatrocientos, absorbiendo y reemplazando a los antiguos tobosos, ya totalmente batidos por los españoles, que van a tener ahora en aquéllos nuevos y más temibles enemigos.

Sin embargo, Nuevo México, frente a su situación angustiosa, subsistía y resistía. Durante las tres décadas largas de Rivera a Rubí, su frontera noroccidental con los navajos se mantuvo en paz, ${ }^{123}$ aunque fracasaron las misiones intentadas para ellos en Cebolleta y Encinal. La reconstrucción del país después del hundimiento de I680 continuaba con toda efectividad, y a mediados de siglo habíase rebasado el índice demográfico de aquella fecha. Si para el momento de la rebelión se calculan algo menos de tres mil españoles, la cifra de 1744 se aproxima a cuatro mil. Y la densidad ha aumentado notablemente, pues la recongutista no ha sido completa y al sucederse las hostilidlades apaches y comanches se producirá una reconcentración de los habitantes de los principales núcleos. Y aún hay que advertir que por esta misma época tiene lugar la fundación del a villa de Tomé junto a Alburquerque, en la región central de Nuevo México, ${ }^{24}$ y la repoblación de Sandía.

La sucesión de gobernadores no introdujo alteraciones de importancia

I 20 Después de la feria de Taos, los comanches intentaron sorprender Galisteo. La vigilancia del gobernador, a quien llamaban "Capitán muchacho", por ser mozo, lo impidió, y habiendo sufrido trescientas bajas hubieron de aceptar la paz. Revillagigedo a Ensenada, México, 28 de junio de I753. A. G. I., Guadalajara, 230.

I I Thomas, op. cit., 7, I 7, I $8,29-30$.

I22 Ibid, 25-36,

123 Worcester, Donald E.: The Navaho during the Spanish rogime in Nequ México. (New Mex. Hist. Rev., XXVI, 2, April 1951, 101-118), págs. 109-112. Reeve, Navaho-Spanish Wars, 1680r770. (New Mex. Hist. Rev., XXXIII, 3 octubre de 1958, 204-23r), págs, 230-231, y The Navaho-Spanisli Peaces 1720's-1770's (New Mex. Hist. Rev., XXV, I, Jan, 1950, 9-40).

124 La cifra de cuatro mil españoles abarca sólo los comprendidos en la porción septentrional de la provincia, sin incluir los del núcleo de El Paso. Los indios en el mismo distrito suman unos nueve mil quinientos. Sobre la fundación de Tomé, vid. Ellis, Florence Hawley, Tomé and Father J. B. R. N. M. H. R, XXX, 2 abril de I955, 89-II4; 3 julio de I955, 195-2210. 
en la vida del país, cuyo principal problema - la amenaza india exteriorsólo Vélez Cachupín supo advertir con clarividencia, logrando una serie de paces que dieron días de tregua a Nuevo México y fueron ocasión sumamente propicia para la captación de los comanches en el plano económico, como lo muestra el hecho de que se reanudase la hostilidad al prohibirles Codallos la asistencia a la feria. ${ }^{125} \mathrm{La}$ realidad y entidad de este comercio se hace patente en el hecho de que a mitad del siglo XVIII se regularice la frecuencia anual del cordón de carros y mulas que desde Chihuahua subía a Santa Fe. ra6

Los apaches sobre Nueva Vizcaya

En el preciso año de I748, apenas quedaban seis o siete indios insumisos de todas las naciones bárbaras que habían ocupado el Bolsón, pero éste se había vuelto a llenar de apaches, que si aún no se habían mostrado hostiles, no dejaban de suscitar algún recelo en los españoles. Sin embargo, en un primer momento incluso se sirvieron de ellos para capturar las últimas cuadrillas de conchos. ${ }^{12}$ ' Pero la situación de Nueva Vizcaya y Coahuila sería siempre la de tener uno de sus costados en continuo riesgo, a no ser que se procurase cerrar la boca del Bolsón, pues ya se daba como natural que a una oleada de bárbaros seguiría otra, "como las olas del mar", dice Berroterán. El capitán de Conchos llega a proponer, en vista del problema, que su presidio y el de Mapimí se trasladen más al norte, al este de la Junta de los Ríos y a Huajoquilla, última población de Nueva Vizcaya, respectivamente. ${ }^{\mathbf{2} 8}$ Pero él mismo desconfía de la eficacia de estas disposiciones, pues desde la Junta al presidio de San Juan Bautista no hay un solo paraje donde establecerse, ${ }^{129}$ y aun cuando esto fuera posible y se construyesen varios fuertes de doce en doce leguas, ni siquiera esto podría impedir la entrada en el Bolsón de los muchos indios que hay al norte, así como los presidios de Nueva Vizcaya no habían evitado los robos, muertes y estragos que habían ejecutado en las poblaciones y mucho menos quedando los presidios tan alejados y batidos por el frente y la retaguardia. Finalmente, concluye Berroterán, "bien puedé ser provechoso en el ahorro de sus situaciones, pero si a su demolición viene

125 Thomas, Plains Indians, 25-38 y 57-58. I26 Moorehead, Max L. Spanish transportationt in the Southrest, $1540-1846$ N. M. H. R.,
XXXIII, 2 abril de 1958, 107-122. Pág. I15.

127 "Informe que en el año 1748 hizo al virrey de Nueva España conde de Revillagigedo el capitán Don José de Berroterán sobre los principales sucesos ocurridos en la Nueva Vizcaya y 1748". Copia en A. G. I., Guadalajara, ejecutó contra los indios enemigos. México, 17 de abril de tomo I, 161-224. Arts. 55-57. I 28 Ibid, arts. 80 y 83 .

I 29 Ibid, art, $8 \mathrm{I}$. 
la venida de las naciones para dominar los parajes, será lo mismo que cortar el comercio, la comunicación y abrir margen para que frecuentemente haya robos, muertos..." I30

Cuando Berroterán hizo el gran informe de I748 llevábase ya, en efecto, varios años deliberando sobre la posibilidad de reducir nuevamente los efectivos militares situados en la frontera.

Antes que Revillegigedo, a quien Berroterán dirige su escrito, ya Fuenclara había tratado de suprimir los presidios fundados por el duque de la Conquista en Sonora ${ }^{\text {3 } 31}$ y poco después, en 1745 , encargaba al alcalde mayor de la villa de León, Don Francisco Benítez Murillo, una pesquisa secreta sobre la utilidad de los existentes en Nueva Vizcaya; ${ }^{13^{2}}$ las sospechas del virrey parecieron confirmadas cuando el alcalde mayor de la villa de León le informó del resultado de su investigación que le había llevado a considerar inútiles los cinco presidios de la cordillera, que bien podían reducirse a uno solo. El único útil parecía ser el de Janos. Las personas a quienes Benítez Murillo había consultado dijeron ser también ocioso el del Paso; que tanto allí como en otros lugares había mucha población, la gente transitaba sin escolta y la tierra estaba pacificada sin que se hiciese campaña desde hacía mucho tiempo; los soldados se ocupaban en jugar y servir a los capitanes, y éstos vivían en las haciendas o en los reales de minas, a muchas leguas de los presidios. ${ }^{13} 3$ Muchos de los declarantes creían extinguido tiempo atrás el presidio de Pasaje; en realidad, éste, que era el sexto presidio de la cordillera, había quedado a cargo del conde de San Pedro del Alamo, en cuyas tierras estaba situado, y que lo solicitó así, lo que fue aprobado por el Consejo de Indias en $\mathrm{I} 743$, ahorrando de este modo la Real Hacienda trece mil cuatrocientos veinte pesos al año. ${ }^{3} 34$ Lo que en general proponían los consultados en la pesquisa de Benítez Murillo era la erección de presidio en la Junta de los Ríos, pero un examen del lugar en 1748 en el que tomaron parte Don José de Idoiaga, capitán de San Bartolomé; Don Pedro Rábago Terán, gobernador de Coahuila, y Don Fermín de Vidaurre, capitán de Mapimí, '35

I30 Ibid, art. 84 .

131 Fuenclara a Vildósola, México, 15 de junio de 1744, A. G. I., Guadalajara, 188.

132 Fuenclara a Benitez Murillo, México, 24 de junio de 1748, A. G. I., Guadalajara, 191.

133 Benitez Murillo a Fuenclara, Villa de León, $t^{\circ}$ de octubre de 1745 . Ibid.

134 En 1737 el conde del Alamo había hecho, por encargo del virrey, una entrada al Bolsón y luego siguió manteniendo la tropa para resguardo de Parras y su comarca. Al año siguiente solicitó licencia para hacer guerra defensiva y ofensiva desde alli, a su costa. E! virrey duque de la Conquista informó favorablemente y en $174 \mathrm{I}$ se autorizaron las campañas del conde pidiendo siempre éste antes autorización del virrey. En 8 de octubre de 1743 , a consulta del Consejo de Indias, se suprimió este trámite concediéndose grado de mariscal al conde, según propuso el fiscal de México. A. G. I., Guadalajara, I91.

I35 Kelley, Charles J.: The historic indian pueblos of la Junta de los Rios N. M. H. R., XXVII, 4 oct. I952, 257-295; XXVIII, I jan I953. Págs. 270-273. Castañeda, Our catholic 
produjo informes contradictorios sobre la conveniencia y utilidad de tal guarnición, y el expediente quedó abandonado.

Sin embargo, en I749 el nuevo gobernador de Nueva Vizcaya Don Juan Francisco de la Puerta y Barrera hacía aparecer ya las cosas de otra manera: mientraas que Mapimí y el Valle de San Bartolomé estaban bastante poblados, Chihuahua y el valle de San Buenaventura experimentaban las más crudas hostilidades. Consultados el capitán de Janos Don José Díaz de Carpio, el comercio y minería de la villa y varios particulares, se mostró claro que los enemigos penetraban por el intervalo de treinta y cinco o cuarenta leguas que mediaba entre aquel presidio y el del Paso. Para remediar la situación convendría crear otro junto al valle de San Buenaventura, en el paraje de Ruiz, y una compañía volante en Chihuahua. El valle era vital para Chihuahua y para las comunicaciones con Janos y Sonora; convendría trasladar el presidio de Mapimí a Ruiz y el de San Bartolomé a la villa. Al parecer los apaches de1 Bolsón empezaban a cometer robos en la zona de Julimes, auncue en San Bartolomé los seis capitanes de presidio de la Cordillera le dijeron no era preciso hacer campaña contra Pascual y el Ligero. ${ }^{1}{ }^{6}$

La presión de los bárbaros sumas y apaches coaligados parece haberse desplazado totalmente a la frontera norte de la provincia cuando el gobernador, en respuesta al informe que sobre su carta diera el auditor Altamira, aceptaba la proposición de éste de reducir los presidios del Bolsón a una sóla compañía volante, ${ }^{137}$ insistiendo en la necesidad de proteger el valle de San Buenaventura y Chihuahua.

Pero las ideas del auditor Marqués de Altamira iban más lejos; ${ }^{138}$ mostrando que los seis presidios de la cordillera habían costado ya a la hacienda más de ocho millones de pesos, indica cuánto más económico y eficaz no hubiera sido la creación de poblaciones españolas, y culpa de que no se haya hecho así a los misioneros, que se resisten a que haya blancos junto a los pueblos de indios, imputación de la que en este caso no hemos hallado fundamento alguno. En fin, por el momento Altamira pide se funden poblaciones en el Pasaje, San Juan de Casta - a la otra banda del Nazas-, Santiaguillo -doce leguas antes de Mapimí-, Pelayo - catorce más ade-

heritage, III, 211, 228. La reocupación de la Junta era promovida desde I 746 por Fray Miguel Menchero, comisionado por el custodio de Nuevo México para establecer las misiones que allí habian existido. Sus demandas y los diarios de las expediciones citadas, en A. G. I., Guadalajara, 191. Sólo un misionero había en la Junta a la llegada de los expedicionarios.

I 36 J. F. de la Puerta a Revillagigedo, Chihuahtra, Is de junio de i749. A. G. I., GuadaIajara, I9I.

I37.J. F. de la Puerta a Revillagigedo, Chihuahua, 21 de noviembre de i75o. Ibid.

I 38 Informes del auditor marqués de Altamira. México, 23 de diciembre de I749 y 25 de febrero de I 75 I. Ibid. 
lante de Mapimí-, y Guajoquilla, también en el camino de Chihuahua. Del gasto que esto ocasionase podría encargarse la Casa del Alamo, liberándola en cambio del mantenimiento del presidio de Pasaje, donde ya sólo había diez soldados o sirvientes del conde difunto. Otras dos poblaciones podrían establecerse en el trayecto de sesenta leguas que mediaba entre los presidios de Janos y del Paso: en los ríos de Bachimba o San Buenaventura y de Casas Grandes, por donde se introducían los apaches, gilas, sumas, y mezcaleros. Del Paso a las cinco misiones de la Custodia de Nuevo México de la Junta había otras setenta leguas despobladas: debería colocarse población y presidio de cincuenta hombres hacia la mitad en el paraje de los Pilares y Serranía del Cajón, por donde entraban los bárbaros, encargándose a Rubín de Celis, capitán del Paso, la erección de poblaciones en Palo Clavado, o Llano de la Paz, o San Eleazario, entre su presidio y los Pilares, mientras que de aquí a la Junta se poblaría el Ancón de los Tecolotes y el Ojo de San Francisco, antigua ranchería de los cibolos. Esto permitía la recuperación de toda la cuenca baja del Conchos, al norte de Chihuahua: misiones del $\mathrm{Cu}$ chillo Parado, de la Ciénaga al Coyame, Santa Cruzz de los Cholomes, hacienda de las Hormigas, etc. Dejando sólo una compañía volante de cincuenta hombres en la frontera oriental, en dos trozos que cubriesen de Nazas al Río Florido y de éste al de San Pedro, se crearían compañías milicianas en las poblaciones, protegiéndose las haciendas con los soldados que llamaban "escolteros" que sus dueños tenían.

Tenaz el auditor en su proyecto, consiguió que fuese estudiado en Junta de Guerra y Real Hacienda de 22 de marzo de $1755,{ }^{139}$ en que se resolvió la supresión de los cinco presidios de la cordillera que serán sustituidos por una compañía volante de sesenta hombres "que reconocerá las armas en el río Florido", recorrerá el terreno y visitará Tarahumara y Tepehuana, obligándose a la Casa del Alamo a establecer el presidio del Pasaje en el plazo de dos meses; la formación de Compañías milicianas y la erección de las cinco poblaciones propuestas por Altamira; la fundación de presidio en los Pilares y de población en Palo Clavado, o Llano de la Paz, o de San Eleazario, y en Ruiz o Casas Grandes, con compañía miliciana. A los gastos de esta última se pediría concurriese el comercio de Chihuahua, tan interesado en la realización de este proyecto. Finalmente, se suprimen los dos mil pesos de paz y guerra del gobernador de Nueva Vizcaya.

En decreto de siete de mayo ${ }^{\mathbf{I} 40}$ el virrey Revillagigedo nombró capitán de la compañía volante a Don Bernardo Bustamante y Tagle, que estaba 
nombrado para la de Cerro Gordo, a quien también se encargó la formación de población y de compañía milicianas y el reparto de tierras. La población de Ruiz o Casas Grandes se encomendó a Don Fernando de Velarde, vecino de Chihuahua que había asistido a la Junta. De la fundación de población y presidio en los Pilares se hacía cargo Rubín de Celis, capitán del Paso, que se trasladaría con su compañía a aquel lugar; el capitán de El Paso fundaría la población de San Eleazario; al mismo tiempo, Revillagigedo se proponía una permuta de capitanes: Díaz del Carpio, de Janos, pasaría o cambiaría con Ruiz de Ael de Terrenate; Tagle y Bustamante de Fronteras pasaría al Paso donde reclutaría nueva compañía. Con estos cambios de destino se proponía el virrey evitar que los capitanes adquiriesen fincas e intereses, despreocupándose de la milicia; y resolver las disensiones entre los capitanes y el gobernador de Sonora que habían costado el cargo a Vildósola, y las que existían entre el capitán y vecindario de E1 Paso. ${ }^{\text {14I }}$

Con estas reformas tendría Nueva Vizcaya en su frontera norte tres ijresidios: Janos, El Paso y los Pilares, y dos en la oriental: el de Guajoquilla en que se estableció la compañía volante, y el del Pasaje que se obligaba a mantener la Casa del Alamo. Los intervalos entre los puestos militares se cubrirían con poblaciones.

Sin embargo, la realidad fue que, verificada inmediatamente la supresión de los antiguos presidios, el de los Pilares no se estableció, porque el paraje de San Diego donde debía ser situado carecía de agua durante tres meses, en vista de lo cual Rubín de Celis puso su compañía en la hacienda de Nuestra Señora de Guadalupe de Agua Nueva, con un destacamento de diez hombres en la de Santa Clara, donde quedó por exhorto del corregidor de Chihuahua. Y la compañía volante de Guajoquilla, al mando de Don Bernardo Antonio de Bustamante y Tagle, estuvo ocupada en la entrega de veintidós misiones jesuitas de la Tarahumara al clero diocesano. Por otra parte el comercio y minería de Chihuahua representaron no poder sufragar los gastos de población en Ruiz, insistiendo en la ventaja de colocar allí un destacamento. ${ }^{142}$ Por aquel entonces la violencia de los ataques se había extremado por los apaches gila, sumas, natajes, cholomes, venados, y otros, que habían robado los ganados, muladas y caballadas de todas las haciendas inmediatas a la villa, y "cuando antes se penetraba con toda seguridad, sin recelo de peligro, al Paso del Río del Norte y aun hasta la Nueva México, el día de hoy no se puede salir de las goteras de Chihuahua sin

I 4 I Revillagigedo a S. M. México, io de julio de I75I. Ibíd. I 43 Informes del auditor D. Domingo Valcárcel y del fiscal Dr. Andreu, México, I4 de
abril, I3 de mayo y 22 de mayo de I754. A. G. I., Guadalajara, I94. 


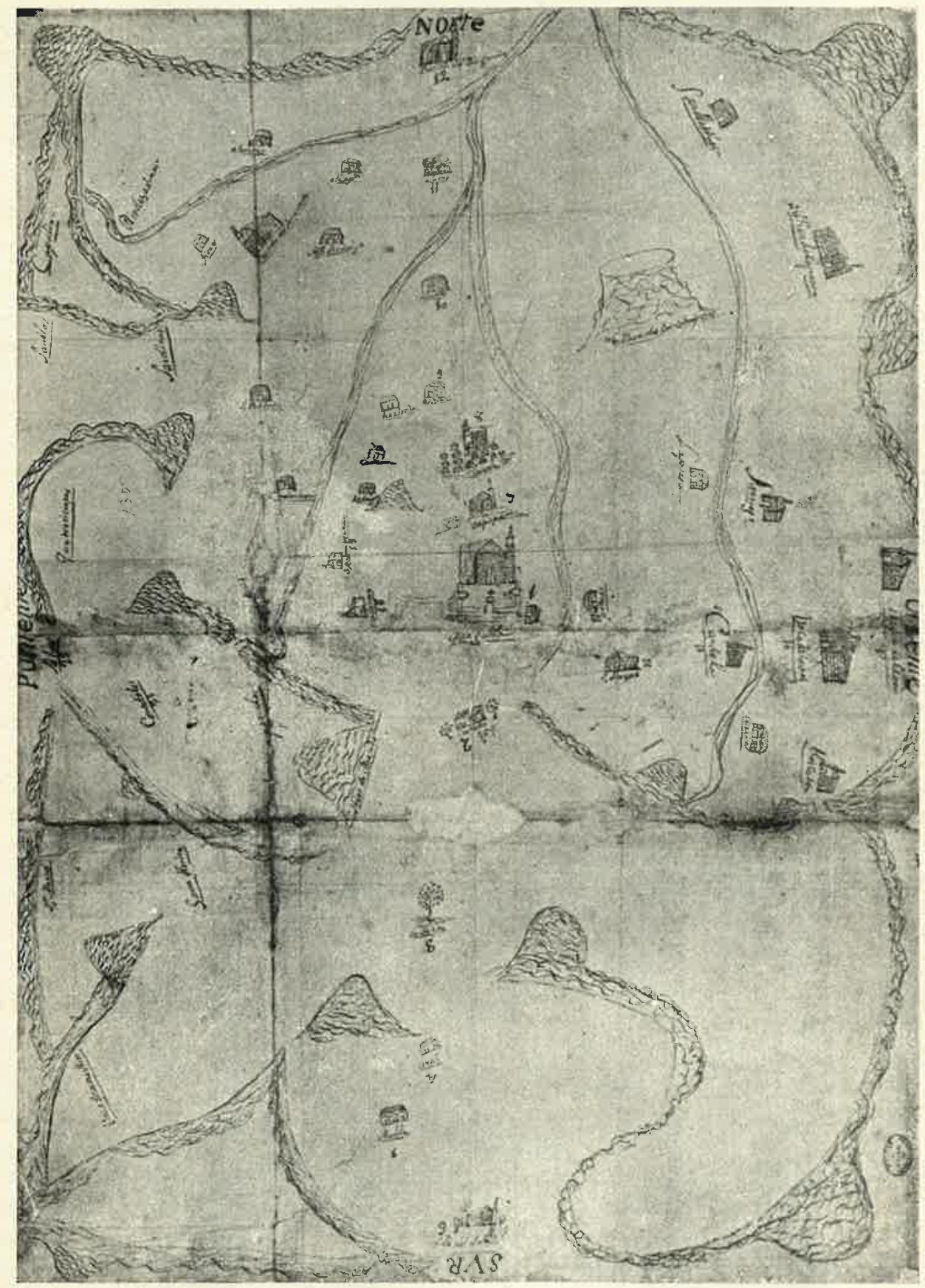

57. Coahuila, por Castilla y Rioja. ¿1730? 


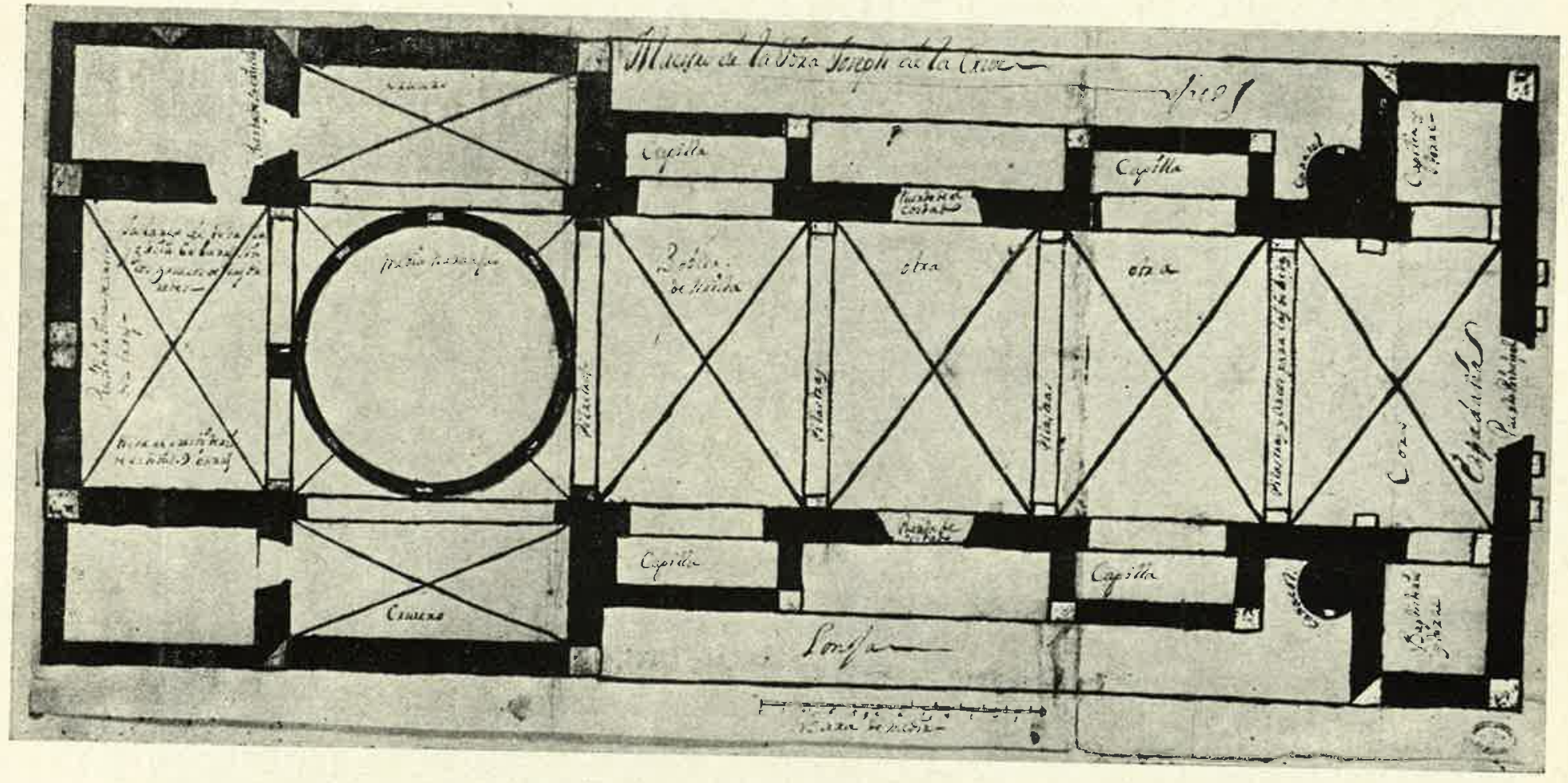

58. Plania de la iglesia de Chihuahua, 1726. 


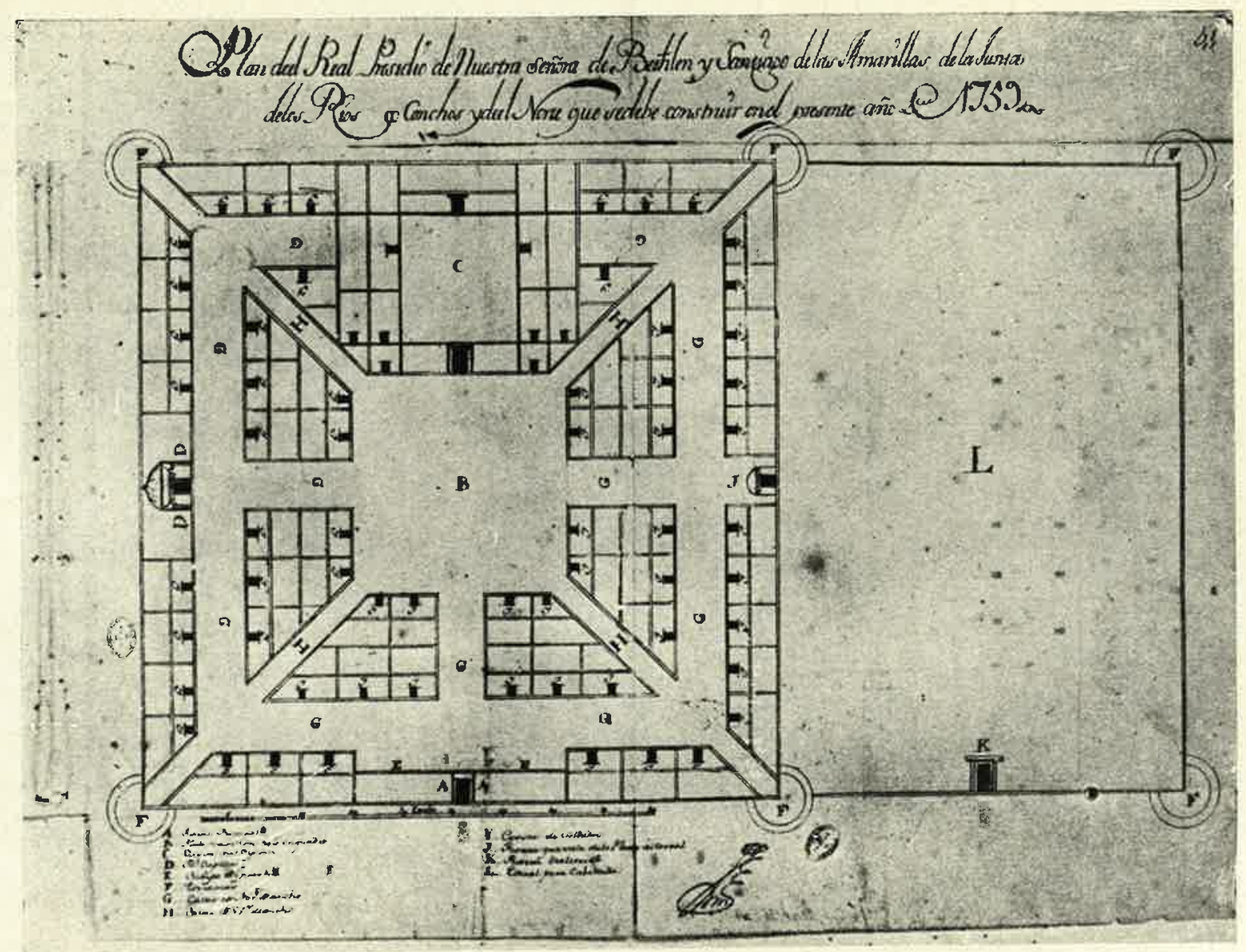

59. Presidio de las Juntas de los ríos Conchos y del Norte. 1759. 


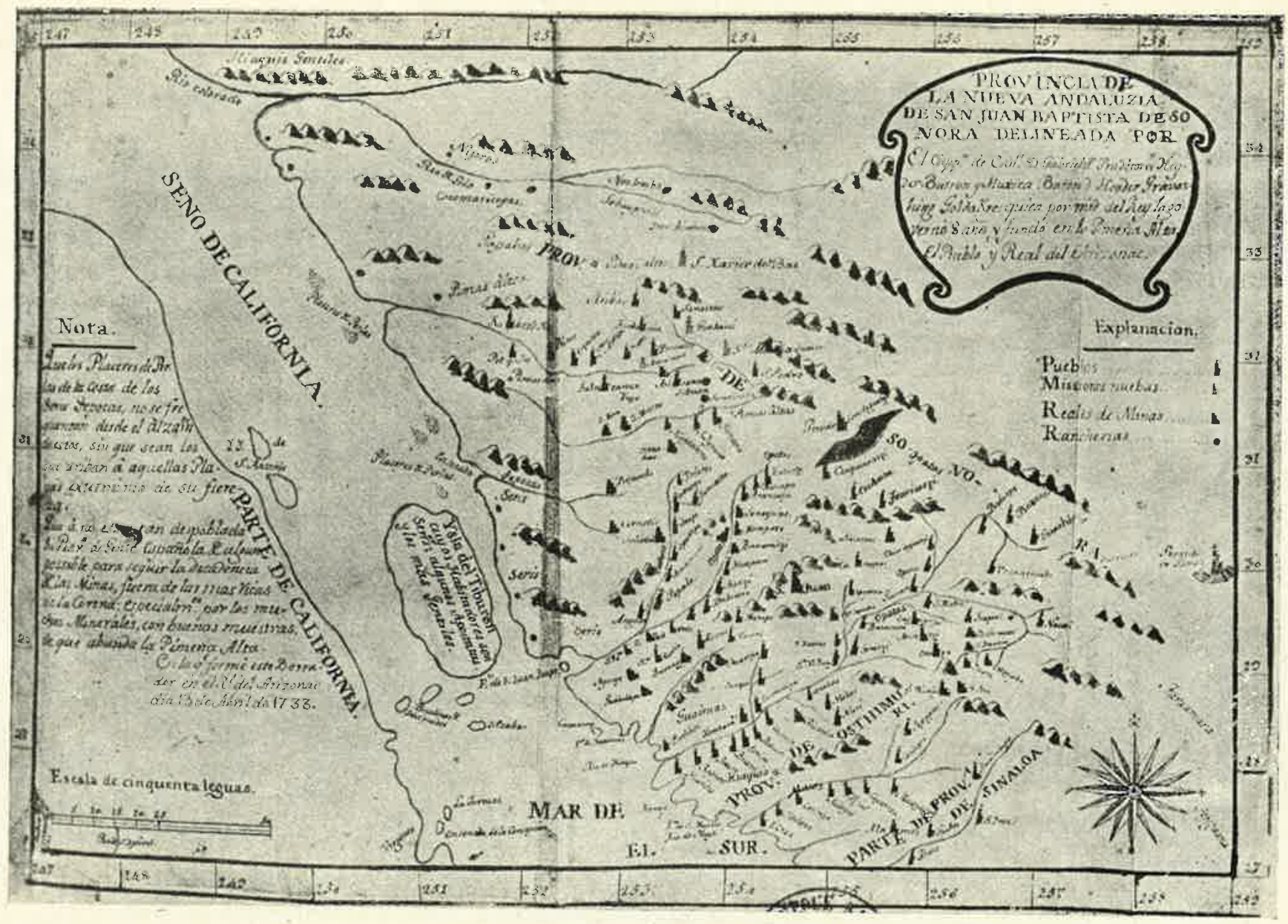

60. Sonora, por el baron de Hayder, 1733 


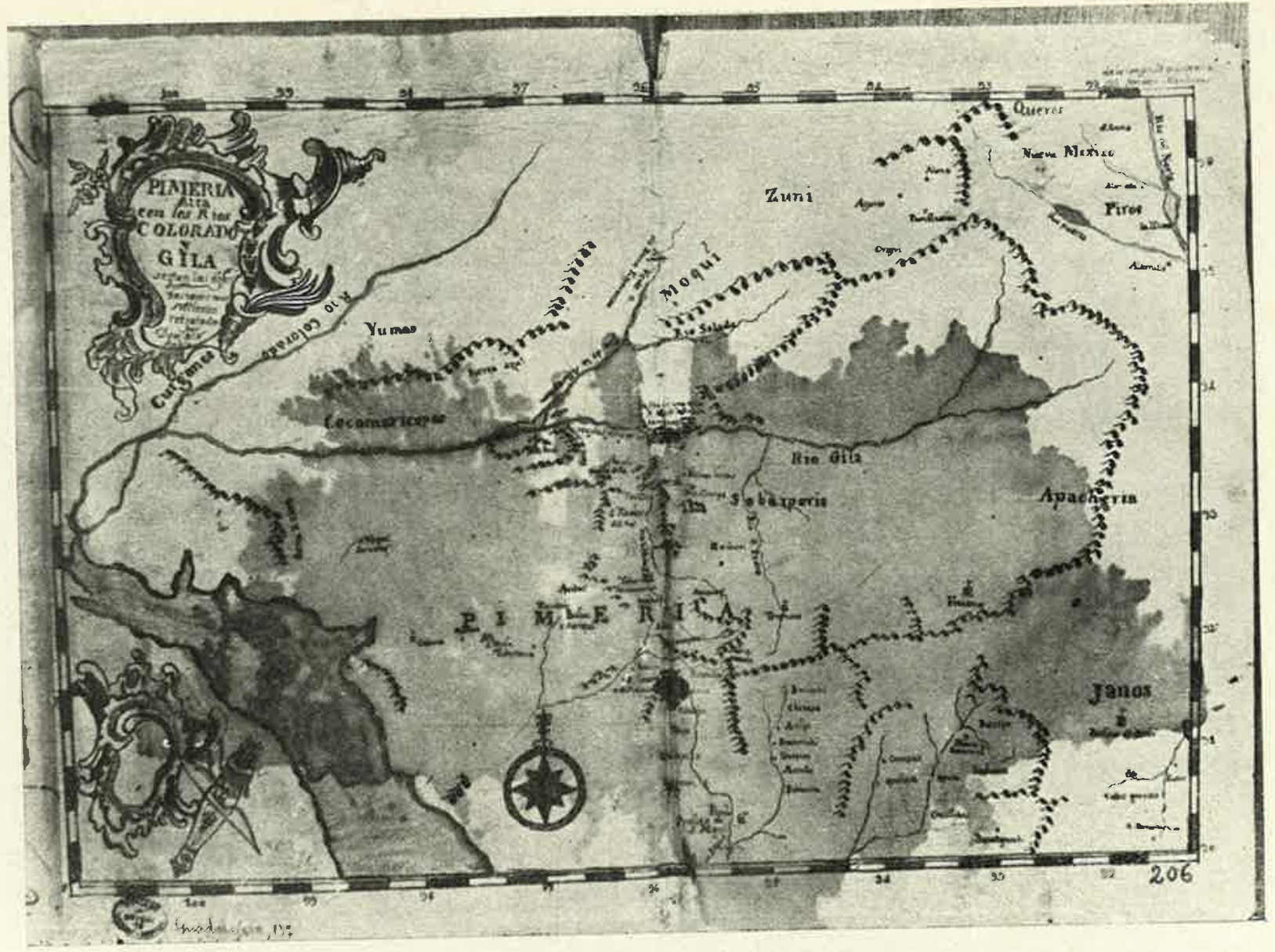

61. Pimeria Alta por Middendorf. 1761. 


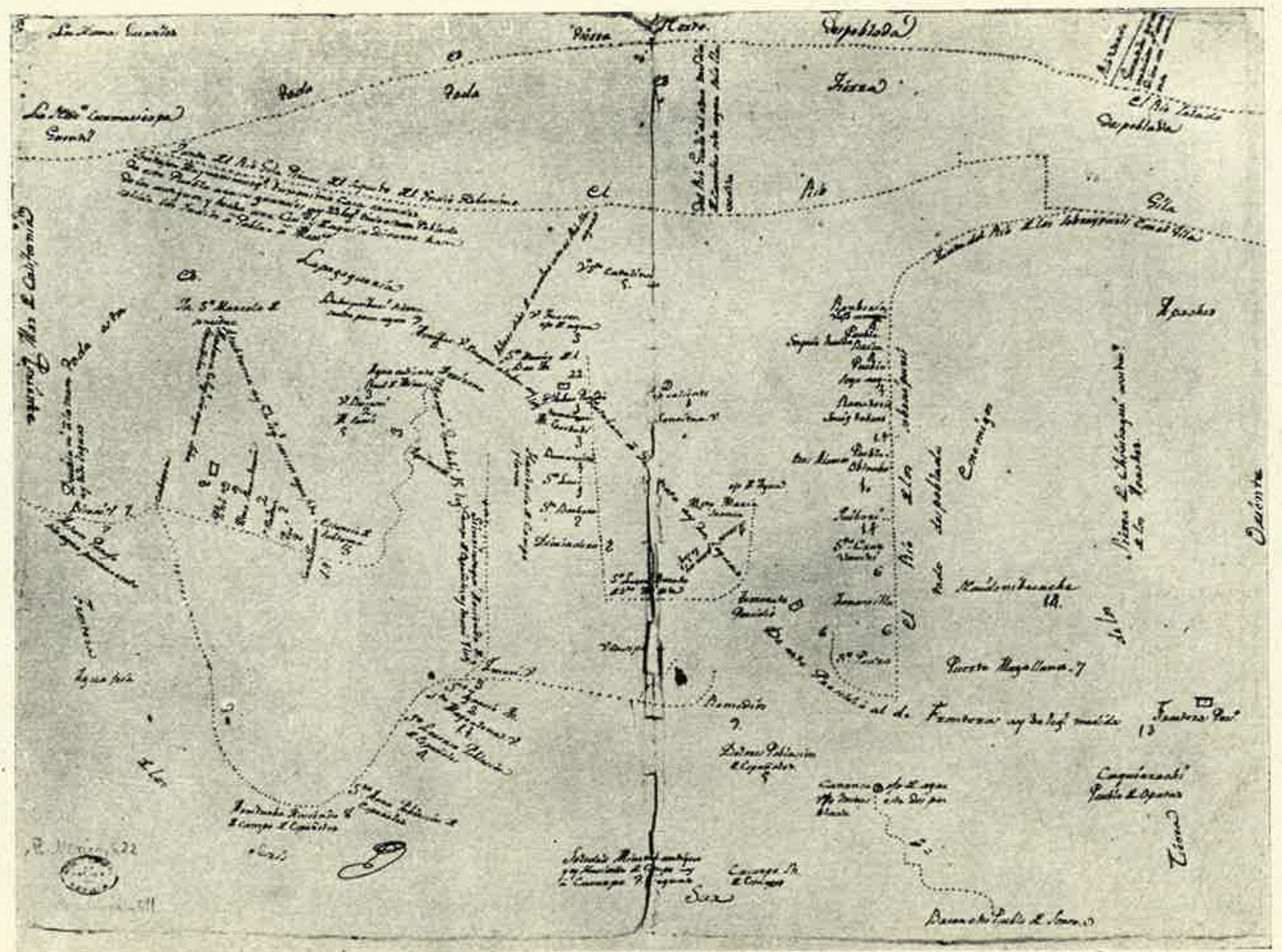

62. Las fronteras de Sonora y el Gila. 1762. 


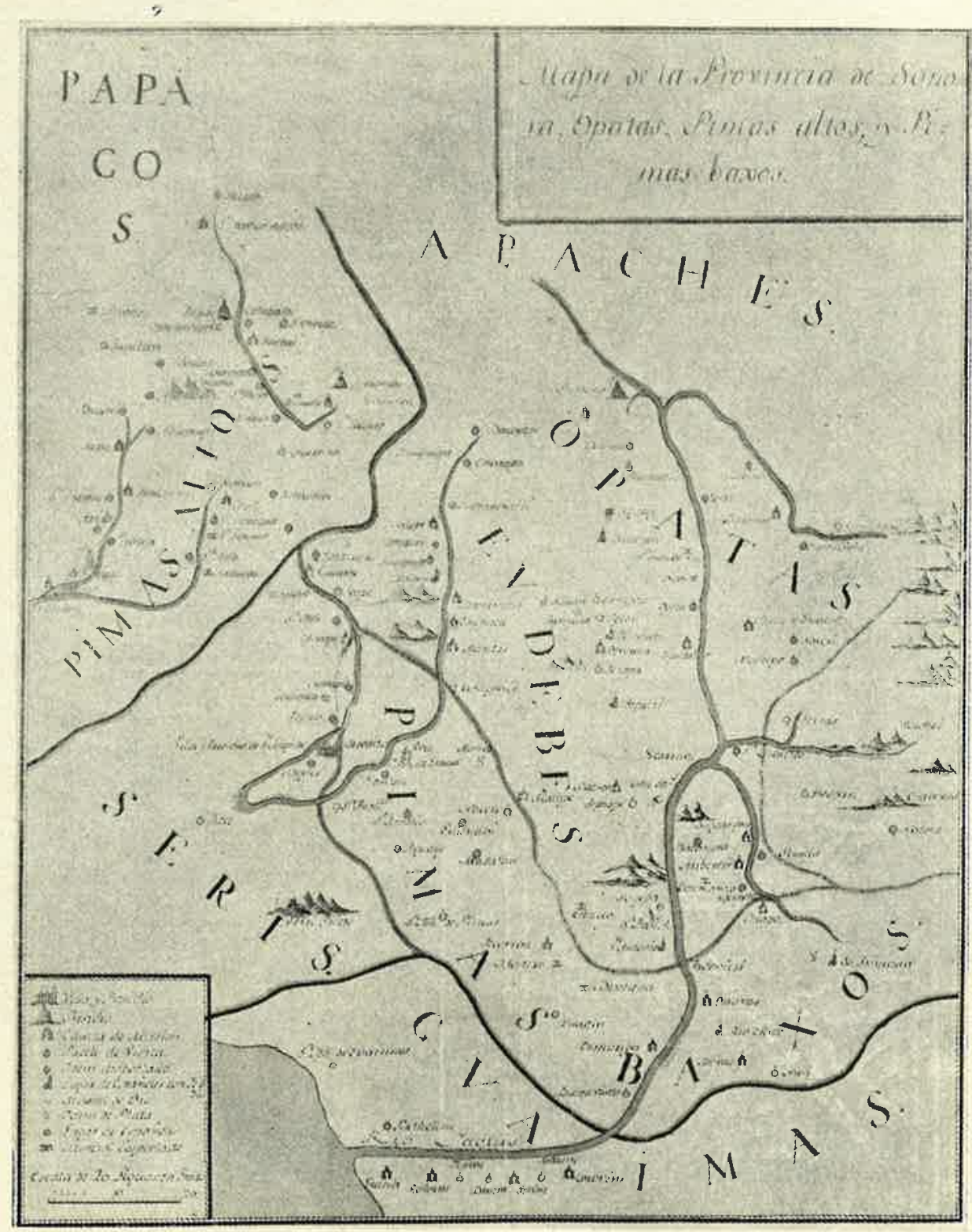

63. Distribución de los grupos indios de Sonora. 1761. 


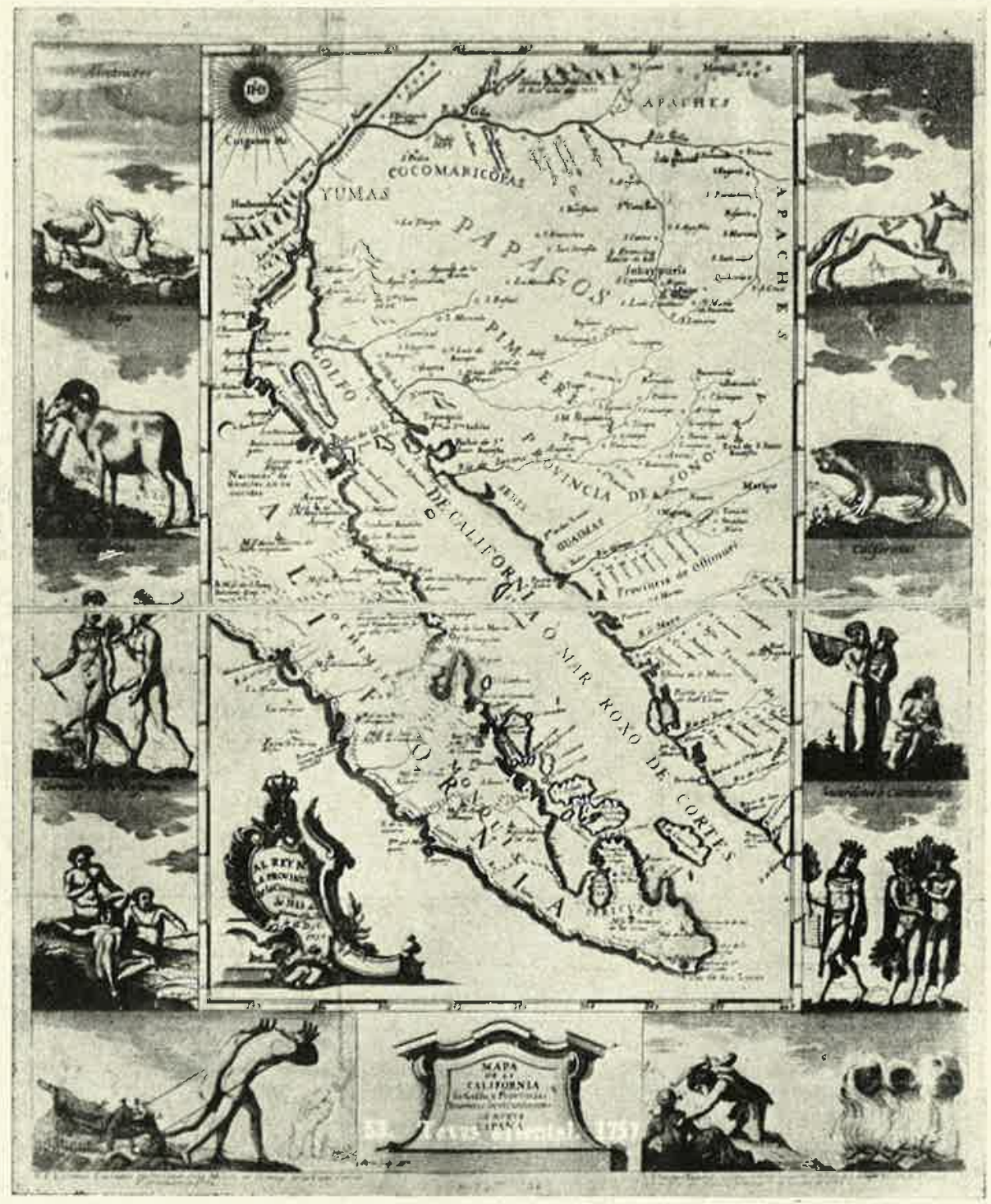

64. Calilornia y Sonora, en la obra de Venegas. 1757 . 


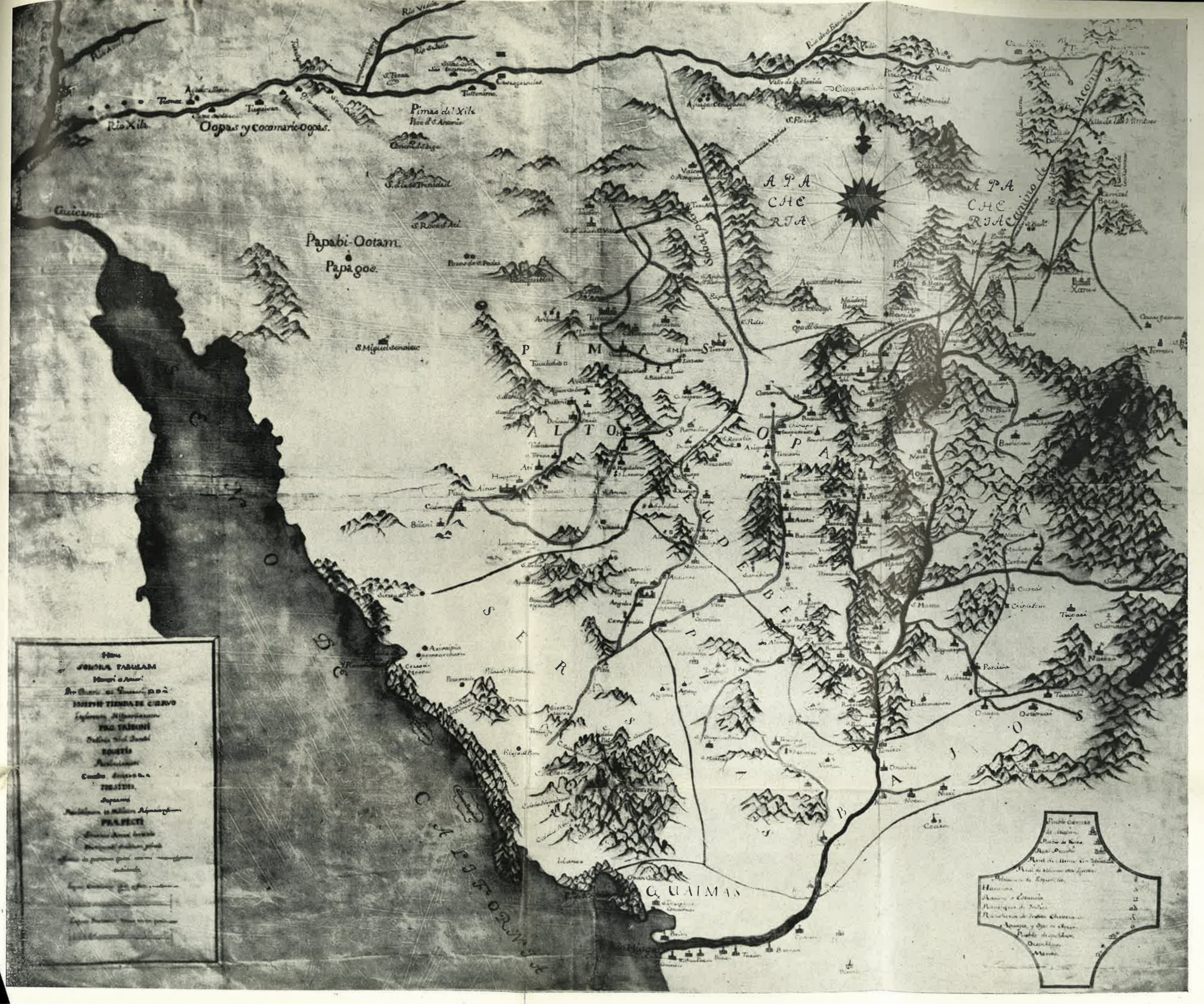





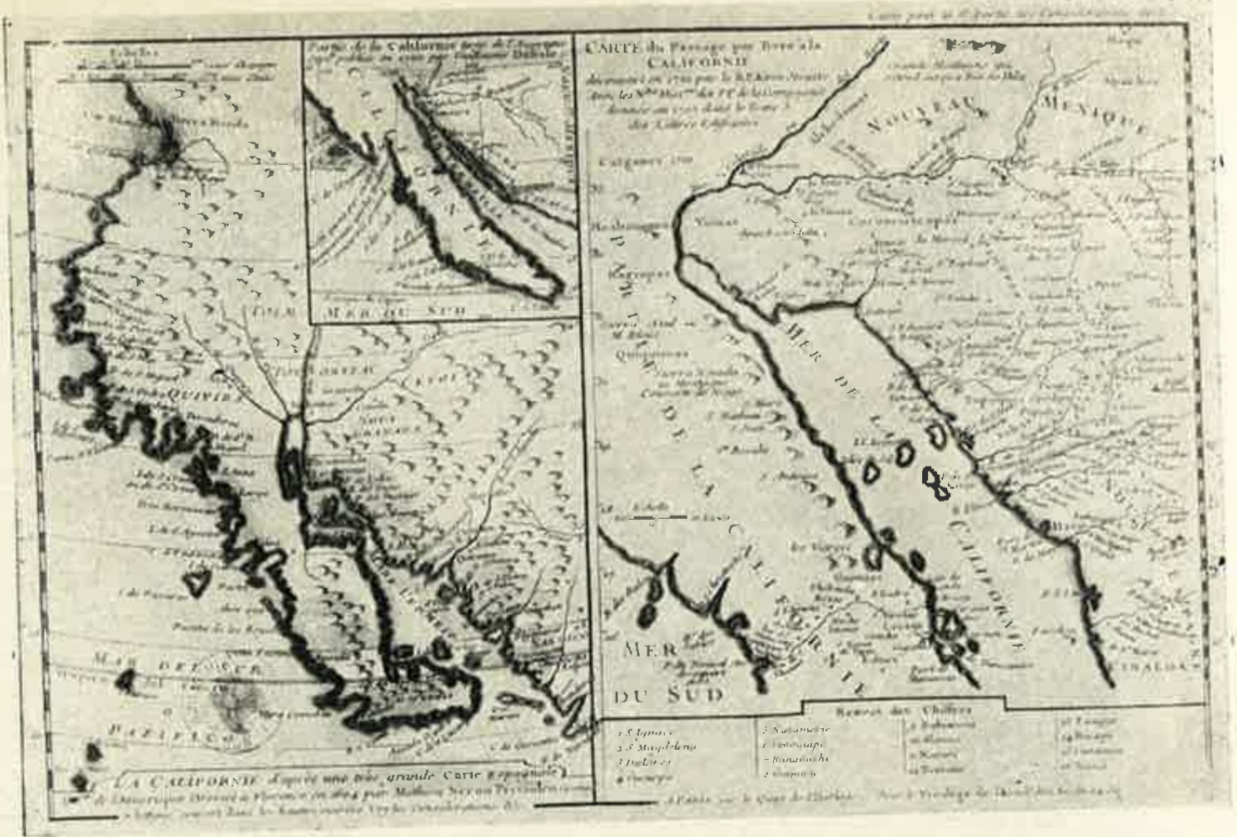

66. Tres mapas de California, publicados en París. 1754.

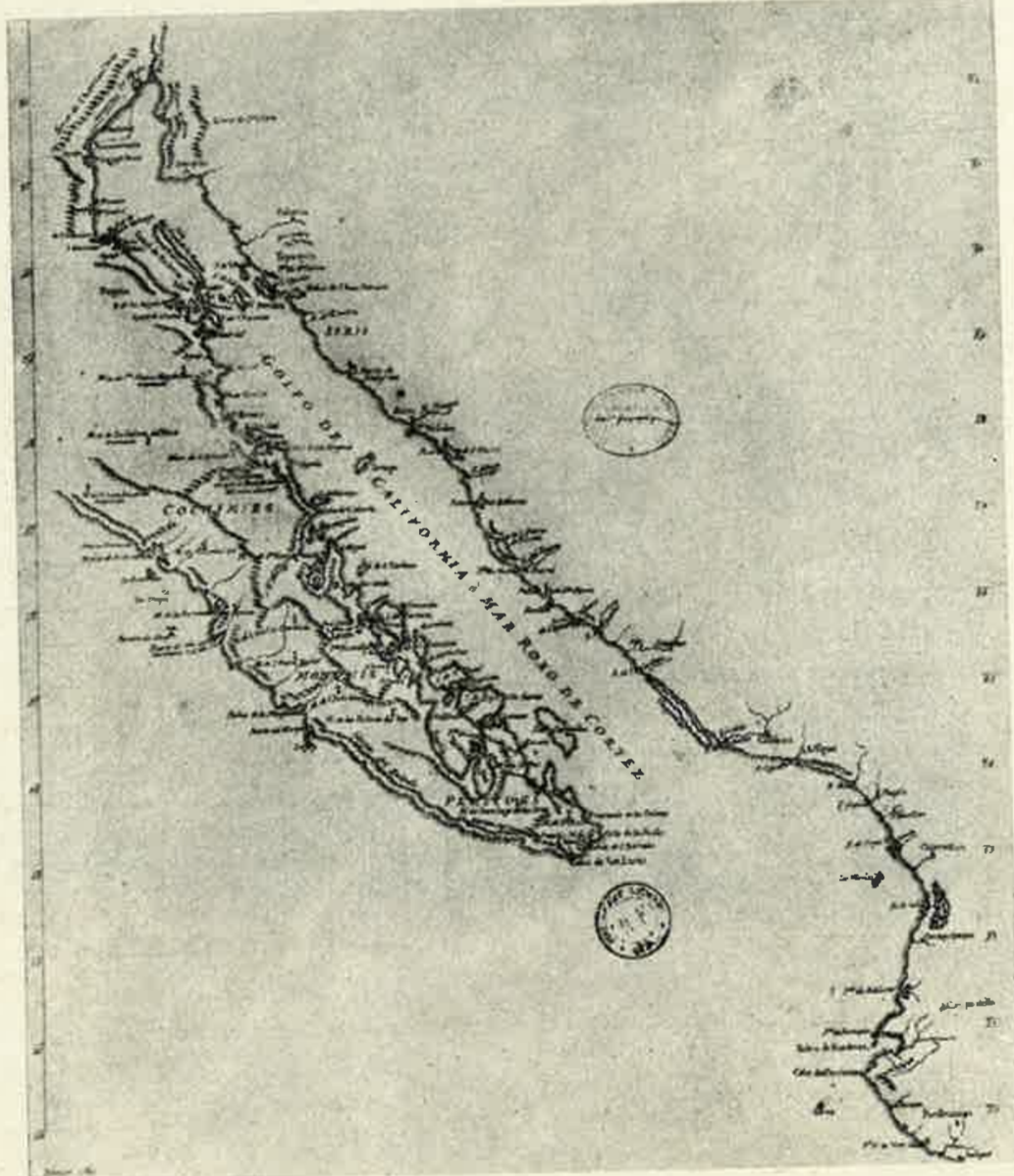

67. Réplica del mapa de Venegas, por D'Anville. 1770. 


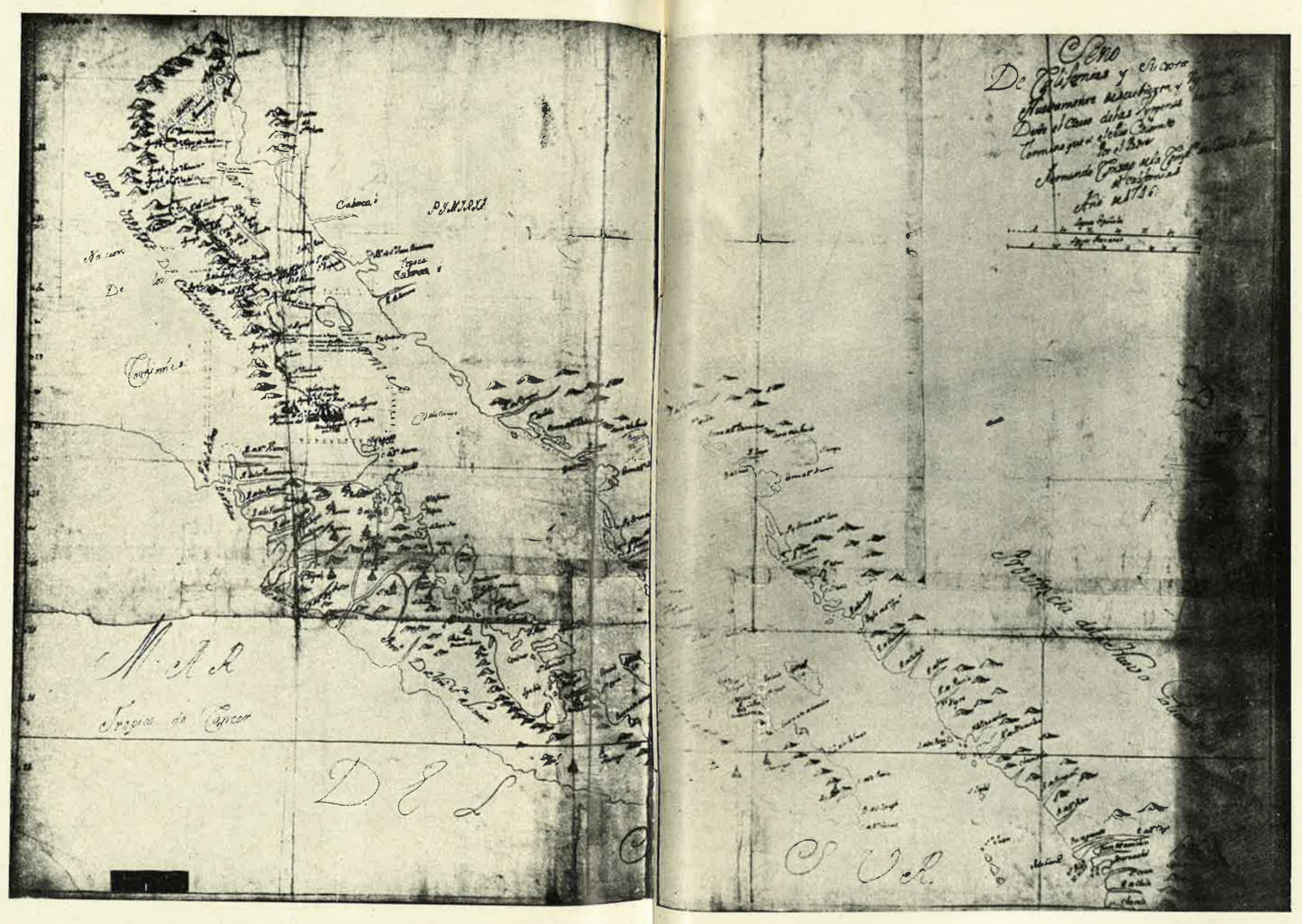

68. Golfo y península de la California, por Consag. 1746 


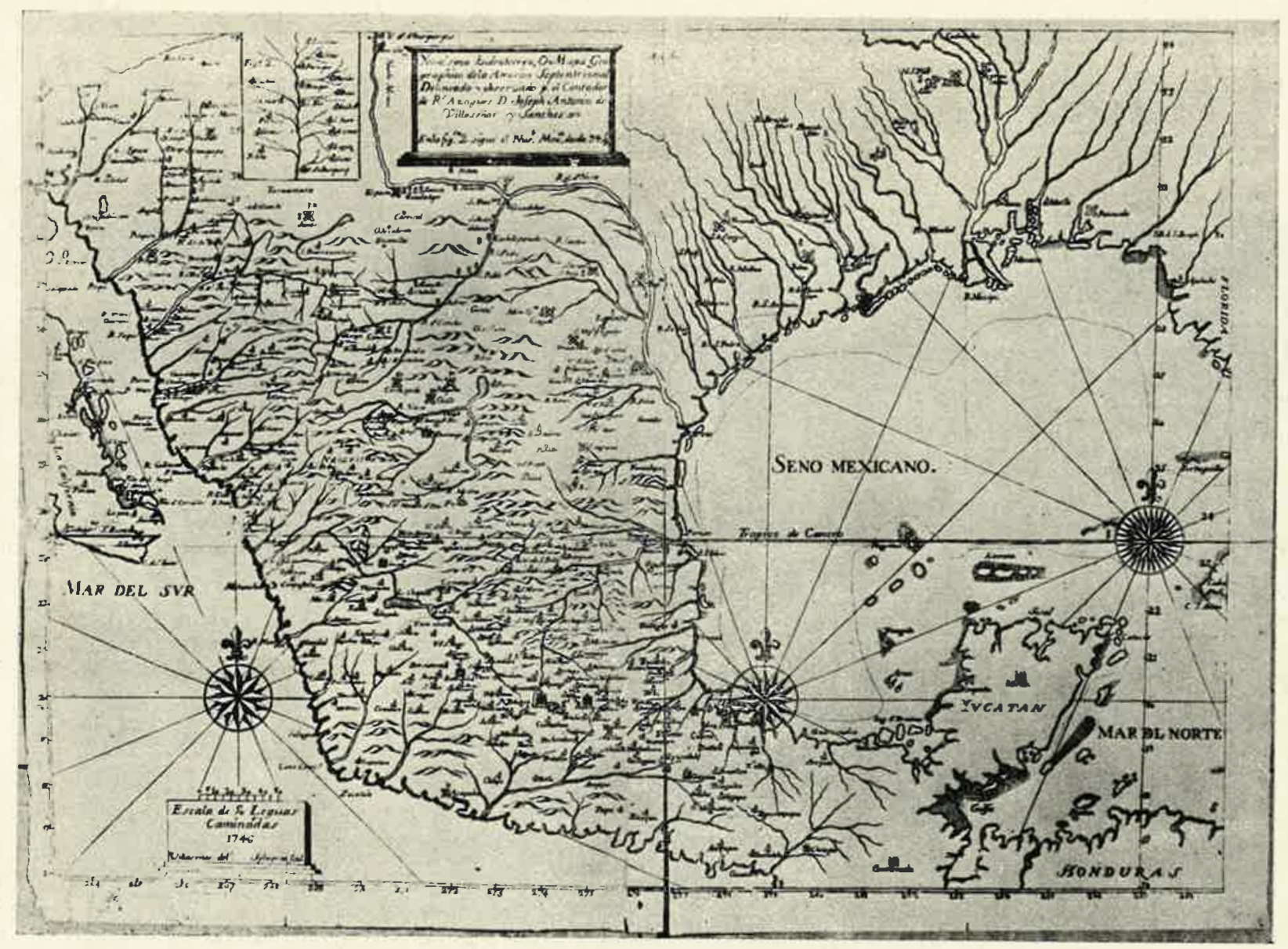

69. Mapa de Nueva España, por Villaseñor. 1746. 

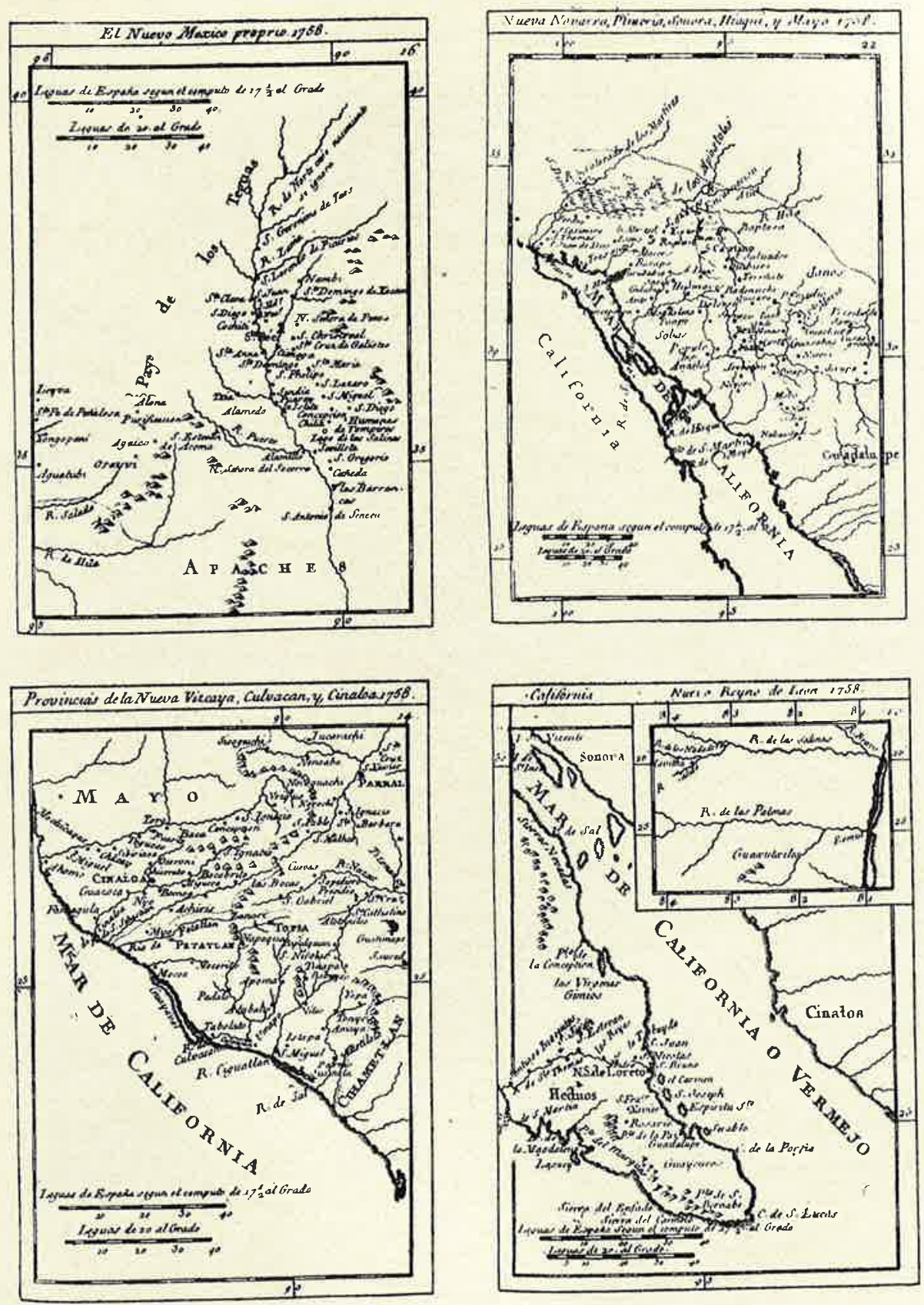

70. Las provincias del Noroeste, por Tomás López. 1758. 


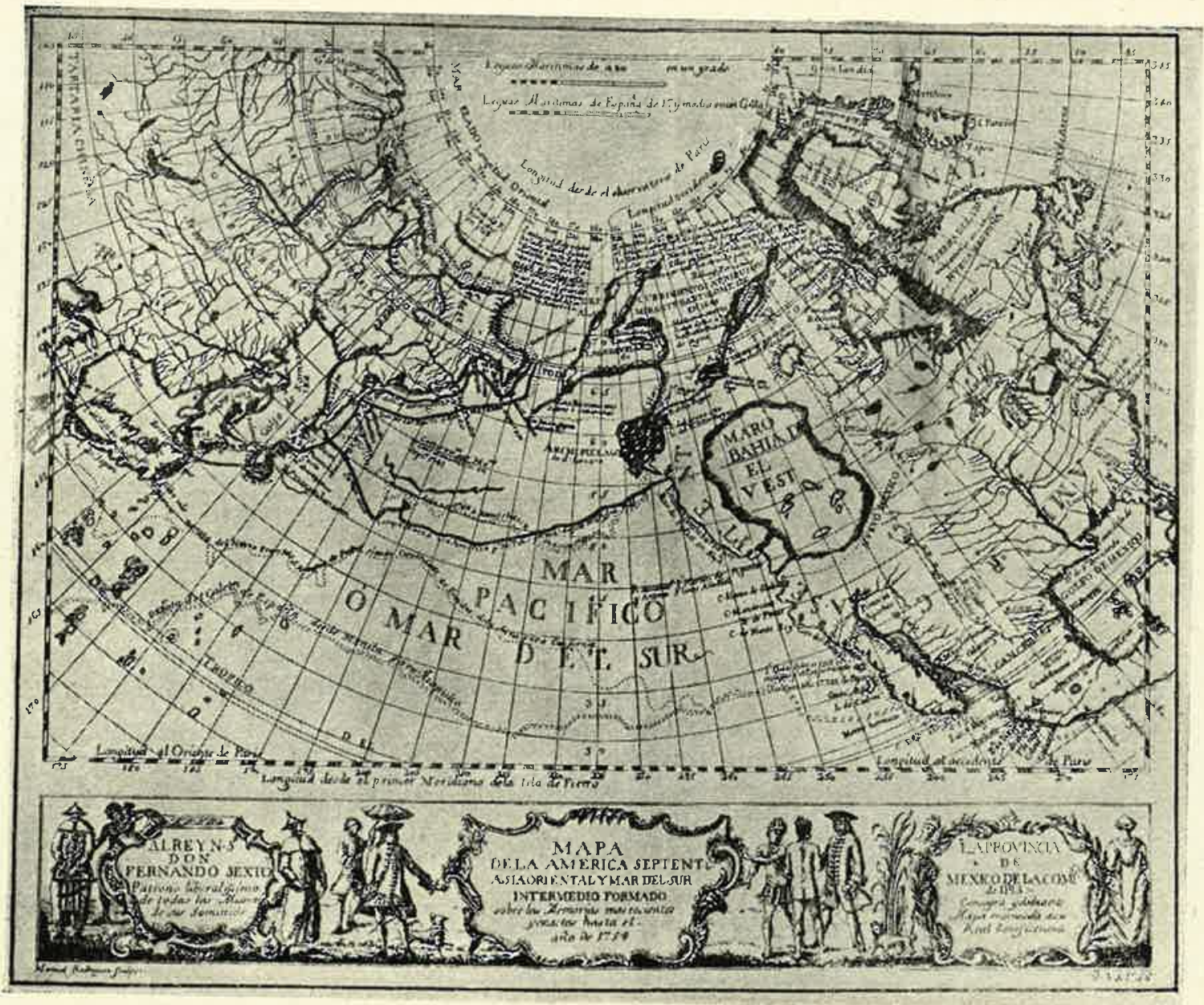

71. Marpa de las costas del Pacifico Norte, en la obra de Venegas. 1754. 


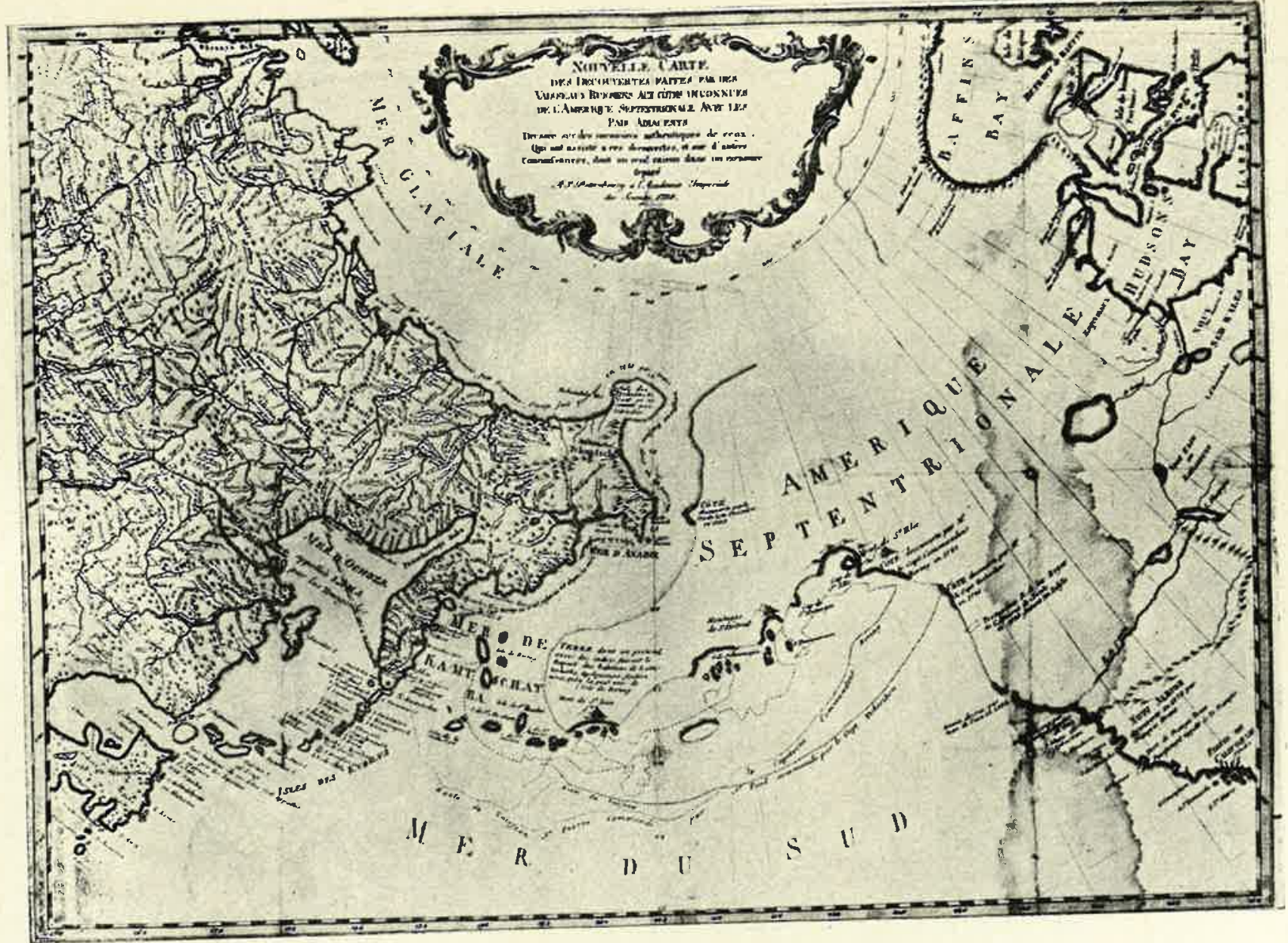

72. Los descubrimientos del Pacífico Norte, según la Academia de Ciencias de San Petershurgo. 1758. 


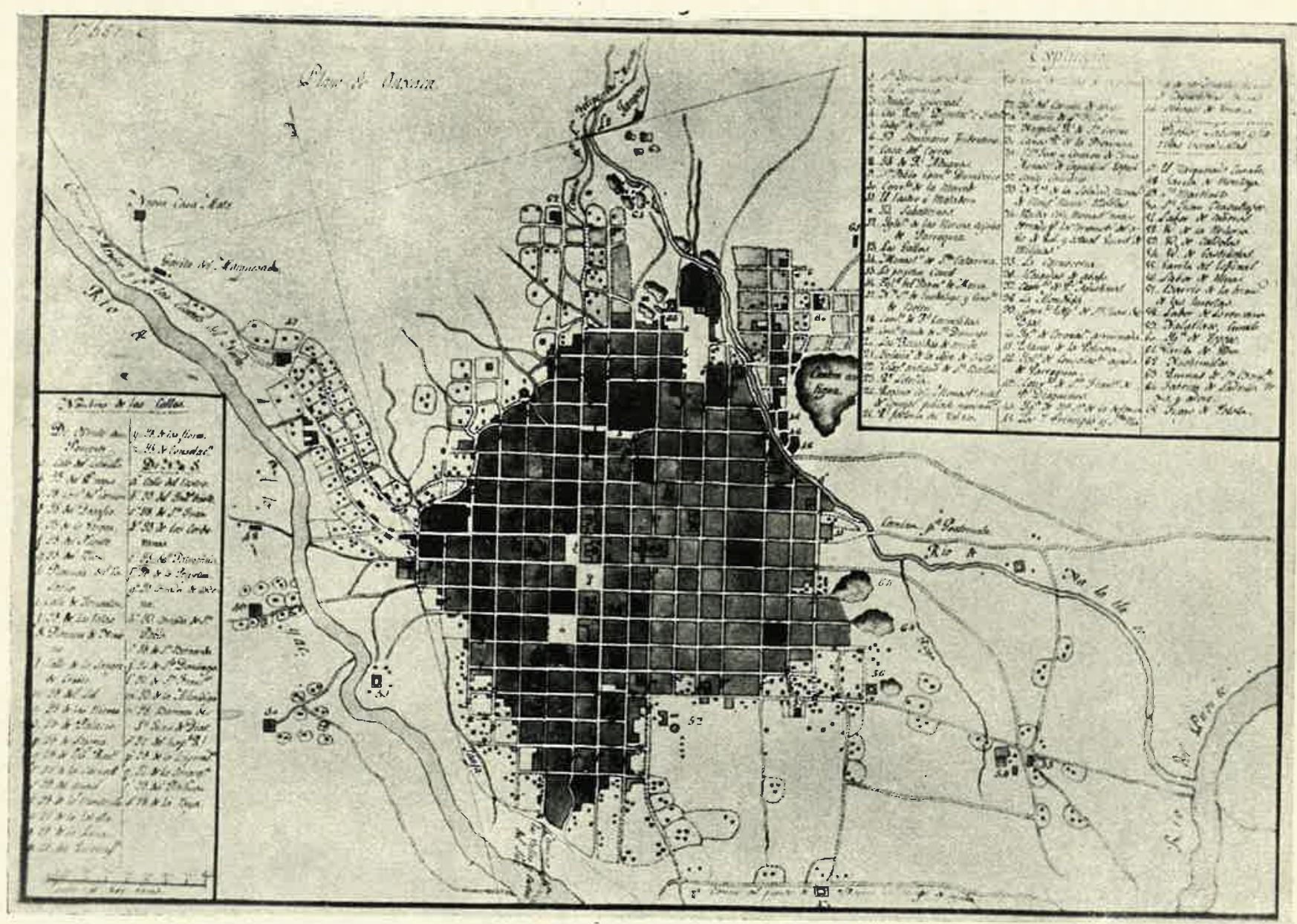

73. Plano de Oaxaca. 
riesgo de hostilidad". ${ }^{143}$ La cuantía de los daños se advierte en la reducción a la mitad del producto de los diezmos del obispado de Durango. ${ }^{144}$ El nuevo gobernador Don Mateo de Mendoza logró se llevase a cabo una campaña contra los enemigos, para cuya realización, a falta de los suprimidos fondos de paz y guerra contribuyeron voluntariamente los vecinos hacendados 3.875 pesos. Dirigieron la expedición los capitanes reformados Díaz del Carpio y Leizaola, porque Mendoza halló incompetentes a los tres de los presidios. Mendoza escribió y expuso al virrey la necesidad de fundar presidios en la Junta y Ruiz, de pagar a los indios auxiliares, lo que sin caudal de paz y guerra no se podía hacer, y de hacer extensiva a la Junta de los Ríos la autoridad del gobernador de Nueva Vizcaya. ${ }^{145}$ Así lo resolvió la Junta de Guerra y Real Haciendo de México de 3 I de julio de I757, que decidió se situase en la Junta de los Ríos el presidio que antes se pensó establecer en los Pilares, y que se repartiese, poblase y guarneciese con veinte soldados de El Paso la hacienda del Carrizal, para defensa del Valle de San Buenaventura. ${ }^{146}$

El presidio de la Junta, que tomó el nombre de Ntra. Señora de Belén y Santiago de Amarillas, llegó por fin a establecerse, no por Rubín de Celis, que lo dificultó, sino por su teniente Don Manuel Muñoz, que costeó de su bolsillo la erección del fuerte, en lo que gastó más de I 4.000 pesos. Mendoza pidió aumento de treinta plazas más sobre las cincuenta que tenía el presidio, para tener dominada la serranía, rochela de los indios. Poco después, como continuase la polémica sobre el emplazamiento oportuno de esta compañía, y Don Bernardo Bustamante clamase por la parte de stı tropa de Guajoquilla que el golernador destacaba al norte para defensa de "Chihuahua, resolvió Cruillas, por decretos de 17 de abril de 1762 , que el gobernador Agüero fuese con el capitán Berroterán a visitar el paraje de la Junta, e informase sobre este punto; y que Bustamante quedaba obligado a proteger Chihuahua por oriente y poniente y por Tarahumara, debiendo dar cuenta de las novedades al virrey dos veces al año. I47

I43 Alonso de Gastezi a Mateo A. de Mendoza. San Bartolóné, 26 de febrero de I754. Ibid.

I44 Vista del fiscal del Consejo. Madrid, i 2 de marzo de i756. Ibid.

I 45 Mateo A. de Mendoz? a Ensenada. Durango, i6 de mayo de I754. A. G. I., Guadala jara, 405. Id. a S. M. Chihuahua, 7 de agosto de I755. A. G. I., Guadalajara, I94.

I46 A. G. I., Guadalajara, 327. Testimonios de este expediente en A. G. I., M'éxico, i700, entre los que aparece 111 últiluno informe de Berroterán de $\mathrm{I} 76 \mathrm{r}$.

147 Mateo A. de Mendoza a Arriaga. Chihuahua, 16 de julio de 1760 . Ibid, El gobernador denuncia en esta carta "la inutilidad y cobardía" de Rubin de Celis. Advierte, por otra parte, que "los norteños - nombre con que ahora empieza a llamarse a los indios de la Junta, cuyo presidio se denominará más tarde "del Norte" - han vivido del robo de ganado para sus ferias y canjes con natajes, apaches y sumas, con los que ordinariamente están coaligados, y el pasaje en donde se hallan en una serrania de las más ásperas y dilatadas de la frontera, y viene a ser la Rochela de los infieles de este reino". Rubín de Celis reclamó más tarde en súplica al rey, en 1763. 
Sin embargo, la situación de la provincia no parecía mejorar y en I76 I el obispo Tamarón y Romeral escribía a Arriaga ${ }^{148}$ que Chihuahua estaba a punto de perderse y todo el territorio invadido por los enemigos, y se apresuraba a pedir dos presidios más y tres o cuatro mil hombres. Tamarón debía hallar terreno propicio para sus demandas, pues ya las cartas que directamente renitía Mendoza al Consejo habían sido favorablemente acogidas aquí, diciéndose al virrey que no se detuviese en gastos, por ser mayores los perjuicios; que formase milicias y armase a los hacenderos y sus sirvientes, que procurase formar las poblaciones de los presidios y preparase una campaña general con tropas de Nueva Vizcaya, Sinaloa y Sonora. ${ }^{149}$

\section{LAS PROVINCIAS INTERNAS A LOS}

DOS SIGLOS DE SU HISTRIA

Cuando Gálvez y Rubí pisen los territorios fronterizos de Nueva España, esta avanzada de occidente estará doblando las dos centurias de exisiencia. El transcurso de dos siglos le ha dado ya una fisonomia especial, y unas dimensiones, una problemática y unos derroteros para el futuro también propios. Diversas provincias se han ido perfilando con creciente nitidez. y personalidad, y su vida ha ido hallando los moldes oportunos en los campos jurídicos, administrativos, económico, religioso y social. Su mayoría de edad, si podemos expresarnos así aludiendo a su ya desmesurado desarrollo espacial, a su potencia demográfica, a su importancia estratégica y a su peso económico, es una realidad. Y la autonomía que para ellas empezará en fecha inmediata a tramitarse y que les será otorgada quince años después viene a ser en buena parte nueva sanción de este hecho. Aunque también es verdad que en estos momentos las provincias se ven abocadas en su más larga y dura crisis, a lo que retrospectivamente considerado puede llamarse la última convulsión de la frontera española en Norteamérica.

Dos visitadores de otro tipo precedieron en esta frontera simultáneamente y con poca antelación al militar Rubí y al político Gálvez. Nos referimos a los obispos de Durango y Guadalajara, Don Pedro Tamarón y Romeral

A. G. I., Guadalajara, 368, y México, 1700. Decretos de Cruillas, I 7 de abril de I762, a consecuencia de Juntas de Guerra y Hacienda de $13,22,23,24$ y 27 de noviembre de I761. A. G. I., México, 1700.

I48 Tamarón a Arriaga, Real del Oro de Agua Caliente, 8 de enero de 1761. Postdata de Sombrerete, 29 de marzo de i76I. A. G. I., Guradalajara, 401.

I49 Vista fiscal. M'adrid, I2 de marzo de 1756 ; aprobado por el Consejo en 6 de abril siguient., A. G. I., Guadalajara, I 94. 
y Fray Francisco de San Buenaventura, que entre I759 y r76r llevan a cabo la visita de sus respectivas diócesis y son fuente la más oportuna para el conocimiento de la situación de aquellos países en vísperas de la transformación que Rubí y Gálvez les van a imprimir.

La población total de las cinco provincias hacia i 760 es, según los datos que nos proporcionan ambos obispos ${ }^{150}$ de más de 230.000 habitantes, casi por mitad indios y no indios. Bien es verdad que el valor de esta cifra es muy discutible, pues el propio Tamarón no vacila en lamentar la inexactitud de los datos recibidos, y en ocasiones asegura es presumible. que "ha faltado - por lo tocante a su diócesis - la expresión de casi una tercera parte de la gente que hay" y teme no hayan incluido los españoles y mixtos habitantes junto a las misiones franciscanas y jesuitas de Tarahumara Alta, o que no consten los párvulos o las gentes que viven en retiros aislados. Por lo que respecta al obispo de Guadalajara nos basta contrastar las cifras que da en cartas, con las que consigna en la relación de curatos y misiones. I5 I

Sin embargo, podemos valernos de aquella cantidad para nuestros cálculos, pues a buen seguro una mayor afinación en los censos no hubiese alterado sustancialmente el cómputo final.

Aquel cuarto de millón largo de pobladores se distribuía muy irregularmente, correspondiendo la mitad a sola Nueva Vizcaya, y casi otro tanto a Sonora y Nuevo México juntos, mientras que Coahuila y Texas tenían apenas siete mil pobladores.

He aquí las cantidades en números redondos:

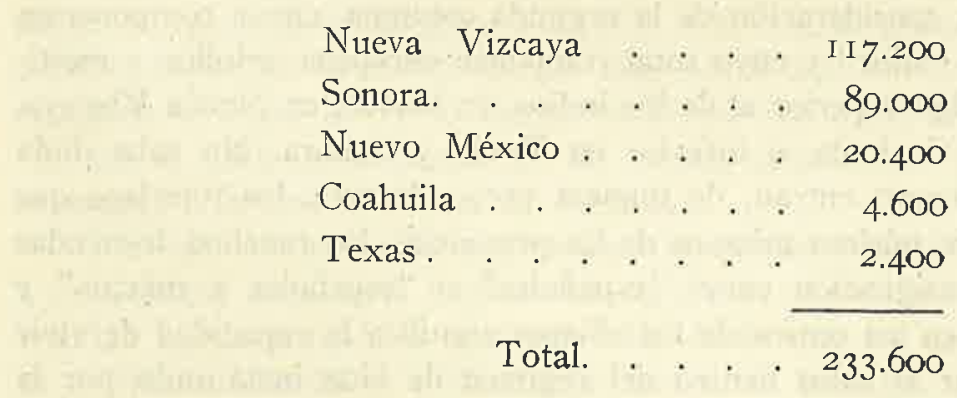

I50 Tamarón y Romeral, Pedro: Demostración del vastisimo obispado de la Nueza Vircaya 1765. Durango, Sinaloa, Sonora, Arisona, Nucvo Mérico, Chihuahua y porciones de Texas, Coahuila y Zacatecas. Introducción y notas por Vito Alessio Robles. México, r937. Relación de los curatos de Nueva Galicia, Guadalajara, 7 de septiembre de 1760. A. G. I., Guadalajara, 401.

I5 I Tamarón, Demostración, I49, I76 y 363. Fray Francisco de Sar Buenaventura a S. M. Guadalajara, r 2 de mayo de i 760 . A. G. I., Guadalajara, 330. 
Estas mismas cifras cobran nuevo color para nosotros si desglosamos las correspondientes a la población india, que viene a expresarse de este modo:

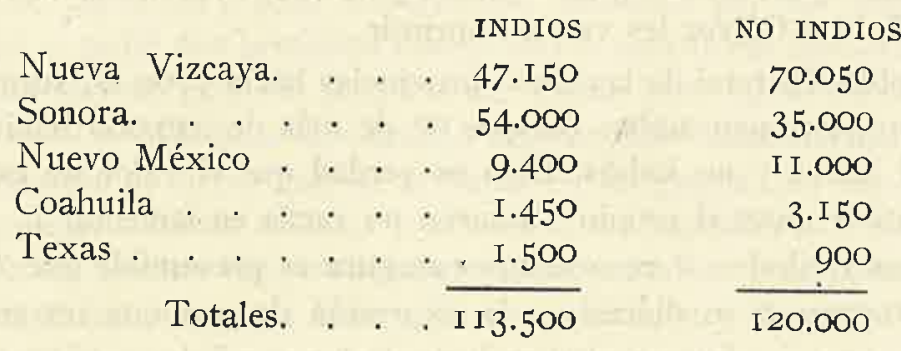

Casi la mitad, pues, de la población de las provincias internas es india. es decir, está clasificada como tal y vive en pueblos de indios, gran parte de ellos de misión. Claro está que nacla tan engañoso como tomar el número de los indios en bloque como si fuese una masa homogénea, de mentalidad semejante, de peso social definido, de apetencias y estímulos comunes y coherentes. Por el contrario, las diferencias raciales o tribales entre los grupos son algo preciso que los divide claramente, a partir sobre todo de la desigualdad de los niveles culturales en que se constituyen y de su actitud ante el dominio español. Pero si hay algo que puede unirlos tiene que ser un aglutinante que los eleve a una entidad social y política de orden superior y en la que se diluyan en el mayor grado posible los rasgos diferenciadores de las distintas procedencias. $Y$ es el dominio español el que proporciona ya esta posibilidad, con el mestizaje intertribal y sobre todo racial.

Aquí entra la consideración de la segunda columna, cuyos componentes figuran como "no indios" y cuyo total componen europeos, criollos y mestizos. Ese total es algo superior al de los indios, en bloque, en Nueva Vizcaya, Nuevo México y Coahuila, e inferior en Texas y Sonora. No cabe duda de que en este número entran, de manera preponderante, los mestizos que nutren los pequeños núcleos urbanos de las provincias, los ranchos, haciendas y minas, cuya consignación como "españoles" o "españoles y mixtos" y "gente de razón" en los censos de los obispos significa la capacidad de vivir independientes, por sí solos dentro del régimen de vida instaurado por la implantación del orden social, las ideas y la civilización españolas en el Nuevo Mundo.

Si los "indios" son los habitantes de pueblos y misiones de indios, y parecen allí concentrados, los "españoles y mixtos" se hallan desparramados por todas partes, aparecen en las ciudades y villas, en los reales mineros $y$ en los campos, dedicados a la agricultura y al pastoreo, o bien precisamente 
como "agregados" a algún pueblo de indios, donde hacen funciones de comerciante, o se dedican a disputar a aquéllos la propiedad de las tierras. Ciertamente que entre ellos se notará la natural distinción entre blancos y mestizos, pero las circunstancias de la frontera, por el mero hecho de serlo, tienden a borrar esta diferencia de origen puramente fisiológico, pues el mestizo ha sabido ya encajar el cuadro de valores del español, y si no es plenamente un hombre occidental, sí está en camino de serlo.

Hay una demostración para este aserto: todas las sublevaciones producidas durante dos siglos en las provincias internas son claramente indias, y su motivación no es otra que el choque cultural o el ansia de recuperar la autonomía perdida. El mestizo no siente aquel desgarrón - aunque su alma tal vez herede la lucha - ni añora siquiera libertad, pues es hombre que se desenvuelve bien en los cuadros de vida traídos por los españoles. Nada prueba en contrario - si no es el resentimiento de inferioridad- el hecho de que alguno de ellos aparezca entre los amotinados, de vez en cuando.

No estamos en condiciones de aclarar si la población india había aumentado a disminuido en número, al cabo de dos siglos de la llegada de los españoles a las provincias internas, puesto que sigue siendo ignorado el volumen de esa población en la etapa anterior al Descubrimiento. Pero lo que realmente sería de esperar, no ya para estas provincias, sino para toda la América española, es que la cantidad de indios se redujese más o menos rápidamente hasta su total extinción, en beneficio de la masa de mestizos. Dé hecho sabemos que constantemente salían de los pueblos de indios individuos que marchaban a los centros de vida de los "españoles". Clamaban los misioneros en estos casos, pero hemos de pensar que cuando el indio se decidía a abandonar la misión para dirigirse a la villa o al real de minas, es porque debía sentirse capaz de desenvolverse en este nuevo ambiente, y la misión había cumplido su cometido, a lo menos en el proceso de la aculturación; y una vez que el indio se desligaba de los suyos, difícilmente dejaría de aportar su sangre a la gran corriente del mestizaje.

Por ello no puede seriamente decirse que la población india aumentase o se redujese durante la dominación española, puesto que el camino que en realidad queda trazado a la masa india desde que los españoles ponen pie en el Nuevo Mundo es el de transformarse en mestiza fundiéndose con los europeos. Y no siendo reversible el proceso de mestización, la conservación y aumento de los indios puros sólo sería posible por exclusivo crecimiento vegetativo y en condiciones de estricto aislamiento, lo cual no resultaría fácil ni lógico dentro de los cauces normales de la conducta humana.

Digamos, finalmente, que el mestizaje es el más apropiado vehículo de la aculturación, y todavía más, que no hay aculturación completa y perfecta 
sin mestizaje. Pues la sangre $-y$ los valores psico-biológicos que con ella se transmiten- es uno más, y no el neenos importante, de los componentes de toda cultura.

Para esta mestización, la frontera proporcionaba un estupendo crisol. La dureza de la vida, y la simplificación de los ragos culturales del español, que impone esa dureza, y la lejanía tienden: un puente aún mucho más fácil para la asimilación del indio, compensando tal vez el más bajo grado cultural de buena parte de aquellos pueblos en época prehistórica. Y esto es de valorar en los casos más extremos de Coahuila y Texas que dan un total de sólo 2.960 indios. Pero, ¿cuántos de los 4.050 "españoles" serían peninsulares o criollos, sino unas docenas a lo más, y cuántos, pues, en realidad perpetuarían la sangre de las tribus nómadas del país haciendo al mismo tiempo posible su elevación a un plano cultural incomparablemente superior? Y estos mestizos de $\mathrm{i} 760$ son los pequeños terratenientes, los vaqueros, los mineros, los soldados de las dos provincias.

Eran estas dos las más jóvenes entre las internas, y las que menos propicias se mostraban por todos conceptos para la constitución de un fuerte núcleo civilizador. Las tres restantes, en cambio, con sus 226.600 pobladores, ofren toda la rica complejidad de una sociedad en desarrollo, de vitalidad esplendorosa fomentada por la minería y el comercio. Nuevo México, que carece de minas, ha experimentado, sin embargo, un notable progreso en el término de poco más de medio siglo transcurrido desde su reconquista. Su estructura racial se ha diversificado aún más con la aparición de los jenízaros, cautivos infieles educados entre los españoles y que pronto alcanzarán número suficiente como para necesitar la fundación de pueblos que ellos expresamente habitarán siendo valiosos auxiliares para la defensa del país. Los indios se mantenían en sus antiguas poblaciones. Los "españoles" ocupaban Santa Fe, Alburquerque, La Cañada y en general ranchos y haciendas aislados, dispersos, y frecuentemente en lugares de bastante riesgo.

En Nueva Vizcaya y Sonora la población no india se concentraba en los valles y junto a los placeres y minas. En Nueva Vizcaya basta una ojeada para advertir cómo lo españoles han adoptado en esta época una clarísima disposición en la periferia de la provincia. Muchos de los antiguos reales, sobre todo los del interior, han desaparecido o decaído de manera sensible. Parral, que se mantuvo durante casi un siglo en cabeza de los centros mineros de la provincia, había perdido mucha parte de su antiguo brillo, de modo que no llegará a contar tres mil habitantes. El Real del Oro escasamente rebasa los mil y el de Indé no alcanza esta cifra. Mapiní, población semejante a Real del Oro, siempre había producido plata de baja ley, pero en cambio 
se extraían allí muy buenas ligas con greta y plomo para beneficiar las platas de otros yacimientos.

Topago y Batopilas estaban en franco hundimiento, y con ellos Coneto, que se despoblaba rápidamente. Guanacevi rendía ya muy poco, y lo mismo Avinito y Pánuco, aunque estos últimos minerales no parecían extinguidos. En cambio, el antiguo real real de San Andrés, en la sierra, estaba totalmente abandonado y sus casas e iglesias se hallaban arruinadas ya. Otros yacimientos se habían descubierto últimamente, aunque con pocas señales de perduración: San Diego del Río era, en el curato de Pueblo Nuevo, un mineral muy rico que había congregado ya unas doscientas personas; pero cuatro años después no contaba más de sesenta. Basis, descubierto en el intervalo, había alborotado a todo el virreinato y pronto se habían denunciado allí más de cien minas y se habían reunido más de dos mil personas, "aunque todas volantonas", en expresión del obispo de Durango; a Tabahueto, otro de los más célebres reales de entonces, le calculaba unos quinientos pobladores fijos, siendo otros tantos la población flotante. Algo menores eran los reales de Canela y Sianori, y podía considerarse extinguido el de Topía, en el mismo distrito.

Los núcleos más importantes de la producción argentífera eran, junto con el de Parral-Santa Bárbara, el de Cuencamé y sobre todo, con enorme diferencia, el de Chihuahua-Santa Eulalia. Esta, para la frontera, enorme población de diez mil habitantes, cuyos dos centros estaban separados a distancia de cinco leguas el uno del otro, era con seguridad la más importante concentración urbana al norte de Zacatecas. Este real, nacido a principios del siglo, y el pequeño pero próspero de Cusihuiriáchic, thabían de consolidar la progresión española hacia el norte, y su cuidado y el de las hostilidades de los apaches hacían bascular también en dicha dirección la atención del gobierno provincial.

La explotación minera, directa en la veta, o en el ingenio, o en la tienda de rescate, pues, podemos calcular absorbía la actividad de unos veintidós mil españoles. $Y$ ésta no es sino una tercera parte de la población censada bajo esa denominación. Durango, la capital tradicional de abolengo, con rango de ciudad, contaba unos nueve mil habitantes, pero Tamarón nos dice que algo menos de la mitad de ellos residian en asentamientos rurales vecinos a ella. Lo mismo puede decirse de todos los demás núcleos, que claramente se agrupan en la región al sur de la capital y ya vecina a la zona minera de Zacatecas, en el río de Papasquiaro, en el Nazas, en la laguna de Parras, y en el distrito de Saltillo, en las haciendas y presidios reformados del camino real y en las explotaciones agrícolas y ganaderas de los valles del norte sobre los ríos del Carmen, de Santa María y de Casas Grandes. 
Estos españoles chocaban con los indios en punto a tierras, "quimera general en lo más del obispado”, dice Tamarón, que atestigua este hecho en Topia, Papasquiaro, Parras y el Alamo. Lo mismo ocurría en Saltillo. Indios y españoles vivían en continuo pleito en Topia porque "como es corto el Valle, no caben para sus siembras y pastos de animales". El problema era más agudo en Santiago Papasquiaro, donde frente a veintinueve familias de indios con ciento una personas, trescientas veintiséis familias de españoles, que sumaban dos mil setecientas veintiocho almas, se sentían frustradas en su deseo de entrar en posesión del valle. Tamarón, a quien nadie podía tachar de parcial, escribe: "estos pocos (indios) resisten que la gente de razón haga casas y se aprovechen de aquellas buenas tierras... y como los indios son tan malos trabajadores da lástima estorben el cultivo que sería muy provechoso si en Papasquiaro se acaban los indios pocos que quedan".

Esta misma cuestión adquiría distintos matices en la zona de Parras a Saltillo, donde los indios agricultores se titulaban tlaxcaltecas privilegiados, siendo así que buena parte de ellos eran de muy diversa procedencia y se amparaban en aquuel nombre para triunfar en sus reclamaciones. También los indios del Alanio, dice Tamarón, "se apellidaban tlaxaltecas para dar que hacer a los tribunales". Aquí el agua se perdía por las contradicciones de los indios, que con sus pleitos ni sembraban ni dejaban sembrar. Decíase que los vecinos de Parras fomentaban estos pleitos para impedir que la producción vinícola del Alamo pudiera competir con la suya. ${ }^{\mathbf{5} 2}$

En Sonora, la porción sur de la gobernación, es decir la que se extiende del rín de las Cañas a Ostimuri, había quedado ya muy rezagada en cuanto a su producción minera, pero conservaba y acrecentaba ya una importante población agrícola y ganadera, con centros de carácter urbano como el antiguo Real del Rosario y comarcas de intensa colonización rural, como las de San Sebastián, Culiacán y Sinaloa, que con sus tres mil quinientos habitantes era el primer núcleo del país. La explotación de yacimientos argentíferos rontinuaha con distintos rendimientos en Copala, Pánuco, Arrona y Charcas, en el Real de las Once Mil Vírgenes de Cosalá, y en el de Palo Blanco, vecino a Culiacán. El último hallazgo era el del Cajón, donde parecía haber un gran mineral, en el distrito de Alava. Chiametla era el puerto que abastecía de pescado a gran parte de Nueva Vizcaya y Nueva Galicia. En cambio, todo el país carecía de producción de trigos y vinos, trayéndose estos artículos de la otra narte de la cordillera. Contaba la "tierra caliente" con producción tan peculiar como la cera y miel, gracias a los colmenares naturales que los habitantes no se cuidaban en absoluto de atender, limitándose a cortar los

I52 Tamarón, Demostración, 77, 78, 92, 93, Iog-1I2. 
árboles en los que habían habitado las abejas; vendían aquella cera amarillenta para el consumo de todas las iglesias de Nueva Vizcaya, a diez pesos la arroba. ${ }^{153}$

Ostimuri y Sonora habían experimentado en los últimos años, junto a un notable desarrollo debido a la puerta en explotación de nuevos yacimientos mineros, un considerable detrimento en las sublevaciones y hostilidades recién habidas y que en parte habían de perdurar y aun recrudecerse en los tiempos venideros. La etapa inmediatamente anterior había sido en verdad fecunda en hallazgos. Desde I759, el real de Soyopa, también llamado San Antonio de la Huerta, iba en aumento por los placeres auríferos allí encontrados. Después apareció el real de Saracachi, y aún más tarde el de Bacuachi, todavía más ricos que el de Soyopa, pues estos últimos tenían no sólo placeres, sino vetas formales de oro. Todo esto llamaba al poblamiento de Sonora, y era lástima que tan bellas perspectivas se vieron coartadas por la hostilidad de los bárbaros del norte. Junto a la villa del Futerte, el realito de Sibirijoa ofrecía unas medianas minas de plata, y acababa también de descubrirse un placer de oro, y de la explotación de ambos metales vivía el real de los Alamos, con sus vecinas haciendas de beneficio de la Aduana, dos leguas al oeste. Alamos era entonces el lugar más rico de la gobernación, y alli se encontraba la caja para el reparto de azogues y la caja marca dependiente de los oficiales reales de Guadalajara. Río Chico, que se decía ser cabecera de la provincia de Ostimuri, había dado y daba riqueza, pero en el real de Topago de la Plata se advertían síntomas de decadencia, y lo mismo en Baroyeca. Estos y otros reales padecían las incursiones, sobre todo, de los seris y muchos se habían extinguido: Jupo, junto a San Miguel de Horcasitas, Santunes, Opodepe, San Javier, Soledad, San Lorenzo, San Juan Nacosari, Arizona... lo más lamentable fue la desaparición de la villa y real de San Juan de Sonora, primera capital de la provincia, cuya posición se hizo insostenible. ${ }^{154}$

Por el momento, la capitalidad se había sostenido en San Miguel de Horcasitas, en la vecindad de los antiguos pueblos de los seris, el Pópulo y Angeles, también desiertos. E1 valle de Horcasitas y Pitic era abundante en granos y viñas. Pero desde estos lugares al oeste no había sino "los desiertos tostados, arenales playosos y costas encumbradas, montañas, serranías, y espeluncas" donde se abrigaban y defendían los seris y parte de los pimas altos sublevados que habían convertido el país en reducto de la barbarie. ${ }^{\text {I55 }}$

Inmediatamente al sur, en cambio, hallábase la numerosísima nación

I 53 Ibid., 2I 2-2I 8 y 224 .

154 Ibid, 266.

I55 Ibid, 284 . 
yaqui, habitante en su superpoblado valle, de donde salían constantemente los yaquis para acudir a Soyopa y a Saracachi, donde había multitud de ellos; a toda Nueva Vizcaya, por donde se hallaban dispersos, y en particular a Chihuahua, en cuya proximidad formaban ya un pueblo, y a Parral, Santa Bárbara, El Oro, etc., siendo utilisimos obreros en la minería. ${ }^{5} 56$

A través cle sus pueblos, los seris habían llegado a hostilizar Río Chico y Baroyeca, mientras por otros rumbos alcanzaban al valle de Sonora o penetraban por la Pimería occidental, causando incalculables daños y el despueble de muchos ranchos, haciendas, villas y reales que el último gobernador Don Juan de Pineda se esforzaba en vano en contener.

\section{LA CAMPAÑa PROPUESTA POR TAMARóN}

Observador serio y responsable de los problemas de su diócesis, Don Pedro Tamarón no podía pasar ciego y sordo a la vista de los daños causados en ella por los enemigos y ante el clamor de los vecindarios sobrecogidos de horror. A su pluma debemos algunas de las pinturas del espanto r ue a los comerciantes, arrieros o soldados causaba el verse sorprendidos por una partida apache, aunque fuese reducida en número. Pero también él consiguió en sus escritos la urgencia de estos problemas, y su extrañeza por la inoperancia de las autoridades superiores para resolverlo. $\mathrm{Y}$ ciertamente que sus reclamaciones no fueron baldías.

Por eso nos detendremos, siquiera sea someramente, a considerar su idea de realizar una campaña decisiva en la frontera, idea que vierte tanto en la relación de su obispado como en las cartas al ministro de Indias: "facilite V. vengan tres o cuatro mil soldados de infantería" dice ya en su carta de 8 de enero de г76r. Un par de meses después, comentando el grado de indefensión general de las provincias y las últimas medidas - fundación de pueblo en Carrizal y de presidio en la Junta, y propuestas de otros en Chihuahua, San Buenaventura y Conchos- escribe tajantemente: "todo esto me parece es gastar a pocos", y a continuación se lanza con toda audacia a proponer una campaña de amplios vuelos, ${ }^{557}$ proyecto que también recoge en su informe general sobre la situación del obispado. Es preciso, a juicio del obispo de Durango, "introducir tropa reglada de infantería, que con tres mil hom-

I 56 Ibíd, 246 .

I57 Tamarón a Arriaga, Real del Oro de Aguá Caliente, 8 de enero de I76I; ibíd. a S. M., Villa de Llerena, real de Sombrerete, 29 de marzo de iz6r. A. G. I., Guadalajara, 40t. Demostración, I 23-I 24, 269-27I. 
bres sería suficiente", dividiendo este contingente por mitad en dos cuerpos. El primero haría una batida desde Chihuahua, por San Buenaventura, hasta alcanzar el Gila, y de aquí seguirá hasta Zuñi, en cuyo lugar se decidiría si continuar hasta el Moqui o si dirigirse al Oeste, por las tierras de los navajos y el río Grande de Navajos "que se dice es cabeceras del Colorado", de modo que se produjese el encuentro con el segundo cuerpo expedicionario. Este segundo cuerpo habría primero acabado con los seris, y luego se enfrentaría a los apaches entrando a las dos Pimerías, siguiendo luego hacia las cabeceras del Colorado. Hecha la convergencia de las fuerzas, se resolvería qué nuevo objetivo procurar.

Tamarón llega a prever que la marcha de estas tropas de México a Sonora estropee a los soldados y dé lugar a muchas deserciones, por lo que estima conveniente se les conduzca por mar desde Acapulco, o desde Panamá, hasta un puerto en el Yaqui. En cambio, una vez en la frontera, de aquellos soldados saldrían muchos pobladores, con notable ventaja para la conservación del territorio.

Una y otra ideas, la de doble campaña simultánea y la del transporte marítimo de las tropas serán puestas en práctica por Gálvez. Pero Tamarón justifica también el empleo de tropas de infantería, mucho más manejable, barata y útil para la guerra con los indios. La infantería resultaba tres veces más económica que la caballería, o en otros palabras, con lo que gravaba un hombre a caballo se mantenían tres a pie; la infantería no estaba sometida a la servidumbre apremiante de aguajes copiosos, a la de retención de hombres por las atenciones de la caballada, o a la de estampidas, huellas o polvaradas; por último, los infantes podían atacar a los enemigos allí donde hasta entonces no habían podido hacerlo los presidiales, es decir, en las sierras y peñascales adonde habitualmente huían a refugiarse. Tamarón contaba además con el mejor armamento de la infantería, el fusil de más largo alcance que la escopeta del presidial. Tampoco este propósito de aplicar tropas a pie en la frontera será olvidado por Gálvez en el momento de acometer su empresa.

Tamarón había insistido por tres veces en la urgencia del remedio para el mal estado de Chihuahua en I76I, la última en diciembre de este año. Por alguna razón esta carta vino a manos de Arriaga en I764, en cuya ocasión el ministro de Indias la anotó de su puño y letra con el estilo conceptuoso que le es propio: "pide lo mejor, pero no lo posible, y no lo es que si estuviese en tanto riesgo Chihuahua no hubiese dado cuenta el virrey en dos años que han pasado después de esta fecha. Dígase al virrey informe 
al estado de aquellas fronteras y progreso de los presidios que la defienden". ${ }^{158}$

En efecto, la real orden de 2 de mayo de $\mathrm{I} 764$ reclama tal comunicación al marqués de Cruillas en los siguientes términos: "Hallándose el rey con noticias de los continuados daños que reciben los naturales de las provincia de la Nueva Vizcaya de los indios bárbaros asolando y acabando las fronteras y lo que urge la defensa del pueblo de Chihuahua que es el más florido en comercio y abundancia de minas, y en que cada día cometen muchas muertes y robos, me manda S. M. decir a V. E. informe en primera ocasión el estado de las citadas fronteras de Chihuahua y provincia de Sonora, y progreso de los presidios que la defienden, y las providencias que $V$. E. haya dado para evitar los citados daños de los indios bárbaros". ${ }^{159}$

Nos interesa este documento tanto por sí mismo como por la atención que indica mostrarse en el ministerio por los problemas de las provincias internas en momento inmediatamente anterior al comienzo de la visita de Don José de Gálvez. En cuanto a la actitud de las autoridades virreinales ante esos mismos problemas, la respuesta de Cruillas a la orden antes copiada ${ }^{60}$ nos hace saber que en Junta de Guerra se acortó ordenar a los gobernadores de Sonora y Nueva Vizcaya que informasen de los parajes más descubiertos a donde se debían llevar los auxilios; y que en Sonora se había resuelto por la Junta establecer en Buenavista un presidio de cincuenta hombres, cuyo primer capitán sería Don Lorenzo Cancio.

\section{EL PRECIO DE LA DEFENSA}

Tal como se ha ido viendo en la exposición de la historia de las provincias posterior a la visita de Rivera, los efectivos militares de la frontera se habían incrementado considerablemente después de aquel acontecimiento, aunque no auntentara en la proporción deseada su eficacia como escudo proiector de las provincias a juzgar por las quejas de sus habitantes y del obispo Tamarón. Pero esa fuerza militar que cubría de Californias a Texas se había hecho ya costosísina. Felizmente poseemos una certificación de los oficiales reales de la caja de México, ${ }^{161}$ que indica el gasto que suponían todos los presidios internos. Este documento está fechado el 24 de diciembre de

I 58 Tamarón a Arriaga, Durango, 26 de diciembre de 176I. A. G. I., Guadalajara 5I I. Todavía insistió el obispo, en carta de $2 \mathrm{I}$ de marzo de I763. A. G. I., Guadalajara 300.

I 59 A. G. I., Guadalajara, 51 1.

160 Cruillas a Arriaga. México, 7 de noviembre de i 764, núm. io. A. G. I., Guadalajara, 5 I I.

I6 I A. H. N., Estado, 3884 , exp. I6, doc. Io. 
I 764 , esto es, en vísperas de iniciarse las visitas de Rubí y de Gálvez que narraremos en el próximo capítulo. La certificación, resumida, es como sigue:

Presidios

Plazas

Costo

Texas

Bahía del Espíritu Santo... . 5I . . . . 19645 Adaes . . . . . . . . . 6I . . . . . . 27765 Sàn Sabá. . . . . . . . IOI . . . . 40760 Trinidad . . . . . . . . . 31 . . . . . . 13245 Béjar. . . . . . . . . 23 . . . . . 8995

Nuero México

Santa Fe . . . . . . . 8I . . . . 34055 E1 Paso. . . . . . . . 50 . . . . . 20265

Nayarit

Nayarit .

Nueva Vizcaya

Junta de los Ríos. . . . . . 50 . . . . . 20265 Janos . . . . . . . . . . $5 \mathrm{I}$. . . . . 20665 Guajoquilla . . . . . . . 5 I . . . . 20665

Coahuila

Río Grande . . . . . . 33 . . . . . 10245

San Francisco de Coahuila. . . . 36 . . . . I 3570

Santa Rosa del Sacramento. . . . . $5^{2}$. . . . . . 2 I065

Nuevo León

San Agustín Ahumada

Sonora

Corodeguachi . . . . . . . $5^{1}$. . . . . . 20665

Guebavi . . . . . . . . 5 I . . . . 20665

Horcasitas . . . . . . . $5^{\mathrm{I}}$. . . . . 24065

Tubac . . . . . . . . . $5^{\mathrm{I}} . . .9 .20665$

Caborca (Altar) . . . . . . . 5I . . . . . 20665

Buenavista . . . . . . . 5 I . . . . . 20665 


\section{California}

Loreto

San José del Cabo.

I 3670

Nuevo Santander

Sta. Ana Camargo .

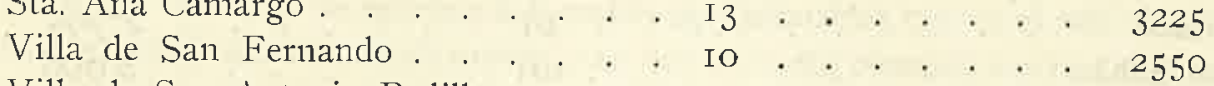

Villa de San Antonio Padilla . . . 5 . . . . . . 1300

Ntra. Sra. de Loreto de Burgos . . . 12 . . . . . . 2866,2

Sta. María de Llera. . . . . . I2 . . . . . 3000

San Francisco de Güemes . . . . 8 . . . . . . 2100

San Juan Bautista Horcasitas . . . . I I . . . . . . 2775

Dulce Nombre de Jesís Escandón . 9 . . . . . . 2220

Soto la Marina

Cinco Señores de Santander

Reinosa .

Sta. María de Aguayo

San Antonio Padilla .

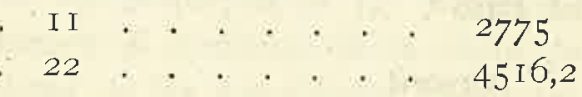

$$
\begin{aligned}
& \text {. II . . . . . } 2775 \\
& 500 \\
& \text { I } 2 \text {. . . } 3000
\end{aligned}
$$

Este cuadro es el primero de los presentados que recoge los dos núcleos de tropa de California - Loreto y El Cabo- y el presidio de Camargo y las trece escuadras de Nuevo Santander, así como el presidio de Buenavista ya decidido por la Junta de Guerra aunque todavía no erigido. Se supone suprimido el del Pasaje; y figura San Sabá como de Texas, aunque era reivindicado por Coahuila.

Si recopilamos los datos totales de los estados de fuerza recogidos hasta aquí, se hará visible la duplicación de su peso en el erario y la más que duplicación de sus efectivos en los sesenta y cuatro años primeros del siglo XVIII, pese a las restricciones impuestas por Rivera.

\begin{tabular}{crc} 
Año & Plazas & \multicolumn{1}{c}{ Costo } \\
\cline { 2 - 2 } I.7OI & 592 & $25 \mathrm{I} .883 \mathrm{ps}$. \\
I.7I & 653 & $299.175 \mathrm{ps}$. \\
I.725 & 905 & $444.883 \mathrm{ps}$. \\
I.729 & 855 & $352.540 \mathrm{ps}$. \\
I.764 & I27I & $485.015 \mathrm{ps} .4$ toms.
\end{tabular}




\section{LAS VÍAS Y EL COMERCIO}

Por toda la época virreinal dependieron las provincias internas como de su centro económico de la ciudad de México, a la que se hallaban inevitablemente ligadas por múltiples vínculos, siendo fundamental a este respecto el de ser México escala y almacén obligado de las mercancías de Europa que llegaban a Veracruz. De México, dos rutas eran posibles hacia el norte, según por qué parte se quisiese penetrar: la más importante era la que por Querétaro y Zacatecas llegaba a Durango; la secundaria se desviaba al este para conducir a Guadalajara, para desde este lugar internarse hacia el norte siguiendo una trayectoria paralela a la costa. Ni que decir tiene que si el núcleo de comerciantes de México intervenía prácticamente todo el movimiento de mercancías del virreinato, el de Guadalajara procuraba aprovechar por lo menos la porción de él que circulaba por su ciudad. Este hecho se nos hace patente en el pleito planteado por los vecindarios de Sinaloa, Culiacán, Ostimuri, Sonora y Rosario contra el comercio de Giuadalajara para que éste se abstuviera de cobrar el derecho de alcabala de las mercancías en tránsito para aquellas provincias. ${ }^{162}$

En efecto, parece ser que desde fines del siglo XVII veníase cobrando un gravamen del $2 \%$ en concepto de alcabala sobre las mercancías dirigidas o expendidas en las provincias costeras. ${ }^{\mathrm{I}}{ }_{3}$ Pero en I 7 I I se arrendó la alcabala de Guadalajara a Don Pedro Otero Bermúdez por quince años, por menos de quince mil pesos anuales. Seis años después, Otero hizo cesión de sus derechos al comercio de Guadalajara, que a su vez, en I772, obtuvo el arrendamiento del cobro de las alcabalas por nueve años más, a treinta y un mil pesos por año.

El caso es que, tanto Otero, de I7I I a I7I7, como el comercio de la Ciudad desde esta fecha a I 736 habían obligado indebidamente al pago de alcabalas a los mercaderes que se dirigían hacia Sonora. El administrador que en I 685 había introducido el ramo de alcabalas podía disponer su exacción, porque su producto iba a la real hacienda, pero los posteriores arrenlatarios se excedían en sus derechos sin duda alguna. Por eso en I754, cuando de nuevo se arrendaron las alcabalas al comercio de Guadalajara, se puso la condición de percibirlas sólo en este distrito, pese a lo cual volvieron a cobrarlas de las recuas de Sonora. De aquí se originó el recurso de estas provincias a Ortiz Parrilla, quien a su vez lo hizo presente al virrey, que ordenó el cumplimiento de aquella cláusula. Las provincias de la costa pedían además el reintegro de las cantidades que se les habían cobrado.

I62 La audiencia gobernadora a S. M. México, 30 de abril de 1760. A. G. I., Guadalajara, 33 I. I63 Vista fiscal en Madrid, 24 de noviembre de I760, y Ig de junio de I764. Ibid. 
E1 fiscai del Consejo estaba de acuerdo de esta actitud. El impuesto fercibido en Guadalajara había sido en realidad un portazgo, lo que estaba fuera de las atribuciones del arrendatario de las alcabalas de Guadalajara; esto era un derecho aéreo que mostraba por otra parte que Sonora y Sinaloa habían permanecido en realidad exentas de alcabalas, como deseaban segtiir estándolo. En cambio, Durango sí que las pagaba, aunque sólo producían dos mil quinientos pesos anuales. ${ }^{164}$

El camino, pues, de Sonora, desde Guadalajara se orientaba inmediatamente hacia la costa, por Suchitepec y Compostela, y de aquí, ascendiendo por Jalisco, Tepic, y Acaponeta, cruzando el río de las Cãnas, penetraba en la gobernación sonorense. Chiametla, Rosario y San Sebastián eran sus priiicipales estaciones hasta Culiacán: trayecto difícil todo éste, pues fácilmen\{e, con sólo algunas lluvias, hacíase intransitable. Una vez en Culiacán, por Mocorito se alcanzaba Sinaloa, y continuando por Ocoroni y las villas del Fuerte y de Alamos pronto se quedaba a las puertas del rico y hostilizado Ostimuri. Las misiones de Conicari y Tepaqui, las localidades de Nuri, y Miobas marcaban el tránsito de esta provincia hasta el río Yaqui y el real de Río Chico.

De aquí, el camino había de saltar al valle de Sonora, que alcanzaba en 1a misión de Ures, aguas abajo del acodamiento del río de Sonora. Las ascención del valle conducía hasta la misión de Bacuachi, y de aquí podría pasarse a la cabecera del río de Guebavi, donde el punto extremo de los establecimientos españoles era Tucson, en la misión de San Javier del Bac.

Al occidente del camino de Sonora, el camino real que desde México llevalua a Santa Fe, describía a partir de Durango una curva entre esta ciudad y la villa de Parral con objeto de evitar las sierras tepehuanas, y así pasaba por los presidios del Pasaje, Gallo y Cerro Gordo. De Parral, por Conchos, se iba a Chihuahua y de aquí al Paso del Río del Norte. Cruzado el río, remontar su curso por la orilla izquierda, a través de la famosa "jornada del muerto" era enpreșa más o menos penosa según que hubiese o no agua en el aguaje del Perrillo, hasta llegar a Tomé: luego ya por Alburquerque, San Felipe y Santo Domingo se llegaba a Santa Fe de Nuevo México, y aún más al norte, hasta Taos.

Diversas travesías de la Sierra ponían en comunicación ambos caminos reales. Unas ochenta leguas enlazaban Durango, en dirección suroeste con el real de Plomosas, vecino al de Rosario, en Sinaloa. Siguiendo un itinerario paralelo, pero más meridional, podía venirse a salir a Acaponeta,

I64 Ibid., Agüero a Arriaga. Durango, 6 de noviembre de i768. A. G. I., Guadlalajara, 332. 
pero entonces era preciso pasar por las tierras de los nayaritas, nunca muy seguros.

Más frecuentado, por diversas razones, era el camino que enlazaba Durango con Culiacán, a través de la Tepehuana, por Papasquiaro, y cruzando la cordillera por Topia. Esta fue la vía principal, desde que la aseguró Ibarra, durante más de medio siglo. Después, fundado Parral, fue posible dirigirse desde esta localidad a la villa de Sinaloa por las misiones de Tarahumara baja, pasando de la cabecera del Conchos a la del Fuerte.

Camino Real de Sonora se llamaba, desde Parral, al que por la misión de Tutuaca se acercaba al Yaqui por Sahuaripa. La situación se alteraría fundamentalmente cuando ya en el tercer cuarto del siglo XVII se abrió el tránsito de Nueva Vizcaya por la cuesta de Carretas, de modo que desde Parral, por Satevó se marchase hacia el norte según los cursos del río Santa María y del de Casas Grande, y de aquí se pasase por Carretas — paso de Carretas o del Púlpito- al río de Bavispe. Era ésta la travesía más cómoda de la sierra, y pronto los presidios de Janos y Corodeguachi sirvieron para mantenerla libre de enemigos. Su tráfico creció necesariamente desde el momento en que nació Chihuahua y la zona del Paso del río del Norte se convirtió en próspera explotación vinícola y ganadera.

No se olvidará la prolongación occidental que Nueva Vizcaya extendía al sur del Bolsón. Desde el presidio del Pasaje un camino conducía al pueblo de Parras, y de aquí, por la hacienda de Patos, a Saltillo. Saltillo fue siempre uno de los más importantes nudos de comunicaciones del norte. En Saltillo desembocaban, vía Zacatecas y Mazapil, las recuas de mercancías de Europa y de Tierra Afuera, y a las ferias de Saltillo concurrían todos los comerciantes, ganaderos, y agricultores de Coahuila, Texas y Nuevo León. Monterrey y Monclova estaban próximas, y una débil cadena de puestos enlazaba Monclova con el extremo establecimiento - Adaes- - de Texas.

Es de advertir, que a mitad del siglo XVIII, sólo los caminos de Sonora y Nueva Vizcaya eran transitados por correos regulares. Nuevo México no se comunicaba más que una vez al año con Chihuahua; Coahuila y Texas carecían de servivio ordinario de postas. El de las otras dos provincias estaba centralizado en Guadalajara, cuya oficina despachaba un correo mensual sólo hasta Rosario, en Sinaloa, donde recogía la correspondencia de toda la gobernación de Sonora, cuyos mensajeros pagaba el vecindario de la provincia. El otro enlace estaba en Zacatecas, que tenía con Durango un correo quincenal. ${ }^{165}$

I65 La audiencia de Guadalajara a S. M. Guadalajara, I6 de septiembre de I765. Ibid. 



\section{CAPITULO TERCERO}

\section{LA EPOCA DE GALVEZ}

\section{LA FRONTERA EN I 765}

Las cartas que en I76r, al regresar de su visita al obispado de Durango, dirigiera Don Pedro Tamarón y Romeral al ministro de Indias tuvieron eco años después cuando Arriaga, extrañado del silencio del virrey sobre la situación de la frontera, que tan deplorable pintaba Tamarón, pidió a Cruillas le informase del estado defensivo de Nueva Vizcaya y Sonora. La respuesta de Cruillas consistió en la exposición de los motivos que hacían necesaria la erección de un nuevo presidio de cincuenta hombres en Sonora, dada la hostilidad de los indios alzados en Cerro Prieto. Este presidio, llamado de San Marcial o de Buenavista, quedó situado junto al pueblo de este nombre, a la orilla derecha del río Yaqui, en $\mathrm{I} 765$, debiendo servir como valladar a las incursiones de los rebeldes. Su primer capitán, el asturiano Don Lorenzo Cancio Sierra y Cienfuegos, daría inequívocas muestras de aptitud en la campaña inmediata. I

I Los autos para la erección del presidio de Buenavista fueron enviados por Cruillas a Arriaga con carta de México, 22 de octubre de 1765 , núm. 18. A. G. I., Guadalajara $5 \mathrm{Ir}$. El capitán Cancio que había empezado su carrera como guardiamarina y tenia tres campañas en su historial, había sido subteniente del batallón del regimiento de infanteria de la Corona que guarnecía Veracruz, y sargento mayor de las milicias del obispado de Puebla durante año y medio. Ya Cruillas había advertido su competencia en 1760 , cuando Cancio solicitaba la capitania de un presidio en la frontera con los bárbaros. Memorial adjunto a carta de Cruillas a Arriaga, núm. 40. México, 2 de noviembre de 1760. A. G. I., México, 1359. Pocos meses más tardé. cuando el coronel Don Diego Ortíz Parrilla, veterano de las campañas de Texas y de la isla de Tiburón y por entonces comandante del presidio de Santa Rosa del Sacramento fue comisionado para conducir un socorro de tropas a Panzacola, Cruillas pudo nombrar a Cancio capitán interino de aquel presidio por decreto de 24 de julio de 1761 . Cruillas a Arriaga, núm. 35. México, 22 de noviembre de 1761. A. G. I., México, 1360. Cuando al año siguiente se promovió expediente contra el gobernador de Coahuila Don Jacinto de Barrios Jáuregui, Cancio fue el comi- 
También entonces, en 9 de octubre de 1765 , una junta de guerra cuya celebración habían pedido el fiscal y el auditor de guerra y a la que asistieron Villalba, Ricardos y el visitador Gálvez decidía la erección de dos presidios más en Nueva Vizcaya: uno se establecería en el valle de San Buenaventura entre los de Janos y Paso del Río del Norte; otro, en Gallo, Mapimí, Conchos o Cerrogordo, en la frontera oriental de la provincia. Ambos debían tener como finalidad la protección de Chihuahua y la cobertura del gran espacio que mediaba entre Nueva Vizcaya y Sonora y con el mismo fin se permitía al gobernador trasladar el presidio de la Junta al lugar que estimase conveniente. ${ }^{2}$

A pesar de lo urgente que parecía la aplicación de este remedio, el gobernador de Durango Don José Carlos de Agüero, a cuyo cuidado se había dejado el nombramiento de los capitanes de aquellos nuevos presidios, no tomó ninguna medida para poner en práctica la resolución de la Junta y hasta el 8 de abril de I766, conociendo la proximidad de la llegada de Rubí a la ciudad, no designó a Don Manuel de Villaverde para que marchase a erigir el que se había pensado colocar en la frontera del Bolsón. Pero Rubí, una vez en la capital de Nueva Vizcaya y oídos los informes de las personas más competentes, creyó su deber exponer que los dos presidios que se había resuelto fundar debían situarse al norte de la provincia, entre Janos y E1 Paso. 3

En cambio, el gobernador decidió por su cuenta trasladar el presidio de la Junta a Julimes, como se hizo, dejando tan sólo un destacamento en Agua Nueva, lo que supuso un retroceso innecesario de las posiciones españolas, quedando al descubierto toda la frontera nordeste, desde El Paso a Coahuila. 4

Finalmente, los dos nuevos presidios fueron establecidos en el valle de San Buenaventura y en el de San Bartolomé - en el paraje de San José, pronto dejado por el de Cerro Gordo-, al norte y al este de la provincia, según se pensara en la Junta celebrada en México, y en estos lugares fueron visitados por Rubí. 5

sionado para recibir la informanción oportuna y para hacerse cargo del mando interino de la provincia al ser Barrios llamado a México. Testimonio de autos contra Barrios,i764. A. G. I., México, I 269 y 1363 , con carta de Cruillas a Arriaga, núm. 5I. México, i 3 de octubre de I764. En A. G. I., México, 2428, patente de alférez agregado al Batallón de la Corona a Don Lorenzo Cancio Donlebun, en 28 de mayo de 1755.

2 Cruillas a Arriaga, México, 22 de octubre de 1765 , núm. I9, con testinonio de autos A. G. I., Guadalajara, 5 I I.

3 Rubí a Arriaga, Durango, 5 de abril de I766, núm, 5 y Avinito, 27 de abril de I766, Ibid.

4 Rubí a Croix. Valle de San Buenaventura, 26 de octubre de 1766 , Ibid.

5 El gobernador Agüero nombró capitán de San Buenaventura a Don Manuel Gómez de la Torre, y de Cerro Gordo a Don Manuel de Villaverde. Ibid. Croix a Arriaga. M'éxito, '2 I de mayo de 1767, núm. 4. Ibid, y México, I 366. 
Estos tres nuevos presidios - Buenavista, San Buenaventura, Cerro Gordo- elevan a seis el número de los de Sonora y a cinco el de los establecimientos defensivos de Nueva Vizcaya. En Sonora esto significa la continuación y el recrudecimiento de las hostilidades y sublevaciones de los indios del exterior y del interior, situación que desembocaría en la campaña formal que practicó la expedición enviada por Gálvez. En Nueva Vizcaya, este refortalecimiento de la frontera marca el fin de la falsa situación creada por el primer conde de Revillagigedo al suprimir los presidios de la cordillera.

\section{LA EXPULSIÓN DE LOS JESUITAS}

En i767 desaparece uno de los factores más significativos de la dinámica de la frontera con la expulsión de los jesuitas de sus misiones en Nueva Vizcaya, Sonora y California. Hondamente vinculados a las provincias y a la población española e india, su marcha dejó en el abandono las diecisiete misiones de Tarahumara, veintinueve de Sonora y quince de California que habían venido atendiendo.

Los comisionados en 6 de junio de 1767 por el virrey Croix para verificar la salida de los jesuitas de aquellas tres provincias, Cuéllar, Pineda y Portolá, no puede decirse que se mostraran remisos en desempeñar su cometido. Bien es verdad que las órdenes de Madrid establecían pena de muerte para el incumplimiento de ellas. Pineda obedeció los despachos a él dirigidos el II de julio y el I 5 nombraba ejecutores de las órdenes a los capitanes Urrea, Anza, Bergosa y Cancio, y al alcalde mayor de Sinaloa Don Sebastián de Azcárraga. Estos se encargaron de reunir a los Padres de Sonora en Matape, y los de Sinaloa en Buenavista, para desde estos lugares conducirlos a Guaymas, donde deberían embarcar con destino a San Blas, lo que no tuvo efecto hasta el 20 de mayo de I768, y sólo fue para tener que fondear en Puerto Escondido (junto a Loreto, California) el i2 de junio, por la difícil navegación del Golfo. El I 5 de julio, cuando ya Gálvez estaba en la península, se hicieron a la vela y el 9 de agosto entraban por fin en San Blas, más de un año después de haber salido de las misiones. Cuéllar, con auxilio del teniente Becerril, envió a los miembros de la Compañía a México, vía Zacatecas. Portolá fue el último en llegar a su destino, por la necesidad de atravesar el Golfo, pero arribó a la misión de San José a mediados de diciembre de I767. El I7 de este mes llegó por tierra a Loreto y comunicaba la orden de expulsión. E1 3 de febrero emprendieron su viaje desde Loreto los padres de la península, yendo a reunirse en Guaymas con los de Sonora, que estaban allí congregados y con quienes navegaron hasta San 
Blas, siendo dirigidos luego todos a Veracruz, en una peregrinación de cuyas fatigas muchos perecieron. ${ }^{6}$

La salida de los jesuitas dejó planteadas al gobierno varias cuestiones. Una de ellas, la de la administración de sus temporalidades, agravada por el hecho de que los comisionados, por error o exceso de celo, confiscaron como tales temporalidades todos los bienes de las misiones, que en realidad pertenecían a éstas. Estos bienes padecieron grandemente en el corto tiempo transcurrido hasta que fueron devueltos a los nuevos misioneros. En remplazo de los jesuitas fueron llevados a la frontera un grupo de franciscanos, mientras que otri parte de las misiones, en Sonora y Tarahumara, fue secularizada, es decir, entregada al clero secular y puesta bajo el obispo de la diócesis.

El problema más interesante para nosotros es el de la sujeción directa al gobierno virreinal de los territorios de las misiones jesuíticas. Esta cuestión no se plantea en Sonora, donde quedaron sujetos a la autoridad de esta provincia, pero sí en California, que hasta entonces no había sido tal, y en Tarahumara. En estos casos, Croix expidió nombramiento de gobernador de California a Don Diego de Portolá, y de Tarahumara Alta y Baja y Tepehuana, comandante de sus fronteras y de las del corregimiento de la villa de San Felipe el Real de Chihuahua a Don Lope de Cuéllar, en junio de 1767 .

Si las razones generales de la expulsión de los jesuitas eran complejas en España, para el caso concreto de la frontera del virreinato mexicano cabe recordar los bulos circulantes en los tiempos inmediatamente anteriores a aquel hecho sobre las riquezas de la península, que los padres exportaban ocultamente, y sus pretensiones a la independencia, en tanto que en Sonora se les acusaba de ser los causantes de las rebeliones de los indios, datando de ía época del primer alcalde mayor de la provincia, Don Pedro de Perea, la larga pugna entre estas autoridades y los miembros de la Compañía de Jesús.

\section{LA VISITA DEL MARQUÉS DE RUBi}

Si I764 es una fecha clave en la historia del Imperio español, ello se debe a que el fin de la guerra de los Siete Años situó decididamente a Inglaterra frente a España en dispita por la hegemonía colonial, al tiempo que la paz de Versalles destruía para siempre el equilibrio de potencias en Norteamérica y planteaba para España la reivindicación de Florida.

$\mathrm{La}$ atención de la corona española no tardó en fijarse en las posiciones

6 Cuevas, Mariano: Historia de la Iglesia en México. 5 vols. México, 1947. Pradeau, Alberto Francisco. $L a$ expulsión de los jesuitas de las provincias de Sonora, Ostimuri y Sinaloa en 1767. México, 1959. 
más setentrionales del virreinato mexicano, que ahora se extendía desde la costa pacífica de California hasta la anchurosa corriente del Misisipí. Desaparecido el peligro francés, surgía una frontera con las colonias inglesas que tan fuertes se habían manifestado en la anterior guerra.

La guerra intercolonial sería inevitable en una previsible futura contienda con Inglaterra, y se hacía preciso robustecer los dominios españoles. Con estas miras fue enviado a Nueva España una misión militar encabezada por el general Don Juan de Villalba con objeto de crear en el virreinato un ejército regular estructurado a la europea. Llegaron regimientos peninsulares, se reclutaron en México otros, llamados veteranos, de infantería y caballería, y se levantaron cuerpos de milicias provinciales.

Todo esto, empero, costaba muchos miles de pesos al real erario, y en previsión de estos dispendios pensóse en reorganizar la hacienda virreinal, misión que fue encomendada al licenciado Don José de Gálvez, 7 futuro ministro de Indias, personaje hasta entonces prácticamente desconocido.

En 7 de agosto de 176.5 , el marqués de Rubí, uno de los componentes del equipo de Villalba, era destinado para la comisión de visitar los presidios de la frontera setentrional del virreinato, ponerlos en buen estado, investigar su utilidad y proponer las reformas que estimase conveniente. Tal decisión de la corte se halla relacionada con el informe hecho por Villalba contra el virrey, del que decía que no le quería entregar el mando de los presidios porque percibía anualmente el $4 \%$ de lo que el rey gastaba en ellos, acusación que parece carecer de todo fundamento. ${ }^{8}$

7 En carta dada en el Pardo, 23 de marzo de 1765 , que entregaría cl propio Gálvez a Villalba, recomendaba el ministro Esquilache al general velase por la armonia con el visitador. A. G. I., México, 2475. La importancia de la misión encomendada a Gálvez y su relación con la de Villalba nos viene expresada en palabras del propio ministro Arriaga a Croix, después de haberle advertido la reforma del ejéricito encargada al general: "No perdió $S$. M', de vista el que a medida de lo que tan nuevos crecidos despendios habian de ser gravosos al erario, era debido reconocer el estado de éste en su recaudación y distribución, examinándose si en uno y otro se había procedido con arreglo a las establecidas leyes, para que se castigasen sus transgresiones si las hallase, cobrasen Ios descubiertos y se tratase de los medios que pudieran adaptar el aumento de aquellas rentas. $Y$ pára estos fines y otros y el de estancar el tabaco determinó $S$. M. el envío de un ministro visitador de cajas y ramos de real hacienda, con subalternos que sirviesen a su orden; y por muerte del primero, nombró para que lo subrogase a Don José de Gálvez, ampliando su comisión a la visita de tribunales, con las facultades y advertencias que constan de sus despachos e instruciones, de que se pasaron copias al virrey Cruillas; y siendo como es el objeto de esta separada comisión el que abraza la posibilidad de tadas en la mejor administración de las rentas reales y su aumento, como raiz de cuyos frutos pende todo lo demás: me manda el virrey el encargar a V. E. auxilie al referido ministro en los casos que necesite de su suprema autoridad para el cumplimiento de sus justas deliberaciones o providencias, y que procediendo en la armonia que pide el mejor servicio del rey y que el juicioso carácter del citado ministro se sabrá granjear se consiga verificar el cumplimiento de las acertadas órdenes de S. M.". A. G. I., México, I508.

8 Real orden de 7 de agosto de 1765 . A. G. I., Guadalajara 5 I I. Id, a Villalba, misma data, A. G. I., México 2475. Rubi acudió a M'éxico para disponer su viaje y recoger los docur mentos y noticias convenientes. Daba por seguro no podría concluir un viaje de cuatro mil 
Aquel mismo año, apenas llegado a Nueva España, Gálvez, enterado de] estado de cosas imperante en Sonora y Nueva Vizcaya, empezaba a tantear las conveniencias y dificultades para realizar la que había de ser su expedición a Sonora. De esta manera, por Rubí y por el propio Gálvez, las provincias internas quedan incluidas en la doble visita para la reorganización militar y económica del virreinato.

Rubí, por de pronto, recorrió toda la frontera desde Sonora a Texas. La comisión le fue dada en agosto de 1765 , pero su partida de México no se verificó hasta el doce de marzo del año siguiente, 9 llevando la Instrucción que dos días antes le expidió Cruillas. Por Zacatecas se dirigió a Durango, donde revistó la escuadra de diez hombres y un cabo que para protección de la ciudad proporcionaba el presidio del Pasaje; ${ }^{\text {ro }}$ luego, por este mismo presidio y el de Huejoquilla llegó a Chihuahua, y de aquí se trasladó a la Junta de los Ríos, El Paso y Santa Fe de Nuevo México. II A su regreso de esta provincia revistó los de San Buenaventura ${ }^{12}$ y Janos en Nueva Vizcaya, y los seis de Sonora. ${ }^{13}$ Cruzando luego la Sierra Madre por el valle de Basuchil volvió a Nueva Vizcaya, visitó los presidios de Huejoquilla y Cerro Gordo, ${ }^{4}$ luego los de Coahuila y Texas y el de San Sabá y las guar-

leguas como el que veía en perspectiva. Rubi a Arriaga. México, 12 de enero de 1766, núm. 2. A. G. I. Guadalajara 511. Villalba a Arriaga. México, 12 de marzo de 1765 , y reales órdenes de 7 de agosto de 1765 , en A. H. N. Estado $3882-7$. Todavía a principios del afio siguiente escribe Villalba aludiendo a la gestión de Rubi: "es la comisión de mayor importancia y que más dolor creo catuse, porque se trata de desprender a los virreyes de una suma considerable que les restulta de los abusos y desarreglo en los presidios". Villalba a Arriaga, México, 15 de enero de 1766. Ibid.

9 Rubi a Arriaga. Zacatecas, 31 de marzo de 1766 , núm. 4. Ibid. Cruillas dice en cambio que Rubí salió de México el 6 de marzo, acompañado por el capitán de Ingenieros Don Nicolás Lafora y por el delineador subteniente del regimiento de América Don José Urrutia. Cruillas a Arriaga. México, 19 de marzo de 1766 , núm. 3. Ibid. La Instrucción para la revista dada a Rubi por el virrey tiene fecha de diez de marzo. Ibid, y México ${ }_{13} 64$. Por último, Villalba da como fecha de la partida de Rubi para la frontera el ${ }^{13}$ de marzo. Villalba a Arriaga, 23 de marzo de г 766. A. G. I., Guadalajara 5 I т.

ro Llegó Rubí a Zacatecas, el 29 de marzo, y a Durango el ir de abril. Rubí a Arriaga. Durango, I 5 de abril de 1766 . Ibid. Entonces acababa de situarse la compañía volante mandada por Villaverde en San José, a diez leguas al nordeste de Mapimí, entre los antiguos puestors de Mapimi y el Gallo. Rubí a Cruillas, Avinito, 27 de abril de I766. Ibid.

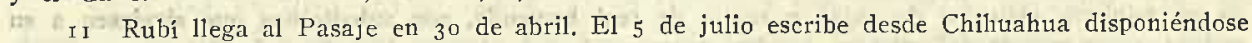
a salir de la villa el 7 ; núms. 7,8 y 9 de Rubi a Arriaga. Ibid.

I Escribe Rubi desde San Buenaventura el 26 de octubre de 1766 . Ibid. Debió pedir su regreso a España antes de pasar a Nuevo M'éxico, pues ya en 22 de octubre se le permite volver, aunque deberá continuar la revista de los presidios hasta que se le nombre sustituto, que seria el marqués de la Torre o Don Francisco Douchet, según indica orden posterior de 5 de enero de 1768 . Ibid.

I 3 Las cartas de Rubí dosde Sonora están dadas en el presidio de San Miguel el 2 I de febrero de 1767 . Ibid.

I4 Llegó al valle de San Bartolomé el iz de abril de i767. Del 5 al ro de mayo estuvo en Cerro Gordo. El 24 del misno mes escribe desde el Pasaje, número 2o, Ibid, disponiéndose : partir el 26 para Coahuila, 
niciones de Nuevo León, ${ }^{15}$ regresando a México después de dar un rodeo por Nayarit, entrando en la capital el 23 de febrero de $1768 .{ }^{16} \mathrm{El}$ total de los establecimientos defensivos visitados por Rubí es de veintitrés, número al que hay que añadir el presidio de Julimes, al que el marqués no pudo pasar revista, y las guarniciones de Nuevo Santander, visitadas por Fernández Palacios. Es decir, que en los mismos territorios inspeccionados por Rivera, había veintitrés años después seis presidios más que los que aquél había dejado en pie, y once más de los que respetara el primer conde de Revillagigedo. Este sólo dato muestra cómo, sin haberse hecho ampliación territorial al norte después de I73o, había crecido la tensión de la frontera, sin que se deje de advertir que, mientras Rivera encontró un ambiente general de paz, la organización defensiva visitada y reformada por Rubí se ha de mostrar en los años sucesivos en gran manera deficiente frente a la presión exterior cada vez más intensa.

Hagamos un rápido cálculo del aumento de los efectivos entre Rivera y Rubí. En Sonora, a los dos presidios encontrados por aquél --Fronteras y Sinaloa-, se han aumentado cuatro - Terrenate, Tubac, San Miguel y Buenavista-; en el perímetro defensivo de Nueva Vizcaya, en vez de los ocho que Rivera dejó - Janos, Conchos, San Bartolomé, Mapimí, Cerro Gordo, Gallo y Pasaje; más el de El Paso dependiente de Nuevo México, reducidos a cuatro por Revillagigedo: Janos, El Paso, Huejoquilla y Pasaje-, tenemos ahora los siete de Janos, San Buenaventura, El Paso, Julimes, Huejoquilla, Cerro Gordo y Pasaje. A los dos existentes en I730 en Coahuila - Monclova y Río Grande- deben añadirse ahora los de Santa Rosa del Sacramento $y$, en cierto modo, San Sabá, que pronto va a quejar sujeto a esta provincia. Un presidio, el de Orcoquiza, se ha aumentado en Texas a los tres de Adaes, Bahía y Béjar. En lugar de los de Cerralbo y Cadereita existe en Nuevo León el de Monterrey, y subsisten en Nayarit el de la Mesa del Tonat, y en Nuevo México el de Santa Fe.

Rubí y Lafora plantean ya con absoluta claridad la unidad de la frontera, $\mathrm{y}$ todo su proyecto respecto del sistema defensivo consiste en la preocupación de cerrar los huecos que han quedado entre algunos de los presisidios. Hueco evidente en el Bolsón de Mapimí. Ellos se esfuerzan en llevar

I5 En 28 de junio de 1767 estaba Rubi en Monclova, según carta de esta data, núm. 22, a Arriaga. El 24 de agosto escribe desde Béjar. El 23 de diciembre llega a Saltillo habiendo visitado Béjar, Adaes, Orcoquiza, Bahia del Espiritu Santo, Rio Grande y Nuevo León. El 28 se proponía salir para Zacatecas. Rubi a Arriaga. Saltillo, 26 de diciembre de 1767 , núm. 24. Ibir.

I6 Rubí a Arriaga, Tacubaya, $10^{\circ}$ de marzo de 1768 , núm. 27. El 3 de abril remitía al ministro un estado de los veintitrés presidios revistados y continuaba la preparación de su dictamen acerca de la colocación de los puestos de la frontera, al que acompañaría un mapa formado por los ingenieros. Ibid. 
definitivamente la línea de los presidios al río Grande, que suponen rectílíneo desde El Paso a San Juan Bautista.

Desde el principio, movido probablemente por el conocimiento de las expediciones llevadas a cabo en el Bolsón por Berroterán, Rábago y Villaverde, Rubí propugnó la actuación conjunta de las tropas de Nueva Vizcaya y Coahuila en el Bolsón, lo cual permitiría llevar el nuevo presidio que Agüero había hecho colocar en el paraje de San José —entre el Gallo y Mapimí-, a otro lugar entre San Buenaventura y El Paso, en la frontera del norte. ${ }^{17}$ La experiencia de Villaverde debió originar en él también el claro juicio de que los indios asaltantes del camino real de Chihuahua eran los mismos que en Coahuila se hallaban de paz con los capitanes de los presidios de esta provincia; de modo que estos apaches vendían en Coahuila ganado herrado por los hacenderos de Nueva Vizcaya. Por eso Rubí pretende trasladar el presidio del Pasaje a Pelayo, lugar por donde los indios de Coahuila entraban al camino real de Chihtıahua. Más al norte, la compañía volante de Guajoquilla podía ser desplazada a los llanos de Jupata o de Banderas, en ruta hacia el presidio de Santa Rosa, con el que sería de este modo posible tomar contacto. Por aquella parte hostilizaban los natajes y coahuileños y las cuadrillas de Pascual y Ligero, que infestaban el camino del Conchos a Chihuahua. Lafora señalaba también la posibilidad de adelantar al río Grande el ya inútil presidio de Monclova, y la de fundar otro entre éste y el de la Junta para asegurar el río como frontera, "siendo la más natural y propia que puede imaginarse, que está dictando la misma naturaleza del terreno y que a menos costa de armas y trabajo pudiera reconocerse y defenderse", según Rubí.

Lafora calcula en cuatro millones de pesos los daños causados en la zona del río de San Pedro al presidio de Fronteras por los enemigos, de I749 a I763. A la real hacienda, las hostilidades le habían perjudicado en unos trescientos mil pesos; ochocientas muertes habían sido causadas, y muchas minas se habían perdido o abandonado. El reducto de los apaches queda ahora claramente fijado en la "provincia de Gila", hacia la Sierra Madre que dividía Sonora de Nueva Vizcaya, penetrando ellos en estas provincias entre Janos, Fronteras y E1 Paso. Otros pasaban el río entre El Paso y la Junta, sin que se pudiese decir si éstos eran apaches y sumas procedentes del Gila, o si venían del otro lado del territorio desierto, al este. Los puntos a ocupar eran el Valle de Ruiz y Agua Nueva; la tropa de Janos debía batir

I7 Rubí a Cruillas. Avinito, 27 de abril de I766. A. G. I., Guadalajara, 5 I I. Rubí trató este punto en junta habida en Durango a la que asistieron Agüero y varios prácticos, recibiendo además informes del vecino de Chihuahua Don Andrés de Velazco, de los justicias y regidores. de Don Manuel Muñoz y de Dor Manuel Villaverde, capitán y teniente respectivamente entonces del presidio de la Junta. 
el terreno hasta Bavispe o Basaraca, y aquí tomaría contacto con la de Fronteras.

De este modo quedarían protegidas las haciendas y valles de Casas Grandes, Ruiz, San Buenaventura, Santa Clara, Encinillas, Hormigas, Sacramento, Dolores, Tabalaopa, Dolores de Mapula, etc., hasta ahora asoladas por los indios. ${ }^{8}$ Sin embargo, la simple ocupación de Agua Nueva, después de junta que el gobernador tuvo el 20 de agosto de 1766 en Chihuahua con asistencia de capitanes y mercaderes, no puso en absoluto remedio, de modo que de agosto a octubre del mismo año fueron atacados Chihuahua, Bachiniba, Temosachi, el Carmen, Agua Nueva, Yepómera, el mismo presidio de San Buenaventura y otros lugares, produciéndose robos y muertes. 19

Las alusiones de Rubí a la posibilidad de organizar una expedición contra los enemigos son frecuentes, antes incluso de llegar al Pasaje. ${ }^{20}$ Alguna vez dice la conveniencia de formar un destacamento de setenta $\mathfrak{u}$ ochenta hombres con los correspondientes indios auxiliares, con gentes de los cinco presidios de Nueva Vizcaya, que se mantuviese en constante guerrilla vigilando a los bárbaros. ${ }^{2 x}$ La necesidad de expedición formal fue reconocida por Arriaga, que ordenó a Croix estudiar los medios de realizarla. ${ }^{2} 2$ Las propuestas de traslado de Monclova y San Sabá al río Girande conducen pronto a la visión de un sistema defensivo unificado para toda la frontera: "las ventajas - dice Lafora- que resultarían de la comunicación de las armas de estas dos provincias (Coahuila y Nueva Vizcaya) serían otro tanto mayores con las de Sonora y Nuevo México; lo que hace ver la precisión de combinar en un proyecto genial la disposición de los presidios para la mayor facilidad de auxiliares recíprocamente estableciendo el método más propio para que todos contribuyan a un mismo fin". ${ }^{23}$

Rubí, en fin, presentó su dictamen, ${ }^{24}$ dividido en treinta puntos, dedi-

I8 Rubi a Arriaga, Chihuahua, 5 de julio de $1766, y$ "Dictamen que para asegurar las fronteras de la Nueva Vizcaya da el capitán de Ingenieros Don Nicolás de Lafora. Fundado en lo que ha visto de ellas, en los informes de la gente más práctica y en los mapas más correctos de este pais". Chihuahua, 2 de julio de 1766 . Ibid.

I9 Rubí a Croix. Valle de San Buenaventura, 26 de octubre de i766. Ibid.

20 Rubí a Cruillas. Avinito, 27 de abril de 1766 . Ibid.

2I Rubi a Arriaga. Chihuahua, 5 de julio de 1766 . Ibid.

22 Rubí a Croix. Valle de San Buenaventura, 26 de octubre de 1766 . Real orden de 20 de abril de 1767 . Ibid.

23 Informe de Lafora a Rubí sobre el presidio de San Sabá. Béjar, I2 de agosto de I767. Respecto del presidio de Monclova, dice Rubi que "solo sirve hoy para asegurar la subsistencia a las rancherias de bárbaros que están en sus inmediaciones, traficando con estos vecinos las mismas caballadas y muladas que traen robadas de la Nueva Vizcaya, y aún las suyas propias, de que no se eximen de pagar el rescate siempre que estos fronterizos logran la frecuente oportunidad de robárselas". Rubi a Arriaga. Monclova, 28 de junio de 1767. Ibid.

24 "Dictamen que de orden del Excmo. Señor marqués de Croix, virrey de este reino, expone el mariscal de campo marqués de Rubi en orden a la mejor situación de los presidios para 
cados los tres primeros a una exposición de "presupuestos", siguiendo luego la "proposición" en los puntos cuarto al veinte, con algunas reflexiones sobre su utilidad -2 I al 26 - y conclusión -27 al $30-$. La línea defensiva propuesta comprendería diecisiete presidios, debiendo suprimirse otros nueve.

E1 mariscal pasó seguidamente a España, y a su llegada a Cádiz fue llamado a la corte, donde comenzó el estudio de sus proyectos, 25 que merecieron la aprobación real en I t de julio de i $769 .{ }^{26}$

La fuerza total de los presidios en el momento de Rubí - sin contar Nuevo Santander, pero incluyendo Nayarit - era de I.I6I hombres, y su

la defensa y extensión de su frontera a la gentilidad en los confines del norte de este virreinato". Tacubaya, Io de abril de 1768 . A. G. I., Guadalajara, 5 I I. Rubí envió este documento a Arriaga desde Veracruz, con carta de 4 de nayo de 1768 , núm. 31. Ibid. Otros ejemplares del Dictamen en A. G. I., M'éxico, 24.22 y 2477 ; A. G. I., Guadalajara, 273.

25 El virrey Croix sólo recibió de Rubí una copia del "Dictamen" y reclamó en vano a Arriaga, en 27 de abril de 1768 , núm. 30 , los demás documentos. En 28 de julio de 1768 , núm. 313 , dice haberse embarcado Rubí en la balandra correo. El i7 de marzo de 1769 avisaba Rubí desde Cádiz su llegada al ministro, que le autorizó a presentarse en la Corte. A. G. I., Guadalajara, 511. Sobre la expedición o visita de Rubí y situación de las provincias puede consultarse: Lafora, Nicolás de, Relación del viaje que hiso a los presidios internos situados en la frontera de la America septentrional portenecientes al rey de España. Liminar bibliográfico y acotaciones por Vito Alessio Robles. México, 1939. Incluye una reproducción del mapa de la frontera, obra del mism) ingeniero, fechado en México, 30 de septiembre de $x 771$. Con la misma visita se relacionan dos piezas anónimas existentes en el Servicio Histórico Militar. "Diario del reconocimiento de una parte de la América septentrional española. I 5 \%", que es una descripción en 138 fols. (S. H. M.,, 5-3-9-8) y "Situación en que se lallan toclas las provincias del reino de Nueva España fronterizas a la gentilidad en las partes clel norte" (S. H., M', 5-3-9-5).

26 A. H. N., Estado, 3.882-7. Poco se sabe de la vida del marqués de Rubi. En cuanto a su actuación en Nueva España, llegado a Veracruz con Villalba el $10^{\circ}$ de noviembre de 1764. ssistió a este general hasta recibir la real orden de 22 de octubre del mismo año que le comisionaba para investigar el comportamiento de los oficiales de real hacienda de Acapulco y el conercio que se hacia por la nao de Filipinas. Este asunto le tuvo al margen de los problemas de Ii creación del ejército virreinal, aunque Villalba le había encargado en mayo de iz65 la formación de un regimiento de infantería miliciana en México y otro en el valle de Toluca. Antes de ser destinado a la revista de los presidios estuvo entendiendo en la organización del regimiento de caballeria de Querétaro, teniendo a sus órdenes a Don Felipe Neve como sargento mayor. Rubi a Squilace, Veracruz, s. d., noviembre de 1764 ; reales órdenes de 22 de octubre de 1764 y de II de netubre de 1765 a Villalba. A. G. I., México, 2475. En cuanto a sus acompañantes, Don Nicolás Lafora había pasado a Nueva España como capitán de ingenieros a las órdenes del virrey por real orden de 9 de mayo de 1764 , con los subtenientes del mismo Cuerpo Don Miguel Costansó y Don Francisco Fersen. A, G. I., México, 2424. Ya en I 767 solicitaba Lafora grado de teniente coronel. Croix a Arriaga, núm. 13. México, 23 de abril de 1767. A. G. I., México, 1366. Don José Urrutia era subteniente del regimiento de infanteria de América y se mantuvo en México hasta abril de 1769 , con objeto de concluir los planos de todos los presidios visitados. Croix a Muniain, México, 25 de abril de 1769 . A. G. I., México, 2429. Hoja de servicios de Urrutia en A. G. I., México, 2459. Regresado Rubí a la capital del virreinato, Croix le encomendó la revista del regimiento de infantería de la Corona y los regimientos de dragones de Espańa y México, en esta ciudad, Puebla y Jalapa. Luego marchó apresuradamente a la peninsula, aunque había una real orden de 5 de enero de ${ }^{2} 768$ para que no volviese hasta la llegada de uno de los nuevos inspestores recientemente nombrados para las tropas de Nueva España, Croix a Arriaga, núms, 216 y 225. México, 27 de abril y 18 de mayo de 1768 . A. G. I., México. 1368 y 1367 , respectivament: 
costo 453.503 pesos, 6 tomines y 6 granos, sin comprender el del Pasaje, mantenido por la casa del Alamo. ${ }^{27}$

\section{REORganización INTERNA DE LOS PRESIDIOS}

No más de veinte años después de la promulgación clel reglamento de presidios de $\mathbf{1} 730$, ya había en España noticias, o bien de su incumplimiento en lo tocante a los precios de los géneros que los capitanes expendían a los soldados debido a la fluctuación de valor de las mercancías en aquel lapso, o bien de auténticos excesos cometidos por aquéllos en su negocio. Por esto, ya en 1753 se ordenaba al primer Revillagigedo la reforma del reglamento. ${ }^{28}$

En I765, no habiéndose producido nada sobre el particular, extraña a Arriaga el silencio del virrey Cruillaș sobre este punto, pero el trámite de la cuestión era lento. Cruillas, a quien ya se le había dado en i 760 copia de la Instrucción que llevó al gobierno su antecesor marqués de las Amarillas, cuyo artículo I I también preveía la reforma del reglamento de presidios, no había encontrado a su llegada más que un compendio de las órdenes expedidas en las instrucciones y una descripción de los presidios, con sus sueldos y precios. Tropezaba además el virrey con la dificultad de que nadie en México podía asesorarle en cuanto al valor de las mercancías en las remotas provincias fronterizas; sin embargo, Cruillas había tenido junta sobre el particular en marzo de $1765 .{ }^{29}$ Pero como Arriaga desconfiara de la resolución ya tan dilatada del asunto, lo encargó con particular interés al marqués de Rubí al encomendarle la visita de los presidios.

Cruillas, por su parte, representaba en agosto no poder confiar en los informes que sobre precios en las provincias internas pudieran darle los mismos comerciantes que conducían sus efectos a aquellos lugares. Otras personas que venían de ellos, al ser consultadas, sólo mostraban sı interés por la variación de los presidios, para que quedasen resguardadas sus haciendas. Por esto prefirió oír los dictámenes de los gobernadores de Sonora y Nueva Vizcaya; pero aquél, Don Juan de Mendoza, murió cuando realizaba la visita a sus provincias, y éste, Don Mateo de Mendoza, acabado su gobierno, se presentó en México totalmente imbuido de los intereses de los poderosos y convertido en aviador de un presidio. Cuando Cruillas pudo obtener informes

27 Estado de los presidios formado por Rubi en Tacubaya, 3 de abril de I768. A. G. I., Guadalajara, 5 I I.

28 Real orden de 24 de julio de 1767 a Rubí. A. G. I., Guadalajara, 5 I I.

29 Real orden de 23 de junio de 1764 . Cruillas a Arriaga. México, i 7 de marzo de 1765 , núm. I ; y M'éxico, 23 de agosto de 1765 , núm. I 7 . Ibid. Ya en carta núm. 37 de México 8 de octubre de 1764 había dicho Cruillas a Arriaga era difícil tener informes de personas desinteresadas sobre esta cuestión. A. G. I., México, I $36_{3}$. 
de comerciantes imparciales, pasó el expediente a manos del fiscal... y allí quedó por mucho tiempo, pues no se volvió a tratar el asunto hasta que en I 770 se proyectó el nuevo reglamento de presidios promulgado por el virrey Croix.

Por otra parte, Cruillas parecía haberse sentido descargado de entender en este asunto desde el momento que se encargó de ello más especialmente a Rubí. ${ }^{\circ 0}$ Croix, a su vez, procedió a nombrar en junta al mariscal Don Juan Fernández Palacios para que visitase los presidios de Nuevo Santander, esperando poder proceder con los informes de Rubí y Palacios a la reforma de todos los presidios. ${ }^{31}$

Las cartas, los extractos de revistas y el dictamen de Rubí son fuente de primer orden para el conocimiento de la situación de los presidios en I 770. Para Rubí era claro que el soldado no podía adquirir los géneros a los precios a que se le ofrecían. En Nueva Vizcaya, Nuevo México y Sonora, el trigo y el maíz se adquirían a peso o peso y medio la fanega, y aun por rescate, por lo que venía a salir a cuatro o seis reales, y al soldado se le vendía a cuatro pesos. Las reses las traían los mismos soldados de rodeo en Nueva Vizcaya y Nuevo México, o alzadas en Sonora, y luego les eran repartidas a ocho pesos, habiéndole costado al capitán a tres o cuatro y sin el menor esfuerzo. Otro tanto ocurría con los caballos.

Rubí propone que los capitanes suministren a sus soldados lo tocante a armamento, furnituras y uniforme, y que luego perciban éstos en dinero la otra mitad del prest. Así podrían incluso hacer ahorros, estableciéndose y poblando aquel país, y además estarían bien equipados, lo que no ocurría entonces. ${ }^{22} \mathrm{~A}$ instancia de Rubí, los capitanes de Tubac y Altar, en Sonora, hicieron voluntariamente cierta rebaja en los precios de algunos géneros, por donde infería el mariscal lo que podría hacerse en los demás, y en los otros presidios. 33 Protestaba, sin embargo, de que él no podía hacer que éstos empezasen a funcionar bien, pues muchas de sus providencias sabía no se cumplían. 34

Declaraba por último Rubí que no había uniformidad en el vestuario, $\mathrm{ni}$ aseo en los soldados. "Su armamento de fuego es de inferior calidad y sin la correspondiente unidad de calibre, observándose la misma desigualdad en

30 Vid. Memoria dada por Cruillas a Croix, México ig de agosto de I766, artículo "Presidios Internos". A. G. I., México, 1507.

31 Croix a Rubí, México 24 de diciembre de 1766. A. G. I., Guadalajara, 5 I I. La designación de Palacios y el Licenciado Osorio para la visita de Nuevo Santander está relacionada con los malos informes que sobre Escandón recibió el nuevo virrey.

32 Rubí a Croix. San Miguel Horcasitas, 2I de febrero de 1767 . Ibid.

33 Rubí a Arriaga. San Miguel Horcasitas, 21 de febrero de 1767 . Ibid,

34 Rubi a Arriaga. Pasaje, 24 de mayo de 1767 , núm. 20. Ibid. 
las medidas de éste y demás armas blancas, y aun en las lanzas, de que no usan en los presidios de las provincias de Coahuila, Nuevo León y Texas. La misma variedad se advierte en las cueras entreteladas de algodón que se estilan en las referidas tres provincias y se consideran menos útiles que las de siete haces de gamuza que se gastan en las demás. En lo general, se advierte esta tropa poco disciplinada y torpe en el uso del fuego, por el común descuido de hacerla cargar al blanco y cargar con agilidad". 35

Como confirmación y complemento de este juicio podemos añadir las siguientes palabras del entonces gobernador de Sonora: "los soldados de estos presidios son incansables a caballo, y aunque en las ocasiones se les ha mandado echar pie a tierra, la falta del ejercicio y el grave peso de las cueras, adarga, espada, carabina y municiones los inhabilita para poder hacer mıcha fatiga. En el fuego de la carabina no están muy diestros, aunque se les instruye, pero en el manejo de la lanza, habilísimos". "36 Seguramente no será aventurado hacer extensivas a todos los presidios de la frontera las palabras que el anónimo informante de Sonora dedica a los de esta zona: "De las fábricas de estos cinco presidios, por buenos respectos, y aun mirando al bien público de estas provincias, juzgo por mejor no decir nada que poco". 37

\section{La idea de la campaña de Gálvez}

Llegado el visitador a México el 25 de agosto de $1765,{ }^{88}$ dos meses después, el 9 de octubre de 1765 tomaba parte en una junta celebrada a instancia del fiscal y del auditor de guerra, con asistencia del virrey Cruillas, Villalba y el mariscal de campo Don Antonio Ricardos, en que tratándose de la difícil situación por que pasaba la frontera se resolvió la erección de

35 Estado de los presidios. Tacubaya, 3 de abril de 1768.

36 Pineda a Cruillas. Horcasitas, i 8 de marzo de 1766. A. G. I., Guadalajara, 4I6.

37 "Descripción geográfica, natural y curiosa de la provincia de Sonora por un servicio de Dios y del rey nuestro señor. Año de fol. $\mathrm{I}-\mathrm{I} 03 \mathrm{~V}$.

$3^{8}$ E1 visitador había nacido el 2 de enero de 1720 en Macharaviaya (Málaga), de familia liadalga y empobrecida. Bajo la protección de los obispos de Málaga González Toro y Molina Oviedo pudo realizar estudios en aquella ciudad y en Salamanca. Abogado en Madrid, pasó a ser de casa y corte. E1 20 de febrero y en 25 de noviembre de 1764 recibió el nombramiento de alcalde por muerte del primer nombrado, dodn Francisco de Ana para realizar la visita de Nueva España, importante comisión, fue elevado esempeñando esta Consejo de Indias. Priestley, Herbert Ingram, José de Gálve 1767 , al rango de ministro togado del 177I). Berkeley, 1916, págs, $1-5$. Vázquez, José de Gálvez, visitor general of New Spain (I765. Gálves, marqués de Sonora. "Revista Don Bernardo de Gálvez, a quien veremos aparecer, núm. 77-78, págs. 448-473. Madrid, 1959. visitador e hijo del herm, a quien veremos aparecer más tarde en la frontera, era sobrino del en Macharaviaya, el 25 de julio de 1746. 
dos nuevos presidios - el de San Buenaventura y otro en la frontera oriental- en Nueva Vizcaya y la formación de compañías milicianas hasta tanto se pudiera realizar campaña formal contra los enemigos fronterizos.

Este fue tal vez el primer contacto de Gálvez con la realidad imperante en las provincias septentrionales, y de este hecho nació con toda seguridad en su mente la idea de llevar a cabo una seria expedición contra los enemigos bárbaros, pues no muchos días más tarde de aquella junta - el 23 de octubre- - resolvía en otra general el comercio de España contribuir a Su Majestad por mano de Gálvez con la mitad del derecho doble de diputación, que ascendió a 78.620 pesos 7 reales, para la expedición a Sonora, Sinaloa y Nueva Vizcaya. 39

Los planes de Gálvez, que, como suyos, no podían menos de ser extraordinariamente ambiciosos, pasaron con éste y otros hechos a ser del dominio público, sin que, en cambio, se hubiesen proyectado aún por la vía oficial, cuando en mayo de ı 766 , un par de meses después de la partida de Rubí hacia la frontera, pedía el auditor Don Domingo Valcárcel se estudiase la pacificación de Sonora de acuerdo con el visitador. "He sabio extrajudicialmente - dice Valcárcel- que el señor visitador general, noticioso sin duda de las infelicidades que padecen aquellas provincias, ha proporcionado medios competentes a poner en práctica cualquiera expedición que se discurra oportuna a reparar la ruina que amenaza sin gravamen de la real hacienda, hasta haber llegado a idea la construcción de los barcos en el puerto de Matanchel". Y añade, ponderando las ventajas que reportaría la expedición: "Dan-

39 Juan Manuel Viniegra, secretario del visitador y el más severo detractor de Gálvez. asienta esta partida con las siguientes palabras: " 78620 pesos fuertes entregados a fines de 1765 por el comercio de España, con cuyo donativo, que fue violento, pudo libertarse de la contribución de la flota". En "Nota de algunas cantidades Jalapa sobre la venta de los géneros, caldos y frutos ciones proyectadas $y$ practicadas por el visitador que tengo noticias que han consumido las expedien el puerto de San Blas, peninsula de Cisitador general de Nueva España Don José de Gálvez que se expresarán y del real erario" Californias y provincia de Sonora, exigidas de los sujetos 52 v., fol. 50 v. En A. G. I., México, 2476, se encuentra una carta de al comercio de España, en México, 25 de se encuentra una carta de pago expedida por Gálvez de haber recibido 78.620 pesos 7 reales de los de 1766 . En ella dice otorgar esta certificación y Nueva Vizcaya "para que en todo tiempo pueda el comercio de España hán a Sonora, Sinaloa este particular servicio". A compaña e incluye pueda el comercio de España hacer constar a S. M. terán, secretario y contador de la real diputación certificación dada por Don Antonio de Ayesen Jalapa, 17 de marzo de 1766 , que dice: "que por la cuenta y espańa en la flota de Idiáquez, contaduría de mi cargo de lo cobrado por razón del derechenta y razón que se ha llevado en la acordó en junta general de 23 de octubre del añ derecho doble de diputación que el comercio por mano del Señor Intendente y visitador general de este reinodo de ${ }^{1765}$ contribuir a $\mathrm{S}$. M. la suma de 78.620 pesos, 7 reales. Siendo prevención de este reino Don José de Gálvez, asciende a fue el que contribuyese al expresado donativo España cado en los efectos que de cuenta de vecinos del reino la cargazón de la flota, no se ha verifiéstos a su pago". El acta de la Junta habida en reino han venido en ella, por haberse resistido de 1765 puede consultarse en A. G. I. México, 1368 . 


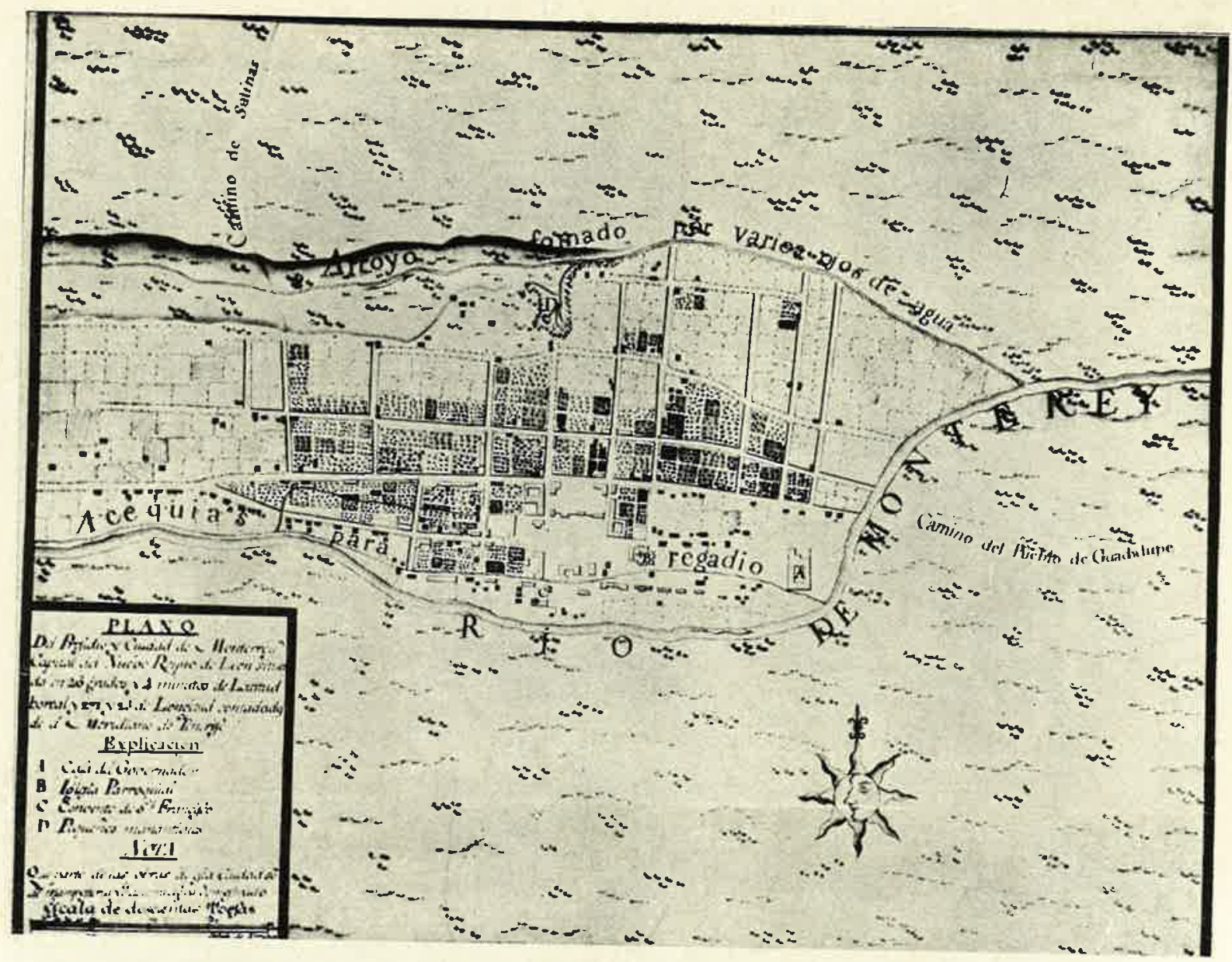

74. Plano de Monterrey, en Nuevo Leén, por Urrutia. 1765. 


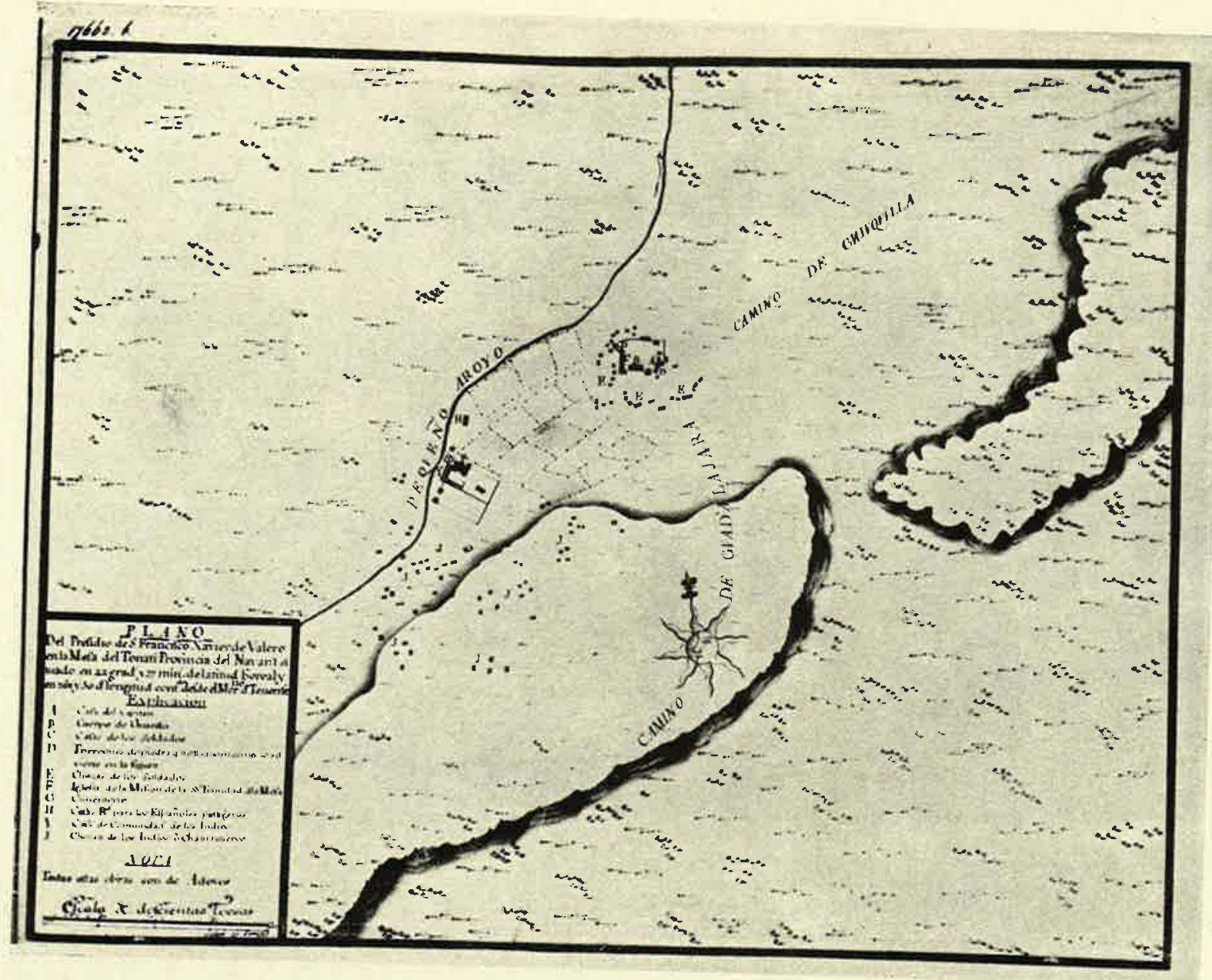

75. El presidio de Nayari1, por [Trrutia. 1765. 


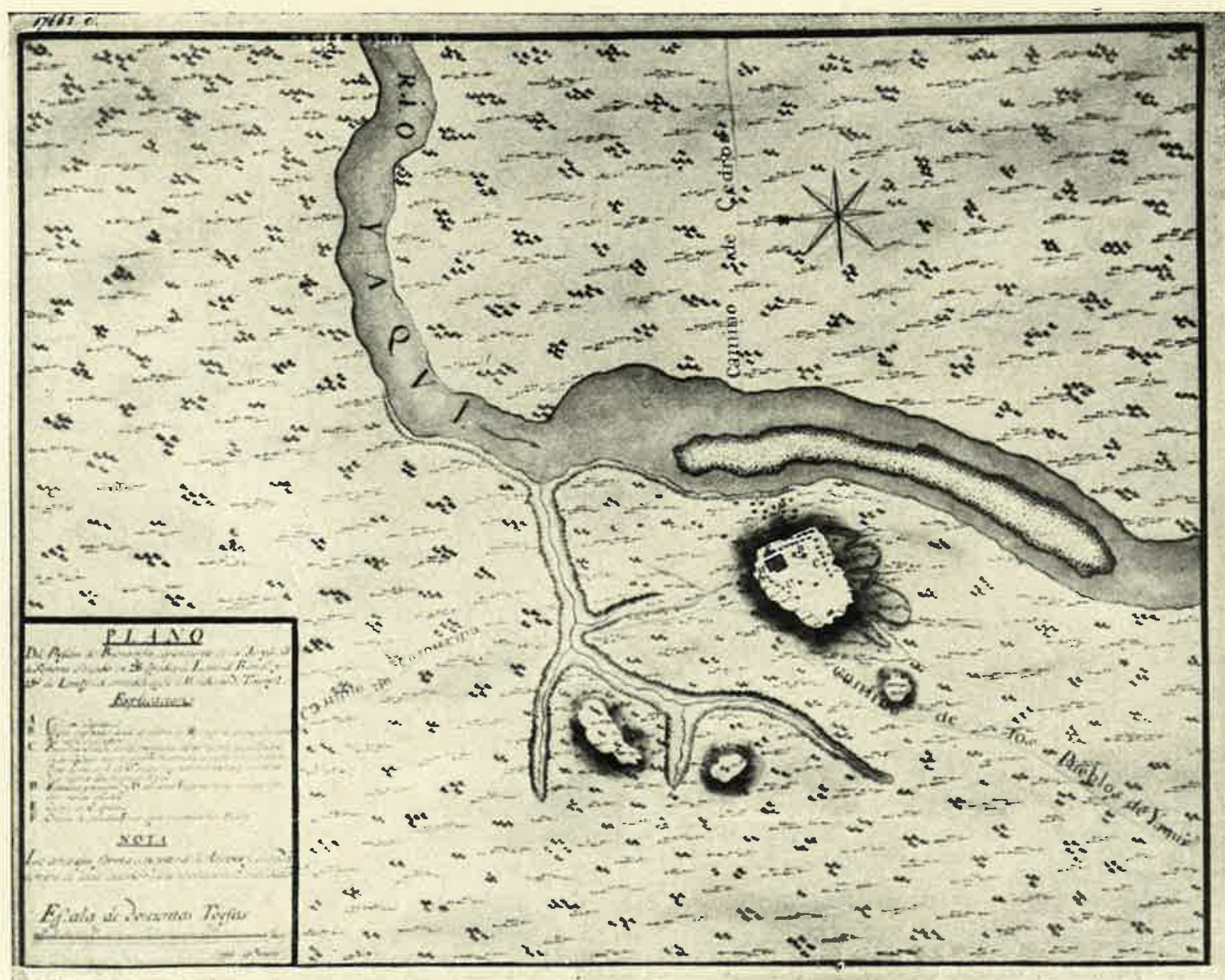

76. El presidio de Buenavista, en Sonora, por Urrutia. 1765. 


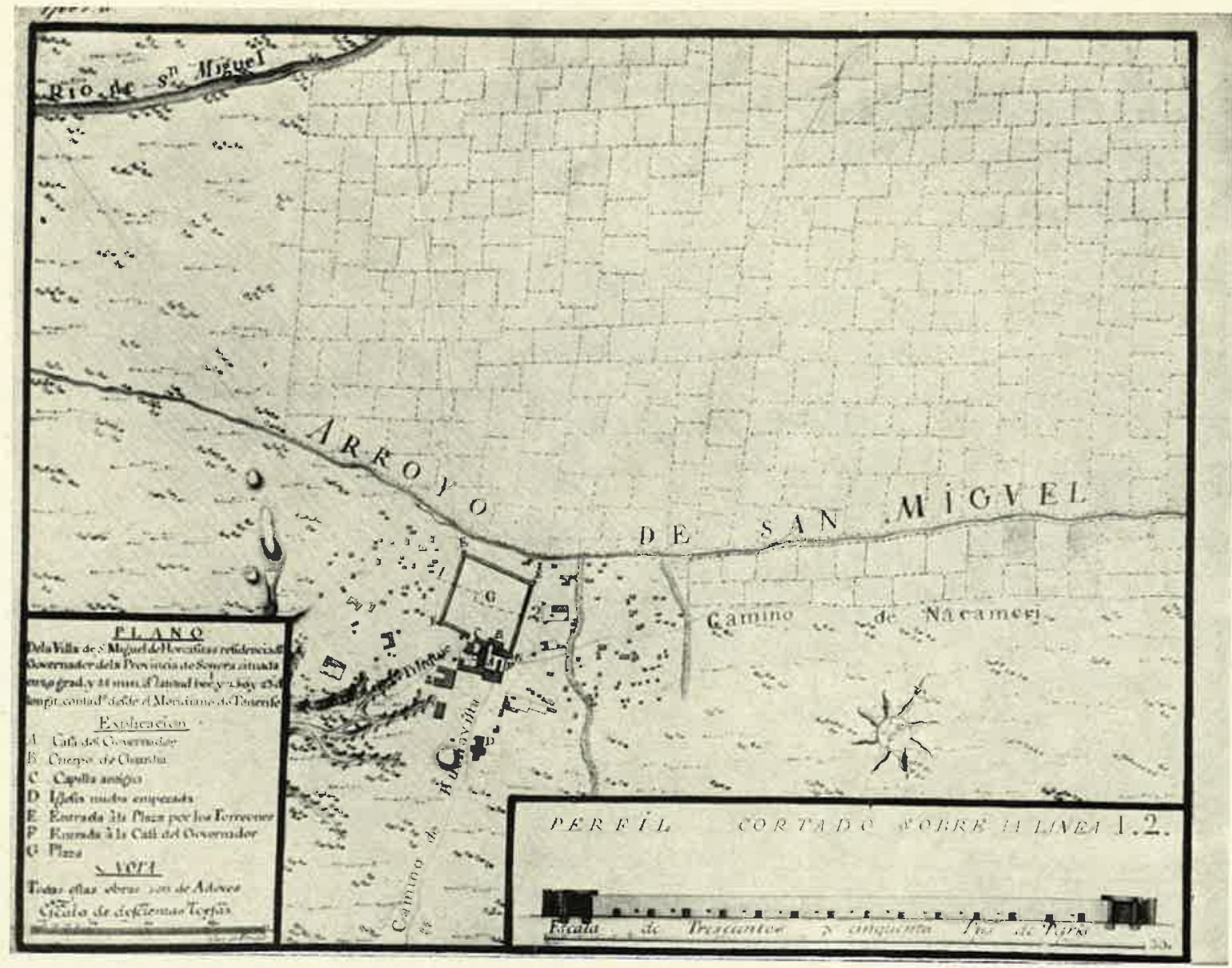

77. El presidio y villa de Horcasilas, en Sonoral 1765 


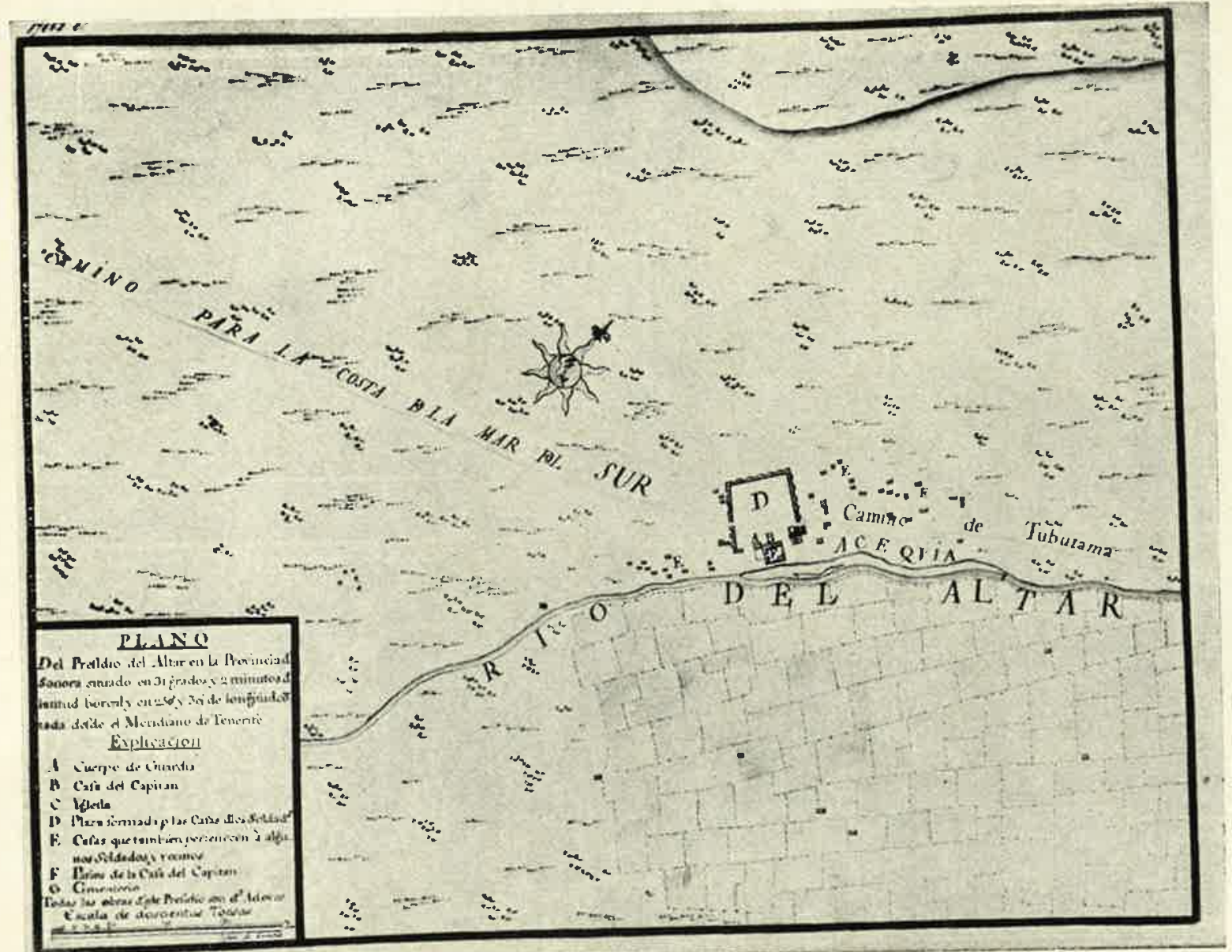

78. El presidio de Allar, en sunora, por Urrulia. 1765. 


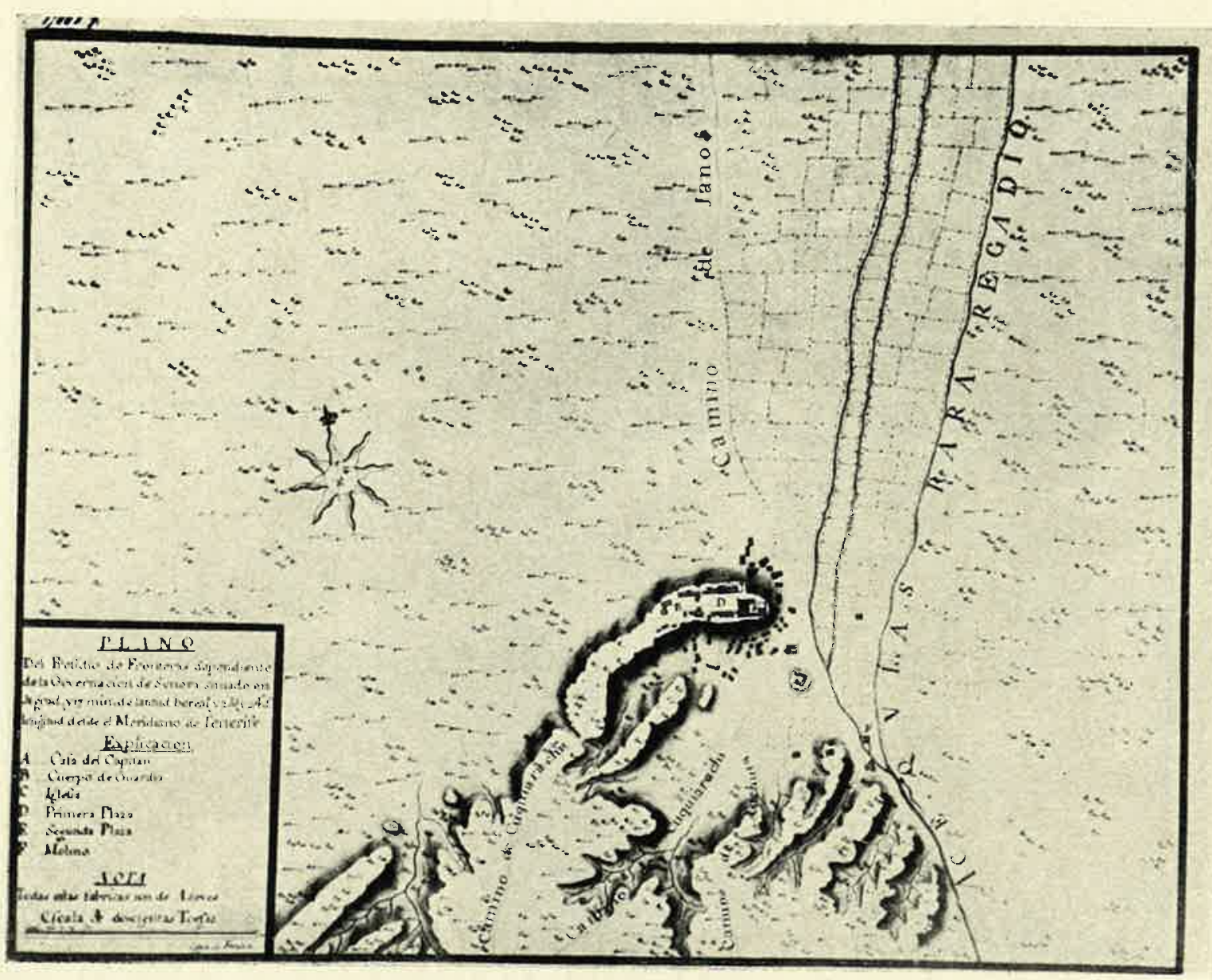

79. El presidio de Fronteras, en Sonora, por Urrutia. 1765. 


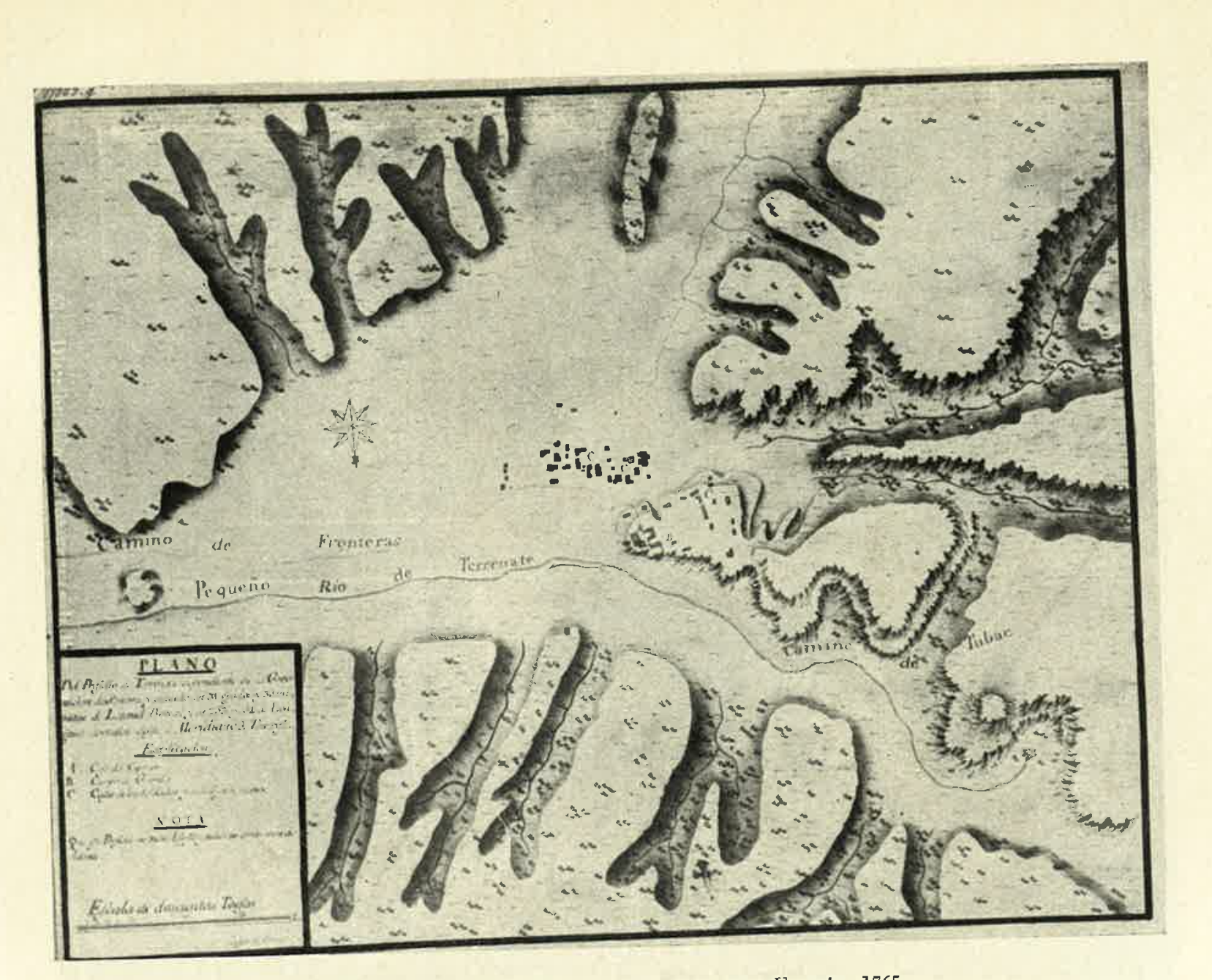




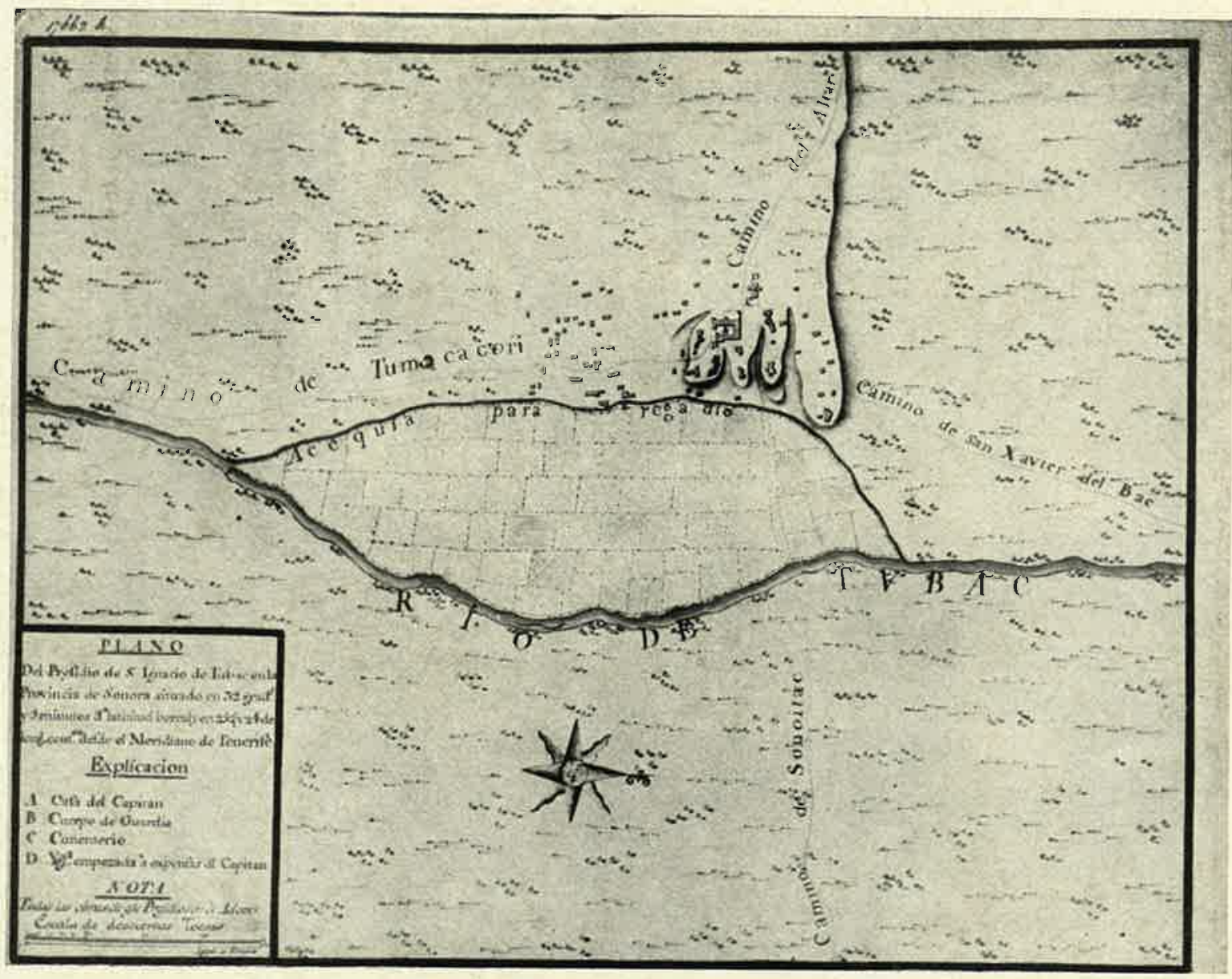

3. El Eresidio de Tubac, en Sonora, por Crrutia 1765. 


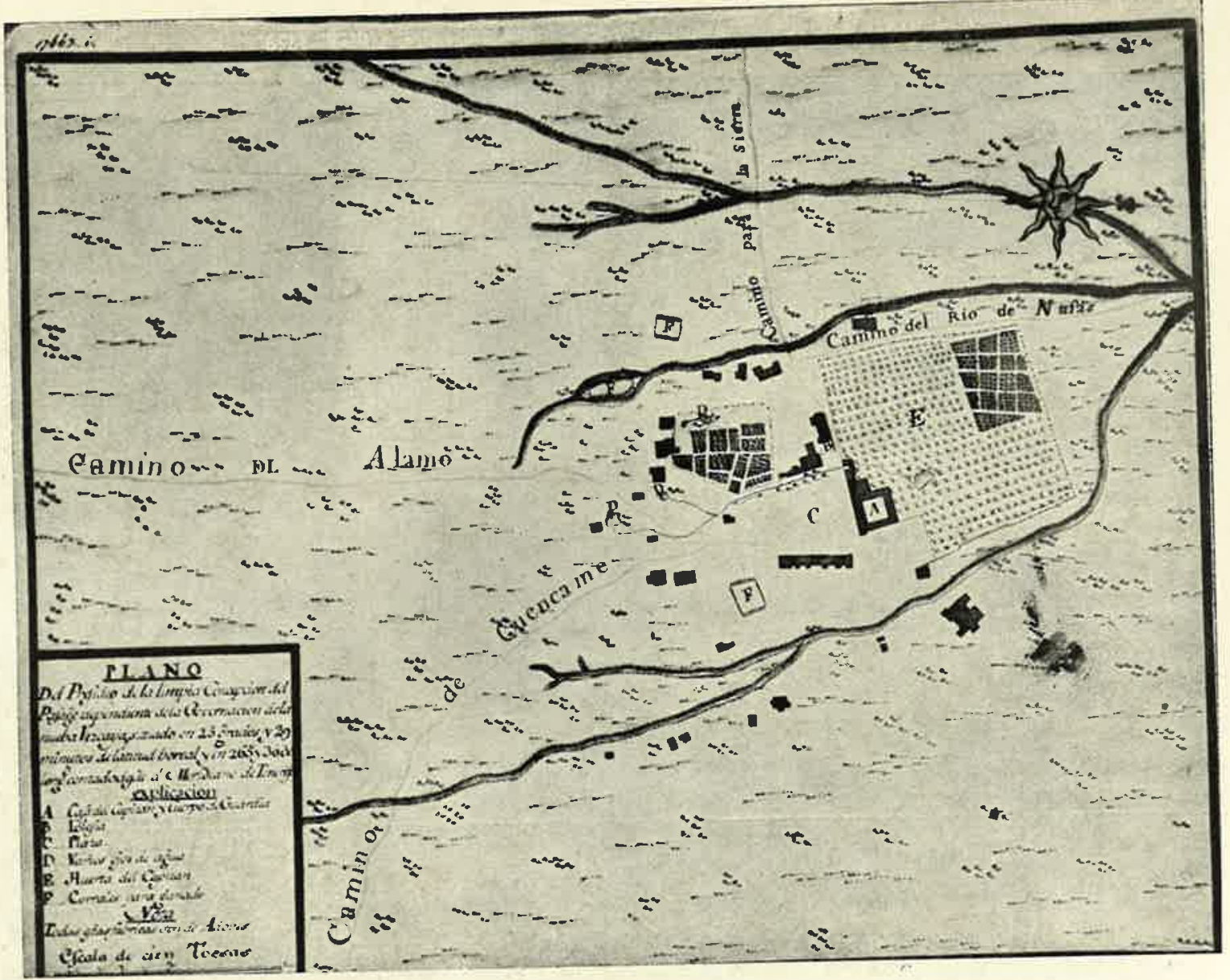

82. El presidio del Pasaje, en Nueva Vizcaya, por Urrutia. 1765. 


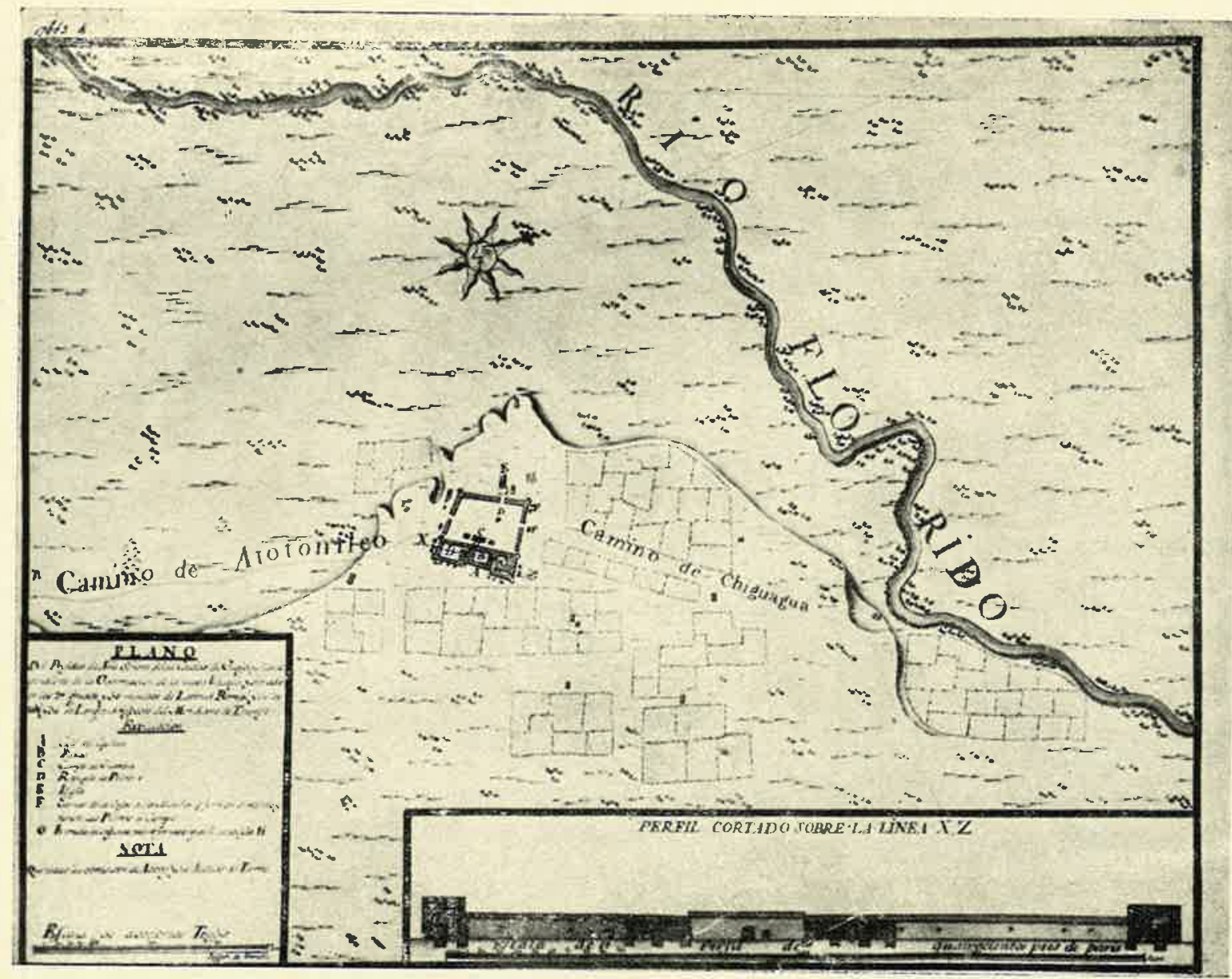

83. El presidio de Guajoquillas, en Nueva Vizcaya, por Urrutia. 1665. 


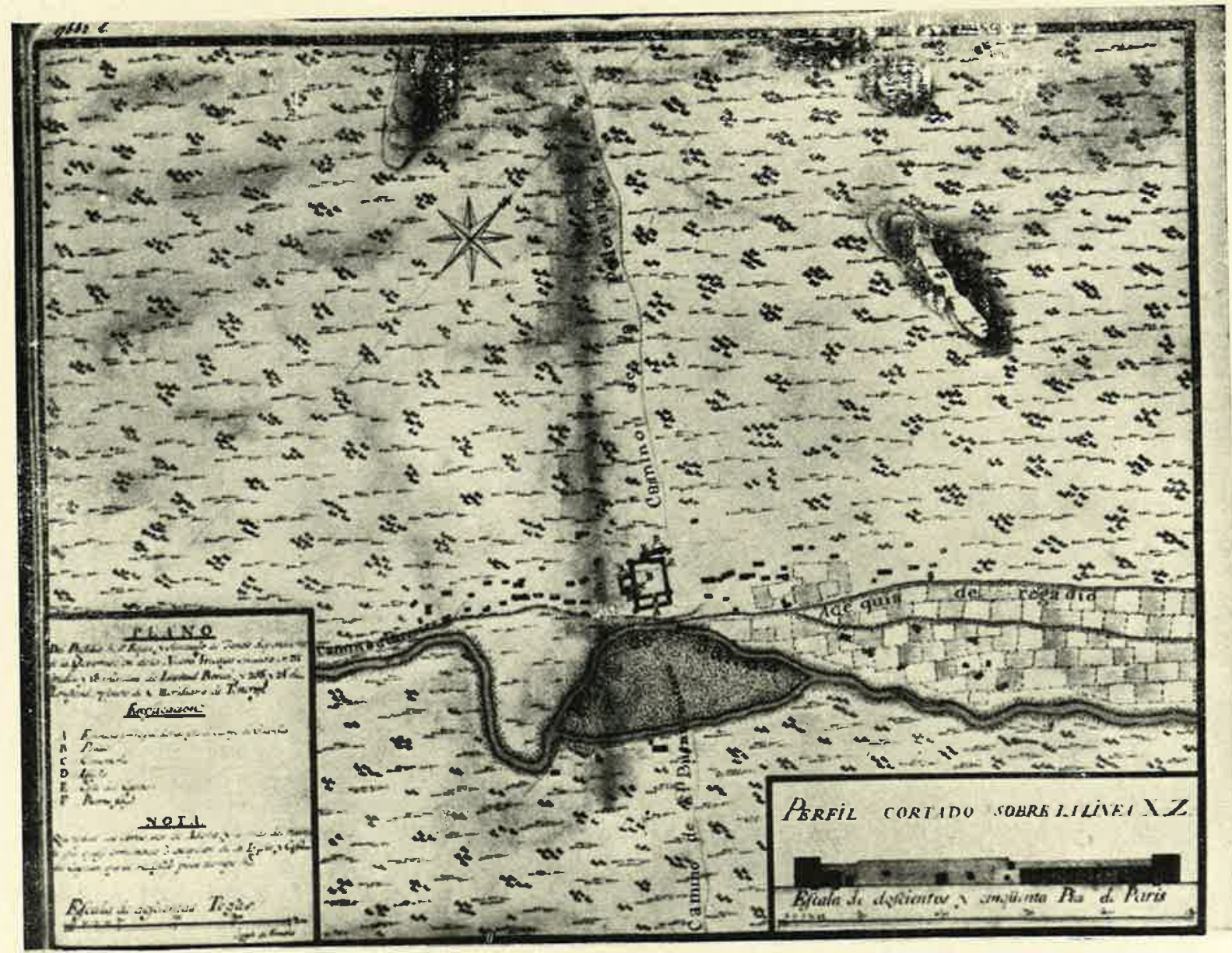

84. El presidio de Janos, en Nueva Vizcaya, por Urrutia. 1765. 


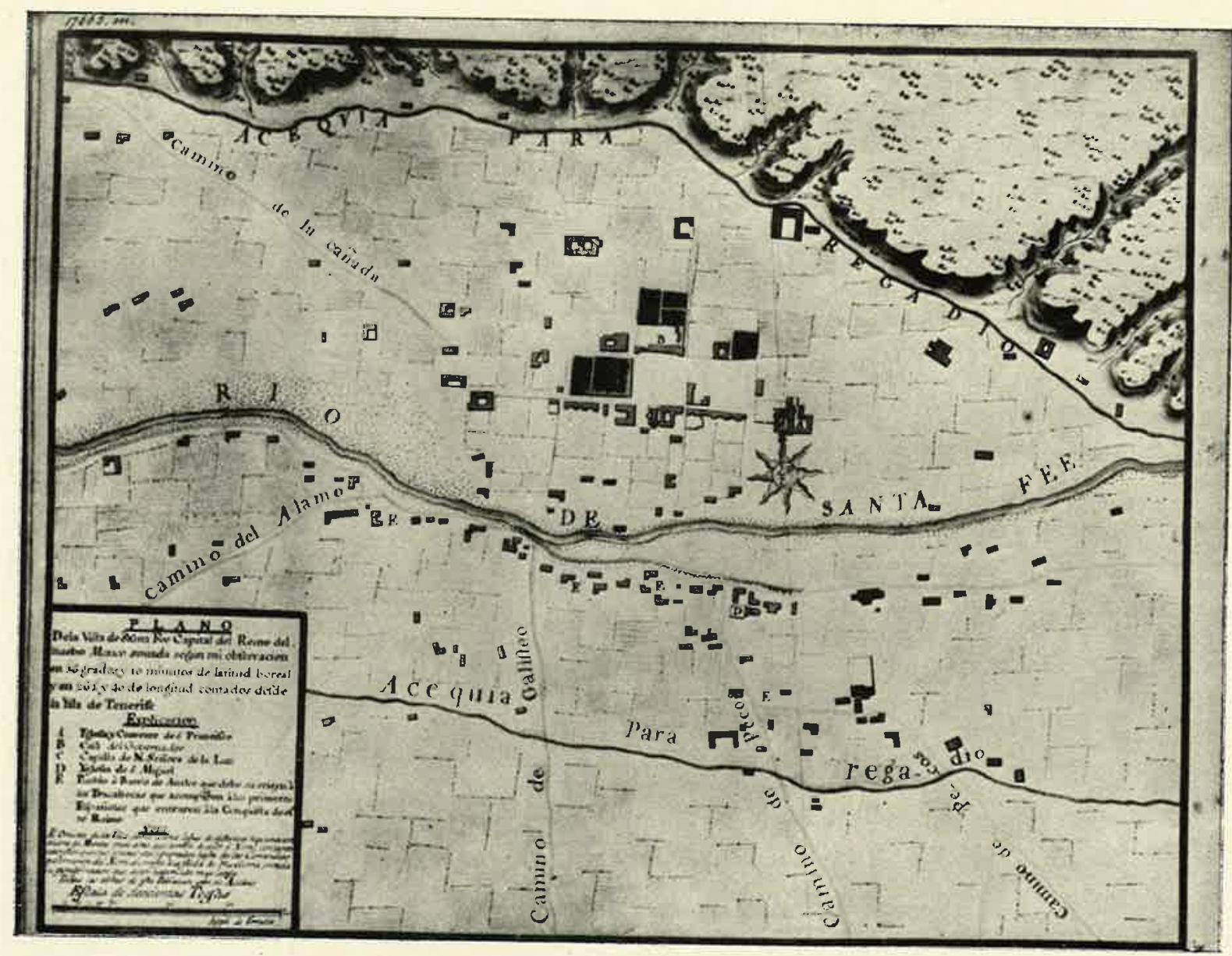

85. La villa de Santa Fe, capital de Nuevo México, por Úrrutia. 1765. 


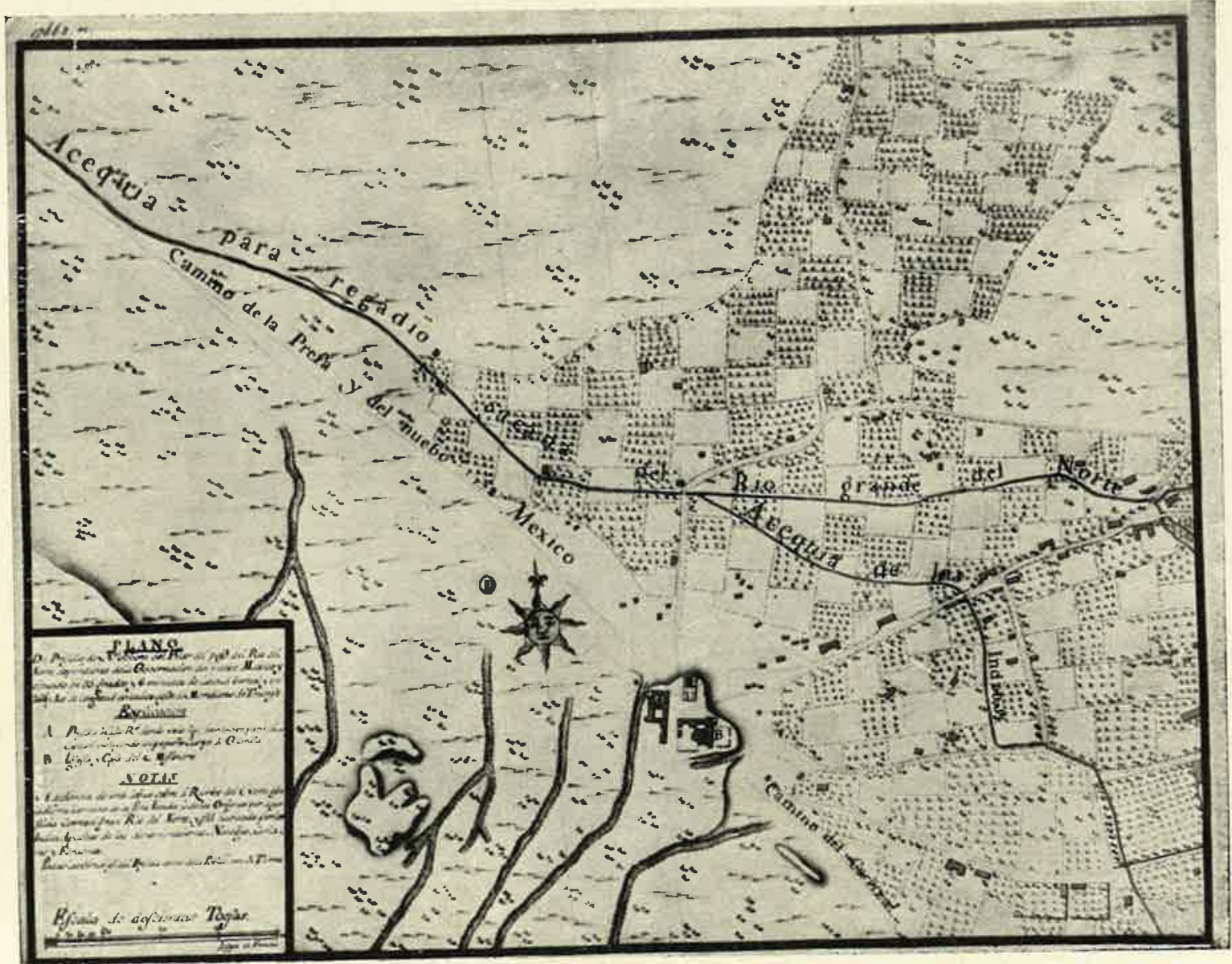

86. El presidio de El Paso, en Nuevo México, por Urrutia. 1765. 


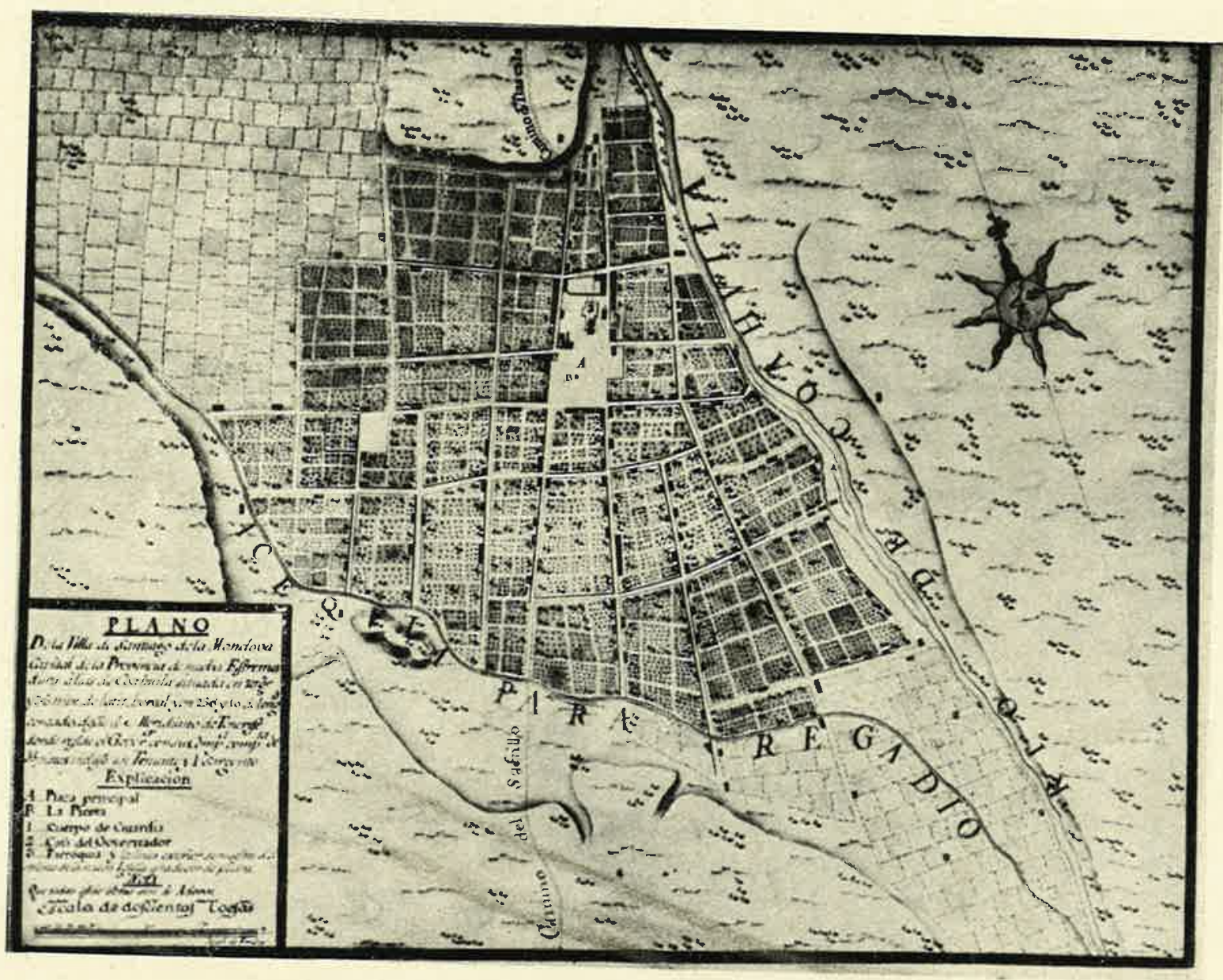

87. La villa de Monclova, capital de Coahuila, por Urrutia. 1765. 


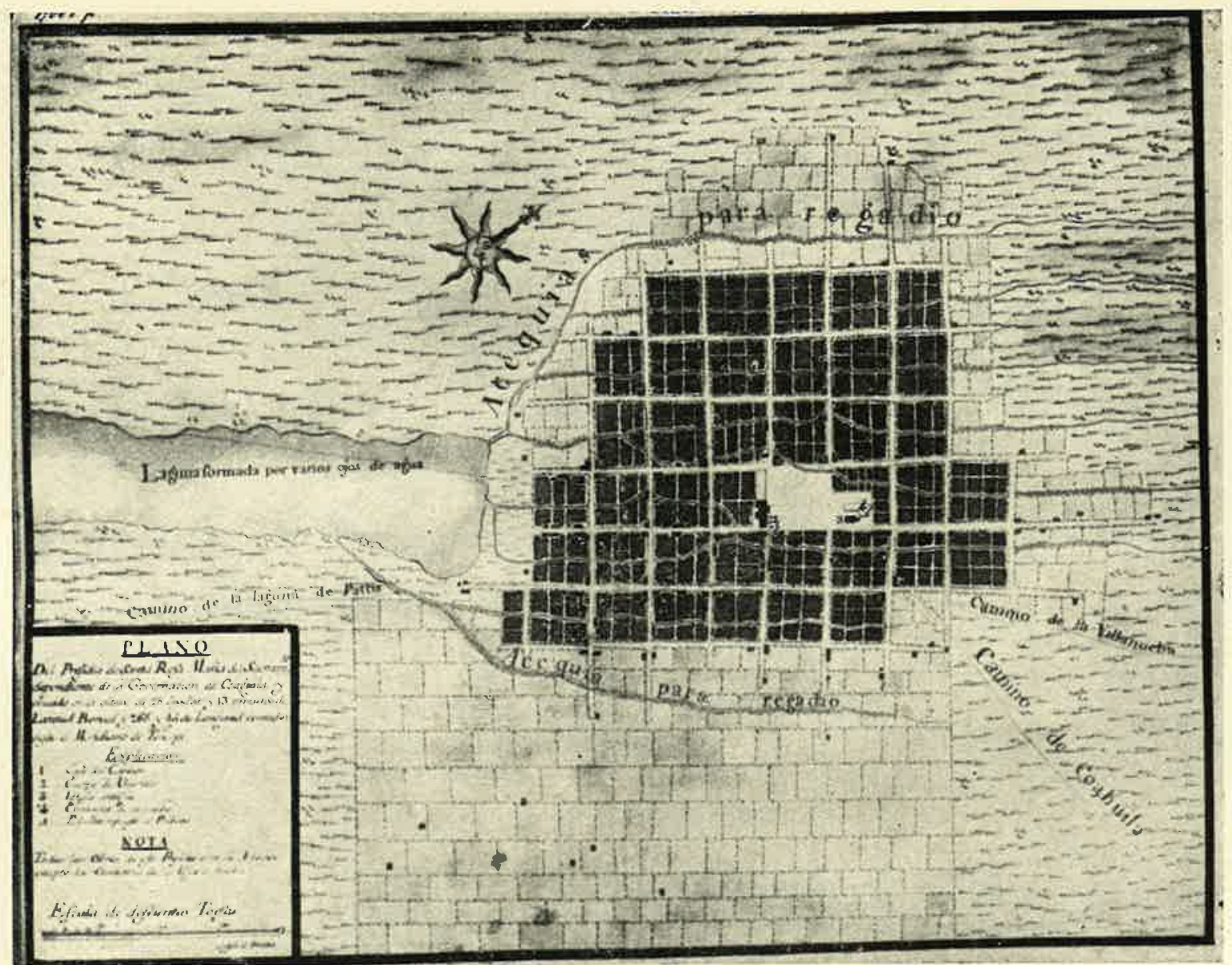

88. El presidio de Santa Rosa del Sacramento, en Coahuila, por Urrutia. 1765. 


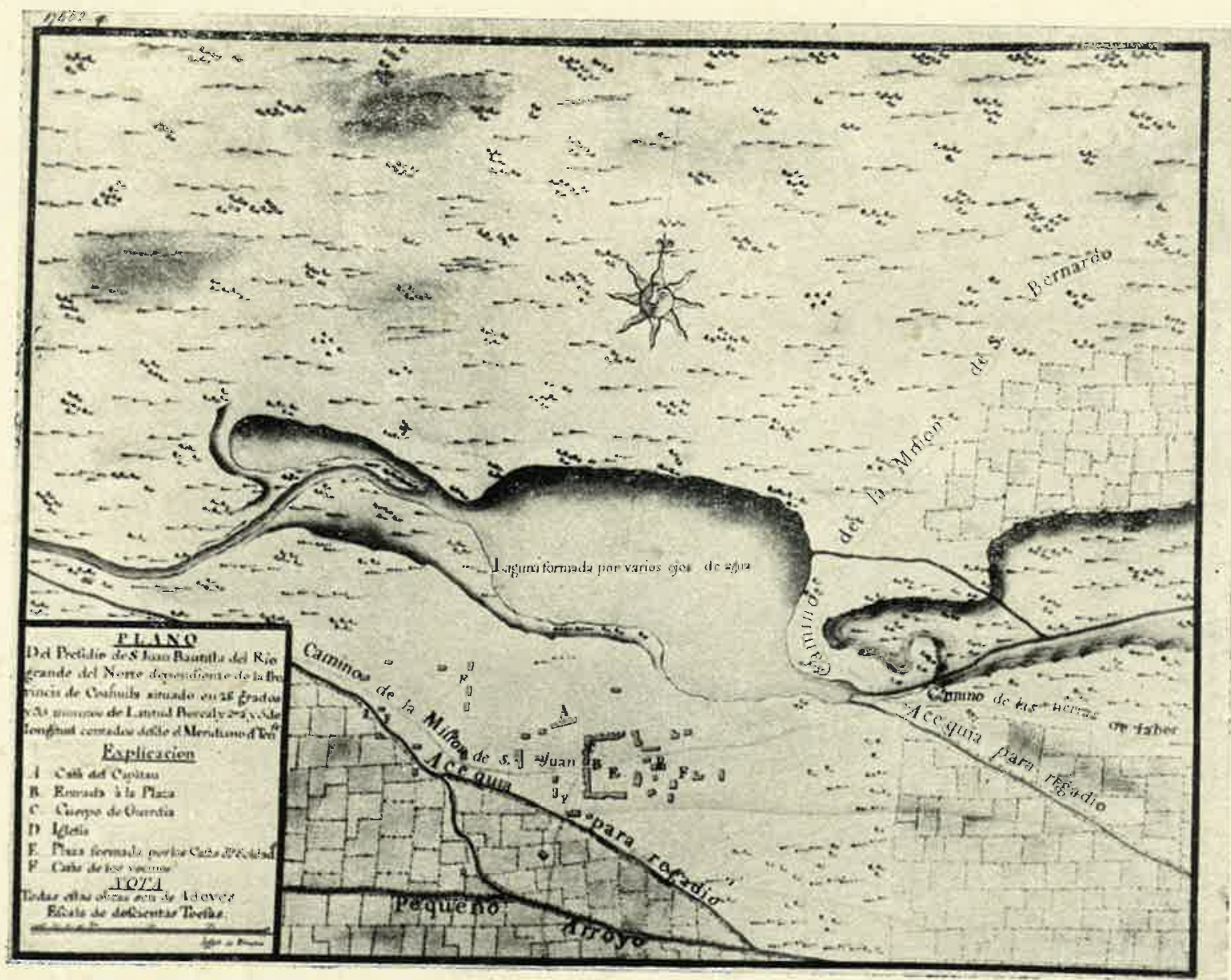

89. El presidio de Río Grande, en Coahuila, por Ũrrutia. 1765. 
do crédito a las historias, en la Sonora hay ricos minerales y aun montañas poco menos que de plata maciza". 40

Para aquel entonces la situación de Sonora se había hecho mucho más difícil. En enero se habían ausentado de sus pueblos, uniéndose a los seris, los indios de Suaqui, trescientas dieciocho personas, de las que unos ciento treinta varones en edad de combatir, buenos conocedores de la tierra, valientes y que luchaban con flechas envenenadas. Cancio escribe que esto había ocurrido a poco más de quince días después de haberse él establecido en Buenavista con su compañía ya equipada, y luego fue objeto de sus ataques el I7 de abril y 5 de mayo. Suaquis y seris se concentraban en Cerro Prieto, en los cajones de los Pilares, de Marcos y del Cosari; los tres presidios de Altar, San Miguel y Buenavista, que flanqueaban el Cerro, no podían cubrir las ciento veinte leguas de perímetro del reducto enemigo, y los otros de Fronteras, Terrenate y Tubac no podían desentenderse de la guerra de los apaches, cien de cuyos guerreros se habían internado por la Sierra Madre hasta el valle de Oposura y causaban allí enormes estragos. Los vecinos, indefensos, habían dejado de salir a los placeres, y Pineda declaraba que, a no ser por los soldados, ya estaría abandonada Sonora. Pero para dominar la situación, cada vez más insostenible, era preciso pasar a la ofensiva. Entre tanto, la contención de los rebeldes pesaba sobre los tres presidios de retaguardia, y algunos cortos destacamentos situados en San José de Pimas, Suaqui y Tecoripa. ${ }^{41}$ En marzo, sin embargo, ya se había hecho preciso suspender la persecución de los apaches, después de una afortunada incursión de Anza hasta la Sierra Florida, donde hizo cuarenta bajas y algunos presos al enemigo, para proceder a colocar un nuevo destacamento en Santa Rosalía con que completar el cerco de los sublevados; pero la escasísima tropa disponible no permitía actuar contra ellos, que, en cambio, atacaron, saquearon y se llevaron toda la ganadería de Tecoripa, Matape, Nacori y Llano Colorado y habían llegado en una incursión hasta Río Chico. Cuando atacaron San José de Pimas, el teniente Azuela calculó en más de trescientos el número de sus adversarios, que se retiraron al fin hacia el Cajón y Carrizal de Ten. Los indios segúán fugándose de las poblaciones sometidas a los españoles, engrosando el número de los enemigos. Pineda se esforzaba en levantar compañías milicianas, pero no fiaba en la aptitud de los paisanos, desprovistos por otra

40 A. G. I., Guadalajara, 416. Indudablemente, los barcos facilitarian y abaratarian el trans. porte y Valcárcel recuerda cómo ya en 1743 ordenó Felipe V hubiese dos balandras armadas en guerra en Matanchel o Valle de Banderas, habiéndose reiterado estado disposición en reales cédulas de 13 de noviembre de 1744 y 4 de diciembre de 1747 a Fuenclara y Revillagigedo.

$4 \mathrm{I}$ Pineda a Cruillas. Suaqui, ix de febrero de 1766, y Matape, 21 de febrero de 1766. Cancio a Cruillas, Buenavista, 20 de febrero de 1766 . A. G. I., Guadajara, 4r6. Cancio a Cruillas, 2I de julio de i766. R. A, H., Boturini, 18. 
parte de armas y caballos. El y Cancio, capitán de Buenavista, insisten una $y$ otra vez en la necesidad de realizar una campaña en forma. 42 "Los apaches han inundado este año la provincia", dice el gobernador sintiéndolos actuar en Arizpe y Oposura.

La fuerza de los rebeldes crecía por días. "Ahora, escribe Pineda en marzo de I766, se gobiernan con nuevo método: han elegido un capitán general y a éste reconocen los antiguos enemigos pimas y los nuevamente alzados. Cualquiera que se les va a incorporar se lo presentan y les da la orden de la ranchería donde han de vivir. Pocos días ha les hizo esta sucinta y expresiva oración. Llamó a todos y les dijo: estad alegres, no sintáis los pocos bienes que habéis dejado; haced muchas flechas con buenos pedernales, que en éstas tenéis los reales para comprar vacas, caballos y ropas con que vestiros. Dicho capitán, añade Pineda, se llama Tiembla laTierra". 43

Por fin, en mayo de aquel año el auditor Valcárcel se declaró partidario de efectuar la campaña pedida por los jefes de Sonora, campaña en la que intervendrían las fuerzas presidiales, encomendando la defensa a los vecinos equipados, armados y a sueldo. Pero debía estudiarse además la conveniencia de enviar dos o tres compañías cle dragones. A poco, apoyaba igualmente los proyectos de Gálvez de que tenía noticias, en especial la idea de contruir barcos en algún puerto del Pacífico. 44

A este respecto, Gálvez había avanzado ya tanto en sus propósitos que había hecho venir de Veracruz a la capital al teniente de navío Don Alonso Pacheco, con quien puede suponerse trató de las posibilidades de establecer el astillero que proyectaba, y en 20 de mayo pedía a Cruillas lo hiciese pasar a las costas del Pacífico para buscar el lugar más a propósito para la fabricación de dos buques que habían de facilitar la conducción de tropas y material hacia Sonora e iniciar ya el corte de maderas. 45 Cruillas, el 25 de mayo, demoró su permiso hasta que se acordase definitivamente lo relativo a la expedición, pero al día siguiente Gálvez insistía en que ya desde la junta de 9 de octubre del año anterior se había considerado inevitable la campaña,

42 Pineda a Cruillas. Horcasitas, 3, I6 y i 8 de marzo de I766. Azuela a Pineda. San José de Pimas, 6 y 8 de marzo de 1766. Cancio a Cruillas, Buenavista, i de marzo de i766. A. G. I, Guadalajara, 416. Anza a Pineda. Tubac, I7 de marzo de 1766. R. A. H., Boturini, i 8.

43 Pineda a Cruillas, 20 de marzo de 1766 . Ibid.

44 Cruillas a Arriaga. México, I 3 de abril de i766. A. G. I., Guadalajara, 51 I. Dictámenes de Don Domingo de Valcárcel. México, 25 de abril 9 y 24 de mayo de 1766 . A. G. I., Guadalajara, 4 I 6 .

45 Ibid. En este documento hace ver Gálvez que tiene el asunto de Sonora en su mente desde la junta de 9 de 9 de octubre de 1765 , en la que el fiscal había declarado la absoluta necesidad de hacer expedición formal contra los indios enemigos de Sonora y Nueva Vizcaya. Indica también que el donativo del comercio de España, que dice ser "la mitad de lo que importase el derecho de diputación", se hallaba invertido en la renta del tabaco y había servido para satisfacer en parte las cosechas de las villas. 
sin que en el tiempo transcurrido desde entonces hubiese dejado de hacerse más urgente su realización. El había buscado la manera de allegar recursos para la expedición y para establecer algunas poblaciones que sirvieran de barrera en Sonora y Nueva Vizcaya, sin causar gasto al erario real, "y con efecto estoy asegurado de juntar ciento ochenta o doscientos mil pesos, inclusos los setenta y ocho mil seiscientos veinte que me dio el comercio de España". En estos términos, consideraba Gálvez que las disposiciones sobre la expedición son tan ejecutivas y recomendables como peculiares y privativas de su empleo de Intendente del Ejército, y como no ha de contar con la real hacienda, tampoco se embarazará con las cajas reales y se limitará a proceder según la Instrucción de Intendentes, cuyas reglas "son muy propias para hacer ver después a S. M. y al público lo que se hubiese conseguido con los medios y auxilios que éste me ha franqueado". 46

El 24 de mayo se adhería Valcárcel al plan de Gálvez, y el 27 hacía otro tanto el fiscal Velarde, que desde 1765 era partidario de la campaña, a la que cree se podrían enviar un cuerpo considerable de tropas veteranas que había en México, y cuatro o más compañías de caballería al mando de un oficial subordinado al gobernador de la provincia. Ahora se cuenta con tropas y con fondos que no salen de las cajas reales. En el proyecto del visitador sólo encuentra la dificultad del lugar apropiado para astillero y de la navegación por el mar de California, con riesgo evidente, de tal manera que quizá fuese más sensato enviar la tropa por tierra. 47

La Junta - que sólo fue de guerra, pues no se trataba en ella de fondos de la Corona- pedida por Gálvez, el auditor y el fiscal, se tuvo en México el 6 de junio de 1766 y en ella se resolvió, en vista de las noticias de los estragos que seguían produciendo los indios hostiles y rebelados, que formase Pineda compañías milicianas y volantes en Sonora - entendiénose para los gastos con el visitador - y la fabricación de "dos barcos de vela y remo, conforme al perfil que se tuvo presente, en el paraje que pareciese más a profósito, donde sean menores los gastos a juicio del teniente de navío Don Alonso de Pacheco y Solís", que también estaría en contacto con Gálvez para todo lo necesario. 48

46 Cruillas a Gálvez. México, 2 I de mayo de 1766. Gálvez a Cruillas. México, 22 de mayo de I766. Ibid. En este oficio dice Gálvez que para atender a la fábrica de los barcos bastará ir tomando las cantidades necesarias de la factoría de tabacos de Guadalajara. En r. ${ }^{\circ}$ de junio comunicaba al virrey haber aprobado S. M., por real orden de it de marzo, el acuerdo que a instancia suya hizo el comercio de España en Jalapa y los tres puntos de facilitarle caudal para pagar los tabacos del reino, concurrir con $s u$ donativo a la expedición contra los seris y alzar la
prohibición del chinguirito. Ibid.

47 Respuesta del fiscal Velarde. México, 27 de mayo de I766. Ibid.

48 Acta de la Junta. Ibid. y México, 1364 , donde está el duplicado de todo el expediente. 
En este momento puede decirse que la empresa de Gálvez en Sonora está en marcha, y su amplitud y sus consecuencias no serán menos notables que la manera con que el Visitador General había proyectado llevarla a cabo.

Primeras realizaciones: el astillero

Y EL EJÉRCITO EXPEDICIONARIO

Casi dos años transcurren desde el primer paso dado para la campaña en la junta de 6 de junio de i 766 hasta el día -9 de abril de 1768 - en que Gálvez sale de México para dirigirse al escenario de la guerra. En el intervalo se enlazan una serie de logros que han de dar a la campaña de Sonora las mayores garantías de éxito.

En los primeros días después de aquella junta sufrió Gálvez una ligera indisposición, pero ya la operación estaba en marcha: Alonso Pacheco pasó a la costa del sur con un maestro constructor, carpintero de maestranza y los demás operarios precisos para la construcción de dos bergantines o goletas que debían tener veintiocho pies de quilla, diez de manga y quince remos por banda. 49

E1 23 de agosto de 1766 se hacía cargo del virreinato el marqués de Croix, y bajo sus auspicios, seis meses justos después de la anterior, el 6 de diciembre de 1766 , una segunda junta resolvía acelerar los preparativos, y una tercera el 8 de enero de I 767 decidía la organización de un pequeño ejército que, a las órdenes del coronel de dragones de México, Don Domingo Elizondo, había de trasladarse a Sonora. Cuatrocientos veintitrés hombres —de los regimientos de dragones de México y España, de Infantería de América, y fusileros de Montaña- compusieron el cuerpo expedicionario que pasó de la capital a la frontera. ${ }^{50}$

Entre estas segunda y tercera juntas, separadas sólo por un intervalo de un mes, se había recibido el lastimoso informe de Pineda fechado en Horcasitas el 13 de noviembre de 1766 . Croix, que se había encontrado el desfalleciente erario que a su salida le legaba Cruillas, podía atestiguar que las arcas reales nunca permitían semejante expedición, pero Gálvez había asegurado firmemente que de los setenta y tantos mil pesos que donó el comercio de España en Jalapa pagaría las fábricas de los barcos y le sobra-

49 Gálvez a Arriaga. México, 77 de junio de i766. A. G. I., Guadalajara, 4i6.

50 Croix a Arriaga, M'éxico, 30 de mayo de 1767 , relaciona en el ejército expedicionario estos contingentes del virreinato: dragones de España, ı o8; dragones de México, io8; infantería de América, 53; fusileros de montaña, I54; total, 423. Con Elizondo iban dos ingenieros, dos artilleros, un proveedor, dos subdelegados, un tesorero, dos capellanes, dos cirujanos, dos practicantes, dos cajas de medicinas. Entre el armamento y utensilios, veinte cañones de bronce de 3 , veinte cureñas de marina, ochenta y nueve tiendas de campaña y una capilla portátil. Ibid. 
rían más de treinta mil; que dos particulares le habían franqueado noventa mil más, y que también esperaba una apreciable contribución del comercio de México. El contigente de tropas previsto el 8 de enero compredía doscientos dragones y doscientos fusileros, de los que cien se suponía habían de ser los de la compañía de fusileros de montaña que existía en la Habana. El virrey asienta que la expedición sería dirigida por el gobernador Pineda, pero que para ayudarle ó sustituirle en caso necesario iría con ella otro jefe de carácter, Elizondo, puesto que aquél se hallaba muy aquejado de gota.

Pineda había proyectado lanzar contra los enemigọ setecientos hombres -doscientos presidiales, otros tantos dragones, cien individuos más de las compañias volantes de a caballo y doscientos indios auxiliares-, que costarían 59.200 pesos al año sobre el presupuesto ordinario, incluyendo la paga de cuatro reales diarios que se daría a los ciento diez vecinos que habría que reclutar para sustituir de alguna manera a los doscientos hombres sacados de los seis presidios; por otra parte, la campaña debía entenderse por tiempo sólo de ocho meses. La junta de 8 de enero de 1767 fue más lejos, elevando el número de combatientes de setecientos a mil al aumentar los auxiliares a trescientos y añadir doscientos hombres entre fusileros de La Habana y cabos, sargentos y veteranos destinados a formar e instruir milicias en las provincias fronterizas; y el presupuesto ya más ajustado ascendería a 89.927 pesos $1 / 2$ real al año, por el tiempo de duración de la campaña. ${ }^{51}$

Gálvez, pues, continuaba agitando el ambiente para lograr el objetivo que se había propuesto. Para ello se había compremetido a que la empresa fuese financiada por los particulares, confiando en promesas de donativos por valor de cientos setenta mil pesos, y aún esperaba hacer subir esta cantidad hasta los doscientos mil. En mayo de 1767 había recibido en efecto I89.628 pesos y esperaba llegar a los trescientos mil, como en efecto logró. ${ }^{2}$

La diputación del comercio español en Jalapa, según se ha visto, los consulados y comerciantes de México, Puebla y Veracruz, los cabildos eclesiásticos de Durango y Oaxaca y algunos comerciantes y mineros individualmente -Don José Manuel Varela, de Puebla; Don Pedro Antonio de Cossío, Don Fernando Bustillo y Don Francisco Gil, de Veracruz- suministraron aquella

5 I Croix a Arriaga, núm. I, México, 24 de enero de 1767. A. G. I., 1366.

5. Croix a Arriaga, núm. I8, México, 26 de marzo de 1767 , cohnunica que en junta del Consulado de México de 20 de marzo consiguió Gálvez un "donativo" de cien mil pesos que el comercio obtendría en préstamo de algunos particulares a los que se reintegraría con intereses del cinco por ciento del producto de un dos al millar que se recargaría con este solo objeto al antiguo impuesto de avería de 6 al millar. Ibid. Croix a Arriaga, México, 23 de mayo de I 767 , remite nota del caudal colectado hasta la fecha. Ibid. y Guadalajara, 4r6. Gálvez a Arriaga, México, 27 de septiembre de I766, dice haber dado el comercio de España i70.00o pesos. A. G. I., Guadalajara, 5ri. En 27 de mayo de 1767 dice espera alcanzar los 300.00o pesos. A. G. I., Guadalajara, 4 I 6 . 
cantidad. El resto fue en buena parte donativo de los vecindarios de la frontera y de las misiones.

IEl contacto de Gálvez con los oficiales de Sonora debía ser frecuente, consultándoles sobre todas las materias relacionadas con la prevista campaña. Así Cancio le escribe en octubre de 1766 , que no sabe si doscientos mil pesos serán bastantes para los gastos de expedición y poblaciones a fundar - punto éste que Gálvez no planteará oficialmente hasta más adelante-, y que estas poblaciones no habría que establecerlas en el Yaqui. Pide Cancio doscientos dragones, que le parecen útiles por su destreza en hacer fuego y su disciplina, y propone lanzar contra los sublevados doscientos de los trescientos presidiales de Sonora, más los cien hombres de las dos compañías volantes que ya se estaban levantando. En lugar de aquellos doscientos presidiales se dejaría en las guarniciones otros tantos milicianos. Sólo se utilizarían doscientos auxiliares, " porque estos, siempre que se estrecha cualquier acción hallan más a manos los pies que los brazos, y después cuentan prodigios de valor", extraño concepto el de Cancio sobre este particular. La época buena para las operaciones militares era de septiembre a febrero, y en estos seis meses estaría la campaña concluida. Desde luego convendría concentrar al enemigo en Cerro Prieto, donde ordinariamente habitaba. Ya habían llegado a la provincia armas y municiones en cantidad suficiente. Cancio muestra la conveniencia de hacer las pagas en dinero, para que circulase la moneda en Sonora. Es sobradamente curioso advertir cómo Cancio, sobre el terreno y teniendo el peligro presente, se conforma con auxilios mucho más reducidos que los que en México promueve el visitador. Así como cree bastantes doscientos dragones, piensa que para conducirlos podrían aprovecharse las canoas de buceo y las de Ocio y Pisón, que iban anualmente de California a Matanchel, y el bergantín o patache de los jesuitas. Tocante a la financiación de la campaña, presenta el capitán de Buenavista a Gálvez una relación de los comerciantes y propietarios más acomodados de Sonora, Ostimuri, Sinaloa y Culiacán, de los que se podría solicitar el correspondiente donativo.

De igual modo escribe a Gálvez, desde el presidio de fronteras, el capitán Don Gabriel Antonio de Vildósola, para proponerle - a solicitud del visitador - la manera de rodear el territorio dominado por los alzados para sujetar a seris y pimas y la de realizar triple incursión al país de los apaches como único medio de alejarlos de la frontera. 53

Contando con estas cantidades, Gálvez lleva adelante la construcción

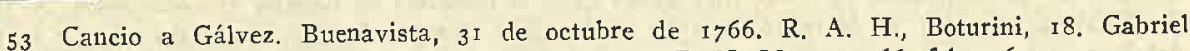
A. Vildósola a Gálvez. Fronteras, I4 de agosto de iz66. B. N. Mss. 19.266, fols. I65-172. 
de los barcos, envía a Sonora doblando jornadas armamento para las compañías milicianas - cuatrocientas lanzas, trescientas espadas, trescientas escopetas, igual número de pares de pistolas y alguna pólvora- y encarga a Don Pedro José de Bringas, comerciante acaudalado del real de San Antonio de las Huertas, en el Yaqui, que aporte a Pineda cuantos medios necesite éste y le pida. Por otra parte nombra comisario o sub-intendente de la expedición a Don Pedro Corbalán, para que sobre el terreno economice los gastos y cuide de que nada falte a los soldados. 54

Pacheco había establecido su astillero en el río Grande o de Santiago, a cuatro leguas del puerto de Matanchel, y para fines de octubre de 1766 calculaba tener concluidas las embarcaciones. Pero muerto Pacheco en septiembre, 55 Don Manuel Rivero se hace cargo de las obras, y el traslado del astillero al puerto de San Blas entorpeció el trabajo, de modo que hasta agosto de ${ }_{7} 67$ no fue botado el "San Carlos". ${ }^{6}$ A principios de octubre, éste y "El Príncipe" estaba ya en franquía en la desembocadura del puerto, y se procedía a colocarles la arboladura. 57

Desde abril estaban en marcha las tropas enviadas de México, a las que más adelante se sumaría una compañía de fusileros catalanes enviada desde España, a falta de la que había en la Habana, de la que el entonces gobernador de Cuba, Bucareli, no se quiso desprender. ${ }^{8} \mathrm{La}$ primera parte

54 El encargo a Bringas fue ya decidido en la junta de 6 de junio de 1766. El envio de Corbalán, "sujeto de toda actividad, confianza y práctico conocimiento de aquel pais" es anunciado en carta de Gálvez a Arriaga. M'éxico, 26 de julio de i 766 . A. G. I., Guadalajara, 4 I6. Corbalán conocía, efectivamente, Sonora, y en 6 de agosto de 176 I el gobernador interino de la provincia Don José Tienda de Cuervo lo había nombrado alcalde nayor de Ostimuri, cargo de que tomó posesión ocho días después en el Real de Loreto y Baroyeca. Al año siguiente, por noviembre pasó desde el real de la Trinidad a Horcasitas para tomar parte en la campaña que Cuervo preparaba contra los indios de Cerro Prieto, y que se suspendió al ser ambos llamados a Veracruz por el virrey con motivo de la guerra con los ingleses. Pasada esta contingencia, el mismo Cruillas lo nombró alcalde mayor interino del real y minas de Tasco, a donde pasó a posesionarse el 30 de marzo de i765. Cruillas a S. M., núm. 3. México, 8 de enero de I 766 , con memorial d'e Corbalán. A. G. I., México, I265. Testimonios de tomas de posesión, A. G. I., Méxi r izo4. Ya en Tasco, Corbalán pidió se agregase a esta alcaldía la de Iguala. A. G. I., México, 1932.

55 Gálvez a Arriaga. México, 26 de julio y 27 de septiembre de 1766 . A. G. I., Guadala jara, 4 I 6 y 5 II.

56 Croix a Arriaga. México, 27 de agosto de I767. A. G. I., Guadalajara, 4I6.

57 Gálvez a Arriaga. Guanajuato, 25 de octubre de 1767 . Ibid.

58 El primero en partir de México, bien escoltado, el r4 de abril, fue Don Francisco Hijosa, que actuaria como tesorero y comisario de la expedición, "por su habilidad, inteligencia y buena conducta", llevando setenta mil pesos. E1 20 salieron ciento cincuenta fusileros de montaña, reclutados en México, europeos, más un piquete de cincuenta hombres con sus oficiales del regimiento de infantería de América, mandados por el capitán Don Diego Peirán. E1. 26 partirían cien dragones del regimiento de España, con su coronel Don Domingo Elizondo, y el 29 otros cien del regimiento de México con el capitán Don Miguel Gallo. Estas tropas acuartelarien en Tepic hasta su embarco. Croix a Arriaga. México, 25 de abril de 1767. Ibid. México, г366. La aprobación del proyecto de expedición a Sonora fue acompañada del anuncio del envío de una compañía de voluntarios catalanes, según real orden de 22 de mayo de 1767 , que al mismo tiem- 
del desplazamiento del ejército expedicionario quedó cubierta cuando éste alcanzó Tepic, adonde fueron llegando a lo largo del mes de junio de 1767 los contigentes de dragones, fusileros y tropas de infantería, salvo los voluntarios catalanes que no llegaron hasta octubre, fecha en que se aproxima a quinientos el número de hombres acuartelados en aquel lugar. Se suponía que en fecha inmediata podría emprenderse la segunda etapa, hasta Sonora, pero de hecho, aunque el bergantín "San Carlos" había sido ya botado, en cambio, el contigente de tropa - veinticinco dragones y otros tantos fusileros- que embarcaba con Portolá en julio en el buque de Don Manuel Ocio para ir a expulsar a los jesuitas de Californias tenía que regresar porque su embarcación hacía mucha agua. El segundo bergantín construido en San Blas, el "Príncipe" estuvo en franquía a principios de octubre, mientras se preparaban las balandras que pudiesen llevar a la península los soldados y los franciscanos destinados a relevar a los jesuitas. Elizondo propuso entonces esperar el regreso de estas embarcaciones, que debería tener lugar en noviembre, para poder entonces hacerse a la mar toda la flotilla que se formando en la nueva base naval del mar del Sur con objeto de conducir de una sola vez a Sonora todo el cuerpo de tropas de la expedición. La segunda vez que se intentó pasar a California, en agosto, el tiempo era adverso y naufragó una de las pequeñas naves; finalmente, ya se ha dicho como Portolá, saliendo de San Blas el ig de octubre con sesenta soldados y doce franciscanos, alcanzó Loreto el i 7 de diciembre de I767, realizó la expulsión y se hizo cargo del gobierno de la península. 59

E1 24 de diciembre se hacía a la vela en San Blas la goleta "Nuestra Señora de la Soledad", alias "La Sonora", destinada a llevar la orden de expatriación de los jesuitas a Manila, y aquel mismo día embarcaba Elizondo con parte de las tropas expedicionarias, los cuatro piquetes de dragones, con rumbo al nuevo puerto de Guaymas, y después de haber llegado a las Islas Marías hubo de desembarcar en San Blas el I. $^{\circ}$ de enero de 1768 , forzado del mal tiempo. Acuartelado en Guaristemba, el 14 de enero emprende la marcha por tierra con ciento ochenta de a caballo camino de Guaymas, dejando dispuesto el viaje de la infantería y fusileros por mar en los bergantines "San Carlos" y "Príncipe" y paquebot "La Lauretana". Por Rosario, Culiacán y Alamos, hizo Elizondo su viaje, en caballos suministrados por

po aconsejaba el empleo de medios suaves para la pacificación. Los catalanes llegaron en agosto a Veracruz, y en octubre a Tepic. Croix a Arriaga, México, 27 de agosto de I767. Gálvez a Arriaga Guadalajara, 25 de octubre de 1767. A. G. I., Guadalajara, 4I6.

59 Croix a Arriaga, México, 22 de junio de 1767 , núm. 31, con estado de tropas en Pitic.

A. G. I., Guadalajara, 4 6 y México, 1366. Croix a Arriaga, México, 4 de julio de I767. A. G. I., Guadalajara, 4I6 y México i 365. Croix a Arriaga, México, 22 de de septiembre de i767. A. G. I., Guadalajara 416. Croix a Arriaga, México, 28 de octubre de \pm 767 . A. G. I., México, I 365. 
los vecindarios, en cicuenta y ocho días, de modo que a su destino arribó el ro de marzo de 1768 . El transporte del pequeño ejército continuó en sucesivos viajes, y a mediados de mayo siguiente estaba concentrada la totalidad de la fuerza en Guaymas y a punto de empezar la campaña general. 6o En Guaymas, el capitán Cancio había hecho construir cuarteles para las esperadas tropas, que fueron recibidas con repiques de campanas y otras manifestaciones de alegría. Finalmente, un núcleo de vecinos fue sacado de Guanajuato y San Luis de Potosí con idea de que colonizasen la frontera, y emprendieron el camino con Gálvez, ${ }^{6}$ quien desde el año anterior había hecho presente a la corte la conveniencia de pasar por sí a Sonora y Nueva Vizcaya a establecer poblaciones, llevando consigo gente vaga de Nueva España. Una real orden de 20 de julio de 1767 dispuso se estudiase en México el asunto. ${ }^{62}$

\section{Preparativos de la marcha del visitador}

La situación de la frontera parecía bastante alentadora cuando en junta de 21 de enero de 1768 , en que Gálvez se abstuvo de votar para que no se le considerarse apasionado, el mismo visitador fue designado por unanimidad para llevar a cabo la fundación de poblaciones que consolidasen el dominio español sobre los territorios que había de ocupar o reconquistar la expedición militar enviada meses atrás. ${ }^{63} \mathrm{La}$ labor que aquí se encomendó a Gálvez, y que él mismo al decir de su secretario Viniegra, habíase hecho conferir ${ }^{64}$

60 Croix da como fecha de salida de Elizondo de San Blas el 24 ó el 25 de diciembre según cartas a Arriaga de México, 26 y 31 de enero de I768. A. G. I., Indiferente General I7I 3 y Guadalajara 4i6, respectivanente. Orden circular de Elizondo, Rancho de Ponce, 2 de febrers de I768. R. A. H., Boturini, 18. La concentración de tropas en Guaymas, según Croix a Arriaga, México, 20 de marzo y 27 de julio de I 768 , núms. I8 8 y 310 . A. G. I., Guadalajara 4 I 6 y México i 367 y г368. Después de mil contratiempos, la "Lauretana" llegó a Guaymas el i. de mayo; el "Príncipe" y el "San Carlos" entraron en el mismo puerto el 5 y ro de aquel mes, respectivamente. "Relación de la expedición", A. G. I., Guadalajara 416.

6 r Viniegra, "Apunte instructivo de la expedición que el Ilmo. Señor Don José de Gálvez, visitador general de Nueva España hizo a la península de Californias, provincias de Sonora y Nueva Vizcaya, desde que la resolvió y emprendió hasta que volvió a México. Comprende las ocurrencias $\mathrm{y}$ hechos más notables con referencias a papeles $\mathrm{y}$ documentos originales que deben existir en la secretaría del virreinato de Nueva España y a sucesos y hechos públicos y notorios en aquellas partes, dispuesto con orden superior por Don Juan Manuel de Viniegra, secretario de dicho señor ministro $y$ de la expedición que siguió y sirvió hasta su vuelta a México". A. H. N., Estado, 2845-I, fols. 26-49; fol. 27: "mandó alistar gentes de Gunajuato y San Luis de Potosí, los que le acompañaron costeados enteramente y con crecidos sueldos algunos, en calidad de nuevos pobladores, con isus familias, y todos esperanzados en establecerse en aquellos manantiales de oro y plata figurados en Californias". Sobre los cuarteles de Guaymas, Cancio a Pineda, cartas de 1767 en R. A. H., Boturini, I8.

62 A. G. I., Indiferente General, I 7 I 3.

63 Acta de la Junta, A. G. I., Indiferente General, I7I3; Guadalajara, 390.

64 La expresión de Viniegra es que "dictó el dictamen tres días antes". "Apunte Instructiva", fol. 27. 
no era sino puramente política y de fomento. Dábase ya por descontado el éxito de Pineda y Elizondo en el campo de batalla. A la salida de los jesuitas atribuíanse también algunas inquietudes en los pueblos del Yaqui, y esto hacía aún más conveniente la presencia de quien pudiera poner remedio, y nadie, en principio, más idóneo para tal misión que el propio visitador, cuya energía se había acreditado en la radical represión de los motines de San Luis de La Paz, San Luis Potosí, Guanajuato Valladolid y Pátzcuara y Uruapán el año anterior.

Pero, ¿jpor qué tanto empeño en la empresa? Las provincias internas occidentales son en este momento objeto por parte del gobierno de una atención sin precedentes, hecho atribuible exclusivanente a Gálvez, a quien un secreto impulso parece llevar a acometer las más difíciles, comprometidas, extravagantes $o$ arriesgadas tareas. La manera como las aborda es también típicamente suya. En ésta de Sonora planea nada menos que la fundación de un puerto, la construcción de barcos, el envío de un fuerte contigente militar, y esto además sin echar mano del real tesoro: "espero en Dios que el suceso haga ver lo mucho que puede adelantarse con moderados medios cuando estos se manejan con la rectitud debida". ${ }_{5}$ No cabe duda que Gálvez busca, ante todo, destacar en el servicio del rey como el más leal, abnegado y desinteresado de sus servidores, y anhela realizar verdaderas hazañas, alcanzando un grado de ejemplaridad en este sentido.

¿Qué espera alcanzar en esta aventura? "V. E. sabe muy bien, escribe a Arriaga atribuyéndole sus propias ideas, que la primera de estas provincias (Sonora y Nueva Vizcaya) es el verdadero tesoro del la América septentrional por la gran copia de minerales de oro y plata que hay en toda ella"; 66 "el verdadero Ofir de esta América", la llama en otro pasaje. Claro que el auditor Valcárcel se había expresado aun con mayor entusiasmo: "Dando crédito a las historias, en la Sonora hay ricos minerales y aun montañas poco menos que de plata maciza”. El visitador calculaba que con sólo los minerales de Sonora se restablecerían el comercio y minería de Nueva España a la opulencia que tuvieron en otros tiempos.

El ministro de Indias Dion Julián de Arriaga se mostraba mucho menos crédulo, aunque aprobaba el intento, tanto más útil cuanto que no gravaría a la Real Hacienda. "El objeto que ha impulsado esta expedición es muy digno, pero el logro de ella merece alguna duda, y por lo mismo acrecienta mi cuidado en saber sus resultas: son tantos los informes que tengo de las ventajas que ofrecería al erario y a la opulencia de ese Reino el poblar aque-

65 Gálvez a Arriaga. México, I7 de junio de I766. A. G. I., Guadalajara, 4 I6.

66 Ibid, ibid. 
llos parajes a que no alcanza la posibilidad por nuestra escasez de gentes, que riéndome (y enfadándome) de los proyectos que abrazan otros ministros sobre varias islas y otros parajes que producen estos y aquellos frutos, abandonados por falta de quien los trabaje, he dicho más de una vez: dénme vuesas mercedes esas gentes que cuentan como apoyo de sus desvaríos, que yo las colocaré donde en lugar de frutos cojan plata y oro". ${ }^{67}$ Estas palabras de Arriaga son una llamada a la ponderación y a la prudencia que Gálvez no oyó.

La expedición militar, desde luego, iba encaminada tanto a Sonora como a Nueva Vizcaya y aun a Nuevo México. Gálvez contaba con que, una vez sometidos los seris, las tropas de Sonora pudiesen pasar por el Gila a Nueva Vizcaya libertando a esta provincia y a la de Nuevo México de los estragos que causaban los apaches. 68 Entre tanto, si no se habían mandado antes las dos compañías que en la junta de 1765 se había decretado enviar en ayuda de Chihuahua, ahora el capitán Don Lope de Cuéllar fue nombrado comandante de las fronteras de la villa y organizó su defensa.

Veamos, finalmente, dos opiniones más y de extraordinario valor ante la aventura de Sonora. Don Antonio María Bucareli, capitán general de Cuba, escribe a Múzquiz, secretario de hacienda: "no entiendo las ventajas de buscar más minas, cuando no tenemos con qué trabajar las descubiertas, ni que sea bueno exponer un número de tropas en tiempo que tratan de aumentarla". 69

"Esta expedición me acuerda -responde Múzquiz- que sería conveniente crear un virreinato en Durango, como se ha pensado varias veces, que Vm. no sería inútil por su mañan y habilidad para la creación de un nuevo empleo tan considerable como éste. No pasa de especie hasta ahora", 70

He aquí cómo Múzquiz se hace eco de una idea que llevaba ya quince años flotando en el ambiente, y piensa para llevarla a la práctica nada menos que en Bucareli, el que llegaría a ser gran virtey de Nueva España y vería la realización de la segregación de las provincias septentrionales de su mando, por obra del mismo que más seriamente la habría de proponer: el entonces visitador y luego ministro Don José de Gálvez.

67 Real orden de ig de noviembre de iz66 a Gálvez. Tbid.

68 Croix a Arriaga, núm. 41. México, I6 de julio de 177 I, respondiendo a Real Orden de 20 de abril de I767. A, G. I., Guadalajara, 416 y México, I366.

69 Bucareli a Muzquiz, confidencial. Habana, 26 de febrero de 1767 . A. G. I., México, i 24r. En esta carta dice también haberse negado a proporcionar tropas de aquella plaza para la expeđición a Sonora, "como no regular, ni posible".

70 Muzquiz a Bucareli, confidencia1. Aranjuez, 24 de abril de 1767 . Ibid. "Vm. se ha salido con la suya -empieza diciendo Muzquiz - negando la tropa que le han pedido de Nueva España para la expedición de Sonora, pero ha sido a costa de remitirla de acá, como se hace". 


\section{PRIMERA AMPLIACión DE LOS OBJETivos}

La expulsión de los jesuitas trajo como consecuencia la necesidad de emplear los barcos que se pensaba utilizar en el transporte de tropas a Sonora para llevar las órdenes correspondientes a aquel negocio a California y Filipinas. ${ }^{I}$ Como segunda repercusión hallose el virrey con la urgencia de reorganizar la constitución de la península californiana, que hasta entonces había sido mera provincia misional en manos de la Compañía de Jesús : consiguientemente, se acordó, en la junta de 2 I de enero de I768, que, de paso para Sonora, hiciese Gálvez una estancia en California para asegurar su permanencia dentro de los dominios españoles.

De esta manera entraba California de lleno en el futuro marco de la actividad de Gálvez. Pero, ¿acaso no había anticipado ya el mismo: visitador sus proyectos sobre todo el país?

En efecto, si el 2 I de enero tuvo lugar la junta que encomendó a Gálvez la reorganización del noroeste del virreinato, del 23 data el "Plan para la erección del gobierno y comandancia general que comprenda la península de California y las provincias de Sinaloa, Sonora y Nueva Vizcaya", ${ }^{72}$ plan que se se fundamenta en "la premeditada resolución que se ha tomado en junta bien autorizada, de que el visitador pase a establecer pueblos en dichas provincias y arreglar el gobierno de ellas con las amplias facultades y comisión del virrey". La proximidad de las fechas parece autorizar la afirmación de Viniegra de que Gálvez dictó el acuerdo de la junta tres días antes de que ésta se celebrase. Con toda probabilidad, lo que en Gálvez había empezado siendo un proyecto, aunque grandioso, de pacificación de Sonora, había adquirido mayores vuelos al ocurrir la expulsión de los jesuitas, y esto y la influencia hasta hoy imposible de precisar del mariscal Don Antonio Ricarcios, que por aquellas fechas reconocía las vulnerables costas de Nueva España y debía ser consciente del peligro de la aproximación de los rusos desde Alaska, todo ello hizo a Gálvez pensar en California y decidirle a proponer la apertura de un firme movimiento expansivo hacia el noroeste. El instrumento de esa expansión sería la Comandancia General. P.or otra parte, la segunda y más decisiva ampliación de la empresa del visitador vendría impulsada por el deseo de la Corte de ocupar los puertos de la Alta California, imprimiendo así un giro inesperado a la actividad de Gálvez cuando ya éste se hallaba en camino.

E1 caso es, pues, por el momento, que en enero de i 768 ya Gálvez tenía

71 Croix a Arriaga. México, 26 de enero de 1768 . A. G. I., Indiferente General, I7r 3.

72 Ejemplares de este Plan en A. G. I., Indiferente General, I7I3, Guadalajara, 252 y 390 , y México, 2477. 
conciencia tiempo atrás de la labor que deseaba realizar en el noroeste y del papel que pretendía reservarse: el de sucesor de Hernán Cortés, cuyo espíritu de actividad y de conquista - dice el Plan- se había apagado con su vida, de tal manera que llevase la luz del evangelio y la dominación de los augustos reyes de España hasta los últimos límites, no conocidos, de aquel inmenso continente.

Del plan de la comandancia nos ocupamos a continuación.

\section{LA VISIÓN DE GÁLVEZ}

Por el plan de la Comandancia general de las provincias internas se hace Gálvez heredero de una tradición orientada a dar cohesión, fomento, personalidad política e impulso expansivo a las posesiones septentrionales del virreinato mexicano. Pero es el mismo Gálvez quien de manera más ambiciosa abrazó este proyecto de cuya plena realización la campaña de Sonora y la esperada actuación del visitador en las provincias no eran más que los cimientos.

De todos modos, Gálvez quería ser autor de una obra de gran envergadura, sin reparar en medios, sin que ningún obstáculo fuese bastante a impedir su desarrollo. Prevé todo lo que pueda facilitar la plasmación de su proyecto infundiendo nueva vida a aquellas apartadas y casi olvidadas provincias.

A la unidad política sigue la reorganización de las jurisdicciones eclesiásticas y ha de seguir más adelante la autonomía judicial. La independencia económica la dará la Casa de Moneda, y ella y las tres intendencias la prosperidad hacendística; la libertad de comercio con California, el habilitamiento de puertos aquí y en Sonora, la concesión de feria en Guaymas, darían enorme incremento al comercio. La fundación de una escuela de marina en Loreto y la introducción de máquinas en la explotación minera, así como su previsión en llevar cantidad de azogue y pólvora garantizaban el florecimiento de otras posibilidades económicas interesantes en una región que de esta manera había de entrar a figurar entre las más opulentas de América.

Pero aún todo esto es poco para la proyección remota del ideal del visitador. Si la comandancia adquiere potencialidad económica, vida pujante, ha de ser para que sirva de base de partida a un movimiento expansivo que empuje la frontera muchos cientos de leguas al norte. En lo que Gálvez deja entender, la progresión se enfoca principalmente a lo largo de la costa, a la Alta California, y en este sentido la simultánea irradiación naval partiría del puerto de San Blas, al que da por esta razón tanta importancia.

La factibilidad del proyecto fundamenta Gálvez en las riquezas que 
incuestionablemente atesoran, según él, California y Sonora. Es curioso que nunca pensase en situar el centro económico y político de la comandancia en Nueva Vizcaya, de hecho la más rica de las provincias de la planeada coman. dancia y de todas las internas. Pero Gálvez está decididamente orientado hacia el noroeste, y concibe su capital en la misma frontera, equidistante de Nueva Vizcaya y de la península, y puesta como una afirmación del decidido propósito de dominar los territorios más al norte del Gila. Las naciones ds indios de esta región, en su teoría - parece que leamos la carta de un ferviente misionero-, son numerosísimas, y sú índole natural la más propia a dejarse persuadir de la verdad infalible de la fe católica.

¿Y de dónde tomó Gálvez estas ideas? No da la impresión sino de que aceptaba las relaciones de los jesuitas acerca de la bondad de los indios, y las calumnias contra ellos sobre las riquezas de California. Todo, por otra parte, o casi todo adquiere en su plan el color vago de las cosas de que se habla sin conocerlas más que de un modo teórico, superficial y lejano. Todos sus proyectos parecen castillos en el aire. Nadie que tuviese una experiencia inmediata de las provincias fronterizas podría creer en la realización de aquellos sueños con que la imaginación de Gálvez cegaba sus sentidos. Soñar despierto era probablemente lo que hacía el visitador cuando se impacientaba en México ansioso de marchar al norte.

\section{EL PLAN DE LA COMANDANCIA}

Son varias y delicadas las circunstancias que Gálvez hace presentes al formular su proyecto de restructuración de la frontera, haciendo caso omiso de la insurrección de seris y pimas, que se espera liquidar en breve.

De una parte, el abandono en que existen las provincias septentrionales por la inmensa lejanía en que se hallan de México. De otra, la inminencia presumible de una penetración inglesa o rusa. En este sentido, Gálvez se hace eco de las noticias circulantes en Europa sobre las navegaciones rusas en el mar de Tartaria y sobre la proximidad de los ingleses a las fuentes del río Colorado. Pero el visitador, aunque expone esta sittuación con claridad, y apunta el peligro que supondría la ocupación de Monterrey por alguna potencia europea, no hace en ello demasiado hincapié.

$\mathrm{La}$ operación de establecer colonias en el puerto de Monterrey y otros de la costa occidental le parece conveniente, y aun fácil, toda vez que se cuenta ahora con las embarcaciones construídas para la expedición de Sonora, y la península no tardará en prosperar entrando en relaciones comerciales con el reino.

Su propósito es engrandecer en poco tiempo las fronteras, para lo cual 
él y el virrey Croix -que firman conjuntamente el Plan- exponen la idea de crear una Comandancia general bien autorizada que comprenda bajo de su privativo gobierno las provincias de Sonora, Sinaloa, Nueva Vizcaya y la península de California. El plan de Gálvez y Croix renuncia a proponer un virreinato según el proyecto de I760 visto en Madrid, por demasiado costoso y no más eficaz que la Comandancia. El comandante sería independiente del virrey y sólo reconocía a este jefe para darle cuenta de los acontecimientos y pedir su auxilio cuando lo necesitase. Su actuación tendría el "fin importantísimo de dar espíritu y movimiento a unos territorios tan dilatados, abundadntes y ricos por naturaleza, que pueden en pocos años formar un nuevo imperio igual o mejor que este de México". He aquí sucintamente expuesto y en propias palabras el magno objetivo de la máquina puesta en marcha por Don José de Gálvez.

Para ello pretende como indispensable y de inmediata realización la erección de una población matriz en los confines de Sonora, en el río Gila 0 en la confluencia de éste con el Colorado. Mientras tanto, debería ponerse la capital en la misión de Caborca, como lugar más avanzado de la frontera.

La fundación de una Casa de Moneda en esta capital surtiría de numerario suficiente a las tres provincias, con el consiguiente beneficio y prosperidad del comercio, en vez de la desdichada situación en que entonces se encontraba; y evitaría a los mineros el tener que transportar su oro y plata hasta la casa de México, con perjuicios y dispendios que casi los arruinaban o por lo menos les reducían considerablemente las ganancias que, de ser cierto lo que se propone, obtendrían.

Podría ser conveniente la erección en la misma capital de una real audiencia, bien de nueva planta, o bien por traslado a ella de la de Guadalajara; pero por el momento no sería preciso verificarlo. En cambio, cree fundamental establecer sede episcopal en Sonora, ctya diócesis se extendería sobre esta provincia y las de Sinaloa y California. El prelado impulsaría ardientemente la conversión de los gentiles, logrando muchas almas para el Criador y nuevos dominios para el monarca.

Yendo a la parte problemática del Plan, Gálvez declara que las pensiones con que en principio habría que socorrer al obispo y su reducida iglesia no serían de larga duración, pues pronto la fertilidad de los terrenos rendiría lo suficiente para subvenir a todo. En cuanto al sueldo de veinte mil pesos que señala al comandante general, y los de los tres intendentes que en otro plan propone para Sonora, California y Nueva Vizcaya, 73 "desde el segundo

73 "Informe y plan de Intendencias que conviene establecer en las provincias de este reino de la Nueva España", firmado por Gálvez y Croix en M'éxico, i 5 de enero de I768. A. G. I., Indiferente General i7r3. Cfr. Navarto García, Luis. Intendencias en Indias, Sevilla, 1959, páginas $22-23$. 
año de establecidos estos empleos no ha de llegar seguramente la asignación de ellos ni aun a la décima parte del aumento que tendrá el sólo ramo de quintos de la plata y el oro que se saquen y beneficien en la Sonora y California, a que debe añadirse el de las perlas, cuya pesquería, pudiendo ser muy abundante en las costas de aquella península, nada producía antes a la real hacienda".

Pero el más considerable ahorro lo constituirá la supresión de los presidios luego de fundadas las poblaciones de frontera. Las tropas necesarias para guarnición de la nueva capital serían, con algún aumento, las veteranas enviadas a la expedición, cuya manutención cuesta la tercera parte de lo que consumen los presidios. Estas cinco compañías que propone, de infantería y caballerías, con las milicias de los pueblos que va a fundar y las que se levanten en el distrito de Chihuahua, bastarían para el resguardo de la frontera.

En resumen, la comandancia tendría una suprema autoridad políticomilitar en el comandante general; dos obispados: Durango, y Sonora con California; y tres intendencias, una cada una de estas provincias. Dependería en lo judicial de la audiencia de Guadalajara, y sería dependiente del comandante general un gobernador militar de Chihuahua y sus fronteras.

Este era el plan que pasó el virrey marqués de Croix a los arzobispos y obispos de México y Puebla, Lorenzana y Fabián y Fuero, que dieron su conformidad acreditando la utilidad del proyecto, y así fue enviado a España por Croix en 26 de enero de I 768.74

\section{LOS PODERES DE GÁLVEz Y LAS PRIMERÁS} MEDIDAS PARA EL FOMENTO DEL NOROESTE

En el mismo Plan de la comandancia se anuncia el otorgamiento a Gálvez de los poderes de virrey, cosa que de manera más explícita se resolvió al presentar el visitador a Croix catorce puntos que representaban otras tantas peticiones de facultades que autorizasen su persona, ya que no se le facilitaban caudales para la empresa que acometía. 75

En aquellos catorce puntos solicitaba fundamentalmente, la expedición de un despacho conforme a lo acordado en la junta de $2 \mathrm{I}$ de enero, en que constase llevar él las amplias facultades de virrey, y que se comunicase a los gobernadores, comandantes, jueces y ministros de real hacienda; la continua-

74 Al día siguiente de firmarlo, esto es, el 24 de enero de 1768 puso el virrey su decreto para que el plan pasase a informe de Lorenzana y Fabián. Aquel dio el suyo en Tulancingo, el 27 de enero, y éste el 28 en Hueyotlipan.

75 Gálvez a Croix, México, 2 I de febrero de i768. A. G. I., Guadalajara, 4I6. 
ción de los situados de barcos y presidios de California, abonándose los dos años de atraso que llevaba este cobro; el permiso para trasladar, si lo creyese oportuno, el presidio de Loreto al cabo de San Lucas o bahía de San José, y para suprimir los demás presidios que juzgase superfiluos; la autorización para fundar poblaciones fronterizas al estilo de las que se establecían en Sierra Morena, en España y para invertir en la reducción de los gentiles la tercera parte del incremento que él proporcionase a la real hacienda.

Igualmente pide se le conceda la erección en la frontera de Sonora de una población que con el tiempo pudiera ser la metrópolis de un gobierno y comandancia general y de una mitra; y la posibilidad de reclutar dos o tres voluntarios de cada una de las compañías de los cuerpos provinciales que formó en su anterior expedición a sofocar las inquietudes ocurridas en San Luis de la Paz, Potosí y Guanajuato al verificarse la expulsión de los pesuitas, que él llevaría para establecerlos como colonos en la frontera.

Para el fomento de aquellas provincias sugiere que el virrey publique en bando la libertad general del comercio en California y Sonora y se concedan una o dos ferias francas al año en Loreto y Guaymas, habilitándose San Blas y Acapulco para el embarque y registro sin derechos de las mercaderías y facilitándose el transporte o moderados fletes en las dos nuevas embarcaciones y en los dos barcos del rey que habían tenido los jesuitas. De la misma manera piensa llevar para impulsar la minería mil quintales de azogue y cien o ciento cincurenta de pólvora, y pide incluso se le permita fabricarla en California, donde supone haber buenos azogues.

Por fin, solicita facultad para poder establecer en San Blas y las tres provincias los ministros de real hacienda que considerase oportunos para llevar adelante su nueva y trabajosa comisión, con los sueldos precisos para mantenerse, bajo la aprobación del virrey y confirmación de Su Majestad. En cuanto a dependientes de la expedición militar, ya vimos que había nombrado a Echeveste y Corbalán tesorero y subintendente.

Concluye rogando que sus gastos personales se carguen al fondo de la expedición -cuidando él de que se formen las cuentas correspondientes y de guardar la economía necesaria- pues su sueldo no es suficiente y ya se hallaba muy empeñado de resultas de sus anteriores viajes.

Croix convocó junta para decidir sobre todo ello, que fue unánimemente aprobado, 76 especificándose que las ferias concedidas a Guaymas y Loreto tendrían lugar en abril y mayo, con franquicia por cinco años. 77

76 Acta de la Junta, 25 de febrero de I768. Ibid. Dos días antes habia llegado Rubí a Mé xico, concluida su visita a los presidios internos.

77 Gálvez y Croix dieron cuenta por separado de lo ocurrido en 26 y 29 de febrero de 1768. Ibid. Croix especifica que el situado vencido de los dos barcos y presidios de Californias es de 
Así, pues, cuando Gálvez sale de México el 9 de abril de I 768 todo su proyecto ha entrado en vías de realización; en su mente está perfectamente claro el plan de actuación a seguir, y en su mano todos los recursos y facultades que ha pedido. El virrey Croix le respalda y comparte sus ilusiones, eficaz armonía que en el plan de la comandancia se expresa de esta manera: "nunca pueden ofrecerse embarazos entre dos fieles servidores del rey que, caminando a un mismo fin con rectas intenciones, convienen siempre en sus discursos y unen con recíproca complacencia sus trabajos".

Sin embargo, el capítulo que abre Gálvez, cuando se pone en marcha para Guadalajara se cierra el 28 de mayo de i 770 dejando a sus espaldas uno de los períodos más confusos, controvertidos y aun desagradables de la historia de Nueva España.

\section{El puerto de San Blas y la guerra de Sonora}

E1 I 3 de mayo alcanzaba Gálvez el puerto que, fundado por él, había de ser desde entonces la más importante base naval española en el Pacífico. Viniendo de Guadalajara hacia San Blas, el 6 de aquel mes había llegado a sus manos remitida por el virrey una orden que disponía el reconocimiento del puerto de Monterrey, ${ }^{78}$ idea que ya él había expuesto en el Plan de la Comandancia, pero que debió ser movida en Madrid por el mariscal Ricardos, y que daría lugar a la segunda ampliación de los objetivos del visitador en el noroeste. Como consecuencia de tal orden obtendría Gálvez su más brillante realización : la ocupación de la Alta California.

La real orden de 23 de enero de 1768 , comunicada por el secretario de Estado marqués de Grimaldi al virrey Croix, encargaba tan sólo la exploración de Monterrey por mar o por tierra, y la formación del correspondiente plano. Croix se limitó a transmitir tal mandato a Gálvez, esperando que éste, como nás próximo al lugar de que se trataba, y revestido de sus mismos poderes, tomase las providencias que estimase oportunas. Pero una vez en el puerto, tuvo alli Gálvez junta el 16 de mayo con el ingeniero Don Miguel Costanzó, el comandante de la Marina y del puerto de San Blas Don Manuel Rivero Cordero, el profesor de matemáticas Don Antonio Faveau Quesada,

\footnotetext{
justicia entregarlo a Gálvez pues procede del Fondo Piadoso destinado al fonento de la península, a la que se continuatia su dotación hasta que al mismo visitador la pusiera en estado de no necesitar auxilio. El virrey habia otorgado a Gálvez tolo lo que este pidió, pero se retrajo hasta cono- cer la aprobación del rey. Sin embargo, asienta que el visitador merece que se confíe y ponga todo en sus manos para que consiga la restauración de aquellas provincias. La aceptación del tey vino dada en orden de 20 de septiembre de i 768 . Ibid. Duplicado de Croix a Arriaga, México, 29 de febrero de 1768 , núm. I67, y testimonio adjunto en A. G. I., México, I368.

78 Viniegra, "Apunte instructivo", fol., $27 \mathrm{v}$.
} 
de quien en el acta de la junta se dice ser práctico en la navegación de estos mares y los de Filipinas, y el piloto de la armada real del mar del Norte Don Vicente Vila, destinado ahora como piloto mayor de las embarcaciones que ya navegan por el mar del Sur. Los cinco congregados acordaron que, una vez regresasen de Guaymas, adonde habían ido conduciendo tropas, los dos bergantines recién fabricados, el "San Carlos" y el "Príncipe", se prepararía formal expedición naval con estos buques, desde San Blas o desde el Cabo San Lucas, en demanda de los puertos de San Diego y Monterrey. La época adecuada para tal navegación sería la estación inmediata de junio a septiembre, y su derrota sería por alta mar, y no por el canal de Santa Bárbara, para evitar los vientos contrarios con que luchó, siglo y medio atrás, Sebastián Vizcaíno. Mandaría uno de los buques Vila, y el otro Faveau, que además actuaría como ingeniero para ayıdar a Costanzó; Gálvez daría sus últimas instrucciones a los pilotos en el Cabo San Lucas, y desde la península enviaría. simultáneamente una expedición exploradora por tierra con igual destino y con objeto de dejar constituido un presidio que consolidase el dominio de la Corona española sobre aquellas costas. De esta manera empezaba a prepararse la expanción castellana por el Pacífico Norte.

Días después, en carta de 20 de mayo, sugiere Gálvez al virrey que le doble expedición a Monterrey se costee del fondo piadoso de California, aunque de todos modos, añade, "yo confío que la misma California, puesta en mejor régimen y algún gobierno, dará con qué indemnizar sobradamente los dispendios que ahora causare el importante objeto de su seguridad". 79

La atención que Gálvez concede a San Blas es uno de los más claros exponentes de la política que el concebía acertado seguir en aquella extremidad del Imperio. Considera que, "el primer objeto, por el más cercano y del que en cierto modo dependen los demás de mi actual comisión es la subsistencia de este puerto y de la pequeña escuadra de embarcaciones del rey en él se han botado al mar", y por ello dedica todo su interés en los días de su permanencia allí a procurar la subsistencia de la base. Para ello estancó las salinas de la costa, desde Colina a Mazatlán, y de las islas María, salinas que calculaba habían de producir veinticinco mil pesos al año, cantidad suficiente para el pago de salarios, conservación del puerto, etc. Además de los bergantines "San Carlos" y "Príncipe", un tercer buque de este tipo se hallaba a punto de ser botado, y la pequeña escuadra que empezaba

79 Gálvez a Croix. Nueva población de San Blas, 20 de mayo de 1768 , oficio núm. 7, con acta de la junta del 16 . Remitido con otras seis cartas del visitador por Croix a Arriaga en núm. 252 de México, 28 de mayo de 1768. A. G. I., México, 1367. En A. G. I., Guadalajara, 416 sólo aparecen los seis primeros oficios, relativos a las medidas de fomento de San Blas, de que hablamos a continuación. En ambos legajos las últimas providencias de Gálvez en el puerto, segúin oficios remitidos por Croix a Arriaga, núm, 259, México, I8 de junio de 1768. 
a surgir allí contaba también con la balandra "Sinaloa", el paquebot "Concepción" y otros pequeños buques. Una población comenzaba a surgir en la vecindad del puerto, bajo los cuidados del sucesor de Pacheco, Don Manuel Rivero, miembro de una familia peninsular de comerciantes y armadores y que había ya anteriormente colaborado con el visitador y virrey en algunas de las empresas por ellos acometidas, y a cuyo directo impulso ha de atribuirse el rápido y eficaz desarrollo de San Blas. 80

Desde San Blas comisionó Gálvez a Don Diego Fernández para el reconocimiento de todas las minas, vetas y placeres de oro y plata y cualesquier otros metales en las tres provincias que había de comprender la futtura comandancia. Fernández había de dar comienzo a la ejecución de esta orden visitando las islas Marías, a quince o veinte legutas de San Blas, hasta entonces despobladas, pero que Gálvez también comprende necesario ocupar, tal como ya había sido dispuesto anteriormente en repetidas reales órdenes. ${ }^{81}$ El mismo Gálvez visitó las Marías, por arribada forzosa a ellas durante su navegación a Californias, pues habiendo partido el 24 de mayo de San Blas a bordo de la "Sinaloa" hubo de refugiarse el $I .{ }^{\circ}$ de junio en la Isabela, pasando el 5 a fuerza de remos a las Marías; en una y otras islas permaneció doce días, en que tuvo tiempo de recorrerlas y tomar poseción de ellas, antes de hacerse de nuevo a la vela en la mañana del iz de junio.

Hasta el 5 de julio no le fue permitido pisar tierra californiana, después de una larga estancia en el puerto de Mazatlán, al que llegó de arribada el Ig de junio obligado por las pésimas condiciones del Golfo para la navegación. En aquel puerto se entrevistó el 26 de junio con Beleña, al que dió órdenes sobre estanco de tabacos, pólvora y naipes. El 2 de juilio pasó a bordo del barco de Pisón, que le dejó por fin en la península. ${ }^{82} \mathrm{El}$ mar de

80 Croix a Arriaga, México, 28 de noviembre de 1767 , con memorial de Rivero adjunto. A. G. I., México I365. Croix a Arriaga, ním. 158, México, 26 de febrero de i768. A. G. I., México 1368 .

8I Gálvez a Croix. San Blas, 20 de mayo de 1768 , núm. 6, Ibid. Es abundante la documentación sobre este momento de la visita de Gálvez a San Blas, pero sólo daremos, por menos conocidas, las líneas de Viniegra en su "Apunte instructivo", fol. 28: "El I3 de mayo entramos en el puerto de San Blas, en cuya nueva población, sin embargo de ser casi inhabitable por lo ardiente $y$ enfermo de su clima, cuanto por la multitud de insectos venenosos que ofrece su terreno, se mantuva el Señor visitador once días nianifestando una exterioridad placentera para no desacreditar un pueblo que él había fundado a costa de mucho dinero y deseaba sostener". Sobre esta base naval española en el Pacifico deben consultarse Chapman, The founding of Spanish Califormia. New York, t916; Gutiérrez Camarena, Marcial, San Blas y los Californias. Estudio histórico del puerto. México, 1956; Delgado Miranda, Pilar, "Historia del puerto de San Blas en la Edad Moderna". Tesis inédita. Sevilla, 1959.

82 Croix a Arriaga. México, 30 de julio de I768, núlm. 319; 27 de agosto de I768, núnn. 3 I9. A. G. I., Guadalajara 5 I I y México I 367 . La estancia de quince días en Mazatlán fue unaj de tantas ocasiones propicias a la capacidad legisladora de Gálvez. Declaró a los habitantes del 
Cortés había demostrado una vez más sus escasas aptitudes como vínculo entre las costas del continente y la península, y la irregularidad de sus vientos y corrientes, pues el paquebot "Concepción", que había salido al tiempo que Gálvez de San Blas con el mismo destino, había llegado a la ensenada de Cerralbo el I4 de junio.

Cuando Gálvez partía de San Blas, Elizondo, llegado con sus tropas a Guaymas el to de marzo, se preparaba a entrar en campaña. A mitad de mayo, todos los contigentes llegados de México se hallaban a punto, tras no. pequeña demora, pues la expedición definitivamente resuelta en enero de 1767 , y que se puso en marcha en abril siguiente desde la capital del virreinato, había tardado más de un año en presentarse en el escenario de la guerra, aunque ahora se disponía a hacer notar su presencia en la frontera. Por de pronto, hubo que comenzar por adaptar a la tropa a las exigencias del terreno y al tipo de combate que ofrecía el adversario. Ya a principios de junio de I768 había empezado Elizondo a hacer acopio de pieles para chupas para los dragones. Además, dice, "no estaré contento... hasta ver mi tropa con el precioso resguardo de la adarga, pues de lo contrario habrá muchos dragones tuertos o desnarizados al fin de la campaña. Nuestras espadas saltan como el vidrio, en cuya consideración, y en la de que no es la más ofensiva ni a que temen, ni causa el mayor respeto a los enemigos, pienso poner una vara de quita y pon a las bayonetas, y quedarán armados de ventajosa arma de la lanza". Así, al mismo tiempo que aligeraba el correaje de los soldados y suprimía la casaca de paño, procuraba proporcionarles cueras, como él mismo se la vistió y adquirió otras a Cancio para sus oficiales. ${ }^{83}$ Tras estos preparativos, un ejército de mil cien hombres estaba a punto para batir de manera decisiva a los rebeldes seris, pimas, piatos, suaquis y sibubapas.

Habíanse unido estos últimos a los seris el año anterior. Por mayo de 1767 , un ataque triple organizado por Pineda había concluido con la prisión de un centenar de ellos, de los que veinticinco hombres de guerra, lo que movió a los demás a volver a sus casas, quedando alzadas sólo tres

pueblo milicianos provinciales con fuero y honores militares, sujetos en lo criminal a su capitán, dependiendo éste directamente del gobernador de Sonora, 'y del alcalde mayor de Copala "y de sus iniquidades e injusticias" como hasta ahora. La frase entre comillas es una muestra de la invencible inquina del visitador a los alcaldes mayores. Gálvez a Croix, Real de Santa Ana de Californias, I5 de agosto de I768. A. G. I., Guadalajara 4I6 y México I367. Beleña a Pineda, Bacubirito, 26 de agosto de I768. R. A. H., Boturini, i 8. Según Olea, Gálvez desembarcó en M'azatlán el I 4 de junio y no se limitó a permanecer en aquel puerto, sino que subió a la villa de San Miguel de Culiacán, en la que entró el 23 de junio, antes de remprender la navegación a California. Olea, Héctor R., La holografia de Don José de Gálves, visitador general de la Nueva Espapia. "Boletín Bibliográfico de la Secretaría de Hacienda y Crédito Público", núms. I 74-I 75, págs, 34 México, 15 marzo y $10^{\circ}$ abril, 1960.

83 Elizondo a Pineda, Guaymas, 6 y I4 de junio de I768. R. A. H., Boturini, I 8 
familias. ${ }^{84}$ Pero en enero de I768 éstos habían hecho cinco muertes entre Buenavista y Alamos. Otras ocho habían cometido los seris en San José de Gracia, Opodepe y Bayoreca, pero las tropas, en dos encuentros, les causaron veinte bajas y les tomaron treinta y ocho individuos, treinta y dos reses $y$ cincuenta $y$ nueve caballos. 85 Ahora los indios se hallaban en el Cerro Prieto, aprovechando las aguas recogidas por las barrancas en la época de lluvias, y la abundancia de la tuna, base de su alimentación. Cuando escasearan una y otras, se dispersarían y entonces sería preciso perseguirles con destacamentos por todo el territorio. La provincia había acogido con admiración y alegría la fuerza expedicionaria, los pueblos echaban sus campanas al"vuelo a su llegada: parecía fundada una esperanza de pronta Y duradera paz. ${ }^{86}$

Las operaciones se iniciaron el $1 .{ }^{\circ}$ de junio de $\mathrm{I} 768$, con la salida de tres destacamentos de Guaymas, Pitic y Buenavista. Para concentrar a todos los enemigos en el Cerro, donde pudiera darse una batalla decisiva, tres partidas de setenta hombres mandadas por Elizondo, Urrea y Cancio batieron los alrededores, con pobres resultados; en cambio se supo que a la llegada de los barcos y tropas los rebeldes tuvieron congreso y recelosos de que no conseguirían la paz aunque la solicitasen se resolvieron a la defensa del Cerro, determinando la retirada a la isla del Tiburón en caso de no poder sostenerse allí. Las partidas tuvieron que volver por falta de agua, observándose que los enemigos quemaban el pasto al retirarse para obstaculizar el avance de la caballería. ${ }^{87}$

Mientras Gálvez emprende su visita a Californias, y la guerra empieza a planearse como una campaña en regla, por otra parte, Don Eusebio Ventura Beleña, uno de los comisionados de la visita general de Nueva España, había sido enviado a Sonora y empezaba a estudiar el establecimiento en el

84 Pineda a Arriaga. San Miguel de Sonora, 18 de mayo de 1767. A. G. I., Guadalajara 51 r.

85 Croix a Arriaga. México, 14 de marzo de 1768. Acompaña Extracto de las noticias recibidas de Sonora con fecha de 18 de enero de 1768. Ibid y México 1368. Este es el primer "Extracto" que conocemos de sucesos de las provincias internas, tipo de comunicación que se hará usual durante décadas, viniendo a ser un parte de novedades. En éste se dice también que el presidio de Terrenate habia sido duramente atacado por apaches armados de cueras y lanzas, que causaron tres muertes. Luego atacaron sin éxito el pueblo de Guebavi.

86 Croix a Arriaga. México, 20 de marzo de 1768, núm. 18r. A. G. I., Guadalajara 416, México 1368. Por aquellos dias, la circular dirigida por el virrey al clero mexicano para que coperase a la campaña de Sonora empezaba a dar fruto: el obispo Fabián y Fuero, de Puebla, entregó tres mil pesos para tal fin; el cabildo de aquella sede dos mil; el arzobispo Lorenzana y su cabildo dieron otros tres mil y dos mil pesos, respectivamente Croix a Arriaga, 29 de febrero $v$ 14 de marzo de 1768 , núms. 163 y 173 . Ibid.

87 Croix a Arriaga. México, 27 de julio y 22 de agosto de I 68 , núms, 310 y 321 . Ibid. Sin enbargo, la "Relación de la expedición" niega que los enemigos hubiesen advertido la impor-
tancia de tal quema de los pastizales. 
real de Alamos de una caja para los quintos del oro ${ }^{88}$ y la conveniencia de Fundar allí una Casa de Moneda, para la mayor comodidad de comerciantes y mineros. Los proyectos apuntados por el plan de la Comandancia estaban, por consiguiente, siendo impulsados hacia su más rápida ejecución. Recientemente acababa de descubrirse en la provincia un rico placer de oro en Bacubirito, junto al río de Sinaloa, de donde se había extraído un grano de más de cinco marcos que se pensaba enviar al rey. La gente afluía al lugar, donde pronto estuvieron congregadas más de seis mil personas, y todo hacía pensar que el país iba a conocer una nueva época de prosperidad. ${ }^{89}$

En cuanto a la posibilidad de fundar Casa de Moneda, las vacilaciones holgaban desde el momento que una real orden de 8 de enero del mismo año había venido a disponer que Gálvez y Croix informasen del modo de establecer una en Guadalajara o Durango, para surtir de numerario a las provincias de Sonora, Sinaloa, California y Nueva Vizcaya, distantes de la capital del virreinato. Esta real orden indica ya la decisión del ministerio de establecer tal Casa de Moneda, sin embargo de que el informe del propio virrey en 21 de enero de 1767 , respaldado por los del superintendente de la Casa de México, Núñez Villavicencio, y el exvisitador de Sonora Rodríguez Gallardo fueron contrarios a dicha medida, que se suponía habría de ser gravosa para los mineros y para el erario. Estos dictámenes fueron vedidos de resultas de una real orden de 30 de junio de 1766 en que se remitía a Croix un papel anónimo que propugnaba la creación de la Casa para evitar cierta negociación que los gobernadores de la provincia practicaban con los azogues, y al parecer tuvo buena acogida, según se desprende de la orden de 1768.90

Simultáneamente, también en Nueva Vizcaya Don Lope de Cuéllar comenzaba a llevar adelante los planes para realizar una campaña contra los apaches del Gila y procedía a recaudar donativos y reclutar soldados para sus compañías de dragones.

88 Gálvez a Croix. San Blas, 20 de mayo de I768, núun. I. Ibid.

89 Croix a Arriaga. México, 22 de mayo de I768, núm. 233. Ibid.

90 Real orden de 8 de enero de 1768 a Croix. En carta de Revillagigedo a Alcudia, reservada. México, 3 I de julio de I793, núm. II, artículo I37. A. G. I., Guadalajara 39o. Croix a Arṛiaga, 21 de enero de 1767 , núm. I2. A. G. I., México r 366. Anterior al expediente de 1767 es el promovido por real cédula de I I de agosto de I762 a instancias de la ciudad de Gruadalajara, que ya entonces pretendía tener Casa de Moneda. Con este motivo informó también Núñez Villavicencio, el Consulado de México, el fiscal Velarde, todos igualmente contrarios a la idea, pero Gálvez los acusará de no ser imparciales y desinteresados en esta cuestión. Croix a Arriaga, México, 28 de octubre de 1768, con carta de Gálvez, Real de Santa Ana, is de agosto de 1768 y testimonio adjunto. A. G. I., México ${ }^{367}$. La carta de Gálvez, también en A. G. I., Guadalajara 416. 


\section{Gálvez en California}

La estancia del visitador en la península, que fuera incluida en su itinerario al ocurrir la expulsión de los jesuitas, duró ocho meses y supuso un intento de estructurar su gobierno y de impulsar su expansión misional hacia el istmo, y al mismo tiempo la realización de la doble expedición que dio como fruto la octpación definitiva de la Alta California por España. Es esto íltimo lo que da interés a la presencia de Gálvez al otro lado del Golfo, que por lo demás careció de toda repercusión en pro ni en contra del bienestar de la nueva gobernación. Aquellos ocho meses fueron tal vez los de más estériles esfuerzos de la vida de Gálvez.

Todo su programa consistirá aquí en ver la manera de hacer la California Baja económicamente autónoma. Según su proyecto, no sólo dejaría de gravar a la real hacienda sino que incluso le dejaría un pequeño beneficio. Sin embargo, "reconocida de cerca la península, se vio no sin admiración todo lo contrario que se había imaginado desde lejos, y que el Ofir de las Américas que ofrecieron los primeros informes del visitador no estaba en la California". 91 En toda la provincia, dividida en quince misiones, no había más que siete mil ciento cuarenta y nueve personas; las raras y pobres vetas que fueron encontradas hizo Gálvez que fueran trabajadas de cuenta de la real hacienda, trayendo de Sinaloa ciento cincuenta operarios yaquis que por órdenes styyas de 30 de agosto, le enviaron Cancio y Beleña en la balandra "Sinaloa" y paquebot "La Lauretana" desde el puerto de Santa María, junto a Ahome, y desde Santa Cruz de Mayo. Semejante remesa de trabajadores era imprescindible, puesto que los mineros traídos de Guanajuato, San Luis de Potosí, Guadalajara y otros lugares consiguieron de Gálvez ser devueltos a sus casas, habiendo visto destruidas sus ilusiones.

Fracasado el punto principal de la riqueza en metales preciosos, de que Gálvez probablemente esperaba sacar recursos para financiar sus ulteriores empresas en la frontera continental, comienza en los desiertos californianos una lucha titánica entre una áspera realidad desoladora y la ardiente y vigorosa ambición de un hombre que no se resigna al fracaso, que se niega a considerarse vencido.

Lo que en verdad se podía esperar de las Californias era bien visible. Ninguno de los acompañantes de Gálvez lo dudó nunca. Sólo Gálvez empieza a falsear el panorama, y por no variar el tono de sus anteriores escritos remite al virrey plata y perlas; aquéllas, procedentes de las cantidades encontrandas en las misiones al ser expusados los jesuitas; las perlas, com-

9 I Viniegra, "Apunte instructivo", fol. $29 \mathrm{v}$. 
pradas a algunos particulares o bien obtenidas del despojo de las que adornaban a la imagen de Nuestra Señora de Loreto. Pero el visitador quería seguir demostrando que California era lo que él había hecho creer antes de su partida de México.

Gálvez sin embargo no era un vulgar impostor o embaucador. Por el contrario, él mismo empieza a creer sus propias mentiras. Cuando llena de palabras grandilocuentes sus informes es así mismo a quien pretende persuadir de que realmente obtendrá lo que en aquellas frases promete. El busca la riqueza. Necesita que la península sea efectivamente rica, y desde el Cabo de San Lucas hasta la misión de Loreto buscará o inventará todo aquello que pudiera ser una fuerte de ingreso para el erario, un origen de prosperidad para la provincia. Si primero son las minas, luego creerá en la agricultura y más tarde en la pesca, para acabar pensando haber encontrado una nueva clase de brea para los barcos, un nuevo lugar de explotación de la grana y el depósito de los mejores pedernales de Nueva España.

Sin otra cosa útil en que invertir su tiempo y su celo, Gálvez amontona decretos y reglamentos sobre navegación del Golfo de Californias, urbanismo de las nuevas poblaciones, milicias provinciales y todo asunto que acudía a su mente.

Cuando sale de la península ha dejado fundado un colegio de Marina en Loreto, al cuidado del padre presidente y del que era maestro un viejo mulato que había navegado en canoas por el Golfo. Pero los veintiocho muchachos que se habían reunido alli, donde deberían educarse todos los huérfanos de las misiones, surtirían de marinos, según Gálvez, las tripulaciones de los barcos del rey y esta empresa, además devolvería a los californianos el amor a los viajes por mar que antiguamente tenían.

Puesto que las Californias eran ya un gobierno, y Portolá debía permanecer en Monterrey, Gálvez pidió a Croix desde el Cabo San Lucas expidiera título de gobernador-intendente a otro oficial; el virrey, designa a Don Matías de Armona, que se hallaba en México; hasta su llegada quedó encargada la provincia al ayudante mayor Don Juan Gutiérrez, dejando el visitador a aquél dos pliegos de instrucciones, indicándole además pasara a Sonora para recibir otras verbalmente. Esta fue la causa de que Armona interviniese en varios acontecimientos importantes en Sonora durante la estancia en ella del visitador.

$\mathrm{La}$ actividad de Gálvez había sido mucho más eficaz en lo tocante a la ocupación del puerto de Monterrey, pues en enero y febrero de 1769 zarparon rumbo al norte el "San Carlos" y el "San Antonio" y en marzo y mayo partirían las expediciones por tierra mandadas por Rivera y Portolá. Estas cuatro fuerzas convergían a principios de julio en el puerto de San 
Diego, y en octubre tenía lugar la ocupación de Monterrey. Señoreados estos dos puertos con otros tantos presidios y fundadas las primeras misiones, daba de esta manera principio la historia de la alta California española. 92 Mientras que Gálvez, habiendo embarcado en Loreto el I. ${ }^{\circ}$ de mayo, llegaba siete días después a las costas de Sonora para poner remedio a los males que aquejaban a esta provincia.

Campaña intCTat, y PRIMER Y SEgundo

ataques al Cerro Prieto

En Sonora, seris y sibubapas constituian el principal enemigo. Rodeando la zona ocupada por los rebeldes, las fuerzas de caballería se distribuían así el I 5 de septiembre de ił68.

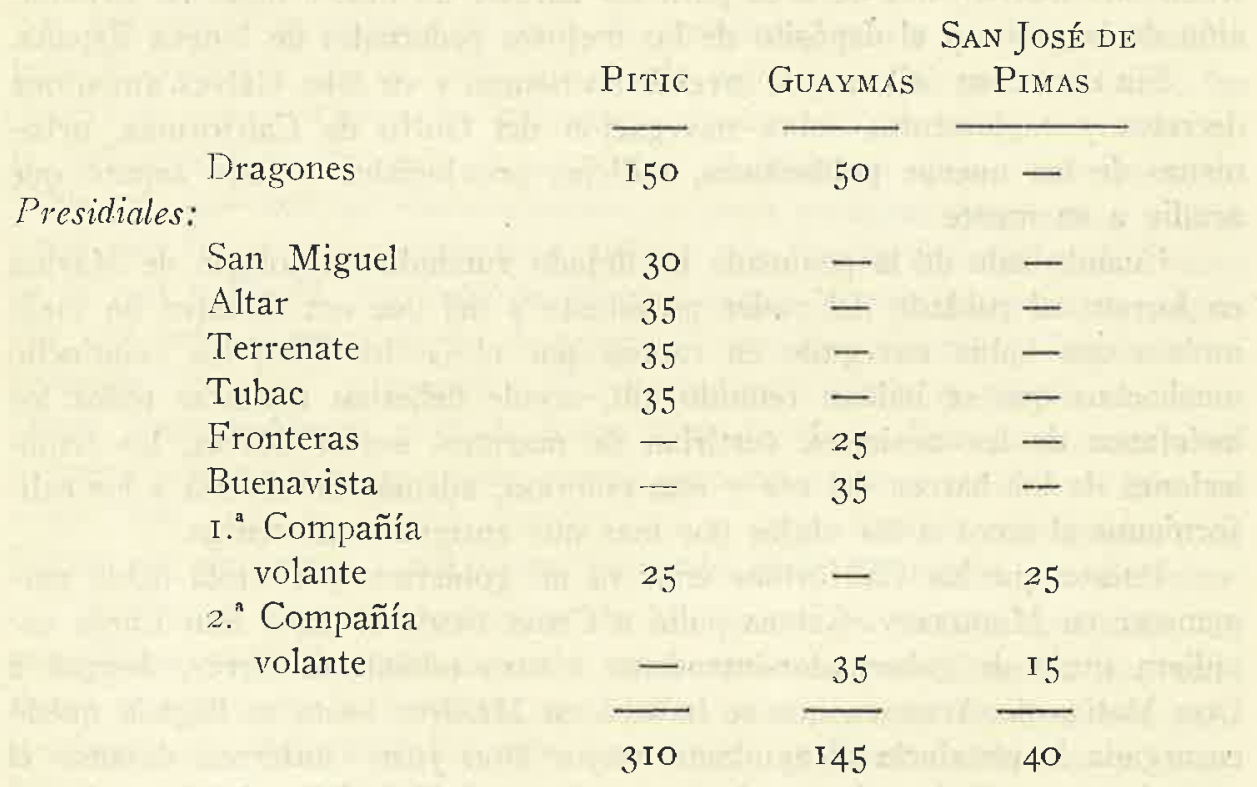

Hallábase además en Pitic la compañía de fusileros de montaña, y en Guaymas el piquete del regimiento de América y la Compañía de voluntarios de Cataluña, siendo estas las tropas de infantería. Se contaba, además en Pitic, con setenta y cinco auxiliares pimas altos, y había otros tantos yaquis en Guaymas. 93

92 Toda la correspondencia amplísima de la estancia de Gálvez en la península en A. G. I., Guadalajara, 4r6. Cartas de Cancio y Beleña en R. A. H., Boturini, is.

93 Estado firmado por Pineda en Pitic, I5 de septiembre de r 768 . Ibid. 
La extracción de ciento treinta soldados de los cuatro presidios exteriores explica la libertad de acción que en esta época van a mostrar los apaches en toda la zona setentrional de Sonora. Después del escaso éxito obtenido por las tres partidas enviadas en junio contra los rebeldes, estos y los apaches continuaron hostigando los pueblos y misiones y las caballadas de los presidios; las tropas se dedicaban a operaciones de reconocimiento y limpieza de determinados sectores. Es ahora cuando empieza a destacarse la figura del capitán Juan Bautista de Anza, de Tubac, a quien un muchacho español rescatado al enemigo declaró que éste se preparaba a esperar en el famoso cajón de la Nopalera, en el Cerro Prieto, a la tropa de la expedición, a la que no tenía miedo porque la veía sin "cueras". Después de conferenciar Elizondo, Pineda y el ingeniero Don Francisco Fersen en San José de Pimas, se habían formado dos destacamentosfuertes de doscientos diez, y ochenta hombres, respectivamente, que a las órdenes de Elizondo y Urrea, saliendo de Guaymas y Pitic, debían dirigirse hacia la costa obligando al enemigo a concentrarse en el Cerro. 94 Pero esta incursión al Tenuaje, comenzada el $\mathrm{I}^{\circ}$ de septiembre, fracasó y continuaron las partidas.

La expedición al denso bosque del Tenuaje había sido sin duda bien concebida y estudiada. En el bosque, pie a tierra la caballería, en un ataque frontal que duró tres cuartos de hora, el 9 de septiembre fue asaltada y tomada una ranchería de más de doscientos jacales, por lo que se calculó que sus defensores deberían haber sido unos doscientos cincuenta indios, que se dieron a la fuga hacia el Sur. Los cien infantes que habían marchado con Elizondo se fatigaron y hubieron de regresar a Guaymas antes de este encuentro. Al regreso de los dos destacamentos se iniciaron los preparativos para nuevas salidas y se dispusieron las tropas según el estado que insertamos poco atrás. Durante los dos meses siguientes, gruesas partidas de tropas recorrieron el país en persecución del adversario, procurando siempre empujarlo hacia el Cerro. Habiendo trasladado su cuartel general de Guaymas a Pitic, salió Elizondo de este lugar al frente esta vez de más de trescientos hombres y se mantuvo en el campo del I2 al 28 de octubre recorriendo ciento cinco leguas en óvalo por la laguna del Año Nuevo, Aribaipía o Carrizal de Picú, y el Pozo Cenizo. Ante tales demostraciones de fuerza no es extraño que algunos prisioneros empezasen a dar noticia de que parte de los capitancillos rebeldes se sentían inclinados a pedir la paz. En este ambiente de optimismo se proyectó el ataque general al Cerro. 95

94 Croix a Arriaga. México, 27 de octubre de 1768 , con Extracto de noticias. A. G. I., Guadalajara 4I6. El extracto documenta ya la presencia de los apaches en Caborca y Altar. Otro ejemplar en A. G. I., México I367.

95 Croix a Arriaga. México, 28 de noviembre de I768, 31 de diciembre de 1768 y 25 de enero de i 769 , con Extractos. A. G. I., Guadalajara. 4I6, y México, 2430. 
Después, el asalto al reducto de seris y pimas del 25 de noviembre acabó con el mismo desalentador resultado que coronaba todas las grandes acciones contra los nómadas. Reunida el 22 de noviembre la tropa de Pitic y Guaymas en el aguaje vecino al Cerro, el 23 por la noche se tomaron posiciones a la entrada del Cajón de la Palma donde se hallaba la ranchería enemiga, mientras una parte de la fuerza se dirigió a cortar la posible retirada de los rebeldes. Una falsa alarma obligó a precipitar el ataque antes de que se hubiese llegado al envolvimiento, y permitió la fuga, favorecida por la niebla, de los atacados, que se refugiaron en un peñón casi inacesible, lejando treinta muertos y dieciséis prisioneros y cuarenta y un caballos en manos de las tropas. El 27 se hizo una batida infructuosa del Cajón, y el 2 de diciembre se hallaba la tropa de Pitic de regreso en sus acuartelamientos. La de Guaymas batió primero los cajones o cañones de la Cara Pintada y Avispa y los pozos de Fastiota, donde se capturaron otros veinte caballos y se rescató un niño yaquí. Mil setenta hombres habían tomado parte en esta entrada al cerro, mandados por Pineda y Elizondo, Armona, Peyran y Vildósola. ${ }^{6}$ Después de este primer ataque general al Cerro Prieto, el enemigo se dispersó. Pequeñas partidas enviadas en su busca para restablecer el contacto hallaron desalojados el cajón de la Palma y el de la Cara Pintada o de los Otates. Las huellas conducían al Cajón de las Avispas, a partir del cual se diseminaban hacia las Marismas, Bacuachi. Aguas Frías y la sierra de las Espuelas. Los comandantes de la expedición proyectaron de nuevo una doble salida, desde Pitic y Guaymas para encerrar otra vez a los rebeldes, operación que no se pudo emprender hasta el 2 I de enero. Este día, trescientos hombres marcharon al Agua Escondida y Campo del Curiel, se reconocieron la sierra de Buenavista, el cerro del Tecolote y el mismo Cerro Prieto, y no se pudo entablar combate. Los rebeldes se daban precipitadamente a la fuga y, según algunos prisioneros, esperaban sólo la venida a Sonora de Don José de Gálvez para solicitar el perdón; un indio del presidio de Buenavista les había hecho saber la próxima llegada del visitador.

Con todo, Elizondo y Pineda planearon un segundo ataque general al Cerro. E1 24 de marzo, unidas las tropas de Guaymas con las del Pitic, se formaron tres divisiones. Cancio, con la primera, tomó las alturas del sur,

96 Cartas de Pineda y Elizondo a Croix. Pitic, 20 y 21 de diciembre de I 768 . Relación de la campaña. Pitic, 20 de diciembre de 1768 . A. G. I., Guadalajara 416. Croix a Arriaga. México, Urrutia, fechado en México, r 6 de febrero de acompaña un plano del Cerro Prieto disefiado por José de 2430 , con duplicados de las cartas fel viero de 1769, y se encuentra original en A. G. I., México, Luis Surville, Madrid, 8 de septiembre virrey y documentos anejos. Copia de este plano, por Don Manuscripts, 17651 , p. 
mientras los dos comandantes, con la segunda, entraban a pie por el Cajón de la Cara Pintada. "Y como la subida al primer puerto era tan áspera y penosa, se fatigó excesivamente el gobernador por estar muy grueso, y aunque se le instó repetidas veces a que se quedara, pudo más su espíritu y honor, ostentando las mayores esfuerzos a superar la fatiga, hasta que faltándole la respiración pudo confusamente pronunciar: No puedo más, y se restituyó al campo con cuatro soldados". Siguió, pues, Elizondo dirigiendo el ataque, resultando vanas todas las penalidades de jefes y tropa para hallar al adversario. De regreso, Cancio hubo de ser traído en hombros por los auxiliares, y casi todos los soldados vinieron descalzos. No parecía ser este el éxito correspondiente a tanta fatiga. Sin embargo, se habían hallados seis cruces como seis significativas propuestas de paz.

A fines de abril, aunque se experimentaban en Ostimuri serios daños, obra de ciertas bandas de forajidos más que de rebeldes, contra las que se movió el comisionado Beleña, seguían apareciendo cruces, y dos cautivas seris se habían ofrecido para ir a buscar a los de su nación para traerlos rendidos; aceptada la idea por los comandantes, partieron las embajadoras el 30 de marzo, con plazo de diez días, para desempenar su misión, y regresaron el to de abril con cuatro personas, entre ellas el famoso capitancillo Crisan' $?$, portador de una gran cruz, y todos, de rodillas, pidieron perdón prometiendo vivir en paz y fidelidad y traer a las demás familias. Efectivamente, el 20 de abril ya había cuatro de ellas asentadas en Pitic y Crisanto salía en busca del jefe principal, Marcos, para moverlo a que se entregara. Tal era la situación al recibirse en Sonora la consigna del rey de buscar la concordia y sometimiento de los indios por vías de amistad, y al llegar a las playas de la provincia Gálvez, que había de ser el llamado a aplicar tal política.

En cambio, aquel invierno los apaches se convertían en durísima amenaza para las poblaciones más avanzadas. La Pimería alta sufre continuados embates. Por Nacosari, Terrenate, Santa María Suamca y San Javier del Bac los robos y muertes son constantes. Por dos veces la tropa de Ti1bac encontró a los apaches a orillas del Gila, teniendo que retirarse en vista de su crecido número. Esta frontera no tendría adecuada defensa mientras durase la campaña del Cerro Prieto: por eso era tan importante concluir con el enemigo interior. 97 Sin embargo, la presión de los apaches en la frontera de Sonora decrece seguidamente, al tiempo que se llevan a cabo, desde Nueva Vizcaya, las campañas de Cuéllar y de Bernardo de Gálvez.

97 Croix a Arriaga, México, 25 de marzo, 26 de abril, 25 de mayo, 26 de junio y 27 de julio de I 769 , con Extractos. A. G. I., Guadalajara 4I6 y M'éxico, 2429. Cartas de Beleĩa en R. A. H., Boturini 18 . 
(jálVEZ, INN SONORA

El visitador general estuvo en Sonora poco más de cinco meses sano, y en este tiempo poco se pudo hacer por mejorar la situación de la provincia, por más que Gálvez intentó lograr la paz de los rebeldes; pero lejos de conseguirlo, su presencia allí coincidió con un extraño levantamiento en el río Fuerte.

A la llegada de Gálvez a las playas de Santa Bárbara, los seris y pimas empezaban a presentarse de paz en los presidios, se rumoreaba que los más se entregarian cuando apareciese el visitador y los indios de los cuatro ríos se mostraban gozosísimos con su venida, de la que esperaban su alivio y fomento. Desde la misma playa de Santa Bárbara dio Gálvez, el 8 de mayo de 1769 , el famoso bando de indilto general a todos los rebeldes que se presentasen en plazo de cuarenta días, y que debería traer como consecuencia la paz inmediata. De no ser así, prometía Gálvez a Dios, al Rey y a Croix que haría todo lo posible por acabar con los rebeldes en poco tiempo, confiando para ello en que "serán muy pocos los moradores de estas provincias, españoles, indios o de otras castas que no salgan a campaña si yo me pongo en ella". No parece fundado este atrevido aserto del visitador, que había naturalmente de sonar mal en los oídos de cualquier persona discreta; por eso Gálvez escribe al secretario de la Guerra, Muniain, cuatro días después, aludiendo al bando: "Si allá pareciere arrogante la intimación que hago a estos enemibos de Dios y del Rey por ser a un mismo tiempo apóstatas y rebeldes, se digne V. E. disculpar por mi lenguaje consideradas las circunstancias de que hablo en la América, y que a la sombra de la toga conservo algunos fuegos del clima de Andalucía, cuyos naturales no es nuevo que pasen por baladrones". La disculpa era tanto más necesaria cuanto que en la misma carta insiste el visitador en los términos del bando, diciendo al ministro: "confío que me continuará el Cielo sus favores para acabar con ellos (los rebeldes) en tres o cuatro meses, pues no tiene el Rey vasallo en estas provincias que no salga a campaña a mi primer aviso, y acaso será forzoso contener otros muchos que vendrían entonces de las más distantes". Sin duda el malagueño se pernitía esta jactancia, demasiado tocada de autosuficiencia y megalomanía, en la seguridad de que no sería preciso volver a sacar las tropas a campaña. En cambio, probablemente Gálvez confiaba en la eficacia del edicto debido a que más de dos meses atrás, estando en Californias, ya había despachado sujetos bien caracterizados y seguros que produjesen la separación de los seris del campo enemigo, y en efecto los seris umpezaban a presentarse en el Pitic - había allí treinta y dos familias a su 
arribo a Sonora- deseando combatir como aliados de los españoles contra los pimas rebeldes. 98

Tres meses y medio - del i I de mayo al 4 de septiembre- estuvo Gálvez en Alamos, y no cabe duda que sus providencias fueron activas en este liempo; apenas llegado, dispuso la formación de estados de las temporalidades de las antiguas misiones jesuíticas, y de padrones de la población de la provincia con separación de castas; lo que quedaba del mes de mayo se le fue en juntas con los comerciantes y mineros, estudiando la manera de promover la prosperidad de la provincia. Sus decretos empezaron a versar sobre los jornales de los operarios de las minas y sobre el envío de azogues desde Guadalajara, rebaja de precios de azogue y pólvora y supresión de los rescatadores que compraban a los obreros el metal robado. $99 \mathrm{El}$ período culmina con la erección el $1 .{ }^{0}$ de junio de la Caja Real de Alamos, vistos los autos que sobre su conveniencia formó Don Eusebio Ventura Beleña, comisionado para ello por Croix y el visitador. En esta Caja Real se administralían todos los ramos de la real hacienda y los estancos de tabacos, pólvora, naipes y salinas, y se manifestarían en ella todos los quintos de oro y plata de las minas y placeres de las jurisdicciones de Culiacán, Sinaloa, Fuerte, Alamos y Ostimuri, excluyendo los partidos de Copala, Maloya y Rosario por más próximos a Guadalajara, pero incluyendo Montserrat, Urique, Puluachi, Uruache, Topago, Santa Ana y Real de Loreto y las jurisdicciones de Cusihuiriáchic y Batopilas, que, aunque pertenecientes a Nueva Vizcaya, quedaban más próximas a la Caja de Alamos, donde, por otra parte, les resultaría más barato el azogue, que llegaría a Sonora fletado por mar. ${ }^{100}$

Al mismo tiempo organizaba Gálvez un cuerpo de milicias provinciales españolas en Alamos, según acuerdo de la junta de i 8 de mayo, y disponía que los cuatro generales de las naciones indias de los cuatro ríos alistasen seis u ocho compañías de indios, a los que concedería exención de tributos, privilegios de llevar armas, doble dotación de tierras y el distintivo de formar las compañías de indios nobles. ${ }^{\text {ror }}$ Para entonces ya los manejos de sus

98 Gálvez a Croix. Santa Cruz de Mayo, i4 de mayo de I769. Guadalajara 4I6. Ya en febrero parece sabían los rebeldes la venida de Gálvez a Sonora y esperaban ese momento para solicitar el perdón, según Extracto de Noticias del 20 de febrero en carta de Croix a Arriaga. México, 25 de abril de 1769. Ibid. Gálvez a Muniain, Playa de Santa Cruz de Mayo, 12 de mayn de I769. A. G. I., México 2429.

99 Gálvez a Croix. Alamos, to de junio de I769. A. G. I., Guadalajara 4r6. Tuvo al visitador dos juntas con los comerciantes y mineros, el 18 y el 30 de mayo. En la segunda solicitaron estos el nombramiento de un intendente o juez conservador. Vid. Navarro García, Intendencias en Indias, 26.

Ioo A. G. I., Guadalajara 4 I 6.

I0I Gálvez a Arriaga. Alamos, i 2 de junio de 1769 . Ibid. Decreto de Gálvez, Alamos, i7 de mayo y 6 de junio de 1769 . R. A. H., Boturini, i 8. 
dependientes habían dado como fruto el que estas cuatro naciones les pidiesen la erección de sus misiones en curatos, el repartimiento de tierras a sus pueblos en común, y la admisión del tributo que deseaban pagar como vasallos. Fueron, por tanto, consiguientes las instrucciones del visitador a sus comisionados para que procediesen a repartir los suelos y a formar matriculas de tributarios, ${ }^{102}$ pues de todas las alcaldes costeras, sólo el distrito de Culiacán pagaba, desde la fecha de su conquista, tributo al rey. Calculaba Gálvez que estos nuevos tributos ascenderían en toda la provincia a cien mil pesos anuales, los que, sumados el ahorro de los sínodos de las misiones secularizadas, suponían un buen ingreso. Tampoco dudaba entonces el visitador de que el éxito de su edicto llevaría a la extinción de varios presidios con la consiguiente economía de situados.

E1 bando de indulto había sido promulgado en tiempo muy oportuno, ya que durante los meses del verano la sequía impedía realizar cualquier campaña, mientras que la que emprendía Cuéllar en Nueva Vizcaya contra los apaches hacía conveniente resguardar la frontera exterior de Sonora, sobre la que la presión de aquél podía lanzarlos. Gálvez proyectaba ya, conseguida la rendición de los rebeldes, la ocupación de la isla del Tiburón, l]evando la tropa en canoas desde Guaymas. Conseguido este pequeño objetivo, sería posible hacer pasar la fuerza de la expedición hasta el Gila sin dejar ningún reducto enemigo a la espalda.

Sin embargo, todos estos planes se demoran al advertirse que los rebeldes no se presentan a solicitar la paz con la rapidez con que se esperaba. El visitador concede una prórroga de diez días al plazo de cuarenta concedido en el primer edicto para que tengan tiempo de presentarse, hasta el 27 de junio, los suaquis y pimas altos. ${ }^{103}$ Los rendidos seris y suaquis en Pitic y Belén eran un centenar al empezar junio, y el 2 I de este mes, a petición del jefe sibubapa Diego y siete capitanes de esta nación que se le presentaron conducidos por el bachiller Valdés, trayendo seis flechas de otros tantos capitanes seris y pimas dispuestos a la paz, Gálvez concedió nueva prórroga de veinticinco días - hasta el 22 de julio- para que tuviesen tiempo de congregarse las familias más alejadas y dispersas. ${ }^{104}$

Pero tiene lugar ahora el primero de los extraños acontecimientos que rodean la presencia de Gálvez en Sonora. Disponíase el visitador a pasar a Pitic, cuando ocurrió un peligroso alzamiento de los seis pueblos indios

I02 Instrucción dada en Alamos, 23 de junio de I769. R. A. H., Boturini, I6.
I03 Gálvez a Croix. Alamos, 14 de junio de I769. Bando de I 3 de junio de I769. A. G. I.,
dalajara 416 . Guadalajara 416 . I04 Gálvez a Croix. Alamors, i 3 de julio de I769. Ibid. Gálvez a Elizondo y Pineda. Ala-
mos, 22 de junio de i769. R. A. H., Boturini, i 8 . 


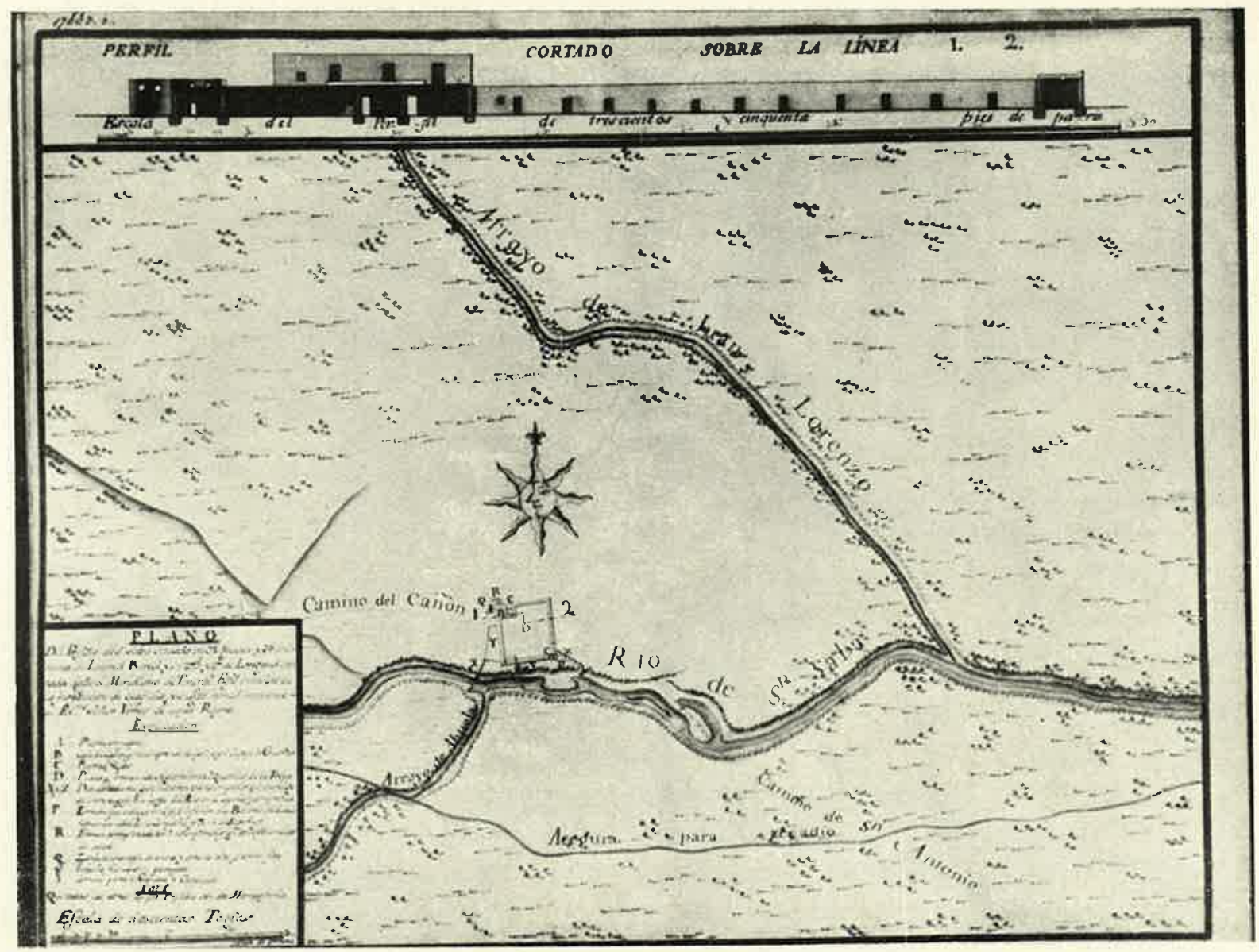

90. El presidio de San Sabá, dependiente directamente del virrey, por Urrutia. 1765. 


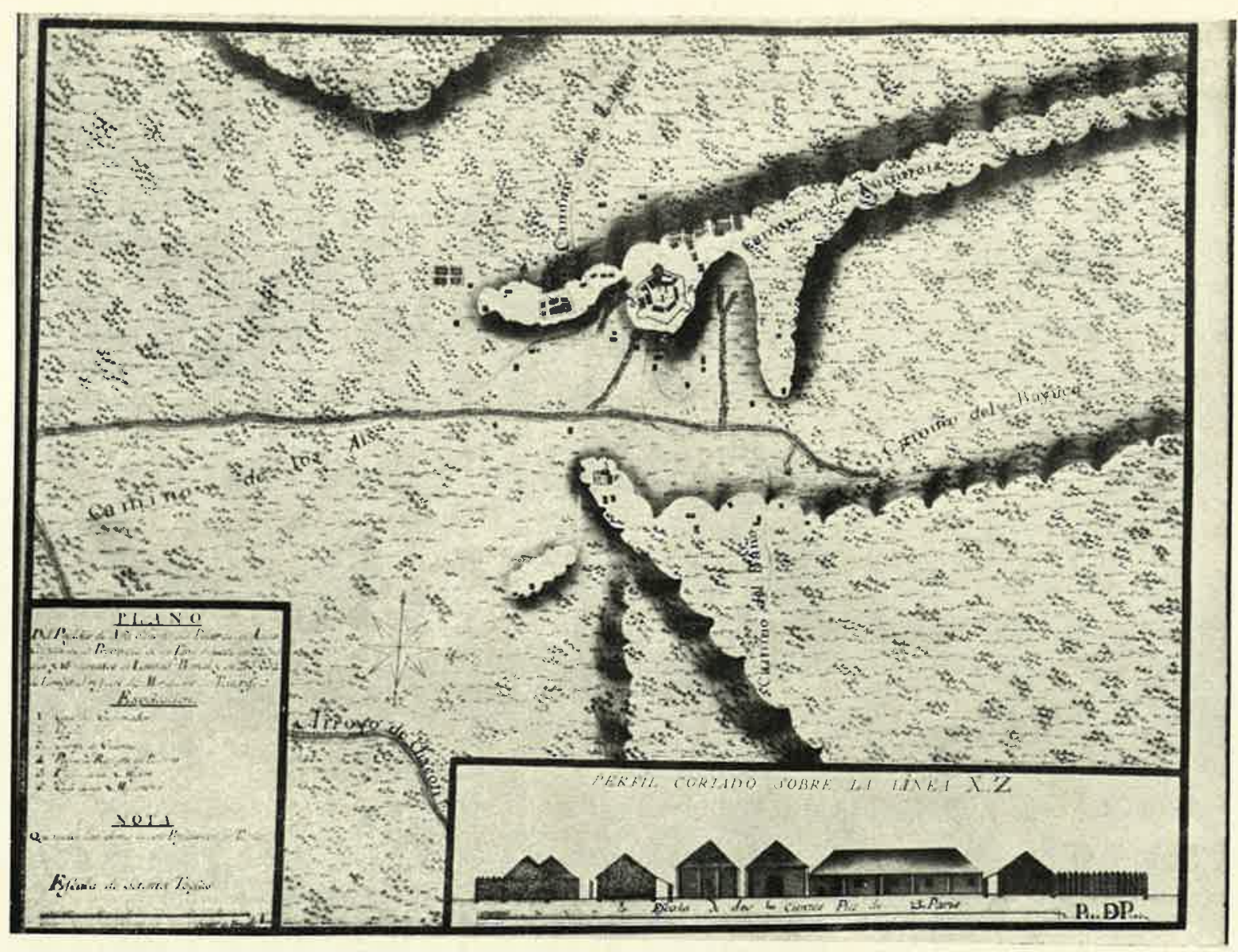

91. El presidio de Adacs, rapital de Texas, por Urrutia. 1765. 


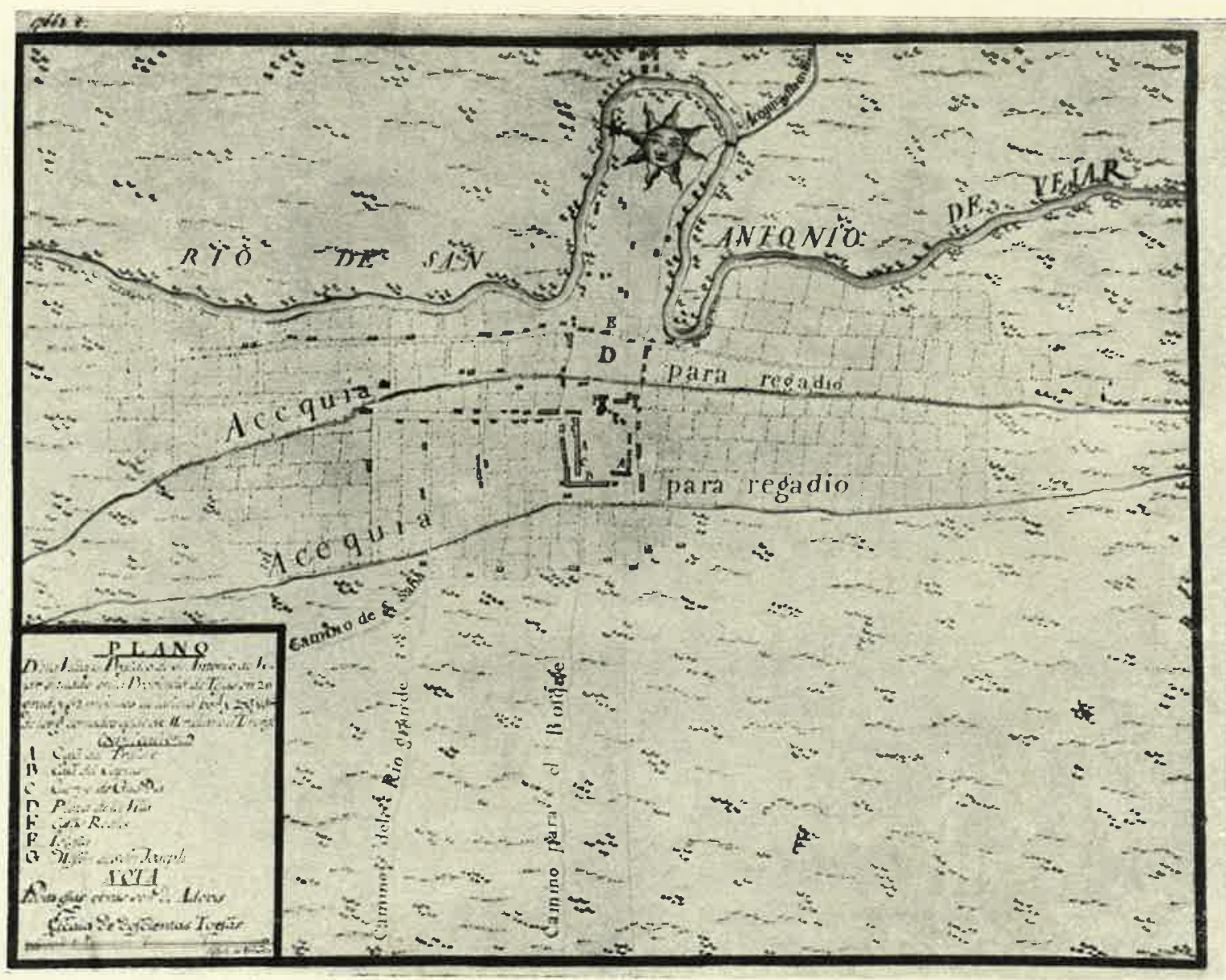

92. El presidio de Béjar, en Texas, por Urrulia. 1765. 


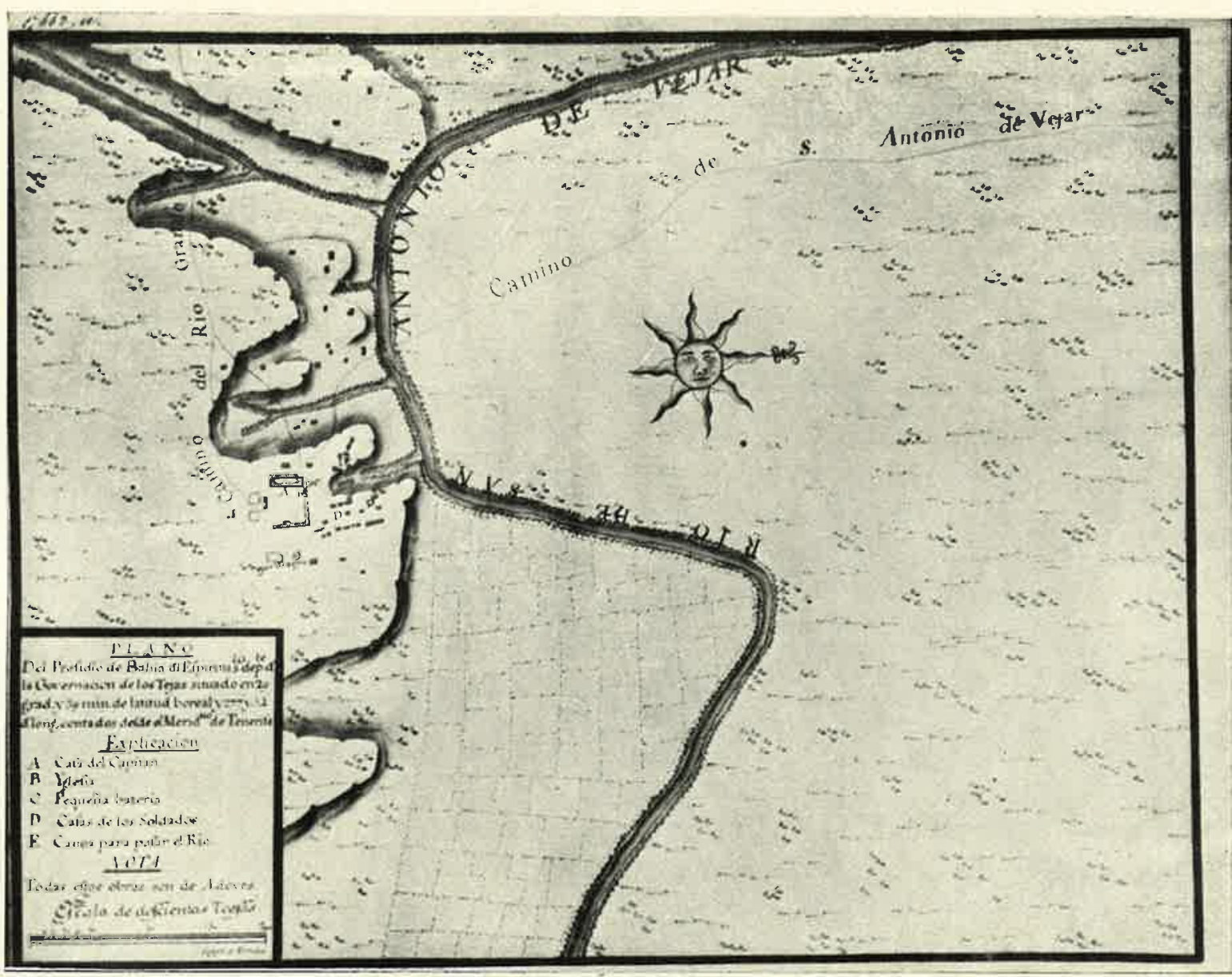

93. El presidio de la Bahíil. en Texas, por Urrulia. 1765. 


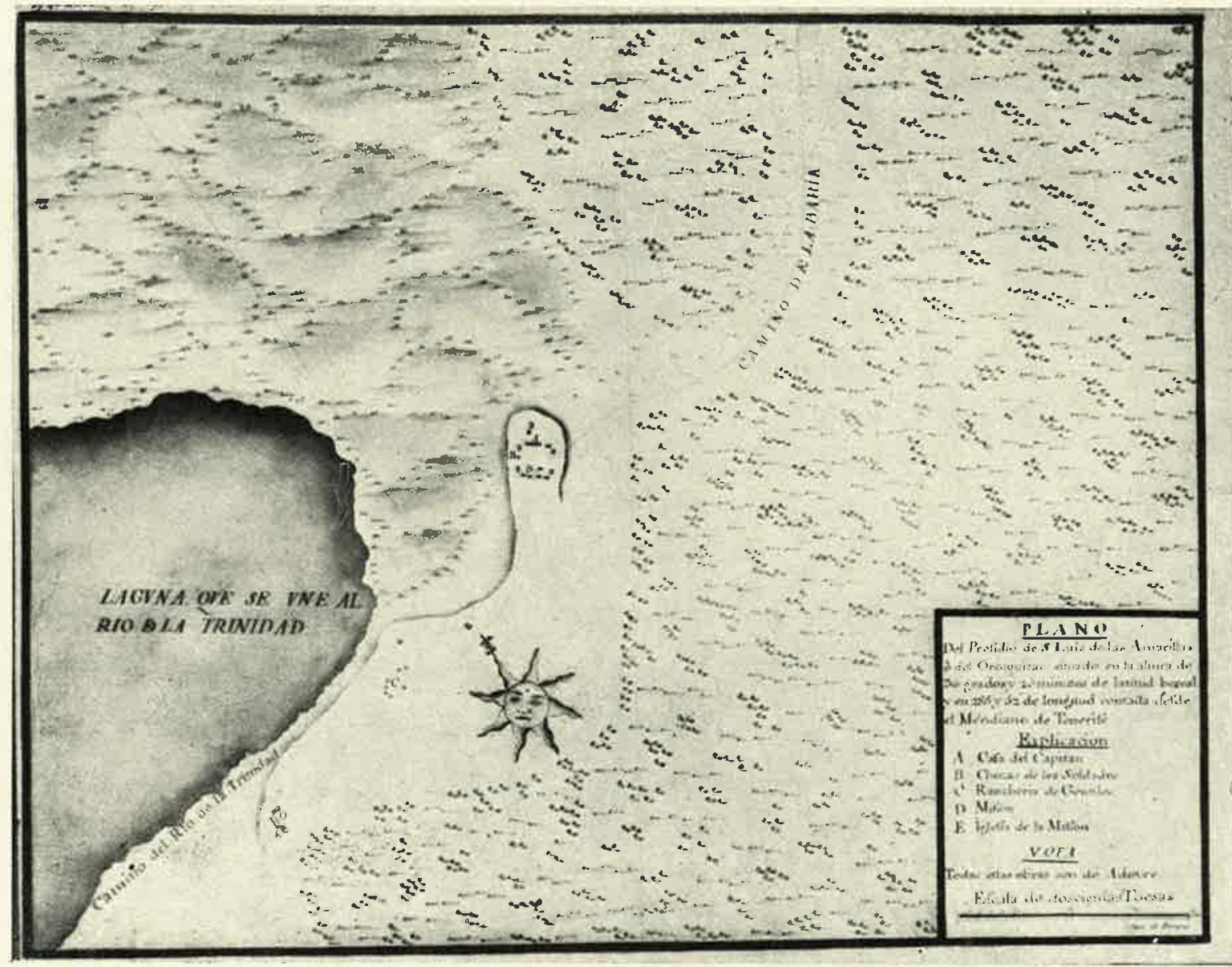

94. El presidio de Orcoquizac, en Texas, por Urrutia. 1765. 


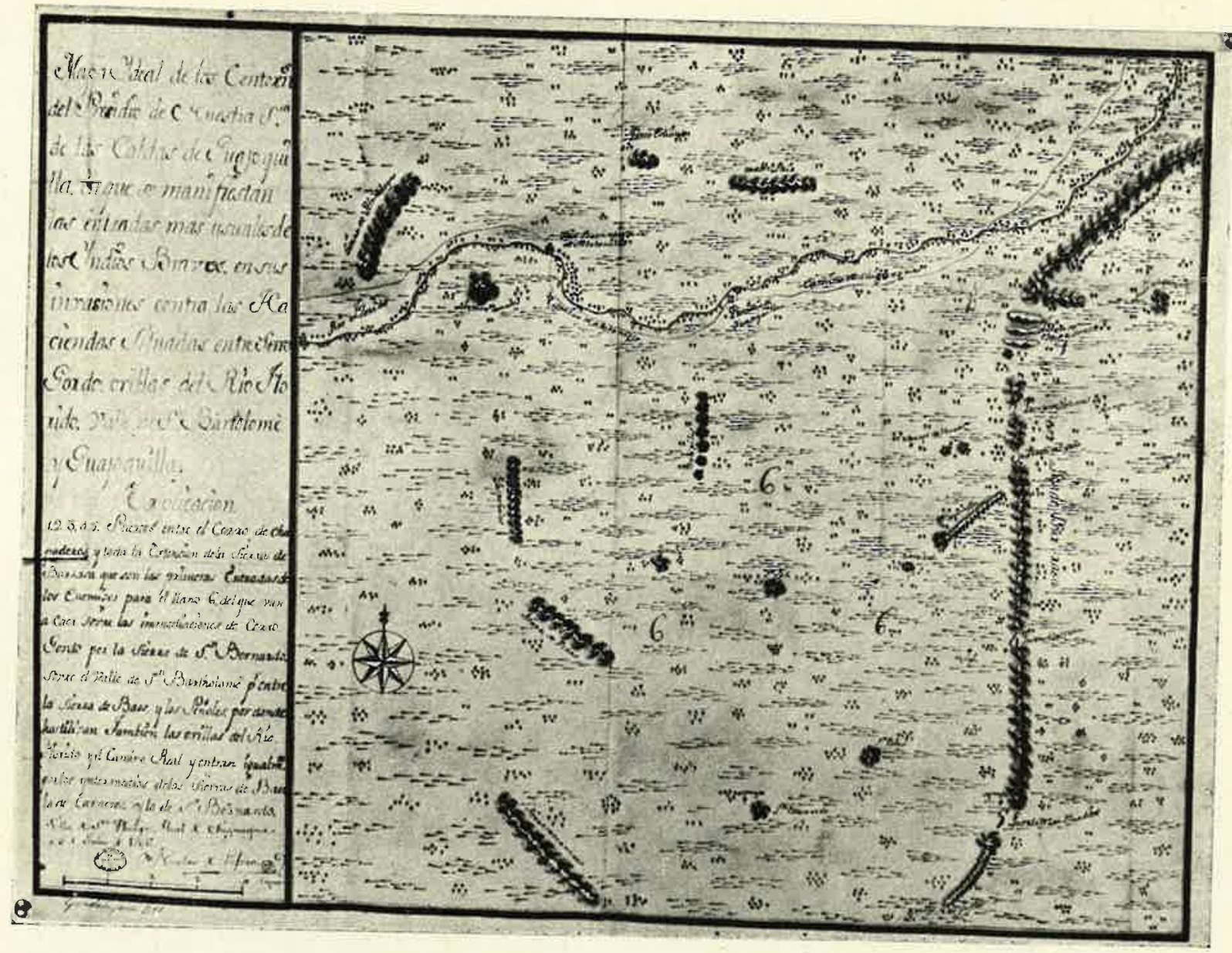

95. Mapa de los contornos del presidio de Guajuguilla, por Lafora. 765. 


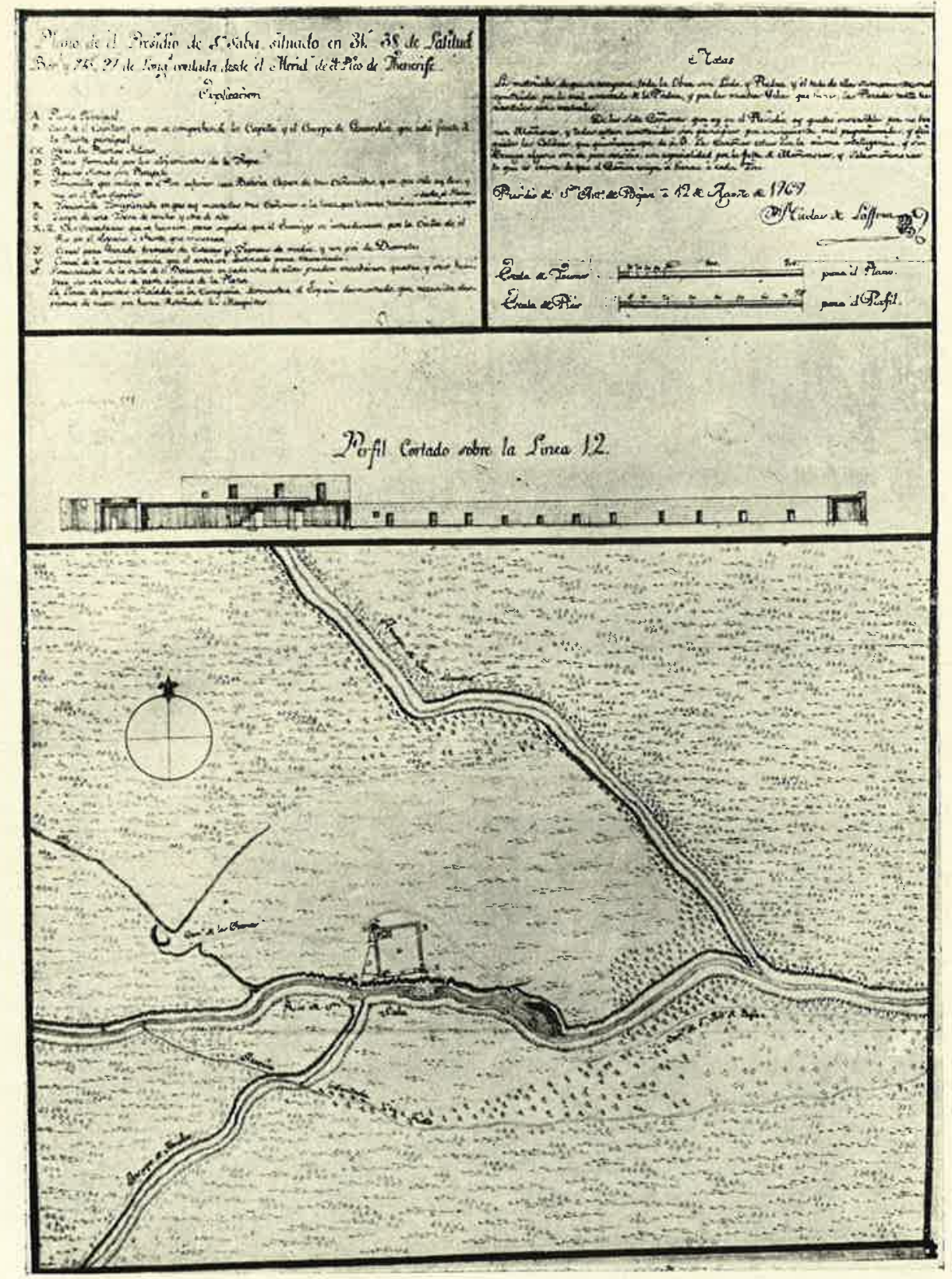

96. El presidio de San Sabá, por Lafora. 176\%. 


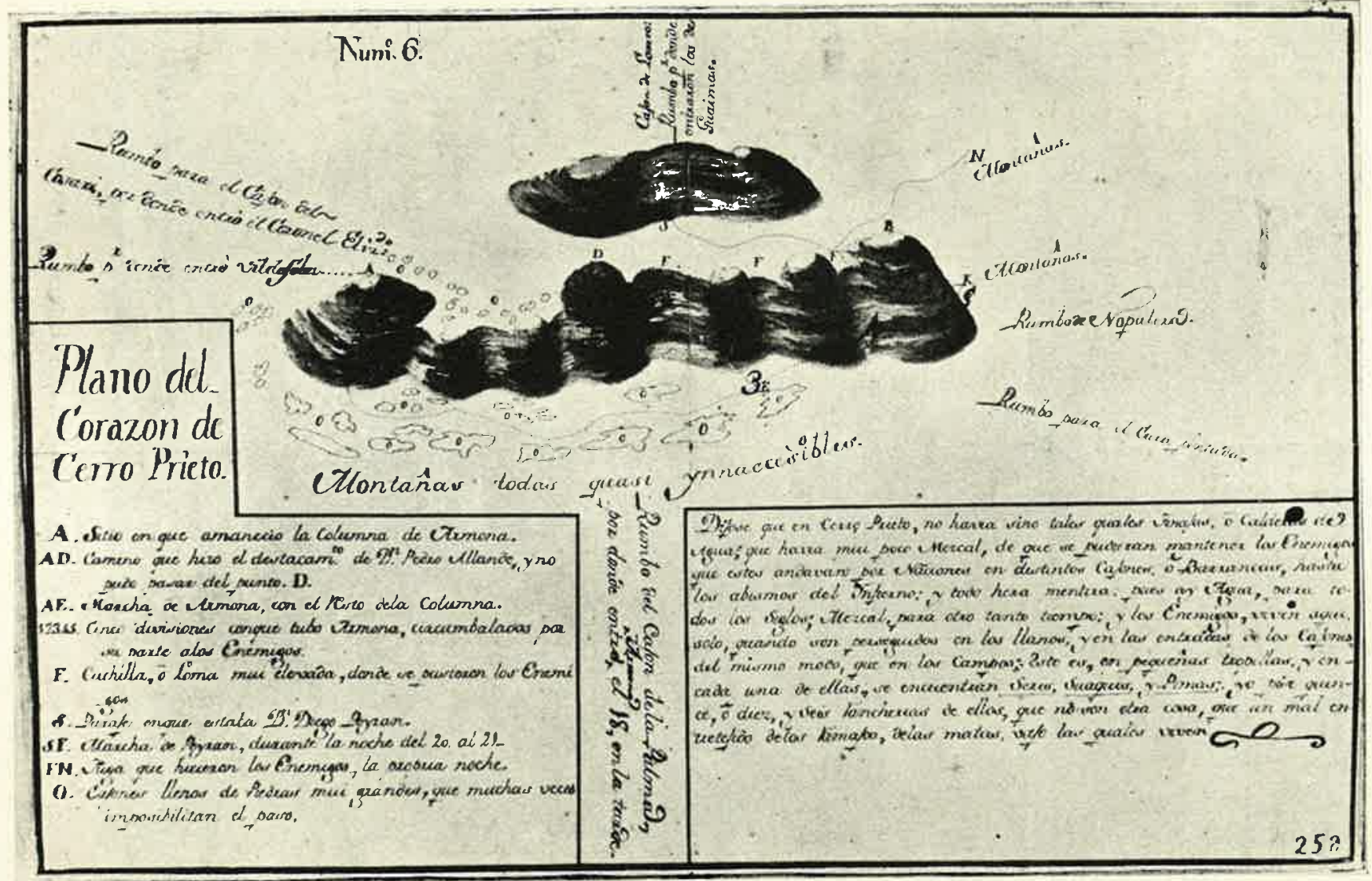

97. Primer ataque al corazón del Cerro Prieto. 


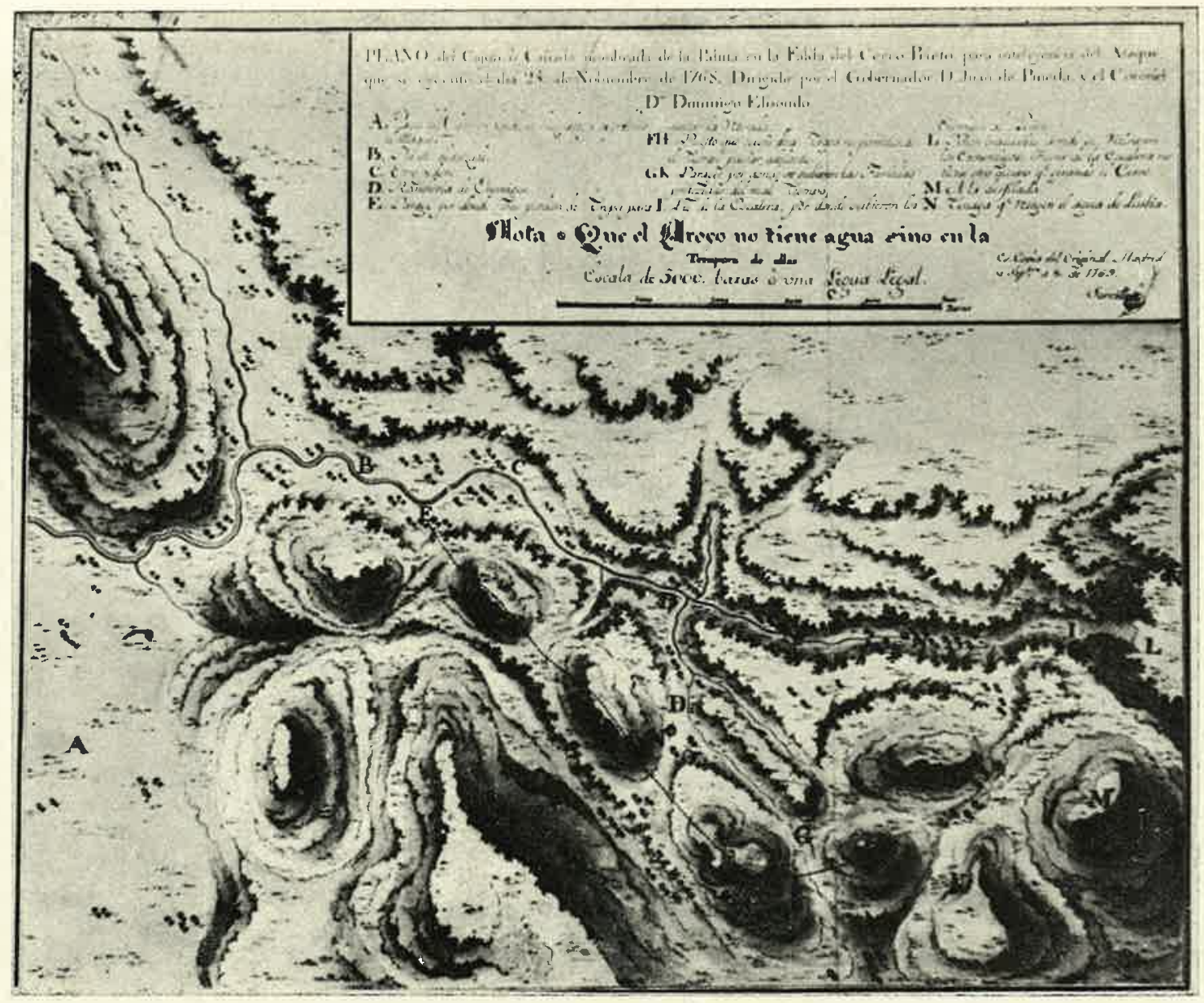

98. Segundo ataque al Cerro Prieto. 


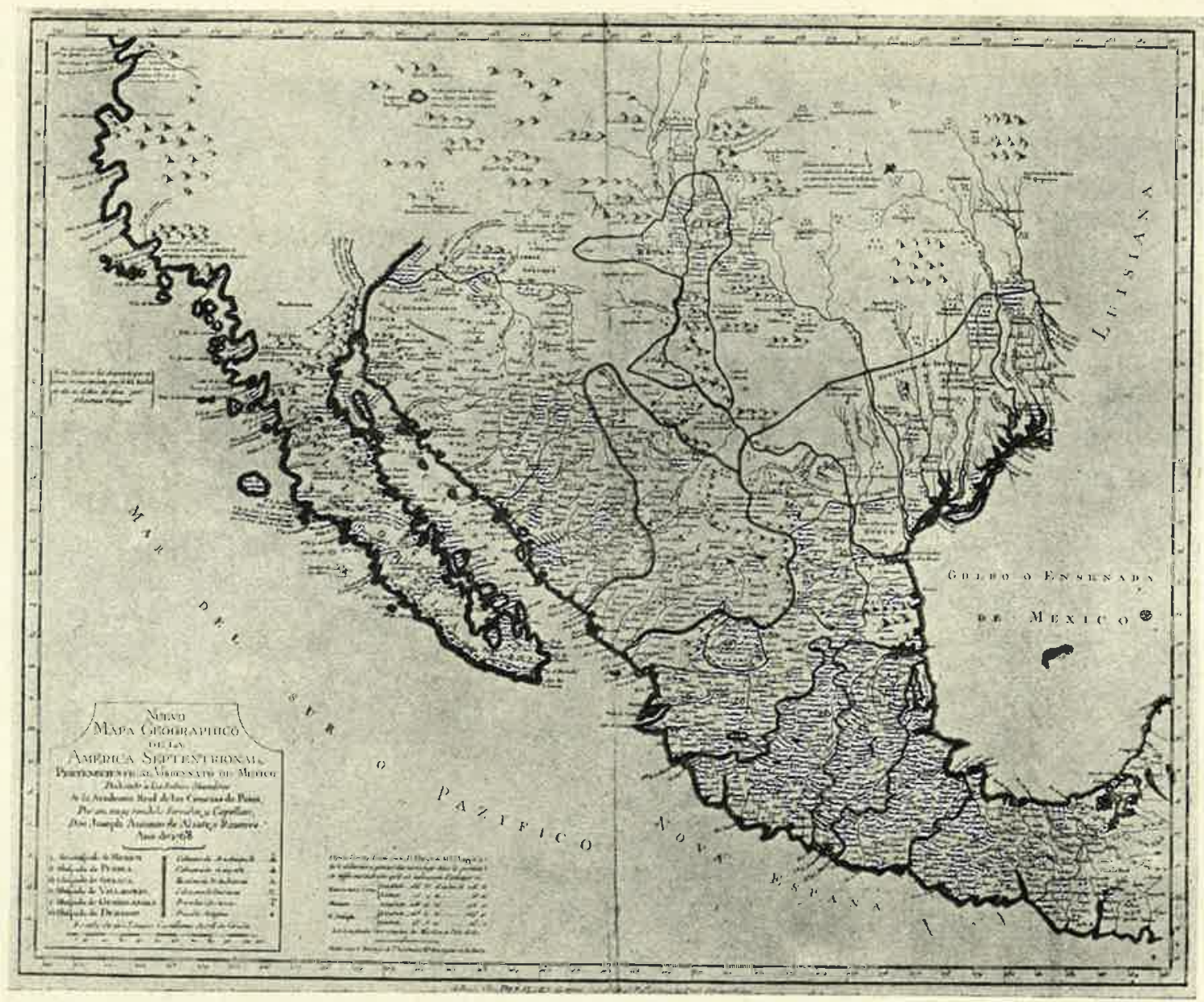

99. Mapa de Nueva España, por Alzale. 1768. 


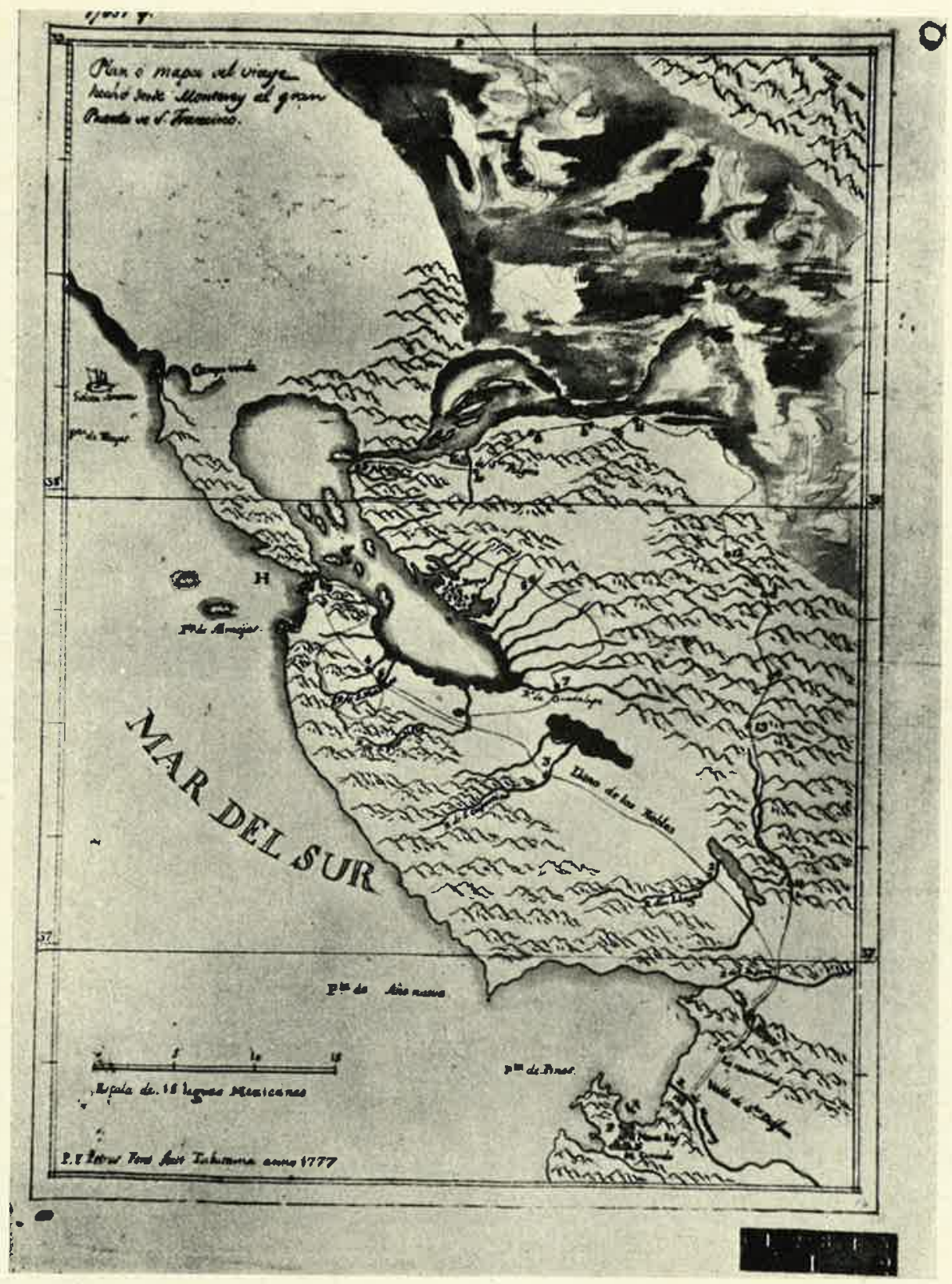

100. Viaje del P. Font de Monterrey al puerto de San Francisco. 1777. 


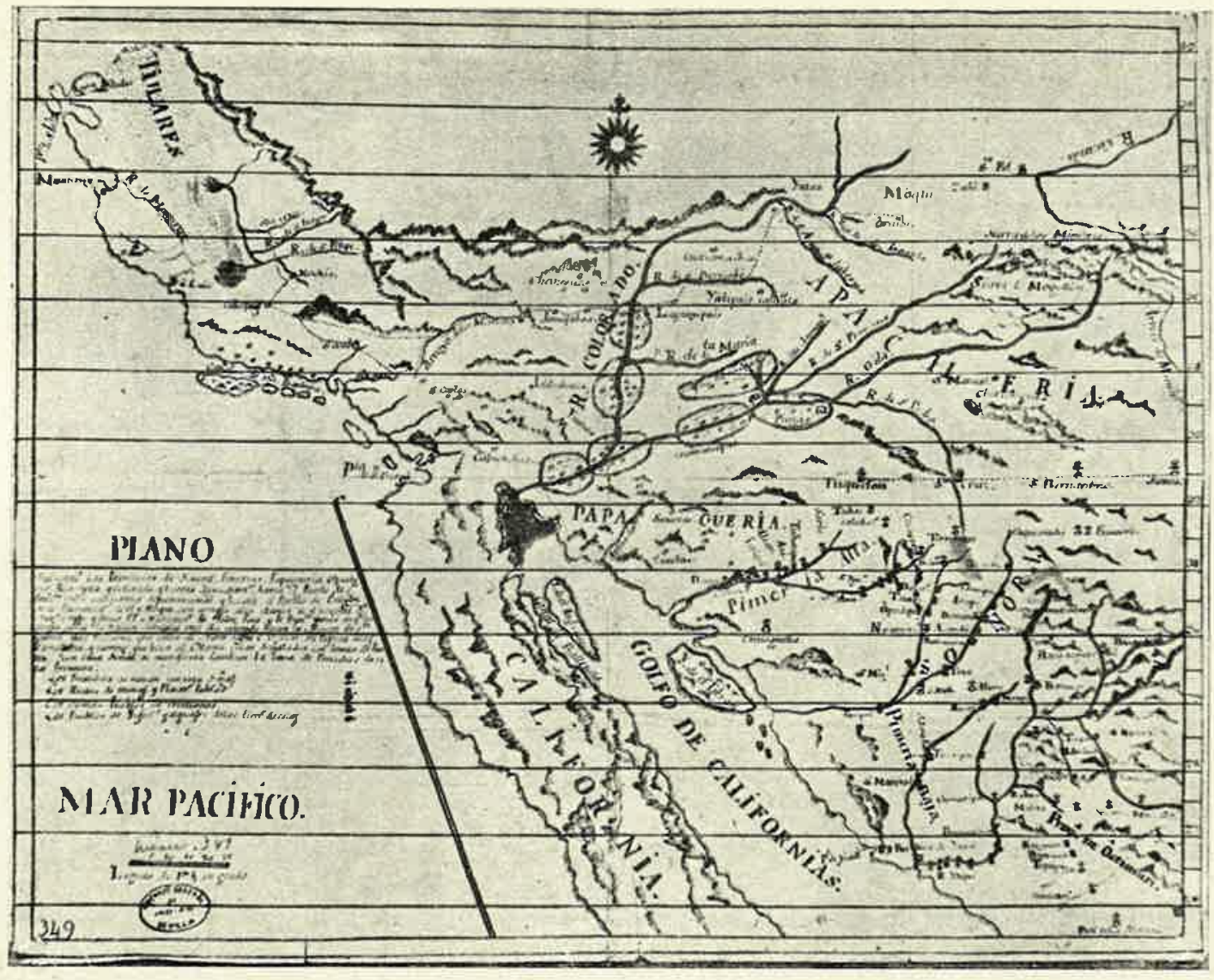

101. El nuroeste y la nueva líneal de presidios. 1777. 


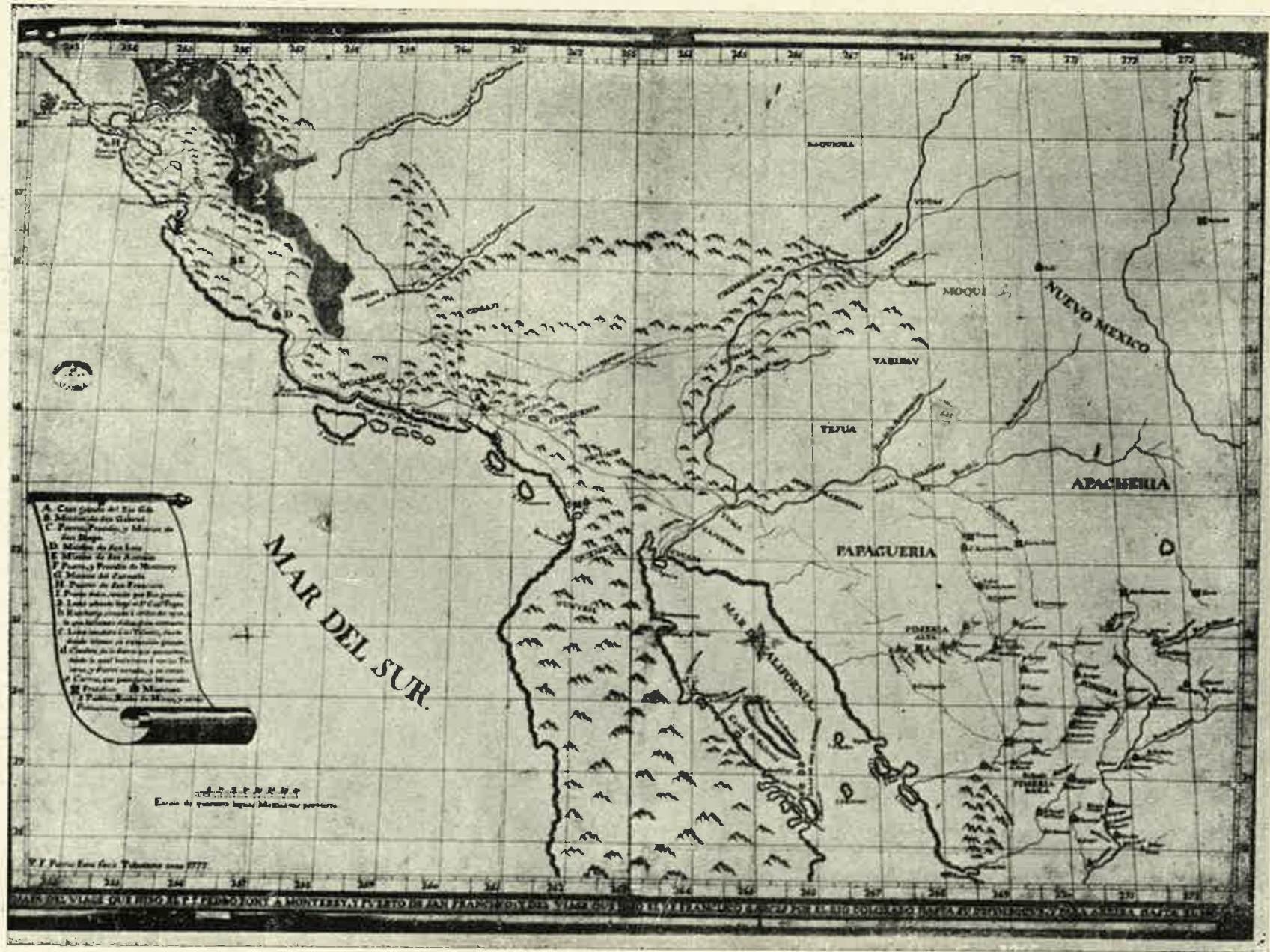

J02. Itinerarios a San Francisco y al Moqui, por Font. 1777. 


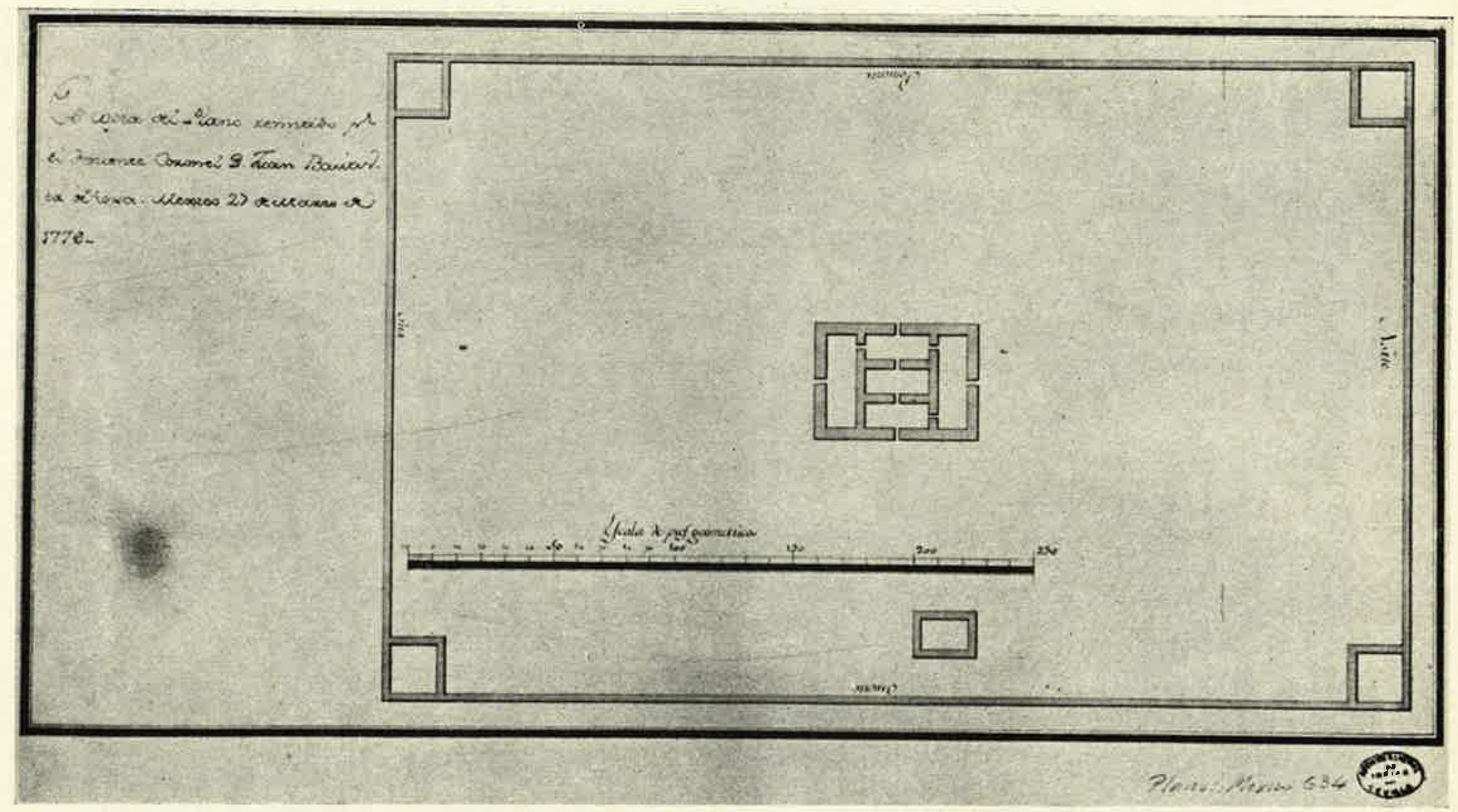

103. Planú de una (ceasal grande» a orillas del Gila, por Anza. 1776. 


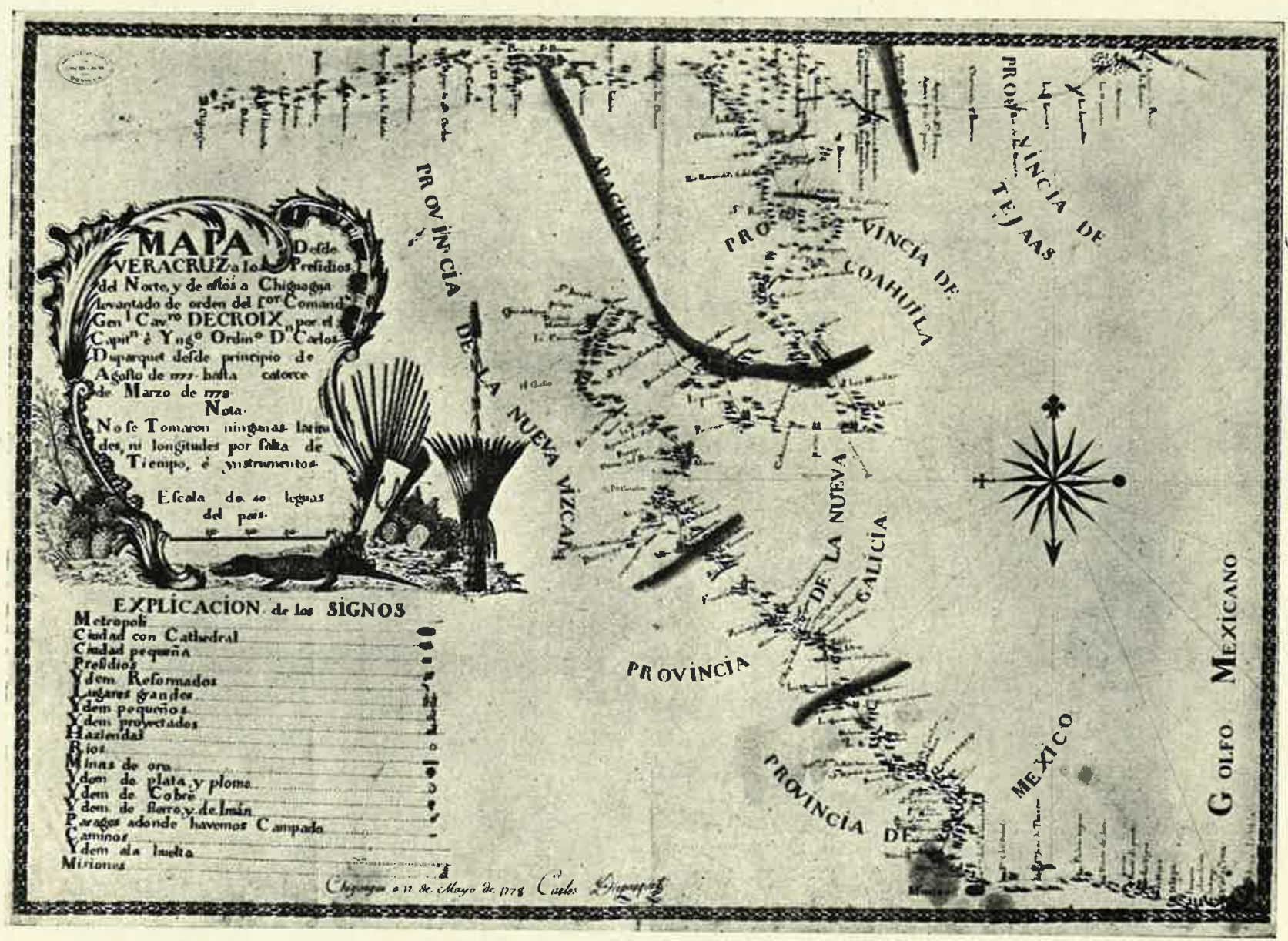

104. Itinerario del Cahallero de Croix, de Veracruz a Chihuahua, por Duparquet. 1778. 


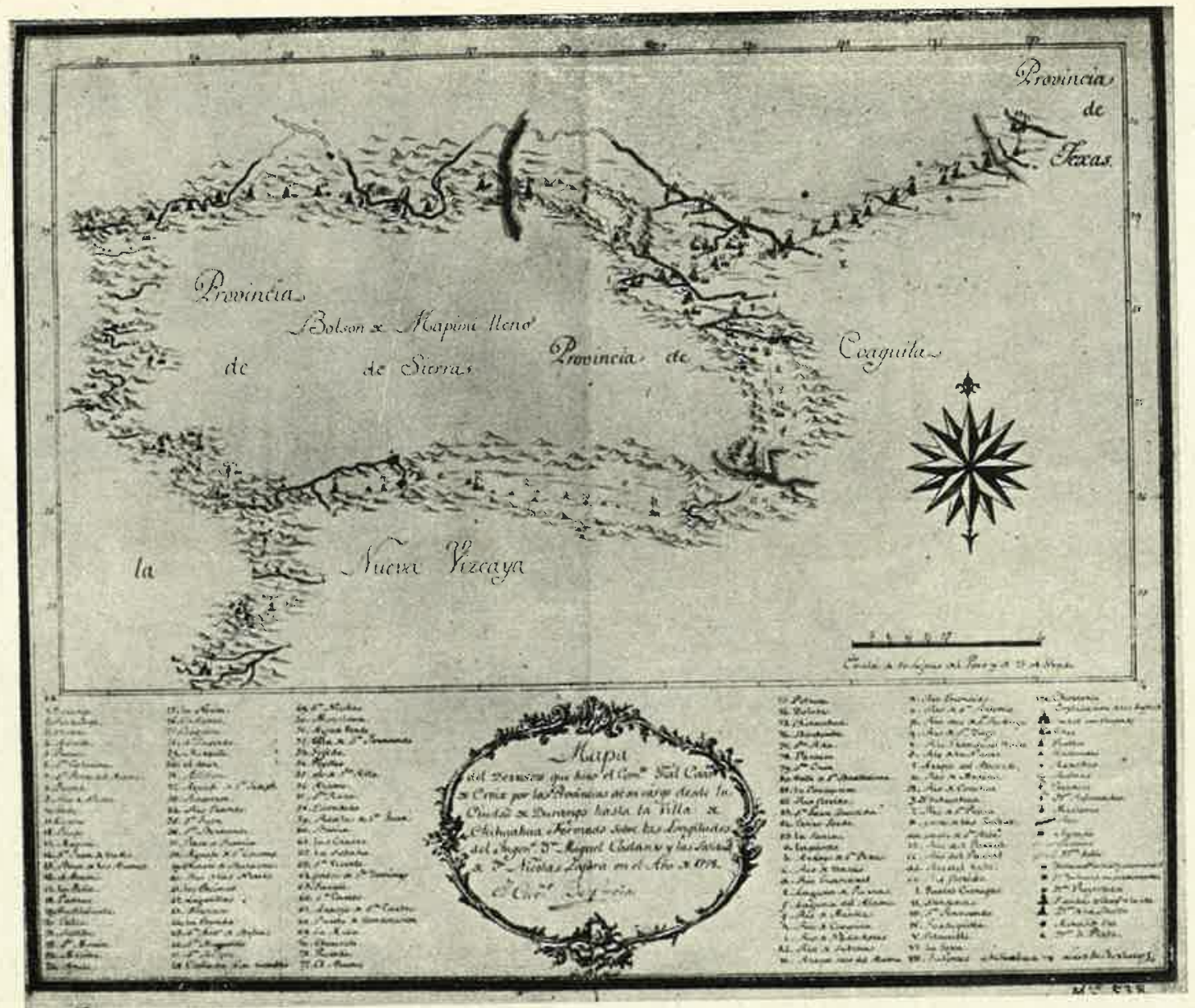

205. Linerario del Cabillero de Croix, de Duranen a Chihnalua, por Bertucat. 1778. 
del río Fuerte, con centro en Charay y Mochicaguy, promovido por un pima bajo de los antiguos sublevados, que extendió la voz de que los cuatro ríos se iban a amotinar simultáneamente para restablecer su independencia.

La elección tumultuaria de otros gobernadores que el que tenían fue el chispazo de la insurgencia. Parece que se habían congregado allí gran número de vagos $\mathrm{y}$ forajidos - bastantes de ellos de la nación yaqui- de los que ordinariamente pululaban por la provincia y hacían muchos de los estragos que luego se atribuían a los pimas alzados y seris. Por otra parte, se halló un motivo de disgusto en el arribo del paquebot "La Lauretana" a la ensenada de Ahome; temieron los indios que su venida era - como meses atrás lo había hecho por orden de Gálvez- para llevar un contingente de ellos para trabajar las pobres minas de California, y ante esta perspectiva se rebelaron.

Contra los alzados envió Gálvez las milicias de Alamos que se encaminaban a Ostimuri en prevención de un ataque de los clel Cerro Prieto. También las milicias de las villas del Fuerte y de Sinaloa marcharon sobre los pueblos levantiscos, pero éstos habían cerrado los caminos con estacadas y aunque las milicias de la villa del Fuerte lograron romper el cerco, hubieron de emprender luego la fuga a rienda suelta, lo que no evitó la muerte del alférez y dos soldados, quedando otros muchos heridos y perdiéndose casi todas las armas y equipajes.

Sin embargo, las tropas milicianas bloquearon el foco insurgente, Gálvez hizo acudir también la segunda compañía volante de la expedición desde Guaymas y el capitán Cancio se puso en camino con ochocientos guerreros yaquis, que acreditaron entonces fidelidad, así como los mayos, que en el puerto de Santa Cruz detendrian poco después a los rebeldes fugitivos. Al presentarse las milicias de Alamos, su jefe el teniente coronel Don Tadeo Padilla of reció el perdón a los amotinaddos que le presentaban batalla, y éstos se rindieron el 3 de julio. Pero Padilla se apresuró a apresar a los cabecillas del movimiento, a los que se hizo juicio sumario, que estuvo a cargo de Don Matías de Armona, llegado casualmente a Alamos, y a quien Gálvez encomendó esta tarea en sustitución de Beleña, que fue el primer designado para realizarla. Armona, que tenía seiscientos hombres a sus órdenes, hizo cumplir las sentencias firmadas por Grálvez el i 8 de julio contra los tres asesinos del cura de Baroyeca, Don Ildefonso Feliz, hecho que había tenido lugar en marzo anterior y el io de agosto contra los sublevados del Fuerte: veinte ahorcados, trece condenados a doscientos azotes y cuatro años de presidio y corte de cabello y otros cuatro a cien azotes y corte de cabello. Los demás fueron indultados, pero privados de sus armas bajo pena de la vida, salvo la compañía de indios nobles. Se procedió a la 
quema de arcos, flechas y macanas, por más que sus consecuencias pudiesen considerarse muy precarias. ${ }^{105}$

Esta rebelión y el considerar cuán contrarios resultaban los efectos de su plan, pues los rebeldes del Cerro Prieto no se rendian y ya faltaban caudales para continuar la guerra, consternaron el espíritu de Gálvez, que se entregó a una profunda melancolía, a la que se siguió un fuerte ataque de tercianas de que no se vio libre hasta fines de agosto. Para el 22 de este mes, cuando da noticias a Croix del fin de los acontecimientos del río Fuerte, ya expresaba su intención de acabar en una sola campaña con los rebeldes del Cerro Prieto, haciéndose conducir al Pitic en una litera que por milagro se había encontrado. Sin embargo, también le parecía próximo el fin de su vida, para cuyo caso hace al virrey algunas recomendaciones acerca de los asuntos de las provincias y de los dependientes de su visita. ${ }^{106}$ Pero siete días después se había repuesto, no sin temor de más peligrosa recaída, y a poco, en la madrugada del 4 de septiembre, se ponía en camino para el Pitic por el real de la Aduana, el de las Animas, Buenavista, Ures y San José de Gracia. En este trayecto se hizo sensible el principio de su locura que no tardaría en estallar violentamente. Ya en Pitic, del $\mathrm{I}^{\circ}$ al I $_{3}$ de octubre conferenció con los jefes militares de la expedición, pero la noche de este día, no pudiendo su espíritu soportar la idea del fracaso de su grandioso intento, flaqueó definitivamente su razón, dando principio la demencia que lo tuvo sujeto seis meses y que fue causa de su regreso a México.

Con esto se deshicieron en el aire los fabulosos éxitos con que el visitador esperaba coronar sı empresa, y ésta terminó con el muy mediocre resultado de una insegura paz muy poco tiempo mantenida.

\section{Tercer atadue al Cerro Prieto}

$Y$ FIN JOE LA EXPEDICIÓN

Expirando el 22 de julio el plazo fijado para la presentación de los rebeldes que quisieren acogerse al edicto de perdón, el i 5 de este mes ordenaba Gálvez a los jefes de la expedición reanudasen la campaña activamente el 23. No se habían experimentado hostilidades en las últimas semanas, pero el

105 Gálvez a Arriaga. Alamos, i3 de julio de 1769, n. ${ }^{\circ}$ 6o. A.G.I., Guadalajara, 416. Cancio a Croix. Río Yaqui, i6 de julio de 1769. A. G. I., Guadalajara 417. México 1369. Gálvez a Croix. Alamos, 22 de agosto de 1769 , remitiendo copia de las sentencias. Ibid. Viniegra, "Apunte instrustivo", 34 v. 36 . Gálvez a Pineda y Elizondo, Alamos, 26 de junio y 2 y 7 de julio de 1769 . R. A. H., Boturini, i8. Armona a Croix. Alamos, 29 de agosto de I 769 . Ibid. A. G. I., Guadalajara, 417 .

106 Viniegra, "Apunte instructivo", 36 y 37. Gálvez a Croix. Alamos, 22 de agosto de 1769. A. G. I., Guadalajara 4I y México I369. Croix a Arriaga, México, 2 de noviembre de I769. A. G. I., Guadalajara 5 I 2 y México I 368 . 
caudillo Marcos y su gente no se habían rendido, aunque habían dado esperanzas de hacerlo así. El visitador confiaba poner ahora en pie de guerra las compañías milicianas y de auxiliares formadas el mes anterior en Ostimuri y Sinaloa. La reapertura de las campañas corrió a cargo del capitán Anza, que con ochenta hombres salió contra los pimas altos y regresó con la noticia de que éstos y los sibubapas y seris que seguían insumisos se hallaban una vez más congregados en el Cerro Prieto. Mediado agosto, una batida del capitán Don Juan José Bergosa concluyó con la destrucción de la ranchería del jefecillo pima Naspre entre las sierras de Buenavista y de la Cieneguilla, al tiempo que se reconocían las marismas hasta el embarcadero frente a la isla del Tiburón y el monte Tenuaje. ${ }^{\text {107 }}$

Las juntas tenidas con Gálvez dieron como resultado la tentativa de un tercer asalto a Cerro Prieto, que se acometió cuando ya el visitador era presa de su locura. En 19 y 20 de octubre, mandadas por Elizondo, Armona, Peirán y Gabriel Vildósola, entraron al Cerro las tropas por cuatro diferentes rumbos, convergiendo en el peñol que siempre había sido refugio de los rebeldes, pero estos habían desalojado el Cerro dos días antes. La campaña duró diez días y supuso incontables fatigas: la división que entró por el cañón del Cosari franqueó dos leguas con agua hasta la rodilla. Pero la que mandaba Elizondo no salió del agua desde las nueve de una noche hasta las siete y media de la mañana siguiente. Tomaron parte en la operación mil sesenta y seis hombres, de los que quinientos cincuenta dragones, presidiales y fusileros, y el resto auxiliares yaquis, ópatas, eudeves y pimas.

Peirán y Armona fueron los primeros en llegar a mediodía del 20 al peñón, "en que siempre han fundado los enemigos su seguridad, así por estas en el riñón del Cerro, como por ser su mayor elevación”. Atacaron la cumbre en la madrugada del 21 , y la hallaron ya desierta, pues unos cuarenta rebeldes que lo ocupaban el día anterior se habían dado a la fuga rquella noche. Sus dos destacamentos y un contigente del de Elizondo bajaron luego al cañón de Loreto, mientras que el propio Elizondo y Vildósola reconocieron el de Cosari, la Cañada Grande, el Cajón de la Palma y el de Cara Pintada, reuniéndose con Armona el 24 en Loreto. Se enviaron exploradores hacia la sierra de los Pilares y al Tenuaje, y finalmente se emprendió el regreso al Pitic, donde entraron las tropas el 30 de octubre.

Elizondo comenta la extensión y aspereza del Cerro, que fue reconocido totalmente. "Hasta la actual general invasión se ha ignorado la fragosidad de esta imponderable serranía, pues el que más ha proferido de ella

ro7 Gálvez a Pineda y Elizondo, Alamos, is de julio y 3 de agosto de 1769 . R. A. H., Boturini, 18. Elizondo a Croix. Pitic, 21 de septiembre de 1769. A. G. I., Guadalajara 512. 
no había visto sino las bocas de los cajones, pues sin embargo de que en las dos penetraciones que se hicieron anteriormente por los cajones de la Palma y Cara Pintada se impuso en una gran parte de sus eminencias, se ha reconocido era infinitamente más lo que restaba por ver; pero en esta ocasión se ha examinado hasta las entrañas, que las forma un laberinto de dilatados e incomprensibles cerros, independientes unos de otros, con sucesivos descenso a las cañadas y ascenso a las cumbres". Pero el fruto de la campaña había sido más deleznable si cabe que el de las anteriores. Sólo habían quedado once seris rebeldes, que se retiraron al Tiburón, mientras que los suaquis se acogían a la sierra de los Pilares, y los pimas altos marchaban a reunirse con el capitán Vicipi, que siempre arranchaba lejos, al oeste del Pitic. Sólo se hicieron al enemigo ocho muertos, y algunos prisioneros, principalmente mujeres. ${ }^{108}$

La dura prueba con que había concluido octubre no hizo decaer el ánimo de los expedicionarios, que aún permanecerían dieciocho meses en campaña en Sonora. Pineda - a quien sus enfermedades impedían ponerse al trente de las tropas - y Elizondo supieron poco después que los restos de la ranchería pima de Vipici, después de haber sido ésta batida por Anza, iban a reunirse con la del también pirna cueras, al que se pudo localizar en el cajón del Purgatorio. Los comandantes enviaron entonces una partida de veinte presidiales y cinco auxiliares, que el 8 de diciembre trabaron combate, no ya con una, sino con tres rancherías con más de sesenta guerreros durante más de cuatro horas. Los españoles, consumidas las municiones y combatiendo pie a tierra en el cajón, casi cuerpo a cuerpo, tuvieron siete bajas, pero capturaron a nueve rebeldes, teniendo luego que buscar una posición que les permitiese resistir hasta la llegada de socorros de Altar, mandados por Anza, y de Pitic. En operación posterior, el capitán Bergosa destruyó la ranchería seri de Chepillo, dando muerte a su jefe en el arroyo de los Tobosos, mientras que el teniente Don Vicente Moreno perseguía con éxito a seris y pimas en la marisna y el Tenuaje. Todavía en diciembre pudo Vildósola al frente de cuarenta hombres aniquilar pie a tierra a la cuadrilla del capitán Sibubapa, única que al parecer había quedado en el Cerro, y que fue sorprendida fuera de éste, en el Malpaís, entre el cajón del Cosari y el de Ana María, adonde apremiados por el hambre habían salido estos enemigos a recoger semillas. ${ }^{109}$

I08 Elizondo a Croix. Pitic, 5 de noviembre de $I 769$, con detalle de la tropa actuante. A.G.I., Guadalajara 4 I 6 y M'éxico 1369. "Plano del corazón de Cerro Prieto". A. G. I., Torres Lanzas México 252. Facsímil en Priestley, José de Galves, frente pág. 272, y en Hernández Sánchez Barba, Mario, La última expansión española en América, Madrid, I957, frente pág. 232. 109 Extracto de noticias, México, $10^{\circ}$ de marzo de 1770. A. G. I., México, I 369. 
El ataque de Moreno a los seris dio sus frutos. A principios de febrero de 1770 se presentaron dos indias de esta nación a buscar la paz, y habiéndoseles dado diez días de plazo, antes de expirar éste acudieron once familias con cuarenta y tres personas. P.or su jefe se supo que recientemente los sibubapas alzados habían padecido una epidemia de vómito amarillo que los había exterminado, quedando ahora esta tribu reducida a número semejante al de los propios seris, que fuera de los ya rendidos sólo contaban veinticinco indios con sus familias, "pues son muchos más los muertos que los que se han visto en el campo". Lo mismo sucedía con las otras dos naciones, hallándose todos atemorizados, razón por la que en los pasados meses apenan se experimentaron daños ni se encontraron rastros. Entre los seris ya sometidos, su capitán Crisanto daba especiales muestras de fidelidad, mientras Peirán, a orillas del mar, sorprendía a cuatro familias de la nación, haciéndoles quince muertos y prisioneros. Como este hecho revela, la actividad de la tropa continuaba, y Elizondo se prometía llevar a cabo una expedición a la isla de Tiburón tan pronto hallase momento favorable. Sin embargo, este mismo mes se rindieron dieciocho familias más de seris y se presentaron tres tiburones a pedir el perdón y que se les dejase vivir en su isla, prometiendo no pisar la costa, lo que se les concedió, exigiéndoseles juramento de fidelidad, tras lo cual se marcharon contentos. A los que estaban en Pitic se les autorizó a eligir justicias, quedando por gobernador Crisanto y como alcalde otro indio llamado Francisco. Simultáneamente tenía lugar el último asalto de los dessesperados yaquis a Ostimuri, causando más de treinta muertes en esta juridicción, con el ataque e incendio del pueblo de Mobas; la réplica española, demostrada en las salidas del teniente Bergosa desde Pitic y de Vildósola desde Guaymas costó a los alzados la destrucción de dos rancherías y captura de unos treinta prisioneros, tras de lo cual cuarenta familias bajaron del Cerro Prieto a solicitar la intercesión del cura de Belén, que los dejó arranchados, y fue a tratar el asunto con los jefes militares de Guaymas. Iro

Frente a un enemigo aterrorizado, exhausto, diezmado y hambriento, los sucesos favorables se sucedían ya rápidamente. El capitán José Antonio Vildósola había atacado cinco veces consecutivas a toda la nación suaqui que sólo se defendia en la huida, persiguiéndola en la sierra de los Pilares, Carrizal de Ten y monte Aricibe, haciéndole treinta bajas entre muertos y presos y capturándoles su ajuar y sus caballos. El fuego de la tropa causaba muchos heridos, que casi invariablemente morían poco después. Tras

I 10 Croix a Arriaga y Muniain. México, 24 y 25 de abril y 31 de mayo de 1770 , con Extractos. A. G. I., "Guadalajara 416 y México I369. Elizondo a Croix, Pitic, 20 de mayo de I77). A. G. I., México 2430. 
este castigo, Vildósola había despachado a una de las indias cautivas para que moviese a los suyos a la rendición y, en efecto, el 3 de mayo se presentaba Ignacio Tuaspe con los suaquis y sus familias - en total ochenta y tres personas- al P. Valdés, en Belén, su antigua morada anunciando además que pronto acudiría el resto de la nación. ${ }^{\text {II }}$ Así pudo el Padre conducirlos el I4 de junio a Guaymas, donde se les recibió de paz. Había ya ciento setenta y un suaquis rendidos.

La desmoralización alcanzaba ya a los pimas altos, enemigos los más obstinados y que un año atrás habían despreciado el bando de perdón. El I5 de mayo recibió Elizondo a un parlamentario, enviado con una cruz por toda la nación, a la que el coronel fijó ocho días para entregarse, junto con los restantes suaquis, que se les habían unido en el Cerro, donde por estas fechas se hallaban concentrados. Sólo comparecieron en este plazo dos familias, pero solicitaron nuevamente perdón y a fines de junio se esperaba al capitán Vicipi, que se había retrasado tratando de traer a la paz al jefecillo Hueijuriguchi. Se calculaba que a esta nación sólo le quedaban cuarenta y ocho hombres de arco y flecha, y Elizondo tenía prevenidos ciento veinte hombres en tres destacamentos que empezarían a operar inmediatamente si no se efectuaba la anunciada rendición. ${ }^{\text {Iz }}$ Tales fuerzas se encontraron, en efecto, frente a los suaquis, a los que hicieron diez bajas, lo que los movió a entregarse en julio y agosto, dándose por seguro que toda esta nación se hallaba ya de paz, salvo seis familias que aún no habían llegado, y Elizondo se disponía a mover su ejército contra los piatos, tan pronto lloviera, en sierra de Picú, Buenavista y El Loro. "113

Los suaquis rendidos se convirtieron en auxiliares de las tropas españolas. El caudillo de la nación, Cristóbal Cainabac, realizó diversas entradas al Cerro, solo o a compañando al capitán Don Diego Peirán, que a fines de septiembre batió los cajones del Salitre y de la Higuera, pero ni él ni Vildósola lograron ventajas de alguna importancia. El propio Elizondo inició las operaciones definitivas contra los piatos haciendo una salida el $I .{ }^{\circ}$ de octubre, pero auncue se mantuvo en el campo hasta el 28 del mismo mes, no logró hallar al adversario. Anza, a quien destacó para que reconociese la sierra de Bacuachi y parajes intermedios entre este lugar y el Campo del Curiel, sorprendió a ocho familias seris en el monte Cenizo, causándoles trece muertes y apresando diez mujeres; a los cuatro hombres

I I Croix a Arriaga. México, 30 de junio de I7zo y Extracto. Ibid.

I 2 Croix a Arriaga. M'éxico, 26 de julio de I770. Con extracto de noticias de Pitic, 23 de junio. A. G. I., Guadalajara 5 I 2 y México 2430.

I 13 Extractos de roticias de Sonora de agosto y de reptielnbre A. G. I, Guadalajara 5 I 2 y México 2430. 
restantes, que pidieron perdón y la devolución de sus hijos, le fue esto concedido para que procurasen la rendición del resto de los suyos o la entrega de una ranchería de piatos, como lo hicieron. Elizondo volvió a salir el 15 de noviembre, y un teniente que destacó a la sierra del Picú encontró dieciocho familias de piatos en la sierra de Mochos, ranchería que se dio a la fuga precipitadamente, borrando con ramas sus huellas. Por cuatro familias de esta nación que ya se habían rendido supo Elizondo que los pimas vistos en Mochos estaban dispuestos a rendirse, y el coronel dispuso que aquéllas saliesen de Pitic el I I de diciembre para traer a éstas de paz II4 luego, el 3 de enero salió en su busca desde el presidio de Altar el capitán Don Bernardo de Urrea, y el 16 de aquel mes se entrevistó en los Pozos de San Ignacio con el cabecilla Vipici, que prestó la obediencia con sus familias y doce guerreros; el 23 se presentó también Guiatanori con su ranchería y nueve gandules, pidiendo todos ser restituidos a sus pueblos. Faltaba el capitancillo Cueras, pero en cambio el 2 de febrero se incorporaron a Pitic seis de las familias seris que tiempo atrás se habían refugiado en Tiburón, avisando que las restantes se hallaban igualmente en camino hacia aquel cuartel. ${ }^{115}$

E1 nuevo año había de ser el año de la paz. Aquel mes de febrero se presentaron los seis últimos suaquis y se esperaba la rendición de Marcos y los tres restantes seris - aquél quería quedarse en Tiburón- y de Hueijuriguchi, cuya ranchería pima hostigaban en el Cerro los destacamentos de Elizondo; el otro jefe piato aún rebelde, Cueras se había unido con cinco guerrero a los apaches, pero como estos no consentían ni daban acogida en su país a nadie que no fuese de su nación, no se dudaba que pronto volvería. II 6 En marzo comenzaron efectivamente a rendirse los piatos que habían quedado con Hueijuriguchi y Elizondo podía asegurar que la provincia gozaba de completa paz. En abril, seguían llegando los hasta entonces rebeldes pimas ante Urrea y éste se comprometía a dejar en paz a toda la nación. ${ }^{\mathrm{II}}$

En marzo de I77I declaraba el virrey que se habían logrado los fines de la expedición, y disponía el regreso de las tropas veteranas, manteniéndose allí sólo la compañía de fusileros de montaña, que quedaría acuartelada

I14 Extractos de noticias de México, 25 de enero y 27 de febrero de I77I, según cartas de Elizondo y Peirán de 18 de octubre, i 8 de noviembre y 20 de diciembre de I770. A. G. I., Guadalajara 512 y México 1269.

I 5 Extracto de noticias, México, 28 de marzo de 1771. Ibid.

I 6 Extracto de noticias de México, 27 de abril de iz7I. A. G. I., Guadalajara 4I6 y México 1269 .

117 Extracto de noticias de Sonora, de México, 27 de mayo de I77r y Elizondo a Croix Pitic, 2 I de abril de I77I. Ibid. 
en Pitic y Guaymas, y dejando completas y armadas las milicias que formó Gálvez. Ir8 Elizondo envió a México tres diputados seris -el gobernador Crisanto y los indios José Antonio, Antonio y Juan Antonio, este último hermano de Marcos - que esta nación quería se presentasen al virrey, después que al cabo de dos noches de deliberaciones decidieron asentarse al pie del cerrito de la Conveniencia, a corta distancia del cuartel de Pitic. Irg Por septiembre de I77 I se avisaba que Corbalán hacía las últimas gestiones para atraer a población a los seris más remisos, como Marcos, que seguía en Tiburón, mientras que hasta setenta pimas se rendían a Urrea, que los dejaba asentados en Pitic. rzo

Las primeras señales de la proximidad de la paz dieron ocasión a un no breve debate sobre lo que más conviniese hacer con los indios que habían estado alzados. No faltó quienes propusieran la deportación de los rebeldes, y frente a esto Elizondo mostró que otros traslados semejantes habían sido causa de la inquietud de los seris. Del mismo modo rechazaba Elizondo la idea de desarmar y quitar sus caballos a los indios. En cuanto a lo primero, los indios necesitaban sus armas para la caza, y los pimas para defenderse de los apaches, y respecto de los caballos, habría que quitárselos también a los blancos, para que no fuesen incentivo del robo, y por otra parte, este despojo hacía ver a los indios, aún a los pacíficos, que después de la expedición militar habían quedado en peores condiciones que antes de ella. Finalmente, el desarme sería inútil, porque mientras pudiesen robar un caballo, con varas, cuerdas y zacate tendrían arcos, flechas, brida y montura, y la carencia de caballos tampoco los haría menos belicosos, ni menos ágiles. ${ }^{12 \mathrm{r}}$

Croix en su carta a Arriaga de 26 de marzo de I77I, se manifectó de acuerdo con Elizondo, pero dejó que fuera el rey quien finalmente decidiese la cuestión, como efectivamente lo hizo resolviendo quedasen los indios en su tierra, "en la observancia de las seguridades que les capitularon los comisionados, y a proporción de los medios con que se discurre pueden vivir en sus países contentos y subyugados, se les auxilie con los ganados y siem-

II Croix a Arriaga. México, 26 de marzo de 1771. Ibid.

I 9 Elizondo a Croix. Pitic, 2 I de abril de 177I. A. G. I., Guadalajara 4I6. Los seris se presentaron en M'éxico el 27 de mayo. Croix a Arriaga. México, 27 de mayo de I 77 I, núm, 1.005.
Ibid.

I 20 Extractos de noticias de Sonora. México, I9 de septiembre y 27 de octubre de I77:. A. G. I., Guadalajara 5 I 2 .

x21 Extracto de noticias de 20 de diciembre de 1770. Croix a Arriaga, México, 27 de febrero de I77I, núm. 852. Elizondo a Croix. Pitic, 3 de febrero de I771. Ibid. Elizondo a Croix. Pitic, 21 de abril de 1771. A. G. I., Guadalajara 416. Vid. también copia de carta anónima (¿Elizondo a Gálvez?), fechada por error en Pitic, 22 de febrero de r778 (¿i77i ?). A. G. I.,
México 252. 
bras que les haga capaces del deseado aprovechamiento y utilidad", y que se procurasen misioneros que lograsen la reducción de los naturales. ${ }^{122}$ Elizondo y Corbalán establecieron a los seris junto al Cerro de la Conveniencia; a los pimas en Caborca, Pitic, y Bisanic y a los sibubapas en Belén, y Suaqui, y para la protección del país dividieron la primera compañía volante entre los presidios de Buenavista y Pitic, de modo que aquél pudiera mantener un destacamento de veinticinco hombres en Guaymas, y el de Pitic pudiese poner en campaña cincuenta en cualquier momento, permaneciendo aquí además, por ahora, la compañía de fusileros de montaña. Ya entonces se hallaba Cancio ausente de Sonora, y el teniente Don Juan Lumbreras se hacía cargo del mando de Buenavista con la media compañía agregada. La segunda compañía miliciana, creada por Don José Antonio Vildósola, se encontraba en Pitic y no se avenía a trasladarse a Terrenate, a donde iba destinada para refuerzo del frente apache. Naturalmente, se reformaban ahora todas las plazas milicianas creadas al principio de la expedición para remplazar a los presidiales sacados de las guarniciones. ${ }^{\text {123 }} \mathrm{A}$ fines de abril era posible a Elizondo emprender la marcha con el cuerpo de dragones, yendo por tierra desde Pitic a México, mientras que la infantería embarca en Guaymas, desembarcando en Tamazula y Mazatlán para continuar su viaje a pie. E1 I2 de agosto entraba Elizondo en México, y entonces se decidía el regreso de la compañía de fusileros de montaña que había quedado en Pitic al mando de Don Antonio Pol. ${ }^{124}$

\section{El gobierno ante la campaña}

Si las palabras de Arriaga que hemos transcrito páginas atrás dejaban percibir un trasfondo de desconfianza en las promesas de Gálvez, no es menos cierto que el secretario y el mismo rey desaprobaban por cuestión de principio en su fuero interno la expedición militar, de la que no esperaban obtener la pacificación de Sonora. Y cuando el virrey da cuenta del fracasado ataque a Cerro Prieto por el Cajón de Palma, que tuvo lugar el 25 de noviembre de I768, Arriaga ya no vacila, el 26 de julio de 1769 , en escribir que $\mathrm{Su}$ Majestad no cree se saque ninguna ventaja de la expedición; que los indios rehuirán siempre un combate formal y nunca será posible establecer un presidio en Cerro Prieto; y exhorta a obtener la paz

\footnotetext{
I 22 Croix a Arriaga. México, 26 de marzo de i77r. A. G. I., Guadalajara 512. Real orden de 5 de julio de I 77 I. Ibid.

I23 Elizondo y Corbalán a Croix. Pitic, 29 de abril de i77I. A. G. I., Guadalajara 4I6.

124 Croix a Arriaga. México, 29 de julio y 26 de agosto de 177 I, núms. I.05I y 1.069. Extracto de noticias de Sonora. México, I9 de septiembre de I77I, con carta J.092 de Croix con la mismma fecha. A. G. I., Guadalajara 5 r 2.
} 
por medio de la amistad. ${ }^{125}$ Las cartas de Croix hacen protestas de que nunca había olvidado atraer a los indios por la suavidad y persuación, pero que ahora renovaría este pensamiento según se le ordenó en febrero. ${ }^{126}$

Pero un año después, cuando se adopta el sistema de guerrillas después del tercer ataque a Cerro Prieto, Arriaga expresa "que S. M. se confirma en su primitivo concepto del ningún fruto de la citada expedición", y espera que Croix se arregle a la real orden de 25 de abril de I770. Esta real orden manifiesta fríamente la reprobación de la empresa concebida por Gálvez. "Por lo que mira al desengaño tocado de lo infructuoso de este empeño, ha tenido S. M. poco que extrañar, pues su superior comprensión previó muy anticipadamente que por vía de fuerza no se lograría el fin deseado", y en anteriores ocasiones se había encargado no se continuase el empeño con repetidas campañas. La expedición, dice el ministro, se deliberó en junio de I766; salió a campaña en marzo de I768, y atacó en octubre de 1769 . Se recela de los gastos que debe haber ocasionado y se advierte por otra parte los desastres que padece Nueva Vizcaya, mostrando los perjuicios de no abrigar proporcionalmente a todas las provincias, y la imposibilidad de sujetar por la fuerza a todas aquellas naciones, y en consecuencia, concluye Arriaga, "me manda S. M. prevenir a V. E. que desistido de la anterior empresa como se cree haya V. E. dispuesto por lo que indica en sus cartas, convoque V. E. una junta con el visitador, generales y aquellos oficiales y gobernadores que por su experiencia del país halle V. E. útiles al objeto y en ella se trate, con examen del plano y demás documentos actuados por el marqués de Rubí, lo que convenga deliberar en la situación de presidios, su número, su guarnición, subsistencia, etc., y los medios de conciliar la paz con los indios, a fin de afianzar por ambos medios la quietud de esas internas provincias, que facilite el logro de su población y consiguiente disfrute de sus copiosas riquezas". Iz7

Esta real orden daría origen al reglamento de presidios formulado por Gálvez y promulgado por Croix, pero entre tanto éste, como en anteriores ocasiones, respaldaba las ideas y actuación de aquél y con cartas de Pineda, Elizondo y Corbalán mostraba la conveniencia de mantener las tropas en Sonora, como efectivamente lo hizo durante un año, y al acusar recibo de la real orden de 25 de abril declara su confianza en que la guerra concluya en ese año; que siempre encargó celeridad en las operaciones a Elizondo y Pineda, pero tuvo que acceder a algunas representaciones suyas, y por otra

I 25 Real orden de 26 de julio de I769. A. G. I., Guadalajara 4I6.

I 26 Croix a Arriaga. México, 27 de mayo de i 769 . Ibid, Real orden de 20 de febrero de I 769. A. G. I., Guadalajara 5 I 2.

I 27 A. G. I., Guadalajara 416. 
parte no cree que los indios hagan nunca la paz sinceramente. Las expediciones - Croix habla de las de Sonora y Nueva Vizcaya - no han sido gravosas "como han abultado ahí los que no se hallan instruidos", y no se deben retirar ahora causando este sentimiento al comercio y al público que gustosamente contribuyeron a ellas, "con cuyos fundamentos he suspendido la ejecución de la real orden, y espero que sea de la aprobación de S. M. y de V. E.". ${ }^{2} 28$ Al recibo de esta carta, Arriaga se limitó participar quedaba el rey enterado de su contenido. ${ }^{129}$

Gracias a esto pudo la expedición sostenerse en Sonora hasta la sujeción voluntaria de los últimos sublevados, concluyendo su actividad sin embargo a tiempo oportuno, de manera que cuando Bucareli sustituyó a Croix en el mando virreinal, ya aquella provincia se hallaba en un estado de relativo sosiego. De esta manera, todavía a Croix y a Gálvez les fue posible publicar la Noticia breve de la expedición militar de Sonora y Sinaloa, su éxito feliz y ventajoso estado en que por consecuencia de ella se han puesto ambas provincias, impresa en México, a I7 de junio de $1775,{ }^{130}$ en que sin proporcionar ningún dato concreto se anuncia la tranquilidad de la frontera, la abundancia de los placeres descubiertos, la docilidad de los indios que piden misioneros, y la creación de una comandancia general, villa episcopal y casa de moneda en Sonora.

\section{La expedición de Nueva Vizcaya}

Parecía clara a los miembros de las juntas de México que aprobaron el envío de la fuerza expedicionaria a Sonora, y en particular estaba en la mente de Gálvez y Croix, que esta fuerza tenía por objeto tanto reconquistar aquella provincia sojuzgando a los rebeldes, como extender sus fronteras y las de Nueva Vizcaya. ${ }^{131}$ La situación de Nueva Vizcaya hacía desde luego necesario el envío de un socorro de tropas que rechazasen a las hordas de apaches que de manera incesante asolaban sus confines. Rubí lo había hecho presente así en 1767 , y la villa de Chihuahua, a fines de aquel año, enviaba al virrey una abultada representación que mostraba los daños causados por los bárbaros que se acercaban hasta sus puertas. ${ }^{132}$

I 28 Croix a Arriaga. México, 25 de septiembre de r z7o. A. G. I., Guadalajara 5 i 2.

i 29 Real orden de 2 de enero de $177 \mathrm{r}$. "Se ha enterado el rey de las últimas noticias que V. E. había recibido de la provincia de Sonora y estado de su expedición". Sorprende tan suave réplica de Arriaga después de los términos antes cambiados por una y otra parte. Ibid.

I 30 Ejemplares de la "Noticia breve" en A. G. I., Guadalajara 252, 390 y 4 I 6.

I 3 Aparte el Plan, esta mente se ve clara en Gálvez a Arriaga, México, 27 de mayo de I767, y Croix a Arriaga, México, i6 de julio de I767. A. G. I., Guadalajara, 4I6.

I32 Chihuahua había presentado un extenso menorial de daños sufridos ya desde i765.

A. G. I., Guadalajara 5 II. 
El capitán del regimiento de infantería de la Corona Don Lope de Cuéllar, que había sido comisionado para la expulsión de los jesuitas de la Tarahumara Alta y luego lo era tambié. de la visita general, fue el conducto por donde aquellos documentos 1legaron al virrey. Chihuahua había ofrecido para cooperar a su defensa dieciocho mil pesos que habían sido colectados para construir una iglesia parroquial y una saca de agua, y con esta cantidad dispuso Croix se levantasen algunas compañías de dragones, hasta que las fuerzas enviadas a Sonora pudiesen subir por el Gila hasta las fronteras de Nueva Vizcaya y se colocasen las poblaciones militares proyectadas por Gálvez. ${ }^{33}$

A fines de i768 estas compañías de dragones estaban formadas y se habían practicado algunas salidas, y a ello atribuía Croix el que no se experimentasen allí las desgracias y robos que antes eran frecuentes. ${ }^{134}$ Las cuatro compañías creadas por Cuéllar, que fue nombrado comandante de las fronteras de Chihuahua, sumaban un total de doscientos veintiocho hombres, y a las órdenes de aquél figuraban, como capitanes, Don Bernardo de Gálvez, sobrino del visitador, llegado a Chihuahua el i I de abril de i 669 ; Don Diego Becerril, que ya figuraba en la expulsión de los jestuitas de la Tarahumara, y Don Francisco de Cuéllar, alférez del regimiento de infantería de América y hermano de Don Lope. ${ }^{135}$

Ya dijimos que Cuéllar había recibido de Croix el nombramiento de gobernador de la Tarahumara alta y baja y Tepehtuana y comandante militar de sus fronteras y las del corregimiento de la villa de Chihutahua. Este hecho y la autonomía con que desde su llegada empezó a comportarse, suscitaron los celos del gobernador de Durango, Don Carlos de Agüero, que sintió lesionada su autoridad, máxime al ver desatendidas por Croix sus reclamaciones. Cuéllar, en efecto, nombraba gobernadores de los pueblos de indios, expedía "mandamientos" de los indios de Chihuahua, y había solicitado un

I33 Croix a Arriaga. México, 3 I enero 1768. A. G. I., Guadalajara, 4r6, y México, 1367. Croix no remitió a España el testimonio enviaclo por la villa, por lo abultado. Cuéllar había puesto ya en campaña una partida de cuarenta y cinco españoles e indios, que no había sido eficaz, Don Lope de Cuellar - uno de los más curiosos y olvidados personajes de la historia de Nueva Vizcayahabía sido ayudante del Estado Mayor de la Habana, y después de haber estado en esta plaza émpleado en la disciplina de sus tropas, pasó a Nueva España a ocuparse del mismo objeto, En la "Memoria que corrige algunos puntos del plan de tropas veteranas y de milicias que tiene hecho presente el mariscal de campo Don Antonio Ricardos- propone este jefe a Cuéllar para una Sargentía Mayor. Veracruz, 8 de febreto de I776. A. G. I., M'éxico, 2475.

I34 Croix a Arriaga. México, 25 de diciembre de 1768, núm. 233. A. G. I., Guadalajara, 5 I I

I35 "Estado que manifiesta la fuerza de las cuatro compañias de voluntarios... arreglado a la revista pasada hoy, día de la fecha". Hacienda de Dolores, 4 de abril de r769. A. G. I., Guadalajara, 4I6. Las compañías tienen $58,57,56$ y 57 hombres respectivamente. Aparecen además en la plana mayor un oficial de guias, el alférez retirado Don Jonquín de la $\mathrm{O}$; el cirujano Don Pedro de Casas, dos ameros, un distribuidor de raciones y un escribiente. Sobre Don Francisco de Cuéllar, Croix a Muniain, México, 27 de julio de I768. A. G. I., M'éxico, 2430. 
donativo en esta villa, en Parral y en Saltillo, hallándose claramente respaldado por el virrey. Sin embargo, las protestas de Agüero fueron también desestimadas en Madrid. ${ }^{136}$ En cambio, desde febrero de I768 estaba nombrado nuevo gobernador y capitán general de Nueva Vizcaya en la persona de Don José de Faini, ${ }^{137}$ quien sostendrá la actitud polémica frente a Cuéllar y su sucesor.

Don Lope de Cuéllar proyectaba ponerse en campaña en mayo de i769 y mantenerse un año expedicionando entre el Pecos y el Gila. Hasta entonces no había podido actuar por no haberle llegado de México el armamento para sus cuatro compañías. Ahora llevaría víveres para seis meses, y mandaría las recuas para seguir bastimentándose con viveres de refresco. Cuando Gálvez, ya en Sonora por aquellas fechas, tuvo noticias de estos preparativos, lo aprobó todo salvo que se antepusiera su sobrino, "joven que podrá dar esperanzas de valor y conducta, pero no las seguridades y experiencias que no caben en su corta edad, al distinguido mérito del teniente de dragones Don Diego Becerril", cuya prudencia y pericia militar dice serle conocida, como a Cuéllar. Por consiguiente, manda a éste dé la primera compañía a Becerril, a cuyas órdenes podrá el joven Don Bernardo aprender su profesión. Gálvez recomienda a Cuéllar disponga su incursión de modo que se aproxime a las fronteras de Sonora a mediados de agosto, para cuya fecha podría hacer conjunción con las tropas de Elizondo, que ya habrían terminado con los rebeldes de "Cerro Prieto. ${ }^{138}$

Partió Cuéllar, pues, de la Hacienda de Dolores, el 8 de junio, y marchó a reunírsele el capitán de San Buenaventura con cincuenta y cinco soldados y cincuenta auxiliares. ${ }^{139}$ Como solía ocurrir, al verse amenazados, los apaches ofrecieron la paz, pero tanto Cuéllar como Gálvez desconfiaban de su intención, y en cambio ahora se presentaba una buena ocasión de castigarlos, pues también el gobernador de Coahtila se había puesto en campaña. ${ }^{140}$ Realizó la suya Cuéllar desde los meses de julio y agosto con setecientos hombres entre soldados e indios, y a principios de septiembre se hallaba en El Paso del Río del Norte, después de haber destruido dos rancherías y parte de otras

136 Agüero a S. M. Durango, 2 I de mayo de 1768. A. G. I., Guadalajara, 337. Los títulos de Cuéllar aparecen en un nombramiento de gobernador de pueblos indios de la Tarahuimara, dado en Chihuahua, 15 de marzo de 1768 , en A. G. I., Guadalajara, 30 I.

I37 Real decreto de Muniain. Palacio, 5 de febrero de I768. Ibid.

r 38 Cuéllar a Gálvez. Chihuahua, 28 de abril de 1769. Gálvez a Cuéllar. Alamos, i 7 de mayo de I769. A. G. I., Guadalajara, 4 6 . El visitador había escrito ya a Cuéllar el I 6 de febrero, desde Californias.

I 39 Cuéllar a Gálvez. Janos, 20 de junio de 1769. Gálvez a Cuéllar. Alamos, 4 de julio de 1769 . Ibid., M'éxico, 1369.

I40 Gálvez a Croix. Alamos, i 3 de julio de i769. Ibid. Gálvez lamenta que el gobernador de Coahvila - lo era ya Don Jacobo de Ugarte y Loyola - no hubiese aguardado a combinar sus operaciones con las de la expedición. 
¿. los indios chafalotes, causándoles sesenta muertos y haciéndoles quince prisioneros, poniendo en libertad dos cautivos españoles que tenían, pero habiendo sido también batido y puesto en fuga por los apaches en el Corral de San Agustín, en la sierra de los Mimbres.

Desde El Paso dirigiose nuevamente a Janos, por orden de Gálvez, para cubrir las fronteras de Sonora y combatir a los gileños, impidiéndoles la comunicación con los seris y pimas, a quienes aquéllos habían enviado flechas como propuestas de alianza. ${ }^{141}$

Pero mientras Cuéllar realizaba aquella campaña aparentemente victoriosa, otros grupos apaches cayeron sobre el pueblo de San Jerónimo, a cinco leguas de Chihuahua, y sobre la misión de Nombre de Dios, a una legua, haciendo cincuenta y siete muertes; incluso hasta Mapimí llevaron las hostilidades, valiéndose de la indefensión en que quedaba toda la provincia por la saca de soldados de los presidios que Cuéllar había efectuado valiéndose de los poderes otorgados por el virrey, de que se lamenta el nuevo gobernador Don José de Faini. La población, además, se vio desolada, pues de los donativos hechos a Gálvez y a su comisionado esperaba verse libre de los indios bárbaros. ${ }^{142}$ En noviembre de aquel año de 1769 se experimentaban robos hasta en las haciendas próximas a Durango y San Juan del Río, y se hacía visible que, por diferentes causas, la situación general empeoraba: en efecto, algunas noticias manifestaban que un gran contingente de apaches había estado cruzando el río Grande durante quince días con sus noches, dividiéndose luego en tres secciones que marcharon hacia Chihuahua, Durango y Parras. Por otra parte, se hallaba con abundancia flechas tarahumares, lo que hacía suponer que éstos se habían aliado con los apaches, como se demostraría años después. El miedo dominaba a los vecinos y nadie se atrevía a salir de su casa. Faini no obtuvo ayuda de Croix, y Cuéllar ni siquiera le contestó, de modo que procuró reunir un cuerpo de vecinos y vaqueros armados, y formó en Durango cuatro compañías del comercio, mestizos y mulatos, esforzándose igualmente en que se reanudase el laboreo de las minas, a pesar de la amenaza constante de los indios. ${ }^{143}$ La llegada de estas noticias a la corte provocó sorpresa y una velada censura a Croix: "atribuye S. M. a extravío de algín pliego de V. E. el no haberse recibido por su conducto

I4I Cuéllar a Croix. El Paso, 8 de septiembre de iz69. A. G. I., Guadalajara, 5 Iz. Sobre la derrota de Cuéllar, Diario de la campaña general de O'Conor, 7 de septiembre al 30 de noviembre de 1775. A. G. I., Guadalajara, 515.

14a Faini a Arriaga. Durango, 7 de noviembre de 1769. A. G. I., Guadalajara, 512. El gobernador remprende, pues, la táctica de sus antecesores de dirigirse directamente al ministro, no sin éxito, pues una real orden de 20 de marzo de 1770 aprobó lo actuado por Faini, que reunió un contingente de tropas puestas al mando del corregidor para la defensa de la villa de Chihuahua, al mismo tiempo que confiaba en los socorros que proporcionase al virrey. Ibid.

I43 Faini a Arriaga. Durango, is de diciembre de 1769. Ibid. 
noticia alguna de estos hechos..."; pero el virrey dejó en el olvido esta y otras advertencias posteriores. ${ }^{144}$

Devolvió por fin Cuéllar a sus presidios y a Chihuahua -cuando la enfermedad de Gálvez puso fin a la empresa de que había sido el alma, obligado ahora el visitador a regresar a México según orden de Croix de 2 de diciembre que el propio Cuéllar le condujo a Ures ${ }^{145}$ - parte de los soldados e indios auxiliares que había llevado consigo, pero esto no remedió la situación. Los enemigos atacaban en pleno día, huyendo luego precipitadamente y todas las medidas tomadas por Faini eran sin resultado a falta de las armas y tropas que pedía al virrey. La última cosecha había sido mala; la que se esperaba, peor, y los pueblos carecían de fondos, pues dieron los de sus propios y arbitrios para la guerra. ${ }^{146} \mathrm{El}$ propio Faini resolvió trasladarse a Chihuahua, reconociendo en el camino los daños sufridos por las hacienda y ranchos. Los enemigos habían penetrado hasta el río Florido, y él no obtenía ningún auxilio del virrey, que había encargado la defensa a "un capitán ded infantería de muy pocos años y ninguna experiencia", a quien acusa de haberlo estropeado todo malversando la ayuda que le dieron los hacendados y la villa. I47 En junio, por orden del virrey, Don Lope de Cuéllar, había sido arrestado por un ayudante del regimiento de dragones de España llegado a Chihuahua para tomar declaraciones, Don Juan Velázquez, que recogió a Cuéllar todos sus papeles originales y minutas, patentes y hojas de servicios. ${ }^{148}$

Esta misteriosa detención, indudablemente relacionada con la intriga que se tejió sobre la locura de Don José de Gálvez, concluyó meses después con el regreso de Cuéllar a México, y luego a España, en compañía del visitador.

Don Bernardo de Gálvez, COMANDANTE DE LA FRONTERA

Partido Cuéllar de Chihuahua, pide Faini al virrey doscientos cincuenta o trescientos hombres de las provincias de tierra afuera para reforzar los presidios, insinuando que se le podían enviar de las milicias de Potosí y Gua-

I 44 Real orden de 25 de abril de 1770 . Ibid.

I 45 Gálvez a Croix, Misión de Ures, 28 de enero de I770. A. G. I., México, I369.

I46 Faini a Arriaga. Durango, 6 de febrero de i770. Ibid.

I47 Faini a Arriaga. Chihuahua, 26 de mayo de i77o. Ibid. Llegó el gobernador a la villa el 14 del mismo mes. Antes de su partida de Durango, presenció el tránsito por la ciudad de Don José de Gálvez, ya curado de su locura.

I 48 Faini a Arriaga. Chihuahua, 26 de junio de 1770. Ibid. Carta orden de Croix a Don Juan Velázquez. México, 15 de julio de r77o. En el testimonio de las cuentas de la expedición a Sonora. México, 21 de enero de 1773. A. G. I., Guadalajara. 4 r6. 
najuato, y manifiesta igualmente que dos tercios de los fusiles que aquél tenía en la hacienda de Dolores estaban inservibles y no había armero que los compusiese. En cambio, el capitán de Janos había llegado a un acuerdo con el general de los indios ópatas, que suministrarían una fuerza de cien hombres bastimentados - -a los que apoyarían veinticinco a treinta soldados de Janos y San Buenaventura-, concediéndoseles el botín de mulas, caballos, etcétera, que obtuviesen en la campaña.

El día de San Lorenzo de 1770 lograron los enemigos un robo de más de mil mulas y caballos, de los que por fortuna un destacamento de indios norteños rescató ochocientas cabezas, no sin luchar y. recibir bajas. ${ }^{149}$

A la llegada a México de estas reclamaciones y noticias -que Faini se cuidaba de participar igualmente a Madrid - Gálvez manifestó su sentimiento por los insultos padecidos en la frontera y ofreció al virrey su sobrino para que cuidase de la defensa. Las milicias de Guanajuato y Potosí no habían podido ser enviadas a Chihuahua porque estaban entonces siendo revistadas por el brigadier Douchet, pero Croix prometió consultar, en junta con Gálvez y los coroneles, los medios para remitir la fuerza necesaria. ${ }^{\mathrm{I}}{ }^{\mathrm{C}}$

Sin embargo, lo único que llegó a la villa fue Don Bernardo de Gálvez,

I49 Faini a Croix. Chihunhua, 24 de agosto de 1770. A. G. I., Guadalajara, 5I 2. E1 acuerclo con el general de los ópatas estaba pendiente de aprobación por el gobernador de Sonora Don Juan de Pineda. A la salida de Cuéllar, todo el armanento que tenía en la hacienda de Dolores fue entregado al síndico procurador de Chihuahua, en depósito. Faini a Arriaga. Chihuahua, 3 I de agosto de i 770 . Ibid.

i5o Gálvez a Faini. México, s. e septiembre de i77o. Croix a Faini. México, 22 de septiembre de 1770 . Ibid. Es hora, sin duda, de aportar algunos datos a la biografía del futuro virrey de Nueva España. Ya lo hemos visto en la frontera. He aquí la carta que el marqués de Croix dirigió al ministro de la Guerra cuando el joven teniente marchó a ella por primera vez. "En esie reino se halla Don Bernardo de Gálvez, único sobrino del visitador general, que inclinado a seguir la carrera de las armas, me ha pedido le dé destino donde pueda acreditar la utilidad que manifiesta en su espiritu y crianza, Fue primer teniente de cazadores en el regimiento de Royal Cantabre cuando en la campaña de Portugal se juntaron a nuestras fuerzas las de Francia, hasta que se reformó el cuerpo en Pau, capital de la provincia de Bearne.

Atendiendo a este mérito, a los muchos de su tío y a la recomendación de su persona, al de llevar consigo dos hombres armados a su costa para que asistan en la expedición contra los apaches, le he destinado a Chihuahua en caliclad de capitán voluntario para que acompañe a Don Lope rie Cuéllar, que debe mandar la que va a emprenderse por la Nueva Vizcaya,

Espero que esta disposición merecerá la aprobación cle V. E., y que 'me hará el honor de solicitar la de S. M., con la patente de tal capitán agregado, para que en la primera vacante de compañía de infanteria o dragones tenga colocación, y mientras el sueldo que corresponde a su empleo, atendiendo a sus servicios y a los notoriamente útiles de su tio". Croix a Muniain. México, 5 de marzo de r769. A. G. I., M'éxico, 2429. I.a enfermedad de su tío atrajo más tarde a Don Bernardo a Ures y a Pitic, a donde llegó el 13 de diciembre de 1769 a comunicar a Pineda y Elizondo una de las pasajeras mejorias del visitador, al que luego acompañaría en su regreso Croix a Arriaga, México, 7 de enero de I770. A. G. I., México, 1369. E1 estudio clásico sobre este fersonaje es de Caughey, John Waiton, Bernardo de Gálvez in Louisiana, $1776-1783$. Berkeley, 1934. Más reciente y mejor informado sobre la etapa que aquí nos interesa, Porras Muñoz, Guillermo, Bernardo de Gálves, Madrid, Instituto "Gonzalo Fernández de Oviedo", 1952, de quien toma sus noticias Vázquez de Acuña, Isidoro, El Conde de Gálves, "Revista de Historia Militar". V, núm. 9, Madrid, 1961. 


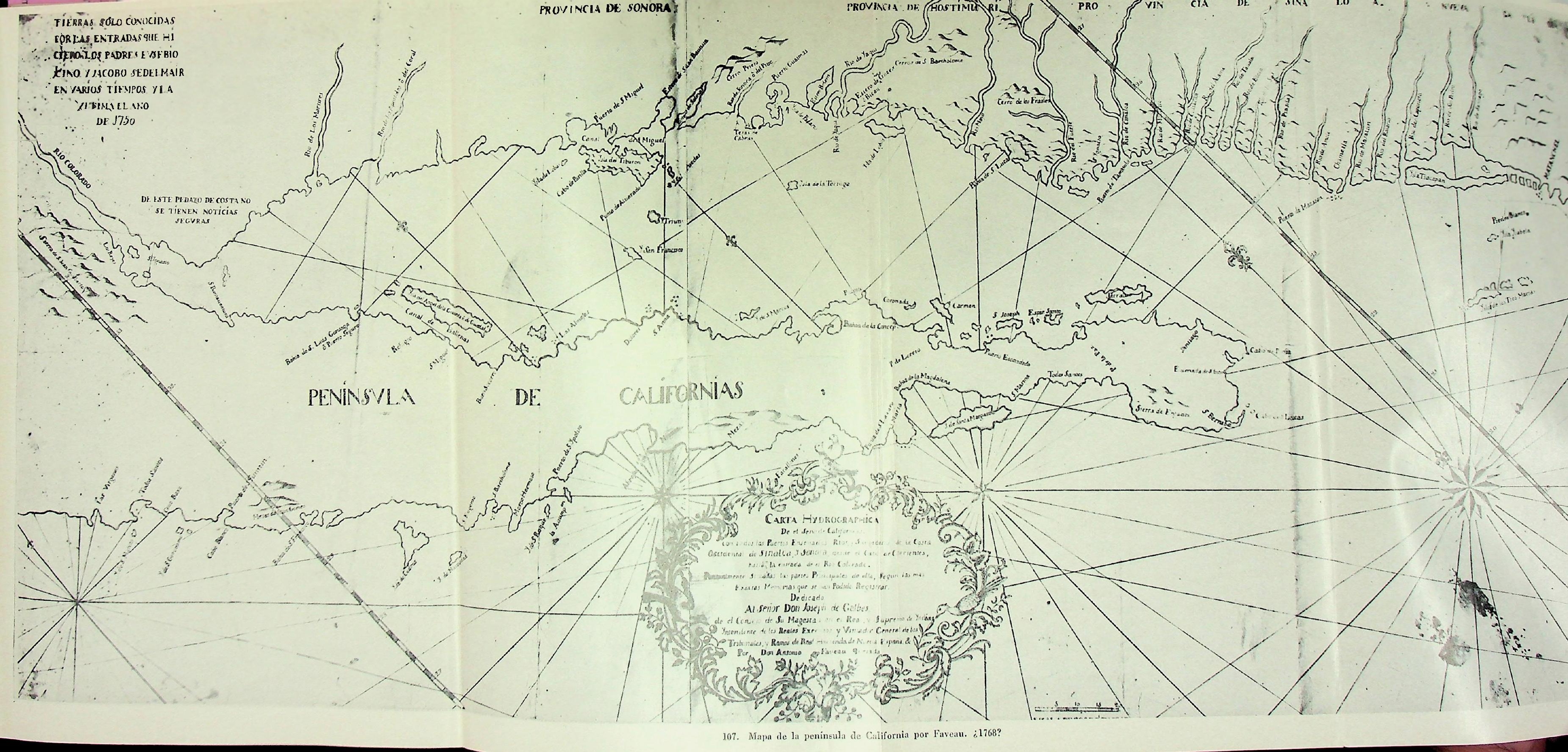


ya capitán del regimiento de infantería de la Corona, con título de comandante de las fronteras de Nueva Vizcaya y Sonora. Para entonces Faini había resuelto no volver a dirigir al virrey protesta alguna, y se limitó a poner a las órdenes de Don Bernardo doscientos cincuenta hombres bien bastimentados y equipados para tres meses, proporcionándole además tres hombres bien experimentados que lo asesorasen, cubriendo él las guarniciones de los presidios, mientras durase la campaña, con paisanos y vaqueros asalariados, armados y montados y con indios amigos. ${ }^{15} \mathrm{r}$

Las quejas de Faini, en cambio, eran constantes en Madrid, lanzando incluso la sospecha de que sus cartas tal vez fuesen abiertas en México, mientras que en la última citada concluye expresando quedar "con el sentimiento de que el director dé las órdenes del señor virrey no estará nunca de acuerdo con el gobernador de la Nueva Vizcaya". Croix, por su parte, presenta a Faini como un sempiterno descontento, como lo fuera su antecesor en el cargo, a pesar de que él le proporciona cuantos recursos encuentra, y le ha concedido el mando de las misiones de la Compañía, ${ }^{152}$ suprimiendo el gobierno de la Tarahumara alta y baja y Tepehuana que había antes conferido a Cuéllar.

Salió, pues, Bernardo de Gálvez de Chihuahua después que la vida había festejado a su patrón San Felipe con corridas de toros a que asistió Faini. E1 I. ${ }^{\circ}$ de noviembre había alcanzado el Pecos con su fuerza de ciento treinta y cinco hombres, sin bastimentos, que habían sido estropeados por las lluvias, de tal manera que iban cogiendo dátiles verdes de las palmas silvestres que hallaban por el camino. Tras dirigir el joven comandante una ardiente arenga a su desmedrada fuerza, cruzaron todos el río y atacaron el día 3 una numerosa ranchería cuya huella iban siguiendo, haciendo veintiocho muertos, sin contar los muchos apaches que se ahogaron en el Pecos, al intentar la fuga, y treinta y seis prisioneros, capturando más de doscientas bestias y muchas pieles de cibolo y gamuza, por valor de más de dos mil pesos. Simultáneamente, otras dos partidas al mando de oficiales de presidios batían la sierra recogiendo ganado robado en bastante cantidad. ${ }^{153}$

Pero si el 23 de noviembre databa Don Bernardo de Gálvez en Chihua-

I 5 I Faini a Arriaga. Chihuahua, I 2 de octubre de I770. A. G. I., Guadalajara, 5I 2.

r5a En términos del virrey, Faini "parece haberse propuesto seguir las huellas de su antecesor". Dice que el gobernador retrasó la salida de Gálvez por asistir a una fiesta de toros en Chihuahua.

I53 Croix a Arriaga y a Muniain. México, 26 de diciembre de r77o. Con extracto de la campaña de Bernardo de Gálvez. A. G. I., Guadalajara. 416. México, 243o. Croix a Arriaga. México, 27 de diciembre de 1770 , núm. 793. A. G. I., Guadalajara, 512. Es de advertir que Faini indica que esta salida de Gálvez se hizo con más de doscientos cincuenta hombres - tal vez incluye las otras dos partidas perfectamente bastimentados de pínole, harina, galleta, piloncillo, cigarros y carne seca. Faini a Croix. Durango, ig de febrero de I771. Ibid. 
hua el diario de su primera campaña, seis días después era atacado en la Jabonera el cordón de diecisiete hatajos de mulas de los arrieros mexicanos que surtían a Chihuahua: los enemigos, mandados por Canastrín, Malaoreja y otro capitancillo, se llevaron mil mulas, destrozaron muchos tercios de fardería, se llevaron los cajones de plata y escopetas y mataron a siete hombres, prendiendo fuego a la capilla de San Antonio de la Hacienda, donde se abrasaron otros veintitrés que se habían refugiado en ella. El daño causado se valoraba en 30.000 pesos. En ocho días se habían producido cuarenta y siete muertes, y bárbaros de todas las naciones habían entrado en la provincia por siete puntos distintos, cortando el camino real entre Chihuahua y el valle de San Bartolomé. El mismo día que era atacada la Jabonera dieron los indios en la Laguna de Castillo, de donde llevaron más de setecientas cabezas toda clase de ganado, y en Carretas y San Andrés, donde cogieron abundante mulada.

La hostilidad llegó a su apogeo cuando el 29 de diciembre, a las diez de la mañana, fue asaltado también el Cordón que bajaba anualmente de Nuevo México, siendo robadas todas las caballerías y quedando en el campo muchos muertos a lanzadas. ${ }^{154}$ Dada la situación, Faini resolvió, aun contra el sentir del virrey, que acababa de concederle el gobierno de Tepehuana y Tarahumara, ${ }^{155}$ suspender todo ataque en proyecto para mejor atender a la defensa, quedando Don Bernardo sin mando de tropa, pues el gobernador hizo volver los soldados a sus presidios; pero Croix hizo valer su decisión de que Faini se retirase a Durango, disponiendo que Bernardo de Gálvez alistase una compañía volante.

El joven comandante de la frontera pudo emprender su segunda campaña el 26 de febrero de I 77 I, en que partió con ciento diez hombres una vez que Croix dio sus órdenes, ${ }^{156}$ y habiendo seguido en sentido inverso el

I54 Nota anónina de San Felipe el Real, 7 de diciembre de I770. A. G. I., Guadalajara, 4I6. Faini a Croix. Chihuahua, 7 de diciembre de 1770 y 4 de enero de r 77 . Croix a Faini, México, 21 de diciembre de 1770. Faini a Arriaga. Chihuahua, 28 de diciembre de i77o. A. G. I., Guadalajara, 5 I 2 .

I55 Croix a Arriaga. México, 27 de diciembre de 1770 , núlm. 793. Ibid. Después de despachar esta carta, recibió Croix al teniente de Julimes, Don Nicolás Gil enviado por Bernardo de Gálvez precisamente para informarle de lo ocurrido en Chihuahua. El i 5 de enero de I77 r rindio Gil por escrito, a petición del virrey, el mismo informe que había dado verbelmente, desprendiéndose de él que a su regreso de la campaña del Pecos tuvo don Bernardo confidencia según las cuales los apaches habíanse puesto de acterdo con los indios tiguas del cordón de El Paso. Sin embargo, Faini no permitió nueva salida de Don Bernardo, y el asalto del cordón se realizó, siguiéndose las demas desgracias. Croix a Arriaga. México, 3 I de enero de I77I, núm. 829. Nicolás Gil a Croix. M'éxico, is de enero de I77r. Ibid.

I56 Parece, en efecto, que a la salida de Cnéllar se disolvieron las tropas que había reunido en sus cuatro compañías. Bernardo de Gálvez actuó la primera vez con gente de los presidios, principalmente. Ahora formó él una compañía volante, aunque también tendría presidiales bajo su mando. Croix a Arriaga, México, 3I de enero de I77I, núm. 829. Ibid. 
curso del río Puerco, el 2 I de abril trabó Bernardo de Gálvez largo y empeñado combate con más de doscientos cincuenta apaches. En esta ocasión hizo cincuenta y ocho muertos y un prisionero, y rescató un cautivo, teniendo en cambio un soldado y veintidós indios amigos muertos. $\mathrm{El} 4$ de mayo estaba de regreso en Chihuahua. Al mismo tiempo y por orden suya batía Leizaola, capitán de Janos, la Sierra de la Boca con ciento tres ópatas y soldados de Janos y San Buenaventura, durante seis días. ${ }^{157}$

Sin embargo, en marzo eran robadas las caballadas y muladas del presidio de Julimes y del Valle de San Bartolomé y Parral, más de cuatro mil cabezas, resultando muchas muertes y muchas más de animales, pues los enemigos mataban vacas, bueyes, carneros, ovejas " $\mathrm{y}$ todo género de ganado que no puede correr". El día del Corpus hicieron tres muertes junto a las mismas casas de Chihuahua, dejando muertos los carneros del abasto de carnicerías y más de mil ovejas de la hacienda de Encinillas, siendo inútil la persecución de Don Bernardo. En el distrito de San Felipe sólo continuaban funcionando dos hornos de minería, y el corregidor avisaba que pronto sería preciso abandonar la villa, pues no había manera de introducir víveres en ella. ${ }^{15}$ Entre tanto, el virrey repetía elogios ya expresados sobre Bernardo de Cálvez y pedía para él el grado de teniente coronel. ${ }^{159}$.

Pero las muertes y robos continuaban, mientras que la frontera se hallaba cada vez más debilitada, puesto que desde febrero de I77I, por decreto de Croix, se había extinguido el presidio del Pasaje, que mantenía la casa de San Pedro del Alamo, ${ }^{160}$ no obstante lo cual, las noticias que el virrey transmitía a la Corte seguían siendo halagüeñas. A mitad de agosto había participado Don Bernardo que se disponía a salir a tercera campaña llevando consigo sesenta soldados y trescientos auxiliares, cifras éstas que ya revelan —en época en que generalmente se sigue en aquella frontera la política opuestala predilección del sobrino del visitador por el soldado indio. El 6 de aquel mes se le había presentado un ex-cautivo de los apaches que le hizo saber que

I57 Extracto de los diarios remitidos por Bernardo de Gálvez, el ro de mayo de I77I. Ibid., México, I 269.

I 58 Faini a Arriaga. Durango, i I de junio de I77I. A. G. I., Guadalajara, 512. El gobernador no tenia inconveniente en asentar haber observado "los malos sucesos que han resultado de las inútiles y perjudiciales empresas del anterior capitán Don Lope de Cuéllar, que dio principio a perder esta provincia, y parece que para que la concluya han destinado el referido Gálvez".

I59 Croix a Arriaga. México, 27 de junio de I77 r, núm. I028. Ibid., México, I269.

I60 Desde I767 tenía solicitado el conde de Alamo se le liberase de aquella carga onerosa -trece mil cuatrocientos veinte pesos anuales- y de escasa tutilidad. Ya Rubí había propuesto la extinción, cuando Don José de Gálvez aconsejó a Croix, en r8 de diciembre de r77o, lo hiciera así, obligando al conde al pago de veinticinco mil pesos, abonables incluso en ganado de su fincal y de la de Aguayo. El 20 de diciembre dio el virrey su conformidad. "Testimonio de los autos hechos a instancias del conde de San Pedro del Alamo, mnariscal de campo de los reales ejércitas, sobre la extinción del presidio del Pasaje", I771. A. G. I., Guadalajara, 370. 
los lipanes, natajes, culcogendis y tisyeendis, sabiendo el buen trato que los que se mantenían junto a Don Bernardo recibían, habían decidido no hacer, daño alguno. Otros grupos que no habían admitido esta decisión habían sido combatidos y puestos en desordenada fuga por los partidarios de la paz. La noticia, según la entendía el marqués de Croix, debía ser cierta, pues desde abril se advertía tranquilidad en la frontera del Bolsón, tan agitada anteriormente. ${ }^{16 r}$

Don Bernardo de Gálvez envió a campaña durante septiembre y octubre de aquel año un cuerpo de trescientos hombres que apenas consiguió nada. En cambio, el i I de octubre por la mañana, cuando se hallaba en la parroquia de Chihuahua asistiendo a una función del octavario del patrón de la villa, le avisaron una incursión de los apaches. Envió un cabo de Cerro Gordo con catorce hombres, pero éstos tropezaron con tan numerosos enemigos que al primer encuentro sufrieron diez bajas. Salió entonces Don Bernarclo solo y topó con cinco indios, recibiendo una flecha en el brazo izquierdo y dos lanzadas en el pecho, una de las cuales le atravesó la cuera, amén de otra que alcanzó a su caballo. ${ }^{162}$ Allí pudo terminar la historia del conquistador de Panzacola, luego virrey de México.

Sin embargo, todavía hizo Don Bernardo nueva campaña -que hubo de suspender, cuando, aún convaleciente de sus heridas, fue arrojado de su caballo, sufriendo un fuerte golpe en el pecho, de cuyas consecuencias se resentiría hasta su muerte en plena juventud - antes de entregar el mando en I9 de diciembre de 1775 a su sucesor Don Hugo O'Conor, ${ }^{163}$ con lo que le fue posible regresar a España con su tío Don José de Gálvez.

Pero no podemos dejar la figura de Don Bernardo de Gálvez, máxime teniendo como tenemos que volver a ella más adelante, sin recordar su "Noticia y reflexiones sobre la guerra que se tiene con los apaches en el norte de Nueva España”, cuya fecha de redacción es incierta, y en la que recoge su experiencia personal sobre los apaches y las tropas presidiales, la manera de combatir de unos y otros, y las características de las tribus indias amigas. ${ }^{164}$

I61 Croix a Muniain, México, ig de septiembre de iz7ı. A. G. I., México, I269.

I62 Bernardo de Gálvez a Bucareli. Chihuahua, is de octubre de I77 I. A. G. I., Guadalajara, 512. Al mismo tiempo estaban actuando el ayudante mayor Don Domingo Díaz y el alférez Don Joaquín de la $\mathrm{O}$, enviados por Gálvez al frente de un destacamento de doscientos noventa y cuatro hombres, cuyo principal logro fue la captura de más de trescientas bestias, que eran devueltas a precio de rescate, por sus dueños, a razón de cinco pesos las mulas y de dos pesos y cuatro reales los caballos. Las bestias sin hierro, se vendian. Bernardo de Gálvez a Bucareii Chihuahua, ${ }^{\circ}{ }^{\circ}$ de diciembre de 1771 . Ibid.

I63 Bernardo de Gálvez a Croix. Chihuahua, 29 de noviembre de I771. Bucareli a Arriaga. México, 25 y 27 de diciembre de 1771 , núms. 132 y 135 . A. G. I., Guadalajara 512. Las vacantes de Gálvez y Cuéllar en el regimiento de la Corona no se cubrieron hasta 1772 y 1775 , respectivamente. Patentes de capitán de Don Agustin Wall y Don Bernardo Sáenz Montero, 26 de diciembre de 1772 y 14 de febrero de 1775 . A. G. I., México 2428.

" 64 Las "Noticias y reflexiones" fueron editadas y anotadas por Felipe Teixidor en Anales del Museo Nacional de Arqueologia, Historia y Esnografia, $4 .^{\mathrm{B}}$ época, tomo III, págrs. 537-555. 


\section{NuEvo MÉxico y LAS PROVINCIAS DE ORIENTE}

Por los días de la inspección de Rubí era un hecho que los ingleses habían comenzado su tráfico mercantil con los indios de la pradera y que los comanches lograban extenderse ya hasta los confines de Texas. Rubí propuso una alianza ofensiva y defensiva con estos últimos contra los apaches: jicarillas, natajes y gileños asolaban el sur y este de Nuevo México, y por el este, habían alcanzado San Sabá, el presidio sobre cuyas malas condiciones informaba Lafora. El segundo mandato del gobernador Vélez Cachupín, de I762 a i767, concluyó, sin embargo, en guerra abierta con los comanches, ${ }^{165}$ que habría de enfrentar su sucesor Don Pedro Fermín de Mendinueta, mientras que clesde El Paso el capitán Don Pedro Francisco de la Fuente expedicionaba contra los apaches refugiados en la sierra de los Organos. ${ }^{\text {I } 66}$

El virrey Cruillas atendía al mismo tiempo a la posibilidad de cooperar a la fundación de un poblado en Chetimanchac que había de realizar Don Antonio de Ulloa, primer gobernador español en Luisiana, y que proporcionaría la pacificación de varias tribus situadas entre esta provincia y Nuevo México ${ }^{167}$ y a la represión de un activo contrabando que los ingleses empezaban a practicar con Nuevo Santander desde su nueva base de Pensacola. Como insistentemente por Ecandón y por el mismo Ulloa antes citado se tenía noticia de que los ingleses habían logrado un asentamiento en la boca del río Grande, se encargó al propio Escandón, y después a Rubí en las instrucciones que le diera Cruillas, que reconociesen aquella costa. Por último, a fines de 1766 se comisionó con el mismo fin al coronel Don Diego Ortiz Parrilla, que llevó a cabo cumplidamente el encargo en octubre de aquel año y entregó con los autos consabidos un hermoso mapa de las islas texanas. ${ }^{\text {i }} 68$

México, 1925. Y anteriormente en la Revista del Ejército y de la Marina, en octubre de 1924, con Rubén García. En esta “Noticia” da Don Bernardo los nombres de aquellos dos apaches, Quitachín y Piticagán, luego Matias y José, capturados por él en su primera salida y que se convirtieron en fieles amigos suyos. Adviértase cómo les impuso los nombres de su padre y de su tío. Ejemplar mantuscrito de las "Noticias" en el Museo Naval de Madrid, Ms. 567, fols, $247-257$ v.

I65 Thomas, Plains Indians, 38. Vélez habia llevado en 1761 a Nuevo México algunos cañones, con la munición correspondiente, y Cruillas le entregó además una instrucción pública, en once capitulos, y otra reservada, en ocho. Cruillas a Arriaga, núm. 79. México, I4 de diciembre de I761. A. G. I., México 1360. Se trataba ya con todo ahinco de cortar el tráfico de armas, de poner orden en las misiones, establecer algunos nuevos pueblos y llevar a cabo la evangelización de los navajos.

I 66 Cruillas a Arriaga. M'éxico, i 5 de noviembre de i 755 y io de febrero de I766. A. G. I., Guadalajara, 5 I I.

I67 Cruillas a Arriaga. México, i7 de marzo de iz66. Ibid.

I68 Cruillas a Arriaga, núm. 4. México, 5 de mayo de i764. A. G. I., México I363. Cruillas a Arriaga, núm. 3 I. México, io de noviembre de 1766. A. G. I., México I 364 . Croix a Arriaga, núm. 30. México, 23 de junio de r767. A. G. J., México i 366 . Copias de los autos de Ortíz Parri$1 \mathrm{la}$ en A. G. I., México 2422. 
La visita de Nuevo Santander que Rubí no practicara había sido encomendada al mariscal Don Juan Fernando de Palacios - que con Rubí, Ricardos y Zayas era uno de los cuatro mariscales que pasaron a Nueva España en compañía de Villalba-, que suprimió las escuadiras de las villas, dejando en su lugar una compañía volante. ${ }^{16_{9}}$ La reforma no parece fuera eficaz, antes al contrario, a partir de entonces empieza a padecer la colonia incesantes hostilidades de los indios que comenzaban a sublevarse.

Durante tres años - I 767 a I 770 - gobernó Texas el sargento mayor Don Hugo O'Conor, que sucedió a Don Angel de Martos y Navarrete que había regido la provincia durante ocho. O'Conor, Caballero de la Orden de Calatrava y sargento mayor del Estado Mayor Suelto de América, procedía de la guarnición de La Habana, y había pasado a Nueva España con grado de sargento mayor a las órdenes de Villalba ${ }^{170}$ pero no recibiendo destino militar, fue en cambio comisionado por el virrey Cruillas para investigar en Texas los acontecimientos sobrevenidos con motivo de la hostilidad entre el gobernador Martos y el capitán de Oreoquiza Don Rafael Martínez Pacheco, hostilidad que había tenido su punto culminante en el incendio de este presidio. Marchó O'Conor a Texas y con toda honradez puso en claro los hechos; en 9 de junio de 1767 pudo elevar su informe documentado al virrey, que lo era ya Croix, quien en consecuencia decretó el I4 de jullio que Martos se le presentase en término de un mes, quedando O'Conor encargado del gobierno interino de la provincia. ${ }^{\text {I7I }}$ Como gobernador de Texas - empleo en que lo encontró el visitador Rubí- se desenvolvió bien haciendo lo posible por mantener relaciones amistosas con los indios, después que el 7 de diciembre de I 767 , con sólo veinte soldados, les dio batalla de tres horas en el río Guadalupe, y con ser ellos trescientos, les hizo veinte muertos y los venció, logrando desde entonces la paz con las naciones circundantes de la provincia, que le dieron el nombre de "capitán Colorado", debido a su rubicunda faz

169 Croix a Arriaga. México, 29 de septiembre de i767. Palacio a Croix. Reinosa, 31 de agosto de I767. A. G. I., Guadalajara 5 I I.

I70 Real orden de to de octubre de 1765 , a Villalba, A. G. I., México, 2475. En 1770 llevaba ya O'Conor más de diecinueve afios en el servicio de las armas. Habia ascendido desde cadete a teniente en el regimiento de infantería de Hibernia. En 1762 había sido promovido a capitán y primer ayudante mayor del batallón de voluntarios de Aragón, que se formó en Zaragoza en tres meses. Tomó parte luego en la campaña de Portugal, en la vanguardia, asistiendo al sitio de Almeida y toma de Chaves, Miranda y otras plazas. Ascendido a sargento mayor, intervine en Cuba en el entrenamiento de las milicias, hasta su pase a Nueva España. Memorial de $O^{\prime} \mathrm{Co}_{0}$ nor, México, 25 de abril de 1770 , con carta de Croix a Muniain, México 29 de abril de 1770. A. G. I., México 2430.

171 Croix a Arriaga, México, 24 de julio de 1767. A. G. I., México, 1366. En su Memorial, ya citado, documentó O'Conor las tentativas de soborno de Martínez Pacheco, preso en México, y de Martos, a que alude tanto él como el virrey, que dice haber tomado su decisión con gran secreto, por las muchas amistades que Martos tenia en la capital. Es curioso que por entonces Barrios, cuya conducta pesquisó el propio Martos, fuese corregidor de México. 
de irlandés. No debió lograrlo, sin embargo, completamente cuando en febrero de I770 el nuevo gobernador Riperdá, que había tomado posesión el 4 de aquel mes, podía escribir que, "a la provincia pronto sólo le quedará el nombre". El ganado caballar y mular había sido destruido por los indios, y sólo quedaba alguno vacuno, menos apreciado por éstos. ${ }^{172}$ En cambio, pronto lograría Riperdá concluir una paz, en I 77I, con los quitseis, tawakonis, iscanis, taobayas y cainiones, gracias a las diligencias practicadas en Cadodachos por Atanasio de Mézières, nombrado por O'Reilly comandante de Natchitoches. ${ }^{173}$

Mendinueta, en Nuevo México, se esforzará en contener a los comanches y descubrir sus añagazas: Quinientos de ellos atacaban la provincia en $\mathrm{I} 768$, y en junio intentaron un ataque por sorpresa contra Ojo Caliente, presentándose al mismo tiempo de paz en la feria de Taos. La previsión de Mendinueta logró destrozar la fuerza de cien comanches que asaltaban aquella localidad, y acudir inmediatamente a fortificar Taos. Sabía que los comanches habían recibido últimamente diecisiete cargas y fusiles de munición de los jumanes, habitantes de la junta de los ríos Napestle y Colorado, que las adquirían de los ingleses del Misisipí. Los apaches natajes y de la sierra Blanca y los gileños chafalotes estaban de paz en Alburquerque. ${ }^{174}$

No parece que las órdenes del virrey Croix a los gobernadores de Coahuila, Texas y Luisiana y al capitán de San Sabá para que investigasen aquel comercio de armas en la pradera diesen resultado. ${ }^{\text {I75 }}$ Por su parte, Mendinueta organizó una campaña represiva contra los comanches, pero un ejército de más de cuatrocientos cincuenta hombre regresó sin haber podido trabar combate. En septiembre y octubre, Ojo Caliente y Pecuries son asediados por aquéllos. Decíase que uno de los caudillos comanches se había alzado como reyezuelo de toda la nación, usando como distintivo una especie de cuerno verde en su tocado. Este Cuerno Verde murió en un combate junto a Ojo Caliente. Por fin se llegó a una tregua tácita que duraba en $\mathrm{I} 773$, con comanches y apaches, cuando se puso en vigor el nuevo reglamento de presidos. ${ }^{176}$

I72 Riperdá a Arriaga. Béjar, I5 de febrero de 1770. Guadalajara, 302. Regresando O’Conor a México, le confió el virrey la comandancia de las tropas del distrito de Guanajuato. Croix a Arriaga, México, 25 de enero de I77I, con estado de la revista pasada por O’Conor a la Legión del Príncipe. A. G. I., México $243 \mathrm{I}$.

I73 John Walton Caughey, Bernardo de Gálvez in Luisiana, 1776-1783. Berkeley, 1934, páginas, 38 y $5 \mathrm{I}-52$.

I74 Mendinueta a Croix, Santa Fe, 18 de junio de 1768. A. G. I., Guadalajara 512. En I76I, Mendinueta era corregidor de México. Cruillars a Arriaga, nủm. I3. M'éxico, 23 de junio de I76I.

A. G. I., México, I 362 .

I75 Croix a Arriaga. México, 3 de septiembre de 1768. Real orden de 20 de febrero de I769. Ibid.

I76 Extracto de noticias de Nuevo México, I7 de septiembre y 9 de noviembre de 1768 . Croix a Arriaga, México, 30 de enero de 1769. Ibid. 
Ultima actuación de Gálvez

y Crolx en MÉxico

En el momento final de este período, confluye la doble actividad de Rubí y Gálvez en el reglamento que éste prepara basándose tanto en el dictamen extendido por aquél al dar por terminada su visita, como en su propia experiencia de la situación de las provincias internas. Pero la actividad de virrey y visitador, que en esta última etapa parecen más estrechamente hermanados que nunca, fue mucho más amplia y compleja.

Llegado Gálvez a México el 28 de mayo de I77o, curado de su dolencia un mes atrás, su visión de la realidad y los problemas de la frontera se ha modificado visiblemente. $\mathrm{Ha}$ advertido, desde luego, que la sujeción de los rebeldes o la eliminación del peligro que presentan las tribus bárbaras del exterior no son cuestiones tan fáciles y soslayables como juzģara al salir de la capital para dirigirse al noroeste.

Pero supuesto que la campaña de Sonora va poco a poco produciendo lá pacificación de los seris y pimas, cree posible avanzar un paso en el objetivo de fomentar aquella provincia, y así un año después, el i 5 de abril de $177^{1}$. sale de las prensas un folleto de ocho páginas en octavo que lleva por título: "PLAN DE UNA COMPAÑIA de Accionistas para fomentar con actividad el beneficio de las ricas Minas de Sonora y Sinaloa, y restablecer la pesquería de Perlas en el Golfo de Californias". En este papel 177 propone al público la formación de esta compañía que autorizaría el gobierno y protegería Su Majestad. Se reunirían ochocientas o mil acciones de quinientos pesos. Cuando hutbiera trescientas, se convocaría junta general para nombrar directores y tesoreros. La suscripción a estas acciones debería enviarse a la secretaría del virreinato.

Para estimular a los posibles interesados se declara que no es cierta la superficialidad de las minas de Sonora y Sinaloa de que habla Villaseñor, y que la expedición militar ha logrado la pacificación del territorio. Además de las minas se puede hallar beneficio en el comercio de efectos, en la compra de oro en polvo y granos, y en el buceo de perlas en ambas costas y en muchas islas del golfo de Californias. Se da publicidad a la concesión por el virrey de una feria franca anual a la población de Guaymas, en Sonora, a la que se 1lama "Cuartel de la Salud", y a la existencia de varias embarcaciones que llevaban los efectos desde San Blas con fletes moderadísimos.

Pocos días después remitía Croix a Madrici varios ejemplares del Plan que dice haber mandado imprimir de acuerdo con Gálvez con vistas a pro-

I77 Ejemplares en A. G. I., Gundalajara 5 I 2. 
mover con vigor el laboreo de los minerales y el aumento de la población de aquellas provincias. Asegura que la idea ha sido bien acogida, habiéndose presentado ya varios accionistas. ${ }^{178}$

A los dos meses de la impresión del Plan de la compañía sale del mismo modo a la luz pública la "Noticia breve de la Expedición Militar de Sonora y Sinaloa, su éxito feliz y ventajoso estado en que por consecuencia de ella se han puesto ambas provincias", fechada en México, I7 de junio de I77I, a la que ya nos hemos referido con anterioridad. Esta "Noticia" nos proporciona la de que para entonces se estaba estudiando el establecimiento del cordón de presidios que había de defender toda la frontera, con la formación de su instrucción correspondiente. El folleto asegura muy de veras la pacificación de Sonora, de donde se obtiene gran riqueza en Cieneguilla y otros cuatro o cinco reales de minas descubiertos, muy productivos, mientras que Don Bernardo de Gálvez ha batido a los apaches "que hace tres meses no hostilizaban la Nueva Vizcaya".

$\mathrm{Al}$ enviar el virrey a Arriaga y Muniain este impreso, les anuncia igualmente que a la llegada de los jefes militares de la expedición a México, les hará formar una relación de la campaña, y del mismo modo avisa tener ya acordado con el visitador un nuevo plan de presidios. ${ }^{179}$

El proyecto de reglamento de los presidios, que con vista de todos los antecedentes había formado Gálvez pasó a manos del fiscal del rey y, a propuesta suya, a ser discutido en junta de guerra y hacienda celebrada el 27 de julio, en la que la obra del visitador fue calificada de útil, por los ahorros que proporcionaba al erario y por las ventajas que parecían desprenderse de las refomras propuestas en la situación de las guarniciones, y en consecuencia, "para que circule con más fácil uso", Croix decidió darlo igualmente a la imprenta, e impresa de orden de S. E. llegó a la corte la Instrucción para. formar una Linea o Cordón de quince presidios sobre las fronteras de las Provincias Internas. ${ }^{180}$ En tal reglamento decide el virrey la reforma de seis

I78 Croix a Arriaga, México, 27 de abril de 1771 , nứm. 883. A. G. I., Guadalajara 5 I 2.

I79 Croix a Arriaga. México, 27 de junio de 1771 , núm. I.030. A. G. I., Guadalajara 4IE. Croix a Don Pedro Garcia Mayoral, México, 28 de junio de I77 . A. G. I., Guadalajara 338. Croix y Gálvez a Muniain, México, 27 de junio de I771. A. G. I., México 1269. En su carta apoya Gálvez la propuesta de su sobrino para el grado de teniente coronel. Ejemplares de la Noticia Breve en estos legajos. Este folleto fue recogido por Pfefferkorn en su obra sobre Sonora, con el fin de combatirlo.

I80 Croix a Arriaga. México, 30 de julio de 177 I, núm. 1.055. A. G. I., Guadalajara 512. El título completo del impreso es: Instrucción para formar una linea o Cordón de quince presidios sobre las fronteras de las provincias internas de esta Nueva España y nuevo reglamento del nimero y calidad de oficiales y soldados que éstos y los demás han de tener, sueldos que gozarair desdée el día primero del año próximo de mil setecientos setenta y dos y servicio que deben hacer sus guarniciones. Año de I77I. Dado en México a I 8 de julio de I77I. Ejemplares en A. G. I., Guadalajara 273, 274 y 522 . Ejemplar manuscrito en A. G. I., México 2422, junto con dos es- 
presidios, con supresión de ciento once plazas y ahorro anual consiguiente de 133.607 pesos 2 reales y 6 granos, mejorándose, sin embargo, la capacidad defensiva de la Línea. Debería ponerse en práctica el nuevo sistema desde $1 .{ }^{\circ}$ de enero de 1772 , "pero - escribe el marqués de Croix a Arriaga- como para esto sea preciso poner antes los necesarios caudales en las cajas de las respectivas provincias, el tiempo restante tan corto, y su ejecución penda ya de mi sucesor, con quien estoy de acuerdo para entregarle después de mañana en el pueblo de San Cristóbal este mando", propone, pues, el virrey que el asunto se estudie en la Corte, en junta militar de Generales, con asistencia de Rubí, que conocía el territorio, y de O’Reilly, que había sabido de las fronteras de Texas durante su estancia en Luisiana. La nueva Instrucción creaba el cargo de comandante inspector, para el que Croix dejaba propuesto a Don Hugo O'Conor, ya teniente coronel desde 18 de febrero de aquel año, y a quien con fecha de Io de septiembre había expedido títulos de capitán de San Sabá y comandante de las fronteras de Chihuahua y Sonora ${ }^{\text {I8I }}$ para que relevase en este puesto a Don Bernardo de Gálvez.

Por su parte, los jefes militares no descuidaron la disposición del virrey. y en primero de septiembre de I 77 I quedaba lista la "Relación de la expedición de las provincias de Sinaloa, Ostimuri y Sonora en el reino de Nueva España", que tal vez sólo por lo tardío de su conclusión -el 22 de septiembre entregaba Croix a Bucareli el bastón de mando- no llegó a aparecer en letra de molde. ${ }^{182}$

Podemos preguntarnos la finalidad perseguida por Gálvez y Croiz al lanzar a la luz pública tres de los cuatro escritos que acabamos de presentar. Parece que los móviles fueron, de una parte hacer visible la continuidad de su propósito de atender la región fronteriza, procurando al mismo tiempo atraer hacia ella el capital del comercio de Nueva España, para su fomento. De otro lado puede suponerse que buscaban dar a conocer al público lo ocurrido en la expedición y sus frutos, habida cuenta que aquélla había sido posible gracias a los donativos de los particulares. Pero, finalmente, no es difícil imaginar que tal vez su principal objetivo consistía en crear, tanto en

critos desfavorables al reglamento, titulados "Reparos que se ofrecen en la práctica de establecimiento del nuevo Reglamento de presidios", sin autor, ni fecha, y "Proposición para continuar la guerra a los indios apaches", México, 24 de octubre de 1774 (sic), siendo este último seguramente obra de Elizondo. En ambos se rechaza la supresión de los presidios de Horcasitas y Buenavista y la traslación de otros de Sonora, asi como ciertas innovaciones en materia de régimen
interior que serían sancionadas en 1772 .

181 Croix a Arriaga, México, 20 de septiembre de I77I, núm. I.I00, remitiéndole cuatro ejemplares de la Instrucción. A. H. N., Estado, $3882-7$. Ascenso y nombramiento de O'Conor, según real orden de 18 de febrero de 1771 a Croix y carta de Bucareli a Arriaga, México, 5 de
octubre de 1771 , núm. 16. A. G. I., Guadalajara 512 .

18 a A. G. I., Guadalajara 4 I 6. 
México como en España, la convicción de que la empresa había alcanzado los ambiciosos fines que Gálvez se propusiera, después que Croix le thabía guardado tan fielmente las espaldas. ${ }^{183}$

De la veracidad y de los efectos de lo publicado por ambos podemos hacernos juicio gracias a los datos existentes para ello. El plan de la compañía de accionistas fue bien acogido y aprobado por el rey, que ofreció protegerla y poner en ella algunas acciones, encargando al nuevo virrey Bucareli informase en qué estado se hallaba y número de acciones que se hubiesen reunido ya, e indicase las reglas más convenientes para su manejo. ${ }^{184} \mathrm{La}$ contestación, que Bucareli no dio sino años después, no podía ser más desoladora, puesto que ni un solo comerciante quiso adquirir una acción en la compañía, a pesar de que el virrey hizo que se les propusiese hacerlo, aisladamente a cada uno de ellos.

La "Noticia breve" no tardó en hallar contradictores. El gobernador de Nueva Vazcaya, Faini, no se demoraba en informar que justamente un mes después de la edición de aquélla, el I7 de julio de I775, a las doce de la mañana, los bárbaros se habían llevado de las inmediaciones de Chihuahua las muladas de dos hacendados y más de doscientas caballerías de varios vecinos pobres, matando además a doce personas de ambos sexos y varias edades; "noticia que aunque no se conviene con la de un impreso hecho en México que the visto aquí, no puedo de ninguna manera dejarla de participar a V. E.". ${ }^{85}$ Desde Madrid se encargó a Bucareli que informase sobre el particular, ${ }^{186}$ pero Faini, no contento con esto, pidió a dos misioneros que regresaban de Cucurpe y Opodepe le informasen "si es cierto el estado de prosperidad de Sonora según se dice en el papel impreso en México el i 7 de junio de $1775 " .{ }^{187}$

Los padres Canales y Reyes, del colegio de Propaganda Fide de Querétaro, no tuvieron a mal hacer relación ${ }^{188}$ de veinticuatro muertes y cuatro

183 A este mismo objeto responderian, pues, igualmente, el Exiracto de noticias del puerto de Monterrey, publicado incluso en fecha anterior, en agosto de $1770, y$ transcrito por el P. Palau en su Vida de Fr. Junipero Serra, y el Diario histórico de los viajes de mar y tierra, de octubre del mismo año, edición esta última no destinada al gran público, y que Croix dirige a Muniain con estas palabras: "pues V. E. comprenderá bien cuánto podría perjudicar a la nación y al Estado las noticias que dicho diario comprende si llegasen a manos de otras naciones, no dudo le merezca el citado ejemplar toda la reserva que conviene y exige la naturaleza del asunto". En la misma carta elogia al visitador, que no ha permitido se le elogie en este "monumento", que verdaderamente refleja su mejor obra: la ocupación de la Alta California. Croix a Muniain, México, 26 de agosto y 28 de octubre de 1770 . A. G. I., México 2430.

I84 Real orden de 15 de noviembre de 1771 a Bucareli. A. G. I., Guadalajara 5 I 2.

I85 Faini a Arriaga. Durango, I2 de agosto de I77I. Ibid.

I86 Real orden de 21 de diciembre de 1771 a Bucareli. Ibid.

I87 Faini a los RR. PP. de Propaganda Fide. Durango, 3 de septiembre de 177r. Ibid.

I 88 Durango, 4 de septiembre de I77r. Ibid. 
cautivos hechos entre abril y mayo por seris, apaches y pimas en Opodepe, Nacameri, Cucurpe, Tonichi, Ures, Cuquiarachi y Bacanuchi, así como robos de bestias y boyadas en San Antonio de la Huerta y Tecoripa, y de las caballadas de los presidios de Fronteras y Tubac, con más muertes de soldados y vecinos. En el Carrizal de San Marcial había sido asaltada la fuerza de la expedición, llevándose los enemigos varios caballos, entre los cuales uno del mismo Elizondo, y junto a Ures había sufrido tres bajas la compañía de fusileros que escoltaba la recua del rey. En cuanto a las minas, de Cieneguilla se iba ya retirando la gente por falta de agua; el placer de Cornelio era de poca importancia, y del de Aguas Frías no habían oído hablar.

Remitiendo a Arriaga copia de esta declaración ${ }^{\mathrm{I}} 89$ añadía Faini que en Nueva Vizcaya habían ocurrido diez muertes, cuatro raptos, y el robo de más de mil quinientas bestias en la hacienda de Santa Gertrudis de Pantita, sesenta leguas al norte de Durango. No era preciso tanto, pues ya en 26 de octubre, respondiendo a la carta en que Faini pronosticaba el despoblamiento de Chihuahua, se ordenaba a Bucareli enterarse de la realidad, "tan opuesta a lo que casi en las mismas fechas se avisa sobre lo remediado por el visitador general Don José de Gálvez en la citada provincia de la Nueva Vizcaya", y poner remedio. ${ }^{190}$

Finalmente, la instrucción para los presidios causó en el propio Bucareli la impresión que dejan entrever sus palabras: "en este estado en que están las fronteras de indios, han soltado un nuevo reglamento de presidios que Vm. habrá visto impreso, en que reduciendo su haber extinguen algunos, mudan la situación de muchos y detallan anticipaciones de caudales, precisa, cuando ni los tiene el erario, ni puede satisfacer los atrasos de dos años que se les está debiendo". r91

De este reglamento conviene decir que fue la base del que efectivamente se puso en práctica con fecha de I772, y al que tan de corazón se había de adherir el propio Bucareli y representa una transacción, impuesta por la realidad, a las ardientes imaginaciones del visitador que, de proyectar la conquista de todo el noroeste del continente y de un planteamiento de la situación internacional en aquella parte del mundo, se reducía ahora a especificar la situación, las obligaciones y el régimen interior de cada presidio, según lo aconsejara Rubí, formando con ellos el cordón defensivo de todo el virreinato.

La postura de Gálvez y Croix respecto de los problemas de las provincias internas había quedado, sin embargo, firmemente establecida. En informe

I89 Faini a Arriaga. Durango, io de septiembre de I771. Ibid.

I 90 Ibid.

I9 I Bucareli a O’Reilly. México, 27 de octubre de I 77 I, confidencial. A. G. I, México, i 242. 
de 22 de junio de $I 77 \mathrm{I}$, contemporáneo por consiguiente de la "Noticia breve" y pedido por la real orden de Io de agosto de I769 que había aprobado el Plan, se ratifican en todos los puntos asentados en el Plan de la comandancia general, habiendo ya esperado a ver el fin de la expedición militar de Sonora, "que hoy se halla terminada con toda felicidad". El conocimiento del terreno lleva a Gálvez a proponer como más conveniente Arizpe que Caborca para sede provisional de la capitalidad de la comandancia, hasta tanto que pudiera ser adelantada el Gila y Colorado. Caborca estaba casi destruida por los ataques de los apaches, mientras que el pueblo de Arizpe, en el río de Sonora, gozaba del terreno más fértil de la provincia y podría tener una buena iglesia catedral, y buenas comunicaciones con todo el territorio de la comandancia.

Cinco misiones debían ser fundadas sobre el Gila y el Colorado, para enlazar con los establecimientos de California, y la mitra que debería erigirse en Sonora impulsaría extraordinariamente el avance de las cristianiazción. En el plano económico, "importa más de lo que pueda explicarse el establecimiento de la casa de moneda en Sonora", por el fomento que la circulación del numerario daría al país. ${ }^{192}$

En estos puntos, pues, han dejado constancia una vez más el virrey y el visitador de su proyecto de expansión al noroeste.

\section{SONORA PACIFICADA}

A fines de diciembre de 1770 informaba Elizondo al virrey de que los seris y suaquis establecidos en Pitic habían construido una cerca y una acequia para sacar agua del río y regar su trigo, maíz, frijol, sandías y calabazas, y. entonces se dedicaban a fabricar la presa para la acequia. Este puede considerarse el verdadero anuncio de la pacificación lograda.

Sin embargo, la entrada del año I 77 I fue desastrosa. El desbordamiento de los ríos - fenómeno común en Sonora- dejó a la provincia en la última miseria, inundando y arrancando las sementeras. Pero entonces, providencialmente, dice Elizondo, a principios de febrero - a fines de noviembre de 1770 , según la "Relación de la expedición"- se descubrió un rico mineral en el paraje llamado Cieneguilla. El hallazgo debió atribuirse al tránsito de un destacamento de la expedición y a la lograda sumisión de los rebeldes, porque el sitio había sido hasta entonces una madriguera que nunca abandonaban los enemigos piatos, de quienes era el territorio, y que disfrutaban de la abun-

I92 Real orden de Io de agosto de I769. A. G. I., Indiferente General i713. Croix y Gálvez a Arriaga. México, 22 de junio de I771. Publicado por Ricardo Mimenza Castillo bajo el título de Sobre el establecimiento de la comandancia general en las provincias internas del norte, 1771 . Boletín del Archivo General de la Nación, México, XII (1941), núms. I, 73-8:2, 
dancia del ganado vacuno cimarrón en el lugar para su mantenimiento, y del asilo que brindaban para su seguridad las sierras vecinas de los Mochos, del Viejo y del Picú. ${ }^{193}$

El mineral de Cieneguilla hizo pasar a segundo término los nuevos descubrimientos verificados en San Antonio, Saracachi y Bacuachi, pues en estos lugares el mayor beneficio se obtenía lavando las tierras, mientras que en Cieneguilla los buscadores obtenían su beneficio sólo con aprovechar el oro a granel, que hallaban sin más trabajo que hacer hoyos y remover las tierras. Así se recogieron muchos granos de tres a catorce onzas, y uno de treinta y dos, otro de treinta y cuatro y uno de nueve marcos. Las varias minas descubiertas y pobladas desde principios de año - la de Bacuachi rendía veinticuatro marcos de plata por carga de metal; en el Cerro del Promontorio en la raya entre Sinaloa y Nueva Vizcaya se anunciaba un mineral de plata virgen - fueron rápidamente abandonadas, concurriendo toda la gente a Cieneguilla. Este placer, que tenía doce o catorce leguas de extensión, se encontraba a doce leguas del presidio de Altar, y su riqueza era tal que los tres primeros meses de la explotación se habían extraído unos mil marcos de oro, todo ello en granos de regular tamaño, puesto que por la escasez de agua no podía beneficiarse el oro menudo, ni alejarse la gente a buscar otros yacimientos a mayor distancia. El corto aguaje de Cieneguilla apenas tenía en la estación lluviosa la suficiente para beber. De poderse lavar las tierras, se aseguraba un rendimiento de doce pesos de oro por carga, lo que significaba que en la temporada de aguas podría sacarse un millón de pesos, pero nadie se ocupaba de esto. ${ }^{194}$ Por mayo de aquel año, dos comerciantes del país, Bringas y Maitorena, habían reunido en Cieneguilla diez arrobas y media de oro, de las que seis correspondían al primero. ${ }^{\text {I } 95}$

A ocho leguas de Cieneguilla, en el paraje llamado Cornelio, y a doce, en Aguas Frías, se habían hecho otros descubrimientos de placeres auríferos por los vecinos de Nacameri y los soldados de Altar, pero la misma escasez de agua que amenazaba a Cieneguilla hacía que éstos se hallasen abandonados. Sin embargo, Cieneguilla prometía ser establecimiento permanente y población la más numerosa que hubiese habido en aquellas provincias - en marzo había mil quienientos operarios- y Corbalán se propuso trasladarse allí para empadronar a los indios, nombrar gobernadores de cada nación, juez español que extendiese guías francas del oro, etc. ${ }^{196}$

I93 Elizondo a Croix. Pitic, 24 de abril de I77I. Guadalajara 4 I6.

I94 Corbalán a Croix. Pitic, 29 de abril de I77I. Corbalán a Gálvez. Pitic, 4 de mayo de I77 I. Ibid.

I 95 E1 Br. Manuel Gil de Samaniego a Gálvez. Alamos, 13 de mayo de I77I. Ibid.

I96 Corbalán a Croix. Pitic, 29 de abril de 1771. Croix a Arriaga, México 27 de mayo de I77I, núm. I.005, con extracto de noticias de Sonora de 27 de marzo y 8 de abril. Ibid. 
Fue en efecto, Corbalán a designar, con asistencia del capitán de Altar Don Bernardo de Urrea, el lugar del poblado, y convocó junta del vecindario. Dejó ya en estado de bastante adelantamiento la edificación de las casas reales y poco después encomendaba al teniente Don Pedro de Tueros el gobierno del real. ${ }^{197}$

Las repetidas noticias de los frecuentes descubrimientos de ricos minerales hicieron concebir risueñas esperanzas a Gálvez y Croix, que no se descuidaron de dar difusión a aquéllas. El beneficio de las minas y el rendimiento de las alcabalas y tributos establecidos por el visitador debían poner a la provincia en situación floreciente. Retirado de su gobierno Don Juan de Pineda, a quien los padecimientos contraídos durante la campaña hicieron renunciar aquel mando, el virrey había nombrado como sucesor a Don Pedro de Corbalán con título, a instancia de Gálvez, de gobernador-intendente y sueldo de seis mil pesos; y pidió confirmación de este nombramiento al rey aunque tenía referencias de estar ya designado otro sujeto para el cargo de gobernador. ${ }^{198}$

Corbalán había pensado en la conveniencia de hacer privativo del rey el rescate del oro de Cieneguilla, y Croix se apresuró a disponer se le enviasen cien mil pesos con que atender a aquella inversión; y poco después decretaba la erección de otra caja real en la villa de Rosario, en Sinaloa, y consultaba al gobernador-intendente la posible traslación de la de Alamos a Arizpe o Ures, encargándole al mismo tiempo el perfeccionamiento de los estanquillos o fielatos del estanco del tabaco, pólvora y naipes que entraría en vigor en Sonora en I772, y el establecimiento de nuevas poblaciones, sobre todo la de Guaymas que debería ser muy útil para la habilitación de barcos y el socorro de California. ${ }^{199}$

Los indios recién sometidos, las ciento ochenta y una familia restantes de las seiscientas que se suponía contaban las tres tribus rebeldes - seris, piatos y suaquis - antes de la expedición, procuraban algunas preocupaciones a Corbalán: cuatro seris habían ido a presentarse al virrey de México, mientras que otros cuatro pasaron a la isla del Tiburón para traerse algunos de sus familiares. Tan pronto regresaron de la capital los cuatro primeros, se entregaron de paz Marcos y su hijo, con sus dos familias. Las cincuenta y. nueve que componían la nación seri parecían tranquilas y se afanaban con visos de sinceridad en emprender vida sedentaria en Pitic. Aparte de las setenta y cuatro familias sibubapas hubo de permitirles volver a su antiguo pueblo de Suaqui, donde se ocupaban en la saca de oro, mientras que otro

I97 Corbalán a Croix. Pitic, 2 de agosto de 1771. A. G. I., Guadalajara 5i 2.

I98 Croix a Arriaga, 27 de junio de I77I. A. G. I., Guadalajara 5 I6.

199 El tribunal de Cuentas a S. M. México, 26 de junio de I77I. A. G. I., Guadalajara 4It). Corbalán a Croix. Pitic, 2 de agosto de I77I. A. G. I., Guadalajara 5 I 2. 
grupo que siempre había sido fiel se trasladó a Tecoripa. En cambio las cuarenta y ocho familias de pimas altos se mostraban reacias al trabajo. ${ }^{200}$

Con suma delicadeza, en medio de las dificultades que significaba el ser unos advenedizos en un campo que había sido de los jesuitas, y el operar sobre pueblos de tan reciente sublevación, los franciscanos empezaban a impulsar su labor misional. Conviene citar aquí el benemérito eclesiástico Don Francisco Joaquín Valdés, cura de Gurivis y Belén, en el río Yaqui. Su papel en la misma pacificación fue singularmente distinguido, pues saliendo con sólo su crucifijo logró atraer a la paz a los sibubapas y suaquis, y aconsejó a los pimas altos presentarse en Pitic. Moviéndose entre Belén, Alamos y Guaymas, el Padre Valdés había presentado a los primeros suaquis a Gálvez, y les procuró su asentamiento en Belén, donde ellos lo querían por misionero, y pronto empezaron sus labores del campo.

En octubre de I77o, el franciscano a cuyo cargo estaba la misión de San Javier del Bac se internó en las tierras de los gentiles, caminando hacia el norte durante siete días, y con esto había iniciado o remprendido una tendencia que costaría muchos esfuerzos a España y la vida a él mismo, pues el misionero del Bac no era otro que el padre Garcés, digno heredero de las aspiraciones del padre Kino, y que hallaría la muerte en la confluencia de los ríos Colorado y Gila, donde éste pusiera su objetivo.

200 Noticias de Sonora. México, ig de septiembre de I77I. Ibid, "Relación de la expedición". A. G. I., Guadalajara, 4I6. 


\section{CAPITULO CUARTO \\ LA LINEA DE PRESIDIOS}

\section{BuCARELI y O'Conor}

Desde diciembre de I77I, en que O'Conor tomó el mando de la frontera, hasta enero de $\mathrm{r} 777$, en que la dejó interinamente encargada a Don Manuel Muñoz, habiendo obtenido permiso para retirarse a México, los seis años intermedios significaron un considerable adelanto en la adopción de medidas tendentes a garantizar la seguridad de las provincias internas. El avance de los presidios al norte en la zona del río Bravo, las campañas incesantes en toda la línea contra los enemigos, las alianzas concertadas con varias naciones antes hostiles, la ejecución de las expediciones por tierra de Sonora a la Alta California y otros sucesos nos indican la vitalidad de la política española en el norte del virreinato mexicano en este momento concreto. Sus motores y directrices principales vienen dados en dos puntos fundamentales: uno de ellos es la aplicación del nuevo reglamento de presidios internos de $\mathrm{I} 772$; el otro, el extraordinario ensamblaje y coordinación habidos entre Frey Don Antonio María Bucareli y Ursúa, sucesor de Croix en el cargo virreinal, y Don Hugo O'Conor, sucesor de Bernardo de Gálvez en la comandancia de las armas de la frontera y luego comandante inspector de todos los presidios internos.

Una serie de circunstancias afortunadas hizo posible esta doble dirección, remota e inmediata, de los asuntos de las provincias internas, que $\tan$ halagüeños resultados produjo.

Ya tenemos presentado a Bucareli en los tiempos de su gobierno en $\mathrm{La}$ Habana. Independientemente de aquella insinuación de Múzquiz - que no había de realizarse - acerca de una posible erección de Durango en sede virreinal, cuyo primer virrey fuese Bucareli, había prestado éste indudable atención, 
'según muestran sus cartas confidenciales, a los acontecimientos ocurridos en Sonora, bien que la envergadura de la campaña y la presencia en ella del visitador bastaban a darle singular relieve. Pero Bucareli se manifestaba desde el principio escéptico acerca de sus resultados y de las promesas de Gálvez, y las extrañas circunstancias que rodearon la última parte de aquella empresa no podían mejorar el concepto en que la había tenido.

No será ocioso presentar la idea formada en la mente del capitán general de Cuba sobre lo ocurrido en Sonora, pues explicará la actitud del virrey ante algunas de aquellas cuestiones. Así, en febrero de 1767 , cuando se proyectaba la expedición, escribe: "no entiendo las ventajas de buscar más minas, cuando no tenemos con qué trabajar las descubiertas, ni que sea bueno exponer un número de tropas en tiempo que tratan de aumentarlas". " Desconfía de las promesos del visitador: "es mucho lo que ofrece a un tiempo, y como el que sabe puede con facilidad formar proyectos, temo que el sostenerlos tenga las dificultades que se encuentran siempre en las novedades". ${ }^{2}$ Al recibir las noticias de la preparación del tercer asalto al Cerro Prieto, repudia con toda claridad aquella guerra: "parece pensaban (en México) hacer el último esfuerzo contra los indios en otro ataque general, de dudoso éxito, porque no encontrarán las tropas objeto, se retirarán los indios como el año pasado, y volverán cuando lo crean desembarazado". 3 A partir de entonces se limita a expresar que stuspende su juicio sobre las noticias tan contradictorias que recibe de la Nueva España, aunque en general afirma el fracaso de la expedición, que "sólo ha producido muchos gastos y pocas esperanzas de lo que se creyó fácil". 4

Cuando en mayo de iz7i se le envían los despachos de virrey de México, su amigo O’Reilly le dirige una carta confidencial autógrafa en que, al tiempo que le comunica el importante servicio que le ha hecho en Madricl, le hace algunas prevenciones reservadísimas sobre Gálvez. 5 L Los contactos de Bucareli con el visitador, diarios, fueron, sin embargo, plenamente satisfactorios para él, ${ }^{6}$ y cuando Gálvez le pidió permiso para su sobrino, con el

Bucareli a Muzquiz. Habana, 26 de febrero de I 776 , confidencial. A. G. I., México, I24 I.

a Bucareli a O’Reilly, Habana, septiembre de 1769 , confidencial. A. G. I., México, I242.

3 Bucareli a Losada, Habana, to de enero de i77o, confidencial. A. G. I., México, i24?.

4 Bucareli a Losada, Habana, I4 de abtil de 1770 , confidencial. Ibid.

5 "Tengo por muy conveniente el decir a Vm. que oiga cuanto Gálvez quiera decirle, sin que éste pueda jamás inferir ni conocer su modo de pensar, que cuando embarcado prosiga Vm. sus averiguaciones y providencie con madurez y reflexión que acostumbra". O'Reilly a Bucareli, Madrid, 17 de mayo de 1772 , confidencial y autógrafa. A. G. I., México, 1242.

6 En diciembre, cuando lleva tres meses en contacto diario con Gálvez, asegura Bucareli: "No ha tenido conmigo el más leve tropiezo y sabe Vm. que no soy de los que digo amér a todo, tanto es su cuidado y tanta su penetración". Bucareli a O'Reilly. México, 27 de diciembre de I77 I, confidencial. Ibid. 
fin de que le acompañara a la península, Bucareli dio curso al nombramiento de comandante de las fronteras de Nueva Vizcaya y Sonora que a favor del teniente coronel Don Hugo O'Conor había dejado extendido y firmado en Io de septiembre el virrey Croix. He aquí cómo el propio Bucareli anuncia a O'Reilly este hecho diciendo "Que Monterrey, las Californias y provincias de Sonora y Sinaloa, ni están regladas su dotaciones, ni apenas se descubre cómo se gobiernan. Que en la provincia de la Nueva Vizcaya, fronteras de Chihuahua, subsiste la guerra con los indios, y que las tropas que oponemos están a cargo del sobrino del visitador, que en medio de que dicen que tiene espíritu, no son permitidas a su edad las experiencias, particular en que espero salir luego de cuidado, porque instado de los deseos del visitador para que lo acompañe a España su sobrino, destiné para que lo releve a Don Hugo O'Conor que marchó bien dispuesto de que me informase de la realidad, y de que me propusiese cuanto juzgue conveniente". 7

Desde este momento Bucareli, O'Reilly y O'Conor quedan estrechamente vinculados, puesto que el segundo, obtenido por Bucareli el virreinato se apresura a recomendarle proteja a O'Conor. La relación entre éste y O'Reilly, que sus sólos nombres irlandeses hace sospechar, es evidente cuando O'Reilly escribe a Bucareli: "El teniente coronel graduado Don Hugo O'Conor, que pasó a este reino desde La Habana cuando yo regresé a España la primera vez, es pariente mío, y de quien tengo por Croix, Cruillas y Rubí muy buenas noticias". ${ }^{8}$ Le pide que lo emplee en cosa que le pueda. proporcionar concepto y ascenso, y al saber el cargo que Bucareli le da y la confianza que en él pone, manifiesta su gratitud y añade: "espero que nunca desmerecerá su concepto y su favor. Y si en lo más mínimo faltase a Vm. no debe contar conmigo para cosa alguna, pero mientras se portara bien debo quererle como a hijo propio. Ninguno hay en su patria de más ilustre nacimiento. Es pariente mío muy cercano y le he tenido a mi lado desde sus más tiernos años. Hago a Vm. esta relación porque debo decirle todo". 9 A esta

7 Bucareli a O'Reilly, México, 27 de octubre de I77I, confidencial. Ibid. El rey había concedido a O'Conor el grado de teniente coronel y la capitanía de San Sabá — si había de subsistir este presidio_ por real orden de is de febrero a Croix. Este, en orden de 9 de septiembre del mismo año, lo había nombrado comandante inspector, con cuatro mil pesos. de la línea de presidios erigida por isu reglamento y Junta de Guerra y Hacienda de 27 de agosto; y al día siguiente le encomendaba la comandancia de las fronteras de Chihuahua con dos mil pesos de ayuda de costa. Rubio Mañé, Jorge Ignacio, El teniente coronel D. Hugo O'Conor y la situación en Chihuahua, año de $177 x$. B. A. G. N., XXX, núm. 3, México, 1959, págs. 353-39I.

8 O'Reilly a Bucareli, Madrid; 25 de septiembre de I77 I, confidencial. A. G. I., M'éxico, I 242.

9 O'Reilly a Bucareli, Madrid, 25 de septiembre de I772, confidencial. Ibid.

Dos meses después añade: "Yo espero que O'Conor desémpeñará con exactitud las órdenes que Vm. le diere y que no se apartará en lo más mínimo de su voluntad, y si faltare a esto no tendría que contar conmigo para cosa alguna, porque nunca perdono a los míos faltas de gratitud y de hombría de bien". Madrid, 25 de noviembre de I 772 . Ibid. 
interesante aclaración hecha por O'Reilly a Bucareli en el momento en que a O'Conor le era concedido el grado de coronel y la comandancia-inspección de los presidios debe añadirse que éste actuó a las órdenes del primero en la campaña de Portugal y debió pasar con él a América cuando O’Reilly fue enviado a Cuba. Ambos irlandeses eran en realidad primos hermanos, y de tanilia tradicionalmente rebelde al doninio inglés. ${ }^{10 .}$

Si Bucareli al entrar en México no hacía el menor aprecio de los esfuerzos realizados por Gálvez en Sonora y cré́a plenamente en el estado desastroso de la frontera de Nueva Vizcaya según lo pintaba Faini, en cambio creía firmemente en la necesidad de remediar ese estado y esperaba desde el primer momento tener por O'Conor noticias fidedignas de la situación y de lo conveniente para establecer la normalidad. Consideraba aquello el mayor cuidado de su gobierno, pero desde el principio puso su fe en O'Conor, "oficial de quien tengo mucho concepto, y de cuya conducta espero el reparo, porque sabrá no inutilizar las fuerzas que se pongan a sı orden”. " I

\section{O'CONOR EN LA FRONTERA}

O'Conor partió de México el so de octubre con la idea imbuida por Bucareli - a quien se la había impuesto una real orden ${ }^{\mathrm{I} 2}$ - de que lo primero que se necesitaba era un informe terminante de la verdadera situación de Niteva Vizcaya: de la importancia de las invasiones apaches, y de la eficacia de la defensa realizada por Bernardo de Gálvez. En compañía del irlandés marchaba, dispuesto a servir como voluntario en la frontera, Don Francisco Menocal, y en Querétaro se les unió el franciscano Fr. José Ignacio María Alegre y Capetillo, a quien se debe un valioso diario que refleja la primera etapa de la actuación de Don Hugo. Llegó éste a Chihuahua el iz de noviembre, cuando Don Bernardo de Gálvez se hallaba en su tercera campaña; regresó el sobrino del visitador diez días más tarde, después de su caída del caballo, y el to de diciembre, cuando todavía seguía en el mando nor enfermedad de O'Conor, fue herido por unos indios enemigos. ${ }^{13}$ En fin, el relevo tuvo lugar el I4 de diciembre de т77, y O'Conor recibió de Don Bernardo el mando de la compañía que éste había alistado para sus expediciones: ciento

\footnotetext{
I a Datos genealógicos de O’Conor en el citado artículo de Rubio Mañé, quien sitúa el nacimiento del inspector en Dublin, en diciembre de 1734 . En 3 de agosto de 1763 se le había admitido como caballero en la Orden de Calatrava.

I I Bucareli a Losada, México, 27 de diciembre de I77I, confidencial. A. G. I., México, I24I.

I 2 Real orden de 26 de octubre y de 21 de diciembre de 1771 , a Bucareli, motivada por los informes de Faini. A. G. I., Guadalajara, 5 I 2.

I 3 Il diario del $P$. Alegre, que proporciona estos datos, ha siclo publicado por Rubio Mañé en el B. A. G. N., XXX, núm. 3, 397-471, y núun. 4, 649-665. Ejemplar manuscrito en R. A. H., Boturini, 24, fols I 2 I-I 94 .
} 
cuatro hombres famélicos y deesnudos. Seis días después remitía a Bucareli el informe pedido. ${ }^{14}$

$\mathrm{Ni}$ que decir tiene que O'Conor pinta de Nueva Vizcaya un cuadro lamentable. En sólo el transcurso del año, desde el $\mathrm{r}^{\circ}$ de enero al 20 de diciembre, había sufrido la provincia ciento cuarenta muertes, dieciséis heridos, otros tantos cautivos y siete mil bestias robadas, sin contar los ganados destrozados. En lo que la hostilidad de los apaches había durado desde el principio de la guerra, que se fijaba en el año I748, habían ocurrido más de cuatro mil muertes y los daños se calculaban en ṇás de doce millones. El comercio y los abastecimientos de las poblaciones se veían entorpecidos por tales hostilidades y consiguientemente se atrasaba y decaía la explotación minera.

Bucareli deseaba tener noticias para sobre ellas convocar junta de hacienda y guerra en que elaborar un plan de acción que devolviese la superioridad a las armas españolas y la paz a las provincias internas. Relaciones semejantes a la suministrada por O’Conor había pedido a Don Jacobo de Ugarte y Loyola, gobernador de Coahuila, ${ }^{15}$ y a Faini, que lo era de Nueva Vizcaya, y ambos obedecieron con presteza, viniendo éste a informar verbalmente a México. ${ }^{16}$ La primera decisión del virrey de mejorar la situación de aquéllos territorios, que se hizo de esta manera visible, suscitó desde entonces un sincero deseo de cooperación por parte de las autoridades provinciales.

Estos tres informes, así como los de diversos organismos de la villa de Chihuahua y su corregidor, ratificaron a Bucareli en sus propósitos. ${ }^{17} \mathrm{Su}$ primera resolución a este respecto consistió en el envío de trescientos fusiles a Coahuila, para que fuesen repartidos entre los vecinos. ${ }^{\text {I8 }}$

I4 Vid. Ocaranza, Fernando, Crónica de las provincias internas de Nueva España. M'éxico, I 939, pág. I 85 y sigs. En A. G. I., Guadalajara, 5 I2, remitido con carta de Bucareli a Arriaga, México, 27 de enero de I772, núm. i 93. Publicado por Rubio Mañé en el B. A. G. N., XXX, número 3, págs. 372-39o. C.fr. el Informe de Hugo O’Conor sobre el estado de las provincias internas del norte, I77I-76, publicado y anotado por Enrique González Flores y Francisco R. $\Lambda 1$ mada, México, D. F., I952, puntos 6 al 42, págs. I9-37. Extendido por el comandante inspector en M'éxico, 22 de julio de I777. A. G. I., Guadalajara, 516. En la edición de González Flore: faltan todos los documentos que acompañan al original y la última página del informe.

I 5 Coahuila acababa de recibir en la villa de San Fernando de Austria, que sólo contaba cuarenta vecinos, la guarnición de San Sabá, aunque un poco mermada, pues veintinueve de sus hombres estaban reforzando la de Béjar. Ugarte y Loyola a Bucareli, Monclova, 27 de noviembre de I77I con "Estado" adjunto. A. G. I., Guadalajara, 5I2. En carta de 4 de noviembre, ibid, comunica otros destrozos. Vid. Velasco Ceballos, Rómulo, La administración de D. Frey Antonio Maria Bucareli y. Ursuia, I, 14-16. M'éxico, 1936. 2 vols.

I6 Faini a Arriaga. México, 27 de diciembre de I771. A. G. I., Guadalajara, 512.

i 7 Bucareli a Arriaga. México, 22 de enero de 1772 , núm. I4I, reservada. Ibid. Vid. Velasco Ceballos, I, 33-34.

I8 Bucareli a Arriaga. M'éxico, 25 de enero de 1772, núm. i77. A. G. I., Guadalajara, 512. Bucareli a Atriaga. México, 27 de marzo de I773, núm. 838. A. G. I., Guadalajara, 5 I 3. 
En sólo los dos primeros meses de su mandato, O'Conor tuvo noticia de nueve asaltos que habían causado cincuenta y seis muertes, sin contar los numerosos heridos y desaparecidos, y considerables robos de ganado. ${ }^{19}$ Particular envergadura revistió la incursión que realizó una muy crecida partida de indios apaches, cholomes, norteños, criados --indios que desde pequeños habían sido capturados por los españoles y habían vuelto luego a los suyos - y tarahumaras que llevaban oculto el rostro, que entrando junto al presidio de Guajoquilla incendiaron todas las cașas que había a ambos lados del río, las haciendas de Guajoquilla y Presidio Viejo, y río abajo las de Tierra Blanca y San Antonio de la Ramada. Balance final: treinta y nueve muertos, dieciséis heridos, varios desaparecidos... ${ }^{20}$ Haciendas, pueblos y recuas de trajinantes eran atacados por igual. Las salidas, tardías, de las tropas sólo servían para comprobar los estragos: eran escasas, mal equipadas, y con las cabalgaduras en mal estado durante el invierno.

En marzo, recibidas estas lamentables noticias, en dos juntas de guerra y hacienda resolvió Bucareli ordenar a O'Conor el reclutamiento de un cuerpo de trecientos hombres con que pudiese salir a campaña sin clejar desguarnecida la villa de Chihuahua, donde se mantendría la antigua compañía de Bernardo de Gálvez, e igualmente se determinó allí, a la vista del plano del marcuués de Rubí, la transmigración de los presidios de Julimes, Cerro Gordo, San Sabá, Santa Rosa y Monclova, a las orillas del río Grande. Se ponían a disposición de O'Conor cien mil pesos para los gastos necesarios. Desde entonces queda claro el plan de operaciones que siempre va a mantener el virrey: indicada la línea donde deben ser colocados los presidios, hay que limpiar primero de enemigos todo el territorio al sur de esa línea y luego trasladar aquéllos a su nuevo emplazamiento. La decisión de Bucareli es tajante, como su sinceridad: "Siempre tengo la desconfianza de que es un terreno que no he visto, y una guerra de que carezco de práctica; y siendo el daño evidente y preciso el aplicar pronto remedio, ni me ha detenido para la resolución los gastos en que va a entrar el erario, ni me detendrá para mayores providencias en lo sucesivo". ${ }^{2 r}$ De una tercera junta habida el 2 de abril de r 772 salió ya el plan detallado de la actuación de O’Conor, remitiéndosele quinientas cincuenta carabinas de caballería y otras tantas espadas, autorizándole a nombrar un comisario y tesorero de guerra. El cuerpo vo-

I 9 O'Conor a Bucareli. Chihuahua, is de febrero de I 772 , con "Diario" adjunto. A. G. I., Guadalajara, 5 工 3 .

20 Faini a Bucareli. Durango, 28 de febrero de 1772. Faini a Arriaga. Durango, 6 de marzo de $177 z$ Bucareli a Faini. México, i 8 de marzo de I772. Ibid.

21 Bucareli a Arriaga. M'éxico, 25 de marzo de $1 / 72$, núm. 295, reservada. Ibid.

Su proyecto fue aprobado "pero sin perder de victál lo conveniente que sería atraer a los indios por medios stuaves a rue permanezcan quietos". Real orden de I de julio de r772, Ibid. 
lante tendría, por fin, incluida la tropa de Chihuahua, cuatro compañías de cien hombres y ciento veinte indios auxiliares. ${ }^{22}$

Decidido, pues, O'Conor a poner en práctica las resoluciones de las juntas, dejó señaladas las batidas que debían practicar las escuadras de los presidios y Chihuahıra, ${ }^{23}$ y poniendo la segunda compañía volante -que había sido la de Bernardo de Gálvez- para el resguardo de esta villa, partió con las otras tres a reconocer los terrenos de la orilla del río Grande donde debían trasladarse los cinco presidios citados, expulsando al mismo tiempo a las partidas de bárbaros que encontrase a este lado del río. Con esto puede decirse que se había puesto en marcha la reanudación de la expedición de Nueva Vizcaya, que adquiría gran semejanza con la de Sonora años atrás. Las cuatro compañías de la fuerza expedicionaria quedaron puestas a cargo de los capitanes Don Domingo Díaz, Don Francisco de la Borbolla, Don Manuel Esteban Alegre y Bohórquez, y Don Francisco Menocal, a los que Bucareli extendió los correspondientes títulos. Cada capitán tenía bajo su mando dos tenientes y dos alféreces, mientras que los dos ayudantes mayores Don Roque de Medina y Don Juan de San Vicente debían auxiliar al propio O'Conor en sus funciones. O'Conor nombró comisario y tesorero de la expedición a Don Manuel Antonio de Escorza, que había pertenecido al comercio de Chihuahua. ${ }^{24}$

El primer problema con el que O'Conor tropezara antes de ponerse en camino fue el hallar caballada para la nueva fuerza. Cuatrocientos hombres necesitaban otras tantas mulas y dos mil cuatrocientos caballos. Faini logró reunir y enviar mil; el conde de San Pedro del Alamo preparó quinientos. El propio O'Conor hizo donativo de otros mil a la real hacienda. ${ }^{2} 5$

E1 3 de diciembre de $177^{2}$ salía O'Conor con su cuerpo expedicionario de Chihuahua y se dirigía a Coahuila atravesando el Bolsón.

\section{EL REgLAMENTO DE I772}

Mientras Bucareli adoptaba sus disposiciones para el resguardo de la

22 Bucareli a Arriaga. México, 24 de abril de I772, núm. 33I. Con testimonios de la junta. Ibid. Vid. Velasco Ceballos, I, 35-52.

23 Informe de Hugo O'Conor, puntos 63 al 76, págs, 47-5I.

24 Bucareli a Arriaga. México, 26 de julio y 26 de septiembre de I 772 , núms. 464 y 57 I. A. G. I., Guadalajara, 5 I 2.

Informe, arts. 80 y $8 \mathrm{I}$, págs. 52-53. He aquí la relación de los demás oficiales según el primer documento citado: primeros tenientes, Don Joaquín de la $O$, Don Jacinto Gutiérrez, Don Antonio de Arce y Amaya, Don Tomás Egurrola; segundos tenientes: Don José Camino y Montero, Don Pedro Macías, Don Pedro Parras, Don José Simón de Ochoa; primeros alféreces, Don Ramón Marrufo, Don José Ortega, Don Manuel Villa, Don Miguel Montiel; segundos alféreces: Don Ildefonso Rodallegas, Don Antonio de Acosta, Don Domingo Marañón, Don Juan José Padilla.

25 Bucareli a Arriaga. México, 26 de septiembre de 1772, núm. 567. Informe, art. 79, pág. 52 , 
frontera, hábilmente secundado por O'Conor, en Madrid, Arriaga había acogido con interés el reglamento de presidios que, formado por Gálvez sobre el dictamen de Rubí y aprobado por Croix y la junta de México, había sido dado conocer ya impreso en I77I. En febrero de I772 pasó Arriaga a O'Reilly, según sugiriera el propio marqués de Croix, este reglamento para su consulta con vista a la aprobación real. O'Reilly hubiera deseado ${ }^{26}$ informes sobre el particular de todos los gobernadores de la provincias fronterizas, y el dictamen final de Bucareli, que ya gobernaba el virreinato. Este, por su parte, aprobaba la reorganización estratégica de la línea, idea patrocinada por Rubí, pero no las demás reformas de sueldos, nombramientos de habilitados para el gobierno económico de los presidios, etc., y en conjunto su valoración del reglamento de Gálvez y Croix era desdeñosa: "Esto ha sido una cosa hecha en los últimos días del gobierno antecedente para figurar ahorros a la real hacienda, como que no habían de experimentar los efectos contrarios que producía". ${ }^{27}$

Todo el abultado expediente sobre el estado de los presidios y el reglamento había sido pasado además el 7 de abril, a instancia de Croix, al marqués de Rubí, 28 quien en su informe de 23 de mayo de 1772 , dado en Barcelona, ${ }^{29}$ se ratificó en el dictamen que redactara a raíz de su visita a las fronteras de Nueva España y se adhirió a las reformas de orden interno propuestas. Halagaba a Rubí, reconocidos los cincuenta y tres documentos y plano recibidos, advertir que su propio "Dictamen" había sido generalmente adoptado. "También pudiera producirse en abono del citado dictamen la impropia atribución de la parte que no tuvo en su formación el ingeniero ordinario Don Nicolás de Lafora, quien en su mapa de la frontera (como en varios otros lugares de este expediente), que redujo a punto menor del que construyó antes el capitán de infantería Don José de Urrutia, cita como trabajo de ambos el que yo hice y formé solo en el pueblo de Tacubaya, separado de residencia y comunicación con el citado ingeniero, que se hallaba en México, bastando este hecho para que se haga menos apreciable su aprobación".

Asienta el marqués que la propuesta línea de fortificaciones venía a ser semejante a la que puso el zar Pedro I de Moscovia en la frontera de la pequeña Tartaria frente a Crimea, y la idea de tal sistema se hallaba también en el Tratado de la guerra defensiva del marqués de Santa Cruz, habiéndola puesto en práctica Portugal, Cerdeña y otras naciones, sobre todo

26 O'Reilly a Bucareli. Madrid, 22 de febrero de 1772 , confidencial. A. G. I., México, 1242.

27 Bucareli a O'Reilly. México, 27 de mayo de 1772 , confidencial. Ibid.

28 Real orden de 7 de abril de 1772 a Rubí. A. H. N., Estado, 3882-7.

29 Ibid. 
en las costas. $\mathrm{Y}$ la había recogido en $\mathrm{I}^{2} 5 \mathrm{el}$ ingeniero Maigret, que además sugería la posibilidad de constituir una segunda línea, que podía ser de poblaciones. Con tales fundamentos, viene Rubí a ratificarse en su propuesta, pero concediendo escasa importancia a la traza y solidez de la fortificación de los presidios, "por la ninguna experiencia de atacarlos los indios de viva fuerza, como no lo ejecutan ni aun en las haciendas, defendidas con una simple cerca de tapial", y consiguientemente consideraba de ninguna utilidad el envío de cañones y artilleros a la frontera.

Son curiosas sus observaciones acerca de las modificaciones introducidas por Croix y Gálvez en el régimen interior de los presidios, pues no se le escapaba el contrasentido de rebajar casi en una tercera parte el haber de los soldados cuando iban a hacerse más difíciles los suministros de las guarniciones al ser éstas desplazadas al río Grande. Por otra parte, no confiaba en la aptitud de los oficiales subalternos que habían de sustituir a los capitanes en el manejo de los situados con la reducida gratificación de un I \%: los capitanes habían tenido hasta ahora un cajero o factor mejor pagado y competente. Rubí creía preferible encomendar la administración de la masa común a los Oficiales Reales y a subdelegados de estos.

No omite Rubí una alusión al nuevo cargo de comandante inspector -que, en su criterio, debería tener su ayudante, ambos con sobrestueldoy un mesurado encomio de la idoneidad y experiencia de Don Hugo O’Conor, a quien desde luego conocía personalmente.

En fin, el I 8 de julio Arriaga ordenó que el marqués de Croix reuniese en su casa una junta de la que formarían parte como vocales O’Reilly, Ricardos, Gálvez y Ortiz Parrilla, capitán del presidio de Santa Rosa en Coahuila que entonces se hallaba en la corte. ${ }^{30}$ Las reuniones se tuvieron a partir del 27 de julio y los cinco vocales pudieron presentar a Arriaga su informe definitivo el $I^{\circ} .^{\circ}$ de agosto, obteniendo la aprobación real de sus acuerdos el to de septiembre. ${ }^{3}$ O'Reilly tuvo cuidado de hacer incluir en el nuevo reglamento un artículo -el i 3 del título i4 - que daba libertad al virrey para poder alterar las normas en aquél contenidas en caso de hallar fuerte reparo en seguirlas, dando luego cuenta al rey: "Todo lo que no esté prevenido en el presente reglamento - dice el punto en cuestión- y no sea

30 Ortiz Parrilla obtuvo permiso para venir a la península después de la inspección realizada en la boca del río Grande. En enero de 1773 se le prorrogaría la licencia en España por un año más, y en octubre de 1774 se le concedió grado de brigađier adscrito al Estado M'ayor de Valencia. Murió en Madrid en I775. En el mando đe Santa Rosa le sucedió el capitán Don Juan Antonio Serrano. A. G. I., México, 514 y 515.

${ }_{3 I}$ Ordenes de 18 de julio de 1772 , informe de la Junta en ${ }^{\circ}{ }^{\circ}$ de agosto, devolución del expediente por Croix el 4 de septiembre y real orden de aprobación en ro de septiembre. A. H. N., Estado, 3882-7 y 9 . 
perteneciente a subordinación y leyes penales, lo determinará mi virrey, y cuanto en este particular observase el inspector comandante se lo hará presente para que determine lo que tuviere por más conveniente a mi servicio. $Y$ si algún punto de este reglamento encontrase en la práctica inconveniente grave, concedo facultad a mi virrey para que providencie interinamente, dándome parte de los motivos para mi resolución". Con estas palabras concluye la parte de reglamento propiamente dicho, pues todo lo que sigue es la instrucción para la nueva colocación de presidios. "Este artículo, dirá el irlandés a su amigo, me tranquiliza sobre el acierto, quedando a Vm. la necesaria facultad para las variaciones que convenga hacer,", 32 sin embargo de que la junta había actuado con toda escrupulosidad, oyendo previamente a Lafora y a Urrutia y tomando noticias de Bernardo de Gálvez.

La promulgación en Madrid del Reglamento e Instrucción para los Presidios que se han de formar en la Linea de frontera de la Nueva España. Resuelto por el Rey Nuestro Señor en Cédula de Io de septiembre de 1772 daba carácter e impulso oficial al proyecto de traslado de los presidios formulado por Rubí, cuya idea había sido adoptada ya por Gálvez y Croix, y cuya puesta en práctica había sido intentada, a lo menos parcialmente, por Bucareli. 33 Era, pues, decretada la transmigración de los presidios de Altar, Tubac, Terrenate y Fronteras a lugares más convenientes al norte y al oeste de sus actuales posiciones, quedando todos a distancias de cuarenta leguas unos de otros y el íltimo respecto del de Janos.

De los de Nueva Vizcaya y Coahuila, los de San Buenaventura, Paso del Norte, Guajoquilla, Julimes, Cerro Gordo, San Sabá, Santa Rosa y Monclova pasarían al valle de Ruiz, Carrizal, valle de San Eleazario, Junta de los Ríos, y cuatro lugares intermedios hasta Río Grande. Se unificaban las dotaciones de los presidios y el vestuario, sueldo y armamento de la tropa, que, por su constante ejercicio en guerra viva, sería considerada como veterana, y se decidía la creación de un comandante de toda la Línea con ocho mil pesos de sueldo, auxiliado en el desempeño de sus funciones por dos capitanes nombrados ayudantes inspectores. Se pretendía con esto la unidad de mando y una supervisión constante del estado y actuación de todos los presidios, que los mantuviese en las condiciones ideales para cumplir con eficacia la misión que les estaba confiada. El rey se reservaba para cuando lo estimase oportuno el nombramiento de un comandante general de las

\footnotetext{
32 O'Reilly a Bucareli. Madrid, 25 de julio, y San Ildefonso, 26 de agosto de I772, confi-
ciales. A. G. I., México, I 242 . denciales. A. G. I., México, I 242.

33 Ejemplares impresos del reglamento en A. G. I., Guadalajara, 522, y dos manuscritos -uno de ellos firmado por los cinco miembros de la Junta y otro con la estampillas del rey y la
autenticación de Arriaga - en A. H, N. Estado,
} 
provincias internas, a quien en este caso quedarían subordinados el comandante inspector y los gobernadores de estas provincias. Semejante idea era firmemente apoyada por la Junta, pero por el momento, el mando del comandante inspector, que debería tener grado no inferior al de coronel de caballería - sin embargo de que el primero, O'Conor, lo era de infantería - era el puramente militar de los presidios. En cuanto al gobierno interior de estos, el punto principal consistía en la separación del capitán de su administración económica, quedando ésta -el pago y avituallamiento de los soldados- encomendada a un oficial habilitado, que con los dos tercios de la paga de los soldados cuidaría de tener siempre bien surtido el almacén del presidio, abonándose a ellos en metálico la tercera parte, con idea de fomentar el comercio de la región.

Dábanse las normas para obtener unas victorias decisivas que procurasen la supremacía indiscutible de las armas españolas sobre los bárbaros, por medio de una guerra llevada a cabo de la manera más justa y humanitaria. $Y$ quedaba finalmente establecido que siempre que los indios pidiesen la paz, se les concedería.

E1 plan a seguir por el primer comandante inspector, según se clesprende del mismo reglamento y de las instrucciones más detalladas que para $\mathrm{O}^{\prime} \mathrm{Co}-$ nor preparó Bucareli, había de consistir en determinar el lugar de emplazamiento de cada presidio, revistarlos en su anterior posición para separar a los oficiales y soldados que no fuesen útiles para el servicio, y trasladar aquéllos a su nueva ubicación, procediéndose ante todo a la fábrica material de los acuartelamientos según el proyecto que para estas edificaciones presentó Lafora, para cuyo gasto se entregarían a cada presidio mil pesos por una sola vez.

Otros puntos de interés que decide el reglamento son la supresión de las compañías del Nuevo Reino de León y de Nayarit, y el pago de los situados de los presidios en las cajas reales de Sonora, Chihuahua y San Luis de Potosí. Quedaban tácitamente suprimidos los presidios de Buenavista, Horcasitas y Orcoquiza, no contando la línea más que con quince, y quedando al norte de ella los de Santa Fe de Nuevo México y de San Antonio de Béjar. Estos dos enlazarían con la Línea gracias a los destacamentos de Robledo y del arroyo del Cibolo que deberían crearse al norte de El Paso el primero, y entre Béjar y la bahía del Espíritu Santo el segundo. La compañía de Nuevo Santander, que no formaba parte de la línea, quedaría subordinada al gohernador de esta provincia, que haría las veces de capitán.

O’Reilly se preocupó también de que la junta de generales de Madrid, a la que Arriaga había pasado el testimonio de lo actuado en México hasta 
adoptar las resoluciones de 2 de abril, hiciese constar en su informe que todas las providencias de Bucareli habían sido las más oportunas y acertadas. 34 En cambio, hay que atribuir a Gálvez el párrafo final de este informe, en que se pide a Carlos III encargue muy especialmente al virrey el sostenimiento, fomento y auxilio de los antiguos y nuevos establecinientos de Californias, "como antemural que son de Nueva España y para su expansión sobre la dócil gentilidad vecina", idea que se repite en el artículo final, número 29 de la Instrucción para la colocación de las guarniciones. El informe establecía que frente al costo anterior de 453.899 pesos 6,6 , de los presidios, el nuevo sistema producía un ahorro de 86.027 pesos $2,6,6$, dejando el gasto en 367.872 pesos 4 , o,, y en el mismo documento se dice: "Es igualmente recomendable la consideración de que para el caso de una guerra con la nación británica que hoy se halla establecida por el último tratado en gran parte de la Luisiana y no es imposible que desde allí intentase hacer alguna irrupción por la provincia de Texas o sobre la del Nuevo México al auxilio de las naciones de indios del Norte que mantiene en su alianza, podrá servir utilísimamente aquella tropa presidial, una vez puesta sobre el pie de vete"ana y aguerrida". La aprobación de Carlos III a la consulta de sus generales se expresa en unas líneas autógrafas de Arriaga del to de setiembre: "S. M. se ha conformado con cuanto se propone, y manda se dé luego curso con las respectivas órdenes que resultan para su cumplimiento".

La decisión real y ministerial a la conclusión de las calamidades que padecía la frontera se mostró tan operativa que por real orden de 18 de setiembre de 1772 no solo se aprobó la leva del cuerpo de trescientos hombres que debía reforzar las tropas de Nueva Vizcaya según acuerdo de la Junta de México, sino que, siguiendo una de las máximas propuestas por los generales en Madrid, se dispuso la formación de un destacamento de cien hombres de la tropa veterana del virreinato que marchase igualmente a tomar parte en las campañas de O'Conor, 35 lo cual entraba en la línea de conducta establecida años atrás en la expedición de Gálvez a Sonora.

En I4 de setiembre le era otorgado a O'Conor el grado de coronel y el empleo de comandante inspector de todos los presidios internos, siéndole expedido el despacho y el título correspondientes en 20 y 23 del mismo mes, liegando estos documentos a manos del interesado cuando se encontraba en la villa de San Fernando de Austria, en Coahuila. 36

34 O'Reilly a Bucareli. Madrid, 25 de septiembre de I772, confidencial. A. G. I., Méxi-
I 242.

35 A. G. I., Guadalajara, 5 I 2.

36 Ibid. Patente de comandante inspector en A. G. S., D. G. Tesoro, inv, 2. ${ }^{\circ}$ 56-I7I. 


\section{PRIMERa EXPEDICIÓN DE O'CoNor}

Siguiendo las instrucciones que había recibido de México en abril, O'Conor, dejando suficientemente guarnecida la frontera de Nueva Vizcaya, $\mathrm{y}$ en posesión del armamento y la caballada que había estado precisando, salió de Chihuahua con trescientos hombres - primera, tercera y cuarta compañías volantes del cuerpo expedicionario- el 3 de diciembre de I772. ${ }^{37}$ E1 30 de noviembre, un destacamento de ciento veinte hombres se había puesto en marcha desde Monclova en dirección opuesta a la de $\mathrm{O}^{\prime}$ Conor. ${ }^{8} \mathrm{El}$ doble objetivo de la expedición consistía en reconocer lọs terrenos donde se debían situar los presidios removentes y castigar al mismo tiempo a los apaches lipanes que hostilizaban Nueva Vizcaya y Coahuila.

Por Tabalaopa y San Jerónimo, O'Conor se dirigió a la hacienda de Hormigas, abandonada, internándose seguidamente en el desierto oriental. También en Collame, por donde pasó, había habido una misión de los indios cholomes, y en el derruido pueblo de San Juan habitaron en otros tiempos los norteños o julimeños. Descendiendo el curso del Conchos, O'Conor alcanzó el iz de diciembre el antiguo presidio de la Junta de los Ríos que pocos años antes había sido retirado más al sur, a Julimes. Sin embargo, su fábrica de adobes bien ideada se conservaba en buen estado, aunque techos y puertas habían sido quemados por los indios enemigos, que alguna vez arrancharían allí. Los dos pueblos de Guadalupe y San Cristóbal se hallaban igualmente quemados y derruidos.

Desde este momento, la marcha hacia el este, procurando no desviarse del río Grande, es constante. Pasado el arroyo de la Mula, el aguaje de San Carlos, donde nutucho tiempo habían estado arranchados los enemigos, pareció apropósito para situar en él el presidio de Cerro Gordo. Aquí se encontró una huella, y yendo en su seguimiento, tres días después - el 25 de diciembre - atacó O'Conor una partida de indios a los que hizo tres bajas y capturó más de doscientas caballerías que llevaban robadas, así como una niña de seis o siete años, que bautizó el capellán. El mismo día tomó contacto con los exploradores del destacamento de Coahuila, y al siguiente se hallaba ante la sierra de los Chizos. El camino de indios que seguía O'Conor le condujo pegado a la muralla de San Dámaso y luego le llevó a cruzar el río Grande, el 27 ; el 30 de diciembre vio a la orilla sur del río el paso de San Vicente, que presentaba no muy buen terreno, pero sería conveniente

37 Diario de operaciones de $O^{\prime}$ Conor, 4 de diciembre de 1772 al 22 de enero de 1775. A. G. I., Guadalajara, $5 \mathrm{r}_{3}$.

38 Extracto de noticias de las provincias internas. México, 27 cle enero de I773. Ibid. 
para establecer en él el presidio de San Sabá. Las muchas huellas que se advertían mostraban que numerosas rancherías de indios habían emprendido precipitada fuga al conocer la aproximación de la fuerza española. El 2 de enero de I773 pasó O'Conor de nuevo a la orilla sur y emprendió la difícil ascensión de la cuesta de las Animas, encontrándose sin agua; el desgaste de la caballada en la larga marcha que ya duraba un mes era perceptible. El Io de enero llegó al paraje de la Babia, dotado con un abundante ojo de agua; el I 3 se detuvo en el río Escondido, cuya agua, sin embargo, enfermó a la caballada, pero el ro hizo alto en el paraje del Oso, que ofrecía agua y pastos abundantes: allí se mantuvo hasta el 20, pero los últimos tres días de aquel descanso fueron incomodados por durísimo viento del norte. "Con trabajo se podía pasar en el campo". Aquel viento que soplaba de los "barren grounds" les trajo una intensa helada, de la que murieron siete caballos. El 20 emprendieron el camino y el $2 \mathrm{r}$, habiendo salido el sol, se encontraron con Don Alejo de la Garza Falcón, teniente de San Sabá, que venía a su encuentro con los jefes lipanes Bigotes y Juan Tuerto, que deseaban pedir la paz a O'Conor, quien se la concedió. El 22 entraba el cuerpo expedicionario en la villa de San Fernando de Austria en Coahuila, donde se hallaba establecido el presidio de San Sabá; su ingreso en la población fue observado por un grupo de indios de la ranchería de Bigotes que estaban "admirados de ver tantos españoles".

Las rancherías de los lipanes, que sumaban más de un millar de hombres de armas, se hallaban entonces concentradas en la confluencia de los ríos Grande y Puerco o Colorado. O'Conor hizo llamar a los capitancillos proponiéndoles un pacto por el que ellos se reducirían a misiones o pueblos, restituyendo las caballadas robadas y los cautivos que tuvieran en su poder: y serían aliados de los españoles en la guerra contra las naciones enemigas. Los lipanes contestaron estar de paz y no tener caballadas ni cautivos españoles, negándose rotundamente a establecerse en pueblos o misiones; ofreciendo desde luego su amistad en la guerra con los comanches. O'Conor les prometió protección a este respecto y "de pura alegría armaron en sus rancherías varios mitotes de los que acostumbraban en iguales casos". 39

Por entonces recibió O’Conor el nuevo reglamento, la instrucción formada por Bucareli, la noticia del destacamento de dragones que marchaba a ponerse a sus órdenes, ${ }^{\circ}$ y la del descubrimiento de una conjuración de los

39 O'Conor a Bucareli. San Fernando de Austria, 31 de marzo de 1773. Ibid.

40 Bucareli a Arriaga. México, 27 de marzo de 1773, núm, 832. Tbid. Velasco I, Io7-110. La instrucción del virrey a O'Conor dada en México, 1. $0^{\circ}$ de marzo de i773, en A. G. I., Guadalajara, 512. Los dragones salieron de México hacia Durango en i 2 y 15 de febrero anterior. Bucareli a Arriaga, México, 24 de febrero de I773, núm. 798. A. G. I., Guadalajara, 4I6. 
tarahumaras de Nueva Vizcaya que acababa de desenmascarar el corregidor de Chihuahua. Dada la negativa de los lipanes a colocarse bajo el gobierno español, O'Conor discutió con el gobernador de Coahuila, Don Jacobo de Ugarte y Loyola, la conveniencia de atacarlos, de lo que el primero no se mostraba partidario pues para obtener una victoria decisiva sería necesario combatirlos por sorpresa, sin darles tiempo a que se dispersaran, y esto sería prácticamente imposible, y de ninguna manera conveniente, supuesto que por el momento se hallaban de paz. ${ }^{\mathrm{I}}$

El 4 de abril remprendió O'Conor la marcha, con el fin de buscar nuevo asentamiento a los presidios de Santa Rosa y Monclova. Partiendo de la villa de San Fernando de Austria con sus dos compañías, se trasladó a San Juan Bautista de Río Grande y desde aquí el 6 de abril empezó a remontar la corriente "por el camino real que tienen hecho los lipanes" a quienes invitó a mantenerse en la orilla norte del río. El 7 llegó al paso de San Sabá, donde el 12 quedó establecido el presidio de Monclova. ${ }^{2}$ El I 5 continuó su avance, deteniéndose en la junta del río de San Diego con el Grande, donde se presentaron los jefes lipanes Javier y Cabello Largo, que al día siguiente entregaron una cautiva tarahumara. Desde el 20 se hace difícil alcanzar la orilla del río Grande, y el 22 empieza O'Conor a retroceder hacia el sur. El 24 estableció el presidio de Santa Rosa en el nuevo paraje del Ojo de Agua Verde, 43 y continuando por aquí su progresión hacia el oeste, con alguna inclinación al sur, se detuso el 2 de mayo en la Babia, donde consideró conveniente se estableciese más alelante el presidio de Orcoquiza que ahora se suprimía en Texas, y así lo propuso al virrey. Enderezando luego su ruta al noroeste, arribó al aguaje de Nuestra Señora del Carmen tres días después, y allí se mantuvo hasta el 9, mientras se le incorporaba el teniente Egurrola, al que el 23 del mes anterior había enviado desde el arroyo de las Animas a reconocer el curso del río Grande hasta el pico de Teria. Tenía O'Conor noticias de que los gileños, natajes y mezcaleros se habían congregado en las inmediaciones del presidio abandonado de la Junta para sorprenderle en su canino de regreso a Chihuahua

El I I de mayo, bajando con mucha dificultad la cuesta de Berroterán, le fue posible a O'Conor pisar de nuevo la orilla del río Grande, tres leguas al norte del pico de Teria, y recorriendo en sentido inverso el camino que siguiera cuando se dirigía a Coahuila, volvió a transitar por el paraje de San Vicente, paso de los Chizos, arroyo de San Carlos, y por el pueblo

4I O'Conor a Bucareli. San Fernando de Austria, 3i de marzo de iz73. Rucareli a Arriaga.

México, 27 de marzo de I773, con Extracto de ncticias. A. G. I., Guadalajara, 5 I3.

42 O'Conor a Bucareli. Real Calmpo del $t: 0$ de San Rodrigo, i 2 de abril de I772. Tbid.

43 Diario de O'Conor, I 3 al 24 de abril cle 1773. Agua Verde, 24 de abril de ry73. Ibid. 
abandonado de los Puliques alcanzó el 27 de mayo la Junta de los Ríos, que se advirtió había sido ocupada por los enemigos un mes antes. En este trayecto se capturaron unas doscientas cincuenta cabezas de ganado y se causó una baja a los apaches en un encuentro, y luego por San Juan, Collame, La Escondida, Hormigas y San Jerónimo, llegó a Chihuahua el 5 de junio, entrando en la villa por la noche para evitar las aclamaciones y recibimientos que en ella querían hacerle, con repiques de campanas y otras demostraciones con que los vecinos deseaban manifestar su alegría por su regreso. 44

Con esto concluyó la primera expedición de O'Conor, que había durado seis meses, dando como resultado el reconocimiento de los territorios de la boca setentrional del Bolsón desde la Junta a San Juan Bautista, la fuga de los indios a la orilla izquierla del río Grande y la determinación de los parajes donde deberían establecerse los presidios, estando ya en construcción los de Monclova y Santa Rosa de Agua Verde, y en proyecto la fundación de otro en la Babia.

\section{LA LUCHA POR LA PAZ EN TODO EL FRENTE}

Cuando O'Conor entra en Chihuahua el 5 de junio de 1773 es ya comandante inspector de todos los presidios de la frontrera septentrional de Nueva España, desde el golfo de Californias al de México. Los gobernadores de las provincias internas le están ya subordinados, y sus preocupaciones defensivas se han ampliado del mero marco de Nueva Vizcaya, a las setecientas leguas que demarcaban los quince presidios cuya vida y operaciones había de regular, más los dos situados a retaguardia en Sonora, y los de Santa Fe y Béjar, que quedaban al norte y fuera de la Línea.

La situación que a O'Conor se le plantea no es en absoluto esperanzadora. Si a fin de diciembre de I77I, Corbalán aseguraba que los indios recién sometidos se mantenían tranquilos, la presión de los apaches sobre las misiones y presidios de la Pimería Alta, que había sido constante durante la expedición pacificadora, se aumenta a partir de este momento. Los capitanes de Tubac, Terrenate y Fronteras se dispusieron a realizar una campaña cuando la muerte del rebelde Cueras daba un respiro en el interior. Todavía a mediados de I 772 seguían presentándose algunos seris y tiburones de paz en Pitic, y algunos pimas y piatos en Altar, pero se atribuía

44 Diario de O'Conor, 25 de abril al 8 de mayo de 177 I. Real del ca'mpo de Nuestra Señosat del Carmen, 8 de mayo de 1773 . O'Conor a Bucareli, 9 de mayo de I773. Ibid. O'Conor a Bucareli. Paso de San Vicente en Río Grande, I 4 de mayo de I773. Presiclio despoblado de las Juntas, 30 de mayo de i773. Chihuahua, 6 de junio de I773. A. G. I., Guadalajara, 5 14. 
a los sibubapas algunos daños. Los apaches se concentraban en gran número en el cajón de Babinioca, y el recelo de fuertes hostilidades se difundía por la provincia de Sonora.

En cambio, en Texas se inicia un período de atracción de las tribus indias del norte cuyo impulsor es Atanasio de Mézières, teniente de gobernador de Natchitoches, en Luisiana, que con seis jefes aliados de aquellas naciones se presentó en Béjar al gobernador de esta provincia, Riperdá, a quien expuso la conveniencia de establecer un presidio en el norte, entre estas tribus amigas, en evitación del posible avance de los ingleses.

La llegada del nuevo gobernador Don Mateo Sastre al Pitic fue ocasión para que se personasen a darle la bienvenida los jefes de los gentiles tiburones Juan Cazoni e Ignacio Tumuzaqui, a los que intentó atraer, con extraño éxito, puesto que el 4 de setiembre de 1772 le presentaron un memorial en que manifiestan su decisión de someterse al rey y aceptar el bautismo, viendo el buen trato que reciben los indios acogidos al Pitic. Solicitaron, pues, una misión en su isla, y Sastre envió al teniente de Horcasitas, Azuela, a reconocerla con ocho hombres, siendo acompañado voluntariamente por el presidente de las misiones de Sonora Padre Fray Juan Crisóstomo Gil de Bernabé. 45

Bucareli se mostró satisfecho de poderse concertar paces con los indios del norte de Texas, cuya amistad, dado su ánimo belicoso y su diestro manejo de las armas no consideraba oportuno rechazar. Sin embargo, hallaba el inconveniente de tener que negarse a la solicitud de fusiles, pólvora y munición porque, aunque sólo les sirvieran para cazar, dificultarían su reducción a la fe, a la vida civil y a la obediencia al rey, ayudánloles a mantenerse vagantes por las montañas. Por su parte, De Mézières y Riperdá exponían las ventajas de una alianza con los indios del norte contra los apaches, haciéndose lo posible por alejar de la amistad de éstos a los texas y vidais, al mismo tiempo que se intentaba reducir de nuevo a los apóstatas jaranames, $4^{6}$ lo que no se había de conseguir. El virrey observaba a raíz de esto que nunca tuvieron éxito las reducciones en Texas, no ocurriendo así en Luisiana, "de que se deduce que o nosotros hemos ignorado el modo de reducir a los indios, o que no ha llegado a éstos la hora dada de las divinas piedades". 47 Pero era un hecho que los pueblos de la pradera deseaban armas y España no podía

45 Sastre a Arriaga. Horcasitas, 4 de septiembre de 1772, con el Memorial de los tiburones. A. G. I., Guadalajara, 5 工 3.

46 Bucareli a Arriaga. México, 26 de septiembre de 1772, núm. 569. A. G. I., Guadalajara, 416. Velasco, I, 66-69.

47 Bucareli a Arriaga. México, 27 de octubre de 1772, núm. 6I I. A. G. I., Guadalajara, 4I6. Velasco I, 69-7I. 
dárselas, en tanto que las habían obtenido antes en Luisiana y las recibirían después de los ingleses. Las circunstancias obligaban no obstante en aquel momento a Ripperdá a acceder al envío de un regalo de fusiles, ropas, tabaco y bermellón a aquellas naciones. Habíase pactado que los españoles alejarían a los pueblos del norte - taobayas, wichitas, quitseis, iscanes y tahuacanesde los pawnees-mahas, para luego establecer entre ellos el presidio que pedían para su protección, y Bucareli había tomado en serio esta posibilidad, que, sin embargo, nunca se realizaría. La infiltración inglesa, aunque hasta entonces nunca demostrada, se hacía sospechar por mil motivos diferentes, de que se tenía noticias tanto en Texas como en Luisiana, $4^{8}$ pero Bucareli reprobó el envío de armas a aquellas naciones 49 aun constándole que a través de los pawnees-mahas les llegaban fusiles ingleses. La embajada española fue bierı recibida de ellas, pero el traslado de su residencia no pudo hacerse por el riesgo de tropezar en la operación con los enemigos guazas. Por otro medio, los españoles obtenían, en cambio, el aislamiento de los apaches, que fueron atacados por los texas, interrumpiéndose de este modo el surtimiento de armas de aquéllos, $5^{\circ}$ y por los pápagos, ${ }^{51}$ que de este modo se convertían en valladar de las incursiones de los apaches sobre Sonora, contra cuya frontera se incrementaban sus ataques al ser rechazados de las de Nueva Vizcaya. Por eso Sastre puso setenta y ocho hombres de los presidios al mando de Don Gabriel Antonio Vildósola, capitán del de Fronteras, para que batiese el terreno intermedio hasta Janos, y Bucareli recomendaba reconocer frecuentemente la sierra de Chiricahui, donde los enemigos iban a proveerse de mezcal, su principal alimento. ${ }^{2}$ Sin embargo, las hostilidades de éstos se hacían sentir constantemente, y en el interior la situación se hizo confusa al ocurrir la muerte del P. Gil de Bernabé, asesinado por algunos de los tiburones a los que se hallaba misionando. $53 \mathrm{La}$ paz que, afortunadamente, man-

48 Riperdá a Bucareli. Béjar, 28 de noviembre de 1772 y 3 de riciembre de i 772 , Bucareli a Riperdá. México, 6 de enero de I773. A. G. I., Guadalajara, 5 I 3.

49 Bucareli a Arriaga. México, 27 de diciembre de 1772, núm. 701. A. G. I., Guadalajara. 416. Bucareli a Arriaga. México, 27 de mayo de 1773, núm. 937. A. G. I., Guadalajara, 5 r2.

50 Bucareli a Arriaga. México, 24 de febrero de 1773 , número 795 , con extracto, A. G. I., Guadalajara, 5I3. A partir de este hecho, los apaches iniciaron francamente la retirada, sintiéndose en cambio en Béjar, cada vez con más frecuencia los ataques y robos de los comanches según comunicaba Riperdá en 30 de marzo y is de abril. Extracto de noticias, México, 27 de mayo de 1773. A. G. I., Guadalajara, 512.

5 I Bucareli a Arriaga. México, 27 de enero de 1773 , núm. 734, con extracto. A. G. I. Guadalajara, 5 I 3 .

5 Bucareli a Arriaga. México, 24 de febrero de I773, núm. 794, y 26 de abril de 1773 núm. 887. Ibid.

53. Bucareli a Arriaga. México, 26 de abril de 1773 , núm. 883 , con Extracto. Relación de la visita de Azuela a la isla del Tiburón, 4 de abril de I773. Bucareli a Urrea. México, 21 de abril de 1773 . Bucareli al Guardián de Querétaro y a O'Conor, misma data. Bucareli a Azuela.
México, 27 de abril de i773. Ibid. 
tuvo el resto de la nación permitió a Urrea, capitán de Altar, gobernador interino a la muerte de Sastre, organizar una serie de campañas mensuales, mandadas por turno por los capitanes de los presidios, a partir de junio de 1773 , según un plạn formulado en 1765 , en junta de guerra que con ellos tuviera el entonces gobernador Don Juan de Pineda. 54

Coahuila, pese a las lamentaciones de Ugarte, era entonces la provincia que disfrutaba de más segura tranquilidad, sobre todo después de la presencia en ella de O'Conor, que hizo alejarse a los apaches y ordenó al capitán Don Rafael Martínez Pacheco, de Orcoquiza, batir constantemente el territorio entre Santa Rosa y el Paso de San Vicente para impedir la entrada de cualquier enemigo. 55 Por su parte, Nuevo México vivía días de peligro, asaltada por tropas de apaches y comanches, en número de doscientos a quinientos, si bien los vecindarios se mostraban tenaces en la defensa y en la réplica, competentemente dirigidos por su gobernador Mendinueta. ${ }^{56}$

En Nueva Vizcaya la paz era algo tan inestable como en las demás provincias. Apenas llegado O’Conor de México se tuvieron los primeros indicios - en el cruento asalto sufrido por Guajoquilla - de la colaboración existente entre tarahuamaras y apaches. 57 O'Conor supo, no obstante, desde un principio imbuir nueva moral a unas tropas cuyo valor empezaba a languidecer en aquella situación enervante de fatigas y sorpresas. Por primera vez después de mucho tiempo, a mediados de I772 un destacamento de sólo diecinueve hombres batió totalmente a una partida de treinta y dos apaches, causándoles treinta bajas en la Lagma de Castillo, a veinte leguas de Chihuahua; $5^{8}$ en Janos fue rechazado un ataque de doscientos gileños por veinticinco soldados, y un dispositivo de defensa establecido en los principales puntos de penetración de los enemigos permitió batirlos a la entrada o a la

54 Ibid.

55 Bucareli a O’Conor. México, 26 de mayo de I773. Ibid. Bucareli a Arriaga, México, 27 de mayo de I773, núm. 934, con Extracto, y núm. 936. A. G. I., Guadalajara, 512.

56 Bucareli a Arriaga. México 27 de enero de 1773 , núm. 735 y Extracto de noticias de la misma fecha. Bucareli a Arriaga. México, 26 de abril de 1773 , núm. 883, y Extracto de esta fecha. A. G. I., Guadalajara, 5 I 3.

57 Diario de O'Conor, i 2 de enero al 17 de febrero de 1772 . Chihuahua, I 8 de febrero de I772. En carta de esta fecha dice O'Conor a Bucareli que los indios enemigos actúan con sagacidad, colocando espías en las alturas para avisar si llega gente que pueda ayudar a los atacados, mientras que las tropas están imposibilitadas por su corto número, sin ninguna habilitación y atraso de la caballada por causa de la crudeza del invierno. A. G. I., Guadalajara, 5 I 2. La colaboración de los tarahumaras la denuncia Faini en carta a Bucareli. Durango, 28 de febrero de 1772 , ibid, y se hace patente también en nota del P. Alegre y Capetillo en su diario, el I 5 de febrero de I772, En noviembre del mismo año fueron concretándose las sospechas y se iniciaro's las correspondientes pesquisar.

58 Bucareli a Arriaga. México, 26 de julio de I772, núm. 46r, y Extracto de igual data. Ibid. 
salida de la provincia, recuperánclose sus robos. ${ }^{59}$ Bucareli aprobó estas disposiciones de O'Conor, instándole a mantenerse a la expectativa mientras no tuviera refuerzos. ${ }^{60}$ En julio y agosto, dos gruesas partidas de enemigos sufrieron descalabros en el puesto de Barrigón. Después de esto, los principales daños vinieron del Bolsón, desde donde las rancherías de Pascual y el Ligero se lanzaban contra Cerro Gordo, Mapimí, Parras y las inmediaciones de Durango. ${ }^{6 r}$ Cesaron, pues, las hostilidades en torno a Chihuahua, e incluso se presentaron unos natajes pidiendo a O'Conor paz para su nación, lo que, aunque con la natural desconfianza, les fue concedido, ${ }^{62}$ y así se presentaba la situación cuando aquél emprendió su expedición a Coahuila, dejando al ayudante mayor Don Juan de San Vicente encargado de las operaciones en Nueva Vizcaya durante su ausencia. ${ }^{6} \mathrm{E}$ El contrataque de los apaches se hizo esperar hasta marzo de I773, en que en número de más de trescientos cercaron el presidio de Janos durante varios días, internándose luego en la provincia: en pocos días causaron más de treinta muertos --mineros, leñadores, vaqueros - e hicieron numerosos cautivos y robos. ${ }^{64}$ Pero seguidamente eran descubiertos por el corregidor de Chihuahua y las justicias del valle de Santiago Papasquiaro y el pueblo de San Juan del Río los hilos de una conjuración de los tarahumaras. ${ }^{65}$ Verificadas las correspondientes detenciones, que pronto pasaron de noventa, confesaron muchos haber actuado con los apaches en las correrías de los íltimos cuatro años y haberles entregado las caballaclas y mutadas obtenidas de este modo. 66 El fiscal de la au-

59 Bucareli a Arriaga. México, 27 de agosto de $э$ r2, núms, 524 y 525, con Extracto de igual fecha. Ibid. Bucareli a Arriaga. México, 26 de septiembre de 7772 , núlus. 566. Con Extracto. A. G. I., Guadalajara, 4 I6.

60 Bucareli a Arriaga. México, 26 de septiembre de 1772, n. ${ }^{\circ} 567$. A. G. I., Guadalajara 512,

6i Bucareli a Arriaga. México, 27 de octubre de 1772 , núm, 6o8, con Extracto de noticias de igual data. A. G. I., Guadalajara, 4I6. Bucareli anuncia que O'Conor saldrá personallmente a campaña contra Pascual y Ligero, antes de verificar el traslado de los presidios. Bucareli a Arriaga. México, 27 de octubre de 1772 , núm. 609. Ibid. Velasco, I, 60-64. Sin embargo, algunos contratiempos sufridos llevaron luego a Bucareli a indicar a $O^{\prime}$ Conor se mantuviese a la defensiva. Bucareli a Arriaga. México, 26 de noviembre de 1772 , núms. 654 y 655 , y Extracto de igrual dats.
A. G. I., Guadalajara, 4I6. y 5 I2.

62 Bucareli a Arriaga. México, 2t de diciembre de r772, núm. 700, y Extracio de ignal fecha. A. G. I., Guadalajara, 4 I 6.

63 Bucareli a Arriaga. México, 27 de enero de 1773 , ním. 733, y Extracto de esta fech?. Ibid. Bucareli a Arriaga. México, 24 de febrero de 1773 , núm. 792, con Extracto, y 793. A. G. 1., Guadalajara, 5 I 3 .

64 Bucareli a Arriaga. México, 27 de marzo de 1773 , núm. 833 , con Extracto, y 834 . Llegado, los dragones a Durango en $2 \mathrm{I}$ de marzo y 2 de abril, Faini dispuso se trasladasen al valle de San Bartolomé, 10 qute ni el virrey ni O'Conor aprobaron. A. G. I., Guadalajara, 513 .

65 O'Conor a Bucareli. San Fernando de Austria, 31 de marzo de 1773; Ojo de Agua Verde y nuevo paraje del real presidió de Santa Rosa, 25 de abril de 1773 . Bueareli a Arriaga. México, 20 de abril de I 773 , con Extracto de igual fecha. Ibid.

66 Bucareli a O'Conor. México, 26 de mayo de I773. Le sugiere ponga a los dragones en persecución de los tarahumaras infieles. A. G. 1. Guadalajard, 5 I3. Bucareli a Arriaga. México, 27 de mayo de I773, núm. 934, con Extracto y 935. A. G. I., Guadalajara, 512. 
diencia de México dictaminó que el gobernador de Nueva Vizcaya sustanciase las causas y las sentenciase con parecer de su asesor, remitiéndolas luego a Guadalajara para la última determinación. Entre tanto, apaches o tarahumaras devastaban la zona de Cerro Gordo, atacando las haciendas de Ramos y del río Florido, Torreón, Real del Oro y Magistral. Entre fines de mayo y principios de junio causaron más de ochenta nuertes, marchando una cuadrilla de más de veinte por el camino real con toda libertad. Entre Torreón y Parral actuaba otra partida de más de doscientos gandules, en opinión común tarahumaras sublevados después de las detenciones realizadas por el corregidor de Chihuahua. ${ }^{67}$

\section{SEgunda EXPEDICIÓN DE O'Conor}

Entre marzo y abril de 1773 llegaron a Durango los cien dragones enviados por Bucareli a la frontera en virtud de la real orden de 18 de septiembre de I772. Componían este cuerpo dos destacamentos formados cada uno por un capitán, un teniente, un alférez, un tambor, dos sargentos, cuatro cabos y cuarenta y tres soldados de los dos regimientos de dragones de México y España existentes en el virreinato. Se procuró que en su mayoría fuesen voluntarios, y gente de valor, robustez, agilidad y destreza a caballo. No faltaban entre ellos algunos veteranos de la campaña de Sonora. ${ }^{68}$ Este incremento de las fuerzas operantes, más valioso por su eficacia que por su cuantía, aún se aumentó al nombrar Bucareli al teniente veterano del regimiento provincial de caballería de Querétaro Don Antonio María Daroca para el cargo de teniente de gobernador en el pueblo de El Paso del Río del Norte, comisionándole para la formación de compañías de milicias en aquel distrito. ${ }^{69}$

O'Conor, de regreso en Chihuahua y ya comandante inspector de los presidios, advirtiendo en el fondo del Bolsón y en Sonora los dos puntos más flacos de la frontera, envió a la provincia vecina el cuerpo de dragones, mientras él mismo, cumpliendo la obligación de revistar los presidios antes de trasladarlos a los lugares que ya había fijado, recorría toda la frontera oriental de Chihuahua. Se consideraba solo para atender a todas las urgencias de la dilatada fronteri, pues no creía que ningún gobernador montase

67 Villaverde a San Vicente. Hacienda de la Mimbrera, 7 de junio de 1773 . Díaz a San Vicente. San Bartolomé, 8 de junio de 1773 ; declaración de Nevares, Correo de Durango, en Chihuhua, i 2 de junio de I773. A. G. I., Guadalajara, 5 I 4.

68 Bucareli a Arriaga. México, 27 de enero de 1773, ním. 74I. A. G. I., Guadalajara, 416. Velasco, I, I I0-I I 2.

69 Bucareli a Arriaga. México, 26 de abril de I773, núm. \$93. A. G. I., Guadalajara, 5 2. Velasco, I, I13-II4. 
a caballo ni diese providencias sobre aquellas guerras, siendo el de Nuevo México el único que había actuado contra los enemigos exponiendo su persona con loable valor y bizarría. Los demás sabían de la frontera lo que oían en sus tertulias. 70

En fin, si el 5 de junio había llegado O'Conor a Chihuahua de una expedición que haría durado seis meses, el I I del mismo mes volvía a ponerse en marcha, esta vez hacia el sur, con la primera compañía volante, con ánimo de ir a pacificar a los tarahumaras, dejando las otras tres al mando de Don Manuel Muñoz, capitán de Julimes, para el resguardo de Chihtuahua, y dando al capitán Don Domingo Díaz el mando de la frontera del Bolsón. El i4, habiendo pasado dos días antes por la hacienda de Bachimba, poblada pero devastada por los adversarios, llegó O'Conor a la laguna de San Pablo, donde se le presentó un indio gobernador de los tarahumaras del pueblo de este nombre, al que aquél exhortó a mantener fiel y a que todos entregasen sus armas, lo que hicieron sin dificultad. El I8, ya junto al río Florido, halló diecisiete tarahumaras que, uno a uno, se habían ido congregando en una hacienda para la siega; O'Conor les reprendió suponiendo que ordinariamente se hallaban vagantes por los caminos y no sería extraño que cometieran fechorías; también éstos entregaron sus armas. E1 20, por la hacienda de San Antonio de la Enramada y el Saucillo, llegó a Atotonilco, donde al día siguiente repitió la operación, y tuvo noticias de hallarse acampados los enemigos al pie de una sierra junto al Bolsón. ${ }^{71}$ Para prevenir cualquier hostilidad en lo sucesivo, O'Conor distribuyó ciento setenta y cinco hombres - ciento veinticinco de la primera compañía volante y cincuenta de dragonesen siete puestos desde Santa Rita, por el Saucillo, los Peñoles, La Parida, Los Patos y Santo Domingo, hasta el Gallo, lo cual dejaría a cubierto todo el territorio desde Ancón de Carros hasta el río Nasas. Las hostilidades de los tarahumaras habían cesado ya. Bastó la presencia de una fuerza de O'Conor para que bajasen de las sierras del Chivato y del Carrizo presentándose a trabajar en las haciendas. ${ }^{2}$ Para evitar nuevos daños, O'Conor pedía se restringiesen los mandamientos que los justicias expedían enviando los indios a trabajar a distintos sitios, y que se prohibiese a los tarahuamaras circular armados por los caminos. Las noticias que entonces se tenían en la conjuración indicaban que el cuerpo de los alzados había contado con mil setecientos hombres mezcla de tarahumaras, cholomos, mulatos, negros, lobos y otras

70 O'Conor a Bucareli. Chihuahua, 8 de junio de 1773 . A. G. I., Guadalajara, 5 ז4.

7 Diario de O'Conor, I I al 23 de junio de 1773 . Atotonileo, 23 de junio de I773. Ibid. Gordo, 3 de julio de 1773 . Ibid. En Extracto de noticias formado en México, 26 de junio de 1773 , consta, que, según Faini, la insubordinación de los tarahumaras empezaba a cundir entre los
tepehuanes. A. G. I., Guadalajara, 5 13 . 
castas de razón, mandados por un indio viejo llamado Calaxtrín, y su hijo, y un español llamado Don Antonio de la Campa. Tenían su refugio en la sierra del Rosario, de donde salían en cuadrillas. ${ }^{73}$

O'Conor, practicadas las revistas de Cerro Gordo y Julimes, se halló el 2 de agosto de regreso en Chihuahua. ${ }^{74}$ Entre tanto, dos rudos combates habían tenido lugar en la frontera norte de la provincia y en Coahuila, pero aunque a mucha costa, se había logrado rechazar a los apaches. 75 La revista de Guajoquilla la practicó el 22 de aquel mes, y desde allí envió al comandante del presidio Don Tomás de Egurrola con ochenta hombres a explorar Acatita, en el Bolsón, al mismo tiempo que encargaba a Ugarte, gobernador de Coahuila, la exploración de la parte oriental de éste, mientras que Muñoz, desde El Paso a San Buenaventura, atacaba con éxito las rancherías de la sierra de Organos. Faini, a quien alarmaron los ataques ocurridos en el fondo del Bolsón, había logrado poner en pie de guerra noventa hombres, españoles e indios, entre Parras y Saltillo, sin contar los treinta escolteros bien equipados que guardaban las haciendas de San Miguel de Aguayo. ${ }^{76}$ La exploración definitiva del Bolsón la realizó el capitán Díaz con la primera compañía volante, atestiguando no haber en todo el territorio recorrido más que un aguaje para seis caballos. 77

Desde mayo de aquel año de 1773 habían sido extinguidos los presidios de Monterrey y Nayarit. 78 Por encargo de Bucareli, O'Conor expidió a Ri-

73 Extracto de noticias. México, 27 de julio de 1773. A G. I. Guadalajara, 514.

74 Diario de O'Conor. Chihuahua, 3 de agosto de 1773 . A. G. I., Guadalajara, $5+3$.

75 Cuarenta apaches murieron de un cuerpo de trescientos que atacó a una partida de presidiales en Ojo Caliente; la victoria costó la vida al alférez de San Buenaventura, doce hombres de cuera y diez auxiliares. La fuerza de Río Grande, engrosada por vecinos de Coahuila, practicaba frecuentes batidas a la mitad septentrional del Bolsón hasta el río y empezaba a obtener resultados halagüeños. Diario de $O^{\prime}$ Conor. Chihuahua, 3 agosto 1773 . Bucareli a Arriaga. México, 25 julio 1773 , núm. 1от6. A. G. I., Guadalajảra, 513. O.Conor a Bucareli. San Bartolomé, 14 de julio de 1773 . Extracto de noticias, México, 27 de julio de 1773 . A. G. I., Guadalajara, 514.

En $\mathrm{r}^{\circ}$ de agosto, sin embargo, un contingente de veintinueve soldados y ocho auxiliares sufrió serio descalabro a cinco leguas de la Babia. Bucareli a Arriaga. México, 26 de septiembre de 1773 , núm. rog1, con Extracto, y 1092. A. G. I., Guadalajara, 513.

76 Diario de O'Conor, 15 al 31 de agosto de 1773 . A. G. I., Guadalajara, 512.

Instrucción de to que debe observar el gobernador de la provincia de Coahuila, dada por O'Conor en Guajoquilla, a de septiembre de 1773,16 artículos; Bucareli a Arriaga. México, 27 de octubre de 1733 , núm. 1149, con Diario del capitán Muñoz, $10^{\circ}$ al 19 de septiembre de 1773 . A. G. I., Guadalajara, 514. Egurrola no encontró al enemigo en Acatita; en cambio, Ojeda logró diez bajas, entre ellas el capitán indio Valerio, en Agua Nueva: Muñoz, con Daroca y el capitán de San Buenaventura, logró dar muerte a otro Valerio, Juanico, y el Canoso, también capitancillos, y combatió a las cuadrillas de Concha, Alonso Berrendo y Sebo. Bucareli a Arriaga. México, 27 de octubre de I773, nú̉n. II44, con Extracto. Ibid.

77 Diario de Don Domingo Díaz, ig de octubre al I4 de noviembre. Juntas de los Ríos, I6 de noviembre de 1773. A. G. I., Guadalajara, 512.

78 El presidio de Monterrey, en Nuevo León, fue reformado por el gobernador Echegaray en I 2 de mayo de I773; el de Nayarit, por el sargento mayor de Guadalajara Garabito, el 30 de mayo. Las instrucciones para la extinción de ambos presidios habían sido extendidas por Buca- 
perdá las instrucciones pertinentes para la reforma de los Adaes y Orcoquiza, y arreglo de los presidios de Béjar y la Bahía. $79 \mathrm{El}$ I I de julio de 1773 avisaba el gobernador de Texas haber cumplido su misión. ${ }^{80}$ También Mendinueta recibió instrucciones para proceder al arreglo del presidio de Santa $\mathrm{Fe}$, como lo hizo. ${ }^{8 x}$

En cambio, en junta de guerra habida en México en 2 de septiembre se había acordado la erección de los dos presidios de la Babia y San Eleazario, pedidos por O'Conor como necesarios para la perfección de la línea fronteriza, siendo de plena creación el segundo, pues el primero se consideró traslación del de Orcoquiza. ${ }^{82}$ O’Conor había mostrado, basado en la experiencia personal, que entre Nueva Vizcaya y Coahuila el río Grande se apartaba hacia el norte formando un semicírculo de más de cien leguas, desde las inmediaciones de Santa Rosa en Agua Verde hasta el paso de San Vicente, sienclo el diámetro de esta curva de más de noventa leguas, "y es precisamente la línea que arreglado a las reales disposiciones han de guarnecer y fortificar los presidios". Las sierras de las inmediaciones - la del Pino y otras innominadas-, ya reconocidas, aumentaban los rodeos a ciento diez leguas entre la Junta y San Juan Bautista. Quedaban noventa leguas entre Santa Rosa y San Sabá, situado en el paso de San Vicente: "este claro es precisamente la entrada de los indios natajes, mezcaleros y ołros al presidio antiguo o población de Santa Rosa, al centro de la provincia de Coahuila y haciendas de Sardinas, Cuatro Ciénagas, Parras y sus inmediaciones; estos pasos los facilitan los cañones de la sierra que corren de norte a sur, ocultándolos al registro de los presidios de Agua Verde y San Vicente así las imposibilidades de sus simas, que siguen de este a oeste, como las distancias del t1no al otro, que es preciso retarden su reconocimiento". No hallaba O'Conor otro remedio que fundar presidio en el Ojo de Agua de la Babia, pues de no ser así quedaría inútil toda la Línea. Aquello era además lógico, pues en

reli en México, 17 de marzo de 1773. A. G. I., Guadalajara, 512. En Nuevo León quedaríat establecidos dos soldados en cada una de las cuatro misiones. En Nayarit se situó como guarnición la compañia de voluntarios de Cataluña, mandada por Don Agustín Callis. Bucareli a Arriaga.

79 Bucareli a Arriaga. México, I., Guadalajara, 513. Velasco, I, 149-151.

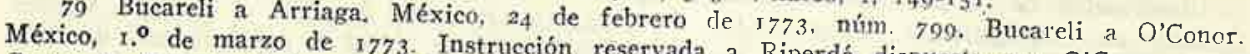
Campo de Nuestra Señora del Carmen, 6 de mayo de a Riperdá dispuesta por O'Conor, Real julio de 1773, núm. tor7. A. G. I., Guadalajara, 512. 8o Bucareli a Arriaga. México, 26 de septiembre

Guadalajara, $513 ;$ y 26 de noviembre de 1773 , núm, de 1773 , núm. rogr, con Extracto. A. G. I. 81 Extracto de noticias. México, 27 de julio de 1187. A. G. I. Guadalajara, 514.

la revista y arreglo del presidio de Santa Fe, I5 de julio de G. I., Guadalajara, 514. Autos de

82 O'Conor propuso la erección del presidio de julio de I773. A. G. I., Guadalajara, 512, Real Campo de Nuestra Señora del Carmen, \& de mayo de ry carta a Bucareli datada en el Bucareli demoró su respuesta hasta tratar el astunto en Junta de. a Arriaga. México, 26 de junio de r773, núm. ror5. A. G. I., Guadalajara, 514 . 
la mente de Rubí era claro que no debía haber más de cuarenta leguas de un presidio al inmediato. Si sólo se colocase un destacamento, no podría defender el paso y además quedarían debilitados los presidios que lo proporcionasen. Como solución, O'Conor había sugerido se trasladase allí la compañía de Orcoquiza, elevando a cuarenta y seis el número de sus plazas. Este sería, pues, el décimosexto presidio de la Línea. La Junta creyó convincentes los argumentos de O'Conor y Bucareli hizo uso de la libertad que le había quedado para modificar el reglamento, gracias a la intervención de su amigo O'Reilly. ${ }^{83}$ En estas condiciones partió O'Conor a su tercera expedición.

\section{'TJRCTERA EXPEDICIÓN DE O'CONOR}

El ig de octubre de I773 partía O’Conor una vez más de Chihuahua con las dos compañías de dragones y las de Julimes y Cerro Gordo para verificar el traslado de estos dos a sus nuevos emplazamientos a orillas del río Grande. El primero quedó en su sitio, en su antiguo y primitivo lugar de la Junta de los Ríos Grande y Conchos, el 28 de octubre. El 2 de noviembre partía el comandante inspector hacia el este, y cinco días después ponía al capitán Villaverde, de Cerro Gordo, en posesión de su nuevo presidio de San Carlos, y el I 3 , habiendo hecho una ligera penetración hacia el sur, regresó a la Junta, donde al día siguiente se le reunió Díaz, que durante dos meses hahía transitado las áridas extensiones del Bolsón. ${ }^{84}$

Con la primera compañia volante y las dos de dragones salió entonces O'Conor hacia el norte en busca de los indios enemigos para obligarlos a retirarse de la Línea. Emprendida esta mariscada el i9 de noviembre, la nieve dificultó la marcha de tal manera que el 23 "apenas pudo la tropa mantenerse a caballo, hallándose la mayor parte de ella sin poder menear pies ni manos". EI 26 , no obstante, se hallaba en la boca de la sierra del Mogano, siguiendo a su vanguardia, que había localizado allí una nutrida partida de apaches. En efecto, al día siguiente por la mañana, habiéndose puesto O'Conor bajo la protección de la Inmaculada, tuvo lugar el ataque, en que logró derrotar a más de quinientos enemigos persiguiéndolos cuatro leguas, causándoles más de cuarenta bajas. E1 3 de diciembre estaba de regreso en la Junta. ${ }^{85}$

83 Testimonio de la Junta, en A, G. I., Guadalajara, 5 53. Bucareli a Arriaga. México, 26 de septiembre de I773, núm. rog6. A. G. I., Guadalajara, 5 I 4. La Real Orden de 8 de febrero de 1774 aprobó el establecimiento de los presidios de la Babia $y$ San Eleazario. Ibjd.

8. Diario de O'Conor, 9 de octubre al $\mathrm{r}^{\circ}$ de noviembre, y 2 al $\mathrm{r} 8$ de noviembre de 1773. Junta de los Ríos, I. ${ }^{\circ}$ y is de noviembre de I773. A. G. I., Guadalajara, 5 I 2.

85 Diario de O'Conor, is de noviembie al 8 de dicienbre de 1773 . Junta de los Ríos, 8 de

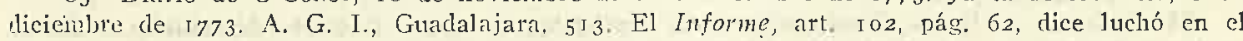
Mogano con más de seiscientos indios. 
No más tarde del 9 se ponía en marcha O'Conor de nuevo, esta vez hacia el oeste, con sólo setenta dragones, presidiales y soldados de la compañia volante. Su intención ahora era reconocer los terrenos que debían ocupar los presidios del Príncipe, recién creado, Guajoquilla, El Paso, San Buenaventura y Janos, y revistar estos tres últimos. El I3 se hallaba reconociendo el paraje de los Pilares, donde debía establecerse el nuevo presidio. Remontando el curso del río Grande, seis días después se detenía en el valle de San Eleazario, y el 20 designó allí el lugar conveniente para establecer el antiguo presidio de Guajoquilla. El 24, por fin, por el Ojo de Canta Recio y la Laguna de Patos llegaba al Carrizal, en donde encontró la compañía del antiguo presidio de El Paso, que por orden suya se había trasładado allí, donde O'Conor le dio nuevo asentamiento, revistándola seguidamente. ${ }^{86}$

El io de enero de 1774 , sólo con cuarenta hombres, prosiguió la ruta al oeste y, cruzando los ríos de Santa María y de Janos, llegó tres días después al presidio de este nombre, y hallándose en él ya pasada la revista, envió a su capitán Don Juan Perú a hacer una expedición a la sierra del Hacha, en la que se consiguió un buen golpe contra los enemigos.

Desde Janos emprende O'Conor el regreso por el río de Casas Grandes al presidio de San Buenaventura, donde llega el 26 de enero, y que revistó en los días siguientes. El $\mathrm{r} .^{\circ}$ de febrero inició el recorrido del último trayectr. $y$, dirigiéndose hacia el sur por el valle de San Buenaventura y la hacienda de Encinillas, el 8 entraba una vez más en la villa de Chihuahua. ${ }^{87}$

\section{Cuarta expedición de O'Conor}

Después de la salida del comandante inspector de Chihuahua, gozó esta provincia algún tiempo de relativa paz. Crecidas partidas de apaches lipanes fueron invitadas a pasar el río Grande, a lo que se prestaron sin dificultad. E1 ayudante inspector Don Roque de Medina pasó allá para atender a la fábrica de los presidios trasladados, en septiembre de I773. O'Conor dio sus instrucciones para que se batiese el Bolsón desde Santa Rosa y M.onclova hasta el Valle de San Bartolomé, con lo que se aseguró la paz. 88 Medina llevó a cabo la revista de los presidios de Santa Rosa, Monclova, Río Grande,

86 Diario de O'Conor, 9 al 27 de diciembre de 1773 . Carrizal, 27 de diciembre de 1773. A. G. I., Guadalajara, 514 . El decimoséptimo presidio se estableció, por consiguiente, en los Pilares, yendo, en cambio, a San Eleazario el antiguo de Guajoquilla.

87 Diarios de O'Conor, 28 de diciembre de 1773 al 26 de enero de 1774 y 27 de enero al 8 de febrero de 1774 . San Buenaventura, 26 de enero de 1774 , y Chihuahua, 8 de febrero de 1774 .
A. G. I., Guadalajara, 513 .

88 O.Conor a Ugarte. Guajoquilla, 3 de septiembre de I773. Extracto de noticias. México, 27 de octubre de I773. A. G. I., Guadalajara, 5 J4. 
San Sabá y la Babia entre octubre de I773 y enero de I774, siendo el fundador de este último presidio. 89 Por esta época Medina informó que los lipanes se mantenían en buenas relaciones y habían hecho fracasar con sus informes una tentativa de ataque por parte de los mezcaleros. ${ }^{90}$ Pero la entrada de I774 presenció una inesperada complicación de la situación cuando más de trescientos comanches y taobayas atacaron a los lipanes en el río de San Diego, al sur del Grande, y después de combatir todo el día se llevaron las caballadas de ios capitanes Malla, Panocha y Rivera. Jamás habían descendido aquellos pueblos tan al sur. ${ }^{91}$ Después, insistentes clamores de Ugarte y Medina movieron a Bucareli a ordenar a O'Conor visitase aquella provincia. ${ }^{92}$

O'Conor llevaba mes y medio residiendo en Chihuahura cuando esta disposición le hizo partir de la villa el 27 de marzo, dirigiéndose a cortas jornadas hacia el este, habiendo encargado al ayudante Bonilla la revista de los presidios de Sonora. 93 La escasez de agua era tan sensible que desde el 30 ya la caballada estaba sumamente cansada y flaca y pronto tuvo una porción de bestias abandonadas. El 5 de abril no había un solo caballo que se pudiese ensillar y al día siguiente tuvo O'Conor que seguir la marcha a pie con los cuarenta y cinco hombres de su escolta. En este viaje había abierto el comandante inspector un nuevo camino que enlazaba directamente Chihuahua con el presidio de San Carlos, al que llegó el 8 de abril, sin pasar por el de la Junta, evitando el rodeo de treinta leguas. En San Carlos halló la ntıeva fábrica material del presidio muy adelantada, así como las siembras, y hacía más de cuatro meses que no se veían indios por los contornos.

Tras un descanso de dos días, el i4 estaba en San Sabá, en el paso de San Vicente. También aquí la construcción había progresado notablemente: hahía siete acuartelamientos terminados, echados los cimientos de la muralla y empezado el baluarte del rey. La guarnición disfrutaba de la misma paz cuue la de San Carlos. A dieciséis leguas de San Sabá, cuatro días después, encontraba $\mathrm{O}^{\prime}$ Conor en una cueva treinta y seis cadáveres recientes de indios,

89 Extracto de revistas practicadas en I 1 y 25 de octubre, I ${ }^{\circ}$ y I6 de noviembre de 1773 y I. $^{\circ}$ y 16 de noviembre de 1773 y I. $^{\circ}$ de enero de r774. A. G. I, Guadalajara, 5 I 3. Medina reclutó la gente del presidio de la Babia en Coahuila. Extracto de noticias. México, 26 de $110-$ viembre de I773. A. G. I., Guadalajara, 5 I 2.

90 Bucareli a Ariaga. México, 27 de diciembre re 1773, n. ${ }^{\circ}$ I 220, con Extracto, y 1221. Ibid.

9 I Bucareli a Arriaga. México, 24 de febrero de I777, núm. I274, con Extracto, y I275. A. G. I., Guadalajara, 5I4. Medina pidió a $O^{\prime}$ Conor refuerzos para la Babia, que pronto estuvo fuertemente defendida. Bucareli a Arriag̨a. México, 27 de marzo de I774, núm. I309. A. G. I., Guadalajara, 5 I 3.

92 Informe, art. i 4 . pág. 6.3. Bucareli a Arriagr. México, 24 de febrero de 1774, n. ${ }^{\circ}$ i 276. A. G. I., Guadalajara, 5 I 4 .

93 Bucareli a Arriaga. México, 26 de abril de I774, núm. I 258. A. G. I., Guadalajara, 513. 
que no tardó en suponer eran los que salieron heridos en el combate que él diera a los apaches en la sierra del Mogano. El zo de abril hacía su entrada en el presidio de San Antonio Bucareli de la Babia, donde habían sido edificados ya un cuartel y un cuerpo de guardia y un lienzo de la muralla principal, hallándose en conjunto casi concluído. 94

Una vez en Coahuila, dictó O'Conor sus disposiciones para el resguardo de la frontera, habiéndose manifestado infundados los recelos que Medina y Ugarte tenían de un fuerte ataque de los indios, y reprendió severamente a los lipanes. Una afortunada salida proporcionó cuarenta y un presos. Por un cuativo rescatado a los mezcaleros se supo la confusión que entre ellos había introducido la derrota del Mogano, que produjo la disolución de la junta que iban formando en el río Puerco, desparramándose sus rancherías. 95 A fin de mayo, pues, el 24, emprendió O'Conor el regreso a Nueva Vizcaya, donde en sı ausencia, después de nueve meses de paz sin precedentes, se había abierto un nuevo período de hostilidades.

Una rápida incursión por la hacienda y mina de Irigoyen, Chuviscar y la Noria produjo siete muertes y dos cautivos y el robo de una mulada. La situación empeoró cuando en una escaramuza en la región de Janos mulrieron ocho soldados. "Conozco - dice a raíz de esto Bucareli, con evidente apasionamiento - lo que vale la presencia del comandante inspector Don Hugo O'Conor, y que todo es malo donde 110 está él”. 96

Pero O'Conor estuvo pronto, el 28 de junio, en Nueva Vizcaya, para reanudar una vez más stıs expediciones. Esperaba que a fin de año estuviesen concluidas las obras y terminados los presidios entre Janos y San Juan Bat1tista. Los trasladados llevaban seis meses ya en sus nuevos emplazamientos, construyéndose y aprovisionándose, sin haber sido inquietados en absoluto, lo que parecía demostrar que no habían quedado enemigos a espaldas de este tramo de la Línea. El éxito final de la empresa hacía decir al virrey que las fronteras estarían en adelante aseguradas con un cordón que no tenía igual en las Américas, habiendo sido desalojados los enemigos, obligados a buscar asilo al otro lado del río Grande, ganando el rey un territorio que medía doscientas cincuenta leguas de norte a sur y setecientas de este a oeste. 97

En los íltimos días de julio, O’Conor se trasladó de Chihuahua al pre-

94 Diario de O.Conor, 27 de marzo al 20 de abril de I774. Babia, 20 de abril de 1774. A. G. I., Guadalajara, 5 I3. Remitido con carta de Bucareli a Arriaga. México, 27 de mayo de i774,
súm. I393. Ibid.

95 Extracto de noticias. México, 27 de nayo, 26 de junio, 27 de julio y 27 de agosto de 1774. A. G. I., Guarlalajara, 5 I3. E.l capitán de la Babia Martínez Pacheco se encargó de canjear los
prisioneros.

96 Bucareli a Arriaga. México, 26 de junio de I774, numıs. I424 y I444, con Extracto. Ibid.

97 Extracto de noticias. México, 27 de ociubre de 1774. A. G. I., Guadalajara, 514. 
sidio de Carrizal, 98 donde parece se mantuvo unos meses, estableciendo en él su cuartel general. Allí fue testigo próximo del primer descalabro serio sufrido por las tropas a su mando, el 29 de septiembre, cuando Don Manuel Alegre, capitán de la tercera compañía volante, que perseguía a dos partidas enemigas que sumaban setenta hombres que por la Sierra Escondida se dirigían hacia San Buenaventura, habiéndolos ya puesto en fuga dos días antes después de nueve horas de combate, los halló en un cerro y se dispuso a darles un ataque general, subiendo a pie con su gente a su encuentro. Logró hacerles cuatro bajas, pero de improviso aparecieron más de cien indios a pie y a caballo que estaban arrochelados en la altura y mataron a Alegre y cuatro de los suyos, dejando a otros diez malheridos. Don Antonio Casimiro de Esparza, antiguo teniente de gobernador de Sonora y que, como voluntario, tomaba parte en aquella baticla, acordó la retirada y el I. $^{\circ}$ de octubre, habiendo recibido refuerzos, le fue posible avanzar de nuevo, hallando el campo abandonado por el enemigo, de modo que hubo de conformarse con recoger los cuerpos de los caídos. 99 Bucareli, conocida la desgracia, escribió a O'Conor hiciese saber a sus tropas que la precaución es tan honrosa como la bizarría. ${ }^{\text {Ioo }} \mathrm{El}$ comandante inspector, por su parte, se apresuró ? preparar una mariscada que proporcionase sobre el mismo terreno el desquite de las armas del rey. Esparza, en atención a sus antiguos servicios y el mérito recientemente contraído, fue nombrado capitán de la misma tercera compañía volante. Sin embargo, la fuerza de doscientos cincuenta y nueve hombres del Carrizal, San Buenaventura y Janos, dragones e indios que O'Conor puso en movimiento en diciembre no logró más que un combate en la sierra del Hacha en que se hicieron siete muertes y trece prisioneros y las posteriores batidas del territorio ni siquiera encontraron indios en él. ror Pero la persecución de que se vieron objeto llevó a algunos gileños a pedir la paz en el pueblo de El Paso al teniente de gobernador Don José Antonio de Arrieta: prometían incluso reunir a otros capitancillos en la sierra de los Organos e inducirles a presentarse de paz. O'Conor se dirigió entonces a El Paso con ánimo de reducirlos a pueblo. ${ }^{102}$

La posibilidad de una sumisión de los apaches en El Paso, adonde llegó O'Conor en 15 de enero, se frustró, como era de esperar, y en su lugar se

98 Diario de O'Conor: 26 al 30 de iulio de r774. Carrizal, 6 de agosto de 1774 . A. G. I., Guadalajara, 514. Remitido con carta de Bucareli a Arriaga, México, 26 de septiembre de I774, núm. I525. Ibid.

99 Extracto de noticias, México, 26 de noviembre de r774. A. G. I., Guadalajara, 514. roo Bucareli a Arringa. México, 26 de noviembre y 22 de diciembre de 1774 , núms. I6 I4 y 1647 . Ibid.

Io I Bucareli a Arriaga, México, 27 de enero de I775, núun. I687, con Extracto, y I684. Ibid.

roa Bucareli a Arriaga. México, 2ł de febrero de 1775, núm. i7 I6, con Extracto. A .G. I., Guadalajara, 5I5. 


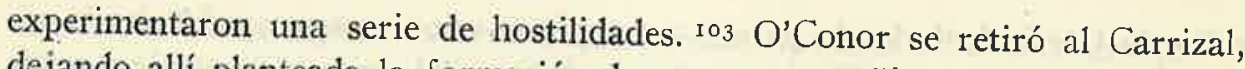
dejando allí planteada la formación de cuatro compañías de milicias de cincuenta y tres hombres que cubriesen el territorio evitando la introducción de los enemigos. I04 Desde el Carrizal, adonde se reintegró el 23 de febrero, envió a Bucareli el 24 de marzo, para su aprobación, un plan de operaciones para una campaña general que pretendía comenzar en $\mathrm{I}^{\circ}$ de agosto. ${ }^{\circ} 5 \mathrm{E} \mathrm{E}_{1}$ virrey aceptó la idea, pero determinó el retraso de esta fecha hasta que los presidios estuviesen suficientemente guarnecidos y hasta que concluyese la expedición que desde Sonora practicaba Anza hasta Nueva California. ${ }^{106}$

La organización de la Línea permitía ya tener a raya a los apaches, y el nuevo armamento que empezaba a llegar daba alguna ventaja a los españoles. A Gil, capitán de San Buenaventura, con sólo quince hombres, le fue posible rechazar a cuatrocientos enemigos que le asaltaron. roz En general, la Línea gozaba de tranquilidad, cuando O'Conor se decidió a pasar a Sonora a repeti. por sí mismo la revista de presidios que ya había practicado Bonilla, después de haber estado en Chihuahua disponiendo lo preciso para la próxima campaña. El 22 de mayo partió para Sonora. 108

El 24 de junio de 1775 se presentaba O'Conor en Fronteras, y de allí pasó a Terrenate, de cuyo capitán Don Francisco Tovar dio los peores informes, y halló la compañía volante agregada carente de oficialidad, mandada por un sargento. Tubac y Altar fueron igualmente revistados, ordenando el comandante inspector la traslación del de Fronteras al valle de San Bernardino; el de Terrenate al paraje de Santa Cruz; el de Tubac, al del San Agustín del Tucsón, y el de Altar al de Cosimac. El i3 de septiembre estaba de regreso en San Buenaventura. rog

\section{LA CAMPAÑA GENERAL}

Desde un principio estaba previsto que, tras el señalamiento de los nue-

103 Bucareli a Arriaga, México, 27 de marzo de 1775 , núm. 1760, y Extracto de igual data con carta núm. 1759. A. G. I., Guadalajara, 514.

104 Bucareli a Arriaga. México, 26 de abril de 1775 , núm. 1793, con Extracto. Ibid.

ro5 O'Conor a Bucareli. Carrizal, 24 de marzo de 1775. A. G. I., 515. a Arriaga. México, 27 de mayo de

I07 Extracto de noticias,

I07 Extracto de noticias. México, 26 de abril de 1775. A. G. I., Guadalajara, 514. acopio de viveres. Remitió los apaches prisioneros a Méxicoló para Chihuahua, donde preparó el nuel Pardo. Formó reglamento para las cuatro compañías volantes y $\mathrm{Y}$ elán de dragones Don MaSonora. Informe, art. 108 , pág. 64. La instrucción a las compoñías, Y el 22 de mayo salió para en Carrizal, I7 de marzo de 1775, en A. G. I., México, 2461.

rog Informe, arts. 108-109, págs. 64-65. Bucareli a Arria

núm. 1997, 1998, 1999 y 2000. A. G. I., Guadalajara, 5 14 y 515 . México, 27 de octubre de 1775, 
vos emplazamientos a los presidios, la revista de éstos y su traslado a la nueva línea, se emprendería una acción conjunta de todas las fuerzas para perseguir sistemáticamente a los indios, obligándoles a alejarse o someterse. Esto es lo que se proponía O'Conor al regresar a principios de septiembre a Nueva Vizcaya, reuniendo una fuerza de trescientos cuarenta hombres con la que salió de San Buenaventura el 23 de aquel mes, dirigiéndose hacia el norte. ${ }^{110} \mathrm{El} \mathrm{I}^{\circ}$ de octubre alcanzaba el río Grande en el paraje del Muerto, sin haber logrado en el trayecto más que un cautivo y cuarenta bestias. Al día siguiente se le reunió el gobernador de Sonora, Crespo, con los hombres a su mando, y le entregó dieciséis prisioneros hechos en la sierra de los Cobres, con cincuenta bestias. Una incursión hecha en los días siguientes no dio ningún fruto. El 8 llegó el teniente Ojeda con la caballada fresca y las recuas de bastimentos, $y$ entonces el campo se movió hacia el norte y remontando un arroyo afluente del río Grande empezó O'Conor a penetrar en la sierra de Mimbres. Se encontraron "infinitas milpas que sembraron los enemigos y muchas jacaleras viejas en que se conoce viven durante el tiempo de la cosecha”. El I4 logró hacer tres cautivas, y empezó la expedición a subir la sierra Madre, incorporándose el i 6 al campo de Sonora, y ya cuando seguía el arroyo o río de los Mimbres se encontró imposible alcanzar a los indios, que al parecer huían a refugiarse a la sierra del Mogollón y al río Gila. Por su parte, los españoles llevaban tres días comiendo carne de caballo por haberse quedado sin bastimentos, y el 20 regresaron al río Grande, donde habían dejado toda la impedimenta, desistiendo de la persecución. Allí encontró O'Conor al capitán de San Eleazario Don Francisco Bellido y al teniente de gobernador de El Paso con cuatrocientos hombres que se habían internado en la sierra Blanca y atacado a los apaches en el Sacramento, haciendo cuarenta bajas y ocho prisioneros a las rancherías de los capitanes Concha y Alonso, Siquilande y Cetocende, con algunos gileños natajes y lipanes y Cachuginde, y les quitaron trescientas bestias y mucho pillaje. Cuando la tropa de El Paso se retiró a sus acuartelamientos, O’Conor se dirigió el 23 hacia el Oeste, rodeando la sierra de los Mimbres por su parte septentrional y subió a la sierra de Mogollón, alcanzando el Gila. En este recorrido capturó quinientas dieciséis bestias e hizo dieciocho prisioneros y cuatro bajas al enemigo, entrando en Janos el i4 de noviembre. Quince días después llegaba al Carrizal, dando por concluida la campaña por su parte. El total de ella había supuesto quince ataques simultáneos dados al enemigo, al que se habían

I I Inclusos los oficiales, la fuerza expedicionaria se integraba de esta forma: dragones de España 42 ; id. de México, 45 ; presidiales de San Buenqventura, ig; íd. de Janos y Catrizal, 49 ; tercera compañía volante, 83 ; cuarta id., ı o2 Total, 339. El diario de la campaña general en A. G. I., Guadalajara, 5 I5. 
hecho ciento treinta y dos bajas y ciento cuatro cautivos, cobrándose unas dos mil bestias y copioso botín en pieles, sin contar que aún no se tenían noticias de las tropas de Coahuila, y que parte del plan había fallado por no haber situado el gobernador de Nuevo México en la Sierra Blanca el destacamento que O'Conor le indicara, y que hubiera cerrado la salida a los indios acosados por las fuerzas de Nueva Vizcaya y Coahuila. Sin embargo, no creía el comandante inspector que esto se debiera a malicia por parte de Mendinueta. II

Cuando en diciembre de 1775 y enero de 1776 pudo Bucareli notificar estos resultados a Madrid, lo hizo pidiendo grado de Brigadier para O'Conor y. de coronel para Crespo, gobernador de Sonora. Por su parte, O'Conor había propuesto a Don Manuel Muñoz para ascenso a teniente coronel, $y$ todas estas presentaciones fueron aceptadas por Gálvez, ya ministro de Indias, en mayo de aquel año. ${ }^{112}$

Precisamente en el mismo mes de enero remite O'Conor a Bucareli un ęstado de los presidios de la Línea, en que detallaba la fecha de su traslado, su fuerza, situados de ganados, su situación económica, etc. ${ }^{113}$ y le hace un bosquejo de su actuación en los cuatro años que lleva encargado de la frontera. Declara haber recorrido 30.037 leguas en este tiempo, "de cuyas incomparables y continuas fatigas, con las excesivas del bufete, me ha resultado gravísimo quebranto en la salud". Reconoce, por supuesto, O’Conor cuánto debe al constante apoyo del virrey, y se felicita del éxito obtenido: los indios, rechazados, han ido a refugiarse entre los ríos Grande y Colorado, en donde por entonces los buscaban las tropas españolas y había fundadas esperanzas de su reducción al dominio del rey, "o acaloarlos con el tiempo y constancia que debe observarse en su persecución". II4 En fin, O’Conor estaba seguro de pacificar todas las provincias internas en el transcurso de 1776 , y Bucareli

I I O'Conor a Bucareli. Carrizal, I. ${ }^{\circ}$ de dicienabre de I575. Ibid.

i a Bucareli a Arriaga. México, 27 de diciembre de 1775 y 27 de enero de I776, números 2083 y 2 108. Gálvez a Ricla, I 8 de mayo de 1776 , comtnica han sido otorgados los ascensos pedidos. Los títulos fueron remitidos por real orden de 2 de junio de i 776 . Ibid.

I 3 El estado, firmado por $O^{\prime}$ Conor en Carrizal, 30 de enero de 1776 , no recoge más que diecinueve presidios, distribuidos por provincias de esta curiosa manera: Texas: Bahía del Espíritu Santo y San Juan Bautista; Coahuila: Monclova, Santa Rosa, San Antonio Bucareli; Nueva Vizcaya: San Sabá, San Carlos, Junta de los Ríos, Príncipe, San Eleazario, Carrizal, San Buenaventura, Janos; Sonora: San Bernardino, Santa Cruz, San Agustín de Tucson, Santa Gertrudis del Altar. Se hallaban más de nu grado fuera de la Línea, en Texas, San Antonio de Béjar con stu destacamento del Arroyo del Cibolo; en Nuevo México, Santa Fe, con el destacantento del Robledo. Total, diecinueve presidios con un costo de 388370 pesos anuales. Es de advertir que el (iestacamento del Robledo nunca existió. A. G. I., Guadalajara, 5 I 5.

I 4 O'Conor a Bucareli. Carrizal, 30 de enero de 1776 , núun. 540. Ibid. Explica aquí no haber incluido en el estado los presidios de Hercasitas y Buenavista, ni la compañía volante agregada al de Terrenate (Santa Cruz), por ser reformables. Asienta, por 1o demás que la actuaeión de las compañías volantes de Nueva Vizcaya ha sido enorme, eficaz y brillante. 
le dio libertad para que dispusiese cuanto le pareciese oportuno, recomendándole no desatendiese Nuevo México, atacado por sus habituales enemigos y por los que pudiesen haberse acercado a sus fronteras, al ser rechazados de las de Coahuila y Nueva Vizcaya, ${ }^{\text {II }}$ y transmitió a Madrid su solicitud de relevo. ${ }^{\text {II } 6}$

Sin embargo, tres meses después de concluida la campaña, los apaches lograban una victoria tan señalada como la muerte del nuevo capitán de la tercera compañía volante, Esparza, con catorce hombres, cuando marchaba de Janos a San Buenaventura, ${ }^{117}$ y en marzo se hacían de nuevo sentir las hostilidades de varias partidas de indios sobre las poblaciones y haciendas de la frontera.

\section{LA SEGUNDA CAMPAÑA GENERAL}

En abril de I776 ya había formado O'Conor un nuevo plan de campaña en que tomarían parte unos dos mil hombres, actuando por diversos rumbos. Bucareli aprobó el proyecto, expidiendo las órdenes correspondientes a los gobernadores de Coahuila, Sonora y Nuevo México. Empezando la campaña a fines de agosto, daría tiempo para que llegasen a esta última provincia los mil quinientos caballos que Bucareli había ordenado se le enviasen. Ir8

Aunque en corto número, los apaches no dejaban de merodear por los pueblos fronterizos, presentándose a veces con pretensiones de paz en El Paso, sin que ni en México ni en Madrid se diese el menor crédito a su aparente buena fe. ${ }^{\text {II }}$ Pero el 26 de abril obtenía notable victoria el alférez de la tercera compañía volante Don Narciso Tapia, con cuarenta y dos hombres, en un combate de cinco horas contra más de trescientos apaches, a los que hizo cuarenta bajas poniéndolos en fuga, en la estancia de Becerras, sobre el mismo terreno en que había caído el capitán de la compañía, Esparza. En este hecho vengó la tercera compañía la muerte de sus dos capitanes. A1 otro lado de la Línea, en una salida preparatoria de la nueva campaña, el capitán de San Sabá Don Francisco Martínez había batido dos gruesas rancherías en el río Colorado, haciéndoles diecisiete muertos y logrando abundante pillaje, rescatando tres cautivos y cerca de seiscientas bestias. ${ }^{\text {r }}$ E Entre tanto, en Sonora se procedía a la construcción de los nuevos presidios. ${ }^{\mathrm{r} 2 \mathrm{~T}}$

I 5 Bucareli a Arriaga. México, 25 de febrero de I776, núm. 2143. Ibid.

I 6 Bucareli a Arriaga. México, 27 de narzo de 1776 , núm. 2180 . Ibid.

I 7 Bucareli a Arriaga. México, 27 de marzo de 1776 , núm. 2 I78, y Extracto de igual data. Ibid.

I 8 Bucareli a Gálvez. México, 27 de mayo de I776, núm. 2242. Ibid.

I 9 Bucareli a Gálvez. México, 27 de mayo de 1776 , núm. 2295. Real orden de 26 de agosto de 1776 . Ibid.

I 20 Extractos de noticias. México, 26 de junio y 27 de julio de 1776 . Ibid.

I2 I Bucareli a Gálvez. México, 26 de junio y 27 de julio de I776, núm. 2299 y 2373. Ibid. 
Contrapartida de la victoria de la estancia de Becerras fue el descalabro sufrido el 7 de julio por la compañía de Santa Cruz en las Mesitas, función en que murió el capitán Don Francisco Tovar con veinticinco hombres. Todas las investigaciones hechas después hicieron responsable de la desgracia al propio Tovar, cuya destitución estaba ya ordenada, acusándosele de incompetencia y negligencia. ${ }^{122}$ Por la misma época, doscientos lipanes asaltaron pastorías de carneros junto a la hacienda de Anahelo, 1levándose caballadas y matando ochenta o noventa cabezas de ganado menor, faitando a la paz prometida desde $1773 .{ }^{123}$

Iil I 4 de septiembre, por fin, partía O’Conor con las fuerzas de su nando del presidio de Janos, con dirección a las Milpas y sierra de las Mimbres, dando comienzo a la segunda campaña general. El 3 I de octubre, desde El Paso, daba cuenta de haher trabado combate con el enenigo cinco veces, causándole veintisiete bajas y dieciocho prisioneros. Desde El Paso pretendía volver a marchar en seguida hacia la sierra Guadalupe y el río Colorado, doncle esperaba encontrar al capitán Berrendo con su ranchería, pero el 2 de noviembre le sobrevino grave enfermedad que le postró en cama, por lo que dio el mando de su destacamento al teniente coronel Don Francisco Bellido que casualmente se hallaba en el pueblo, con orden de, si no hallase a Berrendo, formar tres partidas, enviando una al poniente por el río Colorado; otra al norte, hasta los Arenales, y la tercera al este, hasta encontrar al teniente coronel Don Manuel Muñoz.

Salió Bellido con Don Roque de Medina el 23 de noviembre, y reconoció las sierras de Guadalupe, Aire y del Diablo, del Carrizo, Cola del Aguila y sus colaterales, y tomó contacto con el campo de Muñoz. En total, hasta el ro de diciembre se habían hecho cuarenta bajas y cuarenta y seis prisioneros al adversario, y capturado ciento diecinueve bestias. El destacamento de O'Conor, por otra parte, al hacer presencia en las sierras de Sacramento y Blanca, obligó a los apaches que las habitaban a retirarse al río Colorado, en cuyas proximidades tropezaron con una junta general de comanches, quienes lograron dar muerte a más de trescientas familias. Una partida de Bellido que se presentara más tarde en aquel paraje halló los cuerpos aún frescos y tirados en el campo, con las tiendas todavía puestas y ensangrentadas. Con esto creía O'Conor resuelto el problema apache en aquella zona, donde después de la carnicería ejecutada por los comanches no creía quedasen veinte familias dispersas de la nación enemiga. ${ }^{124}$

I2 Bucareli a Gálvez. México, 26 de septiembre de 1776, núm. 2495, con Extractn. Jbid.

Bucareli a Gálvez. México, 26 de septiembre de 1776 , núm. 2496. A. G. I., Guadalajara, 5 I6.

I23 Bucareli a Gálvez. México, 27 de octubre de 576,11 úm. 2540 , con Extracto. Ibid.

I 2. O'Conor a Bucareli. Carrizal, 20 de diciembie de I776. A. G. I., Guadalajara. 516. 
Con esto, por otra parte, terminaba su actuación en las provincias internas. El 20 de enero había ya ordenado a Don Manuel Muñoz diese en adelante las novedades directamente al virrey, porque "la grave enfermedad que yo padezco - dice el comandante inspector-, y sin esperanza de alivio en estos países por carecer de los medicamentos necesarios y demás auxilios conducentes al restablecimiento de mi quebrantada salud impiden su ejecución por mí". Pedía, en cambio, al virrey permiso para pasar a México, entregando a Muñoz todo su archivo con el mando interino de la frontera, ${ }^{125}$ y el virrey accedió a esta demanda. ${ }^{126}$

Muñoz se hizo, en efecto, cargo de la comandancia de las armas, y es él quien comunica las novedades el 3 de febrero, indicando al mismo tiempo la falta de salud de O'Conor. ${ }^{127}$ Poco después debió emprender éste su marcha hacia la capital del virreinato, adonde llegaría entre el 7 y el i7 de mayo. $\mathrm{Su}$ intervención en los asuntos de la frontera puede darse por concluida cuando firma en 22 de julio el informe dirigido al comandante general Don Teodoro de Croix, que se dispone a pasar a las provincias internas. Este encuentro hizo saborear a O'Conor la amargura de la incomprensión y la desconfianza del nuevo jefe, que poco después no se recataría de contradecir las noticias proporcionadas por O'Conor y de verter las más hirientes sospechas acerca de la veracidad de éste.

De todos modos, O'Conor continuaría el 29 de julio su viaje al sur, para hacerse cargo del gobierno y capitanía general de Yucatán que le había sido conferido en 4 de julio de 1776 . ${ }^{2} 8$

"Yo no sé - escribe el propio O'Conor - si ha sido acierto o dicha la que experimenté en el tiempo de mi mando: la verdad es que procuré desempeñar mi obligación no perdonando fatiga, y que del poco sosiego se me produjeron tantas experiencias que iba ya conociendo lo que convenía en la frontera; ellas fueron las decisivas de los planes que hice observar". ${ }^{22} 9$

I 25 O'Conor a Bucareli. Chihuahua, 20 de enero de I777. Ibid. E1 4 de enero estaba O’Conor todavía en Carrizal, participando al virrey las noticias de Texas.

I 26 Bucareli remitió a Teodoro de Croix la carta antecedente, en I 7 de febrero de I777. Croix estuvo de acuerdo en su respuesta de igual fecha, puesto que el nuevo comandante inspector había de marchar inmediatamente a la frontera. Ibid.

I 27 Bucareli a Gálvez. México, 27 de marzo de 1777 , núm. 2834. Muñoz a Bucareli. Chihuahua, 3 de febrero de 1777. Ibid. Muñoz tuvo el mando interino hasta el 27 de abril, en que Rubio llegó a Chihuahıa. Rubio a Gálvez. Chihuahua, 28 de abril de I777. Ibid.

I 28 Resolución de S. M. según nota de Gálvez de esta fecha a la carta de Bucareli datadil ea México, 27 de marzo de I776, núm. 2180. A. G. I., Guadalajara, 5 г5. El decreto fue firmado en I I de julio de 1776 .

I29 O'Conor a Gálvez. México, 27 de julio de I777. A. G. I., Guadalajara, 516. A mitad de agosto salió O'Conor de la capital, para embarcar en Veracruz el 6 de septiembre con dirección a Campeche, donde desembarcaría el i 7 del mismo mes. E1 ro de octubre tomó posesión de su nuevo cargo, en cuyo desempeño se mantuvo hasta su muerte, acaecida en M'érida de Yucataán el 8 de marzo de r 779. Sobre la actuación del irlandés en esta última etapa, vid. Molina Solis, S. J., IIistoria de Yucatán durante la dominación española; JII. Mérida, I9I3. 
Principio de la última guerra en Nuevo México

Años difíciles tocaron a Don Pedro Fermín de Mendinuteta para su gobierno en Santa Fe. Nuevo México queda en la práctica, hastầ la llegada de Teodoro de Croix, al margen de la política general desarrollada sobre las provincias internas, y la paz inestable obtenida por el gobernador en I77 I había de quebrarse bien pronto. Mendinueta podía decir con razón que en su provincia "todo es frontera" en las cincuenta y cinco leguas de Taos a Tomé, y en las setenta de Pecos a Zuñi. Hostilizando los apaches por oeste y sur, y los comanches por todos los rumbos, imposible era la defensa con sólo los ochenta soldados de Santa Fe. Había unos doscientos cincuenta hombres que disponían de armas, y los indios sometidos tenían arcos y flechas, jero aunque todos estaban dispuestos a salir a campaña sin estipendio alguno cuando el gobernador lo ordenaba, su reunión llevaba bastante tiempo, y además no se podía dejar los pueblos indefensos. Siempre se había venido experimentando la falta de armas y caballos.

Robos y muertes habíanse sufrido de los comanches íltimamente, en Pecos, Sabinal y San Ildefonso, y estos repetidos insultos, y el no haber acucliclo aquellos a solicitar la paz en todo el invierno anterior hacían teme: ¿ Mendinueta justamente en marzo de I 772 que una vez libradas las sierras de nieve continuarían sus irrupciones, dando por cierta la guerra y por muy débil la resistencia, aquejada como estaba la provincia, además, por una epidemia. ${ }^{\text {r } 30}$ Pero era inútil cue Mendinueta pidiese la erección cle nuevo presidio en Taos. La única sugerencia presentada por el fiscal Areche en México sería la de que se procurase unir los pueblos para facilitar la defensa, ${ }^{131}$ idea que más adelante se intentaría llevar a la práctica.

No habían transcurrido dos meses de la redacción de este informe con que el gobernador hacía presente al virrey la situación de Nuevo México cuando el 22 de julio de I772 más de quinientos comanches atacaban Pecos; otro grupo de doscientos atacó cinco veces Pecuries; otros cien intentaron cuatro veces el asalto a Galisteo. En todas partes fueron rechazados, haciéndoseles treinta y una bajas, aunque ellos dieron muerte a cinco indios de aquellos pueblos. Una partida de tropa y vecinos enviada por el gobernador cattsó otras doce bajas al enemigo, al que fueron tomadas sesenta cabalgaduras y una prisionera. Sin embargo de todo ello, no hallaban los comanches inconveniente en presentarse de paz en Taos con ocasión de la feria, a comerciar sus pieles de cibolo, y sus caballos, mulas, fusiles y cautivos, que

I30 Bucareli a Arriaga. México, 26 de junio de I 772, con Extracto. Velasco, I, 52-59.

I3 1 Mendinueta a Bucareli. Santa Fe, 26 de mayo de izz2. Vista del fiscal Areche. México, 3 de agosto de т 72 . A. G. I., Guadalajara, 276. 
cambalacheaban por frenos, leznas, cuchillos, ropas coloradas y maíz, lo cual, por otra parte, era beneficioso a los ciudadanos de la provincia. También Mendinueta aprovechaba la ocasión para hacer canje de prisioneros.

Por el otro frente, también los apaches iniciaron sus hostilidades, aunque con más cautela. En número de cincuenta atacaron Zuñi, donde causaron seis muertes, pero hubieron de retirarse con veintidós bajas y muchos malheridos. ${ }^{132}$ Bucareli, sin embargo, confiaba en que el valor de los vecindarios desvanecería siempre el temor de los daños que pudieran causar comanches y apaches, y sólo esperaba que después de arreglada la Línea de presidios fuese posible castigar a los enemigos ${ }^{133}$ a los que Mendinueta debería atraer a la paz, teniendo siempre prevenidos a los vecinos al mismo tiempo. ${ }^{134}$ El fin de $177^{2}$, con todo, no había sido cómodo para Nuevo México, pues los apaches mataron a tres pastores junto a Tomé, y luego, habiéndose incorporado amistosamente al cordón que bajaba de Santa Fe a Chihuahua durante dos días, concluyeron dando muerte a uno de los arrieros. Los comanches cesaron un tiempo en sus insultos, pero el 7 de enero de $\mathrm{I} 773$ robaron caballada en Santa Fe, mataron a un yuta y cautivaron tres familias de esta nación. ${ }^{135}$

Meses después, el 4 de julio, se producía el hecho sorprendente de que apaches y comanches atacaron, aliados por una vez, en número de más de quinientos, el paraje del Valle, a quince leguas de Santa Fe, logrando llevarse casi toda la caballada del presidio y la de los vecinos de la villa y de los pueblos de Jemez y Cochití. Salió Mendinueta con un pequeño destacamento en persecución de los agresores, pero éstos se dividieron en tres grupos la noche del 7 , tomando diferentes rumbos por la sierra, y fue imposible darles alcance. Otros comanches hostilizaron Tesuque, y un contingente de doscientos cayó, sin éxito, sobre Pecuries. Los asaltos de los apaches siempre eran de menor entidad. La provincia padecía igualmente la carestía de granos, debido a la sequía y a la langosta de $1772 .{ }^{136}$

El golpe del 4 de julio fue muy duro porque quedaron muy pocos soldados con dos caballos siquiera, y se había hecho patente de una vez la debilidad de la guarnición. Mendinueta expuso claramente la imposibilidad de establecer treinta soldados en Robledo según se ordenaba en el nuevo regla-

I32 Noticias comunicadas por Mendinueta en 14 de noviembre de I 772 . En Extracto de noticias. México, 27 de enero de I773. A. G. I., Guadalajara, 5 I 3.

I33 Bucareli a Arriaga. México, 27 de enero de 1773, núm, 735. Ibid.

I34 Bucareli a Arriaga. México, 26 de abril de 1773, núm. 885. Ibid.

I35 Noticias de Mendinueta de I 2 de enero de 1773. Extracto enviado por Bucareli a Arriaga. México, 26 de abril de 1773. Ibid.

I36 Bucareli a Arria. México, 26 de noviembre de 1773 , núm. i 87 , con Extracto. A. G. I., Guadalajara, 5 I 2. 
mento de presidios y lo había indicado O'Conor. Bucareli tuvo que darie la razón, sospechando que tal vez los indios rechazados de las fronteras de Nueva Vizcaya y Coahuila por el comandante inspector fuesen a caer con mayor fuerza sobre Nuevo México. ${ }^{\mathrm{I}} 37$

Todo intento de paz resultaba fallido. A poco de aquel asalto fueron dos partidas de comanches a Taos, y allí fueron rescatados once indios cautivos y dos cristianos capturados por los apaches en Coahuila. Sin embargo, el 8 de agosto y el 20 de septiembre sufrió Taos diferentes ataques por los mismos comanches, la segunda vez en número de más de doscientos. Ocho días después también atacaron Pecuries, aunque de estos incidentes casi siempre salían con pérdida los asaltantes. Los apaches merodeaban entonces por Alburquerque, y el alcalde mayor de esta villa procuraba tenerlos a raya. Mendinueta, en cambio, no podía castigar a los comanches su perfidia por
hallarse sin fuerzas suficientes. ${ }^{138}$

Con la inconsecuencia que les caracterizaba, poco tiempo después doce ranchos de comanches acudieron a Taos para hacer pacíficamente su feria. ${ }^{1} 39$ Más adelante, a los atacantes comanches y apaches se sumó este grupo apache llamado gileño, que mediado I774 había realizado ocho incursiones contra la provincia. Perseguidos una vez, en un serio encuentro los españoles tuvieron seis bajas contra y treinta y tres de los adversarios. ${ }^{140}$ Consuelo de la provincia era esperar que la cosecha de aquel año prometía ser abundante, ${ }^{14 x}$ con lo que se remediaría el hambre pasada, pero el verano fue sumamente
agitado.

E1 27 de julio, más de mil comanches invadieron las jurisdicciones de la Cañada, asaltando tres lugares de españoles y dos de indios. Hubieron de retirarse con veintitrés bajas y sin haber podido incendiar las casas, aunque hicieron siete muertes y tres cautivos, llevándose trescientas bestias. El 25 de agosto, cien comanches atacaron Pecos. Algo debía haberse recuperado la provincia en el año transcurrido, cuando Mendinueta pudo enviar ciento diez hombres entre tropa, vecinos e indios en persecución de aquéllos. Cinco días después, el guía - cautivo doce años de los comanches- ponía a la fuerza española ante una enorme ranchería y les indicaba las tiendas de los grandes jefes. El asalto por sorpresa costó la vida a cularenta comanches, entre ellos

I37 Bucareli a Arriaga. México, 26 de noviembre de 1773, nínı. i 182. Ibid.

diciembre de 1773 . Con cartas de Bucareli, núms. 220 y. Extracto de noticias. México, 27 de

I39 Noticias de Mendinueta, I 2 de noviemb. I 220 y i 22 I. Velasco, I, I I7-I Ig.

de I774. A. G. I., Guadalajara, 514.

I40 Extracto de noticias. México, 26 de septiembre de $177-1$. Ibid. I $78-\mathrm{I} 8 \mathrm{I}$. 
siete capitanes. Aquel día 20 de agosto de 1774 pasó entero para aquel puñado de hombres en constante combate, habiendo formado el cuadro una vez que el enemigo los rodeó. Sólo murió un soldado. Los comanches, al fin, se retiraron, dejando su campo y toda su caballada en manos de los españoles, que. habían perdido la suya.

Aprovechando este tiempo, el gobernador pudo reunir un ejército de seiscientos hombres, mandados por don Carlos Fernández, que el 28 de septiembre atacaron otra ranchería, apresando ciento quince comanches y matando a todos los demás, que se calculaban en más de cuatrocientos, salvo dieciocho que pudieron huir. Más de mil bestias quedaron aquel día en su poder, con toda clase de botín. De esta manera, pudo O'Conor recibir ochenta y tres de aquellos cautivos, enviados por Mendinueta, ${ }^{i 4 z}$ y el virrey podía escribir que "si todos los vecindarios (de las provincias internas) fueran como los de Nuevo México, sería fácil la segura conquista de aquellos bárbaros y el suave dominio del rey". La sequía era siempre el mayor peligro, pero los vecinos se defendían con unión, tesón y espíritu animoso, proviniendo todo ello de la conducta del gobernador. ${ }^{143}$ En consecuencia, Bucareli ofreció a Mendinueta enviarle armas y previno a O'Conor hiciese pasar a Nuevo México una compañía volante si aquél la pedía. ${ }^{\mathbf{1 4 4}}$

Pero la victoria final y la paz estaban muy lejos de conseguirse y, por el contrario, la situación de la provincia aún había de agravarse notablemente cuando en octubre de aquel año Mendinueta informaba al virrey que se habían producido algunos choques con los navajos en el pueblo de la Laguna. ${ }^{145}$ Parece ser que robaron aquí algún ganado menor, que les fue después quitado; pero una expedición practicada contra ellos a fines de noviembre no tuvo éxito, pese a lo cual pronto empezaron a prometer la paz. Los yutas, que también entran ahora en guerra con los navajos, les causaban muchas bajas; een mayo de 1775 los indios de Jemez les habían hecho cinco prisioneros, $y$ se esperaba llegar pronto a las paces, como deseaba el vierrey.

Los comanches, entrando el nuevo año, reanudaron sus hostilidades.

I4 Bucareli a Arriaga. México, 27 de enero de 1775 , núm. 7683 , con Extracto. A. G. I. Guadalajara, 5i4. Mendinueta naria los ataques a las rancherías comanches en carta a Bucareli Santa Fe 30 de septiembre y 20 de octubre de I774. A. G. I., Guadalajara, 515.

I 43 Bucareli a Arriaga. México, 27 de enero de 1774, nún. 1684. A. G. I., Guadalajara, 514.

I 44 Bucareli a Arriaga. México, 24 de febrero de I775, nútm. I 7 I 7 . A. G. I., Guadalajara, 5 I 5. La real orden de 8 de julio de 1775 pide a Bucareli proponga recompensa para Mendinueta. Ibid.

145 Mendinueta a Bucareli. Santa Fe, 20 de octubre de I774. Ibid. Frank D. Reeve supone que la guerra con los navajos debió recomenzar durante el gobierno de Mendinueta, en la primavera o el verano de I774. Reeve, Frank D., Navaho-Spanish Diplomacy, r770-I790. N. M. H. R., $\mathrm{XXXV}, 3 \mathrm{July} 1960,200-235$; pág. 206. Este mismo autor supone que la ruptura pudo deberse a un simple conflicto por disputa de tierras, puesto que ya los navajos eran agricultores y solore todo ganaderos, en The Nar'aho Spanish peace: I720's-I77o's. N. M. H. R, XXXIV, I, Jan. I $950,9-40$; pág. 40 . 
En pequeñas partidas ahora, cometían algunas muertes y depredaciones de ganado en Sandía, Pecos, Isleta y Santa Fe. El 3 de marzo, cien comanches invadieron el pueblo de Huertas, a quince leguas de la capital, donde hicieron cinco muertos y un prisionero, llevándose la caballada. Quince de éstos se internaron en los pueblos de los queres, donde cometieron tres muertes; pero los indios de Jemez, Cía y Galisteo mataron a once de ellos, dándose a la fuga los restantes, siendo posteriormente rechazado un nuevo ataque sobre Pecos. Ocho incursiones de los gileños habidas en el mismo tiempo contra Alburquerque, La Laguna, Acoma, Zuñi y Santa Ana habían causado trece muertes, trece cautivos y el robo de noventa bestias. Los defensores habian producido nueve bajas a los atacantes. ${ }^{\mathrm{I}} 6 \mathrm{~A}$ A poco, el I3 de mayo se presentaba en Taos un jefe comanche con siete ranchos, manifestando deseos de efectuar rescate de objetos, lo que el alcande mayor, cumpliendo orden de Mendinueta, no permitió, gracias a lo cual fracasaron tres emboscadas que luego se conoció tenían los bárbaros preparadas para el fin de la feria. Una madrugada, cuando los indios fieles salían a cazar lobos cercándolos, según su costumbre, tropezaron con la primera partida, de más cien comanches, a los que, sin embargo, batieron. Otro grupo atacó el 27 de mayo las labores del pueblo de Nambé, y el 22 de junio atacaron en gran número Sandía y el pueblo de la Alameda, tendiendo luego una emboscada a sus perseguidores a pie, dando muerte a treinta y tres de éstos, sin otros ocho a los que quitaron la vida en los anteriores encuentros, en los que también robaron mucha caballada y destrozaron ganado mayor y menor. Los atacó luego el alférez Don Francisco Esquivel, con cuatro escuadras, pero no logró desalojarlos de su posición: otras cuatro muertes se produjeron en este combate aunque también los adversarios sufrieron muchas bajas. Junto a esto en agosto de I775, comanches, gileños y navajos seguían hostilizando Pecos, Galisteo, La Laguna y otros lugares. ${ }^{147}$ Con razón decía Mendinueta en I9 de agosto que sus tropas no podían tomar parte en las operaciones de la próxima campaña general planeada por O'Conor, pues harto hacían con defender la provincia. Su demanda principal eran mil quinientos caballos que pretendía recibir de cuenta del rey. Bucareli estaba dispuesto a enviarlos, según su propio sentir npoyado por el fiscal y el tribunal de cuentas, una vez que se decidiese en junta de real hacienda. "La subsistencia de Nuevo México - escribe- siempre será causa de relativa tranquilidad en las demás provincias". ${ }^{\mathrm{I}} 8 \mathrm{La}$ junta

146 Bucareli a Arriaga, México, 27 de julio de 1775 , núm, 1898 , con Extracto que recoge noticias de Mendinueta de 30 de marzo y 12 de mayo. A. G. I., Guadalajara, 514. Bucareli a Arriaga. México, 27 de julio de 1775 , núm. 1899. A. G. I., Guadalajara, 515.

147 Noticias de Mendinueta, 18 de agosto, en Extracto de México, 27 de octubre de 1775. Ibid.

148 Bucareli a Arriaga. México, 27 de octubre de 1775, núms, 1995 y 1996 . Ibid. 
de 26 de octubre de 1775 decidió, en efecto, ordenar a O'Conor comprase y remitiese a Nuevo México la cabaliada pedida, pagándola el tesorero de la expedición de Chihuahua. ${ }^{149}$ En diciembre de aquel año, Bucareli proponía al coronel Mendinueta para el grado de brigadier, que le fue otorgado en mayo de $1776 .{ }^{150}$

Entre tanto, el 24 de agosto de I775 trescientos gileños atacaron Acoma, haciendo quince muertes y tres prisioneros, llevándose todo el ganado. La Alameda y Belén fueron luego teatro de sus acciones de guerra, así como Taos volvía a ser atacada, sin éxito, por los comanches. Después, la tensión que sacudía a Nuevo México desde hacía más de tres años cedió como por encanto. Los navajos, que tiempo atrás pretendían la paz, la obtuvieron por fin de Mendintueta, que en $I^{\circ}{ }^{\circ}$ de diciembre decía haber quedado satisfecho de las pruebas dadas por aquéllos. ${ }^{15}$ I Mostráronse, pues, los navajos de paz por algún tiempo, "observando la amistad poco ha ofrecida y sembrando sus antiguos terrenos". Y toda la primera mitad de 1776 transcurrió sólo con algunas pequeñas acciones de los comanches en Alburquerque y Galisteo. Los vecinos volvían a experimentar escasez y salían a cazar cibolos para remediarla. Mendinueta había previsto tomar parte en la próxinna campaña de O'Conor, y sólo esperaba recibir la caballada de Nueva Vizcaya. ${ }^{152}$ A este fin había enviado a El Paso a un individuo que se hiciese cargo de ella. La escasez de agua había dificultado la reunión de las mil quinientas cabezas, tarea que se había encomendado al capitán Don Rafael Martínez Pacheco. Bucareli dispuso que este mismo capitán, con una escuadra de su presidio y cincuenta vecinos asalariados procediese a la conducción de la caballada rasta Nuevo México. ${ }^{153}$

Sin embargo, esto no llegó a hacerse, pero así y todo el gobernador de Nuevo México destinó al teniente Don Diego Borica para que con doscientos cincuenta hombres reconociese las sierras de la Magdalena y Ladrones interviniendo de este modo en la campaña general de 1776 , aunque no habían dejado de experimentarse daños producidos por gileños y comanches en Alburquerque y Cieneguilla, Santa Fe, Abiquiú y Taos. ${ }^{154}$ Parece ser que,

I 49 Bucareli a Arriaga. México, 26 de noviembre de 1775, núm. 2038. Ibid.

r 50 Bucareli a Arriaga. México, 27 de diciembre de 1775 , núm. 2083. E1 virrey cumple así la real orden de 8 de julio. Gálvez a Ricla, is de mayo de 1776 . Tbid.

I 5 I Noticias de M'endinueta, I. ' de diciembre de I775, en Extracto de México, 25 de febrero de 1776 . Ibid.

I5 Noticias de Mendinueta, 5 de junio de 1775 , en carta de Bucareli a Gálvez. México 27 de agosto de i 776, núm, 2480. A. G. I., Guadalajasa, 516, y ell Extracto de México, 26 de septiembre de I776. A. G. I., Guadalajara, 5 I 5.

I53 Bucareli a Gálvez. México, 27 de agosto de I 776 , núm. 243 I. A. G. I., Guadalajara, 5I6.

I54 Noticias de Mendinueta, I 2 de agosto de 1776 , en Extracto de México, 27 de diciembre cle I $7 \bar{j}^{0}$, con carta de Bucareli, múm. 2639. Noticias de Mendinueta, en Extracto de México, 24 de febrero de 1777 , con carta de Bucareli, núm. 2750. Ibid. 
como consecuencia del último movimiento conjunto de las armas al mando de O'Conor, todos los apaches del Poniente con sus familias y caballadas se retiraron fugitivos de las sierras de Mimbres y del Gila a la misión de Zuñi, donde pidieron la paz. ${ }^{155}$

La lucha con apaches y comanches no terminó aquí, pero Mendinueta había pediclo más de una vez se le relevase de aquel duro y ya largo gobierno, a lo que el rey se avino en febrero de $\mathrm{I} 777$, nombrando en su lugar a Don Juan Bautista de Anza. ${ }^{156}$ Pero ambos personajes tendrían aún importante actuación antes de que se efectuase realmente el relevo anunciado.

También O'Conor, antes de retirarse, hubo de tomar algunas medidas para precaver el surtimiento de armas a los comanches desde algún establecimiento europeo al norte de Nuevo México, al otro lado del famoso río del Tizón, segúin se temía. ${ }^{157}$

\section{Cinco años de transición fen Sonora}

En el tiempo que Sonora vivió bajo la directa autoridad de Bucareli, hallose la provincia en la anómala situación de tener simultáneamente dos gobernadores, que indistintamente atendían a la mayor parte de los problemas de todo orden que se ofrecían. Ello se debió a una extraña inconsecuencia en la línea de conducta del virrey, que probablemente nunca explicó este punto de su comportamiento.

Es el caso que el marqués de Croix había expedido a Don Pedro Corbalán título de gobernador e intendente de Sonora, por renuncia, según decía, de Don Eusebio Ventura Beleña, a quien había sido dado antes igual nombramiento, pero que nunca tomó posesión del cargo, y atendiendo igualmente a la solicitud de Don Juan de Pineda, el anterior gobernador, que deseaba ser relevado del puesto en atención a sus enfermedades. Croix pidió se despachase a Corbalán en Madrid este título con el sueldo anual de seis mil pesos. ${ }^{158}$ Esta carta de Croix no tuvo respuesta, pero Corbalán era ya con-

I 55 O'Conor a Bucareli. Carrizal, 20 de diciembre de 1776 , basándose en carta de Fray Francisco Garcés de is de octubre. Ibid,

156 Bucareli a Gálvez. México, 27 de octubre de 1776. Remite la última solicitud de retiro de Mendinueta. La nota de Gálvez al margen dice: "S. M, confiere este gobierno al teniente coronel D. Juan Bautista de Anza con atención a su mérito y conocimientos prácticos. $\mathrm{Y}$ avísese desde luego al virrey con expresión de que ha nombrado el rey a este oficial atendiendo a los informes reli con que hizo de el para este destino. Febrero 3 de $77 "$. Se comunicó esta decisión a Buca-

157 Real orden de de febrero de 1777 . A. G. I., Guadalajara, 300

158 Croix a Arriaga. México, de 1777 a O'Conor, aprobando stus providencias.

Corbalán había sido nombrado que ya tenía del pais, adquirido en compañin de la expedición de Elizondo por el comocimient? 
siderado gobernador e intendente de Sonora, y dándole este título se ordenó en Io de junio de I77I a los oficiales reales de México entregasen cien mil pesos al tesorero de la expedición Don Juan de Echeveste, quien habría de dirigirlos a manos de aquél, "con destino a las urgencias que ocurran en Sonora y Sinaloa". ${ }^{\text {I59 }}$

Esta situación se mantuvo a lo largo de más de un año y durante este tiempo actuó Corbalán como máxima autoridad de la provincia. En enero de 177 I acusaba recibo del real decreto de I6 de abril de I770 que disponía se procurase la extinción de los idiomas indígenas. Corbalán muestra la conveniencia de fundar escuelas de lengua castellana, $y$ se propone dotar a los maestros con tierras de comunidad, con lo que haría apetecibles estos empleos. ${ }^{\text {I60 }}$

E1 fomento de la provincia, siguiendo las ideas directrices de Gálvez, quedaba en otro aspecto asegurado con la orden de Croix de 12 de junio de I77 I para que se procediese a establecer caja real en Rosario y a trasladar la de Alamos a Arizpe o Ures. Corbalán estuvo dispuesto a fundar la de Rosario y pidió al virrey las cuatro marcas indispensables: las de quinto, diezmo, señoreaje y piezas labradas, y las pesas y demás útiles. En cuanto a la de Alamos, consideraba preferible localizarla en Ures, buscando siempre la mayor proximidad a Nueva Vizcaya para comodidad del comercio y evitación del contrabando. ${ }^{16}$ En estos últimos momentos del gobierno de Don Carlos Francisco de Croix, cuando Tueros procede a regularizar la población de Cieneguilla, Mesía se encarga del asentamiento de los seris y el mismo Corbalán comınica el hallazgo de nuevos placeres de oro en Cocospera, junto a San José de Pimas. El gobernador e intendente estaba también atento a preparar los fielatos para el estanco de tabaco, pólvora y naipes, que empezaría en enero de I772, y a fundar nuevas poblaciones, sobre todo Guaymas, que sería útil para la habilitación de barcos, recaudación de tributos en el Yaqui y el Mayo y socorro de las Californias. ${ }^{\text {r6z }}$ Todos los indios se hallaban por el momento sosegados, aunque los pimas altos se mostraban reacios al irabajo. De las tropas de la expedición quedaban aún la compañía de fusileros de montaña, en Pitic, cuyo regreso o licencia estaba ordenado, y la segunda compañía volante, cuyo destino quedó a discreción de Corbalán, ${ }^{16} 3$ siendo for fin incorporada al presidio de Terrenate.

En septiembre de aquel año, Corbalán ofreció a Bucareli el panorama

I 59 E1 Tribunal de Cuentas a S. M. México, 26 de junio de iz7r. Tbid,

i60 Corbalán a D. Tomés del Mello. Alamos. is de enero de г77r. A. G. I., Guadalajara, 338.

I6 I Corbalán a Croix. Pitic, 2 de agosto de i77ı. A. G. I., Guadalajara, 512.

I6a Croix a Arriaga, México, 26 de agosto de 1775, núm. I069. Ibid.

r63 Noticias de Sonora, comunicadas en Extractos de Croix a Arriaga. México, ig de septiembre de r77r, núm. rog2. Tbid. 
de la prosperidad minera avisándole que se habían repoblado los placeres de Aygame, de oro, "aunque muy delgado", y había dispuesto habilitar al dueño de la mina de Bacuachi, de plata. Mejoraban las extracciones en el Cerro de los Promontorios, y en Cieneguilla no se quejaban los comerciantes, aunque había muchos. Así lo participó Bucareli a Madrid, pero entonces se hizo patente la desconfianza oficial, pues los términos de la real orden de I 8 de marzo de 1772 decían al virrey "que la verdadera noticia de tales descubiertas es confirmarlas V. E. con el producto de los diezmos de las cajas marcas del distrito, sin cuya calificación y otros infcrmes de mineros prácticos y aviadores de éstos que tiene V. E. en esa cápital, con dificultad apurará V. E. la realidad de semejantes avisos, que por lo regular los abulta el deseo - la preocupación". Así hubo de reconocerlo Bucareli, y por ello pidió nuevos informes al mismo Corbalán y al gobernador recientemente nombrado, Sas-
tre. ${ }^{164}$

Entre tanto, el resto de I77 I transcurrió con algún sobresalto de nuevo levantamiento de los sibubapas, ${ }^{165}$ y una entrada del capitán de Tubac, Don Juan Bautista de Anza, con treinta y cuatro soldados y cuarenta pimas, contra los apaches, a los que atacó en el río Gila, junto a la sierra Florida, haciéndoles nueve bajas y ocho prisioneros, dando libertad a un cautivo. I66 Corbalán hallaba dificultad en la exacción de tributos de los yaquis y mayos, de modo que en diciembre no habían pagado ni la cuarta parte de lo correspondiente al primer semestre del año. Los ópatas, por otra parte, se habían negado a satisfacer los diezmos de sus frutos, lo que el gobernador e intendente les toleró. Bucareli aprobó esto por el momento, ${ }^{167}$ y aconsejó suavidad en el cobro de los tributos, pidiendo además, por parecer del fiscal Areche, informes acerca de la cuota y de la matrícula de los tributarios. ${ }^{168}$ Por último, Corbalán anunciaba a fin de año que el placer de Cieneguilla, "el mejor que nunca se viera en Nueva España”, decaía desde junio, a pesar de haber llegado ya las lluvias. De Cieneguilla había que llevar la tierra a hombros hasta cuatro o cinco leguas, y sacar luego el agua a mano de los pozos, siendo los operarios indios sin bagajes donde llevar las tierras, por lo caro, por su escasez, que estaban los bastimentos en todo el país. Don Pedro de

164 Corbalán a Bucareli, 24 de septiémbre de I 77 I. Bucareli a Arriaga. México, 28 de octubre de 1771 , núm. 48. Real orden de 8 de marzo de 1772 .' Bucareli a Arriaga. México,
26 de julio de 1772 , núm. 458. Ibid.

165 Bucareli a Arriaga. México, 28 de octubre de 1771 , núm. 38. Ibid.

166 Bucareli a Arriaga. México, 28 de octubre de 1771 , num, 39. Ibid,

167 Bucareli a Arriaga. México, 28 de octubre de 1771 , núm. 40. A. G. I., Guadalajara, $33 \mathrm{~S}$. brero de 1772 . Bucareli a Corbalámos, 24 de diciembre de 1711 . Consulta de Areche, $12 \mathrm{de}$ fe24 de febrero de 1772 , núm. 226. A. G. I., Guadalajara, 512. 
Tueros, sin embargo, creía que al norte y noroeste de Cieneguilla había oro hasta la sierra del Viejo y Bisani, a dieciséis leguas, y por el sudoeste hasta el carrizal del Picú, a igual distancia. El oro de Aygame no podía explotarse por no haber agua a menos de ocho leguas. También había decaído el cerro de Promontorios, donde al principio se cortaron trozos de plata virgen de hasta cuatro arrobas. Con todo, el 2 de septiembre se quintaron en Alamos 2.033 marcos, 5 onzas y 4 ochavos de oro, sin haber acudido todos los mineros de Sonora, y en dicienibre se esperalsa superar esta cifra. ${ }^{169}$

Pero habiendo recibido con anterioridad cuarenta mil pesos enviados por Don José Trillo, factor de tabacos de Guadalajara, tenía Corbalán los cien mil pesos que luego le había remitido el virrey Croix sin saber qué empleo clarles, y así lo comunicó a Bucareli. Para entonces, éste, que había empezado expresando su esperanza sobre Cieneguilla, "que serán fundadas cuando los efectos se reconozcan en la Casa de la Moneda", izo escribe: "Yo no me he llevado chasco, porque no conté con tesoros extraordinarios; aquella provincia ha dado siempre oro y lo dará en lo sucesivo como señal, y no como cosecha". " $71 \mathrm{El}$ escepticismo del virrey no tenía más remedio que fortalecerse a la vista de la negativa de todos los miembros dęl consulado de México a adquirir acciones en la compañía para el fomento de minas y pesquerías de perlas cuya constitución convocaron Croix y Gálvez. ${ }^{172}$

Hasta ciento ochenta mil pesos tuvo en su poder para rescate de oro en Cieneguilla Don Pedro de Tueros. En diciembre de I77 I había convertido en oro catorce mil. ${ }^{173}$ En mayo de 1772 eran ya cuarenta mil pesos los invertidos en rescate de oro en Cieneguilla, rescatándose a razón de diez pesos la onza de polvo y grano, siendo el oro de veinte y hasta de veintidós quilates. ${ }^{174}$ Por orden cle Corbalán, y según disposiciones mandadas del virrey, cien mil pesos fueron remitidos a Chihuahua, a lomos de mulas de la expedición; cuarenta y dos mil pesos en oro pasaron a manos de Corbalán, a quien Bucareli tenia ordenado enviase a México el oro fundido y quintado resca-

r6g Corbalán a Bucareli. Alamos, 24 de diciembre de r771. Bucáreli a Arriaga. M'éxico, 27 de enero de 1772 , núm. 197. Ibid.

i7o Bucareli a Losada. México, 30 de octubre de Izy, confidencial. A. G. I., México, I 24 I.

I7 I Bucareli a O'Reilly. México, 27 de enero de $I 772$, confidencial, A. G. I., México, I 272. A la misma noticia respondía Muzquiz con estas palabras: "Siento mucho que se desvanezcan las esperanzas que habíamos concebido de las riquezas de la Cieneguilla, pero a bien que 110 faltarán minas como haya azogue por todas partes según conviene". Muzquiz a Bucareli. Aranjuez, 25 de abril de 1772 , confidencial. A. G. I.. México, I24 I.

172 Bucareli a Arriaga, México, 23 de mayo de I772, núm. 257, reservada. A. G. I., México, I 24 I.

I73 Extracto de noticias, México, 26 de julio de I772. En estas fechas eran en general confusas las noticias. Bucareli a Arriaga. México, 26 de julio de 1772 , nún. 459. Ibid.

I74 Extracto de noticias. México, 27 de agosto de $1 / 72$. Ibid. 
tado en Cieneguiila. ${ }^{175}$ Quedaban por último en poder de Tueros otros treinta y ocho mil pesos que estaba convirtiendo en oro en octubre de este año. Durante una ausencia de Tueros se enrareció el ambiente del real: se abandonó toda precaución defensiva, se formaron unas setenta ruedas de juego, que funcionaban día y noche, de tal manera que los indios enemigos pudieron causar varias muertes sin obstáculo, y durante dos meses no se trabajó nada. El subdelegado consiguió restablecer el orden en abril, a su regreso, y llevaba con rigidez la aplicación de las guías para evitar la salida fraudulenta del metal.

Por octubre de I 772 contaba Cieneguilla más de siete mil habitantes, habiendo una gran masa de población flotante. Más de tres mil eran indios, que eran los que principalmente se afanaban en la busca del oro, pues "los españoles no valen nada para este asunto, porque les cuadra muy bien la sombra". Eran los indios precisamente los más difíciles de empadronar, ya que "la mayor parte de ellos residen en los placeres, bajo los árboles, y cuando se les pone en la cabeza suelen desfilar en partidas crecidas para sus pueblos". Aquellos indios de todas naciones, mientras se les tratase bien, darían vida al real; por lo demás, todos los reales de minas se despoblaban con facilidad, como ocurrió con San Antonio de la Huerta al descubrirse Cieneguilla, "que está en el paraje más desproveído y retirado de todas ellas (las provincias), pues el pueblo más inmediato de aquí está a distancia de dieciocho leguas". El oro seguía saliendo, aunque ya no a flor de tierra. ${ }^{176}$

Vencido el verano, toda Sonora empezó a experimentar escasez por haberse perdido la mayor parte de la cosecha, con lo que acudiría a Cieneguilla mucha gente desde las mayores distancias, por ser el real la población más abundante de víveres. "Y siendo tan numeroso el concurso, no se ha verificado la más leve desgracia en medio de la libertad que tienen de divertirse desde el sábado por la tarde hasta el domingo por la noche". Ahora ya las tres cuartas partes de la población eran de indios, pese a lo cual la extracción de oro había sido escasa en diciembre, y Tueros pretendía sugerirles buscasen por otro rumbo. ${ }^{177}$

Bucareli no acertada a explicarse las variaciones de la producción de los

175 Bucareli a Arriaga, México, 27 de agosto de 1772, núm. 526. En marzo de este año comunicaba el virrey que el corte de la caja de Alamos daba un total de $95.24 \mathrm{I}$ pesos, 4 tomines y 2 gramos; el ramo de tributos producia poco más de 2,000 pesos; los correspondientes a quintos de oro y plata constaban antes, naturalmente, en las cajas de Durango y Guadalajara. Bucareli a Arriaga, México, 25 de marzo de 1772 , núm. 296, reservada, aludiendo a número 297 , de la
misma fecha. Ibid, In 6 . Ibid.

Sastre calcula la población dei real en tónésulla, i 6 de diciembre de 1772, A. G. I., Guadalajara, 5 I 3. Huerta a Cieneguilla, en carta a Bucareli de Horcasitas, mil almas y atestigua la emigración de la 177 Tueros a Bucareli. Cieneguilla, o de dicitas, 14 de octubre de 1772 . Ibid. 
reales de Sonora, y su frase repetida es que "todas estas noticias más bien confunden que sirven de instrucción", ${ }^{178}$ pero, en fin, en aogsto volvía a confirmar sus esperanzas en Cieneguilla, "sin que se pudiera contar con cosa sólida, ni con las exorbitantes riquezas que se prometieron en los principios". "r7 Fuera de este real, la mina del Zapote, en el cerro de Promontorios, se había emborrascado, mientras que el real de la Aduana prometía abundante plata de buena ley. ${ }^{180}$ Las pesquerías de perlas habían cesado desde I77I, pero era constante que había perlas en las costas de Californias y de Tepoca, al norte de la isla de Tiburón, por lo que podría habilitarse la falúa mayor de las dos del rey y hacer la pesca por cuenta de la hacienda, utilizando los buceadores yacquis, sumamente diestros. ${ }^{18 x}$

Las desgracias de la provincia eran un hecho. Las inundaciones habían dañado los pueblos de Sinaloa y Culiacán, y el de Charay, de indios mayos, perdió casas e iglesia, habiéndose desbordado el Fuerte a cinco leguas y media. Una peste había reducido estos indios a treinta familias. Saracache y Soyopa estaban despoblados y San Antonio de la Huerta disminuía a ojos vista. La sequía había sido como no se conociera otra antes.

Yaquis, ópatas y eudeves sembraban y recogían con abundancia. Vucho menos los piatos o pimas altos y los mayos, guaymas y pimas bajos. "Las ventajas - dice Sastre- que se han conseguido después de la expedición en estas provincias es el haber quedado casi enteramente pacíficas". ${ }^{182}$

Esta era la paz que se disfrutó, como nunca hasta entonces desde veinticinco años atrás, en 1772 , y que Bucareli advertía ya a principios de éste. ${ }^{183}$ Los seris estaban pacíficos y fieles en Pitic. Sólo algunas partidas de sibubapas hacían pequeños robos. Los piatos y pimas vagantes estaban prácticamente sometidos en abril. Se tenía noticia de una reunión de apaches en el Cajón de Babinioca, ${ }^{184}$ pero la intranquilidad no pasaba de esto. Bucareli exhortaba a reunir con maña a los indios dispersos, ${ }^{185}$ principalmente a los sibubapas o suaquis que vivían bajo los árboles, sin construir sus propios jacales, teniendo la iglesia arruinada. ${ }^{186}$ Con parecer del fiscal de la audiencia el virrey ordenó la redificación de dicha iglesia, disponiendo todo lo con-

I 78 Bucareli a Arriaga. México, 27 de octubre de 1772. A. G. I., Guadalajara, r46. Su confusión era evidente en carta de 23 de marzo de 1772 , núm. 259. A. G. I., Guadalajara, 5 г2.

1.79 Bucareli a Losada. México, 27 de agosto de 1772, confidencial. A. G. I., México, I 24 I.

I 80 Bucareli a Arriaga. México, 27 de octubre de I772, núm. 6 I4, segín noticias de Cotbalán. A. G. I., Guadalajara, 4I6.

18I Sastre a Bucareli. México, 27 de octubre de I772. A. G. I., Guadalajara, 5 I3.

I 82 Ibid.

I83 Bucareli a Arriaga. México, 27 de enero de 1772, num. 196. A. G. I., Guadalajaıa, 51 2. I 84 Extractos de noticias. México, 26 de julio y 27 de agosto de r772. Ibid.

185 Bucareli a Arriaga. México, 26 de julio y 27 de agosto de 1772 , núms. 460 y 527 . Ibid.

I 86 Sastre a Arriaga. Pitic, 29 de julio de I 772 . A. G. T., Guadalajara, 4 I6. 
veniente ${ }^{187}$ y se atuvo a la idea de que no había que confundir las actividades de algunos forajidos con una sublevación. ${ }^{88}$

El mejor suceso fue la avenencia de los tiburones a someterse al rey y a recibir misión, que se intentó ponerles en su isla, ${ }^{189}$ aunque más adelante se viera no ser conveniente así. Los seris, en Pitic, en el pueblo que debía ponerse bajo la advocación de la virgen de Guadalupe por deseo expreso del virrey Croix, ${ }^{190}$ eran objeto de los más vivos esfuerzos civilizadores. Desde el año antęrior, el teniente de Corbalán, Don Francisco Mesía, estaba procurando dotar al pueblo seri de una acequia de regadío. El suelo rocoso dificultaba la tarea, pero el intendente no quería cejar en el empeño. Envió reses, utensilios de labranza, simientes, arados y yuntas. Entre tanto que no se empezasen los cultivos sería preciso proporcionar raciones a los seris. ${ }^{\mathrm{I} g \mathrm{r}}$ La construcción de la acequia pareció entrar en vías de más segura realización cuando el teniente de gobernador político Don Honorato de Rivera se comprometió a hacerla por mil trescientos pesos. ${ }^{x 22}$ Sastre anunciaba que esta obra estaría concluida el 8 de agosto. Los seris, por supuesto, seguían viviendo como idólatras, pero al menos habían accedido a repudiar a sus mujeres, quedándose sólo con la más antigua. ${ }^{193}$ Bucareli se ofreció a proporcionarles un misionero, 194 y ordenó la construcción de iglesia para estos indios $\mathrm{y}$ los tiburones; pidió al guardián de Querétaro designase un religioso que la sirviese y dispuso que Sastre y Corbalán proporcionasen herramientas a los reducidos y la vecindad de algunos sujetos inteligentes en tierras y minas y de buenas partes para que los adiestrasen y educasen. ${ }^{195}$

Este año de 1772 presenció el hecho insólito de que la provincia empezase a vivir bajo una doble autoridad. El 3 I de enero, con ocasión de haber recibido algunos informes sobre la situación de los indios sonorenses, el virrey dispuso el acostumbrado pase de ellos a consulta del fiscal, "aunque — añade-

187 Bucareli a Arriaga. México, 26 de noviembre de 1772 , númı. 660. Ibid.

r88 Bucareli a Arriaga. México, 27 de octubre de I772, núm. 61 o. Ibid.

el memoria atribuido a los jefes de los tiburones Juan Ce 1772. A. G. I. Guadalajara, 513, con fol. 90 .

190 Croix a Corbalán

fracaso de la expedición de Sonora, Bucareli, en los prineros momentos, una manifestación del de 1772 , núm. 204, reservada. A. G. I., México, 150g. carta a Arriaga. México, 22 de febrero

I9a Este contrato fue afinzado por quince, labr.

bio de Tierras Nuevas, en su término, según documento vecinos de florcasitas y de San Euse1772. Biblioteca Nacional, Mss. 176r7, fols, 89-90.

193 Sastre a Arriaga. Pitic,

1772. A. G. I., Guadalajara, 416. 29 de julio de I772, y Extracto de México, 27 de octubre de

194 Bucareli a Arriaga. México, 27 de octubre de I772, núm. 6ro. Ibid.

195 Bucareli a Arriaga. México, 26 de noviembre de 1772 , núm. 660. Ibid. 
carece de autoridad la firma de Corbalán". ${ }^{196}$ Como consecuencia de esta idea debió tener lugar el nombramiento del gobernador Don Mateo Sastre, que llegaba al Pitic, el I9 de julio. 197 Resulta extraño que Bucareli, que desconoció la validez del título de Corbalán como gobernador, no lo destituyese del cargo de intendente, institución extraña al sistema político-administrativo del virreinato y a la que él no veía con simpatía. ${ }^{198}$ Esta ambigüedad dejó a Corbalán en una posición falsa, obligándole a pedir "que V. Exa. sea servido declarar la autoridad y facultades que corresponden al empleo que obtengo de intendente", pues los empleados de tabacos, pólvora y naipes se sustrajeron a su dirección, aunque él lo disimulase. ${ }^{199}$

Esta demanda de Corbalán quedó sin satisfacer, hasta que en junta de 18 de mayo de I775 se decidió que el intendente tuviese las mismas atribuciones que los justicias de los pueblos, sin que absolutamente pudiese librar cantidad alguna sobre la real hacienda, salvo en el caso de una urgencia, avisando al virrey. En realidad no parece tampoco que Corbalán hubiese recibido instrucciones al efecto de Gálvez ni de Croix, y sólo se puede suponer que estuviese en conocimiento de la ordenanza de intendentes de España de I749. De todos modos, la posible disidencia entre Sastre y Corbalán no llegó a producirse, pues aquél murió a los ocho meses de su acceso al gobierno, el I 5 de marzo de I773, ${ }^{200}$ y entonces el virrey encargó el gobierno a Don Bernardo de Urrea, capitán de Altar y el más antiguo de Sonora, pero sólo en calidad de interino.

La muerte de Sastre sobrevino en un momento difícil, pues los indios tiburones, que en un principio pretendieron tener misión en la isla y luego en la playa frontera del Carrizal, sin que fuese posible persuadirles a que se desplazasen hasta el Tenuaje, a doce leguas, lugar mucho más apropiado, zor o al Pitic, ${ }^{202}$ habían empezado a ser misionados en Carrizal por el presiclente

I96 Decreto de Bucareli, 3 I de enero de I772. Biblioteca, Nacional, M'ss. I76r7, fol, 88 v.

I97 Sastre a Arriaga. Pitic, 29 de juljo de 1772. Ibid. Sastre es ya citado como gobernador en orden de Bucareli a Corbalán. México, 28 de abril de 1772 . Biblioteca Nacional, Mss. I76ı 7 , fol. 89 .

I98 Vid. Navarro García, Luis, Intendencias en Indias, 21, 28, 3 I y 54-55. Bucareli llega a escribir ejemplificando el caso de Corbalán: "Una intendencia establecida en las provincias de Sonora en el gobierno antecedente, que lleva ya algunos años, no sólo no ha producido ventajas, sino que ocasiona confusión en el gobierno, dando más quehacer que los demás del reino". Bucareli a Arriaga. México, 27 de marzo de 1774. A. G. I., Indiferente General, i7 14. Velasco, I, I86-242. página 202. folio 92 .

199 Corbalán a Bucareli. Alamos, 3 de marzo de iz73. Biblioteca Nacional, Mss. I76rz,

200 Extracto de Noticias, México, 26 de abril de 1773. A. G. I., Guadalajara, 513. La resolución sobre las facultades de Corbalán, en dictamen de Galindo Navarro. Arizpe, 23 de febrero de I780. A. G. I., Guadalajara, 5 I8.

201 Extracto de noticias. México, 27 de enero de 1773. Ibid,

202 Bucareli a Arriaga, México, 27 de enero de 1773 , núm. 734. Ibid. 
de las misiones de las dos Pimerías, Padre Fray Juan Crisóstono Gil de Bernabé, ${ }^{203}$ que de sus manos recibió la muerte el 6 de marzo. Los autores del crimen fueron inmediatamente ajusticiados o detenidos por los restantes tiburones, y toda la nación se mantuvo en paz, ${ }^{204}$ pero desgraciadamente desde aquel momento se retrajeron de todo intento civilizador y evangelizador.

Quedaban en pie, sin embargo, las disposiciones del virrey para que se buscase la reducción y vida pacífica de todos los indios, facilitándoles cuanto necesitasen para si asentamiento. ${ }^{205}$ El de los seris del Pitic parecía arraigar, favorecido por la entrada en funcionamiento de la acequia, que al cabo se había logrado, de modo que Sastre y el mismo Padre Fray Juan Crisóstomo habían procedido a repartirles tierras, adjudicando al pueblo media legua a los cuatro vientos, tomando por centro el cerro de la Conveniencia. Los seris habían quedado muy contentos; el I7 de noviembre de I 772 habían iniciado sus labores sembrando media fanega de trigo. De perseverar en este camino, desde junio siguiente podrían empezar a sustentarse. Por febrero ya tenían sembradas veinticinco fanegas y media de trigo, y seguían desmontando terrenos para echar los cercos y empezar una copiosa siembra de maíz y frijol, "aunque cuesta esfuerzo hacer trabajar a unos indios acostumbrados a vivir holgazanes, ociosos y vagabundos". Sin embargo, estos mismos indios habían pedido a Sastre vestidos, que en enero ya les fueron distribuidos. ${ }^{206}$

La cosecha, con todo, no fue satisfactoria, lo que se atribuyó a defecto de la acequia y a que los indios vendían por su cuenta las semillas que se les suministraban para siembras y raciones. Bucareli dispuso se añadiese otro misionero para atender aquel núcleo de más de ciento cincuenta familias, y que se situase en Pitic un destacamento que les hiciese guardar disciplina. ${ }^{207}$ Esto indicaba la lentitud del progreso, pues Bucareli siempre tenía ante la vista la perspectiva de que, pudiendo sustentarse los seris por sí solos, y estando en paz ellos, los tiburones y suaquis, se ahorrarían las raciones de aquéllos y los presidios de Horcasitas y Buenavista. ${ }^{208}$ Respecto a los tiburones, nada hubo que hacer a partir de marzo de 1773 , pero los sibubapas

203 Extracto de noticias. México, 24 de febrero de I773. Ibid.

204 Vid, nota 53 de este capítulo. Sólo cuarenta y tres tiburones se acogicron al Pitic en techa posterior. Extracto de noticias. México, 24 de febrero de I/74. A. G. I., Guadalajara, 5 I 4. lajara, 5 工 3 .

206 Extracto de noticias, México, 24 de febrero de 1773. Tbid. Bucareli a O’Conor. México, 1. 'e marzo de 1773. A. G. I., Guadalajara, 512. Bucareli a Arriaga. México, 27 de marzo de I773, núm. 835, y Extracto de noticias de esta fechia. Bucareli a Arriaga. México, 26 de abril
de 1773 , núm. 892. A. G. I., Guadalajara, 513.

207 Bucareli a Arriaga. México, 26 de septiembre de r\$73, uśnn, to99. A, G. I., Guadalajara, 5 I 4 .

208 Bucareli a O’Conor. México, r. ${ }^{\circ}$ de marzo de Iz73. A. G. I, Guadalajara, 5 I 2. 
empezaban a dar muestras de docilizarse construyendo sus chozas o barracas; aunque no se reducían a la labranza y vida civil porque habitualmente salían a los montes para proveerse de raíces, caza y ganado alzado, que eran su alimento. Bucareli providenció lo correspondiente a dotarlos de instrumentos de labranza y semillas, y a que se avecindasen entre ellos algunos individuos que los adiestrasen en las faenas agrícolas. ${ }^{209}$

Los pápagos, en el extremo noroccidental de Sonora, hallábanse más vinculados a los españoles desde el momento que hallaron un enemigo común en los apaches. Su jefe Comaquibuto anunciaba a Urrea en octubre de I772 haber causado a éstos treinta y una bajas y seis presas. También a los españoles convenía fomentar esta amistad, y por eso Bucareli. aprobó los agasajos hechos por Urrea a los pápagos. ${ }^{210}$ Del mismo modo los piatos del Pitiqui y Caborca, aunque a veces se inquietaban, colaboraban en la defensa contra los apaches. A fin de 1772, los apaches del Cajón de Babinioca actuaron contra Tubac, donde robaron cien caballos. El virrey no extrañaba su hostilidad aquí, rechazados como se hallaban por O'Conor en Nueva Vizcaya, pero ordenó poner en Fronteras setenta y ocho hombres de Terrenate y Tubac, que, mandados por el capitán Don Gabriel Antonio Vildósola, corriesen la campaña hasta Janos, coordinando sus movimientos con los de la expedición de Chihuahua, y procurando batir la sierra de Chiricahui, donde los apaches se proveían de abundante mezcal, su principal alimento, y donde se amparaban cuando cometían sus robos. El virrey consideraba conveniente reforzar este destacamento, si fuese preciso, con diez o veinte hombres de cada uno de los presidios de Altar, Buenavista y Horcasitas, si los apaches hostilizasen demasiado la Pimería alta. ${ }^{21}$ Las incursiones de éstos produjeron a fines de 1772 varias muertes y la pérdida de más de doscientos cincuenta caballos en Terrenate, y de cien cabezas de ganado mayor del rancho de Arituaba. Bucareli repitió a Urrea las mismas prevenciones contra los gileños que había hecho a Sastre, entretanto que llegaba el gobernador interino ya designado, teniente coronel Don Francisco Antonio Crespo, capitátı del regimiento de infantería de Granada. ${ }^{212}$

209 Bucareli a Arriaga. México, 26 de abril de 1773, núm. 892. A. G. I., Guadalajara, 51 3 Bucareli a Arriaga, México, 26 de septiembre de 1773, número I098. A. G. I. Guadalajara, 514. 2 so Bucareli a Arriaga. México, 27 de enero de I773, núm. 734, y Extracto de igual data. A. G. I., Guadalajara, $5 \div 3$.

2 I 1 Bucareli a Arriaga. México, 24 de febrero de :773, núm, 794, y Extracto de esta fecha. Ibid. Bucareli a O'Conor. México, 1. de marzo de 1773 . A. G. I., Guadalajara, 512. La desconfianza del jefe de los piatos, Ignacio Yuburigipci, obligó a poner una escuadra de seis hombres en Pitiqui. Extracto de noticias. México, 26 de abril de 1773. A. G. I., Guadalajara, 513.

212 Bucareli a O'Conor. México, 2I de abril de 1773. Bucareli a Arriaga. México, 26 de abril de 1773 , número 884 , y Extracto de esta fecha. Ibid. El teniente coronel Crespo fue recomendado por Muzquiz a Bucarcli en carta de EI Pardo, 18 de marzo de 1772 , confidencial. Buca- 
El destacamento de Vildósola había sido situado por Sastre en el campo de San Bernardino, en la divisoria de Nueva Vizcaya, según dispuso O'Conor, pero no realizó ninguna operación y los soldados empezaron a enfermar por los fríos y las nieves. ${ }^{21} 3$ Urrea, en cambio, puso en práctica el acuerdo tomado ya en ${ }^{7} 6_{5}$ de tener constantemente una partida en campaña, turnándose mensualmente las tropas. La primera salida la hizo Anza con ochenta y tres hombres en junio de $1773,{ }^{214}$ y el sistema empezó a funcionar así, al parecer con éxito, lográndose atraer incluso a los pimas gentiles del Gila, "que reconocen sujeción al rey", que pidieron permiso a Anza, meses después, para atacar a los apaches, como lo hicieron, causándoles veintisiete bajas y ocho prisioneros, prometiendo además hacer nuevas salidas. ${ }^{215} \mathrm{Sin}$ embargo, los daños comenzaron más tarde, perdiéndose ciento treinta caballos de Tubac y siendo sorprendida una partida de este presidio, de que se culpó, 12or negligencia, al capitán de Terrenate Don José Antonio de Vildósola, sobre quien ya pesaban otras quejas, y que ahora fue detenido y encausado, ${ }^{216}$ separándosele por fin del cargo, que fue dado a Don Francisco Tovar. ${ }^{217}$

Entrando I774, cuando ya el gobernador interino Crespo se había hecho con el mando, el ayudante inspector Bonilla, que empezaba a revistar los presidios de la provincia informaba que los apaches se internaban en ella en partidas numerosas, cometiendo hostilidades en lugares muy alejados unos de otros, con lo que sus daños se hacían irremediables. ${ }^{218} \mathrm{El}$ 7 de mayo atacaron en gran número el presidio de Fronteras, llevándose trescientos caballos. Bucareli encargó a O'Conor atendiese a la provincia, 2I9 Por agosto, no obstante, revistados todos los presidios y señalados los lugares a que debían trasladarse, podía el virrey señalar que los apaches se habían retraído en sus asaltos, 220 si bien en enero tendría que informar la pérdida de la caballada

reli reconoció los méritos de Cres1 o: "es muy buen oficial, de mucho juicio, y desempeñará con y está cumplido... es el modierto parece se inclina al de Nuevo México, que tiene Mendinueta y está cumplido...; es el modo que pueda hacer cuatro reales, sin perjuicio de su carrera, en en mi concepto nunca se han podido hacer con cristiandaces tesos entas partes de América, y que el Erario". Bucareli a Muzquiz

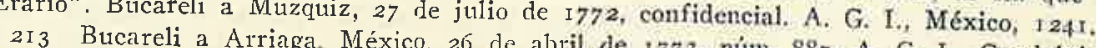

2 I 3 Bucareli a Arriaga. México, 26 de abril de 1773, núm. 887. A. G. I., Guadalajara, 513.

2 I 5 Extracto de noticias. México, 27 de octubre de se han de poner en campaña. Ibid. Guadalajara, 5 I 4 y 512 .

2 I 6 Bucareli a Arriaga. México, 26 de abril de Iร73, núm. 89I. A G, I. Guatalajara, 512.

Extracto de noticias. México, 26 de abril de 1774 . A. G. I., Guadalajata, G. I., Guadrlajara, 5 ra.

2 I 7 Bucareli a Arriaga. México, 27 de enero de I 755 númalajara, 5 I 3.

218 Extracto de noticias. México, 26 de junio de I774. A. G. I. Gu. G. I., Guadalajara, 5I5.

2 I9 Bucareli a Arriaga.

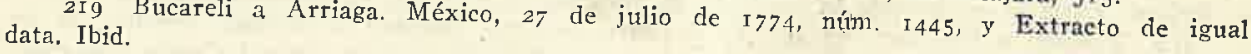

220 Extracto de roticias. México, 27 de agosto de 1774 . Ibid. 
de Fronteras ${ }^{221}$ y más tarde un asalto a una recua de Cieneguilla, en la que causaron dos muertes y un prisionero, llevándose sesenta mulas aparejadas con géneros por valor de tres mil pesos. ${ }^{222}$

Cieneguilla continuaba produciendo oro en abundancia, aunque una noria que se proyectó para el lavado de las tierras no dio resultado porque no proporcionaba agua en cantidad suficiente. Un nuevo real, establecido en San Marcial, sólo ofrecía ventajas problemáticas, ${ }^{223}$ a ocho leguas de Cieneguilla. Ochocientos hombres se habían congregado rápidamente en unos placeres descubiertos algo al oriente con vetas de plata y pepitas de oro. Aquí la sequía pudo ser remediada abriendo un pozo de diez varas de ancho por treinta de largo. En Palo Ensebado o Santa Rosa formó Tueros una plaza cuadrada, con casitas de tierra, y repartió armas y estableció patrullas en previsión de un ataque. ${ }^{224} \mathrm{Ya}$ en $\mathrm{I} 775$ Cieneguilla es el punto al que se orientan los golpes de los apaches a los que intentaron unirse veintidós familias de piatos de Pitiqui, que fueron batidas por el teniente de Altar. ${ }^{225}$ Los ataques menudeaban más ahora, pese a que no se abandonaban las batidas de los destacamentos fronterizos. A un asalto a la caballada de Tubac, siguió otro a una recua que iba de Cieneguilla al valle de Sonora, ${ }^{226}$ a la que hicieron ocho muertes.

La visita de O'Conor a los presidios, que fijó los lugares a que definitivamente debían trasladarse éstos, fue seguida de la campaña general en que tomó parte un cuerpo de tropas de Sonora mandadas por el mismo Crespo, cuyo mérito y buena voluntad fueron recomendados por el comandante inspector, por lo que fue ascendido a coronel. ${ }^{2} 27$ Pero entre tanto el 7 de septiembre los apaches lograron robar la mayor parte de la caballada de Tubac, dirigiéndose a continuación contra Cieneguilla. Tueros pedía una escolta para este real y el de Santa Rosa, lo que Bucareli concedió. ${ }^{228}$ El subdelegado temía siempre que los piatos que seguían vagantes eran los guías de los apaches, a los que introducían por todas partes, en lo que estaba de acuerdo

221 Bucareli a Arriaga. México, 27 de enero de 1775 , número 1684, y Extracto de esta fecha. A. G. I., Guadalajara, 5 I 4.

223 Extracto de noticias. México, 27 de marzo de 1775. Ibid.

223 Extracto de noticias. México, 26 de septiembre de I774. Ibid.

22.4 Bucareli a Losada. M'éxico, 26 de noviembre de i 775 , confidencial, A. G. I., México, I24I. Noticias de Tueros de i9 de septiembre, en Extracto de México, 26 de noviembre de I775. A. G: I., Guadalajara, 5 I 5.

225 Extractos de noticias. México, 27 de julio y 27 de agosto de 1775 . A. G. I., Guadalajara, 5 I 4 y 5 I 5 .

226 Bucareli a Arriagra, 27 de agosto de 1775 , y Extractos de igual data y de 26 de septiembre y 27 de octubre de I775. A. G. I., Guadalajara, 5 I5.

227 O'Conor a Bucareli. Carrizal, ${ }^{\circ}$ de diciembre de 1775. Bucareli a Arriaga. México, 27 de diciembre de I775, núm. 2083. Gálvez a Ricla, is de mayo de I776. Ibid.

228 Bucareli a Arriaga. México, 26 de noviembre de I775, y Extracto de igual data. Ibid. 
O'Conor, que ordenó pasase a Palo Ensebado un destacamento de veinte hombres de Horcasitas, ${ }^{229}$ siendo esta actitud aprobada por el rey, para proteger la explotación minera, concediendo además, con el mismo objeto, la rebaja de la tercera parte de los derechos que contribuía el oro al ser quintado en cajas reales. ${ }^{230}$

Tueros extremaba indudablemente los riesgos que decía corrían los trabajadores de Cieneguilla, ${ }^{2}{ }_{3}$ siendo así que después de la primera campaña general de O'Conor se experimentaba una paz general en la frontera, lo cual permitía proceder al traslado de los presidios de Terrenate y Fronteras a Tucson y San Bernardino. En cambio, el destacamento enviado por el comandante inspector a Palo Ensebado se retiró por el simple motivo de haberse despoblado estos placeres que no se mostraron duraderos, ${ }^{232}$ estando O'Conor y Crespo de acuerdo en que los riesgos anunciados por Tueros eran puramente imaginarios, y absurdos, dándose el hecho de que hutbiese en Cieneguilla más de cuatro mil flecheros yaquis y otras infinitas gentes. O'Conor pasaba adelante a demostrar que los placeres de Cieneguilla "han decaído de año $y$ medio a esta parte, $y$ de tal modo que apenas hay mercaderes que quieran entrar, retirándose también los demás de los que en dichos placeres se hallaban con sus comercios, y cuya verdad será tan fácil de justificar como que en la villa de Chihuahua y comercio de esta ciudad apenas hay negociante que la ignore, testificándola también las varias cartas que en mi poder se hallan de otros tantos mercaderes que residen en la Cieneguilla y en las que se empeñaban para que los habilitados comprasen los géneros que tenían en su poder, por estar parado totalmente el comercio de la Cienegtrilla". Así lo hicieron algunos habilitados de Sonora, que lograron en este real precios más favorables que los del mismo México, por donde se infería la poca esperanza de los mercaderes. O'Conor y Crespo daban por sentada la extremada ligereza de juicio con que se conducía Tueros, y atrajeron sobre éste la reprensión de Bucareli, que tampoco olvidaba la excesiva facilidad con que dio las noticias sobre Palo Ensebado "haciendo creer lo que no había". ${ }^{233}$

A la noticia de la decadencia de los placeres auríferos acompañó en Sonora un repentino enrarecimiento de la situación. A principios de 1776 se temía ya una insubordinación de los pimas de Saric, que aparentemente

229 Extracto de noticias. México, 26 de enero de 1776 . Ibid.

230 Esta medida, debida ya a la mente de Gálvez, debía pasar a informe de los diputados de mineria, el fiscal de la audiencia y de Areche, para tratarse luego en junta de hacienda donde se estudiaria la conveniencia de hacerla extensiva a toda Nueva España. Real orden de 22 de
ma1zo de I776. Ibid.

23 I Bucareli a Arriaga. México, 26 de abril de I776, n. ${ }^{\circ} 2207$, y Extracto de esta fecha. Ibid.

23a Bucareli a Gálvez. México, 26 de junio de 1776, núm, 2299. Tbid.

233 Bucareli a Gálvez. México, 26 de septiembre de 1776, núm. 2497. Crespo a O'Conor. Forcasitas, 3 de julio de 1776 . O.Conor a Bucareli. Carrizal, 9 de agosto de I776. Ibid. 
se desvaneció. ${ }^{2} 34$ Sin enbargo, se tenía noticia de las actitudes de algunos piatos fugitivos, ${ }^{235}$ que a veces merodeaban por los contornos de Cieneguilla o del Pitic, y que eran a su vez hostilizados por los seris. ${ }^{2}{ }^{6} 6$ Crespo se decidió a utilizar escuadras de seris fieles y de ópatas de Ures y Opodepe para batir el territorio amenazado, pese a lo cual el 4 de noviembre los alzados atacaron una vez más la recua de Cieneguilla, aunque fueron castigados y rescatado el botín cuando ya se dirigían hacia la sierra de Babinioca, y en 23 del mismo mes asaltaron Saric, pueblo de su misma nación, ${ }^{237}$ causando diez muertes. Apaches y piatos alzados habían asaltado igualmente La Magdalena seis días antes. ${ }^{238}$ Crespo era particularmente sensible a este daño de la infidelidad de los indios del interior. Algunos seris se habían unido ya en noviembre a los pimas alzados, que iban aumentando en número, y se temía se les agregasen otras familias, entre ellas cuatro o seis de apaches, y Crespo se disponía a hacer operar la compañía volante mandada por Don Luis Antonio del Castillo contra ellos. ${ }^{2} 39$

Era ésta la compañía agregada a Terrenate que debía extinguirse al entrar en vigor el nuevo reglamento de presidios, pero que O'Conor propuso colocar en Horcasitas y Buenavista al suprimirse o trasladarse más al norte estas guarniciones y luego Bucareli conservó para remediar la destrucción del destacamento que el capitán Tovar sacrificó inútilmente a manos de los. apaches. ${ }^{240} \mathrm{E} 1$ mismo virrey la dotó de oficialidad, ${ }^{24 \mathrm{I}}$ a la que asignó los mismos sueldos que gozaba la del cuerpo volante de Chihuahua, ${ }^{242}$ y consiguió la aprobación real de sus decisiones. ${ }^{243}$ Las expediciones punitivas mandadas por Castillo comenzaron seguidamente, al tiempo que se recrudecían las hostilidades de los apaches, a los que batió el 30 de abril en la sierra de Guatepito, ${ }^{244}$ y a él cupo la dirección de las tropas de Sonora en la segunda

234 Bucareli a Arriaga. México, 27 de marzo de 1776 , núm. 2179 , con Extracto de igual data. Extracto de noticias. México, 27 de mayo de 1776 . Ibid. Bucareli a Arriaga. México, 27 de octubre de I776, núm. 2549. A. G. I., Guadalajara, 5 I6.

235 Extracto de noticias. México, 27 de julio de г776. A. G. I., Guadalajara, 5 I 5.

236 Bucareli a Gálvez. México, 26 de noviembre de i776, con Extracto adjunto. $\Lambda$. G. I., Guadalajara, 5 I 6 .

237 O'Conor a Bucareli. Carrizal, 20 de diciembre de i776. Bucareli a Gálvez. México, 27 de diciembre de 1776 , con Extracto adjunto. Ibid.

238 Bucareli a Gálvez. México, 27 de enero de 1776, núm. 2706, y Extracto. Ibid.

239 Crespo a Bucareli. Horcasitas, is de enero de r777. Ibid.

$24^{\circ}$ Bucareli a Arriaga. M'éxico, 27 de octubre de I775, núm. I997. A. G. I., Guadalajara, 5 I 5. Bucareli a Arriaga. México, 26 de septiembre de I776, núm. 2496. A. G. I., Guadalajaira. 516. 241 Bucareli a Arriaga. México, 27 de enero de i776, núms. 2iro, 2 ir y 2 iz. A. G. I. Guadalajara, 5 I 5 .

24a A saber: capitán, I 200 pesos; teniente, 600; alférez, 480. Bucareli a Gálvez. México, 27 de agosto de i 776, núm. 2430. A. G. I., Guadalajara, 5 r6.

243 Bucareli a Gálvez, México, 26 de septiembre de 5776 , núm, 2504. Real orden de 9 de enero de 1777 . Ibid.

244 Extracto de noticias. México, 27 de julio de г776. A. G. I., Guadalajara, 5 г5. 
campaña de $\mathrm{O}^{\prime}$ Conor, en la que dio cinco ataques al enemigo, de septiembre a diciembre, haciéndoles trece bajas y catorce prisioneros. ${ }^{245}$ Fue una suerte, por lo demás, que los apaches fracasaran en la tentativa de lograr la alianza de los pápagos de Aquituni contra los españoles. ${ }^{24} 6$

La situación de Sonora, en suma, distaba mucho de ser satisfactoria y más bien parecía volverse al estado anterior a la campaña general, cuando a principios de 1777 recae el gobierno de la provincia, definitivamente, en manos de Corbalán, lo que se debió a la circunstancia de haber alcanzado Don José de Gálvez el ministerio de Indias, pues habiendo solicitado Crespo el relevo alegando enfermedad, se lo concedió el virrey, nombrando también con carácter interino para sustituirle a Don Francisço de Echegaray. Pero la real orden de 13 de diciembre de 1776 vino a establecer que "habiendo S. M. unido aquel gobierno en lo económico a la intendencia de Sonora y nombrado un comandante general en jefe de aquellas provincias, es su real voluntad que mande V. E. retirar a Don Francisco Echegaray". ${ }^{247}$ El gobierno de Sonora, pues, por lo político y económico, fue conferido a Don Pedro Corbalán, que seguiría percibiendo el mismo sueldo de seis mil pesos, ${ }^{248}$ y que haría el juramento correspondiente en manos del comandante general electo Don Teodoro de Croix. ${ }^{249}$

\section{La ruta de San Francisco y El Mogui}

De ninguna manera podría atribuirse a O'Conor un fin político expansivo, pues toda su actuación estuvo presidida por la pura urgencia de rechazar la invasión apache, sin que jamás pretendiera ampliar al norte la frontera de las provincias españolas con la mira de ampliación territorial, de modo que cuando adelanta los presidios de Sonora, Nueva Vizcaya y Coahuila lo hace con la exclusiva idea de situarlos en más faworables condiciones de defensa, a cada uno de ellos y a la línea como unidad.

Por lo mismo, así como escapa a su dirección la vida de las cinco provincias en todo lo que no sea cuestión puramente militar, rebasa el ámbito de sus atribuciones y de sus proyectos el que tenía ya tres cuartos de siglo de existencia, de buscar el enlace directo de las provincias de Nueva España

245 O'Conor a Bucareli. Carrizal, 20 de diciembre de I776. Bucareli a Gálvez Méxic. 27 de enero de 1777 , núm. 2707. A. G. I., Guadalajara, 5 I 6.

246 O'Conor a Bucareli. Carrizal

reli a Gálvez, México, 27 de enero de, 20 de diciembre de I 776, según noticias de Garcés. Buca-

247 Bucareli a Gálvez. México, 27 de julio de 2706 , con Extracto adjunto. Ibid.

bre de 1776. A. G. I., Guadalajara, 300.

248 Real decreto de I6 de mayo

249 Gálvez al duque de Alba, 7 de julo a Gálvez. A. G. T., Guadalajara, 30 , 
con los estabiecimientos de la Baja y últimamente de la Alta California. Quedará este punto, pues, reservado al virrey, a cuyo apoyo se deberá casi todo lo que en este sentido se realice en la época de O'Conor y que será, por otra parte, casi lo único decisivo que para la conservación de los establecinientos del Pacífico Norte se hizo en la época española.

Las primeras navegaciones desde San Blas han cumplido su objetivo descubriendo y permitiendo la ocupación de los puertos de San Diego y Monterrey. Ya en los planes de Gálvez quedaban fijadas las directrices para buscar la ruta continental a estos mismos establecimientos. Bucareli ahora canalizará y hará posible la realización de las inquietudes del capitán de Tubac y de los franciscanos de Sonora, Californias y Nuevo México, que trazaron, con éxito variable, una serie de rutas destinadas a aproximar estas provincias entre sí, a alcanzar el Pacífico desde el interior del continente, y también a hallar el deseado puerto de San Francisco y el legendario estrecho de Anián, quue también buscan en las "expediciones de altura" los marinos de San Blas.

E1 primer propulsor del avance al Colorado es, en esta época, el franciscano padre Francisco Garcés, que de I768 a I77 I se internó en aquellos parajes por tres veces, desde su misión de San Javier del Bac. Ya desde entonces, llegado a la junta del Gila con el Colorado, albergaba Garcés el deseo de llegar a San Diego, de cuya existencia parecían tener noticias los indios, y al Moqui y Zuñi, que le decían estar a nueve días de camino, aunque obstaculizado por la guerra que los yumas tenían con los quiquimas. ${ }^{250}$ Bucareli ordenó a Corbalán le informase con detalle de las actividades de Garcés, y también Sastre remitió un resumen de las tres entradas del franciscano. ${ }^{25}$ A Aparecen entonces, simultáneamente, las solicitudes de Garcés y del capitán de Tubac, Don Juan Bautista de Anza, para abrir camino hasta Monterrey. El ingeniero Costanzó y la junta retunicla en México el I7 de octubre de 1772 , informaron favorablemente el proyecto, ${ }^{252}$ así como entraba en discusión una vez más la posibilidad de fundar misiones en el Colorado. ${ }^{253}$ Con nuevos informes, en junta de guerra y hacienda de 2 de septiembre de I 773 se acordó conceder a Anza veinte voluntarios de su presidio, con los que acometer la empresa exploradora, acompañándole Garcés y otro misionero, que fue el Padre Fray Juan Díaz. ${ }^{254}$ La decisión de llevar adelante

250 Bucareli a Arriaga. México, 25 de narzo de 1772, núm. 281. Corbalán a Bucareli, 21 de enero de I772. Fray Esteban de Salazax a Fray Mariano Antonio de Buena y Alcalde. Tubutama, I3 de noviembre de 177 r. A. G. I., Guadalajara, 5r2. Diario de Garcés, 8 de agosto $33^{\mathrm{I}}$ de octubre de І $77 \mathrm{~J}$, en A. G. I., Guadalajara, 5 I3

25 I Sastre a Arriaga. Horcasitas, ig de octubie de iz72. A. G. I., Guadalajara, 513.

252 Bucareli a Arriaga. México, 27 de octube de i77.2, núm. 6iz. Ibid.

253 Bucareli a Arriaga. México, 27 de enero de 1773, núm. 738. Ibid.

254 Bucareli a Arriaga. México, 26 de septiemure de i773, núm. 1097. Ibid. 
la expedición a California pesó en Bucareli para hacer retrasar la campaña de O'Conor en presención de que ésta pudiera repercutir en las relaciones hasta entonces amistosas entre los españoles y los indios del Gila y Colo-
rado. 255

El viaje descubridor de Anza halló una circunstancia favorable en el hecho de que el ig de diciembre de 1773 llegase a Caborca el indio Sebastián Tarabal, fugado el 25 de julio de la misión de San Diego. Tarabal había hecho, pues, a la inversa, el viaje al que Anza partía de Tubac el 8 de enero de 1774, llevando al indio como guía, ${ }^{256} \mathrm{El} 5$ de abril cerraba Anza en San Diego el diario de la travesía. Al día siguiente marchaba a Monterrey, que visitó, emprendiendo seguidamente el regreso ya por camino más corto a Tubac. "Están más cerca Monterrey y San Diego de Sonora que de Loreto", asentaba Bucareli, ${ }^{257}$ que preveía las posibles alteraciones del sistema de la frontera que tal vez acarreasen los últimos acontecimientos. ${ }^{258}$ Consultado O'Conor, créa posible trasladar al Gila y Colorado los presidios de Buenavista y Horcasitas.

Llamado Anza a México, inmediatamente comenzaron los preparativos de la segunda expedición, ya con carácter colonizador, con vistas a fundar presidio y dos misiones en el puerto de San Francisco. El virrey pedía para Anza grado de teniente coronal, 259 que para aquella fecha ya le había sido concedido. ${ }^{260}$

El 20 de septiembre de 1775 salía Anza de Horcasitas dando principio a su segunda expedición, pero antes, entre junio y julio, había tenido lugar otra tentativa de penetración al Moqui desde Nuevo México, realizada por Fray Silvestre Vélez de Escalante, que veía la posibilidad de convertir y reducir a los mocjuinos sólo con colocar un presidio entre ellos, y la de pasar de este lugar a Sonora descendiendo al Gila, por donde se llegaría en dos días a Terrenate. Sin embargo, pensaba que el viaje a Monterrey no debía hacerse por el Moqui, sino por tierras de los yutas, que stiponía estaban en la misma latitud que Monterrey y Santa $\mathrm{Fe},{ }^{261}$

E1 4. de enero de 1776 llegaba Anza con sus doscientos cuarenta pobla-

255 Bucareli a Arriaga. México, 26 de abril de 1774, núm. 1258. Ibid.

256 Extracto de noticias. México, 26 de abril de 1774 . Ibid. 257 Bucareli a Arriaga. México, 26 de junio de 1774 , núm, 1421 , remitiendo el diario de
Anza, y Extracto de esta fecha. Ibid.

258 Bucareli a Arriaga. México, 27 de agosto de 1771 , núm. 1491 . Ibid. Bucareli a Arriaga.
México, 27 de octubre de 1775 , núm. 1995. A. G. I., Guadalajara, 515.

259 Bucareli a Arriaga. México, 26 de noviembre de 1774 , núm. ז609. Ibid.

260 Real orden de 8 de octubre de 1774 a Bucareli. El título es de 4 de octubre. Ibid.

Guadalajara, 517. Vid. correspondencia y diario de Vélez de Fscalante ectubre de 1775. A. G. I.. misioneros franciscanos a la conquista de Nuovo Mérico. Sevilla,

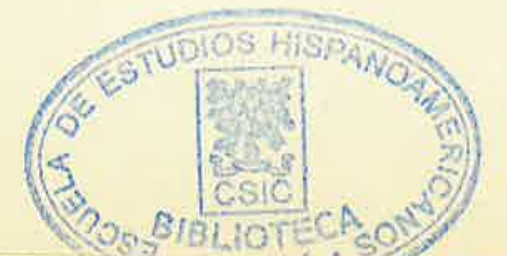


dores por segunda vez a California, a la misión de San Gabriel, donde dos meses antes había octurrido una sublevación de los neófitos que alarmó grandemente la provincia. ${ }^{262}$ Pasó luego Anza a Monterrey, y de aquí penetró más al norte, hasta el puerto de San Francisco que reconoció, dejjando fijada la localización que deberían tener el presidio y las misiones proyectadas; pero regresó a Sonora, dejando esta tarea al teniente Moraga, que estableció allí a los colonos en 17 de septiembre de aquel año.

En este segundo viaje de Anza, quedose el Padre Garcés en el Colorado y descendió por el río hasta el mar por tierras de los cajuenes, quiquimas y cucapas; y a esta misma zona había llegado meses atrás el alférez de Loreto Don Joaquín Velázquez, a quien el gobernador de Californias Don Felipe Neve había ordenado explorar la costa del golfo, más al norte de la misión últimamente fundada de San Fernando de Velicatá. Simultáneamente se pondría en marcha la política de enlazar con una cadena de misiones los establecimientos de la alta y baja California, y de conectar este sistema con Sonora mediante la fundación de misiones y presidios en el Colorado y el Gila. Bucareli concebía claramente este panorama al dar cuenta de los viajes de Velázquez y Garcés. ${ }^{263}$

En esta ocasión Garcés se dirigía del Colorado a San Gabriel, y de aquí a Nuevo México, aunque no pudo pasar de Oraibe, en el Moquii, desde donde escribió al misionero de Zuñi el 3 de julio de $5776 .{ }^{264}$ Un indio de Acoma llevó esta carta de Oraibe a Zuñi, cuyo misionero la comunicó al comisario Padre Fray Francisco Atanasio Domínguez, quien desde hacía un mes estaba en contacto con Fray Silvestre Vélez de Escalante, y ambos de actierdo en emprender viaje para abrir camino hacia Monterrey, como en efecto lo emprendieron partiendo de Santa Fe el 29 de julio de 5776 , regresando a la villa el 2 de enero de I 777 sin haber podido alcanzar su objetivo, pues habiendo tomado un rumbo demasiado al noroeste no pudieron cruzar las Rocosas en el invierno, llegando sólo hasta el lago Utah y el río Severo (Sevier), por lo que su viaje, recogido en casi toda la cartografía posterior, sirvió enormemente para el conocimiento de la vasta extensión transitada, pero también para perpetuar por más de medio siglo la creencia en 111 gran río cule partiendo de açuel lago afluía al Pacífico. ${ }^{265}$

262 Bucareli a Arriaga. México, 27 de marzo de 1 ร76, núm. 2186. A. G. I., Guadalajara, 515.

263 Bucareli a Arriaga. México, 27 de nnarzo de 1776, núms. 21 83 y 2184 . Tbid. En 27 de mayo de 1775 , núm. 1824 , expone el proyecto de traslación de presidios de Garcés y Diaz. A. G. I., Guadalajara, 5 I 4 .

264 Bucareli a Gálvez. México, 27 de diciembre de 1776, nín, 2640, y 27 de enero de 1777 , núm. 2705. A. G. I., Guadalajara, 516. Diario de Garcés. Tubutanna, 3 de enero de I777. Ibid. También en Maas, op. cit., I34-182.

265 Diario de Domínguez y Vélez Escalante. Santa Fe. 3 de enero de 1777. ^. G. I.. Guadajara, 4,6. En Maas, op., cit., g8-r33, y en Doc. hist. México, segunda serie, I, 376-558. 
El 26 de octubre de 1776 se presentaban al virrey Anza y el jefe de los indios yumas Salvador Palma y otros tres individuos de esta nación, que solicitaban el establecimiento de presidio y misión en sus tierras. Palma y sus acompañantes fueron bautizados, sirviendo el bailío Bucareli de padrino al cabecilla yuma. Y sus deseos serían puestos en práctica en el momento posterior, rigiendo las provincias internas el comandante general Don Teodoro
de Croix.

\section{La defensa de Coahuila y Texas}

Sin duda O'Conor consideró clurante todo el período de su mandato que en Nueva Vizcaya residía el punto neurálgico del sistema de presidios cuya organización había sido puesta en sus manos. Nada más exacto que esto, desde luego, y nada más fácil de concluir por otra parte, si se piensa que O'Conor llegó a la frontera como comandante de las armas de Nueva Vizcaya y de las compañías volantes de la expedición de Chihuahua. Junto a esto, a Nueva Vizcaya afectaron fundamentalmente sus medidas de gobierno militar, por lo que respecta sobre todo a la traslación de los presidios que hasta entonces bordeaban el Bolsón de Mapimí. La historia de la provincia en estos breves años la llenan claramente la personalidad, la actividad, las campañas de O'Conor, dejando totalmente en la sombra al gobernador Faini, de tal manera que éste, que tanto se agita en los últimos momentos del mandato de Croix y de la visita de Gálvez, se eclipsa por completo en cuanto aparece la figura del comandante inspector sólidamente respaldado por Bucareli. Sus avisos, todavía entrado ya el año $\mathrm{I} 772$, tendían a atraer la atención del gobierno hacia los problemas de Nueva Vizcaya. A principios de este año, casi millón y medio de pesos de oro y plata de particulares y del rey habían sido enviados a México. Fácilmente podía desprenderse de este dato cuánto más produciría la minería de la provincia en circunstancias de normalidad, y cuánto importaba, por tanto, atender a resguardarla de los ultrajes de los bárbaros. ${ }^{266}$ Esta es la última intervención de Faini en este sentido, dirigida sin intermediarios al ministerio de Indias. Pero después de esto, los acontecimientos importantes de la provincia - las campañas, la defensa- escapan a sus atribuciones y nada indica que él desplegara una actividad especial en otros aspectos. Cuando quiso proceder a formar compañías para la protección de Durango, no parece que su intervención fuese algo eficaz, y el descubrimiento de la infidelidad de los tarahumaras y posterior investigación de este asunto estuvieron a cargo del corregidor de Chihuahua.

266 Faini a Arriaga, Durango, 4 de abril de 7772 . A. G. I., Guadalajara, 5 I2. 
El efecto, finalmente, beneficioso o pernicioso de la actividad de O'Conor sobre Nueva Vizcaya no se dejaría sentir de manera clara sino en época posterior en lo tocante a su prosperidad en todos los órdenes.

Coahuila y Texas, en cambio, sufren ahora una súbita transformación que afecta, en primer lugar - como ocurre en Nueva Vizcaya- a su fisonomía. En Texas, la alteración es radical, pues la supresión de los presidios de Adaes y Orcoquiza, con las misiones vecinas, mutila a la provincia toda su prolongación oriental hacia Luisiana, y la desaparición como tal del presidio de San Sabá deja al núcleo de Béjar totalmente aislado en un medio indígena tradicionalmente hostil. Habiendo quedado, en fin, Béjar y la Bahía como única realidad de lo que seguiría siendo provincia de Texas, llamada a jugar un papel decisivo en el mundo de las alianzas y los movimientos de las tribus indias del más amplio contorno en toda la época posterior.

En Coahuila la transformación consistió sobre todo en la ruptura de la aquí tradicional coexistencia de población y presidio, tan arraigada, que todo el interés del gobernador Ugarte en el momento anterior a la aplicación del Nuevo Reglamento estribaba en radicar definitivamente en la villa de San Fernando de Austria el antiguo presidio de San Sabá. Todavía estaba en pugna la cuestión de si este presidio correspondía a la provincia de Texas, Coahuila o Nuevo León, y si el de Santa Rosa estaba subordinado al gobernador de Nueva Vizcaya o al de Coahuila, cuando la erección del empleo de comandante inspector vino a crear una jurisdicción totalmente distinta de la de las provincias, válida sobre todas las guarniciones fronterizas.

Todavía no había ocurrido esto cuando ya el rumor del próximo traslado de los presidios al río Grande tenía consternados a los vecindarios, 267 cuyas caballadas y muladas "que era su único comercio" estaban siendo destruídas por los enemigos, con la consiguiente secuela de muertos y raptos. ${ }^{268}$ Sin embargo, aunque dos partidas de sesenta y siete lipanes causaron doce muertes a mediados de 1772 en la hacienda del Alamo y pueblo de Candela y destrozaron algún ganado, esto fue un daño esporádico dentro de una situación egneral de paz, a la que indudablemente contribtiría la impresión que causó la visita de O'Conor, escoltado por tres compadías, a lo largo del río Grande. La miseria de los vecinos a pesar de ello era tal que Ugarte consideraba inviable entregarles las armas proporcionadas por el virrey con ánimo de que las pagasen, ${ }^{269}$ Una muerte y pequeños robos de caballada y mulada en Mesillas y de ganado vacuno en Santa Rosa, en mayo de 1773 , bastaban

267 Ugarte y Loyola a Bucareli. Coahuila, 4 de noviembre de I77I. Ibid.

268 Ugarte a Bucareli. Monclova, 27 de noviembre de r77r. Ibid.

269 Bucareli a Arriaga. México, 27 de marzo de 1773 , núm. 8.38. A. G. I., Guadalajara, 513. 
a poner sobresalto en el ánimo del gobernador. ${ }^{270}$ No obstante, también el capitán Don Rafael Martínez Pacheco, dejado por O'Conor al mando de un destacamento que resguardase la provincia permitiendo la construcción de los nuevos presidios, decía haber sido informado de que el número de los lipanes llegaba a diez mil, aunque él no había visto más que cinco mil. En todo caso recelaba de que su tropa no era suficiente; pero habiendo ordenado a Don Vicente Rodríguez, capitán de San Juan Bautista, que batiese el río Colorado desde la confluencia del Escondido hasta el de Sabinas, con sólo sesenta y siete hombres logró Rodríguez hacer pasar de buen grado a la otra orilla del Grande a más de cuatro mil lipanes. ${ }^{271}$

También en Texas había paz con los lipanes, pero tanto éstos como los vidais, texas, taobayas, tuacanas, comanches y norteños eran vecinos peligrosos, y de los íltimos se decía particularmente que "manejan el fusil con la destreza que les facilita el duro continuado ejercicio de la caza en que se emplean, mientras sus mujeres cultivan la tierra recogen las semillas, fabrican sus mal formadas chozas y benefician las pieles de cibolo y venado a que se reduce su comercio, cambalacheándolas por las armas, pólvora y balas en
las colonias inglesas y en el presidio de Natchitoches". ${ }^{272}$

Recientemente, merced a los oficios de Atanasio de Mézières, se habían celebrado paces con estas naciones de norteños; "hoy, prosigue el virrey, no se puede despreciar su amistad porque tendríamos cruda guerra, y no se puede confiar en la buena fe de los apaches. Pero tampoco se puede acceder a su solicitud de armas, pólvora y balas, porque el fin de las conquistas consiste en la sumisión de los gentiles a la fe, a la paz, a la vida civil y a la obediencia al rey, y esas armas, aunque sólo sirvieran para la caza, imposibilitarían su reducción porque andarían vagantes por las montañas". Por eso Bucareli reprobó un regalo de armas enviado por De Mézières, sin embargo de que podía conocer, que éste era el método ordinariamente empleado por los franceses en su trato con los indios, cuando ponderaba la paz con que éstos se comportaban en Luisiana mientras hostigaban Texas, "de que se deduce que o nosotros hemos ignorado el modo de reducir a los indios, o que no ha llegado a éstos la hora feliz de sus divinas piedades". ${ }^{273}$

Sin embargo, Riperdá seguía las ideas de De Mézières, advirtiendo que los norteños recibían armas inglesas a través de los panis-mahas del Misuri, por lo que sería mucho más conveniente que las recibiesen de los españoles.

270 Bucareli a Arriaga. México, 27 de mayo de 1773 , núm. 936, y Extracto de igual data.
A. G. I., Guadalajara, 512.

27 I Extracto de noticias. México, 26 de junio de

27a Bucareli a Arriaga. México, 26 de septiembre de I773. A. G. I., Guadalajara, 5I3.

273 Bucareli a Arriaga. México, 27 de octubre de I772, n. 560 . A. G. I., Guadalajara, 4 I 6. y 70 . Ibid. 
Los apaches, en cambio, tenían fusiles franceses adquiridos de los vidais. Sus esfuerzos tendían a enemistar a los vidais con los apaches como lo consiguió al tiempo que éstos ya se le enfrentaban, advirtiendo la mayor condescendencia del gobernador con los vecinos del norte. ${ }^{274} \mathrm{La}$ política de Riperdá daba sus frutos cuando en marzo de 1773 podía informar que los apaches se habían retirado de la provincia temiendo ser atacados por los indios del norte. En cambio, los comanches daban muestras de malafe. ${ }^{275}$

Pero la retirada de los apaches de Texas sólo podía traducirse en una mayor presión de estos indios sobre Coahuila, donde inevitablemente habrían de empezar los robos de ganado para su subsistencia, como se experimentó a partir de junio con la consiguiente apertura de las hostilidades, ${ }^{276}$ en que los combates no siempre se inclinaron a favor de los españoles. O'Conor propugnó entonces la guerra, pero sólo defensiva, a los lipanés, procurando la conjunción de las tropas de Coahuila y Texas en sus operaciones, para cvitar que el enemigo se introdujese entre los ríos Grande y Nueces hacia Nuevo León y Nuevo Santander. 277 Por octubre siguiente, los lipanes volvían a estar de paz en Coahuila y precavían de los ataques de los mezcaleros. A fin de año, en cambio, ellos y los españoles sufrían ataques de los comanches en ambas provincias, aunque la calma se restableció a poco. ${ }^{278}$ Las sorpresas no por ello faltaban. En Coahuila, en febrero de 1774 , un asalto a la hacienda de Don Diego Borrego causó la muerte de catorce personas; en Texas, el 6 de marzo desapareció la caballada de Béjar, lo que se atribuyó a los comanches, y a la libertad con que Riperdá permitía a los indios de paz entrar y salir del presidio, ${ }^{279}$ y poco después las incursiones de los comanches en Texas habían conducido a un estado de franca guerra, habiendo llegado algunos de ellos hasta Laredo, dando pretexto al gobernador de Nuevo León para pedir la erección de presidio de treinta hombres en la Punta del Lampazo, lo que en principio le fue denegado, ${ }^{280}$ pese a que Don Melchor Vidal de Lorca insistía en los daños que padecían los vecindarios de Vallecillo, Iguana y Sabinas, que habían sufrido treinta y cinco muertos sólo en enero

274 Riperdá a Bucareli. Béjar, 28 de noviembre y 3 de diciémbre de 1772 . A. G. I., Guadılajara, 5 I3.

275 Extracto de noticias. México, 27 de mayo de 1773 y 26 de junio de 4773 . Ibicl.

276 Extractos de noticias. México, 27 de julio y 26 de septiembre de 1773. A. G. I., Guadalajara, 5 I 4 y 5 I3.

277 O'Conor a Riperdá. Guajoquilla, 3 de septiembre de i773. A. G. I., Guadalajara, 5 I4.

278 Extractos de noticias. México, 2 de febrero y 27 de marzo de 1774 . Ibid.

279 Bucareli a Arriaga. M'éxico, 27 de mayo de I774, y Extracto de igual data. A. G. I., Guadalajara, 5 r 3 .

280 Extractos de noticias. México, 27 de julio y 26 de septiembre de I774. A. G. I., Guadalajara, 5 I 3 y 5 I 4 . 
y febrero de I775. ${ }^{281}$ Este mismo año realizaba González Santiáñez, gobernador de Nuevo Santander, violenta campaña contra varias partidas de inclios hipólitos, palihuecos, janambres, aracais, etc., sublevados.

En Coahuila $y$. Texas la inquietud no rebasaba el grado que se puede considerar normal de inseguridad en la frontera. Poco a poco se iba advirtiendo en la última provincia una diferencia de comportamiento entre los comanches y las demás naciones del norte — taobayas, tuacanas, incanis-cuyos jefes acudían a Béjar a ratificar las paces y daban frecuentes muestras de fidelidad. En Coahuila, O'Conor no se mostraba satisfecho de la actividad de los presidios, cuyo defecto atribuía en parte a la incompleta dotación de oficiales, pues el capitán de Santa Rosa, Ortíz Parrilla, estaba en España, y el de Monclova era el propio gobernador Don Jacobo de Ugarte y Loyola, ya achacoso. ${ }^{282}$ Pronto hubo nuevo capitán en Santa Rosa, habiendo muerto Ortiz Parrilla en España. En cuanto a Ugarte, pese a sus enfermedades, realizó tres viajes para reconocer las nuevas fábricas de los presidios, y tomó parte en la campaña general de I775, aunque sus objetivos se malograron, de lo que le culpó el capitán Martínez Pacheco. O’Conor reprendió a éste y elogió al primero: "el gobernador es de un genio tan dócil como amable $y$, por consiguiente, vive en la firme creencia de que nadie lo engaña. El desinterés con que se ha portado en su gobierno es tan constante como notorio a todos los que están instruídos en sus procedinientos y lo acredita superabundantemente su atraso, constándome no sólo sus empeños, sino también que lo más del tiempo se ve en la precisión de pedir prestado para comer, circunstancias todas dignas de la mayor atención y que me precisan en el cumplimiento de mi comisión de suplicar a la superioridad de V. E., que en uso de su notoria piedad sea del agrado de V. E. atender a este honrado oficial en lo que hubiere litgar". ${ }^{28} 3$ Ya el ministerio había resuelto conceder alguna gratificación a Ugarte, a quien Bucareli dispuso se abonasen dos mil pesos por una vez, ${ }^{284}$ y había sido nombrado Don Juan de Ugalde nuevo gobernador de Coahuila.

Los últimos meses de 1776 transcurrieron de nuevo con el sobresalto

281 Extractos de noticias. México, 27 de octubre de 1774 y 24 de febrero y 27 de marzo

de 1775. A. G. I., Guadalajara, 514 y 515.

283 Bucareli a Arriaga. México, 27 de mayo de 1774 , núm. 1395. A. G. I., 515.

habia manifestado al virrey cómo, después de Carmen, 5 de abril de 1776 . Ibid. En 1771 , Ugarte de Guardias Españolas, en 1769 , el rey, sin él solicitar y nueve años de servicio en el regimiento de todas maneras"... "destino nada proporcionado a duado de coronel en su regimiento), aunque en a la mencionada graduación (de teniente graa Bucareli. Coahuila, 4 de noviembre de 284 Bucareli a Gálvez. México, de 1771 . A. G. I., Guadalajara, 512. lajara, 515 . 
de temerse una decidida invasión de Coahuila por los lipanes, hecho que no se produjo y sí sólo algunas muertes de pastores y ataques en pequeña escala a la Babia y el Valle de Santa Rosa, aparte el primero a la hacienda de Anahelo, cuya noticia no se confirmó. ${ }^{285}$ Pero cuando Ugarte da sus primeros informes a Teodoro de Croix ya en 1777 sigue convencido del riesgo que corre la provincia con motivo de la traslación de los presidios y la aparente faz y amistad de los lipanes.

Riperdá, en cambio, a quien en 1776 se concede el gobierno de Comayagua, había logrado separar a los vidais de los apaches, a la vez que cinco naciones norteñas en lo que, siguiendo sus procedimientos, decía haber gastado más de diez mil pesos. Había construido en I77I el fuerte de Cibolo, y en I774 había logrado la fundación del pueblo de Nuestra Señora del Pilar de Bucareli, que contaba cincuenta casas, en el río Trinidad, a ciento treinta leguas de Béjar, nutrido por los antiguos pobladores de Adaes y Nacogdoches y que era un puesto valioso para el contacto con las naciones amigas del norte. La población de la provincia, según Riperdá, se había duplicado durante su gobierno. 286

285 Extractos de noticias de M'éxico, 27 de octubre, 26 de noviembre y 27 de diciembre de 1776, y 27 de enero de I772. A. G. I., Guadalajara, 5I 6.

286 Riperdá a Gálvez. Béjar, I 5 de noviembre de 1776. A. G.. I., Guadalajara, 302 . Sobre la fundación del Pilar de Bucareli, Castañeda, Catholic Heritage, IV, 304-325. 



\section{CAPITULO QUINTO}

\section{CREACION DE LA COMANDANCIA}

\section{EL PRIMER COMANDANTE GENERAL}

No hacía más de tres meses y medio del acceso de Don José de Gálvez al ministerio de Indias ${ }^{I}$ cuando el plan forjado por él y por el virrey Croix en $I 768$ y aprobado por el rey el año siguiente entraba repentinamente en vías de realización al ser expedido en Aranjuez el real decreto de 16 de mayo de I776, por el que se designaba a Don Teodoro de Croix, caballero de la Orden Teutónica, sobrino del virrey del mismo título y apellido, para el cargo de gobernador y comandante general en jefe de las provincias de Nueva Vizcaya, Sonora, Sinaloa y Californias, conforme a aquel plan y a la instrucción que se le expediría por la vía reservada. ${ }^{2}$

Dicha instrucción fue dada en San Ildefonso el 22 de agosto siguiente y su primer artículo declara que en el mando superior conferido a Teodoro de Croix "se han de entender incluidos y agregados los gobiernos subalternos de Coahuila, Texas, y el Nuevo México, con sus presidios y todos los demás que se hallan situados en el cordón o línea establecida de ellos desde el golfo de Californias hasta la bahía del Espíritu Santo", y le encarga el

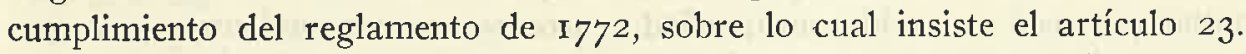

Se hacen precisas ahora algunas palabras sobre la figura del primer comandante general. Es Don Teodoro el más conocido de todos los jefes que ocuparon este puesto, tanto por haber sido él quien lo inaugurara como por su ya citado parentesco con el virrey marqués de Croix, y como por

I Gálvez fue nombtado secretario de Estado con destino a servir la secretaría del Des. pacho Univensal de Indias, vacante por fallecimiento de Don Julián de Arriaga, por real orden dada en el Pardo, el 30 de enero de 1776 . Archivo Histórico Nacional, Estado 2874.

2 Real decreto de Aranjuez, i6 de mayo de I776 a Gálvez. A. G. I., Guadalajara, 301. 
haber llegado luego a alcanzar el virreinato del Perí. Pero aparte de estos pocos hechos - ínicos que conoció la historia durante bastante tiempo-, el hombre que en I 767 se iba a hacer cargo del gobierno de las provincias internas tenía ya entonces en su hoja de servicios un historial si no brillante, sí distinguido y que lo acreditaba como oficial competente y de confianza de las autoridades españolas. Nacido en el castillo de Prevoté, cerca de Lille, el 30 de junio de I730, tercer hijo de los marqueses de Heuchín, pasó muy joven a la corte de Madrid, como tantos otros señores de su propia familia y de su país, con objeto de ingresar en las compañías de níbles de la guardia real, desde donde se podía hacer carrera pasando a otros puestos del ejército y a funciones de mayor responsabilidad en los gobiernos provinciales $y$ en los ministerios. 3

Según su hermano, heredero del marquesado de Heuchín, Don Teodoro "tenía cinco pies y seis pulgadas y tuna hermosa figura; sin ser brillante en su converzación, tenía una inteligencia muy clara, que le permitía prontamente apreciar el lado fuerte y el débil de toda cuestión, una gran decisión, y una modestia tan grande que sólo él dudaba de su mérito". A los diecisiete años desempeñaba ya el puesto de alférez de granaderos de la compañía flamenca de guardias de corps. Algún tiempo más tarde pasó a servir a las órdenes del marqués de Mina en el ejército que operaba en Italia, y en I756 ingresaba en la Orden Militar Teutónica, hecho al que debe su título de Caballero y su celibato. Su carrera se movió en los ámbitos peninsulares y europeos hasta I765, fecha en que, contando treinta y cinco años de edad, y con calidad de exento en su compañía flamenca, Don Carlos Francisco de Croix, marqués de Croix, recientemente electo virrey de Nueva España, solicitó del rey el necesario permiso para poder llevar consigo a México, como sujeto de la mayor confianza, a su sobrino el caballero de
Croix.

El jefe del cuerpo flamenco, marqués de Bournonville, informó favorablemente esta instancia en atención a los servicios de Don Teodoro, y a los de su tío en este cterpo, y propuso que se le nombrase exento supernumerario, con su sueldo, antigüedad y ascensos correspondientes, para que la compañía gozase "el lustre de tener siempre en sus individuos personas de las más distinguidas de su nación”. 4 Así lo ordenó el rey en febrero de I766, disponiendo que los ciento veinte escudos de vellón mensuales que

3 Algunos datos biográficos del Caballero pueden hallarse en Thomas, Alfred-B., Teodoro de Croix and the northern fronticr of New Spain, $1776-178_{3}$. Norman, 1941 ; Romero de Terreros, Menuel. Silhetas de antaño. Memidencias de nuestra historia. México, 1937; Vivero, Domingo 4 Bournonville a Arriaga, 21 de noviembre de in65. A. G. I., México, 1508. 
cobraba el Caballero se pagasen con igual número de pesos, en las Cajas de México. A principio de mayo embarcaron el virrey y su sobrino en el navío "Dragón", y dos meses y medio después hallábanse en Veracruz. El marqués nombró a Don Teodoro capitán de su guardia de alabarderos y castellano de Acapulco. Como tal castellano le correspondió actuar - siguiendo instrucciones precisas del visitador Gálvez y del virrey - en la represión de los faudes que de mucho tiempo atrás venían cometiéndose en el comercio con Filipinas a través del galeón de Manila. Don Teodoro hizo en esto un señaladísimo servicio desenmascarando las mercancías que venían sin registro, exigiendo los impuestos justos de todas y aplicando exactamente lo reglamentado acerca de la salida de metales preciosos por Acapulco. Su intervención en estos puntos mereció las aprobaciones del rey que le comunicaron Arriaga y Grimaldi.

En 1767 fue lógicamente el Caballero una de las dos solas personas a quienes el virrey comunicó con toda reserva la real cédula de aquel año que disponía la expulsión de los jesuitas de todos los dominios de Carlos III. Encargado el virrey de ponerla en ejecución. en Nueva España, deliberó con su sobrino y con el visitador las medidas y precauciones que convenía adoptar, $\mathrm{y}$ entre los tres escribieron con sus propias manos las órdenes dirigidas a todos los puntos de México.

En I 770, Teodoro de Croix, que ya había ascendido a segundo teniente de su compañía de guardias de corps, recibió adenás el grado de Brigadier de los ejércitos reales y el virrey le encomendó interinamente la inspección general de las tropas de infantería y caballería del virreinato. Con igual fecha fue nombrado titular de la encomienda de Ramensdorff, de la Orden Teutónica, lo que le proporcionaría considerables ingresos. Finalmente, en noviembre de I77I embarcó con su tío de regreso a España, a la que ambos llegaron en mayo siguiente. El Caballero se reincorporó a la compañía flamenca por cuatro años, al cabo de los cuales el antiguo visitador de México lo promovió al empleo de gobernador y comandante general de las provincias internas.

\section{INSTRUCCIONES DEL MINISTRO}

Hasta veinticinco artículos tiene la instrucción dada al primer comandante general, 5 y en ella se especifican las atribuciones del cargo recién

5 Real cédula e instrucción a Teodoro de Croix, en A. G. I., Guadalajara, 242 y 390.Velasco, I, 332-342.-Navarro Garcia, Luis. "La gobernación y comandancia general de las provincias internas del norte de Nueva España. Estudio institucional", en prensa en la Revista de Historia del Derecho del Instituto Ricardo Levene, de Buenos Aires, vol. XIV. 
creado. El comandante general sería independiente del virrey de México, pero le comunicaría todas novedades interesantes "para que se halle instruido aquel jefe superior del reino de todo lo que sobrevenga en sus países internos y os facilite los auxilios que necesitareis". El virrey proporcionaría al al comandante, el paso de éste por México, los informes pertinentes a las provincias internas. ${ }^{6}$ En estas provincias ejercería Teodoro de Croix la superintendencia general de la real hacienda 7 y el vicepatronato del mismo modo que lo tenía los virreyes y los gobernadores pretoriales, aunque podría subdelegarlo en los de Sonora y Nueva Vizcaya y demás de igual clase en atención a las grandes distancias que había entre las provincias, "y a que contínuamente debéis visitarlas". ${ }^{8}$ La capitalidad de la comandancia quedaría fijada en el pueblo de Arizpe, sobre el río de-Sonora, muy próximos a la frontera y equidistante de Nueva Vizcaya y Californias; Croix se alojaría en la casa contigua a la iglesia, mientras se edificaba otra "en el mismo pueblo, o donde convenga". 9 En Arizpe daría inmediatamente comienzo a la construcción de casa de moneda. ${ }^{\circ}$

El comandante general tendría veinte mil pesos de sueldo sobre las cajas reales de Sonora y Nueva Vizcaya, ir y tendría un asesor - con dos mil pesos- para entender en los asuntos de gobierno superior y superintendencia de hacienda, y en las causas del fuero de guerra; las instancias contenciosas las actuaría ante un escribano con título de notario real de las Indias. ${ }^{12}$ Admitiría apelación de sus providencias a la audiencia de Guadalajara, pero en los asuntos de guerra y hacienda sólo cabría acudir al rey por la vía reservada. ${ }^{13}$ Para los asuntos gubernativos y militares contaría Croix con los servicios de un secretario de cámara y gobierno, cargo que por el momento en condición de interino, desempeñaría el capitán Don Antonio Bonilla, -antiguo secretario del general Villalba y de la mesa de guerra del virreinato bajo el marqués de Croix- ayudante inspector de presidios en la época de O'Conor, que gozaba tres mil pesos de sueldo, y de dos oficiales escribientes, a razón de ochocientos y seiscientos pesos anuales cada uno. El comandante debería desentenderse lo más posible de los asuntos contenciosos, dejándolos a los gobernadores, pues "vuestro primer objeto y cuida-

6 Artículo 2

7 Artículo 3.

8 Artículo 4 .

9 Artículo 5.

Io Artículo 6.

I I Artículo 7 .

I2 Artículo 8.

I3 Artículo 9. 
dos deben dirigirse a la defensa, fomento y extensión de los grandes territorios comprendidos en el distrito de vuestro mando". ${ }^{14}$

"El motivo principalísimo - dice más adelante la real instrucción-que he tenido para el nuevo establecimiento que os he conferido, es el de procurar la conversión de las numerosas naciones de indios gentiles que habitan al norte de la América setentrional". Por ello el comandante general podría pedir todos los misioneros que necesitase al virrey o al mismo monarca. ${ }^{\text {I5 }}$

La compañías milicianas de Sonora y Nueva Vizcaya, y las de indios nobles de Sonora, recibirían mayor atención, sobre todo las de ópatas "por su acreditado valor y constante fidelidad", ${ }^{16}$ pero se asentaba que el mejor resguardo de las provincias internas sería siempre el establecimiento de poblaciones bien ordenadas". " 77 Dispondría Croix en Arizpe de una guardia personal de un oficial y veinte hombres, sacados de Horocasitas, Pitic y Buenavista; cuando viajara, se procuraría la que le pareciese conveniente. ${ }^{18}$

Cinco artículos atañen a las posibilidades expansivas de la comandancia al noroeste. Se encarga a Croix de reconocer y visitar Alta California y asegurar el camino por tierra desde Sonora, valiéndose de las noticias proporcionadas por Anza, 19 y abrir camino de Monterrey a Santa Fe de Nuevo México, zo atendiendo al mismo tiempo al sostenimiento de Alta California desde Sonora y Sinaloa, enviando ganados, frutos, mercancías y pobladores. ${ }^{21}$ Se autoriza al comandante a capitular en nombre del rey con cualquier persona que se ofreciera para hacer entradas, nuevos descubrimientos y poblaciones en países no reducidos a la religión católica, ${ }^{22}$ y se deja a cargo del virrey la puntual remisión a Californias desde San Blas de todo lo necesario para la subsistencia de aquellos establecimientos. ${ }^{2} 3$

Todos los gobernadores, jueces y ministros de las provincias que integraban la comandancia darían cuenta a Croix de todos los asuntos importantes que en ellas ocurriesen ${ }^{24}$ y para que la actuación de las autoridades ahora elegidas fuese plenamente beneficiosa a sus súbditos prohibía el rey expresa y rigurosamente que ni Croix, ni ninguno de sus dependientes ni criados pudiesen admitir obsequios, dádivas ni regalos algunos bajo ningún concep-

$$
\begin{aligned}
& \text { Artículo I0. } \\
& \text { Artículo I2. } \\
& \text { Artículo I3. } \\
& \text { Artículo I4. } \\
& \text { Artículo I I. } \\
& \text { Artículo I5. } \\
& \text { Artículo I6. } \\
& \text { Artículo I7. } \\
& \text { Artículo I8. } \\
& \text { Artículo I9. } \\
& \text { Artículo } 20 .
\end{aligned}
$$


to; y que en sus viajes se prohibiesen los recibimientos y festejos de los pueblos, donde se pagarían los gastos que la comitiva hiciese ${ }^{25} \mathrm{y}$ otro tanto se entendería respecto de los presidios. ${ }^{26}$

Por el correo mensual informaría el comandante al rey de todas las novedades, pero además rémitiría cada seis meses una relación concisa y exacta del estado de las provincias en lo militar, político y económico, dando especial atención a los puntos de conversión de los indios gentiles y aumento o decadencia de la real hacienda, ${ }^{27}$ y así poco a poco iría preparando el informe circunstancial y completo de los ramos de justiçia, política, hacienda y guerra que entregaría a su sucesor, "cumplidos los cinco años desde que tomáreis posesión del mando, o cuando fuese mi voluntad". 28

Para el momento de expedición de la real cédula e instrucción de Teodoro cie Croix ya había sido decidida la retnión del gobierno y la intendende Sonora, en la persona de Corbalán, ${ }^{29}$ y la sustitución de O'Conor en la comandancia e inspección de los presidios por el teniente coronel Don José Rubio $3^{30}$ a quien poco después se ascendía al grado de coronel, como prevería el reglamento de $1772.3^{31}$ En octubre de 1776 ya Bucareli había participado esta designación al interesado, ordenándole ponerse en marcha para su destino con la brevedad posible. 32

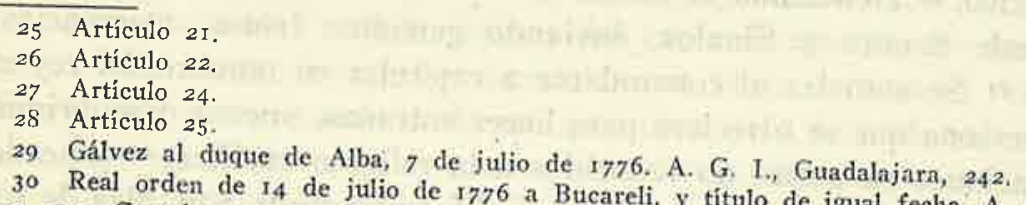

lajara, 515. Contaba entonces Rubio treinta y tres años titulo de igual fecha, A. G. I., Guadacorporado como cadete al regímiento de Lombardia, de servicios, pues en 1743 se había inmientras se desarrollaba la guera de Italia. Concluia, en cuyos cuadros ascendió hasta capitán de guarnición en Orán, que manba el entonces coronel marqués dés pasó tres años en la fuerza tomó luego parte en la guerra de Portugal, en el sitio de Almeida. de la Torre, a cuyas órdenes España con la expedición del general Villalba, y desde entoneida. En 1764 se trasladó a Nueva regimiento de Infanteria de Toluca. El virrey Croix hizo de él actuó como sargento mayor del para realizar la expulsión de los jestritas de los colegios de Puebla. En diciembre de designados Croix lo envio a Nuevo Santander, a las órdenes del mariscal. D. Juan diciembre de I 767 el mismo que atendiese a la formación de la compañia volante que mariscal D. Juan Fernando Palacio, para la provincia. Croix a Arriaga, $8 . n^{\circ}$, México, 25 de diciembre de de levantar para resguardo de núm. 221, México, 26 de mayo de 1768. A. G. I. México, de x767. A. G. I., México, 1364; nombramiento de gobernador de Cartagena, Rubio quedó éxico, 1367. Cuando Palacio recibió el tander y Huaxteca, empleo que desempeñó durante on con igual cargo interino en Nuevo San9 de noviembre de т770. A. G. I., México, 2430. Pósteriormente recibió el de Rubio, Toluca, coronel. En A. G. I., México, 245 I, instancia a Arriaga de Don José Rubio, relativa a la pensión de diez a Arriaga de Doña Nicolasa Salgado, madre de su sueldo. Vid. también Rubio Mañé, Jorge Ignacio, El coronél éste le tenia asignada sobre inspector de las provincias internas. págrs. i2I-I24.

31 Real orden de 26 de agosto de I776 a Bucareli, y despacho de igua! data. Ibid.

En México, 26 de noviembre de 27 de octubre de I776, núm. 2547. A. G. I., Guadalajata, 5 I6. grado cle coronel de Rubio. 
Siguió el nobramiento del auditor de guerra, cargo que fue conferido a Don Pedro Galindo y Navarro, 33 que se unió a Croix en Querétaro, ya camino del norte y el 6 de diciembre eran designados oficiales primero y segundo de la secretaría de la comandancia Don Juan José de la Hoz y Don Bartolomé Sáenz de la Fuente. 34

\section{Teodoro de Crolx en México}

E1 2 I de enero de 1777 hacía su entrada en la capital del virreinato el primer comandante general de las provincias internas de Nueva España, 35 por los mismos días en que O'Conor, enfermó de cuidado, daba cuenta del éxito logrado en la segunda campaña general.

Bucareli acogió con disgusto, pero también con obediencia, la segregación de todo el territorio setentrional del virreinato, "con cuya providencia se descargará este gobierno de una de sus más pesadas cargas". "36 Bucareli hizo la oportuna transmisión de poderes al Caballero de Croix y preparó un informe de lo actuado por su orden en la frontera, enterándole de todo lo que sabía de las provincias internas. El 29 de marzo considera cumplidas sus obligaciones a este respecto y capacitado a Croix para enseguida a desempeñar su mando. 37 No lo creía así el Caballero, que demoraba cada vez más su partida con diversos pretextos, sin que esto le cohibiera de dar órdenes y planear operaciones en la frontera desde México.

Sus actividades en esta ciudad no eran menos variadas. Ya el 8 de febrero podía presentar al virrey una lista de doce oficiales y suboficiales de los regimientos veteranos de México, Puebla y Toluca que deseaban continuar sus servicios en las provincias internas, en los destinos que él les señalaría. ${ }^{8}$ Aquel mismo mes llegarían a su conocimiento el bautizo del jefe yuma Palma en el sagrario de la catedral, y el viaje de los padres Domínguez y Vélez Escalente desde Nuevo México hacia el oeste. 39 Sus cartas al secretario de Indias de 25 y 26 de febrero anuncian la próxima marcha del

33 Galindo Navarro a Gálvez. San Lorenzo, 26 de octubre de i 776 . Pide licencia para elmbarcar rumbo a Nueva España. Ibid.

34 Ibid. Hoz era pupilo del conde de Atanda, según muestra la correspondencia del conde con Gálvez, en el A. H. N., Estado, 2846.

35 Bucareli a Losada. México, 27 de enero de 1777 , confidencial. A. G. I.. México, 124r.

36 Bucareli a Losada. México, 35 de enero de 1777 , confidencial. Ibid. El virrey, que tanto interés se habia tomado por la frontera del virreinato, interpretó probablemente la erección de la comandancia general como una acusación a su incompetencia en la dirección de los asuntos de aquélla, y por eso pidió inmediatamente ser relevado del gobierno. Pero Gálvez y Carlos III, çue pensaban de otra manera, le retuvieron en él.

37 Bucareli a Losada. México, y y 27 de marzo de I777, confidencial. Ibid.

38 Bucareli a Gálvez. México, 24 de tebrero de 1777 , núm. 2756. A. G. I., Guadalajara, 516.

39 Comunicados por Bucareli a Gálvez. México, 24 de febrero de $1777,110^{\circ} 2752$ y 2753 . Ibid. 
nuevo comandante inspector Don José Rubio a Chihuahua, 40 junto con la aprobación clel retiro de O’Conor. 4I Para entonces ya Croix había dispuesto la remoción de una serie de oficiales de los presidios y compañías rolantes y nombrado sus sucesores, $4^{2}$ y pedía la autoridad necesaria para conceder licencia de matrimonio a los que la solicitasen. 43

Para hacerse cargo del estado de las provincias, había ordenado Croix a los gobernadores le proporcionasen un informe detallado de la situación del momento. De resultas de estos informes, el nuevo comandante se apresuró a disponer el envío inmediato de la tercera compañía volante de Chihuahua y Sonora, juzgando sin duda desguarnecidas en' extremo estas provincias, 44 contando la última, además, con un refuerzo de setenta y cinco ópatas distribuidos en los presidios más avanzados.

Desde marzo, sin embargo, empieza Croix a recibir y trasmitir malas noticias. Parece que su entrada al mando de la frontera venga marcada por un hado siniestro. Desde Querétaro le escribe el padre guardián que los misioneros de Sonora relatan y anuncian toda clase de desgracias. Desde Chihuahua y Durango, Muñoz y Barri dan cuenta de golpes dados por los enemigos en la frontera norte de Nueva Vizcaya, y en Parral y en el Real

40 T. de Croix a Gálvez, México, 25 de febrero de 1777 , nimn, I. Ihid.

4 I T. de Croix a Gálvez. México, 26 de felorero de 1777, núm, Io. Ibid.

42 T. de Croix a Gálvez. México, 26 de febrero de 1777 , Júm. 5 Ibid.

He aquí los cambios que de inmediato realizan Croix y Rubio en la oficialidad de los presidios:

C E S A N

Don Bernardo Urrea.......

Don Francisco Bellido.

Don Vicente Rodríguez

Don Manuel Villarerde.....

Don José Cahnilo Chacón.....

Don Jacinto Gutiérrez. . .....

Don José Castilla Terán ....

Don Salvador Rodríguez ....

Estos cargos han cesado por muerte de sus anteriores ocupantes....
Capilán de Altar ........

" "San Eleazario...

" Río Grande ......

" Cerro Gordo .....

Teniente de Janos .........

Teniente del Príncipe. .......

Teniente de San Sabá .......

Alférez de Horcasitas .....

Capitán de Tubac .......

Teniente de Altar ........

Teniente de Buenavista ......

Sargento de Altar . . . . . . .

Alférez de San Buenaventura.

Alférez de Monclova ......

2. Tte de la $2{ }^{a}$ Cía, Vol.

Primer Tte. de la $3^{a}$ Cía. Vol.

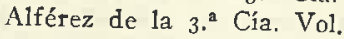

$\triangle S C I E N D E N$

Don Pedro Tueros

Don Francisco Robles

Don Manuel Cerecedo

Don Antonio Tovas

Don Narciso Tapia

Don Pedro Terán

Don Juan de Arellano

Don Vicente Fernández

Don Pedro de Allande

Don Andrés Arias

Don Roque de Garate

Don José Abate

Don Manuel Casanova

Don Eugenio Blanco

Don Vicente Ortega

Don Domingo Matañón

Don Santiago Islas

43 T. de Croix a Gálvez. México, 26 de febrero de 175t, nún. 8. Ibir,

$44 \mathrm{~T}$. de Croix a Gálvez. México, 24 de marzo de I777, núm, 32. T. de Croix a Ugarte
y Loyola. México, r4 de mayo de I777. Ibid. 
del Oro, en la oriental. 45. A poco, Ugarte hace presente el estado de indefensión de Coahuila, de cuyos daños busca el origen la traslación de presidios verificados por O'Conor para construir la Línea, proyecto del que siempre fuera Ugarte enemigo. Ahora con continuos los ataques a los presidios de Monclova, Santa Rosa y la Babia, y ranchos y haciendas y aun la misma villa de San Francisco de Coahuila experimentan el rigor de las incursiones de los apaches. ${ }^{46} \mathrm{La}$ situación de abatimiento, la moral de derrota imperante en la frontera fue recogida por el comandante inspector Don José Rubio en estas palabras: "desde el instante que he pisado los linderos de las provincias internas escuché compadecido continuados lamentos por los estragos que ha sufrido el país al impulso de las reiradas invasiones que los indios bárbaros han ejecutado". 47 En mayo, las noticias de Anza, que a su regreso de México se había encargado de la comandancia de las armas de Sonora, muestran como una realidad el alzamiento de seris y pimas, aunque en corto número, $y^{\prime}$ con él coinciden otros corresponsales de Croix. ${ }^{48}$ Y desde Nueva Vizcaya los datos que se desprenden del diario de una expedición realizada por el capitán Díaz 49 hacen ver la existencia de un continegnte de más de doscientos apaches pertenecientes a ocho rancherías distintas, acogidos a las sierras Mojada y Conula, en pleno Bolsón. Sabido esto, no es de extrañar que a mediados de junio fuesen asaltados, saqueados y arrasados la hacienda de San Juan Bautista de Casta y los ranchos de la Cueva y del Patrón, y sitiado y robado el real de Mapimí, que, despojado de su mulada, sufrió la inmediata paralización de sus faenas mineras, quedando los arrieros abocados a la miseria y todo el real a punto de conocer su cuarto despoblamiento. Los indios enemigos, al retirarse, habían efectuado dieciséis asesinatos, pero exactamente por los mismos días del ig al 25 de junio, más de trescientos indios atacaban la provincia por la frontera sur del Bolsón, cayendo sobre las haciendas de San Miguel de Aguayo, produciendo setenta y seis muertos y llevándose más de mil cabezas de ganado. 50 Casi simultáneamente, después de leves disturbios a fines de junio, en los primeros días de julio, desertaron del Pitic todos los tiburones y casi todos los seris que durante cerca

45 T. de Croix a Gálvez. México, 24 de marzo de 1777, núms. 3x y 32, y Extracto de esta fecha. Fray Diego Ximénez Pérez a T. de Croix. Querétaro, 7 de marzo de 1777. Ibid.

46 Ugarte y Loyola a T. de Croix. Valle de Santa Rosa, 30 de marzo, 2 y 6 de abril de 1777 . Ibid.

47 Rubio a Gálvez. Chihuahua, $28^{\prime}$ de abril de I777. Ibid.

48 Anza a T. de Croix. Horcasitas, 23 de mayo de iz77. T. de Croix a Gálvez. México, 26 de mayo de I777, núm. 44. Ibid.

49 Diario de Díaz, 44 al 28 de mayo. Río Florido, 3 I de mayo de 1777 . A. G. I., Guaralajara, 5 I 5 .

50 El alcalde mayor y vecinos de Mapimí a Barri. M'apimí, 24 de junio de 1777. Barri a '1'. de Croix. Durango, 28 de junio y 5 de julic de I777. T. de Croix a Barri. México, 16 y 23 de julio de 1777 . Ibid. 
de seis años habían permanecido allí, declarándose la sublevación de manera tan repentina que cogió desprevenido al mismo Anza. ${ }^{5}$

A la vista de todas estas desgracias cuya causa no podía explicarse, Teodoro de Croix remitía el I4 de julio a Bucareli diez cartas de Anza sobre la situación de Sonora y una de Barri sobre la de Nueva Vizcaya, quejándose de las dolorosas noticias que recibía de todas partes, y del mal estado de la tropa, según las que le proporcionaba Rubio. La carta de Croix, que parece 111 velado reproche al virrey, plantea la difícil disyuntiva de realizar una campaña, con lo que se quedarían indefensas las provincias, o batir las proximidades de las poblaciones, dejando entretanto desguarnecidos los presidios. Croix manifiesta su resolución de partir hacia la frontera a principios de
agosto.

Sólo dos días después contestaba Bucareli no poder asesorarle por ignorar las disposiciones tomadas por Rubio para cubrir la frontera desde que se hiciera cargo de ella. Bucareli devolvía asi la pelota lanzada por Croix, culpando indirectanente al nuevo comandante inspector de lo ocurrido, pero sido alterado en el dispositivo de la defensa organizado por O'Conor, en el que nunca se previó un ataque a la región del río Nazas. A esto, sin embargo, el virrey se limitó a replicar fríamente que se hallaba enterado, y que esperaba que diera las providenecias que tuviera por convenientes. 52

\section{CaUsas de los nuevos tras'tornos}

La súbita crisis planteada en la frontera a mediados de I 777 por fuerza había de sorprender al historiador de hoy tanto como en sil día al comandante general Don Teodoro de Croix, que veía pender sobre su cabeza la gravedad de unas dificultades imprevistas. Pero si se ha considerado la marcha ascendente de las operaciones de O'Conor hacia la seguridad de las provincias internas al parecer lograda, según asienta el mismo O'Conor en el "papel Instructivo" que dirigiera a Croix y respaldara Bucareli, resulta incomprensible en principio una tan brusca destrucción de aquella halagüeña apariencia para dar paso a una realidad evidentemente enfadosa.

Impulsivamente, Teodoro de Croix no vaciló en imaginar engaño por parte de O'Conor y en reprochárselo de alguna manera al virrey. Es comprensible que Bucareli, desde este momento, considerara con desagrado al comandante general al que debía suponer víctima de su precipitación y bus.

5 I Anza a $T$. de Croix. Horcasitas, 30 de junio de

52 T. de Croix a Bucareli. M'éxico, i 4 y 57 de julio rle 5777. Buca I6 y 18 de julio de I 777 . Ibid. 
case por ello mantenerse al margen de los problemas de la frontera, como lo hará en adelante. No es difícil, sin embargo, llegar a comprender cuál debió ser la verdadera causa de los problemas que tan repentinamente caían sobre el comandante general.

No conocemos razón alguna para tachar de impostor a Don Hugo $O^{\prime}$ Conor, que, muy al contrario, dio siempre, y concretamente en los cinco años que estuvo al mando de la frontera, las más claras pruebas de honradez y sentido del deber. Por consiguiente, hemos de dar crédito a sus informes, y en particular al amplio que dirigió a Don Teodoro de Croix al fin de su actuación a modo de memoria de gobierno. Del conjunto de noticias de O'Conor nos suministra se deduce que al dejar él el mando la frontera experimentaba, si no la paz, sí una temporal minoración de las hostilidades hasta entonces padecidas. Los ataques apaches continuaban, aunque más esporádicos inquietando los puestos fronterizos. O'Conor esperaba solamente, y es comprensible que, de resultas de las dos campañas generales dirigidas por él contra el enemigo, éste se hubiera alejado considerablemente de los establecimientos españoles, y así parecían indicarlo por lo general los datos del momento; confiaba por otra parte en que el Bolsón no sería otra vez refugio de los apaches, ya expulsados de él por las insistentes batidas de las tropas presidiales y volantes.

En cambio, son un hecho las depredaciones y daños que en 1777 sufren las provincias. Pero, considerándolo detenidamente, este recrudecimiento de la guerra no sólo no es imputable a O'Conor, sino que tampoco va contra lo por él asentado en sus escritos. En efecto, si la causa principal de la confusión de Croix está en el nuevo levantamiento de algunas tribus de Sonora, ¿qué iiene esto que ver con lo actuado por O'Conor? E1 primer comandante inspector estuvo siempre pendiente de la frontera exterior; la tinica provincia amenazada interiormente, la misma Sonora, a él se le había entregado como pacificada clespués de la expedición de Gálvez, lo que tanpoco era totalmente cierto; durante su manclato se habían recorrido, sin grandes esfuerzos ni clamores, todos los pasos necesarios para lograr la tranquilidad completa. Si en I 777 los seris y tiburones se alzan, este hecho hubiera sorprendiclo al mismo O'Conor, de estar en el mando, no menos que a Teodoro de Croix.

Por lo que hace a Nueva Vizcaya, el ataque sufrido en la región de de Mapimí y el Nazas, era previsible después que el capitán Díaz descubrió la presencia de los apaches en el Bolsón, y de esto tampoco era culpable O'Conor, puesto que siempre comprendió que, una vez que aquel desierto había sido considerablemente explorado y limpiado de enemigos, la línea de presidios que cruzaba su boca evitaría cualquier posible introducción de una gruesa partida de ellos en su interior, pero no de las pequeñas escuadras que 
podían infiltrarse a través de la Línea, y por eso estableció tropas del cuerpo volante desde Ancón de Carros hasta el presidio del Gallo, y escribe en el artículo 128 de su informe a Croix: "sin embargo de estas disposiciones que mi conocimiento y experiencias me han hecho creer oportunas, es imposible impedir del todo las rapiñas y robos que los bárbaros ejecutan en el interior de la provincia, pero por lo regular suelen ser cuadrillas pequeñas que logren introducirse sin ser vistas por el mismo cordón de presidios". "Así —añade en el I 29 - se ha verificado en mi tiempo y podrá experimentarse en lo sucesivo, si se atiende a la sutileza con que algunos indios peloteros suelen introducirse. Con todo, siempre se verán de bulto las ventajas conseguidas". Le constan, según expresa en el I8r, las muertes y robos que cometen los bárbaros que se introducen por el Bolsón a las inmediaciones del Parral, Valle de San Bartolomé, Real del Oro, Hacienda de la Zarca y todo aquel rumbo, Y por eso señala las maniobras que deben ejecutarse con frecuencia para batir el Bolsón desde Parras al paso de San Vicente, batida que recomienda se haga también al tiempo de ejecutar una campaña general.

No olvida, pues, O'Conor, ni oculta, la verdadera situación de la frontera oriental de Nueva Vizcaya, ni la eficacia a este respecto de la Línea de presidios, a pesar de lo cual no duda del mejoramiento conseguido. De todos modos, desde aquel ataque a mediados de I 775 al que con tanta reiteración alude Croix, ninguna alarma había vuelto a ocurrir al sur del Bolsón, a no ser en las proximidades de Coahuila, donde se atribuían a los lipanes, que guardaban apariencias de paz.

Independientemente de que la presión exterior almentase o que creciese la inquietud entre los indios de Sonora, podemos decir, en cambio, que las condiciones para la defensa disminuyeron después de la marcha de O'Conor, aunque Croix quisiera demostrar lo contrario, ya que sabemos que a poco de llegar a Méximo, retiró la tercera compañía volante de la frontera de Nueva Vizcaya para distribuirla entre Coahuila y Sonora, y en esta provincia Anza había introducido alteraciones, reduciendo al mínimo las guarniciones del interior con vistas a reforzar la línea contra los apaches. Croix, por su parte, había limitado a veinte hombres la dotación de San Sabá, agregando los demás a San Carlos, lo cual equivalía prácticamente a la supresión de aquel presidio, dejando consiguientemente abierta una amplia brecha de ingreso al Bolsón. Todo esto pudo redundar en la facilidad con que desertaron las tribus del Pitic, y en la rapidez con que se pobló de apaches el Bolsón ; y aun todavía pudiera culparse de las desgracias a la lentitud con que se trasladó a Chihuahua Don José Rubio - que, por otra parte, no adoptó el plan ofensivo de O'Conor- y la notable negligencia en emprender igual viaje que manifestó el mismo Croix, y esto último debió comprenderlo así el mi- 
nistro Gálvez cuando le escribió, en respuesta a las malas noticias de la provincia de Nueva Vizcaya: "espera S. M. que la presencia de S. S. en ella y las demás de su mando le proporcione los conocimientos que no podrá tomar desde México, para aplicar con oportunidad los remedios a unos males que deben evitarse y se han precavido en otros tiempos con la mitad de menos fuerzas de las que hay actualmente en la frontera". s3

\section{EL PLAN DE ACCIÓN DE CROIX}

Era cierto lo que Gálvez expresaba en la anterior real orden, ya que desde principios de siglo la frontera, de Sonora a Coahuila, no había experimentado expansión alguna, y sí sólo las fallidas tentativas de ocupación del Bolsón. La presión de los apaches, empujados a su vez por los comanches según sabemos, y la de las tribus insumisas de Sonora se había multiplicado, en cambio, considerablemente, sobre todo en los últimos años, pero a proporción habían sido incrementados los efectivos militares de manera estable o transitoria, habiendo pasado de esta a aquella condición muchas veces. Difícilmente se lleva a efecto algún proyecto de reducción de tropas, y en cambio es constante la creación de nuevos presidios.

De la expedición de Sonora había subsistido sobre las armas una compañía volante, miliciana, sin que, primero por asegurar la paz, y luego po: otras causas, se suprimiesen los presidios del interior, tal como se había pensado y se estableció en el reglamento de I 772 . Al entrar O'Conor en Nueva Vizcaya se levantaron otras cuatro compañias volantes - -una de ellas resto de las fuerzas de Bernardo de Gálvez- que debían licenciarse al término de aquella "expedición" destinada a reformar la línea de los presidios y castigar a los apaches. Estas cuatro compañías, sin embargo, perdurarán para lo sucesivo, y además O'Conor obtendrá la creación de dos nuevos presidios, los de San Eleazario y la Babía, en la Línea; aparte que Arriaga mismo dispuso el refuerzo de los dos piquetes de dragones del virreinato que marcharon a la frontera.

Con todas estas fuerzas, pues contaba Teodoro de Croix a su llegada. A lo largo de su actuación clamará repetidas veces por más y más rẹfuerzos. Durante mucho tiempo insitirá en su más radical petición de dos mil hombres de una vez, para repartirlos por toda la frontera, y en último término recurrirá a diferentes soluciones para proporcionarse tropas.

Pero en el primer momento Croix tiene puesta su esperanza en la orga-

53 T. de Croix a Gálvez. Méxíco, 26 de julio de 1777 , núm. 78 . Real orden de 23 de diciembre de 1777 . Ibid. 
nización de las milicias provinciales de Nueva Vizcaya que se le encargaba en el artículo trece de su instrucción, y para cumplirlo pidió a Bucareli cuatro oficiales - el ayudante mayor Don Juan Gutiérrez y los tenientes Don José Panes, Don Ignacio García Rebollo y Don José Gregori- a los que encomendó el alistamiento, formación y arreglo de aquéllas. Gutiérrez y García acudirían a Durango, Cuencamé, Gallo, Mapimí, Parras y Saltillo, y a las poblaciones, haciendas y ranchos del Nazas y Aguanaval, mientras que Panes y Gregori se hacían cargo de las de San Juan del Río, Real del Oro, Indé y las haciendas de la Zarca, Mimbrera, Torreón y las del río Florida, Parral
y Valle de San Bartolomé, hasta Coahuila.

En los planes de Croix entraba el hacer pasar luego estos oficiales a Coahuila, Texas y Sonora con el mismo objeto de formación de milicias. Por de pronto, preparó el bando que habría de publicarse en Nueva Vizcaya a esto efecto, y desde luego se observa si idea de poner en pie de guerra capaces de llevar armas. 54

Era preciso revistar una vez más todos los presidios, y ésta era la misión del comandante inspector. Pese a que O'Conor declara haber dejado todas las compañías perfectamente montadas, equipadas y abastecidas, pronto se tuvieron noticias en contra. La primera y más contudente fue el aviso dado por Rubio de que los habilitados de siete presidios y dos compañías habían quebrado en distintas cantidades, algunas de las cuales se desconocían; pero las que eran sabidas ascendian en total a más de cuarenta y siete mil pesos. Sólo el teniente de San Sabá se hallaba en clescubierto de quince mil pesos, $y$ en la tercera compañía volante habían quebrado tres habilitados sucesivos: un teniente y los dos capitanes que habían muerto en la guerra. Muchas de las deudas no eran con la tropa, sino con particulares, pero precisamente estos no estaban de recurrir a la superioridad reclamando sus
intereses, 55

Las causas de estas quiebras ptieden hallarse en la falta de aptitud de los oficiales para desempeñar las funciones de habilitado, o en otros casos, a su fracaso al intentar negociar con los fondos estableciendo tiendas o prensalida. Pero el motivo mís comín géneros a los que luego no podían hallar los sueldos de los soldados que, obligade considerarse el de la cortedad de iraslados de los presidios y que, obligados a considerables gastos por los ordenadas por O'Conor las incesantes campañas particulares o generales

54 T. de Croix a Gálvez. México, 26 de julio de I777, núm. 65. Ibid

I4 de jutio de I777. Ibid. 


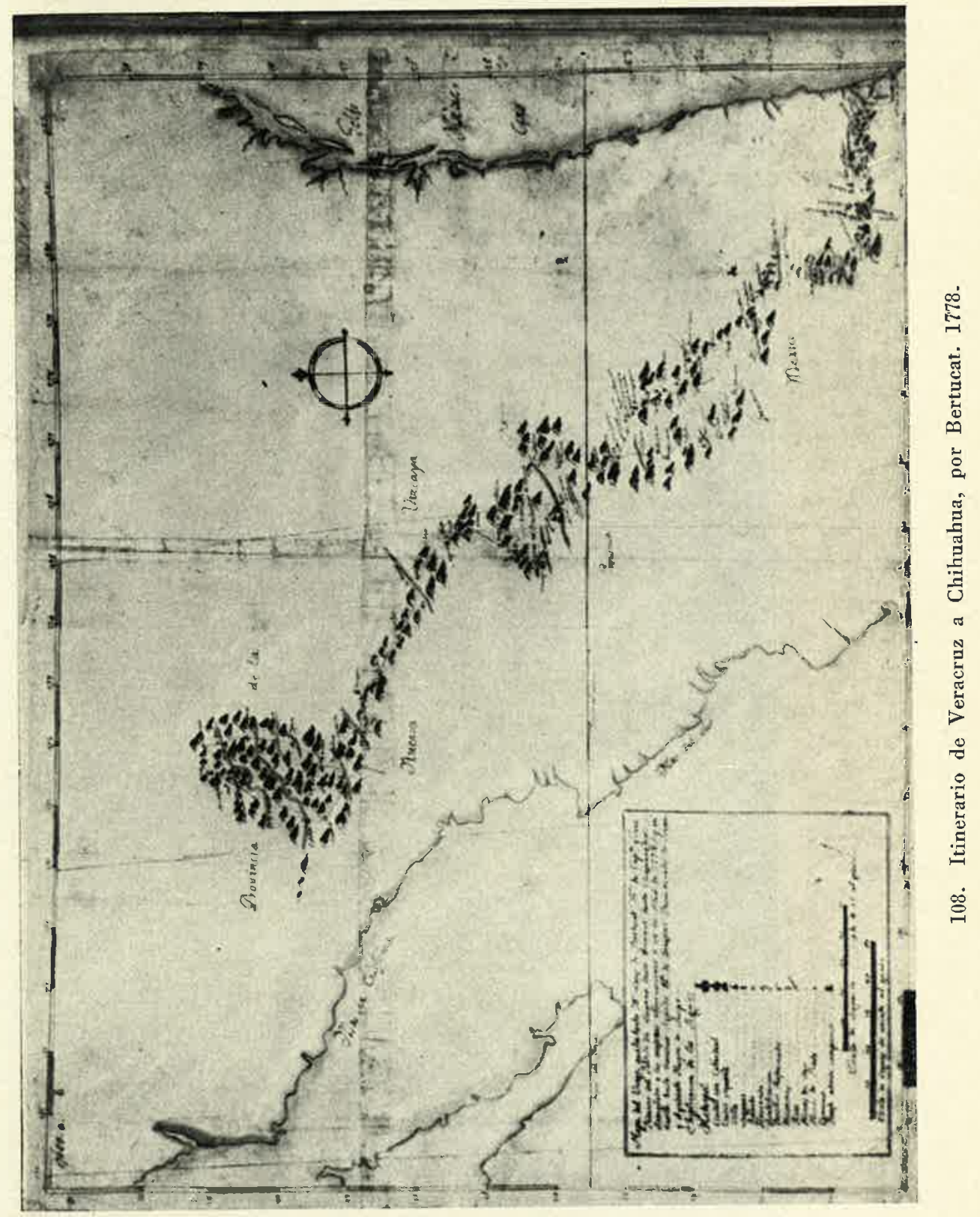




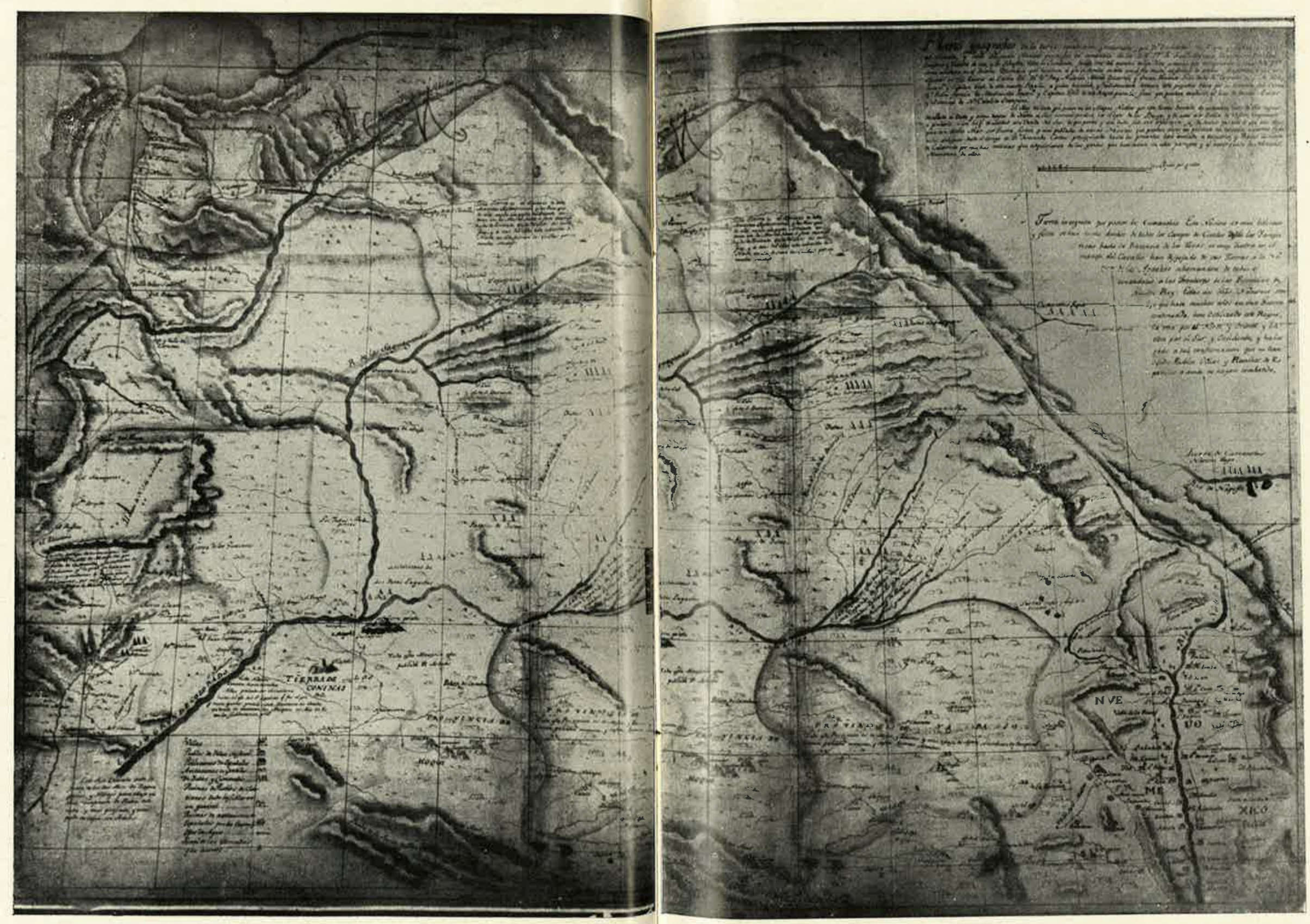

109. Mapa de los descubrimientos de Donúnguez y Vêtaz Escalante en Nuevo México, por Miera. 1777. 


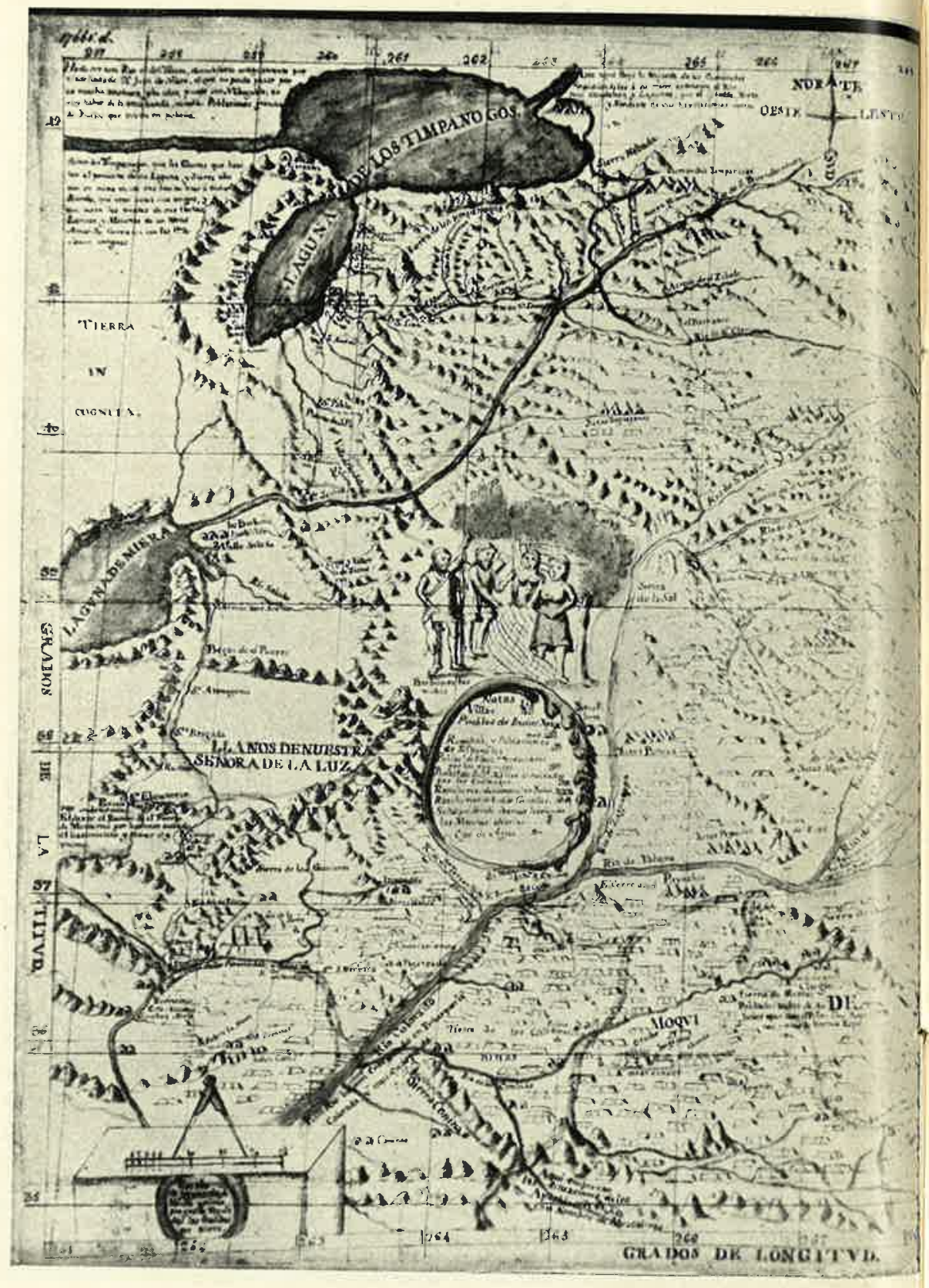

110. Mapa de los descubrimientos

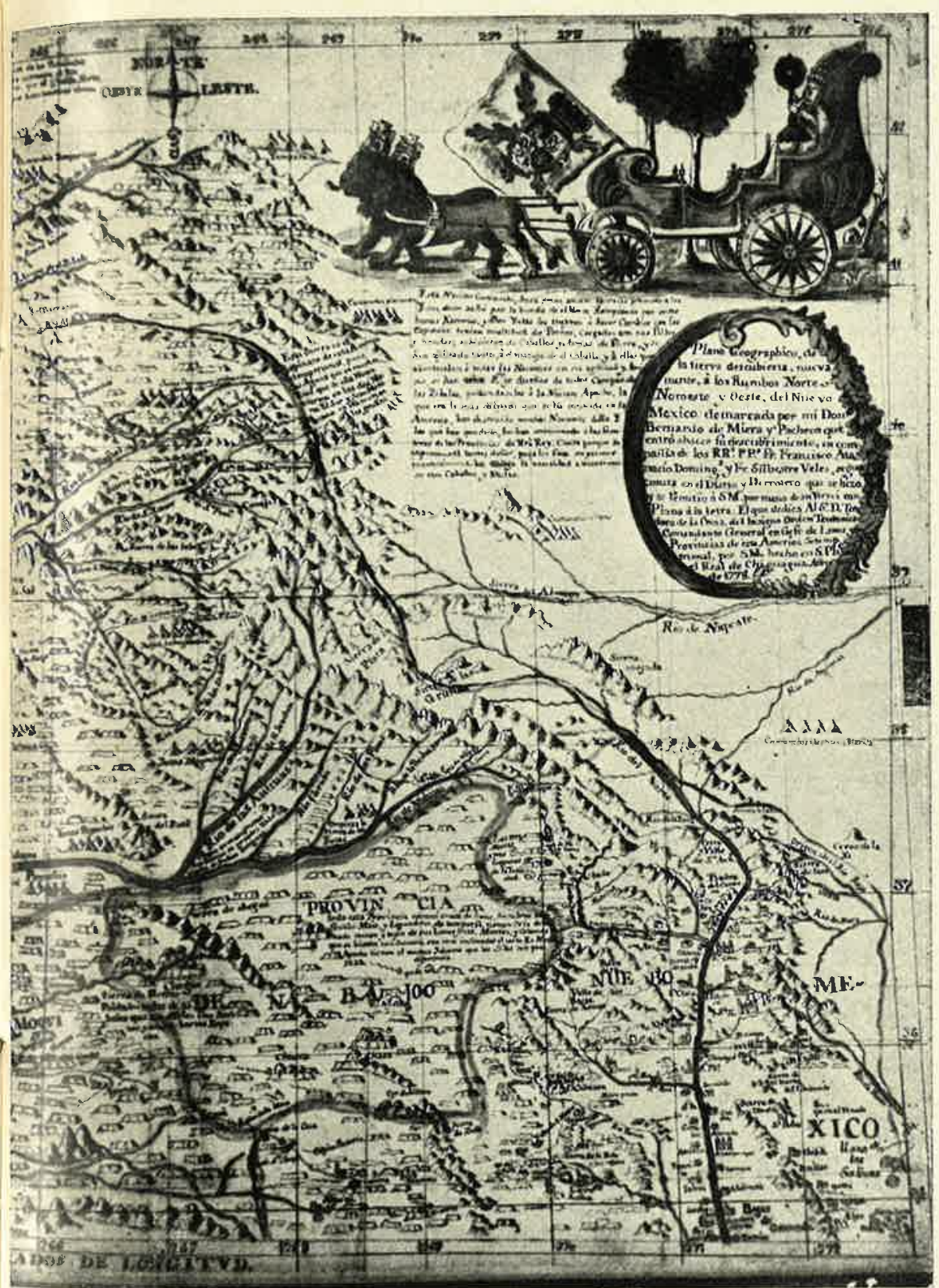

al noroeste de Nuevo México, por Micra. 1778. 


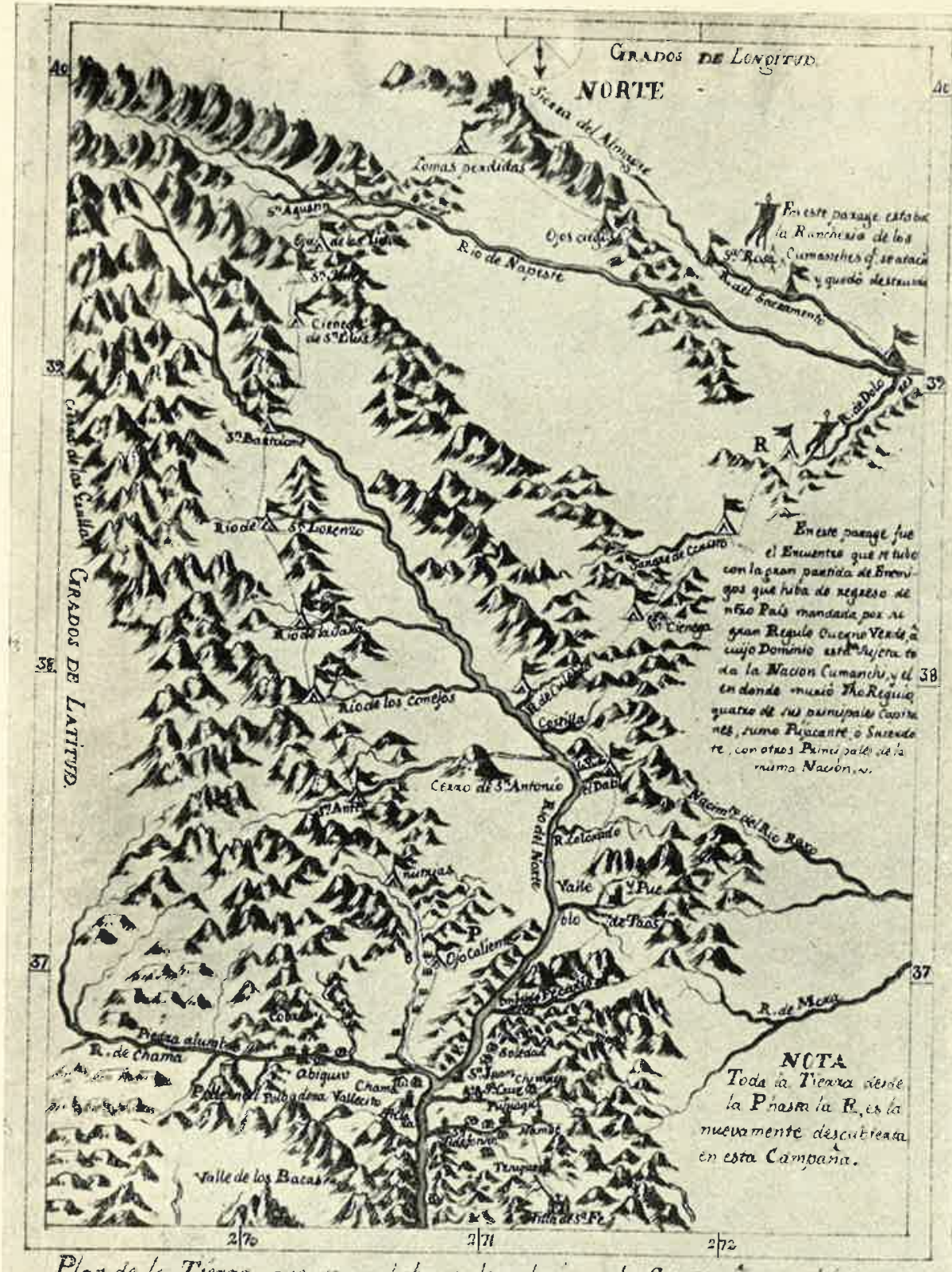

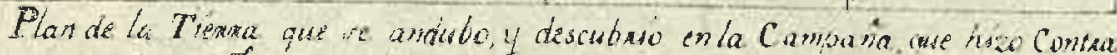

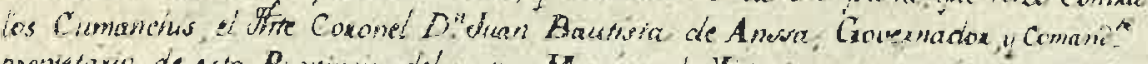

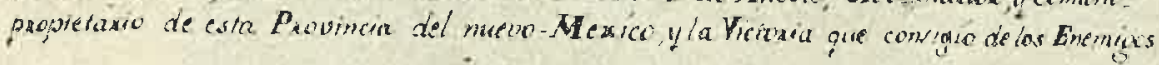

Luscala de vernte iearias pou cirado.

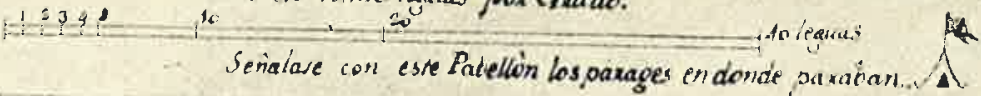

111. Campaña de Anza contra los comanches, en 1777. 


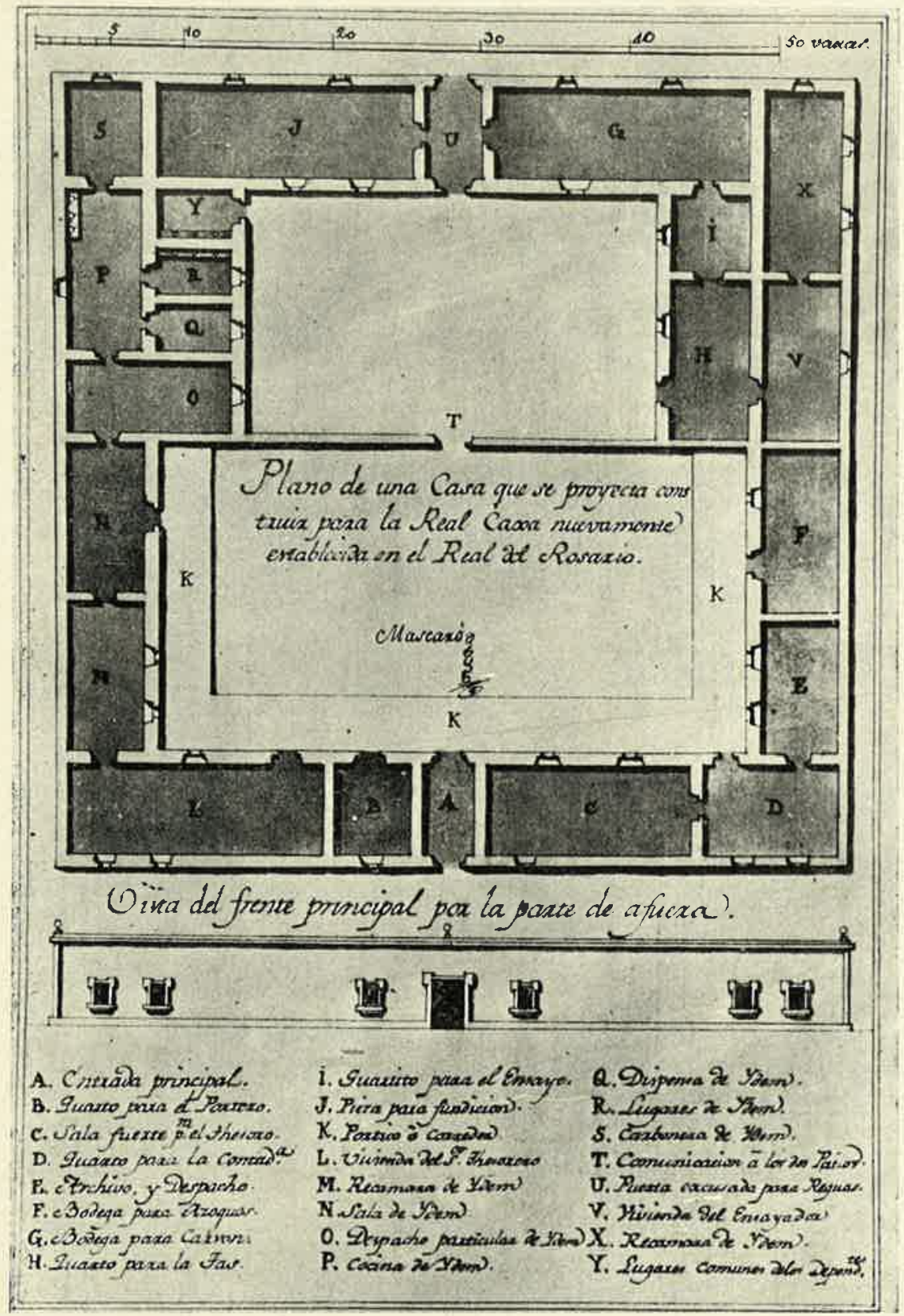

112. Planta de la Caja Real de Rosario, por Mascaró. 


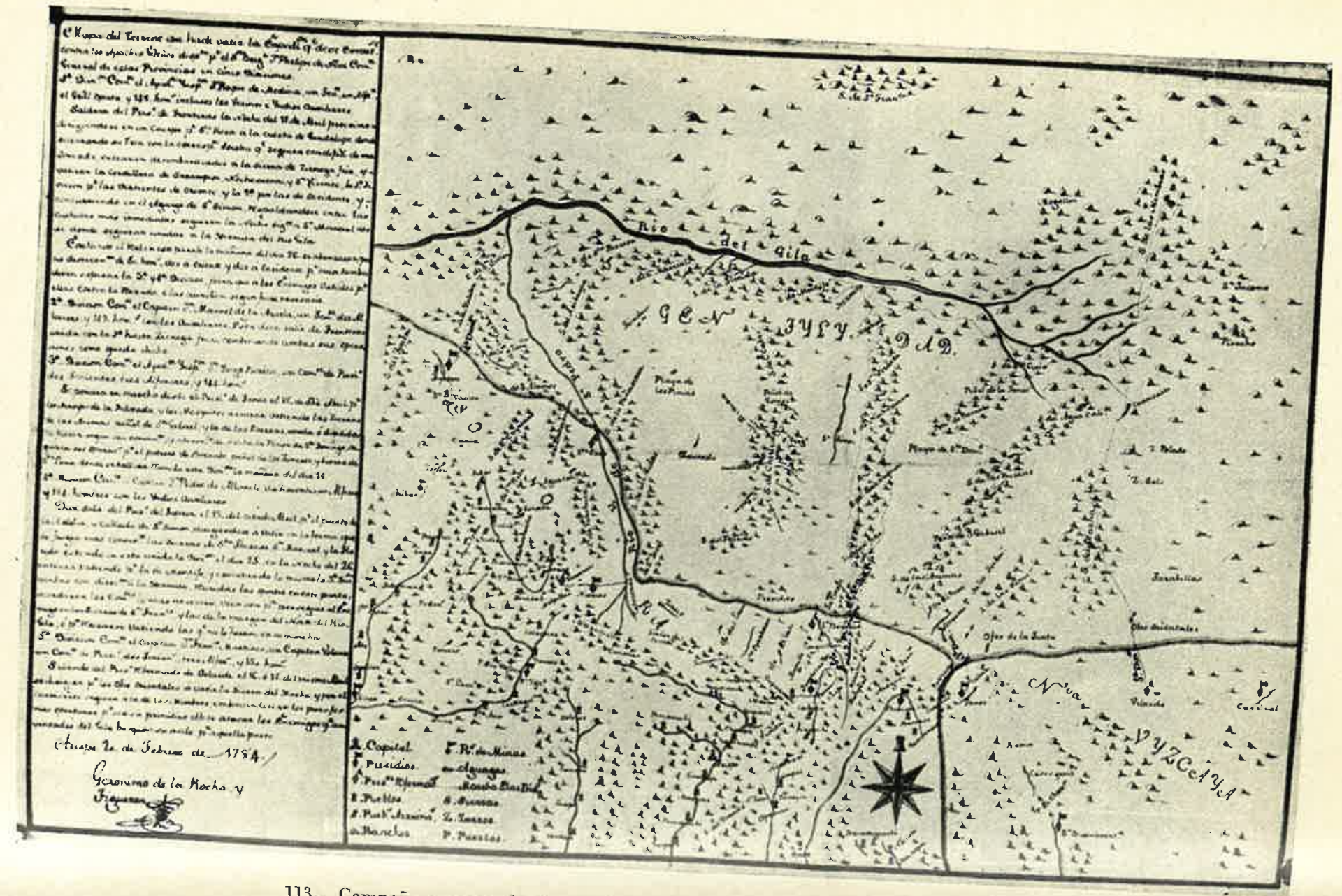

113. Campaña proyectada contra los apaches del Gila. Mapa de Rocha. 1784. 


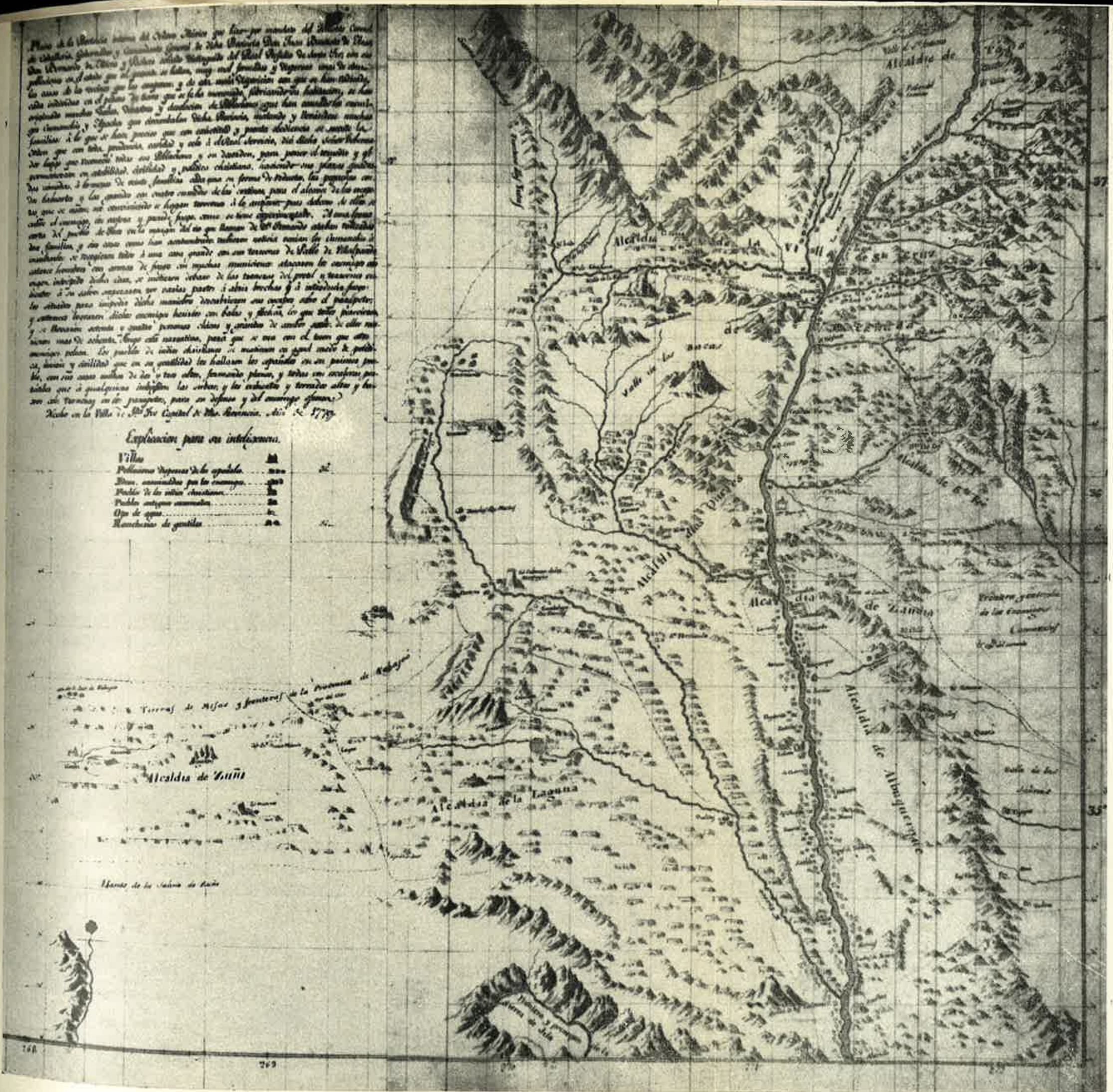



quien a su vez solía estarlo con algún comerciante. Por falta de recursos de la tropa, o de la quiebra de los habilitados, aquélla venía a encontrarse al fin totalmente en la miseria. Así, el comandante del destacamento que operaba en la Pimería Alta declara que su tropa salió de San Bernardino a pie, muchos sin caballos, otros con uno solo, el que más con dos, sin un grano de pólvora, y sin balas; igualmente se hallaban sin ropa ni cigarros. $5^{6} \mathrm{Sin}$ que fuera tan lamentable, hay noticias de que todas las tropas de la fronteras se hallaban en mal estado semejante y por las mismas causas. A remediar este desorden se dirigirá la instrucción provisional en veintidós artículos formada por Rubio en Chihuahua el i 6 de agosto de 1777 , reglamentando el manejo de los situados y el buen gobierno interior de los presidios con normas que fueron aprobadas por el Caballero de Croix. 57

La falta de caballadas - por las que robaban los indios y por las que se inutilizaban por las campañas y con los fríos- era problema constante, y además causa principal de la ruina de los soldados. Por otra parte, el agotamiento de las que en otros tiempos tuvieron Sonora y Nueva Vizcaya se acusa en el dato de que, para reunir los mil quinientos caballos que había que enviar a Nuevo México hubo que acudir a Nuevo Santander y Nuevo León. 58

Con todo este lastre de dificultades, que probablemente no hubieran adquirido tanta gravedad si se hubiera acudido a remediarlas prontamente, empezó a moverse, aunque tarde, Teodoro de Croix, que por fin el 4 de agosto se ponía en camino hacia el norte, habiendo fijado su itinerario primero hacia Coahuila y Texas, para pasar luego a Nueva Vizcaya y Sonora, donde debía ser fijada la capital. De esta manera adquiría una experiencia directa de la situación y de los territorios de la prontera antes de radicarse en Arizpe; por lo demás su idea de una comandancia general centrada en Sonora estaba totalmente plegada a los deseos de Gálvez. Así, por ejemplo, habla Don Teodoro de esta provincia: "merece mi principal atención aquel admirable, riquísimo país donde espero acreditar, si Dios bendice mis votos, el celo que me anima, asegurando al rey la tranquila posesión de la presea más preciosa que tendrá en sus dominios, y que facilita la propagación del evangelio en la numerosa gentilidad ya descubierta y dócil a recibir el catecismo y a rendir vasallaje a nuestro católico, piadosísimo monarca”. ${ }^{59}$ De Sonora,

56 Cayetano Limón a Anza. Horeasitas, 22 de mayo de i777.-T. de Croix a Gálvez. México, 26 de julio de 1777 , núm. 72. A. G. I., Guadalajara, 516.

$57 \mathrm{~T}$. de Croix a Gálvez. Durango, I I de octubre I777, núm. i I7. rcmite este documento. A. G. I., México, 2462 .

58 T. de Croix a Gálvez. México, 26 de julio de 1777 . núm. 73. A. G. I., Guadalajara, 5 I 6.

59 "El principal objeto de mi atención", llama a Sonora $T$, de Croix en carta a Gálvez, México, 26 de julio de I777, núm. 80 reservada. A. G. I., Guadalajara, 515. 
aclemás, pensaba Croix pasar más adelante a Monterrey, en Californias, para conocer esta provincia.

Con Croix marchó el ingeniero Don Carlos I uparquet, que aquel pidió el virrey, ${ }^{60}$ y también el padre lector Fray Juan Morfi, de quien había oído hablar a Don Pedro Antonio de Cossío en Veracruz, y que se prestó a acompañarle a su destino. ${ }^{6}$ I Morfi serviría a Croix de capellán y de cinsejero o asesor.

\section{LA CRISIS DE QULRÉTARO}

A los ocho días de su partida de México, el I2 de agosto se detenía Croix en Querétaro, y allí se declicó a leer veinticuatro documentos - cartas de Neve, Serra y Rivera- sobre los problemas de Californias: estado de los presidios, aumento de tropas, posibilidad de reclutas, lugares apropiados para la población entre San Diego y Monterrey, importancia de ocupar con un fuerte y dos misiones el canal de Santa Bárbara, sublevación intentada por los indios... Esta variada colección de papeles se la había remitido Bucareli el 2 I de julio en los últimos días de su estancia en México, pero examinándola ahora con detenimiento Croix se consideró ignorante de los asuntos de Californias e incompetente en consecuencia para resolver sobre aquellos puntos, y sin vacilar, remitió las cartas de nuevo a Bucareli instándole a tomar las decisiones oportunas y hacerse cargo del gobierno de Californias mientras él se hallaba recorriendo Coahuila y Texas, teniendo en cuenta además que debiendo dirigirse todos los auxilios a Californias por el puerto de San Blas, se demorarían éstos a proporción que él se alejase de México. ${ }^{62}$

$60 T$. de Croix había pedido a Gálvez el envio de dos ingeniero para que levantasen planos particulares y el general de las provincias y dirigiesen la construcción de la casa de moneda de Arizpe. En consectencia fueron nombrados los ingenieros extraordinarios Don Manuel Mascaró y Don Jerónimo de la Rocha, que tendrian sueldos de ochocientos pesos desde su desem. barco en Veracruz. T, de Croix a Gálvez. México, 24 de marzo de 1777, núm. 36. Reales despachos de 28 de setiembre de 1777 .- Mientras llegaban estos dos, el comandante general pidió al virrey le proporeionase los servicios de Don Carlos Duparquet, que estaba en Veracruz, lo que fue aprobado por el rey, a condición de que uno de los dos recientemente nombrados quedase México. T. de Croix a Gálvez. México, 26 de julio de 1777 , núm: 67 . Real orden de 21 de diciembre de 1777 . A. G. I., Guadalajara, $5 \times 6$.

$6 \mathrm{I}$ T. de Croix a Gálvez. México, 27 de jullo de 1777, núm, 88, El comandante general solicitó se dispensase a Morfi de los tres años de lector que le faltaban para jubilarse, gracia especial que fue obtenida del Papa por el embajador Grimaldi, seguin correspondencia en A. G. I. Guadalajara, 276. "La compañía del expresado religioso - dice Croix en la carta citada- me chos asuntos que estarín para oir su dictamen, como para el desempeño y conocimiento de mulas profanas". Morf recibió or y producirán efectos más fructuosos en nanos sagradas que en a Gálvez. Chihuahua, 23 de

63 T. de Croix a Bucareli. Ouerétaro. A. G. I., Guadalajara, 267.

Querétaro, 23 de agosto de Querétaro, 23 de agosto de 1777 , núm, 89. A. G. I., Guadalajara, 5 I 5. 
Semejante propuesta de Croix no podía dejar de causar el asombro de Bucareli, por lo insólito del caso, y desde luego respondió negándose en absoluto a separar ninguna provincia del mando de Croix, pues carecía de facultades para ello, y se limitaba, por tanto, a asesorarle acerca de la conveniencia de acceder a las peticiones de Nere y Serra. ${ }^{6}$ La real orden de 23 de diciembre de 1777 aprobó como justa la decisión de Bucareli, quien quedaba sólo encargado de atender a la provisión de víveres y efectos de los establecimientos californianos, en cuyo invariable concepto debía el comandante general dar sus disposiciones gubernativas sobre Californias desde Sonora y cualquier otro paraje donde se hallase. ${ }^{64}$

Sin embargo, más grave situación se plantea Croix, y mayor es sú confusión, culando recibe las noticias de que en Sonora los pimas altos y bajos se muestran propicios a seguir a los rebeldes seris, muchos piatos de Pitiqui, Caborca y Bisanig se han unido a los apaches, y los ópatas están descontentos; en opinión del justicia de Arizpe, "la provincia se acaba" entre estas turbaciones y los ataques apaches, pues la traslación de los presidios la había dejado indefensa. ${ }^{6}$ En Nueva Vizcaya eran asaltados San Buenaventura, El Paso, Babonoyaba y las cercanías de Chihuahua, y Coahuila era invadida por partidas considerables descle el río Grande, pese a la paz que hasta entonces habían guardado los lipanes. Más de setecientos de éstos se habían aproximado peligrosamente a Béjar, en Texas. ${ }^{66}$ El 22 de agosto, Croix dirigía un largo escrito a Bucareli en que haciéndole presente el mal estado de las provincias internas y de las tropas que debían guarnecerlas pedía al virrey le enviase dos mil hombres, y aún le parecía corto este número, para despejar de enemigos las fronteras; y declaraba que, dada su situación en el momento, no podía hacer nada ni prometer nada en alivio de las provincias. Los últimos lamentables informes le habían hecho variar de dictamen pues aunque desde su llegada a Veracruz tenía malas noticias del estado de su gobernación, había resuelto no tomar grandes providencias ni pedir auxilio hasta ponerse sobre el terreno. Suponía que los dos mil hombres pedidos estarían dispuestos en ocho meses, y que de no atenderse su demanda quedaría expuesto su honor y el de sus oficiales. ${ }^{67}$

Entre tanto, había dispuesto aumentar veinte hombres más a cada uno de los seis presidios de Sonora, y pedido a Bucareli también enviase a esta

63 Bucareli a Gálvez. México, 27 de agosto de 1777 , núm, 3218. Tbid.

64 Real orden de 23 de diciembre de 1777 . Ibid.

65 Manuel de la Carrera a Anza. Arizpe, 17 de agosto de 1777. Ibid. T. de Croix a

Gálvez. Querétaro, 23 de agosto de 1777 , núms. 90, 91 y 93. A. G. I., Guadalajara, 516.

66 T. de Croix a Gálvez. México, 23 de agosto, núms. 95, 96 y 97. A. G. I., Guadalajara, 515.

67 T. de Croix a Bucareli. Querétaro, 22 de agosto de 1777.-T. de Croix a Gálvez. Querétaro, 23 de agosto de 1777 , núm. 98, reservada. Ibid. 
provincia la compañía de fusileros que se hallaba en Guadalajara, y dejaba en manos de Anza la remoción de los presidios, si lo creía conveniente, al los parajes que estimase oportunos, asi como el intentar un ataque a los cajones de la Palma y de la Cara Pintada, donde nuevamente se refugiaban los seris, con un destacamento de ciento setenta hombres. 68

Igual que a la anterior solicitud, Bucareli se negó a acceder a lo que ahora se pedía de él, juzgando desorbitada la reclamación de Croix, y resistiéndose además a creer que la situación fuese de la gravedad con que el comandante general la presentaba. En aquel momento había dos mil hombres sobre las armas en la frontera, cuyo sostenimiento costaba anualmente 777.028 pesos, y pasaban de ochocientos mil si se comprendían los sueldos de Croix y de los dependientes de la nueva Comandancia. El cuerpo de tropas ahora pedido supondría seiscientos mil pesos más, sin contar los gastos de reclutamiento, uniformación, monturas, y armamento, y el erario no podría suportarlo. El virrey no podía aceptar nueva solicitud de refuerzos, y menos de tal entidad, cuando se pensaba ya en extinguir las compañías volantes de Nueva Vizcaya y la volante y dos presidiales de Sonora, considerando además "que establecida, como está, la línea de presidios, no puede haber ocurrencia que sea de mayor cuidado". Estaba convencido de que los estragos que narraba Croix no eran más que las hostilidades comunes de los apaches e indios alzados, que solian ser de mayo a enero, ${ }^{69}$

La real orden de 29: de diciembre de 5 777 aprobó el pensamiento del virrey, aunque se le pedía proporcionase a Croix los auxilios que considerase conveniente, entre tanto que se determinaba el situado fijo que debería remitir a la comandancia anualmente. ${ }^{0}$ Pero el comandante, que marchaba con suma lentitud de Querétaro a Zacatecas para ir disponiendo la inmediata formación de milicias en Nueva Vizcaya, proponía el I I de setiembre a Gálvez la realización de una campaña general contra la apachería de oriente, en la que intervendrían tropas de aquella provincia y de Nuevo México, Texas y Lutisiana, esperando la actuación personal de Bernardo de Gálvez. al frente de un cuerpo de cazadores franceses. Naturalmente, el ministro, en enero de $\mathrm{I} 778$, se linitó a ordenar a su sobrino - entonces gobernador de Nucva Orleans- que ayudase en lo posible a Don Teodoro por medio del comandante de Natchitoches, pués él en persona no debía perder de visi:?

68 T. de Croix a Gálvez. Querétaro, 23 de agosto de 1777 , núms, 90 y 93. Ibid. $\uparrow$. de Croix

a. Gálvez. Durango, io de octubie de 1777, núm. I06. A. G. I., México, 2462.

69 Bucareli a Gálvez. México, 27 de agosto de 1777, núm. 3217 . A. G. I., Guadalajara,5I5. 
la frontera inglesa en Florida. ${ }^{7}$ Para entonces, desde fines de noviembre anterior ya Bucareli había accedido a enviar a Sonora la compañía de fusileros acuartelada en Guadalajara, pero no pasó de esto y de ofrecer la formación de dos compañías volantes, pensando tal vez retirar los dos piquetes de dragones. ${ }^{72}$

Sonora era, desde luego, la provincia más amenazada, principalmente porque la novedad habida con los seris impedía realizar las campañas habituales contra los apaches, temiéndose además que se aliasen unos y otros, $\mathrm{y}$ se alzasen los pimas. Todas las autoridades de la provincia, y el mismo Anza, estaban de acuerdo en los daños que había producido el alejamiento de los presidioș hacia el norte. ${ }^{73}$ En Nueva Vizcaya se compensaban éxitos y derrotas, pero las nuvertes y robos eran cuantiosos, y en Coahuila se había introducido una partida de cuatrocientos apaches que pronto habían ejecutado catorce asesinatos en el camino real de Saltillo. Estas eran las noticias que el ro de octubre, ya descle Durango, podía comunicar Croix a la corte. ${ }^{74}$

\section{Croix en Coahuila y Texas}

Partiendo de Durango, Croix se dirigía poco después a la vecina provincia de Coahuila, casi al mismo tiempo que, por orden suya, cruzaba el bolsón un poco más al norte con igual destino un destacamento de tropas salido del presidio de Cerro Gordo al mando del capitán Don Francisco Martínez. 75 Desde la hacienda de Avinito escribía el Caballero el i6 de octu1bre dando plenos poderes a Anza para atacar a los seris y asaltar la isla de Tiburón, si lo creía conveniente, y para aumentar aún más hombres a los presidios. Tenía seis de estos, una compañia volante, media más de Nueva Vizcaya, ciento veinte milicianos y setenta y cinco ópatas a sus órdenes; en total, seiscientos cincuenta hombres. Al mismo tiempo, Croix insistía en sus peticiones al virrey. ${ }^{76} \mathrm{El}$ renacimiento de la inquietud en Sonora fue tam-

7 I T. de Croix a Gálvez, reservada, s./n. Zacatecas, i I cle setiembre de I777. Reales órdenes de 20 de enero de i 778 a Croix y a Bernardo de Gályez. A. G. I., México, 2462 y British Museum, Egerton ms, I799.

72 T. de Croix a Bucareli. Hacienda de Avinito, i 6 de octubre de 1777.-.T. de Croix a Gálvez. Hacienda de Patos, 24 de noviembre de 1777 , núm. I23. A. G. I., Guadalajara, 5 I6.

73 Anza a $\mathrm{T}$. de Croix. Horcasitas,.$^{\circ}$ de setiembre de $7777 .-$ Tueros a Gálvez, Cieneguilla, I4 de octubre de I777.-T. de Croix a Anza, Haciencla de Avinito, i6 de octubre de I 777 . Ibid.

$74 \mathrm{~T}$. de Croix a Gálvez. Durango, io de octubre de 177\%, numm. io8, y Extracto de esta fecha. Tbid.

75 Croix había previsto esta salida de Mrartínez ya en México, cuando organizaba st propia expedición a las provincias orientales. T. de Croix a Gálvez, México, 26 de julio de I777, núm. 8o reservada. A. G. I., Guadalajara, 5I5. Este viaje dio lugar a Martínez para, desde Aguaverde, promover la disensión entre lipanes y mezcaleros. 
lién causa de que se demorase un importante proyecto: siendo Don Juan Bautista de Anza ya gobernador electo de Nuevo México, había previsto el Caballero de Croix que hiciese su viaje a Santa Fe desde Sonora por el camino ya conocido de Monterrey, buscando la ruta que enlazase las tres provincias más noroccidentales del Imperio - Nueva California, Sonora, Nuevo México--; pero semejante idea requería la formación de un destacamento de sesenta hombres bien armados y bastimentados para dos meses, y de ninguna manera convenía en las presentes circunstancias sustraer tales fuerzas a la frontera sonorense, ni a Croix quitar de su dirección a Anza, que por otra parte, se ofrecía a ejecutar la expedición más ventajosamente en sentido inverso, desde Santa Fe, razones todas que movieron al comandante general a demorar la travesía de Nuevo México a Sonora para mejor oca-
sión. 7 ?

Por la hacienda del Alamo y Parras llegó Croix a Patos, 78 y cle aquí a Saltillo, en los últimos días de noviembre. 79 Durante todo este viaje fue reconociendo las poblaciones, haciendas y ranchos, a ambos lacios del rín Nasas, los reformados presidios del Gallo y Mapimí, la frontera del Bolsón, examinando los aguajes, sierras y puertos por donde se introducían los indios, y toda la región de la Laguna. Después de tomar este conocimiento del terreno se afirmó en la idea de la imposibilidad de defender estos países desde los presidios del río del Norte, estando como estaba el Bolsón poblado de infinitas rancherías de enemigos a los que era imposible expulsar. Por otra parte, al declarar que entre la Cadena, último puesto guarnecido por la primera compañía volante, y Parras quedaban más de ciento cincuenta leguas al descubierto, por donde en I775y en el mismo I777 habían entrado los apaches, confesaba implícitamente no haber proporcionaclo él el remedio oportumo a la situación. ${ }^{80}$

E1 9 de diciembre ya escribe desde la capital de Coahuila, ${ }^{81}$ doncle, ya confortado con las felices nuevas de Sonora de que los seris habían pedido

76 Vicl. notas 72 y 73

77 T. de Croix a Gálvez. Durango, io de octubre de I777, núm. т т. A. G. I. México, 2462 rango, 4 de agosto a 22 de setiembre de 1777 . T. de Croix a Gu viaje deste México a Dis-

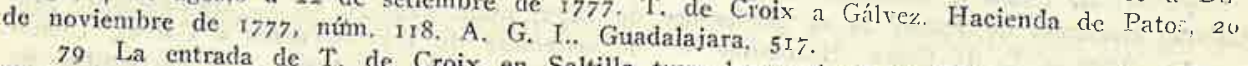

Viaje de indios, ed. Alessio Robles, páginas $152-153$ Sin el 24 de noviembre según Morfi. las cartas del Caballero, núms, páginas 152-153. Sin embargo, esa misma fecha llevan de Patos, como que el camino entre am ${ }^{136}$, en A. G. I., Méxieo, 2462, dadas en la Hacienda

So T. de Croix a Bucareli. Saltillos lugares lo recorrió en ocho horas $y$ media. misms data, núm. 137. A. G. I, Guadalajara, de noviembre de 1777. T. de Croix a Gálvez,

Si Partió $T$ de Croix de Saltillo 5 I6. siguiente. Morfi Piaje de Indios, r6t-162. 29 de noviembre lleganclo a Monclová el + del nes 
la paz y las demás naciones de la provincia volvían a la calma, ${ }^{82}$ y con la victoria del capitán Martínez sobre los mercaderos el 28 de noviembre anterior, ${ }^{8}$ celebró juntas del 9 al I4 con el ex-gobernador Ugarte, con el entonces gobernador Ugalde y los capitanes de los presidios sobre la situación de la provincia, llegándose al acuerdo de la necesidad de practicar una campaña general contra los apaches, natajes, lipanes y mezcaleros con una fuerza de tres mil hombres. ${ }^{4}$ "La acción general contra los lipanes y demás apachería de oriente será una verdadera cacería de fieras", escribe el comandante, que insiste ahora en su plan de movimiento conjunto de las tropas de todas las provincias circundantes de los apaches para arrojarlos a los llanos entre el río Grande y el Colorado de Natchitoches, donde, cercados por españoles e indios del norte, serían reducidos como los antiguos mexicanos, o exterminados como los tobosos y cocoyomes, de que apenas quedaba ya memoria. ${ }^{85}$

Croix no se detuvo mucho más tiempo en la villa de Monclova, sino que por el presidio de Río Grande se dirigió a San Antonio de Béjar. ${ }^{86}$ donde el 3 de enero daba comienzo una segunda junta de guerra, a la que con Riperdá asistieron Cazorla, capitán del presidio de la Bahía, y Bonilla, Martínez Pacheco y Díaz, que acompañaban al comandante general. En esta junta se aprobaron las conclusiones sacadas en la anterior y se estudió particularmente el estado de las relaciones con los indios del norte. Hubo guerras con éstos desde que los lipanes, acogiéndose al antiguo presidio de San Sabá, los hostilizaron. Los insultos se habían hecho más sensibles después del ataque al fuerte de los taobayas que realizó Ortiz Parrilla, y más cuando los jaranames alzados de la misión del Espíritu Santo les sirvieron de guías. Pero por medio del Padre Ramírez, presidente de las misiones, y de Atanasio de Mézières, capitán del presidio de Natchitoches, había logrado Riperdá la paz con las naciones del norte, cuyos jefes habían bajado a Béjar, guardando buenas relaciones desde entonces, salvo los comanches, que eran

8z T. de Croix a Gálvez, Coahuila, 9 de diciembre de I777, núlm. I 4o, A. G. I., México, 2462 .

83 T. de Croix a Gálvez, Coahuila, 9 de diciembre de 1777, núm. 339 . Ibid.

84 Morfi op. cit., $173-174$ dice la duración de la junta y el secreto con que se llevó a cabo. El acta de esta junta es de 11 de diciembre, en A. G. I., Guadalajara, 276, y en ella consta se castigaria con la degradación al oficial que tratase de sus asuntos fuera de ella. Las órdenes derivadas de la junta serian reservadas y selladas con tres sellos en el archivo secreto de la comandancia. Morfi cuenta el aparato de centinelas en puertas y ventanas, a distancia en que 110 pudiesen oir las deliberaciones. Doce personas tomaban parte en ellas.

85 T. de Croix a Gálvez. Coahuila, i i de diciembre de 1777 , núm. i 38 reservada. A. G. T., México 2462. Con este proyecto se consultó nuevamente a Bernardo de Gálvez, por real orden de 3 de mayo de 1778 . Ibid.

86 EI . $^{\circ}$ de enero de $x_{778}$ tuvo lugar la entrada de $T$, de Croix en Béjar. Partió el it del mismo mes y año. Morfi, op. cit., 221 y z3o. 
a la fecha los únicos enenigos declarados de la provincia, aunque apaches y caracaguas practicaban algunos robos. Hecho un cómputo aproximado de la fuerza de los indios, hallóse que todas las tribus de la provincia - texas, vidais, taobayas, tahuscanas, iscanis, quitzeis, tancahuas, orcoquizas, ayes, aovages y jaranames- sumaban unos dos mil quiniento ochenta hombres de armas, mientras que a los comanches se calculaban alrededor de cinco mil, teniendo en cuenta que bajo el nombre genérico de comanches se comprendían varias naciones de indios. Ultimamente comanches, tahuacanas, y tancahuas habían entrado en guerra entre, sí, teniéndola todas estas naciones del norte con la numerosa de los guazas, situada en paraje más setentrional.

Por muchos conceptos las condiciones de los indios de Texas eran muy distintas a las de los demás de la amplia frontera de Nueva España. Su pro-
longado contacto con franceses, e ingleses les había proporcionado la oca-
sión de surtirse de armas de fuego que sión de surtirse de armas de fuego que manejaban diestramente, y en tal cantidad que les sobraban para venderlas a los vecinos de Béjar. Algunos jefecillos de tribus tenían nombramientos de tales dados por el gobernador de Texas, el de Luisiana, o el capitán de Natchitoches, y usaban la bander: de España con la cruz de Borgoña, y bastones y medallas del mérito de las que dejara en Luisiana el teniente coronel conde de O'Reilly.

La línea de, conducta a seguir que se desprendió de las asambleas de Béjar fue la de continuar la paz con las naciones del norte, comisionándose para esto a de Mézières, que no se encontraba allí, por lo que se le dejó orden 1 tió que a su llegada informara sobre todo lo tratado. ${ }^{87}$ De Mézières emijió su parecer en 20 de febrero 88 manifestándose en todo concorde con la junta, y proponiendo además se empleasen en la guerra los oficiales franceses reformados, en particular los canadienses y cazadores, por su aptitud para tratar con los indios. Proponía desde luego hacer la paz con los comannotablemente la expansión hacia el norte por otra parte facilitaría además

Antes de salir de esta provincia

destinado a vigorizar el débil efecto de publicó Teodoro de Croix un bando a delitos comunes, moral pública, etc., y en el que real en el país en punto se reclaman como pertenecientes al monarca el que además, principalmente, mesteñas u orejanos vacuno y caballar, por en su real cámara los ganados conocido, y además por haberse criado por ser bienes mostrencos, sin dueño nadas ni enajenadas, y sobre tales gano en tierras de la Corona, no merceción y los perjuicios que han experimedos, "para evitar su entera destrucparticulares en

87 Según Morti, las juntas duraron liasta el 9. Op. cit., 223. El acta, en A. G. I., Guada-
ra, 276 , es de 5 de enero de

ss A. G. I., Gundalajara, 276. 
los muchos herrados que les han muerto y dejado en el campo sin aprovecharse de otra cosa que del sebo que emplean en fabricar jabón", disponía el comandante general que no se pudiesen coger, matar y correr, bajo multa, sin permiso del gobernador de Texas, que lo daría en determinados tiempos y lugares, cobrando en concepto de gravamen seis reales por cabeza caballar y cuatro reales por res, junto con otras medidas encaminadas a la conservación del mesteño.

En este bandio ${ }^{89} \mathrm{y}$ en la instrucción reservada en diecisiete puntos que Croix expidió a Riperdá desde el presidio de San Juan Bautista de Río Grande el 24 de enero ${ }^{90}$ se prohibe la venta de armas de fuego y pólvora a los gentiles, estuviesen éstos de guerra o de paz, y se encargaba ya concretamente al gobernador en el segundo documento la aplicación de los principios de conducta convenidos en los debates celebrados en Béjar.

\section{CREACIÓN DE LA TROPA LIGERA \\ Y DEL PRESIDIO OPATA}

De regreso de Texas entró Croix por el rumbo de la villa de San Fernando de Autria revistando antes los presidios de Río Grande, Aguaverde y Monclova, yendo a detenerse al valle de Santa Rosa, desde donde el I 5 de febrero tomaba ya una serie de medidas que muestran cómo finalmente iba entrando a conocer la problemática de la frontera y se aplicaba a adoptar soluciones en gran parte revolucionarias. ${ }^{91}$ Para entonces ya sabía que Bucareli había determinado el traslado a Sonora de la compañía de fusileros del capitán Fajes, y el virrey le había autorizado además en carta confidencial a crear dos compañías volantes que constituirían un contingente de doscientos cincuenta hombres. Pero Croix consideró preferible dividir estos efectivos entre los presidios de Sonora, Nuevo México, Nueva Vizcaya y Coahuila, como "tropa ligera". 92 '

Qué sea esta tropa ligera se desprende de otro párrafo de su carta en que dice que estos hombres tendrían el mismo vestuario y fondo de gratificación que los presidiales, pero no tendrían cuera ni adarga, y su armamento consistiría en escopeta, pistolas y espada, simplificándose tam-

89 Bando dado en Béjar, I i de enero de r778. Con carta de 1'. de Croix a Gálvez. Valle de Santa Rosa, I5 de febrero de I778. A. G. I., M'éxico, 2462.

90 Ibid.

9 Desde el presidio de Monclova ya había dispnesto el z de febrero la colocación de destacamentos en San Fernando, Santa Rosa, Cuatro Ciénagas, Sardina, Tapado, villa de Monclova $y^{\prime}$ Potrerillos. Morfi, op, cit., 243.

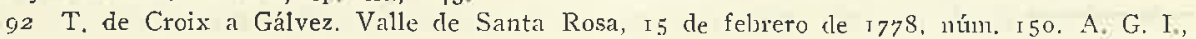
Guadalajara, 276 y México, 2462. 
bién considerablenente las monturas en orden a eliminar peso; por otra parte, cada soldado de esta nueva tropa sólo tendría tres caballos y una mutla. Cuando Croix ha adquirido su propia comprensión de los problemas 110 vacila en introducir innovaciones que atacan directamente a las costumbres guerreras y multiseculares de la frontera y a lo prevenido en el reglamento. Estos nuevos soldados, que se incorporarían a cada presidio después de dos meses de entrenamiento, harían el mismo servicio, pero a pie, que los de cuera, menos el de caballada del que estarían exentos, y las marchas las harían sobre las mulas, reservando los caballos para cuando entrasen en combate. Los soldados ligeros quedarian obligados a atacar a pie al enemigo que éste se arrochelase en los cerros, apoyando su acción los de cuera, que los segutirían a pie o a caballo. Si en el terreno que podemos llamar táctico era importante las transformación ideada por Croix, quien por primera vez se decide a romper los viejos moldes, siguiendo una idea que ya concibiera Bernardo de Gálvez, en el punto de la organización de la frontera la reforma tiene aún mayor trascendencia porque suponía la agregación de un alférez, un sargento y dieciséis soldados a cada uno de los seis presidios de Sonora; los soldados serían treinta y ocho en Santa Fe de Nuevo México y catorce en Janos, San Buenarentura, San Sabá, el Príncipe, y en los cuatro de Coahuila. En total, el número de hombres aumentado sería de doscientos setenta y seis, veintiséis más de los permitidos por las dos compañías volantes.

La creación de esta tropa ligera empezaría en Coahuila; donde por el momento se hallaba Croix, y esto haría posible que a primeros de julio regresase a Nueva Vizcaya la media compañía volante que se había trasladado a Coahuila. En esta provincia, Croix repartió el frente en dos divisiones; la primera habrían de constituirla los presidios de Río Grande, Monclova y Aguaverde, con el clestacamento de la villa de San Fernando, que sumaban ciento cuarenta $y$ un hombres, de los que ciento dieciseis estarían siempre útiles para la acción: formarían la segunda división el presidio de la Babia y los destacamentos situados en Santa Rosa, Cuatro Ciénagas, Sardinas, San Vicente y el Tapado, con un total de ciento cincuenta y cinco hombres, ciento reintidós de ellos listos para entrar en campaña. El mando de la división norte la tendría el capitán Cerecedo, de Río Grande; el del frente occidental, Martínez Pacheco, de la Babia. 93

Desde el valle de Santa Rosa, además, convoca ya Croix la tercera junta de guerra, que habría de tener lugar en Chihuahua, para donde citaba a primeros de mayo a Mendinueta, que dejaba el gobierno de México, y a

93 T. de Croix a Gálvez. Valle de Sauta Rosa, is de febrero de I 58, núm. I 53. Ibid, ibir. 
Anza, que pasaba a ocupar este cargo, mientras que acompañaba a Croix Ugarte y Loyola, que se trasladaba de Coahuila a Sonora como gobernador electo de esta última provincia. 94

Por entonces recibía ya Croix mejores noticias de todas las internas, lo cual parece acreditar el justo concepto que de los acontecimientos anteriormente ocurridos tenía Bucareli, y aunque no fuera así, siempre demostraría que la situación era sostenible y dominable con las fuerzas existentes, puesto que ni la tropa ligera recién creada estaría dispuesta hasta abril, ni los fusileros de Sonora habían entrado aún en acción. El caso es que Don Teodoro empieza a sentirse optimista por diversos motivos: creer contar con dos buenos gobernadores - Ugalde y Riperdá- en Coahuila y Texas, y con un lugarteniente capaz, Rubio, en Nueva Vizcaya. Su propia presencia aseguraría Sonora, tras lo cual se dispondría a pasar a Californias y Nuevo México. 95 Rubio le comunicaba que los apaches gileños y los de la Sierra Blanca habían hecho diligencias para ser recibidos de paz en Janos, en El Paso y en la villa de Alburquerque, movidos por los repetidos asaltos que les daban los comanches $y$ buscando un lugar donde dejar seguras sus familias. Rubio y Croix fueron concordes en la actitud de no dar a los apaches que se encontrase en el campo otro partido que el de rendirse a discreción, principio que fue aprobado por real orden de I 8 de julio de 1778.96

De particular interés son las novedades de Sonora tocantes a los ópatas. Desde México había encargado el comandante general a Anza oyese los motivos por qué esta nación se mostraba descontenta. Los ópatas se quejaron de algunos malos tratos de los misioneros y de haber sido defraudados en ciertas promesas que se les habían hecho, y pidieron además algunas prerrogativas para su capitán general. El caballero providenció sobre todos estos puntos cuando ya se hallaba en Querétaro noticioso del estado general de inquietud por que atravesaba Sonora, ordenando a Corbalán: pusiese al jefe ópata Don Juan Manuel Valera su posesión del gobierno político de Baserac, Bavispe y Guachinera, como lo había tenido su abuelo Don Jerónimo Noperi, declarándolo exento de subordinación a todo ministro que no fuese jefe militar y al mismo Corbalán, y expidió además decreto señalando a Valera el sueldo de cuatrocientos pesos mensuales que le había ofrecido O'Conor. ${ }^{97}$ Ahora, en el Valle de Santa Rosa, recogía Croix los frutos de esta polí-

94 T. de Croix a Gálvez, Valle de Santa Rosa, 15 de febrero de I778, núm. I59. Ibid.

$95 \mathrm{~T}$. de Croix a Gálvez, Valle de Santa Rosa, 15 de febrero de I 778 , núm. I 4 I reservada, A. G. I., M'éxico, 2462.

96 T. de Croix a Gálvez. Valle de Santa Rosa, is de febrero de I778, núm. I49, y real orden citada. Ibid.

$97 \mathrm{~T}$. de Croix a Gálvez. Querétaro, 23 de agosto de 1777, núnı. 94. A. G. I., Guadalajara, 515 . 
tica de atracción. El misionero de Baserac, Fr. Angel Antonio Núñez, contaba que había hecho reconocer al gobernador y capitán general de los tres pueblos, y creía conveniente se extendiese su autoridad a toda la nación; los ópatas quedaban gozosísimos, y el mismo Varela ofrecía constituir un presidio de guerreros ópatas en algunos de sus pueblos fronterizos a los apaches, quizá en Bavispe, que era el más avanzado. La idea era fácilmente realizable, con sólo concentrar allí, como ofreció Anza, los setenta y cinco ópalas que entonces servían en los diferentes presidios de Sonora como auxiliares, pero Croix, que la acogía sin reservas, seguro de su eficacia y poco costo, se abstenía de ponerla en práctica hasta hallarse él mismo en el país. La resolución del rey y del ministro Gálvez, en orden de 18 de julio de 1778 , mostraba mayor confianza aun en los ópatas: "Aprueba S. M. la oferta hecha al general de la referida nación para que los setenta y cinco hombres de ella que ahora están agregados a los presidios de la frontera, en calidad de compañía wolante, recorran y defiendan las poblaciones situadas sobre los ríos de Sonora y Oposura". 98 Así nacería el primer presidio de indios fieles en la frontera del norte de Nueva España.

Siguiendo el camino de los presidios, por la Babia y San Vicente se dirigió Croix al río Grande llevando una escolta de ciento sesenta soldados, y el primero de marzo, cuando marchaba del paso de Santo Domingo al presidio de San Carlos, se encontró con una emboscada que más de cuatrocientos lipanes, mezcaleros, natajes y gileños de la Sierra Blanca habían preparado en venganza del golpe que el capitán don Francisco Martínez les diera tiempo atrás en las proximidades de Aguaverde. Los enemigos sorprendieron a la vanguardia de indios exploradores junto a la muralla de San Dámaso, pero al concentrarse las fuerzas de Croix se dieron a la fuga, hacia el Bolsón unos y hacia las sierras de. San Dámaso y los Chizos los demás. Este es el ínico encuentro que presenció Croix en su larga estancia al frente de las provincias internas, y en esta ocasión se alegró de haber visto combatir a los apaches y a sus tropas. De aquéllos dice: "no luchan como bisoños, nada emprenden sin asegurarse y acechan nuestros descuidos como verdaderos Iadrones". Es de apreciar que no se resistiese a escribir en elogio de Ugarte que fue éste "quien en realidad gobernó la acción felizmente", pues Croix siguió en todo su consejo. 99

El 2 de marzo había hecho su entrada en San Carlos, y habiendo seguido su marcha hacia el oeeste llegó a Chihuahua el I 4 de aquel mes. ${ }^{\text {roo }}$

98 T. de Croix a Gálvez. Valle de Santa Rosa, I5 de febrero de I778, núln. I57, y real orden citada. A. G. I., México, 2462 y Guadalajara, 276.

99 T. de Croix a Gálvez. Chihuahua, 3 de abril de i778, ním. r75. A. G. I., Guadal:ar
jara, 276 y México, 246r.

roo T. de Croix a Gálvez. Chihuahua 3 de abril de 1778 , núm. izo, Ibid. 
lis caballero de Croix, en Chimuahua

Los muchos negocios y una grave enfermedad impusieron a Croix una larga permanencia en la villa de San Felipe el Real, desde el I4 de marzo de $I 778$ al 30 de septiembre de I779, cuando su proyecto original consistía en recorrer toda la frontera en cuatro meses. Pero en esta prolongada estancía se fraguó definitivamente su visión de la labor a realizar desde su puesto.

Indudablemente hay una apreciable diferencia entre el Croix salido de México y el llegado a Chihuahua. Su experiencia, nula entonces, se ha enriquecido notablemente; su criterio se ha afirmado; su iniciativa ha empezado a manifestarse; su postura ante los problemas se ha hecho más serena y reflexiva, abandonando aquel apasionamiento impulsivo que le dominara en los primeros tiempos. Aquel comportamiento le haló́a acarreado la reprensión más o menos directa del ministro. Las órdenes de 2 I y 23 de diciembre de 1777 , que ahora llegan a sus manos, contienen una censura a su actuación frente a las desgracias que había narrado y las reclamaciones y acusaciones que hacía; en más de un caso se le dice que "regula S. M. que, estando V. S. presente en aquellas provincias como jefe de ellas, podrá evitar con sus providencias semejantes sucesos". Y en otro se expresa la confianza de que "todo se arreglará con las órdenes y con la presencia de V. S. en las provincias que han estado muchos meses como abandonadas". 101

La apreciación de Gálvez parece exacta, y dolió a Croix la lectura de estas líneas, por lo que procuró sincerarse. "Si mi corta demora en México ha. podido ocasionarme la desgracia del más leve desagrado de S. M. según V. E. me lo insinúa en distintas reales órdenes..." escribe el 3 de abril desde Chihuahua, en la carta destinada a su propia justificación. Esta se basa en atribuir a Bucareli la culpa de su retraso, al no poner diligencia en proporcionar a Croix los papeles que debían componer su archivo - "conté dos meses y ocho días dentro de México en inculpable inacción”-, pero es más satisfactoria la exposición de su trabajo y preocupaciones desde que saliera de la capital de Nureva España, y mereció una afectuosa respuesta esta vez del ministro: "S. M. está satisfecho clel celo de V. S. y espera que con actividad y celo mejorará el esłado de esas provincias". ${ }^{102}$

La mente de Croix, sin embargo, aparte lo que sobre él pudieran influir sus íntimos, como se verá, conservaba todavía aquel lastre de las disculpas precipitadas en hombros ajenos. Todavía recurre a Bucareli y a O’Conor

\footnotetext{
I01 Real orden de 23 de diciembre de I777. A. G. I., Guadalajara, 5'5. Real orden de 21 de diciembre de I777. A. G. I., Guadalajara, 516.

ro2 $T$. de Croix a Gálvez. Chihuahua, 3 de abril de 1778 , núm. I 70 . Real orden de 22 de agosto de I780. A. G. I., Guadalajara, 276 .
} 
para descargar responsabilidades. El virrey ocasionó su retraso, y le negó luego el refuerzo de dos mil hombres pedidos. O'Conor, con su desacertada actuación, fue causa de las desgracias últimamente acaecidas, y dice haber comprobado este aserto en su reciente viaje a Coahuila y Texas. "La línea establecida desde el presidio de San Eleazario inclusive hasta el de Monclova ha sido la causa motriz de la ruina del territorio". En su criterio, la línea debiera haber contorneado el Bolsón, lo cual quiere decir que se disponía a deshacer la obra de Rubí y O’Conor. Sin embargo, no lo hará precipitadamente así, y poco a poco irá modificando sus puntos de vista, hasta llegar a definir su actitud de la manera sobria y maciza de un gobernante experimentado. Pero aún será preciso para esto alguna otra reprensión del ministro.

Tampoco ha renunciado aún Croix a pedir los dos mil hombres con que reforzar la frontera, si bien poco a poco buscará la manera de suplirlos. Claro que no es Croix el único en pedir refuerzos. El inspector Rubio está convencido de la necesidad de incrementar los efectivos. Por la parte de Sonora se hacen iguales demandas por Crespo y Corbalán. En la realidad, sin embargo, vemos pasar estos momentos difíciles sin que haya ocurrido una notable concentración de tropas.

De uno u otro modo, con la presencia de Croix en Chihuahua se empieza a vislumbrar la proximidad de una verdadera etapa constructiva para las provincias internas, cuyos problemas van a ser tenidos en cuenta y estudiados seriamente y cuyas energías se intentan canalizar, merced a la supervisión de Don José de Gálvez, en empresas de aún más amplio alcance.

Réstanos consiclerar la formación en torno a Don Teodoro de un ambiente de recelo o desprecio de la obra y de las amistades de Don Hugo O'Conor, ambiente creado por los individuos de más confianza del comandante, que habían despojado a éste de sus facultades enteramente - -según el cauto auditor Galindo Navarro, que no da un nombre- "sin que apenas le hayan dejado otro ejercicio que el de la firma", y se servían de esto para satisfacer sus venganzas. En la misma línea que Galinclo informa Don Cristóbal Corbalán, hermano del intendente de Sonora, que acompañaba al caballero desde Madrid; pero éste apunta con toda claridad al autor de las maquinaciones hechas a la sombra del comandante, que no es otro que su secretario Don Antonio Bonilla, acerca de cuya índole, al parecer, ya Gálvez había puesto en guardia a Don Teodoro. Había intentado Bonilla sustituir a Don Pedro Corbalán en el gobierno de Sonora por Don Jacobo de Ugarte y Loyola "proclamado por el más bueno porque era uno de los abatidos por O'Conor, como lo fue Bonilla, y a este tenor todos los que política y racionalmente profesaron amistad con aquél son hoy objeto del odio y aborrecimiento de éste, y por el contrario los que era sus opuestos". En su respuesta a Ga- 
lindo, el ministro Gálvez asegura tener bastante conocimiento de estos hechos, al tiempo que le dice no tema a los subalternos del comandante general, "pues se tomarán los medios de contener a aquélla y desengañar a éste". ro3

\section{LA COMANDANCIA EN I 778}

El año I777 había transcurrido en la frontera sin que se verificara ninguno de los desastres vaticinados por Croix, que creía ver asolada Coahuila, destruicla toda Nueva Vizcaya, invadida hasta Culiacán Sonora. Claro es que el comandante general había sido incapaz de comprender en el primer momento que las guerras fronterizas de Nueva España no eran guerras por la independencia ni contra los españoles, sino meras actividades de bandidaje motivadas por el género de vida de las tribus nómadas. ¿Hasta qué punto puede considerarse sublevación el levantamiento o deserción de los seris, tiburones y pinas altos? Estos movimientos ya no expresan el deseo de sacudir el dominio o acabar con los hipotéticos vejámenes de los españoles, ni siquiera un afán de conquista territorial que un nómada no pudo concebir, sino que tiene causa más honda y sencilla en la nueva repulsión a la vida seclentaria y al trabajo cotidiano. $Y$ una vez que los seris y los pimas se han fugado a los montes ¿qué más natural que basen su subsistencia en el robo de los ganados de los españoles, puesto que ellos no son ganaderos, sino cazadores? Otro tanto ha de pensarse de los apaches, y de sus repetidamente quebrantadas paces: por de contado, lo dilatado de su nación y la extraordinaria fragmentación de sus parcialidades dificultan una paz general; por otra parte, cuando se trataba de que se mantuviese en paz alguna de las tribus, como la de los lipanes en Coahuila, ¿cómo iba a ser esto posible, sino yendo los lipanes a robar a Texas o a Nueva Vizcaya, o incluso asaltando con disimulo los ganados de la misma Coahuila? Para las tribus enemigas, pues, la guerra era una simple y cruda lucha por la subsistencia, en el sentido más material de la palabra: para los españoles, era una lucha por la paz, por 110 perder la vida en alguno de los innumerables ataques de los indios, por defender sus bienes y la prosperidad del país.

Una vez que alguna o algunas de las tribus abandonaban el cumplimiento de lo pactado - que no dañaran los puestos fronterizos es todo lo que los españoles exigían- sus activiclades se reducían al robo y, por este móvil, llegaban al asesinato, bien por eliminar un obstáculo o un testigo, bien porque si natural barbarie les impulsaba a ello. Jamás pensaron en desalojar a los

I 03 Galindo Navarro a Gálvez, Chihuahua, 30 cle marzo de 1778 , y respuesta del ministro en 23 de octubre de I778. A. G. I., México, 246I, Cristóbal Corbalán a Gályez, Chihtrahua, 30 de marzo de i 778 . A. G. T., México, 2462. 
españoles de ningún territorio, ni reclamaron ninguno como propio para lo cual por otra parte no hubieran tenido justificación alguna. En efecto, si hemos de considerar a seris y apaches como los tradicionales enemigos de territorio en el jrims los españoles tuvieron el menor interés por ocupar su que al suyo tuvieran caso, y es incluso francamente discutible el derecho del Gila y del Pecos. Nunca se verdaderos recién llegados a las tierras Nuevo México y Texas, la conjunción deró motivo de guterra por sí sólo, en dero de cibolos o venados. En momento españoles e indios en algún cazadera se planteará la reivindicación por los indios de la historia de la prasuyas, de sus cazaderos, de los rebaños de búfalos tierras que consideran minan. Ahora, no sólo los españoles no de búfalos que los blancos exterun peligro para aquellos animales, sino son, por su número y armamento, de caballos y reses vacunas y, caso sino que en cambio aportan las manadas más los comanches los advenedizo inverso al anterior, son los apaches y aun la vida y el bienestar de los blancos.

Tal situación es siempre plancos. nada que ganar en estas los perjudicial para los españoles que no tienen se va a procurar jamás el exterminio han buscado, por esto y porque tampoco a concertar la paz y, aún mejor, siempre se dios, siempre se estará dispuesto pueblos, civilizarlos y evangelizarlos, ganandeseará asentar a los indios en para una vida más humana, lográndose al sus almas para la verdad y de las provincias.

Erró, pues, Croix, por su inexperiencia al suponer que las exiguas partidas de nómadas iban a acabar con el dominio español en el norte de Nueva
España y de esta manera sobrevaloró el peligro, la defensa se organizó una
vez más, se practicó la sistemática persecución de los asaltantes y vez más, se practicó la sistemática persecución de los asaltantes y éstos amela alianza con los comanches y la campaña contras Croix había planeado guerra. Las paces intentadas habíanse hundido contra los apaches en junta de pio Croix fuera objeto cuando se trasladaba a en el ataque del que el provincia, los apaches gileños y de la Sierra Blanueva Vizcaya. En esta prolos alcances, propusieron una paz que resultó engañosa, los españoles a con aprobación del comandante general, y luego enañosa, por lo que Rubio, poner no se diese a los apaches que se encontrase de guerra Corte, hubo de dispartido que el de rendirse a discreción. ro4 ${ }^{2}$ de guerra en el campo otro cesaban de causar daños, se vieron ción. ${ }^{104}$ En Sonora, aunque los seris no perro Prieto.

ro4 T. de Croix a Gálvez. 200. Ibid. La primera, también en A. G. I. México, 2461 , con la real orden de aprobación de
esta conducta, en 22 de agosto de 1778 . 
Croix aprobaba las disposiciones y actividad del electo gobernador de Nuevo México, le prometía el refuerzo de fusileros y tropa ligera y le encargaba mucho cuidar de los pimas, distinguir a los ópatas y apreciar sobre todos a los yaquis, "buenos para todo". En cuanto al propio Anza, le escribe el comandante: "Desprecie Vm. las voces del vulgo, obre bien y de nada recele, pues yo no sé variar de conceptos y el que Vm. me merece es distinguido". 105 La situación un momento difícil de Sonora se había superado, y la reafirmación de la alianza con los ópatas trajo como secuela que el general de esta nación Don Juan Manuel Varela propusiese a Croix el establecimiento de un presidio de sólo ópatas en uno de sus pueblos para contención de los apaches. Enseguida pareció a Croix provechosa esta idea que proporcionaría una fuerte y al propio tiempo poco costosa defensa; mientras se llevaba a efecto, Anza puso a disposición de Varela los setenta y cinco ópatas entonces agregados a los presidios para que, reunidos en compañía volante, defendiesen los ríos de Sonora y Oposura. ${ }^{\text {I }} 6$

En Nueva Vizcaya, en cambio, pese a su primera determinación y a la ninguna confianza que se podía tener en las paces con los apaches, que buscaban tan sólo guardarse las espaldas para guerrear con los comanches, se dio a aquéllos una última oportunidad. "Irritan mucho las torpes falsedades con que pretende engañarnos esta vil indiada - escribe Croix-; pero considerando que es muy numerosa, que conoce sobradamente nuestros terrenos, que sus repetidos crueles insultos han intimidado a los vecindarios infelices, que no tengo tropas para ocurrir a todas partes, que he visto las actuales en el mayor deesarreglo, que si los comanches continúan la persecución del apache se nos mete éste dentro de casa cuando aquellos más numerosos y temibles se nos acercan, y finalmente, que puedo como hombre sujeto a errar equivocarme en mis conceptos y reflexiones, me ha parecido conveniente hacer la última prueba de la mala fe de los apaches concediéndoles la paz de Janos". Como condiciones se estipulan la reunión en pueblos, la aceptación de misioneros, $y$ la dedicación a las tareas agrícolas. El hecho es que, al mismo tiempo que empezaban a entregarse los seris, desde fines de I777 se presentaban en los presidios de Janos, San Eleazario y El Paso a pedir la paz apaches de las sierras de Enmedio, Blanca, Sacramento, Petaca y Organos.

I05 T. de Croix a Gálvez. Valle de Santa Rosa, 15 de febrero de I778, rúm. I56, y documentos adjuntos. T. de Croix a Gálvez. Chihuahua, 3 de abril de 1778 , núm. i 76 , con Extracto. A. G. I., Guadalajara. 276 .

I06 T. de Croix a Gálvez. Valle de Santa Rosá, I 5 de febrero de I778, núm. I57. Ibid, y A. G. I., México, 2462, 
Los de estas cuatro últimas habían venido a situarse a orillas del río Graiide, rechazados de sus tierras por los comanches. ro7

La ninguna esperanza de paz que tenía Croix se refleja en la tenacidact con que prosigue, sin cejar un momento, organizando fuerzas. En febrero de 1778 habían llegado por fin a Sonora los fusileros de la compañía que mandaba Pajes, y pronto se atendió a bastimentarlos y proveerlos de todo lo necesario para que entrasen en campaña. ${ }^{08}$ Decidido Croix por otra parte a incrementar los efectivos de la tropa ligera de su invención, resolvió convertir en tal las ciento veinte plazas de milicianos que él mismo había sumado a los seis presidios sonorenses. La tropa ligera alcanzó así el número de trescientos setenta y siete hombres, cuyo costo aún sería ligeramente inferior al de las compañías volantes y los nilicianos antes autorizados. Ia recluta se haría, a ser posible, en las regiones más meridionales de las provincias, y en Santa Fe, Horcasitas, Chihulahua y Santa Rosa se procedería a instruir durante dos meses a los nuevos soldados. E1 comandante general incluyó en el número de éstos algunos tambores, proponiéndose que a strs toques maniobrase la tropa como en los cuerpos veteranos, imaginando que con esta serían más eficaces en las operaciones. ${ }^{109}$ Mientras se ocupa en promover la organización de las milicias en Nueva Vizcaya, pide igualmente a Gálvez diez o doce mil escopetas, pares de pistolas y espadas anchas y sables, iparte las tres mil armas de cacla especie que tenía solicitadas tiempo atrás. ${ }^{\text {ro }}$

Entrando mayo, hacía constar Croix la aprensión que le producía la debilidad en que se encontraban los presidios de la Babia y San Sabá y San Carlos, inútiles y en lugares muy expuestos, ${ }^{\text {II }}$ bien que más adelante modificará este juicio, por lo menos en el sentido de que, aun así, son precisos en los parajes en que se hallan. En cuanto al costado oriental de Nueva Vizcaya, entró Croix en nuevos temores cuando tuvo noticias de que gran número de apaches se había congregado en el Bolsón, con cuya alarma dispuso la inmediata formación de dos destacamentos de vecinos de Durango, Cuencamé, Nombre de Dios, San Juan del Río y las haciendas de la comarca, para que cubriesen el río Nasas y el Pasaje, mandados por el gobernador

I07 T. de Croix a Gályez. Chihuahuta, 3 de abril de I778, núm. I74, con Extracto.

108 Guadalajara, 276.

$109 \mathrm{~T}$. de Croix a Gálvez. Chihuahua, 3 de abril de 1778, núm. I73. Ibid.

de igual data, envía las propuestas parhua, 3 de abril de 1778, núm. 171. Ibid. En núm. 172, tropa ligera, a los que se expidió sus despan nombramiento de los veintictratro oficiales de esta agosto de ${ }_{1778}$ que aprueba el auments no T. de Croix a Gálvez. Chihuna de la tropa ligera, Ibid, lajara, 276 .

I I T de Croix lajara, 522 . 
Barri y el teniente Don Juan García. ${ }^{\text {I } 2}$ Su propio plan para la defensa del frente del Bolsón no era mejor que el de O’Conor y seguía su inspiración, cubriendo la zona de Chihuahua y la Línea hasta Mapimí con tres compañías volantes, los dos piquetes de dragones y cuarenta hombres de San Eleazario y Príncipe. El tramo de sesenta y ocho leguas de Guajoquilla a Mapimí, llamado primera división, estuvo al mando del capitán Don Domingo Díaz, mientras que Don Nicolás Gil fue designado comandante de las armas de la frontera de Chihuahtıa, que constituían la segunda división. Ix3

En esta disposición llegó Croix a la celebración de las juntas de guerra en que había de tratarse del plan general de defensa a seguir en la comandancia.

\section{Las JUNTAS DE ChiHUAHUA}

Del 9 al 15 de junio de 1778 tuvieron lugar en Chihuahua, con el aparato acostumbrado cuatro juntas, a las que asistieron, con Croix, Mendinusta, ex-gobernador de Nuevo México; Anza, que marchaba a sucederle; Ugarte, electo gobernador de Sonora y Barri, que lo era de Nueva Vizcaya, junto con el asesor de la comandancia Galindo Navarro y el secretario interino Bonilla. La plaza de comandante inspector estaba vacante desde el reciente fallecimiento de Don José Rubio.

Las dos primeras juntas clel 9 y Io de junio fueron puramente preparativas; fue en las del i I al I5 de aquel mes en donde se trató a fondo la situación y la manera de imponerse al enemigo. En la del i I, Mendinueta y Anza mostraron ser incalculable el número de apaches, muchos más de cinco mil hombres de armas, con duplicado número de mujeres que les ayudaban eficazmente en sus correrías. Hallóse en cambio que todos los apaches eran enemigos de los comanches, mientras que los orientales lo eran además de los indios del norte, y los navajos estaban indispuestos desde 1775 con los yutas, de resultas de las maniobras realizadas por Mendinueta.

Tratóse de los comanches en la cuarta junta, de 15 de junio; explicó Mendinueta que en Nuevo México se conocían sólo tres familias de aquella nación, los yamparicas, gente de palo y come-cibolos, las tres enemigas de los

\footnotetext{
I1 2 T. de Croix a Gálvez. Chihuahua, 1.0 de mayo de I778, núm. $20 \mathrm{I}$. A. G. J., Guadalajara, 267 .

ir 3 Ordenes de Don José Rubio, que acompañan la carta de T. de Croix a Gálvez. Chihuahua r.o de mayo de 1778 , núlm. I98. A. G. I., Guadalajara, 522, La real orden de 30 de octubre de 1778 aprobó lo dispuesto por $T$. de Croix y añade que S. Majestad "fía del celo de V. I. que a proporción de los conocimientos que irá adquiriendo, aplicará los remedios más oportunos a los 'males, sin fatigarse en declamar contra las providencias anteriores, por estar ei manos de V. I. variarlas según lo exijan las circunstancias y necesidades actuales". Ibid.
} 
españoles, con un total de mil quinientos gandules, y que en aquella provincia se daba el nombre de jumanes a los indios del fuerte de los taobayas.

Como conclusiones se decidieron las de buscar o conservar la alianza con los indios del norte y los comanches contra los apaches, encargándose esto especialmente a de Mézières. La necesidad de reforzar las guarniciones de los presidios, cuya tropa útil resultaba ser siempre muy poca, para lo cual, además de las tropas ligeras y las milicianas que se estaban levantando, se esperaban los mil hombres pedidos por Croix. $Y$ la conveniencia de continuar las providencias tendentes al fomento de siembras de maíz, trigo, cebada y demás semillas que debían asegurar la subsistencia de hombres y caballos cuando llegase este refuerzo. Resolvióse también prohibir el comercio de armas y las carneadas de ganado vacuno por los lipanes en Texas, y detallar las posibles operaciones de las fuerzas de Nueva Vizcaya, Nuevo México y Sonora. II4

Cuando Teodoro de Croix da cuenta de lo actuado en las juntas insta por última vez el envío de dos mil soldados pero añadiendo que, si por las circunstancias por que atravesaba Europa no fuera esto posible, por el momento se le apruebe el aumento de trescientos setenta y siete soldados ligeros creados por él y se le permita el aumento de otros doscientos, que subsistan en Sonora los dragones y fusileros, y que se le autorice a modificar los efectivos de los presidios con el fin de proteger a las poblaciones. Todo esto hasta que por fin llegasen los contingentes pedidos, con los que ya sería posible ejecutar las campañas meditadas contra las apacherías de oriente y occidente. Concebía el conandante general establecer una triple línea defensiva en Nueva Vizcaya: la avanzada de los presidios para perseguir todo el año al enemigo en sus tierras; la segunda, interior, de las legiones, que ocuparían. las nuevas poblaciones y junto con las tropas presidia!es batirían el territorio entre las dos líneas; la tercera, de gente miliciana destinada puramente a la defensa de las poblaciones. irs

Cuatro juntas más tuvo Croix con los mismos rocales en la primera quincena del siguiente mes de julio. En las de $I^{\circ}$ y 4 de julio se trató del arreglo de milicias y fomento del vecindario de El Paso, establecimiento del destacamento de Robledo y beneficio y defensa de Nuevo México. No tenía contacto esta provincia más que con Nueva Vizcaya por El Paso. El puesto de Robledo facilitaría su comunicación con Sonora y Coahuila. La discusión de los proyectos tuvo como resultado la elaboración de una detallada instrucción de gobierno para Anza, a quien además se entregaron numerosas copias de do-

I 4 Testimonio de las juntas en A. G. I., Guadalajara, 276.

Is 5 T. de Croix a Gálvez. Chihuahua, 29 de junio de 1778 , núm. 2 I reservada. Ibid. 
cumentos, entre los que el tan interesante de los "Desórdenes que se advierten en Nuevo México". I16

La junta habida el io de julio deliberó acerca de la paga de los situados de los presidios, que suponía la incomodidad de tener que conducir las remesas de dinero de Guaclalajara a Alamos, de México a Guanajuato y San Luis de Potosí, y cle estos dos lugares a Chihuahua y Monclova. La cantidad a enviar desde México sería menor si en el trayecto se lo acumulaba el producto de las rentas de Guanajuato y Potosí, y luego el del tabaco en las provincias internas. Toda la dificultad se salvaría al fundarse casa de moneda en Arizpe, a lo que Croix pensaba dedicarse con Corbalán a su llegada a Sonora. II7

Finalmente la reunión del I3 de julio versó sobre la administración económica de los presidios después de la quiebra advertida en el sistema de los oficiales habilitados. El secretario Bonilla había propuesto la creación de doce ayudantes habilitados en lugar de los veintiún comisionados que entonces existían, y el establecimiento de cabos furrieles en los presidios. El proyecto de Bonilla, que contaba ya con el voto favorable de Rubio y los adversos de Riperdá y Cazorla, fue finalmente aprobado por esta junta, Ir8 pero Croix resolvió no innovar nada hasta tanto no concluyese la revista de toda la Línea, para proceder entonces con mucha cautela.

La última reunión documentada, el i 7 de julio, decidió encomendar a Galindo Navarro la recopilación de las leyes generales penales y de subordinación aplicables a los presidios. ${ }^{\mathrm{II} 9}$

\section{PLAN dE Croix sobre las}

PROVINCIAS DE ORIENTE

Como primer fruto singular del viaje realizado por Croix por Coahuila y Texas merece señalarse el dilatado informe que dirigió desde Chihuahua

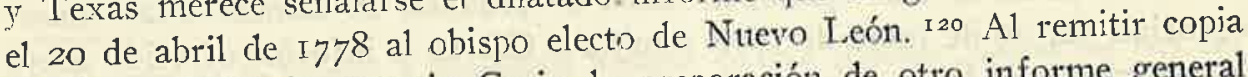
de él al ministerio anuncia Croix la preparación de otro informe general sobre las cuatro provincias de Nuevo León, Nuevo Santander, Coahuila y Texas en que propondría las ventajas de unirlas a todas segregando las dos

i 6 T. de Croix a Gálvez. Chihuahua, 27 de julio de 1778 , núm. 236. A. G. I., Guadalajara, 267. de Croix a Gálvez. Chihuahua, 27 de julio de $177^{8}$, núm, 237. A. G. I., Guadalajara, 276. de Croix a Gálvez. Chihuahua, 27 de julio de 1778 , núm. 238. A. G. I., Griadalajara, 267 . lajara, 276 y México, 2462.

I 20 A. G. I., Guadalajara, 276. 
primeras del virreinato y las clos segundas de su comandancia, poniéndolas bajo el mando de un jefe independiente, lo cual podría hacerse sin aumentar gastos al erario. I2i Pero empezaremos tratando del obispado de Nuevo
León.

En I 5 de diciembre de 1777 habíase erigido una nueva diócesis mexicana al crear la que debía comprender aquellas cuatro provincias antes citadas. Para inaugurar la sede fue designado Fray Don Antonio de Jesús Sacedón, y romo centro de la diócesis se señaló la villa de Linares, en Nuevo León. Aquí encaja el informe de Teadoro de Croix, que no intenta sino desmostrar al nuevo obispo cuánto más ventajoso que Linares no sería el valle de Santa Rosa, en Coahtita. Para ello expone, en primer lugar, la pobreza de Linares y de todo el Nuevo Reino, de tal manera que en realidad éste se proveía de Coahuila. Como contraste presenta el perceptible florecimiento de esta provincia, no obstante las crudas hostilidades que padecía, de las que hace la más viva descripción, lo cual demostraba la fecundidad de su terreno; y trata particularmente de la villa de Santa Rosa, de su maravillosa situación y de su riqueza en aguas, maderas, tierras y minerales. Considera Croix más céntrica Santa Rosa que Linares para el gobierno espiritual de las cuatro provincias, tanto más cuanto que en su proyecto entra la segregación de Nueva Vizcaya de la región de Parras y Saltillo, lengua de tierra que bordea el sur del Bolsón cuya anexión no sería poca felicidad para Coahutila.

El electo obispo de Linares agradeció a Croix el interés que se había tomado por aquella cuestión y manifestó que estaría dispuesto a apoyar su idea, pero calculaba ser ya demasiado tarde para el informe, puesto que desde el principio se pensó establecer la mitra en la villa de Linares, a la que ya había venido título de citidad, y sólo estaba esperando vinieran las íltimas reales órdenes y cédulas para la fundación de la iglesia catedral. I22

$\mathrm{Si}$ el informe de Teodoro de Croix no había de tener éxito en cuanto a la traslación de la sede episcopal, habia de producir en cambio otras consecuencias. En 29 de junio de 1778 remitía a Gálvez el informe ofrecido sobre la separación de las provincias de oriente. Murto repentinamente el segundo comandante inspector Don José Rubio, en carta reservada de 3 de junio había indicado Croix que el único capaz de desempeñar este puesto era Don Bernardo de Gálvez, ${ }^{123}$ y de lo contrario lo mejor sería crear una nueva co-

I2 т T. de Croix a Gálvez. Chihuahua, т. ${ }^{\circ}$ de mayo de i 778 , nún. zor. Ibid.

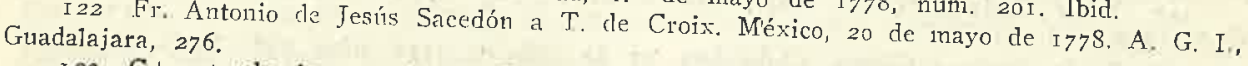
me aliviaba nis justos cuidados, $y$ no tendré consuelo hasta Teodoro: "Le quise como merecía, sujeto que ocupe dignamente la vacante del difunto" hasta que S. M. se digne nombrar otro "no ne atrevo a proponerlo, porque tampoco puedo graduar si es que de Don Bernardo dice: 
mandancia, suprimiendo los empleos de gobernador de las cuatro provincias orientales y los de comandante inspector y sus dos ayudantes, poniendo corregidores en lugar de aquéllos y tres inspectores tenientes coroneles con cuatro mil pesos de sueldo en lugar de éstos - dos se destinarían a las provincias occidentales y uno a la nueva comandancia oriental- Una idea menos radical, en la misma carta, es la de quitar sólo el gobierno de Nuevo León y reducir en cambio, los sueldos de los capitanes presidiales y de la compañía volante de las cuatro provincias.

A decir verdad, ya el 3 de junio veía Croix como inevitable la división de su mando, ${ }^{124}$ pero sin duda nunca se hizo cabal idea de cuán a la ligera había contado con la persona o los auxilios de Bernardo de Gálvez, fuese como gobernador de Luisiana, como comandante inspector de la frontera o como jefe de las provinciales orientales. El único auxilio que de él recibió fue Don Atanasio de Mézières; Don Bernardo estaba dispuesto a enviar también alguna tropa de indios, pero cuando recibió la invitación para acudir a Texas a la cabeza de un cuerpo de cazadores hubo de negarse, "lo primero, por no tener orden de S. M. para ausentarme de esta jurisdicción y hallarme sumamente embarazado con las revoluciones acaecidas en esta provincia entre los americanos e ingleses, según di cuenta a V. E. Lo segundo porque los pocos cazadores que hay en ella son muy útiles para su subsistencia, tanto por las carnes de cibolo, manteca de oso y sebo con que la abastecen, como por las pieles que sacan del comercio que hacen con los indios, sobre cuyas gentes no hay que contar en alguna necesidad, respecto a que no se mantienen en esta ciudad que el poco tiempo que necesitan para sus ventas y compras, y concluidas éstas hacen sus armamentos y vuelven a emprender otro viaje en el que se mantienen viviendo con los indios años enteros". " 25 La primera justificación del futuro virrey nos hace ver una de las maneras en que incide la guerra de independencia de los Estados Unidos de América sobre la histo-

de gobernador de la Luisiana a comandante inspector de estos presidios", aunque con este empleo se le podría ascender a brigadier, con lo que quedaría por encima cie todos los gobernadores de provincias, haciéndolo además gobernador intendente de Nueva Vizvaya, con residencia en Chihuahua. T, de Croix a Gálvez, s./n, rescrvada. Chihuahua, 3 de junio de i 778 . A. G. I., México, $246 \mathrm{I}$.

I 24 A la carta citada en la nota anterior acompaña una esquela autógrafa de $T$, de Croix a Gálvez, de igual data, que literalmente dice: "Anigo y señor: conociendo que ninguno puede ayıdarme como su sobrino Don Bernardo, remito a $\mathrm{Vm}$, la adjunta representación reservad para que, si le pareciere bien la presente al rey, y si no la rompa.

La división de comandancias es muy precisa, pues no puedo atender a tantas partes, y en el caso de que la comandancia inspección no se la quiera clar al sobrino, pido a Vm. que en sar lugar venga Garibay, que no tiene otro defecto de estar algo enfermo, aunque mejor sería la división de comandancias, confiriéndola a su sobrino, o el empleo de comandante inspector con la intendencia y gobierno de la Vizcaya. Yo deseo el mejor servicio del tey y que Vm, esté contento. Su siempre más fiel amigo, Croix". 
ria de las provincias internas; la segunda muestra el tipo del cazador francés, tan poco frectuente en el norte de Nueva España, donde los hombres hallaban sobrado empleo en las minas, la ganadería o la agricultura.

El ministro de Indias se mostrará de acuerdo con su sobrino, a quien responde en real orden de $I 3$ de octubre de $I 778$ "que por ninguna instancia del comandante general debilite las cortas fuerzas de esa provincia que tanto las necesita, y más que todo la personal asistencia de V. S. en ella”. Otra orden, tres días después, contesta en igual sentido a Don Teodoro, mostrando la falta que hace Don Bernardo en Luisiana, "provincia que es la más importante y expuesta de ambas Anéricas mientras dure la guerra entre ingleses y sus colonos". De todos modos, tal vęz la guerra durase ya poco, y al fin de ella podría ponerse Luisiana en otras manos, pero el Caballero debía buscar un inspector interino hasta entonces. ${ }^{2} 6$

Sin embargo, a fines del mismo mes de junio, el inadvertido Don Teodoro proponía ya sin vacilaciones como lo más ventajoso, útil y conveniente la división de la comandancia general en dos, con total independencia una $y$ otra del virreinato, procediendo acordes sus jefes en las operaciones de guerra. Tal plan sólo supondría un gasto inicial de cuatro mil doscientos pesos, y resolvería la cuestión de ser tan imposible gobernar Texas y Coahuila desde Sonora como desde México, mientras que unidas aquellas dos provincias a las de Nuevo León y Nuevo Santander, y agregadas las jurisdicciones de Parras y Saltillo, podría mtty bien erigirse otra comandancia: "ningún gobierno de la Nueva España sería tan feliz" por la fertilidad y la entancia de sus tierras, y la notoria facilidad de sus comunicaciones, salvo la entrada a Texas; dominados o suprimidos los apaches de oriente, podrían avanzarse los presidios hasta Nuevo México, y siempre podría comerciars? por mar con Luisiana, La Habana y Veracruz. Para el gobierno de esta comandancia, propone nuevamente, nadie mejor que Bernardo de Gálvez. Dividida la comandancia no sería necesario el comandante inspector. I ${ }^{2} 7$

No vamos a entrar ahora a discutir algunas de las ventajas e inconvenientes de la idea de Croix, que, andando el tiempo, llegará a hacerse realidad. A puntaremos tan sólo su conveniencia atendiendo al avance que suponía qutina gubernamental. Tal como se encontraban en aquiel exacto momento las cosas, el único vínculo recién aparecido en las cuatro provincias era el

I 25 Bernardo de Gálvez it Jo:é de Gálvez, núm. I53. Nueva Orléns, 9 de junio de izzs.

I 26 Reales

falta de robustez.

I $27 \mathrm{~T}$. de Croix a Guadalajara, 276 . 
obispado de Linares; ahora bien, Coahuila y Texas dependían del comandante general, mientras que Nuevo León y Nuevo Santander eran gobernados por el virrey, y en cuanto al vicepatronato, el mismo obispo había de hallarse sujeto a esta duplicidad de autoridades. En lo judicial, las cuatro provincias correspondían a la audiencia de Nueva España; Croix quiere que dependan de Guadalajara. Y si atendemos al territorio de Parras y Saltillo, estando regido por el gobernador de Nueva Vizcaya, se dividía en lo eclesiástico entre el obispado de Guadalajara, al que obedecía Saltillo, y el de Durango, al que correspondía el pueblo de Parras con su jurisdicción.

Un comandante general independiente y un solo obispado, cuatro gober1iadores provinciales y un intendente para todo el territorio. Esto es lo que propone Croix. La autonomía en el orden judicial vendría acarreada por los otros hechos y llegaría a proponerse la erección de una audiencia en el distrito.

Observemos, para terminar, aquella expresión de Croix: "desde la Sonora es tan imposible gobernar a las (provincias) de Texas y Coahuila, como desde México". Volveremos sobre este párrafo más adelante.

\section{ORganizaCión DE LA COMANDANCIA}

Mientras proponía una reforma tan apreciable para el gobierno de las provincias orientales, luchaba el mismo Croix por conseguir una ordenación semejante en su propio comandancia. Empezaba entonces a sentir lo que de forzado y defectuoso había en el estatuto original de su gobernación y a advertir por otra parte la importante tarea a realizar que le estaba encomendada.

Representaba, pues, Croix, para el caso de continuar unificadas las seis provincias internas, el inconveniente de depender las de Coahuila y Texas de la audiencia de México, cuando las otras cuatro estaban sujetas a la de Guadalajara, y para ésta se le ordenaba a él en la instrucción admitir las apelaciones de sus providencias sobre asuntos contenciosos. Solicitó Croix aclaración sobre este punto, aunque por la pobreza de los vecindarios, falta de correos y lejanía eran muy pocos los recursos que aquellas provincias dirigían a las audiencias. ${ }^{\text {I } 28}$ Por estas mismas causas, en cambio, para superar 1a desorganización que introducían estos obstáculos pidió se nombrase en la comandancia un ministro que se encargase del juzgado general de bienes de difuntos. Cree tener derecho a hacer este nombramiento, para el cual propone a su asesor Galindo Navarro, por considerar sus atribuciones semejantes

z 28 T. de Croix a Gálvez, Chihuahna, 3 de abril de ry78, núm. 180 . Ibid. 
a las de los virreyes $y$ gobernadores pretoriales, que nombran un oidor que sirva aquella comisión por dos años. I29

La tercera representación de Croix en este primer momento atañe al juzgado privativo de ventas y composiciones de tierras realengas y baldías que tocaba en las provincias de oriente a un oidor de la audiencia de México y en las demás a otro de Guadalajara. Alude Croix en este punto a uno de los principales problemas de la comandancia. En su viaje por Texas, Coahuila y Nueva Vizcaya había advertido la facilidad con que algunos particulares habían obtenido mercedes de crecidas porciones de tierras y aguas, cuyos límites habían extendido a voluntad, contribuyendo muy poco o nada al beneficio de la real hacienda y ocasionando en cambio el gravísimo perjuicio de tener yermas y desiertas muchas ciue eran a propósito para establecer y mantener una regular población que acaso pudiera haberla ya si no lo hubiesen impedido los que se titulaban dueños de los territorios. Propugna en consecuencia Croix el reconocimiento y moderación de estas concesiones, la restitución de las tierras usurpadas y el establecimiento de una instrucción para lo sucesiso, que hiciese rendir este ramo y permitiese además el formento de la población. Siendo claro que el desorden hasta el momento existente sobre el particular se debía al desconocimiento que en México y Guadalajara se tenía de las provincias internas, deseaba Croix establecer el juzgado privativo de tierras en la capital de la comandancia, dándole esta comisión al asesor, que ya había adquirido la experiencia del país. ${ }^{3}$ o

Tres meses después, al presentar su proyecto de división de la comandancia general, ya Croix insinúa la utilidad de crear una media o pequeña autliencia en Arizpe, ya que no se trasladase la de Guadalajara, porque los recursos a esta ciudad eran dificultados por la distancia y las hostilidades habituales. I3 I Al mismo tiempo se hace cargo Croix del obstáculo que a su gobierno presenta este mero punto de la dificultad de las comunicaciones. Cortado por los apaches el camino de Janos, el contacto de Nueva Vizcaya con Sonora y Sinaloa debía de hacerse por las asperezas de la sierra Madre occidental, en cuyo centro aún existía el núcleo gentil del Babaroco y la barranca de Tararecua, prácticamente incontrolado y en el que se refugiaban muchos indios escapados de las misiones. Nuevo México estaba en realidad aislado por las cien leguas de desierto que mediaban desde El Paso, no habiéndose abierto aún el camino que ya se proyectaba desde Sonora, y que habría de cruzar las serranías de los apaches de poniente cuidando de docilizar a los moquinos y no alarmar a los yutas. En cambio, la ruta de Sonora

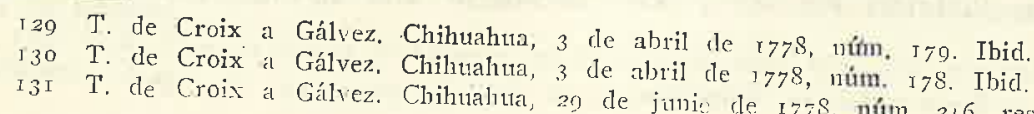


a California septentrional estaba ya fijada, pero había que atender a traer a la numerosa gentilidad que lo cubría.

Por último, y como secuela de la reciente creación del obispado de Linares, Croix pide la erección de otro para las provincias de Sonora, Ostimuri, Sinaloa y Californias, dejando al de Durango Nuevo México, y agregado a la comandancia, para racionalizar el sistema administrativo,. la villa de Nombre de Dios y el real de minas de Sombrerete, que correspondían a esta mitra. ${ }^{\mathrm{I}} 32$

De todo lo propuesto, la audiencia no llegará nunca a establecerse, la mejora de las comunicaciones se intentará seriamente, y en particular dejará Croix establecida la red de correos. La creación de la casa de moneda tan1poco llegaría nunca a ser una realidad en Arizpe, si bien Croix se lo prometía con toda firmeza. La precaria e inestable constitución que siempre tuvo la comandancia, las vicisitudes por que atravesó después del mandato de Teodoro de Croix, obstaculizaron en todo momento el que pudo ser el comienzo de una nueva era para las provincias internas de Nueva España.

En otro orden, son de advertir diferentes rasgos de ese mismo estado de confusión en que se hallan muchos asuntos de la comandancia, como institución aún no definitivamente cuajada, a lo que contribuye no poco la diversidad de proyectos que de todas partes se hacen sobre ella apenas aparecida.

Concernientes a su organización militar, vista ya la irresolución del punto del gobierno económico de los presidios, anotemos la vacante que provoca el caballero de Croix del cargo de comandante inspector a la muerte de Rubio, pues teniendo expedido su informe sobre división de la comandancia, y encomendadas las funciones de aquel cargo, mientras se resuelve su propuesta, a los capitanes Borica y Cazorla, al ayudante Medina y a los gobernadores de Nuevo México y Texas rogaba al ministro que, de no resolverse a dar la inspección a Bernardo de Gálvez, se mantuviese vacante, pues no hallaba persona capacitada para este empleo, y las que había no tenían el grado suficiente. ${ }^{\mathrm{I}} 33$

Planteábase también, muerto Rubio, la necesidad de poner en Chihuahua alggín militar de graduación que atendiese aquella frontera, pero a falta de éste, y viendo también Croix las disensiones que desde los tiempos de Cuéllar habían tenido los comandantes de las armas con los gobernadores de la provincia, resolvió recomendar a Barri ambas comisiones, haciéndola establecer stt capital entre Chihuahua y Durango, en el valle de San Bartolomé. ${ }^{3} 34$

Otro caso típico de la desorientación aún reinante es el de la jura del

132 Ibid.

I 33 T, de Crojx a Gálvez. Chihuahua, 27 de julio de ryy3, núm. 2, reservada. Ibid,

134. T. de Croix a Gályez. Chihuahua, 27 de julio de 1778 , núm, 24o. Ibid. 
cargo en manos del virrey que se ordenaba a Anza al nombrarlo gobernador de Nuevo México. Advirtiendo Croix el retraso y molestias que esto habría de producir, y más aún el contrasentido de tal disposición siendo aquella provincia una de las de su mando y él independiente del virrey, resolvió jurase Anza en sus manos, en Chihuahua, como lo hizo el 8 de agosto de $1778,{ }^{135}$

\section{LAS MILICJAS DE NUEVA VIZCAYA}

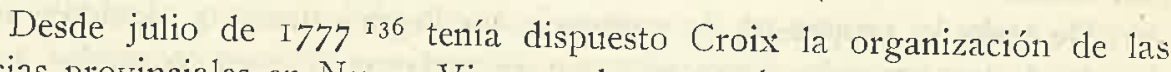
milicias provinciales en Nueva Vizcaya, de cue tenía encargados al ayudente mayor Don Juan Gutiérrez y a los tenientes Panes, García Rebollo y Gregori, y confiaba en la rápida conclusión de esta empresa, puesto que pensabä hacer pasar luego a estos oficiales a las otras provincias de la comandancia con el misnio fin. Los cuatro oficiales debieron hacer con él el viaje hasta Durango, y clescle allí en octubre de aquel año, empezaron a darse los pasos para el levantamiento de las tropas milicianas. Gutiérrez quedó en Durango, con García, comisionados para hacer la leva en esta jurisclicción y las de la villa de Nombre de Dios, San Juan del Río, Papasquiaro y Mezquital; Panes pasó a Parras, y Gregori a Mapimi, estándole encomendada la formación de la milicia también en Cuencamé, Nazas y Aguanaval, Gallo y Saltillo, mientras que otros dos tenientes, Blanco y Soler, se dirigieron a Parral, Indé, Real del Oro, Cerro Gordo, Río Florido, Guajoquilla y Ciénaga de los Olivos. ${ }^{\mathrm{I}} 37$

Hasta junio de 1778 , llegado Croix a Chihuahua, no volvemos a tener noticias de punto tan importante, pero en esta ocasión ya pudo el comandante general reristar en la villa tres compañías milicianas de treinta y seis soldados, y para entonces existían siete nás y once escuadras de tarahumaras en la jurisdicción, dos compañías en Parral, y otras cuatros en Santa Bárhara, Valle de San Bartolomé, Ciénaga de las Olivos, Real del Oro, Cerro Gordo, Guajoquilla y Conchos. Hasta seis compañias podían formarse en

\footnotetext{
I35 T. de Croix a Gálvez. Chihuahua, 24 de agosto de r778, núm. 259. T. de Croix a 5. M! misma data. Testimonio de la toma de posesión de Anza, Chihuahua, 8 de agosto de
I778. Ibid.

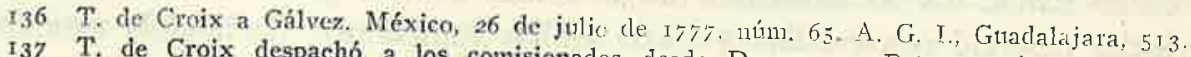

I37 T, de Croix despachó a los comisionados desde Durango y Patos, según sus cartas a Gálvez, Durango, to de octubre de 1777 , num. it6, y Hacienda de Patos, 24 de noviembre de 1777, núm. 126. Les entrego instrucciones pública y reservada, en 20 y 2 artículos respectivapadrones, elección de milicianos organización de 1777 , y en ellas les encarga la formación de $y$ de otros indios de arco y flecha, y una serie de informes de tlaxcaltecas con armas de fuego de los pueblos. Don Teodoro dejaba una serie de informes sobre gobierno, comercio, tierras, etc. formar las milicias de la villa de Chihuahua. A. G. I., México, 2462 .
} 
Durango, pero se consideraron bastantes una o dos, más las tres o cuatro que se levantarían en sil comarca. ${ }^{138}$

A fin de año estaban ya constituidos cinco cuerpos miliacianos de los que el del Príncipe, en Chihuahua, contaba diez compañías; el de San Carlos, que cubría Parral, San Bartolomé, Real del Oro y Santa Bárbara, cinco; el de Durango, en esta ciudad, tres, y otras tantas las de los cuerpos de San Juan Bautista y San Gabriel, reclutados en. San Juan del Río y Nombre de Dios. El total de plazas era ya de mil quinientas cincuenta y tres. La leva y sostenimiento de esta fuerza era algo sumamente util, puesto que no gravaba al erario. El sistema era el siguiente: los oficiales destinados a esta tarea formaban el padrón de cada localidad, y estudiaban su situación económica; aquél les servía para alistar a los hombres en estado de llevar armas, de los que, por sorteo, se cubrían las plazas de las compañías previstas: el cómputo de la riqueza de la localidad les indicaba el modo que podía alcanzar el donativo que se pedía a sus vecinos para el mismo establecimiento de milicias, además de lo cual se invitaba al cabildo a señalar algunos arbitrios cuyo fruto anual sirvicra para mantenerlas. Los donativos se hacían tanto en dinero como en ganados o frutos del campo, dándose también los casos en que los designados para mandar las nuevas tropas se comprometiesen a equiparlas totalmente a su costa: así los capitanes de las tres compañías de la villa de Chihuahua. Capitanes y oficiales procedían, naturalmente, de las más acomodadas familias de mineros, terratenientes y comerciantes del país.

En cuanto a los arbiritios, los propuestos versaban sobre el comercio de ganados, granos, vinos, lanas y tabacos, principalmente, y acerca de ellos se promovieron reclamaciones y disputas de diverso carácter, sobre lo que habremos de tratar más adelante.

A la fecha -28 de diciembre de 1778 - los donativos recaudados 0 prometidos por los lugares donde acababan de crearse las milicias ascendían a 83.405 pesos y los arbitrios aprobados of recían un líquido anual de 51.500 . Como se calculaban 20.000 pesos de donativo y 34.000 pesos de arbitrios de toda la zona donde aún no se había verificado el establecimiento, esperaba Croix: tener de inmediato más de cien mil pesos, y una renta de tal vez de 30.000 para lo sucesivo, con cuyo caudal le sería posible atender a los gastos cie los oficiales comisionados, a la fundación de las poblaciones fronterizas que planeaba, y a mantener en pie de guerra varios destacamentos de la misma tropa miliciana.

El mayor tropiezo que encontraba era, en principio, la falta, desigualdad

I38 T. de Croix a Gálvez. Chihuahua, 29 de junio de 1778 , núm. 219. A. G. I. Guadalajara, 276 . 
o antigüedad del armamento, precisándose con urgencia un considerable envío, dando por seguro que en cortísimo tiempo estaría todo vendido, y podrían adquirirlo también las tropas presidiales de Sonora, Texas y Nuevo México, donde aún no se tenía el nuevo que recibiera O'Conor. Croix procedía ya a nombrar suboficiales y oficiales, pidiendo para éstos despacho real, y lamentaba la falta de comisionados a los que encomendar lo que quedaba por hacer. Croix, entre tanto, había preparado ya una instrucción provisional para el cuerpo de dragones provinciales de Durango, y pasó las correspondientes instrucciones a los gobernadores de Nuevo México, Coahuila y Texas para que procediesen a reclutar las milicias de sus provincias. ${ }^{139}$

Coordinadas con las de Nueva Vizcaya, no conviene olvidar las milicias de $\mathrm{El}$ Paso, organizadas por Daroca y Arrieta en tiempo de O'Conor $y$ revistadas ahora y puestas sobre un nuevo pie por Don Andrés Galindo Navarro, capitán del Príncipe, y por Anza. Según Rubio, El Paso había decaído mucho por los ataques de los apaches; por las campañas a la que $\mathrm{O}^{\prime} \mathrm{Co}-$ nor había hecho salir hasta cuatrocientos hombres del vecindario por cuatro meses a su costa, dejando de trabajar las tierras, perdiendo las bestias, empeñándose; y por las heladas de I776, que destruyeron muchas viñas. ${ }^{140}$

\section{Establecimiento dF CORREOS}

EN LA COMANDANCIA

E1 3I de enero de I779 firmaba Teodoro de Croix en Chihuahua una carta dirigida al virrey Bucareli participándole toclo el plan ya establecido para que a partir del próximo $\mathrm{I}^{\circ}$ de mayo empezase a circular por las provincias internas un servicio mensual de correos que habría de cubrir la ruta de Texas a Sonora desde la Bahía del Espíritu Santo hasta Arizpe, lo cual, sobre el beneficio que reportaba al público, suponía un eficaz instrumento en manos del comandante general para la centralización de todos los asuntos de su jurisdicción y la más estrecha vinculación recíproca de las provincias
de su mando. ${ }^{14 \mathrm{I}}$

I39 El proceso de organización de las milicias provinciales en este año se sigue en carta de T. de Croix a Gálvez. Chihuahua, 27 de julio de 1778, núm. 247; 24 de agosto, núm. 260 y 261. A. G. I., Guadalajara, 276. T. de Croix a Galvez. Chiluahua, 23 de setiembre de 1778 , núm. 284. A. G. I., Guadalajara, 270. T. de Croix a Gálvez. Chihuahua, 28 de diciembre de 1778, núm. 319. A. G. I., Guadalajara, 275. T. de Croix a Gálvez. Chihuahua, 28 de diciembre de 1778 , núm. 318, 320, 321, 322 y 323 . A. G. I., Guadalajara, 270.

140 Galindo fue enviado a fines de 1777 , $T$. de Croix a Gálvez, núm. 125. Hacienda de Patos, 24 de novièmbre de 1777 . A. G. I., México, 2462. La comisión dada a Anza en T. de Croix a Gálvez. Chihuahua, 23 de octubre de 1778 , núms. 298 y 299. A. G. I., Guadalajara,
275 y 267 .

I4I El expediente con que dio cuenta el comandante general de la innovación ha sido publicado por Sanclova], Termando B. El correo de las prozincias intemas. B. A. G. N., XIX, 3; 
Antes de esta fecha, los correos del virreinato no pasaban más al norte de Durango y San Luis de Potosí, y sólo en aquella ciudad en momento no fijado con exactitud, se había dado un paso más al crearse un correo semanal que alcanzaba Chihuahua.

El itinerario ascendente del nuevo correo tenía su punto de partida en el presidio de la Bahía del Espíritu Santo, de donde la correspondencia era conducida a San Antonio de Béjar. El 20 de cada mes salía de Béjar toda la correspondencia de Texas, debiendo concentrarse el penúltimo del mismo mes en Río Grande y al día siguiente en la villa de San Fernando de Austria.

El I. de cada mes partía el correo de esta villa y alcanzaba el 2 el valle de Santa Rosa y el 3 la villa de Monclova. De aquí, por las haciendas de Castaños, Anahelo y Mesillas, llegaba a Saltillo al amanecer del día 5. Por las haciendas de Patos, Castañuela y Pata Galana, hacía su entrada en Parras el 6 , seguía por la hacienda de la Peña y el pueblo de Alamo, hacienda de los Hornos y rancho de San Juan de Casta y el 8 entraba en el real de Mapimí, amaneciendo el día 9 en el Gallo; aquella misma noche en la lacienda de la Zarca recibía y entregaba la correspondencia de y para Durango, y el día ro cruzaba Cerro Gordo y la estancia del río Florido, amaneciendo el I I en el valle de San Bartolomé, y el I 3 en Chihuahua.

E! I 3 por la noche continuaba el correo la ruta ahora en dirección oeste y veinticuatro horas después estaba en el real de Cusihuiriáchic; al día siguiente por la noche estaba en la misión de Paguerachic, y sin detenerse amanecía en Tomochic y anochecía el i6 en la de Tutuaca. Esa noche atravesaba Yepachic y entraba por la mañana en Maycova, en Sonora, y continuando el camino por Yécora, alcanzaba por la noche del iz el real de la Trinidad. Por Milpillas llegaba el is al real de San Antonio de la Huerta, y cruzando Soyopa, Llano Colorado, Mazatán, Santa Rosalía y San José de Gracia amanecía el 2 I en el presidio de San Miguel de Horcasitas, y continuando su marcha aquella tarde por Ures, la Concepción, Babiacora, Aconchi, Valle de Sonora, Guepaca, Banamichi y Sinoquipe, entraba el 22 por la noche en Arizpe.

La ruta descendente del correo se empezaría en Arizpe el I. ${ }^{\circ}$ de cada mes y alcanzaba por el mismo itinerario la villa de San Fernando el 22, y e? penúltimo día del mes se entregaba la correspondencia de Texas en Río Grande.

La distancia cubierta entre Arizpe y San Fernando de Austria era de quinientas cuarenta y cinco legttas, y en este trayecto, recorrido en un mes,

Páginas 337-386. México, 1948. T. de Croix 10 avisó a España en cartas a Gálve\%. Chihuah11a, 29 de marzo de 1779 , núm. 274, según nota en A. G. I., Guadalajara, 267, y Chilhuahua, 27 de agosto de $178 \mathrm{I}$, 11 ím. 668 . A. G. I., Guadalajara, $28_{\mathrm{I}}$, bis. 
se hizo quincenal el correo a partir de diciembre de r780. Obsérvese que Croix, hallando excesivamente expuesto el camino de la Línea de presidios, prefirió desviar el curso de la correspondencia haciéndola circular alrededor del Bolsón, lo que, si bien alargaba considerablemente la ruta, tenía la ventaja de hacer transitar los correos por todos los núcleos de población de Coahuila y Nueva Vizcaya oriental, con el consiguiente beneficio de aquellos vecindarios.

En cuanto a la correspondencia de los presidios, que formaba la masa principal de las cartas oficiales, se incorporaba la de los de Coahuila en la villa de San Fernando, menos la del presidio de la Babia que lo hacía en Santa Rosa. Chihuahua recibía toda la correspondencia de los presidios desde Janos a San Sabá, y San Miguel de Horcasitas la de los presidios de So:10ra, menos la de San Bernardino que acudía a Arizpe.

A más de estas cuatro, y de las dos de Texas, había estafetas en Monclova, Saltillo, Parras, Mapiní, Gallo, Valle de San Bartolomé, Cusihuiriáchic y San Antonio de la Huerta, y en ellas se encargaban de su cuidado los administradores de rentas ya existentes en estas localidades. En los presidios se encomendó esta función a los oficiales habilitados.

Croix declaró franquicia de portes a la correspondencia oficial y fue decidido que los presidios y compañías volantes suministrasen soldados que ejerciesen la función de conductores desde la bahía del Espíritu Santo hasta el valle de San Bartolomé. De aquí a Temaichic llevaban la correspondencia soldados de las compañías milicianas; de aquí hasta el real de la Santísima Trinidad, se nombraron conductores indios; de este real a Santa Rosalía s: encargó a algunos vecinos, y en él último trayecto hasta Arizpe volvían :l hacerse cargo del correo los soldados de Horcasitas. El número de conductores era de dos, que en Texas precisaban tuna escolta de cuantía variable, según las circunstancias de riesgos del momento. Como sólo los indios y los vecinos de Trinidad y San Antonio de la Huerta percibían remuneración por este servicio, el gasto de conducción no excedía de cuatrocientos veintiséis pesos en los primeros tiempos; los milicianos cobrarían salarios del fondo de arbitrios de milicias, y Croix proyectaba que ellos se hiciesen cargo de todos los trayectos que cubrían los presidiales, para que éstos no se distrajesen de su principal función. ${ }^{\mathrm{I}}{ }^{2}$

A principios de 1780 ya había establecido Croix correos quincenales de Arizpe a Alamos y Chihuahua, ${ }^{143}$ y desde diciembre se continuó así hasta

I42 Recibió Croix algunos donativos para el establecimiento de los correos, Rosario y Culiacán contribuyeron con tres mil seiscientos sctenta $y$ nueve pesos; Saltillo, con mil cin-
cuenta y seis.

r 43 T. de Croix a Gálvez. Arizpe, 20 de marzo de i j80, núm. 502. A. G. I. Guadalajara, 267. 
San Femando de Austria, y a partir de entonces quedaron designados diez correos fijos que cubrirían las distancias de Arizpe a Alamos, de San Antonio de la Huerta a Chihuahua, del valle de San Bartolomé a Saltillo, y de aquí a San Fernando. ${ }^{144}$

E1 enlace con California peninsular estaba a cargo de un buque del departamento de San Blas. En I783, gracias a las gestiones del intendente Corbalán, pudieron evitarse los cuantiosos gastos que suponía esta embarcación, y los trastornos que producía el pago de su tripulación y el arreglo del mismo buque. Corbalán procuró el arrendamiento de una canoa propiedad del Padre Don Luis Padilla, cura doctrinero de Santa Cruz de Mayo, por ochocientos pesos anuales. Esta canoa saldría de Santa Cruz para Loreto del I. ${ }^{\circ}$ al 6 de cada mes, y el justicia de Alamos proporcionaría correos que condujesen los pliegos entre Santa Cruz y Alamos, donde se incluirían en la valija del correo semanario a Arizpe. De este modo fue posible hacer retirar a San Blas la goleta "Sonora" y el jabeque "Dichoso", que entonces hacian el servicio entre Californias y Sonora. ${ }^{\mathrm{T}} 45$

\section{Ultima ETAPA DE LA Estancia de Croix en Chinuahua}

A fines de junio de 1778 después de la primera serie de juntas habida en Chihuahua, ya estaba Croix proyectando st inmediato traslado a Sonora. ${ }^{146}$ Los negocios de Nuevo México y formación de milicias de Nueva Vizcaya fueron retrasando la fecha de su viaje, de manera que en agosto confesaba que no le sería posible partir antes de octubre, ${ }^{\text {I } 47}$ a pesar de lo cual, todavía en noviembre, preocupado por la fundación de cinco ciudades en la línea fronteriza subsistía en Chihuahua ${ }^{148}$ y allí le encontró el año nuevo de I779. Finalmente, ${ }^{149}$ dispuesto el envío de su equipaje y de los papeles de la secretaría a Sonora por Sierra Madre para $r^{\circ}$ de marzo, disponiéndose él a partir por la Línea de presidios el $\mathrm{I} .{ }^{\circ}$ de abril. Emprendió el viaje, efectivamente, la impedimenta en la fecha indicada, pero no así Croix, que el I. de mayo caía además gravenzente enfermo. En la tercera

I 44 T. de Croix a Gálvez. Arizpe, 23 de abril y 23 de octubre de i 78o, núms. 5 I 5 y 560 . Ibid.

I 44 T. de Croix a Gálvez. Arizpe, 2ụ de febrero de I783, núm. 889. A. G. I., Guadalajara, 518 y 284 .

146 T. de Croix a Gálvez. Chihuthua, 29 de junio de 1778 , núm. 227. A. G. I., Guadalajara, 276.

I 47 T. de Croix a Gálvez. Chilutuahua, 24 de agosto de 1778 , núm. 254. A. G. I., Guadalajara, 267 .

I $48 \mathrm{~T}$. de Croix a Gálvez. Chihuahua, 23 de noviembre de 1978 , núm. 304. Ibid.

I 49 T. de Croix a Gálvez. Chihılahua, 22 de febreto de s'79, núm. $36 t$. A. G. I., Guadalajara, 270. 
đécada del mes experimentó algún alivio, I50 pero trasladado al pueblo de Nombre de Dios recayó nuevamente en su dolencia y así pasó dos meses sin sueño ni alimento. La enfermedad le impidió el movimiento de brazos y piernas, por lo que para firmar decidió usar estampilla, certificándola el asesor Galindo y el secretario Bonilla, y dio aviso de esta novedad al virrey y a las dos audiencias. A fines de julio empezaba a mejorar, y en esta disposición continío durante el mes de agosto, pensando trasladarse a tomar los baños medicinales de Julimes. ${ }^{51}$ Ya en setiembre, después de cuatro meses de paaecimientos, pudo emprender su vida normal ${ }^{152}$ y el 30 de aquel mes partió para salvar las últimas jornadas de su viaje hacia Arizpe siguiendo la Línea de los presidios, llegando el i 3 de noviembre a la que había de ser capital Ge la comandancia. ${ }^{153}$

Como testimonio de la enfermedad padecida por Croix nos queda el iertificado que extendiera su médico, Don Santiago Augier, doctor en medicina y cirugía por la universidad de Montpellier $\mathrm{y}$ aprobado por el protomedicato de México, quien a principios de julio atestigua que al comandante general "únicamente le asiste el (impedimento) de no poder escribir y firmar de su puño, nacido de una perlesía producida de resultas de un dolor cólico de los pintores o plumberos, que ha padecido durante un par de meses seguidos, y que ha sido complicado, aunque contra lo ordinario, el principio de una calentura errática seguidla por una doble terciana y terminada por una fiebre depuratoria". ${ }^{54}$

Cuando se hallaba en esta situación recibió Croix la real orden de 20 de febrero de I779 en que se le ordenaba abandonar cualquier proyecto de ofensiva contra los indios y renunciar a practicar campañas mientras fuese posible, y poner en práctica en cambio todos los medios conducentes a atraer a los enemigos a la alianza. Esto significaba el definitivo hundimiento de sus planes, aunque el comandante general en la misma carta en que responde haber comunicado la anterior real orden a los gobernadores de las provincias, todavía se atreve a esperar le sean enviados los dos mil hombres tantas veces reclamados, aunque sólo fuese para emplearlos en la defensiva. ${ }^{155}$

I50 T. de Croix a Gálvez. Chihuahua, 23 de mayo de I 779, núm. 392. A. G. I., Guadalajara, 267 .

I5 T. Te Croix a Gálvez. Nombre de Dios, 23 de junio y 23 de julio de i 779, níms. 394 y 404 . Ibid.

I5a T. de Croix a Gálvez. Chihuahua, 23 de septiembre de I779, núm, 432. Ibid.

I53 Informe general de ${ }_{17} 81$, arts. 182 y 21 2, Vid. Tomás, Alfred B., Teodoro de Croirt, pág. 44, y mapa frente a pág. 82 , donde proporciona datos tomados del Diario de M'ascaró, er la Biblioteca del Congreso en Washington.

I 54 Este certificado acompaña a carta núm, 404 de $T$. de Croix, según nota $13 \mathrm{I}$.

I 55 Informe general de $x_{781}$, art. 76 . Ya en Chihuahua, Croix habia insistido en su demanda de dos mil hombres diciendo que "sin este auxilio es imposible que yo pueda responder a S. M. de las provincias de mi cargo", a lo que se respondió que "se haga cargo como debe de la cons- 
Pero al conocer la apertura de hostilidades entre España e Inglaterra tiene que resignarse a comprender que su deseo no se realizará jamás. Desde entonces quedó claro para él que su política debía ser la de procurar cesasen los ataques de los indios, persuadiéndolos para que viniesen a radicarse en la proximidad de los presidios y de las poblaciones fronterizas.

A partir de aquel momento empieza el comandante general a meditar $y$ elaborar el que había de ser el primero de sus abultados informes generales, siendo éste, en ciento noventa y cuatro puntos, el de menor extensión:

\section{Cesión de la superintendencia}

La fijación de Teodoro de Croix en su capital, Arizpe - puesto que nunca continuará viaje hacia California ni Nuevo México como prometiera-, establece un hito importante en el desarrollo de la labor del comandante general. Pero antes de pasar a la consideración del período siguiente hemos de hacer algunas observaciones acerca del hecho que da título a este apartado: la cesión de la superintendencia general de real hacienda, que le otorgaba el artículo tercero de su instrucción, al virrey es uno de los puntos importantes de la actuación de Croix, pues sus efectos van a lastrar casi ininterrumpidamente la labor de todos sus sucesores al frente de la comandancia.

A los dos meses de su llegada a México, Teodoro de Croix avisaloa al ministerio haber acordado dejar a cargo del virrey dicha superintendencia, a lo menos mientras durase su viaje por la frontera, que le imposibilitaría naturaimente para hacerse cargo con la debida responsabilidad de los problemas hacendísticos de tal superintendencia de las rentas de la real hacienda. Había por otra parte, la falta en las provincias internas de los técnicos necesarios para montar en Arizpe las oficinas correspondientes a la comprobación y glosa de las cuentas y a la dirección de los ramos o rentas estancadas y por lo mismo carecíase de toda posibilidad para organizar el cuerpo consultivo de la junta de hacienda, semejante al que funcionaba en la capital del virreinato. Este fue el parecer del fiscal de la audiencia de México y del electo visitador general del Perí Don José Antonio Areche, a cuyas ma-

titución actual y que durante ella no es posible desguarnecer lo principal de ese reino para atender sólo a sus fronteras internas". T. de Croix a Gálvez. Chihuahua, $10^{\circ}$ de junio de 1778 , núm. $211, y$ real orden de 16 de octubre de 1778 . A. G. I., México, 2461 . Todavía renovaría el Caballero sus pretensiones en T. de Croix a Gálvez. Chihuahua, 23 de enero de 1779 , núm. 338 , Ibid, en que dice que ya sabe cómo mantener este contingente con la mitad del costo calculado en noviembre de 1777 . Como consecuencia de la real orden de 16 de octubre de 1778 , estimó Don Teodoro prudente suspender la reclamación "hasta tanto que la monarquía se desahogue de ios preferentes cuidados". T. de Croix a Gálvez. Chihuahua, 29 de marzo de 1779 , núm, 375 . Ibid. La orden de 20 de febrero de 1779 corta toda esperanza de conquistar la paz por la ofensiva. 
nos había pasado Bucareli la instrucción de Teodoro de Croix para que informasen sobre ella. Comunicadas luego estas dudas al mismo comandante, fue éste de dictamen de que el artículo que le concedía carácter y facultades de superintendente no contenía una resolución ejecutiva, sino una prevención útil y futura, con vista a lograr los fines propuestos por el rey en las provincias internas, siendo el primero la quietud y defensa de los terrenos, con la determinación de la capital y la visita de la frontera. Esperaba Teodoro de Croix lograr en esta visita una clara idea de la situación del erario en sus provincias, para luego proponer a S. M. los sujetos que debieran quedar hechos cargo de la superintendencia por lo tocante a asuntos gubernativos y judiciales, superintendencia que él no asumiría en estos puntos y sí solo en cuanto a la libre disposición de caudales por sí mismo, que conceptuaba clebía y podía ejercer, pidiendo para ello al virrey mandase poner a su disposición todos los productos de real hacienda de las provincias internas - salvo el del tabaco, que debía seguir siendo reintegrable a España-, y así lo resolvió Bucareli por decreto de 24 de febrero de 1777 , remitiendo las órdenes oportunas al tribunal de cuentas de México, a los oficiales reales de Durango y Alamos, a los directores de alcabalas, tabaco, pólvora y naipes, al administrador de azoguc y papel sellado, y al tesorero de la expedición de Nueva Vizcaya. ${ }^{156}$

Esta resolución conjunta de Croix y Bucareli fue debidamente sancionada por real orden de $\mathrm{I} 5$ de julio de 1777 , pero sin que ni entonces, $n i$ en fecha posterior, se dispusiese nada con vista a solventar las dificultades que en aquel momento habían impedido a Teodoro de Croix empezar a ejercer plenamente la superintendencia general de real hacienda que le estaba conferida. Un año después, Teodoro de Croix se proponía acordar lo más conveniente, una vez llegado a Arizpe, con Corbalán "y desde luego me persuado que ayudándome la perfecta instrucción de este ministro, sus talentos y celo, resarciaré las facultades de la superintendencia en todo el año próximo de setenta y nueve”. ${ }^{157}$

\section{Anza, Corbalán y Tueros en Sonora}

Desde el 3 de febrero de I 777 estaba el teniente coronel Don Juan Ba11tista de Anza nombrado para el gohierno de Nuevo México, designación

I 56 Bucareli a Gálvez. México, 27 de febrero de 1777 . Velasco, I, 343-348. T. de Croix a Gálvez. México, 24 de marzo de 1777 , núm. 25, según T. de Croix a Gálvez. Arizpe, 2 de junio đee I783, núm. 919. A. G. I., Guadalajara, 284. Bucareli a Gálvez. México, 27 de marzo de 1777 . núm. 2786. British Museum, Mss, room, Egerton, 1799, fols. r88-203.

I57 T. de Croix a Gálvez. Chihurahua, 27 de juljo de 1778, núm, 2.14. A. G. I., Guadalajari, 267. 
que una semana más tarde era comunicada a Bucareli y la Cámara de Indias. ${ }^{\text {I } 8}$ Poco después proponía Bucareli al mismo Anza para ascender a grado de coronel ${ }^{159}$ a tiempo que éste regresaba a Sonora con el jefe yuma Palma. Llegada la noticia de su nuevo destino, Bucareli y Teodoro de Croix pensaron en la conveniencia de que se trasladase inmediatamente a él. ${ }^{160}$ Las urgencias que repentinamente aparecieron en Sonora, sin embargo, retrasaron dos años el cumplimiento de estas disposiciones, pues con anterioridad Croix había nombrado a Anza comandante de las armas de esta provincia, al hacerse cargo de su gobernación el intendente Corbalán. ${ }^{\text {r6r }}$ Anza encontró a Crespo, que regresaba a México, poco más adelante de la villa de Culiacán, y de su boca supo el estado de la provincia.

El 7 de mayo entraba en Horcasitas, encontrando que seris y pimas habían atacado en el paraje de Tortuga la recua de Cieneguilla, siendo providencial la ayuda prestada por el teniente Azuela con algunos soldados, que lograron salvarla. Parecía claro que esta vez los revueltos estaban en connivencia con los apaches, y a Anza se le presentaba un asunto difícil. "Conozco que este oficial me hará notable falta en aquella provincia", escribió ahora Teodoro de Croix, demorando el momento de hacerlo pasar a Nuevo México. ${ }^{162}$

La situación de Sonora, que el comandante debió suponer halagüieña al conocer en México los recientes éxitos del mismo Anza y el bautismo de Salvador Palma y sus compañeros, ${ }^{\mathrm{I}}{ }_{3}$ poco después le pareció sombría como para que se le facilitase a Anza un contingente de setenta y cinco ópatas y se trasladase a Sonora con toda urgencia la mitad de la tercera compañía volante de Chihuahua. ${ }^{164}$ Ello se debió a las cartas de Crespo y del guardián de Querétaro. La fuerza de los apaches sobre las fronteras sonorenses debía ser sin duda considerable cuando cuatrocientos de ellos pudieron sorprender el 6 de febrero al capitán Luis del Castillo en el lugar de la Tinaja, aun-

I 58 Nota de Gálvez de 3 de febrero de 1777 a carta de Bucareli a Gálvez. México, 27 de octubre de 1776 , núm. 2545 . Real orden a Bucareli, 9 de febrero de $1777, y$ real orden a Gálvez, para la cámara, Io de febrero de I777. A. G. I., Guadalajara, 300.

I59 Bucareli a Gálvez, México, 24 de febrero de 1777, núm. 2758. Ibid. La respuesta, en real orden de 5 de junio de 1777 , renovó la noticia de la comisión del gobierno de Nuevo Méxicn.

I60 T. de Croix a Gálvez. México, 26 de mayo de I773, núm. 55. Ibid.

I6I Vid, nota 29.

I62 T. de Croix a Gálvez. México, 26 de julio de I777, núm. 76. A. G. I., Guadalajara, 516. T. de Croix propone retener a Anza en Sonora, y que mientras pasase a Santa Fe Don Jacobo de Ugarte y Loyola, pero como éste aún no había sido relevado del gobieerno de Coahuila, Gálvez no lo permitió, según real orden de 21 de diciembre de 1777 , en la que además se pide a Croix envíe las noticias en Extractos, como lo hacia antes la secretaría del virreinato. Ibid.

I63 Bucareli a Gálvez, México, 24 de febrero de 1777 , núm. 2753. Ibid.

I64 T. de Croix a Gálvez. México, 24 de marzo de 1777, núm. 32. Ibid. 
que hubieron de retirarse sin éxito después de haber combatido de sol a sol. ${ }^{165}$

En mayo, al tiempo de llegar Anza, se abrían las hostilidades de los seris y pimas cimarrones con el asalto de Tortuga, que padecieron los mercaderes Don Francisco Guizarnotegui y Don Felipe Maitorena. ${ }^{166}$ Las noticias recogidas por aquél indicaban que los seris sublevados eran cuarenta y los pimas, veintiuno, estando casados muchos miembros de las dos naciones entre sí, y gobernados los seris por un pima. Pretendían sublevar a los tiburones, pero se llevaban mal con los apaches, "porque estos vienen sin mujeres y quieren que los otros los provean, que si no lo ejecutan las toman a su arbitrio, así como caballos y otros efectos". ${ }^{167}$

Eil i 2 de mayo había tomado Anza posesión de la comandancia del presidio de Horcasitas. E1 I." de junio hacía otro tanto Tueros en Altar, y del mismo modo, el ro, Allande en Tucson. ${ }^{668}$ Este ascenso no relevaba a Tueros de la obligación de conservar y fomentar los placeres de Cieneguilla, y precisannente le alarmaba el reciente ataque en el camino de Horcasitas. Propone declaradamente "despatriar generalmente toda la nación seri, y dejar sus fértiles tierras para los fieles vasallos del soberano". " 69 Sin embargo, los seris del Pitic seguían sosegados, y sus justicias preguntaron a Anza si era cierto, como se decía, que el rey enviaba a la provincia más tropa todavía que la que fue el año i768. "No he tenido por conveniente--escribe Anza- el sacarlos de este concepto, por las ventajas que de él nos pueden resultar". La única fuerza que acudía era media compañía de Nueva Vizcaya, a cuyo capitán pensaba dar Anza el mando de la tropa de Buenavista, al misno tiempo que hacía pasar a Castillo a la Pimería Alta con su compañía volante.

I65 Extracto de noticias. México, 26 de abril de I77\%. Bucareli a Gálvez, misna data, .úm. 29S4. Ibid.

I66 Azuela a $T$. de Croix. Horcasitas, 13 de mayo de I777. Linón a Anza. San Ignacio, I 5 de mayo de 1777. Ibid. Algunas hostilidades de los piatos en marzo habian sido comunicdaạs por T. de Croix a Gálvez. México, 26 de mayo de 1777 , núm. 44. Ibid

I67 Anza a $T$. de Croix. Horcasitas, 23 de mayo de I777. Ibid.

I68 Azuela a $T$. de Croix. Horcasitas, i 3 de mayo de I777. Tueros a Gálvez Santa Gertruiis, 2 de junio de i 777 . Ibid. Allande a $T$. de Croix. Tucson, I 5 de junio de i777. A. G. I. Gua-
dalajara, 5 r5.

169 Tieros a Gálvez. Forcasilas, 23 de máyo de I777, y Sama Gertrudis, i 2 de junio de 1777. A. G. I., Guadalajara, 516. Este es el ínico texto que haga presumir la bondad de los ferritorios de los seris. 
La distribución de la tropa y h́patas ordenada por Anza era ésta:

\section{Presidios}

San Bernardino (antes Fronteras)

Santa Cruz (antes Terrenate)

Tucsón (antes Tubac)

Descacamento de Pimería Alta

Altar

Horcasitas

Buenavista

\begin{tabular}{rcr} 
tropa & aulriliares & total \\
90 & 20 & I IO \\
90 & 20 & I IO \\
86 & 20 & 106 \\
55 & I 5 & 70 \\
55 & - & 55 \\
45 & - & 45 \\
6 & - & 6 \\
\hline 427 & 75 & 502
\end{tabular}

Se observa cómo queda desguarnecido Buenavista, cuya fuerza pasa casi entera a Tucson, mientras que San Bernardino y Santa Cruz recibían la compañía de Chihuahua. ${ }^{170} \mathrm{El}$ comandante general aprobó lo dispuesto con frases laudatorias. ${ }^{\mathrm{7}} \mathrm{i}$

Anza comunica el mal estado de las caballadas y la falta de habilitación de los presidiales, ${ }^{172}$ y se muestra además enemigo de las traslaciones de presidios efectuadas por orden de O'Conor. El de Tucson se halla sin terminar, constantemente atacado, $\mathrm{y}$ cortado por el enemigo su comunicación con la provincia. Teodoro de Croix le autorizó a volverlo a Tubac, y a remover cualquier otro presidio si lo considerase necesario. ${ }^{173}$ Apaches, seris y pimas atacaban unidos, en junio, Calabazas y el rancho del Ocuca, causando ocho muertes y grandes destrozos. ${ }^{174} \mathrm{La}$ inquietud del comandante llegaba al límite cuando incluso se receló un alzamiento de los ópatas, afortunadamente evitado por Anza, que oyó las quejas de sus jefes. ${ }^{775}$ En agosto, Tucson, San Ignacio, Terrenato y Guaymas eran atacados por apaches y seris. Las hostilidades de éstos impedian realizar campaña contra aquéllos. ${ }^{176}$ En julio, ciento cincuenta hombres mandados por el capitán de Terrenate, Trespalacios, habían actuado contra los gileños, pero Teodoro de Croix había de lamentar después que la campaña de esta fuerza había debilitado las guarni-

I70 Anza a T. de Croix. Horcasitas, 23 de nayo de I777. Ibid.

i7 T Te Croix a Anza. México, ig de julio de iz77. T. de Croix a Gálvez. México, 25 de junio de 1777 , núm. 60 .

I72 T. de Croix a Gálvez. México, 26 de julio de I77\%, núm. 72. Ibid.

I73 T. de Croix a Gálvez. Querétaro, 23 de agosto de 1777 , núm. 93. A. G. I., Guadalajara, 5 I 5 .

174 T. de Croix a Gálvez. Querétaro, 23 de agosto de 1777 , núm. 9I. Ibid.

I75 T. de Croix a Gálvez. Querétaro, 23 de agosto de 1777, nún. 94. Ibid.

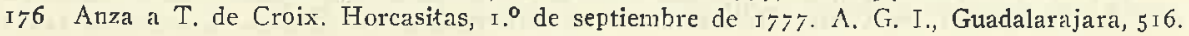


ciones interiores de la provincia en el momento mismo de producirse el rompimiento definitivo de los seris. ${ }^{\text {I77 }}$ En efecto, en junio, tuna rencilla entre el jefe seri del Pitic, Crisanto, y el capitán de los tiburones en el mismo pueblo, terminó con la muerte de éste y el saqueo de la casa de aquél. Cuando Crisanto volvió, todos los tiburones y casi todos los seris se marcharon del Pitic, salvo cinco familias, tomando al parecer el camino del Cerro Prieto. Ante la inesperada deserción de los sometidos, Anza declara que no hará ntievos requerimientos, pues la condescendencia anterior ha sido la causa de este suceso. ${ }^{178}$ Teodoro de Croix le autorizó a agregar veinte milicianos a cada presidio, ${ }^{179} \mathrm{y}$ en septiembre entraría por fin en acción la fuerza procedente de Nueva Vizcaya. ${ }^{180}$ Anza estaba decidido incluso a utilizar la tripulación del paquebot "San Carlos", que inwernaba en Guaymas, en un asalto a la isla del Tiburón, r8工 idea que aprobó Teodoro de Croix siempre que se realizase con seguridad de éxito. ${ }^{182}$ Entretanto, el inspector Rubio temía todos los males para Sonora y proclamaba su impotencia para propor-
cionar cualquier socorro. ${ }^{18} 8_{3}$

En noviembre, a petición del comandante general, el ex gobernador Crespo remitía un informe en el que se hacía constar cómo, en 1773 , de resultas de la campaña de Gálvez, él recibió la provincia en paz. En I775, un grupo de pimas altos se había unido a los apaches, sirviéndoles de guías. Pero ahora las cincuenta familias seris alzadas eran el peor enemigo y convendría desterrarlos de Sonora. En cuanto a los apaches, "todos saben que no tienen crías de caballos (hablo sólo de los fronterizos a Sonora), que cuando hacen algún robo de consideración, separan los que hallan buenos para su uso, o los llevan a cambiar por pieles a los apaches del Nuevo México, moquinos $u$ otras naciones, o se los comen, y esto último lo hacen igualmente con los demás". Por consiguiente, si se les estorbasen los robos, en un año vendrían a quedar a pie, es decir, inermes. Del mismo modo serían porque en su estéril territorio no podían subsistir sin el socorro de los esta-

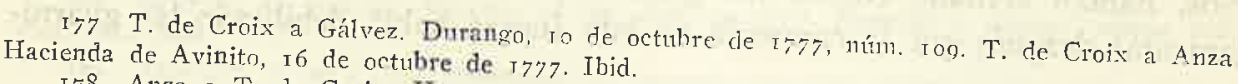
lajara, 5 I 5 .

I79 T. de Croix Anma.

taro, 23 de agosto de 1777 , núm. 90. Tbid. T. de Croix a Ge x777. T. de Croix a Gálvez. Querénúm. to6. A. G. I., México, 2462. Es entonces cuando se renunciarango, to de octubre de 1777, a Nuevo México. ISo Anza a T. de Croix. Horcasitas, ${ }^{\circ}$ de septienfbre de т7\%. A. G. I, Guadalajara, 516.

IS 2 T. de Croix a Anza. Avinito, i6 de octubre de de isร;. Mhid.

I 83 Rubio a $T$. de Croix. Chibuahua, 20 de octul)re de 
blecimientos españoles, a cambio de su trabajo. Crespo era, por lo demás, un nuevo voto contra las traslaciones de presidios efectuadas por O'Conor. ${ }^{181}$

La renovación de las hostilidades había por fuerza de repercutir en ía prosperidad de los yacimientos mineros. En vano se esforzaban Tueros y Anza por mantener despejado el camino de Cieneguilla a Horcasitas, procurando sobre todo resguardo para los conductores y compradores de víveres, y tratando de evitar se retirasen los trabajadores yaquis. Anza luchaba igualmente contra las argucias de los mercaderes, que aprovechaban el sistema de entrada mensual de las recuas de víveres en el real - necesario para obviar la inseguridad de la ruta - para tomarlos al precio que arbitrariamente quisieran imponer, de comín acuerdo, como habían hecho por mayo de 1776 , en que por cuatro pesos y medio de género adquirieron una carga de doce arrobas de harina que había venido desde más de cien leguas de distancia. Por es!e motivo estuvo entonces el real a punto de perecer, sin que Crespo se hubiese decidido a intervenir. Ahora de nuevo iban a faltar los víveres, pero Anza procuró se abasteciese convenientemente el real, poniendo a la vez una tasa razonable a los artículos, que beneficiase a todos. ${ }^{185}$ En junio tuvo que casi obligar a los labradores de Horcasitas para que introdujesen dos hatajos de víveres en el real, pues no habían acudido otros del resto de la provincia. Tueros tenía que luchar con la despoblación y con los desórdenes provocados por un establecimiento de juegos, cosa que tenía prohibida. ${ }^{186}$ Por fin puso allí escolta de ocho soldados de su presidio, y esperaba nueva bonanza de los placeres auríferos. ${ }^{187}$

Sin embargo, todavía setenta seris darían un fuerte asalto en el Tecolote a una recua de Cieneguilla. Pero perseguidos por el teniente de Tucson Don Mignel Urrea sufrieron abierta derrota y siete bajas, entre ellas el cabecilla pima Juan "el Cocinero", el mismo que había capitaneado el ataque de la Tortuga y principal causante de todos los daños padecidos en Pinería Alta en los tútimos cinco años, acción quie valió a este Urrea el grado de capi-

I84 Crespo a T. de Croix. México, 20 de noviewbre de т777. A. G. T., Guadalajara, 276

I 85 Tueros a $\mathrm{T}$. de Croix. Horcasitas, 23 de mayo de r 777. Anza a T. de Croix. Horcasitas, 23 de mayo de r777. T. de Croix a Gálvez. México, 26 de julio de 1777, núm. 77. A. G. I., Guadalajara, 5 I 6 .

I86 Tueros a T. de Croix. Altar, 8 de junio de r777. Anza a T. de Croix. Horcasitas, 30 de junio de 1777. T. de Croix a Gálvez. Querétaro, 23 de agosto de I777, núm. 92. Ibid.

I87 Tueros a Gálvez. Cieneguilla, I4 de cctubre de I777. Ibid. Tueros escribia mensualmente al ministro, comunicándole noticias iguales a las reseñadas. Véanse sus cartas de Altar, I3 de julio; San Ildefonso de Cieneguilla, I4 de agosto, y nuevamente Altar, i5 de septiembre de i777, en A. G. I., México, 2462. A la segunda de estas misivas acompaña otra de Fray Pedro Font, desde Tubutama, 2 de agosto de I777. con la que el benemérito franciscano enviaba a Gálvez su conocido mapa de los confines de Sonora, California y Nuevo México en el que señalan los derroteros de Anza y del P. Garcés; y otro mapa de las dieciséis jornadas entre Monterrey y el puerto de San Francisco y los Tulares. En 20 de marzo de 1778 contestó el ministro a Tueros que comunicase sus informes al comandante general. 
tán. ${ }^{188}$ Las hostilidades continuaban en Matape y San Marcial. Entre fines de 1777 y principios de I778, Anza capitaneó tres expediciones a Cerro Prieto apoyado por grupos de pimas, que fueron los más eficaces combatientes. Simultáneamente se recrudecieron los ataques de los apaches, sobre los pueblos ópatas en particular, pero el incidente más lamentable fue la presencia de los apaches en Altar, donde robaron toda la caballada, lo que muestra, aunquic sea caso excepcional, la extráordinaria dispersión de esta gran familia india. ${ }^{189}$

Corbalán informa a principios del nuevo año que el estado de Sonora es "el más triste". Pide doscientos dragones, y una batida en regla del Cerro Prieto, repudiando también la fatal dispersión de fuerzas de los presidios en escoltas y riajes del habilitado. Propone además el reparto de tierras a los indios reducidos, pues los rebeldes ahora sólo veían la miseria de los convertidos. Iso Para entonces ya el comandante general había obtenido de Bucareli el envío de la compañía de fusileros del capitán Fajes, que llegó a Alamos el 7 de febrero, y esperaba que la solicitud del general de los ópatas prosperaría y daría lugar a un nuevo y valioso presidio. ${ }^{191}$ Cieneguilla entraba en nueva abundancia protegida ya por dieciséis hombres de cuera, y el destacamento de San Ignacio auxiliaba a los corredores de ganado que buscaban en la Arituaba el aprovisionamiento de carne, sebo y manteca para la gente del real. ${ }^{192}$

Poco después partía Anza de Sonora, cumpliendo órdenes de Teodoro de Croix para acudir a las juntas de guerra convocadas en Chihuahua. El mando de las armas de la provincia recayó entonces en Tueros, a quien cupo

I 88 Lo propuso para este ascenso T, de Croix en carta a Gálvez de Valle de Santa Rosa, 15 de febrero de 7778 , núm. I6I. Le fue expedido el título en 25 de julio de $1778, y$ remitido con real orden de 28 del misimo. A. G. I., México, 2462.

I89 T. de Croix a Gálvez. Valle de Santa Rosin, i 5 de febrero de 1778 , núm, I52, con Extracto, y núm. I 56. Chilutrahua, 3 de abril de 1779 , núm. i 76 con Extracto. A.G.I., Guadalajara, 276. La tercera campaj̃a de Anza fue costeada por un minero, don Bernabé Angel de Toledo, que apoutó doscientos sesenta pesos, servicio que le fue agradecido. Ambos documentos también cn 4. G. I., México, 2462 y $246 \mathrm{I}$, respectivamente.

igo Corbalán a T. de Croix. Alamos, 28 de enero de 1778 . Ibid. Corbalán ya opinaba asi en este iltimo punto en informe a Bucareli de 1772 . Villa, Eduardo W., Compendio de Historia del Estado de Sonora. M'éxico, I937, págs. I 4 \$-1 56.

ig I $T$, de Croix a Gálvez. Valle de Santa Rosa, i5 de febrero de 1778 , núms. i50, I56 y I57; Chihuahua, 3 de abril de 1778 , 1uím. I73. A. G. I., Guadalajara, 276. Bucareli avisó en noviembre de 1777 el envio de la compañía de Fajes, que estaba en Sonora, con tres pagas adelautadas. Bucareli a Gálvez. México, 26 de noviembre de 1777 , núm. 3354. Le fue aprobado por real orden de 18 de mayo de 1778 . Teodoro de Croix dispuso luego que por la caja de Alamos se abonase cada ración al pie de siete pesos y media-considerándose una ración a los individuos je la clase de tropas, dos a los oficiales y tres al capitán-, como se hacía con los dragones en Nueva Vizcaya, en atención a la carestía de los víveres. T. de Croir a Gálvez, Valle de Santa Rosa, 5 de febrero de 1778 . Aprobado en orden de 18 de julio siguiente. A. G. I., México, 2462. 192 'T. de Croix a Gálvez. Valle de Santa Rosa, is de febrero de r778, nim. i 58 . A. G. I.,
Guadalajara, 267. 
la fortuna de recibir a los seris, que pronto empezaron a rendirse, como venía anunciándose desde octubre anterior. Las incursiones de los apaches en Fronteras y Cucurpe $^{193}$ y Saric llegan a un punto de extremada violencia cuando en abril de i 778 dan muerte al misionero de Tubutama Fr. Felipe Guillén con cuatro indios que lo acompañaban y cuando empiezan a atacar sistemáticamente las recuas y correos de los presidios de Santa Cruz, San Bernardino y Janos. Por entonces se rindieron a Tueros cinco familias seris, $y$ en mayo eran ochenta y tres los individuos sometidos de esta nación. ${ }^{194}$ Lo peor es que los piatos empezaban a dar muestras de intranquilidad. ${ }^{195}$

La sumisión de los seris había dado principio el 22 de abril, el mismo día en que había entrado la compañía de fusileros en Pitic. Fajes encontró casi arruinado el cuartel que había servido para las tropas de la expedición. Pero viendo ahora más peligro en la frontera norte, Anza dispuso que los fusileros pasasen al presidio de Santa Cruz, y que sólo la compañía volante y la de Horcasitas se ocupasen de los seris aún rebeldes. ${ }^{196}$ Poco después enviaba Teodoro de Croix a Don Roque de Medina para que procediese a revistar los presidios, misión que antes pensó confiar a Tueros. ${ }^{197}$

Los tiburones y tepocas pidieron la paz y ofrecieron formar pueblo en el Carrizal. Los seris seguían entregándose: ochenta más habían acudido a Pitic en septiembre de 1778 . ${ }^{198}$ Boquinete acaudillaba ahora a los pocos que aún seguían alzados, pues cincuenta de los suyos acababan de presentarse a Tueros aquel mismo mes. 199 Desgraciadamente, los apaches habían logrado cuatro golpes de importancia en los presidios de Santa Cruz y Altar, haciendo treinta y tres muertes entre soldados, milicianos y vecinos, $y$ dos prisioneros, y llevándose unas trescientas cincuenta caballerías. Entre los muertos figuraban el capitán y el sargento de Santa Cruz. En septiembre lograron los apaches, arranchados en la sierra de Arizona, otras sesenta bestias del situado de este presidio, al que hostigaban sin descanso. Tueros había conseguido la sumisión de seis nuevos seris, y se hallaba en buenas relaciones con los indios

I93 T. de Croix a Gálvez. Chihnahua, I. de mayo de I $_{778}$, núm. i99, con Extracto. A. G. I., Guadalajara, 276 .

I94 T. de Croix a Gálvez. Chihuahu1a, 29 de junio de I779, núms. 220, con Extracto, 221 y 226. Ibid.

I95 T. de Croix a Gálvez. Chihuahua, 29 de junio de 1779, núm. 222. Ibid

I 96 Detall de las tropas de Sonora, por Anza. Chihuahua, 20 de junio de 5778 . T. de Croix a Gálvez. Chihuahua, 29 de junio de 1778 , núms. 22r, 223 y 22.4. Ibid.

I97 T. de Croix a Gálvez. Chihuahua, 29 de junio y 27 de julio de 1778 , númıs, 218 y 241 . Ibid. La segunda carta, también en A. G. I., México, 2462.

I98 T. de Croix a Gálvez. Chihuahua, 27 de julio, 24 de agosto y 23 de septiembre de I778, núms. 243, 258 y 254. A. G. I., Guídalajaĩa, 276 y 275. Como de costumbre, se presentaban en pequeñas partidas. Tueros a Gúlvez. Forcasitas, i 6 de junio de 1778. A. G. 1., México, 2462.

I99 T. de Croix a Gálvez. Chihuahua, 23 de octubre de 1778, núm. 294, con Extracto. A. G. I., Guadalajara, 275 . 
tiburón. 200 Los tres últimos meses del año transcurrieron ya en tranquilidad por esta parte; los rendidos dieron comienzo a sus siembras de maíz, trigo y frijol, vigilados por un destacamento. En cambio, más de quinientas bestias fueron robadas por los apaches entre noviembre y diciembre, en ataques a San Bernardino, Santa Cruz y Tucson. Los castigos, después, eran de poca importancia, y las tropas presidiales sufrían frecuentes bajas: "La falta de instrucción y malas armas -escribe Teodoro de Croix ya en septiembre de I779- ocasionan estas desgracias; y jlabiendo mandado repartir las que acaban de llegar del nuevo armamento a la caja de los Alamos y recoger las del antiguo que usa la tropa de Sonora, a quien no pudo darse del primero que se remitió por el virrey porque no hubo bastante, espero que en lo sucesivo no sean tan frecuentes los insultos de los indios, ni tan felices sus tentativas". zor La defensa se vigorizaría con la llegada a la provincia de los dos piquetes de dragones que hasta entonces habían permanecido en Nueva Vizcaya, y cuya subsistencia en las provincias internas había Don Teodoro procurado mostrar como necesaria, y logrado por real orden de 23 de mayo de I779. ${ }^{202}$

Desde principios de I779, empezaba Teodoro de Croix a interesarse po: la ocupación del Colorado, poniendo en ejecución la real orden de to de febrero de $I 777$, que disponía el establecimiento de misión con el consiguiente resguardo de tropa entre los yumas. ${ }^{203}$ Palma y sus compañeros llegaron de regreso a Horcasitas el 23 de mayo, y continuaron viaje con Tueros hasta Altar, habiendo insistido de nuevo en sus demandas. 204 Cuatro hombres del presidio de Tucson escoltaron a Palma y sus compañeros desde Altar al río Colorado, trayecto en que invirtieron veintiséis días, permaneciendo luego con ellos otros ocho. Entre los yumas encontraron viviendo a un español de Tubac, llamado Peña, cuyos móviles al obrar así no se indican. z'os Noticioso por Tueros de la conveniencia de atender a los deseos de los yumas, le ordenó el comandante general, en 5 de febrero de 1779 , enviar al Padre Garcés con otro religioso y una escolta para que fundasen la misión, lo que en septiembre se había ejecutado así. ${ }^{206}$

\footnotetext{
200 T. de Croix a Gálvez. Chihuahna, 30 de noviembre de $177 S$, núm. 306, con Extractn.
G. I., Guadalajara, 270.

A. G. I., Guadalajara, 270 .

$201 \mathrm{~T}$. de Croix a Gálvez. Chihuahua, 28 de diciembre de 1778,23 de enero y 22 de febrero de 1779 , núms, 324,336 y 359 con Extractos. Ibil. T. de Croix a Gálvez. Chihuahua, 27 de setiembre de 1779 , num. 442 , con Extracło. A. G. I., Guadalajara, 27I. Taltan extractos entre
febrero y setiembre de este año.

202 A. G. I., México, 2464.

203 T. de Croix a Gálvez. México, 26 de mayo de I $77 \%$ núm. 51 , Bucareli a Gálvez.
México, 27 de mayo de 1777 , núms. 2-86. A. G. I., Guadalajara, 5 I6.

204 T. de Croix a Gálvez. México, 26 de julio de 1777, núm, 82. Tbid.

205 Bucareli a Gálvez. México, 26 de setiembre de I777, 11ún. 3226. A. G. I., México, 2462. 206 . T. de Croix a Gálvez. Ariz.pe, 23 de abril de I 9 So, núm, 505. A. G. I., Guadalajara, 5 I7.
} 
La provincia, finalmente, recibiría algún incremento con la llegada de la colonia catalana que condujo Don Juan Pujol. ${ }^{207}$ Corbalán continuaba sus medidas para el saneaniento de las rentas; en 1778 había tomado algunas para destruir el tabaco llamado macuchi, y admitió la solicitud de dos mercaderes que deseaban despachar dos canoas para el buceo de perlas en el golfo. 208

El 3 I de julio de I779, cuando Don Jacobo Ugarte tomó posesión del mando de las armas de Sonora, ${ }^{209}$ los problemas defensivos de esta provincia se habían simplificado y allanado en gran manera.

\section{Tres años de indecisión en Nuevo México}

Llegado Teodoro de Croix a la capital del virreinato, hallóse las repetidas instancias de Don Pedro Fermín de Mendintreta, que solicitaba el relevo del gobierno de Santa Fe. Croix comprendía la necesidad de velar por aquella provincia, aunque no contribuyese como las demás al erario. Entendía ser precisa la ordenación de las poblaciones dispersas, mal defendidas, repoblar las del Alamillo, Socorro, Senecú y Sevilleta, y facilitar armas y caballos para formar compañías milicianas. Teodoro de Croix creía todavía posible establecer en Robledo el destacamento que indicara el reglamento de I772. ${ }^{210}$

Ciertamente la provincia necesitaba ayuda. De mayo a septiembre de 1777 tan sólo padecieron los vecindario de Nuevo México sesenta y nueva muertes ya diecocho prisioneros causados por apaches y comanches, que además robaron o mataron más de mil doscientas cabezas de ganado, sumando sólo aquellos robos cuya cuantía consta documentalmente. En algunas ocasiones se presentaron gruesas particlas de enemigos, como ocurrió en Taos, atacado por ciento veinte conanches el i 6 de julio, cuando cuatrocientos comanches descendieron hasta Alburquerque e Isleta, hecho en sí significativo, causando el 26 de agosto enormes destrozos. El año I 778 pasó con las habituales alarmas de asaltos de los comanches y robos de los apaches. Aquéllos aparecían en grupos de treinta o cuarenta —alguna vez llegaban hasta cien- y atacaban Galisteo, Pecos y la región circundante. Estos causaban pequeños aunqute continuados daños. ${ }^{2 \text { r }}$ Esto empuja al comandante general a escribir:

207 Sólo marcharon nueve familias con treinta personas. Pujol decía haber hallado minas en Upanguaymas y junto a Pitic. La documentación de esta empresa, en A. G. I., Guadalajara, 403. 208 T. de Croix a Gálvez. Chihuahua, 30 de noviembre de 1778 , núms. 3 I o y 3 I I. A. G. I., Guadalajara, 275 .

209 Informe general de $T$. de Croix, de I 78 . Artículo 285.

żо T. de Croix a Gálvez. México, 26 de febrero de I 777, núm. I7. A.G.I., Guadalajara, 5 I 6.

2 I I Mendinueta a $T$, de Croix. Santa Fe, 9 de setiembre de r777. Ibid. T. de Croix Galvez. Valle de Santa Rosa, is de febrero de I778, núm. I52; Chihuahua, r. ${ }^{\circ}$ de mayo de I 778, núm, 199. A. G. I., Guadalajara, 276. 
"los comanches, que pelean como hombres, matan y mueren en sus campañas; pero el apache, valiéndose de sus cautelas y traiciones, ejecuta impunemente los daños, va consiguiendo la ruina del país con repetidos robos y muertes, y yo no aseguro las que de ellos se supone". La fuerza de los apaches, necesitados de alguna ayuda para resistir a las armas españolas, fue incrementada en este tiempo por la alianza de los navajos, a los que Mendinueta consideraba enemigos encubiertos, ${ }^{212}$ y contra los que el gobernador había movido a los yutas. ${ }^{213}$ Los apaches entraron en la provincia por el intervalo existente entre Socoro y Acoma, Laguna y Ziñi, y así lograron el contacto con los navajos. ${ }^{214}$

Mendinueta proponía erigir un presidio en Taos, que frenase a los comanches, según tenía expuesto desde I772, de modo que el de Santa Fe tuviese las manos libres para actuar contra los apaches. Pero íltimamente venía también a solicitar aún otro presidio en el antiguo pueblo de Socorro, a cincuenta y cinco leguas de Santa Fe, y doce al sur de Sabinal, donde debería ponerse cincuenta presidiales y cien familias. A cuarenta leguas der sudeste de dicho pueblo, la sierra Blanca era refugio habitual de los apaches. y tanto los de esta sierra como los del Gila arranchaban en varias épocas del año en las proximidades de Socorro. ${ }^{215}$ Por entonces, Mendinuteta se veía obligado a poner doce hombres del presidio de Santa Fe en Galisteo de abril a octubre, para precaver los ataques de los comanches, ${ }_{216}$

sas juntas de guerra tenidas por Croix en Chihuahura con asistencia df. Mendinueta y de Anza - a quien sustituia entretanto en el mando de la pro. Evincia Don Francisco Trébol Navarro, alcalde mayor y capitán a guera de Alburquerque- fueron ocasión de revisar diversas memorias y documentos antiguos, o preparađos con este motivo, entre ellos el de los "Desórdenes que se advierten en el Nuevo México", que claramente expone los defectos de la mala disposición de las poblaciones españolas, los empeños de los indios labradores explotados por los comerciantes, la carencia de toda industria ventajosa, la crueldad de algunos alcaldes mayores y los trastornos que ocasionaba el uso de monedas imaginarias. ${ }^{21}$ Teodoro de Croix pudo ordenar

212 Worcester da como segura la alianza navajo-apache en 1777 , movidos los primerns por uno de sus jefes, Ilamado Antonio el Pinto. Worcester, The Navaho during the Spanirh regime in New Mérico. N. M. H. R., XXV, 2, abril 195 I, I0I-II8. pági. II3.

213 Testimonio de las juntas de guerra de Chilunhua, i de junio de iz78. A. G. I., Guadalajara, 276 .

214 Mendinueta a $T$. de Croix. Santa Fc, 3 de noviembre de i 777 . Ibid.

2 I 5 Ibid.

2 I6 Detall de la tropa de Nuevo México, por Mendinueta. Chilnuahna, 22 de junio de 1778 . Ibid.

2 I 7 "Desórdenes que se advierten en el Nuevo México y medios que se juzgan oportunos a repararlos para mejorar su constitución y hacer feliz aquel reino". En 49 artículos, sin fecha; copia certificada por Antonio Bonilla en Chihuahua, 27 de julio de I77S. A. G. I., 
a Anza, cuando por fin éste partió hacia Santa Fe, estudiase la solución de todos estos problemas y concluyese un padrón de la provincia, remitiendo igualmente un mapa de cada jurisdicción. ${ }^{218} \mathrm{Del}$ mismo modo le encargó la formación de milicias. 219

Más de inmediato hubo Anza de atender al arreglo de las milicias de El Paso, tarea en la que habían fracasadó los tenientes de gobernador Daroca, Arrieta y Muñiz. Aquél era único punto de contacto de Nuevo México con Nueva Vizcaya. El comandante general estaba persuadido de que el establecimiento del destacamento del Robledo facilitaría la comunicación de aquella provincia con Sonora y Coahuila. ${ }^{220}$

Anza, que llevaba consigo los mil quinientos caballos destinados a Nuevo México, dejó en E1 Paso ciento cincuenta y siete para el vecindario, con alguna pólvora, organizó la vida del pueblo, de modo que siempre hubiera un grupo sobre las armas mientras los demás trabajaban en sus labores y comercio, y puso la primera piedra para una posible nueva prosperidad del lugar al persuadir a los pobladores para que condujesen sus vinos a Sonora a partir de febrero del año siguiente. Para resarcir al erario de los gastos causados en la implantación de las milicias, creó Teodoro de Croix un impuesto sobre los vinos y aguadientes de El Paso que se expendían en Chihuahua, más el dos por ciento de alcabalas sobre las ventas de sus caldos y frutos, disposiciones que fueron desaprobadas por real orden de 25 de junio de $178 \mathrm{I}$, temiendo fuesen perjudiciales al vecindario. ${ }^{221 .}$

En los meses siguientes se registraron algunas tentativas de paz por parte de los capitancillos apaches vecinos de El Paso. ${ }^{22 z}$ Mientras, Anza informaba de la imposibilidad de guanercer Robledo y de la conveniencia de poner destacamento en Socorro, según aconsejara Mendinueta. 223 Teodoro

Guadalajara, 267. Seguramente fue el propio Bonilla el autor de este papel, que fue "preparadc en la secretaria de la comandancia general" segín se dice en él. En otras ocasiones, también Croix hizo circular consideraciones o proyectos elaborados por Bonilla, ocultando su autor.1776, en Villagrá, Historia de la Nueva México". fechado en Santa Rosa, 3 de setiembre de III, 82-95. Copia de ambos documentos en el British Museum, reimpresa en México, r900; apéndice 2 I8 T. de Croix a Anza, Chihuahna, 22 de julio de Mss. room, Additional mas. 17653. 2 I9 T. de Croix a Gálvez. Chihuahu, 22 de julio de I778. A. G. I., Guadalajara, 267. Guadalajara, 270.

220 T. de Croix a Gálvez. Chihuahua, 27 de julio de $778^{\circ}$ núm

$221 \mathrm{~T}$. de Croix. a Gálvez. Chihuahua, 23 de julio 1778 , núm, 236. A.G.I,Guadalajara, 267. jjara, 267 y 275. Real Orden de 25 de julio de 1778 , núm, 298. A. G. I., Guadalade diciembre de 1778 . Anza a T 25 de junio de $178 \mathrm{I}$. T. de Croix a Gálvez. Chihuahua, 28 dalajara, 267 . 222 T. de Croix a Gálvez. Chihuahua, 23 de enero y 22 de febrero de I779, con Ex-
tractos. A. G. I., Guadalajara, 270. lajara, 267 . 
de Croix decidió esperar a que Anza efectuase la expedición proyectada de Santa Fe a Sonora para tener más elementos de juicio. El propio Anza, en noviembre de 1779 , comunicaba al comandante general otras noticias de extraordinario interés, a saber: que los indios del Mioqui, movidos por el hambre de dos años de sequía, empezaban a abandonar sus pueblos, inter. nándose por bosques y monte en busca de sustento y vendiendo sus hijos para proporcionarse algo que comer. Anza, que había emprendido ya campaña contra los comanches, había enviado al Padre Fray Andrés García, misionero de Zuñi, a buscar a los moquinos, sabiendo que muchas familias habían resuelto acudir a la provincia, pero los navajos les habían impedido e! paso. ${ }^{224}$

Eintre agosto y setiembre había reailizado Anza su primera campaña desde Nuevo México. Con seiscientos hombres - soldados, milicianos y auxiliares- más doscientos yutas y jicarillas, logró dar un golpe en que destruyó a los comanches ciento veinte tiendas, causándoles la muerte de su capitán Cuerno Verde, de un hijo suyo, de su teniente general Aguila Volteada, del Pujacante o sacerdote y de ochenta y dos individuos más, tomándoles treinta y cuatro prisioneros y quinientas bestias. En cambio, cuatrocientos gileños cayeron sobre Jarales y Belón, junto a Alburquerque, e hicieron veinticuatro muerte y varios cautivos, y destruyeron mil quinientas cabezas de ganado lanat y doscientas ochenta reses. 225 De esta manera, concluyendo el año con algunos ataques comanches a Taos y Pecos, ${ }^{226}$ el gobierno de Anza en Nuevo México se ha abierto con una situación súmamente crítica, de la que saldrá triunfante habiendo sido el pacificador de la pradera.

Nuleva Vizcaya cambia de fisonomía

Profundamente habían por fuerza de afectar a Nueva Vizcaya las disposiciones con que Teodoro de Croix alteró el sistema defensivo creado por O'Conor. Sus primeras instrucciones a Rubio detallaban algunas operaciones de vigilancia y limpieza de la frontera, pero abierta la puerta del Bolsón. y debilitada la fuerza de contención por el envío de una compañía a Sonora y Coahuila, pronto hallóse la provincia en apurada situación de estricta defensa ante la doble amenaza de la oleada apache y de las actividades de los

224. Anza a T. de Croix. Santa Fe, I. de noviembre 1779. T. de Croix a Gálvez. Arizpe, 23 de febrero de izSo, núm. 476. A. G. T., Guadalajata, 517.

225 T. de Croix a Gálvez. Arizpe, 23 de enero de 1780 , núm. 46 r con Extracto. A. G. I., Guadalajara, 27I. T. de Croix a Gálvez. Arizpe, 23 de tnero de 1730 , nún. 462 , con carta y diario de Anza. A. G. I., Guadalajara, 278.

226 T. de Croix a Gúlvez. Arizpe, 23 de julio de I 780 , ním. 542, con Extracto, A. G. I. Guadalajara, 267 . 


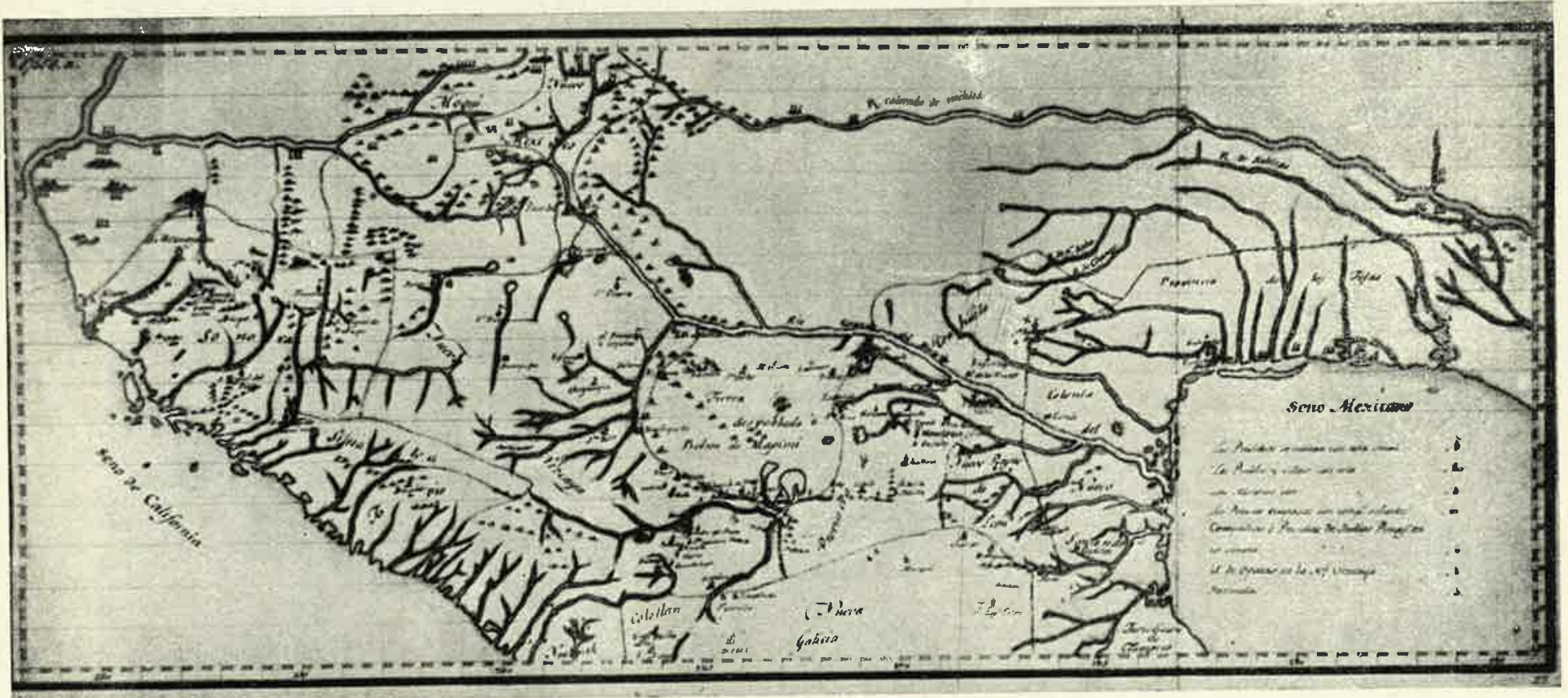

115. Mapa general de las provincias internas continentales. ¿1787? 


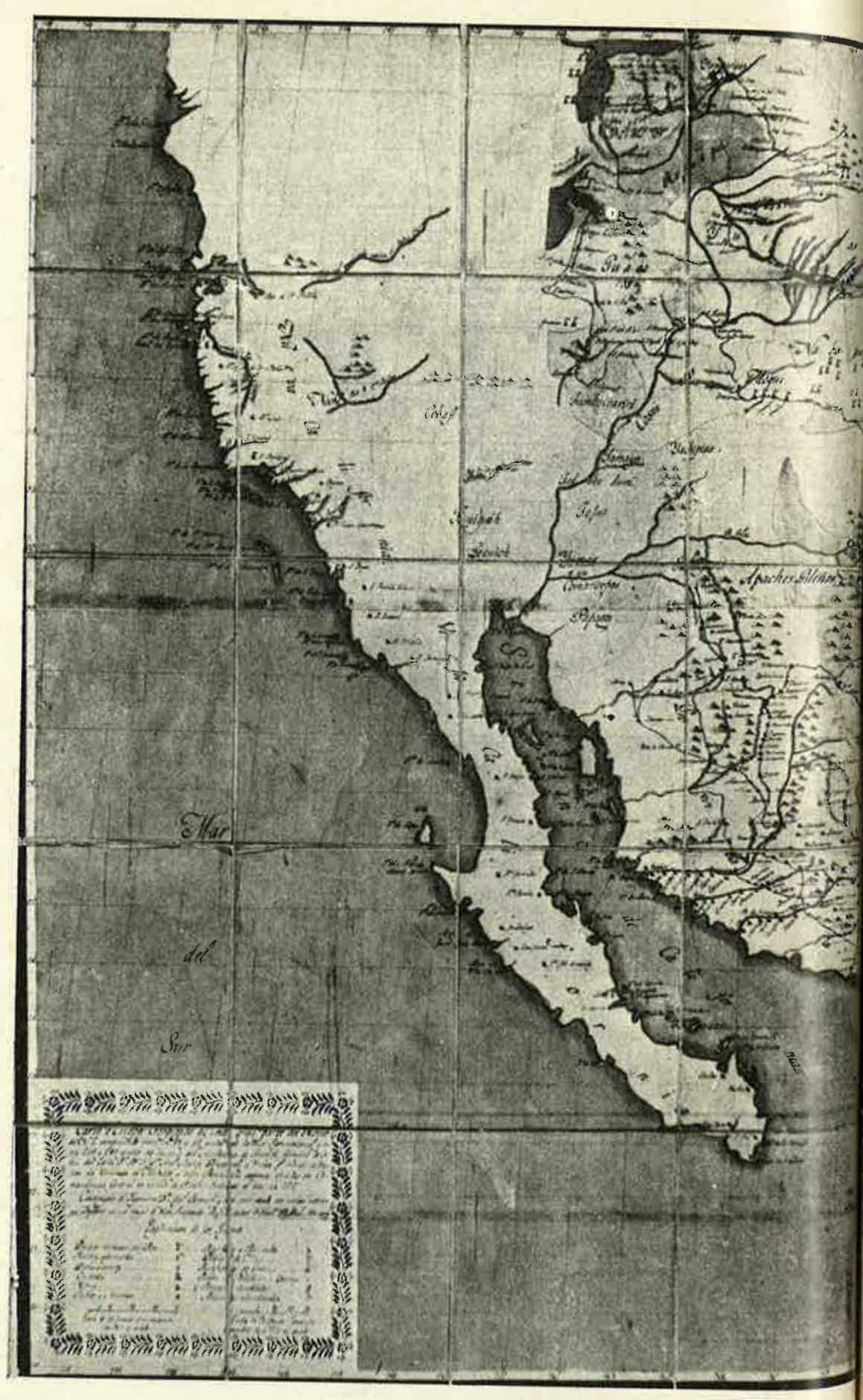

116. Mapa del norte de ta Nue

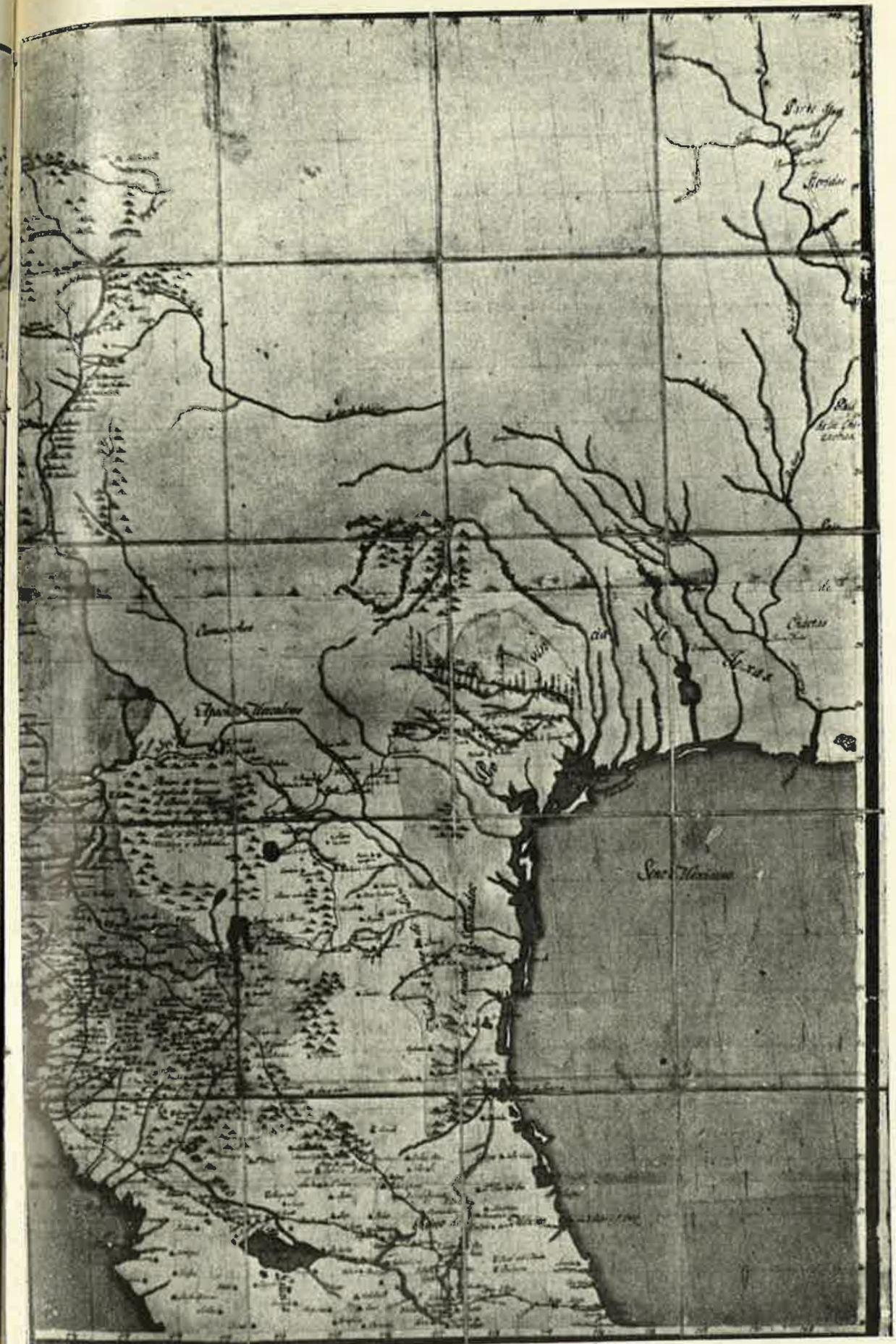

España, por Mascaró. 1777. 


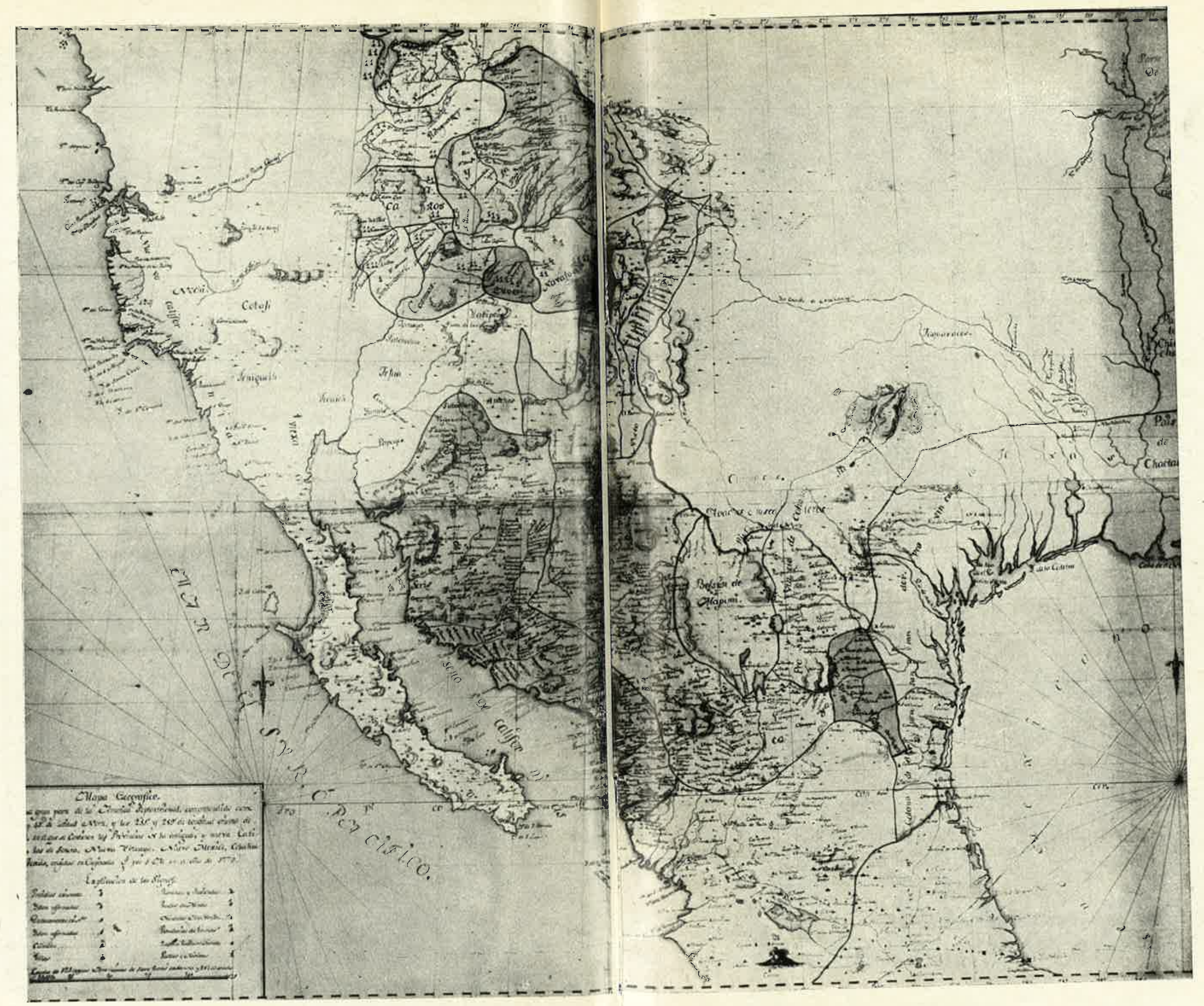

117. Mapa del norte de Nueva España, copia del de Mascaró. 



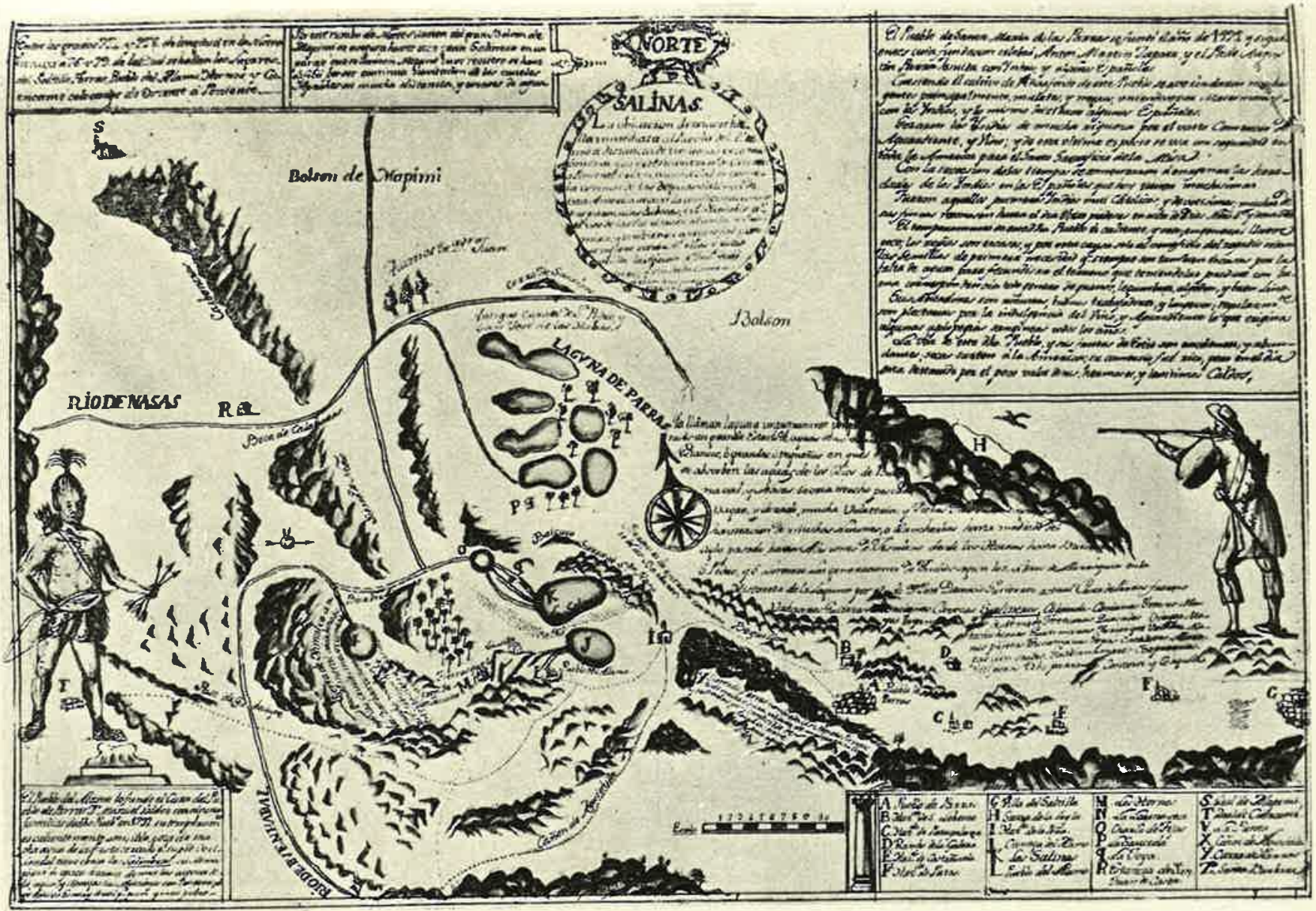

119. Otra versión del mapa de Núñez de Esquivel. 1787 . 


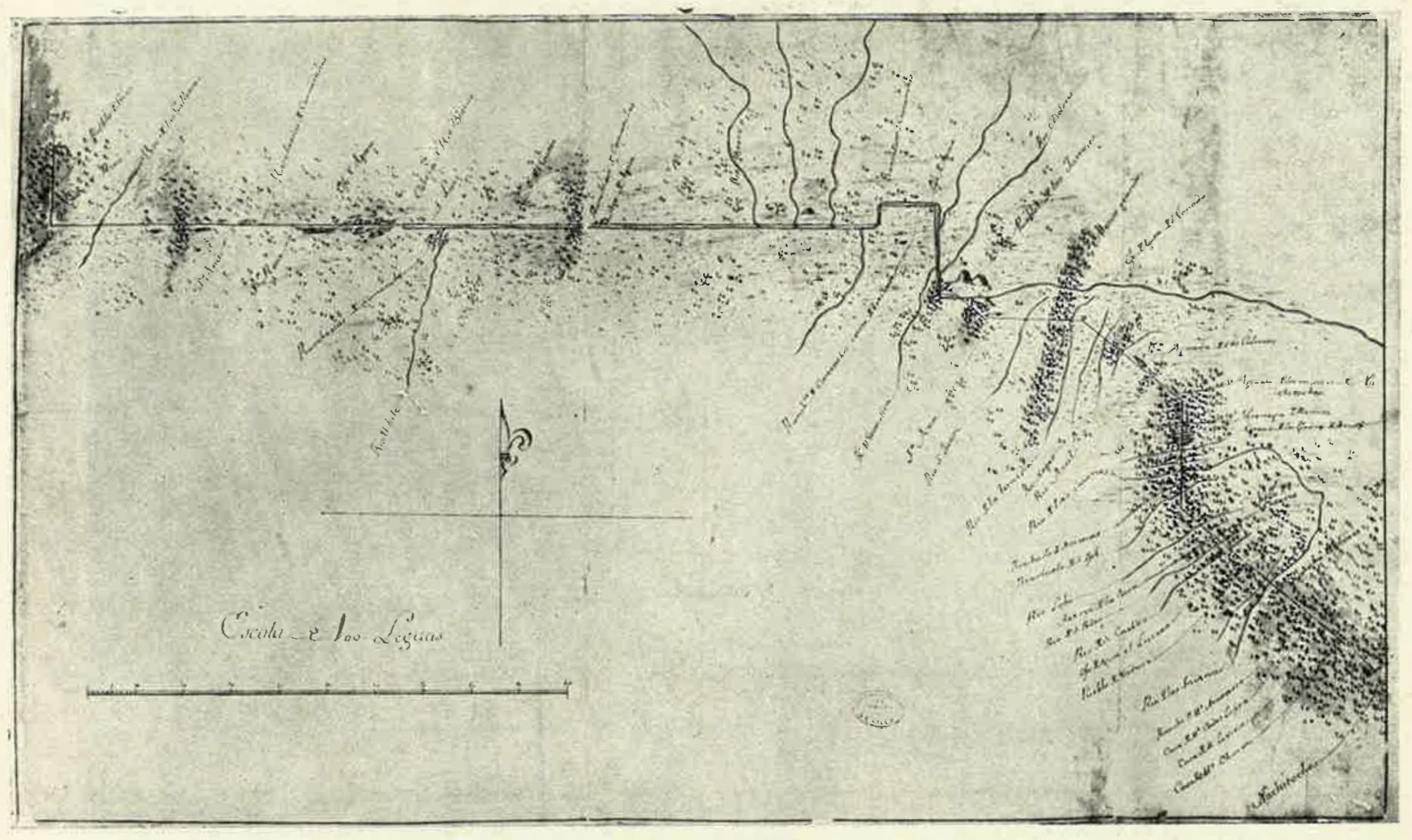

120. Itinerario de Pedro Vial, de Santa Fe a Natchitoches. 1788. 


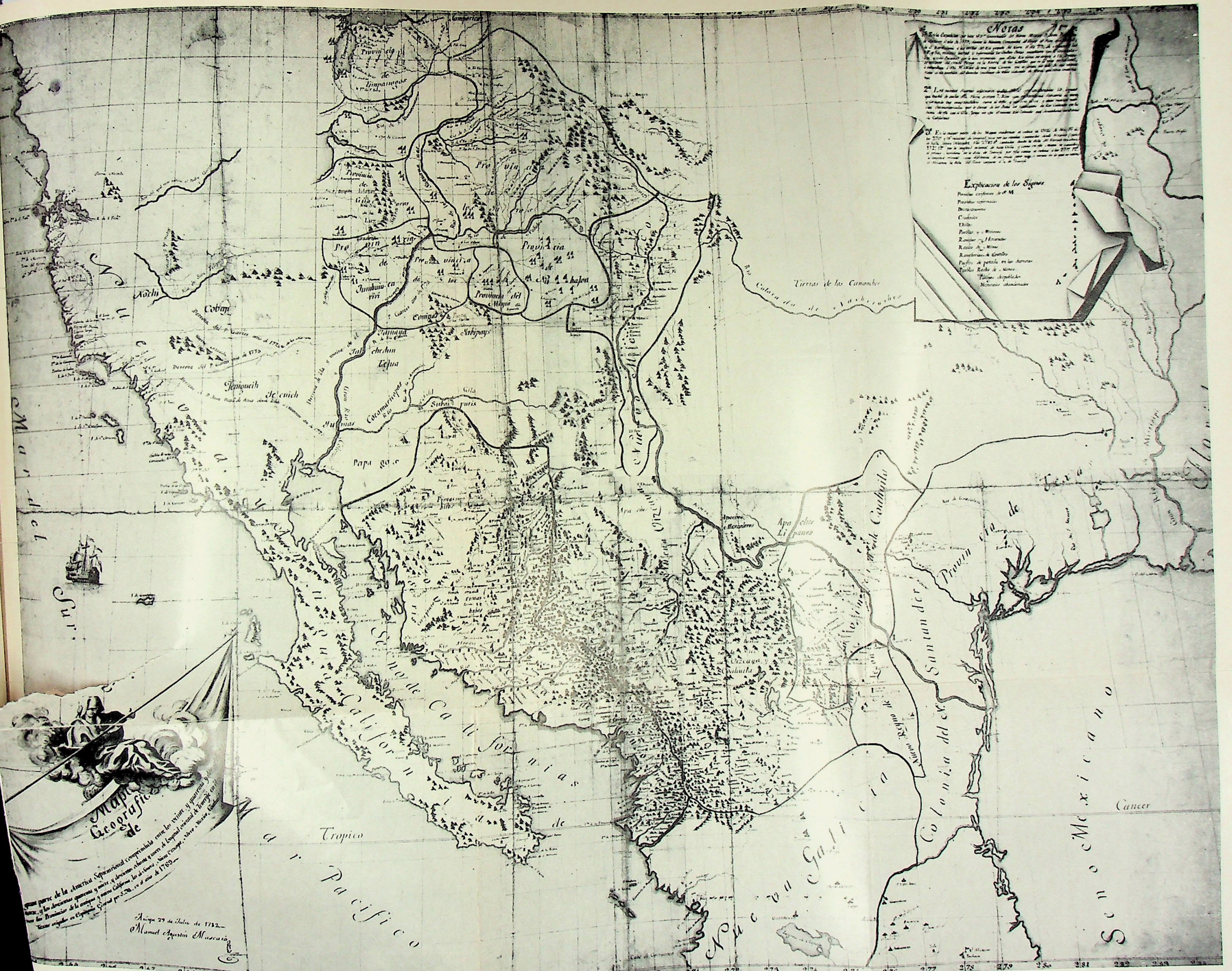




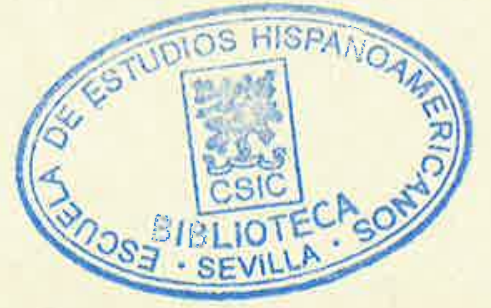


grupos de tarahumaras infidentes. La estancia del Río. Florido, el rancho de Santa Rosalía, junto a Parral, el valle de Ciénaga de los Olivos, la hacienda de Canutillos, experimentaban la destructora fuerza de las incursiones de los tarahumaras alzados que se refugiaban en las sierras del Bolsón. ${ }^{227}$ Los apaches, en cambio, presionaban vigorosamente sobre San Buenaventura, Cusihuiriáchic y Babonoyaba al norte, pero infestaban también el Bolsón varias veces batido por las tropas de la primera compañía volante de Don Domingo Díaz. ${ }^{228}$ Junio de 1777 fue el momento de los más terribles asaltos a los ranchos y haciendas del fondo del Bolsón, en la zona de Mapimí y del Nazas, sobre las tierras del marquesado de Aguayo. ${ }^{229}$

Consiguientemente, es ahora cuando Teodoro de Croix dispone la colocación de un destacamento de dragones en el Nazas y la distribución de armas a los vecinos, criados y dependientes de las localidades amenazadas, ${ }^{230}$ dando el mando de todos los puestos defensivos del costado oriental de la provincia a Don Nicolás Gil. ${ }^{231}$ Poco después, la inmediaciones de Chihuahua y la zona de San Buenaventura, Carrizal, San Eleazario, El Paso y Junta del Norte se veían tan hostilizadas como en la época de Bernardo de Gálvez. ${ }^{232}$ Sólo la tropa de Janos parecía luchar con ventaja contra los enemigos de las sierras Florida y Mimbres. ${ }^{233}$

La gravedad de la situación se hace patente en el estado que el gobernador Don Felipe Barri pasó a Gálvez mostrando que desde I 77I a fines de 1776 Nueva Vizcaya había padecido la muerte de mil novecientos sesenta y tres habitantes y el cautiverio cle ciento cincuenta y cinco; se habían despoblado ciento dieciséis ranchos y haciendas y habían sido robadas unas sesenta y nueve mil cabezas de ganado mayor y menor. Barri atestigua al fin de esta relación que desde la fecha del estado - 30 de junio de 1777 - las hostilidades habían ido en aumento. ${ }^{234}$ Sin embargo, a fin de año se había logrado dar algún castigo a los agresores, aunque a costa de inutilizar las

227 Bucareli a Gálvez. México, 24 de febiero de I777. núm. 2750. T. de Croix a Gálvez. México, 24 de marzo y 26 de abril de 1777 , núm. 3 I y 42 , con Extractos. A. G. I., Guadalajara, $5 \pm 6$.

228 Extracto de noticias, México, 26 de abril de 1777 . Ibid. Diario de Díaz. Río Florido, 3 I de mayo de I777. A. G. I., Guadalajara, 5 I 5 :

229 E1 alcalde mayor y vecinos de Mapiní a Barri. Mapini, 24 de junio de I777. Barri $\Omega$

T. de Croix. Durango, 28 de junio y 5 de julio de I777. Ibid.

230 T. de Croix a Barri. México, I6 y 28 de julio de 1777 . Ibid.

23 I T. de Croix a Rubio. México, 9 de julio de I777. Ibid.

232 T. de Croix a Gálvez. Querétaro, 23 de agosto de I777, núm. 95. A. G. I., Guadalajara, 5I5. T. de Croix a Gálvez. Durango, to de octubre de I777, núm. io , con Extracto. A. G. I., Guadalajara, 5 I6.

233 T, de Croix a Gálvez. Durango, 10 de octubre de 1777, núm. Iog. Ibid. 234 Barri a Gálvez. Durango, 8 de noviembre de i777, con Extracto. A. G. I., Guada-
lajara, 274. 
caballadas de las compañías volantes. ${ }^{235}$ La hacienda del Carmen, de ricas minas, a cuarenta leguas de Chihuahua, se mantenía gracias a la actividad de los treinta escolteros que sostenía su dueño el bachiller Don Francisco Ireneo García y que tenían a raya a los apaches, no sin esfuerzo. ${ }^{236}$

En el momento siguiente, a principios de $\mathrm{I} 778$, los apaches de la sierra Blanca y del Gila solicitaron la paz en Janos, San Eleazario y Jil Paso, y aun en Alburquerque, movidos ahora a tal actitud por la guerra que les hacían los comanches. Rubio y Croix se mostraron inflexibles, previniendo 120 se admitieran tales paces y se proctrasen las de los comanches, no clándose a los apaches que se hallase en el campo otro partido que el de rendirse a discreción. ${ }^{237}$ La pugna se inclinaba en aquel momento a favor de los españoles en el norte, mientras que tarahumaras o apaches catsaban numerosas muertes en la Estancia, Torreón, Parral y Real del Oro. Por eso llegó ahora el momento de los clamores de Parral, que veéa los enemigos arranchados en las vecinas sierras de Santa Bárbara, que su mulada y caballada sufría enormemente con los robos y que la que quedaba custodiada de noche en los corrales perecía de hambre, con el consiguiente detrimento de las labores mineras. ${ }^{23} 8$

Iistando, pues, insegura la victoria, accedió el comandante general a um último intento de atracción de los apaches, aunque toda la oficialidad afirmaba conteste que el único móvil de éstos era el poder asegurar a sus familias mientras que salían a hacer la guerra a los comanches y a continuar sus incursiones contra las provinias, disculpándose unos con otros. La "prueba de la mala fe de los apaches" se haría bajo las condiciones de reducirse éstos a pueblos, admitir misioneros y dar principio a las siembra. Si los indios las aceptaban "conoceré --escribía el comandante-- cuue la llegado la hora feliz destinada por el Altísimo para su milagrosa reducción". Si no, inmediatamente daría comienzo a una acción definitiva contra ellos. ${ }^{239}$ Los apaches, desde luego, no aceptaron las condiciones y sólo se avinieron a efectuar un canje de prisioneros. ${ }^{240}$ Las hostilidades no se habían interrumpido en el norte, aunque sí parecían disminuir; ${ }^{24 I}$ en cambio, en el Bolsón crecía la alarma y Teodoro de Croix y Barri precipitaban las medidas defensivas. ${ }^{242}$

235 T. de Croix a Gálvez. Coahuila, o de diciembre de 7777 , núm. Ifr, con Extracto.

A. G. I., Guadalajara, 5 I6.

236 T. de Croix a Gálvez. Hacienda de Patos, 24 de novienbre de r77y, núm. szł. Ibid.

$237 \mathrm{~T}$, de Croix a Gálvez. Valle de Santa Rosa, is de febrero de iz7S, núm. I49,

A. G. I., Griadalajara, 276 .

${ }_{23} 8 \mathrm{~T}$. de Croix a Gálvez. Valie de Santa Rosa, is de febrero de 7776 , ním, 152; Chihuahua, 3 de abril de I778, núm. I 76 con Extractos, El vecindario de Parral a T. de Croix. Parral, 6 de abril de 1778 . Ibid.

239 T. de Croix a Gálvez. Chihuahua, 3 de abril de 5778 , núm. i74. Ihid.

240 T. de Croix a Gálvez. Chihuahua,.$^{\circ}$ de mayo de 1778 , núm. 200 . Ibid.

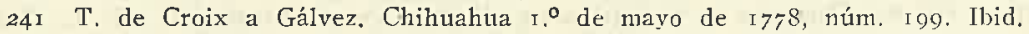

$242 \mathrm{~T}$. de Croix a Gálvez. Chihuahua, I. ${ }^{\circ}$ de mayo de 1778 , núm. r97. Ibid. 
La línea de protección se estabilizó al oriente, en Santa Rita, Cerro Gordo, Gallo, y Mapimí; al norte, en Babonoyaba, Saux - estos destacamentos habían estado antes en la Noria y Salitre-, San Jerónimo, Bachimba y Chihuahua. ${ }^{243}$

En el esquema defensivo de Croix la primera línea la constituian los presidios de Janos, San Buenaventura, Carrizal y San Eleazario (primera división); Príncipe, Norte, San Carlos y San Sabá (segunda división), con un total de seiscientos hombres de tropa presidial, ligera y auxiliares. La segunda línea llamada de poblaciones la cubrirían las compañías volantes con quinientos veinte hombres en Guajoquilla, Santa Rita, Gallo, Mapimí, Conchos, Cerro Gordo y Chihuahua. Por uiltimo, las tres compañías milicianas que constituían la "Legión del Rey", tomarían posiciones en Aguachila, San Juan de Casta, Pelayo, Guajoquilla, Santa Rita, Ancón de Carros, Julimes, Chorreras, Agua Nueva, Valle de Santa. Clara y las Cruces o Namiquipa. ${ }^{244}$ Este plan, presentado por Croix en las juntas de guerra de Chihuahua, entraba en vías de realización cuando el mismo comandante podía anunciar a fin de agosto que la tropa ligera de la provincia estaba ya casi totalmente instruida y habilitada para marchar a Janos, Norte, San Carlos y San Sabá, y que al mes siguiente estaría lista la de San Eleazario y Carrizal, y en octubre la de San Buenaventura y Píncipe; la otra tarea paralela consistía en arreglar y dotar de eficacia a las cuatro compañías volante que decía haber encontrado casi inútiles. ${ }^{245}$

Poco después daba principio a la realización de su más caro proyecto. Con ocasión de hacerse necesaria la traslación del presidio de San Buenaventura, que se hallaba en lugar mal provisto de agua, pastos y leña al paraje de Chavarría, traza el boceto del núcleo de poblaciones que desea fundar en aquella región: San Juan Nepomuceno, adyacente al presidio que uná vez trasladado se llamaría de la Princeso; a diez leguas al oeste, el Valle de Casas Grandes; a espaldas del presidio, el Valle de San Buenaventura. En segunda línea repoblaría las misiones de San Pedro Namiquipa y las Cruces, cada una de las cuales podría tener trescientas familias. Pensaba que esto no gravaría al erario, porque la compañía del presidio daría más de tres mil pesos para los gastos del traslado, y en cuanto a las poblaciones las haría sacando dinero del impuesto sobre las armas y de los fondos de milicias. ${ }^{246}$

243 T. de Croix a Gálvez. Chihuahua, I. ${ }^{\circ}$ de mayo de 1778 , núm. 198. Ibid.

244 Estado de las tropas de Nueva Vizcaya. Chihuahua, 12 de junio de 1778. A. G. I., Gradalajara, 267 .

245 T. de Croix a Gálvez. Chihuahua, 24 de agosto de 1778 , nứm. 254. Ibid.

246 T. de Croix a Gálvez. Chihuahua, 2I de octubre de I778, 17úm. 297. A. G. I., Guadalajara, 270. T. de Croix a Gálvez. Chihuahula, 23 de noviembre de 1778, nún. 304. A. G. I., Guadalajara, 267. 
Al lado de los proyectos no faltaban los momentos de desánimo. Croix lamentaba la falta de caballos, la mala calidad de las armas, el poco espíritir y el comportamiento a veces hasta vergonzoso de la tropa, su incapacidad para actuar en terreno montañoso, su ignorancia y mal gobierno, su disnersión en mil tareas... Confiesa a poco el comandante general que después de haber cubierto todo el costado oriental de la provincia con: más de quinientos hombres, no había conseguido que se observasen sus disposiciones, y sólo se había recobrado algún ganado. ${ }^{247}$

Las hostilidades de los apaches continuaban ctrando ya parecían habei cerado los ataques dirigidos contra el fondo del Bolsón. En agosto fue pur primera atacado tun presidio, el de Janos. Las caballadas seguian siendo asaltadas, y también las recuas de mercancías, los viajeros, las pastorías. Pero a fin de año el parte de novedades nostraba un considerable progreso hacia la tranquilidad y la real orden de 7 de mayo de I 779 podía expresar que "ha tenido el rey el consuelo de ver que se van minorando las desgracias de sus amados vasallos". ${ }^{248}$ A fin de año Teodoro de Croix procedía a emitir todas las órdenes conducentes a la erección de las cinco poblaciones del noroeste que debían enlazar con las de los ópatas de Sonora. ${ }^{249}$

Finalmente, el esfuerzo desplegado por la tropa, por Teodoro de Croix y la oficialidad a sus órdenes no fue estéril. En la lucha, a la larga, siempre habría de ceder el invasor, más ágil en el ataque pero incomparablemente más débil en la defensa y en la potencia numérica, y para cuien la misma guerra no era sino el último recurso para la st1bsistencia. Perdido éste, sólo quedaba someterse o perecer. Así había ocurrido siempre, y últimamente con los seris de Sonora. Así ocurría ahora en Nueva Vizcaya. A principios de I779, los apaches volvieron a intentar la paz pulsada ya un año atrás. Los primeros en solicitarla fueron los mezcaleros, capitaneados por Patule, en el presidio de San Sabá. A Patule acompañaluan noventa indios de las rancherías situadas en las sierras del Carmen y de los Chizos e inmediatas. Poco después insistieron en su demanda, esta vez en el presidio del Norte, después de haber ?cudido tres veces Patule a San Sabá pidiendo la cabeza del jefe lipán Javierillo; sus proposiciones eran las de observar la paz desde el presidio de! Norte al valle de Santa Rosa, demolición del presidio de San Carlos, y auto-

247 T. de Croix a Gálvez. Chihuahua, 25 de octubre de i778, núm. 293. Jbid, Solıre el último punto Cfr. ' $T$. de Croix a Gálvez. Chihuahua, 29 de junio, 27 de julio y 24 de agosto de I778, núns, 220, 243 y 258, con Extractos. A. G. I., Guadalajara, 276. 'T. de Croix a Gálvez. Chihuahua, 23 de setiembre y 23 de octubre de $1 ; 78$, 1úms. 264 y 294 , con Extractos. A. G. I., Guadalajara, 275.

$248 \mathrm{~T}$. de Croix a Gálvez. Chihuahua, 28 de diciembre de 1778, núm. 324. Real orden de 7 de mayo de I779. A. G. I., Guadalajara, 270.

249 T. de Croix a Gálvez. Chihuahua, 28 de diciembre de 1778, nuin. 329. Tbid. 
rización para habitar con su gente entre San Sabá y Santa Rosa. Decía habe1 avisado a su hermano Bigote para que se adhiriese a las paces, pero se negaba a entregar rehenes. No se accedió, desde luego, a las condiciones de Patule, pese a lo cual, movidos sin duda por el temor a un enemigo para ellos menos deseable, los mezcaleros trataron las paces, que les fueron por fin admitidas en los presidios de la segunda división de las provincias, a mediados de 1779. ${ }^{250}$ No por ello desaparecieron los daños que se experimentaban en las jurisdicciones de Parral y San Bartolomé, ni menos aún los que causaban los gileños en la zona de 'Chihuahua. Tal vez por esta razón el propio Teodoro de Croix no era consciente de la importancia de aquel acontecimiento.

Por primera vez los apaches pactaban seriamente un cese de hostilidades en Nueva Vizcaya; un paso muy importante hacia la paz acababa de ser dado, aunque al comandante general le hubiera llevado a ceder, en buena parte, el pésimo estado de las caballadas. En septiembre dio a Don Manuel Muñoz instrucciones acerca de los mezcaleros. Sus jefes Patule, Alonso y Juan Tuerto habían pedido por fin ser establecidos en la misión de Peyotes, en Coahuila, con los julimeños y los sumas de El Paso, que les adiestrarían para entrar en vida más civilizada. Croix hizo nombrar a Patule y Tuerto capitanes a guerra; a Alonso, gobernador del poblado de San Francisco, y a otro cabecilla llamado Domingo Alegre, del de Nuestra Señora de Buena Esperanza, en que se asentaron. De esta manera volvían a entrar en contacto próximo y pacífico con los españoles los indios fugitivos de la Junta de los Ríos, los mezcaleros, a los que por este hecho no puede llamarse propiamente apaches $y$ con los que el teniente coronel Don Manuel Muñoz, cumpliendo órdenes de Teodoro de Croix, concertó las paces el 25 de octubre de 1779. ${ }^{251}$

En el orden interno, poco podía hacerse en las circunstancias del momento por el bienestar de la provincia. Las noticias acerca del moviniento de las minas son inexistentes y las pocas alusiones sólo hacen referenciá -en Parral y Mapimí- precisamente a las dificultades que acarrea la destrucción de las caballadas y muladas por el enemigo. La acción del gobernador interino teniente coronel Don Felipe Barri se advirtió en sus medidas repetidas veces tendentes a asegurar la defensa de Durango e impedir a las partidas hostiles la introducción por el valle de Nazas. La de Teodoro de Croix y su asesor Galindo Navarro, en cambio, se hizo sentir también en la prohibición que impusieron a Barri de seguir la costumbre de sus antece-

250 T. de Croix a Gálvez. Chihuahua, 23 de enero y 22 de febrero de 1779 , núm. 336 y 359, con Extractos. A. G. I. Guadalajara, 270. T. de Croix a Gálvez. Chihuahua, 27 de setiembre de 1779 , núm. 442 , con Extracto. A. G. I., Guadalajara, 271.

251 Informe general de $178 \mathrm{I}$, artículos 181 y 201-205. T. de Croix a Gálvez. Arizpe, 23 de mayo de 1780 , núm. 520. A. G. I,, Guadalajara, 278. 
sores de percibir determinadas cantidades anuales de los alcaldes mayores o tenientes de las veinticinco jurisdicciones de Nueva Vizcaya. He aquí la relación formada por el propio Barri de los justicias de la provincia y de las cantidades que contribuían al gobernador.

Teniente de gobernador Don Felipe Yarto, confrrmado por la audiencia. Alcalde mayor de Tabahueto.

Id. Id. de San Diego del Río.

Id. Id. de San Francisco Mezquital.

Id. Id. de Batopilas.

Id. Id. de Topago.

Id. Id. de San Juan Nepomuceno.

Id. Id. de San Joaquín de los Arrieros.

Id. Id. de San Buenaventura.

Id. Id. de Conchos.

Id. Id. de Gallo.

Id. Id. de Cerro Gordo.

Icl. Id. de Guajoquill.a

Id. Id. de San Juan del Río . . . . . . 400 pesos

Ic. Id. de Real del Oro . . . . . . . . 400

Id. Id. de Real del Parral . . . . . . . . 400

Id. Id. de Parras y Saltillo . . . . . . . 700

Id. Id. de Valle de San Bartolomé. . . . . 300 "

Id. Id. de Guanacevi . . . . . . . . . 150

Id. Id. de Mapimí . . . . . . . . . . . 550 ,

Id. Id. de Valle de Santiago Papasquiaro . 350

Id. Id, de Cusihuiriáchic . . . . . . . . 300

Id. Id. de Ciénaga de los Olivos. . . . . . 200 "

Id. Id. de Cuencamé. . . . . . . . . . Ioo "

Id. Id. de San Andrés de ela Sierra. . . Ioo"

Id. Id. de Sianori. . . . . . . . . . I50"

Id. Id. de Basis . . . . . . . . . I50"

Id. Id. de Santa Bárbara . . . . . . 125 "

4.675 pesos

Las aportaciones de los alcaldes producían cuatro mil seiscientos setenta y. cinco pesos a! ano a Barri, quien se justificaba alegando que estas contribuciones no estaban autorizadas en ninguna real cédula, pero eran cosa 
tradicional, tanto más natural por cuanto él, como gobernador interino, sólo percibía de sueldo mil seiscientos cincuenta y cuatro pesos, tres reales y tres granos, que, deducidos los derechos de mediannata, inválidos y montepío quedaban reducidos a jciento siete pesos y medio mensuales!, o mil doscientos noventa al año. ${ }^{252}$ Barri alegaba que ni atn con el ingreso que le proporcionaban las alcaldías mayores había logrado todasía saldar el empeño de seis mil pesos que gastó en el viaje para hacerse cargo del gobierno de Durango.

También Croix 253 reconoce la mala situación del gohernador que, aun siendo propietario, sólo gozaría tres mil trescientos pesos de sueldo - sin descontar derechos- como único ingreso lícito. Por lo demás, el gobernador de Nueva Vizcaya no ejercía el mando militar de la provincia desde que éste había sido entregado sucesivamente a Cuéllar, Bernardo de Gálvez, O'Conor y Rubio, y tampoco estaba en condiciones de ejercerlo desde Durango. Pero muerto Rubio, y estando decretada la residencia de los gobernadores en Chihuahtia, era precisamente Barri la única persona capacitada para hacerse cargo del mando de los presidios, pese a lo cual Teodoro de Croix adviere que de ninguna manera podría éste subsistir cn la villa con su corto streldo de interino, haciendo frente a las cargas de familia, y que tampoco era Chihuahua lugar oportuno para centralizar alli el gobierno de toda la provincia; por lo que ordenó que desde que Barri salió de Durango para asistir a las juntas de guerra celebradas en Chilutahul se le abonase sueldo compicto, y que después fijase provisionalmente su capital en el valle de San Bartolomé.

Con este motivo quedaba además existente el cargo de corregidor de Chihuahua, que de cumplirse el real decreto debería haberse extinguido. Cesando en dicho puesto el teniente Don Pedro Queipo de Llano, hombre de valía y honradez que lo servía en la pobreza desde fines de i 768 , sin haber nunca sabido qué emolumentos le estuviesen asignados, nombró Teodoro

252 Barri a Gálvez. Durango, 8 de noviembre de 1777. A. G. I., Guadalajara, 274. Se advertirá en la relación que figuran veintisiete alcaldias y precisamente no consta Chihuahua, que era corregimiento. En el estado de daños sufridos remitidos por el gobernador en igual fecha sólo aparecen las siguientes: San Juan del Río, San Bartolomé, Parral, El Oro, Cerro Gordo, Santa Bárbara, Ciénaga, Cuencamé, Mapimi, Parras, Gallo, Cusihuiriáchic y San BuenaVentura, más Chihuahua. Vid, nota 2 ro. Croix dice en 27 de julio de 1778 que las alcaidia de la provincia son veinticinco $y$ da la cifra de veinteseis en el informe general de $x 78 \mathrm{r}$. La relación inserta arriba es, por lo demás, un buen indice de la importancia de aquellas jurisdicciones en el orden demográfico y económico.

253 T. de Croix a Gálvez. Chihuahua, 27 de julio de 1778 , num. 2qo. A. G. I., Guada1ajara, 276 . 
de Croix para que lo sustituyese interinamente al capitán Don Francisco García Menocal. ${ }^{254}$

A decir verdad, la exigüedad del sueldo del gobernador o la inexistencia del del corregidor no se correspondían con el rendimiento que la provincia producía al erario, bien que la sola defensa absorbiese crecidas sumas. Como ejemplo del mismo momento, he aquí el estado de la renta de tabacos correspondiente al año $x 776$.

Durango con el pueblo de Analco y hacienda de Navacoyan. 21.972.6.5. San Juan del Río.

Basis

Parras.

Oro.

Parral.

Papasquiaro.

Chihuahus.

Cuencamé.

Nombre de Dios (villa).

Sombrerete.

Mezquital.

Tejamé.

Boca.

San Francisco Mezquital.

20.318 .4 .6 .

4.286.7.6.

I I. 491.4 .6

I $3.767 \cdot 3 \cdot 0$.

59.482 .6 .6 .

I0.504. I.6.

57.686 .6 .6 .

I 8077.5 .6 .

I3.982.0.6.

3०. 74.2 .0 .

I6. I 35.0.0.

4.093.3.6.

6.035.7.0.

I.929 5.6.

Total.

$289.759 \cdot 0.5$.

Descontados los gastos, dejaba la renta al erario en estas administraciones el incré́ble beneficio lícurido de doscientos cincuenta y tres mil novecientos ochenta $y$ cinco pesos, cuatro reales, once granos, aunque unos ochenta mil pesos de esta suma corresponden a las seis últimas jurisdicciones que no entran en la de la gobernación de Nueva Vizcaya. ${ }^{255}$

Sin embargo, el criterio del máximo ahorro posible aplicado a todas las cargas públicas llevará al misno Teodoro de Croix a una serie de medidas de la misma índole que afectarían precisamente a la oficialidad de las tropas de toda la frontera.

254 T. de Croix a Gálvez, Pates, 24 de noviembre de r777; Chihuahua, 2'7 de julio y 23 de octubre de $7>8$, núns. $132,2+7$ y 299. A. G. I., Guadalajaral, 291. T. de Croix a Ciálye\%. Chihuahıa, 29 de junio de 1778 , núm, 232. A. G. I., Guadalajara, 276.

255 Estado de tabacos en Durango, т>76. A. G, I., Guadalajara, 276. 


\section{La paz inestable en Coahuila y Texas}

La entrada de Teodoro de Croix en el escenario de la frontera viene seguida con algún intervalo por la salida de Ugarte y de Riperdá del gobierno de las dos provincias orientales. Sus sucesores fueron Don Juan de Ugalde y Don Domingo Cabello. Precisamente aquellos dos habían sido los más reacios ejecutores de las órdenes de O’Conor. Ugarte era con toda claridad enemigo de la idea de trasladar los presidios de Coahuila a la Línea del Río Grande, y a su realización, y a la paz aparente establecida por el comandante inspector con los lipanes atribuía los daños que sin dıda alguna experimentaba la provincia. A Ugarte debió Teodoro de Croix algunos de los más alarmistas informes venidos a sus manos. ${ }^{256}$ Riperdá había desafiado incluso las reprensiones de O'Conor y Bucareli para llevar adelante una política de amistad con los indios del norte, a los que permitía entrar libremente en los presidios y a los que enviaba obsequios de armas, contra todo lo prevenido en el reglamento. Tomaba además esta actitud como cosa de responsabilidad personal, gastando en seguirla buena parte de su peculio. En su informe de abril de 1777 al comandante general 257 le hace saber cómo en Texas -algo más de mil habitantes entre la villa y presidio de la capital; unos trescientos en la Bahía, y algo más de esta cifra en el pueblo de Nuestra Señora del Pilar de Bucareli, fundado por el propio Riperdá en agosto de r774 junto al río Neches "que por aquella parte divide esta provincia de La Luisiana", con una compañía miliciana para su resguardo; más el fuerte del Cibolo, establecido en I77 I y cinco misiones en Béjar y dos en la Bahía con poca gente- los únicos enemigos eran los comanches, y octultamente los apaches lipanes, que acudian ahora con más frecuencia porque habían de-

256 Ugarte a T, de Croix, Valle de Santa Rosa, 30 de marzo y 2 de abril de i777. A. G. I. Guadalajara, $5 \times 6$.

257 Riperdá a $T$. de Croix. Béjar, 27 de abril de 1777 . Remitido por T. de Croix a Gálvez, Méxieo, 26 de julio de 1777 , núm. 68. A. H. N., Estado $3883_{-9}(1)$. Catorce meses más tarde informaria el mismo comandante que en Béjar habia quince fanilias de canarios y treinta de criollos, "que forman el más ridiculo eabildo por ser todos ignorantes", y que en la jurisdicción de la Bahía, que poseía enorme riqueza en ganado se lograria aprovechar el suelo si construyese una saca de agua que costaria siete u ocho mil pesos. El pueblo del Pilar de Bucas de indios gentiles dentro de reli aparece como tercera jurisdiccion. Croix indica conocidas cran hoy poco numerosas - así los vidais, la provincia: de ellas, las más antiguamente más distantes conservaban mayor fuerza de hombres orcoquizas, adaes, ayx, nacodochitos-y las mas de armas - los caraucahuas, manos de perro, cocos con otras son los indios del norte-, pero quitseis, taucaluas, taobayas y panis-mahas, que, con cita Don Teodoro los lipanes y comanches, todas se hallaban de paz. Como naciones colos y cadodachos, fieles a los españoles, en Luisiana; enemigos de los indios del norte; los arkas misma provincia; "y los numerosos guerreros osages o los aricaras, misuris y otros en la misma la referida colonia y que lo son de nuestras naguazas, que se han cleclarado enemigos de Croix a Gálvez. Chihuahua, 23 de setiembre de 1778 , ciones amigas y del comanche". T. de Crom unim, 265 . Ibid. 
jado de venir a Béjar los indios del norte, a los que no se visitaba desde hacía un año porque el vecindario de la villa interpretaba mal esta iniciativa suya, que logró tenerlos de paz gracias a los buenos oficios de Mézières, al mismo tiempo que separaba a los apaches de las vidais y texas que les proporcionaban armas. La réplica de Don Teodoro de Croix en 9 de julio de aquel año fue darle plena libertad para que obrase según le dictasen su celo, conocimiento y experiencia, sin temor de calumnias, reanudando el trato amistoso con los indios del norte.

En Coahuila se tenía noticias de la entrada de grtiesals partidas de lipanes, lipiyanes y mezcaleros. El gobernador informaba de las actividades ciel capitán Panocha y de Poca Ropa, que parecía fiel. San Fernando de Austria y Cuatro Ciénegas padecían indudables daños y por ello Teodoro de Croix decidió enviar la mitad de la tercera compañía volante de Chihuahuta a Coahuila. ${ }^{28}$ Sin embargo, cuando pidió consejo a Bucareli, el virrey se limitó a contestar que "en Coahuila se han aparentado varias veces receios que luego se disiparon por su propio fundamento", según había experimentado en dos ocasiones O'Conor. ${ }^{259}$ Los daños que en realidad experimentaba la provincia, ya mediado I 777 , eran francannente mínimos, y más atribuíbles al bandolerismo que a la guerra, que no la había, con los lipanes, quienes en cambio empezalsan a presentarse, en gran número y en dudosa actitud, en Béjar.

Ante los informes, Teodoro de Croix había optado por alcanzar una actitud radical $\mathrm{y}$, camino del norte, desde Zacatacas exponía ya el plan de hostigar a la apachería de Oriente, la más numerosa y la mas fácil de batir pues no contaba, como la de occidente, con el asilo de las sierras del Gila. Para vencerla meditaría "una acción que espero gloriosa. si se me franquean los auxilios que he solicitado y si Dios bendice mis votos". El comanclante general ideaba hacer salir dos cuerpos de tropas de Nueva Vizcaya, uno de los cuales batiría el Bolsón, y otro el río Puerco y Salado desde las Juntas, para así obligar a los mezcaleros y natajes a unirse a los lipanes, como lo habian hecho en otras ocaciones. Otra fuerza de Nuevo México, desde Robledo, batiría la sierra de Guadalupe, junto al Puerco, y se cubrirían todas las posibles retiradas, de modo que los indios vendrían a quedar concentrados frente al presidio del Norte, con cuatro direcciones posibles de fuga: a la sierra del Pino, que estaría ocupada con tropa de Coahuila; a la costa del Norte, ---esto es, del Golfo- por el Nueces, donde también pondría tropas; y a los cañones de San Sabá y de los Nogales, donde estarían

258 T. de Croix a Rubio. México, I4 de mayo de 1777. Ibid.

259 T. de Croix a Bucareli. México, 5 de mayo de 1777 . Bucareli a T. dé Croix. México, 22 de mayo de 1777. Ibid. 
los presidiales de Texas y los indios aliados del norte. De suerte que cuando la apachería así cercada fuese atacada por las compañías de los presidios del Norte, de Aguaverde y de Monclova, no tendría refugio.

Para la puesta en práctica del plan confiaba alcanzar el apoyo de los indios del norte por medio de De Mézières. Deseaba mezclar la gente de cuera con los dragones, ia infantería y los indios, esperando que esta amalgama daría buen resultado; pero quisiera que la infantería la formasen trescientos - cuatrocientos cazadores de Luisiana mandados por Bernardo de Gálvez, y que esta fuerza, luego de concluida la campaña, se distribuyesen entre los presidios de toda la Línea. Consideraba utilísina la intervención de Bernardo de Gálvez "por su experiencia de esta guerra y de los indios, y por su ardorosa bizarría", zúo

El I6 de julio había llegado la media compañía volante al valle de Santa Rosa. Ugarte hizo pasar un destacamento a la villa de San Fernando de Austria, a donde se trasladó él mismo, encontrando que los lipanes habían huido abandonando sus sembrados, alarmados con el movimiento de tropas. Sin enbargo, logró hacerles volver, quedando todos en paz: "mas lo que yo no comprendo - escribe el gobernador saliente de Coahuila- de todo es que ellos no tienen palabra mala ni obra buena", y asegura que la situación no cambiaría hasta que no se deportase a los apaches a los terrenos ultramarinos. Algo después, una partida de cuatrocientos indios causaba catorce muertos en el camino real de Monclova a Saltillo, ${ }^{26 r}$ pese a lo cual los lipanes seguían aparentando paz en los presidios de la Concepción de Monclova y Santa Rosa de Aguaverde. ${ }^{262}$

E1 23 de noviembre entregó Ugarte el gobierno de Coahuila a Don Juan de Ugalde, y el 2 de diciembre entraba el comandante general en la provincia. ${ }^{263} \mathrm{Ya}$ se ha dicho cómo se relaciona este hecho con el nacimiento de la hostilidad entre lipanes y mezcaleros. El capitán Don Francisco Martínez, del presidio de San Vicente, que desde Cerro Gordo, en Nueva Vizcaya, había venido a acampar junto al presidio de Santa Rosa del AguaVerde,

$260 \mathrm{~T}$. de Croix a Gálvez. Zacatecas, I I de setiembre de I777, sin número, reservada. British Museum, Mss, roem, Egarton mss. 1799. fols. 225-23I, y A. G. I., México, 2462. Precisamente se había ordenado a Bernatdo de Gálvez auxiliar a T. de Croix y se le ordenó informar acerca de los planes de este. A. G. I.. Cuba, I748.

26I Ugarte a T. de Croix. Santa Rosa, ro de agosto de I777 y Coahuila, 22 de noviembre de 1777. T. de Croix a Gálvez. Durango, io de octubre de т777, núm. io8. A. G. I, Guadalajkra, 5 I6.

262 T, de Croix a Gálvez. Patos, 24 de novientbre de I777, ním, 124. Ibid.

263 Morfi, Viaje de Indios págs. I70-173. Informe general de i78I, artículos 60-6I. Por real orden de 23 de agosto de 1777 se había confericlo a Ugarte el gobierno militar de Sonota. T. de Croix a Gálvez. Chihuahua, 3 de abril de 1778 , wúm, ı89. A. G. I., Guadalajara, 276. 
"logró persuadir con dádivas y bien mañosas expresiones a uno de los capitanes de la lipanería, nombrado Javierillo, hermano del principal indio de esta nación Cabello Largo, a que le entregara una ranchería de mezcaleros". En efecto, el 26 de novienbre salió Martínez con ciento cincuenta hombres y Javierillo y otro lipán, y el 28 en las cabeceras del río de San Diego, dio a!bazo a una ranchería, atacanclo poco después a otra que se hallaba inmediata, haciendo en total cinco muertos y veintiséis prisioneros, amén de los consabidos cantivos rescatados y botín de utensilios, pieles y bestias. El mayor éxito se cifraba en la clesunión que clesde entonces hàbía entre las dos naciones indias. "Es regular - dirá Don Teodoro- que aprovechando la ocasión que proporciona la perficlia del lipán pueda castigarse el todo o parte de la apachería mezcalera, que según cómputo pruclencial de sujetos inteligentes pasará de cuatrocientos hombres de armas, o conseguirse la paz con estos por medio del canje de las piezas aprehendidas". 264 En el encueniro se vio que los lipanes auxiliares vacilaban, pero luego este hecho sería la razén capital de la enemistad de mezcaleros y lipanes, en beneficio de los españoles. El ataque conjunto que dieron en unión de los natajes, a la comitiva de Croix el $\mathrm{I} .^{\circ}$ de marzo de $\mathbf{7 7} 8$ junto a la muralla de San Dámaso, cuando el comandante se dirigía ya a Chihıahụa, fue su última alianza. A mitad de año se hallaban en guerra con los presidios, y el capitán Martínez Pacheco, de la Babia, pudo derrotarlos en el aguaje cle la sierra de Santo Domingo, primera acción en que tomó parte muy eficazmente la tropa ligera aumentada por Teodoro de Croix: en esta ocasión treinta y ocho hombres combatieron con ventaja contra ciento cincuenta enemigos. ${ }^{265}$

Como réplica, los lipanes se concentraron sobre Texas: querían vengarse de la paz que el gobernador mantenía con los indios del norte. Eran unos mil quinientos, arranchados en el río de las Nueces, $y$ pronto causaron algunas muertes y robos, amén de la destrucción vandálica de más de dos mil reses en la misión del Rosario. ${ }^{266}$ Pero los buenos oficios de Atanasio cie Mézières entre los tancahuas y taobayas dieron como resultado una fulminante campaña de los indios del norte contra los lipanes, a los que causaron trescientas bajas. Entonces éstos hubieron de someterse ante Ripardá. ${ }^{267}$

Entre tanto, desde Coahuila, volvía a procurarse la atracción de los

264 T. de Croix a Gálvez. Coahuila, 9 de diciembre de 1777 , núm. I 39. La real orden de 3 de mayo de 1778 indica que se tendría presente el mérito contraido por Martínez en esta ocasión para premiarlo. A. G. I., México, 2462.

265 T. de Croix a Gálvez. Chihuahua, 24 de agosto de i 778 , núm. 256. Ibid.

266 T. de Croix al Gályez. Chihuahua, 24 de agosto de 1778 , núm. 258 , con Extracto. Ibid.

267 Informe general de $I 7 S_{1}$, artículos 3 y 5 . T. de Croix a Gálvez. Chiluahua, 28 de diciembre de 1778 , nún. 337. A. G. I., Guadalajara, 270. 
mismos indios según lo había encomendado el comandante general al capitán Martínez, antigua jefe del presidio de San Vicente y ahora del de Aguaverde con el mando de la primera división de los de la provincia. Martínez no creía en la buena fe de los lipanes, pero su jefe Javierillo hacía repetidas proposiciones de guerra contra los mezcaleros y soircitudes de poibiamiento en el Ojo de Agua de San Felipe, al otro lado del Río Grande. Los mismos mezcaleros llegaron a pactar con Martínez por medio de su cabecilla Morrión; sólo la parcialidad de los castuenses era reacia a la paz, y Martínez practicó campañas contra ellos durante cuatro meses, y preparó otra en combinación con las fuerzas de Díaz, que operarían desde Nueva Vizcaya. ${ }^{268}$ El I." de noviembre de 1778 tomó posesión del gobierno de Texas Don Domingo Cabello, a quien Croix encomendó la revista de aquellos dos presidios, y el reclutamiento de la tropa ligera correspondiente en las provincias de Nueva España, como lo autorizó el virrey. ${ }^{269}$ Por entonces se había logrado la sumisión de los jaranames alzados y, con esfuerzo, se iba logrando traer a la paz los carancahuas fugitivos de la misión de Rosario. ${ }^{270}$

$268 \mathrm{~T}$, de Croix a Gálvez. Chihuahua, 33 de octulıre y 28 de diciembre de i 7 ' 8 , núms. 300 y 3 I 5. A. G. I., Guatlalajara, 275.

269 T. de Croix a Gálvez. Chihuahua, 28 de diciembre de 1778 , núm. 328. Bucareli a Gálvez. México, 27 de enero de 1779 , núm, 422 I. A. G. I., Guadalajara, 270.

270 T. de Croix a Gálvez. Chihuahua, 23 de enero de 1779 , num. 256 . A. G. I., Guadalajara, 302 . 


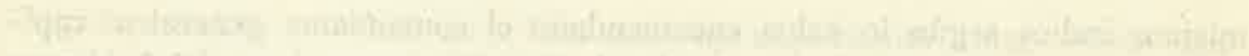

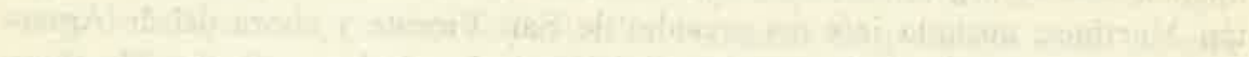

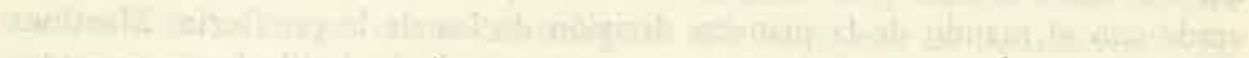

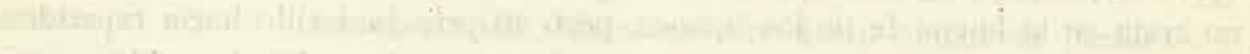

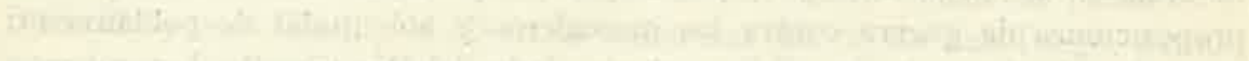

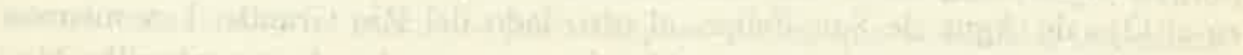

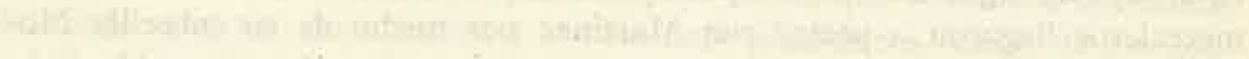

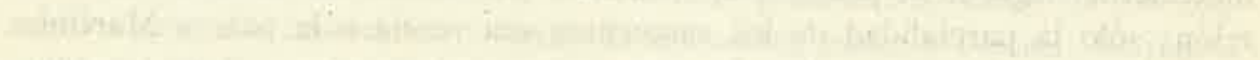

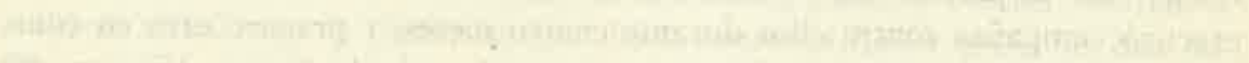

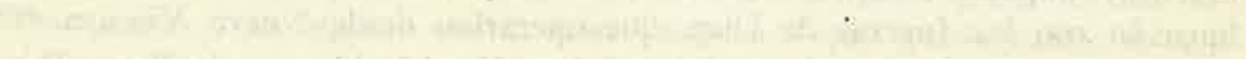

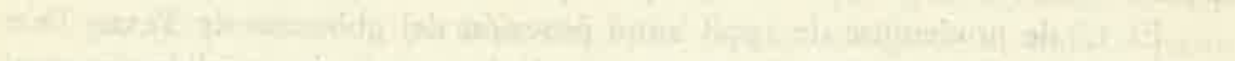

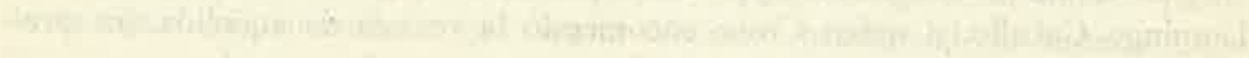

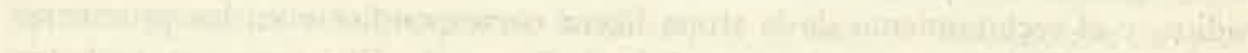
ath

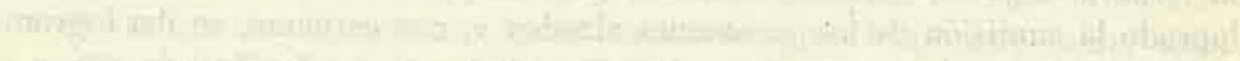

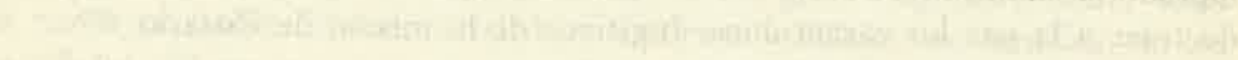

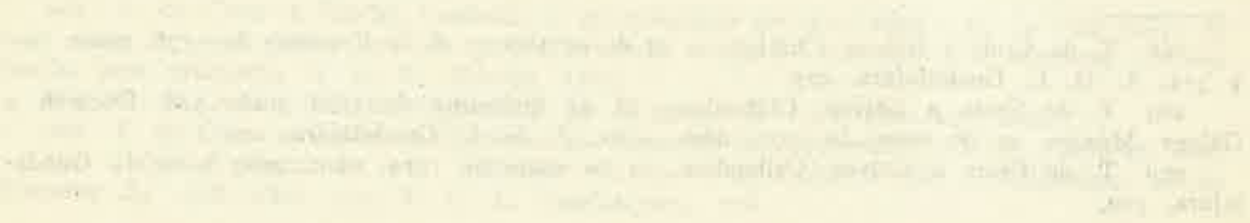




\section{CAPITULO SEXTO}

\section{LA COMANDANCIA ESTABLECIDA}

\section{EL PRIMER INFORME GENERAL}

Tres años y medio de gobernar la comandancia quedan a Croix cuando se establece por fin en Arizpe. En este tiempo se consolidará su labor, apenas apuntada en el período anterior, y él hará plasmar en gruesos informes su personal visión de los problemas de las provincias internas.

Son tres, entre todos, los informes generales que sucesivamente dirige al ministerio Teodoro de Croix. El primero, en 23 de enero de 1780 , apenas llegado a Arizpe. El segundo, en dos partes - debía haber tenido cinco-, fechadas en 30 de octubre de I78I y 23 de abril de I782. E1 tercero, el 7 de octubre de este mismo año.

Cada uno de estos informes tiene características propias y se encamina a un fin determinado: el primero plantea un nuevo método de gobierno; el segundo debió ser una amplísima reseña del estado de toda la comandancia; el tercero, da cuenta de la labor realizada por Croix hasta la fecha en lo tocante a la defensa de las provincias. Cada uno de ellos suministra, pues, al historiador noticias de interés para el conocimiento de diversas facetas de la realidad del momento, y todo ellos hablan de la original personalidad de Teodoro de Croix.

El primero de los tres informes generales es, con mucho, el más decisivo en la forja de esta personalidad. el que supuso en el comandante el más resueelto paso en pro de una radical transformación de las provincias internas. ' Su elaboración misma responde al agudo problema que en Croix

I Este primer informe general, al que el mismo $T$. de Croix da este nombre, aparece como carta de T, de Croix a Gálvez. Arizpe, 23 de enero de I780, núm, 8, reservada.Ejemplares en A. G. I., Guadalajara, 253 y 522 . Dicho informe consta de ciento noventa y cuatro puntos, 
planteó la real orden de 2 I de febrero de I779, que tajantemente vedaba las campañas en persecución de los indios enemigos y le desengañaba del esperado y reclamado envío de refuerzos. En estas circunstancias, Croix enfrenta Ja situación y los problemas de la frontera de manera radicalmente distinta a como lo hiciera hasta entonces.

Croix renuncia, por fin, a los dos nil hombres, con cuya solicitada ayuda esperaba resolver de tha vez, en una campaña de pocos años, la suerte de la comandancia; se decide en último término a aceptar la obligación de atender las necesidades de las provincias internas con sólo los medios que entonces tiene en su mano, en la nueva orientación señalada de mantener la paz cou los indios y procurar los menores dispendios. Lo que para cumplir esto pide, es únicamente la libertad de disponer él, según convenga, del importe íntegro del situado de las tropas y de los fondos de milicias, más los resultantes del impuesto de recargo de armanento, de la alcabala de Sonora, y de todo lo que se aumentaría al erario de las provincias por los desvelos suyos y de Corbalán. Proyecta hacer economías reduciendo pagas y sueldos a oficiales y soldados. Croix pide también se le mantenga en aquel mando el tiempo suficiente para poder llevar a la práctica sus nuevas ideas, pues la situación de las provincias requiere la aplicación invariable de un sistema aprobado, y esta misma razón es la causa de que exponga sus propósitos. ${ }^{2}$

Analizando el estado de la frontera, Croix hace ver la poca eficacia de una tropa mal disciplinada y deficientemente preparada frente a unos indios que ya dominan el caballo y las armas de fuego, al mismo tiempo que no es prudente fiarse de los ya sometidos; como complemento, Croix estima puntos flacos de la defensiva la mala situación de los presidios, las múltiples dificultades que plantean los situados de calballada, y la debilidad de los poblaciones fronterizas. 3

El comandante general comprende que, si se pudiesen reducir a dos caballos y una mula el número de bestias de cada soldado, esto supondría una extraordinaria economía para la tropa y evitaría la búsqueda de las enormes remontas que había que conducir constantemente a los presidios. Para que aquellas tres bestias rindiesen el mismo servicio que las siete que se habían acostumbrado hasta entonces, bastaría a su juticio tenerlas estabuladas, mantenidas con heno y maíz, en vez de pastando, lo cual ahorraría igualmente la incesante fatiga de las escoltas de caballadas. Para la realización de esta idea. se necesitaría construir pesebres en los presidios y hacer acopio de piensos,

2 T. de Croix a Gálvez. Arizpe, 23 de enero de 1780 , núm. 8, reservada. Informe general núnı. 458 , art. $3 .^{\circ}$

3 Informe general, núm. 458 , art. 5-17. 
y esto último sería factible siempre que los presidios tuviesen siembras o las practicasen las poblaciones inmediatas a ellos.

La cuestión de estas poblaciones se ligaba en la mente de Croix a la de la subsistencia de los presidios, puesto que unas y otros no podían vivir aislados y por esto consideraba perniciosa la separación introducida con objeto de constituir la famosa Línea. Ahora, el alejamiento de los presidios imponía continuos y arriesgados viajes para el suministro, lo cual encarecía los géneros, aparte las considerables escoltas que había que destacar. Las poblaciones, por su parte, habían quedado desguarnecidas. Ante este panorama, Croix se dispone a modificar la situación de los puestos avanzados y a procurar el poblamiento en las proximidades de éstos, refiriendo su plan sólo a dos -Nueva Vizcaya y Coahuila - de las tres provincias que cargaban con el peso de la frontera, puesto que en Sonora aún estaba haciéndose el reconocimiento de la situación a la fecha de expedir él su informe.

En Nueva Vizcaya, desce luego, piensa abandonar los presidios del Príncipe, San Carlos y San Sabá, aunque conservándose las fábricas de estos dos; en Coahuila, trasladará Aguaverde a la villa de San Fernando, la Babia a Îa de Santa Rosa y Monclova a la capital. 4 La trascendencia de esta decisión no se oculta a quien conoce los esfuerzos realizados desde la época de Rubí y particularmente por O'Conor, para dar cohesión al sistema defensivo y cerrar al mismo tiempo la boca del bolsón. Croix va a fragmentar esta línea para reorganizar la defensa en torno a tres núcleos: en Nueva Vizcaya constituirán la primera división los presidios de Janos, San Buenaventura y Carrizal, reforzados con la cuarta compañía volante, que además guarnecería Casas Grandes. La segunda división estaría formada por el presidio de San Eleazario y el escuadrón de milicias de El Paso. El tercer núcleo lo integrarían los presidios de la Babia en Santa Rosa, Aguaverde en San Fernando y Río Grande.

El presidio de la Junta de los Ríos, que subsistía en su primitivo asentamiento, y el de Monclova, trasladado de nuevo a la capital de Coahuila, servirían como puntos de apoyo de la segunda línea defensiva que Croix idea establecer. Esta segunda línea de poblaciones tenía dos frentes; el primero - primer cordón - enlazaba el núcleo de la primera división de presidios con el de la Junta de los Ríos; el segundo contorneaba el bolsón desde Chihuahua a Santa Rosa en tres tramos: de la hacienda de Dolores a Pelayo - segundo cordón-, de San Juan de Casta a Saltillo - tercero-, y de Saltillo, por Monclova, a Cuatro Ciénagas - cuarto cordón- Los cuatro cordones de la segunda línea se cubrirían con la tropa de los presidios suprimidos,

1 Ibid, arts. 1 34-137 y J40-I 4I. 
las compañías volantes y algunos piquetes del cuerpo de dragones provinciales de Nueva Vizcaya. 5

El plan detallado de la distribución de fuerzas propuesta puede analizarse en el siguiente cuadro con que Teodoro de Croix acompaña su informe:

Fuerzas de Doce presidios que dispone
Cuerpo volante de Nue-

va Vizcaya........... 620 hombres
875 hombres
I.495 hombres

Distribución :

I." línea de presidios de N. " Vizcaya

1. ${ }^{2}$ línea de presidios de Coahuila

Primer cordón de poblaciones en Nueva Vizcaya

Babia en Santa Rosa ... ... ... ... ... 70

Aguaverde en San Fernando... ...... 70

Río Grande $\ldots \ldots \ldots \ldots \ldots \ldots \ldots \ldots . \quad \ldots \ldots$

210

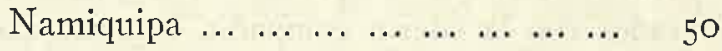

$\begin{array}{lllllllllll}\text { Malanoche } & \ldots & \ldots & \ldots & \ldots & \ldots & \ldots & \ldots & \ldots & 40\end{array}$

$\begin{array}{lllllllllll}\text { Majalca } & \ldots & \ldots & \ldots & \ldots & \ldots & \ldots & \ldots & \ldots & \ldots & 40\end{array}$

$\begin{array}{lllllllll}\text { San Jerónimo } & \ldots & \ldots & \ldots & \ldots & \ldots & \ldots & \ldots & 30\end{array}$

$\begin{array}{lllllllllll}\text { Hormigas } & \ldots & \ldots & \ldots & \ldots & \ldots & \ldots & \ldots & \ldots & 40\end{array}$

$\begin{array}{llllllllll}\text { Chorreras... } & \ldots & \ldots & \ldots & \ldots & \ldots & \ldots & \ldots & \ldots & 30\end{array}$

$\begin{array}{llllllllll}\text { Puteblito... } & \ldots & \ldots & \ldots & \ldots & \ldots & \ldots & \ldots & \ldots & 40\end{array}$

$\begin{array}{llllllllll}\text { Coyame } & \ldots & \ldots & \ldots & \ldots & \ldots & \ldots & \ldots & \ldots & \ldots\end{array}$

Presidio de las Juntas... ... ......... 100 420

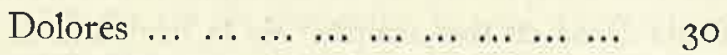

Ancón de Carros... ................. 40

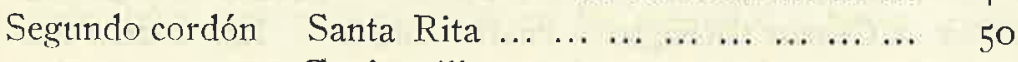

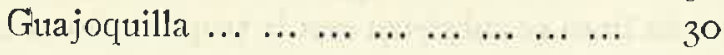

5 Ibid, arts. I $27-146$. 


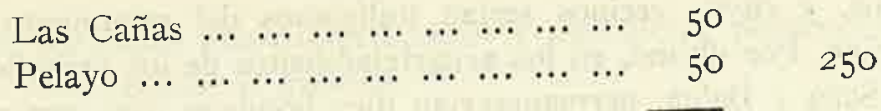

San Juan de Casta... ... . . . . . ...... 30

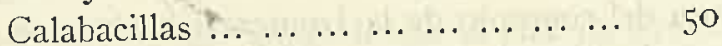

Tercer cordón Tres puestos de cuarenta hombres hasta el frente de Saltillo... ... ... I $20 \quad 200$

Dos puestos de cincuenta hombres de Saltillo a Monclowa... ... ... ... 100

Cordón de po- Monclova.......................... 30

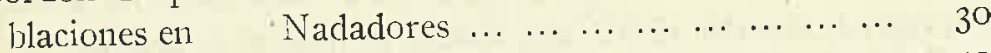

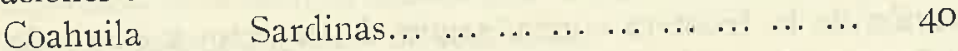

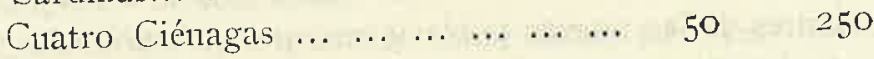

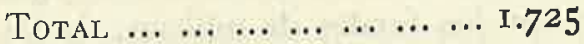

$\begin{array}{llllll} & \text { Fuerza disponible... } & \ldots & \ldots & \ldots & \text { I. } 495\end{array}$

Piquetes de Dragones provin-

ciales de Nueva Vizcaya ... I75

$r .670 \ldots \ldots \ldots$
FaLtan $\ldots \ldots \ldots$

Entre el cordón y la línea de presidios quedarían, ai norte de Nueva Vizcava, el Valle de San Buenaventura, a ocho leguas del presidio de este nombre, que proporcionaba un destacamento para su custodia; la hacienda del Carmen de Peña Blanca, "cuya riqueza rural y mineral ha congregado un vecindario de quinientas almas que defiende una escolta de treinta hombres costeada por el dueño de la posesión", y la de Encinillas, protegida por sus vaqueros, con el auxilio que pudieran prestarle las vecinas nuevas poblaciones de Majalca y San Jerónimo. ${ }^{6}$

Fuera del cordón, al este de la provincia, habrían de quedar Julimes y Santa Cruz, próximos a los puestos de Chorreras, Hormigas y Ancón de 
Carros, y cuyos vecinos serían milicianos del regimiento de dragones clei Príncipe. Por último, en los acuartelamientos de los presidios de San Carlos, San Sabá y Babia, permanecerían diez hombres para guarnición de aquellas fábricas. 7

Con ser revolucionario el plan de Croix en su conjunto, por cuanto supone la ruptura del concepto de la frontera rectilínea, es de destacar como el intento más ambicioso el de la fundación de las poblaciones avanzadas, puesto que era éste el punto que por su mismo carácter había de exigir mayor dedicación y esfuerzo y, al mismo tiempo, era en realidad la base del sistema. La concentración de pobladores en el limes le claría extraordinaria solidez. Y resistencia, ahorraría a los presidios muchísimas fatigas de conducción de suministros y abarataría la ida de la tropa, permitiendo, por último, la introducción del sistema de caballadas estabuladas, cuyas ventajas ya se han nostrado.

La colonización de la frontera corría, según el proyecto, a cargo de los conlandantes de las nuevas poblaciones, que utilizarían los fondos de las milicias provinciales para su fomento. ${ }^{8}$ Eran veintiocho las que Croix pensaba crear, con un costo total de 120 a 150.000 pesos, y para cubrirlo contaba Croix con los fondos de milicias, de los que pensaba tomar cien mil pesos más, pues sólo mantendría sobre las armas los I 75 dragones que ya prestaban servicio y los cincuenta y cinco más que necesitaba para completar los destacamentos propuestos. A esos cien mil pesos sumaría el recargo de tres pesos sobre cada escopeta, fusil o par de pisiolas de las doce mil armas que había pedido al ministerio y que calculaba produciría a razón de dieciséis mil quinientos pesos durante cinco años; más unos treinta y siete mil pesos que quedaban anualmente libres clel situado de los presidios por razón de bajas. El total ascendería a ciento sesenta y tres mil pesos, suficientes para el establecimiento. 9

Previó Croix la principal dificultad que se le habría de oponer, no ya en Madrid, sino en las nismas provincias internas. Los pueblos no podrían comprender fácilmente la conveniencia de invertir en este proyecto los fondos de milicias, en lugar de mantener cada localidad su pequeña fuerza, sin embargo de que él habría de cumplir con bastante exactitud su promesa de organizar la doble línea de presidios y poblaciones, manteniendo además dos destacamentos de cincuenta dragones en Cerro Gordo y Pasaje para la escolta de recuas en el trayecto del río Nazas a Chihuahua y viceversa.

7 Ibid, arts, I $47-148$,

8 Ibid, arts. I $5 \mathrm{I}-\mathrm{I} 60$.

9 Ibicl, arts. I74-I8I. 
La paz que por el momento guardaban lipanes y mezcaleros proporcionaba una ocasión única para realizar el sistema. ${ }^{10}$

\section{AProbación del PLAN de Croix}

De poderse realizar, no cabe duda de que el plan de Croix seria el medio más eficaz para la defensa de las provincias internas, pues el ensamblaje $\mathrm{y}^{\mathrm{r}}$ coordinación de poblaciones y presidios debía dar una solidez tal a la frontera que asegurase su estabilidad y pervivencia. Era de sentir, indudablemente, el retroceso de los puestos que habían cerrado la boca del bolsón, con los que se había intentado garantizar la paz de los pueblos de la cuenca del Conchos y de los establecimientos del occidente de Coahuila llevando el teatro de lá guerra al río Grande. Pero toda vez que éste sistema no había proporcionado la seguridad anhelada, el ideado por Croix ofrecía perspectivas nuevas para lograrla y nuevos motivos de confianza.

Es verdad, desde luego, que entonces como ahora no puede sino muy difícilmente llegarse a determinar con algunos visos de verosimilitud acerca de la eficacia o inutilidad de cualquiera de los sistemas defensivos practicados o propuestos en aquella frontera durante los siglos sucesivos, pues que, juzgando por el éxito o el fracaso en asegurar la paz, no se sabe sino en contadas ocasiones el efecto que en la consecución de estas situaciones tuvieran las medidas militares de los españoles, ya que el aparente efecto de guerra o paz que sucede a la puesta en vigor de cualquier plan ofensivo o defensivo puede haber sido originado por cualquier otra causa que tal vez se nos escapa, como pudo escapar a la percepción de los contemporáneos. Así, una paz prolongada de la que nos quedan testimonios puclo ser provocada bien por una represión contundente o una política conciliadora por parte de los españoles, bien por un alejamiento del enemigo en busca de otros cazaderos. Un período de lucha pudo ser motivado por los robos del adversario, o también quizá por hostilidades cometidas por un grupo infidente de indios sometidos. En cualquier caso, suelen escaparse las motivaciones de los actos de los indios hostiles y sólo aceptando el riesgo de errar no es lícito suponerlas. Con esta misma reserva, pues, nos es dable admitir como oportuno el repudio de la antigua Línea de presidios que hace Croix negando su eficacia para contener a los apaches.

Otra cosa es si vamos a medir el sistema de Rubí y O’Conor por el rasero que pide el de Teodoro de Croix. Los proyectos de éste son inadaptables a las posibilidades ofrecidas por aquéllos. Rubí y O'Conor subordinaron

Io Ibid, arts, I82-I93. 
otras conveniencias a la de empujar la Línea hacia el norte todo lo posible con el doble afán de alcanzar el curso del río Grande y de plantear la guerra en un terreno bien distante de las poblaciones. Croix, en cambio, va a mirar el problema bajo la convicción de que presidio y población eran una dualidad insoluble, y así considerados, los presidios del Príncipe, San Carlos, San Vicente, La Babia y Monclova Nuevo, no le ofrecían las condiciones apetecidas para el cómodo establecimiento de un núcleo de colonos y por eso decide su supresión, independientemente del mayor o menor riesgo en que se hallasen, pues no es el grado de peligrosidad lo que decide la ocupación o abandono de in puesto tácticamente importante.

Siempre se consideró Janos la más valiosa posición de la frontera; ahora Croix para mantenerlo se proponía repohlar el valle de Casas Grandes y la hacienda de Becerra, al tiempo que guarnicionaba el valle de San Buenaventura, que suministraba granos al presidio de este nombre, y a los de Janos y Carrizal. En este último presidio y el de San Eleazario ya se habían ido congregando algunos pobladores, mientras que el de la Junta era muly útil para el sometinniento de los mezcaleros y reagrupación de los antiguos pueblos de norteños y jullimeños, que fueron abandonados al retroceder este presidio a Julimes en 1767. El presidio de San Juan Bautista se mantenía firme con el núcleo de misiones que protegía. ${ }^{11}$

En lugar de los presidios suprimidos, Croix intentará el repoblamiento de la frontera, idea que no es nueva, pues ya a mitad del siglo había sido expuesta; pero ahora el comandante habría de proponérsela seriamente: iba en ello el éxito de su propio plan. Contaba para realizarla con los fondos que empezaba a recabar y manejar, y con la paz concertada en aquel momento con los mezcaleros y lipanes, lo que le permitía dedicarse libremente a la reorganización de la frontera.

Sólo necesitaba la aprobación de su plan por el rey, y en este sentido sus deseos quedaron satisfechos cuando la real orden de 3 de febrero de 178 z sancionó sus propósitos autorizándole a trasladar presidios, arreglar y reducir sus caballadas y erigir poblaciones en la frontera, buscando siempre el consejo del obispo de Sonora, del intendente y del auditor de gutra, aunque no estaría obligado a seguir sus dictámenes. ${ }^{12}$

Cuatro meses después, no obstante, el motivo principal de la elaboración del plan de Croix, la política pacifista propugnada por la Corona, había dejado de existir, pues por real orden de 27 de junio de 1782 se decretaba guerra continua a los bárbaros en sus propios terrenos, "pues está visto por repe-

I I Ibid, arts. $24-3$ I y 59 .

I 2 Real orden de 3 de felorero de 1,82, A. G. I., Guadalajara, 522. 
tidas experiencias lastimosas que no basta mantenerse sobre la defensiva, y que el medio de contenerlos es buscarlos y hacerles una continuada guerrilla sin estrépito". "3 Claro es que la misma situación de la frontera se había alterado mucho.

\section{OrganizaCióN DE LA COMANDANCIA}

Radicado por último Teodoro de Croix en Arizpe, adonde llega el 13 de noviembre de I779, declaró por bando esta población capital de su residencia, con privilegio de exención de alcabalas por cinco años y repartimiento de tierras y solares a perpetuidad. Obraba así por consejo de Corbalán, para atraer vecinos y operarios para las obras públicas que pensaba acometer. Solicitó Croix de la Corona se declarase Arizpe villa o ciudad y se erigiese en ella parroquia independiente de la actual misión, y pidió instrucciones para proceder a los repartos de tierras que hasta entonces habían pertenecido : los indios $y$ dificultaban el establecimiento de pobladores. ${ }^{14}$

Parece que el primer objetivo de envergadura que Croix se propusiera al llegar a Arizpe fue la fundación de casa de moneda, cuyos planos encargó a Mascaró y Corbalán y al mismo tiempo empezó a allegar fondos para los gastos que esto iba a originar; así destinó el producto de la recién creada renta del mezcal a la conducción de aguas a Arizpe, de manera que aprovechasen a las máquinas que se habían de construir en la casa de moneda, aunque también al regadío de tierras para fomento de la población. ${ }^{15}$

Pidió Croix a México informes acerca del número de volantes y hornos de fundición y afinación que se necesitarian para la acuñación de moneda, así como de las oficinas y dependencias necesarias para el servicio de un edificio aproximadamente tan vasto como el de Guatemala. El virrey Mayorga se mostró dispuesto a proporcionar los datos solicitados, ${ }^{15}$ pero a fines de I $77^{2}$ aún no los había recibido Croix, ${ }^{17}$ y en esto quedó todo el intento de establecimiento tan importante para la independencia económica de la comandancia general y para la prosperidad de las provincias internas. $\mathrm{Ni}$ Croix ni

I3 Real orden de 27 de junio de 1782 . A. G. I., Guadalajara, 519.

I4 T. de Croix a Gálvez. Arizpe, 23 de enero de 1780 , núm, 459. A. G. I., Guadalajara, 278. El bando para poblamiento de Arizpe se inserta en Villa, Compendio de historia del estado de Sonora, 158-159. Fue promulgado el 12 de enero de 1780.

I5 T. de Croix a Gálvez. Arizpe, 23 de abril de 1780, núm. 513. A. G. I., Gtradalajara, $27 \mathrm{I}$ y 277 .

I6 T de Croix a Gálvez. Arizpe, is. d. mayo de 1780 núm. 526. Real orden de 2 de marzo

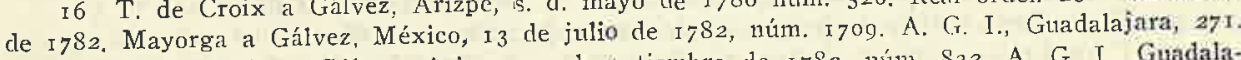
I7 T. de Croix a Gályez. Arizpe, 23 de setiembre de 1782 , núm. 832 . A. G. I., Guadalajara, 518. 
sus sucesores recibieron jamás la información pedida, y la casa de moneda de Arizpe no llegó nunca a existir.

Más éxito tuvo Croix en el establecimiento de las dependencias hacendísticas de Cajas Reales, tesorería y pagaduría. Una pagaduría fue creada en Arizpe a poco de su llegada a la capital, servida por un oficial subalterno de la Caja de Alamos y destinada al pago de los situados de los presidios y sínodos de misiones de la frontera de Sonora. ${ }^{18}$ Pero estaba en trámite el traslado a. Arizpe de la misma Caja de Alamos, donde debía quedar una administración de azogues, re como fue resuelto por real orden de 12 de febrero de $1782 .{ }^{20}$

A la par que crecía Arizpe se desarmollaba Chihuahua, cuya comisaría de guerra y tesorería, fundada en i 772 para atender al cuerpo expedicionario de O'Conor, fue suprinida y remplazada en i73i por uma pagaduría y caja de quintos y azogues, con un oficial real, segín había pediclo el Ayuniamiento, procuradores, síndico general y personero de la villa. ${ }^{21}$

El establecimiento de correo es ahora cuidladosamente perfeccionaclo por Croix. Es en febreno de I 780 cuando solicita de Floridablanca la subdelegación de la superintendencia de la renta. Pronto determina el pago por los remitentes de las cartas que dirigían a las oficinas gubernamentales, 22 y a fin de año se hacía guincenal la comunicación de Arizpe a San Fernando de Coahuila, como ya lo era la que conectaba Arizpe con el real de Alamos, y por él con México. ${ }^{2} 3$ Dos poblaciones, Rosario y Saltillo, hicieron donativos para el estableciniento de los correos, pero no necesitándose eslas cantidades para este fin, se destinó la primera, de 3679 reales de plata, a la construcción de la cárcel de Arizpe, y la de 1056 de Saltillo, a los fondos de milicias. ${ }^{24}$ En 1782 dejó Croix todos los asuntos de correos a cargo del administrador general de la renta en México. ${ }^{25}$ El último complemento dado al sistema fue la contratación de una canoa del cura doctrinero de Santa Cruz de Mayo, por ochocientos pesos mensuales, para que condujese la correspondencia entre Sonora y Califomia, enlazando el correo por tierra

\footnotetext{
Is T, de Croix a Gatvez. Arizpe, 23 de abril de iz8o, núm. 5i2, A. G. 1, Guadalajam, $27 \%$.

19 T. de Croix a Gálvez, Arizne, 23 de febrero de iz80, num. 478. A. G. I. Guadalajara, 5is.

20 T. de Croix a Gálve». Arizpe, 23 cle setiembre de I780, numm. 48 I. A. G. I., Guadalajara, 268.

2. T. de Croix a Gálvez. Arizpe, s. dl, mayo de I780, núm. 634 (a juzçar por el número de orelen, esta carta debe scr de 30 de abril de ry 8 r). A. G. I., Guadalajara, 27 I.

22 T. de Croix al Gálvez. Arizpe, s. d. (23) de abril de ry8o, ním. 5r5. A. G. I., Gundalara, 267 .

23 T. de Croix a Gálvez. Arizpe, 26 de marzo de 1780 , núm. 502. Ibid.

24 T. de Croix a Gálvez. Arizpe, 27 de agosto de 1781 , núm. 660. Tbid.

25 T. de Croix a Gálvez. Arizpe, 26 de enero y $z$ de diciembre de 1782 , núms. 750 y 858 , según nota en A. G. I., Guadalajara, 267 .
} 
con Alamos. Con esto se evitó el costoso mantenimiento en el golfo de algunos de los buques de departamento de San Blas, que se hallaban en Guaymas con el mismo fin. ${ }^{26}$ En julio de 1783 , ya próximo a su partida, pidió Croix a Floridablanca declarase la subdelegación de correos aneja al cargo de comandante general, para sus sucesores. ${ }^{27}$

En el orden administrativo introdujo Croix, sobre el proyecto original de la comandancia, la importante novedad de proponer la extinción del gobierno militar cle Sonora, considerándolo innecesario, puesto que el comandante general había de residir en Arizpe, a la vista de todo lo que ocurriesee en la frontera. La aprobación de esta idea por real orden de 8 de febrero de 1782 abrevió los días del mando de Ugarte y Loyola, ${ }^{28}$ qute a poco de su llegada a Arizpe con Croix había recibido su ascenso a brigadier pero que, ahora como siempre, seguía clamando por aumento de sueldo, sorprendido, además, de que su cargo sólo le produjese tres mil pesos, mientras que a Corbalán la intendencia de la misma provincia le rendía seis mil. Cesante Ugarte, se dirigió al virreinato, donde debía vivir días amargos hasta su regreso a las provincias internas, esta vez como sucesor de Croix.

No fue aprobada, en cambio, la idea de Croix de dividir la comandancia, ordenándosele que propusiese nuevo comandante inspector en lugar de Rubio, y un tercer ayudante inspector que decía necesitar. Ia elección de Croix recayó sobre Don Felipe Neve, hasta entonces gobernador de California, y Don Diego Borica. ${ }^{29}$ Estos nombramientos se hacen en Madrid ya en abri y marzo, respectivamente, de ${ }^{7} 782$. En lugar de Neve pasó a California Don Pedro de Fajes, que ya había estado allí, y ahora se encontraba en Sonora con la compañía de fusileros; del mismo modo había sucedido a Ugarte, en Coahuila, Don Juan de Ugalde, y a éste, después de las dificultades habidas con Croix, Don Pedro de Tueros, ya capitán del presidio de Altar. En Texas se hallaba, desde I779, Don Domingo Cabello. En tiempo de Croix fue, por otra parte, suspendido el nombramiento de teniente de gobernador de Tarahumara. 30

La introducción de los jueces del tribunal de la Acordada fue una complicación para Teodoro de Croix, que aprobó al gobernador Barri de Nueva Vizcaya la recogida del título de teniente provincial de aquel tribunal que el

26 T. de Croix a Gálvez. Arizpe, 24 de febrero de 1783, n. ${ }^{\circ} 880$. A. G. I., Guadalajara, 518.

$27 \mathrm{~T}$, de Croix a Gálvez. Arizpe, 28 de julio de 1783 , núm. 939. A. G. I., Guadalajara, 268.

$28 \mathrm{~T}$. de Croix a Gálvez. Arizpe, 23 de febrero de 1780 , núm. 480. A. G. I., Guadalajara,

278. T, de Croix a Gálvez. Arizpe, 24 de febrero de 1783 . núm. 883. A. G. I., Guadalajara, 518. 278. T, de Croix a Gálvez. Arizpe, 24 de
29 T. de Croix a Gálvez. Arizpe, 23 de abril de 1780 , num, 510 . Real despacho de 4 de
marzo de 1782 . A. G. I., Guadalajara, 519 . Real despacho de 13 de abril de 1782. A. G. I., Gua¿lalajara, 267.

30 T. de Croix a Gálvez. Arizpe, 23 de enero de 778 I, núm. 613. A. G. I., Guadalajara, 28 I. 
juez de México Don Pedro Valiente había expedido a Don Francisco de Mier y Terán, diciendo aquél obrar así con muy graves fundamentos. Valiente se quejó a Gálvez, mostrando la inconveniencia de que no funcionase la Acordada en Nueva Vizcaya, pues con sólo cruzar sus límites quedarían fuera del alcance de los jueces los malhechores de Nueva España y Nuevá Galicia. ${ }^{3}$ Pero Croix explicó claramente su actuación. Mier y Terán no era más que un delincuente expulsado de la jurisdición de San Juan del Río por el antecesor de Barri, que ahora pretendía regresar a ella apoyado en el título otorgado por Valiente. Hizo recoger los demás títulos para enterarse de las calidades de los clesignados, y de esta manera advirtió cómo muchos de ellos sólo buscaban aplicar los vagabundos y delincuentes al trabajo de sus labores de hacienda o de mina; otros sólo pretendían inhibirse de la jurisdición de los jueces ordinarios. Por otra parte, la situación que Valiente decía haber entre Nueva Galicia, Nueva España y Nueva Vizcaya era la misma existente entre Nueva Vizcaya y las demás provincias internas, en las que no estaba establecida la Acordada. $3^{2} \mathrm{Y}$ en todas ellas, por las circunstancias de las hostilidades que suftían, poco podrían hacer los jueces del tribunal. De todos modos, Croix dejó expeditas en Nueva Vizcaya las actividades de Valiente y de su sucesor Don Manuel de Santa María y Escobedo encargando sólo a Barri vigilase la actuación de los comisionados. 33

Estos fueron los principales pasos dados por Croix en orden a la orga. nización y articulación administrativa de la comandancia. Sus más importantes proyectos, elaborados durante su viaje por las provincias, no fueron atendidos, y los cue lo fueron no tuvieron vigencia sino en el último año de su mandato. Importantes innovaciones de otro orden - el obispado de Sonora, las ctustodias de misiones - no fueron fruto de su esfuerzo sino de manera muy relativa, y en cuanto al obispado de Nuevo León no pudo hacer más que repetir sus informes sobre la conveniencia de situarlo en el valle de Santa Rosa, sin mayor efecto que la vez anterior. 34

\section{IAPUISO LTACENDÍSTICO Y ECONÓMICO}

Si en principio parece cierto que para lograr el desarrollo y prosperidad de las provincias internas se necesitaba conseguir la paz en las fronteras de indios, desde el momento en que Croix, según él mismo surgirió en su pri-

3 I Valiente a Gálvez. M'éxico, 29 de mayo de r780. A. G. I., Guadalajara, 267.

32 T. de Croix a Gálvez. Arizpe, 3 I de diciembre de I 781 , nú1n. 703 . Ibid.

$33 \mathrm{~T}$. de Croix a Gálvez. Arizpe, 30 de mayo de 1782 , núm. 768 . Ibid,

34 T. de Croix a S. M. Arizpc, 23 de abril de 1780 , remitida con carta a Gálvez de igua! data, núm. 50\%. A. G. I., Guadalajara, $27 \%$. 
mer informe general, había de actuar sobre la base del rendimiento económico de las provincias parece aún más cierta la proposición contraria: quc para conseguir la paz, la condición principal era la obtención de fondos en las mismas provincias. De aquí el extraordinario interés del gobernador comandante general en el perfeccionamiento del sistema hacendístico y en la creación de nuevas rentas, nuevas fuentes de ingresos.

Desde el primer momento se partió de la realidad incuestionable de que, de las cinco gobernaciones, sólo dos - Sonora y Nueva Vizcaya- eran capaces de proporcionar fondos. Californias y Nuevo México sólo const1mían, y Coahuila y Texas rendian cantidades insignificantes. El plan fue, pues, el de obtener de Nueva Vizcaya y Sonora la mayor masa posible de contribuciones con que atender, no ya a los presidios y misiones, que percibían sus sínodos y situados de la real hacienda, sino al sostenimiento de las milicias provinciales y a la fundación de nuevas poblaciones y conservación de la paz con los indios que la habían concertado, principales objetivos de la política que rige a Croix desde i 780 .

Croix había solicitado se dejase a su cargo el manejo del importe íntegro del situado de las tropas, en lo que pensaba ahorrar alguna cantidad: más el del producto de los fondos que acababan de crearse para milicias, el recargo que él estableció sobre el armamento, el fruto de las alcabalas de Sonora, y el de los demás ramos de real hacienda que él y Corbalán habían de crear.

Retirando o haciendo pasar al ejército a los capitanes de presidios que le pareciesen poco aptos, y que ganaban tres mil pesos, dejaría el mando a los tenientes más antiguios con sólo mil doscientos hasta que demostrasen su capacidad, en cuyo caso les subiría la paga a dos mil pesos. Del mismo modo creía poder economizar en los soldados de cuera, pues los ligeros hacían el mismo servicio con setenta y dos pesos menos al año. ${ }^{35}$ Croix pidió autorización para invertir libremente estos ahorros en diciembre de i 780 , $y$ así le fue concedido en $1782 .{ }^{36}$

Aparte las exacciones que recaían sobre los mineros, y que se percibían tanto en Sonora como en Nueva Vizcaya, habíanse establecido en aquellas provincias diversas rentas reales de las que era la principal la del monopolio del tabaco, introducida durante la visita de Gálvez, y el volumen de cuyo

35 T. de Croix a Gálvez. Arizpe, 23 de enero de 1780 , núln. 8, reservada. A. G. I., Guadalajara, 522. El sueldo de capicán, por otra parte, rutedó fijarlo en 2.400 pesos, por real orden de 19 de abril de 1779 . Teodoro de Croix a Gálvez. Arizpe, 23 de enero de 1780 , núm. 472. A. G. I., Guadalajara, 272.

36 T. de Croix a Gálvez. Arizpe, 23 de diciembre de 1780, núm. 582. Real orden de $10^{\circ}$ de marzo de 1782 . Ibid. 
producto excedía extraorclinariamente al de cualquier otra, aún la más pingüe, pero que era integramente remitida a España. Ahora Croix, recién llegado a Arizpe, decreta el cobro de las cantidades adeudadas en concepto de alcabalas clesde I 5 de agosto de I777. 37 Con esto resuelve un largo trámite iniciado a mitad de siglo, en el cual diversas órdenes y contraórdenes habían dificultado la introducción de semejante impuesto. En los casi dos años y medio transcurridos descle la fecha citada se calculaba en más de medio millón de pesos el valor de las mercancías entradas en Sonora desde Guaclalajara, y se stiponía que aún había entrado mayor cantidad desde Durango. E1 total cle las alcabalas adeudadas ascendía a mas de sesenía y siete mil pesos. En Rosario, Maloya y Copala se habían recaudado en el mismo tiempo más de veinie mil quinientos pesos, sin contar que en aquellos parajes los artículos se encarecían más de un ochenta por ciento sobre el precio de México. Fue el auditor Galindo Navarro quien decidió a Croix a hacer efectivas las alcabalas que en la zona meridional de Sinaloa, donde ya habían sido introducidas, sería de $6 \%$; en los lugares donde ahora se exigía por primera vez, de $4 \%$, y en la región de Batuco, Oposura, río de Sonora y Cieneguilla, que padecía hostilidades, sólo de $2 \%$, estando exentos de alcábala los presidios y los lugares en diez leguas de radio. En I 768 había resistido el gobenaclor la exacción del $4 \%$ que pretendía realizar en Sonora y Rosario el administrador de alcabalas de Guadalajara, y Gálvez retardó el expediente hasta el momento de su visita a la provincia. En I 770 , una orden del virrey Croix en el mismo sentido fue protestada por los comerciantes de San Antonio de la Huerta, Alamos, Trinidad y Río Chico, que lograron sí suspensión. Pero en I 8 de abril de 1777 decretó Bucareli el cobro de alcabalas, exceptuando los lugares hostilizados, y hasta ver la aplicación definitiva de esta disposición, Corbalán publicó bando para que se depositase o afianzase el derecho de alcabalas adeudado desde i 5 de agosto de I777 por razón de mercancías entradas por Guadalajara o por la sierra, y de ventas de esclaros, casas, sitios $y^{r}$ heredades. A partir de tal fecha, pues, pidieron y obtuvieron Corbalán y Galindo el cobro de las alcábalas.

Casi la misma antigüedad tenía el expediente sobre tributos de Sonora, que Gálvez había pretendido imponer; sin embargo, su exacción no había podido tener efecto por causa de las crecidas de los ríos y por no poclerse pagar a los comisionados para el reparto de tierras, que debían formar los padrones. Sólo en la jurisdición de Acaponeta y Culiacán se cobraban tributos. En 1775 se ordenó formar la matrícula de tributarios, lo que tuvo efecto en Rosario y Copala. A su llegada a Arizpe pidió informes Croix a

37 T. de Croix a Gálvez. Arizpe, 23 de enero de i780, núm. 460. A. G. I., Guadalajara, 27 I. 
la audiencia de Guadalajara del estado de este asunto y reclamó del virrey los autos formados a este respecto en el virreinato. ${ }^{38}$ Sin embargo de estos esfuerzos, la imposición de trïutos no llegó a hacerse extensiva a todos los indios de Sonora, y constituyó siempre un débil ingreso en las arcas reales.

Al modo de las alcabalas se decidió el cobro del derecho de un peso por carga de sal a que quedó reducida la renta de salinas que Gálvez se había esforzado en crear. Hasta entonces no habían tenido vigor las disposiciones de Gálvez, ni las de Corbalán, porque los naturales las rechazaron y se temíc nueva inquietud de ellos, sin que hubiese fuerzas para contenerlos. Por eso Corbalán propuso el cobro de un peso por carga en las oficinas de alcabalas de Ostimuri, Alamos y valle de Sonora. 39 De Madrid aconsejaron prudencia para evitar que esto fuese causa de disturbios, pero Croix declaró no recelar nada a este respecto, puesto que los indios gozaban de libertad en lo tocante a sal, sin contribuir cosa alguna de impuestos ni por la sal que consumían ni por la que extraían para vender en otras jurisdiciones, y sólo los compradores los pagaban a los administradores de alcabalas. $4^{\circ}$

La más genuina de las rentas creadas por Croix fue la del mezcal. El vino que se fabricaba de la planta de este nombre se consumía en grandes cantidades en Sonora, y esto fue el motivo de que en I775 preguntara el virrey Bucareli a Corbalán si sería conveniente prohibirlo, igual que el chinguirito en Nueva España. La respuesta había de ser negativa, puesto que el mezcal, sobre no ser nocivo para la salud, no perjudicaba al comercio de vinos españoles, que apenas llegaban a Sonora. La prohibición que sin embargo se dictó fue causa. de que los indios se dieran a fabricar otra bebida, el tesguino, obtenida del maíz y sumamente nociva, hasta que el virrey permitió el mezcal en I777. Estos informes daclos a Croix en I780 por Corbalán y Galindo le impulsaron a decretar la permisión, estanco y administración de cuenta de real hacienda del mezcal en la provincia de Sonora, destinando en principio su producto a las obras de conducción de aguas a la capital, de la misma manera que se hacía en Guadalajara, donde también estaba estancado este producto. ${ }^{4}$

Fue en Nueva Vizcaya donde Croix conoció la ventaja de estancar esta bebida, habiéndolo propuesto como arbitrio para allegar fondos para el establecimiento de milicias los vecinos de la villa de Nombre de Dios en

38 T. de Croix a Gálvez. Arizpe, 23 de febrero y 23 de julio de 1780 y 23 de septiembre de $I 782$, núms. 478,550 y 833 . A. G, I., Guadalajara, 518,267 y 518.

39 T. de Croix a Gálvez. Arizpe, 23 de abril de 1780, núm. 514. A. G. I., Guadalajara, 271.

40 T. de Croix a Gálvez. Arizpe, 23 de septiembre de 1782 , núm. 823. A. G. I., Guadalajara, 282.

4 T. de Croix a Gálvez. Arizpe, 23 de abril de r780, núun. 5 г3. A. G. I., Gualalajara, 277. 
I778. Siendo contradictorios los informes que a este respecto recibía, resolvió Croix crear también algún estanco del mezcal, por considerarlo bebida no nociva y cuya fabricación era además imposible de impedir. Erró tan sólo Croix en el cálculo del fruto del estanco, que imaginaba alcanzase en las dos provincias a más de sesenta mil pesos anuales, cifra que contrasta con la real de menos de diez mil que produjo en los primeros años. ${ }^{42}$

Procuró Croix en Nueva Vizcaya el mejor método de la exacción de las alcabalas de Chihuahua y su distrito, 43 y no dejó de mostrar la conveniencia de que para el cuidado y fomento de todos los ramos estableciclos en esta provincia y la creación de los de salinas y tributos, que no existían efl ella, se nombrase un intendente en lugar del gobernador militar, en cierto modo innecesario. 44

Pronto se advirtió el aumento del producto de las rentas, gracias a la creación y fomento de ellas por parte principalmente de Croix y Corbalán, según se expresa en el cuadro de totales que nos ha sido posible reconstruir solo fragmentariamente.

\section{SONORA}

$\begin{array}{ll}\text { I778 } & 233 \cdot 748.4 \cdot \text { II } / 3 \\ \text { I7 } 80 & 284.5 \text { I9.2.8 } \\ \text { I7 } 8 \text { I } & \text { 30I.I2I.I.3 } \\ \text { I.783 } & 395.520 .4 .5\end{array}$

Nueva Vizcaya

$554.477 \cdot 4.6$

$7 \mathrm{I} 2.883 .6 .7 \mathrm{I} / 4$

$698.055 \cdot$. . 3

Croix se esforzaba por $^{-}$atraer a las provincias internas el azogue preciso para la más extensiva explotación de las minas, "ramo principal, según dice al dar cuenta del producto de las rentas en I78I, y que da movimiento v vigor a todos los denás". Si bien el tabaco producía mucho más cuantiosos ingresos que las minas, según hemos dicho, no cabe duda del incremento que éstas hubieran podido experimentar de atenderse más cuidadosamente al surtimiento de azogues.

La cantidad de azogues que la superintendencia del ramo en México asignaba a las provincias internas era en realidad escasa, puesto que a Parral sólo se concedían dos mil ochocientos dos quintales, y a Alamos, quinientos cuarenta. A esto se agregó en I782, la arbitrariedad de permitir el superintendente Valcárcel que los mineros que lo deseasen pudiesen pedir azogues directamente a México, haciéndose cargo del gasto de fletes desde Veracruz

42 T. de Croix a Gálvez. Arizpe, 23 de enero de i78r, núm. 603, A. G. I., Guadalajata, 271

43 T. de Croix a Gálvez. Arizpe, 2 de diciembre de $1782, n .^{\circ} 857$. A. G. I., Guadalajara, 283.

44 Ibidem, y T, de Croix a Gálvez. Arizpe, 23 de enero de I 78 I, núnı. 505. A. G. I., Guadalajara, 281. Informe General de 1782 , arts. $542-544$. 
a la capital de Nueva España, lo cual suponía una injusticia por cuanto redundaba en perjuicio de los mineros de cortas facultades, que sólo podían proveerse de la ya mermada cantidad que llegaba a las cajas foráneas. Así, de los dos mil ochocientos dos quintales consignados a Parral, mil cuarenta y tres habian sido ya expendidos en México a sólo diecisiete mineros de Nueva Vizcaya, lo cual no obstaba para que luego pudiesen solicitar otras cantidades en Parral. Representó, pues, Croix a Valcárcel para que suprimiese aquella abusiva práctica, lo que le fue concedido, pero continuó luego reclamando mayor surtimiento de azogues a las cajas reales de las provincias internas cuyas minas podrían producir así mucho mayores freutos. 45

\section{LAS NUEVAS POBLACIONES}

Veintiocho poblaciones y dos nuevos presidios pretendía establecer Croix, con un costo aproximado de ciento cincuenta mil pesos. Claro que la tropa y oficialidad de los presidios se costearían en buena parte el traslado. Y para los demás gastos podía contar con los fondos de milicias, los arbitrios creados con el mismo fin, el recargo de armamento, más el ahorro en el situado de los presidios. Con todo ello esperaba Croix tener disponibles unos sesenta y tres mil quinientos pesos anuales, suficientes para el establecimiento.

Dos de las poblaciones - Casas Grandes y la villa de San Juan Nepumuceno- existían ya, y sólo sería preciso guarnicionar aquélla, como se estaba haciendo con cien hombres de la cuarta compañía volante, y Croix contaba también con los vecindarios que se iban formando junto a los presidios del Carrizal y San Eleazario. ${ }^{6}$

Meses después de meditado el plan, recibía el comandante general informes de Muñoz y Díaz, dos de los jefes de la frontera de Nueva Vizcaya. Encargó a aquél el mando de la línea de poblaciones que había de correr de Namiquipa al presidio de la Junta o del Norte, mientras que Díaz atendería las que habían de establecerse desde la raya de Coahuila a Ancón de Carros. Muñoz había de comenzar por la organización del puesto defensivo situado en la Hacienda de Encinillas, que quedaba entre las nuevas poblaciones de Majalca y San Jerónino y los presidios de la primera línea y contaba con un fuerte contingente de vaqueros armados. El valle de San Buenaventura y el vecindario de este presidio y del de Janos, debidamente atendidos, debían

45 T. de Croix a Gálvez. Arizpc, 2 de diciemlure de 1782, nún. 850. A. G. T., Guadalajara, 283. T. de Croix a Gálvez. Arizpe, 21 de abril de 1783 , núm. 9I4. A. G. I., Guadalajara, 284. 46 Informe General, núm. $45^{8}$, arts. I $44^{-1} 4^{8}$. 
pronto experimentar un considerable progreso, de tal manera que desde ${ } 78 \mathrm{I}$ no se necesitaría adquirir bastimentos fuera de la región. 47

Treinta y seis familias, con copiosas siembras de grano existían ya ai abrigo de San Eleazario. Algún vecindario subsistía en San Jerónimo, y otros pobladores se iban congregando voluntariamente en Naniquipa. Los destacamentos destinados a guarnecer estos núcleos estaban allí establecidos desde octubre de 1779 , salvo el de Coyame, y trataban de evitar, no siempre con éxito, las acometidas de los apaches. Se hacían siembras de trigo, cebada, maíz y frijol y los acostumbrados cortes de madera.

Desde $\mathbf{7} 780$ ya se cosechaban dos mil fanegas de maíz en las siembras próximas al presidio del Carrizal, a pesar de la gran epidemia padecida en esta fecha, y desde entonces la producción fue suficiente para abastecer al presidio, por primera vez desde la fecha de traslación a aquel paraje. Ciento sesenta y ocho personas vivían bajo su protección y el gobierno del capitán Don Francisco Martínez, que les infundía laboriosidad. 48

Otro tanto ocurría en San Eleazario, donde ciento veintiséis personas, en su mayoría antiguos vagos de E1 Paso, trabajaban en comunidad bajo la dirección del teniente del presidio Don Tomás de Egurrola. En I780 habíanse dedicado a desmontar el paraje, construir una acequia, y sus propias habitaciones, y se habían obtenido mil fanegas de todas las semillas, consírtyéndose almacenes capaces para cuatro mil fanegas, a que se esperaba ascendiera en seguida la producción, con el consiguiente beneficio de la región y del presidio. La acequia madre tenía tres cuartos de legua, con tres varas de ancho y de dos a tres de profundidad, y la población se iba organizando en torno a dos plazas. Pronto se repartirían tierras a los vecinos. 49

Este éxito halló gran acogida en la corte. Gálvez manifestaba a Croix la complacencia con que el rey recibía estas noticias y le animaba a procurar se arrimasen pobladores a los demás presidios. Para entonces, según mostramos, Janos, San Buenarentura, Carrizal y San Eleazario podían sentirse respaldados en los núcleos de colonos que se situaban junto a ellos o a su retaguardia. De los presidios de Nueva Vizcayạ, sólo el del. Norte carecía de este apoyo, aunque, según veremos, a su lado se asientan los indios recién venidos a la paz.

También desde octubre de I779 se ha extendido el cordón de destaca-

47 T, de Croix a Gálvez. Arizpe, 23 de mayo de i y8o, núm, 519. A. G. I., Guadalajara, 522. T. de Croix a Gálvez. Arizpe, 23 de mayo de I 730 , núm. 520. A. G. I., Guadalajara, 278. T. de Croix a Gálvez. Arizpe, 23 de julio de 1780 , núm 542 . A. G. I., Guadalajara, 267. T. de Croix a Gálvez. Arizpe, 23 de agosto de i 780 , núm. 555. A. G. I., Guadalajara, 27 I.

$48 \mathrm{~T}$. de Croix a Gálvez. Arizpe, 30 de mayo de $178 \mathrm{I}$, núm. 648. A. G. I., Guadalajara, 272.

49 T. de Croix it Gálvez. Arizpe, 30 de mayo de т78 s, núm. 647. A. G. I., Guadalajara, 267 y 28 I. Ibid. 
mentos que cubría de Ancón de Carros al paraje de San José de Pelayo, es decir, la frontera oriental de Nueva Vizcaya, enlazando con el cordón de poblaciones del norte por el corto destacamento de la hacienda de Dolores. Después de Díaz, García Rebollo y el ayudante mayor de milicias Don José de Riaño dieron informes sobre los lugares donde podría colocarse guarnición para prolongar el cordón defensivo desde Pelayo hasta la raya de Coahuila. 50 Este asunto, sin embargo, sufrió una considerable demora, y los dos puestos de cincuenta hombres que Croix pensaba colocar entre Parras y Saltillo no llegaron a existir jamás. El informe de Riaño, de mayo de $I 785^{51}$ aconsejaba situar un destacamento en el rancho de Vinagrillos, en el frente de $\mathrm{Ma}$ pimí, y sugería otro posible en la hacienda de los Hornos, a tres leguas del pueblo del Alamo, donde se había pensado fundar el pueblo de Nueva Bilbao, que de todos modos sería posible crear, pues había en la hacienda cuarenta o cincuenta arrendatarios que deseaban congregarse en población, lo que les permitiría recibir lotes de tierra en propiedad; a ellos podrían agregarse los españoles avecindados junto al pueblo indio del Alamo, y algunas familias pobres de Parras.

La hacienda de Anahelo, en cambio, a unas veinte leguas de Saltillo y ya en la linde de Coahuila, contaba con cincuenta familias de pastores que cuidaban los cuarenta mil carneros que el marqués de Aguayo tenía en sus agostaderos.

Las dificultades surgidas en Mapimí, Parras y Saltillo para la contribución al fondo de creación de milicias fueron causa de que, por último, quedasen desguarnecidas estas poblaciones, y sus territorios fueron los más dañados al reanudarse las hostilidades de los apaches de oriente.

\section{LOS FONDOS DE MILICIAS}

En enero de I78r ya le era posible a Croix enviar un detallado informe sobre lo actuado en orden a la creación de las milicias en Nueva Vizcaya. El establecimiento había sido hecho, y sólo quedaba perfeccionarlo con el transcurso de! tiempo. Sus sugerencias versan sobre la utilidad de crear intendencias, emplear trescientos dragones y los granaderos en la frontera y colocar salvaguardias en las poblaciones, mientras las escuadras de indios auxiliares podían ser dedicadas a recorrer la sierra Madre, para'tener tranquilos los pueblos y recoger a los fugitivos apóstatas y a los gentiles que se ocultaban en las más profundas y apartadas barrancas. ${ }^{2}$

\footnotetext{
50 T. de Croix a Gálvez. Arizpe, 29 de julio de I'782, núm. 791. A. G. I., Guadalajara, 283.

5 I Riaño a T. de Croix. Parras, 5 de mayo de $\mathrm{z} 78$. Ibid.

52 T. de Croix a Gálvez. Arizpe, 23 de enero de I7SI, núm. 595, con diez carpetas de documentos y estados. A. G. I. Guadalajara, 28I.
} 
En ciento cincuenta mil pesos calculaba Teodoro de Croix los fondos recogidos como donativos en las jurisdicciones donde se habían creado las milicias. Parral había dado 'I.342 pesos; San Juan del Río, I 3.000 y cerca de 400 caballerías; Chihuahuta, 20.545 pesos. Durango, 13.656; Nombre de Dios, 8.000; San Bartolomé, 6.935; el real del Oro, 6.933; Santa Bárbara, 966.53

En octubre de ry88 ya envía los primeros proyectos de arbitrios de EL Paso, para su aprobación; en diciembre ya son los del Parral, San Bartolomé y. Chihuahura; en agosto de I 7 9, los de San Juan del Río. En enero de I78I da a conocer los arbitrios propuestos por Real del Oro, Inclé y Guanacevi, Cuencamé, Mapinní, Papasquiaro, Mezquital, Gallo y Cusihuiriáchic y Durango. El estudio de los arbitrios de Nombre de Dios origina el expediente clel cual saldrá el estanco del nezcal en Sonora y Nueva Vizcaya. ${ }^{5+}$

Menos en la prolongación de esta prosincia que alcanzalsa a Coahuila, las milicias habían sido entonces organizadas en todo el territorio fronterizo de las veintiséis alcaldías mayores de Nueva Vizcaya; sólo no las tenían las de Sianori o Real de San José de Canelas, San Diego de Río Grande, San Andrés de la Sierra, San Antonio Tabahueto, San José de Basis y San Pedro Batopilas, todas ellas situadas en la zona interior y libres de hostilidades. 55

Pronto un contingente de estos clragones provinciales milicianos hallóse actuando en la frontera del bolsón y constituyendo una tropa bien disciplinada, instruída y asistida, teniendo para su servicio, como los soldados ligeros, sólo dos caballos y una mula; y percibiendo como haber anual ig6 pesos, de que se rebajaban 18 para el fondo de remonta; obtenían sin embargo fuertes alcances, que percibían en dinero a fin de año. Cien de estos dragones, distribuidos en dos destacamentos en el Pasaje y Cerro Gordo, escoltaban las recuas de y para Chihuahua, y otros veinticinco se hallaban en los puestos del Bolsón. 56

Las dificultades empezaron a surgir, no obstante, cuando llegó el momento de hacer efectivos los arbitrios de cada una de las poblaciones. Casi todas ellas, desde luego, optaron por el sistema de igualas entre los vecinos, o bien por una pequeña subida en el impuesto de alcabalas. Sin embargo, los

$53 \mathrm{~T}$. de Croix a Gálvez. Chihuahua, 24 de agosto de r778, núm. 260. A. G. J., Guadalaj zra, 276. T. de Croix a Gŕlvez. Chihulahua, 28 de diciembre de 1578 y 23 de eisero de r 770. núms. 3 I 7,320 y 342. A. G. I., Guadalajara, 270. T. de Croix a Gálvez. Chihuahua, 30 de agosto de r 779, núm. 430. A. G. I. Guadalajara, 5 I9. T. de Croix a Gálvez. Chihuahua, 23 de octubre de I 778 , nutm. 298. A. G. I., Guadalajara, 267 y 275.

54. T, de Croix a Gálvez. Arizpe, 23 de enero de $781,10 u ́ n$. 596 al 604. A. G. I., Guadalajara, $27 \mathrm{I}$.

55 T. de Croix a Gálvez. Arizpe, 23 de enero de I78I, núm. 607. Ibick.

56 T. de Croix a Gálvez. Arizpe, 30 de julio de $178 \mathrm{r}$, núm. 663. A. G. I., Guadalajara, 267. 
recursos que de todas partes se levantaron al rey empezaron a inquietar al secretario de Indias.

Los pueblos se disculpaban alegando epidemias o malas cosechas, pero peor aún era la actitud de algunos hacenderos de los más principales, y de algunos criadores de ganados, que comenzaron a trasladar a otras partes de tierra afuera sus rebaños para no verse obligados a contribuir. Así, el marqués del Apartado hizo conducir sus ganados a Nueva Galicia. 57 Dos de los más fuertes latifundistas de Nueva Vizcaya, Don Juan Lucas de Lazaga y el marqués de San Miguel de Aguayo, amenazaron con adoptar las mismas medidas. ${ }^{8}$ Aguayo y Lazaga presentaron a Gálvez, por otra parte, los daños que sus haciendas habían sufrido, atribuyéndolos veladamente a incompetencia de Croix, mostrando la paz que disfrutaron en la época de O'Conor. 59

En Parras y Saltillo era dondé ambos potentados tenían la mayor parte de sus haciendas, y fue en estos lugares donde se experimentó la máxima repugnancia, primero en admitir los arbitrios, y luego en pagarlos. Después de tres años de trámites, aún no se llegaba en I782 a un acuerdo sobre el procedimiento de exacciones, pues si se hacía sobre el comercio de ganado, recaía la mayor parte del gravamen sobre Aguayo y Lazaga, mientras que si se hacía sobre la uva gravaría en demasía a los vecinos, que además poco tenían que temer por sus viñas. ${ }^{60}$ Finalmente, rechazado un proyecto de iguala, convinieron recargar la alcabala un $2 \%$ para los vecinos y $4 \%$ para los forasteros viandantes. ${ }^{6}$ Croix, al desechar las quejas de los terratenientes, asienta con firmeza: "ellos poseen bienes como diez, y pretenden que la contribución no los grave sino como dos, y que recaiga el peso sobre los infelices vecinos". ${ }^{2}$ Entre tanto, se había abierto un nuevo período de hostilidades y la frontera sur del Bolsón sufrió la primera embestida de los apaches, que le cogió desprevenida e inerme cuando el rey intentaba que Lazaga y Aguayo fuesen persuadidos a dar ejemplo acudiendo a la defensa de Parras y su territorio. En Parras la contribución de donativos había quedado en 7.000 pesos, y los arbitrios en una contribución de 10.000 por encabezamie11to, lo que era insignificante cuando su comercio se valoraba en 400.000 pesos

57 T. de Croix a Gálvez. Arizpe, 30 de noviembre de 578 I, núm. 696. A. G, I, Guadalajara, 5 I9.

58 El virrey Mayorga a Gálvez. México, 17 de enero de 1782 , núm. 1.48I. A. G. I., Guadalajara, 268 .

59 Lazaga y Aguayo a Gálvez. México, 20 de febrero de 1782 . Remitido por Mayorga a Gálvez. México, 28 de febrero de 178 I, núm. 1.526. A. G. I., Guadalajara, 519.

60 T. de Croix a Gálvez. Arizpe, 29 de julio de 1782 , núms. 787 y 788 . A. G.. I., Guadalajara, 5I9 y 517.

6I T. de Croix a Gálvez, Arizpe, 21 de abril de $78_{3}$, núm, 907. A. G. I., Guadalajara, 517.

$6 z$ T. de Croix a Gálvez. Arizpe, 24 de marzo de 1783 , núm. 89 I de preferencia. A. G. I., Guadalajara, 5 I 9. 
anuales. De todos modos, recurriendo al fondo general de milicias proyectaba Croix formar un cuerpo de trescientos hombres de los que dos compañias culbriesen Parras y Saltillo, que, sin embargo, a proporción de lo que aportaluan, no tenían derecho a esta protección. ${ }^{63}$

E.1 comandante general logró fuesen comprendidas su actitud y sus quejas, pues por real orden de 15 de octubre de $I_{7} 83$ se encomendó al virrey le facilitase todos los medios que pidiese, y persuadiese a Lazaga y Agtrayo a dar ejemplo a los demás vecinos de Parras y de la frontera ayudando a su defensa. 64

Efectivamente, para poner en práctica la línea de conducta preconizada por la real orden de 2 I de febrero de aquel año, el 20 ide septiembre de I 779 el gobernador comandante general había comisionado al teniente coronel Don Manuel Muñoz para que negociase las paces con los mezcaleros, dándole plena autoridad para disponer de los tropas de San Carlos y el Príncipe con objeto de que estableciese los destacamentos de Coyame, Pueblito ty Chorreras, concentrando los máximos efectivos posibles en el presidio del Norte, donde se ocuparían en acciones bélicas y también en 'las siembras y fábricas de nuevas poblaciones, junto con jornaleros e indios de mandamiento. Las capitulaciones hechas por Muñoz con los jefes apaches obligaban a éstos a establecerse en dos pueblos, a los que entrarían también algunos sumas de El Paso y de Peyotes que enseñasen 'el cultivo a los mezcaleros, mientras que Muñoz, que había de ser el jefe protector de esta nación, se comprometía a proporcionarles víveres durante un año, y los mezcaleros actuarían como auxiliares de los soldados españoles. ${ }^{65}$

\section{I_A PAZ EN ORIENTE}

En diciembre de I779, cuando Croix procedía a su radicación definitiva en Arizpe, la frontera de Nueva Vizcaya empezaba a experimentar las paces que se concertaban con los apaches, salvo la parcialidad de los gileños, que hostilizaban la región más septentrional. Una ranchería de salineros se había establecido junto a San Eleazario; estos indios y los chafalotes solicitaban la paz desde julio, y ya entraban sin obstáculo en El Paso. Desde el Príncipe ¿ San Sabá se mantenían buenas relaciones con los mezcaleros," cuyas rancherías empezahan a presentarse en el presidio del Norte, para establecerse en

63 T. de Croix a Gálvez. Arizpe, 24 de marzo de I783, núm. 892, de preferencia. Ibid.

64 Ibid.

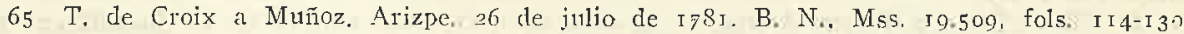
Corresponde este documento a las copias une acompañan a la carta de $T$. de Croix a Gálvez, núm. 836 , Arizpe, 7 de octubre de $x_{7} 82$, A. G. T., Guadalajara, 282. 
los pueblos abandonados por los norteños. Los capitancillos Bigotes, Patule, Juan Tuerto, Domingo, Alegre, Volante, Natajé y Montera Blanca eran esperados allí con sus familias.

Las noticias de Coahuila no indicaban otra novedad que la ide que los lipanes seguían combatiendo con los indios del norte, y lo mismo se sabía de Texas, mientras que las que llegaban de Nuevo México anunciaban la victoria obtenida por Anza, con ochocientos hombres, sobre los comanches, en acción que costó la vida a su jefe Cuerno Verde, su hijo,'su lugarteniente general Aguila Volteada y el pujacante o sacerdote. 66

Tanto la paz con los'indios aliados, como las guerras de los lipanes con ios del norte continuaron en los meses siguientes, aunque desconfiándose a veces de los primeros, temiendo se aliasen lipanes y mezcaleros, y alterándose a veces la situación por causa de los ataques de los gileños, que hicieron de una vez veinticuatro muertes en Ciénaga de los Olivos. ${ }^{67}$ Los lipanes, después de sufrir dos golpes serios de los indios del norte, se replegaron a la zona entre Béjar y Río Grande, no atreviéndose a salir a carnear, mostrando un miedo servil a los comanches, infinitamente más belicosos. ${ }^{6}$ Los mezcaleros se establecían en las ciento trece casas que para ellos fueron edificadas en el sitio escogido por Alonso, y que constituían los llamados pueblos de San Francisco y de Nuestra Señora de Buena Esperanza, y se atendía con jornaleros a limpiarles las tierras para la próxima siembra, mientras que los presidiales cortaban madera y les escoltaban a cazar cibolos, pero todavía se experimentaban algunos pequeños robos de los que continuaban vagantes. ${ }^{6}$ Con todo esto, conforme adelantaba igualmente la fábrica de la población, su comportamiento, sin embargo, y como era de esperar dada su nada consistente organización, distaba mucho de ser homogéneo, de tal modo que el cabecilla Patule hubo de separarse de su gente que se negaba a avenirse a la paz, lo mismo que Bigotes, que habitualmente merodeaba por el Bolsón, mientras que otros delataban por traidor al jefe Juan Tuerto, que se presentaba en la Ramada, junto a Guajoquilla. Otro, apodado Barbitas, desertó del pueblo y fue a refugiarse con su partida a la sierra del Mogano, 70

En julio de 1780 , sin embargo, la desgracia se abatió sobre los mezca-

66 T. de Croix a Gálvez. Arizpe, 23 de enero de 1780, núm. 46r, con Extracto. A. G. I., Guadalajara, 27I. $67 \mathrm{~T}$. de $\mathrm{C}$ con Extracto. Ibid.

68 T. de Croix a Gálvez. Arizpe, 23 de mayo de 1780 , núm. 528, con Extracto. Ibid

69 T. de Croix a Gálvez. Arizpe, 23 de mayo de 1780 , núm. 520. A. G. I., Guadalajara, 278.

70 T. de Croix a Gálvez. Arizpe, 23 de junio, $1_{3}$ de julio y 23 de agosto de 1780 , núms. 540 y 542 , con Extracto. A. G. I., Guadalajara, 267 ; núm. 555, con Extracto. A. G. I., Guadalajara, $27 \mathrm{I}$. 
leros de paz, pues se contagiaron de viruelas y perdieron la cosecha al ocurrir una crecida del Conchos. ${ }^{I}$ Empujados sin duda por esta adversidad, en octubre habían abandonado el pueblo, dejando Alonso en rehenes st1s hijos y familia en el presidio del Norte, pero se recelaba ya del comportamiento de Patule y otros, mientras que en Texas los lipanes cometían pequeños robos, los comanches invadían la provincia y los del norte se hallaban a disgusto porque no se les facilitaban las armas, pólłora y demás objetos que ahora, por la guerra, no podían adquirir de las colonias inglesas. ${ }^{2}$

Açuello significó el fin del breve período de tranquilidad. Diciembre de I780 presenció la primera entrada de los comanches a Coahuila. Un cuerpo de trescientos comanches y jumanes descendió al sur con ánimo de atacar a los lipanes, dividiéndose en dos trozos, pero sin conseguir hallar a sus enemigos porque la mayor parte estaba en Texas, y los demás refugiados il espalda de los presidios coahuilenses. Los comanches pasaron finalmente el Grande $y$ espiaron el presidio de Monclova, donde estaban además las caballadas del de Aguaverde y de los vecinos de la villa de San Fernando. Por un cautivo fugado se tuvo noticia de su proximidad, y el 6 de diciembre el comandante Don Juan de Herrera envió al alférez segundo Don Tomás Munguía con dieciseis hombres en descubierta.. Munguía enconiró a los enemigos que renían en columna, llevando en vanguardia un pelotón de sesenta que lo acometieron a golpe de lanza a distancia de un tiro de fusil del presidio. El combate tan desigual comenzado con esta carga de los comanches se prolongó durante hora y media; al cabo de este tiempo habían muerto cinco de aquellos y un soldado. Munguía mató personalmente a dos adversarios, peleando a pie un rato, hasta que los comanches fueron puestos en fuga por un cañonazo disparado desde el presidio, y ya no se les volvió a ver. 73

La disposición de los mezcaleros que habían vivido en el presidio del Norte se advirtió de inmediato en las hostilidades padecidas en Coahuila, donde apremiados, según Muñoz, por la falta de carnes 74 comenzaron a menudear los robos, justamente al tiempo en que, descle febrero de i $78 \mathrm{I}$, empezaban a concertarse en Janos las paces con los gileños. 75 Teodoro de Croix decidió entonces declarar la guerra a los mezcaleros, tras intentar por

if T. de Croix a Gálvez. Arizpe, 23 de septiembre de I 780 , ním. 556, con Extracto, A. G. 1. Guadalajara, $27 \mathrm{I}$

72 T. de Croix a Gálvez. Arizpe, 23 de diciełulure de rz8o, núm. 579, con Futracto. Ibid

$73 \mathrm{~T}$. de Croix a Gálvez. Arizpe, 23 de enero y 23 de febrero de I 78 r, núms. 608 y 6 тs con Fxtracto. A. G. I., Guadalajara, 271. T. de Croix a Gálvez. Arizpe, 26 de marzo de IรS. núm. 262. A. G. I., Guadalajara, 272.

74. Miñoz a T. de Croix. Cuattel de Dolores, t6 de junjo de I78I. B. N., Ms5. t9.509,
86-95. 75 T. uadalajara, $27 \mathrm{I}$ 
última vez la concordia. Siguiendo sus instrucciones, Muñoz convocó a los jefecillos en el presidio del Norte, al que concurrieron el 3 de setiembre Alonso, Alegre, Patule y Volante, quienes pidieron plazo de veinte días para deliberar. La propuesta española era terminante: los mezcaleros que no se radicasen de manera permanente en los pueblos o como auxiliares de los presidios serían considerados enemigos: en fin de cuentas, venía a pedírseles que pasasen definitivamente a convertirse en agricultores. La solución favorable, como reconocía Borica, era muy difícil. ${ }^{6} \mathrm{El}$ capitán del Norte, Muñoz, consiguió la muerte de Juan Tuerto por algunos de sus parientes, y Croix le encargó procurase lo mismo con los otros jefecillos inquietos. Lo mismo que en Nueva Vizcaya y Coahuila, el panorama se ensombrece en Texas cuando los comanches empiezan a incursionar frecuentemente el territorio en gruesas partidas causando muertes, robos y daños, aunque como resultado de la visita girada por la Matte se presentaron al gobemador embajadas de los indios del norte. 77

Esta es la situación que se va haciendo más y más definitiva según va avanzando el año de $178 \mathrm{I}$ : los comanches combaten a lipanes y españoles, ${ }^{8}$ pero éstos van logrando afianzar vínculos con los indios del norte; los mezcaleros se muestran divididos y una parte de ellos regresa a la vida nómada y causa estragos en Coahuila mientras que otros permanecen fieles a la anterior alianza. 79 Es en octubre cuando, de síbito, vuelven a verse hostilizados los lugares de la frontera oriental de Nueva Vizcaya: Torreón, Guanacevi, Santa Rosalía, San Juan del Río, Dolores. ${ }^{80}$ La mayor parte cle los mezcaleros ha decidido no regresar bajo la tutela del presidio del Norte, dándose por recomenzada la guerra con esta parcialidad apache.. Y: entonces Muñoz, auxiliadlo por Alegre, Volante y Manuel Cabeza, que aparentemente habían aceptado las nuevas capitulaciones de paz, expediciona con éxito en la sierra Guadalape a la captura de los mezcaleros fugitivos, de los que hizo cuarenta y nueve prisioneros pero en noviembre todas las familias que aún quedaban en el pueblo de Nuestra Señora de Buena Espe-

76 Muñoz a T, de Croix. Presidio del Norte, 12 de septiembre de $178 \mathrm{x}$, con acta de la junta de 5 de septiembre, a la que no asistió Volante porque tronaba "y el se tiene por hechicero". B. N. Ms 19.509 , fols $9 \$-107$. Borica a T. de Croix, Chihuahua, 14 de septiembre de 1781. Ibid., Gutiérrez de la Cueva informa a $\mathrm{T}$. de Croix, Chihuahua, 15 de septiembre de 1781 , ibid., fols. 142-147, que Alonso y Alegre parecen de fiar, pero Volante dejaba siempre a su gente y Patule, el más ladino $y$ de gente más belicosa, andaba siempre con Bigotes el Pelón, que habitaba el Bolsón y era el de más numerosa gandulada.

$77 \mathrm{~T}$. de Croix a Gálvez, Arizpe, 23 je junio de $I 78_{1}$, nún. 652 , con Extracto. A. G. I. Guadalajara, 267.

78 T. de Croix a Gálvez. Arizpe, 30 de julio de $178 \mathrm{~J}$, núm. 659, con Extracto. Ibid.

$79 \mathrm{~T}$. de Croix a Gálvez. Arizpe, 23 de septiembre de 1781 , núm, 680, con Extracto. Ibid.

8o T. de Croiz a Gálvez. Arizpe, $3 \mathrm{r}$ de diciembre de ${ }_{178 \mathrm{r}}$, núm. 705, con Extracto. A. G. I.

Guadalajara, 268. 
ranza lo abandonaban con el mismo Alegre y Volante y se temió tratasen de reconciliarse con los lipanes. Perseguidos por el teniente Arce, sufren algunas bajas, pero sus golpes se hacen sentir en el mismo presidio del Norte, en el robo del correo semanario a Durango, en la hacienda de San Juan, Nombre de Dios, Cerro Gordo, Pasaje y San Bartolomé, y simultáneamente son atacados los alrededores de Parras, donde en tres meses produjeron veinticinco muertos asaltando un núcleo de doscientos las haciendas de Aguayo en Boquillas, La Peña, el pueblo del Alanno, Las Habas, Santa Clara, Santa Gertrudis, San Bartolomé y las Aguilillas: robaron enorme cant:dad de caballada y mulada alanceando en Las Habas más de tres mil ovejas y otras tantas crías de Aguayo. Contaban los supervivientes que llevaban en tres palos tres pañuelos blanco, encarnado y negro, como banderas, y transitaban por el camino real asesinando a los viandantes. ${ }^{81}$ De aquí nació la consiguiente represión por parte de los españoles, y más concretamente, desde Coahuila, por Don Juan de Ugalde.

Bon Juan de Ugatde goternador de Coahuila

La injusta carta que los potentados Aguayo y Lazaga escribieran a Gálvez deploranclo la ruina de sus posesiones, de que culpaban a Croix, fue acompañada por el virrey Mayorga con otra del gobernador del Nuevo Reino de León Don Vicente González de Santianes, que narraba varios asaltos padecidos por su gobernación y que habían afectado a Valles, Salinas, Pesquería Grande, Santa Catalina, Vallecillo y la Igutana; el íltimo golpe cayó sobre una hacienda de Aguayo en Anahelo, donde los apaches habían causado treinta y tres muertes. Las hostilidades se hacían sentir igualmente en la vecina colonia de Nuevo Santander, cuyo gobernador Don Diego Lazaga logró apresar varios enemirgos que el virrey destinó a las obras de Veracruz, donde serían educados. ${ }^{8}$

Gálvez remitió a Croix noticia de la representación de Aguayo y Lazaga, para que se informase sobre su contenido, y si bien sabemos la réplica contundente que a aquel escrito dio el comandante general demostrando su falsí? y la poco elogiabie actuación de sus autores, sirvió al menos aquel papel para que ocurriese un cambio en la política gubernamental, que decretó esta vez la guerra a los bárbaros en sus propios terrenos, abandonando la anterior

Si T. de Croix à Gálvez. Arizpe, 26 de enero de I782, nú1u, 709, con Extracto. A. G. I., Guadalajara, 282.

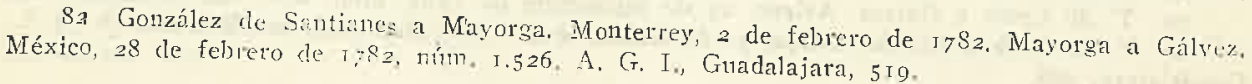


actitud defensiva y haciéndoles "una continuada guerrilla sin estrépito, como lo practicaron, aunque con pocas tropas, Don José Berroterán y Don Bernardo de Gálvez en sus respectivos tiempos", esperando Su Majestad que con esto se pusiese fin a los horrores que se venían experimentando. ${ }^{8} 3$

La ruptura de la paz con los mezcaleros fue sensible para Croix, que declara que en los tres años de paz se gastó en su manutención algo más de siete mil pesos, pero que en las incursiones que batieron de Saltillo a Durango habían causado muchas muertes y pérdidas por valor del triple de aquella cantidad. ${ }^{84}$ Sin embargo, antes de recibir la anterior real orden, las representaciones de Muñoz y Ugalde a la vista de las primeras hostilidades habían decidido a Don Teodoro a ordenar a éste se preparase a batir el Bolsón contra los mezcaleros, combinando sus movimientos con los de las tropas de Nueva Vizcaya. ${ }^{85} \mathrm{El}$ primer efecto de los preparativos de Ugalde, y de los que simultáneamente se efectuaban en Nuevo Santander, fue el de que se retirasen los lipanes a Texas, recelosos de ser atacados. ${ }^{86}$

Ugalde salió a campaña con doscientos hombres el 26 de noviembre de I78I, y se mantuvo en el Bolsón hasta fines de enero de 1782 , logrando hacer en este tiempo siete cautivos y capturar sesenta y tres caballerías; de su parte tuvo un muerto y las mil doscientas caballerías que sacó, muertas o inutilizadas. Para mayor desgracia, el 28 de noviembre, mientras él se internaba en el desierto había dado comienzo la devastadora incursión de los mezcaleros en la zona de Anahelo, Pesquería, Saltillo y Parras que hemos narrado poco atrás. ${ }^{87}$

Más afortunada fue la segunda campaña, de ciento doce días, de marzo a mayo de 1782 , en la que Ugalde consiguió hacer cinco bajas y cuarenta y cinco presas a los mezcaleros, liberar a seis cautivos y cobrar más de cuatrocientas bestias. En el aguaje de la Mula puso en fuga al capitán Dajate; en el de San Juan, a Tagadachilé, Dajunné, Quiéfiéquijá y Pechollé. Dajunné -que en castellano significa "hombre consolado" y no era otro que Alonso, el gobernadorcillo del pueblo de Nuestra Señora de Buena Esperanza- salió herido de esta función, y Patule en otra habida en el aguaje de las Comas. ${ }^{88}$

Patule fue a presentarse con otros dos, al presidio de San Carlos, cuyo comandante los puso en el cepo, avisando al del Norte, que los recogió y

83 Real orden de 27 de junio de 1782 . Ibid.

84. Informe general de 1782 , núm. 835 . T. de Croix a Gálvez. Arjzpe, 7 de octubre de 1782.

Art. I04. A. G, I., Guadalajara, 282.

85 Ibid., art. 140. Ibid.

$86 \mathrm{~T}$. de Croix a Gálvez, Arizpe, 23 de sentiembre de 1782 , núm. 822 , con Extracto.

A. G. I., Guadalajara, 282 .

S7 Informe general, 835, arts. 147-152.

SS Ibidem, arts. 155-I59. 
aseguró con grillos y esposas, persiguiendo a su ranchería en la sierra Murciélago, consiguiendo se rindieran veinte gandules y treinía y cinco mujeres y muchachos: entre aquéllos se halló a Alonso y un nuevo capitancillo, nombrado Zapato Tuerto. Conducidos al presidio del Norte, presentáronse luego treinta y cinco piezas más de paz, pero Croix dispuso que el total de noventa y cinco fuese remitido a Chihuahua, y de aquí pasasen a México, pues a todos hacía culpables de las muertes y robos ejecutados en Saltillo y Parras, Y consideraba patente su mala fe en el intento de presentarse de paz. ${ }^{89} \mathrm{Mu}$ ñoz conseguía en setiembre batir a la ranchería de Bigotes en la sierra de San Cristóbal, haciéndole tres muertos y un preso con treinta y seis bestias, y en octubre la práctica destrucción de la ranchería con la muerte del mismo
Bigotes. 90

En. el mismo setiembre practicaba Ugalde con doscientos trece hombres su tercera campaña por el Bolsón, en el que se mantuvo mariscando hasta el 9 de marzo de 1783 , en que regresó a Monclova. ${ }^{1}$ En casi seis meses había logrado seis muertos y doce prisioneros del enemigo, junto con la liberación de un cautivo y el rescate de ciento cincuenta y cuatro bestias: por su parte había tenido una baja y la inutilización de toda la caballada. ${ }^{22}$ Entre tanto, ochenta o neventa enemigos habían caído sobre Pelayo, Cadena, Cuencamé y San Juan del Río causando cuarenta y cinco muertes, algunos cautivos y el robo de seiscientas bestias. 93

Aquello hubiera sido la causa del definitivo rompimiento entre Croix y Ugalde si aquél no hubiera sobrevenido ya seis meses atrás, pues ya en octubre de 178294 informaba pésimamente de éste el comandante general haciéndole responsable del mal estado en que se hallaban los presidios después de su traslación, y rechazando sus disparatados proyectos de ataque y defensa ela.borados sobre la base de dotar a cada soldado con quince o dieciseis caballos y creación de nuevas compañías. "Es excusado exponer mi dictamen", dice Croix. A este tenor mucho mayores aumentos de fuerzas se harían precisos en Nueva Vizcaya y Sonora y aún en Nuevo México y Texas, y aplicando la plantilla de sueldos propuesta por Ugalde los gastos anuales ascenderían a dos millones de pesos, y la dotación de caballos ni los crecidos sueldos po-

S9 T. de Croix a Gálvez. Arizpe, 7 de octubre de $I>82$, núm. 836 . A. G. I., Guadalajara, 282

$90 \mathrm{~T}$. de Croix a Gálvez. Arizpe, 4 de moviembre y 2 de diciembre de 1782 , núm. 843 y 855 ,

T. de Croix a Galver Guarlalajara, 517 .

$92 T$. de Croix a Gálvez Arizpe a de junio de Gradalajara, 284 .

93 Vid, nota 91

94 Informe gencral num. $8_{35}$. A. G. I., Guaclalajara, $2 \&_{2}$. 
drían mantenerla, ni el territorio acudir a la remontas. Ugalde, por lo demás, obstaculizaba la acción de Croix: "Pretende convencer... que su celo, campañas y fatigas han conservado la provincia de Coahuila, y que mis providencias la han acordado a la ruina... No se cansa de reconvenirme, de pedir declaraciones, de instruirme con notas eruditas, de confundirlo todo y de hacerme emplear vanamente el tiempo... Preocupado... del más raro y furioso fanatismo, ha llegado a persuadirse que es el redentor de estas provincias, cuando yo pienso que, lo deje o no obrar según sus ideas y proyectos, será indubitablemente el destructor del país". En cuanto a sus escritos, respondía siempre "salpicando su oficio con expresiones subordinadas, arfogantes, satíricas, pueriles e impropias de su carácter y el mío, si bien pretende endulzarlas con algunas lisonjas intolerables, siendo lo más particular que cuando el gobernador satiriza la abundancia de mis órdenes es inșaciable en contestarlas, reconvenirlas y desacatarlas. Muchas veces se queja de la falta de respuesta a algunos de sus oficios, suponiendo maliciosamente que se ocultan de mi vista $y^{r}$ conocimientos: en otras ocasiones, según el humor que le predomina, produce la arrogancia de que no se le convencen sus argumentos, como si esto fuera dable conseguirlo de quien todo lo contradice, y por último le parece, y le parece bien, que un soldado debe preferir la espada a la pluma dejándose de escribir para tener más tiempo de pelear; pero yo veo que el gobernador Don Juan de Ugalde es el que más infringe la ley de su dictamen, como lo testifican sus copiosos oficios y el diario de su última campaña, que en extracto compone el número de cien hojas". 95

Ugalde se había opuesto a todos los proyectos de Croix: alcabalas, papel sellado, milicias y arbitrios, y hacía pública burla del comandante general mostrando su insubordinación, al tiempo que por medio del capitán Martínez Pacheco, al que Croix había quitado el mando de su presidio, hacía circular copias del diario insultante y grosero de sus campañas. ${ }^{96} \mathrm{E} 1$ último tropiezo fue la negativa de Ugalde a hacerse cargo de la creación de dos compañías volantes en Saltillo y Parras, para la defensa de sus jurisdiciones que Croix le encomendó, subordinándolas a su mando, y todo esto acumulado hizo que Croix, que en octubre de 1782 prefería se nombrase nuevo gobernador de Coahuila por haber cumplido ya Ugalde en aquel tiempo los cinco años en ese destino, se adelantara en noviembre a sustituirlo, poniendo en su lugar a Don Pedro de Tueros, a quien daría la subinspección de las tropas de la provincia en tanto que el capitán Cazorla se hacía cargo de las que se habían

95 Ibid. art. 43. T. cle Croix n Gálvez. Arizpe, 4 de noviembre de 1781, núm. 850. A. G. I., Gtradalajara, 283 .

96 T. de Croix a Gálvez. Arizpe, 4 de noviemlure de 5782 , nún 484. A. G. I., Gradalajara, 518. 
de formar en Parras y Saltillo y de las revistas del cuerpo de dragones provinciales de Santiago. 97 El 8 de abril de 1783 tomaba posesión Tueros de su nuevo empleo cuando Ugalde, después de su última campaña, representaba que las tropas de Coahuila habían quedado incapaces de hacer el servicio, que se les debía duplicar los haberes por algunos años y dotar con veinticuatro caballos a cada soldado. 98

También aquí, como antes le ocurriera en Sonora, recogió Tueros el fruto del esfuerzo de los que le precedieran. Las campañas de Ugalde, aunque disparatadas en sí, habían producido por el acoso continuado la destrucción de toda capacidad de resistencia por parte de las bandas hostiles, y pronto algunos mezcaleros empezaban a presentarse de paz al nuevo gobernador, que en junio había congregado cincuenta y nueve en el valle de Santa Rosa disponiéndoles siembras. 99 En cambio, los prisioneros hechos por Ugalde, asi como algunos comanches cautivados en Texas serían conducidos en collera a México, ${ }^{100}$ no obstante la sorpresa acaecida cinco meses atrás con todos aquellos que con Patule se presentaron de paz y fueron puestos en prisiones. En tal ocasión, el 20 de enero habían salido de Chihuahua, ciento cuarenta $y$ cinco apaches en total, al cuidado del teniente Don Joaquín de la $\mathrm{O}$, "cuya práctica y experiencia son notorias, igualmente que su esmero en el campo", camino de México. Pero el $3^{\mathrm{r}}$ de enero, al cuarto del alba, se fugaron en la estancia del río Florido cincuenta y seis piezas, "sacando unas las manos de las esposas y llevándoselas otras". Fue Patule quien promovió el alboroto, sin que la escolta pudiera evitar la fuga de aquéllos. En la persecución se dio muerte a este capitancillo y a otros ocho apaches, no siendo posible encontrar a los cuarenta y siete restantes - veintidós hombres, nueve ancianos, dos niños de pecho y catorce mujeres-, que debieron internarse en el Bolsón, y tal vez estaban entre los presentados a Tueros. ${ }^{\text {ror }}$

\section{IA DIFICIL SUBSISTENCIA DE TEXAS}

Desde los sucesos trágicos de San Sabá, Texas tiene que vivir en un peligroso equilibrio entre la pretendida amistad de los indios del norte y la

97 T. de Croix a Gálvez. Arizpe, 4 de noviembre de 1782 , núms. 849 y 851 . A. G. 1 .,

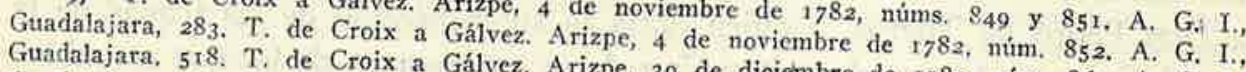
Guadalajara, 267. $98 \mathrm{~T}$. de Croix a Gálvez, Arizpe, 2 de junio de $17^{8} 3$, núm. 925 . A. G. I., Guadalajara, 284.
$99 \mathrm{~T}$. de Croix a Gálvez (firma Neve). Arizpe, 28 de julio de 1783 , núm. 938 , con Ex-
to. Ibid. tracto. Ibid.

soo $\mathrm{T}$. de Croix (firma Neve) a Gálvez. Arizpe, 28 de julio de 1783 , núm. 944. Tbid.

or T. de Croix a Gálvez. Arizpe, 2 de junio de $178_{3}$, núm. 926 . Ibid. 
procurada paz con los lipanes, a despecho de las hostilidades permanentes entre éstos y aquéllos, y sufriendo los constantes daños que producen los grupos nómadas carancahuas de la costa.

Son estos carancahuas los que tienen en perpettio jaque la gurarnición del presidio de la Bahía, que nunca habrá de actuar contra un enemigo exterior como se había temido al fundarlo, y que tampoco había de ser muy eficaz en la sujeción de los indios del contorno, genéricamente llamados "caribes" algo más tarde. Los carancahuas cometían robos de reses y. caballada en el presidio del Espíritu Santo y en la vecina misión del Rosario, arrojándose sólo rara vez a atacar una partida de tropa.

A principios de 1780 los lipanes se habían reducido a vivir entre Béjar y el Río Grande. Estaban ya remotos los tiempos, medio siglo airás, en que eran ellos quienes ocupaban todos los territorios al norte de San Antonio, Ahora los comanches y los indios del norte en general les obligaban a replegarse. Más de mil de estos últimos se habían presentado ante el gobernador Cabello en compañía de Mézières, ofreciéndose a combatir a los apaches. ${ }^{102}$ La muerte del oficial francés, y la política ya adoptada de mantener y procurar la paz hicieron poner un freno a este fruto tardío de las anteriores apetencias belicistas de Teodoro de Croix. Por lo demás, los mismos indios del norte no eran muy de fiar, por cuanto día tras día eran más insistentes sus peticiones de armas y pólvora que en estas fechas, con ocasión de la guerra de independencia de las colonias inglesas, habían dejado de recibir de sus antiguos proveedores y de los tratantes de Luisiana. Al mismo tiempo, los comanches, rechazados de Nuevo México por Anza, acudían en mayor número a Texas en actitud abiertamente hostil, ro3 de suerte que desde mediados de 1780 son con toda claridad el principal peligro para la provincia. La guerra de lipanes y comanches, última que aquéllos se atreven a presentar, es un episodio al margen de los incesantes daños que estos infligen a los ranchos, presidios y misiones de Texas, y además no excede los límites de la habitual pugna entre ambos grupos étnicos. A los lipanes les fracasó un intento de alianza con los carancahuas. ${ }^{\mathrm{x}} \mathrm{04}$

El movimiento de los comanches, en cambio, es perceptible en el hecho de que si al principio merodearon alrededor de los establecimientos del rín

102 T. de Croix a Gálvez. Arizpe, 23 de mayo de 1780, núm. 519. A. G. I., Guadalłjara, 522. T. de Croix a Gálvez. Arizpe, 23 de enero y 26 de marzo de 1780 , núms. 461,496 y 528 , con Extractos, A. G. I. Guadalajara, 271. T. de Croix a Gálvez. Arizpe, 23 de junio de 1780 , núm. 540, con Extracto. A. G. I., Guadalajara, 267.

103 T, de Croix a Gálvez. Arizpe, 23 de diciembre de 1780 , núm. 579 , con Extracto. A.G.I., Guadalajara, 27s. Sobre la muerte de Mézières, T. de Croix a Gálvez. Arizpe, 23 de enero de 1780 , núms. 465 y 466 , Guadalajara, $272 ;$ y núm. 467 . A. G. I., Guadalajara, 278.

to4 T. de Croix a Gálvez. Arizpe, 23 de febrero de $178 \mathrm{r}$, núm. 618 , con Extracto. Ibid. 
de San Antonio, en febrero de $178 \mathrm{I}$ ya los encontramos en número de cien atacando a una partida de tropa del destacamento del arroyo del Cibolo, y en marzo su teatro de operaciones ha alcanzado las proximidades de la Bahía, donde en mayo logran el robo de doscientas cuarenta y seis bestias del presidio, que fueron luego rescatadas. ${ }^{105}$ En junio aparecía ya un cuerpo de trescientos comanches ante el presidio del Espíritu Santo y desde este momento sus daños se han hecho endémicos a todos los establecimientos de la provincia, ${ }^{106}$ y sus actividades ponían en peligro las mismas relaciones pacificas entabladas a través de Don Nicolás la Matte con los iscanis, neches, tahuacanas, texas y vidais, pues si estos enviaron una delegación que se presentó a Cabello, los emisarios del gobierno Andrés Couriere y Juan Bousquet, que llevaban regalos a los taobayas, wichitas y al jefe de éstos Ciscat Gaimón tuvieron un encuentro con doscientos comanches, que fueron rechazados pero que robaron los fardos de mercancías. ${ }^{\text {ro }}$ Pidió entonces Cabello tropas, para poder atender a la protección de la provincia que le estaba encomendada, mientras que Teodoro de Croix representaba la conveniencia de conceder tierras a los vecinos del extinguido presidio de Adaes en el paraje del Río de San Marcos, a dieciocho leguas al nordeste de Béjar, que era de una de las principales entradas de los comanches. Pero entre tanto, los sesenta y tres vecinos españoles solicitantes fueron agregados a la misión de San Antonio de Valero. ${ }^{\text {ro8 }}$

La situación extrema de angustia de Texas creció necesariamente cuando en abril de 1782 los lipanes, perseguidos en Coahuila por Ugalde, se concentraton al norte del río Grande. Sin embargo, la tropa no fue nunca reforzada, y sólo sabemos que en julio los vecinos pidieron armas, municiones y pólvora para ir a combatir a los comanches. "Las tropas de la provincia de Texas - escribe el comandante general- son las de mejor arreglo, asistencia y gobierno de toda la frontera, por el más difícil desempeño de sus funciones, abundancia de víveres que produce aquel feraz territorio y del particular celo de los jefes que han tenido y del actual Don Domingo Cabello". roo

Teodoro de Croix persistía en la idea de procurar el envolvimiento de

ro5 T. de Croix a Gálvez. Arizpe, 23 de enero, 23 de febrero y 23 de marzo de 1781 , núms. 608,618 y 629 , con Extractos. A. G. I. Guadalajara, 271. T. de Croix a Gálvez. Arizpe, 30
de junio y 30 de julio de 1781 , núms. 652 y 659 , con Extractos. A. G. I., Guadalajara, 267 . noviembre de $178 \mathrm{r}$, nums. $670,680,685$ y 27 de agosto, 23 de setiembre, 30 de octubre y 30 de

Io7 T. de Croix a Gálvez Arizpe,

$108 \mathrm{~T}$. de Croix a Gálvez. Arizpe, 27 de junio de $x 78 \mathrm{x}$, núm. 652, con Extracto. Ibid. de 30 de abril de 1782 , dispuso se demorase la fundación de 1781 , núm. 671 . Ibid. La real orden de la guerra con Inglaterra.

rog T. de Croix a Gálvez. A rizpe, 4 de noviembre de 1782 , núm. 854 . A. G. I., Guadalajara, 518. Cabello fue felicitado en real orden de 16 de agosto de 1783 . 
los apaches mediante la alianza con los comanches, de que se prometía logros felices: "si se asegura la paz del comanche serán muy posibles el descubrimiento del corto camino que media desde la provincia del Nuero México a las de Texas y Coahuila, la comunicación de todas y las ventajas de batir y atacar por el frente, espalda y costados la apachería de oriente y poniente". "1 Los jefes Gran Sot y Ciscat Gaimón de los indios del norte mantenían y ratificaban la paz con los españoles, pero Cabello tenía no poco trabajo er: obstaculizar la alianza de los lipanes con los tancahuas y carancahuas, que al fin parece se logró, basada en el intercambio de caballos y mulas por los fusiles que éstos poseían. "I I El capitancillo lipán Roque decía haberse aliado con los tancahtias con ánimo de sorprender la ranchería de éstos, pero Cabello desconfiaba aún más del jefe tancahua, Mocho, "indio osado y que siempre nos será perjudicial por más promesas que haga". rra

Desgraciadamente, la aproximación de lipanes y tancahtuas se fue produciendo poco a poco en la segunda mitad de 1782 . En la junta del río Frío con el de San Miguel se reunieron ocho capitancillos lipanes con más de dos mil quinientas bestias, la mayor parte mulares y todas herradas; los indios de guerra pasaban de mil, con ciento cincuenta fusiles, aunque escasos de pólvora. Aún esperaban la llegada de otros grupos lipanes, para ir todos al río Guadalupe donde carnearían reses y cibolos y a donde acudiría el tancahua Mocho con los suyos y unos comerciantes franceses que les darían muchos fusiles, pólvora y balas a cambio de bestias. Al menos, estas fueron las noticias obtenidas por un vecino de Texas, que las comunicó al gobernador. I13 Croix estaba ya convencido de la necesidad de eliminar definitivamente la amenaza apache. La asamblea de lipanes y tancahus tuvo por fin lugar en el río Guadalupe, en diciembre. Acudieron mil cuatrocientos guerreros de aquella nación y cuatrocientos de ésta, más algunos grupos de orcoquizas, mayeyes, vidais y cocos, doscientos en total, y treinta y tres texas. Eran, pues, dos mil treinta y tres hombres de armas, con sus familias, y ascendían a cerca de cinco mil el total de indios congregados en el río Griadalupe, donde causaron destrozos increíbles exterminando el ganado montaraz $y$ el de las misiones.

El encuentro, en cambio, careció de consecuencias de mayor alcance en otros órdenes, pues los indios se limitaron a un trueque o cambalache mo-

I 10 Informe general núm. 735. A rizpc, 23 de abril de i782, arts, 23 y 504. A. G. I., Guada lajara, 253.

I I T. de Croix a Gálvez. Arizpe, 23 de setiembre de т782, núm. 822, con Extracto.

A. G. I., Guadalajara, 282.

I z $T$. de Croix a Gálvez. Atizpe, 4 de noviembre de 1782 , núm. 843, con Extracto.

A. G. I., Guadalajara, 283.

I 3 T. de Croix a Gálvez. Arizpe, 2 de diciembre de 1782 , nún. 855 , con Extracto. Ibid. 
mentáneo, sin dejar nada resuelto para lo sucesivo, terminado con algunas disputas, muertes e insultos entre lipanes y tancahuas. Cabello quedó en procurar que éstos, con los fieles taobayas, tuacanas, quitseis e iscanis hiciesen campaña contra los apaches. II4

El problema, para Teodoro de Croix, quedó aquí sin que su gestión ein lo tocante a Texas pasara más allá de un intento de regularizar los contactos comerciales de esta provincia con Luisiana, que en clefinitiva serían desautorizados, ${ }^{\text {II }}$ aunque sí quedó dispuesto que el gobernador de Béjar remitiese al de Nueva Orleans el ganado vacuno que pidiese éste y todos los demás auxilios que necesitase y ftuesen posibles, sin precisar autorización superior. II 6 Eil pueblo de Nuestra Señora del Pilar cle Bucareli, trasladado del río Trinidad a la antigua misión de Guadalupe de Nacogdoches, era el punto de contacto de anbas provincias. ${ }^{\mathrm{II}}{ }^{7}$

\section{La política paciftcadora de Anza}

Concluido I779 con las habituales escaranuzas de los apaches, y reprimidos un tanto los comanches con el duro golpe que les asestara el nuevo gobernador, pronto estos últimos comenzaron a solicitar insistentemente en Taos las paces. ${ }^{118}$ La prowincia de Nuevo México hallábase ahora en mejores condiciones de defensa, gracias a la caballada traída de Nueva Vizcaya y Nuevo León, aunque en vez de mil quinientas cabezas sólo se enviaron mil cuarenta y siete, que habían costado diez mil seiscientos sesenta y ocho pesos, de los que nueve mil cargaban a la real hacienda, mientras que el resto se debía a donativos del marqués de Aguayo, que puso cien caballos, y de Don Francisco de Oporto, vecino de Chihuahua, que había entregado mil pesos. Teodoro de Croix había desistido de enviar los cuatrocientos cincuenta y tres caballos que faltaban, por la dificultad y por la necesidad de economizar gastos "y porque conozco lo infructuoso del atxilio, que sería muy proficuo variarlo el sistema de operaciones", segín había representado. II9

La pacificación de los pueblos que circundaban Nuevo México, no obstante, aún se veía dificultada por otro factor que aparece a última hora, como fue la alianza con los navajos lograda por los apaches del Gila a través de

I 4 T. de Croix a Gálvez. Arizpe, 2 de junio de 7783 , núm. 923, con Extracto, A. G. I.. Guadalajara, 284 .

I 5 Hernández Sánchez-Barba, Mario: El Proyecto de comercio entre Teras y Luisiana (I778). "Revista de Indjas", 41, págs, 545-559. Madrid, I950.

i 6 T. de Croix a Gálvez. Arizpe, 23 de octubre de i780, núm. 570. A. G. I., Guadalajara, 267 .

I 7 Castañeda, Cahholic Heritagc, V, $330,343$.

I $8 \mathrm{~T}$. de Croix a Gálvez. Arizpe, 23 de julio de I 880 , nún. 542 , con Extracto. Ibicl.

i 9 T. de Croix a Gálvez. Arizpe, 23 de diciembre de i 780 , núm. 58r. A, G. I., Guadalajara, 271 . 
uno de los jefes de aquéllos, llamado Antonio el Pinto. Las actividades hostiles de los navajos, que también se sentían en Sonora, se experimentaron aquí cuando dieron principio, en mayo de 1780 , al robo de bestias y reses en ja zona de Acoma, Zuñi y Pecos. Los comanches persistían en sus ataques en mayor o menor número. Hasta trescientos intentaron el asalto de Taos en agosto, siendo rechazados por el fuego de un pedrero, que mató a varios. La represión estuvo a cargo de los españoles y de los yutas amigos. Setenta $\mathrm{y}$ seis vecinos de Alburquerque, apoyados por treinta y nueve jenizaros y veinticinco tiguas realizaron en octubre una campaña en que hicieron trece bajas y cautivos a los apaches. Cerca de un centenar de apaches murieron o fueron capturados en este mes y el anterior por los yutas y por los vecinos cle Pecuries. ${ }^{\text {rzo }}$

Pero los meses finales de I780 fueron señalados por la realización de una empresa de distinto carácter y de mayores vuelos, consistente en la búsqueda de la comunicación directa de Nuevo México con Soriora, tarea a que dio principio Anza el 9 de noviembre, saliendo de Santa Fe al frente de ciento cincuenta y un hombres de tropas y vecinos, dirigiéndose al paraje de San Cristóbal y descendiendo el río Grande, que abandonó luego para atravesar la sierra de Mimbres y otras, viéndose obligado a cambiar frecuentemente de rumbos por la fragosidad de los terrenos, la falta de conocimientos de ellos y la escasez de agua, de modo que en vez de alcanzar el presidio de Santa Cruz, en Sonora, vino a salir al camino real de esta provincia con Nueva Vizcaya, casi frente al presidio de Janos, en la sierra de Enmedio. E1 I 8 de diciembre entraba Anza en Arizpe, habiendo recorrido doscientas veintiına leguas. Los capitanes Vildósola y Martínez habian hecho salidas desde Sonora y Nueva Vizcaya simultáneamente con la marcha de la tropa de Nuevo México, de modo que las tres fuerzas habían logrado hacer treinta $y$ un muertos y veinticinco prisioneros a los apaches gileños, rescatando cuatro cautivos y trescientas quince caballerias, habiéndose aprobado la expedición exploradora también como camipaña combinada de las fuerzas de tres provincias.

Ánza creía posible acortar la distancia de Santa Fe a Arizpe a menos de ciento cincuenta leguas si se hallaba el paso de las sierras Mogollón y Mimbres viniendo desde los últimos pueblos de Nuevo México al Gila, para cuya empresa también se ofrecía. Teodoro de Croix se proponía, en efecto, continuar las exploraciones a fin de $\mathrm{I} 78 \mathrm{I}$. $^{\mathrm{I} 2 \mathrm{I}}$

\footnotetext{
I20 T. de Croix a Gálvez. Arizpe, 23 de marzo de $178 \mathrm{I}$, núm. 629, con Extracto. Ibid.

i 21 T. de Croix a Gálvez. Arizpe, 23 de enero de 178 I, núm. 608, con Extracto. A. G. I., Guadalajara, 27I. 'T. de Croix a Gálvez. Arizpe, 26 de marzo de I781, núm. 628. A. G. I., Guadalajara, 272.
} 
Ein enero de este año regresó Anza a Santa Fe por el camino ordinario, siendo atacado en la Jornada del Muerto por los apaches, que poco antes habían hostilizaclo también el cordón de Nuevo México en el Cerrito dei Espía. La situación general de la provincia no se había alterado, siendo quizás los rasgos más significativos en este momento la guerra de los yutas con los comanches y la reactivación de las antiguas hostilidades de los navajos. Iz2 Poco después, los yutas habían de sufrir una epidemia de viruela que casi los exterminó, ${ }^{\text {I }}{ }_{3}$ y la misma desgracia experimentaban los moquinos, que eran al propio tiempo combatidos por yutas y navajos sin que se resolviesen a acudir a Nuevo México. ${ }^{\text {I }}$ a

Anza había pedido ser trasladado a un gobierno en el virreinato alegando "ios males que le agitan, en cinco años a esta parte, originados del perpetuo cuanto violento ejercicio de a caballo, en que se ha ejercitado el tiempc que lleva expreso en iguales inclemencias.y pentrias clel campo, los que recaein sobre la dislocación de ambos pies, con alguna cortedad de vista", por cuyos motivos deseaba ser relevado de aquel clestino, "el mas frío de Nueva España". ${ }^{125}$ Sin embargo, este relevo no le sería concedido sino años después, de niodo que tendría tiempo de establecer la paz con los comanches, su más valioso logro ante los indios. En efecto, los comanches pidieron la jaz en Taos en julio y septiembre; fuéronse la primera vez sin concluirla los tres que se presentaron; en la segunda ocasión, Anza les hizo un largo razcnamiento sobre la materia y ventajas que les resultarían de vivir en amistad con los españoles, tras lo cual se marcharon, al parecer, contentos. Los daños no cesaron, pero eran ya mucho menos cuantiosos, sobre todo en comparación con los que causaban los apaches, que atacaron siete veces este año el cordón en su ida y regreso de Chihutahua, y que tenían constantemente en jaque, con sus robos de ganado, toda la mitad meridional de la provincia. ${ }^{126}$

Entre tanto, Anza, poniendo en práctica las instrucciones recibidas, había organizado las milicias, y había intentado dar nueva forma a las poblaciones para facilitar su defensa. Se había propuesto en I779 trasladar la villa de Santa Fe al barrio contiguo de Analco, suscitando las protestas del vecindario, que recurrió al año siguiente al mismo comandante general, obli-

i 22 T. de Croix a Gálvez. Arizpe, 30 de julio de $178 \mathrm{I}$, núm, 659, con Extracto. A. G. I, Guadalajara, 267.

I 23 Informe general de I782, nún. 735, art. 504. A. G. I., Guadalajara, 253.

I 24 T. de Croix a Gálvez. Arizpe, 23 de abril de I782, núm. 738. A. G. I., Guadalajara, 517.

I 25 Instancia de Anza. Provincia de Nuevo México, r ${ }^{\circ}$ de mayo de i 78 I. T. de Croix a Gálvez. Arizpe, 30 de julio de 1781 , ním. 662. A. G. I., Guadalajara, 300.

i 26 T. de Croix a Gálvez. Arizpe, 24 de febrero de $I 783$, núm. S8o, con Extracto. A. G. I., Guadalajara, 518 . 
gándole a disponer no se innovase nada en la población ${ }^{127}$ pero a lo menos sacó al presidio de su antiguro emplazamiento, llevándolo a diez leguas de distancia, a un paraje entre Santo Domingo y Cochití. ${ }^{128}$

\section{SONORA, LA INESTABILIDAD PERMANENTE}

Pocas cosas más controvertidas que el punto de traslación de los presidios de Sonora se hallan en esta época de la historia de las provincias internas. Teodoro de Croix le dedica largos párrafos en sus informes, sin que en realidad se llegase a un esclarecimiento ni de los principios según los cuales se había de restructurar la línea defensiva, ni de la ubicación más conveniente que pudiera darse a los presidios cada vez más numerosos de este sector del frente indio.

Las guarniciones de Horcasitas y Buenavista, ni se habían suprimido como propusieran Rubí y el reglamento de presidios, ni se habían trasladado al río Colorado, según se decidiera después de las empresas de Anza y Garcés. El presidio de Altar continuaba también en su antiguo emplazamiento, sufriendo los ataques de los apaches desde I774. El de Tubac, trasladado junto a las misiones de Tucson y San Javier del Bac, no servía para proteger la provincia, ni enlazaba con los Altar y Santa Cruz a sesenta y treinta y cinco leguas respectivamente, ni se había construido su fábrica. Este de Santa Cruz estaba muy bien situado para erigir a su abrigo población, frenar a los apaches y alcanzar la línea del Gila y Colorado, pero estaba muy aislado y combatido, de suerte que descle su traslación habían muerto más de ochenta hombres de su compañía, y ya no se encontraba gente que quisiera cubrir las bajas. Tampoco había concluido su fábrica. E1 presidio de Fronteras había sido inútil en la cañada de San Bernardino; el comandante general to hizo regresar a Corodeguachi. A su juicio, el no haber removido los tres primeros presidios, haciéndolo defectuosamente con los otros tres, había dejado a la provincia en pésimas condiciones de defensa, agravadas por la necesidad de atender a las nuevas fábricas en I774 y I775, a las campañas generales en este año y el signiente, $y$ al levantamiento seri y las batidas del Gila en I777. Desde esta última fecha no se había hecho nada. Los presidios se hallaban inconexos, y fragmentada y dispersa la fuerza por la necesidad de atender a los conducciones de víveres y correos y de suministrar destacamentos a los pueblos de Fronteras, San Ignacio, Imuris, Saric, Cieneguilla, Pitic, San Javier y otros. ${ }^{\mathrm{I} 29}$

I 27 "Descripción geográfica del Nuevo México", por el P. Morfi. R. A. H., Boturini, 25;

fol. 89 V-I 06 .

128 Informe general de $178 \mathrm{I}$, arts. T30-1 33 .

I 29 Informe general de 1780 , núm. 485 , arts. $18-69$ 
Ya había encargado el comandante general al gobernador Ugarte, en 12 de julio de I779, y a Corbalán en la misma fecha, que informasen acerca del posibie emplazamiento del presidio que los ópatas se ofrecían a construir para defensa de su país, cuando en i 5 de abril de i780 ordenó al mismo Ugarte proceder en compañía del ingeniero Rocha, al reconocimiento de los terrenos de los cuatro presidios de la frontera setentrional, de su actual ubicación, de la que ocupaban antes del traslado de los tres removidos, y de la que determinaba el reglamento. ${ }^{130}$ El mismo i 5 de abril partió Ugarte ¿ cumplir su comisión. Los tres personajes puestos en movimiento por Teodoro de Croix emitieron sus respectivos informes. Corbalán y Ugarte disentían acerca de la mayor conveniencia de situar el presidio ópata en Bacuachi o Bavispe; Ugarte y Rocha, en cambio, estaban bastante concordes entre sí y con el mismo comandante general en punto a reconocer la desarticulación de la frontera apache, de tal modo que podía decirse que en un frente de más de ciento treinta y seis leguas, de Janos a Altar, no existía línea de presidios. ${ }^{\mathrm{I}} \mathrm{r}$

Tres meses exactos había durado el viaje de Ugarte y Rocha por la frontera, de que el ingeniero elaboró un mapa completo y detallado. Pero la única modificación posible, por el momento, fue un nuevo traslado del presidio de Santa Cruz esta vez al paraje de Nutrias, aprovechando un donativo de dieciseis mil jesos hecho por el capitán Don José Antonio Vildósola, que fue reintegrado a su empleo y ascendido con breve intervalo a los grados de teniente coronel y coronel. Este traslado se efectuó antes del fin del año i 780 , y fue afianzado con el establecimiento de veinticinco familias yaquis ${ }^{1} 3 z$ y simultáneamente se verificó el del presidio de Horcasitas a Pitic, su antiguo emplazamiento abandonado en I749. '33 Se esperaba así una más fácil sujeción de los seris, y la formación en este lugar de un pueblo importante. En cambio, Teodoro de Croix no llegó a ver fundado el presiclio ópata, aunque se decidió claranente por su fijación en el pueblo de Bavispe. ${ }^{134}$ Algún tiem-. po después, en su informe general de 1782 , se muestra además deseoso de establecer nuevo presidio en la estancia de San Rafael de Buenavista, con

I 30 Informe general de I7S r, arts, 294-309 y 328-348. T. de Croix a Gálvez. Arizpe, 23 de abril de r 780 , núun. 5I7. A. G. I., Guadalajara, 5 I 7.

I 3 I Informe general de $\mathrm{I} 78 \mathrm{I}$, art: $349-350$ y 310.

i 32 T. de Croix a Gálvez. Arizpe, 23 de abril de I780, núm. 517. A. G. I., Guadalajara, 5 I 7. T. de Croix a Gálvez. Arizpe, 23 de dicieinbre de 1780 , núm. 589. A. G. I., Guadalajara, 272. Reales despachos de 28 de febrero de $7_{2} 8_{2}$ y i 2 de julio de $7_{7}$, A. G. I., Guadalajara, 5 I 7. Villa, Compendio, $\mathrm{x} 6 \mathrm{x}$.

I 33 T. de Croix á Gálvez. Arizpe, 23 de diciembre de 1780 , núm. 592. A. G. I., Guadalajara, $27 \mathrm{I}$.

I 34 Informe general de $I>8 I$, arts. $352-366$. 
setenta hombres, también indios. ${ }^{\mathrm{I} 35}$ Esto haría subir a ocho las guarniciones de Sonora, más un piquete de dragones del regimiento de España y la compañia de voluntarios. Cuatro presidios -el proyectado en la estancia de Buenavista, que en $\mathrm{I}_{7} 83$ fue establecido con pimas en San Ignacio, los de Terrenate y Fronteras, y el propuesto de Bavispe - más la compañía voluntaris: harían frente a los apaches. Los otros cuatro - Buenavista, Pitic, Aliar y Tucson--, con los dragones atenderían a la expansión hacia el Colorado. ${ }^{136}$

Hay que decir que Teodoro de Croix, que logró las paces de los apaches de oriente, hubo de afrontar la guerra incesante de los de Gila y Chiricahui, que sólo años más tarde cederán ante las armas españolas y la presión comanche, habiendo reforzado sus filas con la alianza de los navajos. En el frente interior, I780 había presentado una debilitación de los seris por la muerte de su cabecilla Boquinete. Algunos seris se presentaban de nuevo en Pitic, pero los tiburones y tepocas continuaban inevitablemente en sus robos. Guaymas sufrió 111 ataque desastroso y poco después se producía nueva desbandada de veinte seris de Pitic, aunque en octubre parece volvían a reintegrarse y algunos tiburones ofrecían presentarse de paz. ${ }^{137}$ Por lo demás el caballero de Croix había pedido informes a Ugarte, Corbalán y Tueros sobre los "medios de extinguir una nación que ha sido siempre la causa principal de los males de esta provincia". Se consideraba preciso capturar las familias de Pitic, sin estrépito, y conducir los varones a ultramar y las mujeres y niños a Californias. Y luego debería realizarse expedición general a Tiburón. Pero de momento era preferible contemporizar hasta encontrar ocasión más propicia, solución pasajera que fue aprobada por Don José de Gálvez y el rev. ${ }^{138}$

Sin embargo, las deserciones de los seris se precipitaron en Pitic, en nímero de treinta, entre febrero y marzo de $178 \mathrm{I}$. "Confieso - dice Teodoro de Croix - que en el mando personal de la provincia no he tenido más éxito que Anza y Tueros". ${ }^{139}$ Como consecuencia, desplazó de nuevo la compañía de voluntarios hacia este frente. ${ }^{140}$ Las deserciones y los ataques continuaban a mitad de año, pero en anxilio de los españoles vino una epidemia de

135 Informe general de I 782 , wím. 735, art. 390.

I 36 Ibid. $5 \times 6-158$.

I37 T. de Croix a Gálvez. Arizpe, 23 de enero, 26 de marzo, 23 de abril y 23 de mayo de I780, núms. 46I, 496, 508 y 528, con Extractos. A. G. I. Guadalajara, 27 I. T. de Croix a Gálvez. Arizpe, 23 de agosto, 23 de setiembre y 23 de diciembre de 1780 , núnis. 555,556 y 579 . A. G. I. Guadalajara, 271 .

${ }_{13} 8 \mathrm{~T}$. de Croix a Gâlvez. Arizpe, 23 de mayo de I780, núm. 525. Real orden de 2 de marzo de 1782 . A. G. I., Guadalajara, 267.

139 Informe general de 1781 , art. 286.

I40 T. de Croix a Gálvez, Arizpe, 23 de marzo de i78I. ním. 629, con Extracto. A. G. I., Guadalaja1a, 27 I. 
viruelas que causó más de cincutenta muertes en Pitic y se contagió a los seris aizados y a los tiburones. ${ }^{141}$ Poco después se ponían en movimiento las tropas de Altar, Buenavista y Pitic y causaban a los rebeldes veintidós bajas, entre muertos y prisioneros. ${ }^{142}$ Con este castigo decayó la tensión en esta frontera, de modo que las hostiliclades no se reanudaron sino hasta el año siguiente, cuando los seris asaltaron y saquearon Bisanig, en julio, con lo que dio principio una serie de rohos. Pero en octubre los pimas altos de Caborca y Pitiqui hicieron a los alzados once muertes y cinco prisioneros en el campo de Aribaipá. ${ }^{143}$

Entre marzo y abril de 1783 fue posible practicar una mariscada a la isla de Tiburón, a cargo del comandante de la compañía de Pitic-que lo era entonces el capitán de dragones Romeu, una vez partido Ugarte- aunque con nulos resultados. ${ }^{1} 44$ Por el contrario, la înga de. los seris del Pitic continuaba por estas fechas, a corta distancia de la marcha de Teodoro de Croix, pese a sus esfuerzos por transformar Pitic en un poblado próspero. ${ }^{145}$

El problema seri era una sangría constante de los fondos, de los hombres, de la atención que estaba simultáneamente reclamando la frontera apache, donde presidiales, pimas y ópatas aunaban su esfuerzo para mantener la integridad de las tierras y poblados hasta entonces pertenecientes a la provincia. Más importancia que los ataques a los pueblos tenían los asaltos a las recuas de aprovisionamiento de los presidios y los robos de caballacla, que en I 780 dejaron a pie a los dos destacamentos de dragones y al piquete de voluntarios que guarnecía San Ignacio. Pero a mitad de año el general de los ópatas Don Juan Varela había iniciado una enérgica represión del enenigo. ${ }^{146}$ En agosto era el presidio de Fronteras el que padecía la pérdicla de parte de sus monturas y ganado, y en noviembre, mientras Vildósol? salía a campaña, más de cien apaches atacaron Santa Cruz, ${ }^{\text {} 47}$ aunque las operaciones conjuntas de Vildósola, Martínez y Anza, con ncasión del viaje de éste desde Santa Fe, resultaron un éxito.

I4 4 T. de Croix a Gálvez. Arizpe, 30 de junio y 30 de julio de I78s, núms. 652 y 650, con Extractos. A. G. T., Guadalajara, 267.

142 T. de Croix a Gálvez. Arizpe, 27 de agosto y 23 de setiembre de I $78 \mathrm{I}$, núms. 670 y 680 , con Extractos. A. G. I., Guadalajara, 267.

I43 T. de Croix a Gálvez. Arizpe, 23 de setiembre de I782, núm. 822, con Extracto. A.G.I., Guadalajara, 28z. T. de Croix a Gálvez. Arizpe, 4 de noviembre de 7882 , núm. 843 , con Extracto. A. G. I., Guadalajara, 283.

I4t. T. de Croix a Gálvez. Arizpe, 2 I de abril de $7 \delta_{3}$, núm. 905, con Extracto. A, G. I., Guadalajara, 5 I 7 .

I $45 \mathrm{~T}$. de Croix a Gálvez. Arizpe, 2 de junio de 1783 , núm. 923, con Extracto. A. G. I, Guadalajara, 284 .

146 T. de Croix a Gálvez. Arizpe, 23 de enero, 26 de marzo, 23 de abril y 25 de mayo de 1781 , nums. $45 \mathrm{~T}, 406,508$ y 528 , con Extractos. A. G. I., Guadalajara, $27 \mathrm{I}$.

147 T. de Croix a Gálvez. Arizpe, 23 de setiembre y 23 de diciembre de 1780 , 11úms. 556 y 579, con Extractos Ihid. 
Pero en febrero de $\mathrm{I} 78 \mathrm{I}$, inesperadamente, el teatro de la guerra se desplazó muy al sur, hasta Ostimuri, donde apaches en número indeterminado asaltaron Teopari, visita de la misión de Sahuaripa, arrasando totalmente el pueblo, que fue incendiado, profanada la iglesia, destruidas las imágenes, robados los vasos sagrados y ornamentos. Cincuenta muertos y veintiocho prisioneros fue el balance de las desgracias personales, mientras que el ganado fue destruido. De otros puntos del interior de la provincia llegaban al mismo tiempo noticias de las hostilidades de igual horror, de manera confusa, ${ }^{18}$ pero en abril y junio, dos ataques a Fronteras y otros a Cuquiarachi y junto a Tucson fueron seguidos por el asalto de trescientos cincuenta apaches contra Cucurpe, donde hicieron ochenta y cinco muertes y prisioneros, y contra Bacantuchi, donde fueron alanceadas mil setecientas cabezas de ganado, junto con otros ataques, muertes y robos en el camino de Dolores, en Chinapa y Arizpe. Algunas referencias indican que gran pärte de los agresores eran pimas, ópatas, yaquis, gente de razón y seris, siendo en menos número los apaches, que sin embargo aprovechaban sin duda estas ocasiones de auténtico bandolerismo. ${ }^{149}$ En julio se perdieron ciento ochenta caballos del presidio de Santa Cruz, y en agosto y septiembre, contingentes de doscientos y trescientos apaches atacaron Tucson y Fronteras, aunque sin verdadero éxito. A fin de año, las operaciones de los ópatas amigos tenf́an más eficacia. ${ }^{150}$

Pasado i $78 \mathrm{I}$, las hostilidades decrecieron hasta casi cesar en el siguiente año de 1782 . En 1783 , el armero Domingo Vergara, con ciento cincuenta hombres costeados por él, hacía una batida en la sierra de los Janeros. Pero cuatrocientos apaches prepararon una emboscada a los pimas del presidio de San Ignacio, que tuxieron diecinueve bajas. Otros cien apaches entraron desde Janos por Carretas, causando destrozos en las haciendas de Tesopaco, Mezcatitlán, Lima y Cedros. Internados los enemigos en la provincia, los daños eran irremediables. El presidio de Santa Cruz sufrió varios ataques. ${ }^{15}$ I EI caballero de Croix dejaría el mando, dejando tan sólo proyectada una campaña al Giila.

De hecho, desde su radicación en Arizpe, como desde su llegada a México, nunca se observa en Teodoro de Croix una tentativa decisiva de resol-

I48 T. de Croix a Gálvez. Arizpe, 23 de marzo de 1781, núm. 629, con Extracto. Ibid. I49 T. de Croix a Gálvez. Arizpe, 30 de jurio de IzSI, núm. 562, con Extracto. A. G. I., Guadalajara, 267 .

150 T. de Croix a Gálvez. Arizpe, 27 de agosto, 30 de octubre y 30 de noviembre de 1781 , núms. 670,685 y 691 , con Extractos. A. G. 1., Guadalajara, 267. T. de Croix a Gálvez. Arizpe, 31 de diciembre de $178 \mathrm{r}$, núm. 705 , con Extracto. A. G. I., Guadalajara, 268.

15x T. de Croix a Gálvez. Arizpe, 2 de junio y 18 de julio de 1783 , núms, 923 y 938 , con Extracto. A. G. I., Guadalajara, 284. 
verse definitivamente a poner término a las hostilidades que padecía Sonora. Si no es verdadera defensa más que aquella que se dirige claramente a la destrucción de las fuerzas del adversario y a su vencimiento, puede asegurarse que el comandante general nunca adoptó esta actitud ni en el frente seri, ni en el apache, siendo así que bajo su mando alcanzó Sonora la máxima concentración de efectivos militares propios que nunca tuviera hasta entonces. Si bien es igualmente cierto que el desastre del Colorado que trataremos seguidamente desconcertó en el peor momento todos los planes fraguados para la expansión de Sonora.

Se nota, en cambio, nutucha mayor actividad de Croix en lo tocante a los asuntos internos de la provincia. Arizpe y Pitic, su fomento y prosperidad, atraen reiteradas veces su atención. Solicita títulos de villa o de ciuclad para Arizpe, siéndole concedido el segundo en real decreto de 6 cle julio de i 780 , y de villa para Piic. Pide normas para atender al reparto de tierras, que pertenecían a los indios y obstaculizaban el establecimiento de otros pobladores, y ordenó la inmediata formación de los planos de la casa de moneda que se debía construir en su capital. I52 El ingeniero Mascaró trazó los planos de este y otros edificios proyectados en Arizpe, entre ellos un almacén de pólvora, y atendió a la construcción de una presa en el río de Bacanuchi, que fertilizaría las tierras recinas a la capital, y otra que costó tres mi] pesos en Pitic, y que tenía boca de cal y canto para impedir que las avenidas la obstruyesen como otras veces había ocurrido. ${ }^{153}$ Con todo, Arizpe no dejaba de ser un prieblo de unos setecientos vecinos, por mitad ópatas y gente de razón, y en donde sólo se veían ciento treinta casillas de adobe, dispriestas sin orden algumo, destacando únicamente la iglesia, que por el esfuerzo secular de los misioneros jesuitas resultaba ahora inchuso rica, y la antigura casa de la misión, donde se alhergaba Don Teodoro, que la hizo reparar y enladrillar las azoteas. ${ }^{\mathrm{I}} 54$

Su medidas tendieron igualmente a respaldar las de Corbalán, que procuraba el conveniente surtimiento de harinas en Arizpe y asegurar sus abastos, y también trataba de fomentar la cría y conservación de ganado vacuno, que padecía enormenente con las incursiones de los enemigos y con el sacrificio de las hembras útiles. Cuatro diputados fueron designados, a falta de

152 T. de Croix a Gálvez. A riz̨e, 23 de enero de 1780, núm, 459. A. G. I., Guadalajara, 298. T. de Croix a Gálvez. Arizpe, 24 de febrero de 1783 , nún. 882. A. G. I., Guadalajara, 518.

${ }_{153} \mathrm{~T}$, de Croix a Gálvez. Arizpe, 29 de julio de 1782 , núm. 812. A. G. I., Guadalajara, 517. T. de Croix a Gálvez. Arizue, 24 de febrero de $178_{3}$, núm, $88_{2}$. Real orden de 29 de agosto de 1783 , que aprueba el títule de villa a Pitic. A. G. I., Guadalajara, 518 ,

154 "Descripción $y$ actual estado del pueblo y misiones de Arizpe, que Su Majestad ha destinado en sus reales instrucciones para capital de estas provincias internas". Museo Naval, Ms. 567 , fols, 36-40 v.; otro ejemplar en el mismo volumen, fols, $301-308 \mathrm{v}$. 
Ayuntamiento que aún no tenía Arizpe, para que atendiesen al suministro de víveres para la población. ${ }^{5} 5$

Anteriormente hemos expuesto el interés del comandante general para establecer o fomentar los ingresos de las rentas de alcabalas, tributos, mezcal, salinas y tabacos. Encargó a Mascaró el proyecto de una presa en Onasas, en el río Yaqui, y el reconocimiento de las obras de la iglesia de Charai. El otro ingeniero, Rocha, atendió en cambio a la fábrica del presidio de Fronteras, del que fue nombrado capitán interino. ${ }^{156}$

Obtuvo el caballero de Croix la supresión del Gobierno militar de Sonora por real orden de 8 de febrero de 1782 , quedando aquél en manos del comandante general, "en quien solamente debe residir dicho empleo". Is7 Previendo este momento había también conseguido Teodoro de Croix el ascenso rápido de Don José Antonio Vildósola, que quedaría como comandante de las armas de la provincia al cesar Ugarte en el gobierno. Al mismo tiempo, Corbalán, que desde la erección de la comandancia era verdadero intendente gobernador de Sonora, habiendo tomado posesión el 2 de abril de I777, pedía grado de intendente de ejército, ${ }^{1} 5^{8}$ gracia que no se le concedería hasta 1787 , al ser promovido a la recién creada intendencia de Veracruz. La partida de Ugarte en diciembre de I782 dejó también vacante la capitanía de Pitic, que fue conferida interinamente al capitán de dragones de España, también allí acuar-

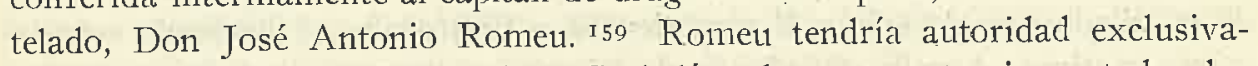
mente sobre la tropa, quedando a Corbalán plena competencia en todos los asuntos civiles, criminales, políticos y económicos de Pitic.

\section{LA REBELIÓN DE LOS YUMAS}

No llegaron a contar dos años de vida los establecimientos españoles en el río Colorado. En septiembre de I779 había llegado allí el padre Garcés, y un mes después su compañero Díaz. Teodoro de Croix decidió poner en práctica el plan preconizado desde Madrid para que se estableciese una misión

I55 Fueron diputados Don José Antonio Serrano, Don Esteban Gach, Don Felipe Mungarrieta y Don Juan Martín de Gortari. T. de Croix a Gálvez. Arizpe, 26 de enero de I782, núm. 7 I2, A. G. I., Guadalajara, 267.

I56 T. de Croix a Gálvez. Arizpe, 29 de enero de I781, s, n. A. G. I., Guadalajara, 272. T. de Croix a Gálvez. Arizpe, 30 de diciembre de i 782 , núm. 863. A. G. I., Guadalajara, 5 I8.

I 57 Real orden de 8 de febrero de 1782 , copia autorizada por Meerino. A. G. I., Guadalajara, 300 .

I5 8 Corbalán a S. Mi. Arizpe, 55 de febrero de i 780. T. de Croix a Gálvez. Arizpe, 23 de febrero de 1780 , núm. 484. A. G. I., Guadalajara, 267. T. de Croix a Gálvez. Arizpe, 26 de marzo de r 78 , núm. 623. A. G. I. Guadalajara, 28 i bis.

i59 T. de Croix a Gálvez. Arizpe, 24 de febrero de 1783 , núm. 883. A. G. I., Guadalajara, 5 I8. 
con dos padies a cada orilla del río. Y una pequeña colonia de pobladores marchó a fundar un pueblo en la recindad de las misiones, protegidas por un destacamento de reinte hombres sacados de Horcasitas, Buenavista y Altar, mandado por el alférez del tiltimo Don Santiago Isla. Comprendía el comanGante general la necesidad de guarnicionar mejor aquel paraje, pero las hostilidiades de seris $y$ apaches impedian hacerlo así, clel mismo modo que obstaculizaloan el traslado de Horcasitas y Buenavista al Colorado y al Gila. Por ello prefrió Teodoro de Croix recurrir al procedimiento cle asalariar a los mismos pobladores para que sirvieran como soldados. Todo esto producía un. gravanen a la hacienda de cuatro mil seiscientos cuatro pesos antales. $Y$ así nacieron las misiones de la Concepción y de San Fedro y San Pablo del Vicuñer, a sesenta leguas del puerto californiano de San Diego. En iz8o, Teodoro de Croix esperaba que sería posible más adelante enlazar los presidios sonorenses con los establecinientos del Colorado y con Californias. ${ }^{60}$

La vida de estos establecimientos transcurrió pacíficamente, entregándose los franciscanos y colonos a su tarea evangelizadora y civilizadora, echando la simiente de un nucvo espíritu y de una nueva cultura, sin que se apreciase nada extraordinario en el desarrollo de los acontecimientos, hasta que el iz de jutio de $17 S_{1}$ los yumas aparentemente sometidos se alzaron destruyéndolo todo, dando muerte a los cuatro misioneros y a la escolta de un trozo de catballada que el capitán Rivera llevaba a Californias, y haciendo setenta y tres cautivos. Aquella expedición de Rivera, en la parte de remonta, reclutas y familias pobladoras que habían cruzado ya el río, y pudieron llegar a su destino, fue la última que atravesó el territorio entre Sonora y la Alta California

Hasta el 6 de agrosto, por un aviso de Don Juan Manuel Bonilla, capitán interino de Tucson, no tuvo el comandante general noticias de lo ocurrido. Poco después Bonilla ampiaba la información y Treros, descle el presiclio dc Altar, suninistraba otros datos. En consecuencia, Teodoro de Croix tuvo itinta con Corbalán y Galindo Navarro, resolviendo enviar tuna tropa numerosa aque se pusiese a las órdenes del gobernador de California, Neve, y rescatase los cautivos y sometiese y combatiese a los yumas. De este modo, el conlingente preparado por Ugarte para combatir a los apaches hubo de ser desviado de su primer objetivo, y la misma frontera apache y seri quedó debilitada cuando ciento setenta hombres, manclados por Fajes y Tueros, enjirendieron el camino del Colorado para ir a sofocar el moviniento de los yumas.

Neve acudió, en efecto, descle Monterrey al Colorado y el alférez Limón,

160 I. de Croix a Gálvez. Arizpe, 23 de abril de $\overline{7} 80$, mum, 505. A. G. T., Guadalajara. 517. Tnforme general de $178 \mathrm{r}$, arts, $522-534$. 
de Buenavistat, exploró las ruinas de los dos poblados. Fajes había llegado al lugar el i6 de octubre, habiendo tenido en el camino un encuentro con los seris, tiburones y pimas alzados. A la otra orilla del Colorado estaba Palma con quinientos hombres, y durante tres días logró Fajes rescatar cincuenta y siete cautivos. Pero el ig los yumas fueron atacados por seiscientos jalchedunes, pimas gileños y cocomaricopas, y se dispersaron después de sufrir muchas bajas. Fajes se retiró a Sonoitac y Altar para bastimentarse.

En nueva junta, el i 5 de noviembre, decidió Croix dar a Neve el mando de las operaciones y la comisión de buscar el asentamiento de un presidio en el Colorado. Fajes se hallaba de nuevo allí el 30 de noviembre, y logró esta vez rescatar los últimos cautivos, pero luego fracasaron dos encuentros con los yumas, en el ́́ltimo de los cuales tomaron parte mil quinientos individuos de esta nación, y Fajes hubo de regresar a Sonoitac, trayéndose los cadáreres de los cuatro padres. Después, por resolución de la tercera junta tenida por Croix con este motivo, el mnino Fajes, con cuarenta hombres, llevó los pliegos a Neve, mientras que Tueros y Romeu dirigieron la fuerza expedicionaria. ${ }^{161}$ Pero estos dos hubieron de retirarse cuando Neve avisó serle imposible actuar antes de septiembre de 1782 . En junta de 16 de mayo resolvió Croix concentrar trescientos hombres en el Colorado para esa fecha: sese̊nta de California, cien dragones y presidiales de Sonora, ochenta jalchedunes, cocomaricopas y cajuenes, enemigos de los yumas, cuarenta pápagos y pinas gileños y unos veinte pimas altos de misión. ${ }^{162}$

Llegado el momento de la acción, Romeu se enfrentó a los yumas y los persiguió tenazmente en un duro encuentro, pero no pudo obtener una victoria decisiva porque los caballos se debilitaban rápidamente en aquel país escaso de pastos. Neve, por su parte, informó además de las dificultades ostensibles que ofrecía el lugar para el establecimiento de un presidio. Las noticias que ahora llegaban del territorio yuma hacían sospechar no habían sido fieles los informes que antes se habían hecho̊ al virrey y al nismo Croix. El país, dice éste, no presenta ciertamente el aspecto halagüeño con que se describió por Don Juan Bautista de Anza y el difunto Padre Fray Francisco Garcés para obligar a su ocupación, ni los indios eran tan dóciles como antes se anunciara. ${ }^{163}$

Las dificultades que ahora se encuentran no son imaginarias. El terreno era malo. Desde Sonora no había más camino que el de Gila y el de la Papaguería por Sonoitac, ambos escasos de pastos y el segundo, además, de agua.

I61 T. de Croix a Gálvez. Arizpe, 28 de febrero de 1782, núms. 718, 719 y 720 . A. G. I., Guadalajara, 517.

i6z T. de Croix a Gálvez. Atizpe, 30 cle mayo de 1782, núm. 749. Ibid.

I63 T. de Croix a Gálvez. Arizpe, \& de noviembre de 1782 , núms. 844 y 845 . Ibid. 
Tampoco había agria en la parte de California, desde el paraje de San Sebastián al de Santa Olalla. El Colorado no era vadeable de mayo a septiembre en aquel lugar. Así, la primitiva decisión de fundar presiclio para castigo y sujeción de los ytumas ha de suspenderse en la junta de 3 de enero de I $_{783}$, con asistencia de Neve, Corbalán, Tueros y Galindo Navarro. De momento al menos, hostilizada Sonora, era imposible además el envío de tropas. Por otra parte, cuando fuese preciso realizar alguna expedición o conducir remontas o provisiones a Californias, el camino estaría libre, ya que los yumas eran enenigos débiles que no podían oponerse a la tropas. Finalmente, se consicleraba intutil esperar ningún fruto de un nuevo establecimiento en el Colorado después de lo ocurrido, y con esta solución se evitaban enormes gastos. La real orden de 23 de agosto de ${ }^{7} 78_{3}$ sancionó el acuerdo de la junta, ${ }^{16} 4$ y de este modo quedó cortado el débil vínculo entre Sonora y la Alta California, que no volvería a anudarse, y quedó, en definitiva, frustrado e! móvil inicial con que Gálvez proyectara ia comandancia general de las provincias internas del norte de Nueva España.

\section{Ias Calffornias bajo Trodoro de Crotx}

Don Felipe Neve fue el primer gobernador de Californias que, por cisposición real, tuvo su capital en Monterrey; dejanclo un teniente de gobernador -Don Joaquín Cañete en este caso-- en Loreto. ${ }^{165}$ La provincia, en el momento inicial de su desarrollo, presentaba un cúmulo de problemas que vinieron a recaer sobre el nuevo comandante general, quien no sabía cómo afrontarlos: estado de las cuatro compañías presidiales, posibilidad de rechutas, lugares apropiados para poblanientos entre San Diego y Monterrey, importancia de ocupar con un fuerte y dos misiones el canal de Santa Bárbara y causa formada contra Don José de Ortega con motiso de la sublevacón intentada por los indios. La imposibilidad en que Teodoro de Croix se vé́a de providenciar por sí mismo en estos asuntos le movió a intentar uná ruelta temporal de California a la jurisdicción del virrey, idea que fue naturalnente reptdiada tanto por Bucareli como por Gálvez. ${ }^{\text { } 66}$ En vista de ello, el caballero de Croix pasó aquellos documentos a consulta de Corbalán, Anza y los oficiales reales de Sonora, que tenían algún conocimiento de Californias y de los recursos con que se podía atender a esta provincia. Sus respuestas, sin embargo, se demoraron hasta el 31 de diciembre de 1777

\footnotetext{
$164 \mathrm{~T}$. de Croix a Gálvez. Arizpe, 23 de enero de $7 \varepsilon_{3}$ núm. 780. A. G. T., Guadalajara, 5 I 8.

165 Cañete a Gálvez. Loreto, 24 de febrero de I777. A. G. I., Guadalajara, 5 16. lajara, 515.
} 
y el 1. ${ }^{\circ}$ y ${ }^{5}$ de enero de 1778 , y se mostraron unánimes acerca de la imposibilidad de apoyar las propuestas de Neve, que estaba decidido a llevar a cabo una intensa colonización del territorio: Sonora no podría suministrar sino muy pocas tropas y familias, y aquí mismo era muy escaso el ganado que hacia falta allí. Sin embargo, mediante la embarcación que el virrey puso en Guaymas para comunicación de las costas del Golio, el comandante general participó a Neve estar dispuesto a ayudarle en lo posible con vistas a la erección de pueblos en los ríos Guadalupe y Porciúncula, y de un fuerte y misiones en el canal de Santa Bárbara. El capitán Rivera y Moncada debería venir a Arizpe para hacerse cargo de la recluta cle soldados y fanilias y de la adquisición de ganados, aperos y utensilios con destino a Californias. Para mejorar la condición de la provincia, finalmente, Neve debería revisar y modificar el reglamento promulgado en 1773 para su gobierno. ${ }^{167}$ Entretanto, ya Neve había realizado la fundación del pueblo de San José, con quince familias sacadas de los presidios de San Francisco y Monterrey. Este pueblo fue situado entre ambos presidios, junto al nacimiento del río Guadalupe. ${ }^{163}$ Los ocho mil habitantes de la doble provincia llevaban la vida dura de los establecimientos aislados, interrumpida o dificultada a veces su comunicación por los ataques de los indios gentiles a las caravanas, ${ }^{169}$ pero desde Madrid se ordenaba a Teodoro de Croix mirase aquellas recienies misiones, presidios y poblaciones "con el esmero que merecen por su importancia". ${ }^{170}$

El principal problema de la provincia estaba, en realidad, en el antagonismo entre las autoridades reales y los misioneros, antagonismo que hizo estéril la primera fundación de San José, que hu1bo de ser trasladado. Neve hacía respetar a todo trance su gobierno y esperaba reducir la importancia de los franciscanos precisamente por medio de la fundación de colonias de pobladores, mientras Croix deseaba que una reforma de las misiones y la fundación de Custodias evitase nuevos choques. ${ }^{171}$ En junio de I779, el mismo Neve tenía concluido un nuevo reglamento provisional para el arreglo $\mathrm{y}$ fomento de las provincias, ${ }^{172}$ que fue aprobado $y$ puesto en vigor el I. de enero de I78 I y reguló la vida de Californias hasta el fin del dominio español.

I67 T. de Croix a Gálvez. Chilutahıı, 23 de setiembre de 1778 , núnts 269 y 270 . A. G. I., Guadalajara, 275.

I68 T. de Croix a Gálvez, Chilutahua, 23 de setiembre de i 778 , núm. 27 1. A. G. J., Guadalajara, 267 .

I69 T. de Croix a Gálvez. Chihuahua, 23 de setiembre de r778, 1úm. 272. A. G. I., Guadalajaria, 275 .

I70 Real orden de 6 de marzo de г779. A. G. I., Guadalajara, 267.

I7 I T. de Croix a Gálvez. Arizpe, 26 de marzo de i78o, 11úm. 498. A. G. I., Guadalajara, 27 ; núm. 499. A. G. I., Guadalajara, 272.

I72 T. de Croix a Gálvez. Arizpe, 23 de abril de i780 núm. 506. A. G. I., Guadalajara, 277. 
Después que en octubre de 1780 fundaran los dominicos de la Baja California la misión de San Vicente Ferrer, el 4 de setiembre de $178 \mathrm{I}$ procedía Neve a la fundación del pueblo de Reina de los Angeles en el río de la Porciúncula, con parte de los pobladores reclutados por el capitán Rivera $y$ conducidos por mar. Sus primeros habitantes no eran más de cuarenta $y$ seis. ${ }^{173}$ Entre marzo y abril del siguiente año de 1782 , hallándose ya Fajes en California, tuvo iugar la creación de la nisión de San Buenaventura y del presidio de Santa Bárbara en el canal de este nombre, con la otra parte de los pobladores sacados de Sonora por Rivera y que pudieron llegar a California desde el Colorado. ${ }^{174}$

Por estas mismas fechas, en abril de 1,72 , se había promovido a Neve al cargo de comandante inspector de los presidios internos, nombrándose ntuevo gobernador de Californias a Tuteros, con grado de teniente coronel. Pero como Teodoro de Croix había ya contado con éste para sustituir a Ugaide en Coahuila, resolvió encargar a Fajes, por segunda vez, el gobierno de Californias, dejándole Neve la correspondiente memoria de gobiemo. ${ }^{175}$

\section{IA VIDA DE LOS PRESIDIOS}

Debemos a Teodoro de Croix una serie de noticias de indudable interés acerca de las condiciones de vida en que se flesenvolvían los oficiales y soldados de las guarniciones que, haciendo frente al empuje de las tribus apaches y comanches, hacian posible la sulssistencia de las provincias internas Estas informaciones que Teodoro de Croix enviaba a la corte, de manera incidental, al tratar algún asunto relativo a las tropas, aparecen ya en fecha tan temprana como febrero de I777, en su carta núm. 8, cuando pide facultades para poder dar licencia de matrimonio a los oficiales de los presidios.

"Cada presidio se reduce, según tengo entendido - escribe el comandante general-, a un caserón de vecindad donde por precisión han de ser ríblicas las operaciones de sus habitantes, y si éstas no son arregladas tendrán el §rave defecto de escandalizar". "Los oficiales que componen la primera clase de esos vecindarios deberían dar buen ejemplo a los demás: pero como gente moza creo que lejos de vivir con la modestia que no se opone a la profesión marcial hacen gala de sus amistades y amancebamientos".

I73 $\Gamma$. de Croix a Gálvez. Arizpe, 30 de noriembre de 1\%8, núm. 692. A. G. I., Guadalajara, $28 \mathrm{I}$ bis. T. de Croix a Gálvez. Arizpe, 28 de febrero de 1782 , num. 726 . A. G. I., Gua-
dalajara, 267 .

I74 T. de Croix a Gálvez. Arizpe, 30 de mayo de $I_{7} 8_{2}$, núm. 749 y 26 de agosto de $I_{72}$ núms. 814 \& 815. A. G. I., Guadalajara, 517.

I 75 Reales órdenes de 5 de abril de 1782. A. G. I., Guadalajara, 267. T. de Croix a Gálvez. Arizpe, 4 de noviembre de $x_{7} 8,11$ úms. 846 y 847 . A. G. I., Guadalajara, $28_{3}$. 
"Para esta vida libre hay las ventajosas proporciones que facilitan las repetidas indispensables ausencias de los padres, hermanos y maridos, la uciosidad que en el descanso de las operaciones de campaña producen aquellas soledades, la falta de operarios evangélicos, pues hasta ahora no lo ha habido en muchos presidios, y aún en algunos se carece todavía de capellanes, y la abundancia del bello sexo, que como menos expuesto a los insultos del indio enemigo sobresale de manera que para aumentar la población comprendo que sería más útil hacer reclutas de hombres solteros, que de familias completas". 176

Teodoro de Croix, cuando ya había recorrido la mitad de la frontera, deploraba la baja calidad de la tropa, punto poco menos que insoluble hasta tanto no fuera posible elevar el nivel de vida y el grado cultural de las provincias. Tendría que empezar por desterrar la idea de que "no necesita el soldado otras circunstancias que las de un vaquero". "La vida triste de un soldado de presidio - añade más adelante-, sı mala asistencia, su ignorancia y falta de obediencia y disciplina lo hacen, cuando menos, inútil; no le incomodan los empeños, como le den lo que pide para sus vicios; el punto de honor lo mezcia con el abatimiento más servil, no cuida de sus armas, ni siente la pérdida de ellas, de stis caballos, vestuarios y monturas".

El cuadro se completa con un extraordinario análisis de la oficialidad, que divide en Ires clases: los oficiales del país, en la primera, son de muy humilde nacimiento, tienen todos los vicios y defectos comunes, están emparentados con los soldados... "No aspiran a otra gloria que la de dejar el servicio para ponerse a la cabeza de una recua con el distintivo de su grado haciendo oficio de arriero". Pero al nismo tiempo, son muly a propósito para la guerra por el conocimiento de los terrenos, huellas, polvaredas y humos de amigos y enemigos, arte que aprenden desde niños. $Y$ son obedientes, $y$ gustan de agradar a los jefes.

Los oficiales del ejército, en segundo lugar, no son aptos para las fatigas que impone la frontera, no tienen espíritu para batallar con los elementos, ni para exponerse a la caída de un caballo, ni a sufrir el hambre y la sed. "No se les pueden confiar - escribe Teodoro de Croix en frase lapidaria- las acciones que desempeñarían con honor en guerra más noble". Sin embargo, algunos oficiales de esta condición eran capaces de adaptarse, y en este caso sobresalían a todos.

La tercera clase de oficiales son europeos, que de la clase de mercaderes y cajeros pasaron a la de oficiales cuando los presidios estaban en el antiguo pie, comprando con costosas dádivas los empleos. Abominan de culanto se

I76 T. de Croix a Gálvez. México, 26 de febrero de 1777, núm. 8, A. G. I., Guadalajara, 516.

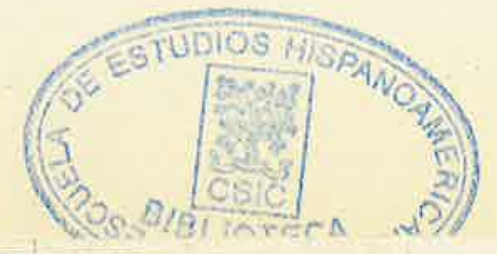


dirija a sacar al soldado de su ignorancia, conservan su codicia, tratan con prepotencia a los súbditos... ${ }^{177}$

A la vista de estas descripciones, se ordenó al comandante general la corrección o separación de los oficiales que lo mereciesen. Pero a partir de ellas mismas se esperaba mejorase pronto el estado de las tropas, "pues conociendo ya prácticamente los males, no estará V. S. distante de aplicar los oportunos remedios". ${ }^{178}$

En cuanto a los oficiales, hubo de representar Teodoro de Croix nuevamente en solicitud de ampliación de la facultades que para conceder licencia de matrimonio le habían sido ya otorgadas por la real orden de 24 de mayo de 1777 . Considera ahora el caballero de Croix necesario dispensar algunos de los requisitos que previenen las ordenanzas del montepío municipal por parte de los contrayentes, y ello forzado por las circunstancias. En efecto, gran parte de los oficiales son de castas impuras, y les resulta difícil hallar mujer de las condiciones requeridas por las ordenanzas --española, de familia de cristianos viejos, que no tuviese parientes penados por la Inquisición, con dote, etc.- Otros oficiales, que habían sido sargentos criollos en los regimientos del virreinato, hallaban la misma dificultad. A los europeos o cadetes españoles se les presentaba la de encontrar nujer de su clase entre las familias de aquellas provincias y de los presidios.

Cree, desde luego, Teodoro de Croix que interesa el matrimonio y radicación de los oficiales allí porcute aumentarían la población y serían origen de familias distinguidas: "Fundado, pues, en estos principios, reputo por matrimonio decente el que contraiga un oficial de estás provincias con mutijer descendiente de familia pobladora 11 honrada, y me parece que teniendo cualquiera estas circunstancias podrá dispensarse la dote, lo primero, por la dificultad de que los haya verdaderos en estos países hostilizados, y lo segundo porque a la falta de este auxilio en la viudedad de la contrayente subvendrán sin duda las proporciones que ofrece un destino fijo en la adquisición de casa y tierras propias, ganados y otros bienes de campo que posibilitan los presidios como nuevas poblaciones de fronteras".

Por consiguiente, en estas condiciones daba él licencia de matrimonio, proponiendo tan sólo que no pudiesen luego pasar a los cuerpos veteranos del ejército aquellos oficiales que no estuviesen casados con mujeres europeas o criollas de las condiciones requeridas por la ordenanza; y que sólo las que hubiesen afianzado su dote tuviesen, llegado el caso, pensión de viudedad. iz7 T. de Croix a Gálkez. Chilubahua, 25 de octulhe de 1778 , rím. 293. A. G. T., Gua-
dalajara, 270 .

I78 Real orden de is de abril de I779. Thicl. 

Pero con esto sería posible evitar los escándalos que a veces se producían en los presidios. "Mi honor - concluye. Croix-, mi conciencia y los deseos del mejor servicio de Dios y del rey son los agentes de esta representación."

Pero nos detendremos a considerar algunos puntos de ella, sumamente ilustrativos. "Muchos de los (oficiales) que cubren los presidios y compañías volantes son naturales del país que han labrado su mérito desde la clase de soldados. En su admisión de reclutas sólo se procura que el color del rostro disimule su naturaleza; ésta, por lo común, los constituye en la esfera de mulatos o de otra de las castas impuras que abundan en este continente $y$, por consecuencia, aunque a esta clase de ofíciales la ennoblezcan los reales despachos parece, $y$ lo es ciertamente, difícil que encuentren mujeres de las calidades y con las circunstancias que previene la ordenanza del montepío". Lo mismo era válido para los antiguos sargentos del virreinato. He aquí, pues, la realidad racial de los presidios, y la dificultad que entrañaba para el matrimonio de los oficiales. Veamos, por la otra cara, la que ofrecían las familias pobladoras.

"Hay algunas (familias), aunque pocas, nobles y de caudal, pero los padres de familia prefieren el casamiento de un mercader o dueño de hacienda al de un oficial subalterno, y aun al de un capitán; los primeros no han merecido aprecio hasta ahora, porque apenas está desvanecida la preocupación de considerarlos como sirvientes de sus capitanes; y de cualquicr modo, siempre es difícil que una mujer que disfruta de conveniencias se abandone a vivir con las de un subalterno en las incomodidades de un presidio o puesto de fronteras".

"Otras familias hay en número grande tenidas y reputadas por nobles, ya en razón de descendientes de pobladores, o ya de conquistadores, pero como sus caudales se han fundado en bienes de campo que son despojo de los indios enemigos, se hallan en la mayor infelicidad y miseria, no pueden afianzar las dotes de sus hijas en otras posesiones que las que han abandonado por la hostilidad, y es dichoso el padre de esta clase de familias que logra acomodar a sus hijos en la de soldados de las compañías presidiales, pues o bien socorre sus necesidades con los empeños o alcances que contrae el hijo soldado para asistir a sus padres, o éstos se trasladan y radican en los presidios con el fin de recibìr más cerca y de economizar los cortos auxilioł de que stubsisten".

"De la indigencia de estas familias cuyos principios por lo conún han sido oscuros, proviene el enlace con las del estado general, y en éstas, que viven en igual pobreza, será muy raro la que se encuentra limpia de casta infesta". 
Maravillosamente, pues, ha expuesto Teodoro de Croix el papel de la frontera como fundente social y racial. 179 Dos fueron, además de las prescupaciones ya ampliamente reflejadas, sus medidas fundamentales para mejorar la situación de los presidios. La primera, dotarlos de capellanes que atendiesen a su vida espiritual. Hecha con este fin la ojortuna concovatoria a los eclesiásticos seculares de las provincias internas y de Nueva España, sin que se presentasen candidatos a las vacantes, hubo de cubrirlas con reigiosos franciscanos, a los que se computarían sus servicios en los presidios y nuevas poblacionese como si estuviesen en misión. I80

JE ABASTECTMIENTO DE LA TROPA

En segundo lugar alsordó Don Teodoro el problema mucho nuás connplejo de ver la manera de stibsanar los perjuicios que sobrevenían a la tropa con motivo de las quiebras de sus oficiales habilitados, según los había creado el nuevo reglamento, disposición que había dignificado la figura del capitán pero que no había redundado en beneficio de la condición del soldado.

"Ha sido muy raro el habilitado que no se haya visto en descubierto; el ignorante, por inepítud; el desidioso, por inaplicación; el vicioso, por la facilidad que se le ha dado; el exacto y escrupuloso, por las dificultades y falta cle auxilio".

"Sólo el que se los ha proporcionado comerciando con los intereses de la tropa ha salido bien de su encargुo y se le han dado las gracias; con justa razón, pues aunque se hayan interesado con su manejo, han mantenido bien provistas sus compañías y sus empeños, y lian puesto precios cómodos. E1 truco era comprar los géneros en México y otros lagares y vender-jos en los presidios al precio del país a más baratos, contentándose con una moderada ganancia, o la misma de los comerciantes del lugar, disfrutándola en uno u otro caso sin conocido per juicio de lá tropa, si bien no con muy segura conciencia, porque los fondos de esie comercio eran los caudales de situados y no los propios". Dentro de este método, gozaban las ventajas de no tener que pagar alcabalas, y de pagar ellos en género a los labradores cuyos productos adquirían. Algunos habían incrementado sus lucros aprovechando también los dos reales diarios que debían abonarse en mano a los cabos y regulares. I8

i79 T. de Croix a Gálvez. Arizpe, 23 đle diciembre de iz8o, núm. 593. A. G, T., Guadalajara, 277 .

I 80 T. de Croix a Gálvez. México, 26 de febrero de I777, núm. 2r. A. G. T, Guadala jara, 516. T. de Croix a Gálvez. Arizpe, 23 de enero de I7So, núm. 437. A. G. I., Guadalajarn, 272 ; núm. 474. A, G. I., Guadalajara, 27 I.

I8 I Informe general de 7782 , num. 753, arts. 59-63. 
Aparte que el reglamento prohibe que los habilitados actúen como comerciantes, Teodoro de Croix no echa de ver que si éstos hacían sus compras en México u otro lugar próximo se hacía inútil la previsión del rey para que los situados se abonasen en las cajas reales vecinas a los presidios con el sabio fin, entre otros, de que la circulación de este numerario fertilizase la vida económica de las provincias. En cambio, el comandante general advierte el riesgo de que los habilitados acaben estancando el comercio de las poblaciones de la frontera. Pero los habilitados no tenían más remedio que lanzarse a negociar, porque si bien el valor del situado se les entregaba en dos semestres, las mercancías - por ejemplo, los frutos del campo- había que adquirirlas, por entero, en un momento deterninado del año, de tal manera que en ese oportuno momento el habilitado necesitaba forzosamente un suplemento de dinero, un fondo de reserva que, si no se lo había procurado él mismo con sus manejos, veíase obligado a solicitarlo de un mercader, porque los fondos de gratificación y de retención que teóricamente debía haber en los presidios no existían.

Con idea de remediarlo, Teodoro de Croix había dispuesto se abonase integro el situado de los presidios de Nueva Vizcaya y Santa Fe de Nuevo México a principios de año en Chihuahua. A partir de ese momento, el presidio de Santa Fe no tuvo quiebras, pero en Nueva Vizcaya se encontraba el entorpecimiento de ser más difíciles los abastecimientos y cada vez más escasas las recuas.

Por todo ello, de hecho, el comercio de los presidios de esta provincia estaba estancado en cuatro casas de comerciantes de Chihuahua, "pues en la de Don Manuel de Urquidi gira el día de hoy la importancia de 227. I 6 pesos de los situados, en la de Don Juan Francisco Javier del Campo la de 6I.300; en la de Don José Antonio Iribarren la de 66.000, y en la de los Herederos de Don Francisco Duro la de 32.280". ${ }^{182}$ Conocida esta situación, durante su estancia en la villa convocó Teodoro de Croix a junta a todos los comerciantes residentes allí. Las juntas fueron dos, celebradas el 30 de mayo y el 8 de jurio de I779, y a ellas asistieron diecisiete comerciantes. En la primera reunión se les informó el deseo del comandante general de que el surtimiento de los presidios fuese ventajoso a todos, y no se convirtiese en un negocio en manos de sólo unos cuantos de ellos. En la segunda asamblea se advirtió que sólo ocho de los asistentes se ofrecieron a la habilitación de las compañías presidiales y volantes, pero sin ofrecer reglas convincentes para hacerlo, de modo que Teodoro de Croix prefirió suspender el proyecto.

Los ocho comerciantes que se mostraron interesados en él fueron: Don

182 Ibid, arts. 65,8 I-85, 96 y I 35 
Bernardo de la Torre, Don Leonardo Calo, Don Francisco Guizarnotegui, Don Blas Calvo y Muro, y los cuatro anteriormente citados. ${ }^{183}$ Después de este intento, resuelto sin duda el caballero De Croix a abandonar el sistema de oficiales habilitados, que recargaba de excesivas atenciones a los presidios, no siéndole posible experimentar el de los ayudantes habilitados y furrieles que desde un principio había estado consiclerando - propuesto por el secretario Bonilla y debatido en junta en 1778 , de modo que cuatro aytudantes se dedicasen en cada provincia a procurar los suministros de los presidios, habiendo en cada uno simplemente un cabo furriel que atendería el despacho de los géneros como un dependiente de la tienda-, decidióse a poner en práctica el sistema de proveduría apuntado ya hacía más de quince años por el fiscal cle México Velarde, que tenía la enorme ventaja de dejar todos los problemas de abastecimiento a cargo del mercader contratista permitiendo a la fuerza del presidio dedicarse de lleno a sus obligaciones puranente militares. Dentro de esta línea de pensamiento, Teodoro de Croix contrató con Urquidi la provisión del presidio de San Eleazario por tres años, a partir del $I^{\circ}{ }^{\circ}$ de enero de I782, y dirigió una circular a los gobernadores para que procurasen nuevas contratas para todos los denás presidios. ${ }^{184}$ Los resultados de esta decisión no se tocarían sino años después.

Finalmente otras disposiciones del comandante general condujeron a la construcción de depósitos de pólvora y municiones en Arizpe, Chihuahua y Monclova, ${ }^{185}$ y a la renovación, auncute sólo parcial, de las armas de fuego y cuidado de todas, de nianera que encarga a los inspectores reconocer en todas las cueras de gamuzas los haces, entretelas y hechuras, y en las de algodón su peso y demás circunstancias, anotando las medianas para su composición y las inútiles para su remplazo; en las adargás observarían la consistencia, tannaños y pinturas "evitando en lo sucesivo las ridículas que se notan, y reduciéndolas a las armas del rey y todas de un color azul, encarnado, etc. y el nombre del presidio". ${ }^{8} 86$

Contó Tendoro de Croix algún tiempo a sus órdenes al teniente Don

183 Los otros nueve asistentes eran Don Francisco Trespalacios, Don Franciseo Losada, Don Francisco Arregui, Don Andrés Calles, Don Pedro Ramos de Verea, Don Pedro Velarde, Don Manuel Ruiz, Don Diego Márquez y Don Juan José Barrandegui. Ibid., arts, 125-127.

184 Otro proyecto antiguo había sido el de poner la habilitación de los presidios a cargo de un comerciante que actuase como factor dando cuenta a la real hacienda pero ofrecia demasiados inconvenientes y $T$. de Croix no 10 tomó en cuenta. Thid. arts. 136-351. T. de Croix a Gálvez. Chihuahua, 27 de julio de 1778 , núm, 238 . A. G. I., Guadalajara, 267.

$185 \mathrm{EI}$ de Arizpe lo edificó Mascaró. El de Chihuahua fue diseñado por el teriente Bertucat. El de Monclova que costó mil quinientos treinta y dos pesos estuvo al cuidado de Ugalde. T. de Croix a Gálvez. Arizpe, 2 de junio de $178_{3}$. A. G. I., Guadalajara, 922,

186 Instrucción a Cazorla, arts. 6 en T. de Croix a Gálvez. Chihuahua, zo de junio de I778, núm. 218. A. G. I., Guadalajara, 276. 
Luis Bertucat, que se le incorporó voluntariamente en La Habana, y al que nombró teniente de milicias de Arizpe. Bertucat le propuso la fabricación de corazas metálicas que sustituyesen con ventaja a las cueras. Construyó varias experimentales con laminillas de hoja de lata imbricadas, que en las pruebas hechas en Chihuahua en presencia de Rubio, Ugarte, Mendinueta, Anza y otros jefes se mostraron capaces de resistir un flechazo disparado desde una distancia mínina de ocho pasos, y un lanzazo dado por un soldado robusto con toda la fuerza de la carrera. Sobre esto tenía la ventaja de pesar de siete a nueve libras, cuando la cuera pesaba de doce a quince, y la de no entorpecer en absoluto los movimientos. En vista de ello, el comandante general expidió a Bertucat patente exclusiva de fabricación de dichas corazas por cinco años y le permitió pasar a España por un año para presentarlas a Gálvez y adquirir algunas cosas necesarias. A su paso por México, con ayuda de Don Antonio Frago construyó cincuenta corazas, cque entregó como donativo, y Croix distribuyó a su escolta. Mas luego Bertucat y Frago se enemistaron y se advirtió algún turbio manejo por parte del primero, que fue encarcelado en Ulía aunque al parecer logró pasar a España, dejando un mapa de su viaje a las provincias internas. Sin embargo, las corazas mostraron su utilidad práctica en un combate librado en setiembre de ${ }^{7} 780$. ${ }^{187}$

\section{LA VIDA. EN LAS PROVINCIAS}

Los cálculos de Teodoro de Croix que atribuyen a las provincias internas una población aproxinada de doscientos veintiocho mil habitantes ${ }^{\mathrm{I}} 88$ no están distantes en conjunto de los elaborados a partir de los datos de los obispos Tamarón y San Buenaventura veinte años atrás, aunque evidentemente rebajan la cifra de doscientos treinta y tres mil seiscientos obtenicla para I 60 , tanto más cuanto que el total del comandante general incluye unas ocho mil almas censadas en Californias. Bien mirado, la diferencia tiene su origen en la vaguedad de los datos empleados por el caballero para Nueva Vizcaya a la que atribuye "mas de cien mil habitantes", por no haber obtenido, sin duda, un censo completo como de las otras provincias; por lo demás, sus datos son sensiblemente semejantes a los de Tamarón para Sonora

I 87 T. de Croix a Gálvez. Chihuahua, 24 de agosto de $177 S$, núm. 262 . A. G. I., Guadalajara, 276. T. de Croix a Gálvez. Chihuabua, 23 de seienbre de iz79, núm. 433. A. G. I., Guadalajara, 267. T. de Croix a Gálvez. Arizpe, 26 de marzo de т780, múm. 495. A. G. I., Guadalajara, 278. T. de Croix a Gálvez. 23 de diciembre de I780, núm. 579, con Extracto. A. G. I., Guadalajara, 27 I. El mapa de Bertucat, en British Museum, manuscript room. Additional mss, I7650. c.

I88 Informe general de $178 \mathrm{I}$, art.s. I, 56, I21, I6 I y 227. T. de Croix a Gálvez. Chihuahua, 23 de setienbre de 1778 , num. 270. A. G. I., Guadalajara, 275. 
y Nuevo México, y casi doblan la cifra fijada por San Buenaventura a las provincias orientales. He aquí la comparación, sin Californias:

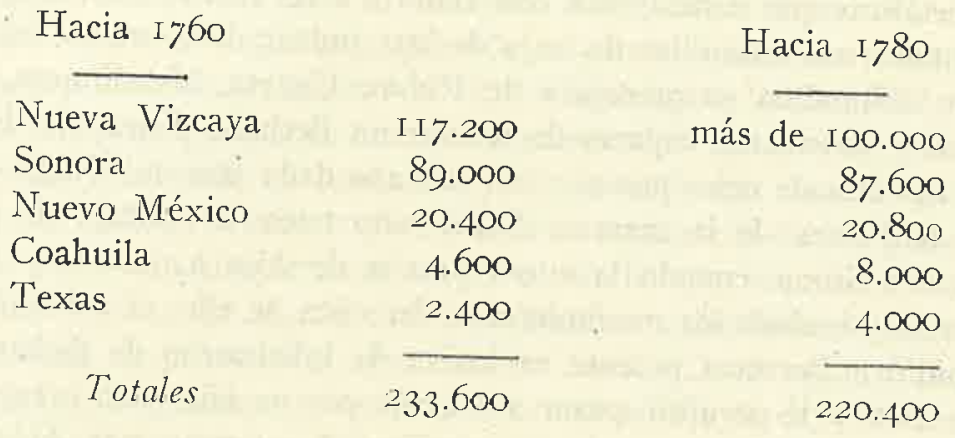

La confrontación de ambas sumas nos permite aseguramos en la exactitud de ambas evaluaciones y nos da pie para considerar, en bloque, la población de las cinco provincias como tal yez ligeramente inferior a un cuarto de millón de habitantes de todas castas y razas, contando tan sólo, naturalmente, a los indios directa y plenamente sometidos al rey, y no a los núcleos hostiles --seris, apaches, comanches- o simplemente en paz y buenas relaciones con los españoles - navajos, yutas, jicarillas, indios del norte, etc.

Estos indios eran, sin embargo, en ocasiones o de manera permanente eficaces colaboradores de los españoles. Tal es el caso en tiempo de O'Conor, de los lipanes y de los pápagos, que prestaron su esfuerzo a la construcción de los nuevos presidios de Coahuila y Sonora, ${ }^{189}$ y en época posterior los indios aliados del norte y los pápagos, pimas gileños gentiles, jalchedunes, cocomaricopas y cajuenes actuaron como aliados, según se ha visto, contra los apaches y los yumas. Distinta era la condición de los jenízaros, asentados en pueblo en la zona del "río abajo" de Nuevo México, y que eran un valioso elemento de choque para la clefensa de la provincia. 190 Grandes grupos de población india políticannente independientes habían visto por fuerza enormemente alterado su género de vida a raíz del contacto con los españoles, en ctyya órbita económica habían entrado insensiblenente. De este modo los pápagos lograban sus medios de subsistencia trabajando en las haciendas y minas del norte de Sonora; los navajos no podían ya prescindir de la renta de sus tejidos en Nuevo México y los indios del norte clamaban porque se les concediesen las armas necesarias sobre todo para el ejercicio de la 189 Sobre el íltimo caso, Pedro de Allende y Saavedra a Croix. Tucsón, 15 de junio de
1777. A. G. I., Guadalajara, 5r5. Guadalajara, 5 I 6. 
caza. Por no insistir sobre la necesidad en que se hallaban los seris y los apaches de pillar los bienes de los españoles para subsistir. La autosuficiencia, la autarquía de los grupos aislados eran ya cosa del pretérito.

En cambio, las dificultades que experimentaban las provincias para su desarrollo por causa de las hostilidades son constantes en las representaciones que algunos núcleos de población - Mapimí, Parras - elevan a las autoridades. La situación de guerra permaneente en país ya de tanto tiempo atrás ocupado por los españoles como era la zona de Santa Rosa en Coahuila es bien visible en la descripción que el padre Morfi hace del procedimiento de defensa ideado por un tal Longoria, propietario de un rancho al pie de la sierra de Santa Rosa, frecuentemente atacado por los apaches. "Imaginó - dice Morfi- nna especie de castillo ambulante, construido en una carreta que sigue a los peones; en él ha puesto unos fusiles; al menor ruido se meten en él los gañanes y dando fuego por las troneras del pequeño fuerte, se defienden desde allí de los tiros de los contrarios, mientras el ruido les atrae socorro; esta invención le ha librado hasta ahora de las sorpresas". 19 las incursiones apaches y comanches tenían arruinadas a muchas familias, paralizadas las minas, destruido en gran parte el comercio. La miseria en que se desenvolvía la existencia de las provincias orientales se percibe claramente en el hecho de que Riperdá, gobernador de Texas, al estar su mujer a punto de dar a luz, la llevó a la cárcel de Béjar, que era la habitación más segura y confortable. ${ }^{\text {rga }}$

Con todo, la población iba en aumento en ambas provincias, aum cuando Teodoro de Croix hubiese aumentado la cifra de sus pobladores. ${ }^{193}$ Texas comprende una villa, dos presidios y siete misiones, más el pueblo del Pilar de Bucareli en Nacogdoches, que el comandante general no cita sino más adelante por no estar oficialmente reconocida su existencia; Coahuila cuenta en sus once jurisdicciones ocho villas de españoles, cuatro pueblos de indios, c11atro misiones, cinco presidios y ocho puestos defensivos. ${ }^{194}$ Texas ofrece ilimitadas posibilidacles de desarrollo y enricuecimiento, pero sin que se vea la manera de actualizarlas. Dado el riesgo que corre la provincia, conviene constituirla de manera cerrada sobre la villa de San Antonio y sus cinco

I9 Morfi, Viaje de indios, ed. Alessio Robles, pág. 253. Se echa de ver la semejanza de este invento con los métodos empleados ya en el camino de Zacatecas mediado el siglo XVI. 192 Morfi anota la pequeñez y defectuosa construcción de la casa del capitán del presidio de esta villa. Ibid, $22 \mathrm{I}$.

I93 El censo de Texas remitido por el mismo Croix en $37 g^{8}$ no suma más que tres nil ciento tres habitantes, de los que 2060 en el clistrito de Béjar y Cibolo, 696 en la Bahia y 347 en Pilar de Bucareli (A. H. N., Estado, $3883-9,1$ ), y otro de fines de $178_{3}$ sólo arroja un total de dos mil ochocientos diecinueve Castañeda, Catholic heritage, V, 83 . En el informe general de 1781 , art. I, dice Croix que escasamente llegan a cuatro mil los pobladores de Texas.

I94 Informe general de $\mathrm{J} 78 \mathrm{I}$, Arts. I, I5, 48 y 56 . 
misiones. ${ }^{195}$ En Coahuila, más en concreto, se ve la conveniencia de fundar o repoblar poblados o haciendas, a costa de hacer algunas obras para aprovechamiento de aguas, regadíos y moliendas, y con objeto de poner en explotación abundantes riquezas desperdiciadas y terrenos que en otro tiempo fueron prósperos, y de cerrar los huecos por donde los enemigos pasaban a hostilizar Nuevo León y Nuevo Santander. Cualquier iniciativa, sin embargo, habría de tropezar con el obstáculo de los latifundios del marqués de Aguayo y del cura de Monclova Don José Miguel Sánchez Navarro y con el monopolio mercantil que ejercían los hermanos de éste, que apenas dejaban actuar a otros tres o cuatro mercaderes ciue había, y que ponían arbitrariamente precio a los artículos y los cobraban en semillas o carneros que tasaban a su antojo, para luego revenderlos en las provincias de tierra afuera. ${ }^{196}$

Monclora $y$ el vecino barrio de Tlaxcala dividido en dos comunidades indias rivales constituían el prinicipal núcleo urbano. El presidio de Río Grande concentraba unos ochocientos habiantes, lo que lo constituía en tercer lugar entre las poblaciones de la provincia. La villa de San Fernando de Austria sólo tenía trescientos. La de Gigedo era pequeñísima, y sólo la del valle de Sanía Rosa ofrecía condiciones de competente incremento, aprovechando las posibilidades que tenía para la molienda de granos y para el cultivo de la caña de azúcar. 197 Tan sólo en la misión de San Bernardo había

En veintiséis alcaldías se distribuía la gobernación de Nueva Vizcaya, hostilizadas las más por el enemigo apache o por los grupos indios infidentes, internadas las menos en la sierra Madre, de muy distintas condiciones todas ellas en cuanto a población y riqueza. Por edicto de 2 de abril de 1777 dispuso el obispo de Durango Don Antonio Macartulla Minguilla, en cumplimiento de la real orden de Io de noviembre de 1776 , la formación de un padrón de todo el obispado, cuyos datos ineritablemente difieren de los que suministraron los oficiales comisionados por Teodoro de Croix para la organización de las milicias provinciales. Estos últimos son, por otra parte, mucho más interesantes por cuanto aluden a la rigueza de cada vecindario como base 1)ara fijar la contribución que debería ajortar al fondo provincial para el
sostenimiento de las nilicias.

Es difícil reconstruir la relación de las veintiséis jurisdicciones a que alude el comandante general. En el capítulo anterior hemos presentado la lista de las veintisiete alcaldías presentadas por el propio gobernador Don

I95 Ibid, a1t. 40.
I96 Morfi, Tiaje, 179.
ryt Ibicl. т78, 106-19\%, 205-206, 245, 252.
IgS Ibid, 203. 
Felipe Barri, advirtiéndose en ella la ausencia de Chihuahua, que era corregimiento, de Nombre de Dios, que sin duda forma parte de la provincia, y del mismo Durango, que es lógico considerar sea contado como una jurisdicción más. Las jurisdicciones de que tenemos noticias a través del expediente de organización de milicias son las siguientes:

$\begin{array}{ll}\text { Basis } & \text { Oro } \\ \text { Batopilas } & \text { Papasquiaro } \\ \text { Cerro Gordo } & \text { Parral } \\ \text { Ciénaga de los Olivos } & \text { Farras } \\ \text { Conchos } & \text { Saltillo } \\ \text { Cuencamé } & \text { San Andrés de la Sierra } \\ \text { Cusihuiriáchic } & \text { San Bartolomé } \\ \text { Chihuahua } & \text { San Diego } \\ \text { Durango } & \text { San Francisco Mezcuital } \\ \text { Gallo } & \text { San Juan del Río } \\ \text { Guanacevi } & \text { Santa Bárbara } \\ \text { Mapimí } & \text { Sianori } \\ \text { Nombre de Dios } & \text { Tabahueto }\end{array}$

Se observa naturalmente el desdoblamiento de Parras y Saltillo, la inclusión de Chihuahua, Durango y Nombre de Dios, y la ausencia de las cuatro alcaldías de Topago, San Juan Nepomuceno, San Joaquín de los Arrieros y San Buenaventura; Guanacevi y Mapimí no figuran, por cierto, en el estado de productos de los arbitrios y milicias. ${ }^{199}$ De las veintiseis jurisdicciones incluidas en la lista precedente, en fin, muchos curatos están representados en las descripciones y padrones del censo del obispo Macarulla, conservados en el Archivo General de Indias, de Sevilla, y en las Bibliotecas Nacionales de Madrid y París.

En cuanto a la riqueza de las diferentes jurisdicciones, los datos fragmeritarios recogidos atribuyen a la de Durango más de treinta mil cabezas de ganado caballar y mular, quince mil vacunas y cien mil de lana, pelo y cerda, amén de copiosas cosechas de trigo y maíz y otras semillas. Pero, al parecer, todos estos bienes de ganado pertenecían a terratenientes que no eran vecinos de Durango. Contaba la ciudad seis mil cuatrocientos sesenta habitantes ${ }^{200}$ y doce mil ochocientos la jurisdicción completa. El volumen

I99 T. de Croix a Gálvez. Arizpe, 23 de setiembre de I 78 , núm. 679. A. G. I., Guadalajara, ${ }_{2} 8 \mathrm{I}$ bis. En cambio, figura en este docunento la jurisdicción de El Paso del Río del Norte, que corresponde a Nuevo México.

200 Saravia, en su croquis núm. 4, correspondiente a 1777 da la cifra de $\mathrm{x} .247$ familias con 6.590 personas, para la ciudad sola. Saravia, Atanasio G. Apuntes para la historia de la Nueva Vi:cayn; núm. 2: La ciudad de Durango, 1563-182I. México, ig1r, frente a pág. I44. 
del comercio de toda ella viene dado en la cifra de cincuenta mil cien pesos a que montaba la alcalsala, de los que cuarenta y cuatro mil cuatrocientos cincuenta quedaban limpios para la real hacienda. ${ }^{201}$

E1 mismo carácter agrícola, ganadero y mercantil tenían los distritos de Nombre de Lios, Parras y Saltillo, entre otros. El de Nombre de Dios comprendía, en un radio de no más de trece leguas, veinte ricas haciendas a orillas del río de las Poanas y del Suchil, que, aparte abundantes cosechas, criaban y mantenían más de mil cabezas caballares y mulares, nueve mil vacunas y más de ciento treinta mil de lanar y cabrío, regulándose el giro anual de sus esquilmos, y del comercio de efectos de Europa y de la tierra en más de doscientos mil pesos, por prudente cálculo, correspondiendo las tres cuartas partes precisamente a los esquilmos de doce a dieciséis mil carneros, quinientas a seiscientas reses, ocho o nueve mil arrobas de lana, novecientas a mil mulas y unos quinientos a seiscientos caballos. El campo producía hasta diez nil cargas de harina, veinte mil fanegas de maíz y cuatro mil de frijol, siendo los habitantes de toda la jurisdicción mos ocho mil, de los que algo más de dos mil trescientos vivían en la villa y sus aledaños, y menos de un millar ctan los indios del pueblo de Malpaís, cuya única ocupación consistía en la tabricación de mezcal. ${ }^{202}$

Parras era cabecera de una alcaldía mayor en cuya jurisdicción entraba, efectivamente, la villa de Saltillo, según atestigua Morfi, 203 pero Saltillo tenía en realidad vida independiente por todos conceptos. Parras fundaba su prosperidad en la producción de vino y aguardiente, carneros y harinas, cuyos esquilmos se valoraban en doscientos mil pesos. El comercio se calculaba en ochenta mil pesos, incluidas las pagas de los sirvientes de las haciendas. Estas haciendas cubrían casi todo el término de Parras, pues el pueblo sólo contaba treinta y ocho sitios de ganado mayor, y los indios poseían media legria de pan llevar por cadá viento, correspondiendo los demás terrenos a

$20 x$ T. de Croix a Gálvez. Arizpe, 23 de enero de 1781 , núm. 602, A. G. I., Guadalajara, 271. Padrón de Durango, 30 de julio de 1777. A. G. I., Guadalajara, 255. T. de Croix a Gálvez. Arizpe, 2 de dieiembre de 1782 , núm. 857 . A. G. I., Guadalajara, 283. Las padrones de Durango, por el cura Don Juan Mijares Solórzano, 7 de agosto de 1778 y $I^{\circ}$ de agosto de 1779 , en A. G. I., Indiferente General 102. El de 1778 suma, para la ciudad, 1.002 familias, y para la
jurisdicción completa, 2.147.

$202 \mathrm{~T}$. de Croix. Arizpe, 23 de enero de 1781 , núm. 603. A. G. I., Guadalajara, 255. Padrón de Nombre de Dios, 20 de mayo de 1777 . Ibid. La descripción de Nombre de Dios en 22 de agosto de 1777 por el cura Don José Florcntino Páez de Alarcón, todavia presenta esta jurisdicción como sujeta en lo politico y temporal al virrey, $y$ en lo eclesiástico al obispado de Durango. B. N., Ms. 2.449, fol. $398-406$ v. El padrón elaborado por el mismo sacerdote en 1779 de los siguientes totales: la villa, 434 familias, con 2.392 habitantes; Malpais, 232, con 1.046; Poanas, 572 , con 3.214 ; Suchil, 335 con 1.863 . Total general: 1.673 familias con 8.515
almas. A. G. I., Indiferente General, 102 .

203 Morfi, Viaje, I4I. 
la hacienda de la Peña, propiedad de Don Andrés José Velasco y Restán, donde se fabricaba jabón con la manteca de chivos y ovejas de la hacienda de Casta; a la hacienda de San Lorenzo, de Don Juan Lucas de Lazaga, que producía doce mil pesos de vino y aguardiente, y a la hacienda de Arriba, del marqués de Aguayo, quedando sólo la de Hornos, que había sido de jestitas y estaba en manos del gobierno de temporalidades. Hacia el este aún se contaban las haciendas de Castañuelas y Patos, también de Aguayo. En ésta había hasta trescientas mil ovejas y un buen obraje de ropas. Teodoro de Croix asienta que la producción total de Parras bien puede valer trescientos cincuenta o cuatrocientos mil pesos. ${ }^{204}$

En Saltillo, en cambio, gobernaba un cabildo de alcaldes, regidores, aíguacil mayor y escribano, presidido por un teniente de alcalde mayor del de Parras. En su jurisdicción se encontraban hasta cuarenta y nueve ranchos y haciendas muy cuantiosos, pero observándose que de unos ocho mil seiscientos cincuenta habitantes de todo el término, cinco mil doscientos residían en la villa y el vecino ptreblo de San Esteban de Tlaxcala - doce mil setecientos y dos mil quinientos, respectivamente-, siendo tan sólo tres mil cuatrocientos el número de la población rural. Podía valorarse en más de ciento cincuenta mil pesos el comercio de Saltillo, a cuya feria anual de septiembre acudía gran cantidad de forasteros, y se calculaba en más de dos mil el número de mulas de arriería de que disponía la villa para la conducción de efectos a Texas, a Nuevo León y a Nuevo Santander. Los esquilmos de harinas, maíz, carneros, etcétera, no pasarían de cuarenta mil pesos. El grupo comerciante se hallaba escindido entre criollos y gachupines, siendo los primeros los más numerosos y de mejores caudales. Morfi, que es quien da la. noticia, no explica las razones ni la fecha inicial de esta oposiciớn. ${ }^{205}$

Un quinto centro no minero se halla en la doble jurisdicción de Papasquiaro y Mezquital, que juntas sumaban diecisiete pueblos y veintidós ranchos, con siete mil trescientos habitantes. No faltaban en el país minerales de plata con ley de oro, pero eran renglón mucho más importante los doce mil caballos y mulas, trece mil reses y mil cutinientas cabezas de ganado de lana, pelo y cerda, a lo que había que sumar abundante producción de mezcal que se llevaba a cabo en Mezquital, y la de granos, pues pese a quedar incultas las mejores tierras por estar en manos de los indios, daba Papascuiaro solo - según cálculo de I793- la cantidad de veintidós a veinticuatro mil fanegas de maíz, de que resultaba un licrativo comercio, pues este pueblo abastecía

204 T. de Croix a Gálvez. Arizpe, 29 de julio de 5782 , núm, 79 r. A. G. I., Guadalajara,

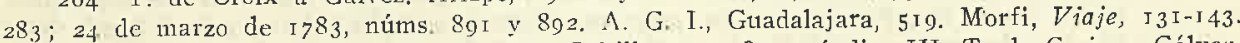

205 Morfi, Viaje, I58-160, y Censo de Saltillo, en 785 , apéndice III. T. de Croix a Gálvez. Arizpe, 29 de julio de 5782 , núm. 79т. A. G. I., Guadalajara, 283. 
a muchos reales de minas del contorno. Poseía para ello el vecindario dos mil ochocientas mulas de albarda o carga, en noventa y un atajos mayores o completos - sin contar las refaccionarias que cada arriero conservaba para reponer las que morian o se inutilizaban- y suponiéndose que cada mula obtuviese sólo una ganancia mínima de quince pesos anuales de fletes para su dueño, lograrían los arrieros de Papasquiaro cuarenta y dos mil pesos, amén de las semillas y efectos que ellos conducían y vendían por cuenta propia. Así iba prosperando esta población, favorecida además por la exención de alcabalas, que en 1747 les concediera el conde de Revillagigedo y que naturalmente había dado lugar a muchos abusos para la introducción de mercancírs en la provincia. 206

De manera semejante a Parras, el partido de Cuencamé se componía de tres pueblos miserables $y$ de treinta y ocho haciendas opulentas - como las del condado del Alamo, San Mateo, Atotonilco, Saucillo, Estanzuela y San Antonio de Nazas- que sumaban más de trescientos cincuenta sitios de tierra de labor y ganado con veinticinco mil cabezas de ganado caballar, diez mil reses $y$ trescientas veinte mil de lanar, que producían entre carneros, mulas, reses, lanas, sebos, harinas y maíces doscientos mil pesos anuales. El comercio se regulaba en ochenta mil, contando el vecindario siete mil achocientas cuarenta almas. ${ }^{207}$ La consistencia de los centros agrícolas se advierte en el hecho de que las antiguas minas de Santa Bárbara contaban mi1. cuatrocientas almas cuando el Valle de San Bartolomé andaba por las seis mil, en 1777.208

Ein contraste con la fisonomía de las anteriores poblaciones, a simple vista se advierten las peculiaridades de otra de carácter minero, como Mapimí, donde una población que no excede de las mil setecientas almas poseía unas mil quinientas yeguas, dos mil quinientas reses y cuarenta y cinco mil

206 T. de Croix a Gálvez. Arizpe, 23 de enero de 1781 , núm. 600. A. G. I., Guadalajara, 519. El alcalde Antoneli al intendente interino Urrutia. Papasquiaro, 20 de noviembre de
1793. Hernández Durango gráfico, 1793. Hernández Durango gráfico, 19-24. El padrón de San Francisco Mezquital, 23 de junio 22 de mayo de 1778 , por el cura Don Joaquín de Guadalajara, 255. El padrón de Papasquiaro, de personas. A. G. I., Indiferente General, $x_{02}$.

207 T. de Croix Gulvez Arizpe, 102.

jara, 519 . El padrón del curato de Cuencamé, 14 de eno de 1781 , num, 598. A. G. I., Guadaladores a 6.800 . A. G. I., Guadalajara, 255. El de 6 de diciembre de 1777 , reduce la cifra de pobladel cura D. Francisco Antonio González del Tanago, de diciembre de 1778 , obra, como el anterior, lias. A. G. I., Indiferente General, 102. 208 Padrones de Santa Búrrara

ral, 1.526. Los de Santa Bárbara en 1788 y San Bartolomé de en A. G. I., Indiferente GeneGeneral, 102. Descripción de Santa de 1777 . B. N., París, Ms. Fond, mexicain, núm el cura Don Juan José Sosa, 18 de septiembre $59-64$ y $73-76 \mathrm{v}$. descripciones de Chinipas, Santa Ana, $47 \mathrm{v}-48 \mathrm{v}$. En el mismo lugar, fols. siones a las minas del contorno. 
ovejas y cabras, siendo así que las únicas dos haciendas del distrito --la de Cadena y la de San Juan de Casta - estaban desatendidas, y producía el real antualmente veinte mil marcos de plata y de seis a ocho mil cargas de greta y plomo que se vendían en los reales de las provincias internas y del virreinato, y tenía un comercio de cien mil pesos de volumen, que iría en aumento si disminuyesen las hostilidades. Erigido en villa el 8 de noviembre de 1777 , la formación de cabildo trajo algunas disensiones internas al vecindario. ${ }^{209}$

La jurisdición del Gallo no tenía en 1777 más que quinientos cuarenta habitantes, ${ }^{210}$ pero las del Oro y Guanacevi, sumaban siete mil novecientos cincuenta, en cinco realitos de minas, cinco pueblos de indios, veintidós ranchos, y doce haciendas - algunas muy extensas, como las de la Zarca, Mimbrera, Torreón y Río Florido-y llegaban a las cuarenta mil cabezas caballares y mulares, más de treinta mil vacunas y más de cien mil de lana y cabrío. ${ }^{2 \text { i }}$ Parral, en cambio, era la tercera jurisdicción en número de pobladores, pues contaba algunos más de siete mil, en novecientas veintiuna familias, en $\mathrm{I777}$, de los que la mitad eran mestizos o de color quebrado, y el resto en su mayor parte españoles, contando en las afueras con el pueblo de indios yaquis establecido en tierras del santuario de Nuestra Señora del Rayo. ${ }^{212}$ El real de Basis acreditaba su fugacidad ya comentada por Tamarón en el hecho de que si en 1778 contaba quinientas noventa y cuatro personas, al año siguiente ya solo eran doscientas ochenta y nueve, lo que marca una reducción del $50 \%$ y un fin muy próximo, como que la famosa veta La Colorada estaba hundiéndose, después de haber ofrecido el máximo esplendor en $\mathrm{i} 763$, año de su descubrimiento, en que Basis fue erigido en alcaldía y curato. ${ }^{2} \mathrm{i} 3$

Son menos abundantes los datos de este tipo para las otras jurisdicciones de la provincia, que en su mayor parte son los pueblos y misiones de indios

209 T. de Croix a Gálvez. Arizpe, 23 de enero de $178 \mathrm{i}$, núm. 599. A. G. I., Guadalajara, 217; 29 de julio de 1782, núm. 791. A. G. I., Guadalajara,283. Padrón de Mapimí en 1777. A. G. I., Guadalajara, 255. Hernández. Durango gráfico, 36. Se percibe un aumento en los padrones de 1778 y 1779 , que dan totales de 1.870 y 1910 persoras, respectivamente.

210 T. de Croix a Gálvez. Arizpe, 23 de enero de 1781, núm. 601. A. G. I., Guadalajara, 281. Padrón de San Pedro del Gallo de 21 de mayo de 1777. A. G. I., Guadalajara, 255. En of de 1778 la cifra disminuye a 512 personas. A. G. I., Indiferente General, 102.

$21 x$ T. de Croix a Gálvez. Arizpe, 23 de enero de 178 r, núm. 696. A. G. I., Guadalajara, 271. Hay un padrón del curato del Zape y Guanacevi que indica 2.358 habitantes en 1778 . A. G. I., Indiferente General, 102, Descripción de la jurisdicción del Oro e Indé, en B. N., Ms. 2.449, fols. 299-308, y B. N., Paris, Ms. Fond Mexicain, núm. 20r, fols. 55-56.

212 Padrones de Parral por Don José Francisco de Frias, 24 de julio de 1777 y 8 de enero de 1778. A. G. I., Indiferente General, I02.

213 Padrones de Basis de 1778 y 1779 en A. G. I., Indiferente General, 102. Descripción del real en B. N., Ms. 2.449, fol. 65, y B. N., París, Ms. Fond mexicaín, núm, 20r, fol. 53-54. 
de la Sierra Madre, y sólo tenemos vagas noticias de los dos centros mineros del norte. En la jurisdicción de Santa Rosa Cusihuiriáchic, que comprendia Papigochic, valle de Basuchil, Temosachic, Valle de Carretas y el nuevo real de Cahurichic - descubierto en $177^{2-}$, vivían cerca de quince mil habitantes, $y$ las ocho minas que se hallaban en actividad producían metales de buenas leyes. ${ }^{214}$ De Chihuahua, Teodoro de Croix sólo dice que "su vecindario es mucho más numeroso que el de Durango, y su comercio más nervióso y floreciente, pues en las tiendas de aquella villa se proveen casi todas las tropas que guarnecen la provincia, las de Nuevo México, y los vecindarios de la última”. Si la alcabala de Chihuahua no producía más que cuatro mil cien pesos ello sólo se debía a la mala administración de esta renta en Ia villa. ${ }^{215}$

En conjunto, la provincia de Nueva Vizcaya se hallaba en puertas de in sugestivo desarrollo, como lo muestran las primeras propuestas que empiezan a hacerse para establecimiento de obrajes de ropas de la tierra y de curtidos, como lo proyectó en Durango el bachiller Don Miguel Hernández Hidalgo, cura de San Juan del Río, quien asienta no haber en toda Nueva Vizcaya fábrica alguna, teniendo que venir todas las ropas de tierra afuera, con el natural encarecimiento, mientras que las lanas y pieles de tierra adentro tenían que ser llevadas con gran costo a tierra afuera para su venta. Desgraciadamente el bachiller Hernández Hidalgo murió antes de ver aprobada su idea. ${ }^{216}$ Sin embargo, un minero y un comerciante acometieron el plan de fundar otro obraje en Chihuahua. Eran Don Martín de Mariñelarena y Don Manuel Urquidi, çuienes, apoyados por el ayuntamiento de la villa, obtuvieron de Teodoro de Croix el necesario permiso, luego ratificado por el Consejo de Indias. ${ }^{21}$ Del mismo modo, el factor de tabacos de Durango Don Miguel de Otermín propuso el establecimiento en esta capital de una fábrica de puros y cigarros, que daría recogimiento, trabajo y ganancias a muchas mujeres, y pagaría en sueldos cincuenta mil pesos que redundarían en

214 T. de Croix a Gálvez. Arizpe, 23 de enero de 1781 , núm. 604. A. G. I., Guadalajara, 281. La descripción de los curatos de Cusihuiriáchic y Coyachic por Don Juan Francisco Rubio, en ro de junio de 1778 , cita varios reales y haciendas despoblados por las hostilidades B. N.,
Ms. 2.449 , fols. $173-179$. El padrón encolo el real de Santa Rosa, y unas 3.500 suma por el mismo autor sólo indica 1.I94 personas en

215 T. de Croix a Gálvez. Arizpe, 2 de dia jurisdicción del curato con el de Coyachic. lajara, 285. Es pobre la descripción he, 2 de diciembre de 1781 , núm. 857 . A. G. I., GuadaArizmendi, B. N., M's. 2.449, fol. 121-1 1 en 1778 por Don Andrés Buenaventura Elexalde fol. 35-42 v.

2I6 T. de Croix a Gálvez. Chihuahua, 25 cle agosto de 1779 , núm. 423. A. G. I., Guada-
lajara, 343. T. de Croix a Gályez. Arizpe, lajara, 267.

217 T. de Croix a Gálvez, Arizpe, 30 de octubre de I785, núm. 687. A.G.I., Guadalajara, $28 \mathrm{I}$ bis. Vista fiscal y aprobación del consejo, en 77 de septiembre de 7783 . A. G. I., Guadalajara, 344. 
mayor prosperidad del país. Todos los informes sobre este proyecto fueron favorables, salvo el dado por la dirección de México que dice estarse en la precisión de minorar las labores de las fábricas por haler exceso de producción. ${ }^{218}$

Chihulahua, en cambio, contaría pronto, como reconociniento a su pujanza minera, con una caja de quintos y azogues, a cargo de un oficial real, que sería Don Domingo Beregaña, quien atendería además al pago de situados de las tropas, quedando por tanto suprimida la comisaría y tesorería de guerra que había estado sirviendo desde 1772 Don Mànuel Antonio Escorza. Esta creación fue dispuesta por el rey, por real orden de 26 de agosto de I 780, a instancias del ayıntamiento, procuradores, personeros y síndico general de la villa. ${ }^{2}$ í

Precisamente la arbitraria distribución de azogues hecha desde México, perjudicial a los pequeños mineros, fue uno de los problemas hallados por Teodoro de Croix. He aquí 220 la relación, en quintales, del azogt1e repartido en i782 a los más poderosos mineros de Nueva Vizcaya, que podían transportarlo a sus expensas desde Veracruz a sus ingenios.

\section{Asogue de Castilla}

Conde del Valle del Suchil . . . . . . . . 450

Don Martín Mariñelarena, Chihıahıаa..... . 93

Don Gregorio de Cea, Cusihuiriáchic . . . . . . . . 39

Don Vicente de la Peña, Cusihuiriáchic . . . . . . . 39

Don Manuel Antonio González, Parral ... . . . 75

Don Manuel Antonio de Escorza, Pánuco y Coneto . . 75

Total. . $77^{\mathrm{I}}$

Azogue del Perí

Conde del Valle del Suchil . . . . . . . . . . 50

Don Pedro López Bringas, Don Juan José Zambrano,

Don Francisco Martín Escudero y Don José Arean,

Canelas, Banome, Guanacevi, Indé . . . . . то2

2 I 8 T. de Croix a Gálvez. Arizpe, 30 de novieumbre de 788 , núm. 605. A. G. I.. Guadalajara, $28 \mathrm{I}$, bis.

2 I9 T. de Croix a Gálvez. Arizpe (30 de abril), I78 I. núm. 634. A. G. I., Guadalajara, 271. T. de Croix a Gálvez. Arizpe, 30 de julio de I78I, núms, 657 y 658. A. G. I., Guadalajara $28 \mathrm{I}$, bis. T. de Croix a Gálvez. Arizpe, 7 de octıbre de 1782 , núm. 837. A. G. I., Guadalajara, 271. 220 Estado del azogue repartido en México, 26 de junio de i 782 . A. G. I., Guadalajara, 283. 
Don Martín Mariñelarena, Chihuahua; Don Pedro Sandoval, íd; Don Joaquín de Amezqueta, Parral; Don Vicente de la Peña, Don Dionisio García y Don Gregorio de Cea, Cusihuririáchic . . . . . . . Ioz

$$
\text { Total. . . } 272
$$

Las dos partidas suman mil cuarenta y tres quintales de azogues, casi la mitad de los dos mil ochocientos dos quintales asignados a la caja de Durango para toda la provincia. En el siguiente cuadro puede verse la cantidad de azogue adquirida por los mismos mineros relacionados antes, durante el quinquenio de 1777 a I78I, en Durango y Parral, igualmente expresada en quintales:
Conde del valle del Suchil
I. 4.39
Don Martín Mariñelarena
Don Gregorio Fernández de Cea . . . . . . 82'50
Don Vicente de la Peña .
Don Manuel Antonio González . . . . . . 53
Don Manuel Antonio de Escorza . . . . . . . 434
Don Pedro López Bringas
Don Juan José Zambrano . . . . . . . . . . $\quad$ I 27
Don Francisco Martínez Escudero . . . . . 66
Don José de Arean . . . . . . . . . . I 8
Don Pedro Sandoval y Moscoso . . . . . 264
Don Joaquín de Amezqueta. . . . . . . I 5 ' 50
Don Dionisio García. . . . . . . . ${ }_{1} 8^{\prime} 75$

El problema del azogue, que reaparece también en Sonora, será permanente hasta el fin del dominio español en América.

Contaba la intendencia-gobernación de Sonora. según el censo de 1783 , ochenta y siete mil seiscientos cuarenta y cuatro habitantes, en diez jurisdicciones, de sur a norte:

Rosario
Maloya
Copala
Cosalá
Culiacán
Sinaloa

Fuerte

Alamos

Ostimuri

Sonora 
Comprendían estas diez jurisdicciones treinta reales de minas, siete villas, ciento seis pueblos, treinta y cinco misiones, seis presidios, veinticuatro haciendas y trescientos setenta y ocho ranchos. Había ciento cincuenta y seis iglesias y ciento once casas de piedra, siendo indeterminado el número de las de paja y de adobes. La riqueza ganadera se comprendía así: yeguas, veinticinco mil quinientas; yuntas de bueyes, tres mil quinientas; cabezas de ganado vacuno, ciento veinte mil novecientas; lanar, treinta y un mil quinientas; caballar, dieciocho mil cuatrocientas; mular, diecisiete mil; asnal, dos mil; de cerda, setecientas; cabrío, diez mil doscientas. Hasta veintitrés minerales de oro y ciento cuarenta y ocho de plata se conocían en la provincia. ${ }^{22 \mathrm{I}}$

Sin embargo, la minería no puede decirse que se encontrase en estado. floreciente debido, sobre todo, a la falta de grandes capitales. En Rosario había once comerciantes, pero ninguno de ellos tenía más de veinte mil pesos. ${ }^{222}$ Su campo de acción eran los reales de Copala y Plomosas. En el mismo Rosario había ciento nueve rastras o tahonas que mantenían los mineros pobres que trabajaban las antiguas minas del lugar, de escasa ley. De Chiametla se traía la sal necesaria, que también servía para salazón de la pesca de este puerto y del de Escuinapa. También había salinas en la jurisdicción del Fuerte.

En general, de Rosario a Sinaloa la agricultura era escasa. En Maloya, la escasez de tierra de labor obligaría a realizar las siembras en algunas cañadas de la sierra, siendo la pesca el alimento fundamental. Sembraban los indios doce fanegas de maíz en julio y recogían cien en octubre. ${ }^{223}$ En Copala se daban las mismas circunstancias, con la agravante de la sequía habitual de mayo a julio, que producía gran escasez y obligaba a traer víveres de Rosario, Chiametla, San Sebastián y Mazatlán. Por lo demás, de julio a octubre las lluvias hacían intransitables los caminos. Pero en julio era

22 Padrón de Arizpe, 20 de agosto de 1777. R. A. H., Boturini, 18, fol. 193. Estado de Sonora y Extracto de los padrones. T. de Croix a Gálvez. Arizpe, 2 de junio de I783, núm. 921. A. G. I., Guadalajara, 284. Padrones de Copala, Piaxtla, Maloya y San Benito. A. G. I., Guadalajara, 255.

222 Niega esta noticia el cura don José Maestro y Cuevas, autor del padrón de 20 de febrero de 1778 , que da 2.728 habitantes, y de la descripción del real hecha en ro de julio del mismo año, donde eleva la población a 3.600 almas y dice que algunas tiendas llegan a tener en corriente un caudal de treinta o cuarenta mil pesos. Padrón en A. G. I., Indiferente General, 102 ; descripción en B. N., M's. 2.450, fols. 124-128 v., y B. N., París, Ms. Fond mexicain, núm. 201, fols. $69-69$ v. El padrón de 2 de julio de 1777 , obra del mismo sacerdote, daba sólo 2.616 personas, habiéndose producido respecto del año anterior un descenso de 342 que se ausentaron a trabajar en las minas de Plomosas y Copala, por falta de trabajo en el decadente real de Rosario. A. G. I., Indiferente General, 1526.

223 Los padrones de Maloya dan un total de 1.200 a 1.300 habitantes, siendo indios y pardos la casi totalidad de la población. A. G. I., Indiferente General, 102. 
posible hacer las siembras en las laderas de las sierras, pues la tierra era excelente. "Con hachas y machetes quitan los árboles en febrero y marzo, a lo que llaman roza; en fin de mayo queman la leña y zacate'seco, y siembran por julio, haciendo hoyos con un palo o estaca aguzada o con un chuzo y enterrando la semilla; por el agosto arrancan con machetes los yerbajos que han crecido, a lo que llaman traspana, y en diciembre cosechan, siendo de tal bondad las tierras que cuando menos rinden cien fanegas por una de sembradura, y cuando más hasta ciento cuarenta y cuatro". Fuera de esto, "no se cosecha fruto alguno". Tampoco en esta región había más de cuatro a cinco mercaderes de muy corto caudal en Copala, y otros seis, "que no merecen el nombre de tales”, en San Sebastián, de la misma jurisdicción, que se limitaban al trueque de géneros por semillas y ganados que luego vendían en los reales. Y era desgracia, porque todo el real de Copala estaba lleno de vetas ricas, aunque el terreno era muy duro, y la zona era la más poblada ai sur de Sinaloa, con unos ocho mil habitantes. ${ }^{224} \mathrm{La}$ mina de Don Manuel López Portillo, en el rancho de Malpica, abastecía de greta a todas las de la región, hasta Cosalá. ${ }^{225} \mathrm{La}$ situación de Culiacán nunca había sido floreciente. La de Sinaloa se declara abiertamente infeliz, y la jurisdicción del Fuerte, donde tuviera lugar la sublevación de Charay tenía sus escasas minas en decadencia. Otro tanto se decía de la población de Río Chico, cabecera de Ostimuri, y de Baroyeca, en la misma provincia, que tanto había padecido en' los años de la expedición militar. ${ }^{226}$

La extensa jurisdicción de Sonora era, sin duda, la más rica de la provincia, pese a que parte de sus reales y haciendas se hallaban en muchos casos despoblados por motivo de las hostilidades de seris y apaches, y se đividía en dieciocho partidos:

224 La jurisdicción de Copala comprendia los curatos de Copala, Piaxtla y San Sebastián, cuyos padrones dan las siguientes cifras en las fechas que se indican: Copala, 3.018 habitantes (1777); Piaxtla, 2.176 (1777); San Sebastián, 3.394 (I778) y 3.745 (1779). A. G. I. Guadalajara, 255, e Indiferente General, 102. Hay una deseripción de Piaxtla, en 4 de diciembre de 1777, en la B. N., Ms, 2.450 , fols. $46-48$.

225 La jurisdicción de Cosalá, centrada por el fámoso real de las Once Mil Virgenes, sumaba 3.576 personas, según el padrón hecho por el cura don Miguel Antonio Cuevas en I 777 . A. G. I., Indiferente General, 102. Otro padrón de 22 de junio del mismo año y autor da 3.709 habitantes, A. G. I., Indiferente General, I.526.

226 Padrones de Guliacán de 1777 en A. G. I., Guadalajara, 225; de 1778 , en A. G. I. Indiferente General, 102. Descripción de Sinaloa, 1777, en B. N., Paris, Ms. Fond Mexicain, núm. 20r, fols, 29-32. Padrón del curato de San Benito, en Sinaloa, con 2.040 habitantes, en A. G. I., Guadalajara, 255. Censo de la jurisdicción del Fuerte, con 1.852 personas, por el subdelegado José Miguel Serra, en B. N., Ms. 2.449, fols. 318-325; descripción de la misma, fol. 315 . Descripción de Río Chico, $x_{778}$, ibid, fols. 115-122 v., y B. N., París, Ms. Fond Mexicain, núm. 201, fols. 65-66. Descripción de Baroyeca, 4 de enero de 1778 , en el mismo Fond Mexicain, núm. 20I, fols, 57-58. 


$\begin{array}{ll}\text { Horcasitas } & \text { Arizpe } \\ \text { San José de Gracia } & \text { Oposura } \\ \text { Matape } & \text { Batuco } \\ \text { Nacameri } & \text { Cieneguilla } \\ \text { Cucurpe } & \text { Presidio de San Carlos Buenavista } \\ \text { San Marcial } & \text { Id. de Santa Cruz } \\ \text { Santa Ana } & \text { Id. de Altar } \\ \text { San Antonio de la Huerta } & \text { Id. de Tucson } \\ \text { Valle de Sonora } & \text { Id. de San Bernardino }\end{array}$

La agricultura se hallaba, de todos modos, entorpecida por el hecho de que las misiones ocupasen todas o las mejores tierras del país, y el resto perteneciese a pueblos de indios y a alguna hacienda, de suerte que lo único realengo en el término de Arizpe eran las sierras. Los vecinos sembraban algún pedazo de tierra que les prestaban o alquilaban los hijos de los pueblos, y subían a los placeres de Bacuachi cuatro o seis semanas al año "para mal comer y peor vestir". La deficiente estructura económica del país se hace palpable en el padrón de la misma jurisdicción de Arizpe -que comprendía Arizpe, Chinapa, Bacuachi, Bacanuchi y Guepaverachi-, que en I777 daba un total de 1.540 habitantes, de los que 500 eran varones adultos; pues bien, de éstos, 335 carecían de destino u oficio conocido; sólo constan 22 labradores y 50 buscadores de oro, y el resto eran en su mayor parte sirvientes de los funcionarios y casas más acomodadas. ${ }^{227}$ No había otro comercio que el que se traía de México a lomo de mulas y que eran ropas desde el zapato al sombrero. No había manufactura, ni industria en toda la provincia, salvo una hacienda de caña de azúcar que tenía trapiche, precisamente en terreno del ejido de la villa de San Sebastián, hecho que el justicia disimulaba "por el beneficio que resulta al vecindario en el trabajo de la gente ociosa".

Repetidas veces piden los justicias y el clero de Sonora mayor remisión de azogues para activar las minas y que se creen fábricas de algodón y azúcar, pero esto no se llevaría a efecto, y aquello era difícil, no estando asignados a la caja de Alamos más que quinientos cuarenta quintales de azogue para surtimiento de toda la provincia. ${ }^{228}$ En toda la demarcación de las cuatro jurisdicciones meridionales, salvo dos o cuatro sujetos de conocidos caudales, que se proveyeron con mucha abundancia de azogues, los medianos estaban dispuestos a romper sus compromisos, para no perder sus créditos

227 Padrón de Arizpe, 20 de agosto de 1777. R. A. H., Boturini, 18, fol. 193.

228 T. de Croix a Gálvez. Arizpe, 21 de abril de 1783, núm. 9i4. A. G. I., Guadalajara, 284. 
de honrados con los que los aviaban, y los de corta fortuna, si duraba mucho la crisis, probablemente se entregarían al bandolerismo. En Copala y Maloya, en 1783 , sólo tenían azogue las haciendas del marqués de Pánuco y del conde del valle de Suchil. En Rosario, el vecino comerciante Don José Antonio de la Parra había donado al rey cuatro quintales y noventa y dos libras de azogue para contribuir a los gastos de erección de la caja real, y en ella se menudeaba "al infinito número de pobres que lo solicitaban para sostener sus familias y continuar su trabajo".

Por falta de azogue se estabilizaba y amenazaba disminuir a ojos vistas el ritmo de la producción argentífera. La extracción de oro habíase reducido hasta casi desaparecer por efecto de la ruina de los placeres de Cieneguilla, San Antonio y Bacubirito, cuyas subsistencias eran un hecho casual y probablemente de no larga duración. ${ }^{229}$ Cieneguilla no contaba en 1778 más de seiscientos setenta y cinco pobladores, y no debía haber aumentado mucho desde entonces.

Si administrativa y hacendisticamente había progresado Sonora de manera extraordinaria desde la visita de Gálvez, a punto estaba ya de pasar el momento oportuno para darle el impulso económico que necesitaba sin que esto se hubiese hecho de ninguna manera.

Finalmente, las veinte mil ochocientas diez personas que poblaban la porción septentrional de Nuevo México se distribuían en las antiguas ocho alcaldías de Taos, Santa Cruz de la Cañada, Queres, Santa Fe, Sandía, Zuñi, Laguna y Alburquerque. Contaba la villa, sede de la gobernación, con una población total de algo menos de dos mil almas, incluyendo el barrio de Analco, formado por los jenízaros, al decir del Padre Morfi. 230 Al sur quedaba la jurisdicción de El Paso, abandonada ya por el antiguo presidio de este nombre, y mucho más vinculada a Nueva Vizcaya que a Nuevo México. Sus habitantes se evaluaban en más de nueve mil. ${ }^{231} \mathrm{Su}$ comunicación con Sonora era perfectamente posible, pero verificado el viaje de los comerciantes a Sonora, movidos por Anza, no hallaron en esta provincia. los beneficios que esperaban.

Al norte, Anza había promovido el arreglo de las poblaciones de los españoles de modo que las casas se situasen formando plazas cuadradas en forma de reductos, con dos o cuatro baluartes situados en medio de las cortinas. ${ }^{232}$ La atención de la provincia estaba puesta en la subsistencia y en

\footnotetext{
$-1$

229 Los oficiales reales a $T$. de Croix. Rosario, I 9 de febrero de $I 783$. Ibid.

230 "Descripción" por Morfi, R. A. H., Boturini, 25, fols. 89 v.-Io6.

231 "Descripción por un vecino de la jurisdicción. Ibid., fols. I 06 v,-Iog v.

232 "Plano de la provincia interna de Nuevo México", por Miera y Pacheco. Santa Fe, i 779. British Museum, Manuscript room, Additional manuscripts. i $7.65 \mathrm{I}$. U.
} 
las posibilidades de traer a la paz a los enemigos. Sólo años después vendrán las primeras tentativas de dar algún fomento a este alejado rincón del Imperio.

\section{LAS MISIONES FRANCISCANAS}

El último medio siglo de dominación española en Nueva España es el moniento de los reinos franciscanos del norte. Expulsados los jesuitas, de mar a mar los frailes presentan un frente misional uniforme en todas las cinco provincias. Sólo la península de Californias ha pasado a manos de los dominicos, intensificándose en cambio en la California Nueva la acción franciscana.

La impresión general que se obtiene de un análisis de la situación es, sin embargo, la de que el momento misional ha pasado, hablando en otros términos y con mayor exactitud, la de que el fervor misionero y los métodos evangelizadores se han disipado, anquilosado, apagado, tal vez en parte debido a que los sacerdotes son hombres de su tiempo y acusan la pérdida de espiritualidad que ya forma ambiente en un mundo europeizado; tal vez también, a que ha cundido entre llos el desaliento a la vista de las nulas condiciones que para su labor of recían los indios sobre los que debían ejercer su ministerio; o bien, en fin, a que se han habituado al fracaso de no penetrar jamás la intimidad del alma compleja de estos indios que acuden a las ceremonias religiosas y rezan sus oraciones sin entenderlas, que muchas veces, en el mejor de los casos, han sustituido unas prácticas y fórmulas mágicas por otras que consideraban como tales.

No es preciso que recojamos aquí algunos de los textos en que el obispo Tamarón muestra la pobre situación espiritual de los indios de Nuevo México; o de aquellos en los que el padre Morfi, franciscano él mismo, enjuicia la labor de sus hermanos de religión en las provincias orientales. Sólo es de lamentar que hombres de selectísima preparación intelectual y espiritual, que tuvieron el arrojo y la generosidad de ir a hacerse cargo de las misiones de la frontera, no lograran más esplendorosos frutos en su tarea.

Cabe conjeturar y aún afirmar y mantener, sencillamente, que la transformación de la mentalidad gentil y mágica del indio en una mentalidad cristiana era un paso que sólo podía darse al cabo de muchas generaciones, de varios siglos más incluso. En tal caso, lo irremediable era que la marcha de los acontecimientos impedía dar ese plazo necesario para la conclusión del proceso. A1 lado de los indios aún no penetrados de la nueva fe, españoles y mestizos han multiplicado su número y reclaman las tierras que en buena parte permanecen sin explotar en manos de una misión que desde el prin- 
cipio había ocupado los mejores lugares del cultivo por la mera razón de haber sido los misioneros los primeros en llegar a asentarse en aquella región. El caso es que buena parte de los problemas de Teodoro de Croix aluden a la necesidad de llevar a cabo una redistribución de las tierras en determinadas provincias - Texas, Californias, viejos y nuevos reinos misionales que no son precisamente presa de los latifundistas.

Hay otra objeción de matiz más moderno, aunque es contemporánea de estos hechos, a la labor de los evangelizadores: la de que preocupados por la doctrina olvidaron hacer de sus neófitos hombres normales dentro de la misna civilización española. Morfi, Teodoro de Croix y Benilla pensaron así advirtiendo que después de un período que oscilaba entre los cincuenta y los ciento cincuenta años, las misiones seguían sièndo misiones y no se habian convertido en curatos; y considerando igualmente que los indios seguían teniendo los bienes en comunidad y suministrados exclusivamente por el misionero, cuando el ideal civilizador que ellos entendían no concluía sino en la propiedad privada. Los misioneros, no obstante, no estaban obligados a hacer más de lo que sabían y podían, en este sentido. La labor de la misión. por otra parte, quedaba completada dentro de esta misma dirección cuando el indio salía de ella para ir a trabajar a una hacienda o a una mina y allí empezaba a vivir emancipado de la tutela del fraile. $Y$ también debido a esto, por el escaso número de indios que venían ya a tener las misiones, había pasado el momento histórico de esta institución fronteriza. El mestizo, esta es la realidad, había desplazado ya al indio de su papel de grupo básico de la sociedad.

Había en tiempo de Teodoro de Croix siete misiones en Texas y siete en Coahuila; veinticinco en Nueva Vizcaya, veintiocho en Nuevo México y treinta y cinco en Sonora, totalizando ciento dos misiones las cinco provincias.

Las misiones de las provincias orientales eran:

\section{Texas}

San Antonio Valero

Purísima Concepción de Acuña

San José Aguayo

San Juan Capistrano

San Francisco de la Espada

Espirítu Santo

Nuestra Señora del Rosario

\section{Coahuila}

Aguayo

Candela

Nadadores

San Bernardo

San Juan Bautista

Vizarrón

Peyotes

Unas y otras estaban bien dotadas y recogían abundantes cosechas, con la diferencia de que en las de Texas los ministros aplicaban todas las ganancias 
al culto, merced a lo cual las iglesias estaban muy arregladas y alhajadas, mientras que en las coahuilenses, por descuido de los misioneros o por otro motivo, las raciones que recibían los neófitos eran más escasas, el vestuario más infeliz, los bienes de campo más cortos, y los indios poquísimos. Las casas de los frailes y las iglesias estaban también en peor estado.

Teodoro de Croix proponía formar con las misiones del Espíritu Santo y Rosario un solo pueblo unido al presidio de la Bahía; agregar Valero y Acuña a la villa de Béjar, y formar otra población con las dos de Capistrano y Espada, dejando como misión sólo la de Aguayo, "la más preciosa y rica de todas, y que-aún se halla mejor situada, amurallada y defendida que cualquiera de los presidios de la frontera". En Coahuila, el comandante general fundiría las dos misiones del río Grande con el vecino presidio, y las de Peyotes y Vizarrón con la villa de Gigedo. Lo mejor sería convertirlas todas en curatos.

Tenían las misiones de Texas los franciscanos del colegio apostólico de Zacatecas, y las de Coahuila los de la provincia observante de Jalisco. Estos últimos atendían las nueve antiguas misiones de fundación franciscana en Nueva Vizcaya, mientras que los apostólicos ocupaban aquella parte de las jesuíticas que no habían sido secularizadas después de la expulsión. En este inismo orden, la relación de las misiones de Nueva Vizcaya ${ }^{233}$ es como sigue:

$\begin{array}{ll}\text { Atotonilco } & \text { Moris } \\ \text { Babonoyaba } & \text { Navogame } \\ \text { Conchos o Tapacolmes } & \text { Baborigame } \\ \text { Julimes } & \text { Guazapares } \\ \text { San Jerónimo } & \text { T'utuaca } \\ \text { Nombre de Dios (S. Cristóbal) } & \text { Tomichic } \\ \text { Santa Isabel } & \text { Guanachic } \\ \text { San Andrés } & \text { Nanarachi y Boquerachi } \\ \text { Bachimba } & \text { Noragachi } \\ \text { Cerocahui } & \text { Tomochi } \\ \text { Chinipas } & \text { San Miguel y San Andrés } \\ \text { Santa Ana y Loreto } & \text { Tubaris } \\ \text { Batopilas y Babaroco } & \end{array}$

Los observantes percibían sínodos muy exiguos, por lo que se veían precisados a cultivar alguna tierra de los indios, quienes se hallaban cada vez más

233 Misiones secularizadas en Tarahumara: San Borja, Nonoava, Carichic, Cusihuiriáchic, Tomochi, Matichiqui, Santo Tómás, Papigochi, Temosachiqui, Coraichicuii. 
constreñidos en sus pueblos, o bien salían de ellos en virtud de los "mandamientos" para ir a trabajar a las haciendas y minas. El arreglo de estas misiones, a juicio de Teodoro de Croix, exigiría una visita previa del obispo de Durango.

Los religiosos de la provincia del Santo Evangelio tenían a su cargo las veintiocho misiones de Nuevo México:

Santa Fe

Tuzuqui

Nambé

Santa Cruz de la Cañada

Santa Clara

San Ildefonso

San Juan

Pecuries

Taos

Pecos

Galisteo

Suchiti

Santo Domingo

San Felipe
Santa Ana

Gemes

Cía

Sandía

Alburquerque

Isleta

Laguna

Acoma

Abiquiú

Guadalupe del Paso

San Lorenzo el Real

Senecú

Corpus Christi

Socorro

Teodoro de Croix dispuso que a estos misioneros y a los de Nueva Vizcaya se abonasen sus sínodos en Chihuahua, y pidió que a los de Coahuila y Texas se los entregasen en Monclova, y no en México, siéndole aprobada aquella medida. 234

De las treinta y cinco misiones de Sonora decía haber advertido en ellas un desorden mayor aún que en Coahuila, Texas y Nueva Vizcaya, z35 pero poco después renunciaban a ellas y a las de Coahuila los religiosos de Jalisco que las servían. En Coahuila dio entrada Teodoro de Croix a los religiosos apostólicos del colegio de Pachuca, que habían solicitado intervenir en aquel campo misional. En cuanto a las de Sonora, hallóse el comandante general con la real cédula de $\mathrm{I}_{4}$ de junio de 1780 para erección de tres custodias en Arizpe, California y Chihuahua y arreglo de la de Nuevo México quedando estas dos a cargo del obispo de Durango, y las primeras al del nuevo prelado de Sonora. Observa el caballero de Croix la imposibi-

\footnotetext{
234 T. de Croix a Gálvez. Chihtrahua, 23 de septiembre de 1778 , núm. 282, Real orden de 13 de abril de I779. A. G. I., Guadalajara, 270.

235 T. de Croix a Gálvez. Arizpe, 23 de abril de 1780 , núm, 5 II. Corbalán a Gálvez. Arizpe, 26 de febrero de $178 \mathrm{I}$, núm. 22. A. G. I., Guadalajara, 277.
} 
lidad de gobernar las misiones de las provincias orientales desde Chihuahua, y aun la de atender las de El Paso desde Santa Fe. ${ }^{236}$

En los primeros meses de 1783 , la llegada a Sonora de su primer obispo Fray Antonio de los Reyes podía significar la reforma y reorganización de las misiones, ${ }^{237}$ pero Teodoro de Croix, llamado inmediatamente al virreinato del Perú, no vería ya este proceso.

236 T. de Croix a Gálvez. Arizpe, I. de julio de I781, núm. 653. A. G. I., Guadalajara. 281, bis. 237 T. de Croix a Ventura Taranco. Arizpe, 24 de marzo de 1783, s. n. El obispo de Sonora a Ventura Taranco. Culiacán, 24 de abril de I783. A. G. I., Guadalajara, 346. 
ans -

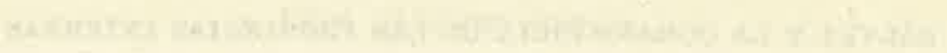

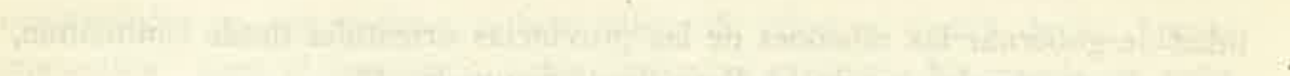

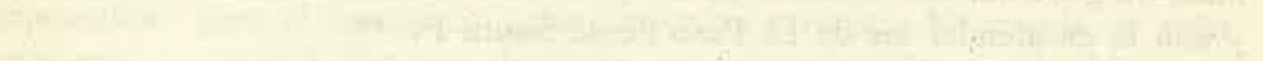

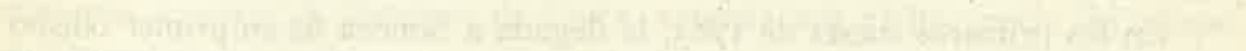

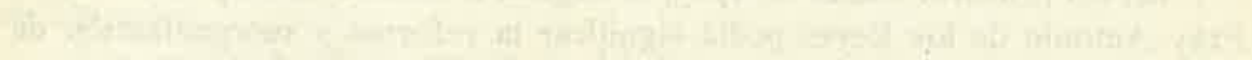

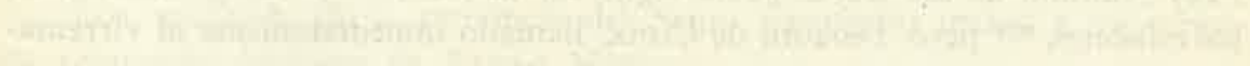

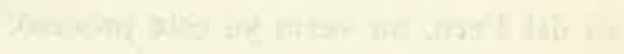




\section{CAPITULO SEPTIMO}

\section{EL FIN DEL SIGLO XVIII}

\section{UN NUEVO MOMENTO HISTÓRICO}

El de Teodoro de Croix es, sin duda, el gran momento político de las provincias internas. No es el momento de los éxitos, pero sí es el de los proyectos, el de los intentos ambiciosos y de los mayores esfuerzos para concretar una realidad nueva en el amplio escenario natural del Atlántico al Pacífico. La realidad sobre la que era preciso actuar - no tan favorable como se hubiera deseado-, y algunas vacilaciones iniciales impidieron que la gestión del primer comandante general resultase más fecunda. Después, cuando Teodoro de Croix dejó la comandancia en manos de su sucesor, ya la gran empresa de Gálvez había quedado definitivamente frenada en sus objetivos primordiales. La incapacidad para someter nuevamente el Moqui, después del levantamiento de Nuevo México, la catástrofe de San Sabá y la rebelión yuma habían marcado sucesivamente el tope a la expansión española en el continente norteamericano, lo cual no le había impedido seguir creciendo, aunque con poca consistencia, por nuevos rumbos.

Ahora, los veinte años que transcurren de $I 783$ a 1802 representan un nuevo momento histórico. Nada pudiera significar por sí sola la desaparición de la figura del caballero de Croix del mando de las provincias internas. Pero de hecho, a partir de ese momento la realidad de la frontera se transforma dando paso, por mil caminos diversos, a una situación distinta que es la que en los primeros años del siglo XIX va a configurar la última etapa de la presencia de España en la frontera india de América del Norte.

El proceso histórico que tiene lugar en esos veinte años encuentra un punto de inflexión muy significativo exactamente en la mitad de su recorrido, 
en r793, de suerte que puede decirse que los acontecimientos ocurridos en la década anterior a esta fecha están presididos por un signo contrario al que marca la etapa posterior. Esa década inicial a la que damos el nombre de "Los Interregnos" es una época de confusión motivada por los principios políticos puestos en contradicción por los ministros cambiantes, por la rápida sucesión de autoridades en la comandancia y en el virreinato de México, por los interinatos precipitados, por la clisolución de las ideas de unidad e independencia del mando supremo de las provincias internas.

En el segundo período de diez años, el gobierno de Nava restablece una seguridad y una continuidad que permiten replantear, sobre nuevos moldes, los objetivos concretos de la comandancia. Las tareas iniciadas por Teodoro de Croix llegan a su fin y son auténticos logros para la felicidad de las provincias. Sin embargo, las grandes realizaciones necesarias para poder obtener la verdadera autonomía de la comandancia no se llevan a la práctica por una serie de entorpecimientos consecutivos y, como resultado, esta entidad administrativa y política cuya solidez era indispensable para que pudiese cumplir su misión de defensa del virreinato de cualquier peligro que amenazase por el norte se verá arrastrada a una serie de vicisitudes de las que, en otras circuntancias, hubiese podido permanecer al margen.

\section{LOS INTERREGNOS}

Damos este nombre al período qute corre entre 1783 , año del traslado del caballero de Croix al virreinato peruano, y I793, en que Don Pedro de Nava asume la comandancia general unificada abriendo una etapa de estabilidad en su gobierno.

En la década intermedia que abarca la primera parte de este capítulo atraviesa la comandancia una profunda crisis que ya no va a ser plenamente superada en los años restantes hasta el fin del señorío español sobre aquellos países. Crisis, por cierto, en cuanto a su entidad política y a la continuidad de su gobierno, crisis institucional, pues este carácter tienen los problemas que ahora se debaten, ya que aquellos otros que planteaba la existencia cotidiana en las provincias van entrando poco a poco en una fase de amortiguamiento de tal manera que, sin que se les haya dado definitiva soloción, van perdiendo la gravedad que en otro tiempo hiciera temer la próxima ruina de los establecimientos más setentrionales del imperio español en América.

La razón de aquella crisis puede encontrarse tanto en la poca firmeza con que quedara establecida la comandancia - siendo esto consecuencia de su relativa inadecuación a los probleemas que debía solventar- como en la 
atrsencia de un ideal duradero de gobierno, o de un gobernante que se mantuviese en el cargo por un prolongado período de tiempo. Esto fue lo que la comandancia halló, por fin, en I793 en la persona de Don Pedro de Nava.

La discontinuidad en el gobierno tiene múltiples causas. Desde 1783 se suceden en el mando de la comandancia Don Felipe Neve, Don José Antonio Riengel y Don Jacobo de Ugarte y Loyola, Don Juan de Ugalde y Don R'amón de Castro.

La unidad y la independencia de la comandancia entran también en juego. Habiendo quedado la comandancia en $\mathrm{I} 784$ subordinada al virreinato, era dividida por la instrucción de 26 de agosto de 1786 , en tres, comprendiendo la primera las dos provincias orientales, más Nuevo León y Nuevo Santander, con Ugalde; la segunda, Nueva Vizcaya y Nuevo México, con Rengel; y la tercera Sonora y las Californias Alta y Baja, bajo el mando de Ugarte.

En 3 de diciembre de $17^{8} 7$, sólo quince meses después, se procedía a nueva organización, de manera que, sin perder las provincias internas su dependencia de México fuesen repartidas en dos comandancias: la de oriente, con Ugalde, abarcaba las cuatro provincias orientales más los dos distritos de Parras y Saltillo que le habían sido agregados en 27 de julio de 1787 . La de Oriente, con Ugarte, comprendería Sonora y las dos Californias, Nueva Vizcaya y Nuevo México.

En 24. de noviembre de $\mathbf{I} 792$, por último, se decidió de nuevo la independencia y unidad de la comandancia, trasladándose su capital a Chihuahua. Pero se segregaron de su jurisdicción las Californias, Nuevo León y Nuevo Santander. ${ }^{\mathrm{I}}$

En el mismo lapso de tiempo, siendo las provincias internas dependientes del virreinato y en constante proceso de reorganización, intercálanse en aquél los interinatos de la audiencia con los cortos mandatos de Matías de Gálvez (I783-I785), Bernardo de Gálvez (I785-1786), Nuñez de Haro (I787) y Flores (I787-I789), hasta que el segundo Revillagigedo inaugura una etapa de relativa continuidad.

\section{Don Felipe de Neve}

Desde julio de $\mathrm{I}_{7} 83$ firma Neve las cartas al ministerio que aún llevan

I Esta sucesión de fechas es casi lo único y más sustancioso hasta ahora conociclo de la historia de la comandancia general después de su real cédula de erección. Vid. Alessio Robles, Coahuila y Texas, 594 ; del mismo, La's provincias internas del norte de México hasta 1846 , "Memoria del primer congreso de historiadores de México y los Estados Unidos en Monterrey, 1949", págs. 137-I51. México, I950. O'Gorman, Edmundo: Cuadro histórico de las divisiones territoriales de México. México, 1948. 
la numeración correspondiente a los pliegos de Croix: 938 a 944. Su nombramiento de comandante general de las provincias internas le había sido conferido en real cédula de I 5 de febrero de aquel año, al tiempo que se le ascendía al grado de brigadier de los reales ejércitos. A Neve se le entregaba la comandancia, por el tiempo de la real voluntad, con las mismas facultades quie tuviera su antecesor. Neve prestó el juramento prescrito en manos de Croix y en presencia del intendente Corbalán y personas de carácter de Arizpe, en esta población, el 12 de agosto de 1783 , quedando desde entonces en posesión del mando. ${ }^{2}$ Seis días después partía Teodoro de Croix para México. 3

Neve llegaba a la comandancia general con una dilatada experiencia en los asuntos de las provincias internas, en algunos de cuyos cargos más destacados había pasado nueve años, siendo gobernador de Californias y comandante inspector de los presidios, puestos que había desempeñado con tal rectitud y capacidad como para granjearse la absoluta confianza de Croix. Su desenvolvimiento como comandante general pudo haber sido definitivo para felicidad de las provincias, de no haber muerto al cumplirse el año de su elevación a aquel cargo, el 2 I de agosto de i 784.

Don Felipe de Neve fue el único sucesor del Caballero de Croix que murió en el empleo de comandante general y gobernador de las provincias internas. También es el único cuya figura nos ha sido al menos fragmentariamente esbozada, lo que se debe a la curiosidad de los investigadores de la historia de Californias, entre cuyos gobernantes españoles Neve hizo un lucido papel, destacando por la sobriedad y firmeza de su autoritaria actuacción y por la eficiencia de su labor civilizadora.

Neve es uno de los escasos andaluces que sobresalen en el norte de México en toda la época hispánica. Nacido en I724 en Bailén, en el corregimiento de Jaén, localidad que no había aún gozado la fama que probó después de las guerras napoleónicas, se dice en su hoja de servicios "de calidad conocida", lo cual es cierto si se tiene en cuenta que la familia Neve era entonces una de las más brillantes y bien emparentadas de Sevilla. En i 780 , cuando Neve firma la hoja que acabamos de aludir, 4 está a punto de contar treinta y siete años de servicios al rey y es gobernador de Californias. Veamos su trayectoria anterior.

2 Real cédula y real orden de I5 de febrero de 1783 . Neve a Gálvez. Arizpe, 25 de agosto de 1783 , núm. I. A. G. I., Guadalajara, 268 . En carta num. I reservada al ministro, de igual
data, Ibid, le agradece su protección a la que atribuye el nombramiento.

3 Neve a Gálvez. Arizpe, 25 de agosto de 1783 , núm. 2. A. G. I., Guadalajara, 268.

4 3 1 de diciembre de 1780 . A. G. I., Guadalajara, 281 B. También puede verse el me-
morial y relación de servicios presentado por Neve en I770. A. G. I., México 2430 . 
A los veinte años, el 13 de marzo de 1744 , había sentado plaza de cadete en el regimiento de infantería de Cantabria, para pasar luego a la primera compañía de guardias de corps, y más tarde al regimiento de caballería de Flandes. Aquí lo encontramos ya con grado de teniente desde 1749. Más adelante figura en los regimientos de Milán y del Rey, habiendo obtenido en 1756 ascenso al empleo de ayudante y realizado toda la campaña de Portugal a las órdenes del marqués de Rubi, del mariscal conde de Egmont y del conde de Ricla: así estuvo presente al sitio de Almeida, expedición de La Guardia y Castel Blanco, destacamentos de Mogadorio y Celorico, retirada de Tras Os Montes y entrada de Lanterio.

Después de este fogueo en las guerras europeas, pasará a América y será destinado por Villalba, como segundo del propio Rubí, a la formación del regimiento de caballería provincial de Querétaro, en cuyos cuadros de mando, figura como sargento mayor. Si la recluta de esta tropa y del segundo regimiento de caballería de Michoacán tuvo parte en el descontento popular que se manifestó en las turbaciones de Querétaro y Valladolid antes y después de la expulsión de los jesuitas, Neve intervino además directamente en la ocupación de los colegios que la Compañía había tenido en Zacatecas, y durante siete años quedó como administrador de ellos: su actuación debió ser eficaz cuando pudo afirmar que había logrado un incremento de más de veintiun mil pesos anuales en la renta de aquellas propiedades. De aquí pasaría a Californias, como gobernador, habiendo ascendido al grado de coronel en I6 de octubre de I774.

Fue Bucareli quien en diciembre de I774 le designó provisionalmente para suceder a Barri en el gobierno de las Californias, puesto difícil del que Barri había pedido reiteradamente el relevo, hastiado de las inacabables disputas que se veía obligado a sostener con los misioneros. El virrey se prometía de la madurez y prudencia de Neve la liquidación de estas diferencias: desgraciadamente, no ocurrió así, pues la pugna entre los representantes del rey y los dominicos o franciscanos había de ser la nota dominante del período final de las Californias españolas. Asentado Neve en Loreto, pronto hizo patente su línea de pensamiento, que le llevaba a procurar que los indios se hiciesen independientes del gobierno temporal de los Padres, autónomos en su comportamiento y subsistencia, cobedientes tan solo a las directrices de la autoridad civil. Desde Loreto envió al alférez Don José Velazquez en busca del Colorado, por tierra, lo que Velázquez logró, así como pasar luego al camino real de la costa, al que salió entre las misiones de San Diego y Monterrey.

Después pasó Neve a este último lugar, con objeto de impulsar la ex- 
pansión de las misiones y nuevos establecimientos de la Alta California, donde el 29 de noviembre de I777, con quince familias sacadas de Monterrey y San Francisco, que hacían un total de sesenta y seis personas, fundaba el pueblo de San José de Guadalupe. De este hecho, primera aplicación práctica de su manera de entender el fomento de la provincia, puede decirse que dimana toda su posterior polémica con los franciscanos, cuyo cronista le hace aparecer como un descreído irreconciliable enemigo de la religión y de los religiosos. Ya en agosto de 1778 se queja Neve de que los misioneros ponen dificultades al progreso de las fundaciones. Naturalmente, la creación de pueblos de españoles, negros y gente de otras castas fortalecía el poder civil del gobernador frente al ideal de territorio exclusivamente de misión que sostenían los franciscanos. En el calor de estas disensiones, Neve obligó al famoso Padre $F_{1}$. Junípero Serra a presentar su patente para administrar el sacramento de la confirmación ante el vicepatrono Caballero de Croix, que otorgó la oportuna ratificación. Desde Loreto tenía pedido Don Felipe el relevo, en $\mathbf{7 7} 6$, en solicitud reforzada desde Sevilla por su mujer, y a la que Bucareli tenía por justo acceder, pero diciendo de Neve que era "un oficial completo", de excelente conducta y hombría de bien, estaba indirectamente consolidando la permanencia del futuro comandante inspector en $\mathrm{Ca}$ lifornias.

Así dio lugar a Don Felipe para redactar en $I .^{\circ}$ de junio de 1779 el nuevo reglamento para el fomento de la provincia. El 4 de septiembre de $I$ 7 8 dejó su nombre vinculado a la fundación del pueblo de la Reina de los Angeles en el río de la Porciúncula, y en I 782 erigía la misión de San Buenaventura y el presidio de Santa Bárbara. En enero de 1778 se le había ascendido a coronel; 5 en 1780 , Don Teodoro de Croix, en carta autógrafa, lo proponía para que se le galardonase con una cruz de la Orden de Carlos III, 6 $y$ al año siguiente, informando su hoja de servicios, ponderaba los talentos, méritos, capacidad y desinterés del gobernador de Californias. 7 Por aquella época libró Neve dos mil pesos sobre el comerciante de México Don Joaquín Dongo como donativo al rey para atender a los gastos de la guerra con los ingleses, acción que mereció el agradecimiento de Carlos III. 8

De octubre a diciembre de $x 78 \mathrm{r}$ dirigió Neve las operaciones punitivas contra los yumas alzados, teniendo bajo su mando a Fajes, Tueros, Romeu y el alférez Limón, con tropas de Californias y Sonora. Nombrado ya comandante inspector a propuesta de Croix, todavía actuó en la campaña del

5 Real orden de 5 de enero de 1778 , a Bucateli. A. G. I., México 2462.

7 A. G. I., Guadalajara, $28 \mathrm{I}$ B.

8 T. de Croix a Gálvez. Arizpe, 26 de enero de 7782 , núm. 7I5. A. G. I., Guadalajara, 268. 
Colorado de 1782 , después de la cual se renunció a ocupar permanentemente aquel territorio. El 4 de septiembre firmó en el Saucillo la instrucción que dejaba a Fajes su sucesor en el gobierno de Californias, y el 25 de octubre escribía ya desde Altar al ministro Don José de Gálvez agradeciéndole su promoción al nuevo empleo. 9 Desde allí mismo comenzó a ejercer las funciones que a este cargo correspondían, revistando los presidios de Sonora, y aún no había pasado los límites de la provincia, cuando le sorprendió la real provisión de 15 de febrero de $I_{7} 83$ que lo designaba comandante general de todas las internas.

\section{EIL MANDO MILITAR DE LAS PROVINCIAS}

El panorama que Neve afronta al ocupar la comandancia general es bien distinto del que tan a duras penas se decidiera Croix a encarar seis años atrás. Esto mismo demuestra que el paso del Caballero por la frontera no fue infructífero, antes al contrario, es curioso que fuese el mismo Neve, obrando al parecer espontáneamente y en una acción que no tiene muchos paralelos en la historia, quien se encargase de hacer la exposición encomiástica de la labor ejecutada por su predecesor, ${ }^{\text {xo }}$ y proponga igualmente se le remunere lo gastado en edificar la residencia de los comandantes generales. ${ }^{\text {I }}$ A sus órdenes, sustituyéndolo en el puesto de comandante inspector de los presidios, viene a ponerse Don José Antonio Rengel.

Debido a la brevedad de su mandato, la actuación de Neve se restringe de manera perceptible a las provincias de Sonora y Nueva Vizcaya; Coahuila y Texas, por aquellas fechas, han dejado de plantear problemas. Los mezcaleros han casi desaparecido del mapa después de las últimas campañas, y si bien los lipanes cometen multitud de fechorías, no pocas veces de suma gravedad, su remedio ya no estará en la mano de Neve, que sólo tendrá oportunidad de noticiarlas. Otro tanto hace respecto de los acontecimientos de Nuevo México y las Californias. En Sonora y Nueva Vizcaya, en cambio, los seris, los apaches gileños y los tarahumaras sediciosos van a atraer sobre sí toda la atención del comandante general, constituyendo los puntos fundamentales de su gobierno. En orden a la consolidación y estructuración de la comandancia son hechos de interés durante su mandato el establecimiento de la sede episcopal de Sonora en Arizpe, adonde llegó el primer obispo Don

9 La instrucción a Fajes, en A. G. I., Guadalajara, 283. La carta a Gálvez, A. G. I., Guadalajara, 267 . I783, núm. 2, reservada. A. G. I., Guadalajara, 520.
I I Neve a Gálvez. Arizpe, 22 de setiembre de 783 , nún. 26. A. G. I., Guadalajara, 269.

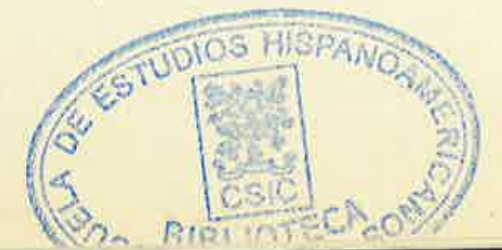


Fray Antonio de los Reyes el 22 de septiembre de $1783 ;{ }^{\text {I2 }}$ la formación de las dos compañías volantes que debían proteger las jurisdicciones de Saltillo y Parras, que, por negarse a levantarlas Ugalde, reclutaron Don Luis Cazorla la de Saltillo en $1 .^{\circ}$ de agosto de $\mathrm{I} 783$, y Don Pedro Tueros la de Parras en $I^{\circ}$ de febrero de I784, quedando con ello cerrado el paso a los apaches en el fondo del Bolsón; ${ }^{13}$ y en tercer lugar, la definitiva resolución acerca del engorroso problema de la administración económica de los presidios, mediante la decisión adoptada por Neve, de conformidad con las últimas experiencias de Croix, de formalizar contratas con los comerciantes que quisieran encargarse de la habilitación de las tropas. Desde $I .^{\circ}$ de enero de 1782 funcionaba este sistema para el aprovisionamiento de San Eleazario por tres años, según acuerdo firmado con Don Manuel de Urquidi, de Chihutahıia. Ahora Neve lo hizo extensivo a todos los demás presidios de la Línea en contratos valederos por tres años, a partir de primero de enero de 1784 , para los de Nueva Vizcaya, y Santa Fe de Nuevo México y cuatro compañías volantes; por cuatro, para los de Sonora. No menos de diez comerciantes tomaron a su cargo el abastecimiento de las tropas, y aún quedaban por atender los dos presidios de ópatas de Sonora y los dos de Texas, éstos por muerte del comerciante que se iba a ocupar de ellos.

Los contratistas eran:

\section{Nueva Vizcaya}

Don Manuel de Urquidi, de Chihuahua, para San Eleazario y Santa Fe.

Don Francisco Javier del Campo, para San Carlos, Príncipe y Norte.

Don Francisco Martínez Pereira, para San Buenaventura y Janos.

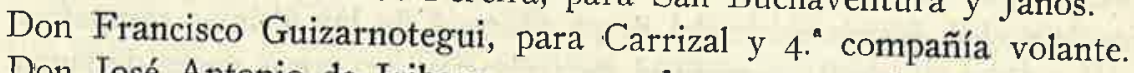

Don José Antonio de Iribarren, para $2 .^{*}$ compañía volante.

Don Joaquín de Amezqueta, de Parral, I." y $3 .^{*}$ compañías volantes.

Coahuila

Don Juan Francisco Yermo, de Río Grande, para Monclova, Río Grande, Aguaverde y Babia.

Sonora

Don Esteban Gach, de Arizpe, para Santa Cruz, Tucsón, Pitic y Altar. Don José Antonio Pérez Serrano, para Fronteras.

I Neve a Gálvez. Arizpe, 22 de setiembre de I78.3, núlnı. 27. A. G. I., Guadalajara, 267.

I 3 Neve a Gálvez. Arizpe, 3 de mayo de I784, núm. ro9. A. G. I., Guadalajara, 5 I 9. 
Don Manuel Romualdo Díez Benítez, para Buenavista y pimas de San Ignacio.

Si bien el sistema es discutible, algunas de sus ventajas son patentes: se hacían cargo de los intereses de las trcipas personas aptas para este negocio y los oficiales habilitados quedaban desde ahora libres para dedicarse a su principal misión bélica. ${ }^{\text {I4 }}$

\section{EL Último LeVANTAMiento DE LOS SERIS}

Si había sido Sonora la provincia que más preocupaciones suscitara a Croix, que había volcado en ella, indudablemente, buena parte de su atención, no lo había de ser menos para Neve, fiel continuador en todo del inatgurador de la comandancia. Tal vez la primera de sus realizaciones en la línea de gobierno de Croix fue la creación de una nueva compañịa de indios ópatas con sede en Bacuachi, según el proyecto de Corbalán, de tal manera que si la de Bavispe había de coordinar las acciones de Janos y Fronteras, la de Bacuachi enlazaría perfectamente Fronteras con Santa Cruz. Neve tenía decidida la erección de esta nueva compañía india desde agosto de 1783 . El presidio quedó constituído el $\mathrm{I} .^{\circ}$ de abril de 1784 y su primera actuación tendría lugar en la campaña del Gila, que se abrió dos semanas más tarde. Formaban la compañía noventa hombres, cuyo sostenimiento costaba catorce mil pesos: cada uno de los ochenta y cinco soldados ópatas cobraría 136 ps. 7 rs. al año, y no tendría uniforme, bastando un distintivo rojo en el sombrero; ni montura, poseyendo sólo aquellas cabalgaduras que se tomasen al enemigo y cuyos legítimos dueños no pareciesen; arco, flecha, lanza, machete y adarga serían sus armas, y podrían tener escopeta y pistola los que supiesen manejarlas. Tenía esta compañía, como las de Bavispe y San Ignacio, un teniente veterano, que lo fue Don José Varela; alférez, Don Eduardo Barri, hijo del ya difunto gobernador de Nueva Vizcaya, y dos sargentos, también veteranos, más un capitán ópata, con 400 pesos. ${ }^{15}$

A fines de 1783 , la doble frontera sonorense empieza a experimentar creciente tensión. Cuatro destacamentos de pimas de San Ignacio y presidiales de Tucson, Fronteras, Altar y Santa Cruz, operan con escaso intervalo, entre diciembre y enero, contra los apaches. Pero al mismo tiempo los seris alzados se ven objeto de una constante persecución por parte de los dragones y presidiales acuartelados en Pitic, mandados por el capitán del regimiento

14 Neve a Gálvez. Arizpe, 20 de octubre de I783, núm, 33. A. G. I., Guadalajara, 518.

I5 Neve a Gálvez. Arizpe, 5 de abril de 1784 , núm. IoI, con Instrucción formada para el gobierno de la compañía opata de Bacuachi. A. G. I., Guadalajara, 519. Aprobación en real orde 1 de 20 de octubre de 1784 y reales despachos de 2 de noviembre de 1784 . Ibid. 
de España Don José Sáenz Rico y el teniente del presidio Don Ignacio Urrea, logrando aquél varios prisioneros en el Malpaís de la Nochebuena y hacer algunas bajas a los seris en el Cerro Colorado. Neve, sin embargo, aún se propone actuar más reciamente frente a ambos enemigos. ${ }^{16}$

Haciéndose cargo de las reales órdenes de 23 de mayo de 1780 y 2 y 6 de marzo de 1782 , que disponían se atacase vigorosamente a los seris y tiburones para escarmiento de los daños cometidos, reunió Neve el 2 de diciembre de 1783 en junta de guerra a Corbalán y Galindo resolviendo que, "siendo el principal obstáculo para el logro de los deseos de S. M. la permanencia en Pitic de los seris allí congregados y mantenidos por la real hacienda, sería conveniente conducirlos bien asegurados a México, para que el virrey los destinase a parte en que no pudiesen volver más a su tierra", oponiéndose a la idea de trasladar las mujeres y niños seris a Californias "porque la vil sangre de esta gente no contamine con el tiempo la fidelidad de aquellos
naturales". I7

Dos meses después, el 26 de enero de 1784 se acordaron varios preparativos para la expedición que debería hacerse contra los alzados, con tropa de infantería: fusileros, dragones de España, ópatas de Bavispe y Bacuachi. Fusileros y dragones permanecerían en Sonora el tiempo necesario para llevar a cabo la proyectada entrada contra los seris, pues ya se había dispuesto st1 regreso al virreinato.

Entre tanto, tropas de Altar, del presidio de pimas de San Ignacio, y de los dragones de España hacían incursiones en el territorio seri. El i6 de febrero, por fin, fue posible apresar al cabecilla Valentín, que con diecisiete de su nación se había presentado en Pitic con ánimo de liberar a los seris cautivos. ${ }^{18}$ Pero un mes después cundió la sorpresa cuando en la noche del ig al 20 de marzo todos los seris del Pitic abandonaron el pueblo, quizá con motivo de aquellas detenciones y de algunos castigos recientemente ejecu-

No confiándose en el éxito de las ofertas de perdón que en seguida se hicieron, dispuso Neve el inmediato traslado a Buenavista y Pitic de la compañía de voluntarios de Cataluña que se hallaba en Fronteras para actuar contra los apaches. Pero aun con este refuerzo, las primeras acciones enca-

I 6 Neve a Gálvez. Arizpe, 26 de enero de 1784 , núm, 77 , y 8 de marzo de 1774 , núm. 2 ก
con Extractos A. G. I., Guadalajara, 5I9.

17. Neve a Gálvez. Arizpe, 8 de marzo de 1784, núm. 4, reservada. Ibid.

I8 Neve a Gálvez. Arizpe, 8 de marzo 'de 1784, 11úm. 90, con Extracto. Ibid.

I9 Neve a Gálvez. Arizpe, 5 de abril de 1784 , núm. 98 , con Extracto. Ibid. 
minadas a sujetar de nuevo a los seris no hallaron al enemigo, aunque tampoco consta que éste ejecutara daño alguno. ${ }^{20}$

La campaña que se pensaba efectuar en octubre quedó suspensa al ocurrir la muerie de Neve, ${ }^{21}$ y ya nunca se realizó. La rebelión de los seris no produjo esta vez consecuenecias sensibles; la guerra, nunca tomada con mucho empeño, languideció a los pocos meses y los seris se fueron presentando de paz poco a poco a partir de octubre de 1785 , hasta que de hecho la situación se normalizó. ${ }^{22}$ El verdadero resultado de este alzamiento fue evitar que se llevase a cabo la meditada deportación de los seris.

\section{La cAmpaña del Gila}

Recogió Neve laureles que realmente hubieran debido corresponder a Croix. Gracias a la labor de éste en la frontera de Sonora, fue posible a aquél organizar y ejecutar cumplidamente la primera campaña decidida llevada a cabo contra la apachería de occidente. Coincidiendo con el fortalecimiento de la línea defensiva que impulsaba Croix, había venido experimentándose un incremento de la potencia de los apaches en aquel sector. El r. ${ }^{\circ}$ de mayo de 1782 había podido ya protagonizar el capitán Don Pedro de Allande la defensa del presidio de Tucsón con sólo veinte soldados durante dos horas contra una horda de quinientos apaches. ${ }^{23}$ Este es un acontecimiento significativo, si hemos tenido en cuenta el rápido desarrollo de las defensas de Sonora, prolongándose constantemente hacia el oeste, desde el momento en que se fundara el presidio de Fronteras. Tucsón era el más occidental de estos presidios --Altar había quedado fuera y al sur de la Línea, dirigido a la sujeción de los seris y no a la contención de los bárbaros del norte, aunque éstos se habían presentado alguna rez ante sur recinto - y la presencia en st1 comarca de una fuerza apache de la entidad apuntada arriba es un excelente indice de la rapidez y dirección del desplazamiento de esta nación siguiendo, en su fuga ante el avance conanche, la línea de menor resistencia. Detenida; al fin y al cabo, por los españoles la intentada penetración al sur ante Janos y Fronteras, las cuadrillas apaches fueron poco a poco corriéndose hacia el

20 Neve a Gálvez. Arizpe, 3 de mayo de 1784 , nứn. I 3 , con Extracto. Ibid. Neve a Gálvez. Arizpe, 3I de mayo y 6 de julio de 1784 , núms. II y i22, con Extractos. A. G. I., Guadalajara, 520 .

2 I Rengel a Gálvez. Chihuahura, 26 de febreto de 1785, núm. I, reservada. A. G. I., Guadalajara, 520 .

22 Rengel a Sonora. Chihuahua, 2 de marzo de 1786 , núm. 142, con Extracto. A. G. I. Guadalajara, 521. Entre octubre de 1785 y enero de 1786 se habian presentado sesenta seris. En agosto, setiembre y octubre de este año se presentaron veinticinco más. Ugarte a Sonora. Chihuahua, 30 de noviembre de 1786 , núm. 40 , con Extracto. A. G. I., Guadalajara, 521.

23 Neve a Gálvez. Arizpe, 26 de enero de 1784 , núm. 76. A. G. I., Guadalajara, 516. 
oeste. Santa Cruz de Terrenate padeció últimamente sus asaltos desde la sierra de Chiricahui. Tucsón no había de tardar en ser igualmente alcanzado, y en efecto lo era ya en I 782 . La presión es, desde este momento, constante a lo largo de toda la frontera sonorense. A fines de 1783 , según hemos dicho ya, se expediciona sin descanso y en gruesas partidas desde los presidios para alejar esta amenaza. Entre los combatientes españoles se cuenta un civil vizcaíno, Don Domingo Vergara, natural de Eibar, y armero principal de los presidios de Sonora, que voluntariamente ejecutó este año dos campañas con indios y vecinos, y con soldados facilitados por Neve, y obtuvo algunos éxitos contra los apaches, gastando en tales empresas más de tres mil pesos, lo que movió al comandante general a solicitar para este voluntario el grado de alférez de caballería, que le fue concedido. ${ }^{24}$ El 5 de enero de 1784 conseguirá Allande hacer al enemigo, junto al Gila, nueve bajas y veinticuatro prisioneros. El total conseguido desde noviembre era de cuarenta y treinta y tres, respectivamente. ${ }^{25} \mathrm{E}$ l objetivo propuesto para entonces por Neve era el de desalojar a los apaches de las inmediaciones de la línea, pero ya estaba planeando una campaña en que habían de tomar parte cinco divisiones de tropas de Sonora y Nueva Vizcaya contra los apaches gileños. ${ }^{26}$

En febrero de $r 784$ tuvo lugar un sangriento y desgraciado encuentro con los apaches por parte de la tropa de Santa Cruz, pero un fuerte destacamento mandado por Medina que partió en aquellas fechas sólo encontró huellas que se dirigían a poniente. En efecto, al amanecer del 2 I de marzo más de quinientos apaches a pie y a caballo atacaban nuevamente la caballada de Tucson, de la que robaron ciento cincuenta cabezas con muerte de cinco soldados. Avisado por el alférez Don Juan Carrillo, con cincuenta y nueve presidiales, vecinos y pimas salió a los alcances el teniente Don Tomás Egurrola, consiguiendo hacer diecisiete muertos al adversario, entre ellos el capitancillo Chiquito, ya que no recobrar la presa, y conoció entonces que aún había cien apaches más emboscados en el río Santa Catalina y sierras inmediatas al presidio. Se suponía que tendrían muchas más bajas de las contadas, pues en la persecución fueron alanceados muchos de los apaches que iban a pie. ${ }^{27}$ Neve se congratulaba, al saber lo ocurrido, de que, previendo él este asalto por las huellas encontradas por el destacamento de Fronteras, como por la experiencia que había de que los apaches hacían sus más fuertes irrupagosto de 1784 . A. G. I., Guadalajara, 521 .

25 Neve a Gálvez. Arizpe, 26 de enero de 1784 , núm. 77 , con Extracto. A. G. I., Gtradalajara, 519 .

26 Neve a Gálvez. Arizpe, 8 de marzo de 1784 , núm. 89. Ibid.

27 Neve a Gálvez. Arizpe, 5 de abril de 7784 , núm. 98, con Extracto. Ibid. 
ciones al comienzo de la primavera, había retrasado el envío de la remonta de caballada a Tucson, gracias a lo cual lo perdido era una fracción despreciable, aunque gravaría el empeño que ya tenían contraído los soldados. ${ }^{28}$ Pero en premio a la heroica acción el rey concedió un grado de ascenso a los oficiales, y el importe de las caballerías perdidas a los soldados, para que no mermase su prest. ${ }^{29}$

La presencia apache en el oeste es tan constante en esta época que tropa de Altar y pimas de San Ignacio pueden hostigarlos en la primera quincena de marzo en las Sierras de San Cayetano y Tasajera, con éxito en bajas y botín de caballada. No ocurre lo mismo en el mal situado presidio de Santa Cruz, que en abril y mayo sufre dos embates de los apaches, en los que perdió siete hombres y hasta quinientas bestias, lo que equivalía a dejar la compañía a pie. ${ }^{30}$

La partida de Don Roque de Medina del presidio de Fronteras con un contingente de ciento noventa hombres de la primera y segunda divisiones el I 5 de abril de 1784 dio comienzo a la campaña contra los apaches del Gila, primera batida general que se hacía a estos enemigos desde los tiempos de O'Conor, y que Neve tenía cuidadosamente planeada desde principios de año, de modo que ya en 20 de febrero había firmado el ingeniero Rocha un cuidado mapa del distrito y de los itinerarios que habían de seguir las fuerzas actuantes, cuyo número y movimientos se especifican con todo detalle al margen; se habían previsto cinco destacamentos, con un total de ochocientos hombres, que al mando de Medina, Azuela, Borica, Allande y Martínez saldrían de Fronteras los dos primeros, y de Janos, Tucson y presidio reformado de Velarde. ${ }^{31} \mathrm{El}$ traslado de los fusileros catalanes a Pitic motivado por la deserción de los seris obligó a fundir las dos primeras divisiones, que mandó Medina, quedando mermados los efectivos totales en ciento cincuenta hombres.

El comandante general tenía puestas sus esperanzas en el éxito de este ataque múltiple. "Desde luego que recibí este mando - escribía el 8 łe marzo de I784-me propuse no sólo continuar haciendo la guerra a les enemigos buscándolos y persiguiéndoles en sus propios terrenos y rancherías como

.28 Neve a Gálvez. Arizpe, 5 de abril de 1784, núms. 99 y 100. 'Ibid.

29 Real Orden de 20 de octubre de 1784, y despachos de capitán y teniente a Egurrola y Carrillo, 2 de noviembre de 1784 . Para esas fechas, ya Carrillo habia muerto en el ataque que los apaches repitieron a Tucson en $10^{\circ}$ de agosto de 1784 . Rengel a Gálvez, Chihuahua, ' $10^{\circ}$ de noviembre de $7_{784}$, núm. 3. A. G. I., Guadalajara, 520.

30 Neve a Gálvez. Arizpe, 3 I de mayo, y Fronteras, 6 de julio de 1774, núms. I I7 y I22, con Extractos. A. G. I., Guadalajara, 520.

3 I El plano de Rocha, en A. G. I., Torres Lanzas. M'éxico, 541, 586 y 586:'B. Datado el primer ejemplar en Arizpe, i 8 de marzo de 1784 . 
tiene S. M. prevenido, sino también desalojarlos de las sierras inmediatas a la frontera en que se establecían, obligándoles a reunirse y refugiarse en otras más distantes donde pudiese atacárseles con fundada esperanza de darles golpes más fuertes que los que sufren hallándose dispersos en los dilatados terrenos donde establecen sus rancherías que reduzcan su número,acaben de aterrorizarlos y de hacerles conocer la constancia y vigor con que se obra contra ellos". La expedición de Medina en febrero y marzo había hecho ver que ya los apaches se refugiaban a orillas del Gila. Allí irían, pues, a buscarlos las armas del rey, ${ }^{32}$ y con ese fin había partido de nuevo Don Roque de Fronteras el I5 de abril de I784. Borica y Allande, al frente de las divisiones tercera y cuarta, penetraban simultáneamente, aquél por la sierra de las Animas y la cañada próxima a la sierra de Burras, y éste desde Tucson remontando el Gila, hasta llegar al punto en que sus fuerzas hicieron conjunción, en el nacimiento del río. Borica hizo batir por los ópatas de Bavispe y Bacuachi, mandados por el general ópata Medrano y el voluntario Don Domingo Vergara, la sierra de Chiricahui, y luego estos tres cuerpos se retiraron a sus bases de partida, mientras la quinta división, dirigida por el capitán Don Francisco Martínez, batía la sierra del Hacha, y situada en las Mimbres, recibía a los grupos de indios que huían ante el avance de los otros campos españoles. El balance de la expedición fue de sesenta y ocho muertos y diecisiete prisioneros apaches, más dos cautivos y ciento sesenta y ocho bestias rescatados, amén de cuantioso botín en pieles de cibolos y gamuzas. 33 Asienta Neve que a los ópatas de Bavispe y Bacuachi se debieron casi todas las ventajas de las cuatro divisiones, porque pie a tierra subieron y pelearon con extraordinario ardor en terrenos en que no podía actuar la caballería ni otra especie de tropas. Sólo una baja había sufrido el campo español, mientras que se daba por seguro que el daño del adversario había sido mucho mayor que el que los diarios de los capitanes hacían ver porque los apaches, cuando podían, tenían por norma ocultar cuidadosamente sus muertos, y otros, heridos en el combate, se retiraban a cuevas y breñales para morir.

Este golpe no fue definitivo en sus consecuencias inmediatas. Las hostilidades apaches sę harán sentir en la frontera setentrional de Nueva Vizcaya y Sonora durante muchos meses todavía. Pero su intensidad se verá pronto disminuida hasta llegarse al último intento de aproximación a los españoles, el más serio de los verificados hasta entonces.

32 Neve a Gálvez. Arizpe, 8 de marzo de 1784 , núm. 89. A. G. I., Guadalajara, 5 r9. Cor esta carta envía el mapa citado en nota antecedente. En núm. 91 de igual data dice que la conpañia de ópatas de Bavispe, que debía operar conjuntamente con Medina, no pudo salir a camdebian conducir su impedimenta. Ibid.

33 Neve a Gálvez. Fronteras, 6 de julio de ${ }^{7} 84$, nún. I23. A. G. I., Guadalajara, 520. 
Correspondió a Neve presidir los destinos de las provincias internas en el momento en que se había de descubrir el cáncer que había estado destruyendo buena parte de la de Nueva Vizcaya y aun Sonora.

Hallábase Neve descontento del giro que claramente tomaban los asuntos de milicias. Dilatábase más y más el cobro de los arbitrios y aun de parte de los donativos ofrecidos, y resolvió en consecuencia hacer uso de la autoriđad del gobernador Barri para lograr la percepción de las cantidades adeudadas. De este modo fue posible obtener las correspondientes a San Juan del Río, Parras, Cuencamé y Papasquiaro. En El Alamo hubo de amenazar Barri con el embargo para conseguir pagase el administrador de las haciendas del conde la parte que a éste correspondía abonar. La situación no parecía en ningún modo duradera, y vista la renuencia de los vecindarios a coniribuir, se preveía que o bien habrían de reformarse las tropas cuando empezasen a hacer menos falta, o bien habría de mantenerlas íntegramente el real erario. 34

La defensa de Nueva Vizcaya, sin embargo, había de hacerse considerablemente más sencilla una vez se cortó de raíz el bandolerismo que malheshores y vagabundos en su mayor parte tarahumaras habían estado comeiiendo bajo nombre y aspecto de apaches. Descubierta palmariamente esta realidad en los últimos meses de 1783 , vióse obligado el comandante a publicar en Io de diciembre de este año un bando que prohibía a los indios ausentarse de sus pueblos sin licencia de los justicias o curas. 35 Sabíase que en la sierra de Barajas hallaban resguardo numerosas partidas de agresores, y ya en noviembre se hacía todo lo posible por darles caza y castigo. Don Manuel Muñoz fue comisionado para perseguir con tropas a los forajidos de la sierra de Barajas, y hacer las pesquisas convenientes para descubrir sus cómplices. Poca después tenía Muñoz en su poder más de ochenta presos, alguno de los cuales confesó haber ejecutado por sí mismo o asistido a más de doscientas muertes en un período cuyo principio puede remontarse hasta 1767 , por lo menos; saliendo a luz también las relaciones que algunos de estos bandiclos tenían con los apaches, a los que entregaban los robos y cautivos que hacían, auxiliándoles también en sus campañas, habiendo concertado pasarse a ellos. Un tal Anicote se había hecho jurar por rey y, en suma, la provincia vivió

34 Neve a Gálvez. Arizpe, 8 de marzo de 1784 , núms. 83 al 86 . A. G. I., Guadalajara, 5 r9.

35 Neve a Gálvez. Arizpe, 26 de enero de 1784 , núm. 74 , con ejemplar del bando firmado por Neve y Corbalán. A, G. I., Guadalajara, 519 . La real orden de 16 de agosto de 1784 aprob6 lo dispuesto por el comandante y le encargó poner en vigor las medidas adoptadas sobre este y otros puntos por Gálvez cuando su ida a Sonora. Ibid. 
días de angustia cuando se supo que pueblos enteros estaban comprometidos en las fechorías padecidas en los últimos años. ${ }^{36}$ Pero la seguridad de Neve en la inmediata pacificación de Nueva Vizcaya hizo que incluso rechazara la posibilidad que se le ofreció de pedir tropas al virrey. 37

Más de veinte penas de muerte tuvo que firmar el comandante contra los facinerosos a consulta del auditor. Otros muchos fueron condenados a azotes y obrajes. ${ }^{38}$ Las cárceles estaban llenas de reos y parecían culpables las jurisdiciones enteras de Chihuahua, Cusihuiriáchic y Ciénaga de los Olivos. Muchos de los que andaban vagando por los caminos y sierras, atemorizados al conocer la represión de la justicia, pretendían volver disimuladamente a sus pueblos, y allí eran detenidos. Entre ellos se ençontraban en no pequeño número mulatos, coyotes y gentes de otras castas: éstos eran por lo común los cabecillas que Neve se proponía eliminar, concediendo luego un indulto general al resto de los encausados. Pero por ser tan crecido su número, y porque de continuar las pesquisas había de resultar la destrucción de poblaciones enteras, determinó el comandante general trasladarse a Chihuahua en junio de 1784 , "si mi quebrantada salud y actuales accidentes que padezco me lo permitieren, a fin de ver más cerca el estado de este grave asunto y arbitrar un medio de cortar este cáncer con la menos efusión de sangre pos:ble". Lo ya logrado era mucho, pues desde que comenzaron las ejecuciones públicas de los delincuentes, "llegan los apaches enemigos a las sierras en que solían convocarse, hacen sus señas por los humos y como no acuden sus malvados anigos se retiran sin atreverse a entrar". ${ }^{39}$ Mala época se presentaba para los apaches si hasta entonces, para subsistir, habían necesitado la complicidad de los tarahumaras.

Pronto se conoció la existencia de otra cuadrilla de bandoleros establecida en la vertiente oriental de la sierra Mojada, en el Bolsón, mandada por Antonio Hernández "el Mordullo", autor de los daños padecidos en la.zona de Cuencamé - cincuenta y cinco muertes en mayo- y San Juan del Río. 40 Santa Bárbara y Parral, Real del Oro, Indé y la hacienda de Casco habían sido así atacadas impunemente en los últimos meses. También Parras era objeto de algunas correrías, lo que sin embargo no bastaba a mover aquel vecndario, que no se mostraba propicio a contribuir a los gastos de levantamiento de milicias.

36 Neve a Gálvez. Arizpe, 8 de marzo de 1784 , núms. 92 y 93 . A. G. I., Guadalajara, $2 \Omega_{5}$.

37 Neve a Gálvez. Arizpe,e 3 de mayo de 1784 , núm. ro8. A. G. I., Guadalajara, 5 I9.

38 Neve a Gálvez. Arizpe, 3 de mayo de 1784 , núm. i I2. A. G. I., Guadalajara, 285.

39 Neve a Gálvez. Arizpe, 3 I de mayo de 1784 , núm. I I6. Ibid.

40 Neve a Gálvez. Fronteras, 6 de julio de 1784 , núm. 122, con Extracto, A. G. I., Guadalajara, 520 . 
La amplitud de la conjura hacía de la infidencia de los tarahumaras un delicado problema político, moviendo al comandante general a pasar a Nueva Vizcaya. Trasladándose, pues, de Arizpe a Chihuahua, pasó Neve por el presidio de Fronteras, y desde allí dio cuenta el 6 de julio de la conclusión de la campaña del Gila, pero a las 4 de la tarde del 2i de agosto moría en la hacienda de Nuestra Señora del Carmen de Peñablanca, donde nueve días antes había otorgado testamento, ${ }^{\mathrm{I}}$ habiendo firmado el inspector Rengel los últimos números de su correspondencia oficial. $4^{2}$

Don José Antonio Rengel

D) urante casi dos años a partir de la muerte de Neve, quedó encargado del mando de la comandancia el comandante inspector de los presidios Rengel, que acababa de llegar de España con este destino cuando ocurriera aqué1la. 43 Carecía, por tanto, Rengel de toda experiencia de la situación de la frontera, lo cual no fue obstáculo, sin embargo, para que su mando fuera en gran manera beneficioso al país.

E1 22 de agosto de 1784 escribió Rengel a la audiencia de Guadalajara y al virrey dando cuenta del fallecimiento de Neve, y de no haber nadie designado para sucederle, y de todo ello pasó noticias al ministerio. La audiencia de Nueva Galicia fue la primera en contestar, autorizándole a ejercer el mando político y militar correspondientes al comandante general, y a determinar lo jurídico tocante a los reos de infidencia con acuerdo del asesor; pero la audiencia le reconocía estos poderes sólo hasta tanto resolviese el virrey. Diez días después el virrey aprobaba con la condición de por ahora lo decidido por la audiencia hasta haber oído el parecer del real acuerdo. 44

Hasta el $\mathrm{I}$. de noviembre no vuelve el interino a dirigirse a Madrid para notificar sus primeras disposiciones en el ejercicio del mando. En los primeros momentos, Rengel se había considerado subordinado a la audiencia de Guadalajara, a la que participaba todas sus novedades, pero después que

4I Testamento de Neve. Hacienda de Peñablanca, I2 de agosto de 1784 , en A. G. S., Guerra Moderna, 7045.

42 Las remitió Rengel con carta a Gálvez. Chihuahua, 25 de diciembre de 1784, núm. 18. A. G. I., Guadalajara, 268 ,

43 Había llegado Rengel a la ciudad de México el it de marzo de 1784 , disponiéndose a pasar en seguida a Arizpe. Rengel a Gálvez. México, iz de marzo de 1784. A. G. I., Guadalajara, 518. Rengel, que en alguna ocasión alega los méritos contraídos sirviendo al rey frente a Gibraltar y en Mahón, había tenido como último empled en la península el de teniente coronel agregado al regimiento de Murcia. Un año antes de hacerse cargo de la comandancia general estaba en Málaga preparándose para embarcar con cuatro criados hacia Nueva España.

44 Don Francisco Fernández de Córdoba a Gálvez. México, 26 de septiémbre de 1784 , núm. 1. A. G. I., Guadalajara, 268. La real orden de 22 de enero de 1785 aprobó la determinación provisional. Ibid. 
el virrey de México sancionó la determinación provisional que le confería el mando, sólo continuó su correspondencia con él. 45 Había ya entonces novecientos reos acusados de infidencia, si bien buena parte de ellos eran tan sólo sospechosos o vagabundos. ${ }^{4} \mathrm{Su}$ propósito al respecto era quintear a los reos capitales si pasaban de cien, y enviar los restantes y los de penas menores : la ejecución a México, para que de allí fuesen trasladados a lugares ultramarinos.

Toca luego Rengel un punto de sumo interés para nosotros: propone, para evitar la repetición de este movimiento de bandolerismo subversivo, establecer el gobierno de Tarahumara Alta y Baja, con un jefe de graduación, que vigilase a todos los naturales, segregando aquel territorio de la provincia de Durango. Ya el ministerio había pensado en esto al nombrar teniente de gobernador de ambas Tarahumaras a Don Francisco Escandón, que entonces estaba preso en Ulúa. Rengel indica como posible jefe de las Tarahumaras al teniente coronel Don Manuel Muñoz, buen conocedor del país, a cuyas órdenes pondría una partida de tropa y un asesor que constituyese un tribunal semejante al de la Acordada. Ya sumiso el territorio y reducidos todos los indios a pueblos, podría quedar como gobierno independiente. 47

Las novedades que por lo demás comunica Rengel de toda la frontera son las de siempre, salvo que, pese a la aparatosidad de los últimos ataques apaches a Sonora, se ha hecho ya muy patente el decaimiento de la intensidad de las hostilidades por parte del enemigo.

La réplica a la campaña del Gila la encontramos en los embates que s11fren entre junio y agosto las áreas de Tucson y Fronteras. En aquella, el 25 de junio atacaron doscientos apaches la misión de San Javier del Bac, cuyos neofitos se defendieron bien, sin caer en la emboscada que se supo luego les habían preparado los asaltantes. Y el I. ${ }^{\circ}$ de agosto, más de trescientos apaches, pimas gileños y pápagos cimarrones sorprendieron la caballada de Tucson - en un golpe semejante al del 2I de marzo- llevándose cien bestias y haciendo dos muertes. El capitán del presidio, Allande, y el ayudante inspector Medina, que actuaba como comandante de las armas de la provincia movieron a Rengel a disponer el envío de un refuerzo de cincuenta hombres de Nueva Vizcaya a Tucson. En el otro sector, una partida de doscientos apaches causó en Bacuachi ocho muertes, entre ellas la de Francisco Tomohua, capitán de los ópatas del nuevo presidio de este pueblo, el 29 de junio; y a

45 Rengel a Gálvez. Chihuahua, J ${ }^{\circ}$ de noviembre de I784, núm. 2. A. G. I., Guadalajara, 520 .

46 Rengel a Gálvez. Chihuahua, $10^{\circ}$ de noviembre de 1784 , núm. 4. Ibid

47 Rengel a Gálvez. Chihuahua, i ${ }^{\circ}$ de noviembre de $\mathrm{I} 784, \mathrm{~s}$, nún. Ibid. 
final de agosto dirigieron dos ataques contra la caballada de Fronteras. Es notable que las expediciones de castigo en estos mismos meses las lleven a cabo las tropas indias: los ópatas de Bavispe y los pimas de San Ignacio baten con éxito las sierras Escondida y de Las Rastras, respectivamente. En setiembre y octubre los presidiales recobran su movilidad sobre las sierras de San Calixto y Chiricahui, y al mes siguiente el capitán Echegaray, de Santa Cruz, conduce doscientos diez soldados y ópatas a este último lugar y a la Peñascosa, repitiéndose la entrada en enero de I785 por Azuela, capitán de Fronteras. Se advierte a fin del año la especial atención que los apaches prestan a las tropas indias, a las que preparan dos emboscadas, en Bavispe, el I I de octubre de 1784 , y en San Ignacio, el I I de enero siguiente, haciendo veintitres bajas a ópatas y pimas. $4^{8}$

En los primeros días de noviembre de 1784 , después de un verano en que las tropas parecen dedicadas a rescatar las bestias y reses que roban los apaches y las tarahumaras infidentes, padece Nueva Vizcaya el último empujón de la oleada apache: cuatrocientos gileños, en partidas de cincuenta a setenta, penetran en la provincia por diversos rumbos, ${ }^{49}$ pero Rengel activó cxtraordinariamente las medidas defensivas, poniendo seis destacamentos sobre las huellas de los invasores, gracias a lo cual la invasión fue rechazada, no sin recibir el enemigo veintidós bajas y un prisioneros; los encuentros tuvieron lugar en un amplio semicírculo entre Julimes, la sierra de las Mimbres y Carretas, y en ellos se recobraron setecientas setenta y cinco bestias, que fueron entregadas a sus dueños sin exigirles premio alguno. Parece ser que los apaches, se habían congregado en la sierra Blanca, a doscientas leguras de Chihuahua persuadidos de que, entrando en Nueva Vizcaya en gruesas cuadrillas, podrían robar los ganados que necesitaban para subsistir aquel invierno, hasta la reanudación de hostilidades que harían en la primavera siguiente. ${ }^{50} \mathrm{La}$ victoria obtenida por. Rengel no había de quedar, pues, sin consecuencias, dada la situación de extrema necesidad en que puede suponerse quedaban sus desgraciados enemigos.

Entre tanto, la situación jurídica e institucional de la comandancia, lejos de aclararse se confundía más y más. La audiencia de México, dirigiendo al virrey la consulta que éste había pedido, le informó que podía hacerse cargo del mando de las provincias internas puesto que éstas nunca se habían separado totalmente del virreinato y que, aunque así fuera, no tenían previsto

48 Rengel a Gálvez, I. ${ }^{\circ}$ y 27 de noviembre y 25 de diciembre de 1784 , y 26 de febrero y 26 de marzo de 1785 , núms. 3, 8, 1 2, 28 y 55, con cuatro Extractos. A. G. I., Guadalajara, 520.

49 Rengel a Gálvez. Chihuahua, 27 de noviembre de 1784 , núms. 7 y 8 , con Extracto. Ibid.

50 Rengel a Gálvez. Chihuahua, 25 de diciembre de 1784 , núm. 12. Ibid. 
sucesor en el caso de fallecimiento de Neve. Por otra parte, urgía la definitiva resolución, por la gravedad del caso de los reos infidentes.

Matías de Gálvez, sin embargo, murió sin haber llegado a decidir, por lo que la audiencia que quedó gobernadora de México determinó entregar a Rengel el gobierno interino de la comandancia, y remitir testimonio de lo actuado a Gálvez para que él resolviese en su vista y en la de los juicios de los militares experimentados en la situación de la frontera, lo más conveniente para ésta, procurando la perfección del que la audiencia llama "admirable e inspirado pensamiento de su erección". A Rengel le comunicó también la audiencia se le consideraban las mismas facultades que a los anteriores comandantes generales en hacienda, provisión de empleos, vicepatronato y demás, "reconociendo siempre V. S., hasta que S. M.. determine otra cosa, la superioridad y expresa dependencia de este gobierno y capitanía general, sin perjuicio de proceder V. S. a obrar por sí en todos los casos urgentes", camino por el que la comandancia general, que había nacido independiente del virreinato, vino a quedar subordinada a México, de resultas de no tener prevista la sucesión del mando. ${ }^{5}$

Diversas reales órdenes de 4 de abril de 1785 aprobaron todo lo expuesto, disponiéndose que Rengel dirigiese sus informes al nuevo virrey y observase sus disposiciones hasta nueva providencia de S. M., en tanto que se comunicaba a Bernardo de Gálvez, que sucedía a su padre en México, la aprobación de lo resuelto en la audiencia hasta que él mismo tomase las providencias que juzgase convenientes. 52

Comienza así el período de sujeción de la comandancia general de las provincias internas al virreinato.

Actividad De Rengel

Sorprende que, después que Neve había declarado no necesitar más refuerzo, volviese a pedir ahora, el 25 de febrero de 1785 , ochocientos hombres a la audiencia gobernadora de México el comandante general interino. Rengel envió incluso al ayudante inspector Don Diego Borica a seleccionar y habilitar las tropas que debían pasar a las provincias internas con destino a las fronteras de Sonora y Nueva Vizcaya y campaña contra los seris, en tanto que él mismo determinaba los lugares de los presidios en que se alo-

5 I La audiencia de México a Rengel. México, 20 de noviembre de I784. A. G. I., GuadaJajara, 390. La audiencia a Gálvez. México, 23 de noviembre de I784, núm. 5. A. G. I., Guada-
lajara, 268.

53 A. G. I, Guadalajara, 268 y 520. Rengel participa quedar eneterado en 27 de agosto
785 . Ibid. 
jarían estas fuerzas a su llegada. El ministro, sin embargo, a quien Rengel no dejó de dar cuenta, ordenó a Don Bernardo de Gálvez abocase a si este expediente e informase de lo que en su vista se le ofreciese, tomando entre tanto las providencias que juzgase oportunas. ${ }^{53}$ Rengel, recién salido de una grave enfermedad padecida entre enero y febrero de 1785 , sin contar con un médico en doscientas legulas a la redonda 54 procuraba sin embargo acelerar en lo posible el fenecimiento de las causas de los reos de infidencia, contando con trasladarse enseguida a Sonora para realizar la campaña que para octubre de $\mathrm{I} 784$ había proyectado Neve contra los seris. ${ }^{55}$

Cuando Cabello y Anza perseguían en Texas y Nuevo México una política de acercamiento y atracción de las naciones del norte y los comanches, esforzábanse todavía por alejar de sus fronteras a los apaches las tropas de Nueva Vizcaya y Sonora. En monótonas relaciones el comandante interino informa de las operaciones de las partidas que hacía estar en campaña en el frente de Janos al presidio del Norte, batiendo desde las sierras Escondida y Mimbres al río Puerco. En esta zona eran duros y frecuentes los encuentros, con bajas por ambas partes. Más al sur, se cuentan por docenas en todo cl año I785 y primer cuarto del siguiente los robos de ganados y persecuciones de los asaltantes, cuyos movimientos alcanzan a todo el límite sur del Bolsón, hasta Parras: las haciendas del Concho, Florido, Nazas y Aguanaval son objetivo predilecto de los enemigos ahora que la mitad norte de la provincia debe hallarse muy empobrecida en sus ganados; la presencia apache ha de ser, al mismo tiempo, tanto más intensa cuanto más real ha sido la necesidad pasada el invierno anterior, y su penetración al sur del desierto se ve facilitada por la desaparición de la antigua Línea de presidios que debía enlazar las guarniciones de Nueva Vizcaya y Coahuila. ${ }^{56}$

Por lo que hace a Sonora, junto a la minuciosa crónica local de robos y represalias, varios hechos van a destacarse, de mayor entidad, a lo largo del año I785. Ya en la batida que el capitán Azuela diera en enero a la sierra de Chiricahti se hizo constar que el I4 de febrero no se atrevió a atacar una gruesa ranchería apache que halló instalada en la sierra de las Espuelas, es decir, al norte del presidio de Janos. Si se tiene en cuenta que Azuela se encontraba en aquel momento al frente de ciento catorce hombres

53 Rengel a Gálvez. Chihuahua, 26 de febrero de I785, núms. 23 y 24. Real orden de 2 de agosto de I785 a Bernardo de Gálvez. A. G. I., Guadalajara, 520.

54 Rengel a Gálvez, 29 de enero y 26 de febrero de I785, s. núm., y núm. 22. A. G. I., Guadalajara, 268.

55 Rengel a Gálvez. Chihuahuta, 26 de febrero de I785, núm. I, reservada. Real orden de 2 de agosto de 1785 a Bernardo de Gálvez. A. G. I., Guadalajara, 520.

56 Rengel a Gálvez. Chihuahua, 26 de febrero, 26 de marzo, 30 de abril y 28 de mayo de 1785, núms. 28, 55, 68 y 70, con Extractos. A. G. I., Guadalajara, 520. Rengel a Sonora. Chihuahua, 2 de marzo de 1786, núiu. I42, con Extracto. A. G. I., Guadalajara, 521. 
podrá tenerse un punto de referencia para inaginar la cuantía de la ranchería, que no osó embestir. Nada tiene, pttes, de extraño que el I 3 de marzo el enemigo cautivara a dos correos ópatas en la chesta de Carretas, y que mientras Allande triunfaba sólo en pequeños encuentros en las sierras de Santa Rita y Santa Catalina, el alférez Vergara con ochenta hombres de Fronteras, Bavispe y Bacuachi encontraba incendiadas las sierras de Chiricahui y sus colaterales y en cambio, reconociendo las de Pitascachi, Embudos y Cucuverachi a espaldas de lo que podía considerarse la frontera española, atacó en la última con sesenta hombres a más de cien apaches que en ella estaban mezcaleando con sus familias, lo que equivale a decir que un importante núcleo de enemigos intentaba desplazarse al sur entre Fronteras y Bavispe. E1 incremento de las clepredaciones en esta.zona se correspondería con tna serie de correrías de las tropas hasta el Gila --en enero de I786 Allande localiza gran número de apaches junto a este río- en las que, sin lograrse combates decisivos, se producía un lento desgaste al adversario, que tan sorprendentemente se había concentrado sobre aquella frontera. 57

Guarnecían la provincia, desde el regreso al virreinato del piquete de dragones del reginiento de México, once compañías, cuyos efectivos sumaban en marzo de ${ }^{7} 85$ un total de ochocientas ctrarenta y cinco plazas, de las que cuatrocientas ochenta y una correspondian a los presidiales de cuera - en San Bernardino, Santa Cruz, Tucson, Altar, Horcasitas y Buenavista-; ciento sesenta y sicte a los ópatas --Bavispe y Bacuachi-, ochenta y cuatro a los pimas de San Ignacio, sesenta y dos a los voluntarios catalanes y cincuenta y uno a los dragones del reginiento de España. 58 Al mismo tiempo,

57 Las mismas cartas y Extractos citados en nota anterior.

58 "Provincia de Sonora. Estado que manifiesta la fuerza efectiva con que ce hallan las compañias presidiales, etc." Por D. Roque de Medina. Arizpe, 27 de marzo de 7785 . Dos copias en el Museo Naval, Ms, 567 , folios 7,8 y $9-10$. He aquí dicho estado, en detalle, con el nombre
fie los capitanes o tenientes comandantes:

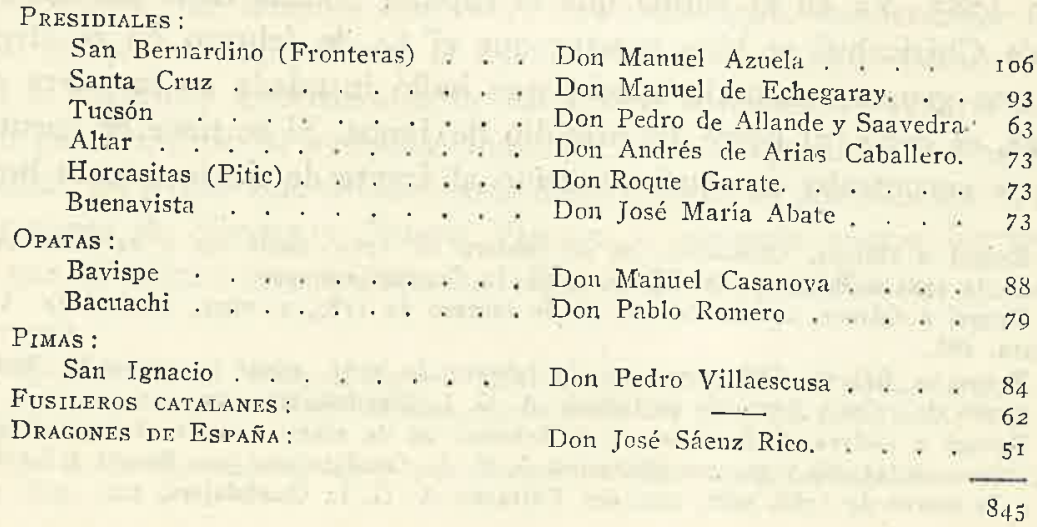


ocupóse Rengel seriamente en acabar con todo posible germen de nueva conjura de los tarahumaras y por ello despachó en setiembre de 1785 al capitán Don Juan Bautista Elguezábal con cien hombres para que recorriese las barrancas de la sierra Madre, refugio de gentiles y apóstatas de las misiones. Cuatro meses y medio empleó Elguezábal en reconocer sesenta y nueve misiones y pueblos de indios y dieciseis haciendas y ranchos de la sierra, apresando a cuarenta $y$ un vagos y setenta y un reos de infidencia que dejó entregados a los justicias. Algunos sujetos prácticos del terreno y la lengua de los tarahumaras, protegidos por un corto número de soldados disfrazados, reconocieron veintiuna rancherías de gentiles que aún subsistían en las asperezas y barrancas de la sierra Madre, y sumaban un total de cuatrocientas veintiseis almas, que se alimentaban de pequeñas siembras, ganados y árboles frutales. Se sacaron de alli cuarenta y nueve personas fugitivas de las misiones, que fueron devueltas a ellas, y para evitar volvieran a repetirse aquellas deserciones ordenó Rengel el pago de jornales en dinero y la supresión de todo servicio personal, que había sido la causa común del alejamiento de los indios. Después de esta visita, algunas rancherías de gentiles habían of recido congregarse en pueblos, y el comandante interino se prometía la próxima felicidad de toda la Tarahumara. 59

Durante mes y medio Rengel estuvo recorriendo las posiciones defensivas de Nueva Vizcaya. Partiendo de Chihuahua el i3 de octubre de I785, visitó los presidios de San Carlos Cerro Gordo en Chorreras, del Príncipe en Coyame, y del Norte en la Junta de los Ríos, reconoció luego el paraje de los Pilares, donde estuvo el presidio del Príncipe, y pasó en seguida a visitar el de San Eleazario, que por el traslado de aquél había venido a quedar a más de setenta leguas del Norte, intervalo despoblado por donde penetraban los enemigos. A continuación se dirigió Rengel al Carrizal, paraje de Velarde, y Janos, y de aquí por el presidio de San Buenaventura, colocado por el caballera De Croix, en Chavarría, y el cuartel de la $4 .^{a}$ compañía en San Jerónimo, regresó a Chihuahua el 28 de noviembre. El comandante interino, que asistió a las revistas pasadas por Gutiérrez de la Cueva, encontró la tropa, armamento, vestuario, monturas y caballadas en regular estado, y por su parte ordenó la construcción de torreones de vigía en algunas lomas inmediatas a San Carlos, Príncipe y Janos. Reconoció Rengel las poblaciones formadas junto a San Carlos, Príncipe, San Eleazario y Carrizal, e impulsó

59 Rengel a Sonora. Chihuahua, 2 de marzo de I786, núm. I38. Es en esta fecha, en núm. I33, cuando Rengel acusa recibo de la real orden de i4 de octubre de I785 en que se le comunicó la concesión del título de Castilla de Marqués de Sonora que el rey había hecho a su minıstro de Indias D. José de Gálvez. Ambas citadas en esta nota en diarios de las operaciones. Ibid. 
la congregación de otra junto a Janos, donde no había más que tres o cuatro vecinos ítiles, lo que obligaba a la compañía de este presidio a abastecerse en el valle de San Buenaventura y hacienda del Carmen, a treinta y cuatro y cincuenta leguas, respectivamente. Para solventar esta deficiencia comisionó al teniente Don Juan Bautista Lizardi para que repartiese tierras a los paisanos, oficiales y soldados que las quisiesen cultivar en los contornos del presidio, asignando un fondo para el auxilio de estos nuevos agricultores. El punto peor de la línea de Nueva Vizcaya era el del presidio de San Buenarentura, que estaba en paraje tan malsano como todos los que había ocupado en épocas anteriores, y Rengel se abstuvo de decidir qué debería hacerse con este presidio. 60

La. estancia del comandante general interino en Janos le permitió organizar una nueva campaña, del tipo de la ejecutada por Neve, contra la apachería de Poniente, que ya se ha dicho cómo presiona sobre Sonora a fines de 1785 , y que naturalmente también se hacía sentir dolorosamente sobre la porción limítrofe de Nueva Vizcaya. A este fin movilizó Rengel 354 hombres, que en dos cuerpos mandados por el teniente coronel Don Francisco Martínez, capitán de Carrizal, y el capitán del Príncipe Don José María Cordero batieron el terreno del sur del Gila hasta la altura de Tucson, aunque sin causar más de once bajas a los apaches y perdiendo más de ochenta caballos porque la nieve cubría los pastos. ${ }^{6 I}$

\section{Don Jacobo de Ugarte y Loyola}

El 20 de abril de I 786 , en tierras de la provincia de Nueva Vizcaya, ya titulada intendencia de Durango, tomaba posesión Ugarte y Loyola de la comandancia general de provincias internas. ${ }^{62} \mathrm{Su}$ nombramiento para este mando, por real cédula de 6 de octubre de I 785 , no venía a terminar la situación precaria de la interinidad de Rengel, puesto que él mismo era designado comandante general interino por vía de comisión. Se le concedían las mismas facultades que tuvo Neve, "pero con precisa sujeción de las instrucciones y órdenes que os diere el conde de Gálvez mientras se mantuviese en el virreinato, tanto en lo militar como en lo político y económico de aquel mando, sin innovar cosa alguna". Ugarte juraría el cargo en manos del virrey, pero

60 Rengel a Gálvez. Janos, 15 de noviembre de 1785 , núm, ir 4 . Rengel a Sonora. Chihuahua, $z$ de marzo de I786, núm. r40. Ibid.

6I Rengel a Sonora. Chihuahua, a de marzo de I786, núm, I 4 I, con plan y diarios de las operaciones. Ibid. 62 Ugarte a Sonora. Chihuahua, I. ${ }^{\circ}$ de junio de 1786 , núm. I. Ibicl, Había llegado a Chi-
huahua el 9 de mayo. 
pese a la nota de interinidad de su gobierno se le otorgaba el sueldo entero que gozó su antecesor. ${ }^{63}$

La vacante de la comandancia general había movido al marqués de Sonora a hacer intervenir en la provisión del cargo a su sobrino, virrey electo de México, Don Bernardo, ya conde de Gálvez. "E1 rey quiere - escribe en real orden de 24 de enero de 1785 - que la comandancia general de las provincias internas de Nueva España, que ha vacado por muerte de Don Felipe de Neve, se provea en un oficial en quien concurran las grandes calidades de instrucción, valor, prudencia y robustez que requiere aquel importantísimo destino. Como V. E. ha servido en aquellos remotos países y sus inmediaciones y ha adquirido el práctico conocimiento de ellos, quiere S. M. que luego que $V$. E. llegue a México y se entere de las providencias.que el virrey Don Matías de Gálvez haya dado en el asunto, informe reservadamente sobre todo proponiendo el sujeto que estime más a propósito para servir aquella comandancia general. S. M., con las repetidas experiencias que tiene del amor de V. E. al real servicio y de su celo por el bien público, espera que desenpeñará este encargo con la pureza e imparcialidad que le es tan propia y corresponde a la particulr confianza con que le distingue, fiando a su honor y conciencia esta elección. De su real orden lo prevengo a V. E. para su cumplimiento". ${ }^{6}$ A esta orden se debió la propuesta hecha por el mismo conde de Gálvèz en 28 de junio de aquel año, en una de sus primeras cartas desde México, en la que Ugarte era presentado como candidato al difícil puesto.

Ugarte se hallaba entonces desempeñando el gobierno de Puebla tle los Angeles y elevaba repetidos memoriales en demanda de empleo mejor retribuido alegando sus largos y honrados servicios. ${ }^{65}$ Aunque de ellos hemos hecho mención en capítulos anteriores, bueno será insertar un resumen aprovechando la hoja presentada por el interesado a Don Teodoro de Croix en Horcasitas el $1 .{ }^{\circ}$ de enero de $1780 .{ }^{66}$ Consta en ella que se le sentó plaza de cadete en el Regimiento de Guardias de Infantería Española, dispensándole la edad, el 5 de abril de I732. Empezó a servir realmente en I740, y en este cuerpo alcanzó el grado de coronel en! i I de enero de 1767 , habiendo combatido en I745 en Italia — sitio de Casal, bloqueo del castillo de Milán, herido en el ataque de Piacenza el Io de agosto de este año-y luego en el sitio de Almeida, en la campaña de Portugal. El ro de marzo de i767 se le había conferido el gobierno de Coahuila, del que tomara posesión el 5 de

63 Real cédula de San Ildefonso, 6 de octubre de 1785. A. G. I., Guadalajara, 268.

64 A. G. I., México, I5 I2.

65 Ugarte a Gálvez. Puebla, 8 de marzo de I 784 . A. G. I., Guadalajara, 267.

66 A. G. T., Guadalajara, 28 r B. 
diciembre de 1769 , y que desempeñó hasta diciembre de 1777 en que se incorporó a la comitiva del primer comandante general de las provincias internas para pasar al gobierno militar de Sonora. El 55 de junio de I779 era ascendido al grado de brigadier, pero en cambio perdía poco clespués su actual empleo, dotado con sólo tres mil pesos, y quedaba reducido a mil pesos que el Caballero tuvo a bien asignarle a buena cuenta de su sueldo de brigadier, que tampoco percibía. En i 784 , ya gobernador de Puebla desde el 7 de marzo de este año, solicitaba otro empleo en que pudiera desempeñarse de sus deudas, y el rey sugirió a Matías de Gálvez lo colocase en Veracruz, lo que no tuvo efecto. En cambio, Don Bernardo lo proponía en 2 de agosto de $\mathrm{I} 785$ para el mariscalato, idea que fue admitida por el ministro de Indias marqués de Sonora, cuando ya Ugarte era comandante general. ${ }^{67}$ Ahora, en enero de I786, cuando le fine comunicada la anterior real cédula, Ugarte se trasladó a México, ${ }^{68}$ y allí conferenció ampliamente con el virrey, que debía darle sus instrucciones, encontrándose ambos conformes con la líne? ie conducta a seguir en relación con los problemas de la frontera.

\section{LA INSTRUCCIÓN DEL CONDE DE GÁLVEZ}

Por su ya lejana experiencia de estos problemas era por lo que el ministro subordinaba a Bernardo de Gálvez la comandancia general. Pocos días después del nombramiento del nuevo jefe se prevenía al conde de Gálvez, en vista de las hostilidades de los apaches de que había dado parte Rengel, "que mediante a los conocimienetos prácticos que tiene de aquella guerra y comandancia, dispoga V. E. por cuantos medios y modos hallare conveniente y le dictare su pericia militar, se escarmiente a los citados indios enemigos, dando a este fin las instrucciones, órdenes y auxilios que regulare oportunas al nuevo comandante general Don Jacobo Ugarte y Loyola y los demás empleados en las referidas provincias internas, pues Su Majestad autoriza a V. E. plenamente para todo lo que crea necesario al efecto de sus reales intenciones con amplias facultades". Para mejor cumplir esta disposición, Don Bernardo, que sólo había visto Nueva Vizcaya y parte de Sonora, llamó a México a Ugarte, que había recorrido la frontera de Béjar a Altar, 69 y ya después de las entrevistas con Ugarte, mientras éste se encaminai. por segunda vez

67 Las repetidas instancias de Ugarte, en A. G. I., Guadalajara, 267.

68 Ugarte a Gálvez, Puebla, 28 de enero de 1786 , agradeciendo el nombramiento. En 30 de marzo de 1786 escribe ya desde México pidiendo se le releve de pagar la media anata. A. G. I., Guadalajara, 268. Cesó en el gobierno de Puebla el 2 de febrero de 1786, según consta en los autos de su residencia, al fol. 21. A. H. N., Consejos, 20.723, núm. 2.

69 Real orden de 17 de octubre de 1785 a B. de Gálvez. A. G. I., Guadalajara, 520. B. de Gálvez a Sonora. México, 27 de enero de 1786 . A. G. I., Guadalajara, 268. 
a las provincias septentrionales, se dio a elaborar una instrucción en la que había de plasmar las directrices a su juicio más oportunas para remediar el que califica de infeliz estado en que se hallaban las provincias internas.

La innovación fundamental que introduce la instrucción de Bernardo de Gálvez dada el 26 de agosto de I 78670 en el régimen de la comandancia es la de dividir ésta en tres sectores, quedando subordinados a Ugarte - pero responsable cado uno de los asuntos puramente militares en el territorio de su mando- el comandante inspector Don José Rengel, bajo cuya dirección se pone la defensa de Nueva Vizcaya y Nuevo México, y el coronel de Infantería Don Juan de Ugalde, a quien ahora encarga el virrey las provincias de Texas y Coahuila, las jurisdicciones de Parras y Saltillo y las que agrega de Nuevo León y Nuevo Santander, que quedan bajo el mando particular de Ugalde sin sujeción a Ugarte, pues estas provincias eran del virreinato, y no de la comandancia general. ${ }^{7}$ No podemos decir que el virrey estuviese acertado al planear la reforma del gobierno de la frontera, pues basta acercarse a la instrucción para comprender la complejidad de las relaciones que establece entre los tres jefes y él mismo, y entre aqu'llos y los gobernadores $o$ intendentes de las provincias. Y claramente se a vierte hasta qué punto queda extraordinariamente desdibujada la figura (lel comandante general.

Bernardo de Gálvez se mostró mucho más agudo al indicar los medios para obtener la paz de la frontera. La atracción de los indios hostiles debía hacerse entablando relaciones comerciales con ellos, vendiéndoles ganados, ropas, armas y bebidas alcohólicas. El virrey ha aprendido desde lnego estos métodos durante su estancia como gobernador en Luisiana, y pone ahora su mayor interés en demostrar que esto, lejos de perjudicar a nuestros establecimientos, les beneficiará. Hechos los bárbaros al consumo de los productos europeos, quedarán en absoluta dependencia de los blancos. Bernardo de Gálvez plantea un claro programa de subordinación económica de las naciones indias de la pradera y, para desvanecer el recelo que a primera vista podría suscitar su instrucción, llega a demostrar incluso las ventajas de que el indio cace y luche con armas de fuego en vez de con arco y flechas, pues el uso de

70 Instrucción formada en virtud de Real Orden de S. M., que se dirige al Señor Comandante General de Provincias Internas Don Jacobo Ugarte y Loyola para su gobierno y puntual observancia de este Superior Jefe $y$ de sus inmediatos subalternos. Impresa. 216 artículos. Prefacio; puntos generales, I al I04; id. particulares correspondientes a Sonora y Californias, I05 al I 6 ; id. id. a Nueva Vizcaya, II7 al I70; a Texas, Coahuila, Nuevo León y Nuevo Santander, I7I al I9I; atros puntos generales, I 92 al 216 . Plublicóse esta instrucción en el Boletín del Archivo General de la Nación, VIII, 4, págs. 49 I-540 México, I937. Edición bilingüe por Donald E. Worcester, con el titulo de Instructions for governing the interior provinces of New Spain, 1786. Berkeley, 195I. Ejemplares originales en A. G. I., Guadalajara, 268 y Ultramar 714, y el más completo en A. G. S., Guerra Moderna $704 \mathrm{I}$.

7 I Arts. 7 al II. 
aquéllas le mantendrá supeditado al suministro de fusiles, pólvora y munición que los españolees podrán regalar según convenga.

La instrucción del virrey no estuvo terminada hasta el 26 de agosto de 1786 y al día siguiente convocaba Don Bernardo por decreto una junta para ratificar sus juicios y asegurar el acierto. Las reuniones comenzarían el 28 de agosto a las diez de la mañana, y a ellas eran llamados el regente de la audiencia de México Don Vicente de Herrera y Rivero; el brigadier Don Pedro Fermín de Mendinueta, subinspector general de las tropas del virreinato y cabo subalterno militar del virrey, el fiscal de la real hacienda Don Ramón de Posada y "los señores coroneles que son y han sido gobernadores de provincia interna y se hallan en esta capital, y por igual regla todos los oficiales que sirvan o hubieren servido en las mismas provincias, debiendo asistir también los principales dueños de haciendas situadas en aquellas fronteras que tienen aquí su residencia". Como secretario actuaría Don Antonic Bonilla, coronel graduado, capitán del regimiento de dragones de México y antiguo inspector de presidios y secretario de la comandancia general. 72 Además de los nominalmente citados en el decreto asistieron a las deliber ciones los siguientes individuos:

Coroneles

Don Francisco Antonio Crespo, ex gobernador de Sonora.

Don Juan de Ugalde, ex gobernador de Coahuila.

Don Melchor Vidal de Lorca, ex gobernador de Nuevo León.

Don Juan Velázquez, ex gobernador de Nuevo Vizcaya.

Don Diego Lazaga, gobernador de Nuevo Santander.

Tenientes coroneles

Don José Romeu, sargento mayor del regimiento de dragones de España, antes destacado en Sonora.

Don Diego Borica, ayudante inspector de presidios. Capitanes ingenieros

Don Miguel Costanzó, que se halló en el descubrimiento y ocupación del puerto de Monterrey.

Don Manuel Mascaró, que ha servido en las provincias internas y acaba de retirarse de ellas.

Capitanes

Don Rafael Martínez Pacheco, retirado de las provincias internas.

Don Domingo Díaz, retirado de las provincias internas.

\section{Hacendados}

E1 marqués de San Miguel de Aguayo.

72 Decreto de M'éxico, 27 de agosto de I786. A. G. S., Guerra Moderna 7041. 
E1 Dr. D. José Juangorena.

Don Juan Antonio Yermo.

Don José Martínez de Chaves.

Don José de los Heros.

Don José Garay.

El conde del Apartado (no concurrió por hallarse ausente).

En las juntas habidas en los días 28,29 y 30 de agosto de 1786 , "hizo S. E. la más viva pintura del crítico estado en que se hallan las provincias internas. Se leyó la instrucción formada para gobierno de Ugarte. Amplió y demostró S. E. los artículos más esenciales, explicando con la mayor claridad las causas y razones en que se fundan, los fines importantes a que se dirigen y los buenos efectos que prometen! si no se equivocan o desgracian en la práctica las providencias que intiman. Y ódo todo atentamente por los señores vocales, dictaminaron de común acuerdo que las superiores resoluciones del Excmo. Sr. Virrey contenidas en la expresada instrucción debían ejecutarse sin pérdida de instante, manifestando los jefes y oficiales militares que según sus conocimientos eran las únicas que podían tomarse para el remedio de las provincias internas en su actual cons itución. Los hacenderos no tuvieron qué exponer ni pedir en vista de unas providencias combinadas con su particular alivio, el general de los demás vasallos, la defensa y pacificación de los territorios y el mejor servicio del rey. E1 Sr. regente Don Vicente de Herrera dijo que la instrucción la consideraba en su clase la obra más completa, que así lo sentía, y que debía imprimirse para consuelo y satisfacción del público de estos reinos. Todos fueron del mismo dictamen, haciendo igual súplica al Excmo. Sr. Virrey, con lo que se concluyeron las juntas, firmándolas S. E. y los señores vocales". 73

En consecuencia, ordenó el conde de Gálvez la impresión de la instrucción y expidió los despachos que ponían a cargo de Don Juan de Ugalde la comandancia de las armas y subinspección de las tropas de Texas, Coahuila, Nuevo Reino de León y Colonia de Nuevo Santander, "por comisión, interinamente, en la clase de segundo cabo subalterno del comandante general, abedeciendo sus órdenes en cuanto no se opongan a las que yo le dirija en derechura", consignándole, sobre el sueldo de coronel de infantería, 3.384 pesos, de modo que tuviese en total 6.000 pesos anuales en la caja de San Luis de Potosí. 74 La división de la comandancia iba, pues, a consumarse. E1 25 de octubre remitía Don Bernardo la instrucción a Ugarte. 75

73 Acta de las juntas, levantada por Bonilla. Ibid.

74 B. de Gálvez a Sonora. México, 25 de setiembre de 1786 , núm. co8. Ibid. jara, 521 .

5 Ugarte a Sonora. Chihuahua, 28 de diciembre de 1786 , núm. 53. A. G. I., Guadala- 
Mientras el virrey prepara la división de las provincias, Ugarte ha ido avisando las ocurrencias de la frontera, que cada vez son más favorables. La inseguridad continúa siendo el ambiente habitual, pero en Sonora y Nueva Vizcaya, desde principios de año, se han terminado las entradas de grupos numerosos de adversarios. La lucha de guerrillas y escaramuzas es ahora lo frecuente, los pequeños robos y los asaltos a las caballadas y en ranchos y caminos, evitando los núcleos de población y los presidios. En Sonora, aunque con gran desgaste de la tropa, se mantenía el sistema de ejecutar una salida nefisualmente con una fuerte partida, con la que se conseguían golpes de alguna importancia. Lo mismo se hacia en Nueva Vizcaya, desde Janos y Carrizal, batiéndose la orilla sur del Gila. ${ }^{6}$ El balance mensual de bajas y cautivos se afirmaba cada vez más a favor de los españoles, hasta que a mediados de 1786 los mismos gileños empiezan a solicitar la paz. En mayo, la cuadrilla del Bronco pidió paz en el valle de San Buenaventura. En setiembre, otros grupos ofrecen asentarse en Arizpe o Bacuachi, aunque una - parte de ellos, para compensar su debilidad frente a los españoles, acudió a aliarse con los navajos. 77 En octubre ya empiezan a presentarse los gileños del capitán Chiquito de la sierra Per̃ascosa en Bacuachi, pidiendo treinta bestias para hacer el traslado completo de su ranchería, radicándose al cabo allí sin dar motivo alguno de desconfianza. Era importante la presentación de este jefecillo, que según el comandante, era "uno de los de más séquito que hoy se conoce entre los gileños". El alférez Vergara condujo las bestias pedidas para facilitar su desplazamiento. Vergara llevó con toda felicidad la negociación del cese de hostilidades, y muy pronto los apaches servían como escolta a los presidiales. 78 En Nuevo México, Anza trabajaba por separar a navajos y gileños, mientras que se iban cimentando las buenas relaciones con yutas y comanches. 79 Ugarte se prometía ya la pronta tranquilidad de toda la frontera, con la consiguiente prosperidad de agricultura, comercio y minería.

Hay que decir, sin embargo, que en este mismo año de ip86 mucha sangre había sido vertida en el costado oriental de Nueva Vizcaya, y muchos

76 Ugarte a Sonora. Chihuahua, $10^{\circ}$ y 29 de junio y 3 de agosto de 5786 , núms. 5,20 y 22 , con Extractos. A. G. I., Guadalajara, 52I. Ugarte a Sonora. Chihuahua, 3 I de agosto de 1786 , núm. 3x. A. G. I., Guadalajara, 286.

77 Ugarte a Sonora. Chihuahua, 2 de noviembre de 1786, núm. 39, con Extracto. Guadalajara, 286.

78 Ugarte a Sonora. Chihuahua, $10^{\circ}$ de febrero de 1787 , ním. 59. Ibid.

79 Ugarte a Sonora. Chihuahua, 30 de noviembre y 21 de diciembre de 1786 , núm. 40 y 42. A. G. I., Guadalajara, 521 y 287 . 


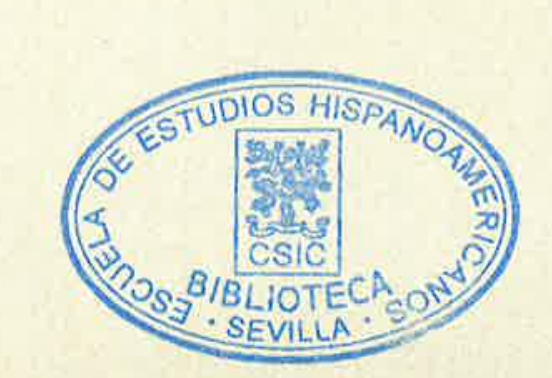




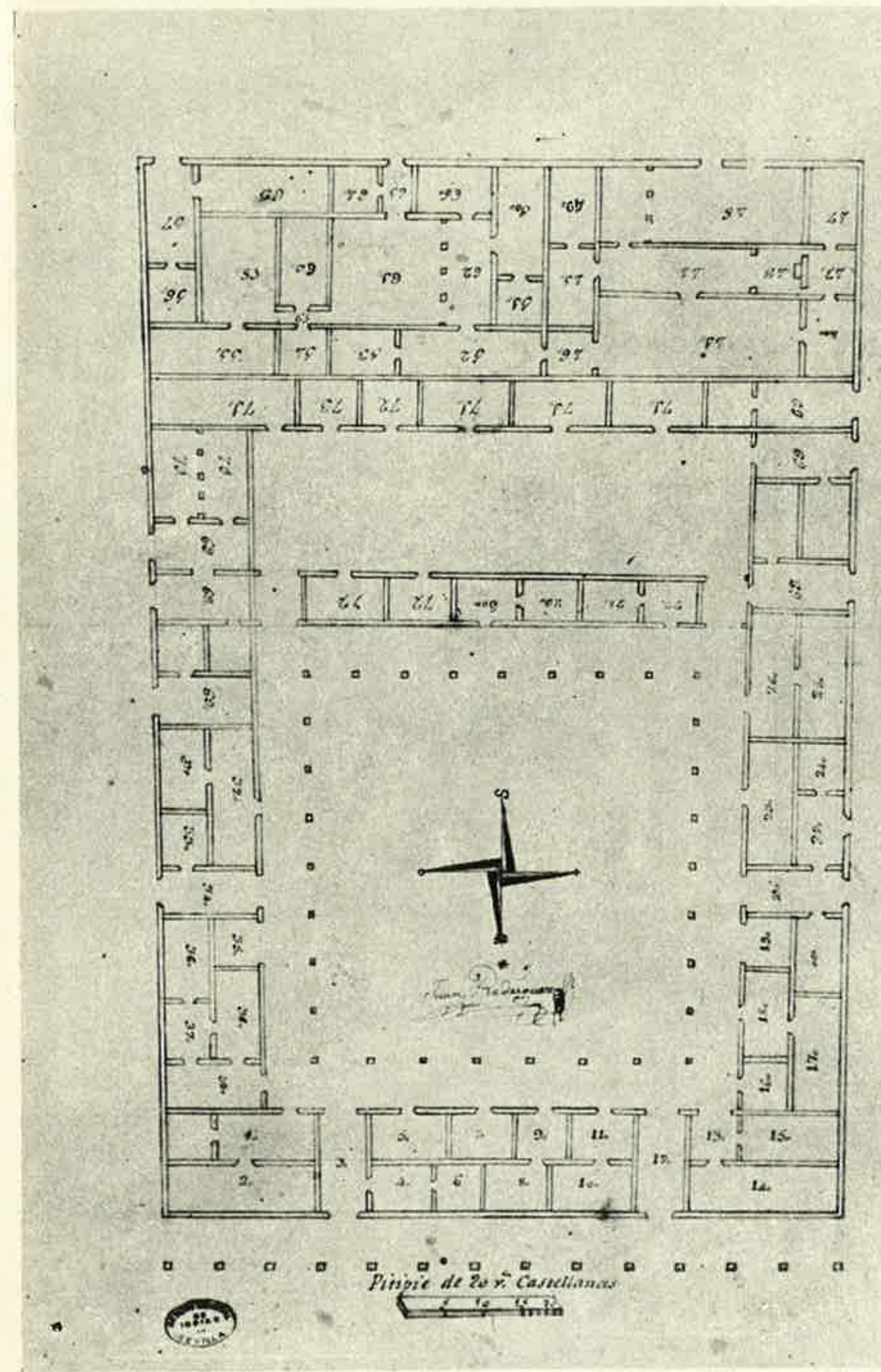

124. Planta del edificio de la Intendencia y oficinas reales de Durango, por Rodriguez. 1786. 


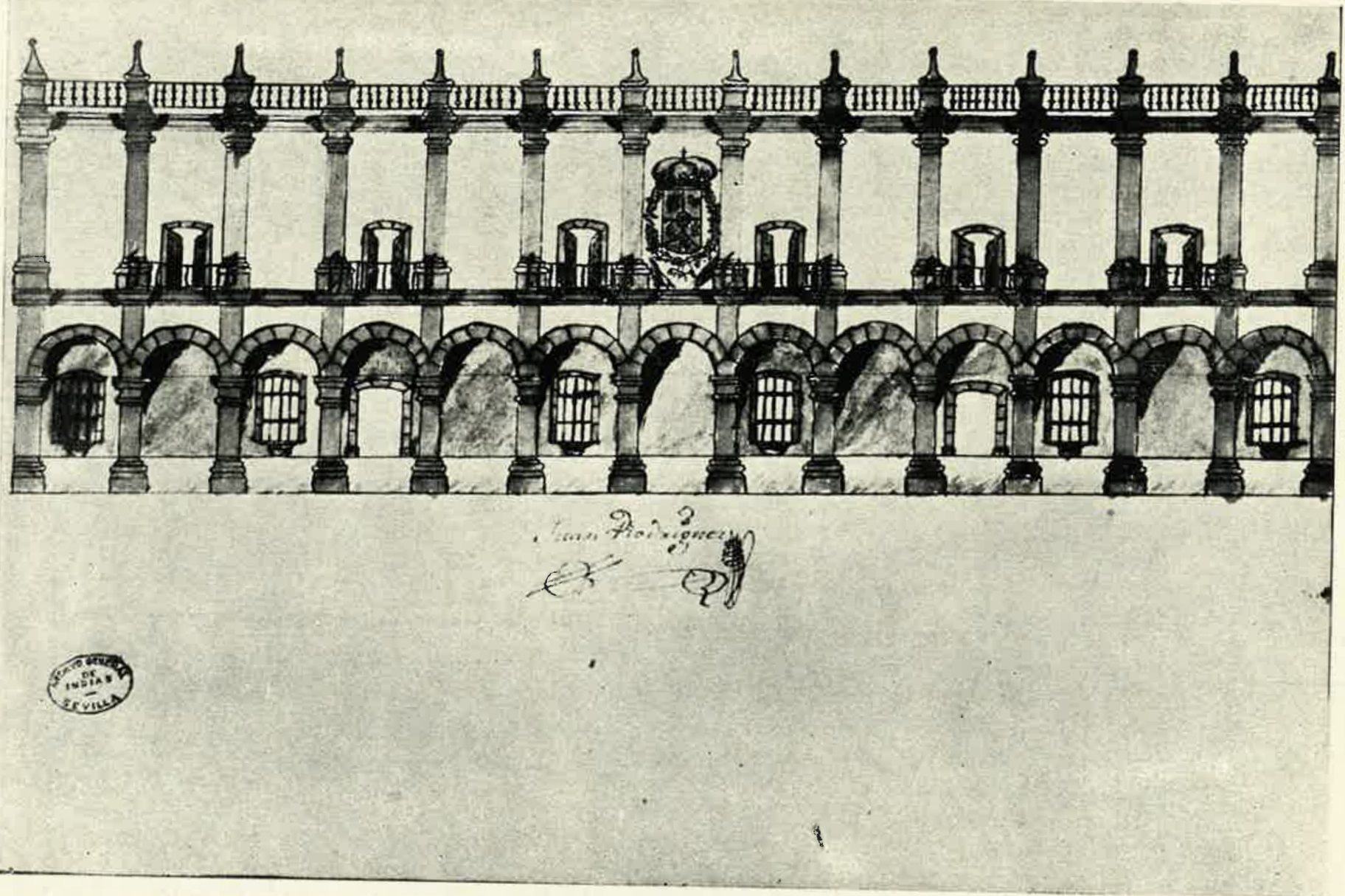




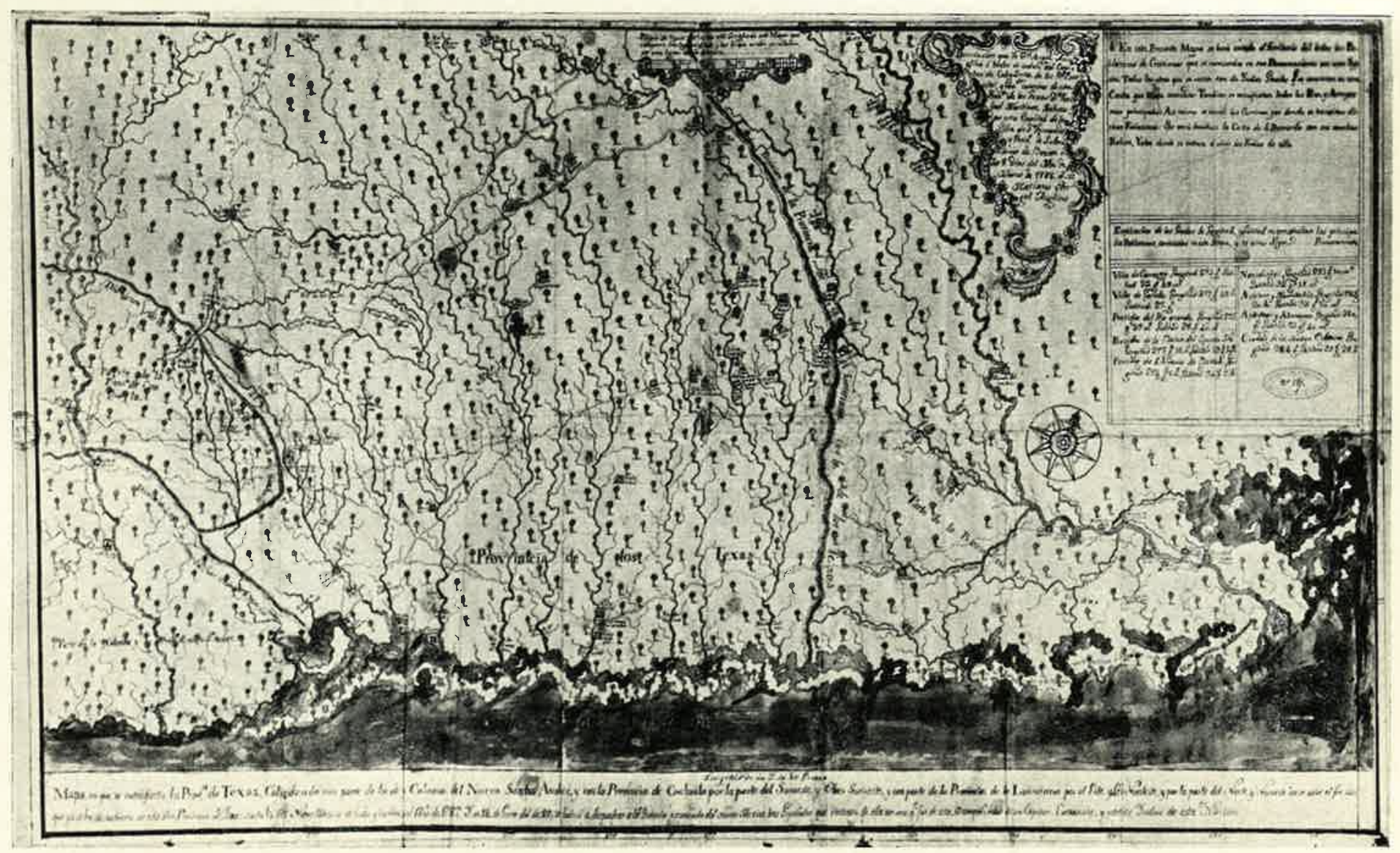

126. Mapa de Texas, por Anglino. 1788. 


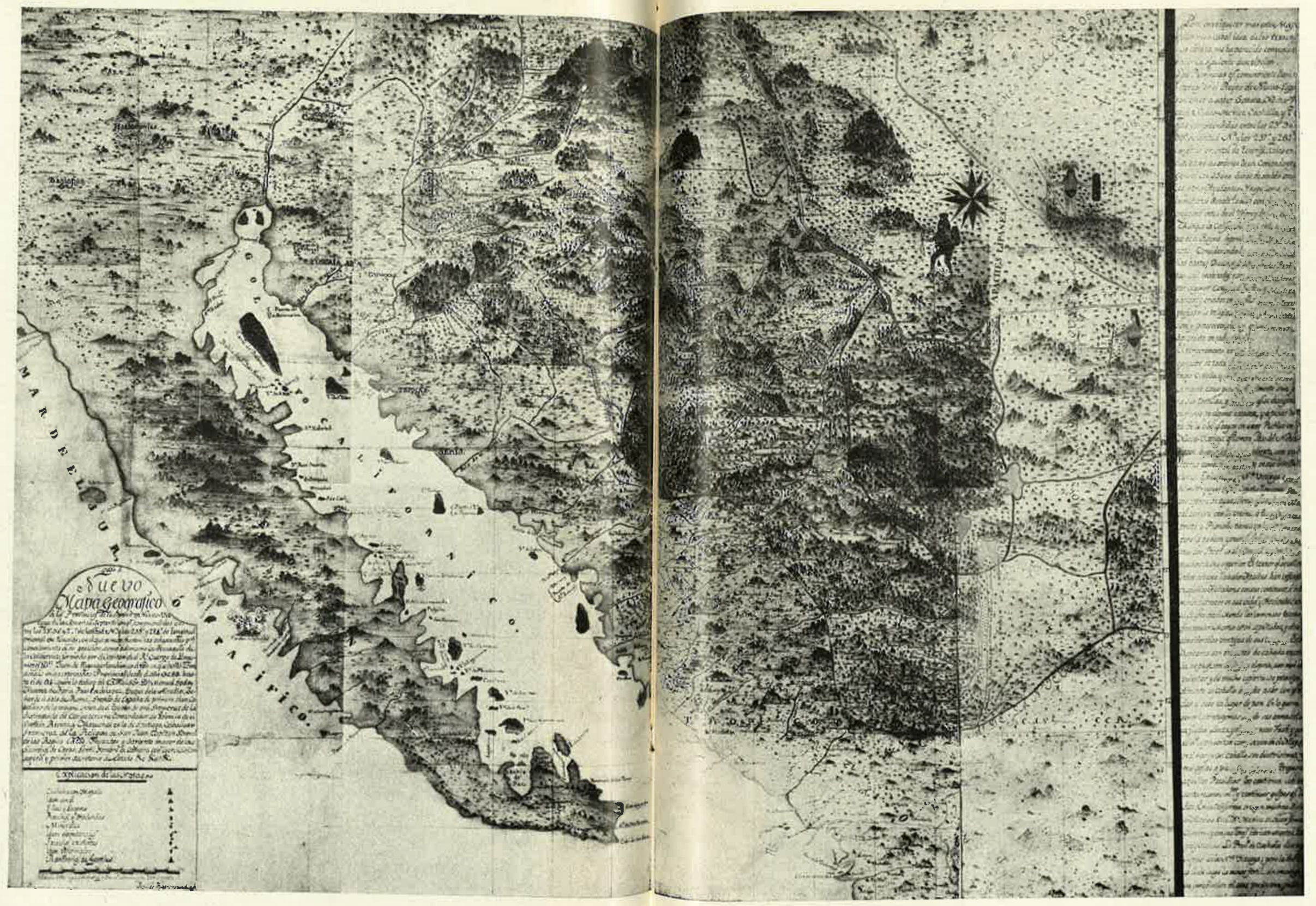

127. Baja California, Sonora y Nuevil Vizalya, por Pagazaurtundúa. 1803. 


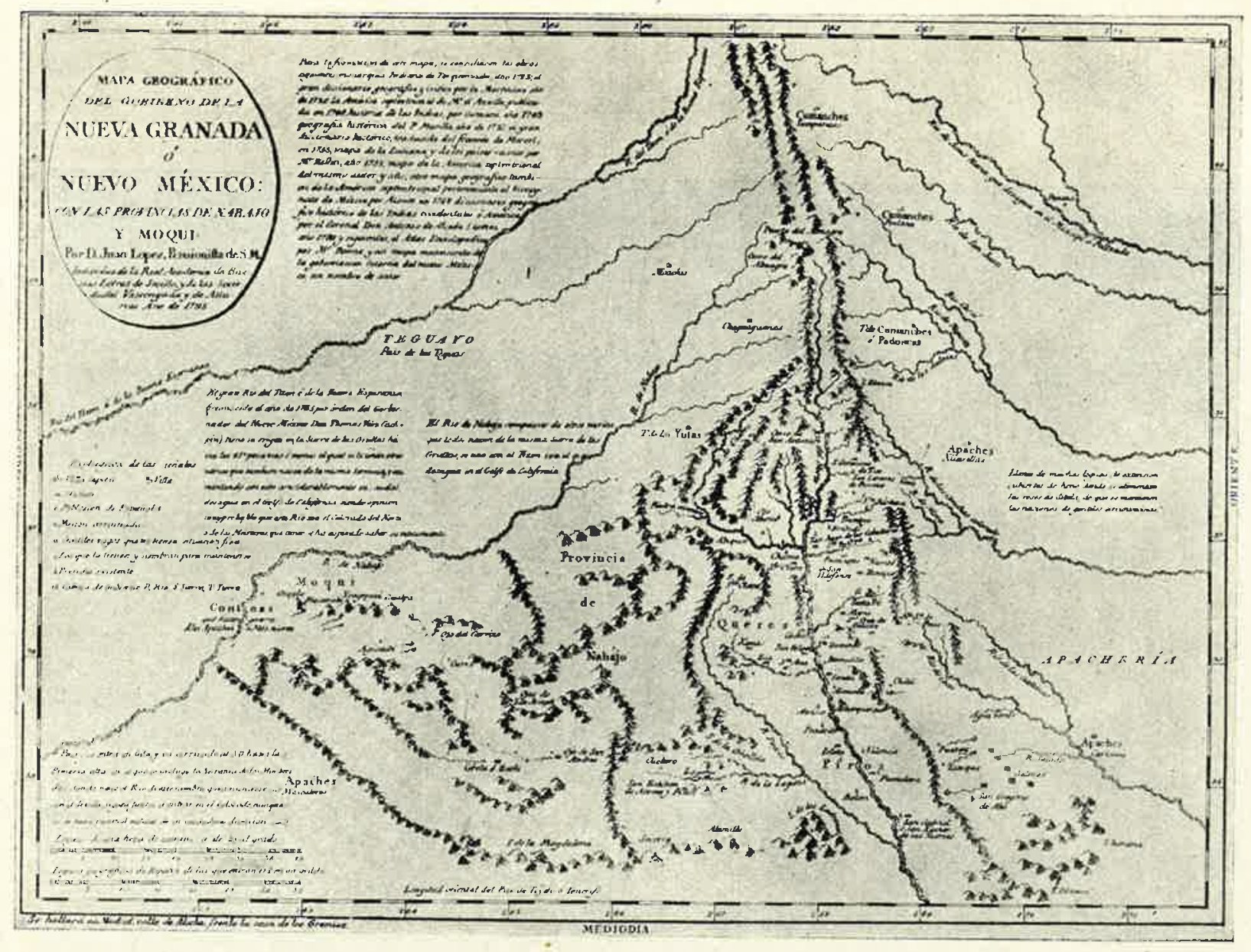

12n. Narvo Míxion, por Tomás Liper. 1795. 


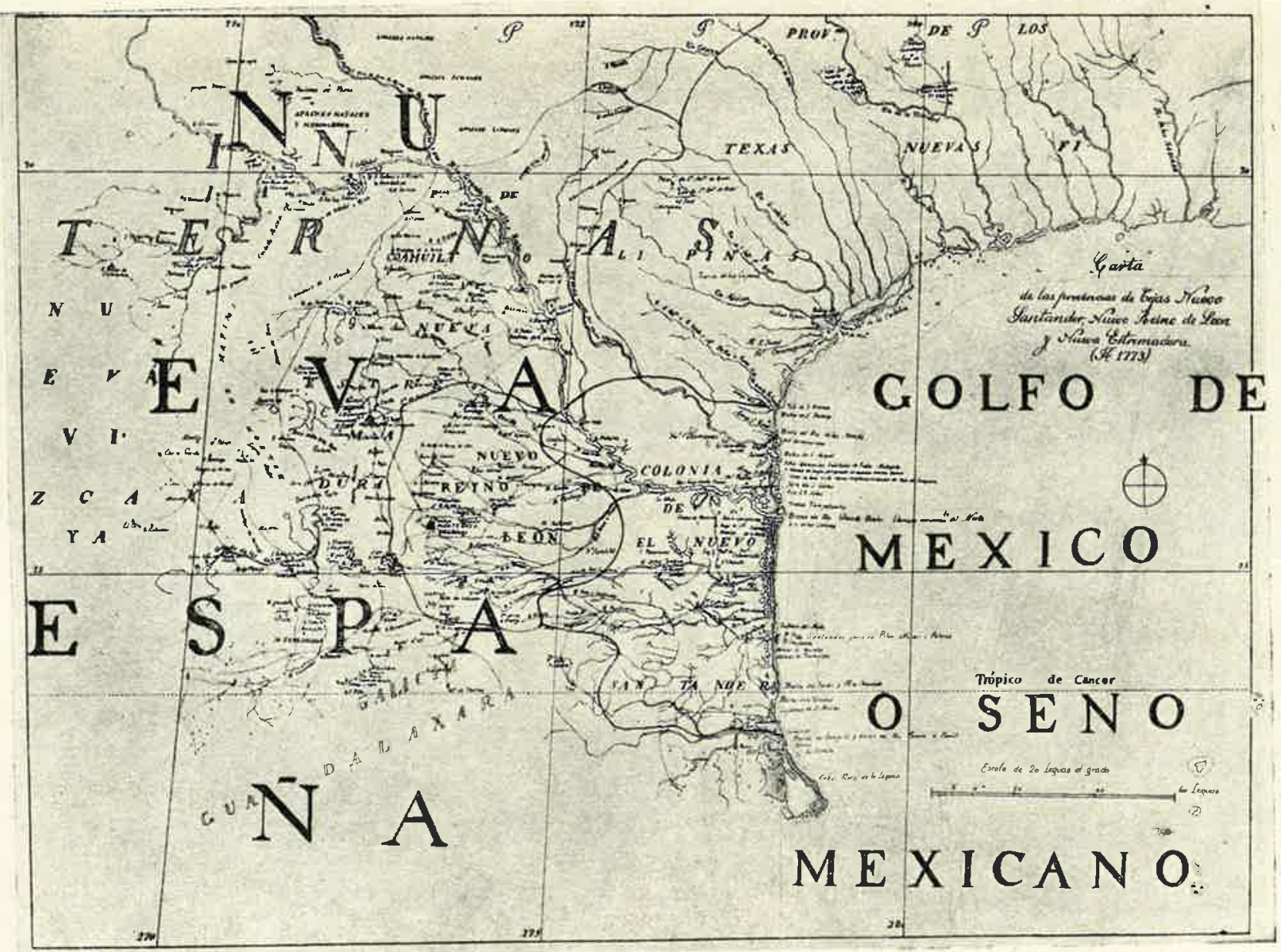

129. Mapa de las provincias internas de Oriente. ¿1790? 


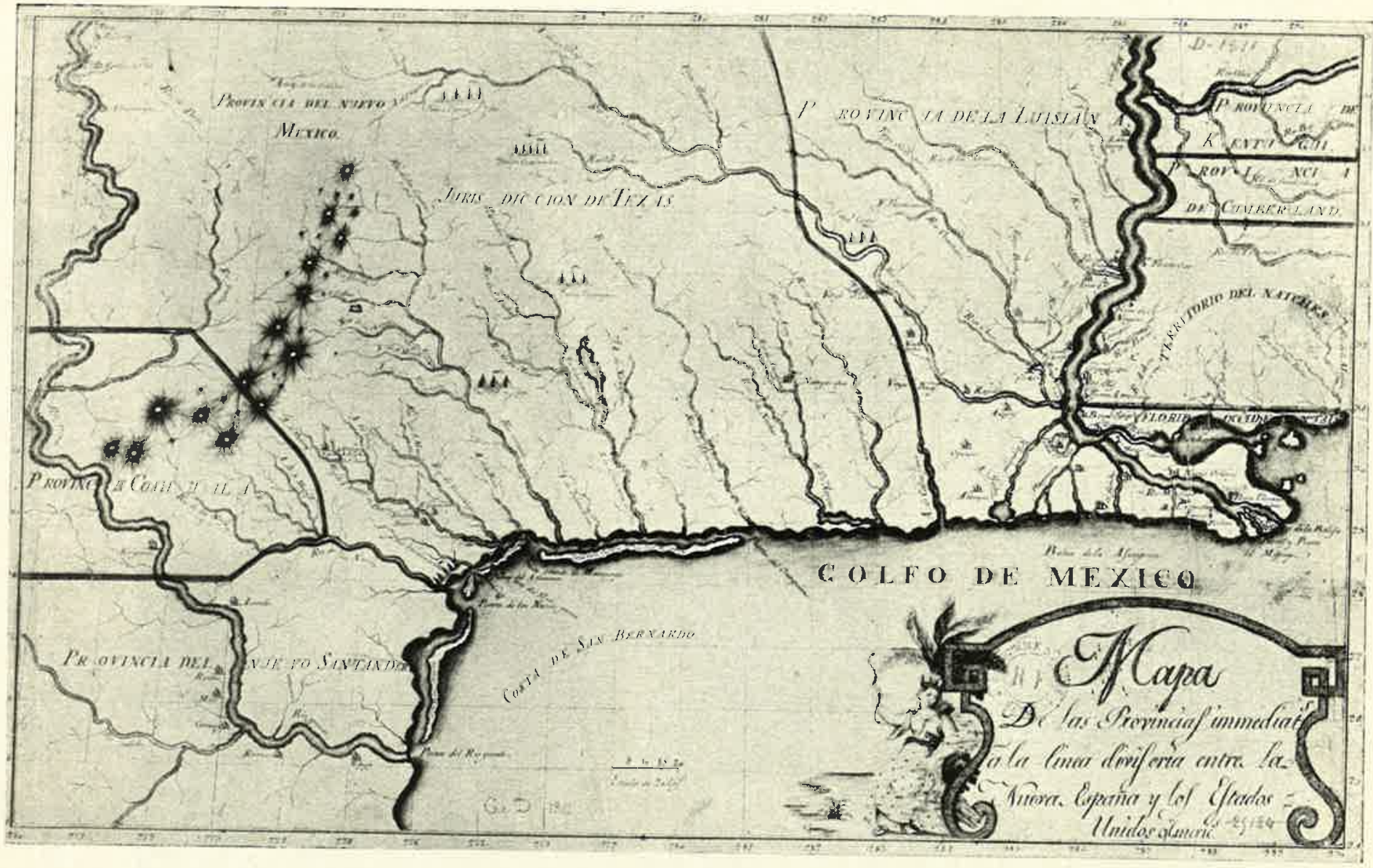

130. Mapar de los contines entre Nueva España y los Estados Unidos de América. 
daños habían padecido los pueblos y haciendas de este sector, mientras Coahuila sufría pequeñas sorpresas, hasta que el 4 de agosto se perdieron más de trescientos caballos de la Babia. Poco después se tomaba contacto con los comanches en este frente, pero como también aquí las resultas fueron favorables a las tropas españolas, Ugarte no sentía flaquear su confianza en una paz inmediata. En esta disposición de ánimo recibió la instrucción de Bernardo de Gálvez, y poco después la noticia del fallecimiento del joven virrey, por lo que creyó, como lo pensó la audiencia, recuperada la independencia original de la comandancia, ya que su título sólo le sujetaba al conde de Gálvez mientras éste se mantuviese en el virreinato, y en consecuencia se preparó a ordenar a Rengel y Ugalde se entendiesen directamente con él, que actuaría con la plenitud de facultades que había tenido el comandante general en tiempos de Croix y Neve, y a trasladarse a Sonora dejando a Rengel como comandante de las armas de Nueva Vizcaya, para ultimar las paces de los gileños, después de lo cual acudiría a la provincia que más necesitase su pre. sencia. ${ }^{80}$ Esta es la mente de Don Jacobo de Ugarte al fin de $I 786$.

\section{¿LA PAZ LOGRADA?}

Cuarenta años han transcurrido desde el comienzo de las hostilidades de Chihuahua, cuando Ugarte puede anunciar que la paz ha sido restablecida. Esos cuarenta años han sido el tiempo necesario para que el desgaste sufrido en la lucha empuje a los apaches a proponer el cese de la guerra al más clemente de sus enemigos, y enemigo forzado, los españoles.

En 1787 la nación apache casi ha dejado de tener contacto con el núcleo setentrional de Nuevo México, y vive replegada en una débil discontinua franja paralela a los establecimientos españoles fronterizos de Sonora, Nueva Vizcaya y Coahuila. Si los comanches los precipitaron contra las provincias internas, tanto ellos como los yutas, navajos y naciones del norte han colaborado con los españoles en su destrucción. Cogidos en la tenaza y más débiles que cualquiera de sus adversarios, los apaches no tenían más disyuntiva final que darse a buen partido o sucumbir. Frente a los comanches, de su mismo o más bárbaro género de vida, y más numerosos y guerreros y mejor armados que ellos, sólo les cabía retroceder. Frente a los españoles, los destrozos causados a las provincias tampoco podían evitar su propio desgaste y debilitamiento: vivían, puesto que los robos motivo de la guerra eran su subsistencia, a costa de su propia vida.

80 Ugarte a Sonora. Chihuahua, 28 de diciembre de I786, núm. 53: A. G. I., Guadalajara, 521 y 287 . En 4 de enero de 1787 , núm. 54, avisa que también dejará a Rengel la comandancia de las armas de Nuevo México. A. G. I., Guadalajara, 287. 
La paz que disfruta Ugarte es completa por cuanto se ha conservado la ya antigua con las naciones del norte y Anza ha fortalecido o pactado las existentes con yutas, navajos y comanches. Y Ugarte puede decir que no hay precedentes del caso cuando el 30 de diciembre de i 786 hacen su entrada en Chihuahua, con el cordón de Nuevo México, doce comanches, de los que Tosacondata era el segundo del gran jefe Equeracapa; Encantime, uno de sus capitanes y Oxamaquea, Tomanaguare y Tahuchimpia, sus propios hijos. Ugarte los recibió solemnemente en presencia del cabildo, oficialidad y sujetos principales de la villa, y ellos le cumplimentaron en nombre de Equeracapa y de la parte de la nación comanche que éste mandaba. ${ }^{8} \mathrm{I}$

A fines de febrero, Ugarte anunciaba que no había motivo para clar parte de novedades: los vasallos respiraban de las pasadas hostilidades, que habían cesado completamente en Texas y Sonora y minorado en las demás
provincias. ${ }_{2}$

Sus disposiciones antes de partir para Sonora versaban sobre la supresión de los arbitrios de milicias en Nueva Vizcaya, aunque provisionalmente, sustituyéndolos por un incremento del $2 \%$ en el impuesto de alcabalas que en la frontera sólo era de otro tanto, $s_{3}$ y sobre la liquidación del asunto de los reos de infidencia, vagabundos y gentiles. Ya sólo quedaban veintiún reos en la cárcel después que dieciseis fueron destinados como pobladores a San Jerónimo y Namiquipa y ctiarenta y uno a los obrajes de Chihuahua y Encinillas y por eso, poniendo en práctica la antigua idea de Neve, Ugarte proclamó el edicto de indulto general y ordenó al capitán Don Domingo Díaz ejecutase la visita de varios pueblos de la Tarahumara que ya el virrey ha-
bía dispuesto. ${ }^{84}$

El I 4 de marzo llegaba Ugarte a Janos, donde encontró a Don Domingo Vergara, entonces comandante de la compañía de ópatas de Bavispe, que había salido a recibirle. Tanto en Janos, como en Bavispe y en Bacuachi seguían presentándose las restantes rancherías de gileños - en el último lugar citado habíá ya más de cuatrocientos_- y el comandante general se proponía i1 reformando tropas conforme se fuera asegurando la paz, para tener fondos con que atender a los gastos del establecimiento de aquellos indios. $85 \mathrm{En}$ cambio, su entrada en Sonora provocó el recelo de los indios de que era para castigarlos, y parte de ellos volvió a fugarse a las sierras. ${ }^{86}$ Quedaron en

8I Ugarte a Sonora. Chihuahua, 4 de enero de 1787 , núm. 55. A. G. I., Guadalajara, 287.

82 Ugarte a Sonora. Encinillas, 28 de febrero de 1787 , núm, 74. A. G. I., Guadalajara, 286.

83 Ugarte a Sonora. Chihuahua, 31 de enero de 1787 , núm. 57 . Ibid.

84 Ugarte a Sonora. Chihuahua, $1^{\circ}$ de febrero de 1787 , núm. 58 . Ibid.

85 Ugarte a Sonora. Janos, 20 de marzo de 1787 , núm 75. A. G. I., Guadalajara, 287. dalajara, 287 . 
Bacuachi doscientos cincuenta y uno gobernados por Ysosé. El capitán Chiquito "en extremo supersticioso y agorero y de ánimo pusilánime" acaudillaba a los fugados. La paz no se hallaba aún plenamente fraguada.

Los mimbreños trataban paces en Janos, donde se esperaba a las rancherías de El Zurdo y Natanijú, mientras que los mezcaleros la solicitaban en el presidio del Norte, donde se presentaron ocho capitancillos, -llamados Alegre, Ligero, Patule, Zapato Tuerto, El Quemado, Montera Blanca, Cuerno Verde y Bigotes el Bermejo- faltando sólo dos - El Calvo y Natajépara el completo de la nación, que Díaz calculaba en tres mil almas. Díaz pronosticaba que estas paces, después de la guerra iniciada en tiempo de Croix, serían duraderas, y proponía se obsequiase a cada capitaricillo con dos caballos, "cosa que apreciarán mucho". ${ }^{87}$ En este punto fue de lamentar la campaña que Ugalde practicaba en el Bolsón a pesar de las noticias que tenía de la paz: para su desgracia atacó las rancherías mezcaleras sufriendo seis bajas y un prisionero. Ugarte empezó a alarmarse ante la actitud de Ugalde, mientras que Rengel trataba de trasladar los mezcaleros al pueblo abandonado de los Tiburcios a seis leguas de El Paso. También en San Eleazario y San Buenaventura se establecían paces. 88

Para residencia de los gileños de Bacuachi pensaba Ugarte en la abandonada misión de Santa María Suamca, a siete leguas de Nutrias, a donde se trasladaría este presidio. Había allí molino y acequias que hacían el lugar muy conveniente, y él mismo se dispuso a visitarlo. El número de los indios huídos de Bacuachi disminuía constantemente, ${ }^{89}$ y al mismo tiempo crecía a ochocientas o novecientas personas el de los mimbreños que con ocho jefes se habían establecido en el Valle de San Buenaventura. Dividíanse éstos, sin embargo, por haber todavía un grupo entre ellos que optaba por la guerra: con este motivo, el 2 I de mayo se produjo una conmoción al ser asesinados un intérprete, un soldado y tres apaches chiricahuis, dándose luego a la fuga los autores, cuya persecución inició el capitán Cordero. ${ }^{90} \mathrm{El}$ propio Ugarte se trasladó a Bacuachi, de donde partió Vergara, con ciento veinte hombres y diez chiricahuis auxiliares con los que logró hacer a los alzados ciento dos bajas, entre muertos y prisioneros, en las sierras del Cobre y de los Mimbres, mientras que Cordero les causaba veintiuna más y otras veinte les produjo un destacamento de Nuevo México. La campaña contra los alzados no pudo ser más fulminante, y la paz apache quedó garantizada en Sonora y Nueva Vizcaya al mismo tiempo que Anza ratificaba las paces con los comanches en

87 Ugarte a Sonora. Arizpe, I6 de abril de 1787 , núm. 77. A. G. I., Guadalajara, 287.

88 Ugarte a Sonora. Arizpe, I4 de mayo de 1787 , núm. 88. Ibid.

89 Ugarte a Sonora. Arizpe, I4 de mayo de 1787 , núm. 9I. Ibid.

90 Ugarte a Sonora. Bactuachi, 8 de junio de 1787 , núm. I04. Ibid. 
junta general de la nación que aclamó por general de todas las armas al cautdillo Equeracapa. Ugarte achacaba a algunas cuadrillas de forajidos tarahumaras los daños que aún se hacían sentir en Ostimuri en el interior de Sonora. 91

Asegurado de la paz interior, pensó el comandante general en temas que hacía tiempo cayeron en el olvido. Su primera preocupación en este sentido fue insistir en la creación del gobierno de Tarahumara, cosa que por otra parte parecía ya próxima, puesto que en el título del nuevo gobernador-intendente de Nueva Vizcaya don Felipe Díaz de Ortega, expedido en Aranjuez el 2 I de mayo de I 585 , se expresaba no extenderse su jurisdicción a la Tarahumara, "por haberla erigido S. M. en gobierno militar separado". Ugarte extrañaba tan sólo no haber recibido aún real orden alguna sobre el particular, y proponía a Borica para el nuevo gobierno. ${ }^{22}$

Aprobado estaba realmente por real orden de 16 de marzo de 1785 el proyecto de Audiencia en Sonora para las provincias internas, según lo presentara Neve. de modo que aquel tribunal se costease con el producto del estanco del mezcal. El comandante general espera que la erección se lleve a efecto y propone a Galindo Navarro para la regencia. 93 Del mismo mocio promovió Ugarte la creación de la casa de moneda, reclamando a la audiencia gobernadora de México los auxilios ya pedidos por sus antecesores. La fundación de la casa permitiría la de la caja de quintos prevenida desde I 782.94

Todos estos esfuerzos de Ugarte habían de estrellarse, sin! embargo, en el nuevo ministerio y en la nueva política a seguir en las provincias internas. Ugarte pensaba en este momento bajo la creencia de la unidad y autonomía de la comandancia: nada más erróneo que esta idea, que se vio destruida por la real orden de 20 de marzo de I787, que le sometió a las disposiciones del sucesor de Don Bernardo de Gálvez, Don Antonio de Flores, 95 quien a su vez resolvió la división de la comandancia general en dos, y su plena sumisión al virreinato.

LA DOBLE COMANDANCIA BAJO

EL VIRREY FLORES

La permanencia de la comandancia general sujeta al virrey, dispuesta por el mismo ministro Gálvez que había propugnado su independencia, hecho

9 I Ugarte a Sonora. Arizpe, 15 de julio y 14 de agosto de 1787 , núms. I Io y I 29 . Ibici,

92 Ugarte a Sonora. Arizpe, 14 de mayo de 1787 , núm. 89 . Ibid.

93 Ugarte a Sonora. Arizpe, 2 de junio de 1787 , núm. 98. Ibid.

94 Ugarte a Sonora. Arizpe, 2 de junio de 1787 , núm. 99 y 100. Ibid.

95 Ugarte a Sonora. Arizpe, I7 de setiembre de 1787 , núm. 149. Ibid. 
que está muy imperfectamente documentado, muestra hasta qué punto el fracaso en una serie de puntos básicos del plan propuesto - expansión al noroeste, autonomía hacendística y judicial, aminoramiento de los gastos de presidios y compañías volantes, etc. - había conducido a la crisis de la idea de aquel cuasi-virreinato del norte de Nueva España en la misma mente de su creador.

El virrey Flores, por otra parte, acredita la total inoperancia y la difícil aplicabilidad de la instrucción formulada por su antecesor Don Bernardo de Gálvez. Rengel se había mantenido inactivo en El Paso aún desptés de haber pasado Ugarte a Sonora, y últimamente se había trasladado a revistar las tropas de Nuevo México. Ugalde había hecho una campaña de siete meses contra los mezcaleros, que al fin se refugiaron en los presidios de Nueva Vizcaya pretextando paces. ${ }^{6} \mathrm{Ya}$ el mes anterior, en dos cartas de 23 y 27 de rctubre de 1787 , cuando empezaba a informarse del estado de la frontera - para lo cual hizo formar un plano nuevo corregido- pensaba que los 3.639 hombres que se contaban sobre las armas debían ser suficientes para guarnecer las provincias. En cuanto a su propia competencia para dirigir las operaciones, asienta ingenuamente: "Alguna cierta confianza me ofrecen mis antiguas experiencias adquiridas en Buenos Aires y en el virreinato de Santa Fe del carácter de los indios bárbaros, de su modo de hacer la guerra y de la mala fe que guardan en sus paces, pues todo esto según hasta ahora he comprendido tiene mucha semejanza con los procedimientos de los gentiles enemigos de las provincias internas de Nueva España". Creía bueno combinar la paz y la guerra, pero prefiriendo ésta de modo que siempre hubiera destacamentos fuertes en la tierra de los bárbaros. También deseaba encender los ánimos abatidos de los pobladores, "y esto - dice- no lo podré conseguir si los comandantes no van por delante en los ataques a los indios. Ugalde es el único que ejecuta esto, y así se ve el efecto. Es un oficial acreditado en ese ejército y sabe aguantar lo que otros sus iguales no podrían sufrir en esta guerra de los indios. Un gran general de Europa, con seis $u$ ocho mil hombres veteranos se perdería en aquella frontera por las inclemencias, las escaseces y demás trabajos anejos a los países incultos. Esta es una guerra de tropas ligeras pero acostumbradas a aquel país, y así es mejor formarlas de aquellos habitantes, que es lo que sabe hacer Ugalde, manteniéndose por las montañas muchos meses seguidos. Los comandantes que hay y ha habido han salido a campaña, pero al mes se han vuelto a sus pueblos con los caballos cansados y otros pretextos. Los indios, que saben ya en lo que ha de venir a parar, huyen, se embreñan y luego que se ha retirado la

96 Flores a Valdés. México, 23 de noviembre de 1787 , núm. 32. A. G. I., Guadalajara, 390 
tropa clel campo vuelven a hacer sus correrías. De esto resulta que nuestras tropas no conocen las retiradas de los indios, y estos hacen burla de ellas. Ugalde, con los mismos caballos y auxilios que tienen los otros comandantes, busca a los indios en sus madrigueras, y si todos hicieran lo mismo se habían de ver precisados los enemigos a bajar el orgullo, porque tienen poco país a donde huir sin encontrar óros indios enemigos suyos a quicnes temen más que a los españoles". 97 Ește injustificado encomio de Ugalde, que al cabo había de desmerecer en el concepto de Flores, da la pauta a seguir por este virrey en los años de su mandato. Pero veamos ante todo la manera en que reorganizó las provincias fronterizas.

A juicio del nuevo virrey, era importante que un solo comandante general atendiese a todas las provincias, comprendiendo que la división tripartita, tal como había sido concebida, acarreaba innecesarias complicaciones. Por consiguiente, decidióse a decretar la división de todas las povincias internas inclusas las de Nuevo León y Nuevo Santander en dos comandancias generales, "tomando en este punto la posible y mejor parte de la proposición que hizo al rey el Excelentísimo Señor Don Teodoro de Croix", y disptiso en 3 de diciembre de 1787 que desde $\mathrm{r} .{ }^{\circ}$ de enero del año siguiente Ugarte gobernase las cuatro provincias del poniente, y Ugalde las del oriente. Los ocho artículos del decreto relativo a Ugarte indican que a su jurisdicción corresponderían California, Sonora, Nuevo México y Nueva Vizcaya, y que conservaría su sueldo, asesor y secrelaría, teniendo a sus órdenes a Rengel y dos de los tres ayudantes inspectores. No tendría Ugarte domicilio fijo, pero se señalaba como muy importante en el momento sti residencia en Chihuahua, desde donde prepararía incesantes campañas contra los enemigos, encargando a un oficial de confianza el cuidado de los apaches de paz.

La comandancia oriental, cuya divisoria con la de Poniente se señala en el río Aguanaval, la desempeñaría Ugalde, con seis mil pesos de sueldo, siendo su mando puramente militar, sin intervención en lo polííico y económico, ni en los asuntos de justicia, hacienda y patronato, pues todas estas funciones quedarían a cargo de los gobernadores e intendentes. Ugalde sería al mismo tiempo inspector de las tropas, con un ayudante inspector a sus órdenes. En toda su jurisdición de Coahuila, Texas, Nuevo Reino de León, Nuevo Santander y distrito de Saltillo y Parras tampoco Ugalde tendría domicilio fijo, dehiendo ocuparse exclusivamente del estado de la tropa y de la gucria y paces con los indios. Flores cree, en fin, que debe haber correspondencia y acuerdo entre los dos comandantes generales para strs operaciones. 98

97 Flores a Valdés, núm. I y y sin núm. reservada. México, 23 y 27 de octubre de 1787.
G. S., Guerra Moderma 7041 .

9s Decreto del virrey Flores. México, 3 de diciembre de $x>87$. A. G. I., Guadalajara, 390. 
Una real orden de i I de marzo de I 788 hizo extensivas al nuevo virrey las facultades que tuviera Bernardo de Gálvez, declarándoselas amplias y a.bsolutas respecto de las provincias internas, que se supone requieren providencias muy urgentes y ejecutivas, de modo que el virrey quedaba autorizado para trasladar los puestos fronterizos y los jefes y subalternos y para reforzar, aumentar o remover las tropas. 99 Tres meses después tenía lugar una alteración interesante, al suprimirse el gobierno de Texas - para el que Ugarte había propuesto a Don Juan Bautista de Anza- que en adelante sería encomendado a un capitán de las compañías presidiales, según el mismo Flores había propuesto en febrero, movido por su afán de economizar los fondos del real erario. ${ }^{100}$ Entre estas dos órdenes, otra de I I de nayo de i 788 aprobó la división de la comandancia dispuesta por el virrey. ${ }^{10 I}$

La perspeciva que de los asuntos de la frontera tenía Flores se hallaba muy desdibujada por la misma oposición de los informes que recibía de los dos jefes supremos de las provincias. El levantamiento de los apaches de $\mathrm{Ba}$ cuachi, la reanudación de las expediciones punitivas al Gila le hacían ver como fracasada la paz intentada en Sonora; y aunque Ugalde había establecido alianza con lipanes y lipiyanes, los mezcaleros estaban de guerra con este general, e indios de dentro y de fuera destrozaban Nueva Vizcaya. A juicio del virrey, los apaches habían tenido siempre todas las ventajas en la paz y en la guerra. "El frecuente y amistoso trato con los españoles ha convertido su inocencia o barbaridad en la más ilustrada malicia". Esta roussoniana frase se contrapesa con otra más real: "Su miseria, su necesidad, su alevoso vengativo carácter y la persecución de nuestras armas los han hecho fuertes guerreros y astutos ladrones sanguinarios obligándonos a multiplicar defensas". En definitiva, Flores se inclinaba, a mediados de 1788 , por la vía de la guerra, es decir, por el criterio de Ugalde. Se proponía combatir a los apaches "hasta que el terror los obligue a rendirse a discreción... sin las dislinciones contenidas en varios artículos de la instrucción formada por el conde de Gálvez. El comercio con los miserables apaches - continúa-- es inasequible, porque el mezquino cambalache del corto número de sus peleterías no puede alcanzar al remedio de sus necesidades, ni trae cuenta a los vasallos del rey, de modo que su real erario había de sostener este comercio, o mejor

99 Flores a Ugarte. México, 17 de julio de 1788 . Ibid.

100 Real orden de 19 de junio de 1788. A. G. I., Guadalajara, 302 y México, I974. Flores, poniendo en práctica su idea, habia hecho quedar como corregidor de México a Don Bernardo Bonavia, que pasaba a Texas como gobernador, y fuc esta decisión lo que se le aprobó en la orden citada.

I 0 r Flores a Valdés, núm. $53^{6}$ reservada. México, 29 de agosto de 1788 . A. G. S., Guerra Moderna 7041. 

dicho, mantener a los indios a costa de grandes gastos”, y esto sin garantía
de paz.

Flores se declara refractacio a toda tentativa de semejante paz. "La tenemos hoy, contra mi opinión, con los apaches lipanes y lipiyanes en Coahuila, con los jicarillas en el Nuevo México, con los chiricahuis en Sonora y aún hay quien pretenda que la tengamos también en Nueva Vizcaya con algunas rancherías de los mezcaleros". "No he convenido en esto último, y a mi pesar condesciendo con las demás". Siendo discordantes los informes de Ugarte y Ugalde, "persuaden unos la utilidad de la máxima prevenida en los artículos 34,42 , 50 y 53 de la instrucción del Conde de Gálvez, que consiste en empeñar los indios de una misma nación a que se ofendan y destruyan recíprocamente, y otros prefieren la mala paz que indica el artículo 29 a los esfuerzos de una buena guerra". Pero el virrey ya había tomado partido: "Estén las provincias como estuvieren, no he hallado fundamento que convenza las ventajas de esta segunda náxima, y he dispuesto que no se siga", aparte lo cual, tampoco estaba muy convencido de la primera. "Debería mandar - dice al ministro - que se hiciese la guerra a toda la apachería sin distinción", evitando así que unos indios, bajo el nombre de lipiyanes gozasen la paz en Coahuila, mientras con nombre de natajes asolaban Nueva Vizcaya; pero aquella medida radical no sería adoptada "hasta que las primeras resultas aclaren mis dudas".

Sus órdenes, por el momento, empujaban a Ugalde a hacer guerra dura a los mezcaleros hasta reducirlos o exterminarlos con ayuda de lipanes y lipiyanes; mientras que conminaban a Ugarte a que, con ayuda de Rengel desde Sonora, atacase a los gileños auxiliado por los chiricahuis amigos. Se trataba de probar la consistencia de estas alianzas: "Y ningún indio de la generación apache será admitido de paz ahora ni después en la provincia de Nueva Vizcaya." En cuanto a los comanches e indios del norte, la paz sería mantenida. ${ }^{102}$ Pero los propósitos belicistas de Flores contra los apaches eran tan claros que en agosto de I788 había dispuesto que el Regimiento Fijo de Dragones de España, habitualmente acuartelado en la capital del virreinato, se trasladase a Durango, para tener un cuerpo respetable de tropa veterana pronto a acudir adonde fuese preciso. Calculaba mantener la plana mayor del regimiento en Durango y destacar compañías a los pueblos cabeceras hasta el Nazas y, si hacía falta, hasta la frontera septentrional de la provincia. Todo ello debería contribuir a mantener en quietud a los tarahumaras. Por supuesto, el entonces obispo Don Esteban Lorenzo Tristán y el

I03 Los tres párrafos precedentes se basan en carta de Flores a Valdés, núm. 390. Mé xico, 24 de junio de I788. A. G. S., Guerra Moderna 704 I. 
gobernador intendente Don Felipe Díaz de Ortega estaban más que satisfechos con esta iniciativa del virrey, y el segundo había ya señalado cuartel - el edificio de un obraje que no había podido entrar en funcionamientoe indicado la conveniencia de poner compañias de dragones en San Juan del Río, Papasquiaro, Cuencamé y Cinco Señores. El Regimiento debía partir hacia Durango en septiembre. ${ }^{103}$

La verdad era que, si bien se experimentaban hostilidades en casi todas las provincias, los daños causados no eran excesivamente importantes. En más de veinte meses transcurridos entre el ig de abril de r 786 y el 3 I de diciembre de $\mathrm{I} 787$, los partes de Ugarte sólo daban trescientas seis muertes hechas por los enemigos, más treinta cautivos, cifras que para las cinco provincias continentales dan un muy escaso índice mensual de pérdidas y se hallaban además sobradamente compensadas con las bajas hechas en el mismo tiempo a los contrarios: trescientos veintiséis muertos y trescientos sesenta y cinco prisioneros, aparte de veintitrés cautivos que les habían sido tomados y rescatados. Desde luego, la mayor crudeza de la lucha tenía lugar en Nueva Vizcaya, que sufría doscientas treinta y siete de las bajas propias, y el perjuicio más considerable se experimentaba, como siempre, en los ganados, pues de casi cuatro mil bestias y reses robadas en aquel tiempo en toda la frontera, menos de la mitad habían sido recobradas. ${ }^{104}$ Las grandes batidas al Gila desde Sonora, mandadas por Vergara, Mata Biñolas, Romero y Sáenz Rico, y desde Janos por Cordero, no dieron grandes frutos. Don Domingo Vergaזa moriría a principios de 1788 , de muerte natural, y en este año seguirían sintiéndose entradas de tarahumaras enemigos en Ostimuri, y daños de éstos, de los mezcaleros y de los gileños en el interior y en la periferia de Nueva Vizcaya. Mención especial merece la campaña que, después de haber revistado en octubre de $\mathrm{I}_{787}$ el presidio de Santa $\mathrm{Fe}$ - que no se revistaba desde que lo hizo Rubí, veintiún años atrás-, dirigió Rengel con trescientos cuarenta hombres, inclusos los auxiliares jicarillas y comanches, mandados éstos por Equeracapa, contra los apaches del sudoeste del Moqui. ${ }^{105}$

Regresado Rengel de Nuevo México, Flores, según su plan, lo destinó a mandar las armas de Sonora con los mismos ocho mil pesos que venía

I03 Flores a Valdés, núm. 524. M'éxico, 28 de agosto de 1788. A. G. S., Guerra Moderna 6956. El virrey tuvo la aprobación en real orden de 22 de febrero de 1789 . Ibid.

I04 Ugarte a Valdés, núm. I69. Chihrtahua, 3 de julio de 1788. A. G. S., Guerra Mo derna, 7042 .

105 Ugarte a Valdés, núm. 170. Chihuahua, 3 de julio de 1788 , con cinco Extractos desde noviembre anterior. A. G. S., Guerra Moderna 7042. Revista de Rengel a la compañía de Santa Fe, 5 y 16 de octubre de 1787 , en A. G. S., Guerra Moderna 7047. Romero entró a mandar Tuoson al pasar Allande al Regimiento de Dragones de México; Sáenz Rico, que ya había ma11dado el presidio del Pitic, entró al de Altar al cesar Arias Caballero. 
gozando, pero en verdad el virrey pensaba que tanto Rengel como Ugarte eran innecesarios en la frontera y debían regresar a España; para el segundo, no había en México empleo proporcionado a su mérito, y en cambio Flores lo consideraba inepto para el desempeño de la comandancia general, y mal invertidos los veinte mil pesos de su sueldo cuando, teniendo el virrey el gobierno de las provincias internas, los dos comandantes debían ser meros jefes militares con ocho mil pesos. Sobre este principio, Filores se atrevía en agosto de 1788 a proponer nuevas modificaciones en la esiructura de las comandancias, sugiriendo la supresión de la intendencia de Zacatecas, cuyo territorio se dividiría entre las de Durango y Potosí; y la restructuración de la comandancia occidental en dos provincias "civiles", con intendentes en Rosario y Durango, y dos gobiernos político-militares en Arizpe y Chihuahua (Tarahumara), dependientes éstos de acuéllos en lo tocante a gobierno, y del comandante en lo tocante a guerra. También podía suprimirse el aytdante inspector de California, y en total, sobre un pie que él consicieraba más eficaz, aún se ahorrarían en el arreglo de los cuadros administrativos de ambas comandancias más de dieciséis mil pesos anuales.

Pero como al mismo tiempo Flores no vacilaba en asegurar que la erección de la comandancia general había sido una idea mity cuerda por la imposibilidad de que el virrey atendiese aquellas remotas provincias, tampoco dejaba de sugerir un camino para la reunificación de las provincias en manos de un mariscal de campo, con sede en el Valle de San Bartolomé, con solo cierta dependencia de México en asuntos de real hacienda y de guerra y con plena autonomía respecto del virrey en lo político, económico y judicial, y aun "con la apreciable lisonjera esperanza de sucederle en el virreinato". Esta innovación, rebajados los dos comandantes a subordinados del mariscal, no sería demasiado gravosa y Flores la contemplaba ya muy necesaria, hasta el punto de insinuar gue tal vez se viera en la precisión de introducirla antes de tener la aprobación del rey: en tal caso, es claro que pensaba poner a Ugalde como comandante de Poniente y a Don Manuel de Flon -entonces intendente de Puebla - en la comandancia oriental, sin que se indique el posible nuevo jefe supremo. ${ }^{106}$

En cambio, respecto de las tropas, Flores adoptó el criterio de reducir efectivos, en beneficio de la tropa restante, pues no se reducirían los situados. En las cuatro provincias orientales había habido mil trescienios cincuenta y nueve hombres, que Ugalde rebajó a mil ciento veintiocho, y que costaban trescientos sesenta y tres mil setecientos ochenta pesos al año. Iо E En palabras

rob Flores a Valdés, núm. 536 reservada. M'éxico, 29 de agosto de i 788 , con Extractos de
gastos. A. G. S., Guerra Moderna $704 \mathrm{I}$. I 7 Flores a Valdés. México, 26 de doril de 1789 , núm. 949. A. G. I., Guadalajara, 390.

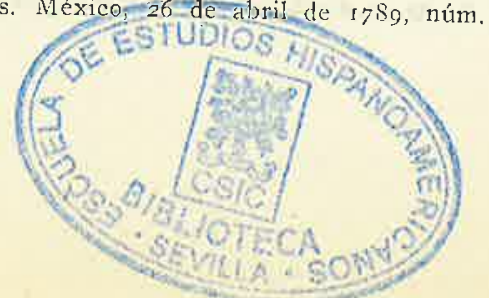


de Ugarte, en las provincias orientales, aun con la reducción, seguía siendo mayor el número de soldados que el de enemigos, que sólo lo eran los mezcaleros, cuyas fuerzas no pasaban de cuatrocientos hombres de armas. Por el contrario, en Sonora, Nueva Vizcaya y Nuevo México no era posible realizar la reforma de una parte de las tropas, y sin embargo parecía conveniente mejorar los prests y pagas de todas y aumentar cuarenta plazas a las tres compañías de indios de Sonora, suponiendo todo ello un recargo de cerca de ciento cincuenta mil pesos al situado anual de la comandancia occidenta1. ro8

Ugarte era, desde luego, el mayor enemigo de las reformas implantadas por el virrey, que, a su juicio, habían hecho imposible un plan general de pacificación, en perjuicio de las vidas y haciendas de los vasallos. Al parecer, Ugarte alude siempre a la impolítica actitud belicista de Ugalde, que había conducido a una reanudación de la guerra. De todos modos, las tropas de la comandancia del poniente habían causado al enemigo, desde que Ugarte tomó el mando, casi mil trescientas bajas entre muertos y prisioneros, ${ }^{\text {rog }}$ siendo así que Flores le había quitado el uso libre de cuatro compañías de la frontera oriental de Nueva Vizcaya, para hacerlas maniobrar a las órdenes de Don Juan de Ugalde. Ugarte sentía en el alma la parcialidad del virrey, la "ciega deferencia" con que Flores se plegaba al criterio de Ugalde, contra su mérito y experiencia, pues ya "en todo - escribe el comandante occidental- he servido más de dieciocho años en estas provincias internas, y no sólo he visto en este tiempo las situaciones de casi todos los presidios, sino también conozco a sus oficiales y a la mayor parte de los soldados por sus nombres, apellidos y circunstancias". ${ }^{\text {1 }}$

De I786 a I790, Ugalde imprime realmente a la historia de las provincias internas de Oriente un giro espectacular lanzándose a una serie de campañas y alianzas, desorbitadas unas y otras, y que rompen, además, la línea política que de manera más o menos impuesta por las circunstancias venían trazando los comandantes generales para conseguir la pacificación general. A Bernardo de Gálvez toca la responsabilidad de haberlo reincorporado al servicio de la frontera y en un puesto de mayor importancia que aquel del que piadosamente lo había destituido el Caballero de Croix. Con Ugalde, como su fiel amigo de antaño en intrigas y desgracias, y como gobernador interino de Texas - en sustitución de Cabello, que pasaba al empleo de te-

I08 Ugarte a Valdés. Chihuahua, I2 de junio de I789, núm. I9I. A. G. I., Guadalajara, 4.26 y A. G. S., Guerra Moderna 7019.

I09 Ugarte a Valdés. Chihuahua, 12 de junio de 1789 , núm. I, reservada. Ibid.

iro Ugarte a Valdés, Chihuahua, i 2 de jurnio de 1789 , núm. igr. A. G. I., Guadalajarn, 426 y A. G. S., Guerra Moderna 7019. 
niente de rey en La Habana-, reaparece también en nuestra escena el capitán don Rafael Martínez Pacheco, al que Don Teodoro había hecho retirar a Durango. ${ }^{\text {IIr }}$ Por los mismos días en que el conde de Gálvez rehabilitaba a Ugalde y Martínez Pacheco, Tueros, como gobernador de Coahuila, lograba un importante éxito al poner en campaña al teniente comandante de Aguaverde Don José Menchaca al frente de doscientos veintiséis hombres en busca de los mezcaleros, cuyas huellas se dirigían hacia los Arenales, paraje muy distante de la provincia, donde se decía que aquellos indios se habían fortificado. Aprovechando que las recientes lluvias, después de dos años de sequía, habían restablecido a la caballada, Menchaca partió el 28 de septiembre de I786. $\mathrm{E} 1$ I. ${ }^{\circ}$ de noviembre encontró abandonado el fuerte enemigo, construido con ramas y arena: no le fue difícil desbaratarlo. El 7 , en cambio, por la mañana, fue atacado por más de trecientos comanches, mandados por Camisa cle Hierro, también llamado Cota de Malla, uno de los jefes principales de los cuchanec orientales que habían hecho la paz en Béjar. En el encuentro murió este caudillo con cinco de su nación. Los otros se retiraron y alzaron una bandera blanca con la cruz de Borgoña, y así se produjo una aproximación pacífica. Los comanches declararon que Cota de Malla era el único jefe partidario de atacar a los españoles para coger caballada. Desaparecido este obstáculo, la tropa india prefería entrar en relaciones anistosas y se retiró contenta después de hacer un cambalache de objetos con los españoles y entregar la bandera. Once días después, siguiendo por el río Puerco, tuvo Menchaca otro encuentro con un grupo apache al que hizo veinticinco muertos y prisioneros. 112

E1 23 de septiembre de I 786 había salido el coronel Ugalde de México para su nuevo y mejor destino. El ex corregidor de Cotabamba y auxiliar militar de la expulsión de los jesuitas de Chile se prometía reverdecer los laureles de las cuatro campañas realizadas durante su mandato en Coahuila de $I 777$ a 1783 , en las que había consumido doce meses y veintiún días, caminando dos mil trescientas una leguas, aunque con tan pobres y aun funestos resultados como ya había escrito Don Teodoro. Sin embargo, la rehabilitación de que le hiciera objeto el conde de Gálvez había de ser parte para que por real orden de 9 de mayo de $I 787$ se considerara acalorada e injusta la decisión del Caballero. Entre tanto, apenas llegado el ro de octubre de i 786 a la hacienda de Patos, por donde entraba a su jurisdicción, da órdenes para

III El aviso del nombramiento de Martínez Pacheco, en B. de Gálvez a Sonora, núm. 909. México, 25 de setiembre de 1786 . A. G. I., Guadalajara, 521 . Aprobado en real orden de 27 de
febrero de 1787 . Ibid. Ugarte propuso a Cabello núm. 50. Chihuahua, 21 de diciembre de 1786. A. G. I Grado de brigadier. Ugarte a Sonora,

II 2 Ugarte a Sonora, núm. 56. Chihuahua, 4 de enero de 1787. A. G. I., Guadalajara, 286. 
preparar una campaña general. De camino hacia el Valle de Santa Rosa, reconoce la frontera de Nuevo León para arreglar la colocación de las tres compañías de esta - la antigua de Punta de Lanpazos, restablecida por Bucareli en I779, y las otras dos creadas en $I 783$ y 1784 por órdenes de Matías de Gálvez; todas tres de cien hombres. Las ejecutivas providencias de Ugalde le permitieron ponerse en campaña, desde Santa Rosa, el I9 de eneru de 1787.

En sólo esta su quinta campaña se mantuvo en el campo seis meses, hasta el 9 de agosto, con cuatrocientos hombres, y recorrió mil doscientas leguas, llegando hasta el nacimiento del Colorado. Aparte cinco encuentros con los enemigos, se le presentó el famoso capitán lipiyán Picax-Ande Instinsle, sumo falso sacerdote de la apachería oriental, al decir de Ugalde. El principal hecho de armas se dio en la sierra de los Chizos, donde destruyó la ranchería de Quijié-Gusia, refugiándose los demás mezcaleros en el presidio del Norte: esta era la campaña tan inoportuna para los planes de Ugalde, de que éste se lamentaba, aparte de ser menos gloriosa de lo que Ugalde quería dar a entender. Por de pronto, Don Juan se vio obligado a admitir de paz a los mezcaleros, sendes, nitajendes y cachucndes. Pero aquella inhibición había de durar poco, puesto que desde $\mathrm{I}^{\circ}$ de enero de $\mathrm{I} 788$, en virtud de las órdenes de Flores, podía considerarse independiente de Ugarte.

E1 13 de marzo de I788 salió Ugalde del Valle de Santa Rosa para realizar la visita de la comandancia puesta a su cargo y en este viaje consumió hasta el 22 de diciembre. En el Paso de las Peñitas encontró a las cuatro naciones de indios recién pacificadas. En el río San Antonio, a los lipanes occidentales y lipiyanes; en el Atascoso y luego en el Nueces, a los lipanes orientales. Ya en Texas se entrevistó con varios capitanes de los indios del norte. Bajó después a las orillas del Golfo, y batió y reconoció varias islas de los carancahuas "y demás caribes" en la costa de San Bernardo; y en la desembocadura del río Grande halló a los borrados de paz. En Croix y Aguayo, los indios de la frontera sur de Nuevo Santander le pidieron también la alianza. Todo marcharía a la perfección a no ser porque tan pronto salió él de Coahuila, las cuatro naciones residentes junto a Santa Rosa reanudaron, el 8 de abril de $\mathrm{I} 788$, las hostilidades. E1 lo supo cuando ya se hallaba en Texas, y pidió refuerzos al virrey Flores, que, impresionado por su grandilocuente belicosidad, le autorizó a practicar nueva entrada de guerra y más tarde a realizar su plan de reducción de efectivos y elevación de sueldos. Esta nueva plantilla significaba la reforma de setenta y cinco hombres en las tres compañías de Nuevo Santander - que antes eran de cien plazas, y eran la antigua de Laredo y dos creadas por Matías de Gálvez en I785- 
y la supresión de dos de cien hombres de las tres de Nuevo León y de una igual en Saltillo.

Para dar comienzo a sus nuevas operaciones de guerra, Ugalde dispuso en marzo de 1789 la captura alevosa de cinco capitanes y setenta y tres indios más de las cuatro naciones, que de nuevo pedían la paz. Al parecer, la sequía era motivo de la demora en iniciar la campaña, que por fin se emprendió desde el río Sabinas, a tres leguas del Valle de Santa Rosa, el I7 de agosto siguiente. Antes había Ugalde llevado a cabo la destitución de Don Pedro de Tueros del gobierno de Coahuila, medida que ya había pedido a Flores el I6 de julio de I788 alegando que el gobernador "se había manejado con irregularidad, servía disgustado a sus órdenes y llevaba cumplidos cinco años en el empleo". Esto último era cierto, puesto que él mismo le había entregado el mando el 8 de abril de I783, y a ello se atuvo Flores, que estaba dispuesto a eliminar cualquier obstáculo en la ejecución de los planes de guerra del comandante. Para ello mandó a Tueros acudir a México, pasando a sustituirle en Monclova el capitán de la Bahía Don Luis Cazorla. Pero como éste murió el 3 de octubre sin tomar posesión, nombró en su lugar al ayudante inspector, Don Juan Gutiérrez de la Cueva. El relevo se hizo, por fin, el 9 de diciembre de $\mathbf{7} 788$, pero Tueros no marchó a la capital, sino que dirigió al virrey un memorial documentado pidiendo se le formasen los cargos, a que daría adecuada respuesta, paso que Flores hubiera querido evitar, para obviar litigios. ${ }^{113}$

El I2 de agosto pasó Ugalde revista a sus fuerzas para la próxima acción, pero aunque dice la emprendió el I7 siguiente, la verdad es que el i6 de setiembre todavía escribe desde el "campo reunido en el Paso del Astillero", en el río Sabinas. Esta empresa, que Ugalde acomete a los sesenta y un años de edad, no había de darle gloria, aunque le tuvo en campaña casi un año, hasta el 2 de agosto de I790. Al frente de novecientos veinticinco hombres se disponía a combatir a los apaches "negando todo cuartel, y usando de perfidia contra perfidia, cautela contra cautela y engaño contra engaño", y al partir pedía ascenso a brigadier y promoción a mariscal de campo, pará compensar el atraso que le había producido su deposición por Teodoro de

113 Con esto desaparece en la práctica Tueros de nuestra historia. En 17 de junio de 1791 se le nombró castellano de Acapulco, en cuyo empleo murió a los pocos meses. A. G. S., Guerra Moderna 6989. A la ayudantia-inspección que dejó vacante Gutiérrez de la Cueva ascendió Don José Maria Echegaray, capitán de una de las compañias de Nuevo León. Flores a Valdés, núm. 833, 834 y 835. México, 26 de febrero de 1789 . A. G. S., Guerra Moderna 7046. Sobre las compañias de Nuevo León y Nuevo Santander. Flores a Valdés, núm. 949. México, 26 de abril de 1789. A. G. I., Guadalajara, 390. 


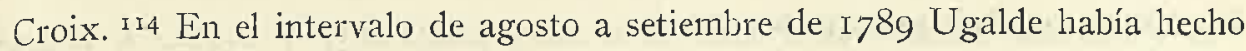
una maniobra e incursión hasta el río Grande para sorprender varias rancherías, pero pese a su astucia y a haber empleado doscientos cuarenta hombres en el ataque qque duró desde el alba hasta pasado el medio día, sólo les causó veintinueve bajas y veintisiete prisioneros. Aseguró que muchos más se ahogaron en el río, y persiguió a los restantes hasta el cañón de San Sabá. Antes de que él volviese al Sabinas, diez capitanes de los alzados dieron un golpe contra la caballada que pastaba junto al campamento y se llevaron mil ciento cuarenta y cuatro cabezas, o sea dos tercios de la disponible, más la caballada propia del comandante. El golpe lo había dirigido precisamente Manuel PicaxAnde Ynstintle de Ugalde, nombre que traducido significaba "Manuel Brazo Fuerte de Ugalde" y debía manifestar la firme alianza de este caudillo con el jefe español, y este hecho hizo que Ugalde renegase de todas sus anteriores exaltaciones de la amistad de los lipanes. La caballada perdida valía 20.000 pesos y para remplazarla dio órdenes terminantes a los gobernadores, asegurando que si no se le ayudaba "verá México en suls goteras antes que pasen muchos años a unos indios que hoy mira distante.", y en tal caso él se limitaría a estar "mirando desde un convento el triste cumplimiento de sus profecías".

Al cabo pudo ponerse Ugalde en el campo, y el I4 de noviembre, en el río Colorado, topó con ciento cincuenta comanches. El I. ${ }^{\circ}$ de diciembre de I 789 entró en el campo de esta nación, donde lo recibieron el jefe Socuina $y^{\prime}$ otros veintiseis capitanes de más de mil quinientos indios que allí estaban en grandes y blancas tiendas de cibola. Después de ocho días de marchar lentamente comanches y españoles convenció el comandante a Socuina para que le ayudase en la campaña con seis capitanes y doscientos guerreros, y así el 9 de enero de rygo pudieron juntos atacar un campo fortificado apache. Su prestigio era entonces tan amplio, según decía, que los taobayas, tahuacanas, wichitas y flechazos enviaron cuatro capitanes a su encuentro para que les avisara la próxima campaña: Ugalde les propuso la alianza general contra los apaches. E1 24 de enero se despidió de los comanches y emprendió el regreso. En toda esta su sexta y última campaña tuvo Ugalde trece encuentros con el enemigo. ${ }^{\text {II }} 5 \mathrm{El} 4$ de agosto de I'y9o, a los dos días a regresar, escribió pidiendo el grado de mariscal y ına encomienda de la orden de Santiago, de la que era caballero desde I776; pero entonces halló en México al conde de Revillagigedo, que iba a poner fin a su carrera.

II4 Flores a Valdés, nún. I294. México, 26 de setiembre de i 89 . A. G. S., Guerra Moderna 6986.

I 5 Los datos más completos para la biografía de Ugalde se hallan en sil carta al ministro Campo Alanje. M'éxico, 22 de mayo de 1792. A. G. S., Guerra Moderna, 7043. 
El CONDE DE Revillagigedo

El relevo de Don Manuel Antonio Flores estaba decretado desde el 2 I de febrero de ' $I 789$, nombrándose para sucederle al conde de Revillagigedo, a la sazón electo virrey de Buenos Aires. Desde esa fecha, el provisto debió tratar ampliamente con el secretario de Indias de todos los asuntos del gobierno de Nueva España, y por eso la instrucción reservada que aprobó el rey el 4 de abril y se pasó al conde el 6 del mismo mes se reduce a exponer brevemente sobre cada punto "la mente de Su Majestad". Sólo once artículos tiene dicha instrucción, y de ellos el segundo toca de lleno el tema de la comandancia general. Se habían facilitado ya a Revillagigedo suficientes documentos para que se informase de la controvertida cuestión, y a él se le conferían facultades absolutas para providenciar el arreglo de las provincias y el método de defenderlas, oyendo cuantos dictámenes particulares pudieran suministrarle luces a tal fin. "Pero irá advertido - dice lâ instrucción- de que la voluntad de Su Majestad está decidida sobre dos puntos: a saber, que el mando y gobierno de dichas provincias, de cualquier modo que se establezca, debe quedar dependiente y subordinado en un todo al Superior del virrey; $y$ que el conde de Revillagigedo, como tal, ha de pasar a reconocer y revistar y reconocer personalmente los presidios y puestos más esenciales de las expresadas provincias, a fin de que enterado ocularmente de su actual estado y constitución resuelva por sí mismo con entero conocimiento y dicte desde México cuantas providencias crea necesarias a su buen gobierno, sin necesidad de estar atenido para darlas a informes y noticias vagas en que suele quedar aventurada la verdad y muchas veces llegar disfrazada a favor de la distancia. Esta expedición, aunque incómoda, hará mucho honor al conde de Revillagigedo, le proporcionará el acierto en sus resoluciones y le será además muy meritoria para con Su Majestad". "ri6 Las al parecer firmes directrices del gobierno se iban pronto a revelar muy frágiles: en cuanto al primer punto, cuatro años después se decretaría la independización de la comandancia general; por lo que hace al segundo, parecía fuera del alcance de las posibilidades humanas de un virrey el repetir un viaje del estilo del de Teodoro de Croix llevando al mismo tiempo las riendas del gobierno de Nueva España.

En octubre de I789, ya en México, Revillagigedo empieza a dar una nota totalmente distinta de la producida por su antecesor. Entre sus primeras disposiciones, cuando aún no ha podido ponerse al corriente de los asuntos de la frontera, está la de ordenar la retirada del Regimiento de Dragones de

Ir6 Borradores de la instrucción, de 4 y 6 de abril de r789. A. G. S., Guerra Moderna, 7orr. Este documento muestra además la tendencia a la difusión del sistema de comandancias militares a Colotlán y Nueva Galicia. 
España a Celaya y Querétaro, pues el coronel Don Vicente Moreno y el intendente Díaz de Ortega habían comunicado ya que en Durango escaseaban la paja y el grano necesarios para el sostenimiento de la caballada, y que el cuartei era insuficiente, y lo mismo el prest de dos reales diarios que cobraban los soldados. ${ }^{\text {II7 }} \mathrm{Al}$ mismo tiempo, Revillagigedo transmite con explicable falia de entusiasmo las resultas de la campaña magna de Ugalde, tan desastrosa que éste pedía no se exigiesen a los soldados los 30.000 pesos que Flores había adelantado para que se habilitasen. "Advertí desde luego - dice el conde- las meditadas máximas de mala fe que usó y puso en acción el. comandante general de las fronteras de Oriente para atacar a los indios". "Yo no puedo aprobar el engaño y mala fe, ni que se pretenda justificar la perficia y el trato doloso contraviniendo a lo que el rey previene en el real reglamento de presidios y dispuso el difunto conde de Gálvez en la instrucción que Su Majestad se sirvió mandar observar con fuerza de Ordenanza". Futera de estos conceptos, Revillagigedo encontraba discordancias notables en los mismos informes de Ugalde, particularmente en los que trataban de los lipanes y lipiyanes, y con especialidad de Picax-Ande, porque unas veces encomiaban a estos indios, y otras se desdecía totalmente. En conclusión, dice el conde, "no he formado el más ventajoso (concepto) de las noticias, máximas y operaciones de guerra de aquel jefe". "r8

Poco días después, en carta reservada autógrafa, exponía Revillagigedo el criterio general que ya había formado sobre la comandancia. Entendía que en las provincias orientales las tropas no se hallaban ya en estado de sufrir nuevas fatigas de guerra, y que ésta además no daría fruto, bien porque los indios no querían avenirse a la paz, bien porque se hallasen soliviantados precisamente por la actuación de Ugalde. En las provincias de poniente, la paz podía considerarse establecida, pero Ugarte carecía de jefe subalterno porque Rengel se hallaba entonces en México reponiendo su salud. El virrey considera que la medida que más urgentemente se debía tomar era ia de variar todos los comandantes. A Ugarte, por su edad, "pues si se hallara con la agilidad correspondiente yo no desearía otro, por su acreditado talento, prudencia y celo en el desempeño de esta comisión”. Este espléndido elogio, después de los años de posterganiento que Flores impuso a Ugarte, concluye con la propuesta de Revillagigedo para que se le ascienda a mariscal cie campo y a una presidencia más descansada, como la de Guatemala. Tambien Ugalde debía ser removido por su avanzada edad, pero además "su

i 17 Revillagigedo a Valdés, núm. i8. México, 27 de octubre de 1789. A. G. S., Guerra Moderna, 7org.

I 8 Revillagigedo a Valdés, núm. I5. México, 27 de cctubre de i 789 . A. G. S., Guerra Moderna, 704I. 
genio e ideas no son en mi concepto cuales se requieren para el mando de que está encargado"; podría elevársele a brigadier y darle un gobierno en la península. En cuanto a Rengel, por su falta de salud, debía ser igualmente destinado en España. En fin, el conde viene a suscribir un plan muy parecido al último de Flores: dar la comandancia unida a un brigadier, con diez mil pesos, poniendo a sus órdenes dos comandantes subalternos con ocho mil. ${ }^{\text {IIg }}$

La réplica del ministerio, en real orden de 7 de marzo de $1790^{\text {I20 }}$ rechazó esta última parte del informe recalcando que el rey quería que subsistiesen las dos comandancias según las había sancionado la real orden de i i de mayo de I788. Y en cambio se procedía al relevo de los jefes destinando a Ugarte, con grado de mariscal, a la presidencia de Guadalajara; y llamando a España a Ugalde, con el de brigadier, y a Rengel. Para la comandancia occidental que. daba ya nombrado el brigadier Don Pedro de Nava, hasta entonces tenience de rey de la plaza de Caracas. La inspección que servía Rengel quedaría acumulada a los dos comandantes generales en sus respectivos distritos. Pocos días después de expedida esta orden, la mesa de la secretaría de Indias avisó que faltaba proveer la comandancia de Oriente y se lanzó a proponer el nombre de Don Fernando de la Concha, entonces gobernador de Nuevo México y ya propuesto para coronel, indicando además las múltiples conveniencias de designar un oficial de los ya experimentados en la frontera, entre otras razones por la del estímulo que para todos ellos supondría. Sin embargo, la elección del rey recayó sobre Don Ramón de Castro, teniente de rey de la isla de Santo Domingo.

La real orden de 7 de marzo de I7go fue obedecida por el virrey en junio siguiente, y el relevo quedó realizado en parte a fin de año cuando Nava sustituyó a Ugarte en el mando de todas las provincias. En el tiempo que Ugarte sirvió bajo el conde de Revillagigedo hubo pocas novedades en su distrito. El conde le dió la razón en cuanto a la imposibilidad de reducir efectivos en las provincias occidentales, y la necesidad, en cambio, de elevar las soldadas de aquellas tropas, ${ }^{x \mathbf{r}}$ y ponderó los triunfos que éstas obtenían en el frente de Nueva Vizcaya — campañas de Don Antonio Cordero, capitán de Janos, de setiembre a noviembre de i 789 y de Don José Manuel Carrasco, capitán de la r." volante, logrando entre ambos doscientos cuarenta y un muertos, prisioneros o rescatados del enemigo-, con un patente afán de rehabilitar a Ugarte ante el ministro. "Debo hacer presente a V. E. -escribe en esta ocasión - en honor de la verdad y la justicia, que en las insinuadas provincias del Poniente se ha trabajado oy trabaja con fruto, tino y cordura,

II9 Revillagigecto a Valdés, sin n. ${ }^{\circ}$, reservada. México, 3 I de octubre de 1789 . Ibid.

I 20 Ibid.

I 2 I Revillagigedo a Valdés, núm. I I4. México, 26 de noviembre de i789. Ibid. 
según los documentos que he examinado hasta ahora y lo que acreditan las resultas de nuestras operaciones". ${ }^{122}$

La solidarización del virrey con el criterio de Ugarte le lleva a considerar funesta la división de las provincias en dos comandancias independientes entre sí, como que podía considerar las malas resultas que para la política de éste habían significado las campañas de Ugalde. La atención se centra en Nueva Vizcaya, pues a principios de 1790 se consideran sin importancia las hostilidades que aún perduran en Sonora y Nuevo México. Revillagigedo aprobó la propuesta de Ugarte de acercar algunos presidios a las poblaciones más inmediatas, sin causar gastos, pero le negó algún posible refuerzo de tropas; era el conde escéptico en cuanto a la existencia de los llamados Tarahumaras infidentes, pero dispuso que una partida de cien hombres hiciese frecuentes visitas a estos indios hasta que se crease el gobierno de la Tarahumara. Su idea de una comandancia unida evolucionaba hacia la constitución de una sola autoridad puramente militar sobre la frontera, dejando todos los asuntos de gobierno, hacienda, vicepatronato, etc. a los gobernadores-intendentes; ${ }^{\mathrm{I} 23}$ y por esta razón se opuso a las reclamaciones de Ugarte en pro de una comandancia general independiente del virrey, "constando a V. E. - dice al ministro- que aun antes de venir aquí y de tener los conocimientos con que en el día me hallo era yo dęl mismo dictamen, y que tuve el gusto de oir que pensaba V. E. uniformemente"; y ofreció cumplir lo que se le había ordenado en su instrucción: "Haré la visita de dichas provincias, como lo he ejecutado con el desagüe de Huehuetoca, para añadir esos conocimientos prácticos a los teóricos que ya tengo, luego que haya puesto en orden todos los ramos del gobierno de esta capital y reino, pero no lo verificaré hasta que haya resuelto S. M. sobre lo que le he representado en cuanto a quién deba mandar las armas del reino en mi ausencia". ${ }^{124}$ Por estos motivos se retrasó tal viaje hasta momento en que llegó a ser innecesario por haber variado la mente del rey. Del mismo modo quedó sin solución el proyecto de crear un gobierno en la Tarahumara, para el que el virrey presentó la terna formada por Ugarte - Borica, Tueros y Gutiérrez de la Cueva-; en cambio, se adelantó a la decisión real al rescindir la contrata provisional suscrita por Ugarte con el comerciante Guizarnotegui para el abastecimiento de los presidios de Nueva Vizcaya y Nuevo México en el quinquenio i 788 -

I 22 Revillagigedo a Valdés, núm. I85. México, 27 de diciembre de I789. A. G. S., Guerra Moderna, 70I9.

I 23 Revillagigedo a Valdés, núm. 308, reservada. M'éxico, 28 de febrero de i 79o. A. G. I., Guadalajara, 390.

I 24 Revillagigedo a Valdés, $\sin$ n. $^{\circ}$, reservada. México, 28 de febrero de I79o. A. G. S., Guerra Moderna, 7041. 
I792, logrando que el comercio de Chihuahua se hiciese cargo de esta función, que Guizarnolegui no había llenado debidamente. ${ }^{125}$

Mientras subía la estrella de Ugarte, declinaba inexorablemente la de Ugalde. El virrey, basado en informes del gobernador y el obispo de Ntuevo I_eón, consideraba ya inoportuna la reducción de tropas llevada a cabo por aquél. ${ }^{126}$ Poco después, en enero de 1790 , siguiendo dictamen del auditor de guerra a consecuencia de la reclamación hecha por Tueros a Flores, aunque no había hallado nada contra Gutiérrez de la Cueva - salvo que no sería imparcial respecto a Ugalde- decidió nombrar nuevo gobernador interino al teniente coronel de Dragones de España Don Miguel Emparán, que llevaría comisión reservada para hacer averiguación sobre Tueros y el teniente Menchaca, a quien Ugalde había formado causa ruidosa y tenía prácticamente arrestado hacía dos años. Revillagigedo pidió confirmación en propiedad del gobierno de Coahtila para Emparán lo que se concedió en real orden de 8 de julio de I790. "Mucho he visto y oido - dice el conde- contra Don Juan de Ugalde desde mi ingreso al virreinato: no aseguro que sea cierto, pero sí que en sus informes y noticias lastima la opinión de toda clase de personas, y que en su difusa correspondencia con esta superioridad se advierten desde luego discordancias y contradicciones manifiestas sobre puntos delicados y del mayor interés del servicio". La instrucción muy reservada que dió a Emparán comprende puntos generales de defensa de Coahuila y otros sobre aclaración de la conducta de Ugalde, su criado Don Ignacio Benaventi y su secretario Don Francisco Ignacio de la Peña, y de manera particular relativos a la actuación del comandante en relación con los lipanes, mezcaleros, comanches e indios del norte. ${ }^{127}$ Revillagigedo repudiaba la mala fe con que Ugalde había procedido para cautivar algunos indios de las dos primeras naciones, así como la muerte a sangre fría de seis lipanes amigos, dentro de su misnna casa en el presidio de Béjar, que por indicación de aquél hizo su amigo el capitán-gobernador de Texas Martínez Pacheco. ${ }^{128}$.Con este motivo aconsejaba el conde proveer de nuevo el gobierno de Texas, lo

125 La tetra para Tarahumara, en Fevillagigedo a Valdés, núm. 647. México, 26 de jurio de I790. A. G. S., Guerra Modema, 6060. La anulación de las contratas en Revillagigeclo a Valdés, núm. 569, reservada. México, 27 de mayo de Iт90; y núm. 127, México, 26 de noviennbre de I790. A. G. S., Guerra Moderna, 7020.

I26 Revillagigedo a Valdés, núm. I I4. México, 26 de noviembre de Iz8.. A. G. S., Guerra Moderna, $704 \mathrm{I}$.

I 27 Revillagigedo a Valdés, nírn. 232, reservada. México, s./rl., cnero de I790; con instrueción a Emparán de 3 de enero de r 790 y real orden de 8 de julio de r 790 . A. G. S., Guerra Moderna, 7033. Emparán, teniente de navío de la Armada, fue nombrado teniente coronel agregado đel Regimiento de Dragones de España por decreto de 9 de abril de r788. En i797 estaba de regreso en España. A. G. S., Guerra Moderna, 6954.

I 28 Revillagigedo a Valdés, núm. 308 reservada. México, 28 de febrero de I79o. A. G. I. Guadalajara, 390. 
que se había suspendido a consulta de Flores, que por hacer economías había subestimado la importancia de aquella provincia, lugar de concentración de los apaches y avanzada frente a los anglo-americanos. ${ }^{129}$

En marzo de I790, Revillagigedo se hallaba aún más convencido de la ineptitud de Ugalde, 530 y en abril completó ya su dictamen con un detenido estudio del historial del comandante y sus amigos y aduladores, que le honraban, como él a sí mismo, con los epitetos de héroe restaurador de las provincias, Alejandro, Catón, y de los guerreros famosos de la Antigüiedad y del momento. Es justísino el juicio sobre el estilo narrativo o polémico de Ugalde, caracterizado por "citas no correspondientes de sagrados textos, de leyes aplicadas con violencia inoportunamente, o sin venir al caso, con cláusılas a párrafos enteros que corren igual fotuna de las obras del marqués de Santa Cruz, y aún iguales copia de la historia de Don Quijote”. Fue entonces cuando el virrey tomó la decisión de ordenar a Ugalde la suspensión de sus campañas y que se le presentase en México haciéndose entre tanto cargo Ugarte del mando militar de oriente. ${ }^{131}$ Simultáneamente dispuso la destitución de Martínez Pacheco del gobierno interino de Texas, que dio con tres mil pesos anuales al veterano teniente coronel Don Manuel Muñoz, fundador del presidio de la Junta o del Norte, que desde mediados del año anterior, a la muerte de Don Melchor Vidal de Lorca, tenía encomendado el gobierno de Nuevo Santander — donde ahora le sucedería el conde de Sierra Gorda. ${ }^{132}$

En junio recibía el virrey la orden de 7 de marzo de 1790 que relevaba a los tres comandantes. Revillagigedo decidió suspender parcialmente su ejecución para modificar a su gusto el estado de las provincias. Precisamente con las últimas medidas iba a concentrar en sólo la mano de Ugarte todas las provincias, y se prometía que de ésta pasarían a la de Nava con la misma unidad. ${ }_{33} \mathrm{El}$ nombramiento de Ugarte y Loyola para la intendencia, presidencia y comandancia general de las armas de Nueva Galicia databa del 27 de febrero de 1790 , y había sido comunicado al virrey por real orden de $\mathrm{I}^{0}$ de marzo. ${ }^{134}$ En cumplimiento de las órdenes de Revillagigegedo, Ugarte pasó

I29 Revillagigedo a Valdés, s/n., reservada. México, 4 de febrero de r79o. A. G. S., Guerra Moderna, 7044.

I30 Revillagigedo a Valdés, núm. 386 reservada. M'éxico, 27 de matzo àe 7790 . A. G. S., Guerra Moderna, 704I.

I3I Revillagigedo a Valdés, núm. 517 reservada. México, 30 de abril de 1790. A. G. S., Guerra Moderna, 7043.

I3a Revillagigedo a Valdés, núm. 308. México, $10^{\circ}$ de mayo de 1790, con instrucción dada a Muñoz en 27 de abril antecedente. A. G. S., Guerra Moderna, 7044.

I33 Revillagigedo a Valdés, núm. 629 reservada. México, 26 de junio de r79o. A. G. S. Guerra Moderna, 704I.

134 E1 decreto e11 A. G. I., Guadalajara, 356. La orden en A. G. S., Guerra Moderna, 7013. Con estas disposiciones se crea la comandancia general de Nueva Galicia, que inaugura Ugarte 
de Chihuahıra a Monclova, donde arregló las paces con los lipanes y entregó el mando a Don Pedro de Nava. E1 5 de enero de I79I anunciaba que se disponía a partir para Giuadalajara. ${ }^{135}$ Tomó posesión el I 5 de marzo siguiente, y murió en el desempeño de este puesto el ig de agosto de I798. ${ }^{136}$

\section{Revillagigedo, Nava y Castro}

De los sucesores de Ugarte y Ugalde, Don Pedro de Nava recibió título expedido el I 2 de marzo de I790, y en él su sueldo quedaba fijado en diez mil pesos anuales, y su autoridad subordinada a la del virrey en lo militar, político y económico. ${ }^{\mathrm{I}} 37 \mathrm{El}$ despacho de Don Ramón de Castro no vio la luz. hasta el 30 de junio del mismo año, y contenía cláusulas semejantes a las del de Nava, salvo que su sueldo se reducía a ocho mil pesos. ${ }^{138}$ Para procurar el pronto traslado de Nava desde Caracas, como urgía el ministro, el capitán general de esta plaza Don Juan Guillelmi dispuso que el comandante electo embarcase en uno de los corsarios que cruzaban entre La Guaira y Puerto Rico, en el "Nuestra Señora del Rosario"; ya en Puerto Rico podría Nava tomar el correo marítimo de julio. ${ }^{139}$ El electo pudo llegar a México por Puerto Rico y La Habana, el 3 de agosto, y Revillagigedo le encargó de la comandancia de oriente que por comisión suya desempeñaba Ugarte desde la destitución de Ugalde; le ordenó atenerse a la instrucción del conde de Gálvez y admitir las paces de los apaches, y se mostró satisfecho del buen modo de jensar, mérito y talento del nuevo comandante, que - según la instrucción que le dio el i7 de setiembre-- debería tomar posesión en Saltillo y entrevistarse allí o en Monclova con Ugarte. En esta instrucción asienta el virrey respecto de California: "Debe estimarse casi nominal la dependencia que tiene de la comandancia general, y he pensado más de una vez segregarla de ella dejándola inmediatamente sujeta al virreinato", para lo que sobraban motivos puesto que los situados de aquella provincia se pagaban en México, los efectos se enviaban desde San Blas, y el gobernador se entendía en alginos asuntos directamente con el virrey. ${ }^{140}$

I35 Ugarte a Lerena, s./n. Coahuila, 5 de enero de 1791. A. G. I., Guadalajara, 268.

I36 Expedientes en A. G. S., Guerra Moderna, 7013. Datos biográficos en Iguiniz, Juan B. Los gobernantes de Nueva Galicia. Memorias de la Academia Mexicana de la Historia, VII. 4, págs. 296 y sigs.

I 37 Título en A. G. I., Guadalajara, 390.

I3 8 Titulo en A. G. S., Guerra Moderna, 7041.

139 Guillelmi a Valdés, núm, 717. Caracas, 29 de junio de I790. Ibid.

140 Revillagigedo a Campo Alanje, núm. 63. México, 26 de septiembre de I790. A. G. S., Guerra Moderna, 7046. En real orden de 21 de febrero de 1791, se eximió a Nava del pago de la media anata. Ibid. Desde $x_{7} 89$ se había suprimido la plaza de ayudante inspector de las tropas de California, nombrándose al que lo era, D. Nicolás Soler, capitán de Tucson a la muerte de Romero. A. G. S., Guerra Moderna, 7032. 
De los dos nuevos provistos, el brigadier Nava era canario, de familia noble, y contaba cuarenta y nueve años. Había ingresado en el servicio el $\mathrm{I}^{\circ}{ }^{\circ}$ de diciembre de 1753 como cadete de Guardias de Infantería Española, y había tenido empleos en las milicias de Canarias y en el Regimiento de Infantería de León hasta ser nombrado el 5 de agosto de I 78 I teniente de rey y comandante del Batallón de Caracas; el i 8 de octubre del mismo año fue ascendido a coronel, y el I4 de enero de 1789 a brigadier. Su experiencia bélica en Europa se reducía a la campaña de Portugal; en Indias, había reconocido toda la isla de Puerto Rico y había mandado Puerto Cabello en la última guerra, mientras estaban allí la escuadra y el ejército francés. ${ }^{14 I}$ Despachado ahora por Revillagigedo hacia el norte, entró en las provincias internas de oriente reconociendo, entre octubre de I790 y enero de I79I Nuevo Santander, Nuevo León y Coahuila, continuando y colaborando en la política de Ugarte y el virrey de procurar la armonía con los indios. Siguió en el gobierno de las provincias orientales hasta abril de I79I, en que las dejó en manos de Castro y pasó a Chihuahua. En ese tiempo el rirrey dejó plena constancia de los desastrosos efectos que en el país había causado el imprudente gobierno de Ugalde, cuyas resultas se sentían en los ataques darlos por los lipanes durante la última campaña de éste en Coahuila y Texas. En esta provincia, según Muñoz, los destrozos habían sido enormes - más de nueve mil cabezas de ganado menor en diez meses - viéndose obligados muchos ganaderos a abandonar sus ranchos. Nuevo Santander y Nuevo León habian padecido igualmente. ${ }^{142}$

En enero de I79 Muñoz no logró atraer a la paz a los jefes lipanes, que se internaron a los ríos Guadalupe y Brazos para hacer amistad y comercio con los vidais, atacapas, orcoquizas y cocos, de los que obtuvieron armas y municiones a cambio de caballos, mulas y prisioneros españoles. En cambio, los lipanes "de arriba" se entrevistaron con Nava en la villa de San Fernando de Austria y se mostraron dóciles y dispuestos a traer de paz a los "de abajo", que sólo querían no ser atacados en Texas para poder actuar contra las demás provincias. ${ }^{4} 43$ Tales novedades eran del agrado del conde, que al mismo tiempo había de hacer frente a la nueva ofensiva de reclamaciones iniciada por Ugalde, quien, alojado ya en uno de los suburbios de México, "se acerca por momentos a la eternidad sin prescindir de sus deli-

I4I Hoja de servicios de Nava, I79i. A. G. S., Guerra Moderna, 7278. Nava a Campo Alanje. Valle de Santo Rosa, 26 de enero de I791. A. G. S., Guerra Moderna, 7045.

I4a Revillagigedo a Campo Alanje, núms. I 52 y I60. México, I3 y 15 de enero de 179 I. A. G. S., Guerra Moderna, 6989 y 7020 , respectivamente.

143 Revillagigedo a Campo Alanje, núm. zio. México, 3 de marzo de 179I. A. G. S., Guerra M'oderna, 7020. 
rios". ${ }^{144}$ Nava abandonó las provincias orientales habiendo acordado con Castro, llegado éste a su puesto, que el comandante oriental atacase a la lipanería de abajo, reacia a admitir capitulaciones de paz. ${ }^{145}$

Aproximadamente dos años estuvo Nava al frente de la comandancia occidental hasta que se produjo la reunificación de las provincias decretada en setiembre de I792. El año I'79I concluyó para él en disputa con el virrey y el obispo de Durango acerca de los honores que le correspondían como vicepatrono. ${ }^{146} \mathrm{Su}$ gobierno no presentaba ya especiales dificultades; la situación de tranquilidad permitía pensar en la inmediata retirada de la compañía de voluntarios catalanes, aunque al ocurrir esto se reforzaron con setenta hombres los presidios. Los siete de Nueva Vizcaya sumaban entonces 686 hombres, aunque muy irregularmente distribuidos: Janos y San Buenaventura tenían I44 cada uno; Carrizal y San Elezario, 73; Norte, I06, y Príncipe y Cerro Gordo, 73. Había que sumar luego los 6i6 soldados organizados en cuatro compañías volantes, y aún se podía contar con los seis cuerpos de Dragones Provinciales - San Carlos, Príncipe, Durango, San Juan Bautista, San Gabriel y Santa Rosa- que sumaban treinta y siete compañías de 4.3 hombres. Pero los I.302 de las volantes y presidiales deberían bastar para contener al adversario. En Sonora los efectivos ascendian ahora a 8 I 8 soldados, de los que los presidios de Buenavista y Pitic retenían 73 cada uno; el de Altar, 9o; los de Tucson, Santa Cruz y Fronteras, Io6; los de ópatas de Bavispe y Bacuachi, 9o, y el de pimas de Buenavista, 84. En Nuevo México sólo se contaba con los I 20 hombres del presidio de Santa Fe, pues las tres compañías de 69 hombres del cuerpo de dragones organizado en I78I en El Paso entraban en realidad en el sistema defensivo de Nueva Vizcaya. ${ }^{447}$

En el verano de I792, Nava resolvió trasladarse a Sonora, viaje intempestivo en el sentir del virrey, porque esta provincia no ofrecía preocupaciones en el día y en cambio Nueva Vizcaya iba a quedarse $\sin$ la vigilancia del comandante. Los presentimientos de Revillagigedo se hicieron realidad cuando en octubre, repentinamente, Nueva Vizcaya fue atacada a la vez por diferentes rumbos: trozos de treinta a cincuenta apaches asaltaron la hacienda de La Cadena, en la jurisdicción de Mapimi; las recuas y correos del camino entre Julimes y Chihuahua, y las cercanías de San Juan del Río, Fapasquiaro y Durango. Nava hubo de volver apresuradamente a organizar

144 Revillagigedo a Campo Alanje, núms. 21 y y 235 . M'éxico, 3 y 27 de marzo de I79I.

A. G. S., Guerra Moderna, 704r.

145 Revillegigedo a Campo Alanje, núm. 267. México, 27 de mayo de i791. A. G. S., Gue-
Moderna, 7021.

I 46 Nava a Bajamar, núms. I y 2. Chihuahua, 2 de diciembre de I79r; y sin nứm., Chihuahua, 30 de diciembre de r7gr. A. G. I., Guadalajara, 288.

I47 Nava a Revillagigedo. Chihuahua, is de junio de 1792. A. G. S., Guerra Moderna, 7022. 
la persecución. ${ }^{148}$ La situación se había seguramente normalizado cuando, cn los primeros meses de I793 asumió Nava el mando stipremo e independiente de toda la frontera.

El colega de Nava, Don Ramón de Castro, había encontrado un panorama mucho más agitado. Castro era de familia noble de Castilla la Vieja, descendiente de los marqueses de Lorca, y sólo contaba treinta y nuteve años al ser promovido a comandante de las provincias de Oriente. En las milicias de Burgos y en el Regimiento de Infantería del Príncipe había alcanzado la graduación de capitán. Luego, había tomado parte en la expedición de Mobila y en la reconquista de Panzacola, y figurado como capitán en el Batallón de Voluntarios formado en el Guarico por Bernardo de Gálvez cuando se proyectaba la invasión de Jamaica. En 30 de marzo de 1789 se le había nombrado teniente de rey, comandante del Batallón veterano y subinspector de las tropas de Santo Domingo, y en noviembre del mismo año se le había graduado de coronel. Nueve meses más tarde era destinado a sustituir a Ugalde. ${ }^{149}$ Castro recibió este nombramiento en septiembre de I790; embarcó el I9 de octubre, en la peor estación del año, y con extraordinario riesgo llegó a México en diciembre. Las atenciones a la salud de su esposa demoraron su partida de esta capital hasta el 23 de febrero de I79I, y entró en el Valle de Santa Rosa el I4 de abril: según su impresión el estado de las provincias era deplorable, y él se dispuso a visitar las fronteras y a entrar a sangre y fuego contra los lipanes. ${ }^{150}$ Pronto se advirtió que Castro era de la misma madera que su antecesor. Apenas llegado a Coahuila, quiso ser recibido como jefe político y económico al mismo tiempo que militar, contra lo prevenido por Flores al dividir la comandancia; Emparán se negó a complacerle, y de aquí arrancaría una polémica, mientras que el virrey tomaría pie de este hecho para rehacer otro plan de la comandancia: esta vez quería crear una intendencia con las cuatro provincias orientales, y un jefe militar de las cuatro subordinado al único comandante general, que sería el de occidente. ${ }^{55 x}$ Revillagigedo no conseguiría ver triunfante su propuesta, pero Castro había de lograr el descrédito de Emparán, a quien acusó de insubordinación y mala fe. "No es sujeto - escribió el coronelcuyo carácter sea capaz de corrección ni de enmienda, y mucho menos sos-

I48 Revillagigedo a Campo Alanje, núm. 763. México, 3 1 de diciembre de rъ92. A. G. S. Guerra Moderna, 7021.

149 Hoja de servicios de Castro, 179r. A. G. S., Guerra Moderna, 7278 ,

150 Castro a Campo Alanje. Santo Domingo, 25 de septiembre de 1790; México, 4 de diciembre de 1790; Valle de Santa Rosa, 16 de abril de 1791. A. G. S., Guerra Moderna, 7045.

I5I Revillagigedo a Campo Alanje, núms, 258 y 433, reservadas. México, 30 de abril y 27 de noviembre de 1791 . A. G. S., Guerra Moderna, 704r, y A. G. I., Guadalajara, 390, respectivamente. 
tenido como se halla por el virrey por ser hechura suya". Castro envió memorial directamente al rey, pues el conde se limitaba a aconsejarle no promoviese escándalo, rehuyendo providencia por la vía ordinaria; al cabo, en agosto de I79I volvió a hacerse cargo del gobierno de Coahuila Gutiérrez de la Cueva, mientras Emparán se hallaba en San Miguel el Grande, para cederlo segunda vez a Emparán en 4 de julio de I792; en octubre de este año Castro logró su propósito haciendo salir a Emparán del puesto que Revillagigedo le había confiado, pues el mismo virrey le hizo retirar a Potosí. 152

Pero la actividad de Castro también tomaba otros cauces. Habiendo convenido con Nava atacar la lipanería de abajo, un cảpitancillo de esta parcialidad se presentó con su séquito pidiendo la paz en el presidio de Río Grande, y luego en el Valle de Santa Rosa donde al fugarse algunos rehenes y acudir a poner remedio Castro fue herido por los que quedaban y se empeñó una lucha en la que perecieron once lipanes y tres mujeres por parte de los indios, y un sargento y un: soldado españoles, con otros ocho heridos; duró la pelea desde las 9 de la noche del $\mathrm{I}^{\circ}$ de mayo a las 8 de la mañana siguiente, y el virrey no consideró nada honrosa la acción, aparte de dar por perdida toda esperanza de paz con los enfurecidos apaches, ${ }^{153}$ que en poco tiempo realizaron diversas incursiones a través de la inconsistente frontera de las provincias. Cuando su hostilidad amenguó fue por haber sido los lipanes atacados por un cuerpo de cuatrocientos indios del norte que entraron por Texas y se llevaron doscientos caballos y mulas de los apaches, al tiempo que se anunciaba la concentración de mil doscientos comanches a orillas del Puerco o del Colorado con iguales intenciones. Por su parte, el capitán Tovar de Río Grande, en un encuentro afortunado, dio muerte a los jefes lipanes Canoso y Lombraña con cinco de los suyos. ${ }^{154}$ E1 I7 de agosto de r79I Castro pidió al virrey 400 hombres de refuerzo, cuando los lipanes habían atacado Nuevo León. El 6 de septiembre llegó a pedir que se duplicaran las fuerzas bajo su mando, que entonces sumaban i. 28 hombres, pretendiendo además se le concediese autoridad política, eco-

I5 Castro a Campo Alanje, núm. 4. Valle de Santa Rosa, 6 de octubre de I7gir. A. G. S., Guerra Moderna, 7045. Relación de las providencias económicas tomadas por Gutiérrez de la Cueva Monclova, 29 de noviembre de I792. British Museum, Egerton, I801, fols. I78-19o. Revillagigedo a Campo Alanje, núms. 563, 6r4 y 679. México, 29 de abril, 30 de junio y 30 de septiembre de I792. A. G. S., Guerra Moderna, 7050.

I53 Revillagigedo a Campo Alanje, núm. 267. México, 27 de nayo de I 791. A. G. S., Gue rra Moderna, 7021. Informe del virrey en hoja de servicios de Castro. A. G. S., Guerra Moderna, 7278 .

I54 Revillagigedo a Campo Alanje, núms. 282, 324 reservada y 331. México, 26 de junio y 27 de agosto de I79I, A. G. S., Guerra Moderna, 704 I y 702 I. 
nómica y judicial en el distrito de su mando; pero el virrey consideraba ociosas estas demandas. ${ }^{155}$

El I6 de noviembre de I79I salió Castro del Valle de Santa Rosa para hacer la visita de las cuatro provincias. El I8 llegó a San Fernando de Austria, donde enfermó, pero se repuso y reconoció la miserable villa y los desaseados soldados y paisanos que la habitaban. En día y medio se trasladó luego a Río Grande, lugar peor que el precedente pero con abundantes siembras, donde se detuvo cuatro días. El 27 de noviembre partió para Béjar, invirtiendo ocho jornadas en la travesía; el 3 de diciembre estaba en la capital de Texas, a la que propuso amurallar para convertirla en el San Juan de Ulúa de Texas, aprovechando el río San Antonio y el arroyo San Pedro que le servían de foso, y comentó la aptitud militar de los frailes, que tan bien protegidas tenían sus misiones. Allí se entrevistó con algunos jefes comanches. El 28 de diciembre marchó a la Bahía, donde permaneció ocho días, para luego, con una pierna llagada, avanzar hasta el río Guadalupe, donde tomó contacto con los carancahuas, a los que prometió la erección de la misión del Refugio, que además serviría de enlace con Nueva Orleáns. El I I de enero, desde la Bahía, partió para Laredo, a donde llegó en una semana. De este pueblo triste, miserable y muy hostilizado, por Revilla, Cántaro, Mier y Camargo, llegó a Reinosa y luego a Santander, cuya guarnición le dejó muy mal impresionado por todos conceptos. El 7 de febrero estaba en Güiemes, y de aquí pasó a Nuevo León, reconociendo Linares, Pilón, Cadereita, Monterrey y Salinas; entró en Coahuila por Monclova y se dirigió a Cuatro Ciénagas para reconocer los puertos y cañones de Santa Rosalía, Jara, San Marcos, Ciénagas, El Marqués y Menchaca, por donde los mezcaleros del Bolsón entraban a Saltillo, Nuevo León, Monclova, y finalmente, por Sardinas, Santa Gertrudis y San Buenaventura llegó al Valle de Santa Rosa, enfermo, pero habiendo adquirido los conocimientos que creía necesarios. El I5 de mayo de I $_{792}$ daba cuenta a Revillagigedo de su viaje, en el que había invertido seis meses; el virrey pidió para él un ascenso, y luego lo propuso para la capitanía general e intendencia de Yucatán, no obstante no querer bien a Castro, según Valdés, porque lo veía más duro que él mismo. Precisamente Valdés apoyaba estas propuestas, cuando había sido decidida la reunificación de la frontera, "pues sobre su mérito conocido en todo el ejército, hay la circunstancia de que, si sale de su destino sin alguna señal de distinción o aprecio temo mucho las resultas que ha de producir

I55 Revillagigedo a Campo Alanje, núm. 432 reservada. México, 27 de noviémbre de 179 r. A. G. S., Guerra Moderna, 7020. 
su pundonoroso modo de pensar". ${ }^{156} \mathrm{Al}$ cabo, por real orden de 23 de julio de I793 se ascendió a Castro a brigadier, cuando ya es!aba cesante del empleo de comandante de las provincias de oriente pero conservando su sueldo, ${ }^{157}$ no $\sin$ que antes Castro hubiese repetido quejas contra Revillagigedo, que permanecía fiel a la idea de atraer a los apaches a la paz y daba poca importancia a la victoria conseguida en la costa de Nuevo Santander, en Palo Blanco, contra el lipán Zapato Zas, que murió en la lucha con dieciocho de los suyos, to que movió a los lipanes en general a buscar la concordia en Béjar, donde los recibió el conde de Sierra Gorda, comisionado al efecto por el virrey. ${ }^{158}$

Revillagigedo, en cambio, tenía sus propios problemas, representado el primero por Ugalde, que lejos de consentir en marchar a España como se le había prevenido se empeñaba en permanecer en México alegando enfermedad e importunaba al virrey pidiendo el ascenso al mariscalato y hábito de Santiago; exigiendo se oyesen sus descargos en el desempeño de la comandancia, y redactando y enviando los voluminosos escritos que acostumbraba acerca de sus méritos y los de sus antepasados. El conde conocía ya de antiguo el especial carácter y "natural fanatismo" de Ugalde, de ctrya conducta "mi antecesor Don Manuel Antonio Flores dudaba ya y desconfiaba mucho de ella, según me dijo en las privadas conferencias que tuvimos en Guadalupe, añadiendo que Ugalde le había dado bastante quehacer; que dejaba pendientes algunos asuntos graves promovidos y ocasionados por el mismo Ugalde, de difícil y aventurada determinación; que lo eran verdaderamente todas las relativas a novedades de indios, operaciones de nuestras tropas, máximas y procedimientos discordes de los jefes de provincias internas; y por último - había dicho Flores- que estos cuidados y responsabilidades habían sido una de las mayores causas que pudieron obligarle a celebrar la admisión de su renuncia de este virreinato y su pronto relevo". ${ }^{159}$ Pese a estos antecedentes, y a haberse visto obligado a destituirle, Revillagigedo, en atención a los antiguos méritos y edad de Ugalde se resistía a formarle expediente, esperando se aviniese a regresar a España ya con grado de brigadier. Pero las abultadas quejas de éste llegaron hasta el rey, y el Con-

I56 Castro a Revillagigedo. Valle de Santa Rosa, is de mayo de I792. Revillagigedo a Campo Alanje, núms. 6o y y J4, reservada. México, 30 de junio y 30 de julio de 179.2. A. G. S., Guerta Moderna, 7045. Revistas de Béjar y Bahía por Castro, en A. G. S., Guerra Moderna, 7047.

I57 Revillagigedo a Campo Alanje, núm. 853. México, 30 de abril de 1793. A. G. S., Guerra Moderna, 7045 .

I 58 Castro a Campo Alanje, núm. i 1, Monclova, is de enero de I793. A. G. S., Guerra Moderna, 7045. El Conde de Sierra Gorda a Revillagigedo. Villa de Santander, 30 de diciembre de 1792. British Museum, Egerton, I801, fols. 233-280 v.

I 59 Revillagigedo a Campo Alanje, núms, 255 y 605. México, 30 de abril de 179 i y 30 de junio de i792. A. G. S., Guerra Moderna, 7043. 
sejo de Guerra ya a fines de 1793 pidió que se le remitiese a España "emplazándolo para el mismo Tribunal, donde se le administrará justicia". En 5 de marzo de 1794 todavía estaba Ugalde en México. ${ }^{160}$

\section{El gobierno de Mazatlán}

El último asunto interesante de que aún no hemos hablado en que el conde de Revillagigedo actuó sobre las provincias internas fue en la erección de un gobierno militar en Mazatlán, en la costa sinaloense. En 2 I de noviembre de 1785 la compañía miliciana de este pueblo de mulatos se quejó al ministro Don José de Gálvez de las extorsiones que les causaban el gobernador de Sonora y el justicia mayor de Copala, de cuya jurisdicción les había inhibido Gálvez cuando, siendo visitador y navegando a California, hizo escala en aquel puerto. La queja fue reexpedida al virrey, pero Núñez de Haro y Flores dejaron languidecer el expediente. A principios de I790, a su ingreso en la provincia, el intendente Grimarest visitó San Juan Bautista de Mazatlán y ya desde Rosario informó el $\mathrm{I} .^{\circ}$ de abril del mismo año que los milicianos de aquel pueblo eran doscientos, que podrían arreglarse en cuatro compañías, poniendo allí un gobernador político y militar "que llenando sus fantásticas ideas ponga a cubierto la autoridad real”, pues los de Mazatlán eran "resueltos y animosos y preocupados hasta el extremo por ser reputados como militares y por la conservación de fuero y privilegios". Parecía cierto que desde que Gálvez pasara por allí habían ellos mantenido la guardia de un cabo y diez soldados en el puerto, día y noche. El antecesor interino de Grimarest, Garrido y Durán, había mostrado a los mazatecos como revoltosos y protectores de todos los criminales fugitivos de la justicia ordinaria de la provincia; pero aquél mismo decía de ellos "que respiran ardor marcial y que bajo distintas reglas, acaso poco satisfechos, podrán retirarse a los montes, creyendo que se pretende oprimirlos, mediante el incremento que ha tomado la libertad y falta de subordinación con que han vivido hasta ahora".

El carácter militar de aquella jurisdicción databa del 8 de enero de I $75^{\circ}$, en que Ortiz Parrilla había nombrado a Tomás de Ibarra capitán de los milicianos dándole además el mando político que hasta entonces había tenido tin alcalde electivo. A Ibarra había sucedido José Pardo, y a éste Mateo Ortega, que lo era actual. Mazatlán se consideraba "real presidio" y pretendía que la exención de tributos y fuero que Gálvez había concedido a los mi-

I60 Representación documentada de Ugalde a S. M., con carta a Campo Alanje. México, I 8 de febrero de 1793 . Real orden de 28 de noviembre de I793 a Revillagigedo. Revillagiged a Cámpo Alanje, núm. I I59. México. 3 I de marzo de 1794. Ibid. 
licianos en I768 era extensiva a todo el pueblo. Revillagigedo decidió seguir la propuesta de Grimarest y nombró a Don José Garibay, sargento mayor de las milicias de Guadalajara, y a Don José Pose, teniente del regimiento de Tlaxcala, para los empleos de comandante y ayudante de las milicias mazatecas con el encargo de arreglarlas en compañías. La decisión fue aprobada por real orden de 23 de marzo de 1792, expidiéndose en junio los despachos, quedando Garibay con el mando político y militar y "bajo la inmediata dependencia del comandante general de la propia provincia". ír Con esta última modificación, la comandancia iba a entrar por nuevos rumbos.

\section{La reunificación bajo Don Pedro de Nava}

Por real orden de 24 de noviembre de $\mathrm{I} 792$ se dispuso la reunificación e independencia de la comandancia general, cuyo jefe llevaría unida la superintendencia de real hacienda en las cinco provincias que comprendiera:.Sonora, Nueva Vizcaya, Nuevo México, Coahuila y Texas. Por primera vez se ve restringida la comandancia a las cinco provincias que propiamente deben recibir el nombre de internas y tienen entre sí verdadera cohesión por igualdad de circunstancias. Las consecuencias de esta resolución son sin embargo todavía otras: las Californias se han segregado, y con la Alta las tendencias impulsoras de una expansión territorial hacia el noroeste, que venían languideciendo desde el tiempo de Gálvez. Nuevo León y Nuevo Santander vuelven por completo a la órbita del virreinato. La capital, por último, se traslada a Chihuahua.

Todo esto indica la apertura de un período nuevo, que dura hasta el fin del dominio español en América continental, en que la comandancia orienta todos sus impulsos hacia la consolidación de la frontera del golfo de Californias al de México. Pero como, simultáneamente, esta frontera empieza a ser cada vez menos difícil de mantener en la nueva situación de las alianzas con las tribus indias, la actividad económica vuelve a renacer con desarrollo creciente en las provincias internas.

La proyección al exterior, más al norte, es nula. Dieciséis años de vinculación de las provincias internas con la Alta California han dejado bien de manifiesto que no es factible, con los medios con que se cuenta en esta época, apoyar desde Sonora ni Nuevo México, una colonización intensa de aquella provincia, con la que ni siquiera se pueden mantener abiertas vías de comunicación, pese a los esfuerzos realizados para conseguirlo. En este

I6I Revillagigedo a Campo Alanje, núm. 209. México, 28 de febrero de I79r, con tode el expediente. Real orden de 23 de marzo de I792. A. G. S., Guerra Moderna, 703.8. Despacho te Garibay, A. G. S., Guerra Moderna, 7035. En i 793 se nombró ayudante de las milicias de Mazatlán a D. Domingo Espinosa de los Monteros. A. G. S., Guerra Moderna, yozz. 
sentido, la sublevación de los yumas fue fatal, e interrumpió definitivamente la ruta de Californias, aislando aquellos establecimientos del que debiera ser su respaldo continental, dejándolos exclusivamente dependientes de las comunicaciones navales con el virreinato merced a los buques del departamento de San Blas, que encuentran en esto más callada pero más eficaz labor que en las exploraciones de la costas de Alaska. Y esto debemos aumentar al haber realizador de Don José de Gálvez: la subsistencia de los establecimientos españoles en la Alta California gracias al esfuerzo de los marinos de la base de San Blas por él creada.

En estas circunstancias, pues, era lógico que las Californias quedasen winculadas al virreinato, $y$ de espaldas al Pacífico a partir de entonces la comandancia general, los problemas militares de la frontera serán desde este momento - como de hecho lo habían sido casi siempre - su principal atención.

El motivo de la reunificación se halla precisamente en las cartas en que Revillagigedo aboga por la supresión de la comandancia. El 24 de marzo de $\mathrm{I} 792$ ordenó el rey se formase expediente con los memoriales, informes y toda clase de documentación que se considerase útil sobre las provincias internas, $y$ que se pasase a la junta de generales restablecida en Madrid para que le propusiese lo más conveniente a la defensa, gobierno, seguridad y fomento de ellas. La junta, presidida por Don Juan José de Vértiz, se reunio en casa de éste a partir del 2 de abril siguiente, y emitió su informe el II de. junio. El dictamen de los generales - Vértiz, Tejada, Mendinueta, Cambiazo y Casaviella - pasó luego a consulta del consejo de estado, el 7 de septiembre, donde, con asistencia del rey y de los consejeros Aranda, Valdés, Campo Alanje, Gardoqui, Alcudia y Acuña, se aprobó la propuesta de la junta que recoge la real orden de 24 de noviembre, añadiendo la concesión de la superintendencia general subdelegada de real hacienda al comandante en las cinco provincias. Se dispuso también que Nava no innovase nada en lo militar, civil, político o hacendístico hasta que tomando pleno conocimiento de su estado pueda informar detalladamente lo que le parezca sobre cada uno de estos ramos. ${ }^{162}$

El brigadier Don Pedro de Nava, teniente de rey en Caracas y luego comandante general de las provincias internas de Poniente, entra ahora a regir la comandancia unida durante diez años, y su actividad en este tiempo muestra la continuidad seguida en un programa por demás simplista

I62 Vértiz a Campo Alanje. Madrid, 3 de abril de 1792. Informe de la junta de generales. Madrid, 11 de junio de 1792. Resolución del consejo de estado. 7 de septiembre de I792. Real orden de 24 de noviembre de 1792 a Nava. A. G. I., Guadalajara, 390. La real orden se cita como del 236 del 24 de noviembre, fechas en que fue expedida por los diferentes ministerios. 
y sin complicaciones: reducción de tropas en lo posible, mantenimiento de las paces con las naciones indias no sometidas, tentativas de enlazar entre si las provincias, penetración en la Sierra Madre para terminar con los núcleos aún gentiles de la Tarahumara.

\section{REPLANTEAMIENTO DE LA COMANDANCIA}

La reunificación de las provincias internas decretada por el Consejo de Estado el 7 de septiembre de 1792 representó ya en principio una economía para la real hacienda, puesto que en vez de los diez mil pesos que hasta entonces cobraba cada uno de los dos comandantes generales, Nava sólo había de percibir quince mil por el gobierno de las cinco provincias. ${ }^{163}$

Esto aparte, insistía la real orden de I792 en la reasunción de la superintendencia general de real hacienda por el comandante general. No vaciló Nava desde que Revillagigedo le comunicó su independencia en I 2 de febrero de 1793 en afrontar este problema, que sin: embargo, no podía menos de hacer presente el ministerio: el ejercicio de la superintendencia requería la formación en Chihuahura, puesto que ésta habría de ser su capital, de una Junta Superior de Real Hacienda y un Tribunal de Cuentas, o por lo menos la designación de algunos funcionarios que hiciesen sus veces. Pero como en las provincias internas no los había, hubo que pedir al virrey que la Junta y el Tribunal de México continuasen en el uso de las facultades que hasta entonces habían ejercido sobre los territorios de la comandancia, sólo que entendiéndose con Nava como antes lo hacían con el virrey. La segregación de la comandancia permitiría, según pensaba, minorar el número de empleados de los tribunales de México, trasladando a Chihuahua los sobrantes para constituir aquí los organismos precisos de real hacienda. ${ }^{164}$

Sabemos ya los esfuerzos practicados y las dificultades aparentemente invencibles para conseguir la autonomía económica y hacendística de la comandancia general. Tampoco esta vez había de obtenerla Nava, y sólo en los últimos tiempos de la dominación española, en circunstancias excepcionales $y$ de manera muy precaria se consiguió una cierta independencia en este sentido. Por el contrario, la sujeción del comandante general al virreinato en materias de hacienda había de producir no pocos ni pequeños problemas en época inmediata, como tendremos ocasión de estudiar.

I63 Nava solicitó dispensa de media anata por su aumento de sueldo. Nava a Gardoqui Chilıuahua, 24 de abril de I793, núm. 4. A. G. I., Guadalajara, 426.

I64 Nava a Gardoqui. Chihuaht1a, 24 de abril de I793, núm. I. A. G. I., Guadalajara, 393 y 426. Nava a Gardoqui. Chihuahua, 4 de julio de I793, núm. I. A. G. I., Guadalajara, 390. Nava a Gardoqui. Chihuahua, 24 de abril y 5 de septiembre de 1793 , núms. 2 y 9. A. G. I., Gundalajara, 426. Se advierte un gran desorden en la numeración de la correspondencia de Navə. 
Por otros caminos, además, venía a ocurrir la no absoluta independencia del comandante general. En efecto, por real orden de I 5 de mayo de 1795 se dispuso que el virrey de Nueva España conociese en todos los asuntos de minas de la comandancia. Nava consideró esto un despojo de sus facultades, perjudicial por añadidura al buen gobierno, puesto que él podía resolver con más conocimiento cualquier problema. ${ }^{165}$ Cierta sujeción al virrey en materia militar le fue igualmente impuesta por real orden de 22 de febrero de 1796 que le obligaba a comunicar a México las novedades de la guerra con los indios, aunque Croix y Neve sólo lo habían hecho con ocasión de pedir refuerzos o cuando era algo refierente a Nuevo León o Nuevo Santander. ${ }^{\mathrm{I}} 66$

En orra ocasión se dispuso que los intendentes García Conde y Bonavia jurasen ante el virrey. ${ }^{167}$

Otras cuestiones se plantean seguidamente a Nava. Una repentina enfermedad le hizo comprender el riesgo ya fatalmente corrido por las provincias internas de que, en caso de fallecimiento del comandante general, quedasen $\sin$ jefe. Y aun antes, como ocurrió a la muerte de Neve, pudo hacerse cargo interinamente Rengel, comandante inspector, pero ahora, suprimido este empleo, quedarían suspensas las facultades propias de la comandancia -mando supreno, superior gobierno, superintendencia de la real hacienda, facultad de provisión de empleos, vicepatronato, subdelegación de la renta de correos- hasta que la audiencia del distrito o el virrey nombrase interino, o viniese la designación de Su Majestad. Nava tocaba con esto otro de los puntos flacos del sistema: la unidad y la coordinación de las cinco provincias se daban exclusivamente en la persona del comandante general, puesto que en este momento no había ni un segundo jefe, ni ningún tribunal u organismo que en un momento dado pudiera hacerse cargo del mando supremo de las provincias internas. $\mathrm{La}$ desaparición del comandante significaría la desintegración de la comandancia general. ${ }^{168}$

El 2 de mayo de 1793 firmaba Nava un informe sobre el estado de las provincias puestas bajo su dirección. Sus conclusiones eran que podía prescindirse del gobierno tiempo atrás propuesto para la Tarahumara y que, con una sabia política, podría garantizarse la paz de los apaches que en número de más de mil se habían asentado ya junto a los establecimientos españoles. Algunos arreglos de sueldo y aumento de tropas constituían el resto de su

I65 Nava a Gardoqui. Chihuahua, 6 de octubre de 179.5, núm. 59. A. G, I., Guadalajara, 426

I 66 Nava a Azanza. Chihuahua, 5 de julio de I796, núm. 286. A. G. I., Guadalajara, 293.

167 Nava a Campo Alanje. Chihuahua, 6 de agosto de I795, núm. 202. A. G. I., Guada-

lajara, 292. jara, 289 . 
programa. ${ }^{169}$ Entre estos arreglos hacía constar algo después la solicitud de aumento de prest que habían fundado los ópatas de la compañía de Bacuachi y que él hacía extensiva a los de Bavispe y a los pimas de Buenavista. ${ }^{170}$

Tal vez la innovación más importante en la problemática de la comandancia en tiempos de Nava consiste en el planteamiento del peligro exterior de la parte de Texas, esta vez por mar, al ocurrir la guerra contra Francia. Esta situación no se había dado desde que se incorporó Luisiana a los dominios de España, y aunque había habido conflictos internacionales desde entonces jamás se enfrentó Teodoro de Croix con la posibilidad de un ałaque británico. De todos modos, lo único que Nava pudo hacer fue ordenar al gobernador Muñoz que pusiese vigías en la costa y que, en caso de necesidal, pidiese ayuda a Coahuila y Nuevo León; y en último término, el comandante general confiaba para sit defensa en la incomodidad de la costa para cualquier desembarco y establecimiento. ${ }^{71}$ Mayor inquietud le proporcionaban los colonos franceses de Luisiana, entre los que empezaban a cundir las doctrinas revolucionarias de su patria de origen. En el orden de la organización, la creación del gobierno político y militar de Mazatlán supuso una curiosa novedad en la costa de Sonora, procediendo el primer gobernador, Don José Garibay, a arreglar las cuatro antiguas compañías de pardos libres. ${ }^{172}$

En Sonora, como venía ocurriendo, el capitán más antiguo actuab? como comanclante de las armas de la provincia una vez que la comandancia general habia establecido su sede en Chihuahua. ${ }^{\text {I73 }}$ En Nueva Vizcaya, en cambio, el gobernador de Durango no podía materialmente controlar la frontera, por lo que Nava pedía se le quitase el título de gobernador militar. Sin embargo, aín le parecía mucho más oportuno que se fijase en Chihuahua el gobierno de Nueva Vizcaya, con lo que el intendenie podría tener el mando de las armas de la provincia en caso de ausencia o enfermedad del comanclante general. ${ }^{174}$

\section{LA DEFENSA DE LAS PROVINCIAS INTERNAS}

Nava se hizo cargo de la doble comandancia en un momento en que la lucha con los indios se presentaba netamente favorable. Comanches, navajos,

I6g Nava a Campo Alanje. Chilutahua, 2 de mayo de I793, núm. 9. Ibid.

izo Nava a Campo Alanje. Chihuahua, 7 de noviembre de 1793, núm. 70. Ibid.

i7 I Nava \& Campo Alanje. Chihuahıla, 5 de diciembre de I793, núm. 82. Ibid.

i 72 Nava a Anza. Guajoquilla, 3 de agosto de 1796 , níms. 2g8. Nava a Azanza. Valle de San Bartolomé, 8 de septiembre de 1796 , núm. 308. A. G. I., Guadalajara, 293.

I73 Nava a Campo Alanje. Chihuahua, 4 de diciembre de I794, núm. I54. A. G. I., Guadalajara, 290.

I74 Nava a Campo Alanje. Chihuahun, 2 de octubre de I794, núm, 142. Ibid, 
yutas y jicarillas se mantenían en franca paz en Nuevo México y Equeracapa, el caudillo comanche, hostilizaba a los apaches en las sierras del Tizón y de Llanos: la continua persecución por comanches y españoles causaba a los apaches, único enemigo declarado, cuantiosas bajas entre muertos y cautivos. ${ }^{175}$ Fuera de esto, más de mil quinientos apaches vivían de paz junto a los puestos fronterizos. Cuando Nava tomó el mando de la comandancia occidental a fines de r79o sólo había un corto número de ellos en Bacuachi, pero chiricahuis, gileños, mimbreños y mezcaleros se iban presentando allí y en Janos, Carrizal y presidio del Norte y en 14 de octubre expidió Nava instrucción a los capitanes para el manejo de estos indios que empezaban a someterse. Confiaba el comandante general en que mientras los enemigos fuesen castigados, no se inquietarían los hasta entonces de paz, y también mientras advirtiesen rectitud, firmeza y buena fe por parte de los españoles y fuesen más felices con lo que de su mano recibían para subsistir que con lo que les proporcionaba el robo y su vida errante llena de riesgos. Nava permitió a los apaches de paz establecerse donde más les agradase, previendo que la dispersión les haría más difícil el confabularse en cualquier momento, al mismo tiempo que su tolerancia les haría posible habitar más próximos a las sierras en que habían habitado, disfrutando el mezcal, caza y las semillas que producían y que miraban como propias.

Eran doscientos veintidós los apaches pacificados en Sonora, distribuidos entre Bacuachi, Fronteras y Tucsón: doscientos veintiséis se congregabar en el puesto de Sabinal, en Nuevo México, y eran setecientos veinticinco los asentados en Janos, Carrizal y San Eleazario, ignorándose el número, que debía ser elevado, de las ocho rancherías de mezcaleros situadas en el presiclio del Norte, $y$ entre las que se calculaban doscientos treinta o doscientos cincuenta hombres de armas. ${ }^{\text {I76 }} \mathrm{La}$ paz con los lipanes y otras parcialidades habia sido también conseguida. ${ }^{177}$

Contaba entre tanto Nava para la protección de la frontera con veinte presidios en las cinco provincias: siete en Nueva Vizcaya, seis en Sonora, uno en Nuevo México, cuatro en Coahuila y dos en: Texas. Había además cuatro compañías volantes en Nueva Vizcaya, y otra en San Carlos de Pa.rras, más tres de indios en Sonora. Algunas tropas existían en Nuevo León y Nuevo Santander, pero estas provincias correspondían ahora al virreinato y, salvo la compañía de Lampazos, las demás se ocupaban en batir la sierra

I75 Nava a Campo Alanje. Chihuahua, 2 de abril de 1793, núm. 8, con Extractos. A. G. I., Guadalajara, 289.

I 6 Nava a Campo Alanje. Chihuahua, 9 de julio de 1793 , núm. 9, arts. 28 al 42. Ibid.

i77 Nava a Campo Alanje. Chihuahua, I $^{\circ}$ de agosto de 1795, núm. 197. A. G. I., Guadalajara, 292 . 
de Tamaulipas, frente distinto al de los apaches. A mediados de 1792 se retiró por orden de Revillagigedo a Guanajuato la segunda compañía de voluntarios, que también había estado guarneciendo Nueva Vizcaya. El Virrey prometió a Nava en compensación un aumento de tropas en los presidios, pero nunca llegaría la hora de este refuerzo. El mismo Nava, por su parte, profuso la supresión del escuadrón de milicias de El Paso, que nunca había sido útil y ahora por la proximidad del presidio de San Eleazario, traído por Flores y Ugarte al paraje de los Tiburcios en 1789 , no era preciso mantener. ${ }^{178}$

La guerra con los apaches continuó ventajosamente durante el verano de $1793,{ }^{179}$ siendo tan sólo de lamentar la muerte del comanche Equeracapa en un ataque victorioso contra los panenes. Mientras los apaches eran hostilizados en la Sierra Blanca, sólo la periferia de Sonora y Nueva Vizcaya iadecía algunas incursiones y robos de ganado. Tal vez Nuevo México era la provincia que más beneficiosa paz empezaba a disfrutar, después de sigios de intranquilidad. A fin de año murió Antonio, general de los navajos, perc la situación no se alteró al ser elegido para sucederle su sobrino Baquienagage, llamado por los españoles José. ${ }^{180}$ Los comanches, por su parte, tuvieron junta general para proclamar nuevo caudillo. El gobernador Concha, que acudió a confirmar la elección halló ochocientas tiendas y cuatro mil quinientos comanches a orillas del río Colorado. El designado fue el capitán Encaguané, al que Concha entregó medalla de mérito con busto de Carlos III, bastón, bandera, un vestido completo y diversos objetos para que él los regalase a su vez, como lo ejecutó. ${ }^{18 x} \mathrm{El}$ año de 1794 comenzó bajo los mejorcs auspicios de paz y de victoria. ${ }^{18 z}$ Una quiebra sufrió Nava cuando una partida de quince hombres de San Eleazario fue sorprendida en la sierra de los Organos; entre ellos cayó el alférez Vidal de Lorca. ${ }^{183}$ Otras hostilidades de Nueva Vizcaya atribuia el comandante general a los tarahumaras, y de

178 Nava a Campo Alanje. Chihuahua, 1. de agosto de ${ }_{1793}$, núm. 47. A. G. I., Guadalajara, 289. Nava a Campo Alanje, Valle de San Bartolomé, 5 de junio de 1795. A. G. I., Guadalajara, 292. Las cuatro compañias volantes de la expedición estaban acuarteladas en Guajoquilla, Namiquipa, Pilar del Conchos y San Pablo o Julimes. La quinta o de San Carlos de Parras, en San Jerónimo. Nava a Caballero. Chihuahua, 7 de mayo de 1799. A. G. I., Guadalajara, 293.

179 Nava a Campo Alanje. Chihuahua, $1^{\circ}$ de agosto, 5 de septiembre, 3 de octubre y 7 de noviembre de 1793 , núm. $48,50,64,71$, con Extractos. A. G. 1., Guadalajara, 289 .

180 Nava a Campo Alanje. Chihuahua, 3 de octubre de 1793 , núm. 65. A. G. I., Guadalajara, 289. Nava a Campo Alanje. Chihuahua, 2 de enero de 1794, núms. 88 y 90, con Extractos. A. G. I., Guadalajara, 290.

I8 I Nava a Campo Alanje. Chihuahua, 2 de enero de 1794, núm. 78. Ibid,

I8z Nava a Campo Alanje. Chihuahua, 6 de febrero y 6 de marzo de 1794, núms. 102, 104 y 105 . Ibid.

I 83 Nava a Campo Alanje. Chihuahua, 3 de abril de I794, núm. III, con Extracto, Ibid. 
vez en cuando se dejaban sentir en Texas los robos de los carancahuas. ${ }^{184}$

E1 I6 de abril de 1795 salió Nava de Chihuahua a revistar la frontera oriental de Nueva Vizcaya y disponer algunas operaciones y reconocimientos. Dio comienzo a su visita por el presidio de San Carlos, siguiendo por los parajes de San Pablo donde estaba acuartelada la segunda compañía volante, Guajoquilla, donde la primera, y Pilar de Conchos, guarnecido por la tercera, y estableció un destacamento en el paraje de la Cruz. Nava se mostraba satisfecho del estado de la fuerza y de la guerra. Había acostumbrado a la tropa a hacer el servicio a pie como a caballo, haciéndola subir con resolución a las eminencias más fragosas, y había suministrado recuas de mulas a las compañías para el transporte de los bagajes. ${ }^{\text {I } 85}$

Las relaciones con los indios no dejaron, sin embargo, de sufrir algunas novedades de gravedad. E1 25 de julio de I795, los mezcaleros de E1 Paso, sublevados por causas desconocidas, causaron veintiseis bajas a tropas de San Carlos, Príncipe y tercera y cuarta compañías volantes en dos emboscadas en las sierras del Carrizo y el Ojo Caliente, no sin que aquellos destacamentos hubiesen dado muerte a veintiún enemigos antes de sucumbir. ${ }^{186}$ La frontera entró de pronto en explosiva actividad; los mezcaleros se habían unido a grupos de faraones, llaneros gileños y mimbreños. Como contrapartida se organizó la campaña con tropas de Nuevo México, Nueva Vizcaya y Coahuila, y al entrar el año I796. tres partidas mandadas por Chacón, Cordero y Emparán habían logrado causar ciento cuarenta y seis bajas a los mezcaleros, entre nuertos y cautivos. ${ }^{187} \mathrm{La}$ operación previa había sido expulsar a todos los alzados fuera de las líneas de las posiciones españolas con to que según Nava se preservó la paz en la provincia que no se vió alterada por estos acontecimientos. En el verano de 1796 continuaron las batidas. Cordero, al frente de un destacamento de doscientos hombres, fue enviado a reforzar las tropas que actuaban con toda diligencia en aquella época, la más favorable para realizar la expedición punitiva, por ser el momento en que las tribus se desplazaban a la caza del cibolo; Nava entre tanto, mandaba otro grueso destacamento en las fronteras del Bolsón para prevenir una posible entrada de los enemigos. ${ }^{188}$

I 84 Nava a Campo Alanje. Chihuahua, to de julio, 4 de septiembre, 6 de noviembre y 4 de diciembre de 1794 , núm. $127,139,145$ y 152 , con Extractos. Ibid. Nava a Campo Alanje. Chihuahua, 6 de agosto de 1795 , núm. 213 , con Extracto. A. G. I., Guadalajara, 292.

I85 Nava a Campo Alanje. Cuartel de San Pablo, 7 de mayo y Chihuahua, 9 de julio de I795, núms. I \&4 y I95. A. G. I., Guadalajara, 292.

I 86 Nava a Campo Alanje. Chihuahua, 3 de noviembre de $1795, n^{\circ}$. 230. con Extracto.. Ibid.

I87 "Estado... de las ventajas obtenidas contra los mezcaleros alzados". Chihuahua, 2 de febrero de I796. A. G. I., Guadalajara, 293.

188 Nava a Azanza. Chihuahua, 5 de julio de 1796 , núms. 286 y 291 , con Extracto. Valle de San Bartoloné, 8 de septiembre de I796, núm. 370. Ibid. 


\section{LA PRESIÓN DE LOS ESTADOS UNIDOS}

Muy pocos años después de la independencia, el movimiento expansivo de los Estados Unidos de América hacia el oeste es una realidad bien patente. En r795 este movimiento se hace sensible a las provincias internas.

El 3 I de enero avisaba el gobernador de Texas, Muñoz, a Nava que el vecino de Béjar Antonio Leal, viniendo de visitar a los indios del norte, encontró un grupo de noventa personas de la parcialidad de los ays que dijeron querer establecerse bajo la protección de los españoles. La razón de esta actitud estaba en el hecho de que los americanos habían expulsado de su territorio a los indios talapuses y alpamo y otras tribus, y éstos habíanse apoderado del de los ays, causándoles trece muertos. El grupo fugitivo se había detenido a orillas del río Trinidad, que experimentaba entonces una crecida, hasta que en mayo envió Muñoz un destacamento a recogerlos.

Sólo dos semanas después de aquella fecha, el I5 de febrero, se presentaron al propio Muñoz doce ahuahues, despachados por su capitán Irisac, y acompañados de varios wichitas y taobayas aliados de los españoles. Los embajadores de Irisac pretendían entrar igualmente en alianza juntamente con otras treinta y tres naciones próximas a la ahuahue. Todas ellas habían sido desplazadas de sus tierras por los angloamericanos. Nava ordenó a Muñoz informase con detalle qué clase de destrozos les habían hecho, cuáles eran las relaciones de estos indios con los aliados del norte, si correspondían a la provincia de Texas o a la de Luisiana y a qué estado pertenecían los americanos en cuestión. ${ }^{189}$

Desde mediados de 1794 se recelaba en México del avance de los americanos por aquel sector, y a consecuencia de órdenes del virrey a este respecto había enviado entonces Nava a Nacogdoches un destacamento de Béjar cuya misión era reconocer las aldeas de los indios aliados y adquirir noticias sobre si los americanos meditaban invadir Luisiana o Texas o apoderarse de algunos territorios de sil frontera. No hubo novedad a este respecto, y las naciones indias se mostraron fieles, ofreciendo avisar la llegada de cualquier sujeto que pretendiese inspirarles ideas contrarias a la paz con los españoles. Pasando adelante en esta actitud, los tahuacanas entregaron un extranjero que vivía con ellos y parecía colono americano, de ejercicio platero o armero, según las herramientas que se le hallaron. rgo

La prevención respecto de los Estados Unidos era ya considerable cuando al tiempo que se ordenaba guardar con ellos la mejor armonía con objeto

\footnotetext{
I89 Nava a Campo Alanje. Chihuahua, 6 de agosto de 1795, núm. 2II. A. G. I. Guadalajara, 293.

Igo Nava a Campo Alanje. Chihuahua, 6 de agosto de I795, núm. 2 I o. Ibid.
} 
de establecer una estrecha alianza se disponía igualmente vigilar a las personas que pasasen o hubiesen pasado de las antiguas colonias inglesas a Nueva España "porque Sı Majestad sabía pensaban enviar emisarios que influyesen a la sublevación de sus habitantes". Y también Carondelet se réa precisado a obrar hostilmente contra los codiciosos vecinos y a permanecer en guardia por los muchos negros que había en Luisiana. En consectencia, Nava decidió evitar la introducción de cualquier extranjero sospechoso en Texas, Coahuila y Nuevo México.

Al extranjero entregado por los tahuacanas se le tomó declaración en Béjar, siendo luego conducido al valle de Santa Rosa. Dijo llamarse Juan Calbert, platero y armero de oficio, y parece era un vagabundo que descle Filadelfia había ido desplazándose durante seis años hasta el fuerte Pitt, en el Ohío, a Natchez, Nueva Orleans y Natchitoches, desde donde pasó a los poblados de los tahuacanas y taobayas, con quienes había vivido catorce meses. Calbert fue mantenido preso en la Babia, siendo más tarde conducido a Potosí y Veracruz y La Habana para su repatriación. ${ }^{191}$

En culanto a las pretensiones de aproximación de las naciones indias, no pasaron muy adelante. En julio de I795 se presentaron por fin a Muñoz veintidós ays y vidais, que no accedieron a establecerse junto a Béjar sino a orillas del río Brazos, que era territorio suyo, a ochenta leguas de la capital y treinta del abandonado Orcoquizas. Pero esto suponía la erección de nueva misión y presidio de cincuenta hombres, y el comandante hubo de suspender la resolución de este asunto. ${ }^{192}$

No se tuvieron nuevas noticias de Irisac. Sin embargo, por el capitán de milicias de Natchitoches Don Bernardo Dortolant supo Muñoz cque los ahuahues vivían al sur del Missisipí, a cien leguas de este puesto, y que ihan a Islas Negras y al fuerte de San Luis a recibir los regalos que el gobierno de Luisiana distribuía a las parcialidades que vivían en paz en su territorio. Los ahuahues eran la barrera contra los americanos, pero éstos habían talado los campos en que hacían sus cacerías, ${ }^{193}$ empujándolos al oeste.

\section{LA CRISIS IIACENDÍSTICA}

Entre 1795 y 1797 padeció la comandancia general un grave trastorno en su administración económica que si bien no fue de larga duración sí re-

19 I Nava a Campo Alanje. Chihuahua, 3 de noviembre de 1795, núm. 229. Ibid.

I92 Nava a Campo Alanje. Chihıahua, I. ${ }^{\circ}$ de septiembre de 1795, núm, 216. A. G. I., Guadalajara, 292.

I93 Nava a Cámpo Alanje. Chihuahua, 3 de noviembre de I795, núm. 228. Ibid, 
vistió los caracteres de apremiante urgencia que pusieron de manifiesto los incontables inconvenientes que stuponía la sujeción de la comandancia al virreinato en materias de real hacienda.

Originóse el problema por haber comunicado Nava a Revillagigedo a fines de 1793 que no sería preciso que al año siguiente lé remitiese el acostumbrado situado de doscientos cuarenta mil pesos de las cajas de Guanajuato para pago de las tropas, sínodos y otros gastos de la comandancia, pues con lo que hasta entonces había recibido, los caudales existentes en Durango y los que entrasen por las rentas de I794 había suficiente este año. Sin embargo, en enero de $\mathrm{I} 795$, disminuidas ya las existencias, pidió Nava al virrey volviese a remitir los doscientos cuarenta mil pesos. El virrey, que lo era entonces Branciforte, creyó ver algo raro en esta petición, pues se había hecho a la infundada idea de que las provincias internas no necesitarían más situados y reclamó a la vez estados anuales de las tesorerías de Chihuahua y Arizpe, con lo que el expediente entró en vías de lenta tramitación, de tal manera que en enero de 1796 tenía que volver a insistir Nava en su demanda, mostrando ahora la urgencia de la remesa, que había de ser aún mayor, por cuanto Branciforte había suspendido en I’ de agosto de I794 el giro de libranzas sobre la caja matriz de México.

La tesorería de Chihuahua tenía que pagar anualmente medio millón de pesos y en su caja sólo se recibían por rentas ciento cuarenta mil. Pedía Nava, por consiguiente, trescientos cincuenta mil .Antes, a la cantidad que se enviaba de Guanajuato se añadían dieciséis o diecisiete mil pesos sobrantes de Durango y se permitían las libranzas. En Arizpe se necesitaban doscientos cincuenta mil pesos al año, y sólo entraban ochenta mil por rentas, librándose por el comercio ciento veinte o ciento cincuenta mil. Revillagigedo había dispuesto el envío de cien mil pesos anuales desde Guadalajara a Rosario. Ahora, suprimidas las libranzas, pedía Nava ciento setenta mil pesos. ${ }^{194}$

La última representación del comandante general había producido el efecto de que se autorizasen nuevamente las libranzas sobre la caja de México, pero el dinero para los pagos seguía faltando en las tesorerías de las provincias internas a mediados de I796. En tan apurada situación, dispuso Nava que las rentas administradas de tabaco, pólvora, naipes y alcabalas entregasen en ellas los productos líquidos. Las direcciones de rentas aceptaron la resolución del comandante, salvo la de tabacos, cuyos dependientes ya habían protestado de la orden: de Nava alegando que los productos bajarían y que se les agraviaba con el gasto de los fletes de caudales hasta las cajas reales, en vez de

194 Nava a Campo Alanje. Chihuahua, 3 de mayo de 1796 , núm. 27o. A. G. I., Guadalajara, 426 . 
permitirles convertirlos en letras o libranzas a particulares. Pero Nava, que no veía en esta oposición más que los intereses perjudicados de los administradores de la renta, acostumbrados a negociar con los caudales del rey, ordenó que le remitiesen mensualmente estados de los consumos, con los del mes correspondiente del año anterior, dispuesto a averiguar la causa de cualquier descenso si lo hubiese.

Por entonces, la penuria de medios con que contaba el comandante general se había hecho extremada. Cuando por fin se le permitió librar contra la caja de México sólo quedaban en Arizpe nueve mil pesos, debiendo pagar a $1 .^{\circ}$ de julio más de cien mil sólo en situados de tropa. ${ }^{195}$ Pero a fin de 7796 todavía no se habia resuelto en México la remesa de caudales a Chihuahua y Arizpe, y Nava se había visto obligado por las representaciones de directores de rentas a suspender el ingreso de sus productos en las cajas reales de su distrito. Echando mano, pues, de los últimos recursos, decidió trasladar a Arizpe el líquido existente en las cajas de Rosario y Durango, para poder atender a las pagas, pero después de este esfuerzo las arcas quedaron exhaustas y la Caja de Durango carecía hasta de lo preciso para sus propias atenciones. ${ }^{196}$

Por fin, en I6 de febrero de 1797 le avisó el virrey haberse resuelto el envío de ciento cincuenta mil pesos de Guanajuato a Chihuahua y de setenta y cinco mil de Guadalajara a Arizpe. Con estas remesas y la continuación del giro de libranzas pudo ya en la comandancia restablecerse la normalidad. ${ }^{197}$

La crisis, había, pues, pasado, pero había demostrado claramente la inconveniencia de la subordinación que para la comandancia suponía no poseer una casa de moneda propia, por lo que dependía de las remesas que se le hicieran desde el virreinato. Las provincias internas producían mucho más que lo que se consumía en ellas, pero la plata pasta había de ser enviada a amonedar a México. El cese de las remesas suponía el principio de la desaparición del numerario circulante, que se escapaba de la comandancia general con tanta más rapidez cuanto que el virrey había suspendido durante año y medio el giro de las libranzas, con lo que muchos comerciantes de tierra adentro habían tenido que enviar afuera la moneda de que disponían para hacer sus pagos.

Este episodio, aunque breve, significó un duro golpe asestado al comercio, en particular por lo tocante a las libranzas que hasta entonces habían facilitado los negocios con los mercaderes que introducían sus hatajos desde

I95 Nava a Gardoqui, Chihuahıa, 7 de junio de г796, núm. 8. A. G. I., Guadalajara, 426.

I96 Nava a Gardoqui. Chihuahua, 8 de noviemebre de I796, núm. 89. Ibid.

I97 Nava a Hormazas. Chihuahua, 5 de diciembre de 1797 , núm. I 16. A. G. I. Guadalajara, 247 . 
Michoacán y que permitían al mismo tiempo retener el numerario en las provincias internas. $Y$ en su conjunto representa una muestra más de la inestabilidad de un espléndido proyecto político, imperfectamente concebido y sólo a medias realizado.

\section{EL DESARROLLO IECONÓMICO}

"En el discurso de mi marcha ---escribe Nava al regreso del reconocimiento de la frontera del Bolsón practicado en I795- he tocado visible la celeridad con que estas provincias van manifestando su feracidad y opulencia. Los campos que ahora poco tiempo no eran de utilidad alguna se hallan en el día aprovechados con cuantiosas sementeras y cubiertos de toda clase de ganados. Algunas pequeñas vecindades, que se vieron desiertas por el terror que en sus individuos infundieron las frecuentes atrociclades de los bárbaros, están a la presente en un estado tan ventajoso, comparado al que tuvieron antes, que continuando la paz y la quietud actual llegarán estos dilatados dominios del rey a una prosperidad no esperada". ${ }^{198}$

Aunque acojamos con reservas esta optimista visión de la prosperidad finisecular de Nueva Vizcaya - no olvidemos que Nava se consideraba al término de su mandato y debía pretender esclarecer su éxito-, no cabe duta al menos de la aseveración de que se lograría un extraordinario forecimiento si se aseguraba la paz. Y una paz bastante completa gozaba Nueva Vizcaya, $y$ en general la tenían las cinco provincias, desde I790. El entorpecimiento hacendístico a que nos hemos referido en el epígrafe anterior fue también acusado, sin embargo, naturalmente, en índice tan sensible como el de la producción minera, ya que la falta de numerario en las tesorerías impidió el rescate de platas por cuenta de la real hacienda, que era el mayor fomento que podía darse a aquel ramo.

A esta causa atribuía Nava que no fueran más elevadas las cifras del oro y plata entrados en cajas reales desde I. $^{\circ}$ de julio de $\mathrm{r} 795$ al 3 I de diciembre de 1796 , después de las cantidades anunciadas en el estado del año y medio anterior. Nava se había mostrado, en efecto, sumamente satisfecho con el rendimiento de las minas desde que él se hizo cargo del mando ínico, no dudando en asentar que el aumento experimentado desde entonces no se había debido a la bonanza extraordinaria de las minas, sino a. la paz que él había procurado a las provincias y con la que habian florecido comercio, agricultura y minería.

э98 Nava a Campo Alanje. Chihuahua, g de julio de 1795, núm. i95. A. G. I., Guadalajara, 292. 
Veamos la producción de esos dieciocho meses: I. ${ }^{\circ}$ de enero de 1794 a 3 I de junio de I795:

$$
\begin{aligned}
& \text { Oro con plata } \quad y \text { azogue } \quad \text { Quintos } \\
& \text { (EN MARCOS, ONZAS Y OCHAVOS) Y GRANOS) }
\end{aligned}
$$

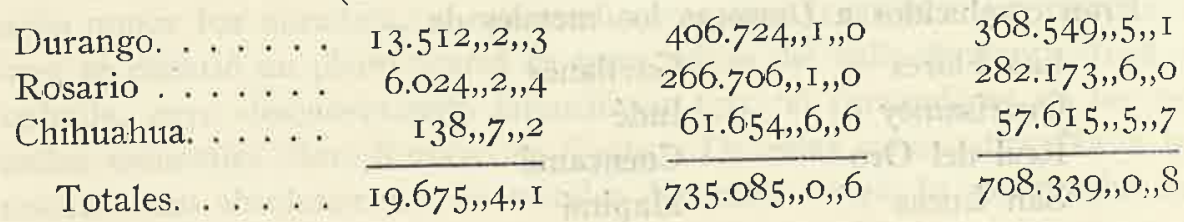

La confrontación del producto de los quintos de 1792 y 1794 daba un halagüieño índice de aumento, sobre todo para un período tan breve.

$\begin{array}{ccc}\text { Quintosen } & \text { Quintosen } & \text { Aumento en } \\ \text { I792 } & \text { I794 } & \text { I794 }\end{array}$

(EN PESOS, REALES Y GRANOS)

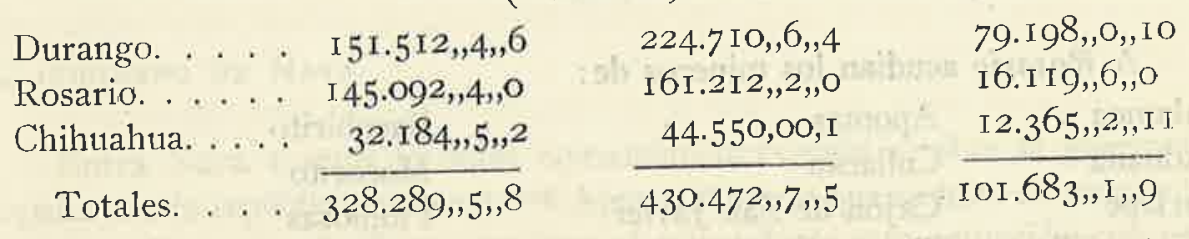

La progresión había sido lo suficientemente regular y homogénea, desde luego, como para confirmar la opinión de Nava de que el progreso se debía al impulso dado por él con la paz lograda en las fronteras. ${ }^{199}$ Por eso era de sentir el contraste con esta otra situación del estado correspondiente al período de dieciocho meses comprendido entre $\mathrm{I}^{\circ}{ }^{\circ}$ de julio de 1795 y $3 \mathrm{I}$ de diciembre de I796.

$\begin{array}{cc}\text { Oro puro } & \text { Plata por fuego } \\ \text { y con plata } & y \text { azogue }\end{array}$

(EN MARCOS, ONZAS Y OCHAVOS)

Durango. . . . . $16.73^{8,, 0,, 7}$

Rosario. . . . . I. I.89I,,2,II

Chihuahua. . . . 424,4, 7

Totales. . . . I 19.052,,3,,7

$$
\begin{aligned}
& 377.690,0,0,0 \quad 354.065,, 6,8 \\
& 209.055,1,4 \quad 193.976,6,6 \\
& \frac{74.083,, 0,4}{660.828,6,0}-\frac{72.609,, 1,, 0}{620.655,6,, 2}
\end{aligned}
$$

I99 Nava a Gardoqui. Chilunahua, r. de diciembre de I795, núm. 66. A. G. I., Guadalajara, 426 . 
Nava atribuía el descenso a la falta de caudales experimentada estos años por la supresión de las remesas de numerario del virreinato, pues las minas atravesaban desde luego una época de bonanzá y era frecuente el descubrimiento de nuevas vetas minerales. ${ }^{200}$

No menos de cincuenta y un reales de minas imporiantes anota el comandante general a fines de I795. He aquí la relación:

Eran conducidos a Durango los metales de:

$\begin{array}{ll}\text { Las Flores } & \text { Gavilanes } \\ \text { Guarisamey } & \text { Indé } \\ \text { Real del Oro } & \text { Cuencamé } \\ \text { San Lucas } & \text { Mapimí } \\ \text { Abinito } & \text { Pánuco } \\ \text { Parral } & \text { San Andrés de la Sierra } \\ \text { Sianori } & \text { Ventanas } \\ \text { Canelas } & \text { Papascuiaro } \\ \text { Coneto } & \text { Basis } \\ \text { Guanacevi } & \text { Topago }\end{array}$

A Rosario acudían los mineros de:

$\begin{array}{lll}\text { Alamos } & \text { Apomas } & \text { Bacubirito } \\ \text { Aduana } & \text { Culiacán } & \text { Mocorito } \\ \text { Arizpe } & \text { Cajón de San Javier } & \text { Plomosas } \\ \text { Cieneguilla } & \text { Tamasula } & \text { Matatán } \\ \text { Copala } & \text { Fuerte } & \text { La Puerta } \\ \text { Juntas } & \text { Sibirijoa } & \text { Jocoistita } \\ \text { Arrona } & \text { San Miguel de Horcasitas } & \text { La Trinidad } \\ \text { Pánuco } & \text { Sinaloa } & \text { San Antonio } \\ \text { Cosala } & & \text { Nuestra Señora del Rosario. }\end{array}$

$Y$ en Chihutahua se quintaban las platas de:

Cusihuiriáchic, Santa Eulalia, Uruapan y la Santísima Trinidad.

Estos eran los centros productores de la riqueza mineral arriba constatacla. ${ }^{2 o r}$ De ellos, el de Guarisamey era el más recientemente descubierto. A setenta y dos leguas de Durango, en el corazón de la Sierra Madre, estaba próximo al real de San Dimas, y a los otros de menor importancia de San Dimas y Tayoltita y al último hallazgo del río de Ventanas. Sus platas se conducían indistintamente a Durango o Rosario. En sólo I793 había produ-

200 Nava a Gardoqui. Chihualuua, 7 de marzo de 1797, núm. 100. A. G. I., Guadalajara, 427. 201 Vid. nota 199 de este capítulo. 
cido más de ochenta mil pesos de plata por fuego y azogue. ${ }^{202}$ Se observa en la relación, naturalmente, la total exclusión de cualquier yacimiento minero en explotación en las provincias de Nuevo México, Coahuila y Texas; así había sido y así sería siempre durante el período español. Siempre en las relaciones de estas provincias, se hace alusión a algunas vetas de metales preciosos, y en Coahuila se cita incluso alguna hacienda de labor pero su explotación nunca fue duradera, ni extraordinariamente fructífera. En tiempos de Nava se debatió un pleito acerca de unas minas del valle de Santa Rosa, en Coahuila, cuyo descubrimiento anunció en 1792 el comandante de las provincias orientales Don Ramón de Castro. De estas minas dice Nava que "aunque sean absolutamente de metales de buenas leyes, lo son mucho más de agua que impide su laboreo si no se constituyen obras costosas para extraerlas, las cuales no pueden hacer sus dueños, todos de cortas facultades, ni la compañía que se formó para trabajarlas". ${ }^{203}$ Los dueños de la mina eran dos indios tobosos, sus descubridores, que lograron sacar unos once mil pesos de plata, pero en I798 ya estaba abandonada, ante el fracaso de la intentada extracción del agua que la inundaba. ${ }^{204}$

\section{EL gobierno de Nava}

Entra Nava a regir la doble comandancia cuando se abre la guerra de España con la república francesa. ${ }^{205}$ Aparte el recelo que se tuvo de un ataque enemigo a las costas de Texas, no tuvo el comandante otra actuación con este motivo que la de disponer la colecta del donativo que voluntariamente quisiesen los pobladores ofrecer para los gastos de la Corona. El obispo y cabildo de Durango ofrecieron diez mil pesos. ${ }^{206}$ Siguieron los comerciantes y hacenderos de toda la comandancia. A fin de 1793 la cantidad recogida ascendía a unos veinte mil pesos. En marzo de I795, a treinta mil. En octubre a más de treinta y ocho mil. ${ }^{207} \mathrm{El} 8$ de diciembre de aquel año se publicó en Chihuahua solemnemente el tratado de paz. ${ }^{208}$ 'Más de 4.000 pesos ingresaron después en virtud del descuento del $4 \%$ que se hizo a los sueldos militares

202 Nava a Gardoqui. Chihuahua, 6 de marzo de 1794, núm. 2o. A. G. I., Guadalajara. 425.

203 Nava a Gardoqui. Chihuahua, 6 de octubre de 1795 , núm. 59. Ibid.

204 Nava a Saavedra. Chihuahua, 4 de septiembre de 1798, núm. i26. A. G. I., Guadalajara. 427.

205 Nava a Campo Alanje. Chihuahua, I. ${ }^{\circ}$ de agosto de 1793 , núm. 4I, acusa recibo del aviso de la declaración de guerra. A. G. I., Guadalajara, 289.

206 Nava a Acuña. Chihuahua, 26 de abril de I793, núm. 3. Ibid.

207 Nava a Gardoqui. Chihuahua, 3 de octubre y 5 de diciembre de I793, 6 de marzo de 1794,5 de marzo, 2 de abril, I. ${ }^{\circ}$ de septiembre y 6 de octubre de I795, núms. I I, I4, I9; 48 , $49,55,64$. A. G. I., Guadalajara, 426.

208 Nava a Campo Alanje. Chihuahua, 8 de diciembre de 1795. A. G. I., Guadalajara, $29 z$. 
de más de seiscientos pesos con el mismo fin, y otro tanto donaron los empleados de la renta de tabacos. ${ }^{209}$ En I798, iniciada la guerra contra Inglaterra, procedió Nava a solicitar nuevo donativo, dando ejemplo con el depósito que hizo de dos mil pesos. Se recogieron cerca de catórce mil en Chihuahua. A mitad de 1799 se habían alcanzado los cincuenta y cinco mil en toda la comandancia y se aproximaban a catorce mil pesos las cantidades entregadas en concepto de préstamo patriótico sin interés. A los ochenta y un mil pesos ascenđió el total del donativo a fin de año. ${ }^{2 \text { to }}$

La guerra no se hizo sentir más que por la presencia en el golfo de Californias de varios pesqueros de ballena ingleses, que reconocieron hasta la desembocadura del Colorado.

Aparte esta cuestión, atendió Nava asuntos de interés nás inmediato para los territorios de su gobierno. Fray Francisco Rouset de Jesús se ocupaba de la conversión y radicación de los gentiles de lạ Sierra Madre. Nava dispuso que los vecinos de las jurisdicciones inmediatas reconociesen tres veces al año las serranías de sus partidos para recoger a los fugitivos. Noventa y siete barrancas visitó el padre Rouset, logrando extraer de ellas seiscientos veintiún gentiles y ciento noventa apóstatas siendo todos agregados a las misiones colindantes. ${ }^{21 \mathrm{I}}$

Con esta visita, en la que el franciscano invirtió once meses, y con la ulterior disposición de Nava de que periódicamente se reconocese la sierra Madre parece quedar concluído el motivo de la preocupación que Croix mostrara por los gentiles y apóstatas del corazón de la cordillera, refugio de malhechores. También en otros asuntos liquidó Nava algunas de las disposiciones de Croix. Uno de ellos fue el del recargo de armamento creado por el primer comandante general y suprimido por Ugarte. Una real orden de 29 de noviembre de 1794 dispuso además que se reintegrase a los que compraron las armas lo que en concepto de recargo abonaron, medida ésta imposible de cumplir porque si bien el recargo había producido, en el tiempo que estuvo en vigor, veinte mil ochocientos sesenta y dos pesos había sido toda esta cantidad

209 Nava a Gardoqui, Chihuahua, 7 de marzo de 1797, núm. 102. Nava a Saavedra. Chihuahua, 4 de septiembre de I798, num. I 25. A. G. I., Guadalajara, 427.

г го Nava a Saavedra. Chihuahua, 9 de octubre, 6 de noviembre y 4 de diciembre de r798, 8 de enero, 5 de febrero, 5 de marzo, 7 de mayo, y II de junio de I799, núms. I 28 , I30, I34, 1 $35,136,137,140,148$ y I56. A. G. I., Guadalajara, 426. Nava a Soler. Chihuahua, 9 de julio, 6 de agosto, 5 de noviembre y 10 de diciembre de I799, núms. I6I, I65, I70, I7I, I74 y I75. A. G. I., Guadalajara, 427. En la primera mitad de 1800 todavía aumentaron los donativos en más de veinte mil pesos. Nava a Soler. Chihuahua, 7 de enero, 4 de febrero, i I de marzo, 8 de abril y 8 de julio de 1800 , núms. 176, 177, 181, 184, 191. A. G. I., Guadalajara, 428. Nava a Soler. Chihuahua, 6 de mayo de 1800 , núm. 185. A. G. I., Guadalajara, 268.

2. I Nava a Campo Alanje. Chihuahua, 2 de mayo de 1793, núm. 9 arts, 2 al 5. A. G. I., Guadalajara, 289. Nava a Llaguno. Chihuahua, 2 de abril de 1795 , núm. 9. A. G. I., Guadillajara, $29 \mathrm{I}$. 
invertida en diversas atenciones de la comandancia y aún había un descubierto de dos mil ochocientos setenta y cuatro pesos en la tesorería de Arizpe, por lo que se había librado con exceso sobre el fondo. La restitución era por otra parte imposible por la muerte, deserción o licencia de muchos de los que compraron las armas, cuando se conocían sus nombres. Por todo ello pidió Nava se diese por fenecido este asunto. ${ }^{212}$

Del mismo modo se liquidó la fracasada tentativa, tantas veces emprendida, de organizar las milicias de El Paso, cuyos arbitrios no habían producido en catorce años más de cuatro mil quinientos cincuenta y seis pesos, dos reales, es decir, trescientos veinticinco pesos por año. Afortunadamente tales milicias se consideraban muy innecesarias gracias al traslado del presidio de San Eleazario a los Tiburcios. Aquella cantidad se invertiría en resarcir los gastos de la remoción. ${ }^{213}$

Tuvo Nava cuidado de procurar el desempeño de las compañías de Coahuila a las que Ugalde, después de sus úitimas campañas, había dejado en la más lamentable situación, y aun debiendo veinte mil pesos de treinta mil que les adelantó para su habilitación Revillagigedo. En I795 había conseguido Nava saldar esta deuda, gracias al desahogo que proporcionaba la paz con los lipanes. ${ }^{214}$

Se hallaban en mal estado las construcciones de los presidios.Sus murallas de adobes hacían precisas varias reparaciones, para las que no había consignados fondos, y ni siquiera había un ingeniero en la comandancia. Por eso pedia Nava libertad para disponer las obras convenientes, dando cuenta de los gastos. ${ }^{215}$ Consiguió en cambio el comandante general el nombramiento de cirujano para las tropas de Coahuila, en Don Jaime Gurza. El hospital que se había de establecer en el valle de Santa Rosa, sin embargo, no llegó a existir, y Gurza quedó con Barceló atendiendo el de Chihuahua. ${ }^{216}$

Entre tanto, la actitud unánime de los virreyes, desde Revillagigedo, era contraria a la inclependencia de las provincias internas. Branciforte, Azanza y Marquina declamaron contra la autonomía del comandante general suponiendo que su propio gobierno, desde México, sería más beneficioso para la

2.1 2 Nava a Cánpo Alanjc. Valle de San Bartolomé, 5 de junio de 1795, 1únn1. I94. A. G. I., Guadalajara, 292 .

2 3 Nava a Campo Alanje. Chihuahua, I. ${ }^{\circ}$ de agosto de I793, núm. 47. A. G. I., Guadalajara, 289. Nava a Campo Alanje. Valle de San Bartolomé, 5 de junio de I795, núm. I93. A. G. 1., Guadalajara, 292.

2 I4 Nava a Campo Alanje. Chihuahua, 9 de julio de I795, núm. I97. A. G. I., Guadalajara, 292.

21 5 Nava a Campo Alanje, Chihuahua, 6 de agosto de I795, núm. 205. Ibid.

2 6 Nava a Campo Alanje. Chilıuhua, 2 de enero de I794. nún. S5. A. G. I., Guadalajara, 290. Nava a Campo Alanje. Chihuahua, 3 de mayo de 1796, núms. 273, 274 y 275. A. G. I., GuadaIajara, 293. 
frontera. ${ }^{217}$ Como consecuencia, había vuelto a plantearse en Madrid a fines de siglo la revisión de este problema, en el Consejo de Indias, donde los votos y dictámenes se mostraron en desactuerdo. El contador Don Pedro Aparici, siguiendo el parecer de los virreyes, optó por la subordinación de la comandancia a éstos. El fiscal del Perú salvaba sólo la autonomía del jefe supremo de las tropas fronterizas en lo puramente militar. Tocó esta vez al fiscal de Nueva España la defensa de la joven pero tan controvertida entidad políticomilitar. "Por más que se declame contra la real orden de noviembre de I792, un virrey, un hombre desde México, rodeado de tantas y tan variadas atenciones, no es posible comprenda ni penetre las dificultades de aquel mando ni las complicaciones de la guerra con los indios como un jefe colocado a su inmediación en medio de aquellos vastísimos desiertos, libre de otros incesantes y gravísimos cuidados, y que puede trasladarse sin aparato y con presteza adonde convenga".

El fiscal propugna la remoción de todos los obstáculos que se interponen para el logro de la completa autonomía de las provincias. creación de audiencia en Chihuahua, establecimiento de una contaduría de cuentas y de unos oficiales reales que administren las alcabalas. Hay que asegurar la subsistencia de la comandancia, y a su juicio el papel que en esto tendría la audiencia es primordial. "Las audiencias han sido desde la reducción el freno de la iniquidad y el apoyo del gobierno. En estos cuerpos respetables por las facultades y autoridad que reciben de las leyes, se ha advertido un constante fondo de rectitud y amor al rey, mucha vigilancia por la conservación de aquellos dominios, propensión a la equidad con aquellos habitantes y decidida predilección al alivio y protección de los utilísimos y miserables indios". 218

E1 expediente no concluyó sino en I804, con la nueva división de la comandancia que, sin embargo, no se llevó a efecto.

\section{VALOR GEOPOLítico DE NuEvo MÉxico}

E1 rasgo, sin duda, más acusado de la vida de la frontera en las décadas

217 Revillagigedo a Campo Alanje. México, 28 de febrero de I793, is. $/ \mathrm{n}$. Revillagigedo a Alcudia. M'éxico, 3 I de julio de I793, núm. II, reservada, con la que remite un informe a $S$. M. de igual data. Branciforte a Alcudia. México, 3I de octubre de 1795, núm. I75, reservada. Branciforte al príncipe de la Paz. México, 29. de agosto de 1796 , núm. 328 reservada. Branciforte a I_laguno. Orizaba, 30 de junio de 1797 , núm. 447. Azanza a Alvarez. México, 27 de setiembre de I798, núm, I 00. A. G. I., Guadalajara, 390. Las instrucciones de Flores, Branciforte y Marquina a sus sucesores son claramente opuestas a la independencia de la comandancia.

218 Informe del contador Aparici. Madrid, 30 de agosto de i799. Informe del fiscal de Nucva España, Madrid, 3 I de octubre de I799. Informe del fiscal del Perú. Madrid, Ig de agosto de I800. A. G. I., Guadalajara, 390. 

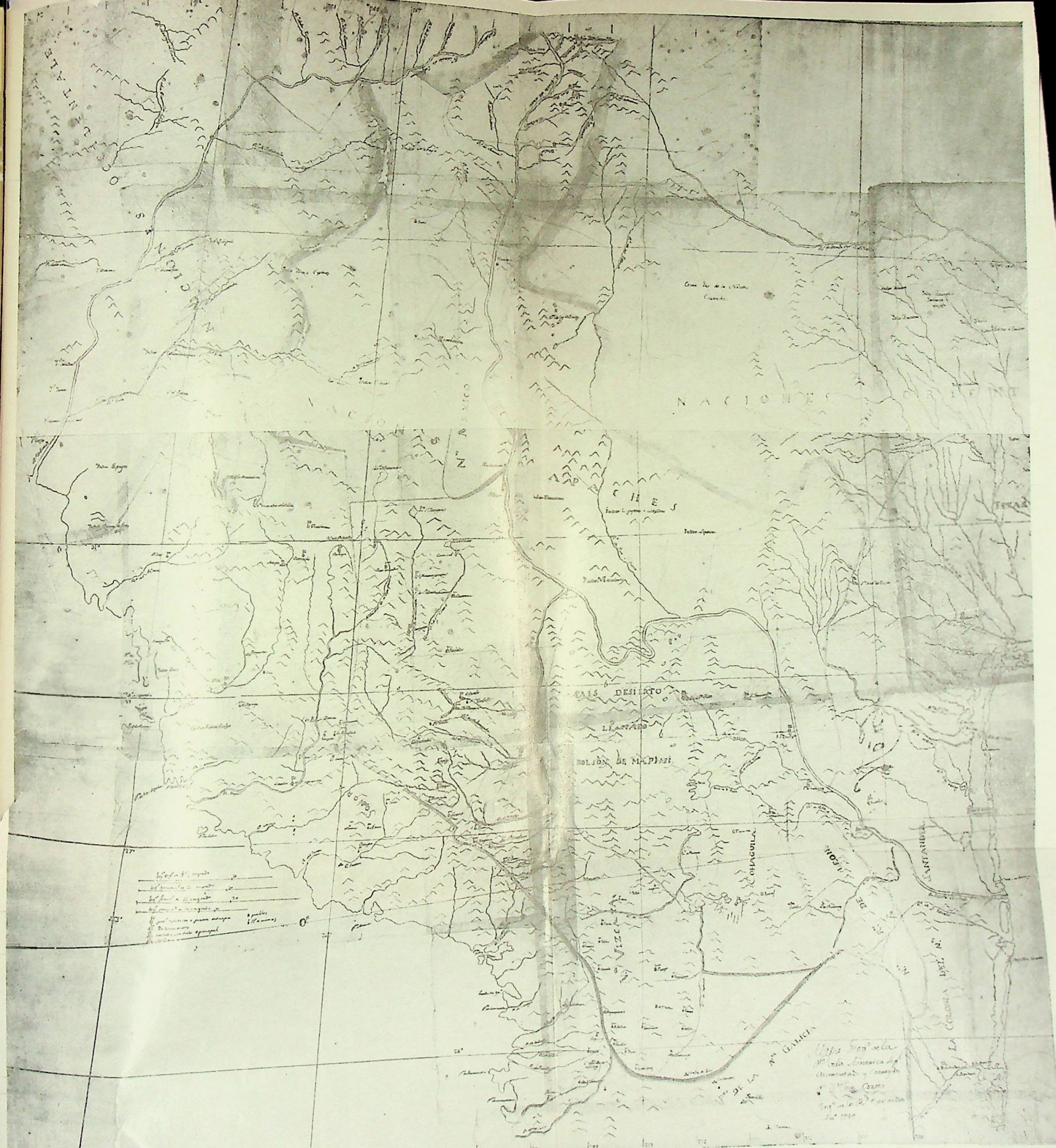


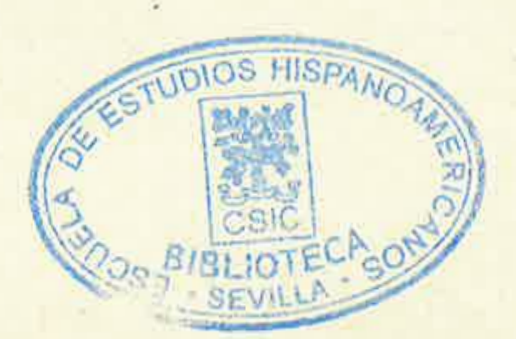




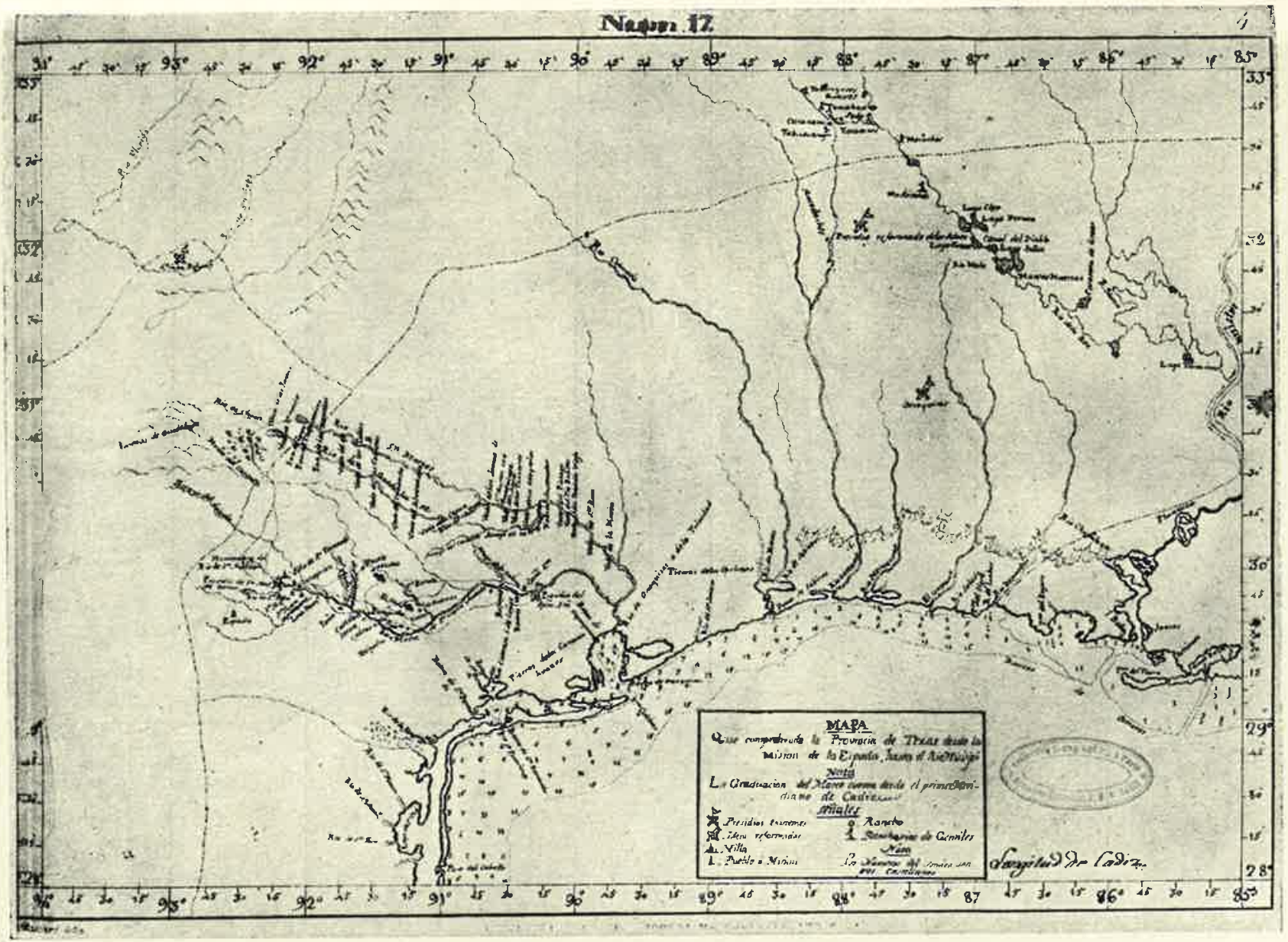

132. Mapa de Texas, por Mascaró. 


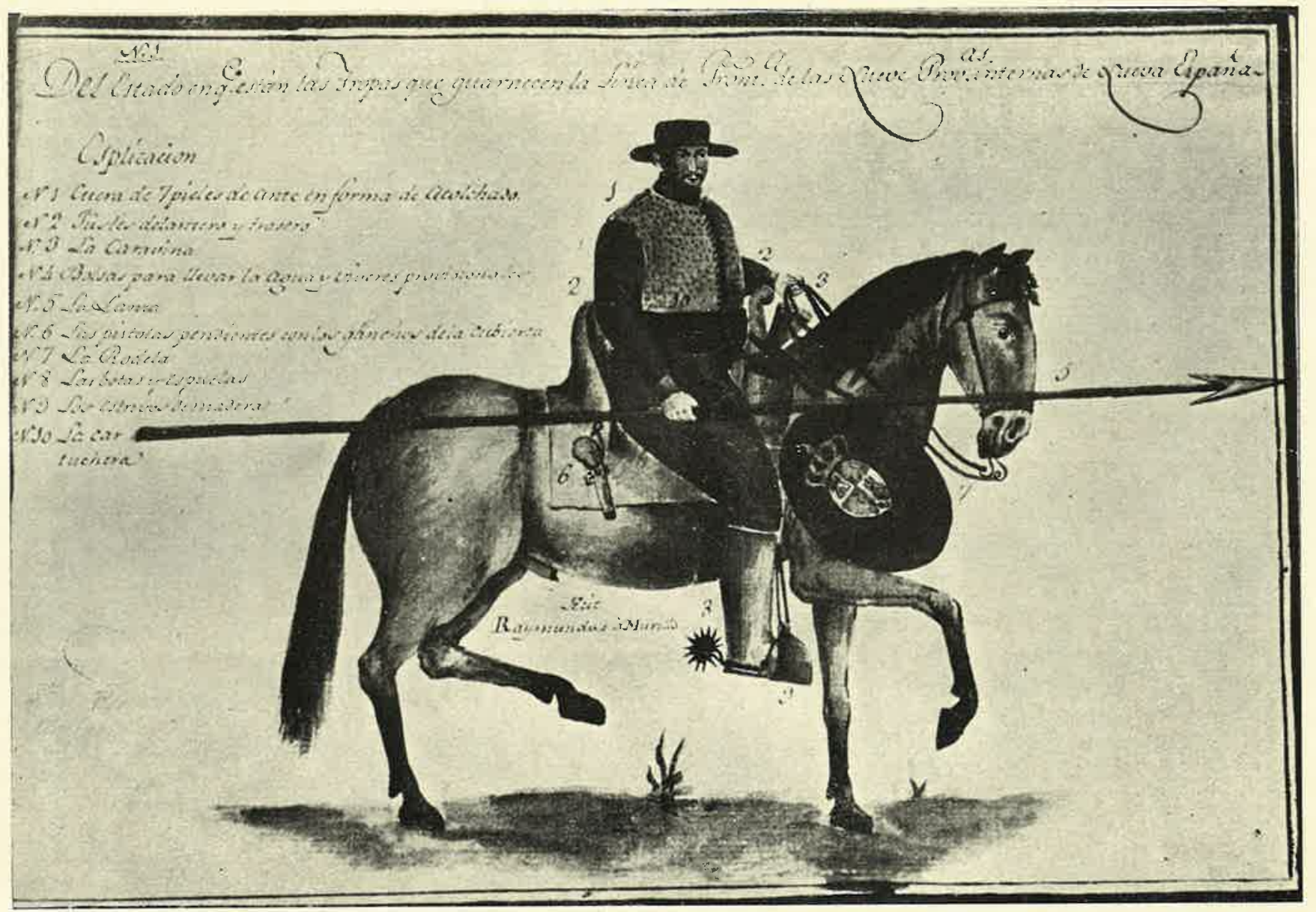

133. Soldado de cuera presidial a calballo. 
finales del siglo XVIII es la paz que se establece y afianza con las naciones indias hostiles hasta entonces: apaches y comanches, reducidos aquéllos después de dura guerra, movidos éstos por la sabia diplomacia de Don Juan Bautista de Anza y sus sucesores. Nuevo México juega, por tanto, en este momento, un papel destacadísimo de puesto avanzado desde el que España puede tener establecida la vigilancia sobre las tribus de la pradera. A los yutas y navajos que hacía tiempo habían entrado en la órbita del Imperio, se suman ahora los comanches, que decididamente pasan al papel de aliados. Esta realidad parece encauzar la política de la comandancia general a buscar la expansión por la conexión de las provincias extremas - Sonora y Texas-con Nuevo México.

Desde marzo de $\mathbf{I} 784$ volvían a presentarse algunos comanches en la provincia tratando de establecer las paces, que al fin quedaron concertadas. Como consecuencia, en ${ }_{1} 785$ acudieron por tres veces a Nuevo México a hacer feria, en la que vendían carne de cibolo, ante y pieles. Las parcialidades de yupas y yamparicas, que habitaban al norte del río Napestle eran las más reacias a la concordia, pero habiendo al fin dado muerte al jefe Toro Blanco, que era quien los enemistaba con los españoles, accedieron a deponer las armas. A fin de este año la paz era un hecho, completado por las diligencias que el gohernador de Texas, Cabello, realizó a través de los taobayas y wichitas. ${ }^{219} \mathrm{La}$ actuación de Anza, que prohibió a los navajos comerciar en Nuevo México, obligó a éstos a romper su alianza con los gileños todavía insumisos. ${ }^{z 20} \mathrm{El}$ paso más delicado fue el de lograr que la paz de la provincia con los comanches no supusiera el rompimiento con los yutas. Cuando Anza obtuvo este éxito, los navajos hubieron de cesar en sus hostilidades más o menos disimuladas, y los apaches quedaron señalados como único enemigo que batir. ${ }^{221}$ Anza empujó a los navajos a declarar la guerra a los gileños, y a petición de ellos, nombró capitán general de toda la región a un indio llamado Don Carlos, y como teniente a otro, por nombre Don José Antonio. Uno y otro solicitaron permiso para volver a las ferias de Nuevo México, lo que les fue concedido, así como la concurrencia a la de los comanches. Ugarte expidió los títulos correspondientes y dictó normas para proteger el comercio de los navajos, de modo que no sufriesen fraudes, ${ }^{222}$ llegando a legislar la

219 Rengel a Gálvez. Chihuahua, $3^{1}$ de diciembre de 1785 , núm. I16. A. G. I., Guadalajara, 286.

220 Rengel a Sonora. Chihuahua, 2 de marzo de 1786, núm. I37. A. G. I., Guiadalajara, 52 I. 22I Ugarte a Sonora. Chihuahua, 2 I de diciembre de I786, núm. 43. A. G. I., Guadalajara, 287 . 222 Ugarte a Sonora. Chihuahua, 21 de diciembre de 1786 , núm. 44. A. G. I., Guadalajara, 521. Vid. Reeve, Frank, Navaho Spanish diplomacy I770-I79o. N. M. H. R. XXXV, 3, Juli, I 960, 200-235. 
celebración de dos ferias anuales en la provincia, en el paraje que designase el gobernador, y otra en tierras de cada una de las naciones comanche, navajo y yuta, acudiendo siempre a estas los españoles bajo la vigilancia de un oficial o alcalde mayor. ${ }^{223}$ Poco después se producía la visita a Chihuahua de algunos jefes comanches que ya hemos narrado, y la conclusión de las paces con las ramas comanches que aún se hallaban al margen de ella. Siguiendo el mismo procedimiento que con los navajos, se hizo reconocer como jefe de toda la nación a. Equeracapa, con dos tenientes igualmente adictos a los españoles - cle los que uno residía entre los yupas y yamparicas y otro entre los cuchanecs o cuchanticas orientales-y cuatro intérpretes. Así se decidió en junta general que Anza presidió en la misma tierra de los comanches. ${ }^{224}$

Poco después se producía el relevo de Anza. En I784 se había nombrado gobernador de Nuevo México a Don Manuel de Flon, ${ }^{225}$ pero éste no pudo hacerse cargo de aquel gobierno pues hubo de atender interinamente al de Durango, siendo luego promovido a la intendencia de Puebla. En I786, en su lugar, se nombró para Nuevo México al sargento mayor del regimiento de infantería provincial de Campeche Don Fernando de la Concha, que tomó posesión en Santa Fe el 25 de agosto de 1787. 226 En I781 y 1786 había solicitado Anza destino en el virreinato, pero ni entonces, ni ahora se le concedió, y aunque Ugarte lo propuso para el gobierno de Texas tampoco esta sugerencia prosperó. En cambio, en $\mathrm{I}^{\circ}{ }^{\circ}$ de octubre de 1788 se dispuso se trasladase Anza a España, con grado y sueldo de coronel. El virrey Flores había ordenado también se le considerase como capitán del presidio de Tucsón, con el sueldo correspondiente. Pero Anza murió repentinamente a poco de su regreso de Nuevo México, el 19 de diciembre de I788, siendo enterrado en la iglesia de Arizpe. ${ }^{227}$

Poco antes de la toma de posesión de Concha tuvo lugar la llegada a Santa Fe de Pedro Vial y Cristóbal de los Santos, enviados desde San Antonio por el gobernador de Texas, Cabello, el 4 de octubre de I786. La paz. universalmente establecida en la pradera hizo posible su viaje, que por tierras de los tawakonis, taobayas, wichitas y comanches los condujo hasta Pecos y

223 Ugarte a Sonora. Chihuahua, 2 I de diciembre de 1786 , núm. 45. A. G. I., Guadalajara, 521 y 287 .

224 Ugarte a Sonora. Arizpe, I4 de agosto de 1787 , núm. 129. A. G. I., Guadalajara, 287. 225 Titulo de gobernador. San Ildefonso, i6 de setiembre de i784. A. G. I., Guadalajara, 300 .

226 Título de gobernador. San Ildefonso, I3 de diciembre de I786. A. G. I., Guadalajara, 300 y 302 . Concha a Sonora. Santa Fe, 10 de noviembre de 1787 . A. G. I., Guadalajara, 300. Concha a Revillagigedo. Santa Fe, I. ${ }^{\circ}$ de mayo de 1793. British Museum, Ms, room, Egerton I BoI, fol. 197-20I v.

227 Expediente sobre concesión de montepío a la viuda de Anza, I789. A. G. I., Guadilajara, 289. 
Santa Fe donde entraron el 26 de mayo de 1787 . Dos meses después, el 3 I de julio, emprendían el viaje en sentido contrario José Mares, Cristóbal de los Santos y Alejandro Martín, intérprete comanche, que el 8 de octubre alcanzaban San Antonio. En I788, el viaje se inteta por ruta distinta: Mares parte de San Antonio el i 8 de enero y por San Sabá y el Colorado pasa a las fuentes del Rojo y! entra en Santa Fe el 27 de abril. ${ }^{228} \mathrm{El}$ I4 de junio siguiente salen de esta villa Pedro Vial, Francisco Javier Fragoso, José María Romero, Gregorio Leiva y Juan Lucero, y siguiendo el primitivo camino llegan a los jumanos o taobayas el 20 de julio, y el 20 de agosto a Natchitoches. Hasta el I8 de noviembre no entran en San Antonio. La última travesía, de regreso, la emprenden el 25 de junio de 1789 , llegando el 20 de agosto a Santa Fe. ${ }^{229}$

Después de éstos, no hay más viajes documentados entre ambas provincias, pero con toda seguridad puede suponerse que se harían particularmente por los comerciantes y sobre todo, que éstos y sus productos irradiarían desde Santa Fe, San Antonio y Nacogdoches a todos los pueblos de la pradera, ahora pacíficamente dispuestos a recibirlos.

También por el costado opuesto, occidental, recibió Nuevo México las expediciones de otra provincia, destinadas a abrir camino para una posible comunicación permanente. En I79I se había frustrado el viaje que pensaba realizar el gobernador de Sonora Don Enrique Grimarest. Pero en I795, el comandante de las armas de Sonora Don Manuel Echegaray preparó un destacamento, a cuyo frente se puso a Don José Zúñiga, capitán de Tucsón, que inició la marcha el I 2 de abril desde el abandono presidio de Santa Cruz y llegó a Zuñi, según prevenía la instrucción recibida, el $\mathrm{r} 0^{\circ}$ de mayo, después de haber hecho alto dos días en el camino y haberse retrasado persiguiendo a algunos apaches. El 7 de mayo emprendía la vuelta desde Zuñi, llegando a Sonora sin otra novedad que la de haber hecho cinco muertes y cinco prisioneros a los apaches en todo el viaje. Las noticias de Tamarón acerca de la facilidad de tránsito de Sonora a Nuevo México se habían, pues, confirmado. De Zuñi a Tucsón mediaban ciento ocho leguas, transitables en veintidós jornadas de recua. ${ }^{230}$ Esta ruta, sin embargo, con la amenaza de los escasos grupos de apaches aún vagantes, no parece se volviese a utilizar.

Los gobernadores Concha y Chacón - nombrado para sustituir a aquuél

228 Castañeda, Our Catholic heritagc, V, I50-I6r.

229 "Derrotero" de Fragoso. Natchitoches, 23 de agosto de 1788 . Con mapa añadiclo coñ arreglo al mismo diario, Habana, 2 de enero de 1789 . A. G. I., Torres Lanzas, México, 413. Castañeda, op, cit., V. I6I-17o.

230 Nava a Campo Alanje. Chihuahua, 9 de julio de 1795, núm. i98. A. G. I, Guadalajara, 292. 
en $1793^{231}$ - cubren los años restantes hasta la fecha tope de este capítulo. Uno y otro supieron permanecer en la línea de conducta marcada por Anza y los comandantes generales, de suerte que la paz no se vio alterada en lo sucesivo. Todas las naciones indias no directamente sometidas se mantenían en fidelidad y amistad con los españoles, interviniendo el gobernador de Nuevo México en sus asambleas y elección de generales. ${ }^{232}$

Como resultado, la provincia empezó a prosperar, pasando en 1794 de los treinta y cuatro mil habitantes, ${ }^{233}$ y pronto empezáronse a tomar las medidas tendentes a facilitar el desarrollo económico y la elevación del nivel cultural y de vida de aquella población, pese a las enormes distancias y dificultades que habían de entorpecer una empresa semejante. ${ }^{2} 34$

\section{LAS INTENDENCIAS}

Aunque ya en 1783 expedía el ministro Gálvez órdenes dirigidas al intendente de las provincias internas, jamás existió este cargo, y por aquellas fechas Corbalán, en Sonora, era el único intendente que había en: la comandancia, y aun en toda Nueva España. ${ }^{2} 35$ Hasta I785 no se expidió al teniente coronel del regimiento de infantería de Burgos don Felipe Díaz de Ortega título de gobernador intendente de provincia del reino de Nueva Vizcaya, ${ }^{236}$ y a decir verdad nunca hubo en las provincias internas más que estas dos intendencias: las de Arizpe y Durango. Barri había muerto el 2 de febrero de I784 en el ejercicio del mando, 237 y pasó a sustituirlo interinamente don Juan Velázquez, que hubo de hacer frente en 1785 a una enorme carestía de granos. Previéndola, hizo reconocer ya en noviembre del año anterior las trojes del valle de las Poanas, cuya producción de maíz y trigo sirvió para remediar

231 Titulo de gobernador. Palacio, II de agosto de I793. A. G. I., Guadalajara, 300.

232 Nava a Campo Alanje. Chihuahua, 3 de octubre de 1793 , núm. 65. A. G. I., Guadalajara, 289. Nava a Campo Alanje. Chihuahua, 2 de enero de 1794 , núms. 87 y 88. A. G. I., Guadalajara, 290.

233 Censo de las misiones de Nuevo México en 1793. Villagrá, II, apéndice III, 98-99. Censo de la provincia en Nava a Campo Alanje. Chihuahua, 2 de enero de I794, núm. 89. A. G. I., Guadalajara, 290.

234 Revillagigedo a Valdés. México, 27 de marzo de 1790, núm. 434. A. G. I., Guadalajara, 354. Instrucción de gobierno dada por Concha a Chacón. Chihuahua, 28 de junio de 1794. Traducida al inglés y editada por Donald E. Worcester en N. M. H. R. XXIV, 3, July, 1949, 236-254. Concha a Revillagigedo. Santa Fe, I. ${ }^{\circ}$ de mayo de 1793. Bristish Museum, Ms. room, Egerton I8oI. fol. r97-20I v. Vid. Feether, Adlai. Coronel Don Fernando de la Concha Diary, 1788. N. M. H. R. XXXIV 4, oct. 1959, 285-304. Moorhead, Max. L. Spanish transportation in the Southwest, 1540-1846. N. M. H. R. XXXII, 2, apr. I958, 107-122, con noticias de Chacón sobre construcción de puentes en Nuevo México.

235 Real orden de 20 de seticmbre de 1783 al intendente de las provincias internas. Corbalán a Gálvez. Arizpe, 12 de marzo de I784, núm. 46. A. G. I., Guadalajara, 5I7.

236 Título de gobernador intendente de provincia. Aranjuez, 2 I de mayo de I785. A. G. I., México, 1973.

237 Neve a Gálvez. Arizpe, 8 de marzo de I784, núm. 87. A. G. I., Guadalajara, 285. 
la necesidad del resto de la provincia. La mala cosecha fue también causa de la pérdida de gran cantidad de ganado. Los reales de Mapimí, Cuencamé : San Luis, las haciendas del condado del Alamo y otros parajes se iban despoblando con igual motivo. Como consuelo se recibió la noticia del hallazgo de un riquísimo mineral de oro en Guarisamey, a setenta leguas al oeste de Durango, en la alcaldía de San Diego del Río. ${ }^{238}$ El 16 de abril de I 786 tomó Díaz de Ortega posesión del gobierno de la provincia, hallando la vida extraordinariamente cara debido a los tres años de esterilidad, dos de peste y continuadas hostilidades padecidas. ${ }^{239}$ Este gobernador, que debía actuar según la ordenanza dada para los intendentes del Río de la Plata, inició pronto su labor de investigación y fomento de la riqueza del país, habiendo chocado de inmediato con Ugarte, cuyas facultades en materias de vicepatronato y hacienda consideraba lesivas para su autoridad.

Tanto el comandante general como el intendente protestaban no ser reconocidos por el otro. ${ }^{240}$ Sin embargo, superadas estas dificultades, Díaz de Ortega se mostró sumamente eficaz en sus realizaciones. Siguiendo las normas de la instrucción de intendentes, formó la que había de regular la administración de justicia y el gobierno político de los pueblos y los reglamentos para el arreglo de los propios y arbitrios de los ayuntamientos. Ninguna comunidad de indios de la intendencia tenía bienes de este tipo. De las poblaciones de españoles, sólo Durango, Chihuahua y Nombre de Dios disponían de algunos fondos, cortísimos.

He aquí su cuantía anual:

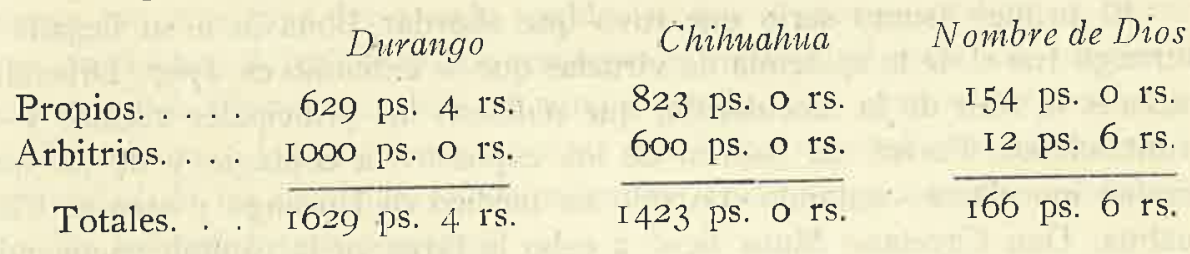

Cargas fijas y al-

terables.

Sobrantes.
I247 ps. 6 rs. 5 gs.

38I ps. 6 rs. 7 gs.
953 ps. I $1 / 2$ rs.

469 ps. $6 \frac{1 / 2}{2 r s}$.
29 ps. 2 rs.

I 37 ps. 4 rs.

E1 total de sobrantes era de novecientos ochenta y ocho pesos, seis reales y ocho y medio granos.

Con tan cortas posibilidades acometió el intendente la construcción en

238 Velázquez a Gálvez. Durango, 23 de abril de 1785 , núm. 6. A. G. I., Guadalajara, 520

239 Díaz de Ortega a Sonora. Durango, 30 de abril de i786. A. G. I., Guadalajara, 30 I

240 Ugarte a Sonora. San Juan Bautista de Encinillas, 28 de febrero de 1787, núm. 72. A. G. T., Guadalajara, 286. Díaz de Ortega a Sonora. Durango, 6 de marzo de r 787. A. G. I, Guadalajara, $52 \mathrm{I}$. 
:Durango de una carnicería aseada, una conducción de agua y una separación de la cárcel. En Chihuahua se sanearoni algunas deudas y se arreglaron la alhóndiga y la cárcel, y este mismo edificio se compuso en Nombre de Dios. Había muchas otras atenciones para las que faltaban medios. ${ }^{24 \mathrm{I}}$

En enero de I792 salió Díaz de Ortega, trasladado a la intendencia de Valladolid, sucediéndole en Durango Don Francisco Javier Potau de Portugal, que se mostró totalmente incapacitado para el mando, 242 siendo nombrado en su lugar el coronel Don Bernardo Bonavía, hombre acreditado durante el desempeño que había tenido de la intendencia y corregimiento de México. ${ }^{243}$ En el intervalo, hasta la llegada de Bonavía, de julio de I793 a marzo de 1796 se hizo cargo de la intendencia el letrado asesor Don Francisco José Urrutia, que se mostró competentísimo en el restableciniento del cabildo y regimiento perpetuo de Durango, que produjo a las cajas reales un beneficio de casi tres mil pesos merced a los oficios vendibles y renunciables, así como dio nueva vida al pósito público, inexistente en la práctica en I794, y que años después tenía más de seis mil pesos. Estableció los alcaldes de barrio o de cuartel, y por disposición de Nava puso alcaldes ordinarios y síndicos procuradores en trece partidos de la provincia. Entró decididamente Urrutia a crear cajas de comunidad en Analco, Tunal, Babiacora, Mezquital, Guazamota y Malpaís, y había dado los pasos para fundar otras. Los indios habían quedado exentos de servicios personales a los curas, obligándose en cambio a entregarles media fanega de maíz o doce reales al año. ${ }^{244}$

E1 primer asunto serio que tuvo que abordar Bonavía a su llegada a Durango fue el de la epidemia de viruelas que se extendió en I797. Difundió entonces la idea de la inoculación, que pidieron los principales vecinos y el ayuntamiento. Formó un padrón de los expuestos a contagio y de los que querían inocularse, contando con sólo un médico en Durango y otro en Chihuahua. Don Cayetano Muns llevó a cabo la tarea en la capital, vacunando a tres mil ochocientas veinticuatro personas, de las que sólo ciento dos murieron, sin que ocurriera ninguna defunción en el hospital que instaló el cabildo de la catedral, ni en el de indios de Analco. Ayudó al doctor Muns el prior del hospital de San Juan de Dios, "que se estrenó en esta práctica en esta ocasión". Bonavía propone ahora decididamente vacunar a todos los

24I Díaz de Ortega a Sonora. Durango, 6 de marzo de 1787. A. G. I., Guadalajara, 405. Díaz de Ortega a Porlier, s./n. Durango, i6 de noviembre de 1790. A. G. I., Guadalajara, 288.

242 Nava a Campo Alanje. Chihuahua, 2 de octubre de I794, núm. I42. A. G. I., Guadalajara, 290.

243 Nava a Campo Alanje. Valle de San Bartolomé, 5 de junio de 1795 , núm. I89. A. G. I., Guadalajara, 292.

244 Nava a Llaguno. Chihuahua, 5 de abril de 1796, nưm. 24. A. G. I., Guadalajara, 293. 
recién nacidos. Sus recomendaciones por los servicios de Muns tuvieron eco, porque fueron otorgados a éste el grado de doctor del colegio médico de Barcelona y honores de cirujano coronel consultor del ejércilo. ${ }^{245}$ Bonavía se ocupó también en formar las ordenanzas del ayuntamiento de Santiago de Papasquiaro, que fueron aprobadas en $1802,{ }^{246}$ y este mismo año se promovió la concesión de una feria anual en San Juan del Río que podía ser origen de mayor prosperidad para la provincia. ${ }^{247}$

El ig de abril de I 787 se habían expedido los títulos a Don Enrique Grimarest y Don Agustín de las Cuentas Zayas como intendentes respectivamente de Sonora y Sinaloa. Este simple hecho motivó una confusión, porque la intendencia de Sinaloa no había sido prevista ni en los planes originales, ni en la ordenanza, y se ignoraba cuáles debían ser sus límites. Después de la inevitable demora, se llegó a la supresión de dicha intendencia en I789, quedando el territorio que le pudiera corresponder agregado a la de Sonora. 248 Promovido Corbalán en 1787 a la intendencia de Veracruz con grado de intendente de ejército, quedó como interino en el gobierno de Sonora el secretario de la comandancia general Don Pedro Garrido y Durán, hasta l: llegada de Grimarest, que en I 790 informaba no había en toda su jurisdicción un solo pueblo que tuviese propios ni arbitrios, sin que existiesen esperanzas de establecer éstos nunca, y siendo muy difícil de crear aquéllos por el poco arreglo y constancia con que se había llevado la distribución de las tierras en la provincia, de modo que se ignoraba la legitimidad con que unos las poseían, el número de las realengas y la propiedad de otras. De esta manera era imposible dar a cada pueblo las que les correspondían en común y en particular, dejar libres las realengas y separar de éstas las suficientes para propios. Girimarest pidió al virrey enviase un agrimensor con cuyo auxilio señalar a los pueblos las tierras que le correspondiesen, reconocer la legitimidad de las particulares, delimitar las realengas y admitir a composición las indebidamente poseídas.

Los arbitrios era imposible establecerlos. Irían en perjuicio de los habitantes. "Apenas se encuentra vecino que adelante cosa alguna en su caudal, antes por el contrario, cada día experimentan menoscabos y pérdidas". A veces les falta aun lo más preciso. Convendría incluso que se les exonerase de algunos de los reales derechos, ya que participaban en la defensa del territo-

245 Bonavia al secretario de Gracia y Justicia. Durango, 15 de abril de I803. A. G. I. Guadalajara, 408 .

246 Nava a Porcel. Chihuahua, 9 de junio de 180 I y 7 de setiembre de 1802, núms. 78 y 101. A. G. I., Guadalajara, 379 .

247 Nava a Soler. Chihuahua, 6 de julio de 1802, núm. 830. A. G. I., Guadalajara, 294.

248 Real orden de 24 de marzo de I789. A. G. I., Guadalajara, 3or. Vid. Navarro García, Luis: Intendencias en Indias, 60-6I. 
rio con sus armas y caballos, que casi todos tenían, exponiendo sus vidas para transitar de un lugar a otro, o para recobrar sus ganados. ${ }^{249}$

Grimarest murió el I I de diciembre de I792 en Nuri, cuando hacía la visita de la provincia, y fue enterrado en Mobas. ${ }^{250}$ Hasta I795 no se le nombró sucesor, Dion Alejo García Conde, coronel de infantería y goberjador intendente de Comayagua en aquella fecha. ${ }^{251}$ Por entonces evacuó Nava un informe que adhiriéndose al parecer del obispo Fr. Antonio de los Reyes proponía la traslación de la capital de Sonora a Ures, desechando en cambio la propuesta de Grimarest de fijar la cabecera en Alamos. En 1o que todos -incluso el virrey Revillagigedo- parecían concordar es en negar las condiciones de Arizpe, ${ }^{252}$ que sin embargo conservó la capitalidad, pues nada de lo discutido se llevó a efecto. Con todo, alguien se había preocupado por Arizpe después de Teodoro de Croix. Durante cinco años, desde la muerte de Grimarest a la llegada de García Conde, Don Alonso Tresierra y Cano, teniente letrado y asesor de la intendencia, hubo de desempeñar el gobierno de Sonora. Entre sus méritos figura el de haber atendido a la policía de Arizpe disponiendo una alameda y una plaza e impulsando la construcción de varios edificios. También preparó una campaña -que no se realizaría - a la isla de Tiburón, con idea de someter a los indios allí refugiados, levantando una compañía de cincuenta hombres que hubo de mantener dos meses a sus expensas en Guaymas para precaver el peligro que suponía la presencia de buques ingleses en el golfo. ${ }^{253} \mathrm{La}$ actuación del intendente García Conde - figura luego tan interesante en la historia de la comandanciadurante sus primeros años al frente de la provincia de Sonora, que abarca este capítulo, no se hizo notar por ninguna empresa de interés.

Las provincias internas orientales habían quedado -como Californias y Nuevo México - al margen de la organización de Nueva España en intendencias. Tueros y Cabello desempeñaron como puros gobernadores militares el mando de Coahuila y Texas, y así continuaron estas provincias después de I787. La novedad ocurrió cuando al año siguiente Texas vino a quedar como un apéndice de Coahuila al extinguirse su gobernación propia después de haberse aprobado interinamente el nombramiento de Martínez Pacheco. En I786, a su vez, Revillagigedo dispuso se considerase a Coahuila y Texas

249 Grimarest a Porlier. Arizpe, I3 de cetiembre de 1790. A. G. I., Guadalajara, 288. Sobre las tierras, carta de Nava a Porcel. Chihuahua, 9 de diciembre de 1800 , núm. 75. A. G. I., Guadalajara, 380 .

250 Nava a Campo Alanje. Chihuahua, 5 de marzo de I795, núm. I76. A. G. I., Guadalajara, 292.

25 I Real decreto de i de enero de I795 a Bajamar. A. G. I., Guadalajara, 30r. Nava a Campo Alanje. Valle de San Bartolomé, 5 de junio de 1795. núm. 190. A. G. I., Guadalajara, I90. 252 Nava a Llaguno. Chilıuahua, ${ }^{\circ}{ }^{0}$ de setiembre de I795, núm. I6. A. G. I., Guadı2lajara, 29 I.

253 Nava a Caballero. Chihuahua, 4 de febrero de 1780 , núm. 43. A. G. I., Guadalajara, 293. 
como incluidas en la intendencia de San Luis de Potosí, de cuyo gobernador intendente serían subdelegados en hacienda y guerra los gobernadores de aquellas provincias. ${ }^{254}$ No obstante, el mismo virrey sería el primero en comprender y proyectar las ventajas que reportaría la creación de una intendencia que abarcase las cuatro gobernaciones de Coahuila, Texas, Nuevo León y Nuevo Santander, con los mismos límites del obispado de Monterrey. Un paso hacia la mejor delimitación de esta posible unidad político administrativa se había dado al agregar los distritos de Parras y Saltillo a Coahuila. Pero este segundo no se daría nunca. La comandancia oriental, siempre que existió, fue un conglomerado amorfo.

De I 783 a 1788 tuvo, pues, Tueros el gobierno de Coahuila, habiendo sido el mejoramiento de la situación de las compañías presidiales y volantes su principal objetivo, junto con la vigilancia de los movimientos de los comanches. Se reconocía el mal estado general de la provincia cuando se decidió reducir todos los gravámenes de alcabalas a sólo un dos por ciento en I785. ${ }^{255}$ De 1789 a 1797 Coahuila pasó varias veces de manos de Don Juan Gutiérrez. de la Cueva a las de Don Miguel José de Emparán, que fueron gobernadores sucesivamente, pero que se suplían en las ausencias mutuas. En I797 entró al gobierno, como interino, Don Antonio Cordero y Bustamante, que al año siguiente tomó posesión como propietario y conservaría el cargo hasta I8II. En Texas, a Martínez Pacheco sucedieron en el mando don Manuel Muñoz y el conde de Sierra Gorda. En ambas provincias la única labor política y de fomento fue la impulsada por el comandante general Nava. En I793 se llevó a cabo la secularización de la misión de Valero, y al año siguiente la de las cuatro restantes del Río San Antonio, conservándose sólo las del Espíritu Santo y del Rosario, en la Babia. ${ }^{256}$ Por disposición del mismo Nava realizó Cordero la fundación de la villa de Nava, cerca de San Juan Bautista de Río Grande, con vecinos criollos, mestizos y tlaxcaltecas, el zo de febrero de I80I. ${ }^{257}$

Las provincias orientales habrían de enfrentarse en estado de gran debilidad, sin duda, a la ola expansiva de los Estados Unidos, cuya vanguardia había hecho acto de presencia al empezar el siglo con el aventurero Philip Nolan, que halló trágico fin en el norte de Texas en I80I. ${ }^{258}$

254 Revillagigedo a Valdés. México, 27 de diciembre de 1789 , núm. 207. A. G. I., México, I 973 .

255 La audiencia gobernadora a Gálvez. México, I 5 de abril de 1785. A. G. I., Guadalajara, 520 .

256 Castañeda, Catholic heritage V. 40-66.

257 Alessio Robles, Coahuila y Texas, 583-585.

258 El mejor relato del incidente de Nolan se hallará en las Memorias de su compañero Bean, publicadas por Jean Delalande. Les aventures au Mexique et au Texas du colonel Ellis Feler Bean (1783-1866). Ses Mémoires. Paris, s. a. 


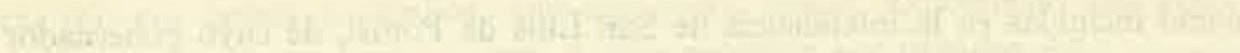

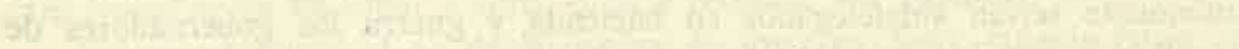

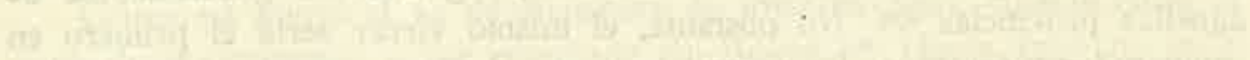

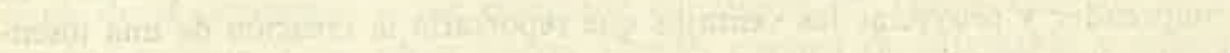

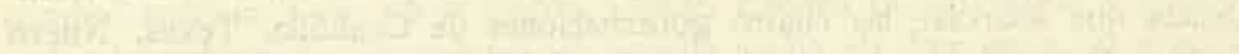

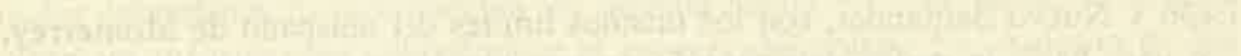

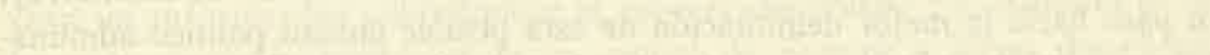

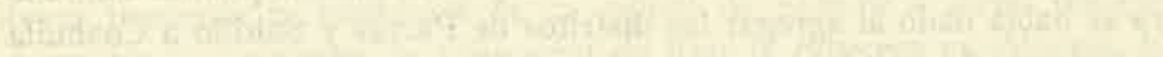

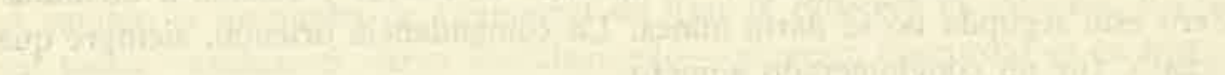

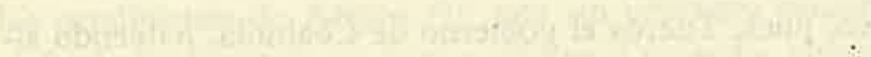

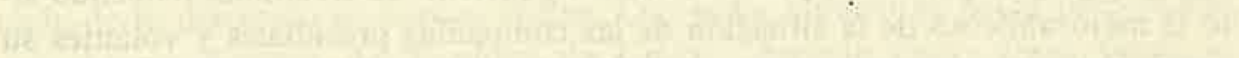

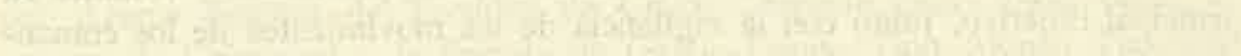

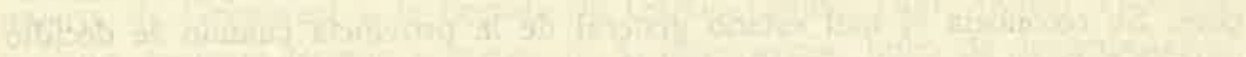

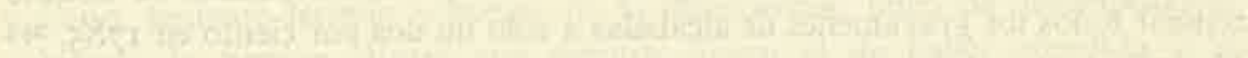

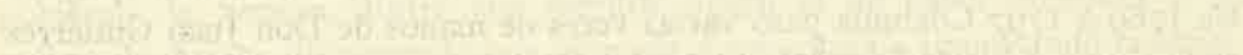

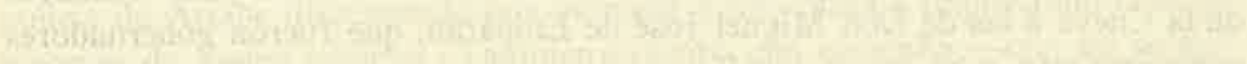

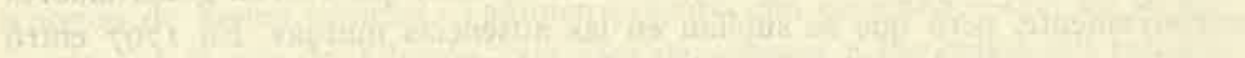

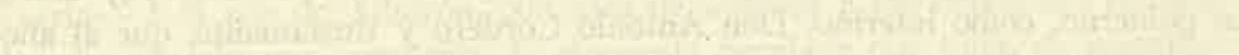

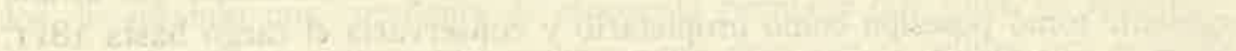

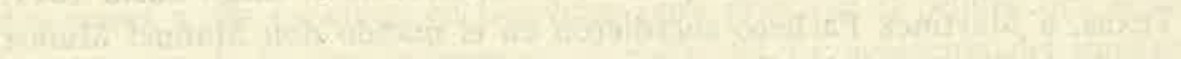

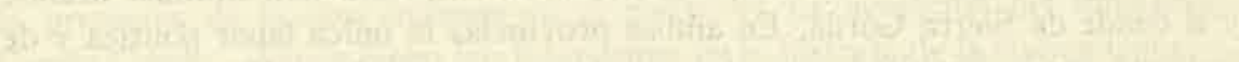

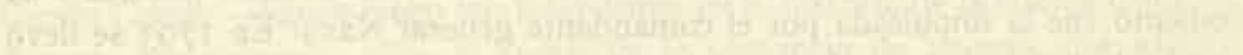

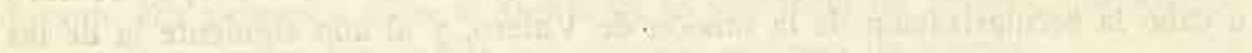

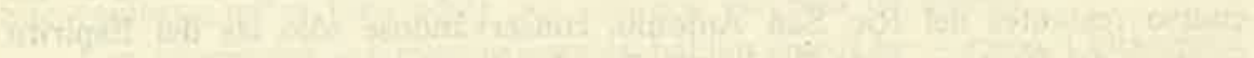

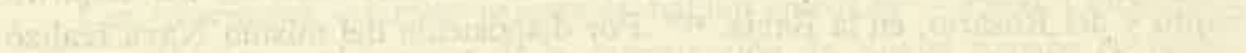
b.1.

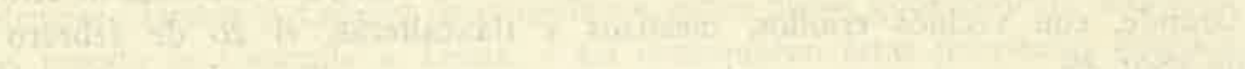

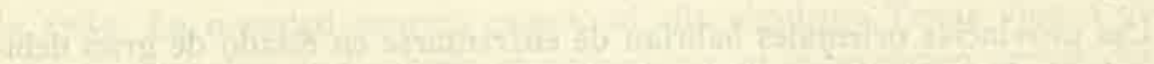

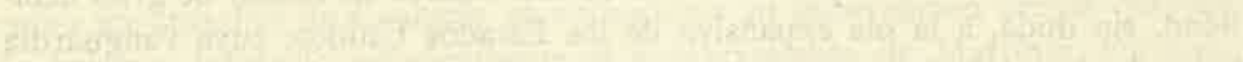

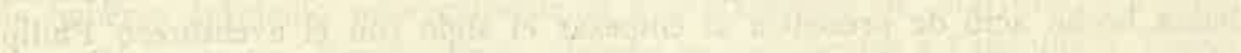

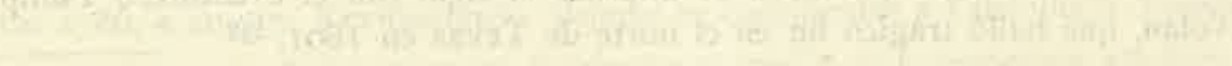

whe

x4.

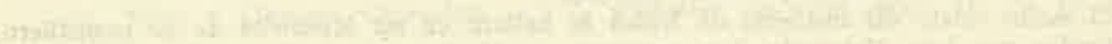

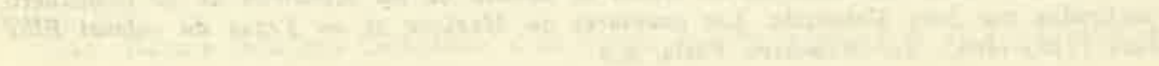


CATÁLOGO COMENTADO DE LOS MAPAS Y PLANOS DE LAS PROVINCIAS INTERNAS 



\section{SIGLAS UTILIZADAS}

A.G.I., T.L.

B. M. Map room.

B. M. Mss. room.

B. N. M.

B. N. P. Ge.

B. N. P. Ge. DD. 2987 .

B. N. P. Hydr.

B. N. P. Klaproth.

B. N. P. Manuscrits mexicains.

B. P. R.

M. N.

S. G. E.

S. H. M.
Archivo General de Indias, Catálogo de Torres Lanzas. British Museum, Map. room.

$\longrightarrow$, Manuscript room.

Biblioteca Nacional de Madrid.

Bibliothèque Nationale de Paris, Catálogue Geográphique.

- Collection D'Anville.

—- Service Hydrographique.

-C, Collection Klaproth.

—, Salle des Manuscrits Fonds mexicains.

Biblioteca del Palacio Real, Madrid. Museo Naval, Madrid.

Servicio Geográfico del Ejército, Madrid.

Servicio Histórico Militar, Madrid. 


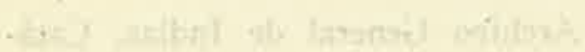

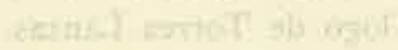
, แก

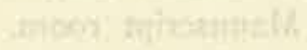

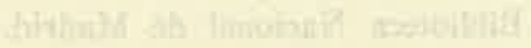

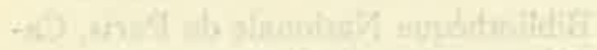

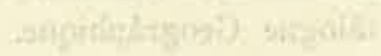
stivert 6 mitsollog

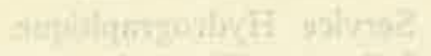

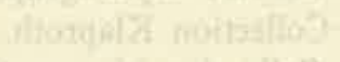

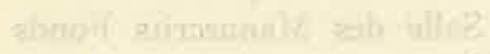

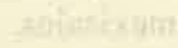

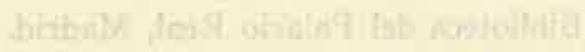

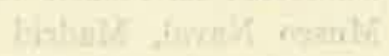

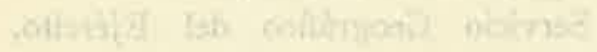
Hinhim

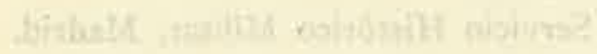

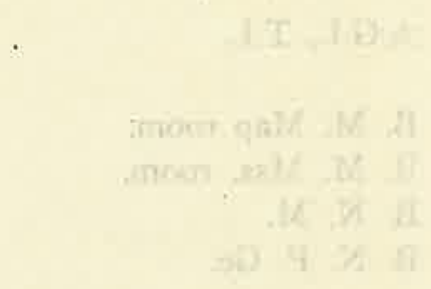

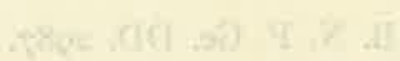

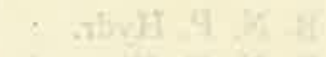

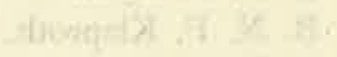

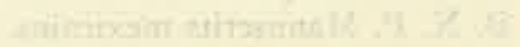
'⿺辶. MA 3972 in $\mathrm{ith}=$ 
1. A. G. I. ['T. L.], México, 56I.

El presidio de Jalpa en ${ }_{5} 576$. Este rarísimo dibujo nos muestra la disposición y figura de los primeros fuertes levantados por los españoles en la frontera de los "chichimecas". Todavía el soldado dibujado en la puerta tiene capacete, coraza, lanza, espada y adarga. La edificación presenta troneras para la artillería y baluartes en tres esquinas; éste será durante siglos el tipo de las haciendas fortificadas del norte de Nueva España.

2. B. N. P., Hydr. $14 \mathrm{I} / 5 / 2$.

Mapa en cuatro piezas que representa las provincias costeras del virieinato de México, en momento inmediato al del nacimiento de Nueva Vizcaya. Tampico, Santisteban del Puerto y Santiago de los Valles son las poblaciones más setentrionales en el extremo nordoriental, mientras que San Miguel de Culiacán lo es en el Pacífico. En el interior aparecen Singuiripac, Jerez de la Frontera, Zacatecas, San Martín, Pachuca y Achachica como presidios de frontera. Nueva Vizcaya está representada por Durango, Nombre de Dios, San Sebastián, Indé, San Juan y Santa Bárbara. El cartógrafo desconoce el territorio de Saltillo y supone, al parecer, que el Nasas y el Pánuco son un sólo y mismo río. Al norte de la provincia de Pánuco se representan el río de Palmas y el Escondido, toda la costa al noroeste aparece bajo la denominación de Florida, y en ella una "Bahía del Espíritu Santo" es el accidente más señalado.

Las proporciones del mapa son sensiblemente regulares, aunque carece de indicación de meridianos.

3. B. N. P., Ge DD. 2987, n. ${ }^{\circ} 8845$.

Mapa francés, impreso, de Nueva España. Culiacán, Durango y Parras son los establecimientos más setentrionales. En el centro de la fron- 
tera se sitúa un río poco conocido en un país despoblado al norte de Zacatecas, primera alusión en un mapa extranjero al Bolsón de Mapimí. Debe ser de principios del XVII, quizá tomado de Herrera.

4. "Descripción del distrito de la audiencia de Nueva Galicia”, según aparece en las Décadas de Antonio de Herrera, editadas en Madrid, I60I-1615. Se advierten los primeros establecimientos en torno a Durango, así como Culiacán y Chiametla y el río de Nuestra Señora, de cuyo nombre se hace derivar el de Sonora.

5. A. G. I., [T. L.] México, 560.

Mapa de los contornos de Guadalajara, mostrando la disposición de los grupos indios hostiles. Se señalan los peñoles del Mixtón, del Teul, de Juchipila, de Nochistlán y de Coina, y una serie de pueblos "de guerra" entre Guadalajara y las "minas ricas de los Zacatecas".

6. A. G. I., Guadalajara, I33.

Croquis del golfo y península de Californias. Por su toponimia parece de la primera década del XVII. El paraje más setentrional que se señala en el continente es el puerto de Carapoa; el más meridional, el cabo Corrientes; este mismo nombre se da al cabo de San Lucas. En la península se llega hasta el cabo Mendocino. Este dibujo corresponde a los viajes de Sebastián Vizcaíno, y es el primero en señalar los puertos de San Diego y Monterrey.

Se advierte el carácter esquemático del trazado de la costa occidental de California y el detalle que en cambio se presta a las costas e islas del Golfo.

7. B. M., Map room, Maps I88. c. I.

Mapa español del noroeste de México, de principios del siglo XVII. Ejemplo de la cartografia que admite la insularidad de California, cuya costa pacífica es mucho más conocida que la del supuesto canal. Figuran allí los puertos de San Diego y Monterrey y de Sir Francisco Draco. La costa continental al norte de Sinaloa es puramente imaginaria, con una hipotética población de San Francisco en la boca del río "del Norte", que se supone sea el mismo de Nuevo México. Más al setentrión pueden verse, entre otros datos, el río del Thecón (Tizón), la "ciudad" del "Rey Coromedo", los pueblos del Moqui y el "real de Nuevo México". El pie de escala está consignado en millas holandesas 
de quince por un grado, apareciendo debajo la inscripción "Hoghenberg".

8. A. G. I., T. L., México, 49.

Mapa del itinerario de Oñate de México a Nuevo México y a Quivira, r6oI. Refleja el resultado de la expedición al país de los escanjaques. Se da noticia de que desde el punto A hasta el pueblo descubierto todo el país es llano y abundante en las llamadas "vacas de Cibola", y también que según los indios en el Río del Oro había numerosa población y un gran señor rico en oro, pero que no había sido posible hallar ni rastro de él. Se advierte que el itinerario señalado desde México tiene como último punto de apoyo Santa Bárbara, en Nueva Vizcaya.

9. A. G. I., [T. L.] México, 518.

Mapa que comprende de Guatemala a California y Nuevo México, para mostrar las costas recorridas por un pirata inglés que quemó el cacao en Huatulco, reparó la lancha en Santiago, surgió luego en el puerto de la Navidad, hizo dos prisioneros en Chacala, barloventeó ante Matanchel; y no pudo entrar en los puertos de Culiacán por ser estos de menor calado del que sus buques requerían, suponiéndose que en vista de ello iría a dar carena a la punta de California. El mapa es de muy singular factura, posterior a la fundación de Nuevo México, pero de momento en que todavía los puntos más avanzados del virreinato y Nueva Galicia son Sinaloa, Santa Bárbara y Nuevo León (Monterrey). La localización de las poblaciones es muy confusa, por la misma forzada disposición semicircular que se ha querido dar a la costa.

10. B. N. P. Ge DD. 2987, n. 8520 .

América del Norte por N. Sansón d'Abbeville, en 1650. Este mapa incurre en el error general de la cartografía francesa de suponer que todos los territorios al norte de Sinaloa, Nueva Vizcaya y Pánuco constituyen una entidad semejante a la de Nueva España bajo el nombre de Nuevo México. En este caso Sansón incluye en esta denominación la misma "isla" de California. Son evidentes los errores que el cartógrafo adoptó del mapa español n. ${ }^{\circ} 8$ de esta colección. Nuevo México y Florida, cuyos límites se establecen arbitrariamente, cierran la expansión al sur de Nueva Francia y Virginia.

11. B. N. P., Ge DD. 2987,33 .

Nuevo México y Florida por Sansón, en 1656. Ampliación de un fragmento del anterior, se advierte como novedad la segregación de 
una parte de Florida con el nombre de Florida Francesa, la Florida española tiene como límite con Nueva España el río de las Palmas, mientras que el río Grande desemboca en el mar Bermejo.

12. B. M., Maps room, K. 122.99 , y B. N. P., Ge DD. 2987, n. 8843. Mapa de Nuevo México trazado en la penúltima década del XVII por el francés J. B. Nolin, basándose en las memorias del cosmógrafo veneciano P. Coronelli, y corregido y aumentado por e! señor de Tillemón. Ya en este mapa el río del Norte desagua en el Golfo de México, y no en el Pacífico. Se dan a Nuevo México los nombres de Nueva Granada y Marata, (esta última designación aparece ya en el Atlas de Ortelio de I 560) y se separa este reino del de Nueva España en el río Conchos, y del Canadá o Nueva Francia, idea que Coronelli adoptó en las relaciones del Conde de Peñalosa. Lo más interesante es la distribución de provincias y tribus indias en ambas márgenes del río Bravo, detalle tomado de las relaciones del P. Alonso de Benavides. La provincia de Culiacán está bien detallada, mien!ras que la de Sonora no figura; y las de Sinaloa y Nueva Vizcaya están sumamente incompletas y aún con errores como el de situar Durango fuera de los límites de la última provincia citada. El presente mapa es, finalmente, otra de las muestras en defensa de la insularidad declarada de California.

13. B. N. P., Ge DD. 2987, n. ${ }^{\circ} 8784$.

Mapa de la región entre el Misisipí y California, mostrando el itinerario del viaje del Sr. de Coutures, emprendido en Illinois el I4 de octubre de I688. Al parecer, Coutures, descendió el Misisipí, remontó el Grande, que navegó, alcanzando la "isla". Presenta una Luisiana asentada sobre el Misisipí y un gran territorio no ocupado por los españoles entre Nueva Vizcaya y Nuevo México, y habitado por indios que eran enemigos irreconciliables de éstos. En cambio, en la región aproximadamente correspondiente a la Pimería se dice estar este país ocupado por indios muy afectos a los franceses. Tanto en Culiacán como en Nueva Vizcaya se asienta haber muy pocos españoles, que en esta última provincia custodiaban muchas minas.

14. A. G. I., México, legajo, 6I7.

Itinerario de Alonso de León en I689, de Monclova al establecimiento francés en la costa de Texas, en la bahía del Espíritu Santo o de San Bernardo. Era cartógrafo de la expedición el famoso Don Carlos de Sigüenza y Góngora. 
Fue publicado este mapa por Gil Munilla, Política española en el golfo mexicano, A. E. A., XII, frente a pág. 509.

15. A. G. I., México, legajo, 6I 7 .

Itinerario de Alonso de León de Monclova a los Asinais, en I6go. Es curioso el nombre de Carolina - por Carlos II-dado a la nueva provincia que surge, a partir de este viaje, en Texas.

Publicado por Gil Munilla, ob. cit., frente a pág. 524 .

16. A. G. I., México, legajo, 6r7.

Mapa del territorio de los indios cadodachos, en Texas, fruto de la expedición de Don Domingo Terán de los Ríos en I69ז.

Publicado por Gil Munilla, ob. cit., frente a pág. 588.

17. "Carta geográfica de un país que nuevamente se ha descubierto en la América setentrional", por Don Antonio Marquina. Editada en la obra de Don Sebastián Fernández de Medrano en Bruselas, 1699. Contiene todos los errores geográficos usuales en los mapas franceses de la época, de los que ha sido sacada, conservándose incluso los nombres franceses de los reinos españoles.

18. A. G. I. Planos de Luisiana y Florida, 29.

Mapa del río Misisipí, por el barón de la Hontan, I699. Los nombres geográficos están escritos en una mezcla de español e italiano. La anotación en el extremo inferior derecha indica que la banda del río Misisipí hacia el este no ha sido aún reconocida. Es manifiesto que el interés de los franceses ha sido puesto desde el principio en la progresión al oeste, buscando la región minera española. Según la Hontan en esta fecha los traficantes en pieles aún no han tomado contacto con los apaches de los que sin embargo tienen ya amplias noticias.

19. A. G. I. Planos de Luisiana y Florida, 2 I.

Este extraño mapa sin indicación de fecha ofrece la más complicada hinótesis sobre el imaginario estrecho de Aniản combinado con el recién descubierto río Misisipí, del que saldría un brazo a la Mar del Sur en altura superior a los $50^{\circ}$ y otra a Virginia hacia los $40^{\circ}$. Parece ser una fantasía apoyada en el hallazgo de los ríos Ohio y Misuri. El río de Tampico es el único paraje identificado sobre el mapa, cuya deformación es notable en la parte correspondiente a México. 
Fue publicado por Roberto Gil Munilla en Política española en el Golfo Mexicano. (Anuario Estudios Americanos, XII, Sevilla, I955).

20. B. N. P., Ge DD. 2987, n. ${ }^{\circ} 8539$.

México y Florida, según Guillermo de L'Isle en 1703 . Sólo cinco años después que de Fer, de L'Isle presenta ya una "Florida" exclusivamente francesa documentada en las memorias de Iberville y Le Sueur, donde únicamente algunos establecimientos se advierte son de españoles. El conocimiento de la parte mexicana del mapa ha mejorado con la inclusión de Sonora, que aparece como una dependencia de Nuevo México, en cuyo distrito figuran todas las poblaciones de Nueva Vizcaya al norte de Parral. La pretensión francesa de reducir los establecimientos españoles al sur del río Grande, queda aquí claramente definida.

21. B. N. P., Ge DD. 2987, n. ${ }^{\circ} 8787$.

Mapa de Luisiana por de Fer, I7 18 . En este mapa "La Florida" ha sido definitivamente sustituida por "la Louisiane", bajo cuya denominación se comprende desde el río Grande a los Apalaches. La misma península viene a ser llamada "Presqu'isle de la Louisiane". La provincia de Nuevo México está muy bien representada, mientras que Nueva España ha sido tan arbitrariamente delimitada como de costumbre.

22. B. N. P., Ge DD. 2987, n. ${ }^{\circ} 8788$.

Mapa de Luisiana por Guillermo de L'Isle, I7 8 . Carta de características muy similares a la anterior en la que además se indican algunas rutas de penetración francesa hacia Texas y Nuevo México. Interesante anotación de tribus hostiles a los españoles en el noroeste de Nueva Vizcaya. Coincide con el mapa n. ${ }^{\circ}$ I de de Fer en el error de suponer el río Conchos afluente del Sabinas. Llama al Pecos "río Salado de apaches de los Siete Ríos" y anota a la altura del Misisipí que, según informes de los indios, los españoles cruzaban este río a caballo para ir a buscar "du fer jaune" a las tribus del noroeste.

Reproducido en Cartografía de Ultramar, Carpeta II, n. 99.

23. B. N. P., Hydr. ${ }^{3} 8$ bis. $/ \mathrm{I} / 8$.

Mapa de Luisiana por el Sr. de Bauvillieres. Elaborado según las memorias de La Harpe, muestra la aproximación de éste a Nuevo México logrando la alianza de algunas tribus indias. Se ratifican noticias 
acerca de la explotación de minas por los españoles de esta provincia, en tierras de los padoukas. La confusión de El Paso con Parral hace que se sitúe a orillas del Grande un "fuerte y misión del Parral". Una línea de puntos en el Golfo indica la dificultad que presentan los bajos a las naves que quieran acercarse a ella.

24. B. N. P., Ge DD. 2987, n. ${ }^{\circ} 8797$.

Mapa francés del curso del río Grande, intimamente relacionado con el anterior, y prueba de la confusa inteligencia que los franceses tenían de la distribución geográfica de las provincias españolas.

25. B. N. P., Ge DD. 2987, n. ${ }^{\circ} 8802$.

Carta de la costa de Luisiana, por Devin, en I719-1720. Devin insiste, como todos los cartógrafos franceses hasta la fecha, en considerar que los territorios de Luisiana se extienden hasta el río Grande. El interés de este mapa reside en el reconocimiento por parte de Devín de que los dos tramos de la costa texana en que el dibujo se interrumpe "nont point été vus", no han sido vistos jamás, según asienta en la explicación.

26. B. N. P., Hydr. I4I/I/3.

Carta francesa del Golfo de México, copia de otra española en pergamino tomada por el barco "Le Bon" en las Antillas en I697. Se consignan algunas noticias relacionadas con la actuación de La Salle, así como se delimita la zona de bajos fondos peligrosa para la navegación. La siguiente serie de mapas se presenta con objeto de mostrar no ya los límites atribuídos por franceses y españoles a sus posesiones en Luisiana y Florida, sino el general desconocimiento del trazado de la costa del Golfo entre Tampico y el Misisipí, por las dificultades que impedían su exploración. Hemos omitido, sin embargo, las abundantes reproducciones de un paraje concreto, como es la Bahía del Espíritu Santo, frecuentemente visitada con ocasión del incidente de La Salle.

27. B. N. P., Hydr, I40/I/IO.

El Golfo de México e islas de Barlovento, por Juan Las Caiz, I 708. Carta española, aunque no parece serlo el autor, que muestra adelantada información de la costa setentrional del Seno. Caiz pudo ser un piloto portugués al servicio de Francia, pues pinta de azul el litoral del río Bravo a Pensacola, pero que trabajó sobre mapas españoles. 
28. B. N. P., Hydr. I40/I/13.

Copia francesa de la carta precedente.

29. B. N. P., Hydr. I $41 / 1 / 9$.

Mapa español del Golfo de México, de mediados del siglo XVIII. Es notable la representación del deita del Misisipí. La desembocadura del río de la Trinidad se da como no reconocida.

30. B. N. P., Hydr. I 38 bis $/ \mathrm{I} / 20$.

Carta francesa del "fondo" del Golfo, i769. Todavía perdura la nota de que la costa texana no ha sido visitada nunca.

31. B. N. P., Ge DD. 2987, n. 08923 .

Las Indias Occidentales de la línea Equinoccial a Terranova en unć carta holandesa del siglo XVII. Muestra una ignorancia casi total de las costas del norte del Golfo. El valor de este ejemplar aumenta por el hecho de haberse trazado sobre él, a mano, la ruta de las flotas y galeones con extraordinario detalle, con anotaciones en francés.

32. B. N. P., Hydr. I4I/I/I5.

Carta española del Golfo de mediados del XVIII. Muy pobre en datos sobre la costa de Texas.

33. B. N. P., Hydr. 140/2/1.

Carta del Golfo y del Caribe elaborada en el depósito de la Marina Francesa a mediados del XVIII. Aparecen manchados de azul -color que indica los territorios franceses - las costas desde la bahía de San Luis a San Bernardo. El trazado de la ruta de los galeones y flotas es mucho más simple que en la carta anterior.

34. A. G. I., T. L., México, IIo.

Mapa del norte de Nueva España por el oidor Oliván y Rebolledo, en 1717. Curiosísimo y valioso ejemplar donde, principalmente se han detallado los rasgos geográficos de Texas, siendo muy desproporcionados los correspondientes a Nuevo México y Nueva Vizcaya. El trazado recto del curso del río Grande en su tramo central que aquí presenta Oliván, será uno de sus presupuestos geográficos en su posterior intervención en los asuntos de la frontera.

La copia de este mapa existente en el S. H. M. ha sido publicada en Cartografía de Ultramar, carpeta II, n. ${ }^{\circ}$ I 8. 
35. B. N. P., Ge DD. 2987, n. ${ }^{\circ} 8879$.

Mapa del noroeste de Nueva España por el P. Kino, I699. Editado y comentado en francés por N. de Fer en I720. Es la última representación de la isla de California o Carolinas por quien había de mostrar su peninsularidad. Los errores son por otra parte evidentes en la porción al norte del río Colorado. Todavía aparece el río del Tizón. Contiene, en cambio, el primer mapa detallado de Sonora y una interesante representación de Nuevo México y Nueva Vizcaya. La primera misión duradera en California no ha sido aún fundada.

Este y el siguiente mapas dan fe de la inmediata difusión que tuvieron en Europa los trabajos geográficos del P. Kino.

36. B. N. P., Ge DD. 2987, n. ${ }^{\circ} 8880$, y B. N. P., Klaproth n. ${ }^{\circ} 699$.

Paso por tierra a California, por Kino, I 705. Carta publicada en francés por Inselín, sin fecha, que recoge los descubrimientos geográficos de su autor. Es sorprendente la comparación del mapa anterior con éste, que definitivamente destruye las fantasías del canal entre California y el continente. Aparece la isla Tiburón como de San Agustín, y se recoge el real de San Juan, capital entonces de Sonora.

37. B. N. P., Ge D. 10653.

Mapa manuscrito de Sonora, que también expresa los más recientes descubrimientos del Padre Kino hasta I700.

38. B. N. P., Ge DD. 2987, n. ${ }^{\circ} 888$ I.

Sonora y California, i710. Mapa español copiado por D'Anville en 1724. Se da a Sonora el nombre de Nueva Navarra. La isla de Tiburón, que Kino llama en sus mapas San Agustín, lleva aquí la palabra "seris" inscrita. Janos, en Nueva Vizcaya, Terrenate y Sinaloa aparecen como presidios.

39. Plano del presidio de Nuestra Señora de Loreto de la Bahía del Espíritu Santo, en Texas, establecido por el marqués de Aguayo, según lo representó Juan Antonio de la Peña en su Derrotero, publicado en México, I722. Reproducido por Francisco Vindel, Mapas de América y Filipinas en los libros españoles de los siglos XVI al XVIII, Apéndice, Madrid, 1959, pág. 37.

La planta estrellada, octogonal, del presidio, con cuatro baluartes, tan poco frecuente en la frontera de indios bárbaros, hace pensar que 
este fuerte se situó para precaver la ocupación del territorio por una potencia europea enemiga.

40. Mapa del presidio de San Antonio, centro de las misiones del río de este nombre en el oeste de Texas, y sostén de la futura población de Béjar. También publicado en el Derrotero de Peña y en el Apéndice de los Mapas de América de Vindel, pág. $3^{8}$.

41. Mapa del presidio de Nuestra Señora de los Dolores de los Texas, restablecido por el Marqués de Aguayo como bastión oriental de las posesiones españolas frente a la naciente Luisiana. Su rara traza cuadrada con solo dos baluartes, para que pudiera ser defendido por veinticinco hombres, no perduró como la presentó Juan Antonio de la Peña en I722. Puede verse la reproducción ofrecida por Vindel en el Apéndice de los Mapas de América, pág. 39.

42. A. G. I., T. L. México, I20.

Mapa de Nayarit, por Barreiro, 1725. Se llama a Nayarit también Nuevo Reino de Toledo. Esta provincia recientemente dominada, vigilada por el presidio de la Mesa del Tonati o del Sol, fue la primera visitada por el brigadier Rivera y su cartógrafo, y éste el plano n. ${ }^{\circ}$ I de los adjuntos a su informe.

43. A. G. I., T. L. México, I21.

Mapa de Nueva Vizcaya y Culiacán, por Barreiro, I726. Este es el primero y único mapa completo de Nueva Vizcaya en un momento en que todavía se extiende del Pacífico a Saltillo. Sonora, Ostimuri y Sinaloa, alcaldías mayores dependientes de Nueva Vizcaya, aparecen en mapa aparte, $n .^{\circ} 45$, siendo éste el $n .^{\circ} 2$ de los presentados por Rivera. Aquí se nos hace patente la serie de los presidios del camino real, desde Pasaje a Conchos, mientras queda Janos al norte, junto al río de Casas Grandes. El Bolsón de Mapimí aparece representado por primera vez ocupándolo los sibulos, conchos y zicimbres gentiles, y los acoclames, tripas blancas y otros apóstatas, así como en el río Grande se encuentran los sumas y cholomes gentiles, mientras que los apaches del Natajé y los faraones se hallan lejanos. Se advierten el trazado casi rectilíneo del Rio Grande y la desproporción e incompleta información acerca de los ríos de la cuenca cerrada del norte de la provincia. En cambio este es el único mapa que representa separadas las dos lagunas en que desembocan los ríos Nasas y Aguanaval. 
44. A. G. I., T.L. México, 122.

Mapa de Nuevo México, por Barreiro, 1727. Plano n. ${ }^{\circ} 3$ del informe de Rivera. Magnífico documento acerca de la distribución de las tribus vecinas a la provincia, que aparecen así: el este de El Paso, los apaches natajes; al norte de éstos, los faraones; al nordeste, los apaches navajos, y, más lejos, los cosninas; al oeste, los pueblos rebeldes del Moqui; al sur de Acoma y Zuñi, los apaches mezcaleros y los del Gila.

45. A. G. I., T.L. México, 123.

Mapa de Sonora por Barreiro, I727. Este plano n. 4 de Rivera completa la provincia de Nueva Vizcaya, a la que todavía correspondían estas tres jurisdicciones costeras; Corodeguachi y Sinaloa son las únicas guarniciones defensivas. Es rasgo destacable en este mapa la delimitación del territorio ocupado por los gentiles Seris y Tepocas, y se anota la presencia al norte de los pápagos, opas, sobaipuris y gileños. Barreiro prescindió de las islas del canal y de la península vecina.

46. A. G. I., T.L. México, 124.

Coahuila y Nuevo León, por Barreiro, I727. Plano n.० 5 de los presentados por Rivera. Ofrece otro diseño del Bolsón, donde además constan los apóstatas cocoyomes y cuyas dimensiones se ven mucho mayores si se prescinde del establecimiento de la Junta de los Ríos que no se efectuó en esta ocasión. Coahuila es en la práctica una provincia mucho más reducida que el territorio delimitado por Barreiro, pues se advierte que la porción al norte del río Grande sólo está ocupada por los gentiles paguasín y pampopas, cuyas tierras se continúan por las de los carrizos, tortugas, socatiles, carbames, pamorames, amiyayas y malincheros, en la faja costera del Golfo, al este del Nuevo Reino. Barreiro llama al Pecos "Río Salado o del Nataje".

47. B. M., Mss. room. Add. I7650. b.

Mapa de las provincias internas, por Barreiro, I727. Copia reducida hecha por Surville, en I770. Ha desaparecido el original del presente mapa, que es el n. 6 de la colección de Rivera, y que comprente la provincia cle Texas, de la que Barreiro ya había hecho con anterioridad mapa individualizado que no se incluyó en el informe. Esta copia de Surville fue sustraída sin duda del informe de Barreiro que se conserva en la Biblioteca del Palacio Real de Madrid, donde se hallan copias semejantes de los cincos mapas anteriores. Denota el presente con claridad que la costa tamaulipeca y texana está señoreada por tribus gen- 
tiles pazolatames, cujanes, toos, carancaguas, cocos, vidai, salineros, y parchenas, más los ya mencionados en el n. ${ }^{\circ} 44$. Dentro de Texas aún se mencionan los pastios y ainais. Del río Grande al de la Trinidad se muestra la enorme difusión de los apaches faraones, natajes, tastazagonis, temitas, jicarillas, carlanes, palomas, nanisue y cuartelejos, sobre las tierras de pastos y cibolos. Sobre Texas hay veintidós naciones casi extinguidas por los apaches. Al norte se hallan los aas, osages, causas, nechas, etc. Sobre Nuevo México, al norte de los yutas, aparecen los comanches o padoucas y al noroeste de los navajos, los coninas. La costa de Sonora es la gran sorpresa de este mapa, que pese a su fecha no recoge los descubrimientos de Kino y mantiene, por omisión, el mito de la California insular.

48. A. G. I., [T. L.] México, 575 .

Mapa del norte de Nueva España por el barón dè Heyder, hacia I730. Heyder, que realizó este gráfico para mostrar las fronteras" por donde pueden verificar (silenciosamente) nuestros vecinos las ideas que manifiesta Daniel Coxe en su Descripción de la Carolina, impresa en Londres, año 1727 , cap. $V$, fol. 63 ", se muestra mucho peor informado que Barreiro. Es notable su ignorancia del tramo medio del río Grande, cuyo trazado se enlaza con el Conchos, recibiendo al final el nombre de río de las Palmas; como consecuencia, los presidios de El Paso y San Juan Bautista aparecen aislados de cualquier curso fluvial. Sorprende también que el alcalde mayor de Sonora pinte separadamente los ríos Colorado y Gila, y en cambio se halle bien informado del Misuri y Misisipí, al que, no obstante, hace desembocar al parecer en la bahía del Espíritu Santo. Se muestra al corriente de los pueblos indios en torno a Nuevo México - moquinos, faraones, comanches, cuartelejos- pero pone una parte de los yaquis en el Colorado. Es interesante la indicación de presidios o destacamentos en Pitquín y Buenavista, en Sonora, en la Sauceda, en Nueva Vizcaya, y en Boca de Leones, en Nuevo León. Da cabida en su gráfico al fabuloso cerro de Bermellón y a la Sierra Azul.

49. S. G. E., J.-2-3-93.

"Mapa del Nuevo México y presidios con las costas del Seno Mexicano, Honduras y Mar del Sur". Debe ser inmediatamente posterior a la inspección de Rivera, pues recoje exactamente los mismos presidios recorridos por el visitador. Lo que da singular interés a este gráfico es la fantástica representación del territorio más al norte y al oeste de 
Nuevo México, en la que se han combinado datos de diferentes viajeros franceses, como La Harpe, con las reminiscencias de la fábula del paso de Anián.

Publicado en Cartografía de Ultramar, Carpeta II, n. II9.

50. A. G. I., [T. L.] México, 524.

Este gráfico, presentado en 1736 por el gobernador de Nuevo León Don José de Jáurequi, hace patente la despoblación de la costa tamaulipeca, desde el río de Pánuco, hasta Texas cuyo límite se sitúa correctamente más al norte del río Bravo. Parece que se ha situado arbitrariamente el presidio de $\mathrm{El}$ Paso en paraje que en realidad corresponde al de San Juan Bautista; se advierte la señal de vado correspondiente, aguas abajo, al Paso del Cántaro, que recibe este nombre en el gráfico siguiente.

51. A. G. I., [T. L.] México, 162.

Mapa de la Sierra Gorda y Costa del Seno Mexicano, indicando las rutas seguidas por las tropas de la Bahía, Río Grande, Nuevo León, Querétaro, La Huaxteca y Tampico en la entrada general dirigida por Escandón para colonizar Nuevo Santander. Es interesante el detalle del presidio y misiones de San Juan Bautista, así como la localización del presidio de la Bahía a bastante distancia de la costa, y la notación de los destacamentos de Cerralbo y Boca de Leones, en Nuevo León.

Pueden consultarse copias y variantes de este mapa $-\mathrm{y}$ de otros derivados de él, formados con ocasión de la erección de obispado en Linares- en la obra del P. Fidel de Lejarza, Conquista espiritual del Nuevo Santander, frente a pág. 440, y en Cartografía de Ultramar, carpeta III, n. ${ }^{\circ} 75$ (pertenecientes éste al SGE, y aquél a la $\mathrm{RAH}$ ).

52. A. H. N., Estado. Carpeta de mapas, América del Norte, sin número. Mapa de Texas, hacia 1750. Comprende de Béjar al río de Cadodachos y Nueva Orleans, muy mal situada. Aparecen los presidios de la Bahía y Adaes, y las dos posiciones del fuerte francés de Natchitoches, así como un supuesto establecimiento francés en la costa texana. Corresponde esta pieza a la alarma suscitada por la captura de Blancpain. E1 trazado de los ríos es puramente convencional, y sobre el de la Trinidad aparece la enigmática inscripción "Misisipi". Parece un plano hecho según descripciones y sin conocimiento directo del territorio. 
53. A. G. I., [T. L.], México, 205.

Mapa de una parte Texas, I757. Comprende el río San Jacinto al Misisipí, cuyo trazado es casi irreconocible. Indica las dos sucesivas posiciones de Natchitoches frente a Adaes, y la de San Agustín de Orcoquiza, y un destacamento en Santa Rosa. Muestra los establecimientos costeros de los franceses. Llama a Luisiana "Nueva Luisiana" y tiene mal indicados los puntos cardinales.

54. A. H. N., Estado. Carpeta de mapas, América del Norte, n. ${ }^{\circ} 18$. Mapa de Luisiana y las colonias inglesas, posterior a I763. Aparece Luisiana con límites en el Misisipí y en el Grande-Pecos. No se delimita Texas - tan sólo se sitúa un Fuerte Español correspondiente a Adaes-, ni tampoco Florida; en cambio se indica la frontera que los franceses intentaron establecer al oeste de los Apalaches. La nomenclatura de Kanoatinos, Cenis, Paso de San Jorge, etc., sugiere las fuentes francesas de este croquis.

55. A. H. N., Estado, Carpeta de mapas de América del Norte, n. ${ }^{\circ} 27$. "Mapa de la parte setentrional de la provincia de Texas y sus inmediaciones con la Luisiana y Florida". Refleja este croquis la situación de Texas en el momento inmediatamente posterior a la cesión de la Luisiana a España por los franceses. El autor propone avanzar los presidios de Adaes y San Sabá a los ríos Colorado y Arkansas para mejor vigilar los movimientos de los ingleses.

56. M. N., Batea VI, Carpeta B, n. ${ }^{\circ}$ I. : [Cartivana].

"Plano que manifiesta la costa del Seno Mexicano desde el río Grande del Norte, que está en $24^{\circ}$ y $40^{\prime}$ de latitud setentrional, hasta la Bahía de San Bernardo, que se halla en la de $29^{\circ}$ y $20^{\prime}$. Reconocida y mandada delinear por el coronel graduado Don Diego Ortíz Parrilla, por comisión que obtuvo del Excmo. Sr. virrey marqués de Cruillas".

Este mapa bellamente coloreado muestra el campamento establecido por el coronel en la playa de Corpus Christi y tres barcos ingleses, con carga uno de ellos de palo de Campeche, perdidos en los bajos de aquella costa, cuyas profundidades se detallan en el sector oriental. Son de particular interés los nombres y ubicaciones de los diferentes grupos de indios que habitaban estos parajes, prácticamente al margen de toda influencia española.

Puede verse reproducido en Cartografía de Ultramar, Carpeta II, n. ${ }^{\circ}$ II 2 . 
57. A. G. I., [T. L.], México, I46.

Mapa de Coahuila, por Castilla y Rioja, hacia 1730. Monclova - con Zapopán y Tlaxcala - y los presidios de Río Grande y Sacramento son los puntos principales de las provincias. Las misiones y haciendas se hallan muy dispersas en el resto del territorio. El mapa abarca hasta Saltillo en Nueva Vizcaya, y Boca de Leones, en Nuevo León.

58. A. G. I., [T. L.], México, 554.

Planta de la iglesia que se ha de construir en Chihuahua i726. Este es el primero y más modesto de los dos proyectos que se hicieron para la edificación del templo, que hoy sirve de catedral, y es un buen índice de la prosperidad de la villa a los pocos años de la aparición del real de Santa Eulalia. Esta y la otra planta, de r730, ya de iglesia de tres naves, ptreden consultarse en la obra de Angulo Iñiguez, Diego, Planos de monumentos arquitéctonicos de América y Filipinas existentes en el Archivo General de Indias (Sevilla, I933) láms. núms. 60 у 6I.

59. A. G. I., [T. L.] México, 62 I.

"Plan del real presidio de Nra. Sra. de Belén y Santiago de las Amarillas de la Junta de los ríos Conchos y del Norte, que se debe construir en el presente año de I759". Este proyecto nos muestra una traza directamente relacionada con la de los presidios erigidos por Aguayo en Texas, reduciendo tan solo los bastiones de las esquinas a unos torreoncillos de planta circular (F), conservándose la planta cuadrada y las calles diagonales. El acuartelamiento se concibe como vecindario de las casas de los soldados (Y), presidido por la casa del capitán (C) y la "real capilla" (D). Es de notar el corral para la caballada (L), también flanqueado por torres. Este es el presidio con cuya edificación comenzó la larga carrera militar de Don Manuel Muñoz.

60. B. N. P., Ge D. 2796.

Mapa de Sonora por el barón de Heyder, 1733. Llama a la provincia Nueva Andalucia. Es el primero en que aparece la isla de Tiburón con este nombre, aunque de desmesurado tamaño. Hace constar las rancherías seris y tepocas, $\mathrm{y}$ los pueblos de los sometidos en los Angeles y el Pópulo, así como los placeres de perlas de la costa.

61. A. G. I., [T. L.], México, 206.

"Pimería Alta con los ríos Colorado y Gila, según las observaciones más recientes, retratada por Don N. N. Anbile". Este mapa se relaciona

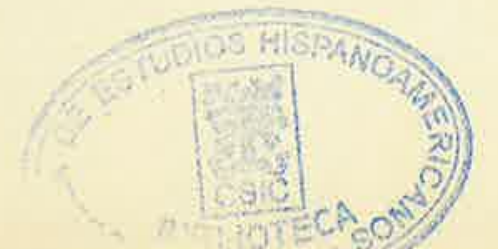


con la actividad guerrera del gobernador de Sonora Don Juan Antonio de Mendoza, que recorrió el país del Gila en compañía del misionero jesuita Padre Bernardo Middendorf, probable autor del diseño. Presenta todavía en Caborca el presidio que se radicaría en Altar; se ha puesto gran énfasis en llamar la atención sobre la proximidad de las poblaciones del Moqui y de Nuevo México.

62. A. G. I., [T. L.], México, 622.

Croquis de las fronteras de Sonora y la región del Gila, I762. Los ríos están figurados por líneas de puntos. El diseño abarca del mar de California al presidio de Fronteras y sierra de Chiricahui, y de los ríos Salado y Gila a Bacuachi. Se ha puesto el mayor interés en anotar las distancias entre cada dos poblaciones o haciendas, y entre los presidios; aparece $\sin$ nombre el situado junto a Caborca. Delimitados los territorios de los seris, de la Papaguería, de los enemigos apaches, tiene gran interés la mención del río de los Sobaipuris, "todo despoblado", y la de los "pimas del séquito de Jabanimó" en las juntas del Gila.

63. S. H. M., o. b. 7. 18.

"Mapa de la Provincia de Sonora, Opatas, Pimas altos y Pimas bajos". Esta pieza a todo color se halla directamente relacionada. con el gran mapa dedicado a Tienda de Cuervo y constituye, como ésta, una clara fuente para el conocimiento de la distribución de los grupos indios. Se purede suponer su factura hacia $176 \mathrm{r}$.

$\mathrm{Ha}$ sido publicada en la Cartografía de Ultramar. Carpeta III, n. ${ }^{\circ} 66$.

64. California en I757.

Mapa elaborado sobre los de Kino y Consag, incluido en la Noticia de la California del P. Miguel Venegas. Es la última representación de las misiones de los jesuitas, dedicada por estos misioneros al Rey. Las ilustraciones son de gran interés etnográfico.

65. Museo Naval. [Cartivana].

La ampulosa dedicatoria latina de este magnífico mapa de Sonora reza asi : "Hanc Sonorae tabulam honori et amori per illustris ac generosi D. Dni. Josephi Tienda de Cuervo, legionum hispaniarum pro-tribuni, ordinis divi Jacobi equitis, provinciarum Sinaloae, Sonorae, \&, \&, praesidis supremi praesidiorum et militum ripariensium praefecti, sincerus amor invenit obsequendi studium pinxit affectus in parenne grati 
animi mnemosynom dedicavit". En razón de esta misma inscripción puede suponerse que es obra de un jesuita y realizada en I76I. Es la más clara y completa representación de la provincia de Sonora siendo dignos de particular mención el empleo de diferentes signos para notar pueblos, presidios, minas, aguajes, etc.; la división de todo el país según la distribución de la población india; y el extraordinario detalle con que se ha dibujado el Cerro Prieto y, en general, todo el teatro de la guerra con seris y pimas, así como las entradas de los apaches hacia los sobaipuris, Cuquiarachi y la sierra de las Espuelas, y el "camino de Acoma".

66. B. N. P., Ge. D. 12839 .

Tres cartas distintas de California, de Nerou Pecciolen, de L'Isle y de Kino, impresas juntamente para ser presentadas en la Academia Francesa de las Ciencias en I 754, con ocasión de los debates acerca de la existencia del estrecho de Anián o del Paso del Noroeste. Es muy abundante y de interés la cartografía producida con este motivo.

67. B. N. P., Ge. DD. 2987, n. ${ }^{\circ} 8882$.

Copia del número 64, por D’Anville, I770.

68. B. M., Mss. room, Add. I7660. c.

Mapa del Golfo y Península de Californias por el P. Consag, I746. Sobre este mapa aparecen anotaciones en letra pequeña roja, tal vez. de mano de Bauzá. La isla de Tiburón vuelve a ser llamada de Sån Agustín. Esta obra del P. Consag aporta a la geografía la verdadera fisonomía de la costa nordoriental de la península y de la desembocadura del Colorado. Igualmente, es de interés la presentación de las misiones de la provincia de Loreto.

69. Mapa de Nueva España por Villaseñor, 1746. Primer mapa en que aparece toda la frontera, después de los generales de Oliván, Barreiro y Prudhom; se observa la aparición del presidio de Sacramento en Coahuila, y de las misiones del Bajo Conchos, y de la Junta. La Laguna de Parras figura como única. En Sonora constan los presidios de Corodeguachi, Guebavi, Pitic y Río Chico (?).

70. California, Nuevo México, Sonora y Nueva Vizcaya, tal como las dio a conocer el Atlas de la América de Tomás López, editado en París, en $175^{8}$. 
71. "Mapa de la América setentrional, Asia oriental y Mar del Sur intermedio, formado sobre las memorias más recientes y exactas hasta el año de I754". Dedicado por la provincia jesuítica de México a Fernando VI, incluido en la Noticia de la California de Venegas, da cabal idea del conocimiento que en España se tenía de la aproximación de los rusos a los establecimientos del Pacífico noroeste.

72. A. G. I. [T. L.]. México, 526 .

"Nouvelle carte des decouvertes faites par des vaisseaux Russieus aux côtes inconnues de l'Amérique septentrionale, avec les pais adjacents". Publicada por la Academia Imperial de Ciencias de San Petersburgo, en I758. Este interesantísimo mapa ruso -uno de los numerosos publicados por rusos, franceses y españoles sobre este particular- recopila los datos de Bering y Chiricov, junto con los del viaje de Drake -véase "Nouvelle Albion" y el puerto de Francisco Drake "faussement appellé de St. François"- con las fabulosas noticias acerca del río de los Reyes, del estrecho de Fuca y del río del Oeste que debía comunicar el lago Winnipeg con el Pacífico y por último con los descubrimientos de Vizcaíno de principios del XVII. El acercamiento de los rusos debía espolear a Gálvez a llevar la vanguardia del Imperio hasta el mismo puerto de San Francisco.

73. B. M., Mss. room. Add. I7651. c.

Plano de Oaxaca. Se incluye en esta serie con fines de contraste con los siguientes planos de los núcleos defensivos de la frontera.

74. B. M., Mss, room. Add. I7662. a.

Plano de Monterrey, capital de Nuevo León, por Urrutia. I765.

75. B. M., room. Add. I7662. b.

Plano del presidio de Nayarit, por Urrutia. 1775.

76. B. M., Moss. room. Add. 17662. c.

Plano del presidio de Buenavista, por Urrutia, I765. E1 acuartelamiento está cercado. Al pie, el pueblo indio de igual nombre.

77. B. M., Mss. room, Add. I7662. d.

Plano de Horcasitas, capital de Sonora, por Urrutia, I775. Las habitaciones de los soldados forman aquí la plaza, a la que se entra por los torreones de los ángulos y cuyo perfil aparece al pie. 
78. B. M., Mss. room, Add. I7662. e.

Plano del presidio de Altar, por Urrutia, I765. De disposición semejante a la de Horcasitas, sin torreones al parecer.

79. B. M., Mss. room, Add. I7662. f.

Plano del presidio de Fronteras, por Urrutia, 1765. El más antiguo puesto fronterizo de Sonora presenta en esta fecha grandes acequias de regadío y un molino; la parte central de la población la constituyen dos plazas, formando la primera el cuerpo de guardia del presidio y la iglesia, con algunas viviendas.

80. B. M., Mss. room, Add. I7662. g.

Plano del presidio de Terrenate, por Urrutia, I765. El presidio carece de forma de tal, siendo una de las poblaciones más dispersas.

81. B. M., Mss. room, Add. I7662. h.

Plano del presidio de Tubac, por Urrutia, 1765. La casa del capitán es la única edificación importante. Se aprecian las tierras cultivadas entre el pueblo y la acequia y el río.

82. B. M., Mss. room, Add. I7662. i.

Plano del presidio del Pasaje, por Urrutia, 1765. La plaza apenas está cerrada por tres lados. Las viviendas de la tropa están dispersas. La gran casa del capitán con el cuerpo de guardia anexo y la extensa huerta a la espalda es el elemento principal del conjunto.

83. B. M., Mss. room, Add. I7662. k.

Plano del presidio de Guajoquillas, por Urrutia, 1765. De disposición cuadrangular, con seis torreones, la casa del capitán ocupa todo un frente. Las casas de los soldados cierran el patio, pero dando sus puertas al campo, donde tienen las cocinas distantes un trecho. La iglesia se halla fuera del conjunto.

84. B. M., Mss. room, Add. i7662. 1.

Plano del presidio de Janos, por Urrutia, 1765 . El presidio es un solo recinto con dos patios, al que se hallan adosados la iglesia y la casa del capitán. Se advierte, próxima, la presa sobre el río que abastece dos acequias.

85. B. M., Mss. room, Add. I7662. m.

Plano de Santa Fe, capital de Nuevo México, por Urrutia, I765. Las 
principales edificaciones se agrupan en torno a una doble plaza: la casa del Gobernador, los acuartelamientos, la capilla de la Virgen de la Luz y el convento franciscano. Al otro lado del río se halla el barrio de Analco, con la iglesia de San Miguel. Se observan dos acequias a ambos lados del río.

86. B. M. Mss. room, Add. I7662. n.

Plano del presidio de El Paso, por Urrutia, i765. Situado a una legua del río Grande, la población de El Paso vive dispersa en las huertas regadas por la doble acequia formando núcleo sólo la misión y la casa del capitán.

87. B. M., Mss, room. Add. I7662. o.

Plano de Monclova, capital de Coahuila, por Urrutia, I765. En medio de las huertas que constituyen la población, sólo la casa del Gobernador, el cuerpo de guardia y la iglesia, se hallan en una plaza irregular.

88. B. M., Mss. room, Add. I7662. p.

Plano del Santa Rosa, por Urrutia, I765. No existiendo construcción formal de presidio, la población se dispone de manera semejante a la de Monclova, atravesada por varias acequias que salen de la vecina aguna y fertilizan el valle.

89. B. M., Mss. room, Add. I7662, q.

Plano del presidio de Río Grande, por Urrutia, i 765. Las casas de los soldados forman tres lados de una plaza, hallándose aislada la casa del capitán y la iglesia.

90. B. M., Mss. room, Add. I7662. r.

Plano del presidio de San Sabá, por Urrutia, I765. Construido de mampostería en forma de cuadrado, con ocho cañones situados en dos torreones en ángulos diametralmente opuestos, se observa la existencia de un corral anexo para ganado y caballada y la construcción de dos cortaduras para impedir que los enemigos se infiltrasen entre el presidio y el río. El mapa no revela la existencia de casas vecinas ni de siembras.

91. B. M., Mss. room, Add. I7662. s.

Plano del presidio de Adaes, por Urrutia, I 765. Este presidio, el de forma más regular de toda la frontera, exagonal con tres baluartes, 
según lo hizo construir el marqués de Aguayo, se halla edificado con tablas y fue algún tiempo capital de Texas. Vecina se encuentra la misión del mismo nombre.

92. B. M., Mss. room. Add. I7662. t.

Plano de San Antonio de Béjar, capital de Texas, después de serlo Adaes, por Urrutia, 1765. Los pobladores de la Villa se encuentran esparcidos en los campos que riegan el río y las dos acequias derivadas de él. El núcleo principal de viviendas forma dos plazas, una de las cuales ocupan la casa del capitán y las de los soldados, y otra, la iglesia y las casas reales.

93. B. M., Mss. room. Add. I762. u.

Plano del presidio de la Bahía, por Urrutia, 1765. El establecimiento se reduce a este presidio, en que la casa del capitán es el elemento más destacado, estando las de los soldados, al pie y más próximas al río. Hacia la desembocadura se hallan las siembras.

94. B. M., Mss. room, Add. I7662, x.

Plano del presidio de Orcoquiza, por Urrutia, I765. Presidio y misión tuvieron corta vida, y aquél apenas adquirió forma. No llega a advertirse que la casa del capitán alcanzara las proporciones que se aprecian en los más de los presidios.

95. A. G. I. [T. L.], México, 578.

Plano de los contornos del presidio de Guajoquilla, por Lafora, I766. $\mathrm{El}$ ingeniero muestra los puntos por los que penetran los enemigos a hostilizar el valle de San Bartolomé, el río Florido y el camino real.

96. A. G. I. [T. L.], México, 579.

Plano del presidio de San Sabá, por Lafora, 1767. Destinado a indicar la mala posición del presidio, debido a la facilidad que los enemigos encuentran en el cañón del río y en el arbolado del territorio circundante para acercarse al presidio sin ser advertidos.

97. A. G. I., T. L., México, 252.

Plano del corazón de Cerro Prieto, en que se indica el movimiento de las tropas en el primer ataque general al reducto organizado por Elizondo. 
98. B. M., Mss. room, Add, I765I. p.

Plano del cajón de la Palma, en el Cerro Prieto, que muestra el segundo ataque de Elizondo en I768. Copia ejecutada por Surville en I 769.

99. B. N. P., Klaproth, 649.

Mapa de Nueva España, por Alzate, I768. Directamente basado en los de Rivera y Villaseñor, indica los presidios extinguidos, y presenta, en cambio, anacronismos como el de anotar indios gavilanes, tobosos, cocoyomes, acoclames, y tripas blancas en el bolsón, y errores claros como el de la ubicación de Indé y Guanacevi. Por medio de este mapa fue conocida la geografía del virreinato en la Academia de las Ciencias de París, que lo publicó.

100. B. M., Mss. room. Add. I 765 I. q.

Mapa del viaje del P. Font de Monterrey al puerto de San Francisco, I777. Es de apreciar, sobre todo, la indeterminación en que queda la extremidad oriental de la gran bahía.

101. A. G. I., T. L., México, 349.

"Plano que contiene las provincias de Sonora, Pimerías, Papaguerías, Apachería, ríos Gila y Colorado y tierras descubiertas hasta el puerto de San Francisco en la California setentrional y hasta el pueblo de Oraibe en la provincia del Moqui, con arreglo a los diarios del coronel Don Antonio Crespo y de los PP. misioneros Fray Pedro Font y Fray Francisco Garcés, de quien los viajes desde la nación jamajaba en el río Colorado hasta la misión de San Gabriel, a las naciones que están al norte de esta misión, su regreso a los jamajabas y camino que hizo al Moqui están señalados con líneas de puntos; con cuya señal se manifiesta también la línea de presidios de esta frontera". Abarca esta pieza desde el real de Alamos al puerto de San Francisco y Santa Fe de Nuevo México; sacada del mapa general de esta zona formado por Font, lo corrige en algunos puntos - véase la isla de Tiburón--, pone interés en delimitar el país de cada nación de indios, y tiene su mayor variante en la manera convencional como procura presentar los presidios de Janos, San Bernardino, Santa Cruz y Tucsón en una misma linea en los $3 \mathrm{I}$ grados.

102. A. G. I. [T. L.], México, 537.

"Mapa del viaje que hizo el Padre Fray Pedro Font a Monterrey y puerto de San Francisco; y del viaje que hizo el Padre Fray Francisco Garcés 
por el río Colorado hasta su desemboque, y para arriba hasta el Moqui". En el ángulo inferior izquierda: "P. F. Petrus Font fecit. Tubutama anno I777". Seguramente este mapa es uno de los enviados por Font a Gálvez en el correo de Tueros. Es de una extraordinaria nitidez y precisión, y nos muestra la frontera desde Janos, con los nuevos emplazamientos de presidios en San Bernardino, Santa Cruz y Tucsón, y es igualmente apreciable la localización de las naciones indias. Sorprende la presentación de San Agustín y Tiburón como dos islas distintas. En el ángulo superior izquierda puede verse la goleta "Sonora". Este mapa es hermano del B. M. Mss. room. Add. I765I. q. que ofrece en' detalle el puerto de San Francisco.

103. A. G. I. [T. L.], México, 634 .

Planta de una de las "casas grandes", cuyas ruinas visitó Anza a orillas del Gila. Remitió este plano el virrey Bucareli; se encuentra otro ejemplar, con descripción, en A. G. I., Guadalajara, 5 I 5 .

104. A. G. I. [T. L.], México, 539.

"Mapa desde Veracruz a los presidios del Norte y de estos a Chihuahua levantado de orden del Sr. Comandante General Caballero de Croix por el capitán e ingeniero ordinario Don Carlos Duparquet, desde principio de sgosto de 1777 hasta 14 de marzo de I778". Al pie: "Chihuahua, a 12 de mayo de 1778 . Carlos Duparquet". Este valioso itinerario de Teodoro de Croix presenta el defecto de incluir Sómbrerete en Nueva Vizcaya -adoptando equivocadamente el limite del obispado-, y nos muestra una convencional divisoria entre Nueva Vizcaya, y Coahuila a partir del Vado de los Chizos, hasta Alamo y Anahelo. La ruta del comandante general de Durango a Béjar y Chihuahua queda aquí perfectamente esclarecida.

105. A. G. I. [T. L.], México, 538.

"Mapa del derrotero que hizo el Comandante General Caballero de Croix por las provincias de su cargo desde la ciudad de Durango hasta la villa de Chihuahua, formado sobre las longitudes del ingeniero Don Miguel Costanzó y las latitudes de Don Nicolás de Lafora, en el año de 1778 ". Firmado por "El Caballero de Croix". Al ángulo inferior derecha: "Chihuahua, 78. Luis de Bertucat".

Es sabido que Don Teodoro había formado mal concepto de Duparquet reprochando la desidia que manifestó en hacer las convenientes observaciones astronómicas para situar los lugares en el mapa, 
y por ello encargó este otro gráfico a Bertucat, que aprovechó los datos de Costanzó y Lafora. El plano de Bertucat ofrece como aportación interesante una panorámica completa de los establecimientos y puestos defensivos españoles en torno al Bolsón. Es igualmente ilustrativa la representación correcta del trazado del río Grande. Es incómoda la constante referencia por números y letras a la toponimia recogida en las seis columnas al pie del mapa.

Se encuentra otro ejemplar de esta pieza, copia sacada en I850, en Chihuahua, por J. M. de Uría, en el Servicio Geográfico del Ejército, 3-3-I-IO, y fue publicado en Cartografía de Ultramar, carpeta III, ก. ${ }^{\circ}$ II.

106. B. M., Mss. room. Add. I7660. a.; S. G. E., J.-2-3-96. [Cartivane? Mapa de la frontera de Nueva España, por Lafora, I77I. Muestra e. sistema defensivo existente y el concebido por Rubí y Lafora en su visita. Pieza importantísima de la cartografía y de la historia de las provincias internas. Como peculiaridades más destacadas en lo geográfico, presenta la de ser el primer mapa que ofrece un trazado regularmente exacto del río Pecos; mientras que supone casi rectilíneo el curso del río Grande entre la Junta y San Juan Bautista; introduce grandes mejoras en el conocimiento de la cuenca cerrada del norte de Nueva Vizcaya; es la representación más completa del río Nasas; es la más completa de la región de la Laguna; muestra con gran detalle el macizo del Cerro Prieto; supone que el río de Navajo, vecino de los pueblos del Moqui, es afluente del Gila; crea entre Nueva Vizcaya y Nuevo México la imaginaria "provincia de Gila" que nunca existió como tal, pero fue reproducida en mapas posteriores, y hace extensiva a la región de Culiacán el nombre de Topia. En cuanto a los enemigos, se advierte que la pradera ha sido ya ocupada por los comanches y los apaches se hallan exclusivamente en las proximidades del Río Grande. Los apaches gileños no aparecen muy extendidos, y no se indica enemigo interior a Sonora, en cuya costa se omite cualquier alusión a los seris. El ejemplar del S. G. E. es original y firmado por Lafora, y ha sido reproducido en Cartografía de Ultramar, II, r22.

107. M. N., Batea VII, Carpeta B, n. 6. [Cartivana].

"Carta hidrográfica del Seno de Californias con todos los puertos, ensenadas, ríos y surgideros de la costa occidental de Sinaloa y Sonora desde el cabo de Corrientes hasta la entrada del río Colorado. Puntualmente situadas las partes principales de ella según las más exactas me- 
morias que se han podido registrar. Dedicada al señor Don José de Gálvez, del Consejo de S. M. en el Real y Supremo de Indias, Intendente de los reales ejércitos, $y$ visitador general de los tribunales y ramos de real hacienda de Nueva España, etc., por Don Antonio Faveau Quesada”. Obra sin duda relacionada con la estancia de Gálvez en la península, lo más curioso de ella es la tela de araña de los rumbos con que se ha decorado. Extraña que Faveau haya omitido consignar el puerto de San Blas, cuando tan detallado conocimiento acredita de las costas e islas de la región. El parentesco de este mapa con el del Padre Consag es evidente con sólo dar una ojeada a ambos.

Un mapa similar, quizá réplica de éste se encuentra en la Biblioteca Nacional.

108. B, M., Mss. room. Add. I7650. c.

Mapa del territorio de Veracruz a Chihuahua, por Bertucat, I778. Bertucat no acompañó a Croix a las provincias orientales, sino que siguió el camino real hasta Chihuahua.

109. B. M. Mss. room. Add. I766I. c.

Mapa de los descubrimientos hechos en Nuevo México por los padres Domínguez y Vélez Escalante. Formado por Miera y Pacheco, I777. Sitúa con precisión la provincia de los Navajos, quedan los yutas sobre la ctrenca alta del Colorado. Los parajes más occidentales alcanzados -lagunas de los Timpanogos y Miera - dejan abierta la posibilidad de un gran curso fluvial que conduzca al Pacífico. Existe copia en el S. G. E., J.-2-3-97, publicado en Cartografía de Ultramar, II, I23.

110. B. M. Mss. room. Add. I766r. d.

Mapa de los descubrimientos hechos al noroeste de Nuevo México, por Miera, I778. Semejante al n. I09. Son notables la pintura de los indios barbones tuavichis y las extensas notas intercaladas o marginales. Es mapa ejecutado en Chihuahua, en I 778 , por Miera, que lo dedicó a Don Teodoro de Croix. Lo reprodujo, como los dos siguientes, Alfred B. Thomas en Forgotten Frontiers (Norman, 1932).

111. A. G. I. [T. L.], México, 577.

"Plan de la tierra que se anduvo y descubrió en la campaña que hizo contra los comanches el teniente coronel Don Juan Bautista de Anza, gobernador y comandante propietario de esta provincia del Nuevo México y la victoria que consiguió de los enemigos". Corresponde este 
mapa a la expedición del verano de $\mathrm{I} 779$, en que se consiguió dar muerte a Cuerno Verde. El gráfico es seguramente obra de Don Bernardo de Miera y Pacheco, aunque parece anónimo, y está exornado con bellísimo colorido.

Comprende desde la villa de Santa Fe hasta la Sierra de Almagre, en los $40^{\circ}$, y desde la Sierra de las Grullas a la junta de los ríos $\mathrm{Na}$ pestle, Sacramento y Dolores. Según su autor, todo el país recorrido al norte de Ojo Caliente y del último río citado era hasta entonces desconocido.

112. A. G. I., legajo Guadalajara, 5 I8.

Planta y fachada de la Caja Real de Rosario, por Mascaró. Es este uno de los edificios que manifiestan el nuevo impulso dado a la econo. mía de las provincias internas.

113. A. G. I. [T. L.], México, 586. b.

Mapa del terreno que ha de batir la expedición contra los apaches gileños, por Rocha, I784. Magnífico documento que permite identificar gran cantidad de parajes de la frontera sonorense. Se advierte que aún no han sido establecidos los presidios indios de Bacuachi y Buenavista, pero sí el de Bavispe. Existe otro ejemplar con signatura México, 54I.

114. B. M., Mss. room. Add. I7651. u. [Cartivana].

Mapa de Nuevo México, por Miera, 1779. Es el mejor mapa de la provincia durante la época hispánica. Presenta la división en alcaldías mayores, faltando la de El Paso, que no está comprendida en los límites de esta carta.

115. B. M., Mss. room. Add. ${ }^{7} 7650$. a.

Mapa de las provincias internas, ¿1787? Muestra la provincia de Coahuila aumentada ya con las jurisdicciones de Parras y Saltillo, y la de Sonora guarnecida con los presidios ópatas y pimas. Es reducción y simplificación del de Lafora, con notables errores. Sitúa Béjar dentro de los límites de Coahuila; supone la existencia de pueblos y haciendas en el Bolsón de Mapimí; establece muy inexactamente los límites de Sonora y Nueva Vizcaya.

116. A. G. I., T. L., México, 346.

Mapa del norte de Nueva España, por Mascaró, I778. El virrey Buca- 
reli hizo preparar este mapa para determinar las provincias que pasaban a formar la comandancia general. Mascaró incorpora tanto los descubrimientos de la costa del Pacífico como del Colorado y Nuevo México. Traza los caminos de México a Santa Fe y Tucsón. Recoge los itinerarios de Domínguez y. Vélez Escalante a los timpanogos y de Teodoro de Croix en su visita a las provincias internas. En conjunto, el mapa está basado en el de Lafora.

117. B. M., Mss. room. Add. I7652. b.

Mapa del norte de Nueva España. Copia del de Mascaró núm. i i6, aunque algo más tardío, pues refleja ya la reforma de algunos presidios llevada a cabo por Teodoro de Croix, así como el dispositivo de defensa montado en torno al Bolsón. Se ha prescindido aquí de indicar los caminos, aunque subsisten todos los topónimos correspondientes a ellos.

118. A. G. I., T. L., México, 4IO.

Mapa de la región de Parras y Saltillo, por Melchor Núñez de Esquivel, I787. Notabilísima pieza cartográfica que muestra una de las contadas imágenes conservadas de un soldado de cuera. Es de extraordinario valor la aportación que representa para el conocimiento de la toponimia del país, así como para la comprensión de la verdadera formación de la Laguna de Parras. $Y$ proporciona una espléndida base para la explicación del extraño nombre del río Aguanaval, que aquí es llamado Buenhabal, probablemente el topónimo original, que por corrupción se transformó en Güenaval, y luego, por ultracorreccionismo, en Guanaval y Aguanaval.

119. A. G. I. [T. L.], México, 640.

He aquí una réplica del anterior mapa. Ambos han sido ejecutados con el fin de indicar las características del país y en particular la existencia y conveniencias de unas salinas próximas al pueblo del Alamo. Ambos comprenden de Mapimí a La Punta, y de Cuencamé a Saltillo. El distinto criterio expositivo hace valiosa la confrontación.

Llama principalmente la atención la figura del "soldado de cuera de tierra adentro", presentada de perfil, con el arma encarada y la adarga suspendida del brazo izquierdo.

120. A. G. I., T. L., México, 4I3.

Itinerario de Santa Fe a Natchitoches, 1788. Elaborado para ilustrar 
1a relación del viaje de Pedro Vial. El dato más interesante es, sin duda, la localización de cinco rancherías comanches, una de ellas de doscientas tiendas, entre Nuevo México y los jumanos.

121. B. M., Mss. room. Add. I7652. a. [Cartivana].

Mapa del norte de Nueva España, por Mascaró, I782. Semejante a los números I 6 y II7 indica, además, la ruta de Anza en su expedición de Nuevo México a Sonora y la de los viajes que enlazaron Sonora con la Alta California y el Moqui, más la de Domínguez y Vélez Escalante, y la de Teodoro de Croix.

122. B. M., Mss. room. Add. i766r. b. [Cartivana].

Plano de Arizpe, capital de la comandancia general, por Mascaró, I780. Con indicación de los proyectos de urbanización. El comandante habitaba la antigua casa del misionero, adosada a la misma iglesia, que era la principal construcción del pueblo. Las tierras de cultivo eran regadas por una acequia sacada del río Bacanuchi, y otra se acababa de construir a partir del río Chinapa. Mascaró proyecta una ciudad de trazado regular con cuatro plazas y una gran alameda que llegaría hasta el río de Sonora. El palacio del comandante, la catedral, el palacio episcopal, la casa de moneda y la del cabildo, serían edificios de gran exorno. Pero nada dello pasó de esta pintura.

123. B. M., Mss. room. Add. I766I. a. [Cartivana].

Mapa de la frontera de Sonora, por Rocha, I780. Es el más detallado mapa, aunque fragmentario, de Sonora en la época hispánica. Rocha indica el itinerario seguido en la visita de la frontera ordenada de Croix. Su mapa denota la presencia de los apaches al sur del Gila y al este del río de San Pedro.

124, 125. A. G. I. [T. L.], México, 638 y 639.

Planta y fachada del edificio proyectado para intendencia, cajas reales, real aduana, factoría de tabacos y ensaye en la ciudad de Durango. Firmadas ambas piezas por Juan Rodríguez. Adjuntas se encuentran descripción y evaluación del costo, fechadas en Durango, ig de octubre de 1786 .

126. B. N. P., Mss. mexicains, I57.

Mapa de Texas, por Anglino, I788. El indudable valor de esta "Descripción" estriba ante todo en el hecho de que Anglino traza con toda 
seguridad el límite de Texas con la entonces también provincia española de Luisiana, al oeste del río de Sabinas, aunque no indica el accidente geográfico en que se apoya, pero basándose al parecer, principalmente, en la divisoria de aguas con la cuenca del Misisipí. Indica también dos derroteros del río Grande a Natchitoches y Nueva Orleáns y otros que conducen de Béjar a los taobayas y comanches y a Nuevo México por San Sabá. Y quedan precisados con todo detalle los grupos indios habitantes en las costas de la provincia.

127. B. M., Mss. room. Add. 17660 . b.

Mapa de Baja California, Sonora y Nueva Vizcaya por Don Juan de Pagazaurtundúa, hacia 1803 . Mapa de gran tamaño, donde los detalles geográficos han sido cuidadosamente anotados, aunque en otros aspectos presenta errores de alguna monta, como el de situar Durango a orillas del río Aguanaval, indicar como provincia de Nayarit toda la porción meridional de Sonora, e incluir Mazapil en las jurisdicciones de Parras y Saltillo, considerando a éstas todavía como partes de Nueva Vizcaya.

128. S. G. E., M.-8." I." a 102.

Nuevo México o Nueva Granada, por Don Juan López, impreso en 1795. En este mapa se identifica con alguna probabilidad el río del Tizón o de la Buena Esperanza con el Colorado y se da la noticia de la exploración de su curso ordenada por Vélez Cachupín en 1765 . Pese a su fecha, no recoge López los descubrimientos de Vélez Escalante y Domínguez; en cambio cita una serie de mapas franceses, el de Alzate, y uno español manuscrito anónimo.

Publicado en Cartografía de Ultramar, II, 124.

129. S. H. M., O. b. 7.2I.

"Mapa de las provincias internas de Oriente, anónimo. Probablemente posterior a 1790 - aunque se le ha atribuido la fecha de hacia 1773 -, pues se advierte que el límite de Nueva Vizcaya se ha puesto en el río Aguanaval, incorporándose Parras y Saltillo a Coahuila. Sin embargo, se dan como subsistentes los presidios de San Vicente, Babia, Aguaverde y Monclova Nuevo, que ya estaban removidos, y en cambio se omite el del Arroyo del Cibolo. Parece que debió ser parte de un mapa más amplio, pues aparecen truncas las palabras "/provinc/ia (sic) /in/ternas".

Publicado en Carografía de Ultramar, Carpeta II, núm. II3. 
130. B. N. P., Ge D IZII.

Mapa de la frontera de Nueva España con los Estados Unidos. Parece que "la línea divisoria" se refiere a la del Calcasieu, semejante a la que trazaron Cortés y Anglino. Del croquis de éste parece derivarse el presente mapa, cuya fecha oscilaría alrededor de 1805 .

131. B. M., Mss. room. Add. I7653. c. [Cartivana].

Mapa de las provincias internas, por Cortés, I799. En este mapa, toscamente trazado, al sur del río Nueces, se da el nombre de Caribes a un grupo de indios. Nueva Vizcaya aparece sumamente comprimida entre Sonora y el Bolsón y la Laguna de Parras pierde sus rasgos habituales.

132. B. N. P., Manuscrits mexicains, núm. I 7o, fol. 4. Mapa de Texas, por Mascaró. Semejante en todo a la imagen de la provincia que el mismo cartógrafo ofrece en el número i 6 , dando con gran detalle la red fluvial del extremo oriental que realmente corresponde a Luisiana. Los límites aquí indicados en esta zona nunca tuvieron realidad. El presidio de Orcoquiza, ya demolido, está mal situado. Aparece aquí el topónimo "río Carcasut", pero inexactamente aplicado.

133. A. G. I., Sección de Uniformes, 71 .

He aquí la representación de un presidial a caballo, hecha hacia 1803 por Ramón de Murillo. Por contraste con las imágenes a pie ofrecidas en otros grabados, se advierte en ésta la cuera reducida a una especie chaquetilla, la amplia silla de montar, las enormes espuelas, el calzón recogido a media pierna por la polaina y las armas reales sobre la rodela.

Forma parte este dibujo de una propuesta hecha al Príncipe de la Paz para la modernización de las tropas de la frontera setentrional de Nueva España. 
INDICE ANALITICO 


\section{5}

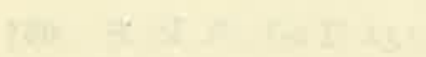

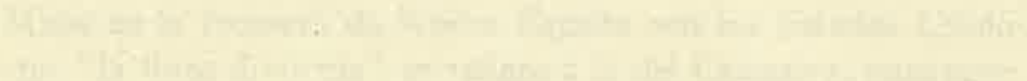

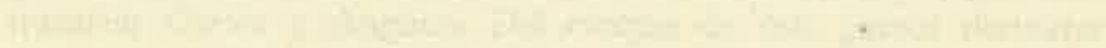

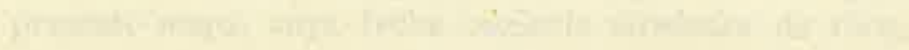

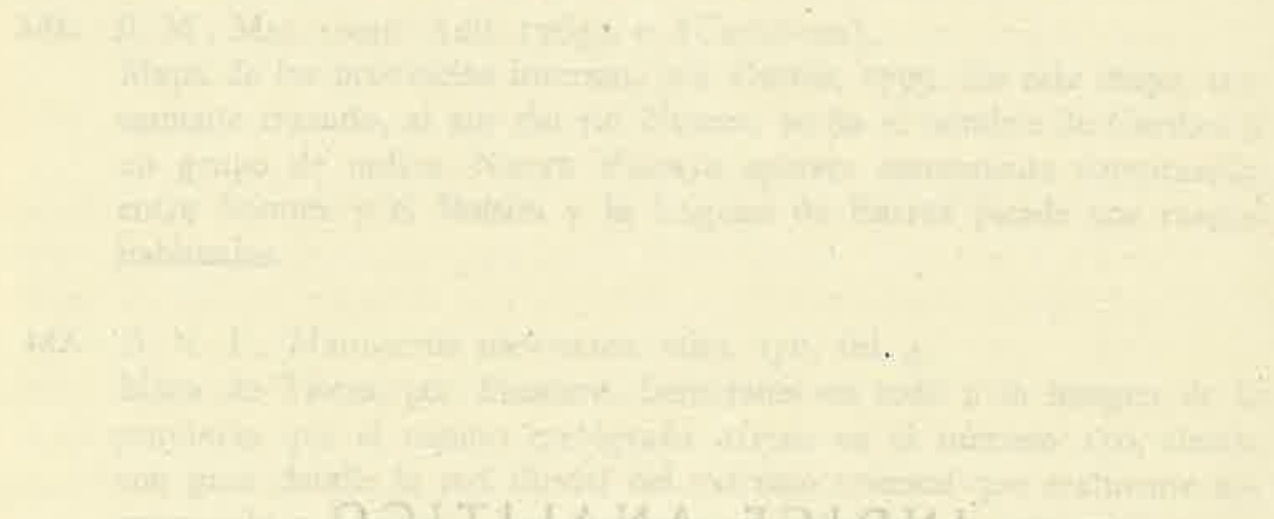

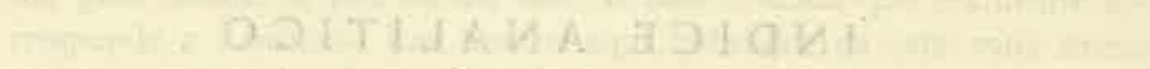

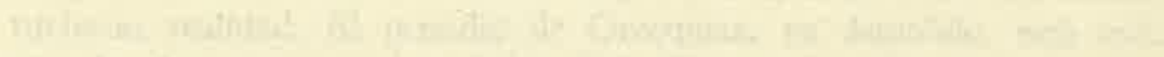

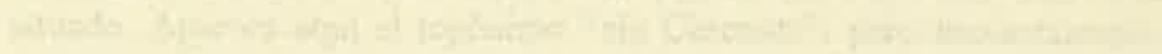
$+1,+1$

that

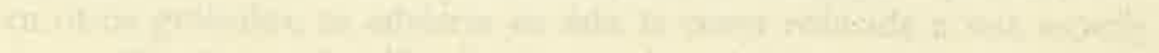
4.

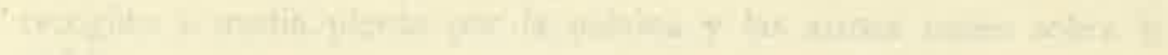
17015: II

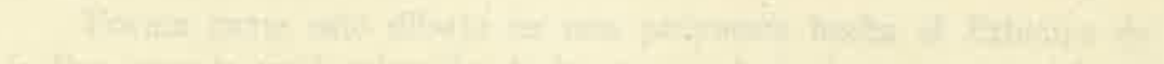

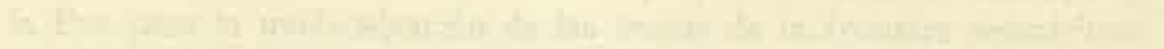

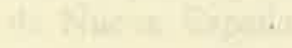




\section{A}

Abalos, provincia de: 91.

Abate, José María de; capitán de Bue' navista: $282,448$.

Abiquiú (N. México) : 249, 424.

Acajees, indios: 8, 9, 15, 16.

Acámbaro: 4.

Acaponeta (N. Galicia): 15, 16, 91, 128, 364.

Acapulco: 67, 93, 123, 140, 161, 277, 470.

Acatita la Grande, aguaje: 80, 231.

Acoclames, indios: $18,23,37,76$. - 523, 540.

Acoma (N. México): 248, 249, 334, 385, 424.-529, 535.

Aconchi (Sonora) : 319.

Acordada, Tribunal de la: $361 \cdot 362,444$.

Acosta, Antonio de; alférez: 215.

Acuña: 487, 501.

Achaclanes, indios; vid. Acoclames.

Achachica (N. España) : 519.

Adaes o Adays, presidio de Nuestra Se ñora del Pilar de los (Texas): 42, 43, $70,71,73,75,76,94,97 \cdot 100,105$, $125,129,137,232,269,273,382$.-$531,532,538,539$.

Adaes, indios: 345 .

Aduana, real de minas (Sonora): 178, 500.

Agramont y Arce, Cristóbal de; alcalde mayor de Culiacán: 51.

Agua Caliente, vid. Real del Oro.

Agua Escondida (Sonora): 172.
Agua Nueva (N. Vizcaya): 37, 112, $132,138,139,231,339$.

Agua Verde, paraje del ojo del (Coahui la): 223; vid. Aguaverde, presidio.

Aguachila, paraje (N. Vizcaya): 339.

Aguanaval, río y valle: $8,9,37,288$, $316,447,462$. - 528, 545, 547.

Aguayo, marqués de, gobernador de Coahuila y Texas: $42,43,47,69,94$. 99.-527, 528, 533, 539 .

Aguayo, marquesado de San Miguel de: $195,283,321,337,369,371,372$, $376,384,408,411,454$.

Aguayo, misión (Coahuila): 422 .

Aguayo, pueblo (N. Santander): 95, 469.

Aguas Calientes: 5, 92.

Aguas del Espíritu Santo, presidio: 6, Aguas Frías (Sonora): 172, 204, 206. Aguaverde, presidio de Santa Rosa del (Coahuila): 223, 224, 227, 228, 232, $234,240,269,272,283,293,297$. 298, 300, 347, 349, 353; en San Fernando de Austria, 353, 354, 374, 434, 468. - 547.

Aguila Volteada, jefe indio: 336,373 . Aguilar, villa de (N. Vizcaya) : 20, 22. Aguilillas, hacienda (N. Vizcaya): 376 Agüero, José Carlos de, gobernador de N. Vizcaya : $113,132,138,188,189$. Ahome (Sonora); 167, 177. Ahuahues, indios: 494, 495. Ahumada de Sámano, Pedro de: 5. Ahumada, presidio de San Agustín de (N. León) : 125. 
Ahumada, vid. Orcoquiza, presidio.

Ainais, indios: 530.

Aire, sierra del: 242 .

Ais o Ayes, indios: 98, 296, 345, 494, 495.-530.

Aiton, Arthur Scott: 3.

Alamillo (N. México) : 333.

Alamo, hacienda del (N. Vizcaya): $269,294,-541$.

Alamo, condado de San Pedro del: 111 112, 141, 195, 215, 412, 441. 509

Alamo de Parras (N. Vizcaya) : 120 . $319,369,376,441 .-545$.

Alamos, real de minas (Sonora): 90 $92,121,128,152,166,167,175,179$. $189,208,251-253,257,309,320$, $321,324,330,332,360,361,364$. $366,416,419,500,512 .-540$.

Alarcón, Martín de: 74.

Alaska: 156, 487.

Alaya (Sonora): 120.

Alba, duque de: 264

Alburquerque, duque de: virrey de N. España: 22.

Alburquerque, villa de (N. México): $3,28,43,68,107,118,128,199$. $246,248,249,299,333,334,336$. $338,385,420,424$.

Alcabalas: $127,128,324,364-366,370$ $379,393,402,412,414,496,504$. 513.

Alcaraz, capitán: 67.

Alcudia, duque de la: vid. Godoy.

Alegre, Francisco Javier, jesuita: 14, $86,87$.

Alegre, Domingo, jefe indio: 341 . 373 . $375,377,378$.

Alegre y Bohórquez, Manuel Esteban. capitán de la $3 .^{a}$ compañía volante: 215, 237.

Alegre y Capetillo, José Ignacio María, franciscano: $212,227$.

Alessio Robles, Vito: 10, 17, 60, 70, $72,74,79,81,83,99,104,115,140$. 294, 407, 429, 513.

Almada, Francisco R.: 213.

Almagre, sierra: 544.
Almeida (Portugal): 198, 280, 4.31 451.

Alonso, jefe indio: $239,341,373-375$ 377, 378.

Alonso Berrendo, jefe indio: 231.

Alpamo, indios: 494.

Altamira, marqués de, auditor de Méxi co: 81, 84, 85, 110, 111.

Altamira, villa (N. Santander) : 95.

Altar, río: 43.

Altar, presidio de Santa Gertrudis del (Sonora) : 87, 90, 125, 142, 145, 170, $171,180,183,206,207,218,224$ $227,238,240,257,261,282,326$ $327, \quad 330-332, \quad 361, \quad 387-390, \quad 394$ $395,419,432,434.437,439,448$, $452,465,480 .-534,537$.

Alvarado, río de: 67 .

Alto Perú, 93.

Alvarez: 504.

Alvarez Barreiro, Francisco, ingeniero militar: $21,72,74 .-528-530,535$.

Alvarez de Tuñón, Gregorio, capitán de Fronteras: 44.

Alzate: Ramirez, Miguel de: $540,547$. Allande y Saavedra, Pedro de, capitán de Tubac y Tucson: 282, 326, 406, $437.440,444,448,465$.

Amarillas, marqués de las, virrey de N. España: 57, 94, 96, 97, 101, 141. Amarillas, presidio, vid. Orcoquiza, y San Sabá.

América, regimiento de infantería de: $140,148,151,170$.

Amezqueta, Joaquín de: 416,434 .

Amiyayas, indios: 529.

Anz Maria, cajón del Cerro Prieto: 180. Anaelo, hacienda (N. Vizcaya): 242 , $273,319,369,376,377,-541$.

Anáhuac: 47.

Analco (N. México) : 386, 420.-538.

Analco (N. Vizcaya): $344,510$.

Anbile, N. N.: 533.

Ancón de Carros (N. Vizcaya) : 230 $286,339,354,355,367,369$.

Ancón de los Tecolotes (N. Vizcaya) : 111. 
Andalucía (España) : 174.

Andreu, fiscal de México: 112.

Anglino: 546, 548.

Anguis, Juan Antonio de, capitán miliciano: 39.

Angulo, Juan de: 54.

Angulo Iñiguez, Diego: 533.

Anián, Estrecho de: 2, 265.-523, 531, 535.

Anicote, jefe indio: 441.

Animas, arroyo y cuesta de las: 222, 223.

Animas, real de minas (Sonora), 178

Animas, río de las: 100.

Animas, sierra de las: 440 .

Ansón, pirata: 89.

Antequera (España): 74.

Antillas: 525 .

Antoneli, alcalde de Santiago Papas. quiaro: 412.

Antonio, jefe indio seri: 184 .

Antonio, jefe indio navajo: 492.

Antonio el Pinto, jefe indio navajo: $334,385$.

Anville, D': 527, 535.

Anza, Juan Bautista de capitán de Fronteras: 82, 88, 89.

Anza, Juan Bautista de, capitán de Tubac y Tucson, gobernador de N. Mé xico: $33,145,146,171,178,180$, $182,238,250,252,260,265 \cdot 268$, $279,283,284,286,289,291.294$, $299,300,304,305,307,308,316$, $318,324-331,334-336,373,381,384$. $387,389,390,395,396,405,420$ $421,447,456,458,459,463,505$, $506,508 .-541,543,546$.

Anza, Pedro Felipe de: 85

Año Nuevo, laguna: 171.

Aovages, indios: 296.

Apacheria: 540.

Apaches, indios: $12,23 \cdot 26,28 \cdot 30,33$, $36,43,44,76-78,82,84,85,87,88$, $90,91,99.103,106,107 \cdot 114,123$. $145,150,155,171,173,183.185$, $189,190,192-197,199,202,203,205$, $213,214,221,224-229,231,233$,
$234,236 \cdot 239,241,242,244-246,250$, $252,255,259-261,263,264,270,271$, $273,283,285-287,291-296,299,300$, $304-308,312,314,318,325-328$, $330-338,340,341,345-347,357,368$, $369,371,372,375,76,380,381,383$, $384,386,387,389-391,394,398,406$. $408,418,434.442,444,445,447,448$, $457,459,462.465,468-471,477,478$, $480,482,484,489,491,492,505$, $507 .-523,528,529,530,534,535$, $542,546$.

Apalaches, montes: 524, 532.

Aparisi, Pedro, contador del Consejo de Indias: 504.

Aparicio, Sebastián de: 4, 6 .

Apartado, marqués del: 371.

Aquituni, paraje (Sonora): 264.

Aracais, indios: 272.

Aragón, batallón de voluntarios: 198.

Aranda, conde de: 281, 487.

Aranjuez (España) : 155, 253, 275, 460, 508.

Arce, teniente: 376.

Arce y Amaya, Antonio de, teniente: 215.

Arce y Arroyo, Pablo, gobernador de Sonora: 86.

Arean, José de: 415, 416

Areche, José Antonio de, fiscal de Mé xico: 244, 252, 253.

Arellano, Juan de, teniente de San Sabá: 282.

Arenales, paraje: $242,468$.

Arias Caballero, Andrés de, capitán de Altar: 282, 448, 465.

Aribaipia o Aribaipá, paraje (Sonora), $171,390$.

Aricibe, monte: 181.

Arikaras o Aricaras, indios: 345 .

Arituaba, caucho (Sonora): 259, 330.

Arizona, estado: 25, 30, 115.

Arizona, sierra y real de minas (Sonora), $88,89,91,121,331$.

Arizpe (Sonora): 146, 205, 207, 257. $278,279,289.291,309,314,315$, $318-324,332,336,341,351,352$, 
$359 \cdot 386,388 \cdot 398,402,404,405,409$, $415,417,419,424,425,430,432$. $443,448.456,458.460,466,496,497$. $500,503,506,508,512 .-546$.

Arizusivi, jefe indio: 82 .

Arkansas, rio: $24,41,532$.

Arkansas, indios: 345 :

Armada de Barlovento: 16, 67, 74 .

Armada de la Guardia de la Carrera de las Indias: 53.

Armada Real: 53.

Armona, Francisco de, visitador electc de N. España: 143.

Armona, Matias de, gobernador-intendente de California: 169, 172, 177 , 179.

Arregui, Francisco: 404

Arriaga, Julián de, ministro de Indias: $57,87,96,97,113,114,122 \cdot 124$, $131,132,135-137,139-141,148,149$, $151 \cdot 156,162 \cdot 164,166,167,171 \cdot 173$, $175,178,181,182,184 \cdot 188,190-193$, $196 \cdot 199,201-207,213-220,222,225$. $229,231,233,235,236-238,240,244$. 263, 265-272, 274.277, 280, 287.

Arriba, hacienda de (N. Vizcaya) : 411.

Arrieta, José Antonio de, teniente de gobernador de El Paso: 237, 239, 318, 335.

Arriola, Andrés de, general de la Ar. mada de Barlovento: 74.

Arrona, real de minas (Sonora): 120. 500.

Arroyo del Cibolo, destacamento ( $\mathrm{Te}$. xas) : $219,240,273,345,382,407$.547.

Asesor letrado del comandante general: 278, 443; vid. Galindo Navarro, Pe. dro.

Asia : 90, 536.

Asientos de Ibarra, real de minas (N. Galicia): 92.

Asinais, indios: $102 .-523,532$.

Astillero, paso del: 470.

Atacapas, indios: 479.

Atapascos, indios: 24; vid. apaches, janos, jocomes, sumas, tobosos, etc.
Atascoso, rio: 469.

Atlántico, Océano: 17, 427.

Atondo y Antillón, Isidro de, almiran. te: 44,45 .

Atotonilco, presidio (N. España): 6 .

Atotonilco, misión (N. Vizcaya): 14 , 22, 74, 230, 423; hacienda, 412.

Audiencia propuesta en provincias internas: $92,159,313-315,460$

Augier, Santiago, cirujano: 322 .

Auxiliares indios de la tropa: 23, 35, $37,66,78,83,99,101,113,149$, $150,170,178.180,189,191-193,195$, $196,231,237,244,252,300,316$, $325,336,339,347,348,369,372$, $375,459,465$.

Avinito, real de minas ( $\mathrm{N}$. Vizacaya): $119,132,136,293,328,500$.

Avino, real de minas (N. Vizcaya): $5,9$.

Avispas, cajón del Cerro Prieto: 172.

Ayala, Miscelánea de (Biblioteca del Palacio Real, Madrid): 67, 91, 92.

Ayesterán, Antonio de: 144.

Ayeta, Francisco de, franciscano: 25.

Aygame, real de minas (Sonora) : 252. 253.

Azanza, Manuel José de, ministro de Guerra y virrey de México: 489, 490, 493, 503, 504.

Azcárraga, Sebastián de, alcalde mayor de Sinaloa: 133.

Azogues, renta de: $121,161,167,175$, 366-367, 415-416, 419 .

Azuela, Manuel de la, capitán de Fronteras: $145,146,225,226,325,326$, $439,445,447,448$.

Azul, sierra: 530 .

\section{B}

Babaroco: 314, 423 .

Babia, paraje y presidio de San An tonio Bucareli de la (Coahuila) : 222 . $224,231.233,235,236,240,273$, $283,287,298,300,306,320,348$ 353; en el Valle de Santal Rosa: 353 
$354,356,358,434,457,495 .-547$.

Babiacora (N. Viz.): $319,510$.

Babinioca, cajón y sierra: 225, 255, 259. 263.

Babonoyaba, misión (N. Vizcaya): 12, 291, 337, 339, 423.

Baborigame, misión (N. Vizcaya) : 412, 423.

Bac, vid. San Javier del Bac.

Bacanuchi, real de minas (Sonora) : 36 , 204, 391, 419.

Bacanuchi, río: $392,453$.

Bacuachi, real de minas (Sonora): 121 . $128,172,206,252,388,419$; pre sidio ópata: $435,436,440,444,448$, $456,458,459,463,480,490,491$.534,544 .

Bacuachi, rio: 534 .

Bacuachi, sierra: 182.

Bacubirito, real de minas (Sonora) : 165 , $167,420,500$.

Bachimba, misión (N. Vizcaya): 339, 423.

Bachimba, río: 111, 139, 230.

Bahía del Espíritu Santo, presidio de Ntra. Sra. de Loreto de la (Texas) : $42,70,71,94.96,99,100,106,125$. $137,219,232,240,269,319,320$. $345,381,382,407,469,483,484$, $513 .-525,527,531,532,539$.

Bailén (España): 430.

Bailey, Jessie Bromilow: 28.

Baimoa (Sonora) : 14.

Bajamar, marqués de: 480,512 .

Bajío, $\mathrm{El}:$ 1, 5.7.

Bajiopas, indios: 89.

Baltisar. P. jesuita: 86, 89, 90 .

Banamichi (Sonora) : 319.

Bandelier, Adoph F. A., y Fanny R.: 16.

Banderas, puerto de: 93.

Banome, real de minas: 415.

Baños, conde de, virrey de México: 23.

Baquienagage, José, jefe indio: 492.

Barajas, sierra de: 441.

Bárbaros, indios hostiles: $23,37,39$, $67,80,81,94,99,107,111,121,124$,
$131,194,200,215,219,247,358$, $377,437,453,461 .-527$.

Barbitas, jefe indio: 373 .

Barbones, indios: 541 .

Barceló, cirujano: 503 .

Barcelona (España) : 74, 216, 276, 511

Barlovento, vid. Armada.

Barlovento, islas de: 525 .

Baroyeca, real de minas (Sonora) : 121, $122,151,166,177,418$.

Barrandegui, Juan José: 404.

Barrasa, Juan de, capitán de Santa Catalina Tepehuanes: 19, 20, 22.

Barreiro, vid. Alvarez Barreiro.

Barri, Eduardo, alférez de Bacuachi: 435.

Barri, Felipe, gobernador de California $y$ de N. Vizcaya: $282-284,307,315$ $337,338,341-343,361,362,408$ $431,441,508$.

Barrigón, paraje (N. Vizcaya): 228.

Barrio Junco y Espriella, Pedro del, go. bernador de Coahuila: 50 .

Barrios Jáuregui, Jacinto, gobernador de Coahuila y de Texas: 97, 101, 131, 132, 198.

Barrutia, Ignacio Francisco de, gober. nador de N. Vizcaya: 82.

Basaraca, misión de Santa María de (Sonora) : 139, 299, 300.

Basaraca, río: 75 .

Basarte, presidente de N. Galicia: 91.

Basis, real de minas de San José de (N. Vizcaya): $119,342,344,370$, 409, 413, 500.

Baso, capitán miliciano: 83 .

Basuchil, valle (N. Vizcaya) : 136, 414.

Batopilas, real de minas de San Pedro de (N. Vizcaya) : 92, 119, 175, 342, $370,409,423$.

Batuco (Sonora) : 364, 419.

Baus, arroyo de (N. Vizcaya) : 37.

Bautista, jefe indio: 85 .

Bauvillieres: 524.

Bauzá, Felipe: 535.

Bavispe, misión (Sonora) : 39, 139, 299, 300, 388; presidio ópata: 389, 435, 
$436,440,445,448,458,480,490 \ldots$ 544.

Bavispe, río: 129.

Bean, Ellis Peter: 513.

Bearne (Francia): 192.

Beaubois, sacerdote francés: 104.

Becerra, capitán: 98.

Becerra Nieto, Antonio, capitán de Ja. nos: 44.

Becerras, estancia de (N. Vizcaya): 241, 242, 358.

Becerril, Diego, teniente: 133, 188, 189.

Becerro, indio: 87.

Béjar, presidio de San Antonio de (Te, xas): $42,70,71,76,98-101,103$, $105,125,137,139,199,213,219$, $224-226,232,240,269,271-273,291$. $295,297,319,345,346,373,381$, $382,384,407,452,468,476,483$. $484,495,506,507,-528,539,541$, 547.

Béjar, villa de San Francisco de (Texas) : $42,73,76,94,99,105,296$, $407,423,494 .-531,541,544$.

Belaunzarán, Juan Bautista de, gober nador de N. Vizcaya: 49.

Beldarrain, Juan Tomás de: 85 .

Belén (Sonora) : 176, 181, 185, 208.

Belén (N. México) : 249, 336.

Beleña, Eusebia Ventura, comisionado de Gálvez: 164-166, 170, 173, 175, $177,250$.

Beltrán de Guzmán, Nuño, vid. Guz, mán.

Bellido, Francisco, capitán de San Eleazario: 239, 242, 260, 283.

Benaventi, Ignacio: 476.

Benavides, Ambrosio de, franciscano: 15. -522 .

Benítez Murillo, Francisco, pesquisidor en N. Vizcaya: 109

Beregaña, Domingo: 415.

Berenguer de Marquina, Félix, virrey de N. España: 503, 504.

Bergosa, Juan José, capitán: 133, 179. 181.
Berkeley (USA): 6, 10, 28, 30, 44, 46, $52,143,199,453$.

Bering, navegante ruso: 90.-536.

Bermejo, mar, vid. California, golfo de.

Bermellón, cerro de: 530 .

Bernabelillo, jefe indio: 83 ,

Bernal de Huidobro, Manuel, gobernador de Sonora: 82, 83, 87.

Bertucat, Luis, ingeniero militar: 404, $405 .-541,542,543$.

Berrendo, jefe indio: 242.

Berroterán, José, capitán de Conchos: $77 \cdot 81,107 \cdot 109,113,138,377$.

Bigotes, jefe indio: 222 .

Bigotes el Bermejo, jefe indio: 459.

Bigotes el Pelón, jefe indio: 341, 373, $375,378$.

Blackfoot, indios: 30 .

Blanca, sierra: 199, 239, 240, 242, 299 , $300,304,305,334,338,445,492$.

Blanco, mar: 90.

Blanco, teniente: 316 .

Blanco, Eugenio, alférez de Monclova: 282.

Blancpain, comerciante francés: 97 , $105 .-531$.

Blondel, sargento francés: 105.

Boca (N. Galicia) : 344.

Boca, sierra: 195.

Boca de Leones, real de minas (Nuevo León) : 92.—530, 531, 533.

Bocas: 5.

Bolaños, real de minas (N. Galicia): 91, 92.

Bolsón de Mapimí: 7, 18, 20-23, 27, 29, $30,33,35-37,39,40,65,70,72,74$, $77.81,107,108-113,129,132,137$, $138,196,215,224,228 \cdot 231,233$, $234,268,283,285-287,293,294$, $300,302,306,307,310,320,336$ $338,340,346,353,357,370,371$, $373,375,377,378,380,434,442$, $447,459,483,493,498,-520,528$, $529,540,542,545,548$.

Bolton, Herbert Eugene: 3, 44, 104.

Bonavia, Bernardo, intendente de Nueva Vizcaya, comandante general de 
provincias internas: $463,489,510$, 511.

Bonilla, Antonio, ayudante inspector de presidios: $43,235,238,278,295$, $302,307,309,322,334,335,404$, $422,454,455$.

Bonilla, Juan Manuel, capitán interino de Tucsón: 394.

Boquerachi, misión (N. Vizcaya) : 423. Boquillas, hacienda (N. Vizcaya): 376. Boquinete, jefe indio: $331,389$.

Borbolla, Francisco de la, capitán de la segunda compañía volante: 215 .

Borica, Diego, ayudante inspector de presidios internos: $249,315,361,375$, $439,440,446,454,460,475$.

Borrados, indios: 5, 469.

Borrego, Diego: 271.

Boturini, colección documental en la Real Academia de la Historia: 63, $83,87,143,145,150,153,165,170$, $173,175,176,178,179$.

Bouchard de Becour, Louis, ingeniero trancés: 60.

Bournonville, marqués de: 276.

Bousquet, Juan: 382.

Branciforte, marqués de, virrey de Mé. xico: 496, 503, 504.

Bravo, río, vid. Grande.

Brazos, río: 96, 102, 479, 495.

Bringas, Pedro José de: 151, 206.

Bronco, jefe indio: 456.

Bruselas: 523.

Bucareli y Ursúa, Antonio María, virrey de México: 151, 155, 187, 196, $202-204,209-216,218,220,222$. $238,240 \cdot 250,252-267,269-273,280$. $281,284,288,290 \cdot 293,297,301$, $318,324-326,330,332,337,345$, $346,349,364,365,396,431,432$, 469. - $541,544$.

Buena y Alcalde, Mariano Antonio de, tranciscano: 265.

Buena Esperanza, vid. Tizón, río.

Buenavista, presidio de San Carlos de (Sonora): $83.85,87,124.126,129$, $133,137,145,146,150,166,170$,
$178,185,202,219,240,258,259$, $263,266,279,282,326,327,387$, $389,390,394,395,419,435,436$, $448,480 .-530,536$.

Buenavista, sierra: 172, 179, 182.

Buenavista, estancia de San Rafael de (Sonora): 388, 389.

Buenavista, presidio pima, vid. San Ig. nacio.

Buena de la Borbolla, Vicente, gobernador de Coahuila: 50.

Buenos Aires: 277, 461, 472.

Burgos (España) : 481, 508.

Burgos (N. Santander) : 95.

Burras, sierra de las: 440.

Burrus, Ernest: 87.

Bustamante y Tagle, Bernardo Antonio de, capitán de la compañía volante de Río Florido: 111, 113.

Bustillo, Fernando: 149.

Bustillo y Ceballos, Juan Antonio, gobernador de Coahuila y de Texas: $50,99$.

\section{C}

Caballero, ministro: 492, 512 .

Cabello, Domingo, gobernador de $\mathrm{Te}$, xas: $345,349,361,381.384,447$, $467,505,506,512$.

Cabello Largo, jefe indio: 223, 348 .

Cabeza, Manuel, jefe indio: 375 .

Cabezas, indios: 19, 23, 38.

Caborca, misión (Sonora): 43, 85, 159, $171,185,205,259,266,291,390$. 534.

Caborca, presidio, vid. Altar.

Caborca, río: 36.

Cachuendes, indios: 469.

Cachuginde, jefe indio: 239 .

Cadena, hacienda de la (N. Vizoaya): $294,378,413,480$.

Cadereita, villa y presidio de San Juan Bautista de (N. León) : 17, 61, 64, $71,137,483$.

Cadereita, marqués de, virrey de N. Es. paña: $16,18$. 
Cadillac, gobernador francés de Luisia. na: 41,42 .

Cádiz: 140.

Cadcdachos, indios: $345 .-523$.

Cadodachos (Luisiana) : 106, 198.-531.

Cahamoa (Sonora) : 83.

Cahurichic a Carichic, misión (N. Viž caya) : $35,414,423$.

Cainabac, Cristóbal, jefe indio: 182.

Cainiones, indios: 199.

Caiz, Juan Las: 525.

Caja de quintos y azogues de Chihua. hua: $360,415$.

Caja Real de Sonord, en Alamos: 167, 175, 207, 219, 330, 332, 360; en Ro' sar1o: 207, 251.-544.

Cajón de San Javier, real de Minas (Sonora) : $120,500$.

Cajón, serranía: 111.

Cajuenes, indios: 267, 395, 406.

Calabacillas, paraje (N. Vizcaya): 355 .

Calabazas, paraje (Sonora): 327.

Calahorra, P., franciscano: 102.

Calbert, Juan: 495.

Calcasieu, río: 548 .

Caldas, presidio, vid. Guajoquilla.

Caldwell (Idaho) : 28.

California Alta: 162, 168, 170, 203, $209,220,238,265,267,279,315$, $394,396,421,429,432,486,487$.$540,546$.

California Baja: 3, 32, 43.46, 71, 72, $81,82,84,87.89,91,124,126,133$. $135,144,150,152,153,156 \cdot 161$, $163,164,166 \cdot 169,174,177,189$, $205,207,211,220,251,255,265$. $267,275,278,290,291,299,315$, $321,323,329,360,361,363,389$, $394-398,406,421,422,424,429$. $431,433,436,453,462,466,478$, $485 \cdot 487,512--520 \cdot 522,527,530$, $534 \cdot 536,542 \cdot 543,547$.

California, golfo de: $10,397,502,512$.$520,522,534,535,542$.

Calo, Leonardo: 404.

Calvo y Muro, Blas: 404.

Calvo, El, jefe indio: 459.
Calles, Andrés: 404.

Callis, Agustín, capitán de los fusileros catalanes: 232 .

Cámara Alta o Cámaras Altas, vid. Ló pez de la Cámara Alta.

Camargo, Santa Ana de (N. Santander): 95, 126, 483 .

Cambiazo: 487.

Camino y Montero, José, teniente: 215.

Camino real: $20,23,31,33,34,37$, $99,119,129,138,229,293,326,347$, $376,385,386,431 .-539,543$.

Camisa de Hierro o Cota de Malla, je. fe indio: 468.

Campa, Antonio de la: 231.

Campa Cos, Joaquín, cura de Papas. quiaro: 412.

Campaña, compañ̃ia de, vid. Compañía.

Campeche: 67, 243, 506.-532.

Campo, Francisco Antonio del: 57.

Campo, Francisco Javier del: 403, 434,

Campo Alanje, ministro de la Guerra: $471,478 \cdot 487,489 \cdot 496,498,501-504$, $507,508,510,512$.

Campo del Curiel (Sonora): 172, 182.

Campos, Agustín de, jesuita : 44, 88, 89.

Canadá: 106, 522.

Canadian, río: 104, 107.

Canadienses: 296.

Canales, P., franciscano: 203.

Canarias, islas: $39,98,479$.

Canastrín o Calaxtrín, jefe indio: 194, 231.

Cancio Sierra y Cienfuegos, Lorenzo, capitán de Monclova y de Buenavista: $103,124,131,132,133,145$, $146,150,153,165,166,170,172$. $173,177,178,185$.

Candela, pueblo y misión (Coahuila): $269,422$.

Candelaria, misión (Texas): 103.

Canelas, real de minas (N. Vizcaya): $119,415,500$.

Canito, jefe indio: 85 .

Canoso, jefe indio: 231.-Canoso, jafe indio, otro: 482. 
Cantabria, regimiento de infantería de: 431.

Canta Recio, o Cantarrecio, ojo o lagu. na de: 234.

Cántaro (N. Santander): 483.

Cántaro, Paso del: 531.

Cantelmi, Tomás: 50, 57.

Canutillos, hacienda (N. Viz.) : 337.

Cañada Grnde del Cerro Prieto: 179.

Cañas, hacienda de las (N. Viz.) : 355.

Cañas, río de las: $8,120,128$.

Cañete, Joaquín, teniente de gobernar dor de California Baja: 396.

"Capitán Colorado", vid. O'Conor.

"Capitán Muchacho", vid. Vélez Cachupin.

Caracas: 4'74, 478, 479, 487.

Carancaguas, indios: $296,345,349,381$, $383,469,483,493 .-530$.

Carantapa, minas: 14.

Cara Pintada, cajón del Cerro Prieto: 172, 173, 179, 180, 292.

Carapoa, San Juan Bautista de (Sono. ra) :8. -520 .

Carbames, indios: 529.

Carcajona, Timonel de: 7.

Caribe, mar: 526.

"Caribes", indios: 381, 469.-548.

Carlanes, indios: 530.

Carlos, jefe indio: 505.

Carlos II, rey de España: 523.

Carlos III, rey de España: 220, 277, $281,492$.

Carmen de Peñablanca, Nra. Sra. del, hacienda (N. Viz.): $139,338,355$, $443,450$.

Carmen, isla del: 74.

Carmen, río del: 119 .

Carmen, sierra del: 340 .

Carolina, provincia, vid Texas y Cali. fornia Baja.-Carolina (USA) : 530.

Carondelet, barón de, gobernador de Luisiana: 495.

Cartagena de Indias: 280.

Carvajal, Gaspar de, gobernador de N León: 17, 47.
Carrasco, José Manuel, capitán 3. com pañia volante: 474 .

Carrera, Manuel de la: 291.

Carrera Stampa, Manuel: 3.

Carretas, misión y valle de (N. Viz.) : $12,27,129,194,391,414,445,448$.

Carrillo, Juan, alférez de Tucson: 438, 439.

Carrizal, hacienda y presidio (N. Viz.) : $76,113,122,218,234,237 \cdot 240,242$, $243,250,261-264,337,339,353$, $354,358,367,368,434,449,450$, $456,480,491$.

Carrizal, paraje (Sonora) : 86, 257, 331 .

Carrizal de Picú (Sonora): 171.

Carrizal de San Mrcial (Sonora) : 204.

Carrizal de Ten (Sonora): 145, 181.

Carrizo, sierra del: $230,242,493$.

Carrizos, indios: 529.

Casafuerte, marqués de; virrey de $\mathrm{N}$. España: $60,71,74,77,79,82,98$, 99.

Casa de la Moneda, proyectada en provincias internas: $157,159,167,187$, $205,278,290,309,315,359,360$, $392,460,497$.

Casal, o Casale (Italia): 451.

Casanova, Manuel de; teniente de $\mathrm{Ba}$ vispe: $282,448$.

Casas, Pedro de; cirujano: 188.

Casa Grandes, misión y pueblo: 12, 20 , $26,27,33,111,112,339,353,354$, 367.

Casas Grandes, "presidio: 32, 35, 61, 64: Vid Janos.

Casas Grandes, río: $111,119,129,134$, 528.

Casas Grandes, valle de: 139.

Casaviella: 487.

Casco, hacienda de (N. Vizcaya) : 30 , 442.

Castañeda, Carlos Eduardo: 43, 79 , $96.99,101,104.106,109,273,384$, 407, 507, 513.

Castaño de Sosa, Gaspar: 17.

Castaños, hacienda (Coahuila) : 319. 
Castañuelas, hacienda (N. Vizcaya): $319,411$.

Castel Blanco, o Castello Branco (Portugal): 431 .

Castilla: 48,481 .

Castilla y Rioja: 533 .

Castilla Terán, José; teniente de San Sabá: 282.

Castillo, teniente de Monclova: 101.

Castillo, Gabriel del; gobernador de N. Vizcaya: 37, 38, 49, 53.

Castillo, Luis Antonio del; capitán de la compañía volante de Terrenate: $263,264,325,326$.

Castillo de Aysa, marqués del; presiden. te-gobernador de Guadalajara: 89.

Castro, Ramón de; comandante de las provincias internas orientales: 429 , $474,478,484,501$.

Castuenses, indios: 349.

Cataluña: 53.

Caughey, John Walton: 192, 199.

Causas, indios; vid guazas.

Cavagnolle, fuerte francés: 104.

Cazcana: 2.

Cazcanes, indios: 7 .

Cazoni, Juan; jefe indio: 225, 256.

Cazorla, Luis; capitán de la Bahía: 295, $309,315,379,404,434,470$.

Cea, Gregorio de; vid Fernández de Cea.

Cebolleta (N. México): 107.

Cedros, hacienda (Sonora) : 391.

Celaya: 5, 473.

Celorico: 431.

Cenis, indios; vid. Asinais.

Cenizo, monte: 182.

Cerdeña: 216.

Cerecedo, Manuel de; capitán de Río Grande: 282, 298.

Cerocahui, misión (N. Vizcaya): 423.

Cervantes, Enrique A.: 96.

Cervantes Saavedra, Miguel de: 7.

Cerralbo, ensenada de (Calif.) : 165.

Cerralbo, villa y presidio de (N. León): 17. $61,64,71,76,95,137 .-531$.

Cerro Gordo, presidio: 19, 20, 22, 23 , $31-33,39,40,60,61,64,65,71,75$,
$112,128,132,133,136,137,196$, $214,218,221,228.231,233$; segunda época: $293,316,319,339,342,343$, $347,356,370,376,409$. Vid. San Carlos, presidio.

Cerro Prieto, sierra (Sonora): 73, 76, $81,82,86,131,145,150,151,166$, $171,173,177,183,185,186,189$, $210,304,328,330,-535,539,540$.

Cerro del Promontorio, real de minas (Sonora): 206, 252, 253, 255.

Cetocende, jefe indio: 239.

Cia (N. México), vid. Zía.

Cibola, provincia imaginaria: 10.-521.

Cibolo, presidio; vid. Arroyo del Cibolo.

Cibolos, indios: $35,100,111 .-528$.

Cicimbres, indios: $76,78 .-528$.

Ciénaga, cañón de: 483.

Ciénaga del Coyame, misión (N. Viz.) : $111,221,224,354,368,372,449$.

Ciénaga Grande, presidio: 5.

Ciénaga de Mata, presidio: 8.

Ciénaga de los Olivos (N. Vizcaya): $316,337,342,343,373,409,442$.

Cieneguilla (N. México) : 249.

Cieneguilla, real de minas de San Ildefonso de (Sonora): 201, 204, 207, $251,255,261.263,293,325,326$, $329,330,364,419,420,500$.

Cieneguilla, sierra: 179 .

Cinco Señores del Nazas, pueblo (N. Vizcaya): 465.

Cinco Señores de Santander, escuadra de (N. Santander) : 126.

Cirimo (Luisiana) : 106.

Ciscat Gaimon, jefe indio: 382.

Cleveland: 90.

Coaguiona (Sonora) : 39

Coahuila, provincia de: $9,15,17,33$, $34,37,38,41 \cdot 43,50,52,54,56,57$, $60,61,65,72,77,79 \cdot 81,99 \cdot 102$, $108,109,115,116,118,125,126$, $129,131,132,136-139,143,189$, $199,213,215,217,218,220,221$, $223,227,228,231,232,234.236$, $239 \cdot 241,246,264,268-273,275,282$, $283,286.291,293,294,297.299$, 
$302-304,308-310,312-314,318,320$, $325,335,336,338,341,345 \cdot 349$, $353,357,361,363,367,369,370$, $373-375,376-380,382,398,406-408$, $422-424,433,447,451,453 \cdot 455$, $457,462,464,468.470,476,481-483$, $486,490,491,493,495,501,503$, $512 \cdot 513 .-529,533,535,538,541$, $544,547$.

Coahuila, villa de; vid. Monclova, villa y presidio.

Coahuiltecos, indios: 96.

Cobián Busto, Antonio; visitador de los presidios de (N. Vizcaya) : 60 .

Cobos, Antonio de los: 50, 51, 56.

Cobres, sierra de los: 239, 459.

Cocomaricopas, indios: 43, 89, 395, 406. Cocomorichic, misión (N. Viz.) : 35.

Cocos, indios: 99, 345, 383, 479.-530. Cocospera, misión (Sonora): 43, 251.

Cocoyomes, indios: $37,38,76,295$.-529,540 .

Cochití (N. México) : 245, 387.

Codallos, gobernador de N. México: 108.

Coina, monte: 520.

Cola del Aguila, sierra: 242.

Cola de Coyote, jefe indio: 38 .

Colder, F. A.: 90.

Colegios Apostólicos de Propaganda Fide, vid. Nuestra Señora de Guadalu. pe,y Santa Cruz.

Colima: 67, 91, 163.

Colonia del Nuevo Santander, vid. Nueva Santander.

Colonias inglesas: 135 .

Colorada, La; veta del real de Basis: 413.

Colorado, cerro: 436.

Colorado, desierto: 35,45 .

Colorado, río: $11,43,45,87.89,91$, $93,123,158,159,205,208,265.267$. $332,387,389,392 \cdot 396,398,431$, $433,502 .-527,530,533,535,540$. $543,545,547$.

Colorado, río (Coahuila): 270.

Colorado, río (Texas) : 96, 105, 106,
$199,295,469,471,482,492,507$ -

532.

Colorado, o Puerco, río: 222, 236, 240, 241, 242.

Colorados, indios: 19.

Colotlán: $65,472$.

Columbus (Ohio): 95.

Comanches, indios: 101-104, 106-108, $197-199,222,226,227,235,242$, $244 \cdot 250,270 \cdot 272,287,295,296,299$, $304-308,333,334,336,338,345$, $373-375,380-386,389,398,406,437$, $447,456-459,464 .-465,468,471$, $476,482,483,490 \cdot 492,505 \cdot 507$, $513 .-530,542,543,546,547$.

Comandancia de Oriente, propuesta: 310-313.

Comanja, real de minas (N. Galicia): 92.

Comaquibuto, jefe indio: 259.

Comas, aguaje: 377.

Comayagua (Nicaragua) : 273, 512.

Come-cibolos, indios: 307.

Compañia de campaña (N. Vizcaya) : $22,31,33,39,43,60,61,64,69$, 70. Vid. Valle de San Bartolomé.

Compañia de las Indias: 105.

Compañia de Jesús, vid. Jesuitas.

Compañia miliciana del real de Frailes (Sonora) : 39.

Compañias de indios nobles, en Sonora: 175, 177, 279.

Compañias milicianas de El Paso (N. México) : 229, 238, 308, 318, 335, $353,370,480,492,503$.

Compañias milicianas, de Nueva Viz. caya: $101,111,112,144$.

Compañias milicianas de infantería, de Sonora: $82.84,145,147$.

Compañia volante, en Chihuahua: 110, 111.

Compañia volante, en Nuevo Santander: $198,280,311$.

Compañia volante ópata: 300,305 .

Compañia volante del Río Florido (N. Vizcaya) : 111. 
Compañia volante, en Sonora: 36,39 , $56,59,60,61,69$.

Compañias volantes de dragones, en $\mathrm{N}$. Vizcaya: $167,188,194,212-213$; con O'Conor: $214,215,220,221,230$, $231,233,234,237.241,263,268$, 282, 287; con T. de Croix: 292-294, $298,307,325-327,330,337 \cdot 339,346$, $347,353,354,367$; con Neve: 434; con Rengel: 449; con Nava: 491-493.

Compañias volantes milicianas de caballeria, en Sonora: 147, 149.151, 170, 177, 185; agregada a Terrenate: 238 , $240,251,263,279,287,292,297$, 298, 306, 326, 331.

Compostela (N. Galicia) : 128.

"Concepción", paquebot: 164, 165.

Concepción (Sonora): 319.

Cioncepción, misión en el río Colorado: 394.

Concha, Fernando de la; gobernador de N. México: 474, 492, 506, 508.

Concha, jefe indio: 231, 239.

Conchas, río de las: 95.

Conchos, indios: $12,14,16,18,19,21$, $23,29,35,108 .-528$.

Conchos, río: $11,12,18,26,29,38,39$, $111,129,138,221,357,374,447$.$522,524,530,535$.

Conchos, misión y pueblo de San Francisco de (N. Viz.): 12, 19.21, 27, $128,316,339,342,409,423$.

Conchos, presidio de San Francisco de: $31-33,35,38.40,60,61,64,65,71$, $76.79,108,122,128,132,137,528$.

Coneto, real de minas (N. Viz.) : 92 , $119,415,500$.

Conicari (Sonora) : 128.

Coninas, indios, vid. Cosninas.

Conquista, duque de la; virrey de $\mathrm{N}$. España: 83, 84, 91, 109.

Consag, Felipe; jesuita: 90.-534, 535, 543.

Consejo de Estado: 487, 488.

Consejo de Guerra: 485.

Consejo de Indias: $11,22,31,32,39$,
$52.54,56,109,113,114,128,143$, $414,504,-5+3$.

Consulado de México: 149, 167, 25.3.

Contrerillas, jefe indio: 38 .

Conula, sierra: 283.

Conveniencia, cerro de la: 184, 185, 258.

Copala, provincia imaginaria: 8.

Copala, real de minas (Sonora): 92 , $120,165,175,364,416-418,420$. 485,500 .

Copuces, indios: 7.

Corachic, a Coraichic, misión (N. Viz) : 20, 423.

Coras, indios: 18.

Corazones, pueblo (Sonora): 67.

Corbalán, Cristóbal: 302, 303.

Corbalán, Pedro; intendente de Sonora: $151,184,185,206,207,224,250$. $253,255-257,264,265,279,280$, $299,302,309,321,324,325,330$, $333,352,359,361,363-366,388$, $389,392-394,396,424,430,435$, $436,441,508,511$.

Cordero, José María; capitán del Prín. cipe: 450, 459, 465, 493.

Cordero y Bustamante Antonio, inspec. tor de presidios: 67; capitán de Janos: $474,513$.

Cordillera, presidio de; vid. Pasaje, $\mathrm{Ma}$ pimi, Gallo, Cerro Gordo, Conchos, San Bartolomé.

Cornelio, placer de oro (Sonora) : 204, 206.

Corodeguachi, vid. Fronteras, presidio. Coromedo, Rey: 520.

Corona, batallón y regimiento de infanteria de la: $131,132,140,188,193$, 196.

Coronado, vid. Vázquez de Coronado.

Coronelli, P.: 522.

Corpus Christi, misión (N. México): 424.

Corpus Christi, paraje (Texas) : 532 .

Corsarios: 73, 74.

Cortés, Francisco; alcalde mayor del Rosario: $51,53,54$.

Cortés, Hernán: 2, 3, 30, 48, 157. 
Cortés, Juan: $545,546$.

Corral de San Agustín, paraje: 190.

Correos: $129,318-321,360,361,376$.

Corrientes o San Lucas, cabo: $520,542$.

Cosala, Real de las Once Mil Virgenes de (Sonora) : 120, 416, 418, 500.

Cosari, cajón del Cerro Prieto: 145, $179,180$.

Cosimac, paraje (Sonora): 238.

Cosninas, indios: $529,530$.

Cossio, Pedro Antonio de: 149, 290.

Cossio y Campa, Enrique de: 49, 52.

Costanzó, Miguel; ingeniero militar: 140, $162,163,265,454 .-541,542$.

Costa del Seno Mexicano, vid. Nuevo Santander.

Cota de Mallia, vid. Camisa de Hierro.

Cotabamba (Perú) : 468.

Courière, Andrés: 382.

Coutures, señor de: 520 .

Coxe, Daniel: 530.

Coyame, o Collame, vid. Ciénaga del Coyame.

Crespo, Benito; obispo de Durango: 89

Crespo, Francisco Antonio; gobernador de Sonora: 239, 240, 259-264, 302, $325,328,329,454 .-540$.

Criados, indios: 214.

Crimea: 216.

Crisanto, jefe indio: $173,181,184,328$.

Croix (N. Santander) : 469.

Croix, Carlos Francisco de; marqués de Croix, virrey de N. España: 92, 132 $134,139,140,142,148,149,151.153$, $155,156,159 \cdot 167,169,171-176,178$. $188,190-207,209,211,216-218,250$, $251,253,256,257,268,275,276$, $278,280$.

Croix, Teodoro de, Caballero de Croix; comandante general de las provincias internas: $243,244,264,268,273$, $275 \cdot 415,417,419 \cdot 420,422 \cdot 425,427$, $428,430,432.436,449,451,452$, $457,459,462,467,468,470.472$, $489,501,512 .-541,543,545,546$.

Cruces, paraje (N. Vizcaya) : 339.

Cruillas, marqués de; virrey de N. Es paña: $97,101,113,114,124,131$, $132,135,136,138,141.143,145$, $146,151,197-199,211 .-532$.

Cruz, paraje de la (N. Vizcaya): 493.

Cuahuchichiles, indios: 21.

Cuarac (N. México) : 25.

Cuartelejo, indios: $25,107 .-530$.

Cuatra Ciénagas, hacienda (Coahuila): $80,232,297,298,346,353,355$, 483.

Cuba: 98, 151, 155, 198, 210, 212.

Cuba, Santiago de: 67.

Cucapas, indios: 267.

Cucurpe, misión (Sonora) : 44, 203, 204, $331,391,419$.

Cucuverachi, sierra: 448.

Cuchanecs, a cuchanticas, indios: 468 , 506.

Cuchanticas vid. cuchanecs.

Cuchilla Parado, misión (N. Viz.) : 111.

Cuéllar, Francisco de: 188.

Cuéllar, Lope de; comandate de la frontera de N. Vizcaya: $133,134,155$, $167,173,176,188 \cdot 191,193 \cdot 196,315$, 343.

Cuencamé, real de minas (N. Vizcaya) : $9,12,14,19,22,31,32,37,92,119$, $306,316,342-344,370,378,409$, $412,441,442,465,500,509 .-545$.

Cuencamé, presidio, vid. Pasaje.

Cuentas Zayas, Agustín de las: 511 .

Cueras, jefe indio: 180, 183, 224.

- Cuerna Verde, jefe indio: 199.-Cuer no Verde, otro jefe indio: $336,373$. 544.--Cuerno Verde, otro jefe indio: 459.

Cuervo y Valdes, Francisco; gobernador de Coahuila y N. México: 50, $54,56$.

Cuesta Mercadillo, Juan de la; alcalde mayor de Nombre de Dios: 51.

Cueva, rancho (N. Viz.) : 283.

Cuevas, Mariano: 6, 14, 95, 134.

Cuevas, Miguel Antonio; cura de Cosalá: 418 .

Culcogendis, indios: 196.

Culiacán, villa de San Miguel de: 2, 8, 
$51,55,74,82,120,127,129,150$, $152,165,175,176,255,303,320$, $325,364,416,418,425,500 .-518$, $520,521,522,528,542$.

Cuitzeo: 4.

Cujanes, indios: 530 .

Cusihuiriáchic, real de minas (N. Viz.) : $20,34,35,38,92,119,175,319$, $320,337,342,343,370,409,414$. $416,423,442,500$.

Custodia de misiones de Sonora: 362 , 424.

Custodias de misiones: $362,397,424$. Cutubantes, indios: 100.

Cuquiarachi, misión (Sonora) : 44, 204, $391 .-535$.

\section{$\mathrm{CH}$}

Chacala, puerto (N. Galicia) : 93.-521.

Chacón, gobernador de N. México: 493, $507,508$.

Chacón, José Camilo; teniente de Janos: 282.

Chacón Medina y Salazar, José; gobernador de N. México: 49, 53.

Chatalotes, indios: 190, 199, 372.

Chalchihuites, real de minas (N. Galicia) : 92.

Chapman, Charles E.: 71, 88, 91, 164.

Chapuis, comerciante francés: 104.

Charay (Sonora) : 177, 255, 393, 418. .

Charcas, minas de: 6, 92, 101, 120.

Charquerias, aguaje: 80.

Chavarria, paraje (N. Viz.) : 339, 449.

Chaves (Portugal): 198.

Chepillo, jefe indio: 180 .

Chetimanchac (Luisiana): 197.

Chevalier, François: 7.

Chiametla, villa y presidio de San Sebas tián de: $3,8,15-17,22,31,32,74$, $120,128,417 .-520$.

Chichimeca, o Gran Chichimeca: 2.

Chichimecas, indios: $4,5,23,65$. 519 .

Chichitames, indios: 38 .

Chihuahua, estado: 29, 91, 115, 119. Chihuahua, villa de San Felipe el Real de: $39,51,74,92,108,110,111-114$, $122 \cdot 124,129,132,134,136,138$, $139,155,160,187 \cdot 196,202 \cdot 204,211$. $215,219,221-224,227-231,233-236$, $238,243,245,248,253,259,262$, $263,268,282,283,286,288,289$, $291,298,300,302,304-323,325,327$, $328,330-335,337-341,343-349,353$, $356,360,366,370,375,378,380$, $386,397,400,403-405,409,414$, $415,424,425,429,434,439,442$. $445,447,449,450,455.458,462$, $465 \cdot 468,476,478 \cdot 480,486,488-512$. $533,541-543$.

Chikasaws, indios: 105 .

Chile: 468.

Chinapa, real de minas (Sonora): 36, $391,419$.

Chinapa, rio: 546.

Chinarras, indios: 29.

Chinguirito: 365 .

Chinipas: 9, 76, 412, 423.

Chiquito, jefe indio: 438.-Chiquito, otro jefe indio: $456,459$.

Chiricahui, sierra: $85,86,226,259$, $389,438,440,445,447,448$ - 534 .

Chiricahuis, indios: 459, 464, 491.

Chiricov, navegante ruso: 536 .

Chizos, indios: $35,38,76$.

Chizos, sierra y paso de los: 221, 223, $300,340,469 .-541$.

Chivato, sierra del: 230 .

Cholomes, indios: $112,214,221,230$.-528.

Cholomes, misión, vid. Santa Cruz de Cholomes.

Chorreras, paraje (N. Viz.) : 339, 354, $355,372,449$.

Chuviscar, paraje (N. Viz.) : 236.

Dajate, jefe indio: 377 .

Dajunné, vid. Alonso, jefe indio.

Daroca, Antonio María; teniente de go bernador de El Paso: 229, 231, 318, 3.35 . 
Dávila Pacheco, gobernador de N. Viz. caya: 22.

Deadoses, indios: 99.

Decorme, Gerard: $15,85,88,90$.

Delalande, Jean: 513 .

Delgado Miranda, Pilar: 164.

Desagüe, río: 94.

Devin, Nicolás: 525.

Deza y Ulloa, Antonio de; gobernador de N. Vizcaya: $49,56$.

Diablo, sierra del: 27, 242.

Diaz, Alonso; capitán de Sinaloa: 9.

Diaz, Domingo; capitán de la $1 .^{\mathrm{a}}$ compañia volante: $196,215,229.231$, $233,283,285,295,307,337,349$, $367,369,454,458,459$.

Díaz, Juan; franciscano: 265, 393.

Diaz del Carpio, José; capitán de Janos: $83,110,112,113$.

- Díaz de Ortega, Felipe; gobernador. intendente de N. Vizcaya: 460, 465, 473, 508.510.

"Dichoso", jabeque: 321 .

Diego, jefe indio: 176.

Díez Benitez, Manuel Romualdo: 435.

Diezmos: 31.

Dolores, Fr. Mariano de los; francisea, no: 99.

Dolores, hacienda (N. Viz.): 139,188 , 189, 192, 353, 354, 369, 374, 375.

Dolores, misión (Sonora) : 43, 391.

Dolores, pueblo (N. Santander) : 95.

Dolores, presidio de Nra. Sra. de los de los Texas: $42,70,71,73,98$ 528.

Dolores, río: 544 .

Dolores de Mapula, vid. Mapula.

Dolores del Sur, vid. Nra. Sra. de los Dolores, misión.

Domínguez, Fr. Francisco Antonio; tranciscano: 267, 281.-543, 545, $546,547$.

Dominicos, misioneros: 421, 431.

Dongo, Joaquín: 432.

Dortolant, Bernardo: 495.

Douchet, Francisco; inspector de caba. lleria de N. España: 136, 192.
Drace, vid. Drake.

"Dragón", navío: 277.

Dragones, piquetes en Sonora: 146, 149, $150,152,167,170,179,185,229$, $237,239,308,330,332,389,390$, $395,435,436,448$; en N. Vizcaya: $220,222,228.230,233,234,293$, $307,332,337,347$.

Dragones provinciales de la milicia de N. Vizcaya: $354-356,369,370,380$, 480.

Drake, sir Francis: 520, 536.

Dublin (Irlanda) : 212.

Dulce Nombre de Jesús Escandón, escuadra de (N. Santander): 126.

Dunne, Peter Masten: 10, 14, 46, 88.

Duparquet, Carlos; ingeniero militar: 293. -541 .

Durango: $8,9,10,12,13,18,20,23$, $33,37,56,60,61,64,65,70,73$, $75,82,92-94,113,114,119,122$, $124,127,129,132,136,138,149$, $155,160,167,188-191,193-195,203$, $204,209,222,228,229,254,268$, $282,283,288,289,292-294,306$, $313,315 \cdot 319,324,328,337,341$. $344,347,364,370,376,377,408$, $409,414,416,424,444,450,464$. $466,468,480,490,496,497,499$, $500,501,506,508,509-511,-519$, 520. $522,541,546,547$.

Durango, Cuerpo de Dragones de: 317 , 318.

Durham: 3, 10.

Dure, Francisco: 403.

\section{E}

Eagle Pass: 41.

Eca, teniente de San Sabá: 101.

Ecay Muzquiz, José de; capitán de Río Grande: 80.

Echegaray, gobernador de N. León: 231 .

Echegaray, Francisco de; gobernador electo de Sonora: 264.

Echegaray, José María; capitán: 470. 
Echegaray, Manuel de; capitán de Terrenate: 445, 448, 507.

Echéverz y Subiza, Ignacio de: 49.

Echéverz y Subiza, Pedro Fermín: 50-54.

Echeveste, Juan; tesorero de la expedi. ción de Sonora: 161, 251.

Egmont, conde de: 431.

Egurrola, Tomás; teniente de Tucson: $215,223,231,368,438,439$.

Elexalde Arizmendi, Andrés Buenaven. tura; cura de Chihuahua: 414.

Elguezábal, Juan Bautista; capitán: 449.

Elizondo, Domingo; coronel del regimiento de dragones de España: 148, $149,151 \cdot 154,165,166,171 \cdot 173,176$, $178-185,189,192,202,204 \cdot 206,250$. 539,540 .

El Oro, mineral, vid. Real del Oro.

E! Oso, paraje (Coahuila) : 222.

El Pardo (España): 135, 259, 275.

E! Paso, misión de Nra. Sra. de Guada. lupe de: 13, 20, 26.

El Paso, pueblo y presidio (N. México) : $25 \cdot 29,36,61,64,71,74 \cdot 76,90,106$, $107,109-113,125,128,129,132$, $136-138,189,190,194,197,218$, $219,229,231,234,237,239,241$, $242,249,291,299,305,308,314$, $318,335,337,338,341,368,370$, $372,409,420,424,425,459,461$, $480,492,493,503,-525,529,530$, $531,538,544$.

El Pópulo, misión (Sonora): 85, 86, $121 .-533$.

E) 2uijote: 7 .

El Zape (N. Vizcaya): 413

Ellis, Florence Hawley: 107.

Embudo, sierra del: 448 .

Emparán, Miguel de; gobernador interino de Coahuila: 476, 481, 482 , $493,513$.

Encaguané, jefe indio: 492.

Encantime, jefe indio: 458.

Encinal (N. México): 107.

Encinillas, hacienda y obraje de San Juan Bautista de (N. Vizcaya): 27, 139 . $195,234,355,367,458,509$.
Encinillas, presidio: 6 .

Engelhardt, Zephyrin: 46.

Enmedio, sierra de: 305, 385.

Enramada, vid. Ramada, hacienda.

Enriquez, Martín; virrey de N. España: 5.

Ensenada, marqués de la: 57, 105-107, 113.

Equeracapa, jefe indio: $458,460,465$, $491,492,506$.

Escandón, villa (N. Santander) : 95.

Escandón, Francisco: 444.

Escandón, José de; conde de Sierra Gorda: 47, 94-96, 142, 197.

Escanjaques, indios: $24, \ldots-521$.

Escondida, sierra: $237,445,447$.

Escondida, paraje de la (N. Viz.) : 224.

Escondido, río: 81, 222, 270.

Escondida, rio: 519.

Escobar, P., jesuita : 89.

Escorza, Juan Bautista de; capitán del Pasaje: 32, 37, 38.

Escorza, Manuel Antonio de; comisario de la expedición de N. Viz.: 215,415 , 416.

Escuadras de Nuevo Santander: 96, 198.

Escudero, Francisco Martín: 415, 416.

Escuinapa (Sonora): 417.

España: 4, 8, 11, 34, 40, 42, 70, 74, $93,106,134,136,140,141,144$, $146,147,148,151,160,161,188$, $191,203,208,211,217,225,257$, $272,277,296,319,323,324,405$, $427,436,443,466,474,476,484$, $485,490,501,505,506 .-532,536$.

España, regimiento de dragones de: 140 , $148,151,191,229,239,389,436$, $448,464,465,472,473,476$.

Esparza, Antonio Casimiro de; capitán de la 3. a compañía volante: 237,241 .

Espejo, Antonio: 13.

Espia, cerrito del (N. México): 386.

Espinosa, Juan Manuel: 28.

Espiritu Santo, bahía y misión del: 40, $42,67,70,275,295,318,422,423$, $513,-519,522,526,530$.

Espiritu Santo, presidio, vid. Bahía. 
Espuelas, sierra: 535 .

Esquilache, marqués de: 135, 140.

Esquivel, Francisco; alférez de Santa Fe: 248.

Estados Unidos de América: 99, 311, $429,494,495,513$.

Estancia del Río Florido (N. Viz.) : 338.

Estanzuela, hacienda (N. Viz.): 412.

Estrada, Andrés de; corregidor de Zácatecas: 56.

Estrada, Bartolomé de; gobernador de N. Vizcaya: $49,56$.

Eudeves, indios: 44, 179, 255.

Europa: 56, 60, 74, 93, 127, 129, 410, $461,479 .-527$.

Ewers, John C.: 30.

Exploradores, vid. Auxiliares.

Extremadura (España) : 74.

Ezquerra, capitán miliciano: 83.

\section{$\mathrm{P}$}

Pabián y Fuero, Francisco; obispo de Puebla: 160, 166.

Faini, José de; gobernador de N. Vizca уа: $189 \cdot 193,203,204,212 \cdot 215,227$, 228, 230, 231, 268.

Fajes, Pedro de; capitán de fusileros: $297,306,330,331,361,394,395$, $398,432,433$.

Palcón, capitán hacendero: 27.

Faraones, indios: 107, 493.--528, 529, 530.

Faveau y Quesada, Antonio: 543.

Pebre, comerciante francés: 104.

Feliciano Velázquez, Primo: 7.

Felipe V., rey de España: 145.

Feliz, Ildefonso; cura de Baroyeca: 177.

Fet, Nicolás de: $524,527$.

Fernández, Carlos: 247.

Fernández, Diego: 164.

Pernández, Vicente; alférez de Horcasitas: 282.

Fernández de Cea, Gregorio: 415, 416.

Fernández de Córdoba, Francisco: 443.

Fernández de la Fuente, Juan; capitár de Casas Grandes y Janos: 27, 32, 35.

Fernández de Medrano, Sebastián: 523.

Pernández de Retana, Juan; capitán de Conchos: $32,35,38$.

Fernández de Santa Ana, Fr. Benito; franciscano: 100.

Fernández Vallejo, Antonio: 50.

Fernanda V1, rey de España: 536.

Fersen, Francisco; ingeniero militar: 140 , 171.

Feuilli, comerciante francés: 104.

Filadelfia (USA) : 495.

Filipinas: $67,87,88,140,156,163$, $277 .-527,533$.

Flandes: 53, 74.

Flandes, regimiento de caballería de: 431.

Flon, Manuel de; gobernador interino de N. Vizcaya: 466, 506.

Flores, real de minas de las (Sonora): 500.

Flores, Atonio de; virrey de N. España: $429,460.467,469.474,476,477,481$, $484,485,492,504,506$.

Flores Mogollón, Juan Ignacio: 49.

Florida: $34,40,134,293.519,521$, $522,524,525,532$.

Florida, sierra: $145,252,337$.

Florida francesa: 522.

Floridablanca, conde de: 360,361 .

Florido, río: 8, 17, 28, 29, 74, 75, 191, $230,337,447 .-539$.

Folmer, Henry: 34.

Fondo Piadoso de California: 45, 162, 163.

Font, Fr. Pedro; franciscano: 329.-540, 541 .

Forbes, Jack D.: 28, 30.

Fort Pitt (USA) : 495.

Forrestal, Peter P.: 15.

Frago, Antonio del: 405.

Fragoso, Francisco Javier: 507.

Frailes, real de minas (Sonora) : 32, 39.

Pranceses: $34,40.43,66,91,93,96.98$, $102.106,135,270,296,383,479$, $490,-522-525,531,532,536$. 
Francia: 42, 97, 192, 490, 501-525.

Francisco, jefe indio: 181.

Franciscanos, misioneros: 8, 9, 11-15, $20,26,27,34,40,41,44,70,95,98$, $101,103,115,134,152,208,394$, $397,402,421,431,432 .-538$.

Fresnillo, real de minas (N. Gal.) : 5 , 91, 92.

Frias, José Francisco de; cura de Parral: 413.

Frio, río: 383 .

Fronteras, presidio de Santa Rosa del Corodeguachi o de (Sonora) : 44, 69, $71,76,82-85,87,90,112,125,129$, $137-139,145,150,170,204,218$, 224, 226, 238; en San Bernardino: $240,259.262,320,327,331,332$, 387; en Corodeguachi, segunda vez: $387,389-391,393,419,434-440,442$, $444,445,448,480,491.529,534$, $535,537$.

Fuca, estrecho de Juan de: 536.

Fuenclara, conde de; virrey de N. Espaกีล : $84,89,90,109,145$.

I. Uensaldaña, Jacinto de, capitán de Fronteras: 44, 56; alcalde de Sinaloa: $51,56$.

Fuente, Pedro Francisco de la; capitán de E1 Paso: 197.

Fuerte, río: 9, 13, 15, 129, 174, 177, 255.

Fuerte, villa del (Sonora): 83, 121, 128, $175,416-418$.

Pusileros catalanes, compañía de voluntarios: $151,152,155,170,179,204$, $232,292,293,297,299,306,308$, $330,331,389,390,436,439,448$, 480 .

Fusileros de montañas, compañías de infanteria: $148,149,152,155,170$, $179,183,185,251,492$.

\section{G}

Gach, Esteban: 393, 434.

Galicia (España) : 39.
Galindo Navarro, Andrés; capitán del Principe: 318.

Galindo Navarro, Pedro; asesor letrado de la comandancia general: 257, 281, $302,303,307,309,313,322,341$, $364,365,394,396,436,442,460$.

Galisteo (N. México): 107, 244, 248, $249,333,334,424$.

Galván, Juan; capitán de San Javier: 100.

Galve, conde de; virrey de N. España: $36,38,39,58,59,70$.

Gálvez, Bernardo de; conde de Gálvez, comandante de la frontera y virrey de N. España: 143, 173, 188, 189 , $191-197,201,202,209,211,212$ $214,215,218,292,293,295,298$, $310-312,315 ; 337,343,347,376$ $425,446,447,450-455,457,461$, $463,464,468,473,478,481$

Gálvez, José de; visitador general de N. Españ?, marqués de Sonora: 58, $90-93,114,115,123,124,131,133$, $135,136,143 \cdot 170,172 \cdot 180,184 \cdot 192$, $195,196,200-208,210 \cdot 212,216 \cdot 218$, 220: ministro de Indias: $240 \cdot 243,249$, $250,253,257,261.265,267,268$, $272,273,275,277,280-283,285$, $287-295,297-333,335-341,343-345$, $347 \cdot 349,351,352,359 \cdot 386,388 \cdot 400$, $402,404 \cdot 406,409 \cdot 415,419,424,425$, $427,430,432 \cdot 452,455 \cdot 460,468,485$. $487,505,506,508.510,513 .-536$, $541,543$.

Gálvez, Matías de; virrey de N. Espaกีa: $143,429,446,451,452,469$.

Gallego, José Ignacio: 10, 70 .

Gallo, presidio de San Pedro del: $31 \cdot 33$, $36,39,40,43,60,61,65,71,75$, $76,128,132,136-138$; pueblo y des. tacamento: 230, 286, 288, 294, 316, $319,320,339,342,343,370,409$, 413.

Gallo, Miguel; capitán del regimiento de dragones de México: 151

Garabito. Diego; sargento mayor de Guadalajara: 231. 
Gárate, Roque de; capitán de Horcasitas: 282.

Garay, José: 455.

Garay, Martín de; gobernador de Col. huila y Texas: 42.

Garcés, Francisco; franciscano: 208, 250, $264,265,267,329,332,387,393$, 395.-540.

Garcia, Andrés; franciscano: 336.

Garcia, Dionisio: 416.

Garcia, Francisco: 50.

Garcia, Francisco Ireneo: 338.

Garcia, Genaro: 17.

Garcia, Rubén: 197.

Garcia Conde, Alejo; intendente de Sonora, comandante general de provin. cias internas: $489,512$.

Garcia Mayoral, Pedro: 201.

Garcia Menocal, Francisco; capitán de 1a 4. ${ }^{a}$ compañía volante: 212,344 .

Garcia de Pruneda, Luis: 50.

García Rebollo, Ignacio; teniente: 288 , $307,316,369$.

Gardoqui, Diego de; ministro de $\mathrm{Ha}$ cienda: $487.489,497,499 \cdot 502$.

Garibay, José; comandante de milicias de Mazatlán: 486, 490.

Garibay, Pedro: 311.

Garza, Juan de la; gobernador de $\mathrm{N}$. León: 23.

Garza Falcón, Alejo de la; teniente de San Sabá: 222.

Garza Falcón, Blas de la; gobernador de Coahuila: 80.

Garza Falcón, Miguel de la; capitán de Sacramento: 80.

Garrido y Durán, Pedro; intendente interino de Sonora: $485,511$.

Gastezi, Alonso de: 113.

Gavilanes, indios: $76 .-540$.

Gavilanes, real de minas (N. Viz.) : 500.

Gemes o Gemez, vid. Jemez (N. Mé, xico).

Gente de palo, indios: 307.

Gibraltar: 443.

Gibson, Charles S.: 7.

Gigedo, villa de (Coahuila): 408, 423.
Gil, Francisco: 149.

Gil, Nicolás; capitán de San Buenaventura: 194, 238, 307, 337.

Gila, provincia de: $138 .-542$.

Gila, río: $24,29,43 \cdot 44,77,87 \cdot 91,123$, $138,155,158,159,167,173,176$, $188,189,205,208,239,252,260$, $265-267,304,334,338,346,384$, $385,387,389,391,394,395,435$, $437.440,444,448,450,456,463$, $465 .-529,530,533,534,540,541$, $542,546$.

Gilas, indios vid. Gileños.

Gil de Bernabé, Juan Crisóstomo; franciscano: 225, 226, 257.

Gileños, indios: 76, 111, 112, 190, 197, $199,227,237, .239,245,248,249$, $259,299,300,304,327,336,338$. $341,372-374,384,438,445,456$. $459,464,465,491,493,505,-529$, $542,546$.

Gil Munilla, Roberto: 34.-522-524.

Gil de Samaniego, Manuel: 206.

Gil de Tejada, Pedro: 50.

Gimulco, hacienda (N. Viz.): 30.

Giraldo de Terreros, Fr. Alonso; franciscano: 100.

Giraud, Marcel: 105.

Gironza y Petriz de Cruzat, Domingo de; gobernador de N. México: 26, 36, $39,44$.

Glendale (USA): 34.

Godoy, Manuel; duque de la Alcudia y Principe de la Paz: 167, 487, 504.

Golfo de California: $45,90,133,147$, $164,165,168,169,200,224,275$, $333,486$.

Golfo de México: 6, 30, 40, 93, 94, 96, $97,224,346,469,486 .-522,524$, $525,526,529,530$.

Gómez, Lino Nepomuceno: 96.

Gómez de Silva, José; capitán de Fronteras: 83,84 .

Gómez de la Torre, Manuel; capitán de San Buenaventura: 132.

González, José Ireneo: 73.

González, Manuel Antonio: 415. 
González Calderón, Juan: 54.

González Flores, Enrique: 213.

González Santiáñez, Vicente; gobernador de N. Santander: 272, 376.

González del Tánago, Francisco Anto. nio: 412.

González Toro, obispo de Málaga: 143.

Gortari, Juan Martín de: 393.

Gorráez y Beaumont, Francisco; gobernador de N. Vizcaya: 22, 23.

Gorrástegui, Francisco de; alcalde mayor de Sonora: 51.

Goyeneche, Juan de: 54.

Granada, regimiento de infantería de: 259.

Grande o Bravo del Norte, río: 11, 13, $17,19 \cdot 21,23,24,26,29,34,37 \cdot 39$, $41,72,78.81,95,96,100,103,106$, $107,138,139,190,197,209,214$, $215,217,221-223,232-236,239,240$, $269.271,291,294,295,300,306$, $345,349,357,358,374,382,385$, $423,469,471,-522,524.526,528$. $532,538,542,547$.

Grande de Navajos, río, vid. Colorado. Grandes Lagos: 104.

Gran Sot, jefe indio: 383 .

Gregori, José; teniente: 288, 316.

Grimaldi, marqués de: 143, 162, 277 , 290.

Grimarest, Enrique; intendente de So, nora: $485,486,511,512$.

Grullas, sierra: 544 .

Guachinango, real de minas: 92.

Guachinera (Sonora) : 299.

Guadala jara: 2, 3, 5, 8, 22, 52, 56, 61, $64,67,73,89,91.94,114,115,127$. $129,147,159,160,162,167,168$, $175,229,253,254,278,293,309$, $313,314,364,365,443,474,486$, 496, 497.- 520 .

Guadalcázar, real de minas: 6, 17, 94.

Guadalupe (N. España): 484.

Guadalupe, pueblo de la Junta (N. Viz. caya): 221 .
Guadalupe, río: $94,96,99,100,383$, $479,483$.

Guadalupe, río: 397.

Guadalupe, sierra: 242, 346, 375 .

Guadalupe de El Paso, vid. El Paso.

Guadalupe Guasinapi, misión (Calif): 45.

Guadiana, villa, vid. Durango.

Guaicurúes, indios: 87.

Guajardo Fajardo, Diego; gobernador de N. Vizcaya: 20, 22.

Guajoquilla, hacienda (N. Vizcaya): $214,307$.

Guajoquilla, compañía volante y presidio de Santa María de las Caldas de (N. Viz.) : $108,111.113,125,136$. $138,214,218,227,231,234,271$, $316,339,342,354,373,490,492$, $493,-537,539$.

Vid. San Eleazario.

Guamares, indios: 7.

Guanacevi, misión; presidio y real minas (N. Viz.) : $14,16,31,119,342,370$, $375,409,413,415,500 .-540$.

Guanachic, misión (N. Viz.) : 423 .

Guanajuato: $3-6,56,64,151,153,154$, $161,168,191,192,199,309,496$, 497.

Guarico: 481.

Guarisamey, misión y real de minas: 14 , $500,509$.

Guarisamey, río: 14.

Guaristemba (N. Gal.) : 152.

Guasapoliglas, indios: 38 .

Guatemala: 74, 93, 359, 473.-521.

Guatepito, sierra de: 263.

Guayalejo o Tamesí, río: 95.

Guaymas, misión de San José de la Laguna de (Sonora): 45, 87.

Guaymas, puerto (Sonora) : 85, 133, $152,153,157,161,163,165,166$, $170.172,176,177,181,182,184$. $185,200,207,208,251,327,329$, $397,512$.

Guaymas, indios: 255.

Guazamota, misión y presidio: 12,16 , 510. 
Guazamota, sierra: 16.

Guazapares, misión (N. Viz.): 423.

Guazas, indios: $226,296,345,-530$.

Guebavi, misión (Sonora) : 87, 89, 166.

Guebavi, presidio, vid. Terrenate.

Guebavi, río: $36,128$.

Güemes (N. Santander) : 95, 483.

Guepaca (Sonora): 319.

Guepaverachi (Sonora): 419.

Guerrero de Ardila: 95.

Guiatanori, jefe indio: 183.

Guillelmi, Juan; capitán general de Ca. racas: 478 .

Guillén, Fr. Felipe; franciscano: 331.

Guizarnotegui, Francisco: $326,404,434$, 475.

Gurivis (Sonona) : 208.

Gurza, Jaime; cirujano: 503.

Gutiérrez, Jacinto; teniente del Príncipe: 215,282 .

Gutiérrez, Camarena, Marcial: 164.

Gutiérrez de la Cueva, Juan; goberna. dor interino de California y Coahuila: $169,288,316,375,449,470,475$, 476, 482, 513.

Guzmán, Diego de: 3.

Guzmán, Nuño Beltrán de: 2, 3, 8, 9, 17.

Guzmán Emanuel, Tomás de; corregidor de Chihuahua: 51.

\section{$\mathrm{H}$}

Habana, La: 67, 76, 149, 151, 155, $188,198,209,312,405,468,478$, 495, 507.

Habas, rancho de las (N. Viz.): 376 . Hackett, Charles Wilson: 16, 28.

Hacha, sierra del: 234, 237, 440.

Haines, Francis: 30.

Hallenbeck, Cleve: 28.

Hammond, George P.: 11, 15.

Harpe, La; explorador francés: 41, 105. $-524,530$.

Heredia, José G.: 3. Hernández, Carlos: 70, 412, 413
Hernández, Antonio, alias "El Mordu-

1lo", bandolero: 442 .

Hernández Hidalgo, Manuel; cura de

San Juan del Río: 414.

Hernández Sánchez-Barba, Mario: 180, 384.

Heros, José de: 454.

Herrera, oidor: 4.

Herrera, Andrés de;contador de la Real Caja de México: 61.

Herrera, Antonio de: 520.

Herrera, José de; alcalde mayor de Nom. bre de Dios: 51.

Herrera, Juan de, capitán de Monclo. va: 374 .

Herrera y Rivero, Vicente, regente de México: 454, 455 .

Herrero, Antonio de: 49, 52.

Heuchin, marquesado de: 276.

Heyder, barón de, vid. Proudhom.

Hibernia, regimiento de infantería de: 198.

Hidalgo, Fr. Francisco, franciscano: 41. Higuera, cajón del Cerro Prieto: 182. Hijosa, Francisco, tesorero de la expe dición de Sonora: 151.

Hill, Lawrence Francis: 85, 96.

Hinas, indios: 14.

Hipólitos, indios: 272.

Hobaomas, indios: 89.

Hoghenberg: 521.

Holandeses: 44, 90, - 526 .

Honduras: 530.

Hontn, barón de la: 523.

Hopi, provincia e indios. vid. Moqui, moquinos.

Horcasitas, presidio de San Miguel de (Sonora): 84, 86, 87, 121, 125, 136, $137,142,145,146,148,151,166$, $170,185,202,219,225,240,254$, $256,258,259,262,263,265,266$, $279,282.284,293,306,319,320$, $325.329,331,332,387,388$; en Pitic: $388,394,448,451,465-536$, 537.

Horcasitas, pueblo (Sonora): 85, 419 , 500. 
Horcasitas, villa (N. Santander): 95

Hornos, hacienda de (N. Viz.) : 319 , $369,411$.

Hormazas, marqués de las: 497.

Hormigas, hacienda (N. Viz) : 111, 139 , $221,224,354,355$.

Hoyos, pueblo (N. Santander): 95.

Hoz, Juan José de la: 281.

Huachichiles, indios: 5.7 .

Huango, 4.

Huatulco: 521.

Huaxteca: 6, 7, 71, 94, 280.-531.

Huehuetoca, desagüe de (N. España): 475.

Hueijuriguchi, jefe indio: 182, 183.

Huertas (N. México) : 248 ,

Hueyotlipan (N. España): 160.

Hugalde Martín de, capitán de Cerro Gordo: 32,38 .

Hughes, Anne E.: 28.

Hugues de San Martín, Manuel, sar, gento mayor de las milicias de Sonora: 82 .

Huidobro, vid. Bernal de Huidobro.

Humas, río: 14.

Humis, indios: 14.

Hurdaide, Diego Martínez de, capitán de Sinaloa: 9.

\section{1}

Tbarra, Francisco de: $8110,17,47,48$, 129.

Tbarra Tomás de, capitán de Mazatlán: 485.

Iberville: 524 .

Idiáquez, Agustín de, jefe de flota: 144. Idoyaga, José de, capitán de San Bar. tolomé: 83, 109.

Iguala (N. España): 151.

Iguana (N. León) : 271, 376.

Iguiniz, Juan B.: 478.

Illinois: 522 .

Imuris, misión (Sonora): 43, 387.

Indé, real de minas (N. Viz) : 9, 19, 31, $92,118,288,316,370,415,442$, $500,-519,540$.
Inglaterra: $106,134,135,220,392$ 382.

Ingleses: 40, 44, 91, 93, 105, 151, 158, $197,199,220,225,226,270,296$, $381,432,502,512 .-521,530$.

Inselin: 527 .

Intendencias en provincias internas: $157,175,313,481,508 \cdot 513 .-546$. Intendente de Ejército: 147.-543.

Intendentes, vid. Corbalán, Grimarest, Cuentas Zayas, Díaz de Ortega.

Iribarren, José Antonio de: 403, 434.

Irigoyen, hacienda y mina de $(\mathrm{N}$. Viz) : 236.

Irisac, jefe indio: 494, 495.

Irritilas, indios: 9.

1sabela, isla: 164 .

Iscanis, indios: $102,199,226,272,296$, $382,384$.

Islas, Santiago, alférez de Altar: 282, 394.

Islas Negras (Luisiana): 491.

1sle, Guillermo de 1": 524, 535 .

Isleta (N. México) : 11, 248, 333, 424. Italia: $53,276,280,451$.

\section{J}

Jabonera, hacienda de la (N. Viz) : 194. Jaén (España) : 430.

Jalapa: $140,144,147,148,149$.

Jalchedunes, indios: $395,406$.

Jalisco: $2,3,128$.

Jalisco, provincia franciscana observan. te de: $423,424$.

Jalpa, presidio: 6,519 .

Jamaica, 481.

lamajabes, indios: 540 .

Janambres, indios: 95, 272.

Janeros, sierra de los: 391 .

Janos, indios: $12,27,29,30$.

Janos, misión, vid. Soledad de Janos.

Janos, presidio de San Felipe y Santiago de (N. Viz.) : $33,35,36,39,44$, $61,64,71,75,76,82,83,90,109$. $112,129,132,137,138,189,190$. $192,195,218,226 \cdot 228,234,236$, 
$237,239.242,259,282,298,299$, $305,314,320,331,337-340,353$, $354,358,367,368,374,385,388$, $391,434,435,437,439,447,449$, $450,456,458,459,465,480,491$ $527,528,537,540,541$.

Janos, río de: 234 .

Jara, hacienda de la (Coahuila): 48.3. Jarales (N. México) : 336.

Jaranames, indios: 225, 295, 296, 349. Jasó: 5.

Jáuregui, José de, gobernador de Nue. vo León: 531.

Javier, jefe indio: 223.

Javierillo, jefe indio: $340,348,349$.

Jémez (N. México) : 245, 247, 248, 424. Jenizaros, indios cautivos de N. México: $118,385,406,420$.

Jerez de la Frontera (España): 92.

Jerez de la Frontera (N. España) : 519.

Jesuitas, misioneros: $8,9,12,15,18$, $20,34,35,45,82,86,88,89,112$, $115,133,134,150,152,154,156$, $158,161,167,175,187,208,277$, $280,392,411,421,431,468$.

Jesús de Tutuaca, vid. Tutuaca.

Jicarilla, paraje (N. México) : 104, 107. Jicarillas, indios: 106, 197, 336, 406, $464,465,491$. -530 .

Jijimes, indios: $8,9,14,16,32$.

Jilotepec: 7 :

Jiménez, P. franciscano: 11.

Jocoistita, real de minas (Sonora) : 500.

Tócomes, indios: 29, 30.

Jofre: 5 .

Jora, minas de: 412.

Jornada del Muerto: 128, 239, 386.

José, apache: 197.

José Antonio, jefe indio: 184. José An' tonio, otro jefe indio: 505.

Juan Antonio, jefe indio: 184.

Juan "el Cocinero", jefe indio: 329.

Juangorena, José: 455.

Juanico, jefe indio: 231.

Juan Tuerto, jefe indio: 222.-Juan

Tuerto, otro jefe indio: $341,373,375$.
Juárez, capitán: 16.

jucherau de Saint Denis, vid. Saint De-

juchipila, monte: 520 .

Julimeños, vid. Julimes, indios.

Julimes, indios: 19, 21, 27, 221, 341, 358.

Julimes, presidio de (N. Vizcaya) : 132 , $13 \%, 194,195,214,218,221,231$, $233,339,358$.

Julimes, misión de San Antonio de (N. Viz) : $27,110,132,322,355$, $424,445,480,492$.

Jumanos, indios: $24,26,29,40,41$, 104, 199, 308, 374, 507.-546. Vid. Taobayas.

lunta de generales, en Madrid: 217, $220,487$.

Junta de Guerra de Indias, Real Con. sejo y: 59.

Junta de guerra en Monclova y Béjar: 295.297, 304; en Chihuahua: 298, $307-309,330,334,339,343$; en Ariz. pe, 394, 396, 436 .

Junta de hacienda y guerra, en México: $31,32,95,97,100,110,111,112$, $113,124,126,132,143,144,146$. $149,151,153,156,160,161,192$, $201,211,213,214,216,220,232$, $233,248,249,265,323,454,455$.

Junta de los ríos Grande y Conchos, misiones de la: 26, 27, 29, 38, 74, $78,79,81,108,109,111,341,346$. $-529,535$.

Junta de los Ríos, presidio de Ntra. Sra. de Belén y Santiago de Amarillas de la (N. Viz.) : 109, 113, 122 , $125,132,136,138,218,221,224$, $231-233,235,337 .-533,542$. Vid. Julimes, presidio.

Junta del río de Pitic: 85 .

Junta del Yaqui: 85.

Juntas, real de minas de las (Sonora): 500.

Jupata, Llanos de (N. Vizcaya): 138. Jupo, real de minas (Sonora): 121. Justiniani, Justino: 54. 
Juzgado de bienes de difuntos y de tie. rras: $313-314$.

\section{K}

Kanoatinos, indios: 532.

Kansas, indios: 104.

Kanrankawas, indios: 96.

Keller, P. Ignacio, jesuita: 88, 89.

Kelley, Charles J.: 38, 109.

Kerlerec, gobernador francés de Luisinna: 97.

Kino, P. Eusebio Francisco, jesuita: 43. $45,88,208 .-527,530,535$.

Kolima, río: 90.

\section{L}

Labores, isla de: 97.

Labaquera, Pedro, teniente de capitár. general de N. Galicia: 91.

La Cañada (N. México) : 118, 246. Vid. Santa Cruz de la Cañada.

Ladrones, sierra: 249.

Lafora, Nicolás de, ingeniero militar: $136 \cdot 140,197,216,218,219 .-541$, $542,544$.

Lagos, vid. San Juan de los Lagos.

La Guaira (Venezuela) : 478.

La Guardia (España) : 431.

Laguna, La (N. México): 247, 243, $334,420,424$.

Laguna, La (N. Viz) : 9, 13, 14, 27, $28,30,294 \ldots 535,542,545$.

Laguna de Castillo (N. Viz.) : 194, 227.

Laguneros, indios: 14.

Lampazos, presidio de la Punta de (N. León) : 271, 469, 491.

Lampazos, vid. Ntra. Sra. de los Dolores, misión.

Lanterio: 431.

La Paz, misión del Pilar de (Califor. nia) : $45,87$.

La Punta, hacienda de: 545.

Laredo (N. Sant): 271. 469, 483.

Larrea, Juan de: 54.

Larrea, Juan Bautista de; gobernador de N. Vizcaya: 49, 51, 53, 59.

La Salle, vid. Salle.

"Lauretana", paquebot: 152, 153, 168, 177.

Lazaga, Diego; gobernador de N. Santander: 376,454 .

Lázaga, Juan Lucas de: $371,372,376$, 411.

Leal, Antonio: 494.

"LG Bon", barco: 525.

Leiva, Gregorio: 507.

Leizaola, Juan Bautista de; capitán de Janos: 113, 195.

Lejarz,a, P. Fidel de: 531.

León, regimiento de infantería de: 479 León, villa de: 5, 109.

León, villa de (N. León) : 64.

León, Alonso de; gobernador de Coà. huila: $17,33,34,40,41,-522,523$.

León, Nicolás: 73.

Lera, villa (N. Santander) : 95.

Lerena, conde de: 478.

Lerma, río: 7 .

Ligero, jefe indio: $78,110,138,228$ Ligero, otro jefe indio: 459 .

Lille (Francia): 276.

Lima: $60,67$.

Lima, hacienda (Sonora): 391.

Limón, Cayetano: 289, 326, 394, 432.

Linares, duque de; virrey de N. España: $39,42,59,60,63,69,74$.

Linares, pueblo (N. Santander) : 95.

Linares, villa (N. León): 310, 313, 315, 483.-531.

Lipanes, indios: 196, 221-223, 234-236, $239,269-271,273,286,291,293$, $295,300,303,308,340,345 .-349$, $357,358,373,374,376,377,381$ $384,406,433,463,464,469,473$, $476,478.482,484,491,503$.

Lipiyanes, indios: $346,463,464,469$, 473.

Lira, Manuel Francisco: 54.

Lizardi, Juan Bautista; teniente de Janos: 450.

Lombardia, regimiento de: 280 ,

Lombraña, jefe indio: 482. 
Londres: 7.-530.

Longoria, hacendero de Coahuila: 407.

López, Tomás: 535.

López, Juan: 547.

López Bringas, Pedro: 415, 416.

López de la Cámara Alta, Agustín; in geniero militar: 96.

López Portillo, Manuel: 418.

López-Portillo y Weber, José: 3.

Lorca, marquesado de: 481.

Lorencillo, jefe indio: 38 .

Lorenzana, Antonio; arzobispo de México: $160,166$.

Loreto, cajón del Cerro Prieto: 179.

Loreto, misión (N. Viz.) : 423.

Loreto, pueblo y misión de Nra. Sra. de (California) : 45, 133, 152, 157 , $161,169,170,175,321 .-535$.

Loreto, presidio (California) : 45, 46, $69,71,126,152,157,161,267,396$, 431,432 .

Loreto, presidio de Nra. Sra. de, vid. Bahía.

Loreto y Baroyeca, real minas (Sonora): 151.

Loro, sierra del: 182.

Losada: 210, 212, 253, 255, 261, $28 \mathrm{l}$.

Losada, Francisco: 404.

Los Angeles, pueblo de Nra. Sra. de los (California) : 6, 10, 44, 46, 52, 398, 432.

Los Angeles, misión (Sonora) : 85, 121. 533.

Los Angeles, real de minas (N. Gal1cia) : 92.

Lucero, Juan: 507.

Luises, los dos; jefes indios: 86.

Luisiana: 41, 42, 73, 93, 94, 96, 97, $105,106,192,197,199,202,220$, $225,226,269,292,296,311,312$. $345,347,381,384,453,490,494$. $495,-522,524,525,528,532,547$ 。 548.

Lumbreras, Juan; teniente de Buenavista: 185

Luquillas, jefe indio: 37 .
Luz, Virgen de la: 538.

Lynch, Cyprian J.: 15.

\section{LL}

Llaguno, Eugenio: 502, 504, 510, 512. Llano Colorado (Sonora): 145, 319.

Llano de la Paz, paraje (N. Viz.): 111.

Llanos, sierra de: 491.

Llerena, villa de (N. Galicia) : 122.

\section{M}

Maas, Otto: 266, 267.

Macarulla Minguilla, Antonio; obispo de Durango: 408, 409.

Macias, Pedro; teniente: 215.

Macharaviaya (Málaga, España): 143.

Madrid: 3, 11, 31, 54, 67, 83, 92, 113, $114,127,159,172,180,189,192$, $193,197,200,210,211,216,217$. $220,240,241,250,252,276,356$, $361,365,384,393,397,409,443$, $487,504 .-520$.

Maestro y Cuevas, José; cura de Rosario: 417.

Magdalena, río: 43 .

Magdalena, sierra: 249.

Magdalena de los Tepocas, misión (Sonora) : 43, 263.

Magistral, hacienda (N. Vizcaya) : 229

Maguaos, presidio: 6.

Mahón (España) : 443.

Maicoba (Sonora): 319.

Maigret, ingeniero: 217.

Maimara, jefe indio: 39.

Maitorena, comerciante: 206, 326.

Majalca, hacienda (N. Viz.): 354,355 , 367.

Málaga (España) : 74, 443.

Malanoche, paraje (N. Viz.): 354.

Malaoreja, jefe indio: 194.

Malincheros, indios: 529.

Maloya, provincia (Sonora) : 175, 364 , 416, 417, 420.

Malpais, San Francisco de (N. Vizca. ya) : 410,510 . 
Malpais del Cerro Prieto: 180.-Malpais de la Nochebuena: 436.

Malpica, rancho (Sonora) : 418.

Malla, jefe indio: 235.

Mallet, comerciantes franceses: 104.

Miamites, indios: 19.

Manila: 44, 71, 91, 93, 152, 277.

Manos de perro, indios: 345 .

Mansos, indios: 27, 29, 30.

Mapimí, misión y real de minas $(\mathrm{N}$. Vizcaya) : 14, 19, 21, 22, 30, 33, 34, $78,79,92,110,118,132,190,228$, $283,285,288,307,316,319,320$, $33 \%, 339,341.343,369,370,407$, $409,412,413,480,500,509 .-545$.

Mapimi, presidio (N. Viz.) : $39,40,62$, $65,69,71,108-111,132,136-138$, 294.

Mapula, hacienda de Dolores en (N. Viz.) : 139.

Marañón, Domingo; teniente de la 3. compañia volante: 215, 282.

Marata, vid. Nuevo México.

Marcos, jefe indio: $87,173,179,183$, 184, 207.

Marcos, cajón del Cerro Prieto: 145.

Mares, José: 507.

Margry, Pierre: 104, 105.

Marias, islas: 91, 152, 163, 164.

Marín, José Francisco; visitador de los presidios: $38,39,58,59$.

Mariñelarena, Martín: 414-416.

Marismas de Sonora: 172, 179, 180.

Marmolejo, Lucio: 6.

Marqués, puerto del: 483.

Márquez, Diego: 404.

Marquina, vid. Berenguer de Marquina.

Miarquina, Antonio: 523.

Martín, Alejandro: 507.

Martínez, Francisco; capitán de Sain Sabá y de Carrizal: 241, 293, 295 , $300,347-349,368,385,390,439$, $440,450$.

Martinez y Aguirre, Jacinto: 56.

Martinez de Astiz, Juan: 56.

Martínez de Chaves, José: 455.

Martinez de Hurdaide, vid. Hurdaide.
Martínez Pacheco, Rafael; capitán de Orcoquiza y La Bahía: 98, 198, 227, $236,249,270,272,295,298,348$, 379,454 ; gobernador interino de $\mathrm{Te}$ xas: 468, 476, 477, 512, 513.

Martinez Pereira, Francisco: 434.

Martos Navarrete, Angel de; gobernador de Coahuila y de Texas: 97, 101, 102, 198.

Marrufo, Ramón; alférez: 215.

Masanet, P.; franciscano: 41.

Mascaró, Manuel; ingeniero militar : 290 , $322,359,392,393,404,454 .-544$. $546,548$.

Mata Biñolas, Pedro; capitán: 465.

Matachic, misión (N. Viz.): $35,42 \hat{3}$

Matanchel, puerto (N. Galicia): 67 , 91, 144, 145; 150, 151.-521.

Matape, misión (Sonora) : 133, 145, 330, 419.

Matape, río: 18.

Matatán, real de minas (Sonora) : 500.

Matehuala, real de minas (N. Galicia) : 92.

Matias, apache: 197.

Maticolla, presidio: 6 .

Maticorena Estrada, Miguel: 60.

Matte, Nicolás la: 375, 382.

Maxcala, presidio: 5 .

Maxorro, indio: 4.

Mayeyes, indios: 99, 383.

Mayo, río: 9, 13, 251.

Mayorga, Martin de; virrey de N. Es' paña: $359,371,372$.

Mayos, indios: 83, 177, 252, 255.

Mazapil: 5, 7, 9, 17, 92, 129.-547.

Mazatlán, San Juan Bautista de (So. nora): $163-165,185,319,417,485$, 486, 490.

Mazoni, Juan José; visitador de los presidios: 59,60 .

Meade, Joaquín: 7.

Mecham, J. Lloyd: 10.

Medel Pecino, Martín: 96.

Mediavilla Azcona, gobernador de Te' xas: 98.

Medina, río: 101. 
Medina Roque, ayudante inspector: 215 , $234.236,242,315,331,438.440,444$, 448.

Medrano, general ópata: 440.

Miello, Tomás del: 251.

Menchaca, José; teniente de Aguaverde: $468,476$.

Menchaca, paraje (Coahuila): 483.

Mendinueta, Pedro Fermín de; gobernador de N. México: 197, 199, 227, $232,240,244-250,260,266,298$, $307,333-335$.

Miendocino, cabo: 520.

Mendoza, Antonio de; virrey de N. Es. paña: 3 .

Mendoza, Juan Antonio de; gobernador de Sonora: $86,87,141 .-534$.

Miendoza, Mateo Antonio de; goberna. dor de N. Vizcaya: 113, 114, 141.

Mera, H. P.: 30.

Mérida. (Yucatán) : 243.

Merino, secretario: 393.

Mesa del Tonat, o del Sol, presidio, vid. Nayarit.

IViescatitlán, hacienda (Sonora): 391.

Mesia, Francisco: 251, 256.

Mesillas, rancho (Coahuila): 269, 319 . Miesitas, paraje (Sonora) : 242.

México: 2.7, 10, 11, 14-17, 23, 26, 28, $30,36,43,54,56,57,59,61,63,67$, $69,72,73,76,77,79,82-87,91-97$, $100 \cdot 102,105 \cdot 109,112,113,115,123$, $124,127,131 \cdot 137,140 \cdot 144,146 \cdot 154$, $156,158 \cdot 165,167,169,171 \cdot 173,175$, $178,180 \cdot 189,191 \cdot 216,219-223,225$. $232,234-238,240-273,276-278,280$. $284,287.294,299,301,302,309$, $310,312 \cdot 314,322 \cdot 327,329,330,332$, $335,337,345,346,359,360,362$, $366,367,371,376,378,380,391$, $399,402,403,405,406,409,415$, $424,428,429,430,432,436,443$. $446,451-453,454,460 \cdot 466,468,470$. $486,488,489,494,496,497,503$, $504,510,513,-519,520,523,524$, $527,536,545$.
México, regimiento de dragones de: 140 , $148,151,229,239,281,448,454$.

Mezcal, renta del: 365, 366, 370, 393, 460.

Mezcaleros, indios: $76,111,232,235$, $236,271,293,295,300,340,341$, $346-349,357,358,372-377,380$, $433,459,461,463.465,467.469$, $476,483,491,493 .-529$.

Mézières, Atanasio de; capitán de Na.t. chitoches: 102, 199, 225, 270, 295, $296,308,311,346.348,381$.

Mezquital, real de minas (N. Viz.) : 93, 316, 344.

Mezquital, río: 8 .

Mezquital, sierra: 16 .

Michilimakinac, factoría francesa: 104.

Michoacán: 92, 431, 438.

Middendorf, Bernardo; jesuita: 534.

Mier (N. Santander) : 95, 483.

Miera, laguna de: 543.

Miera Pacheco, Bernardo de; cartógra. fo: $420 .-543,544$.

Mier y Terán, Francisco; juez de la Acordada: 362.

Mijares Solórzano, Juan: 410.

Milán (Italia) : 451.

Milán, regimiento de: 431 .

Milicias: $149,160,169,175,177,179$, $191,229,288,292,308,333,335$, $379,386,405,492$.

Milicias provinciales de N. Vizcaya: $288,292,306,308,316.318,321$, $354-356,360,363,365,369-372$, 408, 409, 434, 441, 480.

Milpas, paraje (N. Viz.): 242.

Milpillas (Sonora): 319 .

Mimbreños, indios: 459, 491, 493.

Mimbrera, hacienda (N. Viz.): 229, $288,413$.

Mimbres, arroyo o río de los: 239.

Mimbres, sierra: 190, 239, 242, 250, $337,385,440,445,447,459$.

Mimenza Castillo, Ricardo: 205.

Mina, marqués de: 276.

Miranda: 198.

Miranda, capitán miliciano: 83 . 
Misiones: $12 \cdot 14,18,20,21,26,33-36$, $40.46,71,73,77,78,81,85 \cdot 87,89$, $94.97,100,103,106,112,115,129$, $133,134,150,168,171,175,176$, $193,197,205,222,224,225,232$, $256-258,265-267,269,314,345,360$, $362,363,381,383,392,394,397$, $398,402,407,408,417,420,425$. $449,483,495,508,513$.

Misisipí, río: $10,24,34,40,41,96$, $97,104,106,135,199,495,-522$. $526,530-532,547$.

Misuri, río: 24, 207.-523, 530.

Misuris, indios: 104, 345.

Mixtón, monte: 3, 4, 67.-520.

Mobas (Sonora) : 128, 181, 512.

Mobila (Florida occidental): 481.

Mocorito (Sonora): 128, 500.

Moctezuma: 2.

Moctezuma, conde de; virrey de N. España: 59.

Mochicaguy (Sonora): 177.

Mocho, jefe indio: 383.

Mochos, sierra: 183, 206.

Mogadorio: 431.

Mogano, sierra del: 233, 236, 373.

Mogollón, sierra de: 239, 385.

Mojada, sierra: 37, 283, 442.

Mojarras, real de minas: 92 .

Molina Oviedo, obispo de Málaga: 143.

Molina Solís: 243.

Monclova, conde de la; virrey de $\mathrm{N}$. España: 58, 59.

Monclova, villa y presidio de San Fran. cisco de (Coahuila): 33, 37, 54, 61, $64,70,71,75,79,101,103,125$, $137-139,213,214,218,221,223$ Monclova Nuevo o Concepción, nuevo emplazamiento: $223,224,234$, $240,272,282,283,297,298,302$, $347,353,355,358,374,378,404$, $434,470,477,478,482.484,-522$, $523,533,539,548$.

Monserrat, real de minas (N. Viz.): 175.

Montera Blanca, jefe indio: 373, 459.
Monterrey, conde de; virrey de N. Es* paña: 15.

Monterrey (N. León) : 9, 17, 23, 33, $75^{\prime}, 92,94,129,231,376,429,483$, 513.- 521,536 .

Mionterrey, presidio (N. León) : 137.

Monterrey (California) : 158, 162, 163, $169,170,203,21,265.267,279$, $290,294,329,394,396,397,431$, $432,454 .-520,521,540$.

Montes, Ambrosio: 84.

Montesclaros, fuerte de: 15.

Montiel, Miguel; alférez: 215.

Montpellier (Francia) : 322.

Moorehead, Max L.: 108, 508

Moqui, provincia de: $11,13,26,43$, $44,77,88.91,123,264.267,336$, $42 \%, 465,-521,529,534,540,541$, $542,546$.

Moquinos, indios: $11,24,266,314,336$, 386. -530.

Moquis, vid. Moquinos, indios.

Moraga, Joaquín; teniente: 267.

Morales Gómez, Antonio: 17.

Morales Padrón, Francisco: 98.

Morena, Vicente; teniente: 180, 181.

Morenc, Vicente; coronel de dragones de España: 473.

Moreno de Castro, Agustín: 49, 52.

Morfi, P. Juan Agustín: 43, 290, 294, $297,347,387,407,408,410,411$, 420-422.

Moris, misión y pueblo (N. Viz.) : 423.

Morotal, real de minas (Sonora): 92.

Morrión, jefe indio: 349 .

Mota Padilla, Matías: 73, 84.

Motines (N. Galicia): 91.

Muerto, vid. Jornada del Muerto.

Mula, arroyo de la: $221,377$.

Mungarrieta, Felipe: 393.

Munguia, Tomás; alférez de Monclova: 374.

Muni, Calixto; jefe indio: 83.

Muniain, Gregorio; ministro de la Gue. rra: $140,174,175,181,188,189$, 192, 193, 196, 201, 203.

Muns, Cayetano: 510, 511. 
Muñiz, Narciso; teniente de goberna. dor de El Paso: 335.

Muñoz, Manuel; capitán de la Junta, o Julimes, o Norte: 113, 138, 209, $230,231,240,242,243,282,341$, $367,372,374,375,377,378,441$, $444,477,479,490,494,495,513$.533.

Muñoz y Villavicencio, Juan Manuel: 50.

Murcia, regimiento de: 443 .

Murciélago, sierra: 378.

Murilla, Ramón de: 548.

Muzquiz, Miguel de; ministro de $\mathrm{Ha}$ cienda: 155, 209, 253, 259, 260.

\section{$\mathbf{N}$}

Nacameri, real de minas (Sonora) : 204 , 206, 419.

Nacodochitos, indios: 345 .

Nacogdoches, misión de Guadalupe de (Texas) : 102, 273, 284, 384, 407, 494, 507.

Nacori (Sonora) : 145.

Nacosari, San Juan de; real de minas (Sonora) : 36, 121, 173.

Nadadores, misión: 422 .

Nadadores, sierra: 80,355 .

Naipes, renta en provincias internas: 496.

Nambé (N. México) : 248, 424.

Namiquipa, misión de San Pedro de (N. Vizcaya) : 12, 339, 354, 367, $368,458,492$.

Nanarachi, misión (N. Vizcaya): 423.

Nanisue, indios: 530.

Napestle, río: 199, 505.-544.

Nasas, río y valle del: $8,9,14,30,37$, $39,77,110,111,119,230,284,285$, $288,294,306,316,337,341,356$, $447,464 .-519,528,542$.

Nasones, indios: 98.

Naspre, jefe indio: 179.

Natajé, jefe indio: 373,459 .-Río vid. Pecos.

Natanijú, jefe indio: 459.
Natajes, indios: $76,100,112,113,138$, $195,197,199,228,232,239,295$, $300,346,348,464 .-528.530$.

Natches, indios: 105.

Natchez (Luisiana) : 495.

Natchitoches, presidio francés: 42,70 , $97,102,105,106,199,225,270$, 292, 295, 495, 507.-531, 532, 545, 547.

Natividad, misión (N. Viz.) : 12, 20.

Natividad, real de minas (Sonora) : 36 .

Nava, Pedro de; comandante general de provincias internas: $428,429,474$, $477,482,486.503,507.513$.

Nava, villa de: 513 .

Navacoyán, hacienda (N. Viz.) : 344.

Navaho, vid. Navajos.

Navajo, río Grande de, vid. Colorado. Navajos, indios: $24,25,28,106,107$, $123,197,247.249,307,334,336$, $384 \cdot 386,389,406,456 \cdot 458,490,492$, 505,506 - $529,530,543$.

Navarro García, Luis: 159, 175, 257, $277,511$.

Navidad, puerto de la: $92 .-521$.

Navogame, misión (N. Viz.) : 423.

Nayarit, provincia y presidio: $4,5,7$, $8,12,15,18,67,69,71,73,75$, $125,137,140,218,231,232 .-528$, 547.

Nayaritas, indios: 129.

Neches, indios: $98,382 .-530$.

Neches, río: 96, 98, 102, 345 .

Neira y Quiroga, José de; gobernador de N. Vizcaya: $31,34$.

Nevares, correo de Durango: 229.

Nevares, Cristóbal de; capitán de Santa Catalina Tepehuanes: 22.

Neve, Felipe de; comandante general de provincias internas: $140,267,290$, $291,361,394.398,429.443,446$, $447,450,451,457,458,460,489$, 508.

New Haven: 7.

New York: 44, 90, 164.

Nieves (N. Galicia): 92.

Nieves, río: 14. 
Nitajendes, indios: 469.

Niza, Fr. Marcos de: 9, 12, 30.

Nochistlán: 3.-520.

Nogales, cajón de los: 346 .

Nolan, Philip: 513.

Nolin, J. B.: 522.

Nombre de Dios, misión y pueblo (N. Vi2.) : 27, 190, 322, 376, 423.

Nombre de Dios, villa de: $8,12,17$, $51,55,306,315-317,334,365,370$, $409,410,509,510 .-519$.

Nonoties, indios: 18.

Nopalera, cajón del Cerro Prieto: 171.

Noperi, Jerónimo; jefe indio: 299.

Noragachi, misión (N. Viz.): 423.

Noria, hacienda de la (N. Viz.) : 236, 339.

Norman (USA) : 28, 276.-543.

Nonoava (N. Vizcaya): 423.

Norte, río, vid. Grande o Bravo del Norte.

Norte, indios o naciones del: (Texas): $99,102,103,220,225,226,270-273$, $295,296,307,308,345-348,373$, $375,380,381,383,406,447,457$. $458,464,469,476,482,494$.

Norte, presidio del Norte; antes de la Junta (N. Viz.): $113,339,340,346$, $347,353,354,358,367,368,372$, $374-378,434,447,449,459,469$, $477,480,491$.

Norte, naciones indias del río Grande del Norte, vid. Norteños.

Norteamericanos: 477, 494.

Norteños, indios de la Junti de los Ríos: $35,38,74,113,192,214,358$, 372.

Norteños, indios de Texas, vid. Norte, indios.

Nueces, 'río: 548.

Nuestra Señora, río: 520.

Nuestra Señora de Buena Esperanza (N. Vizcaya) : $341,373,375-377$.

Nuestra Señora dét Carmen, aguaje (Coahuila) : 223, 224, 232.

Nuestra Señora de la Concepción de la Frontera: 5.
Nuestra Señora de los Dolores, presidio, vid. Dolores.

Nuestra Señora de los Dolores de la Punta de Lampazos, misión ( $N$. León) : 41.

Nuestra Señora de los Dolores del Sur a de la Pasión, misión (California) : $45,87$.

Nuestra Señora de Guadalupe de El Paso, vid. El Paso.

Nuestra Señora de Guadalupe de Agua Nueva, vid. Agua Nueva.

Nuestra Señora de Guadalupe de Za. catecas, Colegio Apostólico: 42, 95, 423.

Nuestra Señora de Loreto, misión, vid. Loreto, (California).

Nuestra Señora de la Bahía del Espíritu Santo, presidio, vid. Bahía.

Nuestra Señora del Oro, vid. Real del Oro.

Nuestra Señora del Păsaje de Cuenca. mé, presidio, vid. Pasaje.

Nuestra Señora del Pilar, misión (N. México) : 26.

Nuestra Señora del Pilar (Texas), vid. Pilar de Bucareli.

Nuestra Señora del Pilar de Zaragoza de los Adaes (Texas), vid. Adaes.

"Nuestra Señora del Rosario", buque corsario: 478.

Nueva Albion: 536.

Nueva Andalucía de San Juan Bautista de Sonora, provincia, vid. Sonora.

Nueva Bilbao, pueblo proyectado (N. Vizcaya): 369.

Nueva Conquista de la Mayor España: 2.

Nueva España: 1, 6, 7, 10, 14, 15, 17, $26,28,30,54,59,62,63,67,69$, $72,77,91,92,93,94,97,98,114$, $135,136,140,143,144,153 \cdot 155$, $159,165,169,188,192,196,198$, $201,202,210,213,216,218,220$ $224,264,266,277,280,281,295$, $300,303,304,312,313,315,349$, $362,365,366,386,396,402,421$, 
$443,451,461,472,489,495,504$, $508,512 .-519,521,522,524,526$, $530,535,543-546,548$.

Nueva Francia: 521, 522.

Nueva Galicia: 2.9, 55, 65, 73, 84, 91, $93,115,120,362,371,472,477$, $478 .-520,521$.

Nueva Granada o Marata, vid. Nuevo México.

Nueva Orleans (Luisiana) : 97, 104, 105, $292,312,384,483,495 .-531,547$.

Nueva Vizcaya: $1,7,12,15 \cdot 40,43$, $49,52,55,56,58.61,65,69,72,73$, $75,77-80,82,83,91,92,94,101$, $108-116,118,120-122,124,125$, $129,132,133,136 \cdot 139,141,142$, $144,146,147,153-156,158,159$, $167,173,175,176,186,187.196$. $201,203,204,206,211-213,215$, $218,220,221,223,224,226.229$. $232,236,239-241,246,249,251$, $259,264,268,269,275,278,279$, $282 \cdot 289,291-293,297,299,303-308$, $31 \mathrm{C}, 311,313,314,316,318,320$, $321,324,326,328,335-344,346$, $347,349,353 \cdot 355,361,362,363$, $365 \cdot 372,375,377,378,384,385$, $403,405,406,408,409,414,415$, $420,422 \cdot 424,429,433 \cdot 435,438,440$. $447,449,450,452.454,456.465$, $467,474,475,480,486,490.493$. $498,508,-519,520,522,524,526$. $530,533,535,541,542,544,547,548$.

Nuevo México: 1, 2, 10-12, 15-17, 20, $23.29,31.33,36,44,49,52,54.57$, $60.62,64,65,67,68,72,75,88,91$, $103 \cdot 108,111,115,116,118,125$, $129,136,137,139,142,155,194$, $197-199,210,220,227,230,240$, $241,244,250,260,265 \cdot 267,275$, $281,289,292,294,297,298,304$, $305,307 \cdot 309,312,314,316,318$, $321,323-325,328,329,333-336,346$, $363,373,378,381,383-387,406$, $409,414,420-422,424,427,429$, $433,434,447,453,456.459,461$, $462,464,465,467,475,480,486$,
$491.493,495,501,504-508,512$. $520,522,524,526,528,530,53 i$, $534,535,537,542,543,546,547$. Nueva Navarra, vid. Sonora.

Nuevo Reino de Filipinas, vid. Texas. Nuevo Reino de León: 1, 7, 9, 12, 15 . $17,28,33,41,48.50,52,55,56$, $60,61,65,71,72,75,76,94,101$, $125,129,137,143,218,232,269$, $271,289,309,313,376,384,408$, $411,429,453.455,462,469,470$, $476,479,482,483,486,489.491$, $513 .-521,529-531,533,536$.

Nuevo Reino de Toledo; vid. Nayarit.

Nuevo Santander, Colonia del, o Cost. del Seno Mexicano: 68, 92, 95, 101 , $126,137,140,142,197,198,219$, $271,272,280,289,309,312,313$, $376,377,408,411,429,453.455$, $462,469,470,477,479,484,486$, $489,491,513 .-531$.

Núñez, Fr. Angel Antonio, franciscano: 300 .

Núñez de Esquivel, Melchor: 545.

Núñez de Haro, Alonso, arzobispo de México: 429, 485.

Núinez de Villavicencio, Superintendente de la Casa de Moneda de Méxi. co: 167.

Nuri (Sonora): 128, 512.

Nutrias, paraje (Sonora): 459

\section{o}

C, Joaquín de la; teniente: 188,196 , $215,380$.

Oaxaca (N. España) : 92, 149.-536.

Obispada de Nuevo León: 309, 310 , $313,315,362,513$.

Obispado de Sonora, propuesto: 159 , 187, $205,315,362$; erigido: 433 .

Obregón, Baltasar de: 67.

Ocaranza, Fernando de: 6,213.

Oca y Sarmiento, Antonio de; gobernador de N. Vizcaya: 23.

Ocio, Manuel de: 87, 150, 152.

'D'Conor, Hugo; comandante inspector 
de los presidios internos: 190,196 , $198,199,202,209 \cdot 217,219 \cdot 244$, $246 \cdot 250,258 \cdot 266,268 \cdot 272,278,280$. $285,287,299,301,302,307,318$, $327,329,336,343,345,346,353$, $357,371,406,439$.

Dcoroni (Sonora): 128.

Ocuca, rancho (Sonora): 327.

Ochoa, José Simón; teniente: 215.

D'Gorman, Edmundo: 43, 91, 429.

Ohio, río: $495 .--523$.

Ojeda, teniente: $231,329$.

Oja Caliente (N. México) : 199.-544.

Ojo Caliente, paraje y sierra (N. Viz): 231, 278, 493.

Oja de Ramos, hacienda; vid. Ramos.

Ojuelos, paso de los; presidio: 4.6.

Oklahoma (USA): 28.

Olea, Héctor R.: 165.

Oliván y Rebolledo, Juan de; auditor de México: 65, 75, 79, 80.-526, 535.

Olives, indios: 95.

Onavas (Sonora): 393.

Once Mil Vírgenes; vid. Cosalá.

Oñate, Juan de: $4,10,11,13,24,47$, 48. -520 .

Opas, indios: 529

Opatas, indios: $13,14,179,192,195$, $252,255,263,279,282,291,293$, $299,300,305,325,327,330,340$, $388,390,391,392,434,436,440$, $445,448,480,490$. - $534,544$.

Opateria, provincia: 36 .

Opodepe, misión y real de minas (Sonora): $43,76,81,121,165,203$, 204, 263.

Oporto, Francisco de: 384.

Oposura (Sonora): 145, 146, 364, 419.

Oposura, río de: 300,305 .

Oquitoa, misión (Sonora): 43.

Oraibe (N. México): 267.-540.

Orán (Africa) : 280.

Orcoquiza, presidio de San Agustín de Ahumada o de las Amarillas de (Texas): 97, 98, 125, 137, 198, 219,
$223,232,233,269,495 .-532,539$, 548. Vid. Babia.

Orcoguizas, indios: $97,296,345,383$, 479.

O'Reilly, Alejandro, gobernador español de Luisiana: 199, 202, 204, 210 . $212,215 \cdot 219,234,296$.

Organos, sierra: 197, 231, 237, 305, 492.

Orizaba: 84, 504.

Ore, río del: 521.

Orobio, Joaquín; capitán de la Bahía: 96, 97.

Orobia y Basterm, Prudencio; gober nador de Texas: 96.

Orozico, Felipe de; corregidor de Chihuahua: 39, 51.

Orozca Berra: 91.

Ortega, José de: 396.

Ortega, José; alférez: 215

Ortega, Mateo; capitán de Mazatlán: 485.

Ortega, Vicente; teniente de la segun. da compañi volante: 282 .

Ortega Montañés, Juan de; arzobispo. virrey de México: 61.

Ortelius, Abraham: 522

Ortir Parrilla, Diego; gobernador de Sonora y comisionado en Texas: 85 , $86,101,102,127,131,197,217,272$, $295,485,-532$.

Osage, indios: 41, 104.--530. Vid. Guazas.

Osotayoliglas, indios: 38 .

Osorio y Llamas, visitador de N. Santander: 142 .

Ostimuri, provincia: $74,82,83,120$, $121,127,128,134,150,151,173$, $175,177,179,181,202,315,365$. $391,416,418,460,465 .-528$.

Otancahui, "cerro de los huesos": 83.

Otates; cajón del Cerro Prieto; vid. Cara Pintada.

Otatitlán, misión: 14.

Otermin, Antonio de; gobernador de N. México: 26, 28.

Otermin, Miguel de: 414. 
Otera Bermúdez, Pedro: 127.

Otomies, indios: 7.

Oxamaquea, jefe indio: 458 .

\section{$\mathbf{P}$}

Pacífico, océano: $8,17,44,55,74,88$, $90,91,146,152,163,164,265,267$, $424,487 .-519,521,523,528,530$, $536,543,545$.

Pacheco y Solis, Alonso de; teniente de navio: $146-148,151,164$.

Pachina (Luisiana) : 96.

Pachuca, Colegio Apostólico de: 424.

Pachuca (N. España): 519.

Padilla (N. Santander): 95.

Padilla, P. Luis: 321.

Padilla, Juan José, alférez: 215.

Padilla, Tadeo, jefe de las milicias de Alamos: 177.

Padoucas, indios: 525, 530; vid. Co. manches.

Páez Hurtado, Juan, alcalde mayor de Santa Fe: 104.

Páez de Alarcón, José Florentino; cura de Nombre de Dios: 410.

Pagaduria de Arizpe y de Chihuahua: 360.

Pagazaurtundúa, Juan de; ingeniero militar: 547.

Paguasin, indios: 529.

Paguerachic, misión (N. Vizcaya): 319.

Palacios, Juan Fernando de; mariscal de campo, visitador de N. Santander: 137, 142, 198, 280.

Palihuecos, indios: 272.

Palma, cajón del Cerro Prieto: 172, 179, 180, 185, 292.-540.

Talma, Salvador; jefe indio: 268, 281, $325,332,395$.

Palma Tobón, Juan: 49, 51.

Palmar de la Vega: 5.

Palmas, río: 519, 522, 530.

Palmillas: 5.

Paloblanco, real de minas (Sonora) : 92, 120.

Palo Blanco (N. Santander): 484.
Palo Clavado, paraje (N. Viz.): 111.

Palo Ensebado o Santa Rosa, real de minas (Sonora): 261, 262.

Palomas, indios: 107. -530 .

Palou, Fr. Francisco; franciscano: 203.

Pames, indios: 7, 95.

Pamorames, indios: 529.

Pampopas, indios: 529.

Panamá: 123.

Panenes; vid. Panis, indios.

Panes, José: 288, 316.

Panis, indios: $41,106,226,270,345$, 492.

Panocha, jefe indio: 235.-Panocha, otro jefe indio: 346 .

Pánuco, marqués de: 420.

Pánuco, río y provincia de: $3,6,7,17$, $94,119,120,145 .-519,521$.

Pánuco, río Grande de: 2•4, 6, 94.519, 531.

Pánuco, real de minas (Sonora): 9, 92, 500.

Panzacola a Pensacola (Florida occidental) : $131,196,197,480 .-525$.

Pápagos, indios: $86,226,259,264,328$, $395,406,444 .-529$.

Papaguería, país pápago: 395.-534, 540.

Papigochic, misión (N. Vizcaya): 423.

Papigochic, río: 20.

Paquimé, provincia imaginaria: $8,9$.

Parchenas, indios: 530.

Pardiñas Villar de Francos, Juan Isidro; gobernador de N. Vizcaya: 34 , $35,38,49,53,58,59$.

Pardo, Manuel; capitán de dragones: 238.

Pardo, José; capitán de Mazatlán: 485.

Pardo de Navas, Tomás: 84.

Paredes, conde de; virrey de Nueva España: 31,58 .

Paris: 7, 409, 413, 513.-535, 540.

Parra, José Antonio de la: 420.

Parral, real de minas (N. Vizcaya): 12 , $19-23,27,31-33,35,37,38,59,60$, $75,92,118,119,122,128,129,189$. $195,229,282,286,288,316,317$, 
$337,338,341-344,366,367,370$, $409,413,415,416,434,442,500$ 524,525 .

Parral, presidio; vid. Compañía de campaña en N. Vizcaya.

Parral, río del: 74 .

Parras, San Carlos de: 491.

Parras, Santa María de las (N. Viz): $22,92,109,120,190,228,231,232$, $286,294,310,312,313,316,319$, $320,342 \cdot 344,369,371,376-380,407$, $409 \cdot 412,434,441,442,447,462$, $513,-519,535,544,545,547,548$.

Parras, Laguna de: 119.-547, 548.

Parras, Pedro; teniente: 215.

Parry, J. H. 52.

Pasaje, presidio de Ntra. Sra. del - de Cuencamé (N. Viz) : 33, 36, 37, 39, $60,61,64,65,71,75,76,109 \cdot 112$, $126,128,129,136139,141,142$, $195,306,356,370,376 .-528,537$. Pascual, jefe indio: 78, 110, 138, 228.

Baso de Todos los Santos o de la Casita: 90.

Pastios, indios: 530.

Pata Galana, hacienda de la (N. Viz): 319.

Patiño, José; ministro de Indias: 82.

Patos, hacienda (N. Viz.): 37, 129, $293,294,316,319,338,344,347$, $411,468$.

Patos, laguna de (N. Viz.): 234.

Patrón, rancho (N. Viz): 283.

Batule, jefe indio: $340,341,373-375$, 377, 380. - Patule, otro jefe indio: 459.

Pátzcuaro (N. España) : 154.

Pau (Francia) : 192.

Pawnees, vid. Panis, indios.

Paz, Príncipe de la: 548.

Pazolatames, indios: 530 .

Paz y guerra, fondo a disposición del gcbernador de N. Vizcaya: 64, 73, 77, $111,113$.

Pecciolen, Nerou: 535.

Pecos (N. México) : 107, 244, 246, 248, $333,336,385,424,506$.
Pecos, río: 11, 103, 106, 107, 189, $193-195,199,304,346,447,468$. $524,529,532,542$.

Pecuries (N. México): 104, 199, 244. $246,385,424$.

Pechollé, jefe indio: 377.

Pedro I, zar de Rusia: 216.

Pedro, jefe indio: 85 .

Peirán, Diego; capitán del regimiento de infantería de América: 151, 172, 179. 181-183.

Pelayo, hacienda de San José de (N. Viz.) : $110,138,339,353,355,369$, 378.

Pendencia, presidio de la: 6 .

Pénjamo, presidio: 5.

Peña: 332

Peña, hacienda de la (N. Viz.) : 319 , $376,411$.

Peña, Francisco: 15.

Peña, Francisco Ignacio de la: 476.

Peña, Juan Antonio de la: 527, 528.

Peñ?, Vicente de la: 415, 416.

Peñalosa, conde de: 522.

Peñascosa, sierra: $445,456$.

Peñitas, paso de las: 469.

Peñol Blanco, real de minas: 6 .

Perálta, Pedro de; gobernador de $\mathrm{N}$. México: 11.

Perea, Pedro de; capitán de Sinaloa: 1S, 134.

Perea Morales, Benito; capitán de Santa Catalina. Tepehuanes: 32

Pérez de Almazán, Fernando; goberna. dor de Texas: 99.

Pérez Bustamante, Ciriaco: 3.

Pérez de Ribas, P. Andrés; jesuita: 6, 13,68 .

Pérez Serrano, José Antonio: 434.

Pericúes, indios: $82,87$.

Péries, gobernador francés de Luisiana: 105.

Perú: 60, 67, 276, 415, 425, 504.

Perú, Juan; capitán de Janos: 234.

Perrillc. aguaje (N. México): 128.

Pesquería Grande (N. León) : 376, 377

Petaca, sierra: 305. 
Petatlán, río: 8 .

Peyotes, misión (Coahuila): 341, 372, 422, 423.

Pfefferkorn, P., jesuita: 67, 201.

Piacenza (Italia): 451.

Piatos, indios, vid. Pimas Altos.

Piaxtla (Sonora) : 418.

Piaxtla, río: 14.

Picax-Ande Instinsle de Ugalde, Manuel; jefe indio: $469,471,473$.

Picú, sierra de: 182, 183, 206, 253.

"Piernas Gordas", vid. Saint Denis.

Pilar de Adaes, vid. Adaes, presidio.

Pilar de Bucareli, Nuestra Señora del (Texas) : 273, 345, 384, 407.

Pilar de Conchos (N. Viz.) : 492, 493.

Pilar de la Paz, misión (California), vid. La Paz.

Pilares, cajón del Cerro Prieto: 145.

Pilares, paraje de los (N. Viz) : 111-113, 234, 449; vid. Príncipe, presidio.

Pilares, sierra: 179-181.

Pilón (N. León) : 483.

Pilón, río del: 95.

Pimas, indios: $13,28,35,36,43-45,73$, $81 \cdot 83,86,90,150,158,165,172$, $174,175,177,179,180,185,190$, $200,204,224,252,255,283,290$, $293,305,325 \cdot 327,329,330,390$, $391,395,435,436,439,480 .-534$, 545.

Pimas altos, indios: $86,121,165,170$, $176,178,180,182.184,205,207$, $208,224,251,255,261.263,291$, $303,326,323,390,395 .-534$.

Pimas gileños gentiles: $260,395,406$, $444 .-534$.

Pimeria Alta, destacamento de: 327 .

Pimerias Alta y Baja, provincias: 43$45,76,82,89,122,123,173,224$, $257-259,289,326,329 .-522,533$, 540.

Pineda, Juan de; gobernador de Sonora: $86,122,133,143,145 \cdot 149,151,153$, $154,165,166,170 \cdot 173,176,178-180$, 186, 192, 207, 227, 250.

Pino, sierra del: $232,346$.
Pinos, real de minas: 6 .

Piros, indios: $26,27,29$.

Piros, provincia (N. México) : 25.

Pisón: 150, 164:

Pisones, indios: 96.

Pitascachi, sierra: 448 .

Pitic (Sonora) : 73, 83-85, 121, 166.

Pitic, presidio de San Pedro de la Conquista del (Sonora) : 83-85, 89, 90; cuartel general en la campaña del Cerro Prieto: $166,170-174,176,178$. $185,192,205 \cdot 208,224,225,251$, $255-2.58,263,279,283,286,326$, $328,331,333,387$; presidio, segunda épocil: 388-39G, 392, 393, 434,436, $439,465,480 .-535$.

Pitic, río: 85 .

Piticagán, apache: 197

Pitiquín o Pitquín (Sonora): 76, 259, $261,291,390 .-530$.

Pizarro, Francisco: 48.

Plata, virreinato del Río de la: 93.

Platte, río: 104.

Plaza, Gaspar de la: 49, 53.

Plomosas, real de minas (Sonora): 92, $128,417,500$.

Poanas, valle y río de las (N. Vizcaya) : 410, 508.

Poca Ropa, jefe indio: 346 .

Pointe Coupée (Luisiana): 106.

Pol, Antonio; capitán de fusileros: 185.

Pólvora, renta en provincias internas: $164,496$.

Ponce, rancho: 153.

Porciúncula, río de la: 397, 398, 432.

Porlier, ministro: 510, 512.

Portezuelos: 5.

Portillo, Alvaro del: 3.

Portolá, Gaspar de; gobernador de Ca. lifornia: $133,134,152,169$.

Portugal: 53, 192, 198, 211, 216, 280, $431,451,479$.

Porras, Plácido: 49, 56.

Porras Muñoz, Guillermo: 72, 74, 82, 192.

Posada, Ramón de; fiscal de México: 454. 
Pose, José; ayudante de milicias de Mazatlán: 486.

Potau de Portugal, Francisco Javier; intendente de Durango: 510.

Potosi, San Luis de: $3,6,7,12,15,17$, $72,94,95,101,153,154,161,168$, $191,192,219,309,319,455,466$, $482,495,513$.

Potrerillos, rancho (Coahuila): 297.

Powell, Philip Wayne: 6.

Pozo Cenizo (Sonora): 171.

Pozos de Fastiota (Sonora): 172.

Pozos de San Ignacio (Sonora) : 183.

Pradeau, Alberto Francisco: 134.

Presidio, río: 14.

Presidio Viejo, hacienda (N. Viz.) : 214.

Prevoté (Francia) : 276.

Priestley, Herbert Ingram: 143, 180.

Princesa, presidio de la, vid. San Buena. ventura.

"Principe", bergantín: 151-153, 163.

Principe, legión del-en Chihuahua: $317,356,480$.

Príncipe, legión del -, en Guanajuato: 199.

Príncipe, presidio del (N. Vizcaya): $234,240,298,307,339,353,358$ 372, 434; en Coyame: 449, 450, 480, 493.

Príncipe, regimiento de infantería del: 481.

Prudhom, Gabriel; barón de Heyder, a1calde mayor de Sonora: 82, 83.-530, $533,535$.

Puebla de los Angeles (N. España): $67,92,131,140,149,160,166,280$. $281,451,452,466,506$.

Pueblito (N. Vizcaya) : $354,372$.

Pueblo, indios: 2, 13, 24.28, 43, 248.

Pueblo Nuevo (N. Viz.) : 119.

Puerco, río, vid. Pecos y Colorado.

Puerta, real de minas (Sonora): 500.

Puerta Barrera, Juan Francisco de la; gobernador de N. Vizcaya: 49, 78, 110.

Puerta Sánchez de Tagle, Tadeo de la; corregidor de Chihuahua: 51 .
Puerto Cabello (Venezuela): 479.

Puerto Escondido (California) : 133

Puerto Rico: 478, 479.

Pujol, Juan: 333.

Puliques, pueblo de la Junta: 224.

Púlpito, paso del —o de Carretas: 129.

Puluache (N. Viz.) : 175.

Punta de Lampazos, vid. Lampazos, presidio y Nuestra Sra. de los Dolores, misión.

Purgatorio, cajón del Cerro Prieto: 180. Purificación, villa (N. Galicia) : 91.

Purisima, misión de la (California) : 45.

Purisima, misión de la (N. Viz.) : 20.

Purisima Concepción de Acuña, misión (Texas): $422,423$.

\section{Q}

Queipo de Llano, Pedro; corregidor de Chihuhua: 343.

Quemado, El; jefe indio: 459.

Queres (N. México): 420.

Queres, indios: 24, 248.

Querétaro: 3, 5, 40-42, 70, 94, 127, $140,212,226,229,256,281-283$. $290.292,299,325,327-329,337$, $396,431,473 .-531$.

Querétaro, regimiento de caballería provincial de: $229,431$.

Quiefiéquijá o Quijié-Gusiá, jefe indio: $377,469$.

Quihué, jefe indio: 43 .

Quinia, indios: 24.

Quintana, Luis de; capitán del Gallo: 32

Quintos de oro y plata: 499 .

Quiquimas, indios: 265, 267.

Quirós, Diego de; capitán de Sinaloa: $27,32$.

Quitachin, apache: 197.

Quitseis, indios: 199, 226, 296, 345 , 384.

Quivira, provincia imaginaria: 520 .

\section{$\mathbf{R}$}

Rábago y Terán, Felipe; capitán de San 
Javier, de Sacramento y de San Sabá: 102-103.

Rábago y Terán, Pedro; gobernador de Coahuila: 81, 100, 109, 138.

Ramensdorff, encomienda de: 277.

Ramada, hacienda de San Antonio de la (N. Vizcaya): 214, 230, 373.

Ramirez, P.; franciscano: 295.

Ramirez, P.; jesuita: 14.

Ramirez, capitán de Bahía: 101.

Ramirez de Salazar, Francisco; alcalde mayor de Casas Grandes: 27, 28, 36.

Ramón, Domingo; capitán de Río Gran. de: $42,53$.

Ramos, hacienda de (N. Viz.) : 229.

Ramos, hacienda del Ojo de (N. Viz. caya) : 27,40 .

Ramos de Verea, Pedro: 404.

Rastras, sierna de las: 445 .

Real de Borbón (N. Santander) : 95.

Real de los Infantes (N. Santander): 95.

Real del Oro de Agua Caliente (N. Viz(aya): $87,92,114,118,122,229$, $282,283,286,288,316,317,338$, $342-344,370,409,413,442,500$.

Rebollar, Martín de; gobernador de N. Vizcaya: 49, 53.

Red, río: 41.

Reeve, Frank D.: 25, 28, 107, 247, 505.

Refugio, misión del (Tex?s): 483.

Reinosa (N. Santander): 95, 483.

Reinosa, escuadra (N. Santander) : 126.

Remedios, misión (Sonora): 43.

Rengel, José Antonio; comandante ge neral interino de provincias internas: $429,433,437,439,443-450,452$, $453,457,459,461,462,464.466$, $473,474,489,505$.

Respaldizia, José Ventura de: 50, 56, 57.

Retana, Juan de; capitán de Conchos, vid. Fernández de Retana.

Revilla (N. Santander) : 95, 483.

Revillagigedo, primer conde de; virrey de N. España: 77, 81, 84, 85, 87,
$94,97,105-109,111,112,113,137$, $141,145,412$.

Revillagigedo, segundo conde de; virrey de N. España: 167, 471.488, 492, 496, $503,504,508,512,513$.

Rey, Legión del : 339.

Rey, regimiento del: 431.

Rey, Agapito: 11, 15.

Reyes, Fr. Antonio de los; obispo de Sonora: 425, 434, 512 .

Reyes, P.; franciscano: 203.

Reyes, río: 536.

Riaño, José de; ayudante mayor de, milicias: 369.

Riballo, comerciante francés: 104 .

Ribas, vid. Pérez de Ribas.

Ricardos, Antonio; mariscal de campo: $132,143,156,162,188,198,217$.

Ricla, conde de; ministro de la Guerra: 249, 261, 431.

Rio Chico, real de minas (Sonora) : 121, $122,128,145,364,418 .-535$.

Rio Florido, estancia del (N. Vizcaya) : $319,380,413$.

Rio Grande, presidio de San Juan Bautista de (Coahuila): 41, 53, 60, 61, $65,70,71,76,79,81,94,95,99$, $101,103,108,125,137,138,218$, $223,224,231,232,234,236,240$, $282,295,297,298,319,353,354$, $358,373,381,408,423,434,482$, $483 .-536,531,533,538,542$.

Rio de la Loza, Rodrigo del; gobernador de N. Vizcaya: 6 .

Río de la Plata: 509.

Rio Santa Catalina, presidio: 5.

Rio Verde, vid. Santa Catalina Mártir.

Riperdá, barón de; gobernador de Te. xas: $199,225,226,231,232,270$, $271,273,295,297,299,309,345$, $348,407$.

Rivera, jefe indio: 235 .

Rivera, Honorato de: 256.

Rivera y Moncada : $169,290,394,397$, 398.

Rivera Villalón, Pedro de; visitador de los presidios: 42, 60, 70-82, 94, 97 , 
$99,104 \cdot 107,124,126,137 .-528 \cdot 530$ 540.

Rivera Cordero, Manuel; comandante del puerto de San Blas: 151, 162, 164.

Robledo (N. México), destacamento propuesto: $219,240,245,308,333,335$, 346.

Robles, Francisco; capitán de San Elea. zario: 282.

Rocosas, montañas: 267

Rocha, Jerónimo de la; ingeniero mili. tar: $296,388,393,439 .-544,546$.

Rocha, José G.: 38.

Rocha Ferrer, Francisco de la; goberna. dor electo de N. México: 57.

Rodallegas, Ildefonso; alférez: 215.

Rodriguez, capitán de Río Grande: 101.

Rodriguez, Blas E.: 7.

Rodríguez, Juan: 546.

Rodriguez, Miguel; aloalde mayor de Sonora: 51.

Rodriguez, Salvador; alférez de Horcasitas: 282 .

Rodriguez, Vicente; capitán de Río Grande: 270, 282.

Rodriguez Cubero, Pedro; gobernador. de N. México: 49, 53.

Rodriguez Gallardo, José; juez comisario visitador de los presidios de Sonora: 84.86, 167.

Rodriguez del Valle, Mariana: 74.

Roibal, P. Santiago; vicario de Santa Fe: 104.

Rojo, río: 105, 507.

Romero, José María: 507.

Romero, Pablo; capitán de Tucson : 448 , $465,478$.

Romero de Terreros, Manuel: 276.

Romera de Terreros, Pedro: 100.

Romero, José Antonio; capitán de Pitic: $390,395,432,454$.

Roque, jefe indio: 383 .

Rosario, misión de Nra. Sra. del (Texas) : 348, 349, 381, 422, 423, 513.

Rosario, provincia y real del (Sonora) : $51,82,92,120,127 \cdot 129,152,175$,
$320,360,365,416,417,420,466$, $485,496,497,499,500,-544$.

Rosario, sierra del: 231.

Rouset de Jesús, Fr. Francisco; franciscano: 502 .

Royal Cantabre, regimiento de cazadores: 192.

Rubi, marqués de; mariscal inspector de los presidios internos: $72,103,107$, $114,115,132,134 \cdot 144,161,186$, $187,195,197,198,200,202,204$, $211,214,216.218,233,353,357$, $387,431,465,-542$.

Rubin de Celis, Alonso Víctores; capitán de E1 Paso: 111-113.

Rubio, José; comandante inspector de presidios internos: $243,280,282 \cdot 284$, $286,288,289,302,304,307,309$, $310,315,316,318,328,336,338$, $343,346,361,405$.

Rubio, Juan Francisco; cura de Cusihuiriáchic: 414.

Rubio Mañé, Jorge Ignacio: 28, 211. 213, 280.

Ruiz, hacienda y presidio propuesto en paraje de (N. Viz.) : 110-113, 138, $139,218$.

Ruiz, Manuel: 404.

Ruiz, Melchor; alcalde mayor de Sono. ra: 51 .

Ruiz de Ael, Santiago: 112

Rusos: $90,156,158 .-536$.

\section{S}

Saavedra, Francisco de: 501.

Sabinal (N. México): 244, 334, 491.

Sabinas, río: $42 .-547$.

Sabinas, río: 97, 270, 470, 471.-524.

Sabinas (N. León): 271.

Sacedón, $F_{r}$. Antonio de Jesús; obispo de N. León: 310.

Sacramento, misión (N. Viz.): 26.

Sacramento, presidio proyectado en la Junta de los Ríos: $74,79,80$.

Sacramento, presidio de Santa Rosa del (Coahuila): 80, 81, 102, 125, 131, 
$137,138,214,217,218,223,232$, 269.-533, 535, 538, vid. Aguaverde, presidio.

Sacramento, río y valle: 20, 27, 139 .

Sacramento, río: 544.

Sacramento, sierra y paraje del: 239, $242,305$.

Sáenz de la Fuente, Bartolomé: 281.

Sáenz Montero, Bernardo: 196.

Sáenz Rico, José; capitán de dragones: $436,448,465$.

Saeta, P. Francisco Javier; jesuita: 43.

Sahuaripa, misión (Sonora): 129.

Sahuaripa, (Ostimuri, Sonora): 391.

Saint-Denis, Luis Jucherau; explorador İancés: $41,42,102,105$.

Salado, rio: $346 .-534$.

Salado de Apaches, río, vid. Pecos.

Salamanca (España) : 143.

Salazar, Fr. Esteban de; franciscano: 265.

Salgado, Nicolasa: 280.

Salinas (N. León) : 376, 483.

Salinas, provincia de las (N. México): 25.

Salinas, renta en provincias internas: $163,365,366,393$.

Salinas Varona, Gregorio de; gobernador de Coahuila: 55.

Salineros, indios: $16,19,21$.- Salineros, otron indios: $76,372 .-530$.

Salineta (N. México) : 26.

Salitre, cajón del Cerro Prieto: 182.

Salitre, destacamento (N. Viz.): 339.

Saltillo, escuadra del (N. Viz.): 69.71 .

Saltillo, villa de Santiago del (N. Viz.' Coahuila) : $9,12,14,15,17,21.23$, $33,34,64,73,76,92,94,97,100$, $119,120,129,137,189,231,288$, $293,294,310,312,313,316,319$. $321,342,347,353,355,360,369$ $371,372,377-380,409 \cdot 411,434$, $462,470,478,483,513,-519,528$, $533,544,545,547$.

Salvatierra, P.; jesuita: $43,45$.

Salle, Caballero de la; explorador fran. cés: $34,40 .-525$.
San Agustín, isla, vid. Tiburón.

San Agustin, presidio, vid Orcoquiza. San Agustín del Tucson, presidio, vid. Tucson.

San Andrés, misión (N. Viz) : 12, 194, 423.

San Andrés de la Sierra, presidjo y real de minas (N. Viz.) : 9, 14.16, 119 , $341,370,409,500$.

"San Antonio", bergantín: 169.

San Antonio (California): 88.

San Antonio, presidio; vid. Casas Grandes.

San Antonio, río: 42, 70, 73, 98, 99, 101, 382, 469, 483, 513.-528.

San Antonio de Béjar, presidio ( $\mathrm{Te}$. xas); vid. Béjar.

San Antonio de la Huerta, real de minas (Sonora): 121, 122, 151, 204, $206,254,255,319-321,364,419$, 420,500 .

San Antonio de Nazas, hacienda (N. Viz.) : 412.

San Antonio Padilla, escuadra (N. San. tander) : 126.

Gan Antonio Tabahueto; vid. Taba. hueto.

San Antonio Valero, misión (Texas): $382,422,423,513$.

San Bartolomé, hacienda (N. Viz) : 376.

San Bartolomé, misión en el valle de (N. Vizcaya): 12, 13.

San Bartolomé, presidió y valle; vid. Valle de San Bartolomé.

San Bartolomé, río: 14.

San Benita (Sonora) : 417.

San Bernabé, misión (Coahuila) : 41.

San Bernabé de Cusihuiriáchic, misión (N. Viz) : 20.

San Bernardino, valle de: $238,260,262$, 289 , 387.-540, 541.

San Bernardo, Lago de; vid. Espíritu Santo, bahía.

San Bernardo, misión (Coahuila) : 408, 422.

San Blas, puerto (N. Galicia): 133 , $134,144,151 \cdot 153,157,161 \cdot 165,167$, 
$200,265,279,290,321,361,478$, $48 \%,-543$.

San Borja, misión (N. Viz.): 423.

San Borja, misión (California): 88.

San Buenaventura, misión (California Alta): 432.

San Buenaventura, paraje (Coahuila): 483.

San Buenaventura, presidio (N. Vizcaya) : $132,133,136-139,144,189$, $192,195,218,231,234,237-241$, 282, 291, 298, 399; en paraje de Chavarria: $339,353,354,358,368$, 434, 449, 450, 459, 480.

San Buenaventura, Fr. Francisco de; obispo de Guadalajara: 115, 405, 406.

San Calixto, sierra: 445.

San Carlos, aguaje y arroyo: 221, 223.

"San Carlos", bergantín: 151-153, 163, $169,328$.

San Carlos, Legión de-, en Parral: $317,480$.

San Carlos, presidio: 233, 235, 240 , $282,286,300,306,339,340,353$, $356,358,372,377,434$; en paraje de Chorreras: 449, 480, 493.

San Carlos de Parras (N. Viz., Caahui la): $491-493$.

San Cayetano, sierra: 439.

San Cristóbal (N. España): 202.

San Cristóbal, paraje (N. México) : 385.

San Cristóbal, pueblo de la Junta (N. Viz) : 221.

San Cristóbal, sierra: 378.

Sánchez Durán, Juan Clemente; corregidor de Chihuahua: 51 .

Sánchez Navarro, José Miguel; cura de Monclova: 408.

Sánchez Salvador, Fernando; capitán de coraceros: 91.

Sáncheă de Tagle, Pedro Anselmo; obispo de Durango: $85,87$.

San Dámaso, muralla o monte: 221. $300,348$.

Sandia (N. México) : 28, 107, 248, 420, 424.

San Diego, paraje: 112.
San Diego, río: 223, 235, 348 .

San Diego (California Alta) : 163, 169, $170,265,266,290,394,396,431$. 520.

San Diego, Colegio Apostólico: 94.

San Diego del Rio, real de minas (N. Vizcrya): 119, 342, 370, 409, 509.

San Dimas, real de minas (N. Viz): 500.

Sandoval, Fernando B.: 318.

Sandoval y Moscoso, Pedro: 416.

San Eleazario, población (N. Viz.) : 111, $112,368$.

San Eleazario, presidio (N. Viz) : 112 , $218,232-234,240,282,287,30$ ?. $305,307,337-339,353,354,358$, $36 \%, 368,372,404,434,449,459$, 480, 491, 492; en paraje de los Tiburcios: 492,503 .

San Esteban, isla: 87.

San Esteban de Nueva Tlaxcala: 15, 408, 411.-533.

San Eusebio de Tierras Nuevas (Sonora) : 256 .

San Felipe, ojo de agua (Coahuila): 349.

San Felipe (N. México) : 128, 424.

San Felipe del Golfo Dulce (Guate, mala) : 74 .

San Felipe de Jesús (California): 90.

San Felipe el Real, villa de; vid. Chihuahua.

San Felipe de los Reyes: 5, 6.

San Fernando, Colegio Apostólico: 94.

San Fernando (N. Santander): 95.

San Fernando, escuadra (N. Santander) : 126.

San Fernando (Texas) : 98, 99.

San Fernando de Austria, villa (Coahuila) : $81,103,213,220,222,223$, $228,269,297,298,319-321,346$, $347,353,354,360,374,408,479$, 483.

San Fernando de Velicatá, misión (Ca. lifornia) : 267.

San Francisco, ojo de (N. Viacaya): 111. 
San Francisco (N. Vizcaya) : 341, 373. San Francisco (California Alta): 46, $264 \cdot 267,329,397,432.520,536$, 540 .

San Francisco de Coahuila, presidio; vid. Monclova.

San Francisco de Conchos; vid. Conchos, misión y presidio.

San Francisco de la Espada, misión (Texas): $322,423$.

San Francisco de Güemes, escuadra (N. Santander) : 126.

San Francisco de Mezquital, misión (N. Vizcaya) : $12,342,344,370$, $409,412,510$.

San Francisco Solano, misión (Coahuila) : 41 .

San Francisco de los Sumas, misión (N. Viz.) : 26

San Gabriel, cuerpo de dragones de: 317, 480.

San Gabriel, misión (California Alta) : 267. -540 .

San Gabriel de los Caballeros (N. Mé xico) : 11.

San Gregorio, misión (N. Viz.) : 14.

San Hipólito, presidio (N. Viz.): 16, 31,32 .

San Ignacio, misión (California): 45.

San Ignacio, misión (Sonora): 43, 44, $327,330,387$; presidio pima: 389 . $391,435,436,439,445,448,480$, 490. -544 .

San Ignacio, misión (N. Viz.) : 14, 20.

San Ignacio de Tubac; vid. Tubac, presidio.

San Ildefonso (España) : 275, 451, 506.

San Ildefonso (N. México) : 244, 424.

San Jacinto, río: 532 .

San Javier, misión ;(N. Viz.) : 27.

San Javier, presidio (Texas) : 100, 101.

San Javier, río: 99, 100.

San Javier, real de minas (Sonora) : 121.

San Javier del Bac, misión (Sonora): $43,87,89,128,173,208,265,387$, 444.
San Javier Vigé, misión (California): 45.

San Jerónimo, misión y pueblo (N. Viz) : $20,27,190,221,224,339$, $354,355,367,368,423,449,458$, 492.

San Joaquín de los Arrieros (N. Viz): $342,409$.

San Jorge, paso: 532 .

San José, bahía: 161.

San José, paraje (N. Viz.): 132, 136, 138.

San José, misión (N. México) : 26.

San José Aguayo, misión (Texas) : 422, 423.

San José del Cabo, misión (California) : 87.

San José del Cabo, presidio (Califor' nia) : $87,126$.

San José de Canelas; vid. Sianori.

San José Comondú, misión (California) : 45, 133.

San José de Gracia (Sonora) : 85, 166, $178,319,419$.

San José de Guadalupe, pueblo (California Alta): 397, 432.

San José de la Laguna de Guaymas; vid. Guaymas, misión.

San José de Pimas (Sonora): 145, 146, $170,171,251$.

San José de Temaichic; vid. Temaichic.

San Juan, aguaje: 377 .

San Juan (N. México) : 424.

San Juan, pueblo de norteños o julime. ños (N. Viz.) : $221,224$.

San Juan Bautista, cuerpo de dragones de: $317,480$.

San Juan Bautista, isla: 87.

San Juan Bautista, real de minas (N. Viz): 31.

San Juan Bautista de Casta, hacienda (N. Viz.) : $110,283,319,339,353$, $355,376,411,413$.

San Juan Bautista de Horcasitis, escuadra (N. Santander): 126.

San Juan Bautista de Sonora, real de minas: $55,82,85,91,121 .-527$. 
San Juan Bautista de Río Grande, misión (Coahuila): 41, 422.

San Juan Bautista de Río Grande, presidio; vid. Río Grande.

San Juan de Capistrano, misión (Te. xas) : $422,423$.

San Juan de los Lagos: 5, 92.

San Juan de Londó, misión (California) : 45 .

San Juan de Mezquital, misión (N. Viz) : 12.

San juan Nepomuceno (N. Viz.) : 339 , $342,367,409$.

San Juan del Río (N. Viz.) : 12, 37, 75, $190,228,288,306,316,317,342$. $344,362,370,375,378,409,411$, $441,442,465,480,511 .-519$.

San Juan de Santa Cruz, Manuel; gobernador de N. Vizcaya: 63.

San Lorenzo, hacienda (N. Viz.) : 27, 411.

San Lorenzo (N. México) : 26, 424.

San Lorenzo, misión (Coahuila): 100.

San Lorenzo, misión (Texas): 103.

San Lorenzo, real de minas (Sonora): 121.

San Lorenza del Escorial (España) : 281.

San Lucas, cabo: 91, 93, 161, 163, 169. -520 .

San Luis (Luisiana): 495.

San Luis, colonia de franceses: 40.-526.

San Luis, real de minas (N. Viz.) : 509.

San Luis de Amarillas, presidio; vid. San Sabá.

San Luis de 1a. Paz (N. España) : 154 , 161.

San Luis de Potosí; vid. Potosí.

San Marcial; vid. Buenavista, presidio.

San Marcial, real de minas (Sonora) : 261, 330, 419.

San Marcos, presidio y misiones del río de (Texas) : 100.

San Marcos, río: 98, 101, 382.

San Marcos de las Cuatro Ciénagas, sie. rra: $80,483$.

San Martín, minas (N. Viz.) : 5, 27.-519.
San Mateo, hacienda (N. Viz.): 412.

San Mateo, misión (N. Viz.): 20.

San Miguel, iglesia: 538.

San Miguel, misión (N. Viz.) : 20, 423.

San Miguel, río: 383.

San Miguel, río: 43.

San Miguel el Grande: 4, 5, 482.

San Miguel de Horcasitas, presidio, vid. Horcasitas.

San Pablo, laguna: 230, 492, 483.

San Pablo, misión (N. Viz.) : 20.

San Pablo, misión (Son.) : 14.

San Pedro, arroyo: 483.

San Peciro, misión (N. Viz.): 14.

San Pedro, río: 14.

San Pedro, río: 43, 44.--546.

San Pedro, río: 111, 138.

San Pedro del Alamo, conde de: 109.

San Pedro y San Pablo del Vicuñer, misión en río Colorado: 394.

San Petesburgo: 536.

San Rodrigo, río: 223.

San Román, Jerónimo de; capitán: 16.

San Sabá, paso (Coahuila), vid. San Vicente, paso.

San Sabá, presidio de San Luis de Amarillas de (Coahuila): 100-103, $106,125,126,136,137,139,197$, $199,202,211,213,214,218,222$, $232,235,240,241,269,282,286$, $288,295,298,300,306,320,339$. $341,346,349,353,356,358,372$, $380,427 .-532,538,539,547$.

San Sabá, río: 99, 100, 471, 507.

San Sebastián, paraje (California Alta): 396.

Sai) Sebastián, villa de: $128,417,419 . \ldots$ 519. vid. Chiametla.

San Vicente, paso y presidio de: 545.

Sanson d'Abbeville, N.: 521.

Santa Ana (N. México) : 248, 424.

Santa Ana, real de minas (California): $165,167,175$.

Santa Ana (Sonora) : 419.

Santa Ana, misión (N. Vizcaya) : 14, $412,423$. 
Santa Bárbara, canal: 163, 290, 396 . 398.

Santa Bárbara (Sonora): 174.

Santa Bárbara, sierra: 338.

Santa Bárbara, presidio (California Alta) : 423 .

Santa Bárbara, valle (N. Viz.) : 8, 9, $11,18,19,31,92,119,122,316$, $317,342,343,370,409,412,442$.519.521 .

Santa Catalina, río: 438.

Santa Catalina, sierra: 448 .

Santa Catalina (N. León) : 376.

Santa Catalina Mártir de Río Verde: 94.

Santa Catalina de Tepehuanes, misión y presidio (N. Viz.) : 14, 16, 19, 22 , 23, 31-33, 39, 61, 64, 65, 70, 71.

Santa Clara, hacienda (N. Viz.) : 112 , 139, 376.

Santa Clara (N. México) : 424.

Santa Cruz, marqués de: 216.

Santa Cruz, río: 36, 43.

Sant2 Cruz (California) : 2.

Santa Cruz, paraje (Sonora): 238.540, 541; presidio, vid. Terrenate.

Santa Cruz de la Cañada (N. México) : $420,424$.

Santa Cruz de Cholomes, misión (N. Viz.) : 111,355 .

Santa Cruz de las Flores, real de minas: 92.

Santa Cruz de Mayo (Sonora): 168, $175,177,321,360$.

Sant: Cruz de Querétaro, Colegio Apostólico: 40, 41, 203, 226, 256, 282.

Santa Eulalia, real de minas (N. Viz.) : 92, 119, 500.-533.

Santa $\mathrm{Fe}$, villa (N. México) : 11,26 , $28,75,104,107,108,118,244,245$, $248,249,325,333,385,387,420$, $424,425,-537-538,544,545$.

Santa $\mathrm{Fe}$, presidio (N. México) : 61, 62, $71,73,75,125,136,137,199,219$, $224,232,240,244,247,266,267$, $279,294,298,306,325,333-336$,
$385,386,390,403,434,465,480$, $506-508 .-537 \cdot 538,540,544,545$.

Santa Fe de Bogotá: 461.

Santa Gertrudis, misión (California): 88.

Santa Gertrudis, paraje: 483.

Santa Gertrudis del Altar, presidio, vid. Altar.

Santa Gertrudis de Pantita, hacienda (N. Viz.): 204, 376.

Santa Gertrudis de los Sumas, misión (N. Viz.): 26-27.

Santa Isabel, misión (N. Vizcaya): 12, 423.

Santa María, puerto (Sonora): 168.

Santa María, río: 119, 129, 234.

Santa Maria, Fr. Vicente de: 68, 96.

Santa María de Aguayo, escuadra de (N. Santander) : 126.

Santa María de los Angeles, misión (California) : 88.

Santa María y Escobedo, Manuel; juez de la Acordada: 362.

Santa María de los Lagos: 5.

Santa María de Llera, escuadra (N. Santander) : 126.

Santa Maria Otaes, misión: 14.

Santa María de las Parras, misión (N. Viz.): 14.

Santa María del Río, presidio: 6.

Santa María Suamca o de los Pimas; misión (Sonora): 87, 89, 173, 459.

Santander (N. Santander) : 95.96, 483 . 484.

Santa Olalla, paraje (California Alta): 396.

Santarén, P.; jesuita: 13.

Santa Rita, paraje (N. Viz.) : 230, 339, 354.

Santa Rita, sierra: 448.

Santa Rosa, cuerpo de dragones provinciales: 480 .

Santa Rosa (Texas) : 532.

Santa Rosa, misión (California) : 87, 88.

Santa Rosa, real de minas, vid. Palo En. sebado.

Santa Rosa, sierra: 80, 407. 
Santa Rosa del Corodeguachi, presidio, vid. Fronteras.

Santa Rosa del Sacramento, misión (Coahuila) : 37.

Santa Rosa del Sacramento, o del Aguaverde, presidio (Coahuila), vid. Sa. cramento y Aguaverde.

Santa Rosa de Tarahumares, vid. Cusihuiriáchic.

Santa Rosalía, paraje (Coahuila): 483.

Santa Rosalía, rancho (N. Viz.): 337 , 375.

Santa Rosalía (Sonora): 145, 319, 320.

Santa Rosalia Mulegé, misión (California) : 45 .

Santiago, cuerpo de dragones provinciales: 380 .

Santiago: 521.

Santiago, río Grande de: 2-4, 151.

Santiago de Compostela (España): 3. Santiago de los Coras, misión (California) : 45 .

Santiago de Liguig, misión (California) : 45.

Santiaga Papasquiaro, misión y presidio: $14,75,120,129,228,316,342$, $344,370,409,411,412,441,465$, $480,500,511$.

Santiago de Tepehuanes, o de Papasquiaro, río: 13, 14, 119.

Santiago de los Valles, vid. Valles.

Santiaguillo, paraje (N. Viz.) : 110.

Santillana (N. Santander): 95.

Santísima Trinidad, real de minas (N. Viz.) : 500.

Santisima Trinidad, real de minas (Sonora), vid. Trinidad.

Santisteban de! Puerto: 519.

Santo Domingo (N. México) : 128, 387, 423.

Santo Domingo, isla: $474,481$.

Santo Domingo, paraje (N. Viz.) : 230.

Santo Domingo, paso de: $300,348$.

Santos, Cristóbal de los: 506, 507.

Santo Tomás, misión (N. Viz.): 423.

Santurces, real de minas (Sonora) : 121 .

San Vicente, paraje (Coahuila): 298.
San Vicente, paso: 221, 223, 224, 227, $232,235,286$.

San Vicente, Juan de; ayudante inspector: $215,228,229$.

San Vicente Ferrer, misión (California Alta) : 398.

Saracache, real de minas (Sonora): 121, 122, 206, 255.

Saravia, Atan:sio G.: 10, 15, 409.

Sardinas, haciend? (Coahuila): 297, $298,355,483$.

Saric, misión (Sonora): 262, 263, 331, 387.

Sastre, Mateo; gobernador de Sonora: $225-227,252,254.259,265$.

Satevó, misión (N. Viz.) : 20, 129.

Satin, comerciante francés: 104.

Sauceda, hacienda de la (N. Viz.) : 75. 530.

Saucillo, hacienda (N. Viz.) : 230, 412. Saucillo, paraje (California Alta) : 433 . Sauer, Carl: 30.

Sauz, destacamento (N. Viz.): 339.

Schäfer, Ernesto: 49, 52.

Scholes, France V.: 28, 30.

Schroedex, Albert H.: 25, 30.

Sebo, jefe indio: 231.

Secretaría de cámara y gobierno de la comandancia general: 278 .

Sedelmayr, P.; jesuita: 88, 89.

Sendes, indios: 469.

Senecú (N. México) : 25, 26, 333, 424.

Seno Mexicano, vid. Golfo de México.

Sentipac (N. Galicia) : 91.

Seris, indios: $35,36,43,65,73,76$, $81,82,84-87,121-123,145,147$, $150,155,158,165,166,170,172$. $174,176,177,179.185,190,200$, $204,205,207,224,251,255,258$, $263,283,285,291-294,303-305$, $325 \cdot 329,331,340,387 \cdot 391,394$. $395,406,407,418,435.437,439$, $446,447,-527,529,533,534,535$, 542 .

Serra, José Miguel: 418.

Serra, Fr. Junípero; franciscano: 203, $290,291,432$. 
Serrano, José Antonio: 393.

Serrano, Juan Antonio; capitán de Sacramento: 217.

Severo, río: 267.

Sevilla: 74, 82, 96, 98, 159, 164, 266, $409,430,432 .-524,533$.

Sevilleta (N. México) : 333.

Sianori, real de minas (N. Viz.) : 119 , $342,370,409,412,500$.

Sibirijoa, real de minas (Sonora): 121, 500.

Sibubapa, jefe indio: 180.

Sibubapas, indios: $165,166,170,176$, $179,181,185,207,208,225,252$, $255,259$.

Sibulos, indios, vid. cibolos.

Sierra Gorda: 495.-531.

Sierra Gorda, conde de: 477, 484, 513, vid. Escandón.

Sierra Madre Occidental: $6,9,13,14$, $18.22,29,44,73,76,78,136,138$, $145,239,315,321,369,408,414$, $449,488,500,502$.

Sierra Madre Oriental: 6.

Sierra Morena (España) : 161.

Sierra Osorio, Lope de; fiscal de Méxicc, gobernador de N. Vizcaya: 23, $31,79$.

Sierra de Pinos, real de minas (N. Galicia): 92.

Siete Años, Guerra de los: 106, 134.

Siete Ríos, indios: 24.

Sigüenza y Góngora, Carlos de: 28.-. 522.

"Sinaloa", balandra: 164, 168.

Sinaloa, presiclio de San Juan Bautista o San Felipe de: 15, 16, 22, 23, 27 , $31,32,36,39,43,61,64,69,71$, $73,76,82,83,84,87,137,527.529$. Vid. Pitic, Buenavista, Altar, presidios.

Sinaloa, provincia de: $3,9,32,51,52$, $56,68,72.74,76.78,81,85,91,114$, $115,120,127.129,133,134,144$, $150,156,159,167,168,179,187$, $200-202,206,207,211,251,255$,
$275,279,314,315,364,416-418$, $511 .-521,522,534,542$.

Sinaloa, villa y misión de San Felipe y Santiago de (Sonora) : 8, 13, 15, 82, 129, 177, 418, 500.

Singuiripác: 519.

Sinoquipe (Sonora) : 319.

Siquilande, jefe indio: 239.

Sobaipuris, indios: $43,44 .-529,535$.

Sobas, indios: 36,43 .

Socatiles, indios: 529.

Socorro (N. México) : 26, 333-335, 424.

Socuina, jefe indio: 471.

Soledad, real de minas (Sonora): 121.

Soledad de Janos, misión (N. Viz.) : 26, 27.

Soler, ministro: 502, 511.

Soler, Nicolás; capitán de Tucson: 316 , - 478 .

Sombrerete, real de minas: $5,31,37$, $64,75,87,92,114,122,315,344$ 541.

Sonoita, misión (Sonora) : 45, 395.

"Sonora", goleta "Nra. Sra. de la Soler dad", alias: $152,321 .-541$.

Sonora, presidio, vid. Compañía volante de Sonora y Fronteras, presidio.

Sonora, provincia de: $9,18,20,24$, $26.29,32,34.36,38,39,43.45,55$, $56,59.61,65,67,69,72 \cdot 78,81.94$, $109 \cdot 112,114 \cdot 116,118,120,121,123$, $124,127 \cdot 129,131-134,136,137$, $139,141-148,150 \cdot 161,165 \cdot 167,169$. $187,189 \cdot 191,193,200 \cdot 203,205 \cdot 212$, $215,220,224.226,229,235,237$. $241,250-268,275,278-280,282$, $284.289,291.294,297.299,302-309$. $312 \cdot 315,318-321,324-333,335,336$, $340,347,352,353,358 \cdot 361,363 \cdot 366$, $370,378,380,385,387-398,405$, $406,416.420,422,424,425,429$, $432.438,440,441,444,446.448$, $452,454,456.465,467,475,480$, $485,486,490.492,505,507,508$, $511,512 .-52 \mathrm{C}, 522,524,527.530$, $533.535,540,542,544,546,547$. 
Sonora, río: $18,35,128,205,278,300$, $305,364,-546$.

Sonora, valle de: $122,128,261,319$, $365,419$.

Sosa, Juan José; cura de Santa Bárbara: 412 .

Soto la Marina, escuadra (N. Santander) : 126.

Soyopa, real, vid. San Antonio de ha Huerta.

Suamca, vid. Santa María Suamca.

Suaqui, pueblo y misión (Sonora) : 82 . $145,185,207$.

Suaquis, indios: $165,176,180 \cdot 183$, 205, 207, 208, 255, 258; vid. Sibubapas.

Súchil, valle del: 410 .

Suchitepec (N. Galicia) : 128.

Sueur, le: 524.

Sumas, indios: $12,26,27,29,30,74$, $110-113,138,341,372 .-528$.

Superintendencia general de real hacienda en provincias internas: 278,323 . $324,487.489$.

Surville, Luis, cartógrafo: $172 .-529$, 540.

\section{$\mathrm{T}$}

Tabacos, estanco de: $363,364,366,393$, $414,496,502 .-546$.

Tabahueto, real de minas de San Anto. nio $(\mathrm{N}$. Viz.): $119,342,370,409$.

Tabalaopa, hacienda (N. Viz.): 27 , 139, 221.

Tabasco: 74, 92.

Tacubaya (N. España): $137,140,141$, $143,216$.

Tagadachilé, jefe indio: 377 .

Tahuchimpia, jefe indio: 458 .

Tagle y Bustamante, Bernardo; capitán de Terrenate: 84, 112.

Talapuses, indios: 494.

Tamarón y Romeral, Pedro; obispo de Durango: $87,114,115,119,120$, $122 \cdot 124,131,405,413,421,507$.

Tamaulipas, provincia: $6,7,94.96$, vid. Nuevo Santander.

Tamaulipas, sierra: 492 .
Tamazula, misión: 14 .

Tamazula, real de minas (Sonora) : 185, 500.

T'ambor, cerro del: 83.

Tamos, presidio: 6, 61, 94 .

Tampico, río de: 523.

Tampico, villa de: $6,7,17,70,94-96$. $519,525,531$.

Tanos, indios: $24,26$.

Taobayas, indios: $102,106,198,226$, $235,270,272,295,296,308,345$, $348,382,384,471,494,495,505$. 507. - 546, 547, vid. Jumanos.

Taos (N. México): 11, 24, 104, 106, $107,128,199,244,246,248,249$ $333,334,336,384-386,420,424$.

Taos, indios: 25 .

Tapacolmes, misión (N. Viz.): 423.

Tapacolmes, indios: 35 .

Tapado, rancho (Coahuila): 297, 298.

Tapia, P. Juan de; jesuita: $13,15$.

Tapia, Narciso; teniente de Janos: 241 , 282.

Tarabal, Sebastián: 266.

Tarahumara, Alta y Baja: 12, 18.20, $33-37,76-78,111 \cdot 113,115,129,133$, $134,188,189,193,194,361,423$, $444,449,458,466,475,476,487$, 489.

Tarahumiras, indios: $18,19,21,22,28$, $29,78,190,214,223,227-230,268$, $316,337,338,441-443,445,449$ $460,465,475,492$.

Tararecua, barranca: 314 .

Tartaria, mar de: 158; provincia: 216 Tasajera, sierra: 439 .

Tasco (N. España): 151.

Tastazagonis, indios: 530 .

Talwakonis o tuacanas, indios: 102, 198, $226,270,272,296,382,384,471$, 494, 495, 506.

Tayoltita, real de minas (N. Viz.) : 500.

Tazazalco, presidio: 5 .

Tecolote, cerro (Sonora): 172.

lecolote, Don Francisco el, jefe indio: 37.

Tecolotes, Ancón de los: 111. 
Tecoripa, misión (Sonora) : 81-83, 145 . 204, 208.

Teixidor, Felipe: 196.

Tejada: 487.

Tejamé (N. Galicia) : 344 .

Temaichic, misión de San José de (N. Viz.) : 20,320

Temitas, indios: 530 .

Temosachic (N. Viz.) : 139, 414, 423.

Tenuaje, bosque (Sonora): 171, 179 , 180, 257.

Teopari (Sonora) : 391.

Tepaqui (Sonora): 128.

Tepehuana, provincia: $13,75,76,87$, 128, 129, 134, 188, 193, 194.

Tepehuanes, indios: $8,9,13,14,16$, $18,21,35,230$.

Tepehuanes, río, vid. Santiago de Tepehuanes.

Tepehuanes, presidio, vid. Santa Ca. talina.

Tepezala, minas de: 6 .

Tepic (N. Galicia) : 65, 128, 151, 152.

Tepoca, paraje (Sonora): 255.

Tepocas, indios: $35,43,76,331,389 .-$ 529, 533.

Terán, Pedro; teniente del Príncipe: 282.

Terán de los Ríos, Pedro; gobernador de Coahuila: $40,-523$.

Teria, pico de: 223.

Terocodames, indios: 76 .

Terranova: 526.

Terrenate, presidio de San Felipe de Jesús Gracia Real de Guebavi o (Sonora): $82,84,85,89,90,112,125$, $137,145,166,170,173,175,218$, 224, 238; en paraje de Santa Cruz: $240,242,251,259,262,266,327$, $331,332,385,387,388$; en paraje de Nutrias: $388-391,419,434,435$, $438,439,445,448,480,507$.- 527 , $535,537,540,541$.

Tesguino, aguardiente: 365 .

Tesopaco, hacienda (Sonora): 391.

Tesuque o Tuzuqui (N. México): 245 , 424.
Teul, monte: 520.

Teuricachi (Sonora): 39.

Texas, indios: $101,102,225,226,270$, $296,346,382,383$.

Texas, presidio, vid. Dolores.

Texas, provincia: $17,33,34,40-43,50$, $52,57,65,69-71,73,74,76,77,79$, $94,96-105,115,116,118,124-126$, $129,131,136,143,197.199,202$, $223,225,226,232,240,243,268$. $273,275,288.293,296,297,299$, $302 \cdot 304,308,309,311-315,318-320$, $345-349,363,373-375,377,378$, $380 \cdot 384,406,407,411,422.424$, $433,434,447,453,455,458,462$, $463,467,469,476,479,482,483$, $486,490,491,493.495,501,505$, $506,512-513--522-524,526,529-533$, $539,546,548$.

Thomas, Alfred B.: 104, 106.108, 197, 2.76, 322. -543 .

Tiburcios, pueblo (N. México): 459, 492, 503.

Tiburón, isla: $35,86,90,131,16 \hat{6}, 176$, $179-181,183,184,207,225,226$, $255,257,293,328,389,390,512$ $527,533,535,540,541$.

Tiburones, indios: $181,224.227,256$. $258,283,285,303,326,328,331$, $389,390,395,436$.

"Tiembla la Tierra", jefe indio: 146

Tienda de Cuervo, José; gobernador in terino de Sonora: 86, 96, 151, 250. 534.

Tierra Afuera: 129.

Tierra Blanca, hacienda (N. Viz.) : 214.

Tiguas, indios: $27,194,385$.

Tillemon, señor de: 522 .

Timpanogos, Laguna de los: 543, 545.

Tinaja, paraje (Sonora): 325.

Tisné, Du; explorador francés: 40.

Tisyeendis, indios: 196.

Tizón, río del: 250.-521, 527, 547.

Tizón, sierra del: 491.

Tlaxcala (N. España) : 7, 74, 486.

Tlaxcaltecas, indios: $14,21,23,97$, $100,120,316,513$. 
Tobosos, arroyo de los: 180.

Tobosos, indios: $9,16,18,19,21,22$, $30-32,36-38,107,295,501-540$

Todos los Santos, misión (California): 87.

Tolede, Bernabé Angel de: 330.

Tolosa, Juan de: 3 .

Toluca, (N. España): 140, 280, 281.

Tomanaguare, jefe indio: 458 .

Tomé (N. México) : 107, 128, 244, 245

Tomichic, misión (N. Viz.): 423.

Tomochic, misión (N. Viz.): 35, 319 , 423.

Tomohua, Francisco; capitán ópata: 444.

Tonichi (Sonora): 204.

Tonkawas o tancahuas, indios: 101 , $102,296,345,348,383,384$.

Toos, indios: 530 .

Topago, real de minas (N. Viz.) : 92 , $119,175,342,409$.

Topago de la Plata, real de minas (Sonora): 121,500 .

Topia, real de minas y misión $(\mathrm{N}$. Viz. caya) : 8, 9, 12-14, 87, 119, 120, 129. 542 .

Torín, misión (Sonora): 83.

Toro Blanco, jefe indio: 505.

Tortuga, paraje (Sonora): 325, 326.

Tortugas, indios: 529.

Torre, Bernardo de la: 404.

Torre, marqués de la; inspector de in. fantería de N. España: 136, 280.

Torres de Laguna, Juan de: 5 .

Torres Lanzas, Pedro: 180, 439, 507, 517.

Torreón, misión y hacienda de $(\mathrm{N}$. Viz, caya) : $12,27,229,288,338,375$, 413.

Tosacondata, jefe indio: 458 .

Toussaint, Mnnuel: 7.

Tovar, capitán de Río Grande: 482.

Tovar, Antonio; capitán de San Carlos de Cerro Gordo: 282.

Tovar, Francisco; capitán de Terrenate: 238, 242, 260, 263.

Tras Os Montes (Portugal): 431.
Trébol Navarro, Francisco; alcalde mayos: de Alburquerque: 334.

T'resierra y Cano, Alonso; intendente interino de Sonora: 512.

T'respalacios, capitán de Terrenate: 327.

Trespalacios, Francisca: 404.

Treutlein, Theodor E.: 67.

I'ributos en provincias internas: 364 . $366,393$.

Trillo, José: 253 .

Trinidad, presidio del río, vid. Orco. quiza.

Trinidad, real de minas de la Santísima (Sonora): 92, 151, 319, 320, 364, 500.

Trinidad, río: 42, 70, 96, 105, 273, 384, $494,526,530,531$.

Tripas blancas, indios: 76. - 528, 540 .

Tristán, Esteban Lorenzo; abispo de Durango: 464.

Tropa ligera: $297-299,305,306,308$, $339,348,349$.

Tiaspe, Ignacio, jefe indio: 1.87

Tuavichis, indios barbones: 543 .

Tubac, presidio de San Ignacio de (Sonora): $87,90,137,141,145,146$, $170,173,204,218,224,238,252$, $259 \cdot 261,265,266,282,332,387 .-$ 537, vid. Tucson.

Tubaris, misión (N. Viz.): 423.

Tubutama, misión (Sonora): 43, 89, $265,267,329,331 .-541$.

Tucson, paraje (Sonora) : 128, 238.-541.

Tucson, presidio de San Agustín dei (Sonora): 238, 240, 262, 326, 327 . $329,332,387,389,391,406,419$. $434,435,437.440,444,448,450$, $465,478,480,491,506,507,-540$, $541,545$.

Tueros, Pedro de; gobernador de Coahuila: $207,251.254,261,262,282$, $293,324,326,329-332,361,379$, $380,389,394-396,398,432,434$, $468,470,475,476,512,513 .-541$. Tula : 94.

Tulancingo (N. España): 160. 
T'ulares, paraje (California Alta): 329. Tumuzaqui, Ignacio; jefe indio: 225 , 256.

Tunal (N. Viz.) : 510 .

Turbio, río, vid. Grande.

Tutuaca, misión de Jesús de (N. Viz.) : $20,35,129,319,423$.

\section{U}

Ubilla, general de flota: 59.

Ugalde, capitán de Cerro Gordo, vid. Hugalde.

Ugalde, Juan de; comandante de las provincias de Oriente: $272,295,299$, $345,347,361,376-380,398,404$, $429,434,453.455,457,459,461$. $464,466-471,473-479,481,484$, $485,503$.

Ugarte, P., jesuita: 45 .

Ugarte y Loyola, Jacobo de; comandante general de provincias internas: $189,213,223,227,231,234.236$, $269,272,273,282,283,295,300$, $302,307,325,333,345,347,361$, $388.390,393,394,405,429,437$, $450 \cdot 469,473 \cdot 479,492,501,505,506$, 509.

Ulúa, San Juan de: 74, 405, 444.

Ulloa, Antonio de; gobernador español de Luisiana: 197.

Upanguaymas (Sonoras) : 333.

Uranga, capitán: 83.

Urdiñola, Francisco de; gobernador de N. Vizcaya: $10,15$.

Ures, misión de San José de los (Sonoras): $128,178,191,204,251,263$, 319,512 .

Uria, J. M. de: 542.

Urique, real de minas (N. Viz.): 38 , 175.

Urquidi, Manuel de: 403, 404, 414, 434.

Uruache (N. Viz.) : 175.

Uruapan (N. España): 154.

Uruapan, real de minas (N. Viz.) : 500 .

Urrea, Bernardo de; capitán de Altar:
$87,133,166,171,183,207,226$, $227,257,259,260,282$.

Urrea, Ignacio de; teniente de Pitic: 436.

Urrea, Miguel de; capitán: 329, 330.

Urrutia, José; intendente interino de N. Vizcaya: $412,510$.

Urrutia, José de; ingeniero militar: 136, $140,172,216,218 .-536-539$.

Urrutia, José de; capitán de Béjar: 99. Urrutia, Toribio de; capitán de Béjar: 99, 100.

Utah, lago: 267.

\section{V}

Valcárcel, Domingo de; auditor de México: $97,112,144-147,154,366,367$.

Valdés, Cayetano; ministro de Hacien' da: $461.467,470,471,473 \cdot 478,483$, 487.

Valdés, Fr. Francisco Joaquín; franciscano: $176,181,182$.

Valdés, Luis de; gobernador de N. Viź, caya: 19, 20, 22.

Valencia (España); 217.

Valentin, jefe indio: 436.

Valera, Juan Manuel; general ópata: $299,305,390$.

Valerio, dos jefes indios: 231.

Valero, marqués de; virrey de $\mathrm{N}$. España: $59,63,65,69,74$.

Valiente, Pedro; juez de la Acordada: 362.

Valladolid de Michoacán (N. España) : $154,431,510$.

Valle, paraje del (N. México) : 245.

Valle Ameno, marqués de; vid. Moreno de Castro.

Valle de Banderas (N. Galicia): 67, 145.

Valle de Casas Grandes (N. Vizcaya): 339,358 .

V.allecillo (N. León) : 271, 376.

Valle del Río Florido (N. Viz.) : 28 , $229,283,288,316$.

Valles (N. León) : 376. 
$\checkmark$ alles, villa de Santiago de los; presidio: $6,17,69,71,73,94 .-519$.

valle de San Bartolomé (N. Viz.): $12,13,18,37,75,110,113,194$, $195,228,229,286,288,315 \cdot 317$ ( $319,320,321,335,341-343,370$, $376,409,478,466,490,492,493$, $503,508,510,512 .-539$.

Valle de San Bartolomé; presidio (N. Viz.) : 69, 71, 74, 109, 110, 132, $136,137,234$.

Vaile de San Buenaventura (N. Viz.) : $76,110,111,113,122,123,132$, $139,231,234,337,339,342,343$, $355,358,367,409,450,456,459$.

Valle de San Buenaventura, presidio; vid. San Buenaventura.

Valle de San Francisco; presidio: 6 .

Valle de San Clara (N. Viz.) : 339.

Valle de Santa Rosa (Coahuila): 273, $283,297-300,305,306,310,319$, $320,330,333,335,338,340,341$, $345,347,353,354,362,380,407$, $408,469,470,479,481-484,495$, 501.

Valle del Suchil, conde del: 415, 416, 420.

Varela, José; teniente de Bacuachi: 435.

Varela, José Manuel: 149.

Vargas Zapata y Luján, Diego de; gobernador de N. México: 27.28, 49, 54.

Vázquez de Acuña, Isidoro: 143, 192.

Vázquez de Coronado, Francisco: 3, 9, $17,30,67$.

Vázquez de Mercado, Ginés: 3.

Velarde, paraje (N. Viz.) : 439, 449.

Velarde y Cienfuegos, Juan Antonio; fiscal de México: 147, 167, 404.

Velarde, Fernando de: 112.

Velarde, Pedro: 404.

Velasco, Andrés de: 138.

Velasco, Luis de; virrey de N. España: $4,5,11$.

Velasco Ceballos, Rómulo: 213, 215, $222,225,228,229,246,257,277$. 324.
Velasco y Restán, Andrés José: 411.

Velázquez, Joaquín; teniente de Loreto: $267,431$.

Velázquez, Juan; gobernador interino de N. Vizcaya: 191, 454, 508, 509.

Vélez Cachupin, Tomás; gobernador de N. México: 107, 108, 197.-547.

Vélez Escalante, Fr. Silvestre; francis cano: 266, 281.-543, 545, 546, 547.

Velicatá, misión (California); 267.

Venados, indios: 112.

Venegas, Miguel; jesuita: 534, 536.

Ventanas, real de minas (Sonora): 500 .

Ventura T'aranco: 425.

Veracruz: $4,59,67,74,84,92,93$ $12 \%, 131,140,146,149,151,152$ $188,243,277,290,291,312,366$, $376,415,452,495,511 .-541,543$.

Vergara, Domingo de; comandante de Bavispe: $391,438,440,448,456$, $458,459,465$.

Vergara, Juan de: 50.

Vergara Alegri, José de; contador de lil Caja de México: 61.

Versalles, $\mathrm{Paz}$ de: 134.

Vértiz, Juan José de: 487.

Vesga, Mateo de; gobernador de N. Vizcaya, 18.

Vial, Pedro: 506, 507.- 546 .

Vicepatronato real en provincias inter nas: $78,509$.

Vidais, indios: $97,101,106,225,270$, $271,273,296,345,382,383,479$, 495. - 530 .

Vidal de Lorca, alférez de San Eleazario: 492.

Vidal de Lorca, Melchor; gobernador de N. León: 271, 454, 477.

Vidaurre, Fermín de; capitán de Mapimí: 109.

Viejo, Sierra del: 206, 253.

Vila, Vicente; piloto: 163.

Vildósola, Agustín; gobernador de Sonora: $82.84,89,90,109,112$.

Vildósola, Gabriel Antonio de; capitán de Fronteras: 86, 150, 172, 179, 226. Vildósola, José Antonio; capitán de 
Terrenate: $180.182,185,259,260$, $385,388,390,393$.

Villa, Eduardo W.: 86, 330, 359, 388.

Villa, Manuel; alférez: 215.

Villaescusa, Pedro; teniente de San Ig. nacio: 448.

Villagrá, Gaspar de: 11, 15, 67.

Villalba y Angulo, Juan de; inspector y comandante de las armas de N. Es. paña: 132, 135, 136, 140, 143, 198, $278,280,431$.

Villaseñor y Sánchez, José: 95, 99, 200. $-535,540$.

Villaverde, Manuel de; capitán de San Bartolomé o Cerro Gordo: 132, 138, 229, 233, 282.

Vinagrillos, rancho (N. Viz.): 369.

Vindel, Francisco: 527, 528.

Viniegra, Juan Manuel de; secretario de José de Gálvez: 144, 153, 156, $162,164,168,178$.

Vipici, jefe indio: 180, 182, 183.

Virginia: 521, 523.

Vivero, Domingo de: 276.

Vizarrón, misión (Coahuila) : 422, 423.

Vizarrón y Eguiarreta, Juan Antonio; arzobispo-virrey de N. España: 80.

Vizcaino, Sebastián: 163.-520, 536.

Volante, jefe indio: $393,375,376$.

\section{W}

Wall, Agustín: 196.

Washington (USA): 15, 16, 30, 322 .

Wichitas, indios: $102,226,382,471$, $494,505,506$.

Winnipeg, Lago: 536.

Worcester, Donald E.: 25, 30, 107, $334,453,508$.

\section{$\mathrm{X}$}

Xamay, presidio: 5 .

Xichú, presidio: 5.

Xilliú, real de minas: 6.

Ximénez Pérez, Fr. Diego; franciscano: 283.

Xipocales, indios: 18.
$\mathbf{Y}$

Yamoriba, misión (N. Viz.) : 14.

Yamparicas, indios: $307,505,506$.

Yaqui, río: $9,13,17,18,35,83,87$, $123,128,129,131,150,151,154$, $178,208,251,393$.

Yaquis, indios: $83,122,168,170,172$, $177,179,181,252,255,262,305$, $329,388,391,413 .-530$.

Yarto, Felipe; teniente de gobernador de N. Vizcaya: 342.

Yavapai, indios: 30 .

Yberville, Le Moyñe d': 40.

Yécora (Sonora) : 319.

Yepachic, misión (N. Viz.) : 319.

Yepómera, misión ;(N. Viz.) : 35, 139.

Yerbipiames, indios: 99.

Yermo, Juan Antonio: 455.

Yermo, Juan Francisco: 434.

Yojuanes, indios: 99, 101.

Ysosé, jefe indios: 459.

Yuburigipci, Ignacio; jefe indio: 259.

Yucatán: 74, 243, 483.

Yumas, indios: $29,43,89,265,268$, $325,332,393-396,406,427,432$, 487.

Yupas o yupes, indios: 505, 506.

Yutas, indios: 103, 106, 107, 245, 247, $266,307,314,334,336,385,386$, $406,456,457,458,491,505,506$.530,543 .

\section{Z}

Zabala, Martín de; gobernador de N. León: 48.

Zacatecas (N. Galicia) : 1, 3.6, 12, 13, $17,27,31,42,48,61,64,92-94,115$, $119,127,129,133,136,137,292$, $293,346,347,407,423,431,466$, $519,520$.

Zacatecas, indics: 7, 9, 12, 14.

Zambrano, Juan José: 415.

Zapato Tuerto, jefe indio: $378,459$.

Zapato Zas, jefe indio: 484 .

Zapopán (Coahuila): 533. 
Zapote, mina (Sonora): 255.

Zaragoza: 59, 198.

Zarca, hacienda de la (N. Viz.): 286, 288, 319, 413.

Zayas, Cristóbal de; mariscal de cam. po: 198.

Zía, o Cía, o Sía (N. México): 248, 424.
Zubillaga, Félix: 87.

Zuñi (N. México) : 133, 244, 245, 248, $250,265 \cdot 267,334,385,420,507$. 529.

Zuñis, indios: 24.

Zúñiga, José; capitán de Tucson: 507. Zurdo, El; jefe indio: 484. 
ESTE LIBRO SE TERMINÓ DE IMPRIMIR EN la Imprenta del Consejo Superior de Investigaciones Científicas de Sevilla, el día 30 de MARzo DE 1965, FEstividad de Nuestra Señora de la Estrella LAUS DEO 



\title{
P U B L I CA CIONES
}

\author{
DE LA
}

ESCUELA DE ESTUDIOS HISPANO - AMERICANOS

\section{OBRAS PUBLICADAS:}

1 Anuario de Estudios Americanos Vol. I.-Sevilla, 1944.-XII+844 págs., 17 láms. $24 \times 17$ crns. -1.500 grs.-AGOTADO.

2 Pérez-Embid, Florentino: El Almirantazgo de Castilla hasta las Capitulaciones de Santa Fe.-Sevilla, 1944.-XVI+186 págs., 5 ilust., $14 \times 17 \mathrm{cms.;} \mathrm{rústica,} \mathrm{con} \mathrm{sobre-}$ cubierta.-360 grs.-AGOTADO.

3 Giménez Fernández, Manuel: Las Bulas Alejandrinas de 1493 referentes a las Indias. -Sevilla, 1944. $-\mathrm{XVI}+258$ págø., 5 ilustt., $24 \times 17 \mathrm{cms.;}$ rústica, con sobre. cubierta.-450 grs.-AGOTADO.

4 Memoria de Gobierno de José Fernández de Abascal y Sousa, Virrey del Perú. Edición de Rodríguez Casado, Vicente; Valderón Quijano, José Antonio. Estudio preliminar de V. Rodríguez Casado.-Sevilla, 1944. Dos tomos CLII + 495 y 584 págs., 15 lúms., $20 \times 13$ cms. Tela, con sobrecubierta.-1.750 grs.-180 ptas.-AGOTADO.

5 Calderón Quijano, José Antonio: Belice. 1663-1821.-Sevilla, 1944.-XIY + 504 págs., 32 láms., $20 \times 16$ cms.; tela, con sobrecubierta. -850 grs.-AGOTADO.

6 Carro, O. P., Venancio D.: La Teología y los teólogos-juristas españoles ante la Conquista de América.-Madrid, 1944.-2 tomos. 453 y 473 págs., $22 \times 16$ cms.; tela, con sobrecubierta.-1.250 grs.-AGOTADO.

7 Rumeu do Armas, Antonio: Colón en Barcelona.-Sevilla, 1944.-XII + 86 págg. $24 \times 78$ cms.-AGOTADO.

8 Jos, Emiliano: Investigaciones sobre la vida y obras iniciales de D. Fernands Colón.-Sevilla, 1945.-XVIII + 164 págs., 6 ilust., $24 \times 17$ cms.-330 grs.-AGOTADO.

9 Anuario de Estudios Americanos. Vol. II.-Sevilla, 1945.-XVIII + 936 págs., $24 \times 17$ cms. -1.790 gre.-AGOTADO.

10 Bayle, S. J., Constantino: El protector de indios. - Seville, 1945. - VIII + 176 págв., $24 \times 17$ cms. -325 grs.-AGOTADO.

11 Gutiérrez de Arce, Manuel: La colonización danesa en las Islas Virgenes.-Sevilla, 1945.-VIII+161 páge, 6 láms. $24 \times 17$ cms.; 275 grs.-AGOTADO.

12 Lohmann Villena, Guillermo: El arte dramático en Lima durante el Virreinato. Madrid, 1945.-XX +647 páge., $22 \times 16$ cms.; tela, con sobrecubierta; 1.050 grз. AGOTADO.

13 Alonso Getino, O. P., P. Luis: Influencia de los dominicos en las Leyes Nuevas. Sevilla, 1945.-VIII + 94 págs., $24 \times 17$ cms.; 170 grs.-AGOTADO.

14 Las Leyes Nuevas, 1542-1543. Reproducción fotográfica. Transeripción y notas de Antonio Muro Orejón.-Sevilla.-XXI + 26 págs., $24 \times 17$ cms.-AGOTADO.

15 Céspedes del Castillo, Guillermo: La avería en el comercio de Indias.-Sevilla, 1945. VIII + 187 págs., 8 láms., $24 \times 17$ cms.; 300 grs.-AGOTADO.

I6 Matilla Tascón, Antonio: Los viajes de Julión Gutiérrez al Golfo de Urabá. Sevilla, 1945.-VII + 84 págs., 4 láms., $24 \times 17$ cms.; 195 grs.-AGOTADO.

17 Palacio Atard, Vicente: El Tercer Pacto de Familia.-Sevilla, 1945.-XVII+377 páginas; 8 láms., $22 \times$ cms.; tela, con sobrecubierta.-600 grs.-AGOTADO.

18 Múrquiz de Miguel, José Luis: El Conde de Chinchón, Virrey del Perú.-Sevilla, 1945.-334 págs., 16 láms., $22 \times 16$ cms.; tela, con sobrecubierta; 650 grs.-AGO. TADO.

19 Pérez Embid, Florentino: Los descubrimientos en el Atlántico hasta el tratado de Turdesillas.-Sevilla, 1948.-370 págs., 35 láms., $22 \times 16$ cms.; tela, con sobrecubierta; 760 grs.-AGOTADO. 
20 Portillo y Díez de Sollano, Alvaro del: Descubrimientos y expediciones en las costas de California.-Madrid, 1947.-540 págs., 57 láms., $22 \times 16$ cms.; tela, con sobrecubierta; 900 grs.-AGOTADO.

21 Memoria de gobierno de Manuel Amat y Juniet, Virrey del Perú. Edición y estudio preliminar de Yicente Rodriguez Caeado y Florentino Pérez Embid.-Sevilla, 1947. XCII+ 845 págs., 12 láms., $20 \times 13$ cms.; tela, con sobrecubierta; 800 grs. -150 ptas. AGOTADO.

22 Ayaja, F. Javier de: Ideas políticas de Juan de Solórzano.-- Sevilla, 1946. XIII+583 págs., $22 \times 16 \mathrm{cms}$; tela, con sobrecubierta; 1.080 grs.-AGOTADO.

23 Lohmann Villena, Guillermo: El Conde de Lemos, Virrey del Perú.-Madrid, 1946. XVIII +472 págs., 11 láms.; $22 \times 16$ crms., tela, con sobrecubierta; 800 grs.-AGO. TADO.

24 Arregui, Domingo Lázaro de: Descripción de la Nueva Galicia. Edición y estudio do Françoìs Chevalier.-LXXI+161 págs., 4 láms., $24 \times 17$ cms.; 490 grs. -75 pesetas. AGOTADO.

25 Agia, Fr. Miguel de: Servidumbres personales de indios. Edición y estudio preliminar de F. Javier de Ayala.-Sevilla, 1946.-LII + I4I págs., $24 \times 17$ crns.; 450 grs. AGOTADO.

26 Memoria de gobierno de Joaquín de la Pezuela, Virrey del Perú. Edición y Prólogo do V. Rodriguez Casado y Guillermo Lohmann Villena.-Sevilla, 1947.-XLVI $\times 912$ páginas, 3 láms., $20 \times 13$ cms.; tela, con sobrecubierta; 850 grs. -150 pesetas. AGOTADO.

27 Rodriguez Casado, Vicente; Pérez-Embid, Florentino: Construcciones del Virrey Amat.--Sevilla, 1949.-XII +307 págs., 58 láms., $22 \times 16$ cms.; 500 gra. 90 pesetas. AGOTADO.

28 Schafer, Ernesto: El Consejo Real y Supremo de las Indias en la administración colonial.-Sevilla. Centro de Estudios de Historia de América (I tomo) y E. E. H. A. (II tomo), 1935 y 1947.-XVIII + 434 y XV+680 págs., 5 láms., $25 \times 17$ cms.; tela, con sobrecubierta; 2.500 grs, -450 pesetas.-AGOTADO.

29 Rumazu, José: La región amazónica del Ecuador en el siglo XVI.-Sevilla, 1945. $\mathrm{XII}+268$ págs., 12 láms., $24 \times 17$ cms.; 500 grs.-AGOTADO.

30 Palacio Atard, Vicente: Areche y Guirior: Observaciones sobre el fracaso de una visita al Perú.-Sevilla, 1946.-VIII+106 págs., 5 láms., $24 \times 17$ cms.; 200 gramos. 45 pesetas.-AGOTADO.

31 Anuario de Estudios Americanos. Vol. III.-Sevilla, 1946.-XVI +1.306 págs., 50 lá. minas, $24 \times 17$ cms.; 2.300 grs.-AGOTADO.

32 Herráez S. de Escariche, Julia: Don Pedro Zapata de Mendoza, gobernador de Carlagena de Indias.-Sevilla, 1946.-VIII+137 págs., 6 Iáms., $24 \times 17$ cms.; 250 grs. 60 pesetas.-AGOTADO.

33 Giménez Fernández, Manuel: Las doctrinas populistas en la independencia de Hispanoamérica.-Sevilla, 1947.-VIII+156 págs., $24 \times 17 \mathrm{cms}$; 300.-60 pesetas. AGOTADO.

34 Céspedes del Castillo, Guillermo: Lima y Buenos Aires. Repercusiones económicas y políticas de la creación del Virreinato del Plata.-Sevilla, 1947.-VIII+214 págs., ( láms., $24 \times 17$ cms.; 400 grs. 60 pesetas.-AGOTADO.

35 Rumeu de Arnas, Antonio: Los viajes de John Hawkins a América (1562-1595). Sevilla, 1947.-XX + 486 págs., 26 láms., $22 \times 16$ ems.; tela, con sobrecubierta; 650 grs.-AGOTADO.

36 Angulo Iñiguez, Diego: El Gótico y el Renacimiento en las Antillas. Arquitectura, escultura, pintura, azulejos, orfebrería.-Sevilla, 1947.-VIII+101 págs., 81 ilust., $24 \times 17$ cms.; 200 grs. -60 pesetas.-AGOTADO.

37 Díaz Yenteo, Fernando: Las campañas militares del virrey Abascal.-Sevilla, 194.8. XIII + 416 págs., $22 \times 16$ cms.; tela, con sobrecubierta; 500 grs. -120 pesetas. AGOTADO.

38 Anuario de Estudios Americanos. Vol. IV.-Sevilla, 1947.-XVIII+804 págs., 44 lá. minas e ilust., $24 \times 17 \mathrm{cms}$; 1.500 grs,-AGOTADO.

39 Estudios Americanos. Vol. I, núms. 1 al 4.-Sevilla, 1949. 342 págs.; $25 \times 17$ cms. AGOTADO. 
40 Diaz de Iraola, Gonzalo: La vuelta al mundo de la expedición de la vacuna. Prólogo de Gregorio Marañón.-Sevills, 1948.-XVI+102 págs., 20 láms.; $24 \times 17$ cms.; rústicn, con sobrecubierta; 300 grs. -75 pesetas.-AGOTADO.

41 Gil Munilla, Octavio: Malvinas. El conflicto anglo-español de 1770.-Sevilla, 1948. VIII + 154 págs.; $24 \times 17$ cms.; 257 grs.-AGOTADO.

42 Leturia, S. J., Pedro de: La Encielica de Pio VII (30 de enero de 1816) sobre la Revolución Hispanoamericana. - Sevilla, 1948. - VIII +93 págs., $24 \times 17$ cms.; 195 gramos. -40 pesetas.-AGOTADO.

43 Giménez Fernández, Manuel: Hernán Cortés y su revolución comunera en la Nueva España.-VII+144 páge., $24 \times 17$ cms.; 295 grs. -60 pesetas.-AGOTADO.

44 Anuario de Estudios Americanos. Vol. V.-Sevilla, 1948.-XVI+280 págs., 25 láme. $24 \times 17$ cms.; $1.450 \mathrm{gr8} .-$ AGOTADO.

45 Cascajo Romero, Juan: El Pleito de la curación de la lepra en el Hospital de San Lázaro de Lima.-Sevilla, 1948.-VIII+118 págs., 6 láms.; $24 \times 17$ cms.; 200 grs. 60 pesetas.-AGOTADO.

46 Borregán, Alonso: Crónica de la conquista del Perú. Edición y prólogo de Rafael Loredo.-Sevilla, 1949.-124 pág8.; $24 \times 17$ ems,; 200 grs.-AGOTADO.

41 Molina Agüello, Carlos: El Gobernador de Nicaragua en el siglo XVI.-Sevilla, 1949.-XII +256 págs.; $22 \times 16$ cms.; $400 \mathrm{grs}$-Col. Dos Colores:-75 pesetas.-AGO. TADO.

48 Trujillo, Diego de: Relación del descubrimiento del Reyno del Perú. Prólogo y notas de Raúl Porras Barrenechea.-Sevilla, 1948.-XIV+124 págsi; $24 \times 17$ cms.; 210 grs. -60 pesetas, - AGOTADO.

49 Santa Cruz, Alonso de: Crónica de los Reyes Católicos. (Inédita hasta ahora). Publicación de Juan de Mata Carriazo.-Sevilla, 1951.--2 vols. de CCC +367 págs. el tomo I, y X+646, eI II; $22 \times 16$ cms.; 1.750 grs, -270 pesetas.

50 Lohmann Villena, Guillermo: Las minas de Huancavelica en los siglos XVI y XVII.-Sevilla, 1949.-XVII+466 pága., 9 láms.; $22 \times 16$ cms.; 750 grs.; rústica, con sobrecubierta.-AGOTADO.

51 Cátálogo de documentos de la Sección novena del Archivo General de Indias. Dirigido por Bermúdez Plata, Cristóbal: Tomo I.-Sevilla, 1949.-822 págs. 1.450 grs. -180 pesetas.-AGOTADO.

52 Herráez, S. de Escariche, Julia: Beneficencia de Bspaña en Indias.-Sevilla, 1947.II +182 págs., 4 láms.; $22 \times 16$ cms,; 300 grs. -60 pesetas. $-\triangle$ GOTADO.

53 Jos, Emiliano: Ciencia $y$ osadia sobre Lope de Aguirre el Peregrino.-Sevilla, 1950. -XII+168 págs., 7 láms.; $22 \times 16$ cms.; $300 \mathrm{grs.}-40$ pesetas.-AGOTADO.

54 Gil Munilla, Octavio: El Rio de la Plata en la Politica Internacional. Génesis del Virreinato.-Sevilla, 1949.-XIV+464 págs., 8 láms.; $22 \times 16$ cms.; 700 grø.; rús. tica, con sobrecubierta.-AGOTADO.

55 Marco Dorta, Enrique: Cartagena de Indias.-Sevilla, 1951.-XXIV+326 páge.; 8 láminas, 170 figuras; $32 \times 22 \mathrm{cms}$; $1.550 \mathrm{grs.;}$ tela con sobrecubierta.-AGOTADO.

56 Pulido Rubio, José: El Piloto Mayor de la Casa de la Contratación de Sevilla.-Se. villa, 1950.-VIII + 948 págs.; $22 \times 16 \mathrm{cms.;} \mathrm{rústica,} \mathrm{con} \mathrm{sobrecubierta.}-125$ pesetas. AGOTADO.

57 Carvajal y Robles, Rodrigo: Fiesta de Lima. Edición y prólogo de Francisco López Estrada.-Sevilla, 1950.-XXIV + 198 págs., 2 láms.; $22 \times 16$ cms.; 350 grs.; rústica, con sobrecubierta, -45 pesetas, - AGOTADO.

58 Pérez-Embid, Florentino: Diego de Ordás, compañero de Cortés y explorador del Orinoco.-Sevilla, 1950.-156 pígs., 5 láms.; $22 \times 16$ cms.; 225 grs.-Col. Dos Colores, 75 pesetas.-AGOTADO.

59 Estudios Americanos. (Vol. II, núms. 5, 6 у 7).-Sevilla, 1950.-AGOTADO.

60 Calderón Quijano, José Antonio: Fortificaciones en Nueva España.-Sevilla, 1953.XXXVIII + 338 páge., 183 figuras; $34 \times 24 \mathrm{cms}$; $2.000 \mathrm{grs}$; tela, con sobrecubierta.450 pesetas.

61 Anuario de Estudios Americanos. Vol. VI.-Sevilla, 1949.-XIV+875 págs.; $24 \times 17$ cms.-AGOTADO.

62 Estudios Americanos. Vol. III (núms. 8, 9, 10 y 11).-Sevilla, 1951.-25+17 cne. AGOTADO. 
63 Gusinde, Martín: Fueguinos. Traducción de la obra Urmenschen im Feuerland, por Diego Bermúdez Camacho.-Sevilla, 1951.-X+400 págs., 48 láms.; $22 \times 16$ cms.; 600 gramos. -125 pesetas.

64 Anuario de Estudios Americanos. Vol. VII.-Sevilla, 1950.-XVI+608 págs., 8 láms.; $24 \times 17$ cms.; 900 grs. -400 pesetas.

65 Muro Orejón, Antonio: Cristóbal Colón. El original de la capitulación de 1492 y sus copias contemporáneas.-Sevilla, 1951.-12 págs., 8 fotograbados; $24 \times 17$ cms.; 65 grs.-AGOTADO.

66 Marco Dorta, Enrique: Fuentes para la Historia del Arte Hispano-Americano.-Se. villa, 1951.-XXIII + 370 págs.; $24 \times 17$ cms.: 700 grs.-125 pesetas.-AGOTADO.

67 Morales Padrón, Francisco: Jamaica Española.-Sevilla, 1952.-XXXII + 504 págs., 22 láms., 1 mapa; $22 \times 17$ cms.; 650 grs.; tela con sobrecubierta. -200 pesetas.

68 Porras Troconis, Gabriel: Historia de la Cultura en el Nuevo Reino de Granada.Sevilla, 1952.-X+652 págs.; $22 \times 16$ cms.; 700 grs. -125 pesetas.-AGOTADO.

69 Estudios Americanos. Vol. IV (núms. 12, 13, 14 y 15).-Sevilla, 1952.-25 $\times 17 \mathrm{cmq}$. AGOTADO.

70 Mariluz Urquijo, José Maria: Ensayo sobre los juicios de residencias indianos,-Sevilla, 1952. $-\mathrm{XX}+520$ págs.; $22 \times 16 \mathrm{cms}$; 400 grs.-Col. Dos Colores. -90 pesetas.

71 Giménez Fernández, Manuel: El Plan Cisneros-Las Casas para la reformación de las Indias.-Sevilla, 1955.-XXIV+776 págs., 30 láms., $22 \times 16$ cms.; 1.350 grs.; tela, con sobrecubierta. -240 pesetas.-AGOTADO.

72 Anuario de Estudios Americanos. Vol. VIII.-Sevilla, 1951.-XII+658 págs.; $24 \times 17$ centímetros; 980 grs. -400 pesetas.

73 Estudios Americanos. (Vol. V, núms. 16 al 20).-Sevilla, 1953.

74 Estudios Americanos. (Vol. VI, núms. 21 al 27).-Sevilla, 1953.

75 Armas Medina, Fernando de: Cristianización del Perú.-Sevilla, 1953.-XXVIII+640 páginas, 14 fotograbados y mapas; 1.000 grs.; tela, con sobrecubierta.-180 pesetas.

76 León Pinelo, Antonio: El Gran Canciller de las Indias. Edición, estudio y notas' do Guillermo Lohmann Tillena.-Sevilla, 1954.-CLXXIV + 232 págs., $22 \times 16$ cms.; rústica, con sobrecubierta; 500 grs. -105 pesetns.

77 Anuario de Estudios Americanos. VoI. IX.-Sevilla, 1952.-XVI+780 págs., 5 láminna y gráficos. $-24 \times 17$ cms.; 1.050 grs. -225 pesetas.-AGOTADO.

78 Peñalver Simó, Patricio. Modernidad tradicional en el pensamiento de Jovellanos.Sevilla, 1953.-XXXII+168 págg.; $20 \times 13$ cms.; 210 grs.; Col Mar Adentro. 45 pe. setas.-AGOTADO.

79 Elías de Tejada, Francisco: Las doctrinas politicas de Raimundo de Farias Brito. Sevilla, 1953.-196 págs.; $20 \times 13$ cms.; 200 grs.; Col. Mar Adentro. 45 pesetas.

80 López Núñez, Carlos: Horizonte doctrinal de la Sociología Hispano-Americana.-Se. villa, 1953.-164 págs.; $20 \times 13$ cms.; 165 grs.; Col. Mar Adentro.-45 pesetas.

81 Estudios Americanos. (Vol. VII, núms. 28, 29, 30, 31 у 32).-Sevilla, 1954.

82 Tovar, Balthasar de: Compendio Bulario Indico. (Tomo I) Edición y esturlio de Manuel Gutiérrez de Arce.-Sevilla, 1945.-LIII+558 págs.; $18 \times 25$ cms.; 1.050 grs.; tela, con sobrecubierta. -210 pesetas.

83 Larrea, Juan Ignacio: La Santa Sede y el Ecuador.-Sevilla, 1954.-LIII+176 págs.; $18 \times 25$ cms.; 225 grs. - Col. Dos Colores. -90 pesetas.

84 Gil Munilla, Ladislao: Descubrimiento del Marañón.-Sevilla, 1954.-XVI+392 páginas, 13 láms.; $16 \times 22$ cms.; 600 grs.; rústica, con sobrecubierta,-120 pesetas.

85 Asís Garrote, Agustin: Bartolomé Herrera.-Sevilla, $1954 .-148$ págs.; $20 \times 13$ cms.; 200 grs.; Col. Mar Adentro. -45 pesetas.

86 Vila Selma, José: Procedimiento y técnicas en Rómulo Gallego.-Sevilla, 1954. 196 págs.; $20 \times 13$ cms.; 200 grs.; Col. Mar Adentro. -45 pesetas.

87 Tejado Fernández, Manuel: Aspecto de la vida social en Cartagena de Indias duranta el seiscientos.-Sevilla, 1954.-348 págs.; $22 \times 16 \mathrm{cms}$; 500 grs. -90 pesetas. AGOTADO.

89 Anuario de Estudios Americanos. Tol. X.-Sevilla, 1953.-739 págs., 9 láms.; 1.050 gramos. -400 pesetas.

89 Estudios Americanos. Vol VIII. (Núms. 33-34, 35-36, 37, 38 y 39).-Sevilla, 1954.

90 Rodríguez Casado, Vicente: De la Monarquía Española del Barroco.-Sevilla, 1955.180 páge.; $20 \times 13$ cms.; 180 grs.; Col. Mar Adentro. -45 pesetas.-AGOTADO. 
91 Morales Padrón, Francisco: El comercio canario-americano en los siglos XVI, XVII y XVIII.-Sevilla, 1955.-XX + 432 págs., 26 láms.; $22 \times 16$ cms.; 645 grs.; rústica, con sobrecubierta.-105 pesetas.

92 Levillier, Roberto: Los Incas.-Sevilla, 1956.-260 págs. y un mapa plegab]e; $22 \times 16$ cms.; 360 gro.-Col. Dos Colores. -90 pesetes.

93 Morales Padrón, Francisco: Fisonomía de la Conquista Indiana.-Sevilla, 1955.XII+182 páge.; $20 \times 13$ cms.; 200 grs.; Col. Mar Adentro.-45 pesetas.-AGOTADo.

94 Asís Garrote, Agustin: Ideas sociopolíticas en Alonsa de Polo (El Tostado).-Sevilla, 1955.-160 págs.; $20 \times 13$ cms.; 180 grs.; Col. Mar Adentro.-45 pesetas.

95 Rodíl, José Ramón: Memoria del sitio del Callao. Edición, estudio preliminar y notas de Vicente Rodríguez Casado y Guillermo Lohmann Villena.-Sevilla, 1955. $\mathrm{XXX}+344$ págs.: $20 \times 13$ cms.; 500 grs. -105 pesetas.

96 Elías de Tejada, Francisco: El pensamiento político de los fundadores de Nueva Granada.-Sevilla, 1955.-XII+262 págs.; $20 \times 13$ cms.; 275 grs.; Col. Mar Adentro. 60 pesetas.

97 Estudios Americanos. Vol. IX. (Núms. 40-41, 42, 43-44 y 45).-Sevilla, 1955.

98 Estudios Americanos. Vol. X. (Núms. 46, 47, 48, 49 y 50-51).-Sevilla, 1955.

99 Muro Orejón, Antonio: Cedulario Americano del siglo XVIIL.-Sevilla, 1956.XCVI+834 págs.; $24 \times 17$ cms.; 1.300 grs.; rústica, con sobrecubierta. -400 pesetas.

100 Morales Padrón, Francisco: Rebelión contra la Compañia de Caracas.-Sevilla, 1955.-146 págs.; 12 láms,; $25 \times 18$ cms.; rústica, con sobrecubierta; 250 grs. -75 ptas.

101 Estudios Americanos. Vol. XI. (Núms. 52, 53, 54, 55, 56).-Sevilla, 1956.

102 Anuario de Estudios Americanos. Vol. XI, Sevilla, 1954.-24X17 cms.-820 págв., 50 láms. -400 pesetas.

103 Estudios Americanos. Yol. XII. (Núms. 57-58, 59, 60, 61, 62, 63).-Sevilla, 1956, 492 páginas.

104 Anuario de Estudios Americunos. Vol. XII.-Sevilla, $1955 .-989$ págs., 28 lảmı.; $24 \times 17$ cms. -400 pesetns.

105 Estudios Americanos. Vol. XIII. (Núms. 64-65, 66, 67-68, 69-70).-Sevilla, 1957.440 páginas.

106 Arcila Farias, Eduardo: El Régimen de la Encomienda en Venezuela.-Sevilla, 1957.-378 págs.; $22 \times 16 \mathrm{cms}$; 500 grs.-Col. Dos Colores.-90 pesetas.-AGOTADO.

107 Acevedo, Edberto Oscar: El ciclo histórico de la Revolución de Mayo.-Sevilla, 1957.-378 págs.; $20 \times 13 \mathrm{cms.;} 300$ grs.-CoI Mar Adentro.-60 pesetas.

108 Alvar, Manuel: La poesia de Delmira Agustini.-Sevilla, 1958.-VII+113 pág8.; 4 ilust.; $20 \times 13$ cms.-Col. Mar Adentro.-60 pesetas.-AGOTADO.

109 Estudios Americanos. Vol. XIV. (Núms. 71-72, 73-74, 75).-Sevilla, 1957.-277 págs.

110 Estudios Americanos. Vol. XY. (Núms. 76-77, 78-79, 80-81).-Sevilla, 1958.-306 págg.

111 Muro Orejón, Antonio: Ordenanzas Reales para el buen regimiento y tratamiento de los Yndios. (Las Leyes de 1512-1513)._Edición y estudio.-Sevilla, 1959. 85 págs.; 32 láms.; $24 \times 17$ cms.; rústica.-AGOTADO.

112 Rubio Merino, Pedro: Don Diego Camacho y Avila, Arzobispo de Manila y de Guadalajara de México. (1695-1712).-Sevilla, 1958.-XVIII+651 págs.; 7 ilust.; $16 \times 22 \mathrm{cms},-200$ pesetas.

113 Antario de Estudios Americanos. Vol XIII.-Sevilla, 1956.-604 págs.; $24 \times 17$ cms., 225 pesetas.-AGOTADO.

114 Estudios Americanos. Vol XVI. (Núms. 82-83, 84-85, 86.87).-Sevilla, 1958.

115 Anuario de Estudios Americanos. Vol. XIV.-Sevilla, 1957.-636 pígs. $24 \times 17$ cms. Ilustraciones. -225 pesetas.-AGOTADO.

116 Coulthard, G. R.: Raza y Color en la Literatura Antillana.-Sevilla, 1959. VIII+175 páginas; $20 \times 13$ cms.; 190 grs. Col. Mar Adentro. -60 pesetas.

117 Díaz Trechuelo, María Lourdes: Arquitectura Española en Filipinas.-Sevilla, 1959.-193 láms.; $24 \times 17$ cms. -500 pesetas.

118 Navarro García, Luis: Intendencia en Indias.-Sevilla, 1959.-226 págs.-19 mapas, $22 \times 16$ cms. Col. Dos Colores.-100 pesetas.

119 Collantes de Terán, Juan : Las novelas de Ricardo Güiraldes.-Sevilla, 1959.-XV+209 páginas; $20 \times 13 \mathrm{cms}$. Col. Mar Adentro.-65 pesetas.-AGOTADO. 
120 Anuario de Estudios Americanos. Vol. XV. Sevilla, 1958. -769 págs., $24 \times 17$ cms. Ilustraciones. -400 pesetas.

121 Giménez Fernández, Manuel: Politica Inicial de Carlos I en Indias.-Sevilla, 1960.-1.352 pảgs.; 23 láms.; 31 fotoc.; $25 \times 18$ cms. -600 pesetas.

122 Romero Gómez, Manuel: La Constitución Británica.-Sevilla, 1960.-144 páginas; $20 \times 13$ cms.; 55 grs. -65 pesetas.

123 Estudios Americanos. Vol. XVII. (Núms. 90-91, 92-93, 94-95, 96-97, 98-99).-Sevilla, 1959.

124 Muro Orejón, Antonio: Ordenanzas Reales del Consejo de las Indias.-Sevilla, 1957, 3 págs. +56 fotograbados; $24 \times 17$ cms. -60 pesetas.

125 Estudios Americanos. Vol. XIX, núms. 100, 101, 102. Indice-Sevilla, 1960.

126 Anuario de Estudios Americanos. Vol XYI.-Sevilla, 1959.-743 págs.; $24 \times 17$ cms. Ilistraciones. -400 pesetas.

127 Ruiz, Helena: La búsqueda de Eldorado por Guayana.-Sevilla, 1959.-XIV+166 páginas +18 láms. $24 \times 17$ cms. -90 pesetas.

128 Real, José Joaquín: Las Ferias de Jalapa.-Sevilla, 1959.-XII+148 págs.+9 láminas, $24 \times 17$ cms. -90 pesetas.

129 Lohmann Villena, Guillermo: Las relaciones de los virreyes del Perú.-Sevilla, 1959, 218 págs. $24 \times 17$ cms. -100 pesetas.

I30 Muro Orejón, Antonio: Las Leyes Nuevas.-Sevilla, 1961.-59 págs. Reproduccione. facsimilares, transcripción y estudio. $-24 \times 17 \mathrm{cms} .-60$ pesetas.

131 Estudios Americanos. Vol. XX. (Núms. 103, 104, 105).-Sevilla, 1960.

132 Pedro Borges: Los conquistadores espirituales de América.-Sevilla, 1961.-189 págs.; $20 \times 13 \mathrm{cms}$. Col. Mar Adentro. -65 pesetas.

133 Estudios Americanos. Vol. XXI. (Núms. 106, 107, 108).-Sevilla, 1961.

134 Anuario de Estudios Americanos. Vol. XVII.-Sevilla, 1960.-810 págs.; $24 \times 17$ cms. Ilustraciones. -400 pesetas.

135 Anuario de Estudios Americanos. Vol. XVIII.-Sevilla, 1961.-819 págs., $24 \times 17$ cms. Ilustraciones. -400 pesetas.

136 Rodríguez del Valle, Mariana: El Castillo de San Felipe del Goljo Dulce.-Sevilla, 1960.-103 págs. +28 láms. $-24 \times 17$ cms. -90 pesetas.

137 Campo Lacasa, Cristina: La Iglesia en Puerto Rico en el siglo XVIII.-Sevilla, 1962. -127 págs. +20 láms. $-24 \times 17$ cms. -90 pesetas.

138 Luque Alcaide, Elisa: La Sociedad Económica de Guatemala.-Sevilla, 1962.-226 págs. $-22 \times 16$ cms. - Col. Dos Colores. -100 pesetas.

139 Estudios Americanos. Vol. XXII (en prensa).-Sevilla, 1962.

140 Cordoncillo Samada, José Maria: Historia de la Real Lotería en Nueva España (1770.1821).-Sevilla, 1962.-139 págs.+14 láms.-24 $\times 17$ cms. -90 pesetas.

141 Muro Orejón, Antonio: (Antonio de León Pinelo). "Libros Reales de Gobierno y Gracia". Contribución al conocimiento de los Cedularios del Archivo de Indias (1492.1650). Estudio y edición.-Sevilla, 1962.-64 págs.--Reproducción facsimilar. $24 \times 17$ cms. -90 pesetas.

142 Calderón Quijano, J. A., y Navarro García, L.: Biblioteca Nacional de París. Museo Británico. Public Record Office. Guía de Documentos, mapas y planos españoles y anericanos. - Sevilla, $1962 .-70$ págs. $-24 \times 17 \mathrm{cms} .-90$ pesetas.

143 Anuario de Estudios Americanos. Vol. XIX.-Sevilla, 1962.-878 págs. $24 \times 17 \mathrm{cms}$. Ilustraciones. -400 pesetas.

144 Calderón Quijano, J. A.: El Banco de San Carlos y las Comunidades de indios de Nueva España.-Sevilla, 1963. $24 \times 17$ cms., 144 págs. -90 pesetas.

145 Markman, Sidney David: San Crisıóbal de Las Casas.-Sevilla, 1963, 24×17, 115 páginas. Ilusts., 90 pesetas.

146 Pikaza, Otto: Don Gabriel José de Zuloaga Gobernador de Venezuela. Sevilla, 1963, $24 \times 17,195$ págs. 90 pesetas.

147 Muro Orejón, Antonio, Pérez Embid, Florentino, y Morales Padrón, Francisco: Pleitos Colombino.-Sevilla, 1964. XXXI-555 págs. 25’50X18 cms., 1.600 gra., 950 pesetas.

148 Navarro García, Luis: Don José de Gálvez y la Comandancia General de las Provincias Internas del $N$. de Nueva España.-Sevilla, 1965, páge. 604, 133 láms. 
149 Córdoba Bello, Eleazar: Compañías holandesas de Colonización.-Sevilla, 1965, 2 láminas.

150 Muro Orejón, Antonio: Los capítulos de corregidores de 1500.-Sevilla, 1963, 28 págg. 16 fotograbados, $24 \times 17 \mathrm{cms}$, 120 grs., 90 pesetas.

151 Anuario de Estudios Americanos. Vol. XX.-Sevilla, 1963.

152 Rodríguez Macías, Juane: El Correo en Puerto Rico.-Sevilla, 1964, 94 págs., $24 \times 17$ cms., 175 gr8., 60 pesetas.

153 Mariscal Romero, Pilar: Los Bancos de Rescate de Platas.-Sevilla, 1964.-85 págs., 1 lám., $24 \times 17$ cms., 175 grs., 60 pesetas.

154 Lohmann Villena, Guillermo: Las defensas militares de Lima y Callao hasta 1746. Sevilla, 1964, 217 págs., 32 láms., $24 \times 17$ cms., 400 grs., 90 pesetas.

155 Pajarón Parody, Concepeión: El Gobierno en Filipinas de don Fernando Manuel de Bustamante y Bustillo (1717.1719).-Sevilla, 1964, 131 págs., 4 láms., $24 \times 17$ cms., 225 grs., 60 pesetas.

156 Morales Padrón, Francisco, y Llavador Mira, José: Mapas, Planos y Dibujos sobre Venezuela existentes en el Archivo General de Indias (Primera serie).-Sevilla, 1964, 86 págs., 38 láms., $24 \times 17$ cms., 250 grs., 90 pesetas.

\section{COLECCION "MAR ADENTRO"}

Titulos publicados:

Patricio Peñalver Simo: Modernidad tradicional en el pensamiento de Jovellanos.

Francisco Elías de Tejada: Las doctrinas politicas de Farias Brito.

Carlos López Núñez: Horizonte doctrinal de la Sociología Hispano-Americana.

Agustín de Asís Garrote: Bartolomé Herrera.

José Vila Selma: Rómulo Gallegos.

Vicente Rodríguez Casado: De la Monarquía Española del Barroco.

Francisco Morales Padrón: Fisonomia de la Conquista Indiana.

Agustín de Asís: Ideas sociopoliticas del Tostado.

Francisco Elías de Tejada: El pensamiento político de los fundadores de Nueva Granada.

Edberto Oscar Acevedo: El Ciclo Histórico de la Revolución de Mayo.

Manuel Alvar: La poesia de Delmira Agustini.

G. R. Coulthard: Raza y Color en la Literatura Antillana.

Juan Collantes de Terán: Las novelas de Ricardo Güiraldes.

Manuel Romero Gómez: La Constitución Británica.

Pedro Borges: Los conquistadores espirituales de América.

\section{COLECCION "DOS COLORES"}

Títulos publicados:

1 Rodriguez Casado, Vicente, y Pérez-Embid, Florentino: Construcciones del Virrey Amat.

2 Molina Argüello, Carlos: El Gobernador de Nicaragua.

3 Pérez-Embid, Florentino: Diego de Ordás, compañero de Cortés y explorador del Orinoco.

4 Mariluz Urquijo, José María: Ensayo sobre los juicios de residencia indianos.

5 Larrea, Juan Ignacio: La Santa Sede y el Ecuador.

6 Levillier, Roberto: Los Incas.

7 Arcila Farias, Eduardo: El régimen de la Encomienda en Venezuela.

8 Navarro García, Luis: Intendencias en Indias.

9 Luque Alcaide, Elisa: La Sociedad Económica de Guatemala.

\section{DISTRIBUCION EXCLUSIVA :}

Liloreria Científica Medinaceli, Duque de Medinaceli, 4.-Madrid. 


